

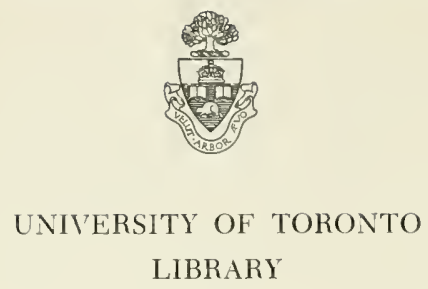

purchased for the

Geology Collection

from the

VARSITY PALAEONTOLOGY

FUND 


\section{B ULLETIN}

OF THF

\section{UNTTED STATES}

\section{GEOLOGICAL SURVEY}

No. $8 \%$

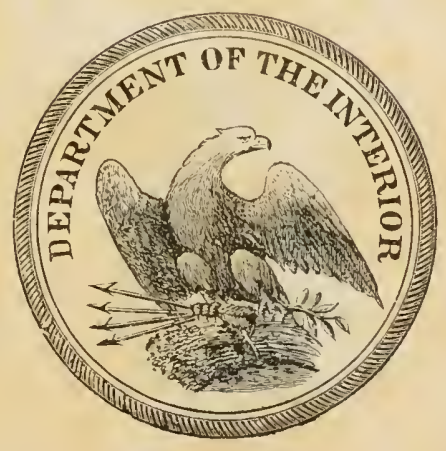

W A S I I T TON

GOVFINMENT PRINTING OFFICE 1897 
Digitized by the Internet Archive in 2008 with funding from Microsoft Corporation 
UNITED STATES GEOLOGICAL SURVEI CHARLES D. WALCOTT, DIRECTOR

\section{A SYNOPSIS}

OF

\section{AIERICAN FOSSIL BRACHIOPODA}

INCLTWING

BIBLIOGRAPII AND SYNONYIIY

BY

OHARLES SCHTCHERT

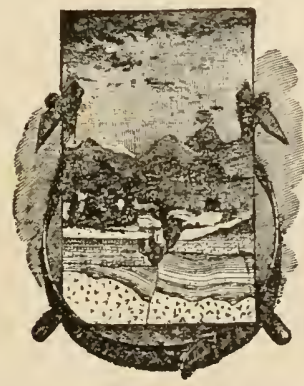

WA STI N G TON

GOVERNIENT PIINTING OFFICE 


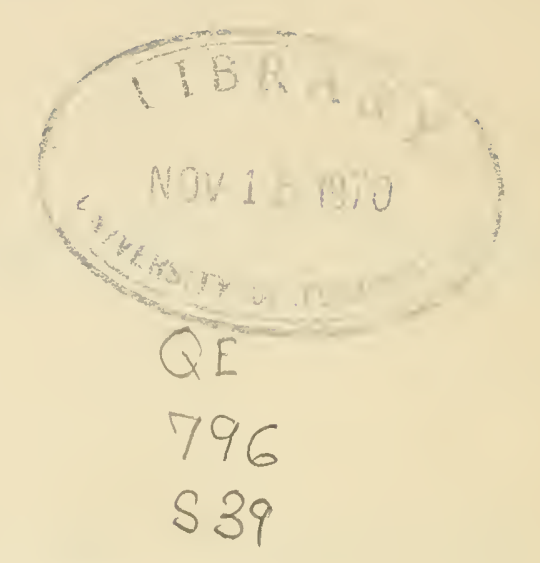




\section{CONTENTS.}

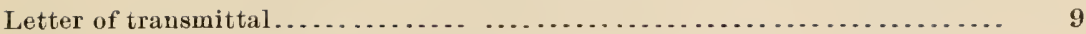

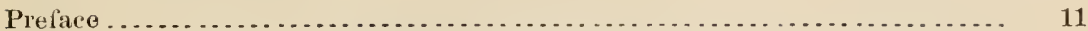

Chapter I. Geologic development and geographic distribution of Americau fossil Brachiopoda.............................. 13

Geologic development. . . . . . . . . . . . . . . . . . . . . . . . . . 13

Geographic distribution . . . . . . . . . . . . . . . . . . . . . . . . . . 17

Table I Brachioporl genera alphabetically arrauged, their geolugic alitribution, and Forth Aucrican specific representation.... -

Table II. North American Paleozoic representation of tho orders, superfamilies, and families, geologically arrangerl. . . . . . . . .

Tables of North and South American species, geologically arranged ...... 26

Table III. Cambrian Brachiopoda ......................... 26

Table IV. Ordovician Brachiopoda... . . . . . . . . . . . . . . . . . . 59

Table V. Silurian Brachiopoda .......................... 36

Table VI. Devoniau Brachioporla . . . . . . . . . . . . . . . . . . . . . . 43

Table VII. Carbouiferous and l'ermian IBrachiopoda............. 57

Table VIII. Mesozoic Brachioporla . . . . . . . . . . . . . . . . . . . . . . 67

Table IX. Cenozoic and recent Brarliopoda................... 68

Table X. South American fossil lirachiopocla . . . . . . . . . . . . . . . 1:9

Chapter II. Brachiopod terminologs, applied to fossil forms............. 73

Chapter III. Biologie developiuent of the Brachiopola. . . . . . . . . . . . . . T8

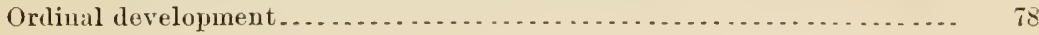

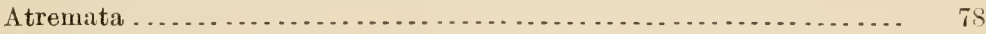

Neotremata . . . . . . . . . . . . . . . . . . . . . . . . . . . . .

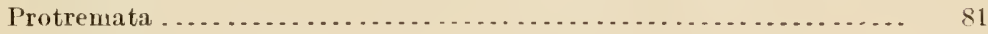

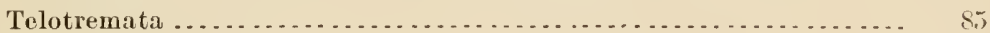

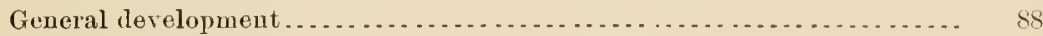

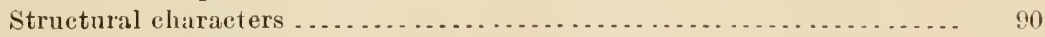

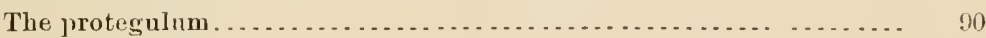

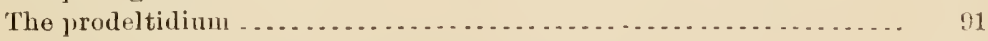

Significance of the prodeltidium . . . . . . . . . . . . . . . . . . . 93

Development of carlinal areas and articnlation . . . . . . . . . . . . . $\quad 47$

Development and siguificance of the deltidium . . . . . . . . . . . . . 98

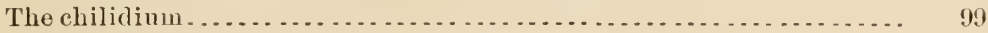

Origin and function of the spondylium . . . . . . . . . . . . . . . . . . . 99

Crura and cluralinm .......................................... 102

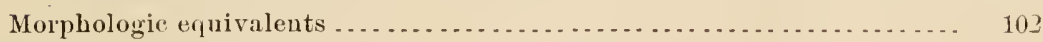

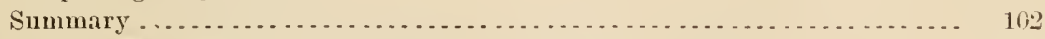

Chapter IY. Morphology of the brachia, by Charles E. lieecher . . . . . . . . . 105

Classification of brachial structures... . . . . . . . . . . . . . . . . . . . . 106

Leiolophns stage ... . . . . . . . . . . . . . . . . . . . . . . . . . . 107

Taxolophusstage ... . . . . . . . . . . . . . . . . . . . . . . . . . . 107

Trocholophusstage ... . . . . . . . . . . . . . . . . . . . . . . . . . . 107

Schizolophus stago................................... 103 
Chapter IV. Morphology of the brachia, hy Charles E. Beecher-Continued. Classification of brachial structures-Continued.

Page.

I'tycholophus stage ..................................... 109

Zugolophus and plectolophus stages......................... 109

Spirolophun stage......................................... 110

References . . . .......................................... 112

Chapter Y. Classification of the lirachiopoda..................... 113

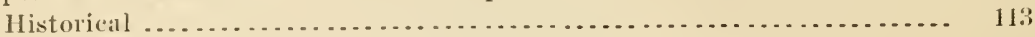

Principles of classification .................................. 115

Classification and synonymy ............................... 118

Atrematil ............................................ 119

Telotremata ............................................. 121

Neotremata........................................... 129

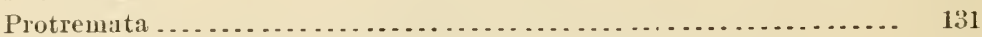

Diagran illustrating geologic distribution of families .............. 13 !

Synopsis of the divisions of Brachiopoda higher than generit . . . . . . . . . 136

Chapter VI. Index aud bibliography of American fossil Brachiopoda ....... 138 


\section{LLUSTRATIONS.}

Phate I. Diagrame.

Plate I. Diagram illustrating geologic distribution of families .......... $13 t$

Fig. 1. Diagram giving the geoloric distribntion of the brachiopod orders ... 96

2. Stages of growth of the lophophore in Thecidea, Cistella, and Mega-

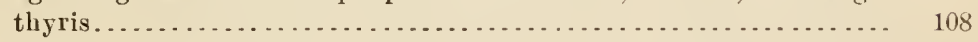

3. Stages of growth of the lophophore in the Terebratellida and Terebratulida ........................................... 109

4. Metamorphoses of the brachidinm in Dielasma tnrgida.......... 110

5. Early stages of the lophophore of Glottidia and adult brachia in Lingula aud Hemithy ris ............................. 110

6. Metamorphoses of the brachidium of Zygospira and the brachidinm

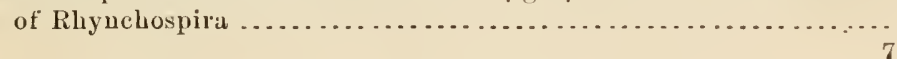



DEPARTMENT OF THE INTERIOR

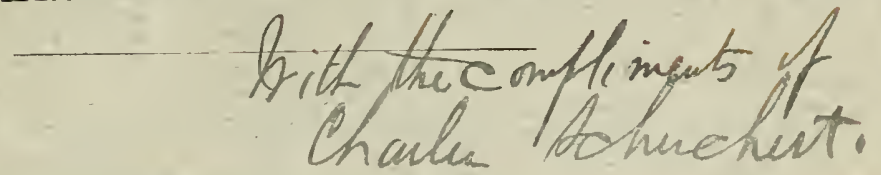

\section{LETTER OF TRANSMITTAL.}

\section{United States National Museum, Washington, D. C., January 9, $189 \%$.}

SiR: I have the honor to transmit herewith the maunseript of $\mathbf{A}$ Synopsis of American Fossil Brachiopoda, including Bibliography and Synonymy, which has been prepared out of official hours. It is presented with a view to its publication as a bulletin by the United States Geological Survey.

Hon. Charles D. WALCoTt',

Charles Schuchert.

Director of the United states Geological Survey. 



\section{PREFACE.}

Probably no continent is more productive of well-preserved Paleozoic brachiopods than North America. 'Throughout the vast territory of the United States which is drained by the Mississippi River the strata have suffered little change, and it is this region which has furnished neirly all the material, from the Middle Ordovician to the top of the Upper Carboniferous. The numerous species of American Cambrian brachiopods which are found scattered along the margins of this great interior plateau and throughont New Brnnswick have also aided largely in determining the evolution of the class. To Mr. Walcott, Director of the United States Geological Survey, much honor is due for making elear the structure of brachiopods from this system.

The present synopsis was begun in Cincinnati eleven years ago, while the writer was engaged in paleontologic work with Mr. E. O. Ulrich. In 1887, when the list had increased to about 700 cards, the position of assistant to Prof. James Hall was entered upon. A nearly complete library of American paleontologic literature thus became available to the writer, and during the next two years the greater part of his leisure was devoted to recorcing brachiopod literature. The large private collection of brachiopods belonging to Professor Hall, together with the many public and private collections then under investigation by Hall and Clarke, also aftorded the writer abundant facilities and a rare opportunity for the study of this class. Every occasion was embraced to examine into the synonymy suggested by authors, and in this work it is believed much has been attained. In addition to the above collections and to the material in his own possession, the writer luas also studied the specimens belonging to this class in the American Musem of Natural History, Yale University Museum, Cincinnati Society of Natural History, and the United States National IInseum. In 1890 the present eatalogue comprised upward of 3,500 ('ards, ar. ranged in boxes having a nnited length of about 4 feet. It now includes nearly 10,000 references relating to North and South American fossil brachiopods.

It is believed that with the exception of local famal lists all the litexature of North and Sonth America pertaining to this subject is recorded in the following synopsis. Much possible synonymy which the writer conld not satisfactorily determine is noted under "Observations." The complete knowu distribution of widely dispersed species 
is not always given, only the more important localities being eited. In every case, however, the locality first mentioned is believed to be the original one.

For the proper generic disposition of the species the work of Hall and Clarke' has been elosely followed, and the entire synopsis is arranged alphabetically to facilitate easy finding. The geologic distribution of the genera is given at the end of Chapter I, and their systematic position in the elassification in Chapter $V$. The evolution of the lophophore, from the simple crescentic condition with ferw tentacles of the protegulum to the most eomplex condition in the Terebratulacea, described in Chapter IV, is wholly the work of Dr. Beecher. From the development of this organ in recent species the peculiarly complicated growth of the lophophore in the Spiriferacea is also explained. Some of the embryonic brachial conditions are likewise indicated as probably existing in a mature condition in early Paleozoic genera.

The danger of neglecting young or small specimens of any organism an not be too often impressed upon collectors. Often by means of such fossils intricate problems in phylogeny or life history may be solved. To have much value, however, young specimens must be very small, and these can not be picked up in the field. Where brachiopods abound, whether in clay or of a siliceons nature in limestone, material shonld be collected in bulk and prepared later by washing or etching with weak muriatic acid. This method of collecting generally results in securing fossils that otherwise will not be observed.

To Dr. Charles E. Beecher, of Yale University Museum, the best thanks of the writer are especially due for the continued interest taken in this catalogne, as well as for valuable suggestions regarding classification; and to Mr. Charles D. Walcott, Director of the United States Geological Survey, for favors relating to the publication of the paper.

To the following gentlemen the grateful acknowledgments of the writer are due for specimens or for suggestions in synonymy: Prof. J. F. Whiteares, Canadian Geological Survey; Prof. H. S. Williams, Yale University; Director Charles D. Walcott, Dr. W.II. Dall, Dr.T. W. Stanton, and Dr. George H. Girty, United States Geological Survey; Prof. R. P. Whitfield, American Mnseum of Natural History; Prof. N. H. Winchell, State geologist of Ninnesota; Mr. E. O. Ulrich, Newport, Kentucky; Mr. S. A. Miller, Cincinnati, Ohio; Mr. R. R. Rowley, Louisiana, Missouri, and Mr. D. K. Gregor, Fulton, Missouri; and to Dr. C. Davies Sherborn, of the British Museum, for valuable suggestions in bibliography.

C. S.

${ }^{1}$ Palicontology of New York, Vol. VIII, 1892-95. 


\title{
A SYNOPSIS OF AMERICAN FOSSIL BRACHIOPODA, INCLUDING BIBLIOGRAPHY AND SYNONYMY.
}

\author{
By Charles Schuchert.
}

\author{
CH A P T E R I . \\ GEOLOGIC DEVELOPMENT AND GEOGRAPIIC DISTRIBU- \\ TION OF AMERICAN FOSSIL BRACIIIOPODA.
}

GEOLOGIC DEVELOPMENT.

Upwarl of 2,500 species of brachiopods have been described or identified from the sediments of the North and Sonth American con. tinents and adjacent islands. Of these, 2,053 are recognized in this catalogue, the other species, about 20 per cent, being consillered as synonyms.

Little is known of the fossil forms from South America. Forty-eight genera are represented by 159 species, ranging from the Cambrian upward. Of these, 125 are from the Paleozoic and $3 \pm$ from the Mesozoic. The Cambrian, Ordovician, and Jurassic brachiopods require further study, since anthors have given little or 110 attention to their internal characters, and also have too readily idtentified them with well-known European species.

In North America there are 1,92: species, of which 1,859 are restricted to the Paleozoic. In 1880 Zittel, ${ }^{1}$ on the basis of Bigsby's Thesaurus, gave a total of 4,243 species of Paleozoic Brachiopoda. Since Bigsby's compilation the total has probably been increased to 6,000 species, about one-third of which ocenr in North America. On account of their good preservation and great abundance, both in speeies and individuals, throughont the Paleozoic, the brachiopods in North America are of particular value in stratigraphic and correlative geology.

In the Mesozoic there is a remarkable scarcity of brachiopods, since but 49 species have been recorded, and many of these are rare. The Cenozoic representation is even smaller, there being but 14 species. This scarcity of post-Paleozoic brachiopods is very apparent in the oldest system of the Mesozoic, the Triassic, from which but 11 species have been described, whereas in the Carboniferous there are 478 
species. In marked contrast, also, is this lack of brachiopod continuity when compared with the $\Lambda$ pine Trias, from which Bittner has describer 380 species: bnt nowhere else is this system known to have so large a development. This evidence not only indicates a decadence of the class during late Paleozoic, but epeirogenic movements as well near the close of the American Carboniferous, for none of the 478 species of this system pass into the Trias.

With the Trias a new facies of brachiopod life is initiated; many of the familiar types of Paleozoic shells luad, at that time, long since ceased to live or had ended in the Carboniferous or Permian. The superfamilies Acrotretacea, Obolacea, and Pentameracea have died ont, while the Lingılacea, Discinacea, Craniacea, Strophomenacea, and Spirifericea are sparingly represented, and commonly by sunall species. Before the close of the Jurassic system the Spiriferacea also disappeared, so that since the Cretaceons era the class is practically represcuted by rhynchonellas and terebratulas, with a few scattering species of Lingula, Crania, and Discinisea.

In the American Jurassic there are bnt 13 species, and all are rare. How remarkable is this representation when contrasted with the Jura of Emope, where certain beds of the Lias, Dogger, and Maln terranes contain millions of specimens of a few species belonging to the families Terebratulidie and Rhynchonellida." The Cretaceons has 26 sjecies, also a meager representation, and yet "outside of Enrope, North America is the most important for the occurrence of Cretaceous Brachiopoda." The American Eocene has 9 species and the Neocene 5. The disparity between the Enropean and American Cenozoic brachiopod famms is partly due to the scarcity of marine deposits representing the different horizons in America.

The gengraphic distribution of the 63 post-Paleozoic species shows that 30 are found along the eastern and southern boider of the United States, 15 on the Pacilic Coast, and 18 from the Arctic Circle south to about the fortieth parallel and between the one hundredth and the one humbled and twentieth meridians.

The Trias of eastern North America, with its unfarorable shore deposits, has but one species, while the Cordilleran Sea ${ }^{3}$ to the east of the Rocky Mountains has 7, and these were there followed by 5 other speries in the Jurassic system. A larger brachiopod fauna may have existed in the deeper waters of the Atlantic Trias, but nothing of it is known. In Cretaceous times conditions were again more favorable, 10 forms being recorded from the Atlantic border of North Anerica, 10 from the Pacific, and 6 from the interior Cordilleran Sca. Toward the close of the Cretaceous the Cordilleran Sea became more and more

${ }^{3}$ For the areas covered by this and the Aississippian and Appalachian seas, see Walcott's presidential aldress, Geologic time as indicated by the sedimentary rocks of North America: Proc. Am. Assoc. Adr. Sci., Vol. XLI1, 1893. 
unfit for marine life, and no brachiopods are known from the Tertiary deposits of this area. From the eastern North American Tertiary 9 species are known, but only 2 from the Pacific border. In recent times conditions are apparently more favorable for the introduction and existence of brachiopods from other areas, as 14 species have been dredged from the Atlantic and 24 from the Pacific continental plateaus of North America.

The living forms are universally distributed in the seas of the world. Their range in depth is no less extended. They occur in shallow waters, at low- mater mark, and varying degrees of depth, from 200 to 600 fathoms being the usual limit of the majority of speeies. Several far-ranging abrssal species were dredged in from 1,000 to 2,000 fathoms. The delicate transparent shell of that interesting little Terebratinloid, Lioth şrina Wyvillei Daridsun, was actualls obtained in a living condition by the Challenger expedition from the enormous rlepth of 2,900 fathoms, or $3 \frac{1}{4}$ miles, at the bottom of the South Atlantic Ocean.

In the North American Cambrian there are 116 species described, a far greater development than in any other comntry. Davidson records but 14 species in Great Britain, while Bigsby, in 1868, gave the total for this system as 126 for all countries. In the next, or Ordorician, system the rapidity of brachiopod differentiation is remarkable. There are 319 species known in North Anerica, an increase nearly three times that of the Cambrian. Bigsby's percentage of increase for this system is even greater, since in 1868 he listed 556 Ordovician species, which represent a growth of nearly four and one-half times that of his Cambrian total of 126 .

While there is much specific differentiation throughout the Ordovieian, it is a notable fact that the essential types of brachiopods of this system are also found near its base in the Calciferous. In the Chazy, or next younger horizon, the species are very much like those of the Trenton, where this class has great and raried representation, which is maintained to the end of the Ordovician. It is also true that the species become more generalized structurally as the Cambrian is approached, and most rapidly so toward the base of the Ordovician.

The evolution of the Cambrian brachiopods is similar in its history to that of the Ordovician, except that there the differentiation was along more fundamental structural lines. In the following table it is seen that the four orders of the class Brachiopoda began with the Lower Cambrian, and that thronghont this system differentiation was mainly of family importance, since none of these divisions has many genera or species. Where minor groups occur in quantity it is always in the more primitive divisions, as in the Atremata. In none of the other three orders is there a similar rapid differentiation in the Cambrian. 
Table showing the differentiation of the Brachiopoda during Cambrian time.

\begin{tabular}{|c|c|c|c|c|c|c|c|}
\hline & $\begin{array}{c}\text { Number } \\
\text { of } \\
\text { species. }\end{array}$ & $\begin{array}{c}\text { Number } \\
\text { of } \\
\text { genera. }\end{array}$ & $\begin{array}{c}\text { Number } \\
\text { of } \\
\text { families. }\end{array}$ & $\begin{array}{c}\text { Atre- } \\
\text { mata } \\
\text { species. }\end{array}$ & $\begin{array}{l}\text { Neotre- } \\
\text { mata } \\
\text { specres. }\end{array}$ & $\begin{array}{l}\text { Protre- } \\
\text { mata } \\
\text { species. }\end{array}$ & $\begin{array}{l}\text { Tolotre- } \\
\text { mata } \\
\text { species. }\end{array}$ \\
\hline Upper Cambrian ... & 51 & 14 & 8 & 30 & 4 & 17 & \\
\hline Midklo Cambrian... & 39 & 12 & 5 & 19 & 16 & 1 & \\
\hline Lower Cambrian ... & 31 & 12 & 7 & 17 & 5 & 8 & 2 \\
\hline
\end{tabular}

The earlicst deep-water deposits of the Silurian, the Clinton forma tion, have a brachiopod fimna which is quite different from that of the Orilovician. The Atremata, Neotremata, and Protremata are much like those of the Ordovician, but the Spiriferacea of the Telotremata, the most characteristic brachiopods of the Silurian, have here attained a great variety of forms, with varied brachyclial structures. Throughout the American Silurian the brachiopods show little structural differentiation, but in the Lower Helderberg, at the base of the Devonian, the spire-bearers are changing and assuming characters which are fully developed in the higher Devonian. Here also occur the oldest loopbearers, or Terebratulacea, though the ontogeny of Zygospira seems to show that this superfamily originated in the Ordovician.

In the Mississippian Sea deposition was apparently quite continuous thronghout Devonian and Carboniferous times, and not much interrupted by earth movements. The faunas of these systems in this area show no rapid evolution along any of the brachiopod phyla. The species of the basal member of the Carboniferous, the Waverly or Kinderhook, are not nnlike those of the Chemung of the Upper Devonian, nor is there any great faunal difference between the Kaskaskia of the Lower Carboniferous and the productive Coal Measures above.

From the foregoing rapid summary of the geologic history of American brachiopods, it follows that differentiation in the Paleozoic is most rapid near the base of the older systems, and diminishes in force from the older to the younger geologic divisions. While earth movements in America were greater and more numerous during the early Paleozoic than later in and just previous to the close of this time, yet the early and rapid evolution of the class is probably dne not only to the varying conditions produced by these movements but also to the greater plasticity of the class during the Cambrian and Ordovician eras.

There are 311 species in the American Silurian, increasing to 662 in the Devonian, while the Carboniferous representation declines to 478 species. In 1880 Zittel gave a total of 1,360 species for the Devonian, 871 for the Carboniferons, and but 30 for the Permian. Waagen's researches in the Permian of India, however, have increased this representation considerably.

There is no more striking evidence than these figures neerled to show 
the very rapid increase of the class during the Ordovician, its culmination in the Devonian era, and its rapid decline in the Carboniferons.

of the 230 established Paleozoic genera, not fewer than 186 are represented in North America.

\section{GEOGRAPHIC DISTRIBUTION.}

The geographic distribution of North American Paleozoie brachioporls is extensive, since 30 per cent, or 537 species, had great areal or horizontal dispersion. One hundred and seventeen species are found in both the Mississippian and Cordilleran seas, and of these 36 are also known to oceur in foreign countries. The number of speeies common to North America and other continents, howerer, is 121.

When considered chronologically, it is observed that 20 per cent of the Cambrian brachiopods have great geographic distribution, and that this increases to 32 per cent in the Orlovician, Silurian, and Devonian, and declines to 28 per cent in the Carboniferous. Greatest specific dispersion, however, is most noticeable in the Devonian and Carboniferons, where Atrypa reticularis, Leptema rhomboidalis, Orthothetes erenistriatus, Productus semiretieulatus, I'. punctatus, Fhynchonella pleurodon, Spirifer Aisjunctus, and S. striatus have almost world-wide distribution and great vertical or chronologic range. Many similar species common to America and several Europenu countries conld be mentioned.

Specific distribution increases with ordinal rank. In the radical orrler Atremata 25 per cent had dispersion, increasing to 27 per cent in the Neotremata, and to 32 per cent in the Protremata and Telotremata.

From the above consiclerations it is evident that brachioporls, as a rule, can not be of great value in correlating over wirle areas minor Devonian, but particularly Carboniferous, horizons. In the Cambrian, Ordovician, and Silurian, however, these fossils are of great value for stratigraphic purposes. Since post-Paleozoie brachiopods are not common in America, they can lave little stratiglaphie value, but in the Trias and Jura of Europe, where species and individuals are common, reliance can be placed upon them, and they are there regarded as next in importance to the Ammonoilea for correlation. When paleontology shall have advanced sufficiently, so that extracontinental colrelation of Paleozoic formations can be taken up in detail, it will be seen that brachiopos,s, becanse of their wide dispersion, abundance, and favora. ble preservation, will be of great service in working ont paths of migration and intereommunicating oceanie basins.

Bull. Si—ב 
TAm,: I. - Rrachiopod genera alphabelically arranged, their geoloyio distribution, an Forth American sperific represenlution.

[In the column "Orilinal rank" $\Lambda$., N., P., 'L. equal the first letters of Atremata, Nootremata, Protr mata, amb Telotromata, respectively. The geologic crecurrence of nou-A meriean genera or the earlie appearance or later "outimunce of American genera in other countries is indicated by a black line Small superior numerals indicate the mumber of species laving distribution.]

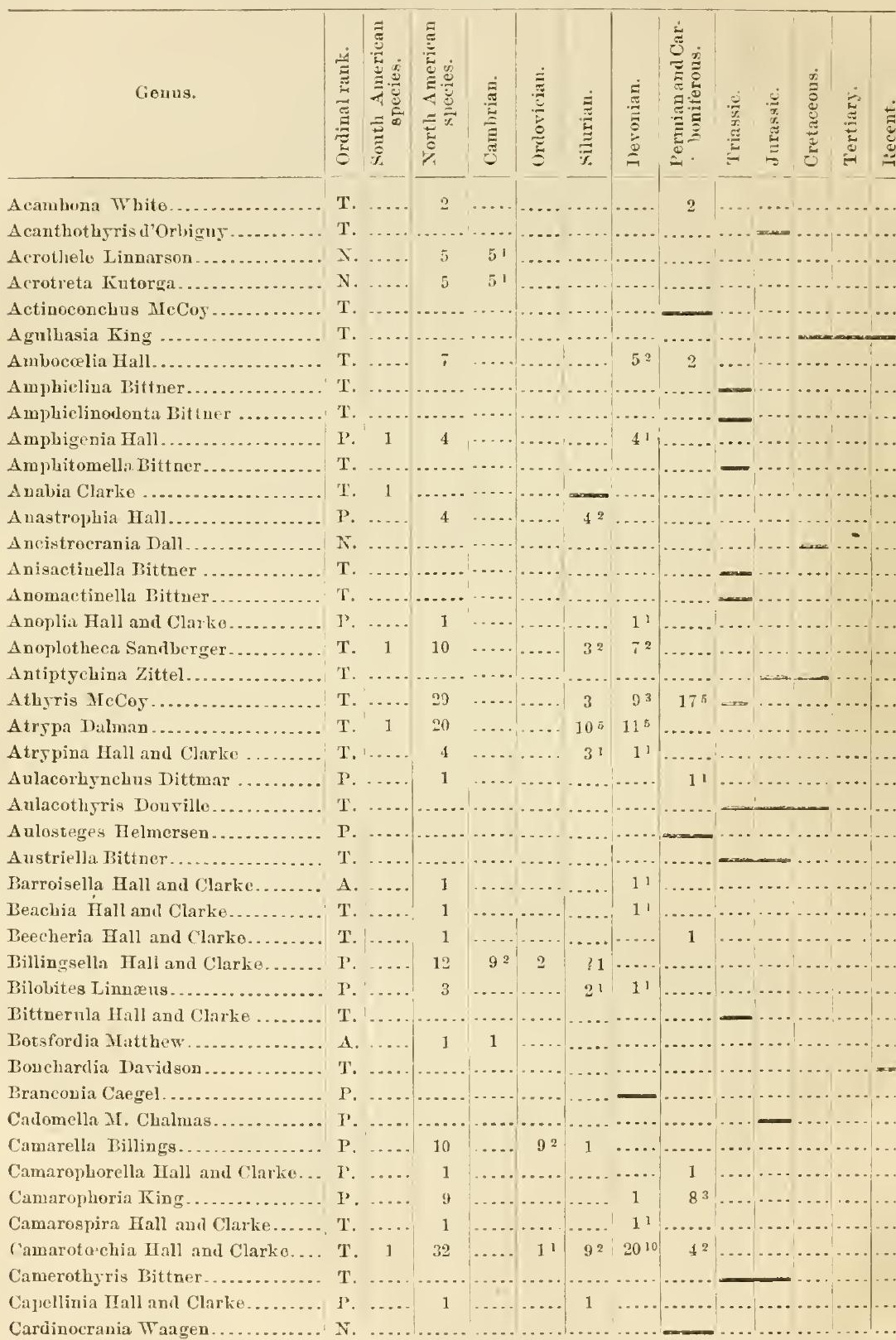


TABLe I.-Brachiopod genera alphabetically aranged, ete.-Continned.

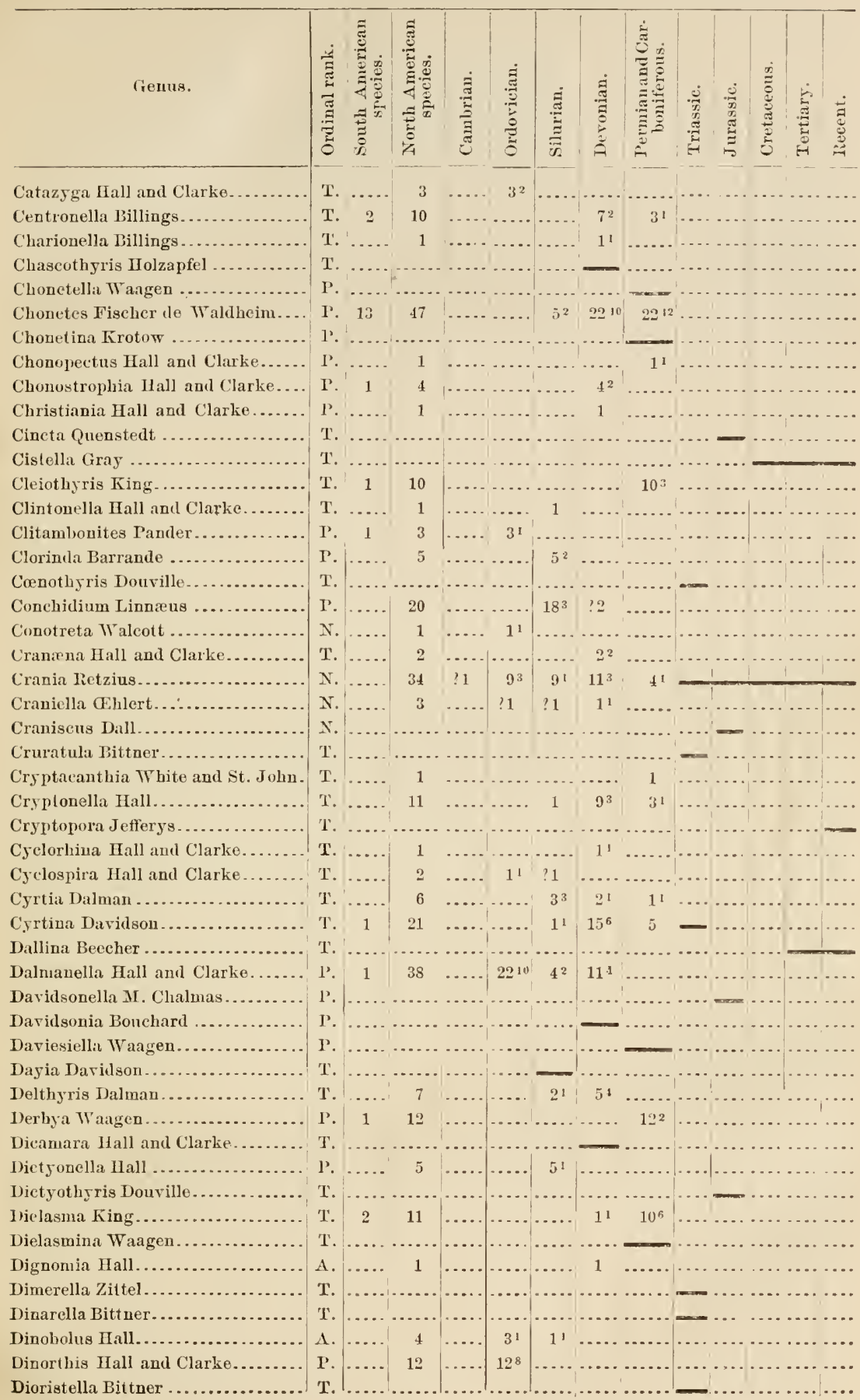


TA1L1: I.-Bruchiopod genera alphabetically arranged, etc.-Continued.

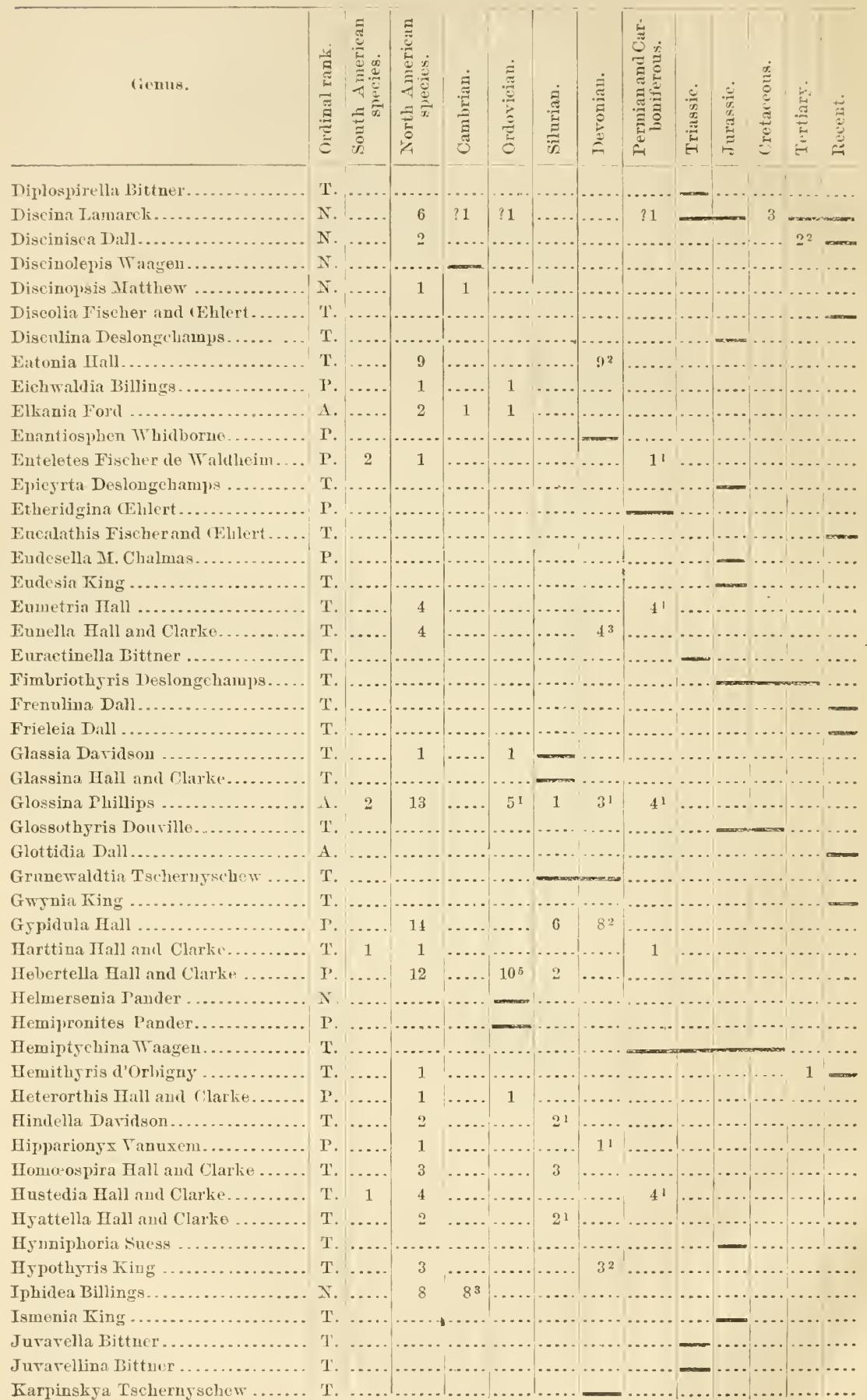


TABLE I.-Brachiopod genera alphabetically arranged, efo-Continued.

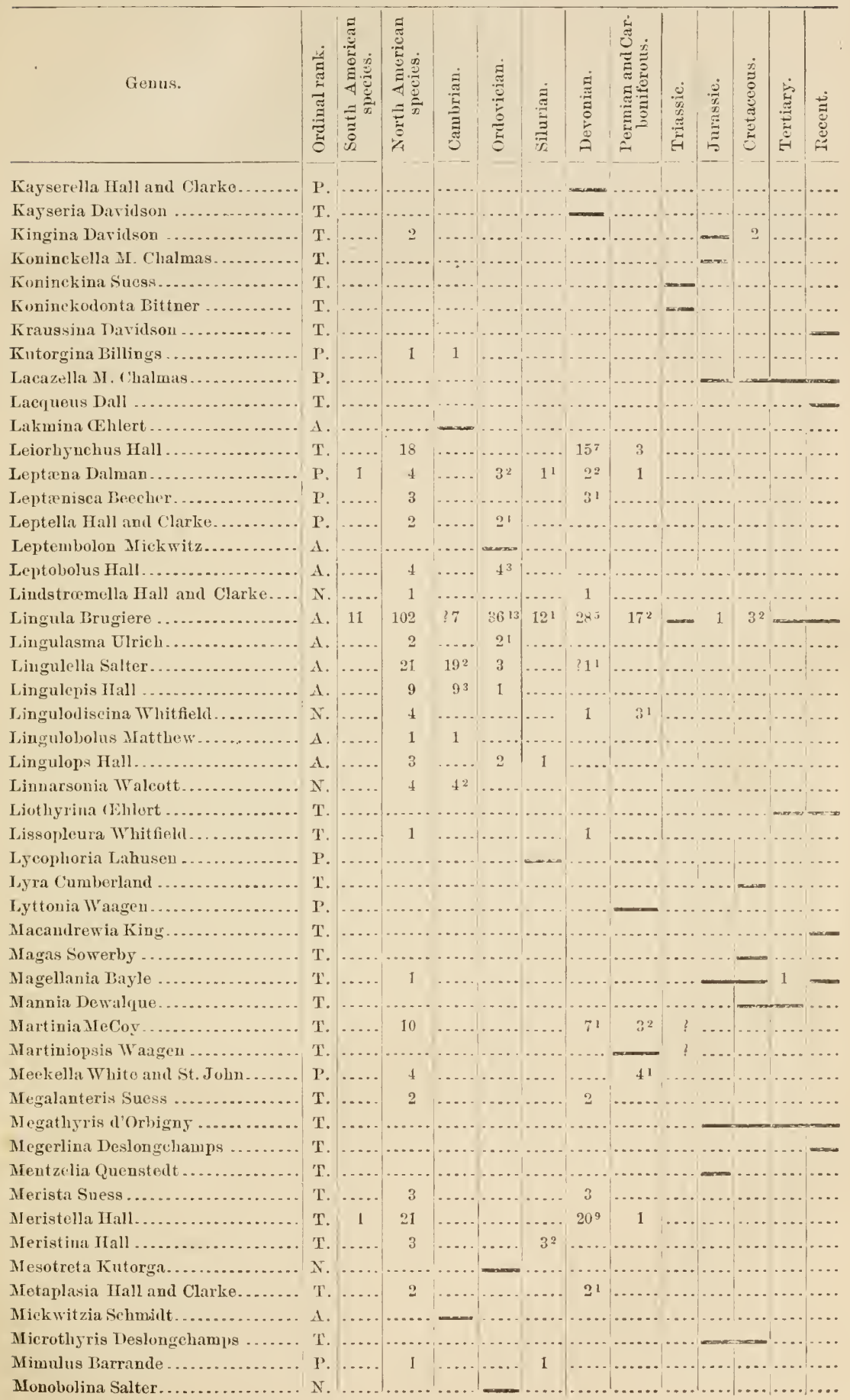


TABLe I.-brachiopod genra alphabetieully arranged, ele.-Contimed.

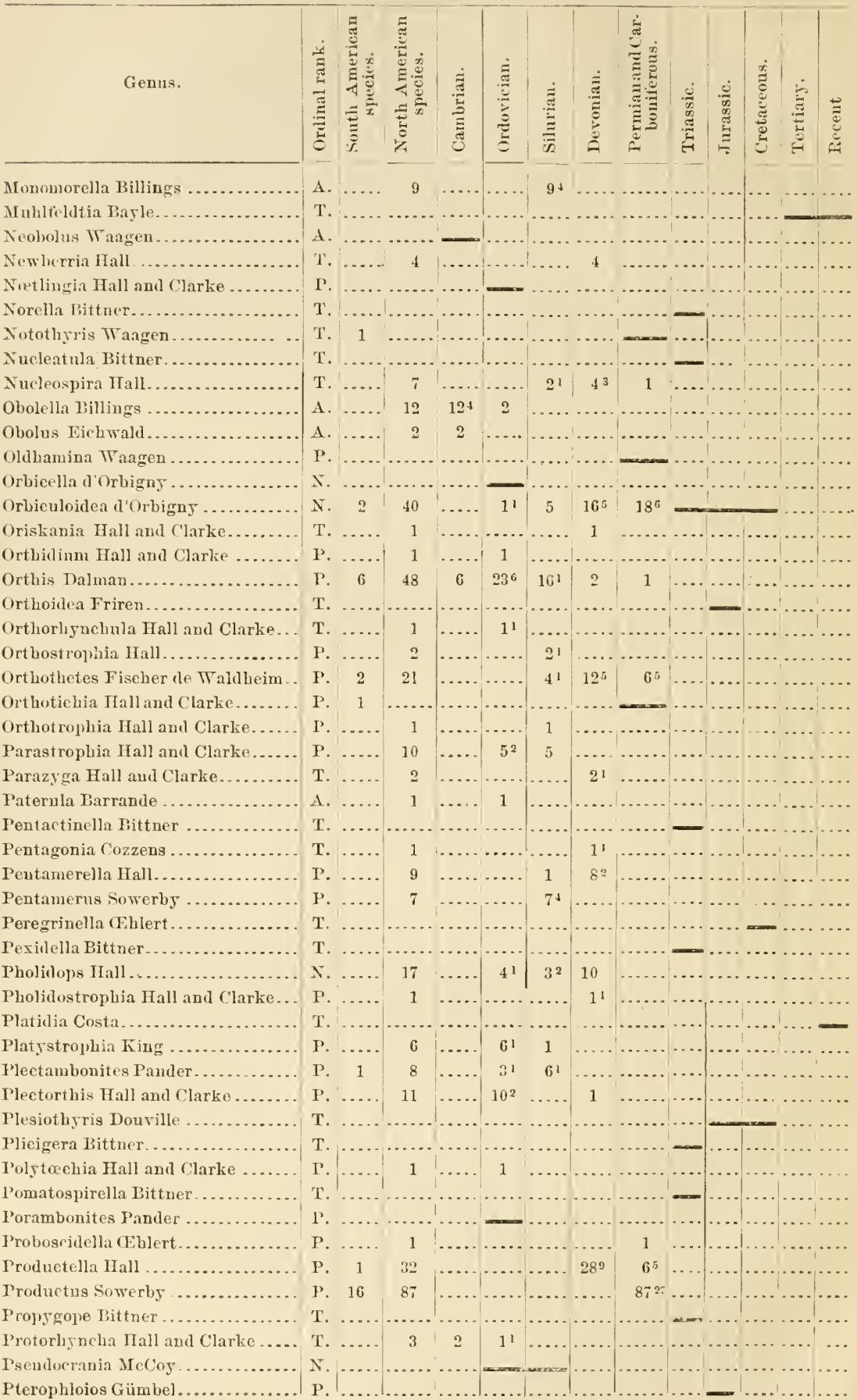


TABLE I.-Brachiopod yentra alphabetically arranged, ete,-Continuerl.

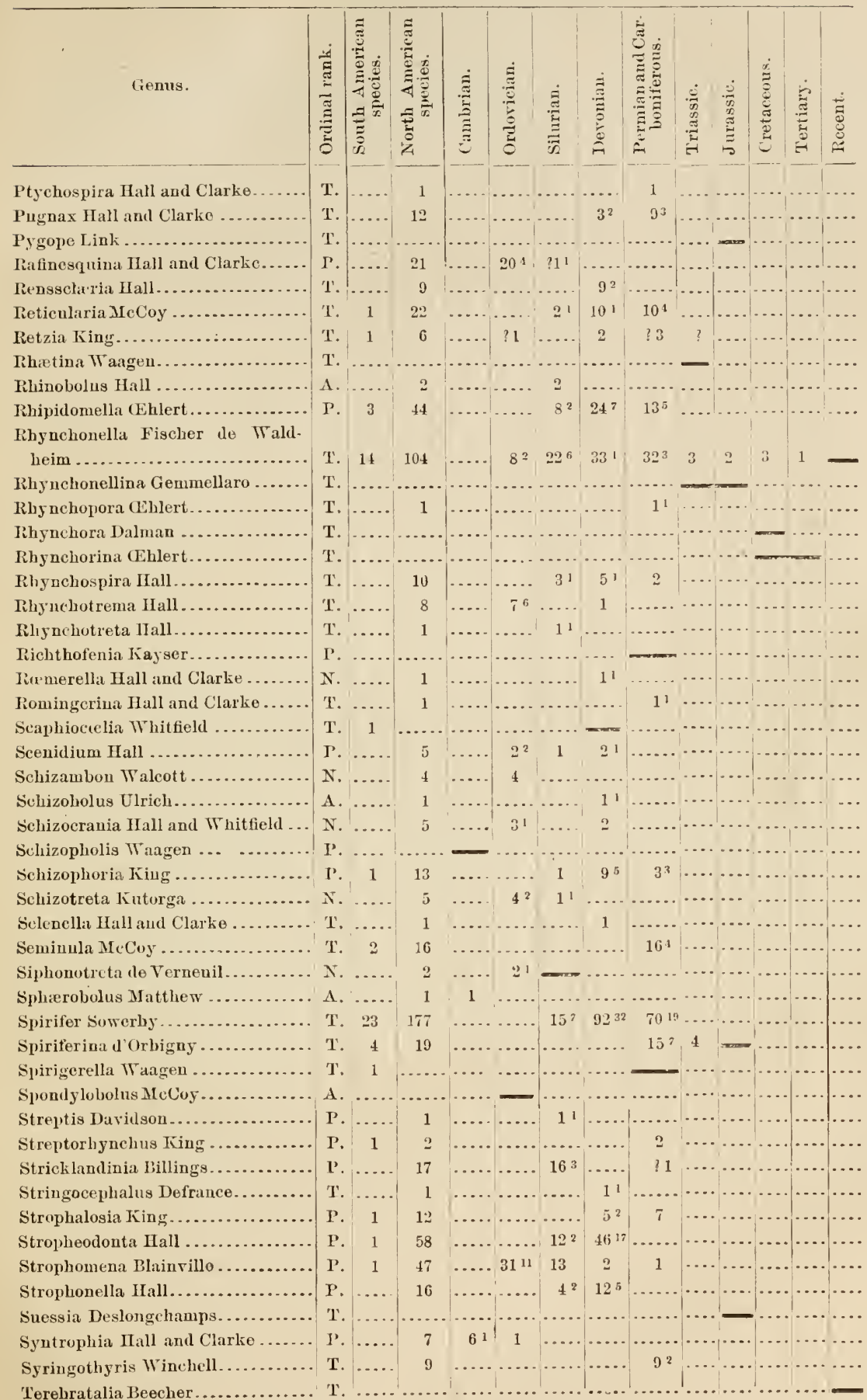




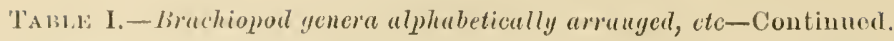

Tereliratella il Orbigns

'Lerebratula Lliw yil.

ierebratulina d'Orbigny

Terelurataloidea Waagen

Tetractinella Bittnex.

The eitclla M. Chalmas.

Theridia Lefranee.

Theeidiopsis MI Chalunas.

Theeocytella Bittuer.

Tlecospira Zügmejer.

Thysanotes Mickwitz

Tomasina IIall aud Clarke.

'Iorynifer Hall and Clarke.

Trematis Sharpe

Trematobolus Matthew.

Trematospira Hall.

Trigeria (Bayie) Irall and Clarke.

Trigonosemus Koenig............

Trimerella Billings...............

Triplecia Iall. ................ P

Tropideleptus Ilall.............. T.

Cneinella Waagen .............. T

Tncinulus Bayle................ 'T

Tneites Defrance............... T

Terneuilia Hall and Clarke.......

Titulina Hall. . . . . . . . . . . . . . . .

Folborthia von Müller...........

Whittieldella Hall and Clarke.....

Tilsunia Kiayser.................

Zeilleria Bacle.

Zullania Moore

Zngmejeria Wragen............

Zyrospira HaIl.

Total.

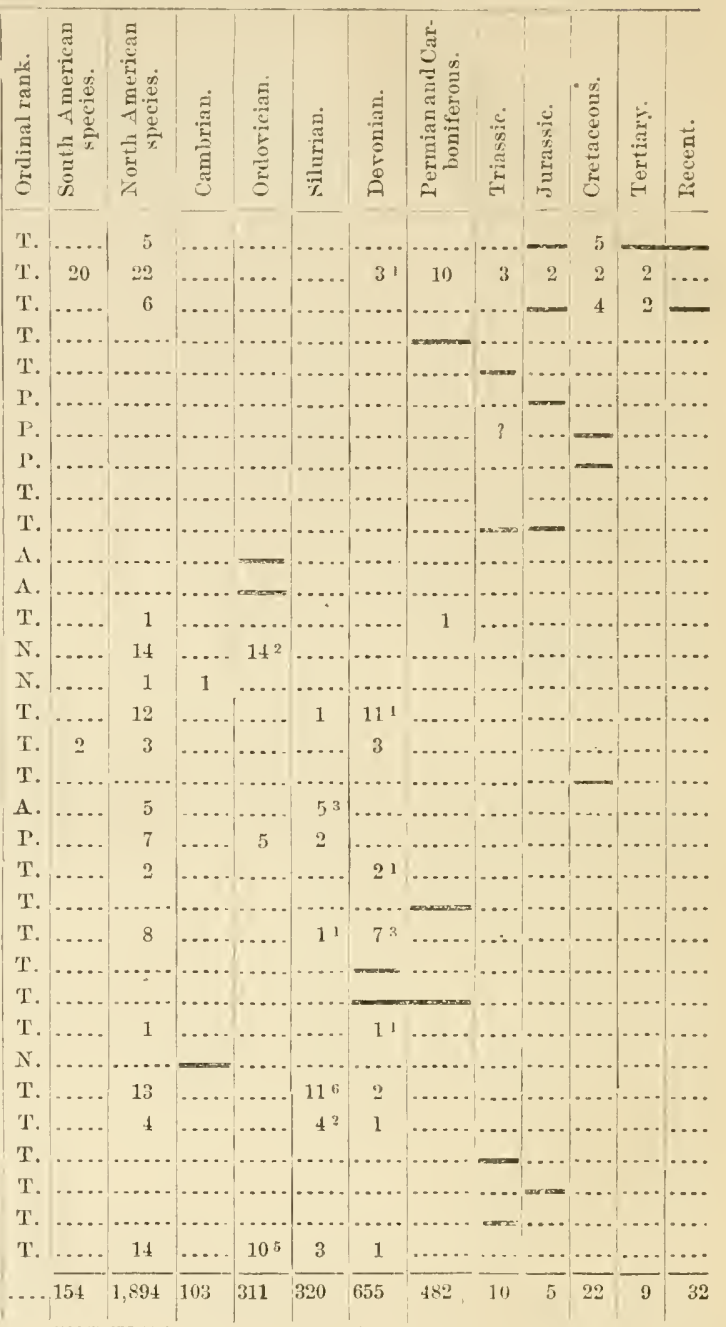


TABLE II.-North American Paleozoic representation of the orders, superfamilies, and families, geologically arranged.

Order Atremata

Supert. Obolacea

Fam. Paterinidie.................. 8

Obolidie................... 17

Trimerellide.............. 20

Supert. Lingulacea................. 153

Fam. Lingulellida $x^{2} \ldots \ldots \ldots \ldots \ldots . . .6 \quad 35$

Lingulidw.............. 113

Lirıgulasmatida........... 5

Order Neotremata...................... 153

Superf. Discinacen ................. 99

Fam. Trematida $\ldots \ldots \ldots \ldots \ldots \ldots . .24$

Discinidæ................ 50

Acrotretide............... 16

Siphonotretidक ............ $t$

Superf. raniacea .................. 54

Fam. Craniidre................ 54

Order Protremata ...................... 735

Siperf. Thecacea.................... 608

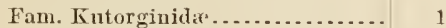

Eichwaldiidie ............... 6

Billingsellida ............... 12

Strophomenidæe........... 211

Productida ................. 186

Orthilæ.................. 192

Superf. Trullacea................... 127

Fan. Clitambonitide ............ 9

Syntrophiidm .............. 7

Porambonitilia............. 24

Pentameridie.............. 87

Order Telotremata ..................... 762

Superf. Rostracea ................... 197

Fan. Protorhynchidie ............ 3

Rhynchonellidi............. 194

Superf. Terebratulacea............. $\quad 79$

Fam. Centronellidio ............... 30

Terebratulidæ ............. 47

Tropidoleptiida............ 2

Supert. Spiriferacea ................. 486

Fam. Atrypidzo............... 45

Spiriferidr................. 278

Athyridie................ 163

\begin{tabular}{|c|c|c|c|c|c|}
\hline 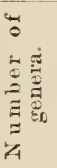 & 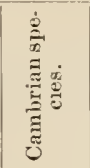 & 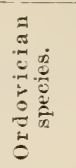 & 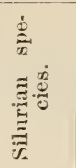 & 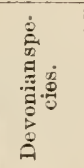 & 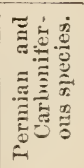 \\
\hline 19 & 57 & 60 & 31 & 30 & 21 \\
\hline 9 & 22 & 6 & 17 & 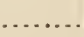 & \\
\hline 1 & $8^{2}$ & ... & $\ldots$ & & \\
\hline 4 & 164 & 3 & ... & & \\
\hline 4 & ....... & $3:$ & $17^{8}$ & $\ldots$. & \\
\hline 10 & 35 & 54 & 14 & 30 & 21 \\
\hline 4 & $28^{5}$ & $9^{3}$ & ..... & $1^{\prime}$ & \\
\hline 4 & 7 & 1114 & $13^{1}$ & $29^{5}$ & 21 \\
\hline 2 & $\ldots$. & 41 & 1 & ..... & $\ldots$ \\
\hline 21 & 20 & 44 & 21 & 42 & 26 \\
\hline 18 & 19 & 80 & 8 & 20 & 22 \\
\hline 4 & ... & $17^{3}$ & 2 & 21 & $\sigma$ \\
\hline 5 & 1 & $6^{3}$ & 61 & $18^{6}$ & $19^{6}$ \\
\hline 5 & $15^{5}$ & $I^{\prime}$ & & & \\
\hline 3 & 1 & 61 & $\ldots$ & & \\
\hline 3 & 1 & 14 & 13 & 22 & * \\
\hline 3 & 1 & $1 t^{4}$ & $13^{3}$ & 224 & $4^{1}$ \\
\hline 62 & 22 & 173 & 161 & 210 & 179 \\
\hline 45 & 16 & 152 & 96 & 185 & 169 \\
\hline 1 & 1 & ... & .... & $\ldots$. & \\
\hline 2 & $\ldots$. & 1 & 51 & ... & \\
\hline 1 & $0^{2}$ & 2 & 1 & ........ & .. \\
\hline 19 & & 6519 & $48^{\prime \prime \prime}$ & $77^{31}$ & $26^{8}$ \\
\hline 9 & $\ldots$ & ...... & 51 & 6024 & $125^{46}$ \\
\hline $1: 3$ & 6 & $84^{32}$ & 377 & 4816 & $18^{9}$ \\
\hline 17 & 6 & 21 & 6.5 & 25 & 10 \\
\hline 3 & & $6^{3}$ & 1 & $2^{\prime}$ & \\
\hline 1 & 61 & 1 & ..... & & \\
\hline 3 & 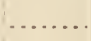 & $14^{\prime}$ & $10^{3}$ & & \\
\hline 10 & $\ldots$. & ..... & $54^{12}$ & $23^{5}$ & $10^{3}$ \\
\hline 76 & 2 & 20 & 109 & 369 & 269 \\
\hline 14 & 2 & 18 & 37 & 24 & 49 \\
\hline 1 & 2 & $1^{1}$ & ..... & ..... & $\cdots$ \\
\hline 13 & & 1710 & 3712 & $94^{28}$ & $49^{3}$ \\
\hline 10 & & 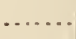 & 1 & 50 & 30 \\
\hline 8 & & & & $26^{5}$ & $4^{2}$ \\
\hline 10 & & $\ldots .$. & 1 & 2211 & $26^{7}$ \\
\hline 1 & & .... & .... & 21 & $\cdots$ \\
\hline 43 & & 2 & $\pi 1$ & 225 & 190 \\
\hline 8 & & ..... & $14^{7}$ & 18 & $11^{6}$ \\
\hline 11 & ......... & $1^{1}$ & $24^{13}$ & 13848 & $115^{35}$ \\
\hline 24 & ........ & 1 & $33^{14}$ & $69^{23}$ & \\
\hline
\end{tabular}




\section{TARLES OF NORTH AND SOUTH AMERICAN SPECIES GEOLOGICALLY ARIRANGED.}

Table ili, Camblian.-Table IV, Ordovician.-Table V, Silubian.-Table Vi,

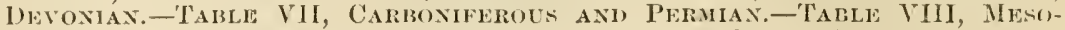

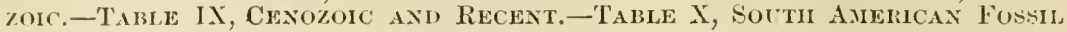
BRACHIOPODA.

TABLE III.-Cambrian Brachiopoda.

[Species preceded log an asterisk (") are found in the Ordovician alse.]

\begin{tabular}{|c|c|c|c|}
\hline Species. & $\begin{array}{l}\text { Lower } \\
\text { Cam. } \\
\text { brian. }\end{array}$ & $\begin{array}{c}\text { Middlle } \\
\text { Cam- } \\
\text { brian. }\end{array}$ & $\begin{array}{l}\text { Cpper } \\
\text { Can- } \\
\text { brian. }\end{array}$ \\
\hline \multicolumn{4}{|l|}{$\begin{array}{l}\text { Acrothele (?) dichotoma Walcott... } \\
\text { Acrothele matthewi (Hartt)........ }\end{array}$} \\
\hline Acrothele matthewi (Hartt)......... & & $x$ & \\
\hline rothele matthewi costata Matthe & & $x$ & \\
\hline natthewi lata Mat thew.. & & $x$ & \\
\hline thewi prima Matthew & & $\times$ & \\
\hline sidua (Th hite)... & $x$ & x & \\
\hline eyi Matthew... & & $x$ & \\
\hline a Billings............ & $x$ & $x$ & \\
\hline pressa Walcott.. & & $x$ & \\
\hline & & $\times$ & \\
\hline a (Shumard).. & & $x$ & \\
\hline & & $x$ & \\
\hline gsi (Hartt) ........... & & $x$ & \\
\hline \multicolumn{4}{|l|}{ 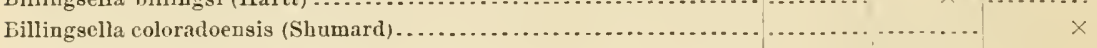 } \\
\hline \multicolumn{4}{|l|}{ Billingsella festinata (Billings) .................................... } \\
\hline \multicolumn{4}{|l|}{ 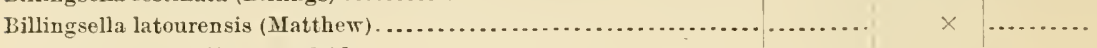 } \\
\hline \multicolumn{4}{|l|}{ 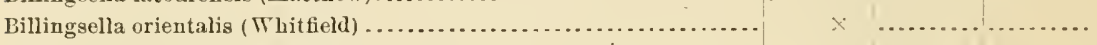 } \\
\hline \multicolumn{4}{|l|}{ 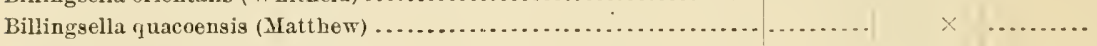 } \\
\hline \multicolumn{4}{|l|}{ 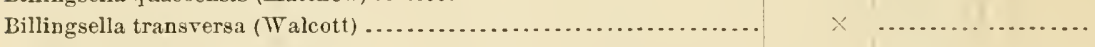 } \\
\hline \multicolumn{4}{|l|}{ 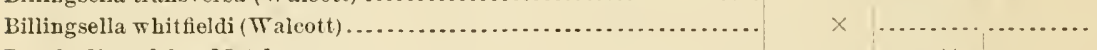 } \\
\hline \\
\hline \multicolumn{4}{|l|}{ Crania (?) columbiana Walcott........................................ } \\
\hline \multicolumn{4}{|l|}{ 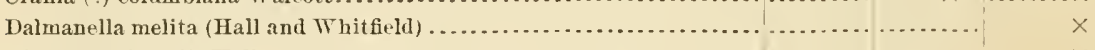 } \\
\hline \multicolumn{4}{|l|}{ 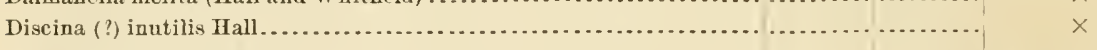 } \\
\hline \\
\hline \\
\hline \multicolumn{4}{|l|}{ 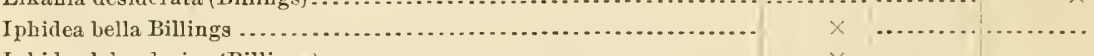 } \\
\hline \multicolumn{4}{|l|}{ 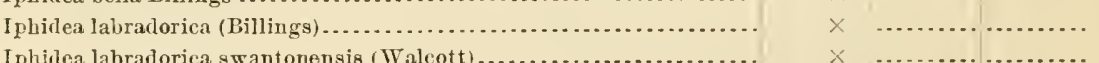 } \\
\hline \multicolumn{4}{|l|}{ 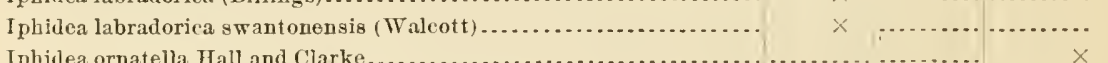 } \\
\hline \multicolumn{4}{|l|}{ I phidea ornatella Hall and Clarke................................... } \\
\hline \multicolumn{4}{|l|}{ 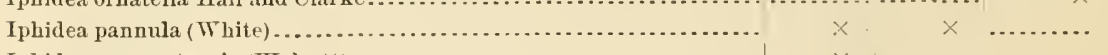 } \\
\hline \multicolumn{4}{|l|}{ 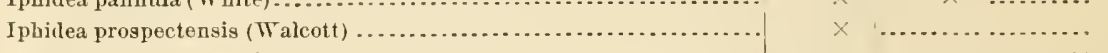 } \\
\hline \multicolumn{4}{|c|}{ 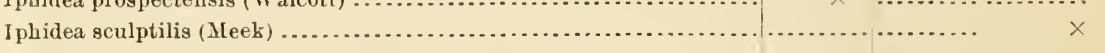 } \\
\hline \multicolumn{4}{|c|}{ 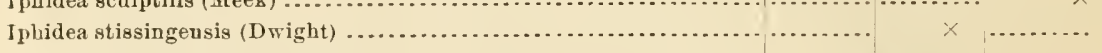 } \\
\hline \multicolumn{4}{|l|}{ Kutorgina cingulata Billings ...................................... } \\
\hline \multicolumn{4}{|c|}{ 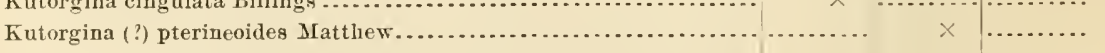 } \\
\hline Lingula (?) calnmet X. H. Winchell............... & & & \\
\hline Lingula (?) elliptica Emmons .......... & ? & & \\
\hline Lingula (?) manticula White.. & & & \\
\hline Lingula (?) mosia $\mathrm{H}$ & & & \\
\hline Lingula (?) murrayi Dillings ... & & & \\
\hline${ }^{*}$ Lingula quebecensis Billings. & & ‥ & \\
\hline striatia & $\times !$ & & \\
\hline$n g$ & & $\lambda$ & \\
\hline & & & \\
\hline
\end{tabular}


Table III.-Cambrian Brachiopoda-Continued.

\begin{tabular}{|c|c|c|c|}
\hline Speeiєs. & $\begin{array}{l}\text { Lower } \\
\text { Cam- } \\
\text { brian. }\end{array}$ & $\begin{array}{c}\text { Middle } \\
\text { Cam- } \\
\text { brian. }\end{array}$ & $\begin{array}{l}\text { Upper } \\
\text { Cam- } \\
\text { brian. }\end{array}$ \\
\hline ) billingsana (Thite & & & \\
\hline Lingulella (?) cælata (Hall)............ & $x$ & $\cdots$ & \\
\hline Lingulelia dawsoni Matthew.......... & $\cdots$ & $x$ & \\
\hline Lingulella ella (Hall and Whitfield) ....... & $x$ & $x$ & \\
\hline Lingulella granvillensis Walcott $\ldots \ldots \ldots \ldots \ldots \ldots \ldots$ & $x$ & & \\
\hline Lingulella (?) inflata Mattliew................. & & $x$ & \\
\hline Lingulella (?) inflata ovalis Matthew ... & & $x$ & \\
\hline${ }^{*}$ Lingulella irene (Billings) ......... & & & \\
\hline lavis Matthew .............. & & & \\
\hline Lingulella lamborni Meek .............. & & $\cdots \cdot$ & \\
\hline Lingulella linguloides Mattliew ........ & & $x$ & \\
\hline Lingulella macconelli W alcott ......... & & $x$ & \\
\hline inousis Matthew........ & & $x$ & \\
\hline zuta Hall and Whitfield...... & & .... & \\
\hline Lingulella radula & & $\ddot{x}$ & \\
\hline Matthew .......... & & $x$ & \\
\hline Lingulella s & & & \\
\hline aitfield $\ldots . . . . . . . . . . .$. & & 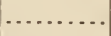 & \\
\hline ella winona Hall ....................... & & $x$ & \\
\hline Lingulepis acuminata (Conrad).... & & & \\
\hline Ling & & & \\
\hline \$ Whitfield........... & & & \\
\hline all and Whitfield. & & & $>$ \\
\hline Lingulepis matina & & & \\
\hline Owen......... & & & \\
\hline ingulepis prima (Hall) ......... & & & \\
\hline Whitfield........ & & & $\gamma^{2}$ \\
\hline ? $\ldots \ldots \ldots \ldots \ldots$ & & $\cdots$ & $>$ \\
\hline ngs) $\ldots . . . . . .$. & & $x$ & \\
\hline Limnars & & $\cdots$ & \\
\hline Linnarsonia sagittalis taconica Walcott ... & $x$ & $x$ & \\
\hline Linuarsonia transversa $($ Hartt) ........... & & $x$ & \\
\hline Olonlella atlantica Walcott ................ & $x$ & & \\
\hline sillings........... & $x$ & & \\
\hline Obolella $\mathrm{c}$ & $\times$ & & \\
\hline Obolella erassa (HaIl) . . . . . . . . . . . . & $x$ & & \\
\hline A IIall and Whitfield & - & & $x$ \\
\hline Obolella gemma Billings ............... & $x$ & & \\
\hline $5 \ldots . . . .$. & & & \\
\hline gs................ & & & $x^{2}$ \\
\hline 11 and Whitfield). & & . & $>$ \\
\hline Obolella nana Meek and Hayden......... & $\cdots$ & $\lambda$ & \\
\hline Obolella nitida Ford .................... & $x$ & $\cdots$ & \\
\hline bole & & $\ldots$. & \\
\hline 1$] \ldots . . . . .$. & -. & $x$ & \\
\hline Obolus (?) major Matthew ........ & $x$ & & \\
\hline Obolus (?) murrayi Billings ......... & & $\times ?$ & \\
\hline Obolus pristinus Matthew ........... & & $x$ & $\ldots$. \\
\hline Obol & & & \\
\hline refulgens Matthew ...... & & & $x$ \\
\hline mmons ... & $\times ?$ & & \\
\hline $8 . .2$. & & & \\
\hline & & & \\
\hline this (?) lighlandensis Walcott ... & $x$ & & \\
\hline
\end{tabular}


'TaBde: 111.-Cambrian Brachiopoda-c'ontiuned.

\begin{tabular}{|c|c|c|c|}
\hline Species. & $\begin{array}{l}\text { Lower } \\
\text { Cam- } \\
\text { briat1. }\end{array}$ & $\begin{array}{l}\text { Mirldo } \\
\text { Cam- } \\
\text { brian. }\end{array}$ & $\begin{array}{l}\text { Upluer } \\
\text { Can. } \\
\text { lorian. }\end{array}$ \\
\hline (Ortlis (?) lenticularis Wahlenberg............ & & & $x$ \\
\hline Orthis (?) lenticularis atrypoides Mattbew ....... & & - & $x$ \\
\hline (Orthis (?) leuticularis lyncioides Mattlew ............ & & & $x$ \\
\hline ()rtlis (?) lenticularis strophomenoides Mratthew ............ & $\cdots$ & & $x$ \\
\hline 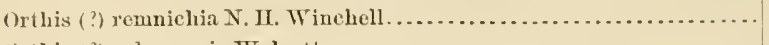 & $\cdots$ & & $x$ \\
\hline (?'this (?) salemensis Tralcott.............. & $x$ & & $\cdots$ \\
\hline Ortlis (?) sandbergi N. H. Winchell..... & & & $x$ \\
\hline Orthisina (?) jobannensis Matthew .............. & & & $x$ \\
\hline 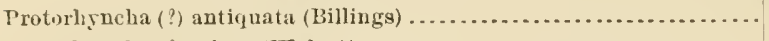 & $\therefore$ & & \\
\hline Protorhyneha (?) minor (Walcott)................. & $\hat{\imath}$ & & -.. \\
\hline Syntroptia aracline (Billings) ..... .... & & & $x$ \\
\hline Syntrophia arethusa (Billings)............ & & & $x$ \\
\hline 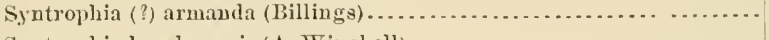 & & & $x$ \\
\hline 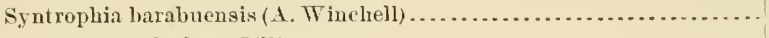 & & & $x$ \\
\hline Syntrophia calcifera (Billings) $\ldots . \ldots \ldots \ldots \ldots \ldots \ldots \ldots$ & & & $x$ \\
\hline Syntrophia primordialis ( $\$$ hitfield) ............. & & & $x$ \\
\hline 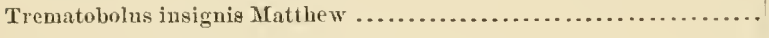 & & : & \\
\hline Number of Cambrian species, 116. & & 30 & 51 \\
\hline 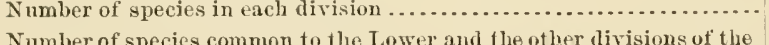 & 31 & 39 & 51 \\
\hline 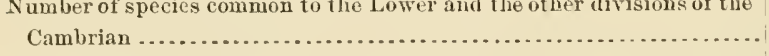 & & 5 & 1 \\
\hline Number of species common to the Middle and the other divisions of & & & \\
\hline 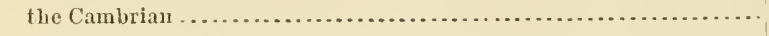 & 5 & & 1 \\
\hline Number of species common to the Cambrian and Ordovician system, 6 . & & & \\
\hline Number of species passing from each division into the Ordovician. & 0 & 0 & 6 \\
\hline
\end{tabular}




\section{Table IV.-Ordorician Brachiopoda.}

$[\mathrm{Bi}=$ Birdseye $; \mathrm{BR}=$ Black River $\mathbf{C i}=$ Cincinnati and Lorraine; $\mathbf{E O}=$ Eoordovician; $\mathbf{M O}=\mathbf{M e s o}$. ordovician; $\mathrm{NO}=$ Neoordovician; $\mathrm{T}=$ Trenton; $\mathrm{U}=\mathrm{C}$ tica. Species preceded by an asterisk (') are fonnd in the Silurian also; by an obelisk ( $\dagger)$, in the Cambrian.]

\begin{tabular}{|c|c|c|c|c|}
\hline \multirow{2}{*}{ Species. } & \multicolumn{2}{|c|}{ Eoordovician. } & \multirow{2}{*}{$\begin{array}{c}\begin{array}{c}\text { Mesoorlo- } \\
\text { vician. }\end{array} \\
\begin{array}{c}\text { Trenton, } \\
\text { Black River, } \\
\text { Birdseye. }\end{array}\end{array}$} & \multirow{2}{*}{$\begin{array}{c}\begin{array}{c}\text { Neoordo. } \\
\text { rician. }\end{array} \\
\text { Cincin- } \\
\text { nati, } \\
\text { Utica. }\end{array}$} \\
\hline & $\begin{array}{l}\text { Calcifer- } \\
\text { ous. }\end{array}$ & Chazy. & & \\
\hline \multirow{2}{*}{\multicolumn{5}{|c|}{ 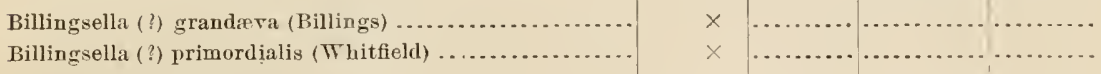 }} \\
\hline & $x$ & & & \\
\hline \\
\hline \multicolumn{5}{|l|}{ Camarella breviplicata Billings......................... } \\
\hline \multicolumn{5}{|l|}{ 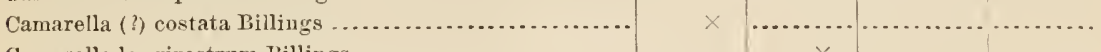 } \\
\hline \multirow{2}{*}{\multicolumn{5}{|c|}{ 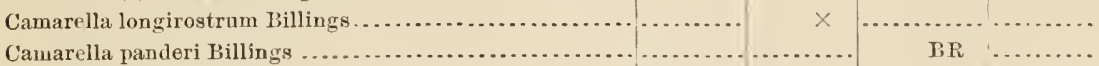 }} \\
\hline & & & $\mathrm{BR}$ & \\
\hline \multicolumn{5}{|l|}{ 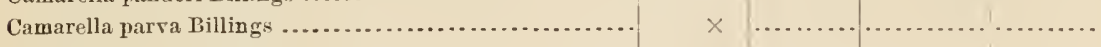 } \\
\hline \multicolumn{5}{|l|}{ 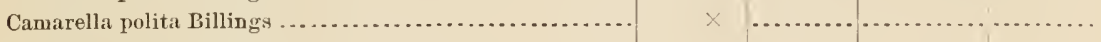 } \\
\hline \\
\hline \multicolumn{5}{|l|}{ 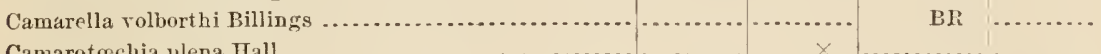 } \\
\hline \multicolumn{5}{|l|}{ 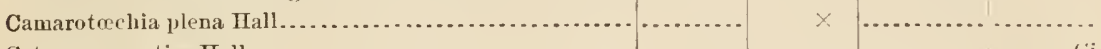 } \\
\hline \multirow{2}{*}{\multicolumn{5}{|c|}{$\begin{array}{l}\text { Catazyga erratica Hall. } \ldots \ldots \ldots \ldots \ldots \ldots \\
\text { Catazyga headi (Billings) } \ldots \ldots \ldots \ldots \ldots \ldots \ldots \ldots \ldots \ldots\end{array}$}} \\
\hline & & &. & $\mathrm{I}^{-}, \mathrm{r}^{\prime} \mathrm{i}$ \\
\hline \multicolumn{5}{|l|}{ Clitambonites (?) borealis (Castelnau) .................. } \\
\hline \multicolumn{5}{|l|}{ 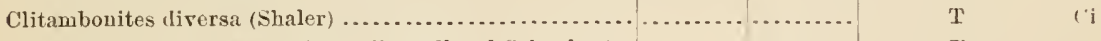 } \\
\hline \multicolumn{5}{|l|}{ Clitambonitcs diversa altissima $W$ inchell and Schuchert.. } \\
\hline \multicolumn{5}{|l|}{ Clitambonites plana retroflexa de Verneuil............... } \\
\hline \multicolumn{5}{|l|}{ 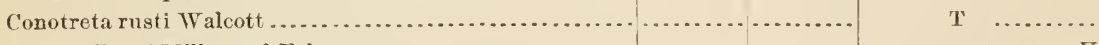 } \\
\hline \multicolumn{5}{|l|}{ Crania albersi Miller and Faber. . } \\
\hline 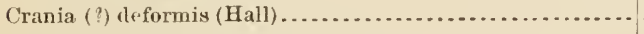 & & $x$ & & \\
\hline Crania dyeri Miller ...................................... & & & 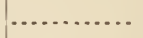 & $\mathrm{U}$ \\
\hline Crania granulosa N. H. Winchell.. & & & $\mathrm{T}$ & \\
\hline Hall ........... & & & & $\mathrm{U}, \mathrm{Ci}$ \\
\hline rsa Sardeson. & & $x$ & & \\
\hline Crania sc & & & $\cdots$ & U, r $\mathrm{i}$ \\
\hline Crania setigera Hall .......... & & & $\mathrm{T}$ & $\mathrm{Ci}$ \\
\hline Crania socialis Ulrich....... & & & & $\mathrm{U}$ \\
\hline nensis Hall ...... & & & $\mathrm{T}$ & \\
\hline Craniella (?) 1 & & & $\mathrm{T}$ & \\
\hline Cyclospira bisulcata ( & & & $T^{\prime}$ & \\
\hline Dalmanella amona X. H. Winchell... & & & $\mathrm{T}$ & \\
\hline Dalmanella bellula (James) ? & & & & $\mathrm{Ci}$ \\
\hline Dalmane & & & & $\mathrm{Ci}$ \\
\hline electra (Billings & $x$ & & & \\
\hline Dalmanella electra major Matthew ... & $x$ & & & \\
\hline Dalmanella electra levis Matthew..... & $x$ & & & \\
\hline Dalmanella (?) eradne (Billin & $x$ & & & \\
\hline Dalmanella hainburgensis ( & & & $\mathrm{T}$ & \\
\hline Dalmanella macleodi (Whitfield)........... & $x$ & & & \\
\hline 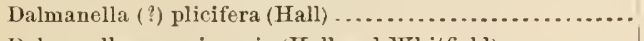 & 然 & $x$ & & \\
\hline Dalmanella pogonipensis (Hall and Whitfield)......... & $x$ & & & \\
\hline Dalmanella ston & & & $\mathrm{T}$ & \\
\hline ubæquata (Con & & & $\mathbf{T}$ & \\
\hline Dalmanella subæquata circularis N. H. Winchell. & & & $\mathrm{T}$ & \\
\hline Dalmanella subæquata conradi $\mathrm{X}$. H. Winchell.. & & & $\mathrm{T}$ & \\
\hline Dalmanella subæquata gibbosa Billings. & & $x$ & BR, T & \\
\hline almanella subaquata perveta (Conrad) & & & $\mathrm{l}$ & \\
\hline 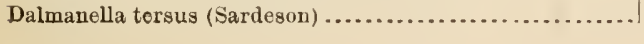 & & & & \\
\hline
\end{tabular}


TABLE IV.-Ordorician Brachiopoda-Continued.

\begin{tabular}{|c|c|c|c|c|}
\hline \multirow{2}{*}{ Species. } & \multicolumn{2}{|c|}{ Eoortovician. } & \multirow{2}{*}{$\begin{array}{c}\begin{array}{c}\text { Megoordo- } \\
\text { vician. }\end{array} \\
\begin{array}{c}\text { Trenton, } \\
\text { Black River, } \\
\text { Birdseyo. }\end{array}\end{array}$} & \multirow{2}{*}{$\begin{array}{c}\begin{array}{c}\text { Neoondo- } \\
\text { vician. }\end{array} \\
\text { Cincin- } \\
\text { nati, } \\
\text { Utica. }\end{array}$} \\
\hline & $\begin{array}{l}\text { Calcifer- } \\
\text { ous. }\end{array}$ & Chazy. & & \\
\hline Dalmanella testudinaria (Dalman). & & $x$ & $\mathrm{Bi}, \mathrm{BR}, \mathrm{T}$ & $\Gamma, \mathrm{Ci}$ \\
\hline Dalmanella testudinaria emacerata Hall . & & & . & $\mathrm{i}$ \\
\hline Dalmanella testudinaria meeki (Jfiller) ............... & & & & $\mathrm{Ci}$ \\
\hline Dalmanella testudinaria multisecta (James) Meek ap.... & & & & $\mathrm{r}$ \\
\hline 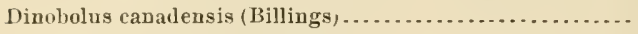 & & & $B R, T$ & \\
\hline Dinobolus magnificus (Billings) $\ldots . . . \ldots \ldots . . . . . . . .$. & & & BR, T & \\
\hline Dinobolus (?) parrus Whitfield... & & & $\mathbf{T}$ & \\
\hline Dinorthis detlectat Conrad.............. & & & $\mathbf{T}$ & \\
\hline 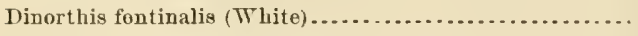 & $x$ & & $\ldots$ & \\
\hline 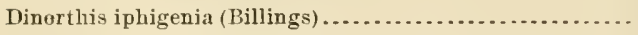 & & & $\mathbf{T}$ & \\
\hline Dinorthis meedsi Winchell and Schuchert............ & & & $\mathrm{T}$ & \\
\hline Dinorthis meedsi germana Winchell and Schuchert...... & 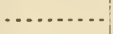 & & $\mathrm{T}$ & ... \\
\hline 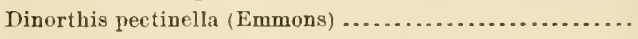 & & . & $\mathrm{T}$ & \\
\hline Dinorthis pectinclla sweeneyi N.H. Winchell........... & & & $\mathrm{T}$ & \\
\hline 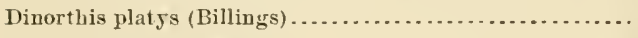 & & $x$ & $\cdots$ & \\
\hline Dinorthis poreata (McCo5)................. & & & $\mathrm{T}$ & $\mathrm{Ci}$ \\
\hline Dinorthis proarita Winchell aud schuchert ............. & & & & $\mathrm{Ci}$ \\
\hline 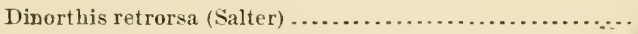 & & & $\mathrm{T}$ & $\mathrm{Ci}$ \\
\hline Dinorthis subquadrata Hall .......... & & & & Ci \\
\hline Discina (?) sublamellosa Vlrich....... & & & .... & Ci \\
\hline Eich waldia subtrigonalis Billings......... & & & $\mathrm{T}$ & ... \\
\hline Elkania ambigua (Walcott) $\ldots \ldots \ldots$ & $x$ & & $\ldots$ & ... \\
\hline Glassia romingeri Hall and Clarke....... & & & $\mathrm{T}$ & \\
\hline Glossina crassa (Hall) ......... . & & & $\mathrm{T}$ & \\
\hline 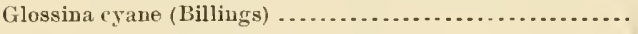 & $x$ & & $\ldots$ & \\
\hline Glossina deflecta Winchell and schuchert ............... & $\cdots$ & & $\mathrm{T}$ & $\mathrm{Ci}$ \\
\hline Glossina hurlbuti N. H. Winchell............. & & & $\mathrm{T}$ & \\
\hline Glossina trentonensis (Conrad) ....... & & & $\mathrm{T}$ & U \\
\hline 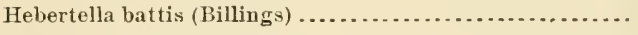 & $x$ & & -.. & \\
\hline 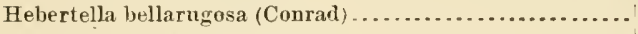 & & & $\mathrm{T}$ & \\
\hline 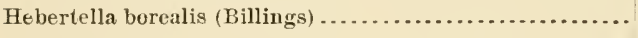 & $\cdots$ & $x$ & $\mathrm{BR}, \mathrm{T}$ & ...... \\
\hline Hebertella imperator (Billings) ........ & & $x$ & $\cdots$ & \\
\hline Hebertella insculpta Hall........................ & & & .... & $\mathrm{Ci}$ \\
\hline 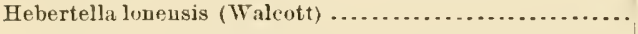 & $x$ & & & \\
\hline 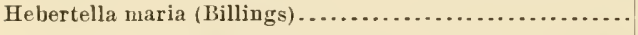 & & & ..... & $\mathrm{Ci}$ \\
\hline Hebertella occidentalis Hall.............. & & & $\ldots$. & $\mathrm{Ci}$ \\
\hline Hebertella occidentalis sinuata Hall........... & & & … & $\mathrm{Ci}$ \\
\hline Heterorthis clytie Hall............... & & & $\mathrm{T}$ & -. \\
\hline Leptæna charlottæ Winchell and Scbuchert ............. & & & $\mathrm{T}$ & ............ \\
\hline${ }^{\star}$ Leptiena rhomboidalis (Wilckens) .................... & & & $\mathrm{T}$ & $\mathrm{U}, \mathrm{Ci}$ \\
\hline Leptæna unicostata Meek and Worthen... & & & & $\mathrm{Ci}$ \\
\hline 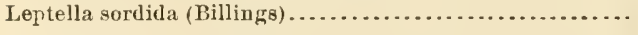 & $x$ & & & \\
\hline Leptella decipiens (Billings) .............................. & $x$ & & & \\
\hline 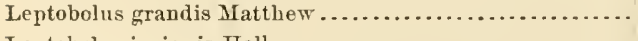 & $x$ & & & \\
\hline Leptobolus insignis Hall .......... & & & & $\Pi$ \\
\hline Leptobolus lepis Hall.................. & & ... & $\ldots . . . . . .$. & $\Gamma$ \\
\hline Leptobolus occidentalis Hall ................ & & & $\ldots$ & $\mathrm{U}$ \\
\hline 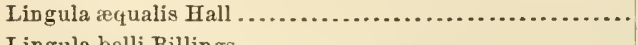 & & & $\mathbf{T}$ & . \\
\hline Lingula belli Billings. . . . . . . . . . . . . . & & $x$ & & \\
\hline Lingula beltrami Tinchell and sshuchert & & & & $\mathrm{Ci}$ \\
\hline Lingula bisulcata Clrich ............. & & & $\cdots$ & 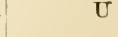 \\
\hline Lingula briseis Billings. . . & & & T & \\
\hline
\end{tabular}


TABLE IV.-Ordovician Brachiopoda-Continued.

\begin{tabular}{|c|c|c|c|c|}
\hline \multirow[b]{2}{*}{ Species. } & \multicolumn{2}{|c|}{ Eoordovieian. } & \multirow{2}{*}{$\begin{array}{c}\text { Mesoordo- } \\
\text { vician. } \\
\begin{array}{c}\text { Trenton, } \\
\text { Black River, } \\
\text { Birdseye. }\end{array}\end{array}$} & \multirow{2}{*}{$\begin{array}{c}\begin{array}{c}\text { Neoordo- } \\
\text { vician. }\end{array} \\
\begin{array}{l}\text { Cincin- } \\
\text { nati, } \\
\text { Ctica. }\end{array}\end{array}$} \\
\hline & $\begin{array}{l}\text { Calcifer- } \\
\text { ous. }\end{array}$ & Cliazy. & & \\
\hline ingula (?) $\mathrm{c}$ & & & $\mathrm{T}$ & \\
\hline Lingula cincinnatiensis Hall and Whitfield.... & & & & \\
\hline Lingula clathrata Winchell and Schuchert....... & & & $\mathbf{T}$ & \\
\hline 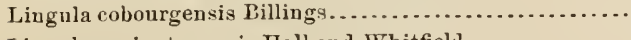 & & & $\mathrm{T}$ & \\
\hline Lingula covingtonensis Hall and Whitfield....... & & & $\mathbf{T}$ & \\
\hline 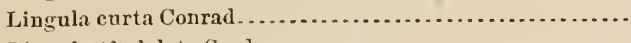 & & & $\mathrm{T}$ & \\
\hline Lingula (?) dolata Sardeson .................. & $x$ & & & \\
\hline Lingula elderi Whitfield........ & & & $\mathrm{T}$ & \\
\hline Lingula elongata Hall ............ & . & & $\mathrm{T}$ & \\
\hline Lingula era Lillings.......... & & & $\mathrm{BR}$ & \\
\hline Lingula forbesi Billings ......... & & & & \\
\hline Lingula howleyi Matthew ....... & x & & & \\
\hline Lingula huronensis Billings .... & & $x$ & & \\
\hline Lingula iolo Billings........... & $x$ & & & \\
\hline Lingula iowensis Owen.......... & & & $\mathrm{T}$ & \\
\hline $\begin{array}{l}\text { Lingula iris Billings............. } \\
\text { Lingula kingstonensis Billings . }\end{array}$ & $x$ & & & \\
\hline $\begin{array}{l}\text { Lingula Kingstonensis Billings .... } \\
\text { Lingula l Felli Billings .............. }\end{array}$ & & & $\mathrm{BH}$ & \\
\hline $\begin{array}{l}\text { Lingula lyelli Billings ............ } \\
\text { Lingula mantelli Billings......... }\end{array}$ & ... & $\times$ & & \\
\hline $\begin{array}{l}\text { Lingula mantelli Billings......... } \\
\text { Lingula modesta Ulrich .......... }\end{array}$ & $x$ & & & \\
\hline 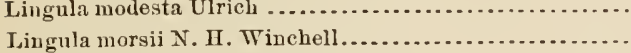 & & & $\mathrm{T}$ & $\mathrm{U}, \mathrm{Ci}$ \\
\hline $\begin{array}{l}\text { Lingula morsii N. H. Winchell............ } \\
\text { Lingula nympha Billings . ................ }\end{array}$ & & $x$ & & \\
\hline $\begin{array}{l}\text { Lingula nympha Billings................ } \\
\text { Lingula obtusa Hall . . .................. }\end{array}$ & $x$ & & & \\
\hline $\begin{array}{l}\text { Lingula obtusa Hall ........... } \\
\text { Lingula papillosa Emmons.... }\end{array}$ & & & ' $\mathbf{T}$ & ( \\
\hline Lingula papillosa Emmons.... & & & $\mathrm{T}$ & \\
\hline Lingula perryi IBillings ......... & & $\times ?$ & & \\
\hline Lingula philomela Billings ........ & & & $\mathbf{T}$ & C \\
\hline Lingula progne Billings .......... & & & 'T' & I \\
\hline †Lingula quebecensis Billings .... & $x$ & & $\mathbf{T}$ & c \\
\hline Lingula rectilateralis Emmons.... & & & $\mathrm{T}$ & \\
\hline $\begin{array}{l}\text { mis II all........................... } \\
\text { rmis galenensis Winchell and }\end{array}$ & & & $\mathbf{T}$ & \\
\hline 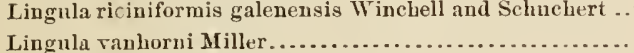 & & & 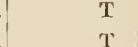 & \\
\hline $\begin{array}{l}\text { Lingula ranhorni Miller.............. } \\
\text { Lingula whitfieldi Ulrich............. }\end{array}$ & & & $\mathrm{T}$ & $c$ \\
\hline $\begin{array}{l}\text { Lingula whitfieldi Ulrich............. } \\
\text { Lingulasma galenensis Winchell and }\end{array}$ & & & & \\
\hline Lingulasma galenensis Winchell and Sc & & & $\mathrm{T}$ & \\
\hline $\begin{array}{l}\text { Lingulasma schucherti Clrich........... } \\
\text { Lingulella (?) cuneata Matthew ........ }\end{array}$ & & & & \\
\hline $\begin{array}{l}\text { Lingulella (?) cuneata Matthew ....... } \\
\text { †Lingulella irene (Billings)........... }\end{array}$ & $\begin{array}{l}x \\
x\end{array}$ & & & \\
\hline $\begin{array}{l}\text { †Lingulella irene (Billings)............ } \\
\text { †Lingulclla minuta Hall and Whitfielc }\end{array}$ & $\begin{array}{l}x \\
x\end{array}$ & & & \\
\hline $\begin{array}{l}\text { †Lingulclla minuta Hall and Whitfielc } \\
\text { Lingulella roberti Matthew............ }\end{array}$ & $\begin{array}{l}x \\
\times\end{array}$ & & & \\
\hline $\begin{array}{l}\text { Lingulella roberti Matthew.......... } \\
\text { Lingulella selwyni Matthew......... }\end{array}$ & $\begin{array}{l}x \\
x\end{array}$ & & & \\
\hline $\begin{array}{l}\text { Lingulella selwyni Matthew.......... } \\
\text { fLingulepis (?) mæra Hall and Whitfe }\end{array}$ & $\begin{array}{l}x \\
x\end{array}$ & & & \\
\hline $\begin{array}{l}\text { fLingulepis (?) mæra Hall and Whitfe } \\
\text { Lingulobolus affinis Billings ........... }\end{array}$ & $\begin{array}{l}x \\
x\end{array}$ & & & \\
\hline 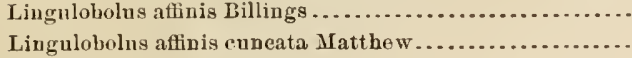 & $x$ & & & \\
\hline 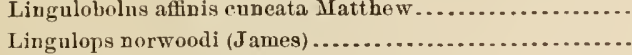 & $x$ & & & \\
\hline $\begin{array}{l}\text { Lingulops norwoodi (James) .......... } \\
\text { Lingulops whitfieldi Hall ............. }\end{array}$ & 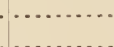 & & $\mathrm{T}$ & \\
\hline $\begin{array}{l}\text { Lingulops whitfieldi Hall ................. } \\
\text { fObolella (?) discoidea Hall and Whitfield. }\end{array}$ & & & & ( \\
\hline Fbolella (?) discoidea Hall and Whitfielel. & $x$ & & & \\
\hline 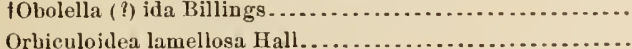 & $x$ & & & \\
\hline $\begin{array}{l}\text { Orbiculoidea lamellosa Hall. .......... } \\
\text { Orbiculoidea tenuistriata (Clrich) .... }\end{array}$ & & & $\mathrm{T}$ & \\
\hline Orbiculoidea tenuistriata (Clrich) .......... & & & & \\
\hline Orthidium gemmicula (Billings) ........... & $x$ & & & \\
\hline this (?) acuminata Billings ........... & & $x$ & & \\
\hline rthis carausii Salter $\ldots . . . \ldots \ldots \ldots \ldots \ldots \ldots . . . .$. & $\mathrm{x}$ & & & \\
\hline
\end{tabular}


TABLE Mr-OUdotician Brachiopoda-Continned.

\begin{tabular}{|c|c|c|c|c|}
\hline \multirow{2}{*}{ Slecies. } & \multicolumn{2}{|c|}{ Foordovician. } & \multirow{2}{*}{$\begin{array}{l}\begin{array}{c}\text { Mesoordo- } \\
\text { rician. }\end{array} \\
\begin{array}{l}\text { Trenton, } \\
\text { 13lick River } \\
\text { Birdseye. }\end{array}\end{array}$} & \multirow{2}{*}{$\begin{array}{c}\begin{array}{c}\text { Neoordo- } \\
\text { vieiant. }\end{array} \\
\text { Cincin- } \\
\text { nati, } \\
\text { Utica. }\end{array}$} \\
\hline & $\begin{array}{l}\text { Calcifer- } \\
\text { ons. }\end{array}$ & Chazy. & & \\
\hline \multirow{2}{*}{\multicolumn{5}{|c|}{$\begin{array}{l}\text { Orthis (?) centrilineata IIall... } \\
\text { Ortlis corinna Billings ........ }\end{array}$}} \\
\hline & & & & \\
\hline \multicolumn{5}{|l|}{ Orthis costalis Hall ....................................... } \\
\hline \multirow{2}{*}{\multicolumn{5}{|c|}{ 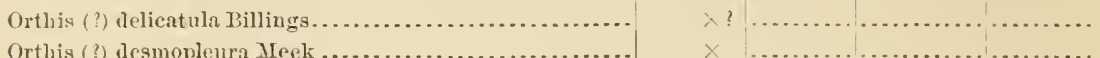 }} \\
\hline & $x$ & & & \\
\hline \multicolumn{5}{|l|}{ Ort his (?) endocia Billings .............................. } \\
\hline \multicolumn{5}{|l|}{ 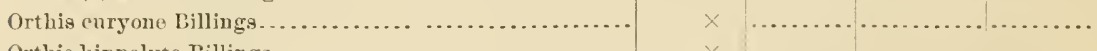 } \\
\hline \multirow{2}{*}{\multicolumn{5}{|c|}{$\begin{array}{l}\text { Orthis lippolyte Billings } \ldots \ldots \ldots \ldots \ldots \ldots \ldots \ldots \\
\text { Orthis (?) lolstoni (Safioril) Пall. }\end{array}$}} \\
\hline \multirow{2}{*}{\multicolumn{5}{|c|}{ 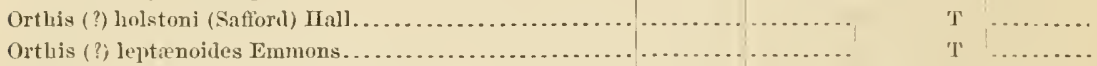 }} \\
\hline & .. & & T & \\
\hline \multicolumn{5}{|l|}{ Orthis menapir Hicks................................ } \\
\hline \multicolumn{5}{|l|}{ Orthis (?) minna Billings ................................. } \\
\hline \multicolumn{5}{|l|}{ Orthis (?) morrowensis James........................... } \\
\hline \multicolumn{5}{|l|}{ Orthis (?) mrcale Billings................................... } \\
\hline \multicolumn{5}{|l|}{ Orthis panderiana Hall................................... } \\
\hline \multicolumn{5}{|l|}{ Orthis (?) pigra Billings ....................................... } \\
\hline \multicolumn{5}{|l|}{ Orthis (?) porcia Billings............................... } \\
\hline \multicolumn{5}{|l|}{ Orthis (?) pumila Llrich.......... } \\
\hline \multicolumn{5}{|l|}{ Orth is (?) saffordi Fall and Clarke ....................... } \\
\hline Orthis (?) sola Billings ............................. & & & & $\mathrm{c}$ \\
\hline Orthis tricenaria Conrad ................ & & & $\mathrm{T}$ & \\
\hline Orthis (?) tritonia Billings ........ & $x$ & & & \\
\hline Orthor & & & & \\
\hline aras & & & & $\mathrm{Ci}$ \\
\hline Parast & & & T & \\
\hline $\begin{array}{l}\text { Parastrophia hemiplicata rotunda (Tinchell and Schuch- } \\
\text { ert) }\end{array}$ & & & & \\
\hline Parastrophia obscura (Hall and & $y$ & & & \\
\hline 1 it & & & $\mathrm{T}$ & \\
\hline Pater & x & & & \\
\hline pls cincinne & & & $\cdots$ & \\
\hline Pholidops s & & & ... & $\mathrm{C}$ \\
\hline Pliolid & & & $\mathrm{T}$ & \\
\hline minor Winchell and Sc & & & $\mathrm{T}$ & \\
\hline Platystrophia & & & .......... & $\mathrm{C}^{\mathrm{i}}$ \\
\hline Platystrophia acutilirata (C & & & (n....... & ('i \\
\hline * Platystrophia biforata (Schlotheim) & & & $\mathrm{BR}, \mathrm{T}^{2}$ & T.Ci \\
\hline Platystrophia crassa (James)........... & & & ... & $\mathrm{C}$ \\
\hline Platystro & & & & $\mathrm{C}$ \\
\hline Platystr & & & & $\mathrm{C}$ \\
\hline tes gibbosa & & & $\mathrm{T}$ & \\
\hline Plectaml & & & ......... & \\
\hline * Plectambonites sericea (Sower & & & BR, ' $T$ & L. Ci \\
\hline Plectortlis æquiralris Hall. & & & & C \\
\hline Plectorthis dicho & & & & $\mathrm{C}$ \\
\hline Plectorthis ellia I & & & & $c$ \\
\hline Plectorthis fissicosta Hall.... & & & .. & $\mathrm{c}$ \\
\hline Plectorthis jamesi Пall........ & & & & $\mathrm{c}$ \\
\hline Plectorthis kankakensis ( $\mathrm{McCh}$ & & & ... & $\mathrm{C}_{1}$ \\
\hline Plectorthis plicatella Ifall ..... & & & $\mathrm{T}$ & $\mathrm{U}, \mathrm{Ci}$ \\
\hline ta (Tlri & & & & \\
\hline ectorthis triplicatella (MIeek). & & & & \\
\hline
\end{tabular}




\section{TABLE IV.-Ordovician Brachiopoda-Continued.}

\begin{tabular}{|c|c|c|c|c|}
\hline \multirow[b]{2}{*}{ Species. } & \multicolumn{2}{|c|}{ Eoordovician. } & \multirow{2}{*}{$\begin{array}{c}\begin{array}{c}\text { Mesoordo- } \\
\text { vician. }\end{array} \\
\begin{array}{c}\text { Trenton, } \\
\text { Black liver, } \\
\text { Birdseye. }\end{array}\end{array}$} & \multirow{2}{*}{$\begin{array}{c}\begin{array}{c}\text { Neoordo- } \\
\text { vician. }\end{array} \\
\begin{array}{c}\text { Cincin- } \\
\text { nati, } \\
\text { Utica. }\end{array}\end{array}$} \\
\hline & $\begin{array}{l}\text { Calcifor- } \\
\text { ous. }\end{array}$ & Chazy. & & \\
\hline Plectorthis whitfieldi (N. H. Winchell). & & & & $\mathrm{Ci}$ \\
\hline Polytœehia apicalis (Thitfield) ....... & $x$ & & & \\
\hline Protorhyncha dubia Hall........................ & - & $x$ & ... & ...... \\
\hline Ratinesquina alternata (Conrad) Emmons .... & & & $\mathrm{BR}, \mathrm{T}$ & $\mathrm{U}, \mathrm{Ci}$ \\
\hline Rafinesquina alternata alternistriata Hall.. & & & ...... & ('i \\
\hline Rafinesquina alternata fracta (Mreek)......... & & & & $\mathrm{Ci}$ \\
\hline Rafinesquina alternata loxorhytis (Meek) ....... & & & ............... & $\mathrm{Ci}$ \\
\hline Rafinesquina alteruata nasuta (Conrad) ........ & & & $\cdots$ & $\mathrm{Ci}$ \\
\hline Rafinesquina (?) atava (Matthew) ........... & $x$ & & $\ldots$. & -... \\
\hline * Rafinesquina ceres (Billings) ........... & & & ..... & $\mathrm{Ci}$ \\
\hline Rafinesquina deltoidea (Conrad) ............ & & & $\mathrm{T}$ & U \\
\hline Rafinesquina fasciata Hall................ & & & & -.. \\
\hline Rafinesquina imbrex (Pander)........... & & & . & Ci \\
\hline Rafinesquina incrassata $(\mathrm{H} a l l) \ldots \ldots \ldots \ldots \ldots \ldots$. & & & $\mathrm{BR}$ & ... \\
\hline Rafinosquina kingi (Whitfield) .......... & & & & $\mathrm{Ci}$ \\
\hline 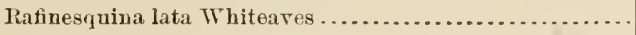 & & & $\ldots$. & Ci \\
\hline Rafinesquina mesacosta (Shumard)............... & & & $\mathbf{T} ?$ & 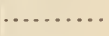 \\
\hline Rafinesquina minnesotensis (N. Il. Winchell) ....... & & & $\mathrm{T}$ & $\cdots$ \\
\hline Rafinesquina minnesotensis inquassa (Sardeson) ... & & & $\mathrm{T}$ & $\ldots$. \\
\hline Rafinesquina nitens (Billings) ............ & & & & $\mathrm{Ci}$ \\
\hline Rafinesquina squamula ( $J$ ames) ........... & & & ... & U, Ci \\
\hline Rafinesquina tenuilineata (Conrad)..... & & & $\mathrm{T}$ & ...... \\
\hline Fafinesquina ulrichi (James) .......... & & & & U \\
\hline Fetzia (?) granulifera (Meek).............. & & & -.. & $\mathrm{Ci}$ \\
\hline Rilynchonelia (?) acutirostris Hall ....... & & & & $\cdots$ \\
\hline Rhynchonella (?) anticostiensis Billings............ & & & & Ci \\
\hline Fhynchonella (?) rorinthia Billings ................ & $x$ & & & ... \\
\hline * Rhynchonella (?) janea Billings.......... & & & & $\mathrm{Ci}$ \\
\hline Rhynchonella (?) neenah Whitfield ............... & & & ... & ('i \\
\hline Rhynchonella (?) orientalis Billings........... & & $x$ & & - \\
\hline Rhynehonella (?) sordida Hall... & & & $\mathbf{T}$ & \\
\hline Rhynchonella (?) subtrigonalis Hall.......... & & & $\mathbf{T}$ & \\
\hline Khynchotrema ainslei (N. H. Winchell) .... & & & $\mathbf{T}$ & $\cdots$ \\
\hline Rliy nchotrema capax (Conrad) ................ & & & & ('i \\
\hline Rhynchotrema dentata (Hall) ................ & & & $\mathrm{T}$ & Ci \\
\hline Rhynchotrema inaquiralvis (Castelnau) ............... & & & $\mathrm{T}$ & ... \\
\hline 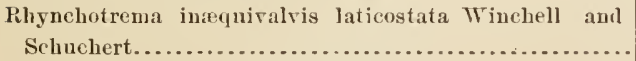 & & & $\mathrm{T}$ & \\
\hline Fhynehotrena ottawaeusis (Billings) ........... & & & $\mathrm{T}$ & \\
\hline Rhynchotrema perlamellosa (Whitfield)........ & & & ... & ('i \\
\hline Scenidium anthonensis Sardeson ............... & & & $\mathrm{T}$ & ... \\
\hline 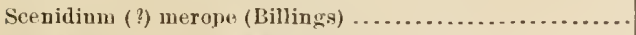 & & & $\mathrm{T}$ & $\mathrm{Ci}$ \\
\hline Schizambon (?) dodgii Winchell and Schuchert ..... & & & $\mathrm{T}$ & $\cdots$ \\
\hline Schizambon (?) fissus eanadensis $A m i . . . . . . . .$. & & & . & U \\
\hline Schizambon (?) lockii Winchell and Schuchert ....... & & & - & $\mathrm{Ci}$ \\
\hline Schizambon typicalis Walcott .......................... & $x$ & & -.. & ....... \\
\hline Sehizocrania filosa Hall ...................... & & & $\mathbf{T}$ & $\mathrm{U}, \mathrm{Ci}$ \\
\hline Sehizocrania (?) rudis Hall ............ & & & $\mathrm{T}$ & ........... \\
\hline Sehizocrania sehucherti Hall and Clarke..... & & & $\mathrm{T}$ & \\
\hline Schizotreta conica (Dwight) ................ & & & $\mathrm{T}$ & ........... \\
\hline Schizotreta minutula Winchell and schuchert .. & & & & $\mathrm{Ci}$ \\
\hline Schizotreta ovalis Hall and Clarko & & & $\mathbf{T}$ & \\
\hline
\end{tabular}


TABLE IV.-Ordovician Irachiopoda-Continued.

\begin{tabular}{|c|c|c|c|c|}
\hline \multirow{2}{*}{ Species. } & \multicolumn{2}{|c|}{ Eoordovician. } & \multirow{2}{*}{$\begin{array}{l}\begin{array}{c}\text { Mesoordo- } \\
\text { viciau }\end{array} \\
\text { Trentou, } \\
\text { Blackliver, } \\
\text { Birdseyo. }\end{array}$} & \multirow{2}{*}{$\begin{array}{c}\begin{array}{c}\text { Neoordo- } \\
\text { vieian. }\end{array} \\
\begin{array}{c}\text { Uincin- } \\
\text { nati, } \\
\text { Utira. }\end{array}\end{array}$} \\
\hline & \multirow[t]{2}{*}{$\begin{array}{c}\text { Calcifer- } \\
\text { ons. }\end{array}$} & Chayy. & & \\
\hline Schizotreta pelopea (Billings) & & & $\mathrm{T}$ & $\mathrm{Ci}$ \\
\hline Siphonotreta (?) micula MlcCoy................ & $x$ & & & \\
\hline Siphonotreta (?) minnesotensis Hall and Clarke .. & & & $\mathrm{T}$ & \\
\hline Sphar robolus spissus Billings.................. & $x$ & & & \\
\hline Strophomena approximata (James)... & & & $\ldots$ & Ci \\
\hline Strophomena (?) arethusa Billings .......... & & & .... & $\mathrm{Ci}$ \\
\hline Strophomena billingsi W'inchell and Scluchert .... & & & 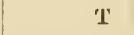 & \\
\hline Strophomena cardinale (Whitfield) .............. & & & & $\mathrm{Ci}$ \\
\hline Stropliomena conrarli Hall............... & & & $\mathrm{T}$ & $\ldots$ \\
\hline Strophomena (?) declivis James ................. & & & & Ci \\
\hline Strophomena emaciata Winchell and Schuchert ... & & & $\mathrm{T}$ & $\cdots$ \\
\hline Strophomena thuctuosa Billings....... & & & & $\mathbf{U}$ \\
\hline Strophomena lallii Miller ....................... & & & $\cdots$ & $\mathrm{Ci}$ \\
\hline Strophomena hecuba Billings............ & & & & Ci \\
\hline Strophomena (?) imbecilis Billings ............ & $\times ?$ & & & \\
\hline Strophomena incurvata (Shepard) ............ & & & $\mathrm{T}$ & \\
\hline 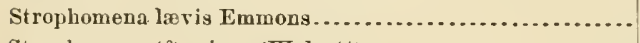 & & & $\mathrm{Bi}$ & \\
\hline Strophomena (?) minor $($ Walcott) $\ldots \ldots \ldots \ldots \ldots \ldots$ & $x$ & & & \\
\hline 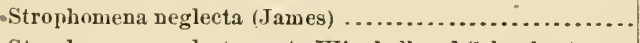 & & & & $\mathbf{C i}$ \\
\hline Strophomena neglecta acuta Winchell and Schuchert .... & & & $\cdots$ & Ci \\
\hline 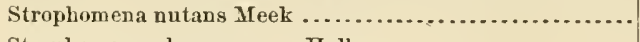 & & & & $\mathrm{Ci}$ \\
\hline 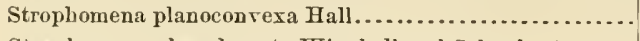 & & & ... & $\mathrm{Ci}$ \\
\hline Strophomena planodorsata Winchell and Schuchert..... & & & .... & $\mathrm{Ci}$ \\
\hline Strophomena rugosa (Rafinesque) Blainville ......... & & & .... & $\mathrm{Ci}$ \\
\hline Strophomena rugosa subtenta Hall ............ & & & & $\mathrm{Ci}$ \\
\hline Strophomena scofieldi Winchell aud Schuchert........ & & & $\mathbf{T}$ & -.. \\
\hline Strophomeua septata Winchell and Schuchert....... & & & $\mathrm{T}$ & ... \\
\hline Strophomena sinuata Meek... & & & & $\mathrm{Ci}$ \\
\hline Stroplomena suleata (Verneuil) .............. & & & ... & $\mathrm{Ci}$ \\
\hline 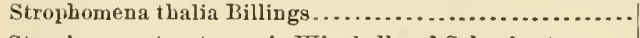 & & & $\mathrm{T}$ & \\
\hline Strophomena trentonensis Winchell and Schuchert . & & & $\mathrm{T}$ & $\cdots$ \\
\hline Strophomena trilobata (Owen) $\ldots \ldots \ldots \ldots \ldots \ldots \ldots$ & & & $\mathrm{T}$ & .......... \\
\hline Strophomena retusta James.................. & & & ... & Ci \\
\hline 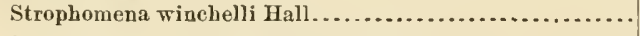 & & & $\mathrm{T}$ & ... \\
\hline Strophomena wisconsinensis Thitfield.............. & & & & $\mathrm{Ci}$ \\
\hline 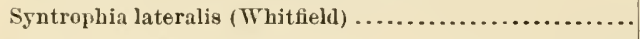 & $x$ & & & $\cdots$ \\
\hline Trematis crassipuncta Ulrich ............... & & & & $\mathbf{C i}$ \\
\hline Trematis (?) dyeri Miller..................... & & & & $\mathrm{Ci}$ \\
\hline Trematis fragilis Ulrich .............. & & & $\mathrm{T}$ & ........... \\
\hline Trematis huronensis Billings......... & & & $B R$ & ........... \\
\hline Trematis millepunctata Hall............... & & & & $\mathrm{U}, \mathrm{Ci}$ \\
\hline Trematis montrealeusis Billings... & & & $\mathrm{T}$ & .......... \\
\hline Trematis oblata Ulrich ............... & & & & $\mathrm{U}, \mathrm{Ci}$ \\
\hline Trematis ottawaensis Billiugs............ & & & $\mathrm{T}$ & $\mathrm{C}_{\mathrm{i}}$ \\
\hline Trematis punctostriata Hall ................ & & & & $\mathrm{Ci}$ \\
\hline 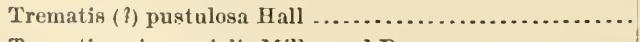 & & & & $\mathrm{Ci}$ \\
\hline Trematis quinenneialis Miller and Dper ................ & & & ... & $\mathrm{Cl}$ \\
\hline Trematis reticularis Miller . .......................... & & & . & $\mathrm{Ci}$ \\
\hline Trematis terminalis Emmons . . . . . . . . . . . . . . . & & & $\mathbf{T}$ & -.. \\
\hline Trematis nmbonata Ulrich. & & & - & $\mathrm{Ci}$ \\
\hline Triplecia cuspidata Hall.... & & & $\mathrm{T}$ & \\
\hline Triplecia extans (Emmons). & & & $\mathbf{T}$ & \\
\hline
\end{tabular}


TABLE IV.-Ordovician Brachiopoda-Continued.

\begin{tabular}{|c|c|c|c|c|}
\hline \multirow{2}{*}{ Species. } & \multicolumn{2}{|c|}{ Eoordovician. } & \multirow{2}{*}{$\begin{array}{c}\begin{array}{c}\text { Mesoordo- } \\
\text { vician. }\end{array} \\
\begin{array}{c}\text { Trenton, } \\
\text { Black River, } \\
\text { Birdseye. }\end{array}\end{array}$} & \multirow{2}{*}{$\begin{array}{c}\begin{array}{c}\text { Neoordo- } \\
\text { vician. }\end{array} \\
\text { Cincin- } \\
\text { nati, } \\
\text { Utica. }\end{array}$} \\
\hline & $\begin{array}{l}\text { Calcifer. } \\
\text { ous. }\end{array}$ & Chazy. & & \\
\hline \multicolumn{5}{|l|}{ 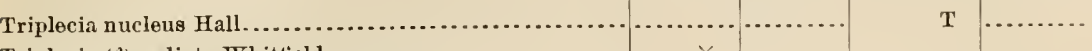 } \\
\hline \multicolumn{5}{|l|}{ Triplecia (?) radiata Whittield. . . . . . . . . . . } \\
\hline \multicolumn{5}{|l|}{ Triplecia ulrichi Winchell and Schuchert $\ldots . . . \ldots \ldots \ldots \ldots$} \\
\hline \multicolumn{5}{|l|}{ 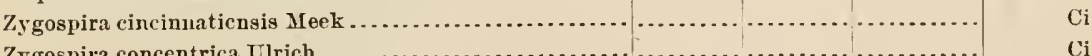 } \\
\hline \multirow{2}{*}{\multicolumn{5}{|c|}{ 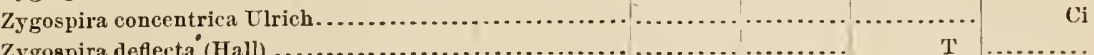 }} \\
\hline & \multicolumn{4}{|c|}{ 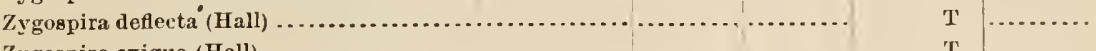 } \\
\hline \multicolumn{5}{|l|}{ 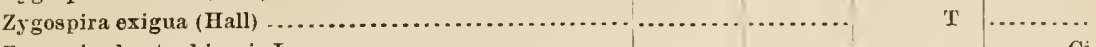 } \\
\hline \multicolumn{5}{|l|}{ 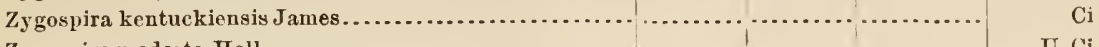 } \\
\hline \multicolumn{5}{|l|}{ 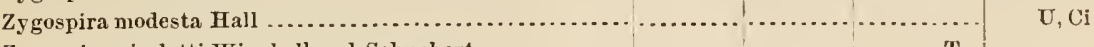 } \\
\hline \multicolumn{5}{|l|}{ Zygospira nicoletti Winchell and Schuchert................. } \\
\hline \multicolumn{5}{|l|}{ 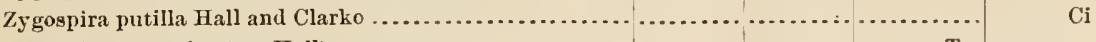 } \\
\hline \multicolumn{5}{|l|}{ Zygospira recurvirostra (Hall) ............................ } \\
\hline \multicolumn{5}{|l|}{ Zygospira saffordi Winchell and schuchert............... } \\
\hline \multicolumn{5}{|l|}{ Number of Ordovician species, 319.} \\
\hline 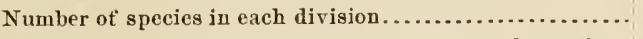 & 63 & 26 & 128 & 136 \\
\hline \multicolumn{4}{|l|}{ 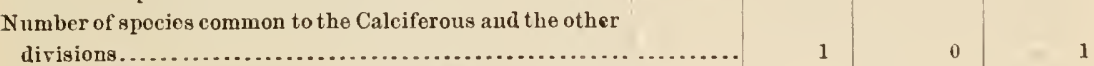 } & 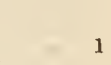 \\
\hline \multicolumn{4}{|l|}{ 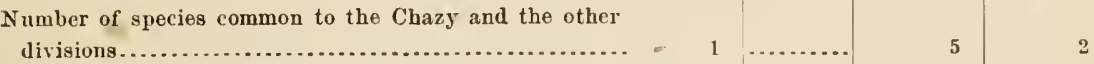 } & 2 \\
\hline \multicolumn{5}{|l|}{ 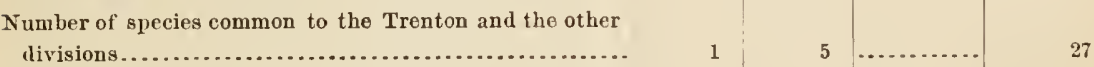 } \\
\hline \multicolumn{5}{|l|}{ Number of species common to the Cincinnati and tho other } \\
\hline$\ldots \ldots . . . .$. & 1 & 2 & 27 & $\cdots$ \\
\hline Number of species passing from each division into the & & & & \\
\hline 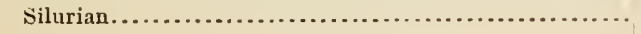 & 0 & 1 & 3 & 5 \\
\hline
\end{tabular}


'TABLE V,-Silurian Brachiopoda.

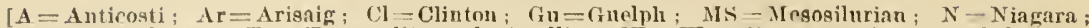
NS-Neosilurian: Te= Tentaculite fud Corallino; $W=$ Waterlime. Specien preceded by an asterisk $\left({ }^{*}\right)$ are found in the Devouian also; by an welisk $(\dagger)$, in the (lrdovician.]

\begin{tabular}{|c|c|c|c|c|}
\hline \multirow[b]{2}{*}{ Speries. } & \multirow{2}{*}{$\begin{array}{c}\begin{array}{c}\text { Eo- } \\
\text { silurian. }\end{array} \\
\text { Medina. }\end{array}$} & \multicolumn{2}{|c|}{ Mesosilurian. } & \multirow{2}{*}{$\begin{array}{c}\text { Neosi. } \\
\text { lurian. } \\
\text { Tentac- } \\
\text { ulite, } \\
\text { Water- } \\
\text { lime. }\end{array}$} \\
\hline & & $\begin{array}{c}\text { Anti- } \\
\text { costi, } \\
\text { Clinton. }\end{array}$ & $\begin{array}{l}\text { Fruelph, } \\
\text { Ariaiga, } \\
\text { Niagara. }\end{array}$ & \\
\hline Anastrophia brevirostris (Sowerby) Hall. & & & $\mathrm{N}$ & \\
\hline Anastrophia internascens Hall ........... & & . & & \\
\hline Anastrophia interplicata (Hall)............ & & . & $\mathrm{N}$ & \\
\hline Anoplotheea hemispherica (Sowerby)........ & & $\mathrm{Cl}$ & & \\
\hline 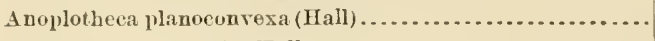 & & $\mathrm{Cl}$ & & \\
\hline 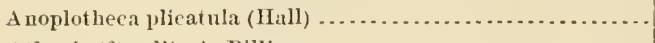 & & $\mathrm{Cl}$ & & \\
\hline Athyris (?) solitaria Billings . . . . . . . . . . . . . & & A & $\ldots$ & \\
\hline Athy ris (?) tumidula Billings.............. & & $A$ & $\cdots$ & \\
\hline Atbyris (?) turgida Shaler........... & & A & … & \\
\hline Atrypa (?) gibbosa Hall........................ & & $\mathrm{Cl}$ & $\cdots$ & \\
\hline Atrypa (?) lara (Billings) ...................... & & A & $\cdots$ & \\
\hline Atrypa laticorrugata Foerste.............. & & $\mathrm{Cl}$ & .... & \\
\hline Atrypa marginalis (Dalman) ............... & & ...... & $\mathrm{N}$ & \\
\hline Atrypa nodostriata Hall .................. & & $\mathrm{Cl}$ & $\mathrm{N}$ & \\
\hline Atrypa phoca (Salter) . . . . . . . . . . . . . . . . . . . . . . . . . . . & & …..... & MS & \\
\hline *Atrypa reticularis (Linnæus) ....................... & & $\mathrm{Cl}, \mathrm{A}$ & $\mathrm{N}$ & \\
\hline Atrypa reticularis niagarensis Nettclroth ......... & & ...... & $\mathrm{N}$ & \\
\hline 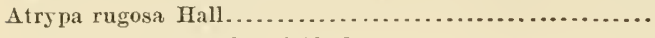 & & $\cdots$ & $\mathrm{N}$ & \\
\hline 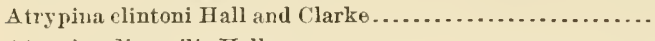 & & $\mathrm{Cl}$ & $\cdots$ & \\
\hline Atrypina disparilis Hall............. & & & $\mathrm{x}$ & \\
\hline Atrypina intermedia Hall. ........... & & .... & Ar & \\
\hline Billingsella (?) lanrentina (Billings).... & & A & .... & \\
\hline Bilohites acutilobus (Ringueberg) .......... & & $\cdots$ & $\mathrm{N}$ & \\
\hline Bilobites bilobus (Linnzeus) ................. & & … & $\mathrm{N}$ & . \\
\hline Camarella lenticularis Billings .............. & & A & .... & \\
\hline Camarotoechia (?) acinus Hall................... & & $\cdots \cdot$ & $\mathrm{N}$ & \\
\hline Camarotoechia (?) acinus convexa (Foerste) ............ & & $\mathrm{Cl}$ & & \\
\hline Canarotcechia equiradiata Hall ..................... & & $\mathrm{Cl}$ & & \\
\hline Camarotnechia fringillat Billings................... & & A & & \\
\hline Camarotrehia glacialis Billings................. & & $A$ & $\cdots$ & \\
\hline Camarotechia (?) indianensis Hall ............ & & .... & $\mathrm{N}$ & \\
\hline Camarotœchia (?) neglecta Hall......... & & $\mathrm{Cl}$ & $\mathrm{N}$ & \\
\hline Camarutechia (?) obtusiplicata Hall....... & & $\therefore \ldots$. & $\mathrm{N}$ & \\
\hline Camarotuchia (?) whitii Hall................ & & 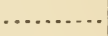 & $\mathrm{N}$ & \\
\hline Capellinia mira Hall and Clarke. ...................... & & -..... & $\mathrm{N}$ & \\
\hline Chonetes cornuta Hall............. & & $\mathrm{Cl}$ & $\cdots$ & \\
\hline Chonetes nova-scotica Hall .......... & & $\cdots$ & Ar, $\mathrm{N}$ & \\
\hline Chonetes striatella (Dalman)........ & & & $\mathrm{N} ?$ & \\
\hline Chonetes tenuistriata Hall ........... & & & Ar & (........ \\
\hline Chonetes undulata Hall. ................. & & - . . & $\mathrm{N}$ & $-\ldots$. \\
\hline Clintonella vagabunda Hall and Clarke....... & & $\mathrm{Cl}$ & ... & \\
\hline Clorinda arcuosa (MeChesney) .............. & & .... & $\mathrm{N}$ & \\
\hline Clorinda areyi (Hall and Clarke) . ................. & & $\mathrm{Cl}$ & .... & \\
\hline Clorinda barrandii (13illings) ......................... & & $A$ & $\cdots$ & \\
\hline Clorinda fornicata (Hall) . ........................... & & $\mathrm{Cl}$ & $\mathrm{N}$ & -..... \\
\hline 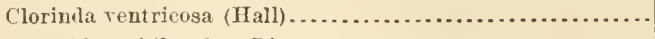 & & $\cdots$ & $\mathrm{N}$ & \\
\hline Conchidium biloculare Linnæus .......... & & & MS & ....... \\
\hline Conchillimm colletti Miller............. & & & ...... & \\
\hline Conchidium erassiradiatum (McChesney). & & & $\mathrm{N}$ & \\
\hline
\end{tabular}


Tanle Y.-Silurian Brachiopoda-Continued.

\begin{tabular}{|c|c|c|c|c|}
\hline \multirow[b]{2}{*}{ Sinecies. } & \multirow{2}{*}{$\begin{array}{l}\text { Eo- } \\
\text { silurian. }\end{array}$} & \multicolumn{2}{|c|}{ Mesosilurian. } & \multirow{2}{*}{$\begin{array}{c}\begin{array}{c}\text { Neosi- } \\
\text { lurian. }\end{array} \\
\begin{array}{c}\text { Tentae- } \\
\text { ulite, } \\
\text { Water- } \\
\text { lime. }\end{array}\end{array}$} \\
\hline & & $\begin{array}{l}\text { Anti- } \\
\text { costi, } \\
\text { Clinton. }\end{array}$ & $\begin{array}{l}\text { Guelph, } \\
\text { Arisaig, } \\
\text { Niagara. }\end{array}$ & \\
\hline Conchiclium erassiplicum Hall and Clarke & & & N & \\
\hline Conchidium decussatum (Whiteaves) ................ & & & $\mathrm{N}$ & \\
\hline Couchidium exponeus Hall and rlarke ............... & & & $\mathrm{N}$ & \\
\hline Coucbidium georgix Hall and Clarke ............. & & $\mathrm{Cl}$ & ... & \\
\hline Conchidinm greenii Hall and Clarko... & & & $\mathbf{N}$ & \\
\hline Conchidium knappi (Hall and Whitfield)... & & & $\mathrm{N}$ & \\
\hline Couchidium laqueatum (Conral) ... & & & $\mathrm{N}$ & \\
\hline Conchidium littoni (Hall) . ................ & & & $\mathrm{N}$ & \\
\hline Conchidium uulticestatuw (Hall)........ & & & $\mathrm{x}$ & \\
\hline Conchidium nysius (Hall and Whitfield)... & & & $\mathrm{N}$ & \\
\hline Conchidium obsoletum Hall and Clarke. & & & $\mathrm{N}$ & \\
\hline Conchidium occidentalo Hall .............. & & & Gu & \\
\hline Conchidium scoparium Hall and Clarke ............... & & & Giu & \\
\hline Conchidium tenuicostatum (Hall and $\mathrm{Wh}$ hitfield)... & & & $\hat{N}$ & \\
\hline Conchidium unguiforme (Ulrich) .......... & & & $\mathrm{N}$ & \\
\hline Crania acadiensis Hall................ & & & Ar & \\
\hline Crania anna Spencer................ & & ..... & $\mathrm{N}$ & $\cdots$ \\
\hline Crania dentata Ringueberg........... & & & $\mathrm{N}$ & \\
\hline Crania dubia Foerste ............ & & CI & -... & \\
\hline Crania gracilis Ringueberg....... & & & $N$ & \\
\hline Crania setifera Hall.................... & & & $\mathrm{N}$ & \\
\hline Crania siluriana Hall ............. & & & $\mathrm{N}$ & \\
\hline Crania spinigera Hall . . . . . . . . . . & & & N, & \\
\hline Craniclla (?) clintonensis Foerste.. & & $\mathrm{Cl}$ & $\cdots$ & \\
\hline Cyelospira (?) sparsiplica Foerste..... & & $\mathrm{Cl}$ & $\cdots$ & \\
\hline Cyrtia exporrecta (Wallenberg)....... & & & $\mathrm{N}$ & \\
\hline Cyrtia uneta IIaIl .................... & & $\mathrm{Cl}$ & N & \\
\hline Cyrtia myrtia Billings.................. & & A & N & \\
\hline Cyrtina pyramidalis (Hall) ............ & & ..... & $N$ & \\
\hline Dalmanella arcuaria IIall aud Clarke.... & & -.... & $\mathbf{N}$ & \\
\hline Dalmanella elegantula (Dalman) .......... & & C'l & $\mathrm{N}$ & \\
\hline Dalna auella elegatula parra (Foerste). & & Cl & & \\
\hline Dalmamella parva do Verueuit..... & & $A$ & … & \\
\hline Delthyris (?) rugicosta (Hall) ...... & & & Ar & \\
\hline $\begin{array}{l}\text { Delthyriy sulenta Hisinger......... } \\
\text { Dict yonella anticostiensis Billings }\end{array}$ & & A & $N$ & \\
\hline Dictỹonella concinna Hall. ....... & & & $\mathrm{N}$ & \\
\hline Dietyonella coraliifera Hall ............. & & ". & $\mathrm{N}$ & \\
\hline Dictyonella gibbosa Hall............. . & & & $\mathrm{N}$ & \\
\hline Dir tyonella reticulata Hall............. & & ..... & $\mathrm{N}$ & \\
\hline Dinoholus conradi Hall ............ & & $\ldots$ & $\mathrm{N}$ & \\
\hline Glossina perovata (Hall) . . . . . . . . . . . & & C:1 & .... & \\
\hline Gypidula coppiugeri (Etheridge) ... & & $\ldots$ & MS & ..... \\
\hline Gypidula globosa (Nettelroth) ........ & & & N & \\
\hline 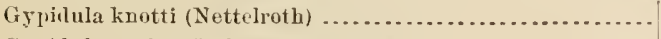 & & & $\mathrm{N}$ & \\
\hline Gypidula nuclea (Hall and Whitfield)................... & & $\mathrm{Cl}$ & $\cdots$ & -.. \\
\hline Gypidula roemeri Hall and Clarke.... & & ... & N & (...... \\
\hline Gypidula uuiplicata (Nettelroth)..... & & & $\mathrm{N}$ & - . . n \\
\hline 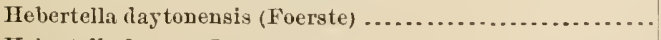 & & Cl & . & \\
\hline 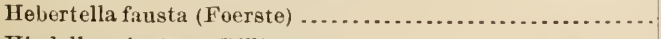 & & $\mathrm{Cl}$ & & \\
\hline Hindella prinstana (Billings) ..... & & A & & \\
\hline Hindella umbonata (Billings). & & $\Lambda$ & & \\
\hline
\end{tabular}


TAвь: V.-Silurian Brachiopoda-Continued.

\begin{tabular}{|c|c|c|c|c|}
\hline \multirow[b]{2}{*}{ Species. } & \multirow{2}{*}{$\mid \begin{array}{c}\begin{array}{c}\text { Eo- } \\
\text { silurian. }\end{array} \\
\text { Medina. }\end{array}$} & \multicolumn{2}{|c|}{ Mesosilurian. } & \multirow{2}{*}{$\begin{array}{c}\text { Neosi- } \\
\text { lurian. } \\
\text { Tentac- } \\
\text { ulite, } \\
\text { Water- } \\
\text { lime. }\end{array}$} \\
\hline & & $\begin{array}{c}\text { Anti- } \\
\text { costi, } \\
\text { Clinton. }\end{array}$ & $\begin{array}{l}\text { Guelyh, } \\
\text { Arisaig, } \\
\text { Niagara. }\end{array}$ & \\
\hline Howeospira apriniformis Hall . & & & $\mathrm{N}$ & \\
\hline Homcespira evax Hall.................... & & & $\mathrm{x}$ & \\
\hline Homeeospira sobrina (Beecher anil Clarke) & & … & $\mathrm{N}$ & \\
\hline II yattella cengesta (Cenrad) ................... & & Cl & & \\
\hline$\Pi_{5}$ atella junia (Billings) ................... & & A & & \\
\hline f* Leptæna rhomboidalis (Wilckens)...... & $\cdots$ & $\mathrm{Cl}$ & $\mathbf{N}$ & \\
\hline Lingula acutirostra Hall ................ & & $\mathrm{Cl}$ & & \\
\hline Lingula bicarinata Ringueberg.... & & $\cdots$ & $\mathrm{N}$ & \\
\hline Lingula clinteni Vanuxem.. & & $\mathrm{Cl}$ & & \\
\hline Lingula cuneata Conrad................ & $x$ & & & \\
\hline Lingnla gibbosa Hall ............. & & & $\mathrm{N}$ & \\
\hline Lingula ingens Spencer.... & & $\cdots$ & $\mathrm{N}$ & \\
\hline Lingala insularis Billings... & & $A$ & & \\
\hline Lingula lamellata Hall...... & & & $\mathrm{N}$ & \\
\hline Lingula linguata Hall anel Clarke. & & $\mathrm{Cl}$ & & \\
\hline Lingula oblata Hall............... & & $\mathrm{Cl}$ & & \\
\hline Lingula subelliptica d'Orbigny..... & & Cl & & \\
\hline Lingula treniola Hall and Clarke .... & & $\Leftrightarrow$ & & \\
\hline Lingulops granti IIall and Clarke.... & & $\cdots$ & 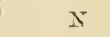 & \\
\hline Meristina n & & & $\mathrm{N}$ & \\
\hline Meristina re & & & $\mathbf{N}$ & \\
\hline Meristina tr & & & $\mathrm{N}$ & \\
\hline Mimulns waldrone & & & $\mathrm{N}$ & \\
\hline Ione & & $\cdots$ & $N$ & \\
\hline Mione & & & $\mathrm{N}$ & \\
\hline Monomor & & . & $\mathrm{N}$ & \\
\hline Menomor & & & $\mathrm{N}$ & \\
\hline Monom & & & Gu & \\
\hline Ionomor & & $\cdots$ & $x$ & \\
\hline Lonomore & & $\cdots$ & Gu & \\
\hline Monomorella & & & Gu & \\
\hline Monom & & $\cdots$ & Gu & \\
\hline *Nucle & & .. & $\mathbf{N}$ & \\
\hline $1 \ldots \ldots \ldots \ldots \ldots$ & & . & N & \\
\hline Nucleospira rotundata Whitfield .................... & & .... & $\cdots$ & W \\
\hline Orbiculeidea numulns IIall and Clarke................ & & $\therefore$ & $\ldots$ & W \\
\hline Orbiculoidea parmulata Hall .......................... & $x$ & & & \\
\hline 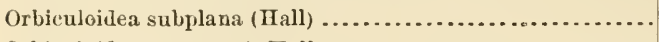 & & & Ar & \\
\hline 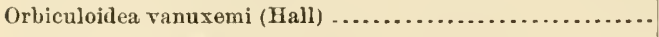 & & $\cdots$ & Ar & W \\
\hline Orthis benedicti Miller ................................. & & & N & \\
\hline Orthis daridseni de Verneuil .................... & & $\Delta$ & $\mathrm{N}$ & \\
\hline Orthis (?) fissiplica Roemer............. & & & $\mathrm{N}$ & \\
\hline Orthis flabellites (Hall) Foerste.......... & & $\mathrm{Cl}$ & N & \\
\hline Orthis flabellites spania I & & . & $\mathrm{N}$ & \\
\hline Orthis (?) & & & $\mathrm{N}$ & \\
\hline Orthis & & & $N$ ? & \\
\hline Orthis & & & $\mathrm{N}$ & \\
\hline Orthi & & & N & \\
\hline Orthis (?) rugipl & & . & $\mathrm{N}$ & \\
\hline Orth & & $A$ & & \\
\hline & & ..... & N & \\
\hline Orthis (?) tenuidens Hall & & Cl & & \\
\hline
\end{tabular}


Table V.-Silurian Brachiopoda-Continued.

\begin{tabular}{|c|c|c|c|c|}
\hline \multirow[b]{2}{*}{ Specie } & \multirow{2}{*}{$\begin{array}{c}\begin{array}{c}\text { Eo- } \\
\text { silurian. }\end{array} \\
\text { Medina. }\end{array}$} & \multicolumn{2}{|c|}{ Mesosilurian. } & \multirow{2}{*}{$\begin{array}{c}\text { Neosi- } \\
\text { lurian. } \\
\text { Tentac- } \\
\text { ulite, } \\
\text { Water- } \\
\text { lime. }\end{array}$} \\
\hline & & $\begin{array}{c}\text { Anti. } \\
\text { costi, } \\
\text { Clinton. }\end{array}$ & $\begin{array}{l}\text { Guelpl, } \\
\text { Arisaig, } \\
\text { Niagara. }\end{array}$ & \\
\hline \multirow{2}{*}{\multicolumn{5}{|c|}{ 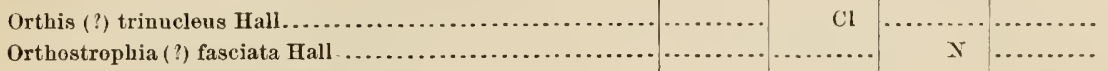 }} \\
\hline \multirow{2}{*}{\multicolumn{5}{|c|}{ 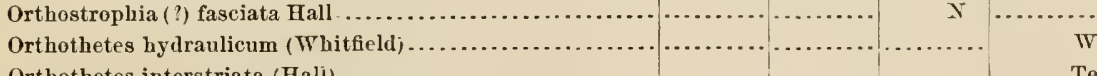 }} \\
\hline & & & & \\
\hline \multirow{2}{*}{\multicolumn{5}{|c|}{ 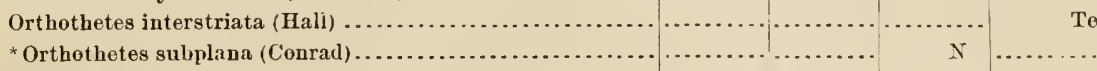 }} \\
\hline \multirow{2}{*}{\multicolumn{5}{|c|}{ 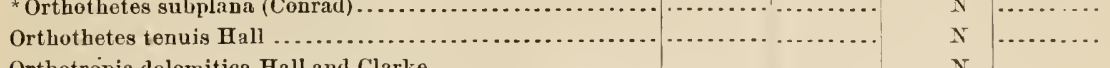 }} \\
\hline & & & & \\
\hline \multicolumn{5}{|l|}{ Orthetropia dolomitica Hall and Clarke..................... } \\
\hline \multirow{2}{*}{\multicolumn{5}{|c|}{ 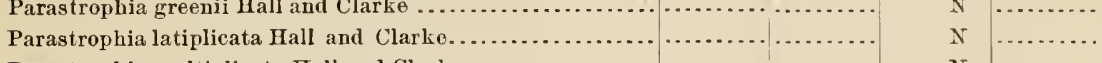 }} \\
\hline & & & & \\
\hline \multicolumn{5}{|l|}{ Parastrophia multiplicata Hall and Clarke ................... } \\
\hline \multirow{2}{*}{\multicolumn{5}{|c|}{$\begin{array}{l}\text { Parastrophia ops (Billings) } \ldots \ldots \ldots \ldots \ldots \ldots \ldots \\
\text { Parastrophia reversa (Billings) } \ldots \ldots \ldots \ldots \ldots \ldots \ldots \ldots \ldots \ldots \ldots\end{array}$}} \\
\hline \multirow{2}{*}{\multicolumn{5}{|c|}{$\begin{array}{l}\text { Parastrophia reversa (Billings) } \\
\text { Pentamerella (?) compressa Ringneberg } \ldots \ldots \ldots \ldots \ldots \ldots \ldots \ldots\end{array}$}} \\
\hline & & $\cdots \cdot$ & $\mathrm{N}$ & \\
\hline Pentamerus oblongus Sowerby ......................... & & $\mathrm{Cl}$ & N & \\
\hline \multicolumn{5}{|l|}{ Pentamerns oblongus cylindricus (Hall and Whitfield)..... } \\
\hline \multicolumn{5}{|l|}{ Pentamerus oblovgus maquoketa Hall and Clarke .......... } \\
\hline \multicolumn{5}{|l|}{ Pentamerus oblongus subrectus Hall and Clarke.............. } \\
\hline \multirow{2}{*}{\multicolumn{5}{|c|}{ 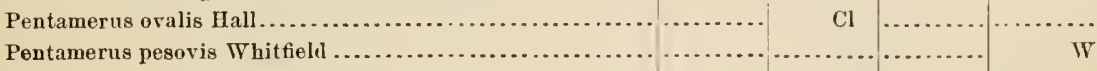 }} \\
\hline & & & & \\
\hline \multicolumn{5}{|l|}{ Phelidops oralis Hall ............... } \\
\hline \multicolumn{5}{|l|}{ Plolidops squamiformis Hall ................................ } \\
\hline \multirow{2}{*}{\multicolumn{5}{|c|}{ 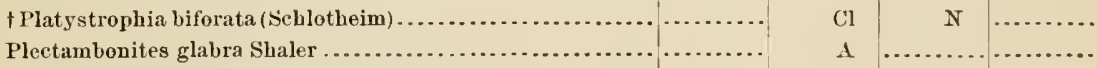 }} \\
\hline & & A & & \\
\hline Plectambonites producta Hall and Clarko... & & & $x$ & \\
\hline †Plec & & $\mathrm{Cl}$ & & \\
\hline Plect & & $\mathrm{Cl}$ & $\mathrm{N}$ & \\
\hline Plect: & & $\mathrm{Cl}$ & & \\
\hline Plecta & & $\mathrm{Cl}$ & & \\
\hline$\nmid$ Rafi & & $d$ & & \\
\hline Rafinesquina (?) & & $\mathrm{Cl}$ & & \\
\hline Reticula & & & $N$ & \\
\hline Reticu & & & $N$ & \\
\hline Rhinobelus davic & & & N & \\
\hline Rhinobolus galtensi & & & Gu & \\
\hline Rhipidomella circuli & & $\mathrm{Cl}$ & & \\
\hline Rhipidomella hybrida & & & $N$ & \\
\hline Rhipidomella media (: & & A & & \\
\hline Rhipidomella rhynehe & & A & & \\
\hline Rhipidomella subcireu & & $\mathrm{Cl}$ & & \\
\hline Rhipidomella nbera (Billings) ............... & & $\Lambda$ & & \\
\hline Rhynchenella (?) argentea Billings ........ & & $\Delta$ & & \\
\hline Rhynchonella (?) bellaforma Nettelroth .... & & & $\mathrm{x}$ & \\
\hline Rhynchonella (?) biclens Hall ................ & & CI & & \\
\hline Rhynchonella (?) bidentata (Hisinger). & & & N & \\
\hline Rhynchonella (?) colletti Miller.... & & & N & \\
\hline Rhynchonella (?) decemplicata Sow & & $\mathrm{Cl}$ & & \\
\hline (?) emac & & $\mathrm{Cl}$ & Ar & \\
\hline Rhynchonella (?) eva Billings & & A & & \\
\hline hync & & & & \\
\hline (1) & & A & & \\
\hline at & & Cl 1 & & \\
\hline hynchonella (?) lamellata I & & & & \\
\hline
\end{tabular}


TAnLE: 1.-Siluriun Brachiopode-Continted.

\begin{tabular}{|c|c|c|c|c|}
\hline \multirow[b]{2}{*}{ Species. } & \multirow{2}{*}{$\begin{array}{l}\begin{array}{c}\text { Eo- } \\
\text { silurian. }\end{array} \\
\text { Mudina. }\end{array}$} & \multicolumn{2}{|c|}{ Mesosilurian. } & \multirow{2}{*}{$\begin{array}{l}\text { Neosi- } \\
\text { lulian. } \\
\text { Trntate- } \\
\text { ulite, } \\
\text { Wator. } \\
\text { lime. }\end{array}$} \\
\hline & & $\begin{array}{l}\text { Anti- } \\
\text { costi, } \\
\text { Clinton. }\end{array}$ & $\begin{array}{l}\text { Guelpl, } \\
\text { Arisaig, } \\
\text { Niagara. }\end{array}$ & \\
\hline Rhynchouella (?) nucula (Sowerlyy). . & & & $\mathrm{N}$ & \\
\hline Rhyouhomella (?) nutrix Billings ............. & & 1 & & \\
\hline Rhynchonella (?) pisa Hall and Whit field .......... & & … & $\mathrm{N}$ & \\
\hline 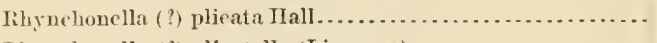 & $x$ & & & \\
\hline rihynchonella (?) plicatella (Linureus) ..... & & 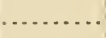 & $\mathrm{N}$ & \\
\hline Rily-uchonella (?) pyrrlıa Billings............ & & 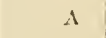 & $\cdots$ & \\
\hline Rilynehonella (?) robustiı IIall ............... & & C'I & $\ldots$ & \\
\hline Iilisnchonella (?) rugacosta Nettelroth...... & & ... & Y & \\
\hline Rhynehonella (?) tenuesseensis Roomer ..... & & ... & $x$ & \\
\hline Rihychonella (?) vicina Billings............ & & $A$ & $\cdots$ & \\
\hline Rilignchospira (?) aeadia (IIall) .............. & & & $\Lambda r$ & \\
\hline Rhynchospira (?) helen: & & & $\Lambda$ & \\
\hline Rliynchospira (?) sinuata Hall................ & & & Ar & \\
\hline Rliynchotreta enneata americana Hall ........ & & & $x$ & \\
\hline Scenidium pyramidale Hall................. & & … & $x$ & \\
\hline Sclizophoria senecta Mall and Clarke ........ & & Cl & .... & \\
\hline Schizotreta tenuilamellata Hall .............. & & & N & \\
\hline Spiriticr asperatus Ringneberg.............. & & & $\mathrm{N}$ & \\
\hline Spiriter erispatus Hall and Clarke........... & & & $x$ & \\
\hline Spirifer crispus (Hisinger) ................... & & & $N$ & \\
\hline 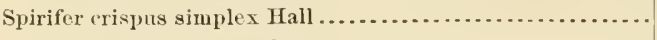 & & & N & \\
\hline Spirifer dubius Nettelroth.................. & & & $\mathrm{N}$ ? & \\
\hline Spiriter endorus Hall . . . . . . . . . . . . . . . . . . . & & & $N$ & \\
\hline Spirifer foggi Nettelroth ................... & & & 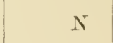 & \\
\hline Spirifer gibbosus Hall ........................... & & & N & \\
\hline 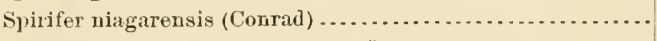 & & & $\mathrm{N}$ & \\
\hline Spirifer niagarensis oligoptychus Roemer ... & & & N & \\
\hline 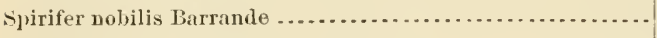 & & & $\mathrm{N}$ & \\
\hline Spirifer radiatus Sowerby . . . . . . . . . . . . . . . . . . . . . & & $\mathrm{Cl}$ & $N$ & \\
\hline Spirifer rostellum Hall and Whitfield............. & & & $\mathrm{N}$ & \\
\hline Spirifer similior Winchell and Marey .......... & & & N & $\cdots$ \\
\hline Spirifer subsuleatus Hall .................. & & & Ar & . \\
\hline Spirifer vanuxemi Hall.................. & & & ... & \\
\hline 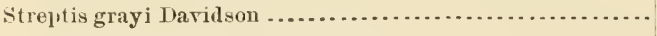 & & & $N$ & \\
\hline Stricklandinia anticostionsis Billings..... & & 1 & .... & \\
\hline Stricklandinia billingsana Dawson ..... & & & $\mathrm{Ar}$ & \\
\hline 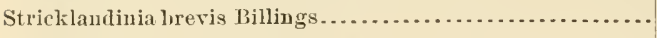 & & A & ... & \\
\hline 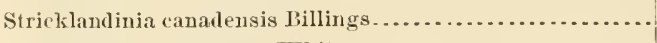 & & $\mathrm{Cl}$ & $\ldots$ & \\
\hline Stricklandinia castellana White .............. & & & 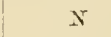 & \\
\hline Stricklaudinia rhapmani Hall and Clarke.... & & & $\mathrm{N}$ & \\
\hline StrickIantlinia davidsoni Billings............ & & A & … & \\
\hline Stricklandinia deformis Meek and Worthen... & & & $\boldsymbol{N}$ & .... \\
\hline Stricklandinia gaspensis Billing........... & & & $\mathrm{N}$ & $\ldots$ \\
\hline Stricklandinia lens (Sowerby) ............. & & & $x^{2}$ ? & \\
\hline Stricklandinia lirata Billings. ................ & & A & & \\
\hline Stricklandinia (?) louisvillensis Nettelroth........... & & . & $\mathrm{N}$ & \\
\hline Stricklandinia unelissa Billings $\ldots . \ldots \ldots \ldots \ldots \ldots \ldots$ & & $\Lambda$ & $\cdots+$ & \\
\hline Stricklandinia multilirata Whitficlıl............. & & & Gil & (....... \\
\hline Stririklandinia salteri Billings .............. & & $\Lambda$ & & \\
\hline Stricklandinia triplesiana Foerste $\ldots \ldots \ldots \ldots \ldots \ldots \ldots . . . . . . .$. & & ('I & ...... & ...... \\
\hline Stropheodonta acanthoptera (Whiteares). & & & $N ?$ & \\
\hline tropheodonta corrn mata Courad & & $(1$ & & \\
\hline
\end{tabular}


TABLE V.-Silurian Brachiopoda-Continued.

\begin{tabular}{|c|c|c|c|c|}
\hline \multirow[b]{2}{*}{ pecie } & \multirow{2}{*}{$\frac{\begin{array}{c}\text { Eo. } \\
\text { silurian. }\end{array}}{\text { Medina. }}$} & \multicolumn{2}{|c|}{ Mesosilurian. } & \multirow{2}{*}{$\begin{array}{c}\begin{array}{c}\text { Neosi- } \\
\text { lurian. }\end{array} \\
\text { Tentac- } \\
\text { ulite, } \\
\text { Water- } \\
\text { line. }\end{array}$} \\
\hline & & $\begin{array}{l}\text { Anti. } \\
\text { eosti, } \\
\text { Clinton. }\end{array}$ & $\begin{array}{l}\text { Guelph, } \\
\text { Arisaig, } \\
\text { Niagara. }\end{array}$ & \\
\hline \multirow{2}{*}{\multicolumn{5}{|c|}{$\begin{array}{l}\text { Stropheodonta corrugata pluristriata Foerste } \ldots \ldots \ldots \ldots \ldots \ldots \ldots \ldots \ldots \ldots \ldots \ldots \ldots \\
\text { Stropheodonta (?) geniculata (Shaler) } \ldots \ldots \ldots \ldots \ldots \ldots \ldots \ldots\end{array}$}} \\
\hline \multirow{3}{*}{\multicolumn{5}{|c|}{ 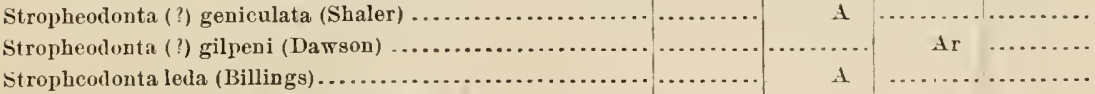 }} \\
\hline & & & & \\
\hline \multirow{2}{*}{\multicolumn{5}{|c|}{ 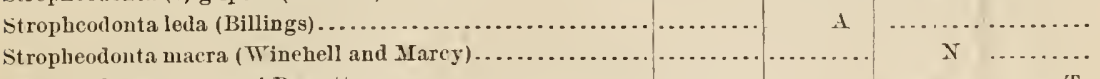 }} \\
\hline \multirow{2}{*}{\multicolumn{5}{|c|}{ 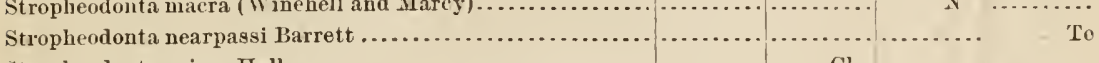 }} \\
\hline & & & & \\
\hline \multicolumn{5}{|l|}{ 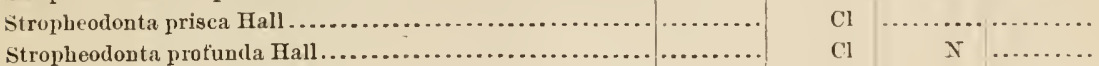 } \\
\hline \multirow{2}{*}{\multicolumn{5}{|c|}{ 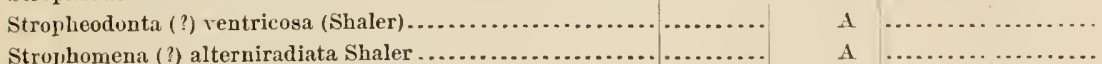 }} \\
\hline \multirow{2}{*}{\multicolumn{5}{|c|}{ 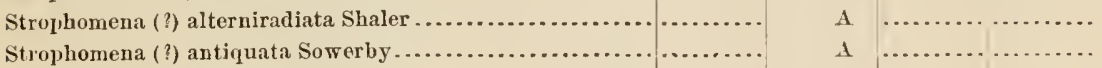 }} \\
\hline & & 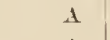 & & \\
\hline \multicolumn{5}{|l|}{ 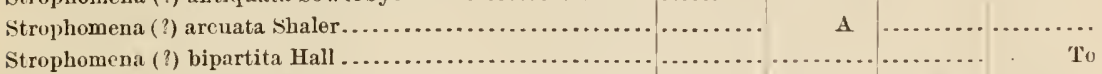 } \\
\hline \multirow{2}{*}{\multicolumn{5}{|c|}{$\begin{array}{l}\text { Strophomena (?) bipartita Hall } \ldots \ldots \ldots \ldots \ldots \ldots \ldots \ldots \ldots \ldots \ldots \ldots \ldots \ldots \ldots \ldots \ldots \ldots \ldots \ldots \ldots \\
\text { Strophomena (?) doneti Salter } \ldots \ldots \ldots \ldots \ldots \ldots \ldots \ldots\end{array}$}} \\
\hline \multirow{2}{*}{\multicolumn{5}{|c|}{ 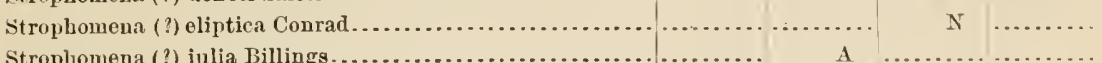 }} \\
\hline \multirow{2}{*}{\multicolumn{4}{|c|}{ Stroplomena (?) julia Billings ............................. }} & \\
\hline \multirow{2}{*}{\multicolumn{4}{|c|}{ 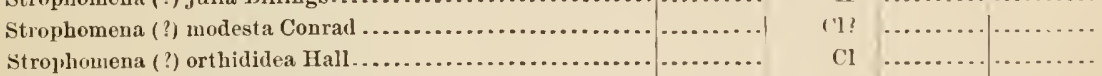 }} & \\
\hline & & $\mathrm{Cl}$ & & \\
\hline \multicolumn{5}{|l|}{$\begin{array}{l}\text { Strophomena (?) orthididea Hall } \ldots \ldots \ldots \ldots \ldots \ldots \ldots \ldots \ldots \ldots \\
\text { Strophomena philomela Billings } \ldots \ldots \ldots \ldots \ldots \ldots \ldots \ldots \ldots\end{array}$} \\
\hline \multirow{2}{*}{\multicolumn{5}{|c|}{ 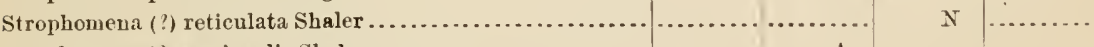 }} \\
\hline \multirow{2}{*}{\multicolumn{4}{|c|}{ Strophomena (?) semiovalis Shaler........................ }} & \\
\hline Strophomena (?) siluriana Daridson...................... & & & T & \\
\hline Strophonolla costatula Hall and Clarke................. & & .... & $x$ & \\
\hline Strophonella (?) patenta Mall. & & $\mathrm{Cl}$ & & \\
\hline Stroph & & & $\mathrm{N}$ & \\
\hline Strophon & & & $x$ & \\
\hline Trematospira & & & $\mathrm{N}$ & \\
\hline Trimerel & & & Gi1 & \\
\hline Trime & & & Gu & \\
\hline n and King .. & & & (ril & \\
\hline s................ & & $\ldots$ & Gı & \\
\hline n.................. & & & $N$ & \\
\hline all and Clarke..... & & & $x$ & \\
\hline .................... & & $\mathrm{Cl}$ & & \\
\hline (Sowerby) ............... & & & $\mathrm{N}$ & \\
\hline eek and Worthen) .... & & ...... & N & \\
\hline $1 \ldots \ldots \ldots \ldots \ldots \ldots \ldots \ldots . . .6$. & & $\mathrm{Cl}$ & $\mathrm{N}$ & \\
\hline 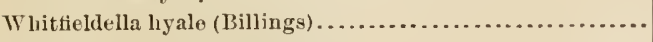 & & & Gu & \\
\hline a (Hall) ........................ & & $\mathrm{Cl}$ & $x$ & \\
\hline lings) ........ & & A & & \\
\hline nis (IIall) ... & & $\mathrm{Cl}$ & $\mathrm{N}$ & \\
\hline & & & $N$ & \\
\hline $1 . .$. & & & $N$ & \\
\hline bit & & & & \\
\hline Whitfieldella oblata ( & $x$ & & & \\
\hline Whitfieldella sulcata (Vanux & & & & \\
\hline Wilsonia kokomoensis (Miller) ..... & & & & \\
\hline * Wilsonia saffordi Hall............... & & & $\mathrm{N}$ & \\
\hline Wilsonia saffordi depressa Nettelrotb.. & & & $\mathrm{N}$ & \\
\hline ilsonia wilsoni (Sowerlyy) ............. & & & N & \\
\hline & & A & & \\
\hline
\end{tabular}


'TabLE Y.-Silurian Brachiopoda-Continued.

\begin{tabular}{|c|c|c|c|c|}
\hline \multirow{2}{*}{ Species. } & $\begin{array}{l}\text { Eo- } \\
\text { silurian. }\end{array}$ & \multicolumn{2}{|c|}{ Mesosiluriau. } & $\begin{array}{l}\text { Neosi- } \\
\text { luriant. }\end{array}$ \\
\hline & Mediua. & $\begin{array}{l}\text { Anti- } \\
\text { eosti, } \\
\text { Clinton. }\end{array}$ & $\begin{array}{l}\text { Guelph, } \\
\text { Arisaig, } \\
\text { Niagara. }\end{array}$ & $\begin{array}{l}\text { ulite. } \\
\text { Water- } \\
\text { lime. }\end{array}$ \\
\hline 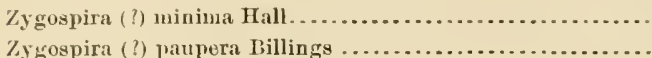 & & & $\mathrm{N}$ & \\
\hline Number of Silnrian speeies, 311 . & & & & \\
\hline 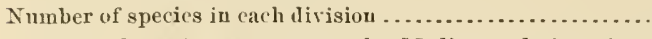 & 4 & 116 & 195 & 17 \\
\hline 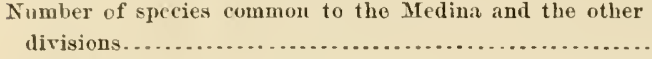 & 0 & 0 & 0 & 0 \\
\hline 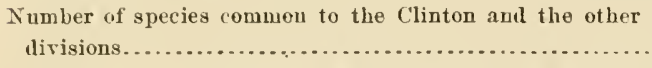 & - & & 19 & 0 \\
\hline 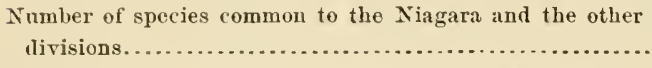 & 0 & 19 & & 2 \\
\hline 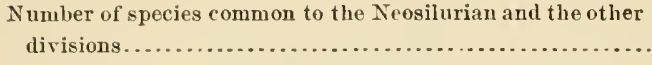 & 0 & 0 & 2 & \\
\hline Species common to the Silurian and Devonian systems, 5. & & & & \\
\hline 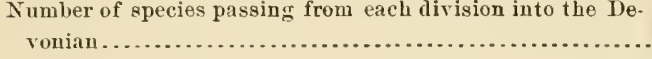 & 0 & 2 & 5 & 0 \\
\hline
\end{tabular}




\section{'TABLE VI.-Devonian Brachiopoda.}

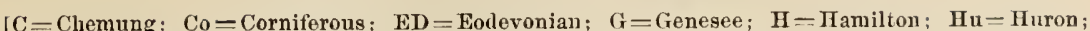
$\mathrm{I}=$ Ithaca; $\mathrm{M}=$ Marcellus; $\mathrm{MD}=$ Mesodevonian; $\mathrm{ND}=$ Neodevonian; $\mathrm{P}=$ Portage; $\mathrm{S}=$ Schoharie; Tu Tully. Species preceded by an asterisk $\left(^{*}\right)$ are found in the Carboniferons also; by an obclisk (t). in the silurian.]

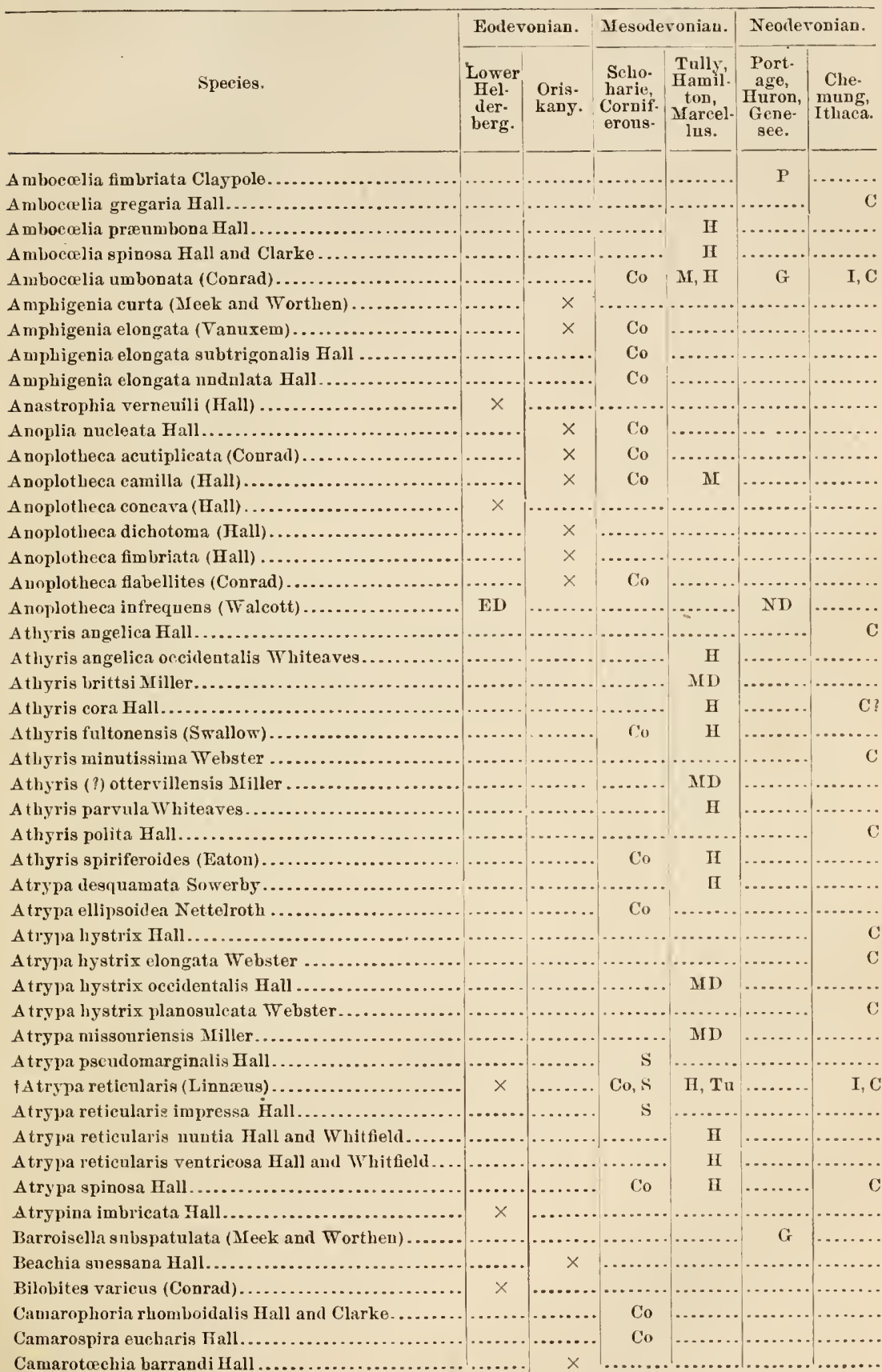


'TaBLE VI.-Devonian Brachiopoll-Continued.

\begin{tabular}{|c|c|c|c|c|c|c|}
\hline \multirow[b]{2}{*}{ Specier. } & \multicolumn{2}{|c|}{ Eoderonian. } & \multicolumn{2}{|c|}{ Mesoleronian. } & \multicolumn{2}{|c|}{ Neoderonian. } \\
\hline & $\begin{array}{c}\text { Lower } \\
\text { Hol. } \\
\text { der- } \\
\text { berg. }\end{array}$ & $\begin{array}{l}\text { Oris. } \\
\text { kany. }\end{array}$ & $\begin{array}{l}\text { Scho. } \\
\text { harie, } \\
\text { Coruit- } \\
\text { erous. }\end{array}$ & $\begin{array}{c}\text { Tull } \\
\text { Jamil- } \\
\text { ton, } \\
\text { Marcel- } \\
\text { lus. }\end{array}$ & $\begin{array}{c}\text { Port- } \\
\text { age, } \\
\text { Huron, } \\
\text { Gene- } \\
\text { see. }\end{array}$ & $\begin{array}{l}\text { Che. } \\
\text { muag, } \\
\text { It haed. }\end{array}$ \\
\hline \multirow{2}{*}{\multicolumn{7}{|c|}{ 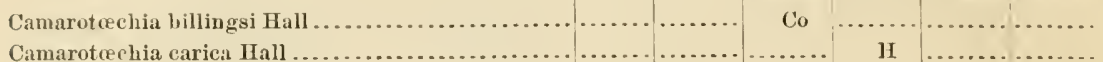 }} \\
\hline & & & …... & HI & & \\
\hline C'umarotochia carolina Hall .. & & & Co & 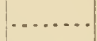 & & \\
\hline Camarotcehia congregata (Conrall).......... & & & .. & H & & \\
\hline * Camarotochia coutracta Hall ................ & & & & $\cdots$ & $\mathrm{P}$ & C \\
\hline Camarotechia contracta saxatilis Hall......... & & & & $\mathrm{H}$ & & \\
\hline Camaroteehia dotis Hall ........... & & & & $\mathbf{M}, \mathrm{H}$ & & \\
\hline Camarotechia duplicata Hall............ & & & & & & C; \\
\hline Camarotochia eudlichi (Meek). ? Devonian. & & & & & & \\
\hline Camarotechia eximia Hall....... & & & & . & 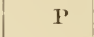 & I, C \\
\hline Cauarotcechia horsfordi Hall ....... & & & & $\mathbf{M}, \mathrm{H}$ & & \\
\hline Camarotechia orbienlaris Hall ........ & & - & & & & C \\
\hline Camarotcechia pleiopleura (Conrad) ..... & & $x$ & & -...... & & \\
\hline Camarotoechia prolifica Hall............ & & & & $\mathrm{M}, \mathrm{H}$ & & - \\
\hline * Camarotechia sappho Hall ........ & & & & MI, H & & $\mathrm{C}$ \\
\hline Camarotoechia speciosa Hall ....... & & $x$ & & & & 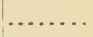 \\
\hline Camarotechia stephani Hall ....... & & $\cdots$ & & & 了' & $\mathrm{C}$ \\
\hline Camarotochia tethys (Billings) ........... & & & Co & & & \\
\hline Camarotcechia ventricosa Hall ........... & $x$ & & & & & \\
\hline Centronella alveata Hall.... & & & Co & & & \\
\hline Centronella glansfagea Hall ...... & & $x$ & Co & - & & \\
\hline Centronella glaucia Ḧall................ & & & & H & & \\
\hline Centronella impressa Hall............. & & & & H & & * \\
\hline Centronella (?) navicella (Hall)... & & & & & & $\mathrm{C}$ \\
\hline Centronella orata Hall ........... & & & Co & & & \\
\hline Centronella tumiula Billings....... & & $x$ & Co & & & .. \\
\hline Chartonella scitula Hall.............. & & & Co & & & \\
\hline Chonetes acutiradiata Hall ............ & & & Co & & & \\
\hline Chonetes antiope Billings...... & & $x$ ? & & & & \\
\hline Chonetes arcuata Hall.......... & & & Co & & & \\
\hline Chonetes canadensis Billings......... & & $\times$ ? & ... & - . & & \\
\hline Chonetes coronata (Conrad) $\ldots . . . . . . . . . .$. & & & & H & & \\
\hline Chonetes emmetensis A. Winchell ........... & & & $\cdots$ & H & & \\
\hline Chonetes filistriata Walcott ........ & & ED & & & & \\
\hline Chonetes hemispherica Hall........... & & & Co & $\ldots$ & & ... \\
\hline Chonetes koninckiana Norwood and Pratten .. & & & & Mit & & ... \\
\hline Chonetes lepida Hall..................... & & & & $\mathrm{M}, \mathrm{H}$ & $\mathrm{G}, \mathrm{P}$ & $\mathrm{I}, \mathrm{C}$ \\
\hline Chonetes lineata (Conrad) ........... & & & Co & MI & & \\
\hline${ }^{*}$ Chonetes logani aurora Hall ............... & & & & $\mathrm{Tu}$ & & \\
\hline Chonetes manitobensis Whiteaves........... & & & & & & $\mathrm{ND}$ \\
\hline Chontes melonica Billings ..... & & $x$ & & & & \\
\hline Chonetes mucronata Hall .................... & & $x$ & Co & M, H & & $\therefore$ \\
\hline Chonetes punctata Simpson........... & $x$ & & & .... & & \\
\hline Chonetes pusilla Hall .......... & & & & II & & .... \\
\hline C'bonetes scitula Hall ....................... & & & & M, $\mathrm{H}$ & $\mathbf{P}$ & $\mathrm{I}, \mathrm{C}$ \\
\hline * Chonetes setigera (Hall) .................. & & & & $\mathrm{M}, \mathrm{H}$ & G & $\mathrm{C}$ \\
\hline Chonetes subquadrata Nettelroth........ & & & & H & & \\
\hline Chonetes vicina (Castelnau) ... & & & & $\mathrm{H}$ & & \\
\hline Chonetes yandellana $\amalg$ all................... & & & $\mathrm{Co}$ & & & \\
\hline Chonostrophia complanata Hall... & & 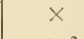 & & & & \\
\hline Chonostrophia dawsoni (Billings). & & $x$ & & & & \\
\hline
\end{tabular}


TABle VI.-Devonian Brachiopoda-Continued.

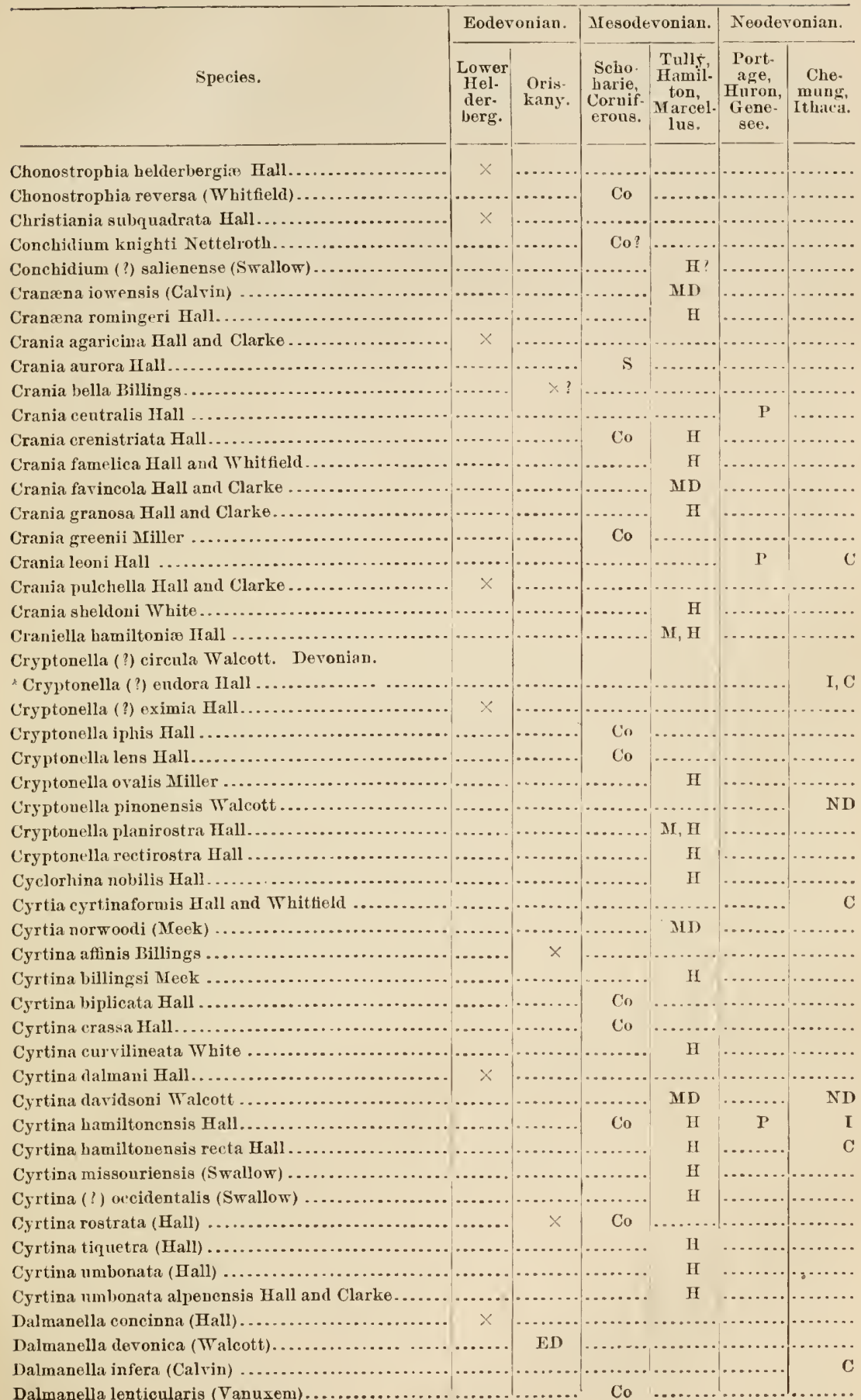


TaBLe VI.-Devonian Brachiopoda-Continued.

\begin{tabular}{|c|c|c|c|c|c|c|}
\hline \multirow[b]{2}{*}{ Species. } & \multicolumn{2}{|c|}{ Eotevonian. } & \multicolumn{2}{|c|}{ Mesolevonian. } & \multicolumn{2}{|c|}{ Neodevonian. } \\
\hline & \begin{tabular}{|c|} 
Lower \\
Hel- \\
der- \\
berg.
\end{tabular} & $\begin{array}{l}\text { Oris. } \\
\text { kany. }\end{array}$ & $\begin{array}{l}\text { Scho. } \\
\text { harie } \\
\text { Cornif. } \\
\text { erous. }\end{array}$ & $\begin{array}{c}\text { Tully, } \\
\text { Hamil. } \\
\text { tou, } \\
\text { Mirce] } \\
\text { lus. }\end{array}$ & $\begin{array}{c}\text { Port- } \\
\text { age, } \\
\text { Huron, } \\
\text { Gene. } \\
\text { see. }\end{array}$ & $\begin{array}{l}\text { Che. } \\
\text { Iunng, } \\
\text { Ithaca. }\end{array}$ \\
\hline almanella lepida Hall. & & & & $\mathrm{H}$ & & \\
\hline Dalmanella perelegans Hall ... & x & $x$ & & & & \\
\hline Dalmanella planoconrexa Hall ..... & $x$ & $x$ & & & & \\
\hline Dalmanella quadrans Hall................ & $x$ & & & & & \\
\hline Dalmanella subcarinata Hall ............ & $x$ & & & & & \\
\hline Dalmanella superstes Hall and Clarke. & & & & & & C \\
\hline Dalmauella tenuilineata Ilall ....... & & & & & & $\mathrm{C}$ \\
\hline Delthyris consobrina (d'Orbigny)... & & & 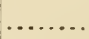 & $\mathrm{H}$ & & \\
\hline Delthyris mosacostalis Hall ........ & & & & & & $\mathrm{I}, \mathrm{C}$ \\
\hline Delthyris perlamellosa (Hall) ... & $x$ & & & & & \\
\hline Delthyris raricosta Conrad ....... & & & Co & & & \\
\hline uptilis Hall........ & & & & $\mathrm{H}$ & & \\
\hline ielasma calvini Hall and Whitf & & & & & & $\mathrm{C}$ \\
\hline ignomia al reata Hall........... & & ... & & II & & \\
\hline Eatouia coulteri Miller and Gurley & - & $x$ & & & & \\
\hline Eatonia eminens Hall. . & $x$ & & & & & \\
\hline Eatonia $m$ & $x$ & $x$ & & & & \\
\hline Eatonia peculiaris (Conrad).... & $x$ & $x$ & & & & \\
\hline Catonia pumil & $\cdots$ & $x$ & & & & \\
\hline Eatonia singularis (Tanuxem) ... & $x$ & ... & & & & \\
\hline atonia sinuata Hall .......... & 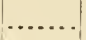 & $x$ & & & & \\
\hline Eatonia (?) variabilis Whiteares.......... & .. & .. & & H & & \\
\hline Eatonia whitfieldi Hall ................... & ... & $x$ & & & & \\
\hline unella harmonia 1 & & 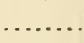 & Co & & & \\
\hline Eunella lincklæni Hall..... & & .. & . & $\mathrm{M}, \mathrm{H}$ & & \\
\hline Eunella simulator Hall......... & $\cdots$ & & - & H & & \\
\hline Eunella sullivanti Hall ........ & & & Co & & & \\
\hline Glossina leana (Ball) ......... & & & & $\mathrm{H}$ & & \\
\hline Glossina spatiosa (Hall) $\ldots . \ldots \ldots \ldots \ldots \ldots \ldots \ldots \ldots$ & $x$ & & & & & \\
\hline Glossina triangulata (Nettelroth) ............... & & & & $\mathrm{H}$ & & \\
\hline Gypidula comis $(0 w e n) \ldots \ldots \ldots \ldots \ldots \ldots . . . . .$. & & & & $\mathrm{MD}$ & & \\
\hline Gypidula galeata (Dalman) ............. & $x$ & & & & & \\
\hline Gypidula & & & & $\mathrm{MD}$ & & . \\
\hline Grpid & & & & & & ND \\
\hline Gypidu & & & & MD & & \\
\hline Grpid & $x$ & & & .... & & \\
\hline ypid & & & & $\mathrm{H}$ & & \\
\hline ypids & & $\ldots$ & & $\mathrm{H}$ & & \\
\hline ipparion & & $x$ & & & & \\
\hline ypothyris cast & & & & MD & & \\
\hline Hypothyris cub & & & & $\mathrm{Tu}$ & & \\
\hline Wypothyris cmmonsi & & & & MD & & \\
\hline giorhynchus dubium Hall ....... & & .. & & MI & & \\
\hline eiorhy achus globuliforme (Vanuxem) ... & & & & & & $\mathrm{C}$ \\
\hline eiorhynchus hecate Clarke ..................... & & ... & & $\because$ & G & \\
\hline iorhynchus iris Hall ............................ & & & & $\ldots$ & & C \\
\hline eiorhynchus kelloggi Hall .............. & & & & $\mathrm{H}$ & & \\
\hline eiorhynchus laura Billings....... & & 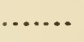 & & $\mathrm{M}, \mathrm{H}$ & & \\
\hline orhynchus lesleyi Hall and Cla & & & & ........ & ( & ND \\
\hline & & & & M & & \\
\hline 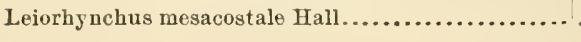 & & & & & $\mathbf{P}$ & $\mathrm{I}, \mathrm{C}$ \\
\hline
\end{tabular}


TABLE VI.-Devonian Brachiopoda-Continued.

\begin{tabular}{|c|c|c|c|c|c|c|}
\hline \multirow[b]{2}{*}{ Species. } & \multicolumn{2}{|c|}{ Euderonian. } & \multicolumn{2}{|c|}{ | Mesoderonian. } & \multicolumn{2}{|c|}{ Neodevonian. } \\
\hline & $\begin{array}{l}\text { Lower } \\
\text { Hel- } \\
\text { der- } \\
\text { Lerg. }\end{array}$ & $\begin{array}{l}\text { Oris- } \\
\text { kany. }\end{array}$ & $\begin{array}{l}\text { Scho- } \\
\text { liarie, } \\
\text { Cornif- } \\
\text { erous. }\end{array}$ & $\begin{array}{c}\text { Tull, } \\
\text { Hamil } \\
\text { ton, } \\
\text { Marcel. } \\
\text { lus. }\end{array}$ & $\begin{array}{c}\text { Port. } \\
\text { age, } \\
\text { Huron, } \\
\text { Gene. } \\
\text { see. }\end{array}$ & $\begin{array}{l}\text { Che- } \\
\text { mung, } \\
\text { Ithaca. }\end{array}$ \\
\hline Leiorhyuchns mysia Hall. & & & & M & & \\
\hline Leiorbynclus neradense Walcott........... & & & & $\mathrm{MID}$ & & \\
\hline Leierhynchus quadricostatum (Tanuxcm)... & & & & HI & G & \\
\hline Leiorhynchus robustum Ifall and Clarke........ & & & & ... & & \\
\hline Leiorhynchus sesquiplicatum A. Winchell ..... & & & & H & & \\
\hline Leiorhynchus sinuatum Flll . . . . . . . . . . . . . & & & & & & D \\
\hline$f^{*}$ Leptiena rbomboidalis (Wilckens)........... & $\times$ & $x$ & Co & H & & $\mathrm{U}$ \\
\hline Leptæna rhouboidalis ventricosa Hall...... & ... & $x$ & & & & \\
\hline Leptænisca adnascens Hall and Clarke.......... & $x$ & & & ... & & \\
\hline 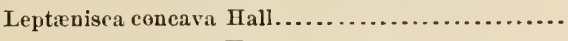 & $x$ & & & & & \\
\hline Leptenisca tangens Hall................. & $x$ & & & $\cdots$ & & \\
\hline Lindstroemella aspidium Hall...... & & & & H & & \\
\hline Lingula albapiuensis TValcott..... & & & & & & \\
\hline Lingula artemis Billings .............. & & $\times ?$ & & & & \\
\hline Lingula centrilineata Hall................. & $x$ & & & & & \\
\hline Lingnla ceryx Hall. . .................... & & & $\mathbf{S}$ & $\cdots$ & & \\
\hline Lingula complanata Williams............... & & 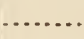 & 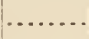 & $\mathrm{H}$ & & \\
\hline Lingula cempta Hall and Clarke............... & & & ..... & H & & \\
\hline Lingula concentrica Conrad....... & & & $\mathrm{Co}$ ? & & & \\
\hline *Lingula cuyahoga Hall........... & & & & & & \\
\hline Lingula delia Hall............ & & & & $\Pi$ & & \\
\hline Lingula densa Hall............... & & & & H & & \\
\hline Lingula desiderata Hall.. ........... & & & $\mathrm{Co}$ & … & & \\
\hline Lingula ligea Hall .................. & & & & II & $\mathrm{P}$ & \\
\hline Lingula ligea nevadensis Walcott... & & ED & & 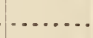 & & \\
\hline 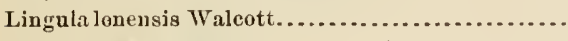 & & ED & & ... & & \\
\hline Lingula lucretia Billings...................... & & $\times ?$ & & … & & \\
\hline Lingula maida Hall....................... & & & & $\mathrm{H}$ & & \\
\hline Lingula manni Hall................... & & & Co & $\cdots$ & & \\
\hline Lingula minuta Meek...................... & & & & H & & \\
\hline 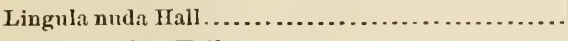 & & & & II & & \\
\hline Lingula perlata Hall. ......................... & $x$ & & & ... & & \\
\hline Jingula punetata Hall............. & & & & II & & \\
\hline Lingula rectilatera Hall..................... & $x$ & & & ... & & \\
\hline Lingula scutella Hall and Clarke............... & & & & & & \\
\hline 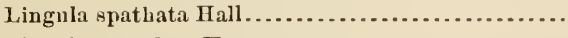 & $x$ & & & $\cdots$ & 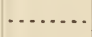 & \\
\hline Liugula spatulata Tanuxem .................. & & & & II & $\mathrm{G}, \mathrm{P}$ & I \\
\hline Lingula thedfordensis Whiteaves ......... & & & & H & ........ & \\
\hline Lingula triquetra Clarke................... & & & & ... & $\mathbf{P}$ & \\
\hline 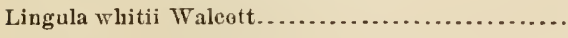 & & $\mathrm{ED}$ & & $\ldots$ & & \\
\hline Lingnlella (?) paliformis Hall............... & & & & II & & \\
\hline Lingulodiscina exilis (Hall) . . . . . . . . . . . . . . & & & & II & & \\
\hline Lissopleura æquivalvis (Hall).............. & $x$ & & & $\cdots$ & & \\
\hline Martinia athyroides $A$. Winchell .............. & & & & H & & \\
\hline Martivia glancerasi (White) .................. & & & & $\mathrm{H}$ & …... & \\
\hline Martinia (?) insolita A. Winchell ..... & & & & & H & \\
\hline Martinia maia (Billings) .............. . & & & Co & & & \\
\hline Martinia meristoides Mroek.......... & & & & $\mathrm{H}$ & & \\
\hline Martinia sublineata Mcek............... & & & & II & $\cdots$ & \\
\hline Martinia subumbona (Hall) ................... & & & & $\mathrm{M}, \mathrm{H}$ & $\mathbf{P}$ & \\
\hline Megalanteris condoui (McChesney). & & $x$ & & & & \\
\hline
\end{tabular}


TABLe VI.-Jeronian Brachiopoda-Continued.

\begin{tabular}{|c|c|c|c|c|c|c|}
\hline \multirow{2}{*}{ Species. } & \multicolumn{2}{|c|}{ Eodevonian. } & \multicolumn{2}{|c|}{ Mesolivonian. } & \multicolumn{2}{|c|}{ Neodevonian. } \\
\hline & $\begin{array}{l}\text { Lower } \\
\text { Hel- } \\
\text { der. } \\
\text { berg. }\end{array}$ & $\begin{array}{l}\text { Gris- } \\
\text { kany. }\end{array}$ & $\begin{array}{l}\text { Scho- } \\
\text { harie, } \\
\text { Cornit: } \\
\text { erous. }\end{array}$ & $\begin{array}{l}\text { Tully, } \\
\text { II:mil- } \\
\text { ton, } \\
\text { MarreI- } \\
\text { lus. }\end{array}$ & $\begin{array}{l}\text { Port- } \\
\text { age, } \\
\text { Huron, } \\
\text { Gene- } \\
\text { see. }\end{array}$ & $\begin{array}{l}\text { Cho. } \\
\text { mumg, } \\
\text { Ithaca. }\end{array}$ \\
\hline $\begin{array}{l}\text { Megalanteris ovalis Hall } \\
\text { Merista elongata Hall... }\end{array}$ & $\cdots \cdot$ & $x$ & & & & \\
\hline $\begin{array}{l}\text { Merista elongata Hall ........... } \\
\text { Merista tennesseensis Hall ...... }\end{array}$ & $x$ & 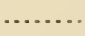 & & & & \\
\hline & $x$ & & & & & \\
\hline & $x$ & & & & & \\
\hline & $x$ & & & & & \\
\hline $\begin{array}{l}\text { Meristella barrisi Hall. ............. } \\
\text { Meristella bella (Hall) }\end{array}$ & $\cdots$ & & & $\mathrm{M}, \mathrm{II}$ & & \\
\hline & $x$ & & & & & \\
\hline $\begin{array}{l}\text { Meristella (?) blancha (Billings) ..... } \\
\text { Meristella clusia (Bjllings)........... }\end{array}$ & $x$ & & & & & \\
\hline & & * & Co & & & \\
\hline Meristella doris Hall .................. & 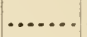 & ... & $\mathrm{Co}$ & $\cdots$ & & \\
\hline Meristella haskinsi Hall................ & & & & H & & \\
\hline Meristella (?) houghtoni (A. Wincbell) .. & & & & & $\mathrm{Hu}$ & \\
\hline feristella lævis (Tanuxem) ... & $x$ & $\ldots$ & & & & \\
\hline all.......... & & $x$ & & & & \\
\hline Ieristella lens (A. Winchell)... & & ... & & H & & \\
\hline Meristeila lenta Hall ....... & 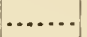 & $x$ & & & & \\
\hline Meristella me & $x$ & & & .... & & \\
\hline Meristella meta Hall ........... & & & & II & & \\
\hline (Conrad) ... & $\cdots$ & & $\mathrm{Co}$ & & & \\
\hline Meristella princeps Hall....... & $x$ & & & $\cdots$ & & \\
\hline Meristella rostrata Hall ........... & - & & & $\mathrm{H}$ & & \\
\hline Meristella sube & $x$ & & & - & & \\
\hline Meristella walcotti Hall : & . & $x$ & & & & \\
\hline Metaplas & & ... & Co & 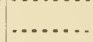 & & \\
\hline Metaplasia pyxida & & $x$ & & $\ldots$ & & \\
\hline Newberria clayl & & & & H & & \\
\hline Newberria $\mathbf{j}$ & .... & & & $\mathrm{MID}$ & & \\
\hline ek) $\ldots \ldots \ldots \ldots \ldots \ldots \ldots$ & $\cdots$ & & & $\mathrm{H}$ & & \\
\hline Newberria missouriensis Hall. .............. & ... & & & $\mathrm{H}$ & & \\
\hline Nucleospira cor & $x$ & & & & & \\
\hline Nucleospira co & $\ldots$ & & Co & $\mathrm{H}$ & & \\
\hline \$Nucleospira & $x$ & & & & & \\
\hline $11 \ldots \ldots \ldots$. & $\times$ & & & & & \\
\hline Orbicnloidea alleghania (Hall).......... & & & & & & \\
\hline Orlyiculo & & $\times$ & & & & \\
\hline Orbiculo & $x$ & & & & & \\
\hline $1 \ldots \ldots \ldots \ldots$ & $x$ & & & & & \\
\hline Orbiculoidea doria (IIall) ................. & & & & H & & \\
\hline Orbiculoidea elmi & & & & & & \\
\hline Orbiculoidea hur & & & & $\mathrm{Mr}, \mathrm{H}$ & & \\
\hline rbict & & $x$ & & & $\cdots$ & \\
\hline rbic & & & & ........ & $\mathbf{G}^{\mathbf{r}}$ & \\
\hline Orbieuloidea lodensis media Hall............. & & & & $\mathrm{M}, \mathrm{H}$ & & \\
\hline Orbirnloidea marginalis (Whitfield)........ & & & & $\mathbf{H}$ & & \\
\hline Orbiculoidea minuta Hall ............... & & & & M, II & & \\
\hline 11).... & & & & ..... & & \\
\hline Orbiculoidea randalli Hall...... & & & & II & & \\
\hline Orbiculoidea seneca (Hall). & & & & $\mathrm{H}$ & & \\
\hline rbiculoidea tullia (Hall).... . & & & & $\mathrm{Tu}$ & & \\
\hline riskania navicellia IIall and $\mathrm{C}$ & & $x$ & & & & \\
\hline rthis (?) eryna Hall. & & & & & & \\
\hline
\end{tabular}


Table VI.-Devonian Brachiopoda-Continued.

\begin{tabular}{|c|c|c|c|c|c|c|}
\hline \multirow[b]{2}{*}{ Species. } & \multicolumn{2}{|c|}{ Eoderonian. } & \multicolumn{2}{|c|}{ Mesodevonian. } & \multicolumn{2}{|c|}{ Neoderonian. } \\
\hline & $\begin{array}{l}\text { Lower } \\
\text { Hel- } \\
\text { dor- } \\
\text { berg. }\end{array}$ & $\begin{array}{l}\text { Oris. } \\
\text { kany. }\end{array}$ & $\begin{array}{l}\text { Scho- } \\
\text { harie, } \\
\text { Cornif- } \\
\text { erous. }\end{array}$ & $\begin{array}{c}\text { Tully, } \\
\text { Hamil- } \\
\text { ton, } \\
\text { Marcel- } \\
\text { lus. }\end{array}$ & $\begin{array}{l}\text { Port- } \\
\text { age, } \\
\text { Huron, } \\
\text { Gene- } \\
\text { see. }\end{array}$ & $\begin{array}{l}\text { Che- } \\
\text { mung, } \\
\text { Ithaca. }\end{array}$ \\
\hline \multicolumn{7}{|l|}{ Orthis (?) tenuistriata Hall......................... } \\
\hline \multirow{2}{*}{\multicolumn{7}{|c|}{ 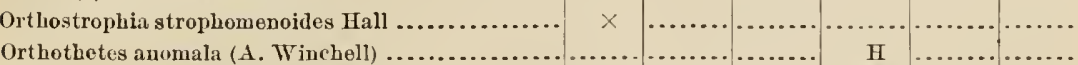 }} \\
\hline & & & & H & & \\
\hline \multicolumn{7}{|l|}{ Orthothetes bellulus Clarke .................. } \\
\hline \multicolumn{7}{|l|}{ Orthothetes ehemungensis (Conrad) ................. } \\
\hline \multicolumn{7}{|l|}{ Orthothetes chemungeusis arctostriata Hall } \\
\hline \multirow{2}{*}{\multicolumn{7}{|c|}{$\begin{array}{l}\text { Orthothetes chemnngensis perversus Hall ............ } \\
\text { Orthothetes deformis Hall ......................... }\end{array}$}} \\
\hline & & & & & & \\
\hline \multicolumn{7}{|l|}{ Orthothetes deformis sinuata Hall and Clarke........ } \\
\hline \multicolumn{7}{|l|}{ Orthothetes flabcllum (Whitfield) .................... } \\
\hline \multicolumn{7}{|l|}{ Orthothetes pandora (Billings) . } \\
\hline \multirow{2}{*}{\multicolumn{7}{|c|}{ 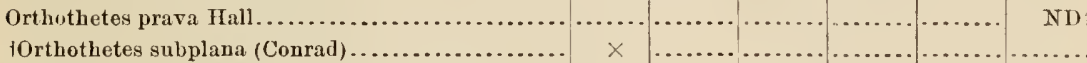 }} \\
\hline & & & & & & \\
\hline \multicolumn{7}{|l|}{ Orthothetes wool worthana Hall .................... } \\
\hline \multicolumn{7}{|l|}{ Parazyga deweyi Hall .............................. } \\
\hline Parazyga hirsuta Hall............................ & & 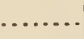 & Co & H & & \\
\hline Pentagonia unisulcata (Conrad) .. & & $x$ & Co & H & & \\
\hline \multicolumn{7}{|l|}{ Pentamerella arata (Conrad).... } \\
\hline \multicolumn{7}{|l|}{ Pentamerclla borealis (Meek) ....................... } \\
\hline \multicolumn{7}{|l|}{ Pentamerella dubia Hall............ } \\
\hline Pentamerella intralineata (A. Winchell) ............. & & & & $\mathrm{H}$ & & \\
\hline Pentamerella micula IIall......... & & & & H? & & \\
\hline Pentamerella obsolescens Hall.... & & & & H? & & \\
\hline Pentamerella parillionensis Hall .. & & & & H & & \\
\hline Pentamerella thusnelda Nettelroth . & & & Co & & & \\
\hline Pholidops arenaria Hall .... & & $x$ & ... & & & \\
\hline Pholidops areolata Hall.... & & & s & & & \\
\hline Pholidopes bellula Walcott.... & & ED & & & & \\
\hline Pholidops calceola IIall and Clarke & $\cdots$ & & Co & 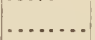 & & \\
\hline Pholidops greenii Miller and Gurley. & & & … & H & & \\
\hline Pholidops hamiltonia Hall .......... & & & ... & H & & \\
\hline Pholidops lepis Hall and Clarke.... & & & Co & & & \\
\hline Pholidops oblata Hall..................... & & & . & H & & \\
\hline Pholideps ovata Hall ....................... & $x$ & & & & & \\
\hline Pholidops patima Hall and Clarke.. & & & Co & & & \\
\hline Pholideps quadrangularis Walcott . & & ED & & & & \\
\hline Pholidops terminalis Hall ................... & & $x$ & & ... & & \\
\hline 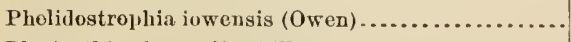 & & & Co & $\mathrm{H}$ & & \\
\hline Plectorthis (?) aurelia (Billings) ............ & & $x$ & & & & \\
\hline Productella aretirostrata Hall............ & & & & & & \\
\hline Prodnctella bialveata Hall.............. & & & & & & \\
\hline Productella boydi Hall ................. & & & & & & \\
\hline Productella costatula Hall............ & & & & & & \\
\hline Productella costatula strigata Hall. & & & & & & $\mathrm{C}$ \\
\hline Productella dumesa Hall ...... & & & & H & & \\
\hline Productella eriensis Nicholson .... & & & Co & & & \\
\hline Productella exant hemata Hall.... & & & Co & $\mathrm{H}$ & & \\
\hline roductella hallana $W$ alcott...... & & & & & & $\mathrm{ND}$ \\
\hline oductella hirsuta Hall...... & & & & & & D \\
\hline dnetella hirsuta rectispina Hall... & & & & & & \\
\hline oduct & & & & & & NI \\
\hline
\end{tabular}

Bull. 87-4 
TABLE: VI.-Devonian Brachiopoda-Continued.

\begin{tabular}{|c|c|c|c|c|c|c|}
\hline & Eoder & onian. & Mesode & evonian. & & \\
\hline Sprecies. & $\begin{array}{l}\text { Lower } \\
\text { Hel- } \\
\text { tler- } \\
\text { berg. }\end{array}$ & $\begin{array}{l}\text { Oris. } \\
\text { kany. }\end{array}$ & $\begin{array}{l}\text { Srho. } \\
\text { harie. } \\
\text { Cornif- } \\
\text { erous. }\end{array}$ & $\begin{array}{c}\text { Tully, } \\
\text { Hamil- } \\
\text { tou, } \\
\text { Marel- } \\
\text { lus. }\end{array}$ & $\begin{array}{c}\text { Port. } \\
\text { age, } \\
\text { Muron. } \\
\text { Gene- } \\
\text { see. }\end{array}$ & $\begin{array}{l}\text { Che. } \\
\text { mung, } \\
\text { Ithaea. }\end{array}$ \\
\hline P'roductella lachrymosa (Conrad).. & & & & & & \\
\hline P'roductella lachrymosa lima (Conrad)... & & & & & & C \\
\hline *Productella lichrymosa stigmata IIall. & & & & & & C \\
\hline Productella marquessi Rowley .......... & & & & $\mathrm{H}$ & & - \\
\hline Prodnctella murchisoniana Do Koninck & & & & H & & . \\
\hline Productella naricella Hall............ & & & Co & H & & . \\
\hline roductella onusta Hall ............ & & & & & & $\mathrm{C}$ \\
\hline roductella papulata Hall.............. & & & & H & & \\
\hline roductella productoides (Murehison). & & & & H & & ... \\
\hline roductella rarispina Hall........... & & & & & & C \\
\hline Productella semiglobosa Nettelroth .. & & & Co & & & .... \\
\hline${ }^{\star}$ Productella speciosa Hall.. & & & & & $P$ & I, $\mathbf{~ : ~}$ \\
\hline Prodnetella spinulicosta Hall... & & & Co & $\mathrm{MI}, \mathrm{H}$ & & \\
\hline Productella striatula Hall ...... & & & & & & c \\
\hline Productella subalata Hall ... & & & & MD & & \\
\hline Productella tullia Hall........ & & & & H & & \\
\hline Pugnax pugnus Martin......... & & & & & $P$ & I \\
\hline Pagnax pugnns altus (Calvin) ...... & & & & & & ND \\
\hline Rensselæria æquiradiata (Conrad)..... & $x$ & & & & & \\
\hline Rensselæria cayuga Hall & & $x$ & & & & \\
\hline Rensselæria cumberlandiæ Hall . & 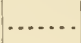 & $x$ & & & & \\
\hline Rensselæria elliptica Hall ... & $x$ & & & & & \\
\hline Rensselieria intermedi & 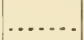 & $x$ & & & & \\
\hline liensselæria marylandica Hall......... & $\ldots$ & $x$ & & & & \\
\hline Rensselæria mutabilis Hall.......... & $x$ & & & & & \\
\hline Rensselæria ovoides (Eaton) ........... & .... & $x$ & & $\cdots$ & & \\
\hline Rensselæria ovaluu Hall and Clarke ....... & ... & $x$ & .. & & & \\
\hline Reticularia canandaigua (I & & & .... & H & & \\
\hline Reticularia fimbriata (Conrad) ............. & ... & $x$ & Co & $\mathrm{II}, \mathrm{H}$ & & I \\
\hline Reticularia franklini (M & & & $\cdots$ & $\mathrm{H}$ & & \\
\hline Reticularia knappiana (Nettelroth) ....... & ... & $\cdots$ & Co & & & \\
\hline Reticularia læris (Hall) ................. & 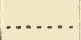 & ... & ... & ... & $\mathrm{P}$ & I \\
\hline Reticularia modesta (Hall) ..................... & $x$ & $x$ & ... & & & ... \\
\hline Reticularia nevadensis (Walcott) .............. & $\ldots$ & & & & & ND \\
\hline Reticularia (?) nympha (Billings) .............. & $x$ & & & & & ..... \\
\hline Reticularia præmatura (Hall) ................... & & & 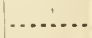 & * & & C \\
\hline Reticularia subundifera (Meek and Worthen)... & & & & H & & \\
\hline Retzia (?) polypleura A. Winchell.............. & & & & & $P$ & \\
\hline Retzia (?) subglobosa IIall... & & & s & & & \\
\hline 1ilipidomella alsa Hall .... . & & & $\mathrm{s}$ & & & \\
\hline Rhipidomella assimilis Hall & $x$ & & & & & \\
\hline Phipilomella $\mathrm{cl}$ & & & Co & & & \\
\hline Rhipidlomella cumberlandix $I$ & & $x$ & & & & \\
\hline Rhipidomella (? & & & & H & & \\
\hline Rhipidomella $\mathrm{ey}$ & 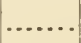 & & & $\mathrm{MI}, \mathrm{H}$ & & \\
\hline Rhipidomella di & $x$ & & & & & \\
\hline hipidomella eminens H & $x$ & & & & & \\
\hline bipidom & & & & H & & \\
\hline hipidon & & & & H & & \\
\hline hipidon & & & $\cdots$ & H & & \\
\hline & & & Co & & & \\
\hline & & & & & & \\
\hline
\end{tabular}


Table VI.-Devonian Brachiopoda-Continued.

\begin{tabular}{|c|c|c|c|c|c|c|}
\hline \multirow[b]{2}{*}{ Species. } & \multicolumn{2}{|c|}{ Eoderonian. } & \multicolumn{2}{|c|}{ Mesodevonian. } & \multicolumn{2}{|c|}{ Neodevonian. } \\
\hline & $\begin{array}{l}\text { Lower } \\
\text { Hel- } \\
\text { der- } \\
\text { verg. }\end{array}$ & $\begin{array}{l}\text { Oris. } \\
\text { kany. }\end{array}$ & $\begin{array}{l}\text { Scho- } \\
\text { harie, } \\
\text { Cornif- } \\
\text { erous. }\end{array}$ & $\begin{array}{c}\text { Tully, } \\
\text { Hanil- } \\
\text { ton, } \\
\text { Marcel- } \\
\text { lus. }\end{array}$ & $\begin{array}{l}\text { Port- } \\
\text { age, } \\
\text { Huron, } \\
\text { Gene- } \\
\text { see. }\end{array}$ & $\begin{array}{l}\text { Che. } \\
\text { mung, } \\
\text { Ithaca. }\end{array}$ \\
\hline \multicolumn{7}{|l|}{ 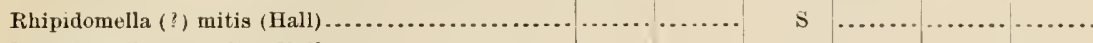 } \\
\hline \multicolumn{7}{|l|}{ Rhipidomella musculosa Hall................... } \\
\hline \multicolumn{7}{|l|}{ Khipidomella oblata Hall ......................... } \\
\hline \multicolumn{7}{|l|}{ Khipidomella oblata emarginata Hall............. } \\
\hline \multicolumn{7}{|l|}{ Rlipidomella peloris Hall ........................ } \\
\hline \multicolumn{7}{|l|}{ Rhipidomella penelope Hall . . . . . . . . . . . . . . . . . } \\
\hline \multicolumn{7}{|l|}{ Rhipiclomella pennş̧lvanica (Simpson) ............. } \\
\hline \multicolumn{7}{|l|}{ Rhipidonella semele Hall ......................... } \\
\hline \multicolumn{7}{|l|}{ Rhipidomella solitaria Hall . . . . . . . . . . . . . . . . } \\
\hline \multicolumn{7}{|l|}{ 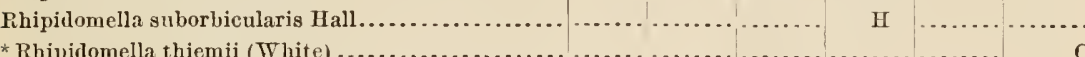 } \\
\hline * Rhipidomella thiemii (White) ...................... & & & & & & \\
\hline \multicolumn{7}{|l|}{ 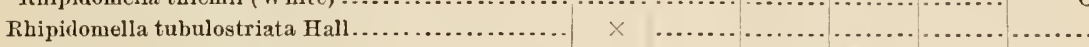 } \\
\hline \multicolumn{7}{|l|}{ 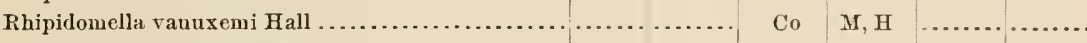 } \\
\hline \multicolumn{7}{|l|}{ Rhynchonella acutiplicata Hall.................... } \\
\hline \multicolumn{7}{|l|}{ Rhynchonella allegania TVilliams................ } \\
\hline \multicolumn{7}{|l|}{ Rhynchonella altiplicata Hall ....................... } \\
\hline Rhynchonella ambigua Calvin .................. & & & & $\mathrm{MD}$ & & \\
\hline Rhynchonella aspasia Billings .... & $x$ & & & & & \\
\hline Rhynchonella bialveata Hall ..................... & $x$ & & & & & \\
\hline Rhynchonella dryope Billings .................... & $\cdots$ & $x$ & & & & \\
\hline Rhynchonella eminens Hall ................ & $x$ & & & & & \\
\hline Rhynchonella excellens Billings............ & 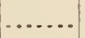 & $x$ & & & & \\
\hline Rhynchonelia fitchana Hall.................. & $\ldots$. & $x$ & & & & \\
\hline Rhynchonella gainesi Nettelroth ............. & & & & II & & \\
\hline Rhynchonella huronensis A. Winchell......... & & & & & Ни & \\
\hline Rhynchonella huronensis precipua A. Winchell. . & & & & & $\mathrm{Hu}$ & \\
\hline Rhynchonella inæquiplicata Hall....... & ... & & $\mathrm{Co}$ & & & \\
\hline Rhynchonella inutilis Hall .............. & $x$ & & & & & \\
\hline Rhynchonella louisvillensis Nettelroth. & & & Co & & & \\
\hline Rhynchonolla mainensis Billings .............. & $x$ & & & & & \\
\hline Rhynchonella medea Billings.............. & & & $\mathrm{Co}$ & & & \\
\hline Rhynchonella multistriata Hall........... &. & $x$ & & & & \\
\hline Rhynchonella oblata Hall............. & .. & $x$ & & & & \\
\hline Rhynchonella occidens Walcott .... & 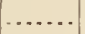 & ED & & & & \\
\hline Rhynchonella planoconvexa Hall.... & $x$ & & & & & \\
\hline Rhynchonelia principalis Hall............ & $\cdots$ & $x$ & & & & \\
\hline Rhynchonella ramsayi Hall............ & ... & $x$ & & & & \\
\hline Rhynchonella raricosta $W$ hitfield ...... & & & Co & & & \\
\hline Rlyynchonella royana Hall......... & . & & Co & & & \\
\hline Rhynchonella rudis Hall .......... & $x$ & & & & & \\
\hline Fhynchonella semiplicata (Conrad)............ & $x$ & & & & & \\
\hline Rhynchonella septata Hall ................ & ... & $x$ & & & & \\
\hline Rhynchonella subacuminata Webster ..... & $\ldots$ & & & & & \\
\hline Rhynchonella sulcoplicata Hall... & $x$ & & & & & \\
\hline Rhynchonella tenuistriata Nettelroth ...... & ... & & Co & & & \\
\hline Rhynchonella transversa Hall.................. & $x$ & & & & & \\
\hline Rhynchonella warrenensis Swallow ... & ... & ED & & & & \\
\hline Rlyynchospira electra Billings ...... . & $x$ & & & & & \\
\hline Rhynchospira (?) eugenia Billings.... & $\cdots$ & & Có & & & \\
\hline Rhynchospira formosa Hall............. & $x$ & & & & & \\
\hline Rhynchospira globosa Hall.. & $x$ & & & & & \\
\hline
\end{tabular}


TABLE: VI.-Devonian Brachiopoda-Continued.

\begin{tabular}{|c|c|c|c|c|c|c|}
\hline \multirow[b]{2}{*}{ Speries. } & \multicolumn{2}{|c|}{ Eoteronian. } & \multicolumn{2}{|c|}{ Mesodevonian. } & \multicolumn{2}{|c|}{ Neodevonian. } \\
\hline & $\begin{array}{l}\text { Lower } \\
\text { Hel- } \\
\text { der- } \\
\text { berg. }\end{array}$ & $\begin{array}{l}\text { Oris- } \\
\text { kany. }\end{array}$ & $\begin{array}{l}\text { Scho- } \\
\text { harie, } \\
\text { Cornif. } \\
\text { erous. }\end{array}$ & $\begin{array}{l}\text { Tully, } \\
\text { IIamil. } \\
\text { ton, } \\
\text { Iarcel. } \\
\text { lus. }\end{array}$ & $\begin{array}{l}\text { Port. } \\
\text { age, } \\
\text { Huron, } \\
\text { Gene. } \\
\text { sees. }\end{array}$ & $\begin{array}{l}\text { Che. } \\
\text { mung, } \\
\text { Ithaca. }\end{array}$ \\
\hline \multicolumn{7}{|l|}{ Rhynchospira rectirostra Hall... } \\
\hline \multirow{2}{*}{\multicolumn{7}{|c|}{$\begin{array}{l}\text { Phynchotrema formosa }(\text { Hall }) \ldots \ldots \ldots \ldots \ldots \ldots \ldots \ldots \\
\text { Riemerella grandis Vanuxem } \ldots \ldots \ldots \ldots \ldots \ldots \ldots \ldots\end{array}$}} \\
\hline & & & & H & & \\
\hline \multicolumn{7}{|l|}{ Scenidium insignis Hall ......................... } \\
\hline \multicolumn{7}{|l|}{ 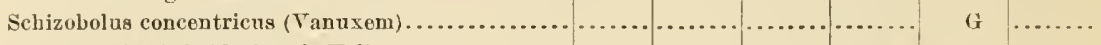 } \\
\hline \multicolumn{7}{|l|}{ Schizocradia (?) helderbergia Hall.................. } \\
\hline \multirow{2}{*}{\multicolumn{7}{|c|}{ 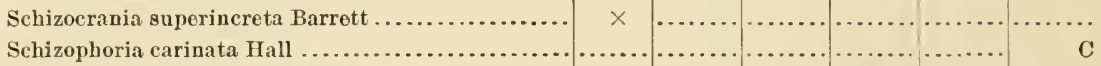 }} \\
\hline & & & & & & $\mathrm{C}$ \\
\hline \multicolumn{7}{|l|}{ Schizophoria macfarlanii (Meek) .................... } \\
\hline \multicolumn{7}{|l|}{ 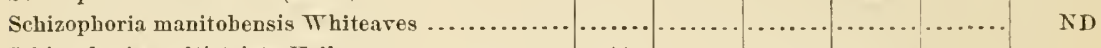 } \\
\hline \multicolumn{7}{|l|}{ Schizophoria multistriata Hall ................... } \\
\hline \multicolumn{7}{|l|}{$\begin{array}{l}\text { Schizophoria (?) peduncularis Hall ................ } \\
\text { Schizophoria propinqua Hall ...................... }\end{array}$} \\
\hline \multicolumn{7}{|l|}{ 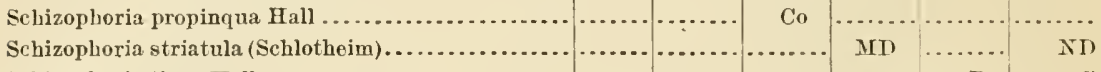 } \\
\hline \multicolumn{7}{|l|}{ Schizophoria striatula (Schlothoim)............... } \\
\hline \multirow{2}{*}{\multicolumn{7}{|c|}{ 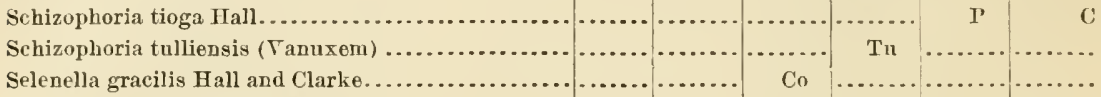 }} \\
\hline Schizophoria tulliensis ( Tanuxem) ................. & & & & & & \\
\hline \multicolumn{7}{|l|}{ Selenella gracilis Hall and Clarke.................. } \\
\hline Seminula (?) rogersi Hall and Clarke.............. & & & & & & \\
\hline 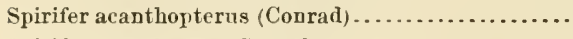 & & & & $\mathrm{H}$ & & \\
\hline Spirifer acuminatus (Conrad)................ & & & $\mathrm{Co}$ & $\mathrm{H}$ & & \\
\hline Spirifer alæe formis de Terneuil........... & & & $\mathrm{Co}$ & & & \\
\hline Spirifer aldrichi Etheridge. Devonian. & & & & & & \\
\hline Spirifer amarus Swallow ............. & & & & II & & \\
\hline Spirifer angustus Hall. . . . . . . . . . . . . . & & & & $\mathrm{H}$ & $\mathrm{P}$ & \\
\hline Spirifer anna Swallow . . . . . . . . . . . . . . & & & & H & & \\
\hline Spirifer arcticus Haughton. Devonian. & & & & & & \\
\hline Spirifer aretisegmentus Hall ......... & & & Co & & & \\
\hline Spirifer arenosus Conrad ............ & & $x$ & Co & $\cdots$ & & \\
\hline Spirifer asper Hall.................... & & & & II & & \\
\hline Spirifer andaculus (Conrad) ............. & & & & MI, II & & \\
\hline Spirifer audacnlus macronotus $\mathrm{Hall} . . . .$. . & & & & $\mathrm{H}$ & & \\
\hline Spirifer belphegor Clarke............. & & & & & G & \\
\hline Spirifer bidorsalis $A$. Winchell................. & & & & H & & \\
\hline Spirifer billingsanus Miller.............. & & $x$ & & & & -... \\
\hline Spirifer bimesialis Hall ...................... & & & & & & NI) \\
\hline Spirifer byrnesi Nettelroth . . ................ & & & & $\mathrm{H}$ & & \\
\hline Spirifer concinnus.IHall.................. & $x$ & & & $\cdots \cdot$ & & \\
\hline Spirifer consors A. Winchell ........... & & 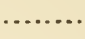 & & $\mathrm{H}$ & & \\
\hline Spirifer corticosus Hall. . . . . . . . . . . . . . . . & & & & H & & \\
\hline Spirifer (?) costalis Castelnau ......... & & & Co? & & & \\
\hline Spirifer cumberlandiæ Hall............ & & $x$ & & & & \\
\hline Spirifer cyclopterus Hall .................. & $x$ & $x$ & & . & & \\
\hline Spirifer davisi Nettelroth..................... & & & & $\mathrm{H}$ & & \\
\hline Spirifer disjunctus Sowerby ..................... & & & & & & C \\
\hline Spirifer disjunct us occidentalis Whiteaves........ & & & & & & ND \\
\hline Spirifer disjnnetus suleifor Hall and Clarke.... & & & & $\cdots$ & & $\mathbf{C}$ \\
\hline Spirifer divaricatus Hall........................ & & & Co & H & & \\
\hline Spirifer duodenarius Hall...................... & ... & & Co & $\ldots \ldots$ & & \\
\hline Spirifor dupliplicatus (Conrad)................ & & & & H & & \\
\hline Spirifer engelmanni Meok .......... & & & & MID & & \\
\hline Spirifer euruteines Owen ..... & & & & H & & \\
\hline
\end{tabular}


TABI, VI.-Deronian Brachiopoda-Continued.

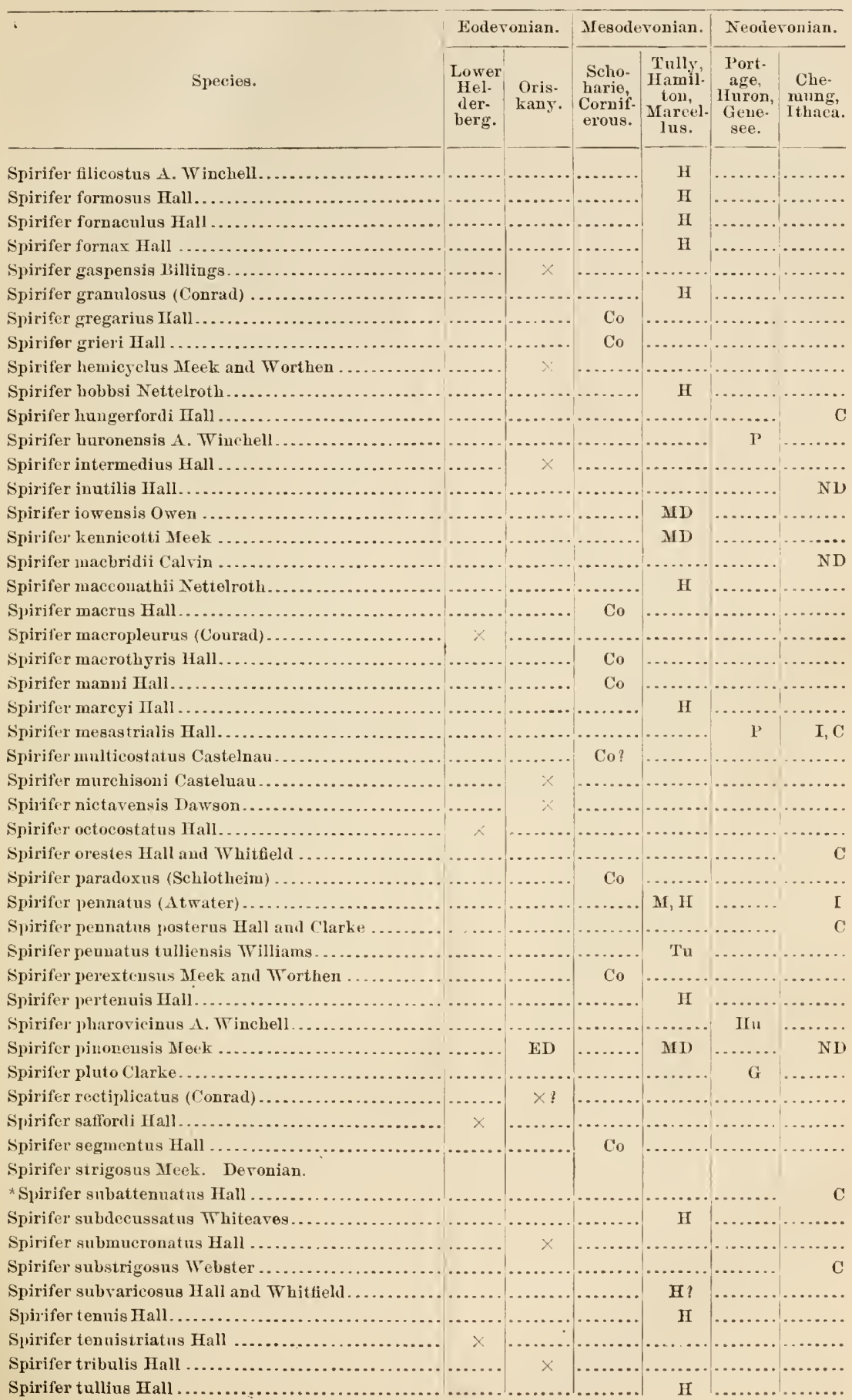


TAmer VT,-Deronian Brachiopoda-C'outiuned.

\begin{tabular}{|c|c|c|c|c|c|c|}
\hline \multirow[b]{2}{*}{ Speries. } & \multicolumn{2}{|c|}{ Eodevonian. } & \multicolumn{2}{|c|}{ Mresolevonian. } & \multicolumn{2}{|c|}{ Neodevoniatu. } \\
\hline & $\begin{array}{c}\text { Lower } \\
\text { Hel. } \\
\text { der. } \\
\text { berg. }\end{array}$ & $\begin{array}{l}\text { Oris- } \\
\text { kany. }\end{array}$ & $\begin{array}{c}\text { Selio. } \\
\text { harie, } \\
\text { Cornit- } \\
\text { erous. }\end{array}$ & $\begin{array}{c}\text { Tully, } \\
\text { Hamil- } \\
\text { ton, } \\
\text { Mareol. } \\
\text { lus. }\end{array}$ & $\begin{array}{l}\text { Port- } \\
\text { age, } \\
\text { Mninon, } \\
\text { Gene- } \\
\text { see. }\end{array}$ & $\begin{array}{l}\text { Che. } \\
\text { mung, } \\
\text { Ithace. }\end{array}$ \\
\hline er urbanus Calvin & & & & $\mathrm{H}$ & & \\
\hline fer varicosus Hall. & & & Co & & & \\
\hline fer whitneyi Hall. . & & & & $\cdots$ & & $\mathrm{C}$ \\
\hline fer willianisi IIall and Clarke. & & & & . & & $\mathrm{C}$ \\
\hline fer wortlenamns Schuehert & & & & 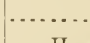 & & \\
\hline fer wortheni Hall..... & & & & H & & \\
\hline gocephalus burtini Defrane & & & & MU & & \\
\hline phalosia hystrienla Hall.. & & & & & & $\mathrm{C}$ \\
\hline pphalosia muricata Irall .... & & & & ... & & $\mathrm{C}$ \\
\hline phalosia radicans ( $A$. Winchell) ... & & & . & H & & .. \\
\hline ophalosia rockfordensis Hall ..... & & & & & $\ldots$. & $\mathrm{C}$ \\
\hline plualosia truneata (Hall) ..... & & & $\cdots$ & $\mathrm{M}, \mathrm{H}$ & $P$ & I \\
\hline pheodonta alveata Hall.... & & & $\mathrm{Co}_{0}$ & & & \\
\hline pheodonta areuata Hall.... & & & & & & $\mathrm{c}$ \\
\hline plreodonta beekii Hall...... & & . & $\cdots$ & ..... & & .. \\
\hline pheodonta hlainvillii (Billings)... & & ED & $\cdots$ & .... & & \\
\hline pheodonta callawayensis Swallow & & & & H & & \\
\hline pheodonta callosa Hall ........... & & & Co & & & \\
\hline pheodonta calvini Miller. & & & & & & C \\
\hline pheodonta canace Hall and Whitfield.. & & & & ... & & $\mathrm{C}$ \\
\hline pheodonta cincta $\mathrm{A}$. Winchell ......... & & & .... & $\mathrm{H}$ & & \\
\hline pheodonta concava Hall ........ & & & Co & H & & \\
\hline pheodonta (?) costata Owen.... & & & .... & $\mathrm{H}$ & & \\
\hline pheodonta erebristriata Hall ... & & $\cdots$ & Co & ... & & \\
\hline pheodonta demissa (Conrad) .............. & & -... & -... & $\mathrm{MD}$ & & ND \\
\hline pheodonta demissa imitata $\mathrm{A}$. Winchell.. & & ...... & .... & $\mathrm{H}$ & & \\
\hline pleodonta erratica $A$. Winchell .......... & & ...... & ..... & II & ... & .... \\
\hline pheodonta fieldeni Etheridge....... & & $\mathrm{ED}$ & .... & & & \\
\hline pheodonta galatea (Billings) .......... & ... & $\mathrm{ED}$ & ... & $\cdots$ & & \\
\hline beodonta hemispherica Hall ......... & & .... & Co & ... & & \\
\hline pheodonta inæequiradiata Hall......... & & … & $\mathrm{C}$, & ..... & & \\
\hline pheodonta inæquistriata (Conrad).... & & 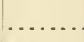 & $\mathrm{Co}$ & $\mathrm{M}, \mathrm{HI}$ & & \\
\hline pheodonta indenta (Conrad) .......... & & & . & ....... & & \\
\hline pheodonta interstrialis (Phillips)....... & & & 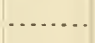 & $\mathrm{MD}$ & & \\
\hline pheodonta interstrialis (Vanuxem) ..... & & & & & $\ldots$ & I \\
\hline pheodonta jowensis Owen ............ & & & … & 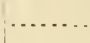 & $\ldots$ & $\mathrm{ND}$ ? \\
\hline pheodonta irene (Billings) .... & & & $\mathrm{Co}$ & & & \\
\hline phreodonta junia Hall .......... & & . & ..... & $\mathrm{H}$ & & \\
\hline pheodonta kemperi Swallow........ & & & & $\mathrm{H}$ & & \\
\hline opheodonta lincklæni Hall............ & & $x$ & & & & \\
\hline pheodonta macrostriata (Walcott)... & & ED & & & & \\
\hline pheodonta magnifica Hall....... & & $x$ & & & & \\
\hline pheodonta magniventra Hall...... & & $x$ & & & & \\
\hline heodonta mucronata (Conral)..... & & & & ...... & $\mathrm{P}$ & 1 \\
\hline heodonta navalis Swallow ............. & & & & II & & \\
\hline heodonta navalis boonensis Swallow & & & & II & & \\
\hline heodonta parva Owen... & & & $\cdots$ & II & & \\
\hline heodonta parva Hall .... & & & Co & & & \\
\hline lueodonta patersoni Mall...... & .... & $x$ & Co & ..... & & $\cdots$ \\
\hline heodonta perplana (Conrad).. & $\cdots$. & $x$ & Co & II & ....... & $\mathrm{I}, \mathrm{C}$ \\
\hline
\end{tabular}


TABLE VI.-Devonian Brachiopoda-Continued.

\begin{tabular}{|c|c|c|c|c|c|c|}
\hline \multirow[b]{2}{*}{ Species. } & \multicolumn{2}{|c|}{ Eoderonian. } & \multicolumn{2}{|c|}{ Mesodevonian. } & \multicolumn{2}{|c|}{ Neodoronian. } \\
\hline & $\begin{array}{l}\text { Lower } \\
\text { Hel- } \\
\text { der- } \\
\text { berg. }\end{array}$ & $\begin{array}{c}\text { Oris- } \\
\text { kany. }\end{array}$ & $\begin{array}{l}\text { Scho- } \\
\text { larie, } \\
\text { Cornif- } \\
\text { elous. }\end{array}$ & $\begin{array}{c}\text { Tull, } \\
\text { Hamil- } \\
\text { ton, } \\
\text { Marcel- } \\
\text { lus. }\end{array}$ & $\begin{array}{c}\text { Port- } \\
\text { age, } \\
\text { Huron, } \\
\text { Gene- } \\
\text { sce. }\end{array}$ & $\begin{array}{l}\text { Che- } \\
\text { mung, } \\
\text { Ithaca. }\end{array}$ \\
\hline Stropheodonta perplana tulliensis Williams & & & & Tu & & \\
\hline Stropheodonta planulata IIall .............. & $x$ & & & & & \\
\hline Stropheodonta plicata Hall................. & & & & II & & \\
\hline Stropheodonta tullia (Billings) ........ & & & Co & & & \\
\hline Stropleodonta variabilis Calvin .......... & $\cdots$ & & & & & \\
\hline Stropheodonta varistriata (Conrad)........... & $x$ & & & & & \\
\hline Stropheorlonta varistriata arata Hall........... & $x$ & & & & & \\
\hline Stropheodonta vaseularia Hall...... & & $x$ & & & & \\
\hline Strophomena (?) elongata Conrad...... & $x$ & & & & & \\
\hline Strophomena (?) gibhosa Conrad....... & & & Co & & & \\
\hline Strophonella ampla Hall............ & & & Co & & & \\
\hline Strophonella cæelata Hall .......... & & & & & & $\mathrm{C}$ \\
\hline Strophonella cavumbona Hall.......... & $x$ & & & & & \\
\hline Strophonella (?) conradi Hall........... & $x$ & & & & & \\
\hline Strophonella crassa Rowley ........................ & $\cdots$ & & & II & & \\
\hline Strophonella geniculata $($ Hall) ............. & $x$ & & & & & \\
\hline Strophonella headleyana Hall............ & $x$ & & & & & \\
\hline Strophonella leaveuworthana Hall ................ & $x$ & & & & & \\
\hline Strophonella punetulifera (Conrad) ................. & $x$ & & & & & \\
\hline Strophonella (?) radiata (Vanuxem) ........... & K & & & & & \\
\hline Strophonella reversa Hall...... & & & & & & $\mathrm{C}$ \\
\hline Strophonella schohariensis Castelnau. & $\cdots$ & & Co? & & & \\
\hline 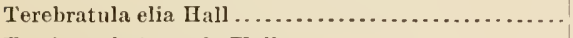 & ... & & 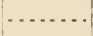 & $\mathrm{MI}$ & & \\
\hline Terebratula jucunda Hall .... . . . . . . . . . . . . . . & ... & & $\mathrm{Co}$ & . & & \\
\hline 'Terobratula ontario Hall ................. & $\cdots$ & & & $\mathrm{H}$ & & \\
\hline Terebratula traversensis A. Winchell....... & .. & & & II & & \\
\hline Trematospira costata Hall.......................... & $x$ & & & .. & & \\
\hline 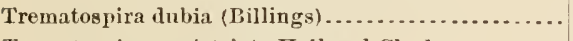 & $x$ & & & & & \\
\hline Trematospira equistriata IIall and Clarke........... & $x$ & & & $\cdots$ & & \\
\hline Trenatospira giblosa Hall .......... & $\cdots$ & & & $\amalg$ & & \\
\hline Trematospira hippolyto (Billings) .................. & $x$ & & & & & \\
\hline Trematospira (!) liniuscula $\mathrm{A}$. Winchell ............ & - & & & HI & & \\
\hline Trematospira maria (Billings) . .................... & $x$ & & & & & \\
\hline Trematospira multistriata Hall................ & $x$ & $x$ & & & & \\
\hline Trematospira perforata Hall. . . . . . . . . . . . . . . . . . . . & $x$ & & & & & \\
\hline Trematospira simplex Hall ...................... & $x$ & & & & & \\
\hline Trematospira tennesseensis Hall and Clarke ......... & $x$ & & & & & \\
\hline 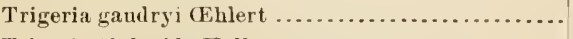 & $\cdots$ & $x$ & & & & \\
\hline Trigeria (?) lepida Hall . . ........................... & $\ldots$ & & & $\mathrm{H}$ & & \\
\hline 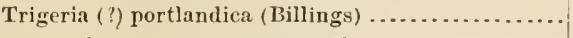 & $x$ & & & & & \\
\hline Tropidoleptus carinatus (Courad).............. & $\ldots$ & & & M, II & & \\
\hline Tropicloleptus occidens Hall ........... & & & & H & & \\
\hline Cocinalus abruptus (Hall) .......... & $x$ & & & & & \\
\hline Uncinulus campbellanıs (Hall) ..................... & $x$ & & & & & \\
\hline Uncinulus mutabilis Hall . . . . . . . . . . . . . . . . . . . . & $x$ & & & & & \\
\hline Uncinulus nobilis (Hall) $\ldots . . . . . . . . . . . . . .$. & $x$ & & & & & \\
\hline Uncinulus uucleolata (Hall) ............... & x & & & & & \\
\hline Uncinulus pyramidatus (Hall) ................. & $x$ & & & & & \\
\hline Uncinulus vellicata Hall . . ....................... & $\therefore$ & & & - & & \\
\hline Vitulina justulosa Hall .......................... & & & & II & & \\
\hline Whitfieldella (?) bisulcata (Tauuxem).. & X & & & & & \\
\hline
\end{tabular}


'TABLE VI.-Devonian firachiopoda-Continued.

\begin{tabular}{|c|c|c|c|c|c|c|}
\hline \multirow[b]{2}{*}{ Species. } & \multicolumn{2}{|c|}{ Gorlevonian. } & \multicolumn{2}{|c|}{ Mesodevonian. } & \multicolumn{2}{|c|}{ Neoderonian. } \\
\hline & $\begin{array}{l}\text { Lower } \\
\text { Hel- } \\
\text { der- } \\
\text { berg. }\end{array}$ & $\begin{array}{l}\text { Oris- } \\
\text { kally. }\end{array}$ & $\begin{array}{l}\text { Seho- } \\
\text { harie, } \\
\text { Cornit: } \\
\text { erons. }\end{array}$ & $\begin{array}{l}\text { Tully, } \\
\text { Hamil. } \\
\text { ton, } \\
\text { Marcel- } \\
\text { lus. }\end{array}$ & $\begin{array}{l}\text { Port- } \\
\text { age, } \\
\text { II uron, } \\
\text { Gene- } \\
\text { stee. }\end{array}$ & $\begin{array}{l}\text { Cho: } \\
\text { mung, } \\
\text { It liacit. }\end{array}$ \\
\hline Whitfieldella (?) harpalyce (Billings).... & $x$ & & & & & \\
\hline Zygospira (?) subconeara Meek and Worthen....... & $x$ & & & … & & $\cdots$ \\
\hline $\begin{array}{l}\text { Number of Devonian species, } 663 . \\
\text { Number of species in each division................. }\end{array}$ & 129 & 104 & 128 & 238 & 41 & 117 \\
\hline 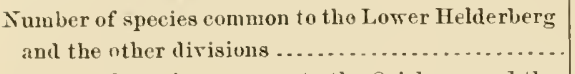 & & 8 & 2 & 2 & 1 & 2 \\
\hline 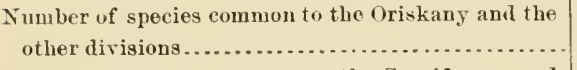 & 8 & & 15 & 7 & ") & 3 \\
\hline 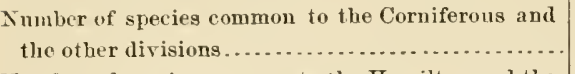 & 2 & 15 & $\cdots$ & 27 & 2 & 7 \\
\hline 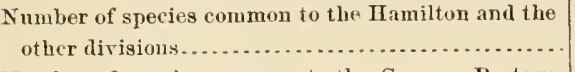 & 3 & 7 & 27 & -. & 12 & 22 \\
\hline 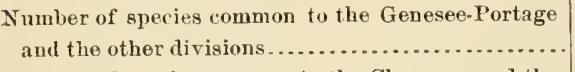 & 1 & 1 & 4 & 12 & & 17 \\
\hline 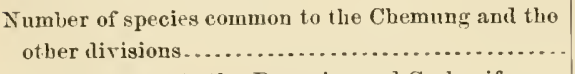 & 2 & $\frac{1}{2}$ & 7 & $\because 4$ & 17 & $\cdots$ \\
\hline $\begin{array}{l}\text { Species common to the Devonian and Carboniferous } \\
\text { Hystems, } 11 \text {. }\end{array}$ & & & & & & \\
\hline $\begin{array}{l}\text { Number of speeies passing from each division into } \\
\text { the Carboniferous............................... }\end{array}$ & 1 & 1 & 1 & 4 & 3 & 10 \\
\hline
\end{tabular}


TABLe VII.-Carboniferons and Permian Brachiopoda.

$[B=$ Burlington $; \mathbf{E C}=$ Eocarboniferous $; \mathrm{K}=$ Keokuk; Ka=Kaskaskia $\mathbf{S L}=$ St. Louis. Species preceded by an obelisk ( $f$ ) are found in the Deronian also.]

Acambona osagensis (Swallow)

Acambona prima $W$ hite

species.

A mbocelia minuta Thite.

Ambocolia planoconvexa (Shumard)

Athyris biloba (A. Winchell).

Athyris (?) corpulenta (A. Winchell)

Athyris densa Hall and Clarke.

Athyris hannibalensis (Swallow)

Athyris incrassata Hall.

Athyris interrarica McChesney.

Athyris (?) jacksoni (Swallow)

Athyris lamellosa (L'Eveille)

Athyris missouriensis (A. W inchell)

Athris monticola (White).

Athyris ohivensis (A. Winchell)

Atlyris papillioniformis McChesney

Athyris (?) perinflata McClesney

Athyris prouti (Swallow)

Athyris ultravarica McChesney

A ulacorhynchus millipunctata (Meok and Worthen).

Becheria daridsoni Hall and Clark $\theta$.

Camarophorella lenticularis (White aud Whitfield)....

Camarophoria (?) bisulcata Shumard.

Camarophoria caput-testudinis ( $W$ hite)

Camarophoria explanata (McChesnes)

Camarophoria occidentalis Miller

Camarophoria ringens (Swallow)

Camarophoria subcuneata Hall.

Camarophoria subtrigona Meek and Worthen

Camarophoria tluera Walcott.

Camarophoria (?) wortheni (Hall)

Camarotochia contracta Hall

Camarotøechia sagerana (A. Winchell)

iCamarotoeclia sa]pho Hall

Centronella (?) allii A. Winchell.

Centronella (?) crassicardinalis Whitfield

Centronella (?) flora A. Winchell.

Chouetes geniculato Whito.

Chonetes glabra Geinitz.

Chonetes granulifera Owen

Clonetes illinoiensis Worthen

Chonetes logani Norwool and Pratten

tChonetes loganj a urora Hall.

Chonetes loganensis Hall and Whitfield

Chonetes mesolobus Norwood and Pratten.

Chonetes michiganensis Sterens

Chonetes multicosta A. Winchell

Chonetes ornata Shumard.

Eocarboniferous.

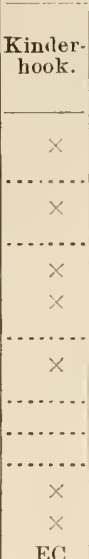

B

\begin{tabular}{|c|c|c|}
\hline $\begin{array}{l}\text { Keo- } \\
\text { kuk, } \\
\text { Bur- }\end{array}$ & $\begin{array}{c}\text { Kaskas- } \\
\text { kia, } \\
\text { St. Louis. }\end{array}$ & $\begin{array}{l}\text { Coul } \\
\text { Meas. } \\
\text { nres. }\end{array}$ \\
\hline
\end{tabular}

EC

K

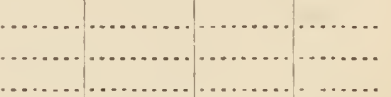

K

Ka

$\mathrm{K}$

B

Ka

B

K

K

EC

SL

SL

Meso- Neocarbon. carbon-

iferous. iferous.

nian. 
TABLe VII.-Carboniferous and Permian Brachioporda-Continued.

\begin{tabular}{|c|c|c|c|c|c|}
\hline \multirow{2}{*}{ Speeien. } & \multicolumn{3}{|c|}{ Eocarbuniferous. } & \multirow{2}{*}{$\begin{array}{c}\begin{array}{c}\text { Meso- } \\
\text { carluon- } \\
\text { iforons. }\end{array} \\
\begin{array}{c}\text { Coal } \\
\text { Meas- } \\
\text { ures. }\end{array}\end{array}$} & \multirow{2}{*}{$\begin{array}{c}\text { Neo } \\
\text { carbon } \\
\text { iforons } \\
\text { Per. } \\
\text { miall. }\end{array}$} \\
\hline & $\begin{array}{c}\text { Kinder- } \\
\text { hook. }\end{array}$ & $\begin{array}{l}\text { Keo- } \\
\text { kuk, } \\
\text { Bur- } \\
\text { lington. }\end{array}$ & $\begin{array}{l}\text { Kaskis- } \\
\text { kia, } \\
\text { St. Louis. }\end{array}$ & & \\
\hline \multicolumn{6}{|l|}{ Chonetes parva Shumard } \\
\hline \multirow{2}{*}{\multicolumn{6}{|c|}{$\begin{array}{l}\text { Chonetes permiana Shumard ......................... } \\
\text { Chonetes planumbona Heek and Worthen............ }\end{array}$}} \\
\hline & $\cdots$ & K & & & \\
\hline \multicolumn{6}{|l|}{ 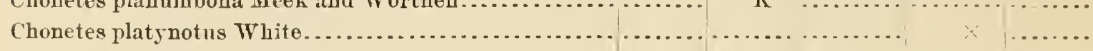 } \\
\hline \\
\hline \multicolumn{6}{|l|}{ 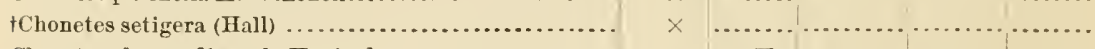 } \\
\hline \multicolumn{6}{|l|}{ Chonetes shumardiana de Koninek .................... } \\
\hline \multicolumn{6}{|l|}{ 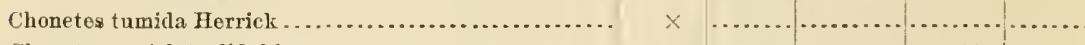 } \\
\hline \multicolumn{6}{|l|}{ Chonetes variolata d'Orbigny ......................... } \\
\hline \multirow{2}{*}{\multicolumn{6}{|c|}{$\begin{array}{l}\text { Chonetes verneuiliana Norwood and Pratten.. } \\
\text { Chouetes verneuiliana utahensis Meek........ }\end{array}$}} \\
\hline & . & .. & & $x$ & \\
\hline \multicolumn{6}{|l|}{ Chonopectus fischeri (Norwood and Pratten) ........... } \\
\hline \multicolumn{6}{|l|}{ Cleiothyris elintonensis (Swallow).................. } \\
\hline \multicolumn{6}{|l|}{ Cleiothyris crassicardinalis (White) $\ldots \ldots \ldots \ldots \ldots \ldots \ldots$} \\
\hline \multicolumn{6}{|l|}{ 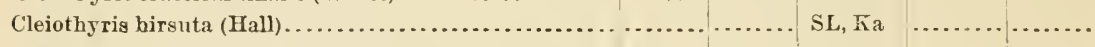 } \\
\hline \multicolumn{6}{|l|}{ Clelothyris missouriensis (Swallow) ... } \\
\hline \\
\hline \multirow{2}{*}{\multicolumn{6}{|c|}{ 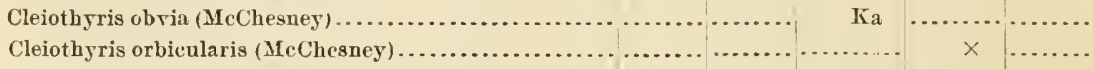 }} \\
\hline & & & & & \\
\hline Cleiothyris reflexa (Swallow)... & & & SL & & \\
\hline Cleiothyris roissyi (L'Eveille) .......... & . & K & SI, Ka & & \\
\hline Cleiothyris squamosa & & & SL & & \\
\hline esterensis Miller and Gurley ............... & $\cdots$ & & Ka & & \\
\hline Crania levis Keyes .................. . & $\times$ & & & & \\
\hline esta White and St. John ........ & & & & $x$ & \\
\hline 1.................... & & & & $x$ & \\
\hline bite $\ldots \ldots \ldots . . . . . . . .$. & $\cdots$ & $\mathrm{B}$ & & & \\
\hline leyi Gurley . ........................ & $x$ & & & & \\
\hline Crrptacanthia compacta White and St. John .... & & & & $\times$ & \\
\hline tCryp & $x^{\prime}$ & & & & \\
\hline ...... & $x$ & & & & \\
\hline tica Hall and Clarke ....... & $x$ & & & & \\
\hline 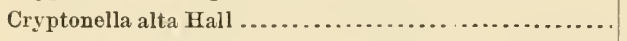 & $x$ & & & & \\
\hline Cyrtina acutirostris (Shumard).............. & $x$ & & & & \\
\hline Cyrtina b & ... & B & & & \\
\hline Cyrtina lachrymosa Hall and & $x$ & & & & \\
\hline Cyrtina neogenes Hall and Clarke ......... & ... & B & & & \\
\hline Cyrtina triplicata Simpson........... & $x$ & & & & \\
\hline Uerbya affinis Hall and Clarke ..... & & & & $x$ & \\
\hline Derbya bennetti Hall and Clarke..... & & & & $x$ & \\
\hline Derbya biloba Hall . . . . . . . . . . . . . . . . . . . & & & & $x$ & \\
\hline Derhy a broadheadi Hall and Clarke....... & & & & $x$ & \\
\hline Derbya (?) costatula Hall and Clarke...... & & & Ka & & \\
\hline Derbya crassa (Meek and Hayden).............. & & & & $x$ & \\
\hline Derbya cymbula Hall and Clarke .............. & & & & $x$ & \\
\hline Derbya kaskaskieusis (McChesney) .......... & & & Kal & & \\
\hline Derbya kookuk Hall ...................... & $x$ & K & & & \\
\hline Derbya pratteni (McChesney) & & & & $x$ & \\
\hline erbja robusta (Hall) . . ..... & & & & $x$ & \\
\hline Derbya ruginosa Hall and Clarke. & & $\mathrm{K}$ & & & \\
\hline
\end{tabular}


TABLE, VII.-Carboniferous and Permian Brachiopoda-Continued.

\begin{tabular}{|c|c|c|c|c|c|}
\hline \multirow{2}{*}{ Species. } & \multicolumn{3}{|c|}{ Evearboniferous. } & \multirow{2}{*}{$\begin{array}{c}\text { Meso- } \\
\text { carbon- } \\
\text { iferous. } \\
\text { Coal } \\
\text { Meas- } \\
\text { ures. }\end{array}$} & \multirow{2}{*}{$\begin{array}{c}\begin{array}{c}\text { Teo- } \\
\text { carhon } \\
\text { iferous }\end{array} \\
\begin{array}{c}\text { Per- } \\
\text { mian. }\end{array}\end{array}$} \\
\hline & $\begin{array}{l}\text { Kinder- } \\
\text { look. }\end{array}$ & $\begin{array}{c}\text { Keo- } \\
\text { kuk, } \\
\text { Bur- } \\
\text { lington. }\end{array}$ & $\begin{array}{l}\text { Kaskas- } \\
\text { kia, } \\
\text { St. Louis. }\end{array}$ & & \\
\hline ielasma bovidens (Morto & & & & $x$ & \\
\hline $\begin{array}{l}\text { Dielasma burlingtonensis White } \\
\text { Dielasma formosa Hall .......... }\end{array}$ & $x$ & & & & \\
\hline $\begin{array}{l}\text { Dielasma formosa Halt............. } \\
\text { Dielasma gorbyi M[iller ............. }\end{array}$ & & & SL & & \\
\hline Dielasma oborata Hall and Clarke.. & & $\kappa$ & & & \\
\hline Dielasma accidentalis (Miller) ......... & x & & & $\times ?$ & \\
\hline Dielasma (?) rowleyi (Worthen) .............. & 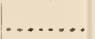 & $1 ;$ & & . & \\
\hline Dielasma sacculus (Martin) ...................... & & & & Y & \\
\hline Dielasma shumardana Miller.......... & & & Ka & $x$ & \\
\hline Dielasma turgida (Hall) ................ & & & & & \\
\hline Enteletes hemiplicata Hall............. & & & & 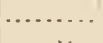 & \\
\hline 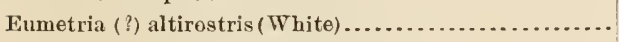 & & & & $x$ & \\
\hline Eumetria mareji (Slummard) . ...................... & & & & $\cdots$ & \\
\hline Eumetria mareyi costata Hall..... & & & 8 & . & \\
\hline Eumotria woosteri (White) ....... & & & Ka & ... & \\
\hline Glossina flabellula Hall and Clarko ................ & $x$ & & & $x ?$ & \\
\hline 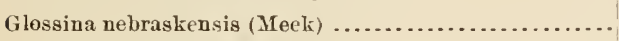 & & & & & \\
\hline Glossina sedaliensis (Miller) ................ & X & & & $x$ & \\
\hline Glossina warerlyeusis (Herrick) ....... & $x$ & & & & \\
\hline Harttiua anna (Hartt) . ................ & & & & ... & \\
\hline Fusterlia (?) meekana (Shumard) .... ....... & & & & $x$ & \\
\hline 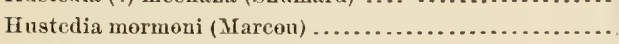 & & & & 火 & \\
\hline Hustedia (?) papillata (Shuuard) ....... & & & & $x$ & \\
\hline Hustedia (?) triaugularis (Miller)........... & $x$ & & & $x$ & \\
\hline Leiorhynchus booneuse (Shumard) .......... & & 13 & & & \\
\hline 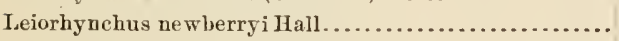 & $x$ & & & & \\
\hline †Leptaua rhomboidalis (Wilckens) .......... & $x$ & & & & \\
\hline Lingula atra Herrick . . .................. & $x$ & & & & \\
\hline Liugula carbonaria Shumard . . . . . . . . . . & & & & $\cdots$ & \\
\hline Lingula crawfordsvillensis Gurley.......... & .. & K & & $x$ & \\
\hline 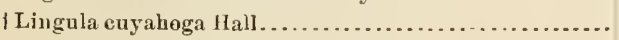 & $x$ & & & & \\
\hline 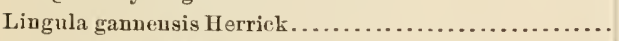 & $\hat{x}$ & & & & \\
\hline Lingula gorbyi Miller............. & $x$ & & & & \\
\hline Lingula balli White...................... & & & & & \\
\hline Lingula indianensis Miller and Gurles....... & $\ldots$. & K & & & \\
\hline Lingula meeki Herrick.................... & $\times$ & & & & \\
\hline Lingula melie Hall................ & $x$ & & & & \\
\hline Lingula meubranacea $\mathrm{A}$. Winchell ......... & $x$ & & & & \\
\hline Lingula mytiloides Sowerby ............. & & & & & \\
\hline Lingula paracletus Aall and Clarke.............. & $x$ & & & $x$ & \\
\hline Lingula parrishi Miller ...................... & & & & & \\
\hline Lingula tighti Herrick....... & & & & $x$ & \\
\hline Lingula umbonata Cox.............. & & & & $x$ & \\
\hline Lingula varsevienso Worthen . . . . . . . . . . . . & & & & $x$ & \\
\hline 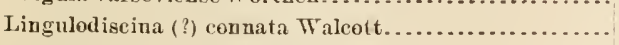 & & $\mathrm{EC}$ & & & \\
\hline Lingulodiscina newberryi Hall. . . . . . . . . . . . & & & & & \\
\hline Lingulodiscina pleurites (Meek) ... & & & & & \\
\hline Martinia glabra (Martin)........ & $x$ & & & & \\
\hline Martiuia glabra contracta Mcek and Worthen. & & & & $x$ & \\
\hline rrtinia lævigata (Swallow) & & & & & \\
\hline
\end{tabular}


'TABi.e VII.-Carboniferous and P'ermian Brachiopoda-Contimed.

\begin{tabular}{|c|c|c|c|c|c|}
\hline \multirow{2}{*}{ pecies. } & \multicolumn{3}{|c|}{ Eocarboniferous. } & \multirow{2}{*}{$\begin{array}{l}\text { Meso- } \\
\text { carbon. } \\
\text { ifinrous. } \\
\text { Cual } \\
\text { Meas- } \\
\text { mres. }\end{array}$} & \multirow{2}{*}{$\begin{array}{c}\text { Nio- } \\
\text { carbon } \\
\text { iferous } \\
\text { Per- } \\
\text { uían. }\end{array}$} \\
\hline & $\begin{array}{c}\text { Kinder- } \\
\text { hook. }\end{array}$ & $\begin{array}{l}\text { Koo. } \\
\text { kuk, } \\
\text { Bur- } \\
\text { lington. }\end{array}$ & $\begin{array}{l}\text { Kaskas. } \\
\text { Kia, } \\
\text { St. Louis. }\end{array}$ & & \\
\hline \multicolumn{6}{|l|}{ Mreekella occidentalis (Newberry)... } \\
\hline \multicolumn{6}{|l|}{ 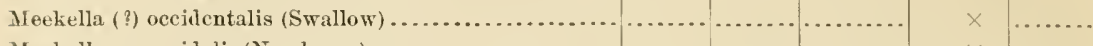 } \\
\hline \multicolumn{6}{|l|}{ 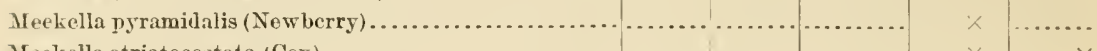 } \\
\hline \multicolumn{6}{|l|}{ 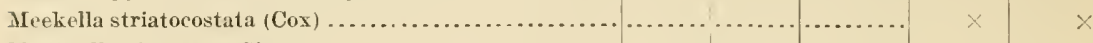 } \\
\hline \multicolumn{6}{|l|}{ 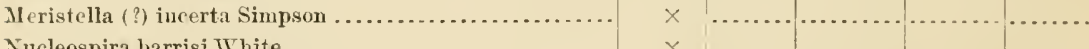 } \\
\hline \multirow{2}{*}{\multicolumn{6}{|c|}{ 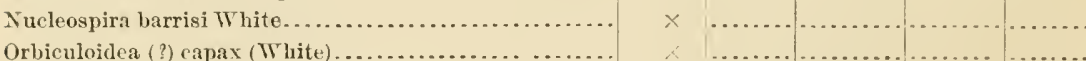 }} \\
\hline \multirow{2}{*}{\multicolumn{6}{|c|}{ 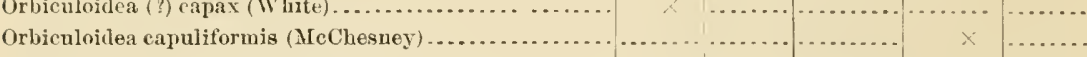 }} \\
\hline & & & & & \\
\hline \multicolumn{6}{|l|}{ Orbiculoidea convexa (Shumard).. } \\
\hline \multicolumn{6}{|l|}{ Orbiculoidea gallaheri (A. Winchell) $\ldots \ldots \ldots \ldots \ldots \ldots . . . . . . . .}$. \\
\hline \multirow{2}{*}{\multicolumn{6}{|c|}{ 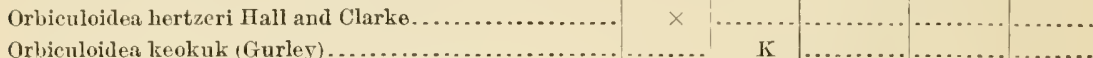 }} \\
\hline & & K & & & \\
\hline \multicolumn{5}{|l|}{ 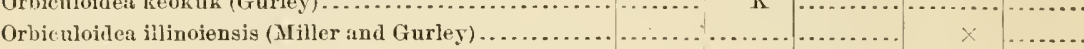 } & \\
\hline \multicolumn{6}{|l|}{ Orbiculoidea magnifica Herrick ..................... } \\
\hline \multicolumn{6}{|l|}{ Orbiculoidea manbattenensis (Meek and Hayden) ........ } \\
\hline \multicolumn{6}{|l|}{ Orbiculoidea missouriensis (Shumard) .................. } \\
\hline \multicolumn{6}{|l|}{ Orbiculoidea (?) munda (MIiller aud Gurley) ............. } \\
\hline \multicolumn{6}{|l|}{ Orbiculoidea nitida (Philli]ıs) ... } \\
\hline Orbiculoiden patellaris $(A$. Winchell) $\ldots \ldots \ldots \ldots \ldots \ldots . . . . .$. & $x$ & & & & \\
\hline Orbiculoidea saffordi (A. Winchell) ................. & EC & & & & \\
\hline rbiculoidea sampsoni (Miller) ............... & $x$ & & & ... & \\
\hline Orbiculoidea subtrigonalis ( & & & & $x$ & \\
\hline rbiculoidea tenuilincata (Meek and Hayden)... & 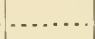 & & & $x$ & \\
\hline rbiculoidea utahensi & & & & $x$ & \\
\hline rbiculoidea varso & ... & K & & & \\
\hline Orthis (?) flara A. Wincl & $x$ & & & & \\
\hline rthothetes crenistrins ( & ... & $\mathrm{EC}$ & & . & \\
\hline rthothetes deside & $x$ & & & & \\
\hline (n) & $x$ & & & & \\
\hline Orthothetes inflatus (White and Whitfield)........... & $x$ & & & & \\
\hline Orthothetes lens (White) ......... & $x$ & & & & \\
\hline rthothetes nmbraculum $\lambda$ uthors .......... & $\cdots$ & $\mathrm{EC}$ & & $\because$ & \\
\hline la (?) clava (Norwood and Pratten)...... & . & & & $x$ & \\
\hline all $\ldots \ldots \ldots \ldots \ldots \ldots \ldots \ldots \ldots . . .6$. & $x$ & & & & \\
\hline roductella concentriea (Hall)............ & $x$ & & & & \\
\hline †Productella lachrymosa stigmata IIall....... & $x$ & & & & \\
\hline rodnctella pyxidata IIall....... & $x$ & & & & \\
\hline all.................. & $x$ & & & & \\
\hline † Productella speciosa Hall.................... & $x$ & & & & \\
\hline Productns alternatus Norwood and Pratten... & & $\mathbf{K}$ & & & \\
\hline roductus altonensis Norwood and Pratten... & & & & 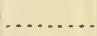 & \\
\hline I'roductus auriculatus Swallow............ & & & & $x$ & \\
\hline roductus bisinuatus Hall.................. & & & $S \mathrm{~L}$ & & \\
\hline Productus blairi Miller. . ......... & $x$ & & & & \\
\hline Productus boliviensis d'Orbigny........ & & & & $x$ & \\
\hline Productus boonensis Swallow ............ & & & & $x$ & \\
\hline Productus boonensis elevata Swallow ....... & & & & $x$ & \\
\hline Productus buchianus de Koninck........... & & & & $x$ & \\
\hline roduetns burlingtonensis 1Iall. . & & B & & & \\
\hline Productus carbonarius de Koninck. Ca & & & & & \\
\hline
\end{tabular}


Table VII.-Carboniferous and Permian Brachiopoda-Continued.

Productus confragosus Conrad.

Productus cooperensis Swallow

Productus cora d'Orbigny

Productus cora mogoyoni Marcon.

Prodnctus coræe formis Swallow

Productus costatoides Swallow

Productus costatus de Koninck.

Productus curtirostratus A. Winchell

Productus delawari Marcou.

Productus depressus Swallow.

Productus dolorosus A. Wiuchell.

Productus duplicostatus A. Winchell

Productus fasciculatus Michesney

Productus fentonensis Swallow

Productus fimbriatus Sowerby.

Productus flexistrius McCoy

Productus giganteus (Martin).

Productus gracilis A. Winchell

Productus gradatus Swallow

Productus granulosus Phillips

Productus hepar Morton

Productus hildrethanus Norwood and Pratten

Productus indianensis Hall.

Productus inflatus MeChesney.

Productus ivesi Newberry.

Productus levicostus White.

Productus lasallensis Worthen

Productus latissimus Sowerby

Productus leuchtenbergensis de Koninck.

Productus longispinus Sowerby?

Productus longus Mreek. Carboniferous.

Productus magnicostatus Swallow

Productus magnus Meek and Worthen

Productus margaritaceus Phillips.

Productus marginicinctus Prout

Productus mesialis Hall

Productus mesolobus Phillips. Carboniferous.

Productus mexicanus Shumard.

Productus morbillianus A. Winchell

\begin{tabular}{|l|c|c|} 
Eocarboniferons. & $\begin{array}{c}\text { Meso- } \\
\text { carbon- } \\
\text { iferous. }\end{array}$ & $\begin{array}{c}\text { Neo- } \\
\text { carbou- }\end{array}$ \\
iferous.
\end{tabular}

Productus multistriatus Meek. Carboniferous.

Productus muricatus Norwood and Pratten.

Productus nanus Meek and Worthen

Productus nebrascensis $O$ weu

Productus novadensis Meek

Proluctus newberryi Hall

Productus newberryi annosus Herrick

Productus nodocostatus Herrick.

Productus nodosus Newberry.

Productus norwoodi Swallow.

Productus occidentalis Nemberry.

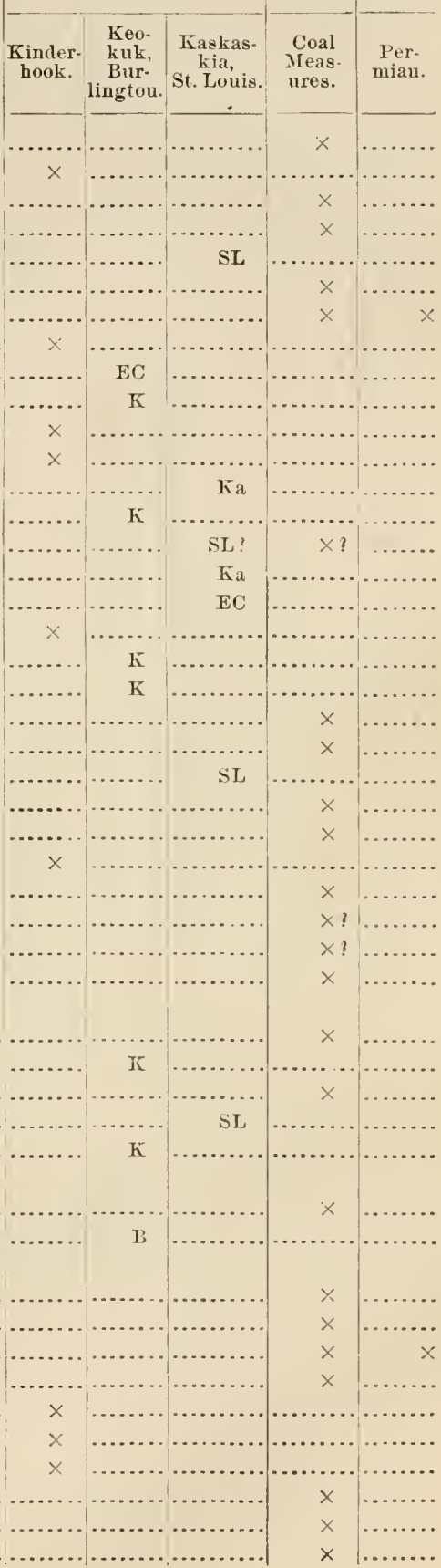


Tames VII.-Carboniferous and Permian Brachiopoda-Continued.

\begin{tabular}{|c|c|c|c|c|c|}
\hline \multirow[b]{2}{*}{ Species. } & \multicolumn{3}{|c|}{ Eocarboniferous. } & \multirow{2}{*}{\begin{tabular}{|c}
$\begin{array}{c}\text { Meso- } \\
\text { carbon- } \\
\text { iferous. }\end{array}$ \\
$\begin{array}{c}\text { Coal } \\
\text { Meas- } \\
\text { ures. }\end{array}$
\end{tabular}} & \multirow{2}{*}{$\begin{array}{c}\begin{array}{c}\text { Neo- } \\
\text { carbon- } \\
\text { iferous. }\end{array} \\
\begin{array}{c}\text { Per- } \\
\text { mian. }\end{array}\end{array}$} \\
\hline & $\begin{array}{l}\text { Kinder- } \\
\text { hook. }\end{array}$ & $\begin{array}{c}\text { Keo- } \\
\text { kuk, } \\
\text { Bur- } \\
\text { lington. }\end{array}$ & $\begin{array}{c}\text { Kaskas- } \\
\text { kia, } \\
\text { St. Louis. }\end{array}$ & & \\
\hline \multicolumn{6}{|l|}{ 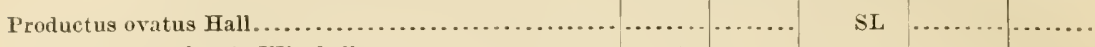 } \\
\hline 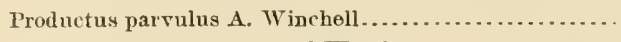 & $x$ & & ...... & & \\
\hline Productus parvus Meek and Wortheu....... & & & Ka & .... & \\
\hline Productus pertenuis Meek.............................. & & & $\ldots \ldots$ & $x$ & \\
\hline Productus phillipsi Nor wood and Pratten. Carboniferous. & & & & & \\
\hline Productus pileolus Shumard...................... & & & & $x$ & \\
\hline Productus pocillum Morton....................... & & & ...... & $x$ & \\
\hline Productus popii Shımard............. & & & & $x$ & \\
\hline Productus punctatus (Martin)....... & & & & $x$ & \\
\hline Productus pustulosus Phillips................. & & & & $\times$ & \\
\hline Productus raricostatus Herrick................. & $x$ & & & -.. & \\
\hline Productus rushvillensis Herrick............... & $x$ & & & $\cdots$ & \\
\hline Productus scabriculus (Martin).............. & & & $\mathrm{EC}$ & $x$ & \\
\hline Productus scitulus Meek and Worthen................ & & $\cdots$ & SL & …. & \\
\hline 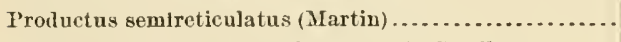 & & k & $S L$ & $\times$ & $x$ \\
\hline Produetus semireticulatus kansasensis Swallow....... & & & $\cdots$ & $x$ & \\
\hline Productus semistriatus Meek ................... & & & $\cdots$ & $x$ & \\
\hline Productus subhorridus Meek. Carboniferous. & & & & & \\
\hline Productus swallovi Beecher................... & & & $\mathrm{Ka}$ & & \\
\hline Productus symmetricns McChesney .............. & & & $\cdots \cdot$ & $x$ & \\
\hline Productus tenuicostatus Hall $. . . \ldots \ldots \ldots \ldots \ldots \ldots . . . . .$. & & & $S L$ & ..... & \\
\hline Productus undiferus de Koninck.......... & & & & $x$ & \\
\hline Productus viminalis White............ & & B & & & \\
\hline Productus wortheni Hall................... & $\ldots$ & $\pi$ & - & … & \\
\hline 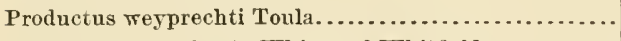 & & & & $x$ & \\
\hline Ptychospira sexplicata White and Thitfield......... & $x$ & & & $\ldots$ & \\
\hline Pugnax dawsonianus (Davidson)............. & & & ... & $x$ & \\
\hline Pugnax globulina (Davidson) ................ & & & - . & $x$ & \\
\hline Pugnax grosrenori Hall................... & & $\cdots$ & SL & & \\
\hline Pugnax mutatus Hall ....................... & & 太 & SL & & \\
\hline Pugnax ottumwa (White) ....................... & & & SL & $\cdots$ & \\
\hline Pugnax pugnus missouriensis (Shumard) ......... & $x$ & & & & \\
\hline 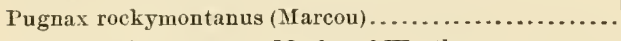 & & & & $x$ & \\
\hline Pugnax striatocostatus (Meek and Worthen) ........ & $x$ & & & & \\
\hline Pugnax swallovanus (Shumard)........... & & & & $x$ & \\
\hline Pugnax utah (Marcou) ........................ & $\cdots$ & & & $\times$ & \\
\hline Reticularia cooperensis (Swallow).................. & $x$ & & & ... & \\
\hline Reticularia guadalupensis (Shumard)......... & & & & $x$ & \\
\hline Reticularia perplexa (McChesney) ............. & & & & $x$ & \\
\hline Reticularia perplexa striatolineata (Swallow). & & & & $x$ & \\
\hline Reticularia pseudolineata (Hall) ............... & & $\mathbf{B}, \mathbf{K}$ & & & \\
\hline Reticularia setigera (Hall) .................... & & & Ka & & \\
\hline Reticularia (?) temeraria (Miller).......... & $\cdots$ & $B$ & & & \\
\hline Reticularia tenuispinata (Herrick)........... & $x$ & & & & \\
\hline Reticularia translata (Swallow) .............. & & & Ka & & ..... \\
\hline Retzia (?) circularis Miller .............. & $x$ & & & & \\
\hline Retzia (?) plicata Miller ........................... & $x$ & & & & \\
\hline Retzia (?) popeana Swallow.................. & $x$ & & & & \\
\hline Rhipirlomella burlingtonensis Hall.... & & B & & & \\
\hline Rhipidomella clarkeusis (Swallow) . & & K & & & \\
\hline
\end{tabular}


TABLF VII.-Carboniferous and Permian Brachiopoda-Continned.

\begin{tabular}{|c|c|c|c|c|c|}
\hline \multirow[b]{2}{*}{ Species. } & \multicolumn{3}{|c|}{ Eocarboniferous. } & \multirow{2}{*}{$\begin{array}{c}\begin{array}{c}\text { Meso- } \\
\text { carbon- } \\
\text { iferous. }\end{array} \\
\begin{array}{c}\text { Coal } \\
\text { Meas- } \\
\text { ures. }\end{array}\end{array}$} & \multirow{2}{*}{$\begin{array}{c}\begin{array}{c}\text { Neo- } \\
\text { carbon } \\
\text { iferons }\end{array} \\
\begin{array}{c}\text { Per- } \\
\text { mian. }\end{array}\end{array}$} \\
\hline & $\begin{array}{l}\text { Kinder- } \\
\text { hook. }\end{array}$ & $\begin{array}{c}\text { Keo- } \\
\text { kuk, } \\
\text { Bur- } \\
\text { lington. }\end{array}$ & $\begin{array}{l}\text { Kaskas- } \\
\text { kia, } \\
\text { St. Louis. }\end{array}$ & & \\
\hline \multicolumn{6}{|l|}{ Rhipidomella dalyana (Miller)... } \\
\hline \multicolumn{6}{|l|}{ Rhipidomella dubia Hall.............................. } \\
\hline \\
\hline \multirow{2}{*}{\multicolumn{6}{|c|}{$\begin{array}{l}\text { Rhipidomella missouriensis (Swallow)................. } \\
\text { Rhipidomella nevadensis (Meek). Carboniferous. }\end{array}$}} \\
\hline & & & & & \\
\hline \multicolumn{6}{|l|}{ 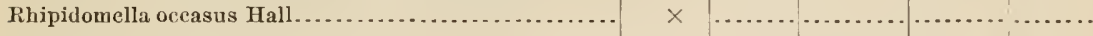 } \\
\hline \multicolumn{6}{|l|}{ 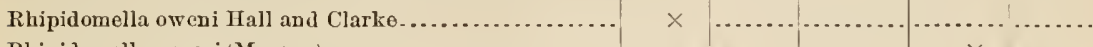 } \\
\hline \multicolumn{6}{|l|}{ 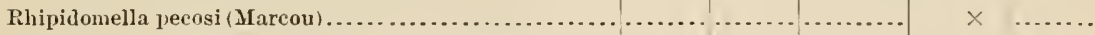 } \\
\hline \multicolumn{6}{|l|}{ Rhipidomella subelliptica (White and Whitfield)........ } \\
\hline \multicolumn{6}{|l|}{ 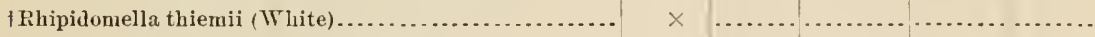 } \\
\hline \multicolumn{6}{|l|}{ Rhipidomella vanuxemi pulchella Herrick............... } \\
\hline \multicolumn{6}{|l|}{ 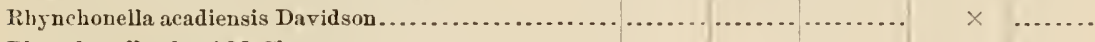 } \\
\hline \multicolumn{6}{|l|}{ Rhynchonella algeri McChesney . . . . . . . . . . . . . . . . . } \\
\hline \multicolumn{6}{|l|}{ 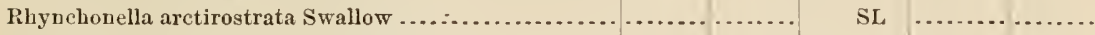 } \\
\hline \multicolumn{6}{|l|}{ Rhynchonella barquensis A. Winchell................. } \\
\hline \multicolumn{6}{|l|}{ Rhynchonella camarifera A. Winchell.................. } \\
\hline \multicolumn{6}{|l|}{ Phynchonella carbonaria McChesney ................ } \\
\hline Rhynchonelli cooperensis Shumard................. & $x$ & & & & \\
\hline Rhynchonclla eurekensis $W$ alcott............ & & & $\mathrm{EC}$ & & \\
\hline Rhynchonella evangeliua Hartt...... & & & & $x$ & \\
\hline Rhynchouclla guadalupe Shumard.... & & & & $x$ & \\
\hline Rhynchonella lieteropsis $A$. Winchell... & $\times$ & & & & \\
\hline Rhynchonella hubbardi $\Lambda$. Winchell............. & $x$ & & & & \\
\hline Rhyıchonella ida Hartt. . . . . . . . . . . . . & & & & $x$ & \\
\hline Rhynchonella illinoisensis Worthen...... & & & & $x$ & \\
\hline Rhynchovella indentata Slumard.......... & & & & $x$ & \\
\hline Rhynchonella macra Hall ..................... & . & & SL & & \\
\hline Rhynchonella medialis Simpson............... & $x$ & & & & \\
\hline Rhynchovella metallica Whito....... & & & & $x$ & \\
\hline Rlygnchouella micropleura A. Winchell... & x & & & & \\
\hline Rhynchouclla obsolescens Hall...... & $x$ & & & & \\
\hline Rhynchonella opposita White and Whitfield........ & $x$ & & & & \\
\hline Rhynchonella jerrostellata Swallow ...... & . & & SL & & \\
\hline Rhynchonella persinuata $\mathrm{A}$. Winchell ........... & $x$ & & & & \\
\hline Rhynchonella plenrodon (Phillips).............. & $\cdots$ & & & x & \\
\hline Rhynchonella ricinula Hall ................. & & & SL & & \\
\hline 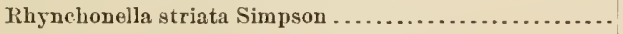 & $x$ & & & & \\
\hline Rhynchonella subcircularis A. Winchell..... & $x$ & & & & \\
\hline Rhynchonella tetraptyx A. Winchell........... & $x$ & & & & \\
\hline Rhynchonella texana Shumard ............... & & & & $x$ & \\
\hline 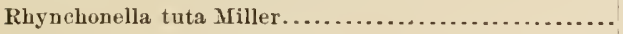 & $\ldots$ & $B$ & & & \\
\hline Rhynchonella unica A. Winchell................. & $x$ & & & & \\
\hline Rhynchonella whitii A. Winchell ......... & $x$ & & & & \\
\hline Rhynchopora pustulosa (White) ................ & $x$ & & & & \\
\hline Rhynchospira (?) ashlaudensis Herrick............ & $x$ & & & & \\
\hline Rhynchospira seansa Hall aud Clarke.............. & $x$ & & & & \\
\hline Romiugerina julia ( $A$. Winchell) ....... & $x$ & & & & \\
\hline Schizophoria resupinata (Martin).. & & $\mathrm{EC}$ & & & \\
\hline Schizophoria resupinoides (Cox) .... & & & & $x$ & \\
\hline Schizophoria swallovi Hall ....... & & & & & \\
\hline
\end{tabular}


ТАнL. VII.-Carboniferous and I'ermian Brachiopoda-Continned.

\begin{tabular}{|c|c|c|c|c|c|}
\hline \multirow[b]{2}{*}{ Sprecies. } & \multicolumn{3}{|c|}{ Eocarboniferous, } & \multirow{2}{*}{$\begin{array}{l}\text { Meso- } \\
\text { carlion- } \\
\text { iferous. } \\
\text { Coal } \\
\text { Meas. } \\
\text { ures. }\end{array}$} & \multirow{2}{*}{ 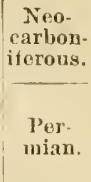 } \\
\hline & $\begin{array}{l}\text { Kinter- } \\
\text { hook. }\end{array}$ & $\begin{array}{c}\text { Kón- } \\
\text { knk, } \\
\text { Bur- } \\
\text { lingfon. }\end{array}$ & $\begin{array}{l}\text { Kaskas- } \\
\text { kia, } \\
\text { St. Louis. }\end{array}$ & & \\
\hline Seminnla argentea (Sliepaud). & & & & $x$ & $x$ \\
\hline Seminula caput-serpentis (Swallow) ......... & & & & $x$ & \\
\hline Seminula charitonensis (swallow).............. & ... & & & $x$ & … \\
\hline 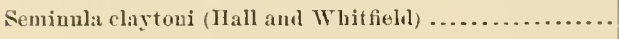 & $x$ & & & $\cdots$ & \\
\hline Scminula dawsoni Hall and Clarke......... & & & & $x$ & \\
\hline Seminula formosa (Swallow) ........ & & K & & .... & \\
\hline Seminula hawni (Swallow).............. & & $\cdots$ & & $\times$ & ... \\
\hline Seminula maconensis (Swallow)............... & & $\cdots \cdot$ & …. & $x$ & ... \\
\hline Seminula parva (Srallow) .................... & & $\pi$ & & & \\
\hline Seminula persinnata (Meek). Carboniferous. & & & & & \\
\hline Seminnla (?) plattensis (Swallow) ........... & & & & $\times$ & \\
\hline 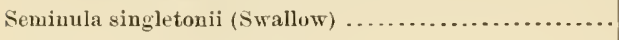 & & & … & $x$ & \\
\hline SenimnIa subquadrata (Hall) .................. & & & Ka & & \\
\hline Seminula trinuclea Irall. .................... & & & SL & $\cdots$ & \\
\hline Seminula wasatchensis (White).... & & & & $x$ & \\
\hline Spirifer acuticostatus de Koninck............ & & & & $x$ & \\
\hline Spirifer agelains Meek $\ldots . \ldots \ldots \ldots \ldots \ldots \ldots \ldots \ldots$ & ... & $\mathrm{EC}$ & & & \\
\hline Spirifer albapinensis 11 all and $\pi$ hitfielıl........... & $x$ & .......... & & & \\
\hline Spirifer annectans Walcott.................. & ........ & EC & & & \\
\hline Spirifer biplicatus Hall .......................... & $x$ & & & & \\
\hline Spirifer boonensis Swallow................. & 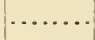 & .. & & $\times$ & \\
\hline Spirifer eameratus Morton ............... & & & & $x$ & \\
\hline Spipifer cameratus percrassns Swallow....... & & & & $x$ & \\
\hline Spirifer centronatus A. Winchell.............. & $x$ & & & & \\
\hline Spirifer clavatulus MeChesuey . . ............ & $\cdots$ & B & & & \\
\hline Spirifer deltoidens Herrick..................... & $x$ & & & & \\
\hline 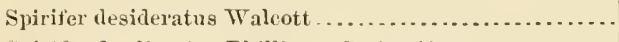 & & $\mathrm{EC}$ & & & \\
\hline Spirifer duplicostrus Phillips. Carboniferons. & & & & & \\
\hline Spirifer fastigatus Morton. Carboniferous. & & & & & \\
\hline Spirifer (?) fimbriatus Morton . ............. & & & & $x$ & \\
\hline Spirifer forbesi Norwood and Pratten......... & & B & & & \\
\hline Spirifer fultonensis Worthen........ & & & & $x$ & \\
\hline Spirifer grimesi Hall................. & $x$ & B & & & \\
\hline Spirifer imbrex Hall .................. & & B & & & \\
\hline Spirifer incertus Hall ..................... & & B & ........ & & \\
\hline Spirifer inerebescens Hall. ................... & & & Ka & & \\
\hline Spirifer increbescens americanus Swallow ........... & & ... & Ka & & \\
\hline Spirifer increbescens transversalis Fall .............. & & ... & Ka & & \\
\hline Spirifer kelloggi Swallow ................... & & $\mathrm{K}$ & & & \\
\hline Spirifer keokuk Hall...................... & & K & & & \\
\hline Spirifer keoknk shelbyensis Swallow ........... & & & SL & & \\
\hline Spirifer lateralis Hall ...................... & & & SL & & \\
\hline Spirifer latior Swallow................ & $\times$ & & & & \\
\hline Spirifer leidyi Norwood and Pratten............. & & & SL & & \\
\hline Spirifer leidyi chesterensis Swallow............... & & & Ka & & \\
\hline Spirifor leidyi merimacensis Swallow .......... & & & SL & & \\
\hline Spirifer littoni Sirallow ................ & & $\cdots$ & SL & & $\cdots$ \\
\hline Spirifer logani Hall ........................... & & 爪 & & & \\
\hline Spirifer marcoui Waagen ....................... & & & & $x$ & $\cdots$ \\
\hline pirifer marionensis shumard & & & & & \\
\hline
\end{tabular}


Table VII.-Carboniferous and Permian Brachiopola-Continued.

\begin{tabular}{|c|c|c|c|c|c|}
\hline \multirow{2}{*}{ Species. } & \multicolumn{3}{|c|}{ Eocarboniferous. . } & \multirow{2}{*}{$\begin{array}{c}\text { Meso- } \\
\text { earbon- } \\
\text { iferons. } \\
\begin{array}{c}\text { Coal } \\
\text { Meas. } \\
\text { ures. }\end{array}\end{array}$} & \multirow{2}{*}{$\begin{array}{c}\begin{array}{c}\text { Neo- } \\
\text { earbon- } \\
\text { iferous. }\end{array} \\
\begin{array}{c}\text { Per- } \\
\text { mian. }\end{array}\end{array}$} \\
\hline & $\begin{array}{l}\text { Kinder- } \\
\text { hook. }\end{array}$ & $\mid \begin{array}{c}\text { Keo- } \\
\text { kuk, } \\
\text { Bur- } \\
\text { lington. }\end{array}$ & $\begin{array}{c}\text { Kaskas- } \\
\text { kia, } \\
\text { St. Louis. }\end{array}$ & & \\
\hline \multirow{2}{*}{\multicolumn{6}{|c|}{$\begin{array}{l}\text { Spirifer meeki Swallow } \ldots \ldots \ldots \ldots \ldots \ldots \ldots \ldots \ldots \ldots \\
\text { Spirifer mexicanus Shumard } \ldots \ldots \ldots \ldots \ldots \ldots \ldots \ldots \ldots \ldots \ldots \ldots \ldots\end{array}$}} \\
\hline \multirow{2}{*}{\multicolumn{6}{|c|}{ 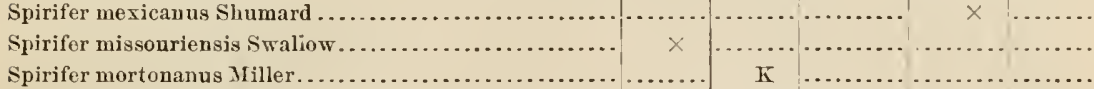 }} \\
\hline & & & & & \\
\hline \multirow{2}{*}{\multicolumn{6}{|c|}{ 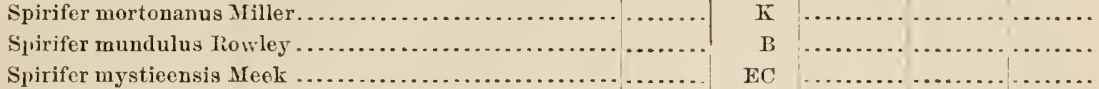 }} \\
\hline & .. & & & & \\
\hline \multirow{2}{*}{\multicolumn{6}{|c|}{ 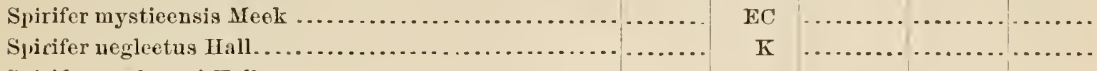 }} \\
\hline \multirow{2}{*}{\multicolumn{3}{|c|}{ 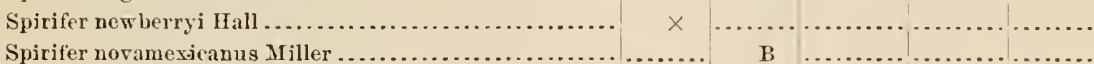 }} & & & \\
\hline \multirow{2}{*}{\multicolumn{6}{|c|}{$\begin{array}{l}\text { Spirifer novamexieanus Mriller ........................... } \\
\text { Spirifer oregonensis Shumard ........................... }\end{array}$}} \\
\hline & & & & & \\
\hline \multirow{2}{*}{\multicolumn{6}{|c|}{$\begin{array}{l}\text { Spirifer osagensis Swallow............................. } \\
\text { Spirifer ovalis Phillips. Carboniferons. }\end{array}$}} \\
\hline & & & & & \\
\hline \multicolumn{6}{|l|}{ 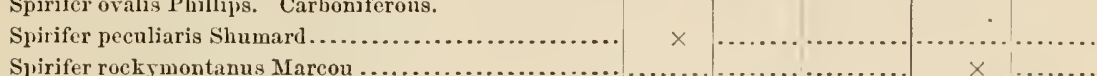 } \\
\hline \multicolumn{6}{|l|}{ Spirifer rockymontanus Marcou ..................... } \\
\hline \multicolumn{6}{|l|}{ Syirifer rostellatus Hall............................... } \\
\hline \multicolumn{6}{|l|}{ Spirifer rostratus Morton ............................. } \\
\hline \multicolumn{6}{|l|}{ Spirifer scobina Meek. Carboniferous. } \\
\hline \multirow{2}{*}{\multicolumn{6}{|c|}{ 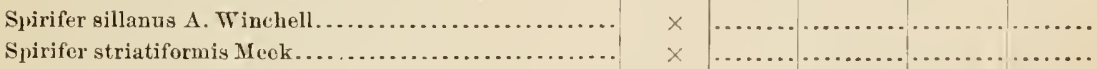 }} \\
\hline \multirow{2}{*}{\multicolumn{4}{|c|}{ 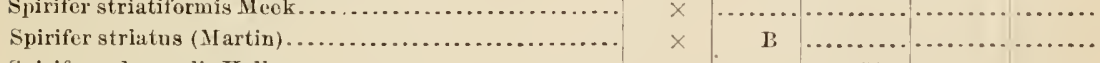 }} & & \\
\hline & $x$ & B & & & \\
\hline \multicolumn{6}{|l|}{ Spirifer subæqualis Irall . . . ......................... } \\
\hline \multicolumn{6}{|l|}{ ispirifer subattenuatus Hall ......................... } \\
\hline \multicolumn{6}{|l|}{ Spirifer subeardiformis Hall. } \\
\hline Spirifer suborbienlaris $\mathrm{Ha}$ & & $\mathrm{K}$ & & & \\
\hline Spirit & $x$ & & & & \\
\hline Spirif & & & & $x$ & \\
\hline Spirif & $x$ & & & & \\
\hline Splri & 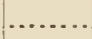 & K & SL & & \\
\hline Spiri & ... & K & & & \\
\hline Spiri & & & $\cdots$ & $x$ & \\
\hline Spiri & $\cdots$ & & $\mathrm{EC}$ & & \\
\hline Spir & $x$ & & & & \\
\hline Spir & $x$ & & & & \\
\hline Syir & $x$ & & & & \\
\hline Spiri & $x$ & & & & \\
\hline wley ............. & $x$ & & & & \\
\hline umard ............. & & & & $x$ & \\
\hline Spiriferina biuacuta $\mathrm{A}$. Winchell ........ & $\cdots$ & $\mathrm{B}$ & & & \\
\hline Spiriferina clarksvillensis & $x$ & & & & \\
\hline Spiriferina eristata & & & & $x$ & \\
\hline Spiriferina depressa Herriek. & $x$ & & & & \\
\hline Spiriferina gonior & & & & $x$ & \\
\hline Spiriferina norwoodana (Hall) & & & SL & & \\
\hline Spiriferina octoplicata (Sowerl & & & & $x$ & \\
\hline Spiriferiua $p$ & & & & $x$ & \\
\hline Spiriferina solidiros & $x$ & & & & \\
\hline Spirif & & & Ka & & \\
\hline Spiriferina sub & & $\mathrm{K}$ & & & \\
\hline & & B & & & \\
\hline & & & & & \\
\hline
\end{tabular}


TABLe VII.-Carboniferous and Permian Brachiopoda-C'ontinned.

\begin{tabular}{|c|c|c|c|c|c|}
\hline \multirow[b]{2}{*}{ Species. } & \multicolumn{3}{|c|}{ Eocarboniferous. } & \multirow{2}{*}{\begin{tabular}{|c|}
$\begin{array}{c}\text { Meso- } \\
\text { rarbon- } \\
\text { iferous. }\end{array}$ \\
$\begin{array}{c}\text { Coal } \\
\text { Meas. } \\
\text { ures. }\end{array}$ \\
\end{tabular}} & \multirow{2}{*}{$\begin{array}{c}\text { Nen- } \\
\text { carbon- } \\
\text { iferous. } \\
\text { Per- } \\
\text { mian. }\end{array}$} \\
\hline & $\begin{array}{l}\text { Kinder } \\
\text { hook. }\end{array}$ & $\begin{array}{l}\text { Keo- } \\
\text { kuk, } \\
\text { 13ur- } \\
\text { lington. }\end{array}$ & $\begin{array}{l}\text { Kaskas- } \\
\text { kia, } \\
\text { St. Louis. }\end{array}$ & & \\
\hline \multicolumn{6}{|l|}{ Streptorhynchus (?) nultistriata Ifeek and Hayden.... } \\
\hline \multicolumn{6}{|l|}{ Streptorhynchus ulrichi Hall and Clarke ............... } \\
\hline \multicolumn{6}{|l|}{ Stricklandinia (?) subquadrata Herrick................ } \\
\hline \multicolumn{6}{|l|}{ 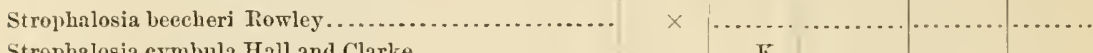 } \\
\hline \\
\hline & ... & & & $\therefore$ & \\
\hline \multicolumn{6}{|l|}{ Strophalosia keokuk Eiecher ........................ } \\
\hline \multicolumn{6}{|l|}{ 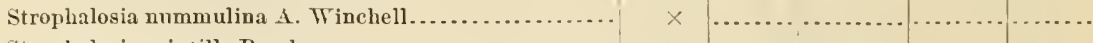 } \\
\hline \multicolumn{6}{|l|}{ 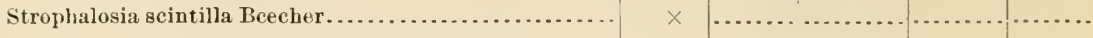 } \\
\hline \multicolumn{6}{|l|}{ Strophalosia spondyliformis (White and St. John) ........ } \\
\hline \multicolumn{6}{|l|}{ Strophomeua (?) nassula Courad. Carboniferous. } \\
\hline \multicolumn{6}{|l|}{ 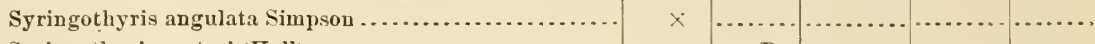 } \\
\hline \multicolumn{6}{|l|}{ 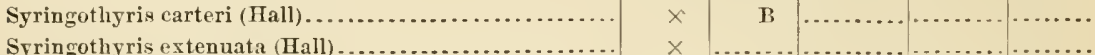 } \\
\hline \multicolumn{6}{|l|}{$\begin{array}{l}\text { Syringothyris extenuata (Hall) .................................... } \\
\text { Syringothyris gigas (Troost), Lower Carboniferous. }\end{array}$} \\
\hline \multicolumn{6}{|l|}{ Syringothyris herricki Schuehert...................... } \\
\hline \multicolumn{6}{|l|}{ Syringothyris missouri Hall and Clarke................. } \\
\hline \multicolumn{6}{|l|}{ Syringothyris (?) plena (Hall) . . . . . . . . . } \\
\hline \multicolumn{6}{|l|}{ 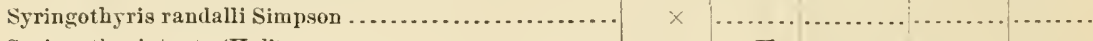 } \\
\hline \multirow{2}{*}{\multicolumn{6}{|c|}{ 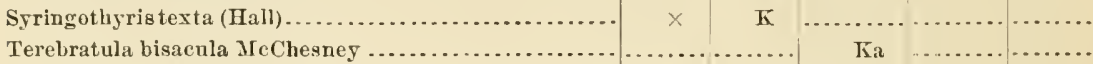 }} \\
\hline & & & Ka & & \\
\hline \multicolumn{6}{|l|}{ 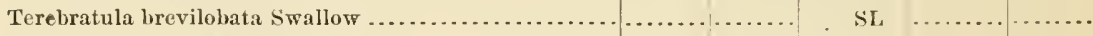 } \\
\hline \multicolumn{6}{|l|}{ 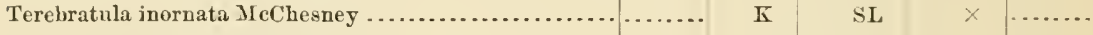 } \\
\hline \multicolumn{6}{|l|}{ 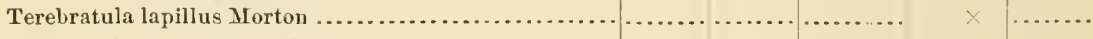 } \\
\hline \multicolumn{6}{|l|}{ Terebratula mexicana Hall . . . . . . . . . . . . . . . . . . . . . } \\
\hline \multicolumn{6}{|l|}{ Terebratula perintlata Shmmard...................... } \\
\hline Terebratula subretzinforma \rchesney.... & & & Ka & & \\
\hline Terebratula swallorana Miller ...................... & $\cdots$ & . & Ka & & \\
\hline Terebratula utab Hall and Whitfield.................... & $x$ & $\cdots$ & . & & \\
\hline Torynifer criticus Hall and Clark $\theta . . . . . . . . . . .$. & & & SL & & $\cdots$ \\
\hline Number of Carboniferous species, 478 . & & & & & \\
\hline 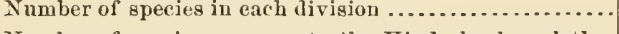 & 156 & 93 & 74 & 158 & 9 \\
\hline 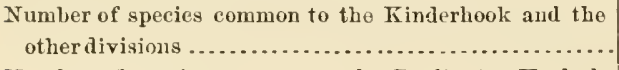 & & 9 & 0 & 0 & 0 \\
\hline 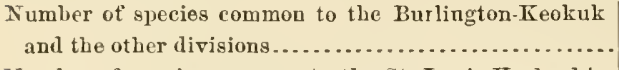 & 9 & $\cdots$ & 5 & 4 & 1 \\
\hline 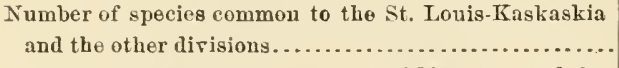 & 0 & 5 & & 5 & 1 \\
\hline 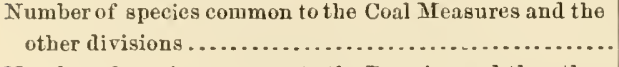 & 0 & 4 & 5 & & 9 \\
\hline 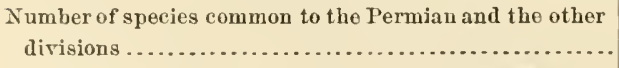 & 0 & 1 & 1 & 9 & ........ \\
\hline Nospecies pass from the Carboniferous in to the Mesozoic. & & & & & \\
\hline
\end{tabular}


TaBLE VIII.-Mesozoic Brachiopoda.

\begin{tabular}{|c|c|c|c|c|}
\hline Species. & Triassic. & Jurassic. & $\begin{array}{l}\text { Lower } \\
\text { Creta- } \\
\text { ceous. }\end{array}$ & $\begin{array}{l}\text { Upper } \\
\text { Creta- } \\
\text { ceous. }\end{array}$ \\
\hline istella beecheri Clark. & & & & $>$ \\
\hline Cistella plicatilis Clark........................ & & & & $>$ \\
\hline Discina (?) pileolus Wbiteares .............. & & & $x$ & \\
\hline Discina (?) semipolita Whiteaves........... & & & & $x$ ? \\
\hline Discina (?) vancourerensis Whiteares........... & & & $\cdots$ & $\times ?$ \\
\hline 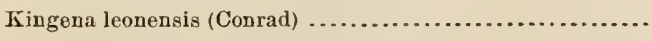 & & & $x$ & \\
\hline 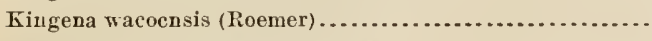 & $\ldots$ & ..... & $x$ & \\
\hline Lingula brerirostris Meek and Hayden .......... & & $x$ & & \\
\hline Lingula nitida Meek and Hajden. ......... . & & & - & $x$ \\
\hline Lingula shumardi Cragin ...................... & & & $x$ & \\
\hline Lingula subspatulata Hall and Meek............ & $\cdots$ & & & $x$ \\
\hline Rhynchonella equiplicata Gabb ............ & $x$ & & & \\
\hline Rhyuchonella gnathophora Meek......... & .. & $x$ & & \\
\hline 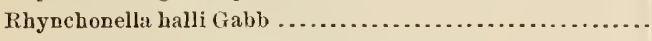 & $\times$ & & & \\
\hline Rhynchonella lacumosa (Schlotheim) ................. & ... & $\times$ & & \\
\hline Rhynchonella lacunosa arolica Oppel ............... & .... & $x$ & & \\
\hline Rhynchouella lingulata Gabb................ & $x$ & & & \\
\hline Rhynchonella maudensis Whiteares......... & & & & $x$ \\
\hline Rhynchonclla myrina Hall and Whitfield ....... & 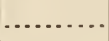 & $x$ & & \\
\hline Rhynchonella plicatilis (Sowerby)............... & & & & $\times ?$ \\
\hline Rbynchonella schucherti Stanton............. & & & & $x$ \\
\hline Rhyuchonella tayloriana Lea. Habana, Cuba...... & & $x ?$ & & \\
\hline Rhyuchonclla whitneyi Gabb................... & & & & $x$ \\
\hline Spiriferina (?) alia Hall and Thitfield .......... & $x$ & & & \\
\hline 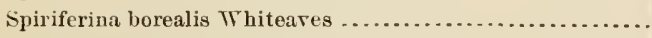 & $x$ & & & \\
\hline Spiriferina homfrayi (Gabb) ............. & $x$ & & & \\
\hline Spiriferina obtusa (Gabb) ................. & $\lambda$ & & & \\
\hline Terebratella californica Stanton ................. & 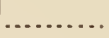 & & & $x$ \\
\hline Terebratella (?) dubitanda (Cooper) ............. & $\cdots$ & & & $\times ?$ \\
\hline Terebratella (?) imbricata (Cooper) .......... & & & & $x ?$ \\
\hline Terebratella obesa Gabb................ & & & & $x$ \\
\hline 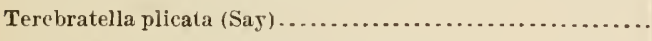 & & & & $x$ \\
\hline Terebratella ranuxemi Lyell and Forbes.......... & & & & $\times$ \\
\hline 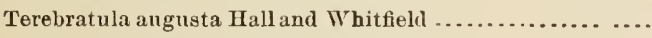 & $x$ & $x$ & & \\
\hline Terebratula dorenbergi Felix. Mexico......... & & $x$ & & \\
\hline Terebratula harlani Morton .............. & & & & $x$ \\
\hline Terebratula helena Whitfield................... & $\ldots$ & & & \\
\hline Terebratula lumboltensis Gabb................. & $x$ & & & \\
\hline Terebratula liardensis Whiteaves ............. & $x$ & & & \\
\hline Terebratula poeyana Lea. Habana, Cuba... & & $x ?$ & & \\
\hline Terebratula repellini d'Orbigny. Mexico .. & - & $x$ & & \\
\hline Terebratula robusta Whiteares .............. & . & $\times ?$ & & \\
\hline Terebratula semisimplex White .............. & $x$ & & & \\
\hline Terebratula efr. zieteni Loriol. Mexico.... & & $x$ & & \\
\hline Terebratuliua atlantica (Morton) ... & & & & $x$ \\
\hline Terebratulina filosa Conrad ................ & & & & $\times ?$ \\
\hline Terebratulina tloridana (Morton) ................. & & & & $x$ \\
\hline Terebratulina guadlalupa: (Roemer) .................... & & & & $x$ \\
\hline Waldheimia (?) catorcensis Aguilera. Mexico........... & & $x$ & & \\
\hline $\begin{array}{l}\text { Number of Mesozoic species, } 49 . \\
\text { Number of species in each system..... }\end{array}$ & 11 & 13 & 4 & 2 \\
\hline
\end{tabular}


'Table 1X.-Cenozoic and Recent Brachiopoda.

\begin{tabular}{|c|c|c|c|c|}
\hline \multirow[b]{2}{*}{ Specios. } & \multicolumn{2}{|c|}{ TENOZOIC. } & \multicolumn{2}{|c|}{ RECENT. } \\
\hline & Eoceue. & Neocene. & $\begin{array}{l}\text { North } \\
\text { and cen- } \\
\text { tral } \\
\text { Americau } \\
\text { Atlantic. }\end{array}$ & $\begin{array}{l}\text { North } \\
\text { aud Cen- } \\
\text { 1ral } \\
\text { American } \\
\text { I'acific. }\end{array}$ \\
\hline Diseinisea lugubris (Conrad) & & $x$ & & \\
\hline Discinisca multilineata (Conrad) .......... & $\cdots$ & $x$ & & \\
\hline 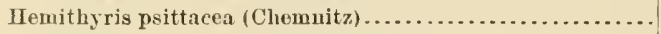 & & $x$ & & \\
\hline Rhyuchonella wilmingtonensis (Ljell and Sowerby).... & $x$ & & & \\
\hline Terebratula canipes Ravenel .............. & $x$ & & & \\
\hline 'Terebratula carneoidlea Guppy. Trinidad..... & $x$ & & & \\
\hline 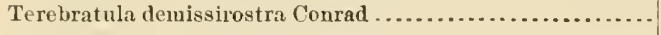 & $x$ & & & \\
\hline Terebratula lecta Gupps. Trinidad.................. & $x$ & & & \\
\hline 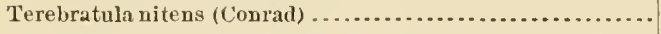 & …. & $x$ & & \\
\hline Terebratula trinitatensis Guppy. 'Trinidad ........... & $x$ & & & \\
\hline Terebratulina gracilis (Schlotheim)....... & $x$ & & & \\
\hline 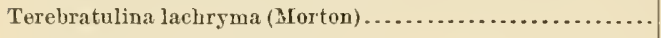 & $\times$ & & & \\
\hline 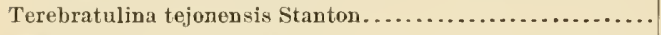 &.$\times$ & & & \\
\hline Waldheimia kennedyi Dall ............. & & x & & \\
\hline Number of species in each division............. & 9 & 5 & & \\
\hline Atretia gnomon Jeffrys............... & & & $x$ & \\
\hline Cistella cistellula (Wood).............. & & & $x$ & \\
\hline Dallina floridana (Pourtales) ..................... & & & $x$ & \\
\hline 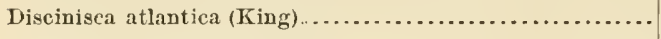 & & & $x$ & (........... \\
\hline Discinisca cumingi (Broderip) ....... & & & & $x$ \\
\hline Frieleia halli Dall.................... & & & & $x$ \\
\hline Glottidia albida (Hinds) ............. & & & $\lambda$ & $x$ \\
\hline 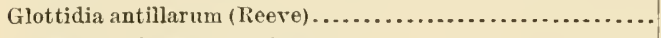 & & & .. & $x$ \\
\hline Glottidia audebarti (Broderip) ............. & & & & $x$ \\
\hline 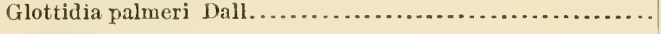 & & & & $x$ \\
\hline Heinithyris eraneana Dall .......................... & & & … & $x$ \\
\hline 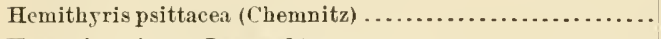 & & $\therefore$ & $x$ & $\times$ \\
\hline Kraussina pisum (Lamarck) ...................... & & & $\cdots$ & $\times$ \\
\hline 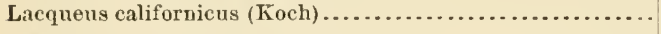 & & & & $x$ \\
\hline 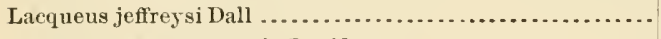 & & & & $x$ \\
\hline 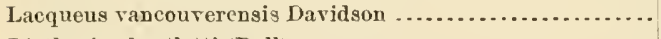 & & & & $x$ \\
\hline 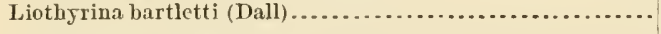 & & & $x$ & ...... \\
\hline Liothyrina clarkeana Dall ...................... & & & $\because$ & .......... \\
\hline Macandrevia americanum Dall .......... & & & & ! \\
\hline Macandreria craniella Dall................... & & & $\cdots$ & $x$ \\
\hline Macandrevia cranium (Miiller) ................... & & & $x$ & ........... \\
\hline Macandrevia diamantina Dall ....................... & & & $x$ & $x$ \\
\hline Magasella aleutica Dall...................... & & & $\cdots$ & $x$ \\
\hline 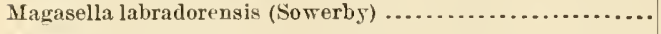 & & & $x$ & (........... \\
\hline 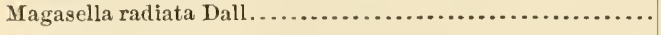 & $\cdot$ & & $x$ & $x$ \\
\hline 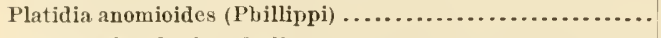 & & & .. & $x$ \\
\hline 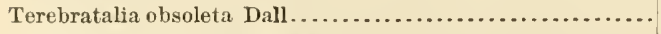 & & & $\cdots$ & $x$ \\
\hline Terebratalia occidentalis Dall ........................ & & & ..... & $x$ \\
\hline 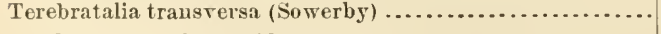 & & & ... & $x$ \\
\hline 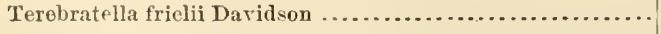 & & & $x$ & \\
\hline 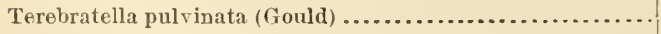 & & & $\cdots$ & $x$ \\
\hline 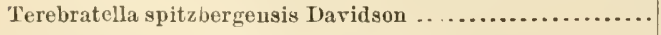 & & & $x$ & ............ \\
\hline 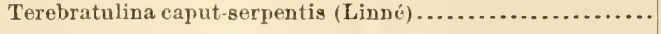 & & .... & .... & $x$ \\
\hline Terebratulina küensis Dall and Pillsbry ................... & & & -. & $x$ \\
\hline 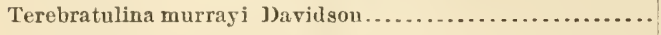 & & & $x$ & ... \\
\hline 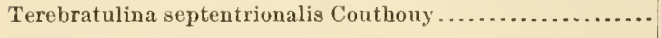 & & & $x$ & ............ \\
\hline Number of species in each ocea & & & 15 & 24 \\
\hline
\end{tabular}




\section{TABLE X.-South American fossil Brachiopoda.}

$\left[J=J u r a s s i c\right.$. Species preceded by an asterisk $\left(^{\star}\right)$ are found in North America also. $]$

* Ambocotia planoconrexa (Shumard)

* Amphigenia elongata (Vanuxem)

Anabia paraia Clarke.

* A noplotheca flabellites (Conrad)

* Camarotcechia dotis Hall.

Centronella (?) areii A. Ulich

('entronella (?) sil retii A. Ulrich

Chonetes amazonica Derby

Clionetes (?) arcii $A$. Dlrich

Chonetes comstockii Rathbun

Clonetes curuaensis Rathbun

Clıonetes falklandiea (Morrịs and Sharpe)

Chonetes freitassii Rathbun.

* Chonetes glabra Geinitz

* Chonetes granulifera Owen.

Clionetes berlert-suithi liathbun

Clionetes onettiana Rathbun

Chonetes rncki A. Ulrich

' Jonetes stübeli A. Ulrich

* Chonetes variolata d'Orbigny

Chonostropbia complanata Hall?

* Cleiothyris roissyi (L'Eville)

Clitambonites adscencleus (Pander?)

Cyrtina (?) curupira Rathbun

Daluanella (?) nettoana (Rathbun)

Derbya correanus (Derby)

Dielasma hochstetteri (Toula)

Dielasma it ajtubensis (Derby)

Enteletes andii (d'Orbigny)

Enteletes gaudryi (d'Orbigny)

Glossina dubia (d'Orbigny)

Glossina trentonensis (Conrad?)

IIarttina coutinhoana (Derby)

* Hustedia mormoni (Marcou)

Leptana (?) stelzueri Kayser.

Lingula coheni A. Ulrich

Lingula ererensis Rathbnn

Lingula gracana Rathbun

Lingula metensis 'Terquem

Lingula musteri d'Orbigny

Lingula plagemanni Möricke

Lingula rodriguezii Rathbun .

* Lingula spatulata Vanuxem.

Lingula stantoniana Rathbun

Lingula submarginata d'Orbigny

Liugula truncata Sow erby

Meristella riskowyi A. Ulrich

Notothyris (?) smithii Derby

Orbiculoidea baini Morris and Sharpe

* Orbiculoidea lodensis ( $\nabla$ anuxem)

苟

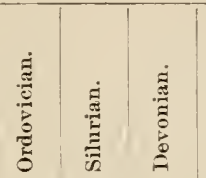
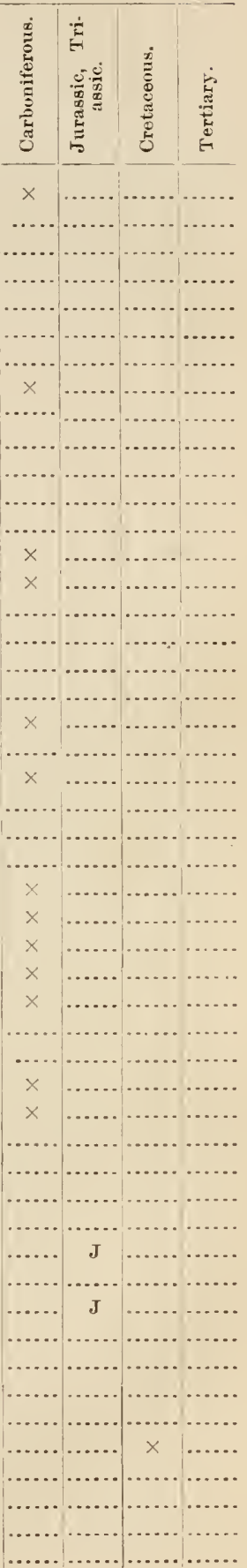
TABLE X.-South imerican fossil Brachiopola-Continued.

Orthis buchi d'Orbigny

Orthis calligramma (Davidson) Kayser.

Orthis concinna Morris and Sharpe.

Orthis disparilis Kayser.

Orthis humboldti dOrbigny

Orthis (?) laticostata d'Orbigny

Orthis lenticularis Wahlenberg ?

Orthis obtusa Pander.

Orthis (?) pectinata d'Orbigny.

Orthis saltensis Kayser.

Orthis (?) sulivanti Morris and Sharpe

Orthis (?) tenuis Morris and Sharpe.

Orthis respertilio Sowerby

Orthothetes agassizi (Rathbun)

Orthothetes tapajotensis (Dcrby)

Orthotichia morganiana (Derby)

* Plectambonites sericea (Sowerby)

Productella mæcuruensis Rathbun

Productus batesianus Derby.

* Productus boliviensis d'Orbigny

Productus capacii d'Orbigny

Productus chandlessii Derby

Productus clarkianus Derby.

* Productus cora d'Orbigny .

* Productus costatus (Sowerby) do Koninek

Productus humboldti d'Orbigny

*Productus longispinus Sowerby?

Productus papilio Gabb

Productus peruvianus d'Orbigny.

Productus reticulatus Gahb

Productus rhomianus Derby

* Productus semireticuatus (Martin)

Productus villiersi d'Orbigny.

Productus wallacionus Derby

${ }^{*}$ Reticularia perplexa (McClesney)

Retzia (?) jamesiana Ratlibun

Rhipidomella hartti (Rathbun)

Rhipidomella inca (d'Orbigny)

Rhipidomella penniana Derby

Rhynehonella anigma (d'Orbigny)

Rbynchonella and uin Crottsebe.

Rhynchonella antisiensis (d'Orbiguy)

Rhynchonella antonii Gabb.

Rhyncbonella belemnitica Quenstedt

Rhynchonella caracolensis Gottsche.

Rhynchonella ererensis Rathbun.

Rbynchonella manflasensis Möricke.

Rhynchonella pipira Derby.

* Rhynchonella pleurodon (Phillips).

Rhynchonella plicatissima Quenstedt

Rhynchonella subtetræda (Conrad).

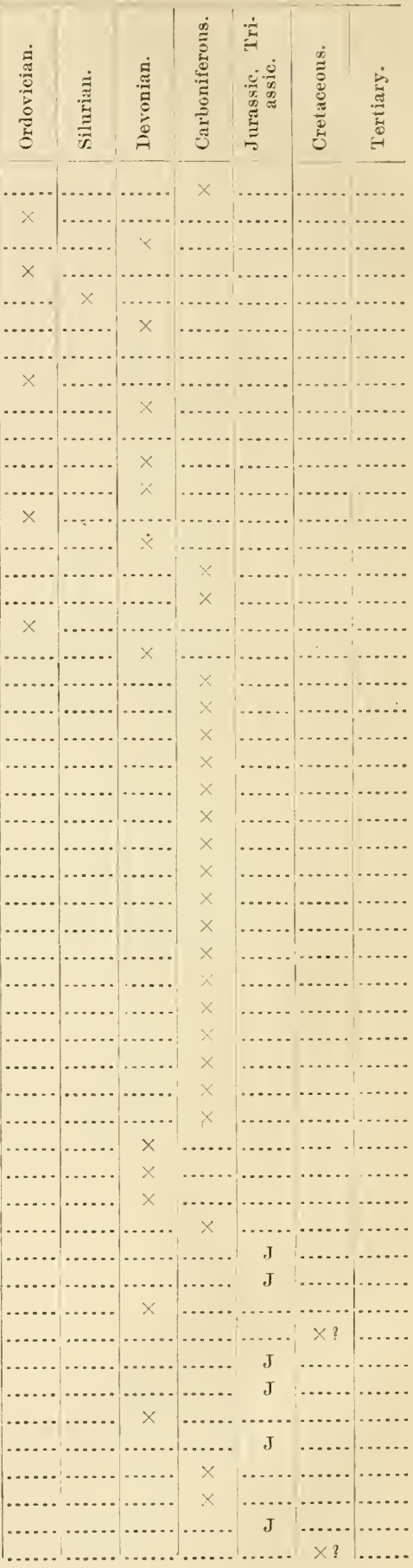


TABLE X.-South American fossil Brachiopoda-Continuer.

Rhyuchonella tetræda (Sowerbs).

Rhynchonella triplitata Quenstert.

Scaphioccelia boliviensis Whitfield

Schizophoria cora (d'Orbigny)

* Seminula argentea (shepard)

Seminula titieaceusis (Gabb)

Spirifer autareticus Morris and Sharpe

Spirifer buarqnianus Rathbun.

Spirifer boliviensis d'Orbigny

Spirifer chuquisens Clrieh

Spirifer condor d'Orbigny

* Spirifer duodenarius Hall

Spirifer elize liathbun

Spirifer hartti Ratbbuu

Spirifer hawkiusi Morris and Sharpe.

Spirifer maenruensis Rathbun

* Spirifer murehisoni Castelnau.

Spirifer orbignii Morris and Sharpe

Spirifer yedroanus Ratbbun

Spirifer pentlandi d'Orbigny

Spirifer quichuns d'Orbigny

*Spirifer rockymontanus Marcou.

Spirifer valenteanus Ratbbun

Spirifer rogeli von $A$ mmou .

* Spiriferina cristata (Schlotheim).

Spiriferina efr. müusteri Davidson

Spiriferina rostrata Schlotheiu.

*Spiriferina spinosa (Norwood and Pratten)

Spirigerella derbyi Waageu.

Streptorlynclus hallianus Derby.

Strophalosia cornelliana Derby

* Stropheodonta perplana (Conrat)

Strophouena (?) talacastreusis Kayser.

Terebratula bicanalieulata Schlotheim

Terebratula chilensis d'Orbiguy

Terebratula eopiapensis Möricke

Terebratula derbyana Rathbun.

Terebratula domeykana Bayło and Coquand.

Terebratula emarginata Sowerby

Terebratula ficoides Bayle and Coquand

Terebratula gottschii Steinman

Terebratula hohmanni Möricke

Terebratula ignaciana d'Orbigny

Terebratula lacunosa Schlothein

Terebratula meridionalis Conrad

Terebratula patagonica Sowerby

Terebratula perforata Piette.

Terebratula perovalis Sowerby .

Terebratula punctata Sowerby

Terebratula raimondiana Gabb

Terebratula subexcarata Conrad

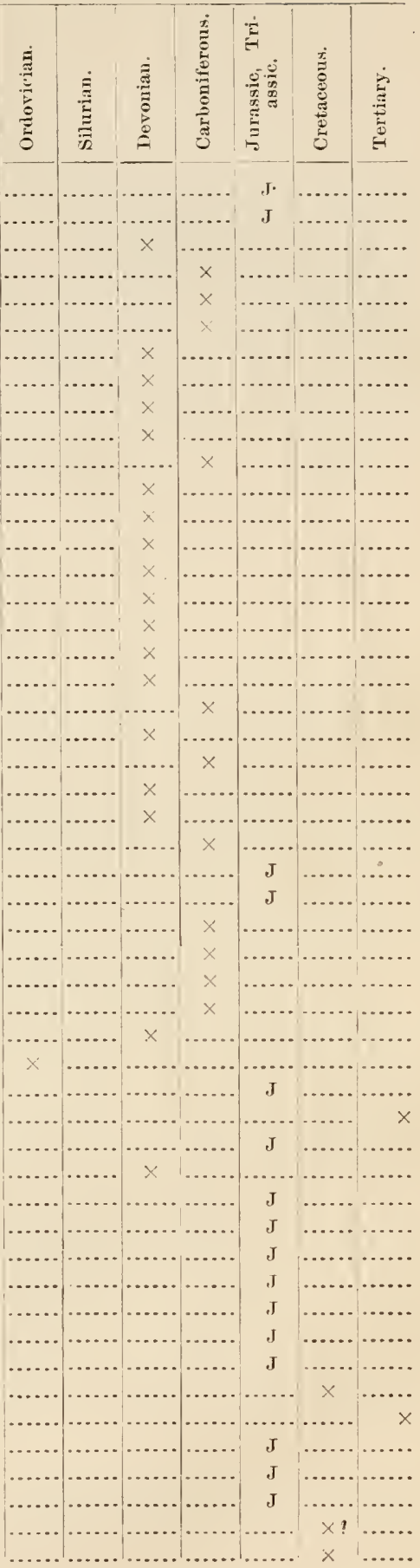





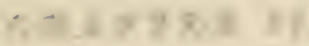

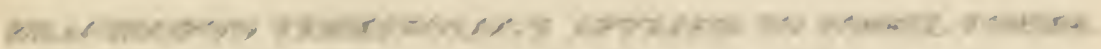

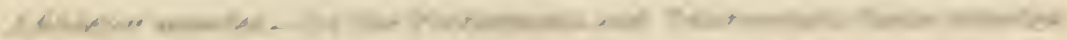

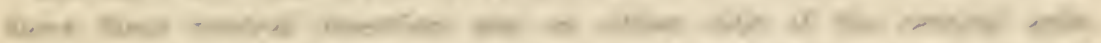

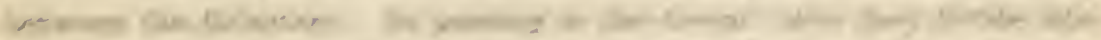

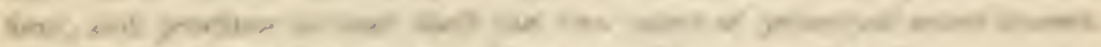

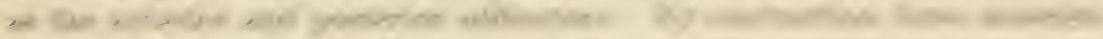

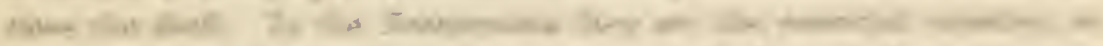

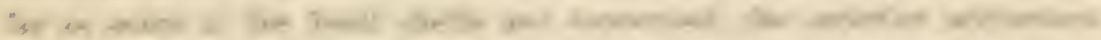

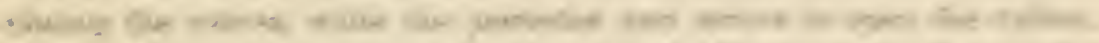

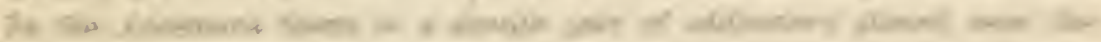

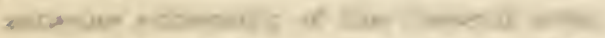

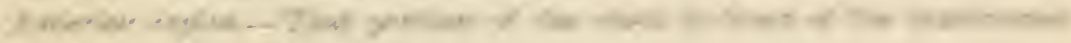

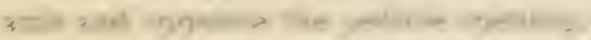

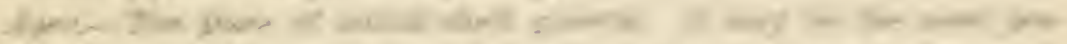

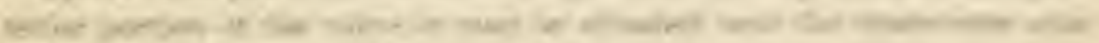

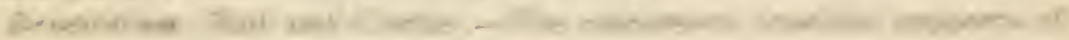

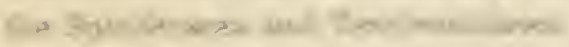

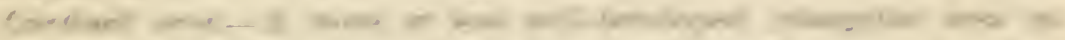

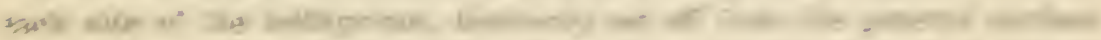

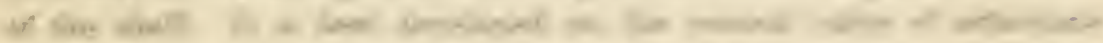

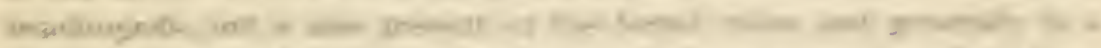

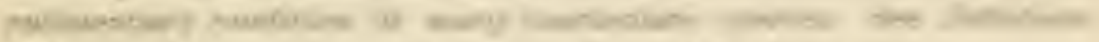

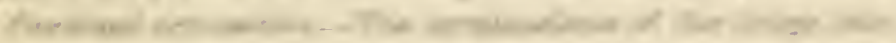

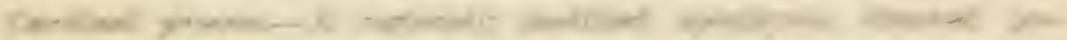

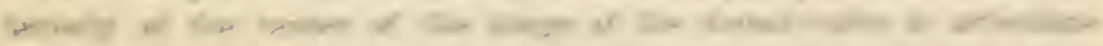

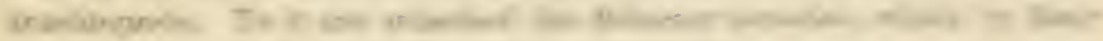

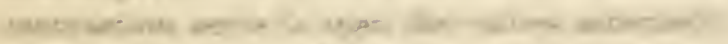

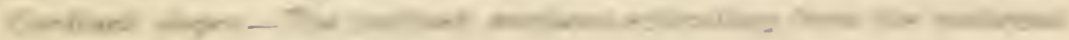

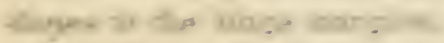

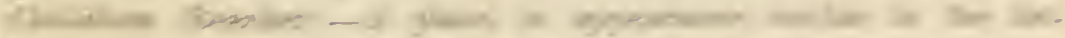

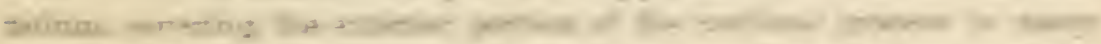

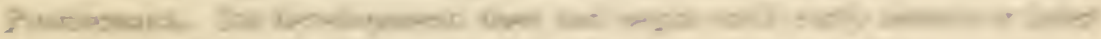

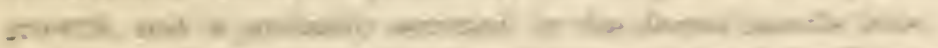

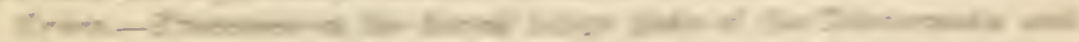

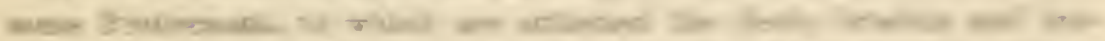

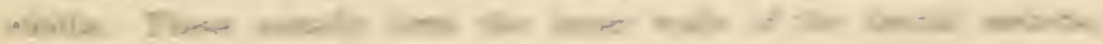

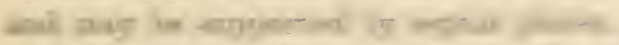

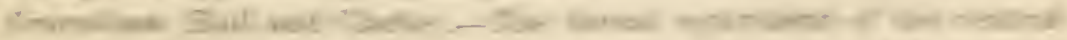

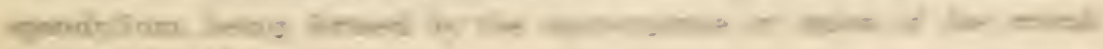

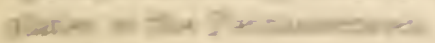


Delthyrium (II:ll and Clarke).-Whe triangular aperture transecting medially the eardinal area, or the posterior surface from the apex to the posterior margin of the ventral valve, through some portion of which the pedicle passes. It has also been termed the fissure or foramen. The delthyinm may or may not be closed by a deltidium or deltidial plates.

Deltidium.-A plate of one piece which grows over the delthyrium of many Protremata and some Neotremati. In the early larval stage of Theridim this plate begins as a secretion from the dorsal side of the body segment, and becomes anchylosed to the ventral valve in the phylembronic stage, subsequent additions being secreted by the body wall and pedicle. The convex or coneave central portion of the rentral cardinal area in some Atremata is not homologous with the deltidinm. It is but a part of the area, and does not have its origin in the prodeltidium, as in Thecidium.

Deltidial plates.-Two plates growing medially from the walls of the delthyrimm after neanic growth. These usually unite medially, and close the delthyrium more or less completely. They are restricted to the Telotremata, and are secreted by extensious of the ventral mantle lobe. Hall and Charke introduced the terms deltarium and deltaria for the same plates, and for the coalesced coudition of the deltaria, Bromn's pseudodeltidium.

Dental plates. - Tertical plates supporting the teeth of the ventral valve.

Dentul sockets.-Excavations in the dorsal cardinal margin in which the teeth of the ventral valve articulate. The inner wall of the socket is elevated and forms the base of the crural plate.

Diductor muscles.-In the Protremata and Telotrenata the principal pair of diductor muscles lias the larger end attached to the ventral valve near the anterior edge of the visceral area, while the other end has its insertion on the anterior portion of the cardinal process. There is another pair of small accessory diductor muscles, but these are seldom shown in fossil shells. By contraction these muscles open the valves.

Dorsul velce.-Usually the smaller and imperforate valve and the one to which the brachia are always attached. Brachich, hemal, socket, and entering valves are other terms more rarely employed.

Ephebic (Hyatt, emend. Bather and Buckman).-Designating the mature shell.

Fortumen.-A small circular passage throngh the deltidium or deltidial plates, either below or at the apex of the ventral vaive. Sometimes the foramen encroaches by abrasion upon the umbo of the ventral valye.

Genital markings.-Radial markings or pits within the posterior portion of the visceral space, indicating the position and extent of the genitalia. 
Geroutic (Hyatt, emend. Bather and Buckman).-Designating old age. It is indicated in the ontogeny of many species of brachiopods by extreme thickness of the valves, obesity, or by numerons, crowded growth lines near the anterior margin, a condition which sometimes produces truncation and absence of strice at the margin.

Hinge line.-The line along which articulation takes place.

Jugum (Hall and Clarke).-The transverse band and its accessory processes uniting the spiralia. When this band is medially incomplete the parts are termed jugal proeesses.

Lateral areas.-That portion of the shell on each side of the ventral axis.

Listrimm (Hall and Clarke).-In some Neotremata a plate closing the progressive track of the pedicle opening or pedicle eleft, posterior to the apex of the ventral valve.

Longitudinal axis.-A median line through the shell from the beak to the opposite margin.

Loop.-The calcareous brachial supports of the Terebratulacea. It is usually composed of descending and ascending lamellie, nnited by a transverse band.

Median septum.-An internal vertical plate commonly developed along the vertical axis and between the muscles of the ventral valve. Sometimes there is also a dorsal median sejtum. Lateral septa are rarely developed.

Teanir (Hyatt, emend. Bather and Buckman).-Designating youthfulness, or the stage in which specific characters begin to develop.

Nepionic (Hyatt).-Designating the smooth-shell stage succeeding the protegnlum.

Pallial sinuses.-Two convergent or divergent primary sinuses of the circulatory system, traversing the mantle and originating in the posterior medial region. They usually have numerous secoudary branches, and both often leave impressions in the shell.

Pedicle.-The Hexible musenlar organ of the ventral valve by means of which brachiopods may be attached to extraneous objects.

Pelicle muscles.-In the Protremata and Telotremata one pair originates on the rentral valve at points just outside and behind the diductors and another on the dorsal valve behind the posterior addnctors, while the opposite encls of both are attached to the pedicle. Besides these, there is an unpaired muscle lying at the base of the pedicle, attaching it closely to the ventral valie.

Platform.--See Spourlylium.

Posterior region.-That portion of the shell back of the transverse axis and toward the beak, or apex.

Primary lamella.-The primary descending bands of the spiralia, the posterior ends being attached to the crura.

Prodeltidium (Hall and Clarke restricted).-The third shell plate developed in the earlier embryonic growth of species of Atremata, 
Neotromata and Protremata, and subsequently becoming more or less firmly attachel to either the dorsal (Atremata) or ventral valve.

Protegulum (Beecher). - The initial shell of brachiopods. It is smooth and of microseopic size, in ontline being semicircular or arcuate, and without cardinal areas.

Protractor muscles.-In the lingnlacea one pair has the rentral ends fastened at the anterior extremity of the visceral area, extending loackwarl and inserted near the lateral margin of the lorsal valve, ontside the rotators. I second pair originates just behind the adductors of the rentral valve, and is inserter posterior to the first pair. These muscles draw the dorsal valve forwarl. They are apparently present in the Obolida and Trimerellida, but their position is different.

P'sendodclidium.-Properly this term applies only to the mited condition of the deltidid plates in the Protremata and Telotremata. It is provisionally applied to the concave or convex medial portion of the earlinal areas in Atremata and Protrenata.

lictractor muscles.-In the Atremata these extend from the outer lateral margius of the visceral area in the ventral valve to its anterior extremity in the dorsal valve, and serve to readjust the dorsal shell.

hotator muscles.-In Lingulacea these are situated posteriorly justin advance of the umbonal muscle, two on one side and one on the other. By their contraction the dorsal valve turus alternately first in one direction and then in the other.

Septal plates.-Plates supporting the crural processes, also known as crural plates.

Spondylium.-A plate in the Pentameracea, formed by the union of converging dental plates, to the upper surface of which are attached the adductor, diductor, and pedicle museles. The spondylimm may rest upon the ventral valve or may be supported by a median septum. This plate is rarely present in the Telotremata, but more commonly in the Atremata, where it is known as the platform. There is sometimes developed in the dorsal valve a plate similar in appearance to the spondylium, but different in origin, and known as the cruralium.

Spiralia (Beecher).-The calcareous spiral brachial supports in the Spiriferacea. A connecting jugum may be present or absent.

Syrinx.-A tubular structure leveloped in the delthyrium of some Spiriferacea, opening ventrally and partially inclosing the pedicle.

Tecth.-Two processes of the ventral valve of articulate brachioposts, serving for articulation.

Transverse axis.-A line throngl the sliell from right to left, midway between the beak and anterior margin.

Umbo.-The elevated or prominent portion of the valve anterior to the apex.

Umbonal muscle.-A single muscle situated in the umbonal region of most Atremata. By its eontraction the valves are opened anteriorly. In Obolus this muscle divides toward the ventral valve. 
Umbonal slopes.-The inelined surfaces abont the umbo and opposite the eardinal slopes.

rentral valie.-The valve situated on the ventral side of the animal, and having in youth or maturity a delthyrium or pedicle opening through which the pedicle is protruded, except in Iphidea, Obolelli, Lingula, etc., where the pedicle protrudes between the valves. Wheli the shell is cemented to foreign bodies it is always by the ventral valve. It is usually the larger and deeper of the two valves. Pedicle, larger, dental, neural, and receiving valves are synonymous terms. 


\section{BIOLOGIC WFVEIOPMEN'T OI THE IBRACHIOPODA.}

\section{ORDINAL DEVELOPMENT.}

A'TREMA'T $\Lambda$.

This order, which began in the Lower Cambrian, is represented by 199 species, or orer 10 per cent of American Paleozoic brachiopods. Its greatest representation, both in species and genera, was duriug the Cambrian and Ordovician eras. A very marked decine set in during the Silnrian and Devonian, with almost extinction in the Carboniferous, where only Lingula and its subgenus Glossina occul.

The terminal families Trimerellida and Lingulidx contain species which attain the greatest individual growth. Lingulida has the longest phylogenetic history. It is the last important and most specialized family of the Atremata, and manifests the greatest persistency and specific differentiation. Lingula, the essential genus of the family, lived at least from the Ordovician system through all succeeding time, and is represented in modern seas. During this enormous period the only change observable is that in the ancient forms the viscera oceupied a little more and the brachia somewhat less space.

In the more primitive types of Atremata, Obolacea, the shell is usu. ally much thicker and less ehitinous than in the higher o! derived families, Lingulacea. The shell is thickest in the Trimerelliclae and thinnest in the Lingnlida. From their mode of ocenrence in roeks it seems probable that Paterinidie, Obolida', and Trimerellidie (=Obola. cea) never lived in the mud or sand of the sea bottom, as did Lingulidie, Lingulasmatida, and probably Lingulellide (=Lingulacea). ${ }^{1}$ The oboloids in all probability had short pedicles, while the linguloids have very long pedicles. The long, flexible, tubular pediele of Lingula, associated with the buried habit of the animal, apparently explains

\footnotetext{
ISince all the species of Oholacea are knowu only as fossils, it nay seem hazardous to aseribe to them a mode of living different from that of Lingula. These shells had short peduncles, aro round or oral, sometimes very gibbous, always comparatively thick shelled, and not elceidedly phosphatic. The writer has never ubserved any species of this superfamily in situ transverse to sedimentation, or in other words "on edge." In the Lingulacea the peduncle is very long, and the shells are elongate quadrangular, triangular, spatulate, or acuminate, and, as a rule, are decidedly thin and phosphatic. Recent Lingulas all live partially buried in the sea bottom, and not infrequently fossil species are found in situ, on edge, with their apices downward. Lingulops and Lingulasma also have been observed situated on edge. The round, thick shells of Obolacea are strongly contrasted with the elongate thin slells of Lingulacea. These peculiarities aro in all prohability due to mechanical eauses. The Linguloids, with their long, powerful, and flexiblo peduncles, aro luried in the sedi. ments, while the posterioriy pointed shell is au adaptation to the same end, caused by the frequent peduneular pulling on that part of the valves.
} 
the canse for the thinness of the shell and the long, narrow, attenuated form of its valves.

The ontogeny of Obolella and Lingula shows that one branch developed directly from the Paterinidie to Obolidxe and Trimerellide, while another branch began in the Obolide. The derived branch continued to diverge by changing the thick round shells of the radical stock into thin spatulate or elongate subquadrate valves, first in the Lingulellidie and culminating in the Lingulidxe. The latter family then gave rise to Lingulasmatide, which, in accordance with the law of morphologic eqnivalents, developed some of the internal diagnostic characters of the terminal family of the first phylum in the platform of the Trimerellidx.

Hall and Clarke refer the genera of Lingulasmatide to Trimerellide, and thus the latter family, as understood by them, embraces two stocks having widely separated origins. This is peenliar, since they clearly understand the independent origin of these stocks, as will be seen by the following quotation, but more particularly by their diagram.'

There is no single feature in the entire group of the edentulous brachiopods so striking as the great platforms in Trimerella and its allies, and it is rarely that so beautiful and well established an illustration of the attainment of sueh a remarkable resultant along two distiuct lines of development ean be presenter.

The writer holds that a natural family can have but one stock, a stock can liave bnt one origin.

Nonfunctional articnlar proresses are developed in this order in a number of genera and at various times. Such are slightly developed in Trimerella and Monomorella, and more strongly in Tomasina, Barroisella, and Spondylobolus. In the Neotremata, articulation is also approached in Trematobolus, and in Crania a false hinge is sometimes developed in Ordovician species. A cardinal process so characteristic of the Protremata and Telotremata is faintly dereloped in Neobolus, Lakmina, and Trimerella of the Atremata.

\section{NEOTRE]IATA.}

The order Neotremata begius in tho Lower Cambrian, and is represented by 156 species, or over $S$ per cent of the brachiopods of the American Paleozoic. It has considerably ferer species than the Atremata, and exhibits a lack of specific differentiation, snch as form and surface ornamentation. This probably is largely dne to the fact that the pedicle is very short, or even obsolete, in this order, and that the pedicle foramen is subcentral, prodncing in the Trematidie and Craniida more or less of a parasitic growth, while in the families Discinidic and Acrotretidie the great majority of species are eircular or oval, with more or less cone-shaped shells.

As in the Atremata, great tenacity of life is also manifested in this order, since its two essential families, Discinidre and Craniidie, have representatives thronghont all time since the Ordovician system. 
Greatest representation in both genera and species was during the Ordovician, after whieh generic differentiation was practically restricted to the loiscinide and Craniidar. Crania persisterl throughont the postOrdovicum, and for longevity equals the atrematous genus Lingula.

The percentage of widely dispersed species is about the same as in the Atremata, and likewise is greatest in those families with the longest phylogenetic history, as Acrotreticle, Discinida, and Craniida.

Ievelopment was aloug two lines. In one a broad fissule (the most primitive condition of the pedicle opening in this order) is retained as a mature cliasacter (Trematida). Later geologically, and at the maturity of the individual in derived forms, the fissure is gradually closed posteriorly, leaving a long, narrow slit, at one end of which the pedicle emerges (Discinidix). The other line (Acrotretacea) probably developed and inherited holoperipheral growth in the ventral valve, very rapilly produciug a small subcentral circular foramen, since this feature is already well developed in the Lower Cambrian Acrotretidie, and in advance of the greatest development of the Discinida. It is probably this second branch that gave origin to the degraded family Craniidie. The protegulum in the dorsal valve of Acrotretacea is probably always marginal, whereas in the Discinacea it is always more or less central.

It is remarkable that Crania, so mulike other living brachioports and occurring abundantly in the seas of to-day, has never been completely studied developmentally or ontogenetically. The taxonomic position of the Craniide is therefore not actually determined, and Hall and Clarke incline to follow Waagen in regarding the Craniacon as erfuivalent in rank to the Atremata and Neotremata. These authors write: ${ }^{1}$

It is nevertheless to bo observed that no trace of a former pedicle-slit incision or perforation is found on mature or immature shells, and it would be difficult to comprehend in what mamer sneh an essential modification of the shell could be wholly eoncealed by later growth. Were the pedicle marginal iu primitive growth stages, and subseqnently atrophied, the obliteration of the marginal opening hy later resorption and growth wonld be a readily intelligible process. There is, bence, in this defanlt of evidenee, a good reason to doubt the close affinities of Crania and Pholidops to the Diacaulia [= Neotremata]. Present knowledge would seem to indicate that they were primarily of the type of the Mesocanlia $[=$ Atremata $]$, and that their resemblance to the Diacanlia is wholly of secondary growth. Waagen's term for this group, Gastropegmata (or Craniaeea), may therefore prove to be equivalent to each of these other two divisions.

Brachiopod embryology demands a pedicle in the early stages of Crania. The ventral valve carries the pedicle, and it is always this valve which is attached by cementation or otherwise. The writer has observed in Tale University Musenm a specimen of Tholidops ovata with a cicatrix of attachment, around which point growth is loloperipheral, as in all Neotremata. Specimens of Pholidops are sometimes preserved with both valves in position and delicately attached to Bryozoa, 
from the Falls of the Ohio. These are believed to be actual and not chance attachments. In Crania eementation occurs very early and is complete, cansing all obliteration of the protegulum and subsequent stages of growth in the ventral shell. That cementation cloes obliterate nearly all the younger characters is also shown in the remarkable genera Richthofenia and Ostrea. On the interior of Pholidops and Crania the four large muscular scars, which are more those of the Neotremata than of the Atremata, are arranged medially. in the center of which, probably, was the pedicle opening. Some proof of this is seen in the excavated, posteriorly terminating muscular pit of Crania iunabergensis, whieh, if carried tirough the valve, will make the pedicle opening subcentral and surrounded by shell deposit. If an Acrotreta, Linnarssonia, or Conotreta became cemented, there would result practically a Crania. In no atrematous brachiopod is there the slightest indication of cementation, but where shell tixation does occur it is always (excepting in Zugmeyeria and Thecocyrtella) in such as have the pedicle very early surrounded by shell matter, as in the strophomenida and Productide. For these reasons the characters of Craniacea seem more in accord with the Neotremata than with the Itremata. The character's of Craniacea are certainly not of ordinal importance, and possibly not even of superfamily value.

In the development of its pedicle foramen the family Siphonotretida is unlike any other of this order. During neanic growth the pedicle opening was posterior to the protegulum, but later it gradually moves anteriorly through the shell by resorption, producing a narrow slit similar in appearance to that of the Discinidie. A pedicle foramen of the same nature is also developed in Eichwaldia and Dictyonella of the Protremata. As yet no explanation has been given as to the causes producing this aberrant development. The writer suggests that since these animals had delicate pednneles, with the shell elongate oval and sometimes cone-shaped in form, they probably stood nearly upright on their pedicles in early growth. Shell accretion being more rapid anteriorly; with the ventral side of the animal the larger and heavier, a tendency was initiated for the shell to lean against the ventral side of the peduncle. This pressure would produce resorption of the ventral shell anterior to the pedicle, and eventually, this tendency becoming hereditary, the ventral valve would lie nearly flat, with the pedicle emerging at a great angle subcentrally.

\section{PROTREMATA.}

This order is represented by 738 species, or nearly 40 per cent of American Paleozoic brachiopods, and is eminently characteristic of the post-Cambrian Paleozoic systems. Like the Atremata and Neotremata, it is represented in the Lower Cambrian. It was not, howerer, until Ordovician times that the Protremata attained rery rapid evolntion. In the Cambrian there are but 4 genera and 22 species, while in Bull. 87-6 
the Ordovician there are 20 genera and $17: 3$ species, a specific increase of more than seven and one-half times the mumber in the Cambian. Greatest generie diforentiation oceured during the silnrian, where 30 genera appear. Then began a steady lecline, with extinction in the Carboniferous of Nortl America. In the Triassic of Enrope this order is sparingly represented by small species, and is there essentially restricted to the family 'Thecidiida, which continues to have living representatives in the Mediterraneari Sea.

The widely distributed species gradually increase in percentage from 14 in the Cambrian to 36 in the Carboniferous, and are most marked in the family Producticlie. 'This family is one of the last of the order to origiuate.

The largest of all brachiopods occur in this order, in the families Pentamerida and Productidie, exceeding the Spiriferida of the 'Ielotrenata. In the former family greatest size is attained in the Silurian Inring the acme of the order, and in the Prodnctide in the Carboniferous system. Productus giganteus of the Lower Ouboniferous is the giant of all brachiopors, attaining a diameter of nearly 1 foot. In both these families the earliest species are small, but certain gromps gradually attain larger and larger size with geologic time. Upon the appearance of the giants, vitality of the families, as exemplified in specific differentiation and robustness of individuals, is at its highest. After this these families rapidly declinc, and the species dwarf far more rapidly than they leveloped to the climax.

In the Protremata, as in the two previons orders, greatest specific differentiation does not occur in the radical families, but in those of later development. The Kutorginida, Clitambonitidre, and Billingsellidie are the radical and, geologically, the oldest families of the Protremata. These are best but sparingly developed in the Cambrian, whereas the younger fanilies, Pentamerida, Strophomenidie, Productide, and Orthidiv, contain over 95 per cent of the species and nearly 90 per cent of the genera. Orthida and Strophomenidre, beginning in the Cambrian, are best developed in the Ordovician and silurian systems, respectively; while I'rodnctide, originating in the Silurian, attained a climax in the Carboniferous. The latter family was one of the last of the Protremata to originate aud has the shortest geologic history and least generic differentiation, yet many of its species have greater geographic dispersiou.

The Protremata are clearly divisible into two phyla, Strophomenacea and Pentameracea. The former superfamily has the greater mumber of species, and is characterized by the nondevelopment of a spondylium or cruralium. 'The Pentameracea has, in addition to the delticlium, an internal spoon-shaped plate, or spondylimm, serving for the attachment of muscles, and a discrete or mited ermalinm. The superfamily Strophomenacea in Torth America has 608 species, and represents the most primitive phylum, since it is far better developed in the Cambrian than 
is the Pentameracea, and has almost without exception a straight eardinal area. The Pentameracea has 127 speeies, and its earliest forms also have straight hinge-lines in the 16 species of the families Clitambonitidxe and Syntrophiida; but the rostrate family Pentameridre, which attained maximum development in the Silurian, has 87 species. The Strophomenacea has living species, while the Pentameracea disappeared with the Permian. The cause for the rapid extinetion of the latter is probably due to the high degree of specialization expressed by the spondylium.

Two well-marked types of shell form are developed in this order. By far the most prominent is the group which includes the long-hinge fanilies Kutorginidæe, Clitambonitida, Billingsellidæ, Strophomenidre, Prodnctidx, Thecididxe, and Orthidx. The other group, represented by Pentamerida, is largely rostrate in form, but occasionally also (levelops a straight hinge line. This, however, is never so prominent as in the former group. In the Telotremata the general form is rostrate, but very notable exceptions are present in the families Spiriferida and Terebratellidie, and oceasionally in the Rhynchonellidre and Athyrida. The form of the shell, however, has no great taxonomie value, and can not be aceorded more than generie rank. The predominating type of shell form within an order probably has phyletie value, since the oldest protrematous shells are loug-linged, while the telotrematous shells are usually rostrate. Nevertheless, as indieated above, in the deriver forms of both orders there are notable exceptions, and these changes are probably always induced by shortening or lengthening of the pechneles. Sinee Orthorhynchula has a well-developed eardinal area, it is not in itself "evidence of the first significance as indieating' the sonree from which the extensive group of the Rhynchonellas originated." 1 The oldest rhynchonelloids are rostrate shells (Protorhynchu? minor and $P$.? ambigua of the Lower Cambrian), and the ontogeny of several species of Rhynchonella and of Zygospira has not revealed a long-linged stage with cardinal areas. There is, therefore, no conclusive proof for the deduction of Hall and Clarke, "that some of the Rhynehonellidie, early in their [geologic] history, occasionally retain a well-defined cardinal area, and that, in default of other evidence, the presence of this character may be regarded as indicative of the common origin of Orthis, the Strophomenidie, and the Rhynchonellas." 2

In this order far more than in any other is found the closure of the pedicle passage and atrophy of the pediele, together with pecnliar special adaptations which entirely or partially replace the funetions of the pedicle. In the family Productide the ventral shell develops more or less abundant tubular spines, either along the cardiual line or over the entire valve. These are always most abundant in, or ale

IPaleontology of New York, Tol. VIII, Part II, 1895, p. 336.

${ }^{2}$ Ibicl., p. 342. For further remarks bearing on this subject, see pages $93-95$ on the significance of the prodeltidium. 
restricterl to, the posterior region. The functions of the spines are to hold the animal to its place of habitation, for there is no apparent perlicle opening in these shells when mature. In other's of the same family the ventral apex is cemented to extraneous objects (Strophalosia), and in still others the spines clasp the object of support when smail (Strophalosia goldfussi and Etheridgina). In the Strophomenidie the older species all seem to have functional pedicles throughout life, but in the Devonian, forms occur in which the apex is cemcnted to foreign objects (Leptienisea). Some of the Middle and Upper Devo nian Stropheodontas show no trace of a pedicle opening when adult. In the Carboniferous cementation is far more common, and occurs in Derbya and Streptorhynchns; and when taken in connection with Strophalosia, Chonostrophia, Aulosteges, aud Richthofenia, it is seen that nearly all the contemporaneous species of this order have developed other methods for fixation than the normal one. In Richthofenia calcareons cementation is complete, and the modifications resulting therefrom have so changed the shell that the lower or fixed valve is very suggestive of a cyathophylloid coral, not only in form but even in shell structure.

The ehief cause for atrophy of the pedicle lies not only in the fact that this organ, in all long-hinged brachiopods, is short, but more particularly in the fact that thronghont this order, and in the Acrotretacea of the Neotremata, the young shells always have the pedicle completely surrounded by shell, and this to a great extent linit its growth. Even among the Orthidie, where the species geologically older often have thick pedicles, which is indicated by the large open delthyrium, they gradually diminish in size thronghout the Paleozoic. In the Strophomenide the pedicle is nerer a thick organ, and shortly after this family gives rise to the Productidx, in Chonetes, the first appearance of cementation takes place. This mode of attachment constantly increases in the different phyla to the end of the family histories. In the Productidie the early inheritance of a reak pedicle soon leads to its complete loss by the additional fixation developed. This additional fixation has its first appearance in the cardinal spines of Chonetes, which are periodically developed by mantle extensions. The degen. eracy of the pedicle, once well established, is inherited at earlier and earlier periods by acceleration. The spines become more numerous, and are finally developed over the entire ventral valve. In the dorsal valve, the spines are never so long as in the ventral valve, and often are not developed at all, but are replaced by numerous concentric orerlapping lamellæ. As the spines begin to develop more numerously and longer, the ventral valve attains more convexity, with a strongly incurved beak and the complete loss of a pedicle opening. Productus, therefore, does not stand erect on the carlinal areas, as in Chonetes, but lies on the ventral shell, anchored by the numerous spines. The spines are of the same nature as the shells, and nerer flexible. When 
they came in contact with hard objects during their growth, they followed along or elasped the object of support.

The slender shell-incased pedicle of the Strophomenacea probably leads to the growth of long, straight hinges for additional support, further weakening the pediele and necessitating accessory fixation in four of its families, and finally ocrasioning in many speeies complete loss of this organ at the maturity of the individual. With the exception of the 'Thecididae, the order Protremata has become nearly extinet since the Jurassic era.

\section{TELOTREMATA.}

This order, though but 2 Cambrian and 20 Ordovician forms are known, is represented by 766 species, or about 41 per cent of all American Paleozoic brachiopods. It is as well developed specifically as the Protremata, and exhibits a far greater variety of structures. Telotremata was probably the last order to originate, and has the greatest number and variety of living speeies. Its highest development is in the Devonian, where 369 species in 50 genera occur, while 109 speeies are known from the Silurian, a growth more than five times greater than that of the Ordovician system. Here, too, as in the Protremata, considerable time was consumed in estahlishing a few primitive characters, and these are no sooner obtained than an almost sudden development of great specific and generic differentiation takes place.

It is highly probable that no telotrematous Paleozoic genus continned to live throngh lualf the geologie time that Lingnla and Crania dicl. Rhynchonella, a primitive genms of this order, is often said to have continned since the Ordovician, and Terebratnla since the I)eronian, era. This is now very donbtful, since Hall and Clarke have demonstrated that in all of the Paleozoic forms of these genera where it has been possible to examine their interiors none belong to Rhynehonella or Terebritula. In this catalogue both genera are rerognized as ocenrring in the Paleozoic, but this is dne to the fact that the internal structure of those species is not known.

Telotremata has three distinct types of brachial supjorts, which readily serve to differentiate 3 superfamilies. The simplest, Rhyncho. nellacea, has but crnra, and is represented in the American Paleozoic by 14 genera and 202 speeies, of which 66 are widely distribnted. The superfamily Terebratulacea, having more or less simple $V$ or $W$ shaper brachial smpports, is present with 19 genera and 75 speeies, of which 23 are widely distributed. In the structurally mole complex super. family Spiriferacea, having spiral brachial supports, there are 41 genera and 466 species, and of these 161 become widely distributed. This again confirms the previonsly noted fact that the groups latest developer have the greatest generic and specific differentiation. In Spinferacea this likewise oecurred in the family Athyrida. 
If the pereentage of widely distributed species within a superfamily is a criterion of its vitality, it will be seen that the Rynchonellacea begin in the Ordovician with 50 per cent and decline to 23 per cent in the Carboniferous. The Spiriferacea, also beginning in the Ordovician, have in per cent of their species widely distributed, becoming reduced to 20 per eent in the carboniferous. On the other haud, the 'Terebratulacea were not widely dispersed in the Silurian, whereas in the beronian their distribution reached nearly 30 , increasing to 34 per cent in the Carboniferons. Since no statistics of the Enropean Mesozoic and Cenozoic species of this nature are available, the writer can not determine whether or not the Rhynchonellacea contimue to decline with such rapidity. It is known, however, that this superfamily has declined considerably in the Cenozoic and late Mesozoic. After the Triassic the Spiriferacea are essentially represented by Spiriferina, yet it too died ont with the Jurassic, while the Terebratulacea, which manifested progressively greater vitality during the Paleozoic, are believed to have continned so nearly thronghont the Mesozoic into late Cretaceous time. Since then, however, they have also declined.

In the ontogeny of Dielasma and Zygospira-loop-bearing and spirebearing genera respectively-Dr. Beecher and the writer have shown that the Terebratulacea may not have been the last superfamily to develop, as was formerly supposed, and that it may have given rise, luring early Ordovician times, to the spire-bearing superfamily Spiriferacea. The Terebratulacea probably originated in the Rhynchonellacea, though no loop-bearing species are known until the spire-bearing forms are well advanced, or until early in the Devonian system. While some of the largest species of Terebratulacea are found in the Devonian of America and Europe, yet throughont the Paleozoic this superfamily is not a conspicuons one. In the Jurassic and Cretaceons systems of Emope, however, great specific differentiation and abundant individual development took place. There is but 1 species of this superfamily in the Ameriean Silurian, $\pi$ hile the Devonian has 50 species in iis genera, an increase fifty times greater than that of the Silurian. In the Carboniferons a sharp decline set in, and the superfamily is reduced to 30 species and $S$ genera.

These facts suggest that either the superfamily Terebratulacea did not oricinate in American seas or-which seems less probable-that diminutive species occur whose interior characters have escaped detection. Further, since the earliest American prinitive genera, Rensseluria and Trigeria of the Lower Devonian, have very large species, noither these nor Centronella can be the earliest adult representatires of this superfamily. When quite young, Zygospira, also, has a "centruncla-like loop;" and it is possible that the primitive Terebratulacea had their origin before the earliest appcarance of Zygospira, or during the rarliost part of the middle Ordovician era.

'T'he great majority of telotrematous genera are rostrate in form, but 
at diflerent times and in separate phyla straight cardina areas are more or less well developed. In America, the oldest members of this order (Protorlyucha? minor and P.? ambigua, members of the family Rhynchonellidir) occur in the Lower Cambrian. In these species, and in the great majority of this family, there is no carclinal area; but occasionally this charaeter is present, the carliest conspicuous example being the Ordovician genus Orthorhynchula. Among the Paleozoic Terebratulacea cardinal areas are seldom developed. A conspienons exception, however, necurs in Tropidoleptus. But in the Mesozoic and Ceneozoic, in the family Terebratellidie, cardinal areas are very often present, aud in living forms are accompanied by a short pedicle. It is, moreover, in the spiriferacea, the youngest superfamily of the Telotremata to originate, that the greatest development of eardinal areas takes place. The ollest genera of the Spiriferacea are all rostrate, as in the Ordovician Kygospila, Catazyga, and Cyclospira. In the Silurian the Spiriferidie tend to develop rapidly long, straight, and wide cardinal areas, attaining greatest development in the Devonian and early Carboniferous. This excessive development of cardinal areas is no doubt due to the shortening and decline of the pediele, since in the Triassic system forms ocem in which cementation is complete (Zugmeyeria and Thecocyrtella). Cardinal areas are also dleveloped in other families of the Spiriferacea, but in no case can such he traeed to Ordovician long-hinged ancestors.

In this order, more than in the Protremata, internal specialization of the brachia has progressed from a simple to a highly complex condition. In the Protremata, in its latest developer smperfamily, Pentameracea, crma are also present, of the same phase of ilevelopment attained by the Rhynehonellacea, the most primitive superfamily of the Telotremata. In this orler, lonwerer, there are, with but few exceptions, no internal special structures, as spondylia. The specialization in the Telotremata is expressed in the progressive complication of the calcareons brachial supports. In the most primitive species of the Rhynchonellacea no ermira are present (Protorhyncha), but in all later forms these appendages are well developed, and finally in the Trias and Jura attain very great length in Rhynchonellina. In the next more complicated superfanily, Terebratulacea, the erura in the primitive members have united anteriorly, thus forming the simple unchanging loop of Centronella and Rensselieria, which is also known to occur in the very young of some species of the highest superfamily, the Spiriferacea. The geological history of the loop has shown that the brathia have been constantly changing, causing more or less eom. plete resorption of the harl parts and adaptation to later requirements. The progressive development of the loop is also repeated ontogenetically and more or less fully in living terebratuloids.

hn $/ \mathrm{yg}$ gospira, the oldest known genus of the suborder Spiriferacen, the primitive loop of Centronella is reproduced in the earliest phase in 
the development of its brathidium. 'This is partially resorbed and changed in form, and to it is then added laterally the two spirals and medially the simple or, in the highler forms, the complex processes, or jug'un. The rolutions of the spirals in the oldest genera geologically are rery few, but subsequently they beeme more numerous, and attain their maximum in the long-hinged Devonian and Carboniferous spirifers, where 35 volutions liave been observed, with 24 in Atrypa.

The form of the pairen spirals varies but little except moder the neessity of conforming to the interior cavity of the valves. Their inelination and direction is a feature of mueh significance when considered with reference to the development of the entire shell. It is the loop, or to employ a term more appropriate in view of the homologies of the spire-bearing aml loop-bearing shells, the jugum, however, whieh is sulject to the most frequent variations in form, and which serves as the generic index. When the spirals are clirected outward toward the lateral margins of the valves, the jugnu seems to be much more variable than in shells where the spitals are introverted or take some internediate position. In the latter there is a ruch greater variation in the pusition of the loop upon the primary lanelle than oecurs in the former. ${ }^{1}$

\section{GENERAL DEVELOPMENT.}

In the preceding pages it is shown that the four types of pedicle openings which serve as the prime characters in distingnishing the four orders, Atremata, Neotremata, Protremata, and Telotremata, are present in the oldest division of the Cambrian, the Olenellus zone. From the pre-Cambrian sedimentary rocks, or Algonkian system, practically no fossils are known, thongh there is evidence in them that life existed. The fact that the Olenelhus zone has a varied marine fanna alone indicates that the sea duriug Algonkian times must have swarmed with living things. When the enormons time represented by the great thickness of Xorth American pre-Cambriau serliments is considered, or that of Bohemia, it is evident that anple time elapsed for life to attain the degree of complexity manifested in the basal Cambrian zone. Kayser says that this pre-Cambrian time was "probably so long that the heginning of the Cambrian period may be consirlered as comparatively a recent event." ${ }^{2}$ Van Hise, in writing on the sance subject, says: ${ }^{3}$

If geological listory wore to be diviled into three approximately equal divisions. these divisions would not improbably be the time of the Archean, the time of the clastic series between the Archean and the ('ambran, and the time of Caubrian and post-fambrian. In this connertion it is well to recall that many years ago Loyin mirgester that the thickness of tho Laurentian and Huronian may surpass that of all sneceeding formations, and that the appearance of the so-called Primordial fam may be considered as a complaratively nodern event.

In the Lower Cambrian there are not many species of brachiopods, nor is the specifie differentiation in any order very varies, indioating

1 Hall and Clarke, Palacontology of New Tork, Vol. TIIl, Part 1I, 1895, p. 343.

2 Text-Bowk of Comparative Geology, 1893, p. 13.

3. Sixteeuth Ann. liept. U. S. Geol. Survey, Fart I, 1896, 1. 760. 
either that evolution in pre-Cambrian eras was mneh slower than sub. sequently or that the class had its origin late in the Algonkian. Cambrian brachiopods usually differ fundamentally from one another, and do not appear to have been persistent, as but 4 of the 22 genera pass into the Ordovician. Differentiation also appears to have been slow during the Lower and Middle Cambrian, but toward the close of this system species begin to be more numerons and varied. In Middle Ordovician times all the orders and superfamilies are well established except Terebratulacen. The zenith of the elass was attained in the Silurian and Devonian eras, but decline began during late Devonian, and steadily continued to the close of the Paleozoie. But 7 of the Carboniferous genera are known to have survived the break between the Paleozoic and Mesozoic. During the latter time the spire-bearing brachiopods pass out of existence, while the great Paleozoic superfamily Strophomenacea is represented by a few small speeies of the Thecilliilie, which eontinne to be represented up to the present time. After the Cretaceous system the orders Atremata, Neotremata, and Protremata are represented only by Lingula, Discina, Discinisca, Crania, and Thecidium. The Terebratuidde may have had their inception below the middle of the Orlovician, but are not a pronounced Paleozoic gronp. However, in the Jurassic and Cretaceons systems the roeks abound with the shells of this family, and from that time on they are the chief representatives of the class. Lingula and Crania are present in the Ordovician, and, as far as can be determined, have persisted to the present time.

Of the 49 families and snbfamilies constituting the class, 43 became differentiated in the Paleozoie, and of these 30 disappeared with it, while but 13 eontinned from the P'aleozoie into the Mesozoie. Of Paleozoie families, 6 are represented by living species, viz, Lingulidx, Dis cinida', Craniida', Thecidiilde, Rhynchonellida, and Terebratnlidae.

Of the 327 genera now in use, 227 had their origin in Paleozoic seas, or nearly 70 per cent of the entire class, and of this great number but $S$ are positively known to pass into the Mesozoie, viz, Lingula, Orbiculoidea, Crania, Rhynehonella, Spiriferina, Athyris, Terebratula, and Hemiptychina. Besides these, Streptorlıynchus, Cyrtina, Retzia, Martinia, and Martiniopsis, are mentioned as occurring in the Triassic, bnt these species probably in great part belong to other genera.

The Atremata, which contains the oldest and the simplest forms structurally, is represented by 29 genera, while the Neotremata and Protremita have 30 and 89 , respectively. Telotremata is the last order to appear, and has by far the greatest number of genera, 179 .

The chronogenetic history of brachiopods shows that the four orders begin with smooth shells, and that subsequently various kinds of surface orluanentation are developed or disappear with varying degrees of rapidity. The ontogeny of strongly plieated and lamellose shells, wherever observed, begins with smooth shells. All new surface ebaracters 
are first introdnced during adoleseent growth or senility, and these by the law of acceleration appear earlier and earlier in later species. In the Lower Cambrian there are species of Billingsella with at few hroad undulations in the shell, but in the Middle Cambrian the plications are pronomeed and cover half or more than half the anterior portion of the valves, while in the Upper Cambrian these folds apprear upon the umbones. In the oldest rostrate pentameroids the shells are either smooth or have a few folds (Camarella), which become more dis tinet in Parastrophia, and culminate in numerous sharp plieations in Anastrophia. The rhynehonelloids, beginning in Protorthis of the Lower Cambrian as smooth shells, gradually become more and more plicated in the Silurian and Devonian, yet in the Triassic many species again appear nearly smooth.

\section{STRUCTURAL CHARACTERS.}

\section{THE PROTEGULUM.}

The order Atremata is the radieal brachiopodons stock, which early in its history gave origin more or less direetly to the other three orclers of brachiopods. Beeher has observed: '

That all brachiopods, so far as studied by the writer, have a common form of embryonic shell, which may be termed the protegulum. The protegulum is senicircular or semielliptical in ontline, with a straight or arcuate hinge line, and no hinge area. A slight posterior gilping is prodnced by the ventral valve being usmally more convex than the hrachial. 'The modifications noted are apparently dne to accelerated growth, by which characters primarily nealogic [= neanic] becomeso advanced in the devolopment of the individual as to be impressed tinally apon the embryonic shell. This feature is well shown in the development of Orbiculoidea aud Discinisca.

As the protegninm las been olsserved in about 40 genera, representing nearly all the leading families of the eliss, its general presence may bes safely issumed. [In structure it is corneous ant imperforate and varies in size from 0.05 to $0.60 \mathrm{~mm}$. The] prototyle preserving throughont its development the main features of the protegulum, and showing no separate or distinet stages of growth [is fond in the Lower Cambrian genns Paterina]. The resemblance of this form to the protegnlum of other brachiopods is very marked aud significant, as it represents a matnre type having ouly the common enbryonal features of other genera.

Since the above was written Mr. C. D. Waleott has shown that the type speeies of Paterina has a well-developed cardinal area, and that it is synonymous with Iphidea. ${ }^{2}$ The latter, however, is generally assumed to have an apical pedicle opening as in the Acrotretide. This is now known not to be the ease. The supposed perforation is but a slight depression or short groove in the apex of the ventral valve, and does not pass throngh the shell. Iphidea is therefore in harmony with Paterina, since both have more or less well-developed cardinal areas. The theoretical Paterina or prototype of the protegnlum is therefore 
not yet known. It is evident, however, from the material Mr. Walcott possesses, that Iphidea-like forms will be discovered in which the cardinal area is undeveloped and in harmony with the protegulum. It is in this sense that the terms Paterina and paterina stage are used throughout this work.

\section{THE PRODELTIDIUM.}

The term prodeltidium is applied by Hall and Clarke to the third shell plate originating on the dorsal side of the body wall in the cephalula stage of Thecidium mediterrancum, the only living species of Protremata. 'This plate, lowever, is not restrieted to that order, but has been observed by author's as also oceurring in the Atremata and Neotremata. The term prodeltidium is here applied to this embryonic plate wherever it oceurs nnmodified.

Beecher has shown that the prodeltidium in the Protremata is the first cause for the development of the deltidinm so characteristic of this order. That this plate is also present in the Neotremata is apparent from the description of a braehiopod larva of Diseina (= Discinisca) given by Fritz Mueller. These larva were eaptured in abundance off' Desterro or Santa Cathrina, Brazil, but Murller was not so successful as Kovalevsky and others in securing the earlier larval stages of other genera developing in the brood poneh, and therefore nothing is known as to the place of origin of the prodeltirlium in Neo tremata. Since, however, the prodeltidium is also present in yonng Lingula of the order Atremata, where it is wholly attached to the interior of the rlorsal shell, it appears safe to assume that this plate invariably develops on the dorsal side of the thoraeic segment of embryonic brachiopods, and later becomes attached either to the dorsal (Atremata) or vential valve (Neotrenata and Protremata), except where, as in the Telotremata, it does not reeur.

Pefore taking up the phylogenetic significance of the prodeltidium, it will be advisable to state what is known of this plate in the Atremata and Neotremata. Since it was first discovererl by Fritz Mneller in the Neotremata, whore also it is best developerl, and subsequently was homologized by Brooks with a similar plate in Glottidia, it will here be given first consideration. Mueller writes: ${ }^{1}$

Mitilnrem IHinterrande dem ansgebnchteten Hinterrande der Banchshale anliegend, gewahrt man $\mathrm{z}$ wischen den Schalen eine querorale I'latte, $0.06 \mathrm{~mm}$. lang, 0.11 breit, mit clunklerem, oft brammötblieh gefïrbtem, ringfürmigen lande. Sie haftet an der Banehsehale, deren Bewegnngen sie folgt, nnd steht mit der Riickenschale nur dureh Inskeln in Verbindung.

There is, then, in this Discinisea, a transversely oval plate somewhat loosely attached to the ventral shell near its posterior margin, the movements of which it follows. Mueller adds: ${ }^{2}$

Die querovale Platte tritt unter deq bis zum Vorderrande der Riickenschale vorgeschobenen Banchschale vor, beginnt sich nach hinten $z u$ verläneran nut eits faseriges Ansehen zn zeigen (Stiel?); sie folgt, nach wie vor, den Bewegungen der Banchseluale. 
Since in this stage of Discinisea there is no perlicle present, Mueller appirently was disposed to regard the prodeltidium as the equivalent of the pedicle. That this is an erroneous interpretation seems certain, for in his second paper he states: ${ }^{1}$

1)io bis dahin zwischen den Schalen verhorgene querovale Platte (der stiel) tritt herror, inclem sio sich wie es scheint, um dem ansgehuchten Hinterrando des bauchschale vollst:̈ndig herumdreht und so ihr vorlerer hand zum hinteren wird.

In (ilottidia the pedicle does not appear until sometime after the prodeltidimm is developed, and it seems reasonable to assume from the description of Ineller that, on tine development of the pedicle, the prodeltidimm is pushed and turned backward, and between this and the notehed ventral margin the pedicle passes. The pedicle opening at this stage is therefore surronnded by shell matter, anteriorly by the protegulnm and posteriorly by the prodeltidium, characters duplicated in Thecidium. In the latter genus the prodeltidinm develops into the deltidium, whereas, according to Mneller, this plate subseqnently disappears in Discinisca. Brooks, also, is not disposed to accept Mueller's interpretation of this plate as the pedicle, since he writes: ${ }^{2}$

If it is the same [the transversely oval plate of Discinisca and the dorsal semicircular plate of Glottidia], Mueller is certainly in error in his suggestion that it is the peduncle, for there is no connection between the two structures.

In Glottidia pyramidata, Brooks has shown that the prodeltidinm is also present, yet here it does not become attached to the ventral shell, but is firmly fistened to the dorsal valve, and this apparently was consummated in the paternia stage. Brooks writes:

I was not able to learn anything of the significance of the semicircular plate shown in figures 1 and 3 . It is found only in the dorsal valve, and is either a mark upon its inner surface or a plate between the body and the valve. According to Fritz Mneller, the Brachiopod larva studied by him possessed a similar structure. * * * The embryo of Lingula is so small and thin that if this were a separate plate, it would be rather difficult to prove withont seeing it move, or find it bent ontward. In the absence of snch evidence, we seem warranted in concluding that it is a similar structure to the movable plates of IIneller's larva, although, in Lingula at least, it is in connection with the dorsal, not the ventral valve.

No one has yet mentioned the presence of the prodelticlium in living Telotremata, and it may prove to be absent in this order, as it is not developed in the three species carefully studied by Morse, Kovalevesky, and Shipley.

Recapitulation.-The prodeltidium is present in Atremata, Neotremata, and Protremata. In the embryonie brachiopods developing this plate it is first found on the dorsal side of the body wall, and later is anchylosed to the ventral shell in Protremata (Thecidium). In the Neotremata, the earliest embryonic stages of which are not known, it is found completely developed and loosely attached to the ventral shell, anterior to the posterior margin. It snbsequently turns backward to 
the posterior margin of the same valye, and the pedicle is believed to emerge between the plate and the valve (Discinisea). The prodeltidinm is therefore alike in final position in the Neotremata and Protremata. In the Atremata this plate is either attached by its entire surface or by the posterior margin only to the dorsal shell, as in Glottidia, where the earliest embryonic stages are also unknown. The prodeltidium is likewise dorsal in the cephalıla stage of Thecidium (Protremata), but subsequently is attached to the ventral sleell, yet in reality remains dorsal to the animal. In Glottidia (Atremata) this plate remains attached to the dorsal valve, and in nowise affects the pediele opening, as in the Neotremata and Protremata. In the Telotremata the prodeltidinm has not been observed, nor has any fossil species in this order shown the least trace of a deltidinm, and wherever the delthyrinm is closed it is always by plates growing medially from its walls, secreted by the mantle and never by the peduncle. Therefore, when the prodeltidium remains stationary or with the dorsal valve, it is not known that this plate affects the original pedicle opening (Atremata and Telotremata), but when subsequently attached to the veutral valve and partly surrounds the pedicle with shell matter, it completely modifies the primitive pedicle opening by restricting it to the rentral shell (Neotremata and Protremata). In the derived or later-appearing families of the Neotremata and Protremata the effects of foraminal modification initiated by the prodeltidium may be wholly lost, as in Craniida and Orthiida.

\section{SIGNIFICANCE OF THE PRODELTIDIUM.}

The deltidinm is the chief character of ordinal importance in the Protremata, and since this plate is attached to the rentral valye, ytt originates in the dorsal prodeltidium, it seems reasonable to assume that if similar developmental couditions are found in other orders such orders would possess closer phylogenetic relationship than those having differing conditions. It has been shown that the prodeltidium is also attached to the ventral valve in the Neotremata, and so fin both orders show relationship in their earliest embryonic growth. Beecher has shown that the protegulnm or initial shell of the Protremata is discinoid in form and more like that of the Neotremata than that of the Atremata or Telotremata. Ile writes: ${ }^{1}$

Discinisca shows a subcirenlar ventral protegulum with a pedicle notch, and the evidence of any hinge in the dorsal protegulum is very slight. The discinoid character appearing in the second and third nepionie stage of the Paleozoie Orbiculoidea has become so accelerated in Neozoic and recent Discinisea as to produce a discinoid protegulum.

The strophomenoid shells usnally retain a normal protegulum in the dorsal valve, but from the acceleration of the discinoid stage in the ventral valve the protegulum, has an abbreviate hinge and arenate hinge line. (P.346.)

The nepionie stage of Leptena rhomboidalis is represented by a shell without radii, having a comparatively large pedicleopening in the veutral valveand a large leltidium. The hinge is not well defined and the shell is discinoid in form. 
The external waracters as oxpressed by both valves aro manilestly nearer to Kutorgrina than to any tolotremate genus. * * * It should bo noted, however, that the young of Chonetes, Productus. Stropheoclonta, Orthothetes, Leptinna, l'lect ambonites, and strophomena, all have little or no indication of a siraght hinge lins, and that the extension of this member takes plaee during later nealogic and ophebolie growth. (I'l. 150-15I.)

By far the greatest number of Neotremata occuring in the lower Cambrian are species of the family Acrotretidar. To the writer it has always seemed strange to suppose that this family has been derived through the Trematidie, but the above interpretation of the prodeltirl. ium in Discinisca indicates that the turning of this plate posterior to, the pedicle at once led to holoperipheral growth in some of these early forms. In some species of tile Acrotretidar there is a true deitidium. In Acrothele the carclinal area is flat, withont any trace of a deltidinm, whereas in Acrotreta and Conotreta, which have high cardinal areas, there is a narrow concave depression bisecting it. These deltillia, whether convex or concave, are in all probability initiated by the prodeltidinm, as in the Protremata. In the family Trematida there appears to be nothing homologous with the deltidinm, since the plates sitnated in the apex of the wide triangular fissure of Schizocrania and Lingulodiscina seem to be formed anterior to the pedicle and subse. yuent to its movement posteriorly with growth, and not posterior to the pedicle, as in the Acrotretidx. These plates in the Trematide should probably be lomologized with the listrinm of the Discinida.

The complete harmony of the muscular system in the Protremata and Telotremata is no evidence in itself that the latter were derived from the former. The occurrence at the base of the Cambrian of very primitive species of the four brachiopod orders is proof that divergence took place very early in the history of the class, and while there is little knowlerge of the muscles in either Iphidea, Kutorgina, or Pro. torhyncha ( $P$ '.? minor and I'.? ambigua), the earliest genera of Atreuata, Protremata, and 'Telotremata, respectively, there is some evidence for supposing them to be as in the type embryo stage of living species. The high degree of specialization attained by Lingula (Atremata), as exemplified by the burrowing habit, long pedunele, and absence of ralve articulation, is the cause for their complex muscular system, while the development of a functional hinge in the Protremata and Telotremata has led to the retention of very primitive conditions or to the simplification and harmony of the muscles throughout these two orders.

'The presence of a terminal intestinal opening in the living speeies of the Atremata and Neotremata and its general absence in those of the Protremata and Telotremata is no longer held to have phylogenetic significance, as many of the Paleozoic species of the two latter orders afford good eridence of such having been present in the median line as in living Crania. ${ }^{1}$ 
The known protegula, or initial shells, of the Neotremata and Protremata have been shown to be harmonions, and to differ from the normal ummodified protegula of the Atremata and Telotremata. The paterina stage in the two last-named orders is followed by the "obo. lella stage" in the highest families of the Atremata (Lingulellidie and Lingulide), and probably thronghont the Telotremata, since it has been observed in a number of Ordovician and Silurian Rhynchonellacea, Spiriferacea, and recent Terebratulinas. ${ }^{1}$ In the Neotremata and Protremata the paterina stage is not followed by the obolella stage, but usually by holoperipheral growth, except where the pedicle slit remains for a time wholly unincloserl by shell matter. ${ }^{2}$

In tabulater form the above-presented facts appear thus:

Table of fundamental brachiopod characters ordinally arranged.

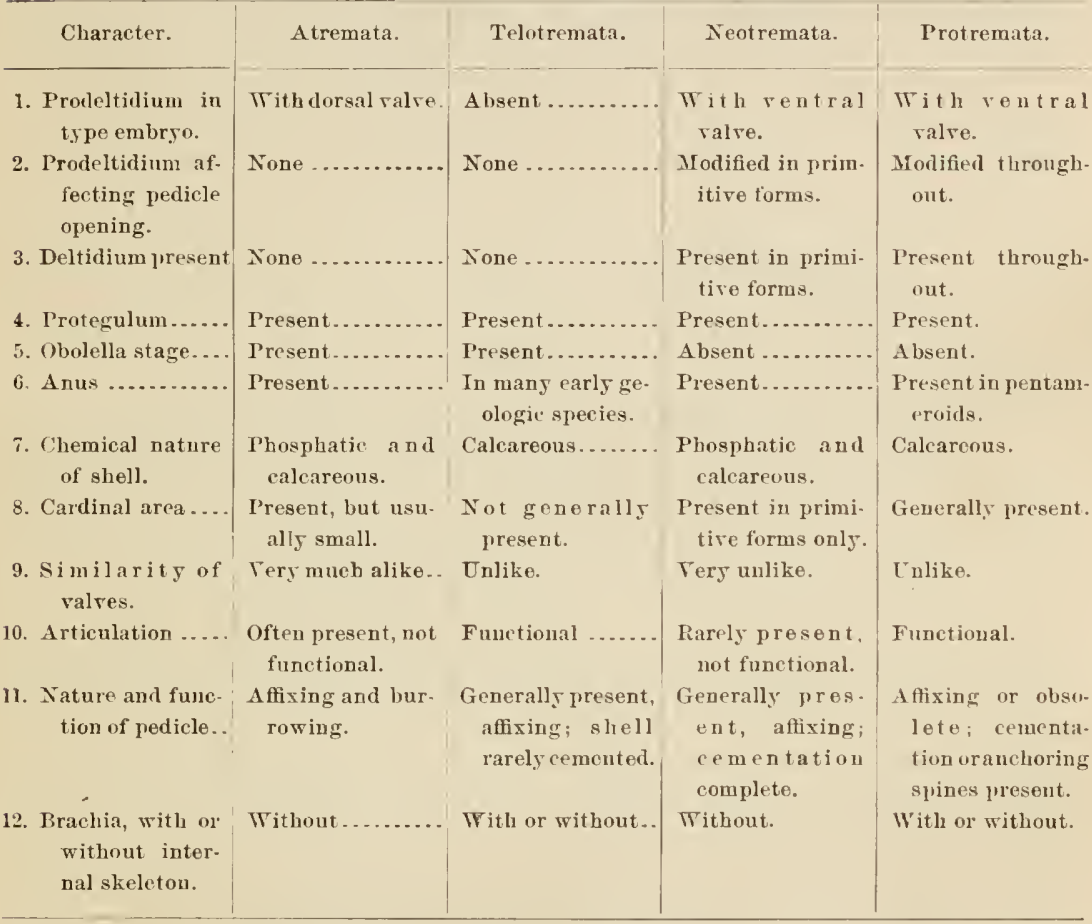

It now appears evident that the two great divisions of brachiopods heretofore based on the presence or absence of functional articulation have no phylogenetic significance, and as they "do not appear to have a primary developmental basis in nature, * * * they fail to express the true relationships of the various groups included in them." ${ }^{3}$

'See papers ly Beecher and Clarke, Brooks, Morse, Beecher and Schuchert, and Winchell and Sehuchert.

2 See Am. Jour. Sci., 3d series, To]. XLIV, 1891, pp. 150-151.

${ }^{3}$ Beecher, A m. Jour. Sci., 3d series, Tol. XLI, 1891, p. 353; also see Fol. XLIV, 1892. 
Articulation was developed along two independent lines, and therefone the terms Lyopomata and Arthropomata have no phylogenetic significance. The presence or absence of articulating processes was at one time considered a fixed line, on either side of which all brachiopods could be arranged; but now artienlation is known to be nearly finctional in several lyopomatons gevera, as in Spondylobolus, Trimerella, Honomorella, Tomasina, Barroisella, of the Atremata, and in Trematobolus of the Neotremata. Among the Arthropomata, artienlation is harily functional in Kuntorgina, Schizopholis, Eichwaldia, and Dictyonella. Ifowever, it appears probable that two superorders exist, each having two orders. Atremata and Telotremata are the more primitive gronps, and agree in the following fundamental cluaracters: Prodeltidium attached to the dorsal valve or absent; perlicle opening primarily unmodified, and generally closed later hy calcareous plates secretul by the ventral mantle extensions; presence of a functional pedicle throughout the life of the individual (except in Thecospira, Theencyl-

\begin{tabular}{|l|l|l|l|l|}
\hline Algonkian & Paleozoic & Mesozoic & Cenozoic & Recent \\
\hline & & & & Protremata \\
& & & & Neotremata \\
\hline & & & & Atremata \\
\hline & & & & Telotremata \\
\hline
\end{tabular}

Fig. 1.- Diagram giving the geological distribution of l,rachiopor orders.

tella, and Bittnernla); general presence of the "obolella stage" in the ontogeny of atremate and telotremate species, and the development of complicated calcareous brachial snpports in the derived order. The Neotremata and Protremata agree in having the prodelticlinm attached to the ventral valve with complete nepionic modification of the perlicle opening; delthyrium often elosed by a single plate secreted by the pediele and never by mantle extensions; the perlicle is very often lost before maturity is attained, along with the development of new anchoring adaptations; absenee of the "obolella stage" and complicated calcarious braehial supports.

Owen's superorder's Lyopomata and Arthropomata have no basis in nature, and should be dropped. It is to be hoped that students will determine the complete embryology of Lingula, Discinisca, Crania, Rhy nehonella, and Terebratulina, for until more of the ontogeny of some species of these genera is known, no satisfactory relationship which the orders bear to one another can be established. However, it apjears probable that Atremata and Telotremata have superordinal relationship' 
differing from that of the Neotremata and Protremata. If the characters above pointed out are of superordinal value, it will be convenient to refer to these divisions as Homocanlia and Idiocaulia, respectively. ${ }^{1}$

\section{DEVELOPMENT OF CARDINAL AREAS AND ARTICULATION.}

The earliest suggestion of eardinal areas ocenrs in Iphidea of the Atremata and in the Acrotretidie of the Neotremata. In none of these forms, however, is there a true cardinal area comparable with those of the Protremata and Telotremata, sinee it is not bisected by a delthyrinm, nor are deltidial plates developed. A convex psendodeltidium is often present, but this feature is not homologons with the deltidium of the higher forms. It is due to holoperipheral growth and interference by the pedicle. In the dorsal valves of primitive genera in both the Atremata and Neotremata grow th is hemiperipheral, but in the ventral valve of Iphidea, the most primitive known genns of A tremata, and in the Acrotretida of the Neotremata, growth is holoperipheral.

The ontogeny of many species of Protremata shows that this order had its origin in some atrematous paterina-like gems. This must liave oceurred in pre-Cambrian times, since in the Lower Cambrian there are several speeies of Billingsella, a highly developed protrematous gems when rompared with the theoretical Paterina. Kutoryinu cinguluta Walcott, also of the Lower Cambrian, is a more primitive species than any Billingsella, and it gives evidence as to the course of evolution from the inarticulate paterina-like ancestor to this rudimentary, articulate, long-hinged genus. $K$. cingulata in conneetion with the Indian genns Schizopholis Wagen shows that the opening between the widely gaping valves of Paterina, which was entirely oeenpied by the perlicle, was partially elosed by a gradnal thiekening of the latelal wills, and there was slowly developed a primitive, ventral, carrlinal area. This

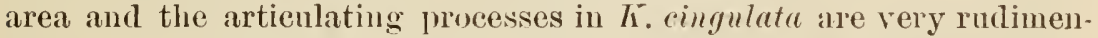
tary, and are situated at the lateral extremity of the cardinal area; thus this species still retains a very large open delthyrium, mnch as in the theoretical Paterina. In Sehizopholis this wille fissmre is rentueed to a narrow triangular delthyrium by the development of a true cardinal area, and the articnlating processes are now no longer at the lateral extremities, as in Kutorgina, but are situated more medially. Naturally, in the older Cambrian, complete articulation did not obtain, as in post-Cambrian times. Some of the oldest protrematous species, such as $K$. cingulute, Billingsella whitfieldi, and possibly others, also retain considerable phosphatie material in their shells, but in later and more highly speeialized species the shell is deeidedly ealeareous.

Some of the species of Iphidea have the ventral posterior region

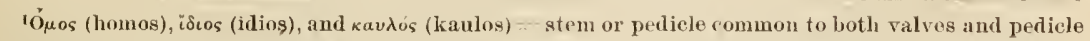
restricted to one valve, respectively. These characters may be retained throughout life or restrieted to the nepionic and neanic stages of growth.

Bull. $87 \longrightarrow 7$ 
more drawn ont beyour the dorsal posterior margin than others. If this rostrate condition were carried a little further and the psendodeltidium resorbed, there would practically result a telotremate shell dinpli. cated by the neanic condition of many rostrate 'Telotremata. The articulation would at first be nearly obsolete and situater extremely lateral, as in the Protrenata, but as the cardinal area became greater the teeth would attain a more medial position. While there are no known genera to fill in the gap between the theoretical Paterina and P'otorlyucha ( $P$. minor and $P$. ambigun), yet the hiatus hetween the Atremata and 'lelotiemata is not greater than between theoretical Paterina and Kintorgina, or between the Atremata and Protremata.

\section{DEVELOPIENT AND SIGNIFICANCE OF THE DELTIDIUM.}

The most characteristic mature feature of ordinal importance which distinguishes Protremata from the other three orders is found in the plate that more or less completely covers the delthyrim. However, in two of the families of this order, Pentameride and Orthida, this plate is generally wanting in the mature individual, since here it msually develops only during early growth, and later is lost by abrasion or hidden beneath the incurved beak. Again, in the Acrotretidae of the Neotremata, and in Iphidea of the Atremata, a deltidinm-like plate is also often developed, but as these shells are strongly phosphatic it is not difficult to distinguish the ordiual position of auy shells with a true deltidium. In Lacazella mediterranea, the only living species of Protremata, this plate has its origin in the cephalula stage along with the rudiments of the dorsal and ventral valves, when the embryo is yet free and swimming about by the aid of eilia. The dorsal shell and the prodeltidium apuear first, and are secreted by the rudimentary dorsal mantle and the dorsal surface of the body, which subsequently becomes the perlicle. The ventral shell appears last, and is then widely separated from the dorsal valve. Between the two valves is the thick and short pedicle, on the dorsal surface of which still remains the third plate, or prodeltidium. Subsequently the latter is anchylosed to the posterior margin of the ventral valve. The prodeltidinm is also known in the Atremata and Neotremata, yet in the Telotremata this embryonie third plate does not exist, lont a covering to the delthyrium is developed sometime after the animal has become attached. In its origin this covering is wholly different from the deltidium of the Protremata, which has its beginning in the prodeltidium and grows down from the shell apex over the delthyrim, while the deltidial plates of Telotremata grow out medially from the walls of the delthyrium. The deltulial plates are secreter by extensions of the ventral mantle, and at no period of rlevelopment has the pedicle any share in their formation. It is not always easy to distinguish mature protrematous and telotrematoms shells on the basis of these character's alone, but the young of both orders are 
easily classified by the covered or open delthyria, respectively. In some of the Telotremata, toward maturity the deltidial plates anchylose medially posterior to the pediele, or they may surround the pedicle, thus resembling the deltidium, but, since their origin is quite different, they are termed "psendodeltidia." Such psendodeltidia in Cyrtia, Cyrtina, and some spirifers resemble the deltidium of Clitambonites. Even the median line of anchylosis is often obliterated by the continuous secretion of the completely united prolongations of the ventral mantle lobe. In the Pentancrida the deltidium is generally absent, as in the Orthidie, but in Pentumerus and Conchidium it is often retained as a thin, fragile, concave plate. This reversal in form from the generally prevalent, convex, or flat deltidium may be due to the rostrate and arched ventral umbones so common in these genera. In the aberrant rostrate genus Dietyonella, which has an arehed ventral umbone, a concave plate is also present, between which and the shell the pedicle passes and emerges upon the umbonc, as in the Siphonotretidac. It is not certainly known that this plate in Dictyonella is a deltidium, but its form and position in the rostral cavity are very suggestive of that organ in Pentamerus and Conchiclinn. 'The peculiar umbonal pedicle opening in Dictyonella also finds its ecpuivalent in Leptama.

THE CHILIDIUM.

The chilidium is a convex plate often covering the rardiual process of the dorsal valve in the Protremata. It is particularly well developed in the families Clitambonitida and Strophomenida, and is uot to be confoumderl with the deltidium, since it filst makes its appearance not earliur than neanic growth, and apparently is a secretion of the dorsal mantle lobe. The origiu of the ehilidium and of the deltidium is therefore wholly different, and both have very dissimilar phyletic siguificance.

\section{ORIGIN ANI FUNCTION OF' THE SPONDYLIUN.}

The spondylinm is an internal ventral plate traversing the posterior portion of the animal. 'The upper surface of this plate is usually trunsversely marked by strice, which, in the Pentaneracea have three distinet curvatures in passing over it.

Since their position and the area occupied agree with the muscular sears of this valve in Orthis, they are here regarded as homologous with the alductors, dirluctors, and adjustor's of that genns. In Lingulasma, Lingulops and the trimerellids the $1 m$ scular scars are not found in front nor underneath, but on the "platform" of those genera. The platform, therefore, is homologous with the spondylinm of clitumbomites and Pentumerus. * * * The portiou of the valve immediately beneath the spondylium, and occasionally the sides of the septum, are strongly marked by the genital sinuses. Sinee there is no space posterior to these markings for the attachment of the inuscles, this clearly indicates that they were situated on the upper surface of the spondylinm. ${ }^{1}$

1 Winchell and Sehuehert, Final hept. Minn. Geol. Survey, Vol. III, L'art I, June, 1893, 1, 378. 
The spondylinm is developed as the "platform" in Lingulasmatidate and Trimerellidie of the $A$ tremata; as a "spondylium" in Pentameracea of the Protremata, and in Cyrtina, Camerospira, Merista, and Dicamara, of the Telotremata. In the Atremata and Telotremata, spondylia-bearing speeies are not numerous, but the individnals are usually abundant, often of large size, and generally are of short geologic duration.

The development of the spondylium or its morphologie equivalent probably had its origin in an excessive deposit of testaceous matter about the bases of the powerful adductors, diductors, and pedicle museles. Growth of the individual necessitates the progressive anterior movement of the museles, and when these are large there is but little or no space left between or ontside of them for the viscera and genitalia, which are therefore erowded farther and farther anteriorly. This condition naturally produces constant pressure of the genitalia against the anterior base of the forming spondylim, and since pressure canses resorption or diverts testaceous deposition, it follows that these orgaus will gradually produce eavities for their relief beneath this plate. In the older species of the Trimerellidie and in all of the Lingulasmatidie displacement of the genitalia does not appear to have been excessive, as the platforms are but slightly excavated. However, in the terminal genus 'Trimerella the genitalia ehambers are very deep, and these are present in both valves. Throughont the Pentameracea the spondylium is a thin, freely terminating or medially supported plate, and never solid as in the older species of the Trimerellida. It is likewise thin and excavated in the order Telotremata.

Hall and Clarke alvance quite a different explanation as to the origin of the spondylium. They write: ${ }^{1}$

The spondylium is an area of muscular implantation. In its early or incipient condition it is evident that it originates from the convergence and coalescence of the dental lamelle, and forms a receptacle for the proximal portion of the pedicle, and for the capsular or pedicle muscles.

Considering this strueture in its incipent condition, where, as in Orthis, it is represented only by the convergent dental plates which usually unite with, or rest upon the hottom of the valve, and inelose onily the base of the pedicle and its muscles, it will be evident that the plate is aetually but a modification of the original pedicle-sheath. It is evidently the inner moiety of this sheath snrrounding the pedicle, which has become involved or inclosed by the growth of the pediele-valve, and further modified by the development of articulating processes where it comes in contact with the brachial valve It therefore follows, as a natural inference, that wherever the spondylium is pres. ent, whether in the incipient condition or in the more advanced stage of derelopment in which it supports all the muscles of the ralve, it is, or, at some period of growth. has been aceompanied by the external portion of the sheath, which is termed the deltidium. Thus the spondslium appears to be but the complement of the deltidium, or the original plate formed upon the body of the embryo, and that portion of the adult shell to which the term deltidium has heen applied, is the other part of the original or primitive deltidial plate or pedicle-sheath. 
The writer also previonsly entertained this view, but when it became known that spondylia are developed where no dental lanellie exist, as in the Lingulasmatide and Trimerellide of the Atremata; that spondylia are never present in the Neotremata, where a pedicle-sheath is sometimes well developed, as in the Acrotretide; and finally, that a spondylium is even present where no deltidium ever existed, as in the two first-mentioned families, and in Cyrtina, Camerospira, Merista, and Dicanara of the Telotremata, sucl: an explanation became nntenable. The fact that solid or excavated spondylia exist in three orders, two of which never developed a pedicle-sheath (Atremata and Telotremata), and one had no dental lamelle (Atrentata), is good evidence that the prodeltidinm primarily had nothiug to do with the development of spoudylia. Further, no spondylia are developed in the Cambrian until long after the deltidinm was well established, and therefore the spondylium can not be "but a modifieation of the original pedicle-sheath." However, it is very probable that when the dental lamelle in the Protremata became sufficiently wide to join the ventral shell, crowding all the muscles of this valve into a small area, these took advantage of the inner sides of the dental lamella for insertion, and thus a continuous layer of testaceous matter was deposited within the rostral eavity. With growth, the muscles move forward and press against the genitalia, which eauses resorption or nondeposition for their relief. No spondylia appear before the Upper Cambrian, and here also are the first completely developed dental lamellax. The so-called Lower Cambrian camarellas have no completely developed dental lamellir, and are related to the rhynchonelloid genus Protorhyncha, and to Protorthis billingsi, which also has no spondylinu.' Therefore, the further conchsion of IIall and Clarke can not he accepted, that, "where the teeth are wholly without dental lamellar, or where such lamellar do not extend to the bottom of the valve, it seems neessary to regard them is instances of degeneracy or resorption of the primitive spondylium."

It seems clear to the writer that since the "sloe-lifter" plate, or spondylium, in Merista and Dicamara is for nusenlar insertion, this plate in the ventral valve of these genera is the morplice equivalent of the spondylinm in the Pentameracea, and that the dorsal muscular plate in Dicamara is the eqnivalent of the cruralinm, and can not "he interpreted as an entirely different structure from the spondylimm." It is true that the spondylia of these genera are not exactly like those of the Pentameracea, but since this plate in the Atremata is not formed by the union of dental lamella, as these do not exist in this order, there is no reason for rejecting the terminology for these plates in Merista and Dicamara.

'Camarella minor and $C$, antiqua are more closely related to Protorhyncha than to any other genus. Of Orthis billingsi, the type of Protorthis, very good casts of specineus in the Cornell Lniversity Museum are iu the National Museum, which show that this genus also has no spondylium, and that its character's are those of Billingsella.

${ }^{2}$ Hall and tharke, ibid., p. 333.

${ }^{3}$ Ibid., p. 335. 


\section{CRURA ANI CRURALIUM.}

Calcareous processes for the support of the brachia are also developer in the Protremata, in the superfamily Pentameracea, but nerer to the same degree attained by the Spiriferacea or Terebratulacea ot the Telotremata. In the Protremata these supports are first developed in the Syntrophiidar, and attain their greatest length in the Pentamorida. Since the two parts often mite medially, forming a plate for muscular insertion either resting upon the valve or supported by a septum, this has been termed a crumalium by Hall and Clarke, to distingruish it from the spondylium of the ventral valve. When the parts remain separate, aud are therefore not for muscular insertion, they are homologons with and the equivalent of the cruma in the Rhymchonellidre. The cruma of the Pentameracea and Rlynehonellacea arise independently, and are therefore morphologic equivalents.

\section{MORPHOLOGIC EQUIVALENTS.}

Tecause of the presence of similar or identical morphological structures in diflerent groups of mature brachiopods, it is unsafe, on the basis of these alone, to suppose such to have close relationship. The spondylium has been shown to originate independently in three orders: Atremata, Protremata, and Telotremata. Identical mature loops liave resulted in different ways in two stocks of the same family, one boreal (1)allina) and the other anstral (Magellanina). Flat and more or less wide cardinal areas develop independently of one another in Protremata and Telotremata (Spiriferacea). Cementation of valves takes place at different and widely separated geologie epochs in Neotremata, Protremata, and Telotremata, and shell plications arise from smooth stocks in Pentameracea, Rhynchonellacea, Spiriferacea, and Terebratulacea. Natural phylogenies can only be established uyon ontogenies checked by chronogenesis or geologic succession.

\section{SUMMARY.}

In North America there are 1,S̃g Paleozoic, 49. Mesozoic, and 14 Cenozoic species of fossil Brachiopoda. There are 116 species in the Cambrian, 319 in the Ordovician, 311 in the Silurian, 663 in the Deronian, and $478 \mathrm{in}$ the Carboniferous.

The remarkable searcity of post-Paleozoic species in America is supposed to be due not so much to the general decline of the class as to great orograplic movements during the close of the Paleozoic, which produced complete barriers against the introduction of species from other areas.

Specific differentiation was most rapid in the Ordovician, having exceeded the Cambrian representation more than three times.

'Thirty per cout of all American Palleozoic species larl wirle geo. graphic distribution, which is most pronouncer in the Devonian and 
Carboniferons systems. One hundred and twenty-one American species are also found on other continents.

Widely dispersed species are least common in the most primitive order, Atremata, and greatest in the highest orders, Protremata and Telotremata. The difference, however, is but 7 per cent.

The order Atremata is represented by 199 species, or over 10 per cent of the American Paleozoic representation. In the Neotremata it is $15 t$, or over $S$ per cent. The Protremata liave 738 species, or nearly 40 per cent; and the Telotremata 766 species, or abont 41 per cent.

'The order Atremata is best developed in species and genera in the Cambrian and Ordovician systems; the Neotremata in the Ordovician; the Protremata in the Ordovician, Silurian, and Devonian; and the Telotremata in the Devonian. The climax of differentiation is therefore chronologieally related to phylogenetic or sequential origin.

Since the four orders of Brachiopoda are present in the Lower Cambrian, ordinal differentiation must have taken place in pre-Cambrian times. The two more primitive orders, Atremata and Neotrematn, have in Lingula and Crania, respectively, genera with longest life listories. This probably is due not so much to their primitive structures as to their modes of living.

The last order to originate, Telotremata, has the greatest nnmber of generic and superfamily characters, and probably also of species.

The last superfamily to appear, Spiriferacea, manifests most rapid evolution and is the second one to die ont, being preceded by the l'entameracea. These two superfamilies are the most highly speeialized in the orders to which they belong, and their great specialization may be the canse of their early disappearance.

The trunk families of later origin throughont the class manifest the greatest specific and generic differentiation and the widest specilic dispersion, and have species of the largest size and often of longer geologic persistence.

The oldest or most primitive families nearly always have short geologic duration (except Rhynchonellide) and the least generie and speeifie differentiation, and commonly the individuals are of small size.

The largest of all brachiopods occur in the families Pentamericlie, Prodnctidie, and Spiriferide, at a time when the class was at the height of differentiation.

Large specific size is probably often gradually attained in genetic lines, and is due to favorable food conditions. The gigantic brachiopods always ocenr in the later-developed trunk families, and just before their deeline in differentiation.

Buts genera are known to pass from the Paleozoic to the Mesozoic. There are in all 327 brachiopod genera, 227 of which are Paleozoic. The Atremata have 29 genera, the Neotremata 30, the Protremata 89, and the Telotremata 179.

All brachiopods begiu with smooth shells aud protegula. 
The prodeltidium, or third embryonic shell plate, is known in the Atremata, Neotremata, and Protremata. In the A tremata this becomes attached to the clorsal valve, while in the Telotremata it is apparently not dereloped at all. In the Protremata it becomes attached to the ventral valve, as in Neotremata. In the two last-named oriers it modifies the pedicle opening. For this and other ontogentic and morphologic: (haracters, Owen's terms Lyopomata and $A$ rthropouata are abandoned. The Atremata and Telotremata are provisionally arranged under the superordinal term Homoculiu, and the Neotremata and Protremata under Idiocaulia.

Morphologic equivalents, or similar structural features, are developed independently, as follows: A spondylium in Obolacea, Lingulacea, Pentameracea, and rarely in Spiriferacea; crural processes in Ientaneracea and Rhynchonellacea; functional articulation in P'rotremata and Telotremata; straight, more or less loug, cardiual areas from rostrate forms in Rlynchonellacea, Spiriferacea, and Terebratulacea; rostrate shells from long curdinal areas in rentameracea, and loss of pedicle and ventral shell cementation in Craniacea, Strophomenacea, and Spiriferacea. 


\section{CH A P T R I V.}

\section{MORPHOLOGI OF THE BRACHIA.}

By Charles E. Beecher. ${ }^{1}$

The diagnostic value of the brachiclium, or ealeareous arm supports, of brachiopods has long been reeognized, and forms one of the chief characters for generic and family subdivision among the Terebratulacea and Spiriferacea. This character fails in all other brachiopods, which have simply fleshy arms, unsupported by ealcareons skeletons. There is, however, generally the most obvions analogy and intimate relationship between the arms themselves and the brachidinm, so that whenever either structure can be ascertained it furnishes important data aiding in the determination of the systematic position of any genus within a family or order.

The growth of the arms, or lophophore, in recent genera may be divided into distiuct stages, which often have a direct correlation with other important features of the shell. In many cases it is also possible to infer the form and arrangement of the brachia in fossil genera from markings on the interior of the valves and from the caleareous arm supports, and thus to obtain the chronogenetic as well as the morphogenetic history of these organs.

The most detailed accounts of arm development are given by Brooks ${ }^{5}$ for Glottidia, by Morse ${ }^{11}$ for Terebratulina, and by Kovalevski ${ }^{10}$ for Cistella and Thecidea. These results, combiued with original observa. tions by the writer ${ }^{1,2}$ and occasional descriptions of arm structure by Davidson ${ }^{\tau}$ and other anthors, are sufficient to include aud properly interpret all the leading varieties of structure.

As shown by Brooks, ${ }^{5}$ the tentacles, or cirri, in Glottidia originate on the dorsal side of the oral disk. They grow in pairs, one on each side of a central lobe. New tentacles are added between the first pair formed and the median lobe. Thus the cirri farthest removed from the median lobe are the oldest. Tentacles are added rapidly until the first are is extended to a semicircle, and then progressively the whole disk becomes surrounded by a circle of these organs. The further introduction of cirri can only take place by the enlargement of the oral disk or through the deformation of the circle by lobes, loops, or extensions. In Glottidia, Lingula, Discinisea, Crania, and Rhynchonella the two points of tentacular increase, originally together and on 
opposite silles of a median lobe, or tentacle, gridnally separate, and the further multiplication of tentacles results in strap-shaperl extensions on each side, which finally assume a coiled form, due to the linited space in which they grow. Therefore the arms in adult individuals of these genera have a single cirrated edge, extending from their free extremities to the sides of the oral disk, and, continuing posteriorly, unite on the ventral side of the disk behind the month. Each cirrated edge in the adult lophophore apparently has two approximate rows of alteruating cirri (Hancock ${ }^{9}$ ), but as they were originally a single row in early stages, this appearance is evidently the result of a crowding of the cirri or a crumpling of the edge.

Kovalevski ${ }^{10}$ has shown that in Cistella the tentacles also originate in pairs on each side of the dorso-median line, without a central tentacle or lobe. The same mode of increase has been shown by the writer to be present in Magellania and Terebratalia. In young stages of Cistella, Terebratuliua, Magellania, and other terebratuloid genera, as well as in Thecidea, after the eirclet of tentacles is complete the two points at which new ones are added do not separate, but remain close together throughont the life of the animal. In this case the cirrated margin is lengthened by means of lobation and looping, and often by the final growth of a single, median, coiled arm, cirrated on both margins. Grynia illustrates the completed circle of tentacles abont the mouth. Adult Cistella shows an advance in having the anterior margin of the lophophore introverted, making it bilobed. Megathyris is slightly more complicated by two additional lobes. This simple method of increase is further elaborated in the Thecidiidie. In the higher genera, especially among the Terebratulicle, the maximum is reached by means of a median, mpraired, coiled arm, as in Magellania and Terebratulina.

The development of the different types and varieties of arm structure is presented in the accompanying figures (figs. 2-6), which are necessarily somewhat diagrammatic in order to show the features clearly, but the essential structure can readily be verified from consultation of the works eited or from a study of actual specimens. In the case of fossil forms, such as Dielasma, the Atrypidie, and Atlyridx, the brachial supports have sufficient aualogy with the arm structures of Terebratulina and Rhynchonella to warrant their interpretation as given. Also the spiral impressions on the valves of Davidsonia, and those oceasionally present in Leptiena and Produetns, clearly point to the possession of coiled arms by these genera.

\section{CLASSIFICATION OF BRACHIAL STRUCTURES.}

From what has already been shown it is seen that the various types of lophophores admit of a simple elassification into stages and gromps. It is proposed to give to these distinctive names, which may be used with facility in makiug comparisons and correlations. They may be found 
useful, also, in designating the kind of brachial complexity attained in any genus the arm structure of which can be determiued, thus helping to fix its place in a genetic scale. It should be emphasized, however, that the form and complexity of the cirrated margin of the lophophore (an have a taxonomic value only within comparatively narrow limits. This at once becomes evident when the arms of Lingula, Discinisca, Crania, Rhynchonella, and all the Spiriferacen are considered. Each has spiral arms, which were probably developed through similar changes of form, and yet each is genetically distinct, as shown by all the other leading characters. But when this elassification of arm structures is applied within a family or genus, or even when made the basis of comparison among some elosely related families, it is sometimes possible to reach very satisfactory conclusions relating to the systematic position of various forms.

\section{LEIOLOPIIUS STAGE.}

It is hardly necessary to direct attention to the embryonic brachial structure before the growth of any of the tentacles, or cirri, on the edge of the lophophore, while the animal is in the typembryonic stage. For the sake of designating all the stages, this may be called the leiolophus stage, thongh it las no special significance beyond indicating the beginning of the lophophore.

TAXOLOPHUS STAGE.

The first stage in which a true brachial strueture is manifest is an early larval form, often the protegulum stage, when the tentacular portion of the lophophore is a simple are, or crescent. This may he called the taxolophus. The tentacles are few in number, and increase takes place on each side of the median line, dorsally, in front of the mouth. In figs. $2 a, e, 3 a, f, 5$ this character is clearly shown. The tentacles at the ends of the are are the oldest, and new ones are being formed in the middle portion. In Thecidea, Cistella, and Magellania the tentacles of the taxolophus are centripetal, dne to the edge of the lophophore being near the margin of the shell; while in Terebratulina, Discinisea, and Lingula they are centrifugal, ine to the smaller and central lophophore.

So far as known, there is no adnlt living form which has the taxolophian brachial structure. It may have been present in alult Iphidea of the Cambrian.

\section{TROCHOLOPHUS STAGE.}

By the continual addition of new cirri and the pushing back of the old ones, the finged margin of the lophophore passes from a crescentic to a circular form, thus making a complete ring about the month. This may be termed the trocholophus stage. It appears in the late larval and early adolescent stages of Thecidea (fig. 2b), Cistella (fig. 2f), Magellania and Terebratalia (fig. 3b), Terebratulina (fig. 3g), Clottidia (fig. 5b), 
and Discinisea, and, like the former stages, is undoubtedly common to all brachiopods, exeept, periaps, Iphidea.

Gwynia is an adult living representative of this stage, and never develops any higher type of brachial strueture. 1)yscolia also belongs here, since it has a diseoid lophophore surrounded by a marginal fringe of tentacles (Fischer and (Ehlert ${ }^{8}$ ). It is possibly a little more advanced than (iwynia, as it his a slight median anterior notch, suggesting the beginning of the bilobed structure of the next ligher type.

The absence of septnm, hinge-plate, and dental plates are other primitive eharacters belonging to Jyseolia.

\section{SCHIZOLOPHUS S'TAGE.}

After the eompletion of the trocholophus stage in all brachiopods, except such simple forms as Gwynia and Diseolia, no further increase
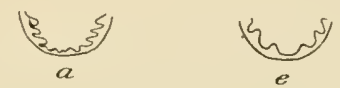

Taxolophus.
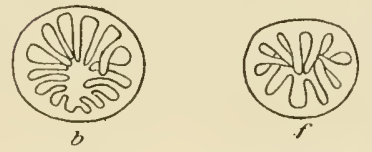

Trocholophus.
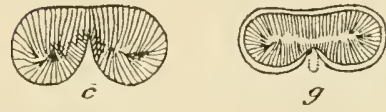

Schizolophus.
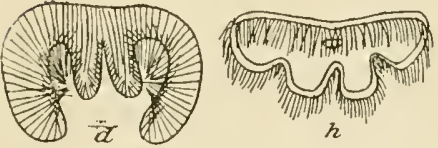

Ptycholophus.

Fra. 2.-Stages of growth of the lophophore in Theciclea, Cistella, and Megathyris. $a, b, c, d$, stages in the grow th of the lophophore in Thecidea (Lacazella) mediterranea, enl. ( $\alpha-c$ after Kovalevski, $d$, after Lacaze-Duthiers). $e, f$, early stages of lophophore of Cistella neapolitana, enl. (after Kovalerski). $y$, adult lophophore of Cistella $(C$. eistellula), enl. (after Davidson). $h$, labial appendages of Megathyris decollata, enl. (after Daridson).

stage (fig. 3c). Terebratulina (fig. 3h), Glottidia (fig. 5c), and other higher forms, also have corresponding schizolophian stages, but are without the median septum. Lacuzella mediterranea presents a similar larval structure, and in $L$. barretti it is retained to maturity. The fossil genera Davidsonella and Thecidella of the Thecidida, and Zellania of the Terebratellidie, never developed beyoud the schizolophus stage, and they must therefore be considered as quite primitive genera in their respective families.

From this point the further development and complication of arm structure proceeds in three distinct diverging lines, producing the 
three characteristic types of brachia of all the higher brachiopods. as exemplified in Thecidea, Terebratulina, and Rhynchonella.

\section{PTYCHOLOPHUS STAGE.}

The simplest of the types of brachia just cited is developed out of the schizolophus by the additional lobation, or looping, of the primary lobes, making a structure which may be called the ptycholophus. Megathyris and Lacazella mediterranea both have 4 lobes (fig. $2 l, h$ ); Theeidea radiata has 6 ; T. vermicularis and Eudesella mayale, 8 ; E. digitata, 10 ; Pterophloios and Oldhamina, about 20. Lobation in some (Thecidea) is produced by the forking or branching of the median septum; in others (Pterophloios) the septum remains simple while the lateral borders of the lophophore are lobed.

\section{ZUGOLOPIIUS AND PLECTOLO-} PIIUS STAGES.

All the higher Terebratulacea reach the final growth of the lophophore through an intermediate stage which from its form may be called the Zugolophus-fig. 3d, i. Eucala_his and Platidia (?Tropidoleptus) are apparently adult representatives of this stage, while Kraussina and probably Bouchardia are slightly more advanced by the grow th of a short mediau, coiled arm, and lead to the next highest, or plectolo-
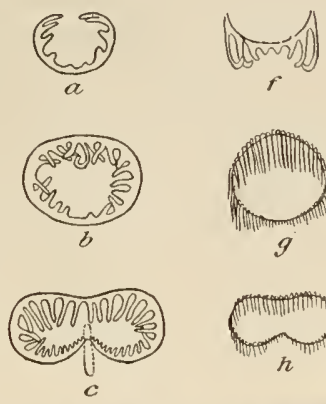

Taxolophus.
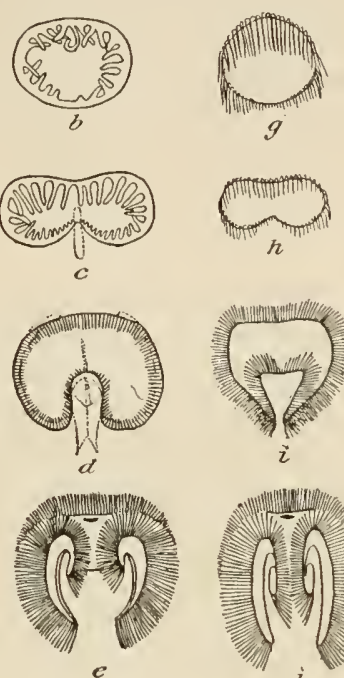

Trocholophus.

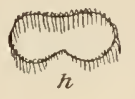

Schizolophus.

Fia. 3.-Stages of growth of the lophophore in the Terebratellidis and Terebratulidia. $a, b, c, d, c$, fire stages in the development of the lophophore in the Terebratellidre. $a-d$, Terebratalia obsoleta, enl. (after Beeeher $\left.{ }^{2}\right\rangle$. e, Magellania kerguelenensis, nat. size (after Davidson $\left.{ }^{7}\right) . \quad f, g, h, i, j$, development of lophophore in the Terebratulide. $f-i$, early stages in Terebratulina septentrionalis, enl. (after Morse "l). $j$, adult Terebratu. lina eaneellata (after Davidson ${ }^{7}$ ).

phus, stage, in which there is a well-developed spiral arm with a fringe of eirri on each edge-fig. $3 e, j$.

A long loop pointed in front like liensselieria and Centronella conld not have supported a median arm, as the pallial cavity is thus fully occupied, and the development of the brachidium in the Terebratellidie shows that the central space between the branches of the loop is to accommodate such an organ. The same is doubtless true of Dielasmi, which first has a Centronella-like loop, and through the subsequent resorption of the anterior portion the asceuding branches are formed 
and space allowed for the median arm-fig.4a-d. In a spire-bearing genus like 'Zygospira this is more obvious, for here the transverse pro-

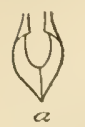

FIG.4.-Metamorphoses

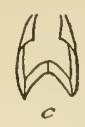

c

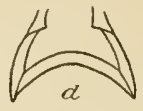

a cess or jugum is clearly the result of the growth and resorption of the centronelliform loop to admit

the spiralia.

The calcareous loop in Terebratulina and Liothyrina is only a posterior basal support, and does not repeat the outline of the cirrated margin of the lophophore, exchusive of the arm. Therefore it is impossible in these and elosely allied genera to infer the stage of development of the lophophore from the loop alone. Dyseolia is an excellent example. since the loop is the same as in Terebratulina; but the lophophores are quite distinet in each, the former being of the trocholophus type and the latter belonging to the plectolophus.

SPIROLOPHUS STAGE.

The last type to be noticed is the one in which there are two separate coiled arms, each with a row of cirri on one edge onlyfig. $5 d, e$. It embraces the greater part of the families of brachiopods in the orders 'Telotremata and Protremata, and includes all the living species in the orders Atremata and Neotremata.

In the early stages of development of the spiral lophophore there is an agreement with the early stages of the families already noticed, and the taxolophus, trocholophus, and schizolophus stages may be determined-fig. $\tilde{a} a, b, c$. The separation and grow th of the spiral arms seem to be due to the widening or expansion of the median lobe or tentacle, on each side of which is the formative tissne for new cirri. This is very apparent in the young Discinisca deseriber by Muller, ${ }^{12}$ and the Glottidia deseribed by Brooks. ${ }^{5}$
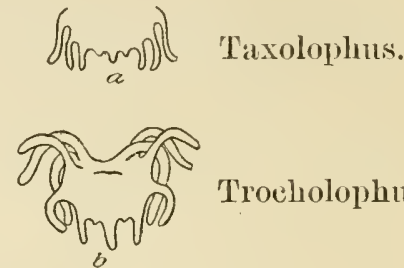

Troeholophus.

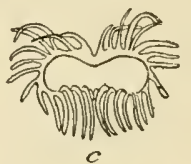

S.hizolophus.

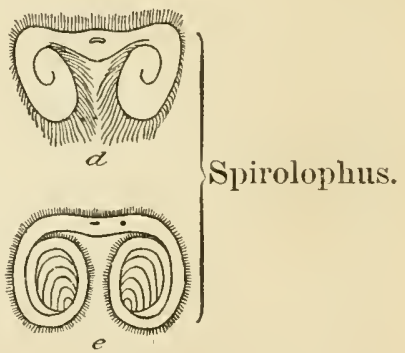

Fig. 5.-Early stages of lophophore of Glottidit and adult brachia in Lingula and Hemithyris. $a, b, c$, early stages of lophophore of Glottidia audebarti, enl. (after Brooks). d, adult brachia in Lingula (after Wood ward). e, adnlt brachia in Hemithyris psittacea (after Hancock).

The brachidinm in Zygospira passes, through a series of changes which have been deseribed in detail elsewhere. ${ }^{4}$ These metamorphoses are of great assistance in understanding the development and comparative morphology of this feature in other groups of the Spiriferacea. The earliest stage observed (fig. $6 a$ ) has the form of a simple terebratuloid loop, which, from its resemblance to Centronella, was ealled the 
centronelliform stage. Since approximately this form of brachidium is also characteristic of the young of recent terebraluloids, it may be taken in Zygospira as inclicative of the trocholophus stage of brachial development. With this as a starting point for comparison, the further correlation of the succeeding stages is very simple.

The first resorption of the end of the loop in Zygospira produced a schizolophus condition, and further resorption carried the brachidium to a stage closely resembling Dielasma (fig. 6l). The dielasmatiform stage has already been explained as due to the requirements of space for the growth of the coiled brachis. Next, the initial calcification of the spiral arms resulted in the extension of the descending branches beyond the jugum (fig. $6 c$ ), and, lastly, complete calcification manifests the spirolophus structure and produced the characteristic brachidium of the Spiriferacea.

The Atrypida and the Athyridie seem to stand to each other in the same relation as the Terebratellidae and Terebratulidie. In the first the descending branchesare widely separated and follow the edges of the valves; in the seeond the descending branches are rlose together. This difference in the Spiriferacea produces the converging cones of the Atrypidla (fig: 6 ( 7 ) and the diverging cones of the Athyrida, Spiriferidie, Retziida (tig. $6 e$ ), etc.

It seems doubtful whether the fleshy portions of the brachia in the Meristellida and Athyrida possessed additional characters
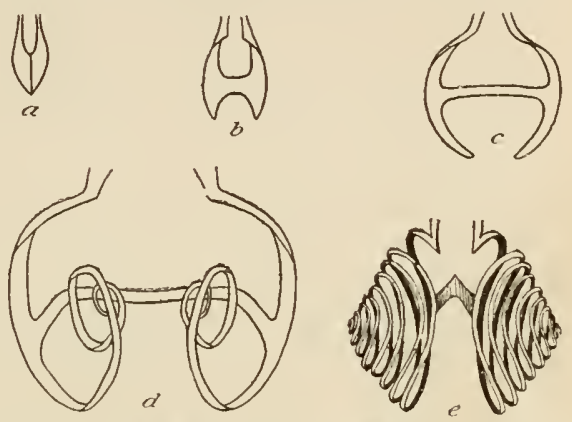

FiG. 6.-Metamorphoses of lirachidium of Zygospira amil adult brachilium of Rhynchospira. $a, b, c$, d, metamorpheses of brachidim of Zygospira recus. virostra, enl. (after Beecher aud schuchert). e, Brachidium of Rhynchospira evax (after Beecher and Clarke). expressing the complexity and elaboration reached by the jugal processes, even when the lamellac were duplicated, as in Koninckina and Íayseria.

From the above descriptions and illustrations it appears that the mode of growth of the cirrated lophophore, or brachia, is alike in the larval stages of all brachiopods. They first develop tentacles in pairs on each side of the median line in front of the mouth (taxolophus stage). New tentacles are continually added at the same points, until, by pushing back the older ones, they form a complete circle about the mouth (trocholophus stage), later becoming introverted in front (schizolophus stage). From this common and simple structure all the higher types of brachial complication are dereloped through one of two methods: (1) The growing points of the lophophore, or points at which new tentacles are formed, remain in juxtaposition; or (2) they separate. Complexity in the first is produced $(a)$ by lobation, as in 
Megathyris, Eudesella, Pterophloios, Thecidea, etc. (ptycholophus type), and (b) by looping (zugoloplus) and the growth of a median, musired coiled arm (plectolophns), as in Magellania, Terebratulina, etc.; in the second $(c)$ by the growth of two, separate, eoiled extensions or arms, one on each side of the median line (spirolophus), as in Lingula, Crania, Discinisca, Rhynchonella, Leptena, Davidsonia, Spirifer, Athyris, Atrypa, ete.

\section{REFERENCES.}

1. Becher, C. E., 1893: Revision of the families of loop-bearing lbrachiopoda. Trans. Conn. Acad., Vol. IX.

2. Beecher, C. E., 1893: The development of Terelbutulia obsoleta Dall. Trans. Conn. Aead., Vol. IX.

3. Beecher, C. F., and J. M. Clarke, 1889: 'The developnent of some Silurian Brachiopoda. Mem. N. Y. State Miseum, Yol. I, No. 1.

4. Beccher, C. E., and Charles Schuchert, 1893: Development of the lurachial supports in Dielasma and Zygospira. Proc. Biological Soc. Washington, Yol. VIII.

5. Hrooks, W. K., 1879: The development of Lingula and the systematic position of the Brachiopoda. Johns Hopkins Tniv., Chesapeake Zool. Lab.

6. Davidson, T., 1851-1885: A monograph of the British fossil Brachiopoda. Pal. Soc.

7. Daridson, T., 1886-1888: A monograph of recent Brachiopoda. Trans. Linn. Soc., London, Yol. IV.

8. Fischer P., and D.-P. Ehlert, 1892: Résultats des campagues scientifiques accomplics sur son yacht par Albert $1^{\text {re }}$, Prince Souverain de Nonaco. Fs. III, Brachiopodes de I'Atlantique Nord.

9. Hancock, A., 1858: On the organization of the Brachiopoda. Phil. Trans., Vol. CXLYIII.

10. Tovalevski, A. O., 1874: Observations on the development of Brachiopoda. Pror. Imp. Soc. Amatenr Naturalists, etc., held at the University of Moseow, 11 th year, Vol. XIV.

11. Morse, E. S., 1873: (In the early stages of Terebratnlina septentrionalis (Couthouy). Mem. Boston Sor. Nat. Hist., Vol. II.

12. Miiller, F., 1860: Beschreihuug einer Brachiopodenlarve. Archiv Anat. Physiol, Jahrg. 1860. 


\section{H A P T E R V.}

\section{CIAASIFICATION OF TILE BRACHIOPODA.}

\section{HISTORICAL.}

Fabius Columna, in 1616, and Martin Lister, in 1678. were the first to deseribe brachiopods, ealling them Conche anomic. Grundler, in 1774, was, however, the first to give a good illnstration of a brachiopod in Terebratulina caput-serpentis. In 1818 Lamarck recognized 5 genera, ineluding the operculate coral Calceola. Other genera were added by Sowerby, Dalman, and Defrance, from 1820 to 1830 , and in the early forties abont 1,500 species had been defined. In $1849 \mathrm{King}$ recognized 49 genera in 16 families, and Bronn, in 1862, knew nearly 2,000 species and 51 gevera. At present there are probably no fewer than 6,000 species known in 321 genera, gromped in 31 families, 9 superfamiles, 4 orlers, and 2 superorders.

Since 1858 the class Brachiopoda has been divided by nearly all sprstematists into two orders, based on the presence or absence of articnlating processes. These two divisions were reeognized by Deshayes as early as 1835 , but not nutil twenty-three years later were the names Lyopomata and Arthropomata given to them by Owen. These terms have been generally adopted by anthors, though some prefer Inarticulata and Artienlati of Huxley, or Bromn's Eeardines and Testicardines. Bronn, in 1862, and King, in 1873, while retaining these divisions, considered the presence or absence of an anal opening more inportant than articulation, and aceordingly proposed the terms Plenropygia and Apygia, and Trententerata and Clistenterata, respectively. In many Paleozoic genera of Clistenterata it has been shown that an anal opening was also present, and therefore the absence or presence of this organ is not of superordinal value. Beecher writes: ${ }^{1}$

The dorsal beaks of Amphigenia, Athyris, Cleiothyris, Atrypa, and Rhynchonella are usually notchel or perforate. The perforation comes fromthounion of the crural plates above the floor of the beak leaving a passage through to the apex. A similar opening occurs between the cardinal processes in Strophomena, Stropheodonta, and allied genera, and thechilidium may also be furrowed, as in Leptana rhomboidalis. This character is evidently in no way connected with the pedicle opening, but points to the existence, in the early articulate genera, of an anal opening dorsal to the axial line, as in the recent Crania. This dorsal foramen was described and figured hy King

\footnotetext{
'Am. Jour. Sci., 3d series, Vol. XLIV, 1892, p. 147. See also King, A Monograph of the Permian Fossils of England, 1850; and Ehlert, Fischer's Mtanuel de Conchyliologie, Appendice, 1887.
} 
in 1850 , lall in 1860, and hyseveral authors since, and has commonly loen termed a viscral foramen. (Ehlert suggests that it was probably oceupied by the termual portion of the intestine. The persistence of the foramen seems to indicate an anal opening.

\section{Hall and Clarke state: 1}

It has hecome evident, from a study of the hinge plate, that the so-ealled visecral foramen whieh perforates it, and which is often present in Athyris, Rensseliria, Cryptonella, ete., is a remuant of this aperture, the remainder of the median opening having become filled by a testaceons seeretion. There is every reason to believe that the visceral formen was actually traversed by the lower alimentaly eanal, and if this were true, then the deep and narrow median chamber bomblerl by the crural plates must also have inelosed the terminal portion of the intestine.

In 1834 Von Buch also divided the class into two sections, founded on the mode of attachment. The first section contained all brachiopods fixed by a pedicle to foreign bodies, while the second was restricted to those forms in which there is no perlicle at matnrity, the entire lower or ventral valve being cemented to other objucts, as in Cranis. The first section was again divided into three groups, on the basis of the pedicle: (a) Pedicle emerging from between the valves, as in Lingula; $(b)$ ventral valve perforated for the protrusion of the pedicle; and $(c)$ nncemented shells withont a pediele opening. 'The third gromp, however, is identical with l, since Leptrena, Productus, and Strophomena, genera referred to section $c$, do possess a pedicle opening. While this classification lacks a complete understanding of the features in ruestion, it is remarkable that Von Buch nearly sixty years ago, and Jeslongchamps twenty eight years later, recognized some of the principles upon which the classification of the Brachiopoda is now establisherl, viz, the nature of the pedisle opening.

$\mathrm{Up}_{\mathrm{p}}$ to 1846 the general external features of brachiopods served the majority of anthors as the essential basis for generic differentiation. In that year, however, King pointed out that more fundamental and constant characters exist in the interior of the shell, a fact which soon came to be generally recognized, mainly throngh the voluminons writings of Thomas Davillson.

In 1848 Gray, probably stimulated by King's paper, divided the Brachiopoda into two subclasses, Ancyloporla and Ilelictopoda. These divisions rest entirely on the basis of the structure and the pres. ence or absence of calcareous supports. The Anrylopoda are distinguished in having the "oral arms recurved and affixed to fixerl appendages on the disk of the ventral [dorsal] valve," while in Ifelictopoda "they are regularly spirally twisted when at rest." The brachia, however, in all recent species, are recurved and more or less spirally enrolled, except in some gerontic forms of loop-bearing genera, as Cistella and Gwynia. Therefore Helictopoda, as far as the brachial structure is concerned, will also include the Ancyloporla. In finct, to the former Gray referred only the terebratuloids, if Thecichia is 
exclucled, while the Ancylopoda contained all other brachiopods, both articulate and inarticulate forms. These subclasses are, further divided, on the basis of the brachia, into four orders: Ancylobrachia, Cryptobrachia, Sclerobrachia, and Sarcieobrachia. Of these the first only has value as a superfamily, since it includes the "loop-bearing" genera, or Terebratulacea. The other order's have so heterogeneous an assemblage of forms as to be of no permanent value.

Beyond the iutroduction of new families, no further attempt was made by writers to divide the Brachiopoda into other orders than Lyopomata and Arthropomata until 1883, when Waagen published his great work on the fossils of this class from the Salt Range group of India. He found it "absolutely necessary" to further divide the Lyopomata and Arthropomata into seven suborders. The basis for these suborders has no underlying principle of general application, yet the majority of the divisions are of permanent value, for each contains an assemblage of characters not to be found in any of the others. Waagen's genealogy of the Arthropomata, with Orthis as the prototype, falls at once to the ground, since the comprehensive studies of the geuns Orthis by Hall and Clarke have shown that it is questionable "whether any of these primordial forms can be included under Orthis according to the strict definition of the term or even under any of the subdivisions" " proposed by them. There are, however, a few species in the Upper Cambrian which seem to agree with such dalıanellas as 0 . subcequata, but these originated long after many undoubted Protremata and Telotremata had lived in the Lower and Middle Cambrian. Lingula, on the other haud, was usually regarded as the prototype of all brachiopods, but this is also impossible, since a number of inarticulate genera flourished for ages before Lingula was developed.

\section{PRINCIPLES OF CLASSIFICATION.}

No classification can be natural and permanent unless based on the history of the class (chronogenesis) and the ontogeny of the individual. However, as long as the structure of the early Paleozoic genera of Brachioporia remained practically unkuown and the ontogeny untouched, nothing of a permanent nature could be attempted. In the recent volumes by Hall and Clarke many of these early genera are clearly defined, so that their structures and geologic sequence are now far more accurately known. The ontogenetic study of Paleozoic species was initiated in 1891 by Beecher and Clarke, and was continued by Beecher and Schnchert. 'These results, combined with those derived from the development of some recent speeies, and published by Kovalevsky, Morse, Shipley, Brooks, Beecher, and others, confirm the conclusions reached throngh chronogenesis. Moreover, the application by Beecher of the law of morphogenesis, as defined by Hyatt, and the 
recognition and establishment of certain primary characters have resulted in the discovery of a fundamental structure of general application for the rlassitication of these organisms. It has for its hasis the nature of the perlicle opening and the stages of shell growth. On thest dharacters Beecher has divided the class into four orders-the Atremata, Neotremata, Protremata, and Telotremata.

I1all and Clarke reject Beecher's ordinal terms Atremata and Neotremata for the subordinal names Mesokaulia and Daikanlia of Waagen, on the ground of priority, and because the latter terms are " an admiraable expression of the significance of the pedicle passage." If some of Waagen's subordinal terms are elevated to ordinal rank and amended by Hall and Clarke, then these terms are no longer Waageirs, but slould be credited to Hall and Clarke. Such being the case, the law of priority demands the retention of Beecher's terms, as they do not ronflict with those of Waagen but with the secondary definition and rank accorded them by Hall and Clarke.

On the other hand, Dall claims ${ }^{3}$ that "names of higher" rank than genera are not subject to the rule of strict priority, on account of the mutability of their limits." Again, if Waagen's snboldinal terms (and there are seven of them) are to be elevated to ordinal l'ank-i. e., if the characters upon which they are establisher are orlinal charactersthen all should be elevaten alike in rank. Besides the two mentioned above, Hall and Clarke accept also Gasteropegmat and Helicopegmata. The latter, however, they retain as suborders, and would do likewise with Kampylopegmata if Gray's term Ancylobrachia of earlier date did not cover the same group of brachiopods; while Gasteropegmata. having certainly no greater value than a superfamily, is elevated to an order. Again, they accept Beccher's Protremati, when Waagen's suborder Aplianeropegmata could as well be raised to ordinal rank and adapted so as to include the former, since Waagen based the latter upon families having the diagnostic character of the Protremata, namely, the well-developed deltidium. However, a far mole important reason why WVagen's terms should not be elevated to ordunal rank and made to displace Beecher's names is that the latter clearly nuder. stood the valne of the different ordinal characters and defined then excellently, which definitions are accepted by Hall and Clarke. He pointed ont the most primitive shelled condition in the protegulum, and found this first shell-growth stage in all the importaut families in the class. He observed that not the mere pedicle slit of the Daikaulia is the or diual character for Neotremata, but the way in which growth pro. ceeds to form this derived pedicle slit from the open pedicle noteh of primitive forms. He was the first to interpret the true morphologic

${ }^{1}$ Development of the Brachipoda, Part I, Am. Jour. Sci., 3l series, Vol. XLI, 1891; Part II, ibid., Vol. XLIT, 1892.

2 Palæontology of Now Fork, Tol. VIII, Part II, summary, 1895.

${ }^{3}$ Trans. Wagner Freo Institute of Science, Phila., Vol. III, Part III, 1895, j. 565, Rule XII. 
meaning of the deltidium and deltidial plates, and subsequently, from the works of others, chiefly Kovalevsky, was able to demonstrate the great morphologic significance of the deltidium. Withont any injustice to the monmmental work of Waagen-and there is no more careful work on the Brachiopoda-it can safely be asked, Were Waagen's suborders based on a fundamental morphologic eharacter of general importance throughout or on ontogeny? Mesokanlia and Daikanlia are the only two of the seven suborders having, as now understood, the required ordinal characters, and these divisions were established by Waagen on the form, general expression, and the position of the pedicle, and not on the morphologic development of the pedicle opening. Four of the other five suborders are based on superfamily and the fifth on family characters. Five of Waagen's seven suborders, therefore, are here retained as superfamilies, and practically in the sense of their anthor.

Since order's are established on the nature of the pedicle opening, persistent internal characters of the shell are, as a rule, used for superfamily purposes. Snch are the absence or presence of a spondylinm (Strophomenacea and Pentameracea, respectively); the absence or presence of calcareous brachial supports, and their nature (crura only in the Rhynchonellacea, loop in the Terebratulacea, and spirals in the Spiriferacen).

Families within the superfamilies are based upon a combination of external and internal generic characters eommon to many genera, or even to one gemus. Such characters are: Onter form; nature and posi. tion of muscles (Obolidre, Lingulide, ete.); internal plates (Trimerellirlae, Lingulasmatida, Pentameridie); peenliarities of the cardinal process (Ortlidae, Strophomenidie); imperfection or perfection or persistent peculiarities of ordinal and superfamily characters (Orthide, Trematidre, Discinida, Siphonotretide, ete.); simplicity or complexity of the jugum (Hindelline, Diplospirine, etc.); and oceasionally the nature of the shell structure (Rhynchospirine). When families are large it is not rare to find groups of genera having a common origin which have characters in eommon but not differentiated sufficiently to introduce new characters of family importance. In such eases it is arlvisable to divide the family into subfamilies, which facilitates systematic review and discussion. Such is the case in the large families Strophomenidie, Terebratulide, Terebratellidie, Spiriferida, and Atbyridie.

No division, however, has any value unless the group contains forms of but one phylum. A phylum, or line of descent, can not originate twice. It happens, however, that the same or nearly the same combination of mature eharacters is developer along different phyla. When this occurs the ontogeny will show it. It is therefore not correct to group these different stocks as belonging to one family. For instance, 
the Trimerellidir and Lingulasmatida have family strnetures in common and were referred to the same family. Ontogeny and chronogenesis, however, show that the former family originated directly in the Obolidir, while the latter was not evolved from the linguloid phylnu until the Obolidie had given origin to the Lingulellidie and the Lingn. lin:1. Again, the fanily Terebratellidir, probably during early Mesozoic times, divided, one stock drifting into boreal and another into austral regions. These two stocks agree in the earliest shelled condition and at maturity, but between these two stages of growth the austral group (Magellanina') passes through a series of loop metamorphoses rlifferent from that through which the boreal group) (Dallina) passes. Therefore it is umnatural to inelude both in one subfumily, as was formerly done.

It was by the application of the above-mentioned principles that the writer, in 189:, arranged all brachiopod genera under the four orders instituted by Beecher. Since then this subject has received considerable attention, and the many Cambrian brachiopods brought together by Walcott have been examined as to their generie structures. These sturlies have led to some changes in the classifieation which follows, the most important being that the order Telotremata could not have originated in the Pentameriidx, since no Pentameracea are known in the Cambrian until long after that order had representation. The divisions Lyopomata and Arthropomata, introdneed by Deshayes and Owen, have been abandoned for reasons given in previons fiages.

\section{CLASSIFICATION AND SYNONYMY.}

\section{Class BRACHIOPODA Cuvier, 1802; Duméril, 1}

Spirohranchiophora Gray, 1821; Palliobranchiata Blainville, 1824; Branchiopoda Risso, 1826 (not Latreille); Brachioportid Broderip, 1839; Branchionopoda Agassiz, 1847 ; Brachionocephala Bronn, 186?; Spiroluranchia Bronn, 1862 ; Branchionohranchia Paetel, 1875.

Bivalved Molluscoillea with inequivalved, equilateral shells attached to extraneous objects by a posterior prolongation of the body, or perlicle, (1) throughout, (2) during a portion of life, or (3) eemented ventrally. Valves ventral and dorsal. In composition, phosphatic or ealcareons, or both. Animal consisting of two pallial membranes intimately relater to the shell. Within the mantle cavity at the sides of the mouth are inserted the two, more or less long, oral, usually spirally enrolled, cirrated brachia, which are variously modified, and are supjorted in the two terminal superfamilies by an internal calcareons skeleton, or brachislium, attached to the dorsal valve. Anus present of absent. Central nervous system consisting of an a'sophageal ring, with weakly

I All uanes jusmall type and intented are syuonyms of the term in larere type immediately pre. ceding. 
developed brain and infracesophageal ganglionic swellings. Bloodvasenlar system probably present, with the sinuses developed into vas. cular dilatations at the back of the stomach and elsewhere. Sexes separate. Exclusively inhabitants of the sea. The class is present in the Lower Cambrian, attained maximum development in the Silalian and Devonian, and is represented by abont 140 living species. During this time, probably npward of 6,000 fossil and recent species have been developed, and these are distributed in 328 genera, grouped in 31 lamilies, 10 superfamilies, and 4 orders.

\section{Order A'TREMATA Beecher, 1891.'}

Mesokaulia, or Lingulacea (partim) Waagen, 1885.

Inarticulate Brachiopoda with the pedicle emerging freely between the two valies, the opening being more or less shared by both. Growth taking place mainly around the anterior and lateral mangins, never inclosing or surrounding the pedicle. Aperture mumoditied. Prodeltidium attached to dorsal valve.

\section{Superfamily 0BOLACEA Seluchert, $18960^{2}$}

Rounderl or semicircular aud more or less lens-shaped, thick-shelled, primitive Atremata, fixed by a short pedicle throughout life to extraneons objects.

\section{1. ${ }^{3}$ Family PATERINII)E Schuchert, 1893 (emend.). ${ }^{4}$}

Obolacea with the dorsal valve semicircular and the ventral subeircular in outline. Posterior region more or less closed by cardinal areas.

Ipinidea Billings, 1872.

Volborthia von Möller, 1873.

Paterina Beecher, 1891.

\section{Family OBOLID E King, 1846.}

Obolina Gill, 1871.

Thick-shelled Obolacen of nearly cirenlar or ovois outline, biennex, usmally smooth, with rudimentary cardinil areas traversed by shallow

' Siuce in this classification no superordinal terms are for the present adopted, it will be well to grise licte all such terms used by authors and others which are of lower rank and not readily referrer as synonyms to their proper places:

Aneylobrachia Aneylopeda, Helictopoda, Sarcicobrachia Gray, 1848; Lyopomata and Arthropo uata Owen, 1858; Pleuropygia, Sarcicobranchiona, Sclerobranchiona Bronn, 1862; Articulata and Inarticulata II uxles, 1864; Clistenterata and Tretenterata King, 1873.

${ }^{2}$ Text book of Paleontology, by Zittel and Eastman, 1896, p. 305. Also see page $7 \diamond$ of this bulletin.

${ }^{3}$ The numbers and letters beforo a faunily or suhfamily term indicate the phyletic relations which these have to one another within a superfamily. The phylogeny of the lamilies, however, is uore clearly represented in the diagram on P1. I, facing p. 134.

'Recent discoveries have slown that Iphidea has no pedicle opening, aud should inelude forms referred to Paterina. Therefore this family is of doubtful ralue, and is provisionally retained lor the reception of genera uore primitive in structure than those of the Obolidw. 
pedicle grooves. Muscular scars distinct, consisting of two pairs of adinctors and three of sliders, or adjustors.

Obolella Billings, 1861.

Direllomns Hall, 1871.

Elkania Ford, 1886.

Billingsia Ford, 1886.

Neobolus Waagen, 1855 .

Botsfordia Matthew, 1593.

?Spondylobolus MeCoy, 1852.

Obolus Eichwalı, 1899.

Ungrula Pauder, 1830.

Ungulites bromn, 1818.

Anlontreta kutorga, 1848.

Euobolus Mickwitz, 1896.
Acritis Volborth, 1869.

Schmicltia Volborth, 1869 (not Bals.

Criv., 1863).

Thysanotos Mickwit\%, $18 ! 16$.

Leptembolon Mickwitz, 1S!).

3. Family TRIMERELLID E Davidson and King, 1874.

Large, thick-shelled, inequivalved Obolacea, with the ventral cardinal area usually very prominent, triangular, and transversely striated. Adjustors and anterior adductor muscles elevated upon solid or deejly excavated platforms, or spondylia.

? Lakmina Ehlert, 1857.

Pavidsonella Waagen, 1885 (not $\mathbf{M 1 1 -}$ nier-Chalmas, 1880).

Lingulobolus Matthew, 1896.

Spharobolus Miatthew, 1896.

Dinobolus Hall, 1871.

Conradia Hall, MS., 1862.

Obolellina Billings, 1871 .

ITugnlites Quenstedt, 1871 (not, Bronn, $1818)$.
Monomorella Billings, 1871.

Trimerella Billings, 1862.

Gotlandia Dall, 1870.

Rhinobolus Hall, 1874.

Superfamily LINGULACEA Waagen, 1885 (restricted). ${ }^{1}$

Elongate, thin-shelled, burrowing, derived Atremata, with a more or less long, worm-like, tubular, flexible pedicle.

\section{Family LINGULELLID E Sehuehert, 1893.}

Spatulate, inequivalved Lingulacea, structurally intermediate between the Obolide and Lingulide.

Lingulella Salter, 1866.

Lingulepis Hall, 1863.

Leptobolus Hall, 1871.
? Paterula Barrande, 1879.

Cyclus Barrande, 1879.

? Mickwitzia Schmidt, 1858.

${ }^{1}$ Waagen's term Mesokanlia, or Lingulacea, is based upon the families Obolida, Trimerelliclit, and Lingulidir. Since this term lias ralue, and to aroirl proposing another, Lingulacea is here restricted to the latter family and two others recently proposed. Waagen in using this term gave a dual series; the second one is here alopted to eonform in euphony with other superfamily terms. 
2. Family LINGULID A Gray, 1840.

Lingulidit Gill, 1871.

Attennate, subquadrate or spatulate, almost equivalved Lingulacea, derived through Lingulellidie, with a more or less long, tubular, flexible pedicle. Muscles highly differentiated and consisting of six pairs, two of adductors, and four of sliders, or adjustors.

Lingula Bruguière, 1792.

Pharetra Bolton, 1798.

Lingularius Dunnéril, 1806.

Glossina Phillips, 1848.
Diguomia Hall, 1871.

Glottidia Dall, $18 \pi 0$.

Barroisella Hall and Clarke, 1892.

Tomasina Hall and Clarke, 1892.

3. Family LINGULASMATID E Winchell and Schnehert, 1893.

Platform-bearing Lingulacea derived througb Lingulidie.

Lingulops Hall, $18 i 1$.

Lingulasma Ulrich, 1889.

Lingulelasma Miller, 1889.

\section{Order TELOTREИATA Beecher, 1891.}

Sclerobrachia Gray, 1818; Kampylopegmata (partim) Waagen, 1883; Pegmatobranchiata (partim) Neumayr, 1883.

Articulate Brachiopoda, with the pedicle opening shared by both valves in nepionic and early neanie stages, usually confined to one valve in later stages, and becoming more or less modified by deltidial plates in ephebic stages. Brachia supported by calcareous erura, loops, or spiraliar. Prodeltidium absent.

Superfamily RHYNCHONELLACEA Schuchert, $1896 .{ }^{1}$

Rostracea Schnchert, 1893; Avcistropegmata (partim) Zittel, 1895.

Rostrate, primitive Telotremata, with or without crura.

1. Family PROTORHYNCHID E Schuchert, $1896{ }^{1}$

Primitive Rhynchonellaced, without deltidial plates or crura. Protorhyncha Hall and Clarke, 1893.

2. Family RHYNCHONELLID E Gray, 1848.

Hypothyricliæ (partim) King, 1850; Rhynchonellinie Gill, 1871; Waagen, 1883.

Rhynchonellikea with more or less long erura. 
Orthorhynchulit llall and Clarke, 1893.

Rhymehotrema Hall, $1 \mathrm{~s} 660$.

Stemorhisma comrat, 1839; Hall, 1817 .

Rhynchotretal Hall, 1879.

Camarotuelia IIall and ('larke, 1893.

Plothorliyuchus llall and Clarke, 1893.

Leiorhynehus Ilatl, 1860.

Wilsonia Kayser, 1871.

Tnciuluina Bayle, 1878.

Uneinulus Bayle, 1878.

Hypothyris King, 1846 (not Phillips, 1s41).

Pngnax Hall and Clarke, 1893.

Eatonia IIall, 1857.

Cyclorhina Itall and Clarke, 1893. Rhyelıpora King, 1556.

Rhynchoporiua Ehlert, 1887.
Terebratuloidea Waggen, 1si:;.

Fhynchonella Fisherde Waldheim, 1809 .

Oxyrhynehus l, lhwyd, lig9) (not Aristotlo).

Rilyugronella Bronn, 184!).

Bicornes Quenstealt, $18 ., 1$.

Rhynchonellopsis 13ose, 1891.

IIalorella Bittner, 1890.

Austriella Bittner, 1890.

Norella Bittuer, 1890.

Peregrinella (Ehlert, 1887.

Rhynehonellina fiemmelaro, 1871.

Dimerella Zittel, 1870.

Acanthothyris d'Orbigny, 1850.

Hemithyris d'Orbigny, 1847.

Frieleia [)all, $18 ! 5$.

Cryptopora Jeftreys, 1869.

Atretia Jeffreys, 1876.

Neatretia Ehlert, 1891.

\section{Superfumily TEREBRATULACEA Waagen,1S83(restricted). ${ }^{1}$}

Aneylopoda, Cryptubrachia, and Ancylobrachia (partim) Gray, 1848; Kampylupermata Waagen, 1883; Aneylopegmata Zittel, 1895.

Derived Telotremata with the brachia supported by caleareous, primitive, or metamorphosed loops.

\section{Section A. TEREBRATULA.}

Terebratulacea with the loops unsupported by a median dorsal septum at any stage of growth. Brachial cirri directed outwarl in larvil stages.

\section{Family CENTRONELLID H Hall and Clatre, $1895 .{ }^{2}$}

Centronellini: Wagen, 188:; Beecher, 1893; liensseleridie: Hall aud Clarke, 1895.

Terebratulas with the loop developing direct and composed of two lescending lamellar, uniting in the median line and forming a broad, arched plate.

\footnotetext{
ITerebratulacea Waagen is used here in preference to Aneylobrachia Gray, in violation of the law of priority, for the sake of emplony.

2 Since Beecher"s "lievision of the families of loopluearing lirachiopota" ('Trans. Conn. Acad., Fol. IX, 1893), it has been shown hy beecher and schnchert (Proc, Biol. Soc. Washington, Vol. VIII, 1893) that the lool, in the fanily Terebratulisle, as limited in the former paper, does in part pass through a short series of melamorphoses. This neressitates the removal of Centronelliuse from the family Terebratulidie, since its loops remain essentially without change throughout growth.
} 
Rensselaria Hall, 1859.

Be:ıchia Hall and Clarke, 1893.

Newberria Hall, 1891.

Rensselandia Hall, 1867.

Oriskania Hall and Clarke, 1893.

Trigeria (Bayle, 1875?) Hall and Clarke, 1893.

?Scaphiocerlia Whitfield, 1891.

Centronella Billings, 1859.

Cryptonella Hall, 1863 (not 1861 and 1867).
Chascothyris Holzapfel, 1895.

Selenella Hall and Clarke, 1893.

Romingerina Hall and Clarke, 1893.

Juvavella Bittner, 1888.

Juvavellina Bittner, 1896.

Nucleatula ('Zngmayer) Bittner, 1890.

Dinarella Bittner, 1892.

?Lissopleura Whitfield, 1896.

\section{Family TEREBRATULTDA Gray, 1840.}

Terebratulas developing originally a Centronella-like loop, and thenee by a short series of metamorphoses resulting at maturity in a free loop of varying form.

Subfamily STRINGOCEPHALINA Dall, 1870.

Stringocephalidar King, 1850; Davidson, 1853.

Terebratulider with a "long loop, following the margin of the dorsal valve, not recurved in front. Probably no median eoiled arm" (Beecher). ${ }^{1}$

Stringocephalus Defrance, 1827.

2a. Snbfamily MegaLanterine Waagen, 1882.

Terebratulid: with a long loop having ascending branches.

Megalanteris Ehlert, 1887.

Megant ris Sness, 18 ; 5 .

? Cryptacanthia White and St.

Jolıı, 1868.
Cryptonella Hall (1861?), 1867.

Harttina Hall and Clarke, 1893.

\section{¿a". Subfamily Terebratudinde Dall, 1870.}

Terebratulirle with a short loop. "A median unpaired coiled arm exists in recent genera" (Beecher).

Eunella Hall and Clarke, 1893. Crancena Hall and Clarke, 1893. Dielasma King, 1859.

Epithyris King, 1850 (not Phillips, 1841 ).

Seminn]a MeCoy, 1855 (not 1844).
Dielasmina Waagen, 1852.

Notothyris Tragen, 188\%.

Zugmeyeria Waagen, 18s:.

Dictyothyris Donvillé, 1880.

Glossothyris Douvillé, 18 so.

Pygope Link, 1830. 
Becheria Hall and Clarke, 1893. Hemiptyehina Waagen, 188:. Rhatina Waagen, 1852 . Terebratula kilein, 1753.

Tereluatula Lihwyd, 1699.

Sacenlus Llhwyd, 1699.

Lampas Menscheu, 1787.

Tereloratularius Duméril, 1806.

Nucleata Quenstedt, 1871.

Insenhs Quenstedt, 1871 (not Klein, 1753).

Diphyites Schroter, 1799.

Pugites de Hann, 1833.

Antinomia Catnllo, 18.0.
Propygope Bittuer, 1890.

Liothyrina Ehlert, 1857.

Fithyris Desiong'hamps, 1 (x62 (not king, 18.18).

Gryphus Megerle, 1811 (not lirisson, $1760)$.

Liothyris Douville, 1880 (not Consarl, $1875)$.

Terebratulina d'c rbigny, 1847.

? Disculina Deslongehamps, 1884.

$2 a^{b}$. Subfamily Discolinde Beecher, 1893.

Discoliide Fischer and (Ehlert, 18:2.

Terebratulide with the "loop short and continuous with the eirrated edge of the lophophore. No eoiled median am" (Beecher).

Discolia Fischer and (Ehlert,1890. ?.Agulhasia King, 1871. Eucalathis Fischer and Ehlert, 1890.

\section{Section B. TEREBRATELLA.}

Terebratulacea with the loop supported by a median dorsal septnm thronghont life, or only in the younger stages. Brachial ciri directed inward during larval stages. This section has two phyla haring a common origin now geographically separated in two provinces, one anstral, the other boreal.

1. Family TEREBRATELLID King, 1850 (emend Beecher, 1893).

Waldheimida Douvillé, 1880; Waldheimiius Waagen, 188:2.

Terebratulacea with the "loop in the higher genera composed of two primary and two secondary lamelle, passing throngh a series of distinct metamorphoses while attached to a dorsal septum" (Beccher).

\section{Subfamily Tropidoleptind Schuchert, 1896.}

Terebratellida with the loop consisting of tro slender descending branches, uniting with a high, vertical septum. Apparently the ancestral stock for the Terebratellidie.

Tropidoleptus Hall, 1859. 
1a. Subfamily Megatmrrin 2 Dall, 1870 (emend Beecher, 1893).

Argiopidae King, 1850; Megathyridie Chlert, 1887; Argiopide Davidson, 1884; Argiopince Davidson, 1887.

Terebratellidie in which the "loop is composed of descending branches only, passing in the highest genus through stages correlative with Gwynia, Cistella, and Megathyris. The lower genera do not complete the series" (Beecher). The original stock for the two following subfamilies :

Megatlyyis d'Orbigny, 1847.

Argiope Deslongchamps, 184: (not

Savigny and Autouin, 1827).

Zellania Moore, 1854.

Gwynia King, 1859.

Cistella Gray, 1850.

\section{1a $a^{a}$ Subfamily Daldinde Beecher, 1893.'}

Platiliin: Dall, 1870.

Terebratellide with the "loop composed of descending and ascending lamelix, passing in the highest genera throngh metamorphoses comparable to the adlult structure of Platidia, Ismenia, Miihlfeldtia, Terebratalia, and Dallina. The lower genera, therefore, do not pro. gress to the final stages" (Beecher). Recent genera restricted to boreal seas.

Dallina Beecher, 1893. Macandrevia King, 1859.

Terebratalia Beecher, 1893.

Lacqueus Dall, 1870.

Frenula Dall, 1871.

Frenulina Dall, 1895.

Miihlfeldtia Bayle, 1880.

Megerlia King, 1850 (not Robinean

Descoidy, 1830).

Platidia Costa, 1852.

Morrisia Davidson, 1852.

Ismenia King, 1850 (not Dall, 1871).

Kingena Davidson, 1852.

Kingia Schoenbach, 1867.

Trigonosemus Koenig, 1825.

Fissurirostra d'()rbigny, 1847.

Fissirostra d'Orbigny, 1847.

Delthyridea King, 1850.

Lyra Cumberland, 1816.

Terebrirostra d'Orbigny, 1817.
Eudesia King, 1850.

Orthotoma Quensterlt, 1871.

Trigouella Quenstedt, 1871.

Flabellothyris Deslongehamps, 1881.

Zeilleria Bayle, 1878.

Fimbriothyris Deslongchanı!s, 1884.

Mierothyris Deslongehamps, 1884. Ornithella Deslongehamps, 1884.

Aulacothyris Douvillé, 1880.

Cainerothyris Bittner, 1890.

Epicyrta Deslongchamps, 1884.

Cincta Quenstedt, 1871. !!

Antiptychina Zittel, 1883.

Plesiothyris Douvillé, 1880.

?Hynniphoria Suess, 1858.

?Cruratula Bittner, 1890 .

?Orthoidea Friren, 1875.

1 Since many of the fossil genera here referred to this family have not been studied in the light of Beecher's and CEhlert's recent researches, it is not known that all belong to this boreal stock. 


\section{1ab". Subfamily Magellanindi Beccher, 1893.}

Waldheinisla (partim) Douvillo, 1880: Torobratellina and Magasinar 1)avislson, 1887; Magasider (partiun) d'Orbigny, 1847; King, 1850; Rhyuchorisla: (partim) Kingr, 1850; Miihlfeldtiur Ehlert, 1887; Kranssininie Dall, 1870; Krausside Davidson, 1870 .

'Terebratellidar with the "loup' enmposed of' descending and asecuding branches, passing in the higher genera through metamorphoses comparable to the adult structure of Bouchardia, Magas, Magasella, Terebratellat, and Magellania. The lower genera become arlult before reaching the terminal stages" (Bcecher). Recent genera are restri ted to austral seas.

Nagellania Batyle, 1880.

Waldheimia King, 18.50 (not Brulle, 1816 ).

Neothyris Donville, 1880.

Terebratella d'Orbigny 1847.

Delthyris Menke, 1830 (not Dalman, 18.8).

Iвmеnia King, 1850 (not Dall, 1870).

Waltonia Davidson, 1850.

Magasella Dall, 1870.

Rhyuchorina Ehlert, 1887.
Magas Sowerby, 1816.

Megerlina Deslongehanps, 1884.

Bouchardia Davidson, 1849.

Pachyrhynchus King, 1850.

Kraussina Davidson, 1859.

Kranssia Davidson, 1852 (not Dana, 1852).

Cenothyris Donvillé, 1880.

Manuia Dewalque, 1874.

? Rhyuchora Dalman, 1828.

\section{Superfamily SPIRIFERACEA Waagen, 1883.}

Helicopegmata Waagen, 1883.

Telotremata with the arlult brachia supported by calcareous spiral lamelle or spiralia.

\section{Family ATRYPID AE Gill, 1871.}

Atrypidæ Dall, 1877.

Spiriferacea with the erura directly continuous with the primary lamella', which diverge widely and have the spiral cones between them. Jugum simple, complete or incomplete.

\section{1a. Subfamily Zygospirin E Wagen, 1883.}

Anazygidie Davidson, 1884; Zygospiride Hall and Clarke, 1895.

Atrypidat with a simple jugum either posteriorly or anteriorly directed. Spiralia with their apices toward the median dorsal region.

Kygospira Hall, 186:.

Stenocismi Hall, 1864 (not Conrad, 1839; Hall, 1867).

Anazyga Davidson, 188:.

Orthonomira Hall, 1858.

Hallina Winchell and Schuchert, 1892.

Protozyga Hall aud Clarke, 1893.
Catazyga Hall and Clarke, 1893.

Atrypina IIall and Clarke, 1893.

Glassia Davidson, 1882.

? Clintonella Hall and Clarke, 1893. 
Subfamily Darin A Waagen, 1893.

Atrypida with the jugum drawn out posteriorly into a simple short process. Spiralia laterally directed.

Dayia Davidsol, 1582.

$1 a^{n}$. Subfamily ATRYPIN X: Waagen, 1883.

Atrypicle with the jugum situater extremely posterior, complete in young stages, but at maturity discontinuous. Spiralia dorso-medially directed.

Atrypa Dalman, 1828.

Cleiothyris Phillips, 1841 (not King, $1830)$.

Spirigerina al'Orbigur, 1874.
Gruenewaltia Tschernyschew, 1.885 .

?Karpinskya Tschernyschew, 18.5 .

\section{Family SPIRIFERIDA King, 1846 (emend Davidson).}

Martininir and Reticnlarina Waagen, 1883; Spiriferinide Davidson, 1884.

Spiriferacea with the erura directly continuous with the bases of the primary lamellx, which are situated between the laterally directed spiralia. Jugum simple, complete or incomplete.

\section{2a. Subfamily Suessinn Wa Wen, 188:3.}

Spiriferillid with the jugum continnous and more or less V-shaperl. Shell structure punctate.

Cyrtina Davidson, 1858.

Theocyrtella Bittuer, 1892 .

Cyrtotheca Bittner, 1890 (not Salter).
Spiriferina d'Orbigny, 184 .

Suessia Deslongehamps, 1854.

\section{Subfamily Unditine Waagen, 1853.}

Spiriferilie (?) with the jugum as in Suessina. Just within the posterior margin of the dorsal valve are pouch-like plates. Deltidial plates united, deeply enneave. Subfamily anomalous.
Uncites Defrance, 1925.
? Uncinella Waagen, 18s:3.

2b. Subfamily Trigonotretin e S'huchert, 1893.

Delthyrin: (partim) Waagen, 1883.

Spiriferida: with the jugum at maturity discontinuons, represented by two short jugal proeesses, one attached to each primary lamella.

? Cyelospira Hall and Clarke, 1893. Syringothyris Winchell, 1863. Spirifer Sowerhy, 181\%.

Spirifer Meek and lanyden, 1861.

Choristites Fisher de Wallluein, 1825.

Trigonotreta Koenig, 1825; Meek audI

Hayden, 1864.

Spiriferus Hiaiuville, 1827.

Spirifera J. de C. Sowerby, 1835.

Brachythyris MeCoy, 1844 .

Fusella MeCoy, 1814.

Hysterolithus Queustert, 1871.

Cyrtia Dalman, 1828.

Delthyris Dalman, 18.s.

Martinia MrCoy, $15+4$.

Martiniopsis Waagen, 1883.

Mentzelia Quenstedt, 1871.

Ambocelia Hall, 1860.

lieticularia McCoy, 1844.

Verneuilia Hall and Clarke, 1893.

?. Metaplasia Hall and Clarke, 1893. 


\section{Family ATHYRID E Phillips, 1841.}

Nuclenspirida Davidson, 1882; Koninckinida Davidson, 1853.

Spiriferacea with the bases of the primary lamellat situated betwen the spiralia, and shapply recurved dorsally at their junction with the crura. Spiralia more or less laterally directed. Jugrum complete, V-shaped, with the apex drawn out into a simple, bifurcated, or otherwise molitied process.

3a. Subfamily Rhynchospirin as Schnchert, 1894.

Retzinie Waagen, 1883 ; Retzidde and Rhynehospirida Hall aud Clarke, 1895.

Athyrida with the single process of the jugum commonly recurved, but sometimes bifurcated. Shell structure distinctly punctate.

Homcospira Hall and Clarke, 1893. Parazyga Hall and Clarke, 1893. Rhynehospira Hall, 1859.

Acambona White, 1862.

Ptychospira Hall and Clarke, 1893. Hustedia Hall and Clarke, 1893.

Enmetria Hall, 1864.

Trematospira Hall, 155\%.

Retzia King, 1850.

Trigeria Bayle, 1878.

\section{$3^{a}$. Subfamily Hindeldind Scluchert, 1894.}

Colospirilie and Nucleospirid:e Hall and Clarke, 1895.

Athyride in which the jugum has a single process which may be simple, or it articulates in a ventral septal socket, and sometines (rarcly) is sharply reeurved terminally. Shell structure impunctate.

Sindella Davidson, 1882.

\{ Whitfieldella Hall and Clarke, 1893.

Meristina Daridson, 1882 (not Hall, 1867).

Nucleospira Hall, 185. Hyattella Hall and Clarke, 1893.
Anoplothec: Santberger, 1856.

Bifida Davidison, 1882.

Colospira Hall, 1863.

Leptoccelia Hall, 1857. 1859.

Titulina Hall, 1860.

?Anabia Clarke, 1893.

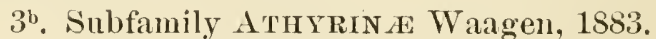

Athyridit in which the single process of the jugum bifurcates. The branches may or may not terminate between the first and second volutions of the spiralia.

Meristina Hall, 1867.

Athyris Davidson, 1853 (not McCoy, 1814).

Whitfieldia Davidson, 1882.

Glassina Hall and Clarke, 1893. Athyris MeCoy, 1844.

Spirigera d'Orbigny, 1847.

Euthyris Quenstent, 1871.

Actinoconehus MeCoy, 1844.

Torynifer Hall and Clarke, 1895.
Cleiothyris King, 1840 (not Phillips, 1S41).

Seminula MeCoy, 1844 .

Spirigerella Waagen, 1883.

Anomactinella Bittuer, 1890.

Pomatospirella Bittner, 1892.

Amphitomella Bittuer, 1890.

Tetrartinella Bittner, 1890.

Plicigera Bittner, 1890.

Pentactinella Bittner, 1890. 
3c. Subfamily Drplosprarn E Schuchert, 1894.

Athyridie (partim) Hall and Clarke, 1895.

Athyrida with the jugal bifurcations very long, lying between the volntions of the spiralia, and continuing with these to their outer ends. Sometimes there is an additional jugal process which articulates with the ventral valve, or recurves and joins the jugum.

Kayseria Davidson, 1852. Diplospirella Bittner, 1890. Enractinella Bittner, 1890.
Pexidella Bittner, 1890. Anisactinella Bittner, 1890. ? Dirlymospira Salomon.

$3^{\text {the }}$ Subfamily Konrnkinrnas Waagen, 1883.

Koninckinidie Davidson, 1853; Amphiclinine Waagen, 1883; Diplospidre and Diplospiridie Munier-Chalmas, 1880.

Athyridie with jugum and spiralia essentially as in Diplospirida. The spiralia in Koninckinina, however, are not laterally directed as in the former group, but point ventrally, this being due to the concave form of the dorsal shell.

Koninckina Suess, 1853. Ampliclina Laube, 1865. Koninckella M.-Chalmas, 1880.
Koninckodonta Bittner, 1893. ?'Thecospira Zugmeyer, 1880.

? Amphiclinodonta Bittner, 1890.

\section{$3^{\text {ba }}$ Subfanily Meristellinde Waagen, 1883.}

Meristellidie Hall and Clarke, 1895.

Athyridre in which the jugal bifureations do not enter the spiralia, but recurve and join near their origin.

Meristella Hall, 1860.

Charionella Billings, 1861.

?Pentagonia Cozzens, 1846.

Goniocelia Hall, 1861.

Dicamara Hall and Clarke, 1893.
Merista Suess, 1851.

Camarium Hall, 1859.

Dioristella Bittner, 1890.

?Camarospira Hall and Clarke, 1893.

\section{Order NEOTREMATA Beecher, 1891.}

Circular or oval, more or less cone-shaped, inarticulate Brachiopoda, with the perlicle opening restricted throughout life to the ventral valve. Pedicle aperture modified by a deltidium or listrium. Prodeltidium attached to the ventral valve.

\section{Superfamily ACROTRETACEA Schuchert, $1896 .^{\text {. }}$}

Daikaulia (partim) Waagen, 1885; Diacaulia Hall and Clarke, 1895.

Neotremata with phosphatic shells and a more or less well-rleveloped pseudodeltidium. Dorsal protegulum marginal. 


\section{Family ACROTlETIDA Schnchert, 1893.}

Acrotretacea with the perlicle opening posterior to the proteguhm.

Acrothele limmarsson, 1876.

Linnarssonia Waleott, 1885.

Diseinopsis (Matthew) Hall and

Clarke, 1892.

Aerotreta Kintorga, 1848.
Conotreta Walcott, 1889.

? Mesotreta Kutorga, 1848.

? Orbicella d'Orbigny, 1S4!).

Keyserlingia l'ander, 1861.

?Helmersenia Pander, 1 sti1.

\section{Family SIPHONOTRE'TID K Kintorga, 1 st8.}

Acrotretacen with the pedicle opening passing by resorption anteri orly throngh the protegulum and the umbo of the shell.

Yorkia Walcott, 1897.

Trematobolus Natthew, 1893.

Siphomotreta de Vernenil, 1845.
Protosiphon Matthew, 1897

Schizambon Walcott, 1884 .

Schizambonia Ehlert, $18 \times 7$.

\section{Superfamily DISCINACEA Wagen, 1885.}

Daikanlia (partim) Waagen, 1885; Diacanlia (partim) Hall and Clarke, 1895.

Neotremata with phosphatie shells, a listrium, but with uo deltidinn. Dorsal protegulum usnally subcentral.

\section{Family TREMATIDA Schnchrrt, 189:3.}

Prinitive Discinacea, in wheh the posterior margin of the ventral valve has a triangnlar pediele noteh thronghont life. A listrinm is nsually present.

Diseinolepis Waagen, 1885. Trematis Sllarpe, $18+7$.

Orlicella 11 all and Whitfield, 1875 (not d'Orbigny, 1819).

Schizocrania Hall and Whitfield, 1875.
Schizobolns Utrich, $188 t$. Lingulodiscina Whittield, 1890. Elilertella Hall and clarke, 1890. ? Monobolina Salter, 186.5.

\section{Family DISUINID E Gray, 1840 .}

Orbienliular MeCoy, 1841.

Derived Discinacea with an open pedicle notch in early life in the posterior margin of the ventral valve, which is closed posteriorly during neanic growth, leaving a more or loss long, narrow slit partially closed by the listrium.

Orbicnloidea d'Orbigny, 1847.

Schizotreta Kutorga, 1848.

Lindstrumella Hall and Clarke, 1590.

Rormerella Hall and Clarke, 1890.
Discina Lamarck, 1819.

Orbicula Sowerlyy, 1830 (not Cuvier, 1798).

Discinise: Dall, 1871. 


\section{Superfimily CRANIACEA Waagell, 1855.'}

Gasteropegmata Waagen, 1885.

Cemented calcareous Neotremata without pedicle or anal openings at maturity.

\section{Family CRAN AADE King, 1846.}

Orbiculie Deshayes, 1830; Cranialie Gray, 1840.

Craniacea with the pedicle functional probably only during nepionic growth.

Crania Retzius, 1781.

Nummulus Stoeboens, 1732.

Ostracites Beuth, 1776.

Criopus Poli, 1791.

Criopodermia Poli, 1795.

Orbicula Cuvier, 1798 (not Sowerby, $1830)$.

()rbienlarius Dnméril, $1 \times 06$.

Craniolites Schlotheim, 1820.

Discina Turton, 1832 (not Lamarck, 1819 ).

Criopodtermat Whambere, ${ }^{2 \prime}$

Choniopora schauroth, 1854.
Craniella Ehlert, 1888.

Cardinocrania Waagen, 1885. ?

Ancistroerania Dall, 1877.

Cranopsis Dall, 1871 (not A. Adams).

Craniseus Dall, 1871.

Siphonaria Qnenstedt, 18551 (not Sowerby).

Pholidops Hiall, 1860.

Craniops Hall, 1859

Psendocrania McCoy, 1851.

Palieocrania

\section{Order PROTREMATA Beecher, 1891.}

1) rived, articulate Brachiopoda, with the pedicle opening restricted to the ventral valve throughout life or during early growth. Prodeltidiun originating on the dorsal side of the borly wall in the cephlalula stage, and later anchylosed to the ventral shell, thus initiating the development of a deltidium. Pediele aperture modified by the delticlium. Brachia unsupported by a ealcareous skeleton except in the Pentameracea where there are crura.

\section{Superfamily STROPHOMENACEA Sehuchert, $1896 .{ }^{2}$}

Lineicardines (partim) and Denticardines (partim) Bronn, 1862; $\Lambda$ planeropegmata (partim), Productacea, Coralliopsida, and Kanpylopegmata (partim) Waagen, 1883; Elentherohranchiata (partim) Nenuayr, 1883; Cryptobrachia (partiu) Gray, 1848; Thecacea Schnchert, 1893.

Primitive Protremata withont spondylia and eruralia.

Family KUTORGINID E Schuchert, 1893.

Primitive Strophomenacea with ineipient eardinal areas, great delthyrial opening, and very rulimentary articulating processes and deltidium.

Kutorgina Billings, 1861 (emend ?Sebizopholis Waagen, 1885.

Waleott).

The writer believes that when the young growth stages of Crania are studied it will be shown that the Craniacea have the superfamily characters of Acrotretacea rather than thoso of Discinacea.

${ }^{2}$ Text-book of Paleontology, by Zittel and Eastman, 1896, p. 312. 


\section{? Family EICHWALDHDE Sehuchert, 1893. ${ }^{1}$}

Primitive or aberrant, rostrate Strophomenacea, with narrow lateral grooves and ridges for articulation. Delthyrium elosed by a concave plate (?deltidinm). Pedicle emerging through the ventral umbone and moving with growth anteriorly by resorption through the shell, as in Siphonotretidae.

Eichwaldia Billings, 1858.

Dietyonella Hall, 1867.

\section{Family BILLINGSELLID A Sehuehert, 1893.}

Strophomenacea with well-developed cardinal areas and deltidium. Cardinal process obsolete or very rudimentary. Articulation fairly well developed.

Billingsella Hall and Clarke, 1892.

Protorthis Hall and Clarke, 1892.

\section{Family STROPHOMENIDA King, $18 \pm 6$.}

Strophomenacea with well-developed cardinal areas, deltidium, chilidium, carlinal and articulating processes.

\section{2a. Subfamily RAFINESQUININA Sehuehert, 1893.}

Leptænacea Braun, 1840; Orthiside (partim) d'Orbiguy, 1847; Davidsonidx King, 1850; Davidsoninit Gill, 1871; Strophomenine (partim) Gill, 1871; Waagen, 1884; Cadomellinæ Munier-Chalmas, 1887; Leptænidæ Hall and Clarke, 1895.

Strophomenoids with ventral valve convex and dorsal coneave, except in Strophonella. The relative form of the valves is the reverse of the Orthothetinæ.

Rafinesquina Hall and Clarke, Pholidostrophia Hall and Clarke, 1892.

Leptæna Dalman, 1828.

Leptagonia McCoy, 1814.

Strophomena Meek, 1873 (not Blainville, 1825).

Plectamhonites Ehlert, 1887 (not Pander, 1830).

Stropheodonta Hall, 1852.

Brachyprion Shaler, 1865.

Douvillina Ehlert, 1887.

Leptostrophia Hall and Clarke, 1892 .

1892.

Strophonella Hall, 1879.

Amphistrophia Hall and Clarke, 1892.

Cadomella MI.-Chalmas, 1887.

Leptella Hall and Clarke, 1892.

Plectambonites Pander, 1830.

Leptirna Davidson, 1853; Ehlert, 1877 (not Dalman, 1828).

Leptænisea Beecher, 1890.

Christiania Hall and Clarke, 1892.

Davidsonia Bouchard, 184i.

In 1893 the writer referred this family with doubt to the Rhynchonellacea. The absence of crural plates in Eichwaldia forbids that disposition. If the concare plate closing the umbonal pedicle passage is a deltidium, there can be no cloubt that this family belongs to the Protremata. Students should search for the very young of Eichwaldia or Dictyonella, since it is through ontogeny alone that the true systematic position of this family will be determined. 


\section{2b. Subfamily OrThothetinж Waagen, 1884.}

Strophomenina (partim) Waagen, 1884.

Strophomenoids with the ventral valve convex during early growth, becoming subsequently coneave.

?. Orthidinm Hall and Clarke, 1892. Streptorhynchus King, 1850.

Strophomena Blainville, 1825.

Hemipronites Meek, 1872 (not Pander, 1830).

Orthothetes Fischer de Waldheim, 1837.

Orthis King, 1850 (not Dalman, 1828). Hipparionyx Vanuxem, 1842.

Derbya Waagen, 1884.

Kayserella Hall and Clarke, 1892. Meekella White and St.John, 1870. Triplecia Hall, 1859.

Dicraniscus Meek, 1872.

Mimulus Barrande, 1879.

Streptis Davidson, 1881.

\section{Family THECIDIID E Gray, 1840.}

Cemented Strophomenacea in which the interior of the shell is impressed with variously indented brachial furrows.

$3^{\text {a }}$. Subfamily LrtTonire: Waagen, 1883.

Theeidida with the brachial markings common to both valves.

Lyttonia Waagen, 1883.

.Oldhamina Waagen, 1853.

Leptodus Kayser, 1882.

\section{3". Subfamily 'THecidin ג Dall, 1870.}

Thecidiide with the braehial markings restricted to the dorsal valve.

Thecilia Defrance, 1822.

Thecillium Sowerby, 1824.

Lacazella M. Clialmas, 1880.

Thecidiopsis M.-Chalmas, 1887.

Thecidella M.-Chalmas, 1887.
Lundesella M. Chalmas, 1880.

Pterophloios Giimbel, 1861.

Bactryuium Emmerich, 1855.

(In error. Not Bactrillium Hebr.)

Davidsonella M. Chalmas, 1850.

\section{2a . Family PRODICTIDA Gray, 1840.}

Prodnctina Gicbel, 1846.

Strophomenacea with hollow anchoring spines.

$$
2 a^{\text {aa }} \text {. Subamily Chonetrind Waagen, } 1884 .
$$

Chonetide Bronu, 1862; Hall and Clarke, 1895.

Productidx with the anchoring spines restricted to the ventral cardinal margin.

Chonetes Fischer de Waldheim, Chonostrophia Hall and Clarke, 1837. 1892.

Leptiena MeCoy, 1844 (not Dalman, Chonetina Krotow, 1888. 1828).

Anoplia Hall and Clarke, 1892.

Chouetella Waagen, 1884.

Chonetella K rotow, 1881 (not Waagen, 1884). 


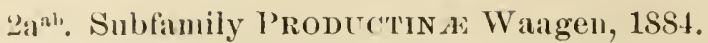

Productidar with the anchoring spines more or less abmudant over the ventral valve and sometimes also over the dorsal valve.

Daviesiella Wagen, 1854.

Productella Hall, 1867.

Prolluetus Sowerby, 1812.

l'yxis C'hemnitz, 1781.

Producta G. B. Sowerlis, 1825.

Arbusenlites Murray, $1 \times 31$.

rrotonia linck, 1830 (not Rafilles(jue).

Marginifera Waagen, $188 t$.

Proboscidella Ehlert, 1987.
Etherilgina Whlert, 1887.

Chomopectus Hall and Clarke, 1892.

Strophalosia King, 1844.

Orthothrix Geinitz, 1847.

Leptienalosia King, 1845.

Aulosteges von Helmersen, 1847 .

"Aulacorliynchus Dittmar, 1871.

Isogramma Mcek and Worthen, 1873.

Zan. Family RICITHOFENIDA Wagen, 1855.

Strophomenacea probably derived through the Prodnctidar, and remarkably modified by ventral cementation. The form of the shell is that of cyathophylloid corals with an operculiform dorsal valve. Shell structure cystose.

Richthofenia Kayser, 1881.

\section{1a. Family ORTHID E Woodward, 1852.}

Orthisidie (partiu) d'Orbigny, 1847; Orthinx and Enteletme Waagen, 1884.

Strophomenacea usually with large open delthyria; deltidium only developed in younger growth stages.

Orthis Dalman, 1828.

Orthambonites P'auder, 1830.

SPlectorthis Hall and Clarke, 1892.

(Hebertella Hall and Clarke, 1892. Sehizophoria King, 1850.

Orthotichia Hall, 1892.

Enteletes Fischer de Wallheim, 1830.

Syutrielasma Meek, 186 i.

Platystroplia King, 1850.

Orthotropia llall and Clarke, 1895.
S Dinorthis Hall and Clarke, 1892.

$\{$ Plir'siomys Hall and Clarke, 1892.

Orthostrophia Hall, 1883.

(Dalmanella Hall and Clarke, $1 s 92$.

Heterorthis IIall and Clarke, 189 .

Bilobites Linné, 1775.

Dicelosia King, 1850.

Rhipidomella CEhlert, 1890.

Rhipidomys (Ehlert, 1887 (not Wagner).

\section{Superfamily PENTAMERACEA Sehuchert, 1596. ${ }^{1}$}

Trullacea Schuchert, 1893; Ancistropegmata (partim) Zittel, 1895; Aphaneropex.nuta (partim) and Proluctacea (partim) Waagen, 1883; Elentherobranchiata (partim) Nemmayr, 1883.

Derived Protremata with spondylia to which are attached the adductor, diductor, and ventral perliele museles. Commonly cruralia are present.

1. Family CliTAMBONITID E Winchell and Schuchert, 1893.

Orthisida (partim) d'Orbigny, 1849; Orthisine Wrageu, 1884.

Primitive Pentameracea with long, straight cardinal areas and a well.developed deltidium. No cruralium. 


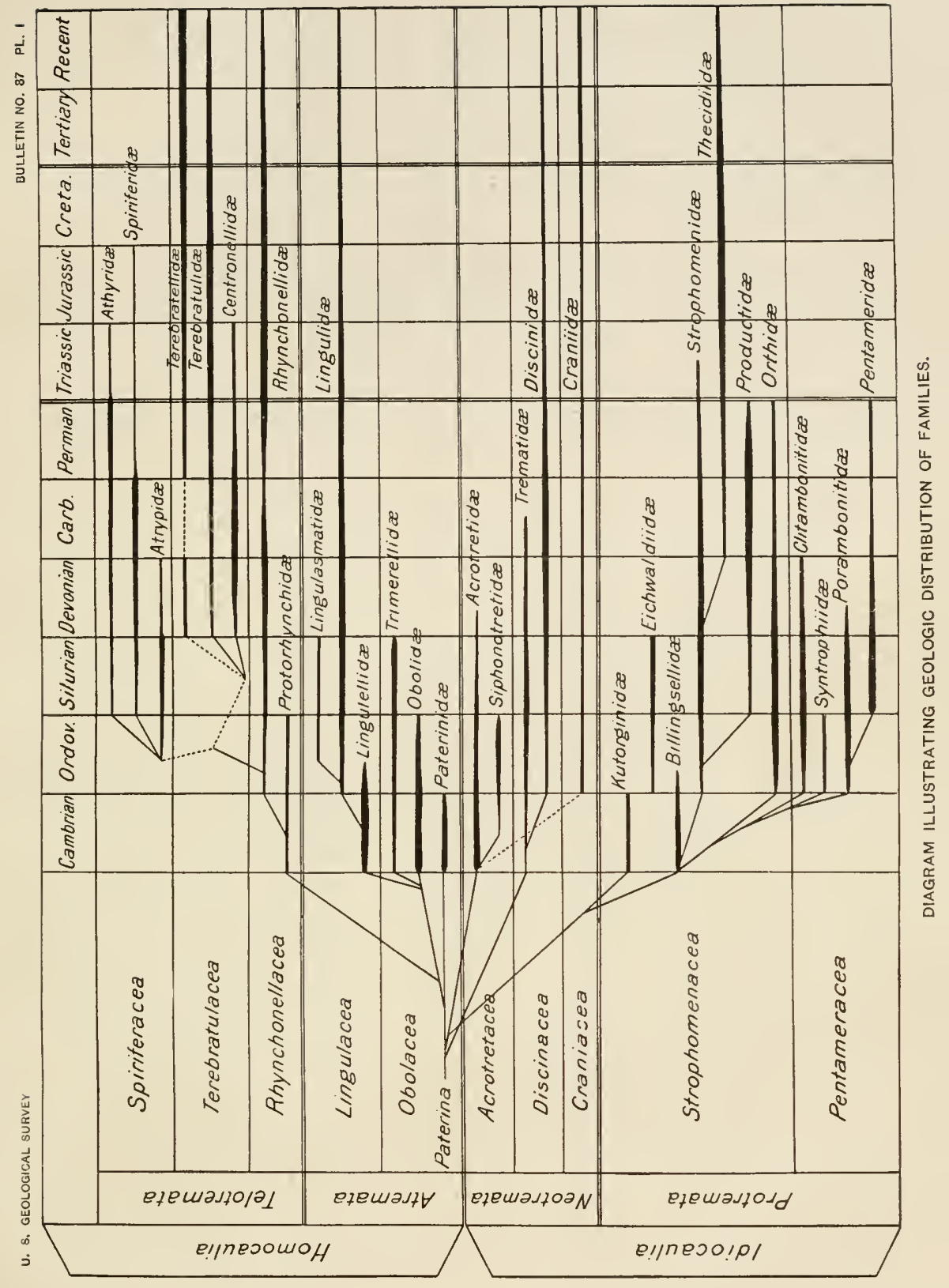



Clitambonites Pander, 1830. r'ronites Pander, 1830. Gonambonites Panter, 1830. Orthisina d'Orlbigny, 1847.
I'olytochia IIall and Clarke, 1892. Hemipronites Pander, 1830.

Scenidium Hall, 1860.

Mystrophora kiayser, 1871.

3. Family SYNTROPHIID E Schuchert, $1896 .{ }^{1}$

Stricklandmiid:e (partim) IIall and Clarke, 1895.

Prinitive P'entameracea with long, straight cardinal areas, deltidia, and cruralia.

Syntrophia Hall and Clarke, 18!12-93.

¿a. Fimily PORAMBONITID D Davidson, $1853 .{ }^{2}$

Poramlonitin: Gill, 1871; I'orambonitida (partim) Notling, 1883; Camarellide (partius) Hall and Clarke, 1895.

I'entamericea intermediate in structure between the Syntrophiidie and Pentamerida, in that the deltidium and the straight cardinal areas of the former family tend to obsolescenee, particnlarly the delticlium. The Porambonititle approach the Iatter family in tending to develop a rostrate shell. Cruralinm present.

Camarella Billings, 1859 (emend

Hall and Clarke, 1893).

Palastrophia Hall and Clarke,

1893.

Anastrophia Hall, 1867.

Brachymerus Shaler, 1865 (not 1)ejean, 1834).
Braneonia Gagel, 1890.

Porambonites Pander, 1830.

Priambonites Agassiz, 1847.

Isorhynchus King, 1850 .

Netlingia Hall and Clarlie, 189:3.

?Lycophoria Idalıusen, 1855.

\section{2b. Family PENTAMERIDA MeCoy, 1844.}

Hypothyrid:e (partim) King, 1850; Pentameride IIall, 1867; Canmeroplorinine Waagen, 1883; Pentamerina Gill, 1871; Waagen, 1883; Poramboniticle (partim) Noetlug, 1883; Stenochismatine and C'onchidiine (Ehlert, 1887; Camarellidie (partmu), Stricklandinidae (partim), and Amphigenida IIall and Clarke, 1895.

Rostrate P'entameracea rarely with straight cardinal areas. Delticlium commonly absent, hut sometimes present as a concave plate, being the reverse of the ordinary form of the deltidium and ane to the incurverl beaks. Crumalium present.

Stricklandinia Billings, 1863.

Stricklandia Billings, 1859.

P'entamerus Sowerby, 1813.

l'entastire Blaiuville, 18:4.

Capellinia Hall and Clarke, 1593.

Pentamerella Hall, 1867.

Gypidula Hall, 1867.

Sieberella dihlert, 1887.

Camarophorella Hall and Clarke, 1893.

Amphigenia Hall, 1867.
Conchidlium Limné, 1753.

Antirhyuchonella Quensterlt, 18it.

Zelimir larraule, 1879.

Cypirlia Daluan, 1״․

Clorinda Barrande, 1879.

Barrandella Hall and ('larke, 1893 .

Enantiosphen Widborne (IIolzap)fel), 1893.

Camarophoria King, 1846.

Stenochisma Dall, 1877; (Ehlert, 1887

(not Courad, 1839).

\footnotetext{
1 Text book of Palcontologs. by Kittel and Eastman, 1896, p. 320.

2Sinee 11 all and Clarke's fanily Camarellida (1895), after removing Camarophoria and ('amarophorella, is based upon the same family characters as those of the Porambonitidie (1853), as Poram. bonites is now interpreted, Davidson's family is retained on the ground of priority.
} 


\section{Synopsis of the divisions of liruchiopoda higher than genera.}

superorders. Orders. Superfamilies. Fumilies.

Tedicle common to both ralves throughout life or ouly in $y o u t h f n l$ growtl. (Hemocaulia.)

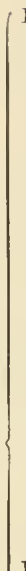

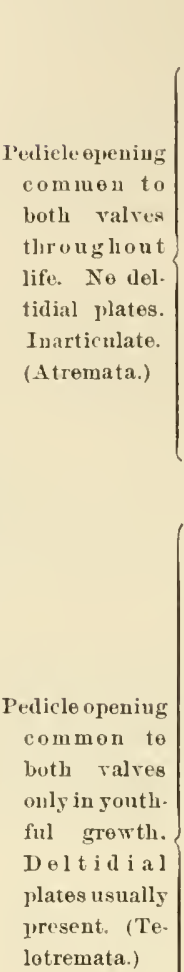

B ported by spiralia. (Spiriferacea.)
Valves senicirenlar; perli. cle oponing more or less

\begin{tabular}{r|c|c|} 
Shells rounded. & large & $=$ Taterinidae. \\
Pedicleshort. & Falves rutuded, justeri-
\end{tabular} Animal not orly acuminate; pedicle burrowing. opening sma!l = Obolidat. (Obolacea.) Valves round or oval, thick, with solid or excavated platforms = Trimerellidic.

Shells elongate. $\left(\begin{array}{c}\text { Shells thin, elongate, with } \\ \text { ebeloil interiors }=\text { Lingulellidæ. }\end{array}\right.$ Pedicle leng. Shells thin, elengate, with Animal bur-\{ muscular system highly rewing. (Lin- specialized = Lingulid:e. gulacea.) Shells elongate, wilh solid platforms = Lingulasmatidx.

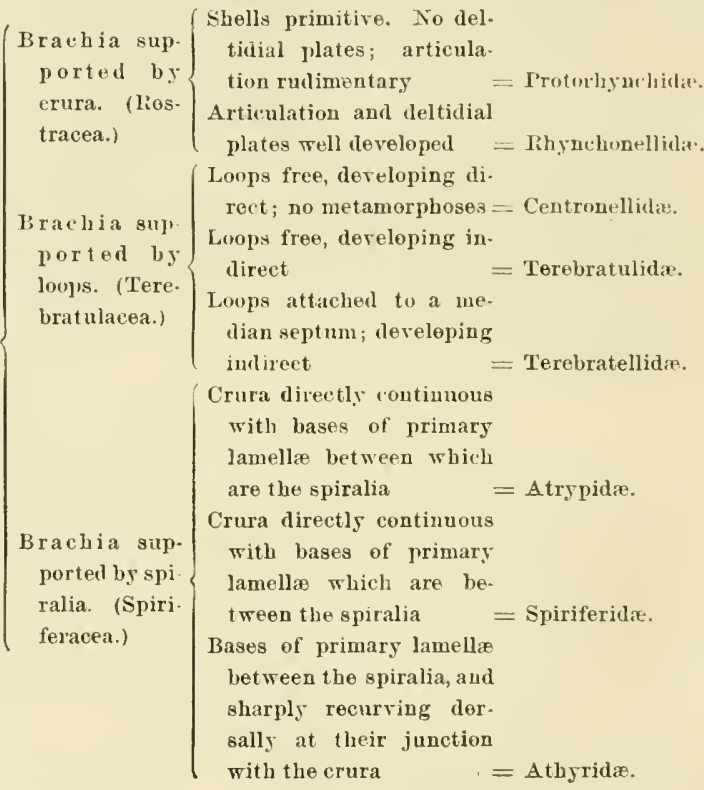


Synopsis of the divisions of Brachiopoda higher than genera-Continued.

Superorders.

Pedicle restricted to ventral valve through. out life or only in $50 u t h f u l$ growtb. (Idioraulia.)
Orders. Superfamilies.

Families.
Pediclerestrict-
ed to ren-
tral ralve
throughout
life. Inartic-
ulate. (Neo-
tremata.)

Pedicle restrict. ed to rentral ralve througheut or a pertion of lite. Artic. ulate. (Pro. tremata.)

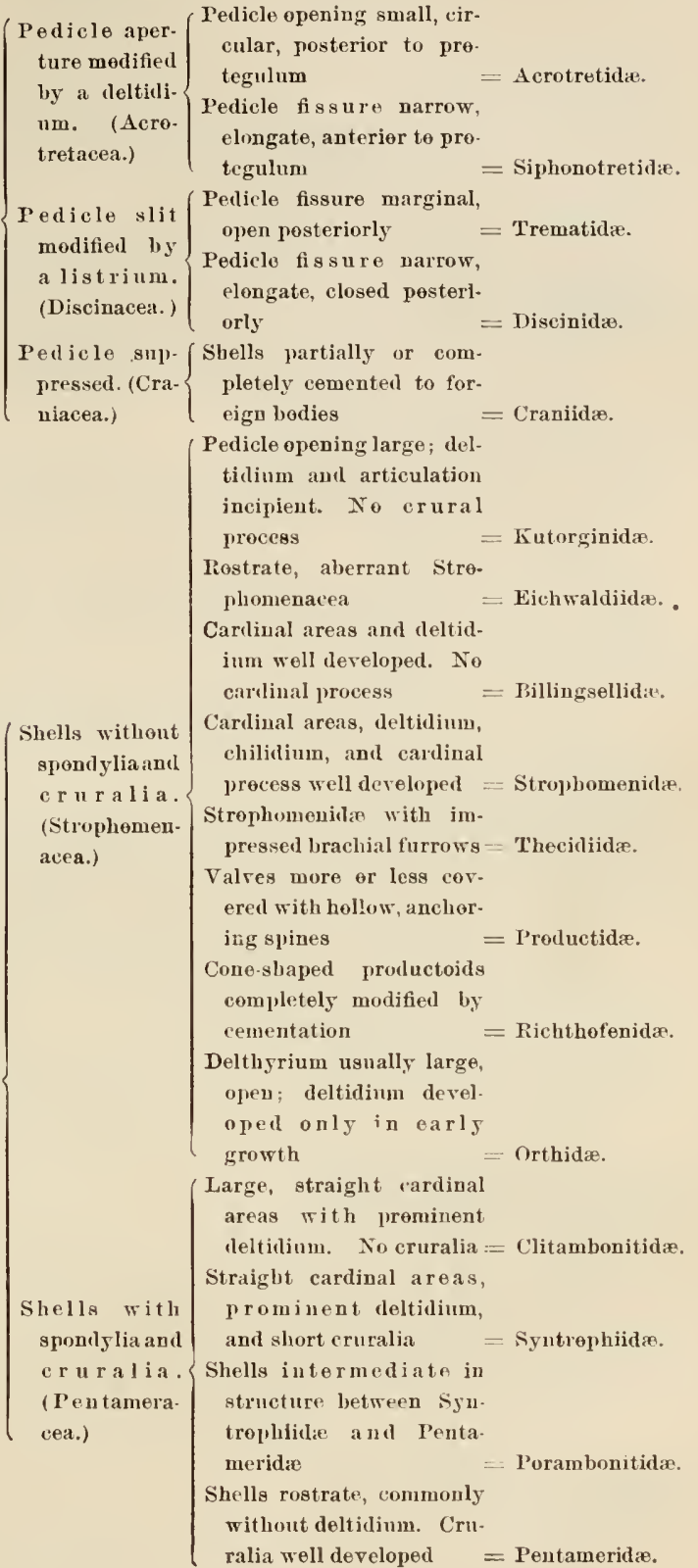

Pedicle opening 


\section{CHA P T ER VI.}

\section{INIEA AND IBLBEIOGRAPIIY OF AMELICAN FOSSII, BRACHIOPODA.}

ACAMBONA White.

Genotype A. prima White.

Acambona White, l'roe. Boston Soe. Nat. Hist., IX, 1862, p. 27, tigs. 1, 2.--Hall and Clarke, Pal. New York, VIII, Pt. II, 1893, p. 119;--Thirteenth Ann. Rep. N. Y. State Geologist, 1895, p. 797.

Acambona osagensis (Swallow). Choutean (1. Carlo.).

Retzia osagensis Swallow, Trans. St. Louis Acud. Sci., I, 1860, 1.65:3.

Acambona? osagensis Hall and Clarke, Pal. New York, VIIl, l’t. II, 1893, 1. 120, pl. 51, figs. 38, 39 .

Retzia? osagensis Kieyes, Goul. Survey Missonri, V, 1895, p.94.

Loc. Cooper and Bentou counties, Missonri.

Acambona prima White.

Burlingtou (L. Carb.).

A cambona prima White, Proe. Boston Soc. Nit. Ilist., IX, [862, 1. 27, tigs. 1, 2.Hall and Clarke, Pal. New York, VIII, Pt. 1I, 1893, p. 119, pl. 51, figs. 10, 41.

Eumetria prima Miller, North American Geol. and I'al., 18k9, p. 346.

Loc. Burlington, Iowa.

Obs. It is probable that this species is ilentical with A. osiggensis.

ACROTHELE Limmarsson.

Genotype A. coriacea Limnarsson.

Acrothele Linnarsson, Bihang till Kgl. Svenska Vetens.-Akad. Handl., III, 1876 , p. 20.-Walcott, Bnll. U. S. Geol. Snrvey, 30, 1886, p. 107.-Hall and Clarke, Pal. New York, VIII, Pt. I, 1892, pp. 98, 167;-Eleventh Anu. Rep. N. Y. State Geologist, 1892, p. 249.

Acrothele bellula Walcott.

Millle Cambrian.

Acrothele bellula Walcott, Proe. IT. S. National Mus., XIX, 1897, P. 716, pl. 60, figs. 4-4e.

Loc. Cowans Crook, Cheroken County, Alahama.

Acrothele decipiens Walcott.

Lower Cambrian.

Acrothele decipiens Walcott, Pruc. U. S. National Mus., XIX, 1897, p. 716, pl. 60, fig. 2.

Loc. Near Stouer's, York County, P'nnsylvania.

Aorothele (?) dichotoma Walcott.

Lower Cambrian.

Acrothele? dichtoma Walcott, Mon. U. S. Geol. Survey, VIII, 1881, p. 1., pl. 9, fig. 11 ; -Bull. U. S. Geol. Survey, 30, 1886, 1) 107.

Loc. Eureka distri॰t, Nevarla.

Acrothele matthewi (Iartt).

Middle Cambrian.

Lingula matthewi Hartt, Dawson's Acadian Geology, 2d ed., 1868, p. 644, fig. 221 ;-Ibidem, 3d cil., 1874, p. 644, fig. 221.

Acrothele matthewi Matthew, Trans. Royal Soc. Canada, III, 1886, p. 39, pl. 5, fig. 15.-Hall and Clarke, Pal. New York, VIII, Pt. I, 1892, p.99, pl. 3, fig. 29.Matthew, Trans. N. Y. Aead. Sci., XIV, $1 \times 95$, 1). 128 , pl. 5, figs. 6, 7, 8 .

Lor. Portland, New Brunswick; Manuels Brook, Conception Bay, Newfoumdland. 
Acrothele matthewi costata Matthew.

?Middle Cambrian.

Aerothele matthewi var. costata Matthew, Trans. N. Y. Acad. Sci., XIV, 1895, p. 128 , pl. 5 , fig. 9.

Loc. Hanford Brook, New Brunswick.

Acrothele matthewi lata Matthew.

Middle Cambrian.

Acrothele matthewi var. lata Matthew, 'Traus. Royal Soe. Canada, III, 1886, p. 41, pl. 5, fig. 17.-Hall and Clarke, Pal. New York, Vill, Jt. I, 18:2, pl. 3, figs. $26-28$.

Loc. Portland, New Brunswick.

Acrothele matthewi prima Matthew.

Middle Cambrian.

Acrothele matthewi var. prima Mattliew, Trans. Royal Soc. Canada, I11, 1886, p. 41, pl. 5, fig. 16.-Hall and Clarke, Pal. New York, V'll, Pt. I, 1892, p]. 3, fig. 25.

Loc. Hanforl Brook, New Brunswick.

Acrothele subsidua (White).

Lower and Middle Cambrian.

Acrotreta? subsidua White, Wheeler's Geogr. Geol. Expl. aud Surv. west 100 Merid., Prelim. Rep., 1874, p. 6;-Ibidem, Final Rep., IV, 1875, p. 31, p]. 1, fig. 3 .

Acrothele snbsirha White, Proc. U.S. National Mus., III, 1880, p. 47.-Walcott, Bull. U. S. Geol. Survey, 30, 1886, p. 108, p]. 9, fig. 4;-Tenth. Ann. Rep. U. S. Geol. Surves, 1891, p. 608, pl. 70, fig. 1.-Beecher, American Jonr. Sei., XLI, 1891, p. 357, p]. 17, fig. 12.-Hall and Clarke, Pal. New York, VilI, l't. I, 1892, \}. 100, pl. 3, figs. 30, 31.

Lor. Antelope Spring, Utah: Pioclie, Nevada.

ACROTRETA Kutorga.

Genotype A. subconica Kintorga.

Arrotreta Kutorga, Verhand. Kais. Min. Gessel. zn St. Petersburg, 1848, p. 275.-Waleott, Mon. U. S. Geol. Survey, VIII, 1884, 1. 16.-Hall aud Clarke, Pal. New York, VIII, Pt. 1, 1892, pp. 101, 166;-Eleventh Ann. liep. N. Y'. State Geologist, 1892, ]. 250.

Acrotreta attenuata Heek $=$ A. gemma.

Acrotreta baileyi Matthew.

Middle and Upper Cambrian.

Acrotreta baileyi Matthew, Trans. Royal Soc. Canada, III, 1886, 1. 36, pl. 5, fig. 13. - Hall and clarke, Pal. New York, VIII, Pt. I, 1892, p. 102, p]. 3, figs. 32-34.-Matthew, Trans. Royal Soc. Canada, IX, 1842, p. 43, pl. 12, fig. 7ı.

Loc. Hanford Brook and Long Rearh, New Brunswick.

Acrotreta gemma Billings.

Lower to Upper Cambrian. Acrotreta genina Billings, PaI. Fossils, I, 1865, p. 216, tig. 201.-Waleott, Mon. U. S. Gieol. Survey, VIII, 1884, p. 17, pl. 1, fig. 1; pl. 9, fig. 9;-Bull. U. S. Geol. Survey, 30, 1886, p. 98, j)l. 8, tig. 1;-Tenth Aun. Rep. U. S. Geol. Survey, 1891, p. 608, pl. 67, fig. 5.-Hall and Clarke, Pal. New York, VIII, J't. I, 1892, p. 102, figs. 55-57. - Matthew, 'I'rans. N. Y. Acad. Sei., XIV, 1895, p. 126.

Acrotreta sulwonica Meek, Haylen's Sixth Ann. Rep. U. S. Geol. Survey Terr., 1873, ?. 463.

Acrotreta attenuata Meek, Ibidem, 1873, p. 463.

Acrotreta pyxidicula White, Wheeler's Geogr. Geol. Expl. and Survey wrst 100 Merid., Prelim. Rep., 1874, p. 9;--1hidem, Final Rep., IV, 1875, p. 53, pl. 3, fig. 3.

Loe. Near Portland Creek, Newfoundland; Lnreka and White Pine mining districts, Nevada.

Acrotreta gemma depressa Walcott.

Middle Cambrian.

Acrotreta gemma var. depressa Walcott, Proc. U. S. National Mus., XI, 1888, p. 441.

Loc. Monnt Stephen, British Columbia. 
Acrotreta gemmula Matthew.

Mildle Cambrian.

Acrotreta gemunla Matthew, Trans. Royal Soc. Canada, X, 1894, p. 87, pl. 16, fig. 2 ;-Trans. N. Y. Acad. Sci., XIV, 1895, p. 126, pl. 5, fig. 万.

Loc. St. Martins, New Brunswick.

Acrotreta gulielmi Matthew $=$ Discinopsis gulielmi.

Acrotreta microscopica (Shmmard).

Middle Cambrian.

Discina microscopir:a Shumard, Anterican Jonr. Sei., XXxI, 24l ser., 1861, p. 221.

1oc. Oceurs : lhudantly in Burnett and Llano counties, Texas.

Aerotreta pyxilienla White=Aerotreta gemma.

Acrotreta subconiea Meek (non Kntorga)= Aerotreta gemma.

Acrotreta (?) subsidua White=Acrothele subsilna.

Figilops Hall. A genus of pelecypods.

AMBOCELIA Hall.

Cienotype Orthis umbonata Conrad.

Ambocelia Hall, Thirteenth Rep. N. Y. State Cab. Nat. Hist., 1860, p. 71, figs. 1-3; p. 72, figs. 4-6.-Meek and Hayden, Pal. Upper Missouri, Smithsonian Cont. to Knowl., 172, 1864, p. 20.-Hall, Pal. New York, IV, 1867, p. 258Davidson, Suppí. British Sil. Brach., Palieontographical Soc., 1882, p. 131.Nettelroth, Kentucky Fossil Shells, Mem. Kentueky Geol. Survey, 1889, p. 85. - Hall and Clarke, Pal. New York, VIII, Pt. II, 1893, p. 54;-Thirteenth Ann. Rep. N. Y. State Geologist, 1895, p. 761.

Ambocœlia fimbriata Claypole.

Portage (Dev.).

Ambocœlia fimbriata Claypole, Proc. American Phil. Soc, NXI, 1883, p. 232.

Loc. Perry County, Pennsylvania.

Ambocetia gemmula MaChesney=Ambocelia planoennvexa.

Ambocelia gregaria Hall.

Chemung (1)ev.).

Orthis unguiculus IIall (non Phillips), Geol. New York; Rep. Fourth Dist., 1843, p. 267 , fig. 5 .

Amboecelia gregaria IIall, Thirteenth Rep. N. Y. State Cab. Nat. Hist., 1860, p. 81 ;-Fifteenth Re'p. Ihidem, 1862, p. 186.-Williams, Bull. U. S. Geol. Survey, 3, 1884, p. 11.

Amboccelia umbonata var. gregaria Hall, Pal. New York, IV, 1867, p. 261, pl.44, figs. 19-25.

Loc. New York; Pennsylvania, and Yirginia.

Obs. See Martinia subumbona.

Ambocœlia minuta White.

Kinderlook (L. Carb.).

Ambocœlia (Spirifer?) minuta White, Proc. Boston Soc. Nat. Hist., IX, I86?, p. 26.

Loc. Hamuurg, Illinois, and Hanuibal, Missouri.

Ambocolia planoconvexa (Shumard).

Upper Carboniferons.

Spirifer planoconvexa Shnmard, Geol. Rep. Missonri, 1855, p. 202.-Geinitz, Carbon u. Dyas in Nebraska, 1866, p. 42, pl. 3, figs. 10-18.

Ambocœlia gemmnla McChesney, New Pal. Fossils, 1860, p. 41;-Ibidem, 1865, pl. 1, fig. 3 .

Spirifer (Martiuia) planoconvexa Meek and Hayden, Pal. Upper Missouri, Smitlsonian Cont. to Knowl., 172, l’t. I, 1864, p. 20, figs. a-e.-Meek, Final Rep. U. S. Geol. Survey Nebraska, 1872, p. 184, pl. 4, fig. 4; pl. 8, fig. 2.

Martinial planoconvexa MeChesney, Trans. Chicago Acad. Sci., I, 1868, p. 34, pl. 1, fig. 3. 
Ambocolia planoconvexa (Shumard)-Contiuued.

Spirifera (Martinia) planoconvexa Derby, Bull. Cornell Univ., I, 1874, p. 19, pl. 8 , figs. 12, 16, 18; pl. 9, fig. 7.-White, Wheeler's Geogr. Geol. Expl. ant Survey west 100 Merid., IV, 1875, p. 135, pl. 10, fig. 3;-Thirteenth Rep. Indiana state Geol., 1884, p. 134, pl. 32, figs. 23, 24.-Herrick, Buli. Denison Univ., II, 1887, p. 46, pl. 1, fig. 12.-Keyes, Geol. Survey Missouri, V, 1895, p. 85.

Ambocolia planoconvexa Hall and Clarke, Pal. New York, VIII, Pt. II, 1893, p. 56 , pl. 39, figs. 10-15.

Loc. Missouri; Iowa; Illinois; Ohio; Indiana; Kansas; Nebraska; New Mexico; Elko Mountain, Nevada; Bomjardim and Itaituba, Brazil.

Ambocœlia præumbona Hall.

Hamilton (Dev.).

Orthis prieumhona Hall, Tenth Rep. N. Y. State Cab. Nat. Hist., 1857, p. 167.

Ambocœlia præunbona Hall, Thirteenth Rep. Ibidem, 1860, p. 71 ;-Pal. New York, IV, 1867, p. 262, pl. 44, figs. 1-6.

Loc. Seneca, Cayuga, and Canandaigua lakes, New York.

Amboccelia spinosa Hall and Clarke.

Hamilton (Dev.).

Ambocelia spinosa Hall and Clarko, Pal. New York, VIII, Pt. II, 1895, pp. 56, 363, pl. 39, figs. 16-18.--Clarke, Thirteenth Ann. Rep. N. Y. State Geologist, 1895, p. 177, pl. 4 , figs. $6-8$.

Loc. Livingston County, New York.

Ambocoelia subumbona Hall= Martinia subumbona.

Ambocœlia umbonata (Conrad).

Marcellus-Chemung (Der.).

Orthis umbonata Conrad, Jour. Acad. Nat. Sei. Philadelphia, VIII, 1842, p. 264, pl. 14, fig. 4.-Hall, 'Tenth Rep. N. Y. State Cab. Nat. Hist., 1857, 1. 167, tigs. 1-3.

Orthis nucleus Hall, Geol. New York; Rep. Fourth Dist., 1843, p. 180, fig. 8.

Ambocuelia umbonata Hall, Thirteenth Rep. N. Y. State Cab. Nat. Hist., 1860, 1. 71 ;-Pal. New York, IV 1867 , p. 259, pl. 44, figs. 7-18.-Nettelroth, Kentucky Fossil Shells, Mem. Kentucky Geol. Survey, 1889, p. 86, pl. 17, figs. 25, 26.-Hall and Clarke, Pal. New York, VIII, Pt. II, 1893, pl. 29, tig. 17; pl. 39, figs. 4-9.

Martinia umbonata Herrick, Geol. Ohio, VII, 1895, pl. 20, fig. 3.

Loc. New York; Pennsylrania; Falls of Ohio.

Ambocœlia umbonata gregaria Hall=Ambocœlia gregaria.

AMPHIGENIA Hall. Genotype Pentamerus elougatus Tanuxem.

Amphigenia Hall, Twentieth Rep. N. Y. State Cab. Nat. Hist., 1867, 1. 163 ; Pal. New York, IV, 1867, pp. 374, 382.-Hall and Clarke, Pal. New York, VIII, Pt. II, 1893, p. 252 ;-Thirteenth Ann. Rep. N. Y. State Geologist, 1895, p. 848 .

Amphigenia curta (Meek and Worthen).

Oriskany (Dev.).

Stricklandinia elongata var. curta Meek and Worthen, Geol. Survey Illinois, III, 1868, p.402, pl.8, fig. 1; pl. 9, fig. 5.- \& Hall and Clarke, Pal. New York, VIII, Pt. II, 1893, p. 254.

Loc. Union County, Illinois.

Amphigenia elongata (Vanuxem). Oriskany and Up. Helderberg (Dev.).

Pentamerus elongatus Vanuxem, Geol. N. Y.; Rep. Third 1)ist., 1812, p. 132, fig. 1.-Hall, Geol. N. Y.; Rep. Eourth Dist., 1813, Tablos of Organic Remains.

Megauteris elongatus Hall, Tenth Rep. N. Y. State Cab. Nat. Hist., 1857, p. 123, figs. $1,2$.

Rensselaria elongata Hall, Twelfth Rep. Ibidem, 1859, p. 38;-Pal. New York, III, 1859, p. 4 53.

Stricklandia elongata Billings, Canadian Jour., VI, 1861, p. 267, figs. 91, 92. 


\section{Amphigenia elongata (V:umxem)-Contimued.}

Stricklamdinia elongata !illings, Geol. Canada, 1863, 1.371, fig. 3910.

Auphigenia elongata Hall, Pal. New York, IV, 1867, 1. 383, 11. 58A, figs. 21-24; lI. 5!, tigs, 1-11.-CBillings, Camadian Nat. Geol., n. ser., VII., 1874, 1. 210.Rathbm, l'roc. Boston Soc. Nat. Ilist., $\mathrm{xx}, 1879,1$. 34.-IIall and clarke, P’al. New York, VIII, Pt. II, 1893, p. 253, pl. 73, figs. 16-20; pl. 7t, figs. 1-9; pl. 76 , tig. 9.

Loc. New York; Michigan; Caynga, Ontario; Rio Maecuru and Rio Curua, Brazil. Amphigenia elongata subtrigonalis Hall.

Up. Helderberg (Dev.).

Megranteris subtrigonalis Hall, Tenth liep. N. Y. State Cab. Nat. Hist., 18ir7, 1'. 123.

Amphigenia elongata rar. subtrigonalis Hall, Pal, Now York, IV, 1867, 1. 384.

Loc. Erie County, New York.

Amphigenia elongata undulata Hall.

Ul). Inelderberg (Dev.). Amphigonia elongata var. Indulata Hall, Pal. Now York, IV, 1867, 1. 381, pl. 5 A A, figs. 25-27.

Loc. Mackinac, Miehigan.

AMPHISTROPHIA Hall and Clarke. (ienotype Strophonelia striata Hall.

Amphistrophia Hall and Clarke, Pal. New York, VIII, I't. I, 1894, p. 292; Eleventh Ann. Rep. N. Y. State Geologist, 1894, 1. 283.

(Obs. Proposed as a subgenns of Strophonella.

ANABAIA Clarke.

Genotype A. paraia Clarke. Anabaia Clarke, Pal. New York, VIII, Pt. II, 1893, 1. 14l.-Hall ani Clarke,

Thirteenth Ann. Rep. N. Y. State Ceologist, 1895, p. 805.

Anabaia paraia Clarke.

Silurian.

Anabaia paraia Clarke, Pal. Now York, VIII, P’t. 11, 1893, p. 111, figs. 124-127. Loc. Rio Trombetas, Province of Para, Brazil.

ANASTROPHIA IIall.

Genotype Pentamens vermenili Hall.

Brachymerus Shaler (nou Dej., 18.34), Bull. Mus. Comp. Zool., 4, 1865, p. 69.

Anastrophia Hall, Twentieth Rep. N. Y. State Cab. Nat. Hist., 1867, p. 163;-Pal.

New York, IV, 1867, p. 374.-Nettelroth, Kentneky Fossil Shells, Mem. Kentncky Geol. Survey, 1889, p. 47.-Hall anl Clarke, Pal. New York, VIII, J't. II, 1893, p. 224 ; -Thirteenth Anu. liep. N. Y. State Geologist, 1895. p. 839.

Anastrophia brevirostris (Sowerby?) Hall. Niagara (Sil.).

Tereloratula brevirostris Sowerby, Murchison's Sil. System, 1839, 1. 631, pl. 13, tig. Jis.

Atrypa hrevirostris? Ifall, Pal. New York, II, 1852, p. 278, pl. 58, tig. 1.

Pentamerns lirevirostris IIall, Twelfth Rep. N. Y. State Cab. Nat. Hist., 1859, 11. 77. Rhynehonella brevirostris Billings, Geol. Canala, 1863, p. 315, fig. 324.

Loc. Lockport, New York.

Obs. Comprare with Anastrophia interplieata. If a pentameroirl, this species is probably identieal with Anastrophia interplicata IIall.

Anastrophia hemiplieata W. and S.= Parastrophia hemiplicata.

Anastrophia internascens Hall.

Niagara (Sil.).

Anastrophia verneuili Hall (non Hall, 1859), 'Twenty-eighth Rep. N. Y. State

MIns. Nat. II ist., Doc. erl., 1876, pl. 26, figs. 41-49.

Anastrophia internascens Hall, Ibidem, 1879, p. 168, pl. 26, figs. 41-49;-Eleventh Rep. State Geol. Indiana, 1882, p. 311, pl. 26, figs.41-49.-Nettelroth, Kentueky Fossil Shells, Mem. Kentncky Geol. Survey, 1889, p. 47, pl. 32, figs. 17-20.Beecher and Clarke, Nem. N. Y. State Mus., 1, 1889, p. 32, pl. 3, figs. 14-16.Hall and Clarke, Pal. New York, VIII, Pt. II, 1893, p. 221, pl. 63, tig. 30.

Loc. Walıron, Incliana; Lonisville, Kentucky; Milwankee, Wisconsin. 
Anastrophia interplicata ( $\mathrm{H}$ all). Niagara (Sil.).

Atrypa interplicata Hall, Pal. New York, 1I, 1852, p. 275, pl. 57, fig. 2.

Pentamerus interplicatus Hall, 'l'welfth Rep. N. Y. State Cab. Nat. Hist., 1859, p. 77.

Anastrophia interplieata Niller, Ameriean Pal. Fossils, 1877, p. 104.-Hall and Clarke, l'al. New York, VIII, l't. Il, 1893, p. 224.

Loc. Lock port, New York; Lonisville, Kentucky; Wisconsin.

obs. See A. lorevirostris.

Anastrophia reversa Miller $=$ Parastrophia reversa. Anastrophia scofieldi W. and S.=Parastrophia scofieldi. Auastrophia verneuili Hall, 1876 (non 1859)=Anastrophia internascens. Anastrophia verneuili (Hall). Lower Helderberg (Dev.).

Atrypa litemnosa Vannxem (non Sowerby), Geol. N. Y.; Rep. Third Dist., 1842, p. 117, fig. 3, aud p. 119.

Pontamerus vernouili Hall, Tenth Rep. N. Y. State Cab. Nat. Hist., 1857, p. 104, figrs. 1, 2 ;-Pal. New York, III, 1859, p. 260, pl. 48, fig. 1.-Billiugs, Grool. Canadil, 1863 , p. 957 , fig. 453.

Anastrophia vernenili Nliller, N. American Geol. Pal., 1889, 1. 334.-Hall and Clarke, Pal. New York, VIII, Pt. II, 1893, p. 224, pl. 63, tigs. 31-38; pl. 84, figs. 43,44 .

Loc. Wastern New York; Perry County, Tennessee; Petermann Fiow, Greenland. Anazyga recurvirostra Davidson =Zygospira recurvirostris.

ANOPLIA Hall and Clarke.

Genotype Leptiena nucleata Hall.

Anoplia IJall and Clarke, l'al. New York, VIII, Pt. I, 1892, p. 309 ;-Eleventh Aun. Rep. N. Y. State Geologist, 1894, p. 293.

Anoplia nucleata Hall.

Oriskany and Corniferons (Dev.).

Leptiena nucleata Hall, Tenth Rep. N. Y. State Cal). Nat. Hist., 1857, 1. 47.

Leptena? nucleata Hall, Pal. Now York, HI, 1859, p. 419, pl. 94, fig. 1.-Nleek and Worthen, Geol. Survey Illinois, III, 1868, p. 393, pl. 8, tig. 8 .

Anoplia uueleata Hall and Clarke, Pal. New York, VIlI, I't. I, 1892, p. 309, pl. $15 \mathrm{~A}$, fiugs. 17,$18 ;$ pl. 20, figs. 14-17.

Lor. Albany County, New York; Alexanler County, Illinois; Caynga, Outario.

Obs. It is probsule that Prorluetella nneleata Nieholson is a synonym of this species.

ANOPLOTHECA Sandberger (emend Hall and Clarke). Genotype Productus lamellosus Sandberger =Terebratula venusta Sehuur.

Anoplotheen F. Sandberger, Sitzb. d. k. k. Akad. d. Wissens., math -naturw. Classe, XVI, 1853, p.5; XVIII, p. 102.-Hall and Clarke, Pal, New York, VIll, I’t. II, 1893, p. 129, figs. 113-121.

Leptocklia Hall, Tenth Rep. N. Y. State Cab. Nat. Hist., 1857, p. 108;-T'welfth Rep., Ihislem,.1859, p. 32, figs. 1, 2, 4 ;-Pal. New York, III, 1859, p. 417.Billings, Canadian Jour., VI, 1861, p. 351.-Hall, Ameriean Jour. Sci., XXXVI, 1863, 1. 14.-Rominger, American Jour. Sci., XXXV, 1863, 1, 84.Ilall, Pal. New York, IV, 1867, p. 365.-Dall, Ameriean Jour. Coneh., VII, 1871, 1. 60. -Nettelroth, lieutucky Fossil Shells, Mem. Kentucky Geol. Survey, 1889, p. 151.-Hall and Clarke, Pal. New York, VIII, I’t. II, 1893, p. 136.

Colospira Hall, Sixteentlı Rep. N. Y. State Cab. Nat. Hist., 1863, p. 59 ;-Trans. Albany Institute, IV, 1863, p. 146;-Pal. New York, IY, 1867, p. 328.-l Hall and Clarke, Pal. New York, VIII, Pt. II, 1893, p. 134, figs. 122, 123.

Bifida Davidson, Supplement to British Dev. Blaeh., Palarontograplical Soe., 1882, p. 27 .

Anoplotheea, Culospira, and leptocelia Hall aud Clarke, Thirteenth Anu. Rep. N. Y. State Geologist, 1895, Pl. 801-803. 


\section{ANOPLOTHECA Sandberger (emend Hall)-Continmed.}

Ob., IIall and Clarko have shown that Anoplotheca and Bifila are synonymous terms and that Corlospiral is also strneturally iclentical. The latter nanc, however, they retain as a subgenus of Anoplotheca. While the braehydim is not jet fully known in Leptocolia, all its other characters are che same as those of Colospira. Under theso circumstances it appears liest, for the present at least, to refer all American species of Leptocelia and Culospira to Anoplotheea.

Anoplotheca acutiplicata (Conrad).

Corniferons (Der.).

Atrypa acntiplicata Courad, Fifth Ann. Rep. N. Y. Geol. Survey, 1841, 1. 54.Hall, Fifteentl Rep. N. Y. State Cab. Nat. Hist., 1862, pl. II, fig. 17.

Leptoecrlia acutiplicata Hall, l'al. New York, IV, 1867, 1. 365, pl. 67, figs. 30-39. Corlospira asutiplicata Hall and Clarke, Ilsiclem, VIII, Pt. II, 1893, p. 136, 11.53, figs. 32-39.

Loc. Waterville, Cassville, Last Victor, ote., Now York.

Anoplotheca camilla (Hall). Oriskany aud U1. Hellerberg (Dev.). Colospira concava Hall (non Hall 1863), Pal. New York, IV, 1867, 1. 329.

Colospira eamilla IIall, Ihilem, 1867, pl. 52, figs. 13-19;--Twentieth Rep. N. Y. State Cal. Nat. Hist., 1867, p. 168.-Hall and Clarke, Pal. New York, VIll, Pt. II, 1893, p. 136, pl. 53, figs. 24-31.

Loc. Caledonia, New York; county of Haldimand, Ontario.

Anoplotheca concava (Hall).

Lower Helderberg (Dev.).

Leptocolia concava Hall, 'Tenth Rep. N. Y. State Cab. Nat. Hist., 1857, p. 107;Pal. New York, III, 1859, p. 245, pl. 38, figs. I-7.-Billings. Canadian Jour., VI, 1861, p. 352, fig. 127; -Geology Canarla, 1863, p. 369, fig. 383; p. 957, fig. 451.

Celospira concava Hall, Sixteenth Rep. N. Y. State Cah. Nat. Hist., 1863, p. 60 ;Trans. Albany Institute, IV, 1863, p. 146.-Meek, Americau Jour. Sci., 2d ser., XL, I865, n. 33.-Hall and Clarke, Pal. New York, VIII, Pt. II, 1893, 1. 134, figs. 12:, 123; pl. 53, figs. 20-23.

Loc. Albany and Schoharie counties, New York; Kennedy Channel, Aretic region.

Anoplotheca dichotoma (Hall).

Oriskany (Dev.).

Leptocalia dichotoma Hall, Pal. New York, III, 1859, p. 452, pl. 103B, figs. 3.-

Hall and Clarke, Ibiden, VIII, Pt. II, 1893, p.137.

Loc. Cumberland, Maryland.

Obs. Possibly the young of Anoplotheca flabellites.

Anoplotheca fimbriata (Hall).

Oriskany (Dev.).

Leptocolia fimbriata Hall, Twelfth Rep. N. Y. State Cab. Nat. Hist., 1859, 1. 33 , fig. 3;-Pal. New York, III, 1859, p. 450, pl. 103B, fig. 2.-Hall and Clarke, Ibidem, VIII, Pt. II, I893, p. 137, pl. 53, figs.47-52, 51, 55.

Loc. Cumberlaud, Maryland.

Anoplotheca flabellites (Conrad). Oriskany and Corniferous (Dev.). Atrypa flabellites Conrad, Fifth Ann. Rep. N. Y. Geol. Survey, 1841, p. 55.

Atrypa palmata Morris and Sharpe, Quart. Jour. Geol. Soc. London, II, 1816, p. 276 , pl. 10 , fig. 5 .

Orthis palmata Sharpe and Salter, Trans. Geol. Soc. London, $2 d$ ser., VII, 1856, p. 207 , 1. 26 , figs. $7-10$.

Leptocolia propria Hall, Tenth Rep. N. Y. State Cab. Nat. Hist., 1857, 1. 108. Leptocollia flabellites Hall, Twelfth Rep. Ibidem, 1859, p. 33, figs. 1, 2, 4 ;-Pal. New York, IIl, 1859, 1. 449, pl. 103B, fig. 1; pl. 106, fig. 1.-Hillings, Canadian Jour., VI, 1861, p. 33i, fig. 126;-Geology Canarla, 1863, p. 369, fig. 382.-Neek and Worthen, Geol. Survey Illinois, III, I868, p. 397, pl. 8, fig. 3.-Billings, Pal. Fossils, II, 1874, p. 42, pl.3, figs. 5, 6.-Steinmann, American Naturalist, XXV, 1891, p. 856.-A. Ulrich, N. Jahrb. f. Mineral., Beilageband, 


\section{Anoplotheca flabellites (Conrad)-Continued.}

VIII, 1892, p. 60, pl. 4, figs. 9, 10-13.-Hall and Clarke, Pal. Now York, VIII, Pt. II, 1893, p. 137, pl. 53, figs. 40-46, 53.-Von Ammon, Zeits. Gesells. fiir Erdk., Berlin, XXVIII, 1893, p. 363, fig. 7.

Orthis aymara Salter, Quart. Jour. Geol. Soc. London, XVII, 1861, 1. 68, pl. 4, fig. 14 .

Orthis palmata Sharpe and Salter, Trans. Geol. Soc. London, $2 d$ ser., VII, 1856, 1. 207 , pl. 26, figs. 7-10.

Loc. Schoharie, etc., New York; connty of Haldimand, Ontario ; Gaspé; Cumberland, Maryland; Union County, Illinois; Bolivia; Tanquarassu, Matto Grosso, Brazil; Falkland Islands; Sonth Africa.

Anoplotheca hemispherica (Sowerby).

Clinton (Sil.).

Atrypa hemispherica Sowerby, Murchison's Silurian System, 1839, p. 639, pl.20,

fig. 7.-Hall, Pal. New York, II, 1852, p. 74, pl. 23, fig. 10.-Billings, Geology Cauada, 1863, p. 318, fig. 337.

Atrypa fıemispherica? Hall, Geology, N. Y.; Rep. Fourth Dist., 1843, p. 73, fig. 4. Leptocœlia hemispherica Hall, Twelfth Rep. N. Y. State Cab. Nat. Hist., 1859, p. 77.-Nettelroth, Kentucky Fossil Shells, Mem. Kentucky Geol. Survey, 1889, p. 152, pl. 32, figs. 21-23, 36-39.-Foerste, Pror. Boston Soc. Nat. Hist., XXIV, 1890, p. 325 , pl. 6, figs. $18,19$.

Atrypa Habella Shaler, Bull. Mus. Comp. Zool., 4, 1865, p. 68.

Coelospira? hemisptuerica Hall and Ciarke, Pal. New York, VIII, Pt. II, 1893, p. 136, pl. 82, figs. $1-4$ (? pl. 52, fig. 16).

Loc. England; Rochester, Sodns, and Walcott, New York; Louisville, Kentucky; Cnmberlaud Gap, Tennessee; Ringgold, Georgia; Collinsrille, Alabama; Arisaig, Nova Scotia (Ami); Anticosti.

Anoplotheca infrequens (Walcott).

Lower and Upper Devonian.

Trematospira infrequens Walcott, Mon. U. S. Geol. Survey, VIlI, 1884, p. 151, pl. 4 , fig. 3 .

Loc. Lone Nountain, Nevada.

$\mathrm{Obs}$. The exterior is like that of A. flabellites.

Anoplotheca planoconvexa (Hall).

Clinton (Sil.).

Atrypa planoconvexa Hall, Pal. Now York, II, 1852, p. 75, 11. 23, fig. 11.-Bil-

lings, Geology Canada, 1863, p. 318, fig. 336.

Leptocxlia planoconvexa Hall, Twelfth Rep. N. Y. State Cab. Nat. Hist., 1859,

p. 78.-Nicholson and Hincle, Canadian Jonr., n. ser., XIV, 1874, p. 144.

Colospira ?planoconvexa Hall and Clarke, Pal. New York, VIII, Pt. II, 1893, p. 136 , pl. 52, fig. 15 ; pl. 53, figs. 11-16.

Loc. Flamborough Head, Ontario; Niagara of Wisconsin (Whitfield).

Anoplotheca plicatula (Hall).

Clinton (Sil.).

Atrypa plicatula Hall, Geol. N. Y.; Rep. Fonrth Dist., 1843, p. 71, fig. 4 ;-Pal.

New York, II, 1852, p. 74, pl. 23, fig. 9 .

Leptocolia? plicatnla Hall, Twelftl Rep. N. Y. State Cab. Nat. Hist., 1859, p. 78 .

Rhynchonella plicata Miller, N. American Geol. Pal., 1889, p. 369.

Colospira? plicatula Hall and Clarke, Pal. New York, VIII, Pt. II, 1893, p. 136, pl. 52 , figs. $12-14$; pl. 82 , fig. 5 .

Loc. Reynales Basin, Now York; Niagara of Wisconsin (Whitfield).

ATHYRIS McCoy (emeud Hall and Clarke).

Genotype Terebratula concentrica von Buch.

Athyris MeCoy, Carb. Fossils Ireland, 1844, pp. 128, 146.-Hall, 'Thirteenth Rep.

N. Y. State Cab. Nat. Hist., 1860, p. 73.-Billings, Caudian Jour., V, 1860,

Bull. $87-10$ 
ATHYRIS M(Coy (emend Hall and Clarke)-Continned.

p. 273;-lbislem, Y1, 1861, p. 138;-Pal. Fossils, 1, 1862, p. 144.-lanll, Twentieth Rep. N. Y. State Cal. Nat. II ist., 1867, pl. 152, 258;-Pal. Now York, IV, 1867, p. 282.-Billings, American Jonr. Sci., XLIV, 1867, p.48.-Herrick, 3ull. Denison Univ., IV, 1888, p. 14.-Nettelroth, Kentucky Fossil Shelle, Ment. Kentucky Gcol. Snrvey, 1889, p. 87.--Ilall and Clarke, Pal. New York, VIIl, Pt. II, 1893, p. 83, fig. 57 on J. 86 ;-Thirtcentl Ann. Rep. N. Y. State (ieologist, 1845, 1. 777 .

Spirigera d'Orbigny, Paris Acal. Sci., Comptes Rendıs, XXV, 1817, p. 268.

Euthyris Quenstedt, Petrefactenkunde Dentschlands, 1871, 1. 442.

Atlyyis americana Swallow=Clejotlyyis roissyi.

Athyris angelica Hall.

Chemulng (Dev.).

Atlyris angeliea Hall, Fourteenth Rep. N. Y. State Cab. Nat. Hist., 1861, 1. 99 ;Fifteenth Rep. Ibidem, 1862, pl. 3, figs.10-13, 24;-Pal. New York, IV, 1867, p. 292, pl. 47, figs. 9-20.-Walcott, Mon. I. S. Geol. Survey, VIII, 1881, p. 14s.-Wall and Clarke, Pal. New York, VIII, Pt. II, 1893, p. 90, pl. 45, figs. $26-30$.

Loc. Phillipslurg, Rockville, etc., New York; Moudville, Pennsylvania; Eureka listriet, Nevada.

Athyris angelica occidentalis Whiteaves.

Hamilton (Dev.).

Atlyris angelica occidentalis Whiteaves, Cont. Canalian Pal., I, 1891, 1. 227, pl. 33 , lig. 3.

Loc. Athabasca River, Canada.

Athyris ashlandensis Herrick=A. lamellosa.

Athyris biloba (A. Wincliell).

Kinderlıook (L. Carb.).

Spirigera bilola A. Winclell, Proc. Acad. Nat. Sci. Philadelphia, 1865, p. 118.

Loc. Rockforl, Indiana.

Obs. This species is not well established and is based npon a single ventra] valve.

Athyris blancha Billings= Meristella blancha.

A thyris borealis Billings=Catazyga erratica.

Athyris brittsi Miller.

Middle Devonian.

Athyris lorittsi Miller, Eighteenth Ann. Rep. Gool. Surrey Indiana, 1894, p. 314, pl. 9, figs. 16-18.

Loc. Near Otterville, Missonri.

Obs. Probably the same as A. spiriferoides.

A thyris caputserpentis Swallow = Semimula eaputserpentis.

Athyris charitonensis Swallow = Seminnla charitonensis.

A thyris chloe Billings= Parazyga hirsuta.

A thyris clara Billings= Meristella nasuta.

A thyris elaytoni Swallow = Semimula claytoni.

A thyris clintonensis Swallow=Cleiothyris clintonensis.

A thyris elusia Billings= Meristella elusia.

Athyris concentrica Billings (non von Bnch)=A. spiriferoides.

Athyris congesta Con rad = Hyatella congesta.

Athyris cora Hall.

Hanilton and Chemung ? (Der.).

Athyris cora Hall, Thirtcenth Rep. N. Y. State Cab. Nat. Hist., 1860, p. 94; Fifteenth Rep. Ibidem, 1862, pl. 3, figs. 15, 16 ;-Pal. New York, IV, 1867, p. 291, pl. 47, figs. 1-7.-Hall and Clarke, Ibiden, VIII, Pt. II, 1893, p. 90, pl. 45, figs. 6-10.

Loc. Delphi, New York. 
Athyris (?) corpulenta (A. Winchell).

Kinderhook (L. Carb.).

Spirigera corpulenta A. Winchell, Proc. Acad. Nat. Sei. Philadelphia, 1863, p. 6.

Loc. Burlington, Iowa.

Athyris crassicardinalis White=Cleiothyris crassicardinalis.

Athyris crassirostra Billings $=$ Whitfieldella eylindrica.

Athyris cylindrica Billings = Whitfieldella cylindrica.

Athyris densa Hall and Clarke. St. Louis (L. Carb.).

Athyris densa Hall and Clarke, Pal. New York, VIII, Pt. II, 1895, 1. 361, 1l. 46, figs. $6-12$.

Loc. Washington County, Indiana; Colesburg, Kentucky.

Obs. Compare with Centronella (?) crassicardinalis.

Athyris differentis McChesney=Seminula argentea.

Atlıris eborea A. Winchell=A. vittata.

Athyris euzona Swallow = Semiuula formosa.

Athyris(?) formosa Swallow= Seminula formosa.

Athyris fultonensis (Swallow).

Corniferous and Hamilton (Dev.).

Spirigera fultonensis Swallow, Trans. St. Louis Acad. Sei., I, July or August, 1860, p. 650 .

Spirigera minima Swallow, Ibidem, 1860, p. 649.

Athyris vittata Hall, Thirteenth Rep. N. Y. State Cab. Nat. Hist., 1860, 1. 89;Pal. New York, IV, 1867, 1. 289, pl. 46, figs. 1-4.-White, Second Aun. Rep. Indiana Burean of Statistics and Geol., 1880, p. 502, pl. 4, figs. 8, 9;-Tenth Rej.. State Geol. Indiana, 1881, p. 134, pl. 4, figs. 8, 9.-Nettelroth, Kentucky Fossil Shells, Mem. Kentucky Geol. Survoy, 1889, p. 87, pl. 16, figs. 25-32.Whiteaves, Cont. Canadian Pal., I, 1892, p. 228.-IIall and Clarke, Pal. New York, VIII, Pt. II, 1893, p. 90, figs. 62, 63; pl. 45, figs. 1-5.-Keyes, Geol. Survey Missouri, V, 1895, 1. 90, pl. 41, fig. 1.

Spirigera eborea A. Winchell, Rep. Lower Peninsula Michigan, 1866, p. 94.

Loc. Callaway County, Missouri; Iowa City and New Buftalo, Iowa; Falls of Ohio; Alpena, Michigan; Lake Winnipegosis, Manitoba.

Obs. Specimens of S. fultononsis Sivallow and S. eborea Winchell in the writer's collection provo to be the same as $A$. vittata Hall.

Athyris hannibalensis (Swallow).

Choutean (L. Carb.).

Spirigera hannibalensis swallow, Trans. St. Lonis Acad. Sci., I, 1860, P. 649.

Athyris hannibalensis Ilall and Clarke, Pal. New York, VIII, P't. II, 1893, 1. 90, pl. 46, figs. 13-15.-Keyes, Geol. Survey Missouri, V, 1895, p. 90, pl. 40, fig. 9.

Loc. Clarksville, Irannibal, otc., Missouri; Sciotoville, Ohio.

Obs. Meek was inclined to regart this species the same as A. lamellosa. It is, however, distinct. See A. missouriensis.

Athyris harpalyce Billings = Whitfieldella harpalyce.

Athyris luawni Swallow=Seminula bawni.

Atlyyris headi Billings=Catazyga headi.

Athyris headi anticostiensis Billings=Catazyga erratica.

Athyris headi borealis Billings=Catazyga erratica.

Athyris hirsuta Hall=Cleiothyris hirsuta.

Athyris incrassata Hall.

Burlington (L. Carb.).

Athyris incrassata Hall, Geol. Survey Iowa, I, Pt. II, 1858, 1'. 600, p]. 12, fig.

6.-Hall and Clarke, Pal. Now York, VIII, Pt. II, 1893, p. 90, pl. 46, fig. 21;

pl. 83 , fig. 39.

Athyris incrassatus Kejes, Geol. Survey Missouri, V, 1895, p. 91, pı. 41, fig. 10.

Loc. Burlington, Iowa; Quiney, Illinois; Hannibal, Missouri. 


\section{Atlyyis intermedia Nicholson=Whitfieldella intermedia.}

Athyris intervarica MeCheshey.

Burlington (1. Carb.).

Athyris intervarica McChesney, Deseriptions New Pal. Foss., 1861, 1'. 78.

Loc. Burlingtou, Iowa.

Obs. May bo the same as A. lamellosa L'Evoillé.

Athyris (?) jacksoni (Swallow).

Upper Coal Heasures.

Spirigera jacksoni Swallow, Trans. St. Louis Acad. Sci., I, 1860, p. 651.

Loc. Cass County, Missouri.

Athyris julia Billings= Whitfieldella julia.

Athyris junia Billungs=Hyattella junia.

Athyris lamellosa (L'Eveillé).

Waverly-Keokuk (L. Carb.).

Spirifer lamellosus L’Éveillé, Mém. soc. Géol. de France, II, 1835, p. 39, figs. $21-23$.

Athyris lamellosa Meek, Pal. Ohio, II, 1875, 1. 283, pl. 14, tig. 6.-Herrick, Bull Denison Univ., III, 1888, p. 49, pl. 2, fig. 7.-Hall and Clarke, Pal. New York, VIII, Pt. II, 1893, p. 90 , pl. 46, figs. 16-20.

Athyris ashlandensis Herrick, Bull. Denison Univ., IV, 1888, p. 24, pl. 3, tig. 6;Geol. Ohio, VII, 1895, pl. 23, fig. 10.

Loc. Enrope; Sciotoville, and Licking County, Ohio ; Lebauon, Kentucky; Crawfordsville, Indiana; New Mexico.

Obs. See A. intervarica MeChesney.

Athyris lara Billings=Atrypa lara.

Athyris maconensis Swallow= Seminula maconensis.

Athyris maia Billings=Martinia maia.

Athyris minima Swallow $=$ A. fultonensis.

Athyris minutissima Webster.

Chemnng (Dev.).

Athyris minutissima Webster, American Nat., XXII, 1888, p. 1015.

Loc. Near Rockford, Iowa.

Athyris missourieusis Swallow=Cleiothyris missouriensis.

Athyris missouriensis (A. Winchell).

Chouteau (L. Carb.).

Spirigera missouriensis A. Winchell, Proc. Acatl. Nat. Sci. Philadelphia, 1865, p. 117.

Loc. Loujsiana, Missouri; Medina County, Ohio.

Obs. Should be compared with A. hannibalensis.

Athyris monticola (White).

Lower Carboniferous.

Spirigera monticola White, Wheeler's Geogr. Geol. Expl. and Survey west 100 Meriıl., Prel. Rep., 1874, p. 16;-Final Rep. Ibidem, IV, 1875, p. 91, pl. 5, fig. 11.

Loc. Mountain Spring, Nevada.

A thyris naviformis Billings= Whitfieldella naviformis.

Athyris nitida Billing's= Whitfieldella nitida.

Athyris obmaxima MeChesney=Cleiothyris obmaxima.

Athyris obvia McChesney=Cleiothyris obvia.

Athyris ohioensis (A. Winchell).

Waverly (L. Carb.).

Spirigera ohioensis A. Winchell, Proc. Acad. Nat. Sci. Philadelphia, 1865, p. 118.

Athyris ohioensis Herrick, Bull. Denison Univ., III, 1888, p. 49, pl. 2, fig. 1.

Loc. Akron and Sciotoville, Ohio.

Athyris orbicularis McChesuey $=$ Cleiothyris orbicularis. 
Athyris (?) ottervillensis Miller.

Middle Devonian.

Athyris ottervillensis Miller, Eighteenth Aun. Rep. Geol. Survey Indiaua, 1894, p. 314 , pl. 9, figs. $14,15$.

Loc. Near Otterville, Missouri.

Athyris papilioniformis MeChesuey.

Káaskaskia (L. Carb.).

Athyris spiriferoides McChesney (non Eaton, 1831), Descriptions New Pal. Foss., 1860, p. 46.

Athyris? papilioniformis McChesney, Ibidem. 1865, pl. 6, fig. 4 ;-Trans. Chicago Acarl. Sci., I, 1868, p. 33, pl. 6, fig. 4 .

Loc. Fountain Bluff, Illinois.

Athyris parvirostris Meek and Worthen=Cleiothyris roissyi.

Athyris parvula Whiteaves.

Hamilton (Dev.).

Athyris parvula Whiteaves, Cont. Canadian Pal., I, 1891, p. 228, pl. 32, figs. 1, 5.

Loc. Athabasca River, Canada.

Athyris pectinifera? Swallow (non Sowerby)=Cleiothyris roissyi.

Athyris (?) perinflata McChesney.

Keokuk (L. Carb.).

Athyris perinflata MeChesuer, Deseriptions New Pal. Foss.. 1861, p. 81.

Loc. Nauvoo, Illinois.

Athyris persinuata Meek=Seminnla persinuata.

Athyris planosulcata American anthors (non Phillips)=Cleiothyris roissyi.

Athyris plattensis Swallow = Seminula plattensis.

Athyris polita Hall.

Chemung (Der.).

Atrypa polita Hall, Geol. N. Y.; Rej). Fourth Dist., 1843, Tables of Organie Remains, 65, fig. 5 .

Athyris ? polita Hall, Pal. Now York, IV, 1867, p. 293, pl. 47, figs. 21-33.

Athyris polita Hall and Clarke, Pal. New York, V1II, Pt. II, 1895, pl. 46, figs. 1-5

Loe. Jasper, Randolph, and Albion, New York.

Athyris*prinstana Billings = Hindella prinstana.

Athyris prouti (Swallow).

Choutean (L. Carb.).

Spirigera pronti Swallow, Traus. St. Louis Acad. Sci., I, 1860, P. 649.

Athyris prouti Keyes, Geol. Survey Missouri, V, 1895, p. 91.

Loc. St. Lonis County, etc., Missouri.

A thyris reflexa Swallow=Cleiothyris reflexa.

Athyris roissyi $=$ Cleiothyris roissyi.

Athyris singletoni Swallow=Seminula singletoni.

Athyris (?) solitaria Billings.

Anticosti (Sil.).

Athyris solitaria Billings, Catalogue Sil. Foss. Anticosti, 1866, p. 48.

Loc. Anticosti.

Athyris spiriferoides MeChesney (non Eaton)=A. papilioniformis.

Athyris spiriferoides (Eaton). Corniferous and Hamilton (Dev.).

Terebratula spiriferoides Eaton, American Jour. Sei., XXI, 1831, p. 137;-Geological Text-book, 1832, p. 46.

Atrypa coucentrica Conrad (nou von Buch), Ann. Rep. Geol. Snrvey New York, 1838, p. 111. - Hall, Geol. New York; Rep. Fourth Dist, 1843, p. 198, fig. 5.

Spirifera spiriferoides Hall, Tenth Rep. N. Y. State Cab. Nat. Hist., 18.57, p. 153, figs. 1, 2.-Rogers, Geol. Pennsylvania, II, Pt. II, 1858, p. 828, fig. 667.

Athyris spiriferoides Hall, Thirteenth Rep. N. Y. State Cab. Nat. Hist., 1860, p. 93, figs. 1-4;-Fifteenth Rep. Ibidem, 1862, p. 180, figs. 1-4;-Pal. New York, IV, 1867, p. 285, pl. 46, figs. 5-31.-Hall and Clarke, Pal. New York, VIII, Pt. II, 1893, p. 89, figs. 60, i1 ; pl. 45, figs.11-27. 
Athyris spiriferoides (Eaton)-Continued.

Athyris concentrica libllings, Canadian Jonr., V1, 1861, p. 145, figs. 54-57;-Ceol. Can:tla, 1863, p. 373, fig. $399 ;$ p. 385, fig. 421.

Loc. New York; Pennsylvania; Maryland; Virginia ; Caynga and Widder, Canada. Athyris squamosa Worthen=Oleiothyris squamosa.

A thyris sublamellosa Hall=Cleiothyris roissyi.

A thyris subpuadrata Hall= Seminula subquadrata.

Athyris subtilita Hall=Seminula argentea.

Athyris trinucleus Hall=Semiuula trinucleus.

Athyris trisinuatus MeChesney= Meristina trisinuata.

Athyris tumida Roemer=Meristina tumida.

Athyris (?) tumidula Billings.

Anticosti (Sil.).

Athyris tumidnla Billings, Catalogne Sil. Foss. Anticosti, 1866, p. 47.

Loc. Anticosti.

Obs. Probably a species of Whitfieldella.

Athyris (?) turgida Slıaler.

Anticosti (Sil.).

Athyris turgila Shaler, 13ull, Mus. Comp. Zool., 4, 1865, p. 69.-Miller, N. Aneri. can Geol. Pal., 1889, p. 335.

Loc. Anticosti.

Athyris ultravarica MeChesney.

Keokuk (L. Carb.).

Athyris ultravariea McChesney, Descriptions New Pal. Fossils, 1861, p. 79.

Loc. lieokuk, Iowa.

A thyris umbonata Billings = Hindella umbonata.

Athyris misulcata Billings=Pentagonia unisuleata.

Athyris vittata Hall= $\Lambda$. fultonensis.

ATRYPA Dalman.

Genotype Anomia reticularis Iinnsus.

Atrypa Dalman, Kongl. Srenska Vet.-Akad. Haudl., fïr 1827, 1828, p. 102.-Billings, Cinadian Nat. (Geol., I, 1856, p. 134;-Canadian Jour., VI, 1861, p. 264.-Whitfield, Twentieth Rep. N. Y. State Cal. Nat. II ist, 1867, p. 141, pl. 1.-IIall, Pal. New York, IV, 1867, p. 312.-Nettelroth, Kentucky Fossil Shells, Mem. Kentucky Geol. Survey, 1889, p. 88.-Hall and Clarke, Pal. New York, VIII, Pt. II, 1893, ア. 163;-Thirteenth Ann. Rep. N. Y. State Geologist, 1895, p. 818 .

Atrypa sequiradiata Conrad = Rensselaria sequiradiata.

Atrypa acutiplicata Conral=Anoplotheca acntiplicata.

Atrypa acutirostrum Hall= Rhynchonella acutirostris.

Atrypa affinis Vanuxem $=$ A. reticularis.

Atrypa altilis Hall=Camarotœehia plena.

Atrypa ambigua Hall = Camarella ambigua.

Atrypa aprinis Hall= Homorospira apriniformis.

Atrypa arati Conrad = Pentamerella arata.

Atrypa aspera American authors=A. spinosa.

Atrypa aspera oceidentalis $\mathrm{Hall}=\mathrm{A}$. hystrix occillentalis.

Atrypa bidens Hall= Rhynchonella bidens.

Atrypa bidentata Hall= Rhynehonella bidentat.

Atrypa bisuleata Hall (non Vannem)=Cyelospira lisnleata.

Atrypa bisulcata Vannxem (non Mall) = Whitficllella bisuleata.

Atrypa brevirostris Hall=Anastrophia brevirostris. 
Atrypa calvini Nettelroth $=$ A. rugosa.

Atrypa camura Hall=Trematospira camura.

A trypa capax Conrad = Rhynehotrema capax.

Atrypa chemungensis Conrad $=$ A. reticularis.

Atrypa circulus Mall=Parastrophia liemiplicata.

Atryla comis $\mathrm{O}$ wen=Gypidula comis.

Atrypa concentrica Conrad, and Hall= Athyris spiriferoides.

Atrypa concinua Hall = Nucleospira concinna.

Atrypa congesta Conrad = Hyattella congesta.

Atrypa congregata Conrad = Camarotrechia congregata.

Atrypa contracta Hall= Camarotechia contracta.

Atrypa corallifera Hall=Dictyonella corallifera.

Atrypa crassirostrum Hall = Whitfieldella cylindrica.

Atrypa cuboides Vannxem, and Ifall = Hypothyris cuboides.

Atrypa cuneata Hall=Rhymchotretra cuneata americana.

Atrypa cuspidata Hall= Triplecia cuspidata.

Atrypa cylindrica Hall = Whitfieldella cylindrica.

Atrypa deflecta Hall=Zygospira deflecta.

Atrypa dentata Hall=Rhynchotrema dentata.

Atrypa desquamata Sowerby.

Middle Devonian.

$\Lambda$ trypa desquamata sowerby, Trans. Geol. Soc., $2 d$ ser., V, 1840, pl. 5ti, tiggs. 19, 20.-Waleott, Mon. U. S. Geol. Survey, VIII, 1884, p. 150, pl. 14, lig. 4.

Loc. Europe; Petoskey, Michigan; Eureka district, Nevada.

Atrypa disparilis Hall=A trypina disparilis.

Atrypa dubia Hall=-l'rotorhynclia duloia.

Atrypa dlumosa Hall=A. spinosa.

Atrypa cluplicata IIall=Camarotcechia (luplicata.

Atrypa ellipsoidea Nettelroth.

Comiferous (I)er.).

Atrypa ellipsoidea Nettelroth, Kentucky Fossil Shells, Mem. Kentucky Geol. sirvey, 1889, p. 90.

Loc. Falls of Ohio.

Atrypa clongata Conrad=Rensseliria ovoides.

Atrypia emacerata Hall= Rhynchonella emacerata.

Atrypa equiraliata 11 all = Camarotechia equiradiata.

Atryla exigna Hall='Zygospira exigua.

Atrypa eximia Hall=Camarotrechia eximia.

Atrypa extans Emmons=Triplecia extans.

Atrypa flabella Shaler = Anoplotheca hemispherica.

Atrypa flabellites Comad = Anoplotheca flabellites.

Atrypa galeatus Dalman=Gypidula galeata

Atrypa(?) gibbosa Hall.

Clinton (Sil.).

Atrypa gibbosa IIall, Pal. New York, II, 1852, 1. 79, pl. 20, 1ig. 10.

Loc. Clinton, New York.

Atrypa globuliformis Vannem=Leiorhynchus globuliforme.

Atrypa hemiplicata Hall= Parastrophia hemiplicata.

Atrypa hemispherica sowerby = Anoplotheca hemispherica.

Atrypa hirsuta Hall= Parazyga hirsuta. 
Atrypa hystrix Hall.

Chemmug (l)ev.).

Atrypa lystrix Hall, Geolory N. Y. ; Rep. Fourth Dist., 1843, p. 271, tig. 2.-liogers, Geol. Penusylvania, II, Pt. II, 1858, p. 829, fig. 681.-Hall, l'al. New York, IV, 1867, 1. 326, pl. 53A, figs, 15-17.-Whitteld, Gool. Wisconsin, IV, 1882, 1. 333, ,1]. 26, tig. 5.-IIall and Clarke, Pal. New York, VIII, Jt. II, 1895, ll, 55, lig. 23.

Loc. Steubew Connty, Now York; Penusylvania; Rockford, Iowa; Milwankee, Wisconsin.

Obs. See A. spinosa.

Atrypa hystrix elongata Webster.

Chemung (Dev.).

Atrypa liystrix var. elongata Webster, American Nat., XXIl, 1888, p. 1101.

Loc. Near Rockfort, Iowa.

Atrypa hystrix occidentalis Hall.

Mirllle Devonian.

Atrypa aspera var. occidentalis Hall, Geol. Survey Iowa, I, Pt. II, 1858, 1. 515, 1l. 6, fig. 3.-Hall aud ('larke, Pal. New York, VIII, Pt. II, 1895, pl. 55, figs. $18-20$.

Atrypa aspera Meek and Worthen, Geol. Survey Illinois, III, 1868, p. [03, pl. 13, fig. 7 .

Loc. Independence, Darenport, ete., Iowa; Roek Island, Illinois.

Obs. This variety is probably more closely related to A. hystrix than to A. aspera.

Atrypa hystrix planosulcata Webster.

Chemung (J)ev.).

Itrypa hystrix var. planosuleata Welster, American Nat., XXII, 1888, p. 1104.

Loc. Near Rockford, Iowa.

Atrypa imbrieata Hall (non Sowerby)=A. nodostriata.

Atrypa impressa Hall $=\lambda$. reticularis impressa.

Atrypa impressa Shaler (non Hall) =A. reticularis.

Atrypa increbescens Hall=Rhynchotrema inceuivalvis.

Atrypa intermedia Hall= Whitfieldella intermedia.

Atrypa interplicata Hall=Anastrophia interplicata.

Atrypa lievis Tanuxem=Meristella lievis.

Atrypa lacunosa Vaunem = Anastrophia verueuili.

Atrypa lamellata Hall=Rhynchonella lamellata.

Atrypa(?) lara (Billings).

Anticosti (Sil.).

Athyris lara Billings, Catalogue Sil. Foss. Anticosti, 1866, p. 47.

Atrypa lara Davirlson, Suppl. British Sil. Brach., Pala ontographical Soc., 1882, p. 121.

Loc. Anticosti.

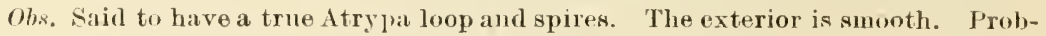
ably the type of a new genus.

Atrypa laticorrugata Foerste.

Clinton (Sil.).

Atrypa lati-corrugata Foerste, Geol. Ohio, VII, 1895, P. 591, pl. 57 A, fig. 16.

Lor. Dayton, Ohio.

Atrypa laticostata Hall (non Phillips)= Camaroterhia contracta.

Atrypa lentiformis Vanuxem $=\mathbf{A}$. retieularis.

Atrypa limitaris Hall=Leiorhynchus limitire.

Atrypa (?) lingulata Nicollet.

Lower Carboniferous.

Atrypa lingulata Nicollet, Rep. Hydrog. Basin Up. Miss. River, 1843, p. 167.

"Sulfusiform; valves nearly erfually convex; inferior valve with a longitudinal sinus; base projecting in the middle, the margin of the projection truncated. St. Lonis, aud also the bluff' beneath Rockwell, Illinois." 
Atrypa marginalis (Dalman).

Terebratula marginalis Dalman, Kongl. Svenska Vet.-Akad. Hanll., för 1827, 1828, 1. 59, pl. 6, fig. 6 .

Atrypa marginalis Roemer, Sil. Fauna west. Tennessee, 1860, p. 69, pl. 5, fig. 10.Billings, Catalogue Sil. Foss. Anticosti, 1866, p. 46.-Hall and Whitfield, Twenty-fourth Rep. New York State Cab. Nat. Hist., 1872, p. 197.-Foerste, Proc. Boston Soc. Nat. Hist., XXIV, 1890, p. 314, pl.6, figs. 8, 9 ;-Geol. Ohio, VII, 1895, p. 591, pl. 25, figs. 6,9 ; pl. 31, figs. 8, 9.-Hall and Clarke, Pal. New York, VIII, Pt. II, 1895, pl. 55, figs. 24, 25.

Trematospira matthewsoni McChesney, Descriptions Now Pal. Foss., 1860, p. 71;-Trans. Chicago Acad. Sci., I, 1868, p. 32, pl. 7, fig. 3.

Atrypa nodostriata Foerste (non Hall), Bull. Denison Univ., I, 1885, p. 90, pl. 13, fig. 9.

Atrypa marginalis var. multistriata Foerste, Proc. Boston Soc. Nat. Hist., XXIV, 1890 , p. 316 , pl. 6 , fig. 8 .

Loc. Europe; Anticosti; Dayton, Ohio; Hanover, Indiana; Luuisville, Kentucky; Decatur County, Tennesseo; Bridgeport, Illinois.

Atrypa masonii (Salter).

Silurian.

Rhynchonella masonii Salter, Sutherland's Jour. Voyage Baffius Bay, ete., II, 1852, p. cexxi, pl. 5, fig. 5.-Etheridge, Quart. Jour, Geol. Soc. London, XXXIV, 1878, p. 596.

Loc. Near Wellington Channel, Bessels Bay, lat. $81^{\circ} 6^{\prime}$.

Atrypa medialis Vanuxem=Eatonia medialis.

Atrypa mesacostalis Hall=Leiorhynchus mesacostale.

Atrypa missouriensis Miller.

Middle Devonian.

Atrypa missouriensis Miller, Eighteenth Ann. Rep. Geol. Survey Indiana, 1894, p. 315, pl. 9, figs. 19-21.

Loc. Near Otterville, Missouri.

Atrypa modesta Hall=Zygospira modesta.

Atrypa nasuta Comrad = Meristella nasuta.

Atrypa naviformis Hall = Whitfieldella naviformis.

Atrypa neglecta Hall=Camarotoechia neglecta.

Atrypa nitida Hall= Whitfieldella nitida.

Atrypa nitida oblata Hall= Whitfieldella oblata.

Atrypa nodostriata Foerste (now Hall)=A. marginalis.

Atrypa nodostriata Hall.

Clinton and Niagara (Sil.).

Atrypa imbricata Hall (non Sowerby), Geol. N.Y.; Rep. Fourth I)ist., 1843,

Tab. Organic Remaius, 13, fig. 1.

Atrypa nodostriata Hall, Pal. New York, II, 1852, p. 272, pl. 56, fig. 2.-Hall and

Whitfield, Pal. Ohio, II, 1875, p. 133, pl. 7, figs. 12-14.

Lor. Lockport, New York; Yellow Springs, Ohio; Louisville, Kentucky; Wisconsin.

A trypa nucleolata Hall $=$ Whitfieldella nucleolata.

Atrypa nucleus Fall=Triplecia nucleus.

Atrypa nustella Castelnau=Eatonia peculiaris.

Atrypa oblata Hall=Whitfieldella oblata.

Atrypa obtusiplicata Hall=Camarotechia obtusiplicata.

A trypa octocostata Courad $=$ Pentamerella arata.

Atrypa palmata Morris and Sharpe=Anoplotheca flabellites.

Atrypa peculiaris Conrad=Eatonia peculiaris. 
Atrypa phoca (Salter).

Siluriaı.

Rhynchomella phoca salter, sutherlaud's Jour. Voyage Baflins Bay, ete, II, 1852,

1). “×xvi, pl. 5, tigs. 1-3.

Atrypa phoca Ethoridge, Quitt. Jour. Geol. Sow. London, XXXIV, 1878, p. 576.

Loc. (ape Riloy, Cornwallis, Seal Islands, Bessels Bay, lat. $81^{\circ} 6^{\prime}$, and Dobbins liay, lat. $79 \circ 11^{\prime}$, Aretic America.

Atrypa planoconvexa Hall=Anoplotheca planoconvexal.

Atrypa pleioplenra Conrad = Camarotechia pleiopleura.

Atrypa plena Hall=Canarotochia plena.

Atrypa plicata Hall= Rhynchonella plicata.

Atrypa plicatella Hall=Rhynchonella plicitella.

Atrypa plicatula Hall=Anoplotheca plicatula.

A trypa plicifera IIall=Camarotrechia plena.

Atrypa polita I Iall= A thyris polita.

A trypa prisca Vamuxem $=\Lambda$. reticularis.

Atrypa pseudomarginalis II:Ill.

Up. IIelderberg (I)ev.).

Atrypa psendomargiualis Hall, Thirteenth Rep. N. Y. State Cab. Nat. Hist.,

1860, p. 81;-Fifteenth Rep. Ibidem, 1862, p. 189;-1’al. New York, IV, 1867,

p. 327 , pl. 53, figs. 1, 2.-Hall and Clarke, Ibidem, VIII, Pt. II, 1895, 11. 55, figs. 26,27 .

Loc. Schoharie, Now York.

Atryplat quad ricostata Hall, 1843=Leiorhynchus quadricostatum.

Atrypa quadricostati Hall, 185\%= Hyattella congesta.

Atrypa rectiplicata Conrad $=$ Spirifer rectiplicatus.

A trypa reeurvirostris Hall=Zygospira recurvirostris.

Atrypa reticularis (Limmetus).

Silurian and Devonian.

Anomia reticularis Linné, Systema Natur:^, ed. xii, I, 1767, 1. 1132.

Atrypa chemungensis Conrad, Jour. Acad. Nat. Sci. Philadelphia, VIII, 1812, p. 265. - Vanuxem, Geol. New York; Rep. Third Dist., 1842, p. 182, fig. 4.

Hipparionyx consimilaris Vannxem, Geol. Now York; Rej. 'Thinl Dist., 181?, ]. 132, fig. 2.

Atrypa affinis Vanuxem, Geol. New York; Rep. Thirl Dist., 1842, p. 88, fig. 12.Hall, Ibiclem, Rej. Fourth Dist, 1843, J. 88, fig. 12.

Atrypa prisea Vanuxem, (ieol. New York; Rep. 'Third Dist., 1812, 1. 139, lig. 5.Hall, llidem, Rep. lourth Wist., 1843, 1. 175, fig.5; 1. 198, fig. 4.-O)wen, Geol. Expl. Iowa, Wisconsin, Illinois, 1844, pl. 12, figs. 2, 10.-Billiugs, Canarlian Nat. Geol., l, 1856, p. 47 1, pl. 7, tig. 11.

Atrypa lentiformis Vanuxem, Geol. New York; Rep Third Dist., 1842, 1. 163, tig. 3 ; 1. 161.-I Iall, Ibidlem, Rep. Fourth Dist., 1843, p. 215, tig. 3.

Strophomena ithacensis Vamxem, Geol. Now York; Rep. Third Dist., 1E4', l.

174, fig. 2. (On the anthority of Professor Willians.)

Atrypa tribulis Ilall, Geol. New York; Rep. Fourth Dist., 1843, 1. 27I, fig. 3.

Terobratula prisea Castelıau, Essai Syst., Sil. l'Amérique Septentrionale, 184:3, p. 40 , pl. 13 , lig. 8.

Tereloratula reticularis Hall, American Jour. Sci., 21 ser., XX, 1819, 1. 227.Yindell and slimmard, Cont. Geol. Kéentucky, 1847, p. 10.

Atrypa reticularis Ilall, I'al. Now York, II, 1852, p. 72, pl. 23, fig. 8; p. 270, pl. 55, fig. 5.-Billings, Canadian Nat. Gool., I, 1856, p. 137, pl. 2, fig. 10.-1lall, Geol. Survey Iowa, II, 1858, p. 515;-Pal. Now York, III, 1859, p. 253, pl. 42, lig. 1.-Roemer, Sil. Fanna west. Tennessec, 1860, 1. 69, p1. 5, fig. 9.-Billings, Canadian Jour., VI, 1861, p. 26.t, tigs. 84-87;-Geol. Canada, 1863, p. 318, 


\section{Atrypa reticularis (Linneus)-Continned.}

fig. 335 ; p. 384, tig. 416.-Hall, l'al. New York, IV, 1867, p. 316, pl. 52, figs. 1-3, 7-12; pl. 53, figs. 3-19; pl.53A, figs. 22, 23.-Meek, Trans. Chicago Acad. Sci., I, 1868, p. 97, pl. 13, fig. 13.-Neek and Worthen, Geol. Snrvey Illinois, IlI, 1868, p. 432, pl. 13, fig. 11.-Meek, Simpson's Rep. Expl. Great Basin 'Terr. Utah, 1876, p. 347, pl. 1, fig. 6;-King's U. S. Geol. Survey Fxpl. 40th l'arl., IV, 1877, p. 38, pl. 1, fig. 7; pl. 3, fig. 6.-Etheridge, Quart. Jour. Geol. Soc. London, XXXIV, 1878, p. 596.-Hall, Twenty-eiglith Rej. New York State Mus. Nat. Hist., 1879, p. 162, pl. 25, figs. 44-47.-White, Sec. Amm. Rep. Indiana Bureau Statistics and (ieol., 1880, p. 502, pl. 5, figs. 7-9;Tenth Rep. State Geol. Indiana, 1881, p. 134, pl. 5, figs. 7-9;-Ibidem, Eleventh Rep., 1882, p. 304, pl. 25, figs. 14-47.-Whittield, Geol. Wiseonsin, IV, 1882, p. 333, p]. 26, fig. 6.-Walcott, Mon. U. A. Geol. Survey, VIII, 1881, p. 150, pl. 14, fig. 6.-Beecher and Clarke, Mem. New York State Mus. Nat. Hist., I, 1889, p.51, pl. 4, figs. 12-20.-Nettelroth, Kentncky Fossil whells, Mem. Kentucky Survey, 1889, p. 91, pl. 11, figs. 12-23; pl. 15, fig. 1.-Foerste, I'roc. Boston Soc. Nat. Hist., XX1V, 1890, p. 314.-Whiteaves, Cont. Canadian Pal., I, 1892, p. 289, pl. 37, fig. 8.-Hall and Clarke, Pal. New York, VIII, Pt. II, 1893, 1. 165, fig. 153; pl. 55, figs. 1-17.-Horrick, Geol. Ohio, VII, 1895, pl. 20, fig. 7 .

Atrypa impressa Shaler (non Hall), Bull. Mus. Comp. Zool., 4, 1865, p. 68.

Loc. A characteristic fossil of the Silurian and Devoniau throughont the worle.

Atrypa reticularis impressa Hall.

Sehoharie grit (1)ev.).

Atrypa impressa Hall, Tenth Rej. New York State Cab. Nat. Hist., 1857, p. 122,

figs. 1-7;-Pal. New York, IV, 1867, p. 315, pl. 51, tigs. 1-9.

Loc. Schoharie, Clarksville, ete., New York.

Atrypa reticularis niagarensis Nettelroth.

Niagara (Sil.).

Atrypa reticnlaris var. niagarensis Nettelroth, Kentneky lossil shells, líem.

Kentueky Geol. Survey, 1889, p. 92, pl. 32, figs. 5-8, 11-17.

Loc. Jefierson County, Kentncky; Clarke Connty, Indiana.

Atrypa reticularis nuntia Hall and Whitfield.

Hamilton (Dev.).

Atrypa retienlaris Hall, Pal. New York, IV, 1867, p. 316, pl. 51, figs. 10-2.1.

Atrypa reticularis var. nnutia IIall and Whitfeld, Twenty-fourth Rep. New

York State Cal. Nit. IIist., 1872, 1. 199.

Loc. Falls of Ohio.

Atrypa reticularis ventricosa Hall and Whitfield.

Hamilton (Der.).

Atrypa reticularis IIall, Pạl. New York, IV, 1867, p. 316, pl. 52, figs. 4-6.

Atrypa reticularis var. ventricosa Inall and Whitfield, Twenty-fourth Rel. New

York State Cib. Nat. Hist., 1872, p. 199.

Loc. Falls of Ohio.

Atrypa robusta Hall= Rhynchonella robusta.

Atrypa rostrata $\Pi$ all = Meristella rostrata.

Atrypa rugosa Hall.

Niagara (Sil.).

Atrypa rugosa Hall, Pal. New York, II, 1852, p. 271, pl. 56, fig. 1.-Hall and

Clarke, Ibilem, V'HI, Pt. II, 1893, p. 171.

Rhynehonella rngosa Billings, Geol. Canada, 1863, p. 315, fig. 321.

Atrypa calvini Nettelroth, Kentucky Fossil Shells, Mem. Kentucky Geol. Survey, 1889, p. 89, pl. 32, figs. 64-66.

Loc. Lo :- ^rt, New York; Anticosti; Osgoorl, Indiana; Lonisville, Kentucky. Atrypa scitula Hall=Cliarionella scitula.

A trypa semiplicata Conrad = Rhynchonella semiplieata.

Atrypa singularis Vanuxem=Eatonia singularis. 
Atrypa sordida Hall= Rhynchonella sordida.

Atrypa spinosa Hall.

Corniferous-Chemung (Dev.).

Atrypa spinosa Hall, Geol. Now York; Rep. Fourth 1)ist., 1813, 1. 200, figrs. 1, 2.-Whitfield, Geol. Wisconsin, IV, 188*, p. 333, jl. 26, figs. 7, 8.-Hall and Clarke, J'al. Now York, VIII, l't. II, 1895, pl. 55, figs. 21, 22.

Atrypa dumosa IIall, Geol. New York; Rep. Fourth Dist., 1843, p. 271, fig. 1.

Atrypa aspera Hall (non Fchlotheim), Tonth Rep. New York State Cal. Nat. Ilist., 1857, p. 168.--liogers, Geol. Pennsylvania, II, 1858, Pt. II, p. 828, tig. 671.-Meek, 'Trans. Chicago Aend. Sei., I, 1868, p. 96, pl. 13, fig. 12.-Nettelroth, Kentucky Fossil Shells, Mem. Kentueky Geol. Survey, 1889, p. 88, p1. 14, figs. 1-11.

Atrypa aspera vel aspera Hall, Pal. New York, IV, 1867, 1. 322, pl. 53A, figs. $1-14,18,24,25$.

Atrypa aspera? Meek. Simpson's Rep. Expl. Great Basin Terr. Utah, 1876, p. 348 , pl. 1, fig. 2.

Atrypa reticularis var. aspera Whiteaves, Cont. CaIadian Pal., I, 1891, pp. $229,289$.

Loc. New York; Pennsylvania; Maryland; Virginia; Kentucky; Ohio; Illinois; Iowa; Wisconsin; Ontario; Lockhart and Athabasca rivers, etc., Northwest Territory, Canada.

Ols. The Corniferous limestone specimeus of A. spinosa are not always easily distingnished from A. reticularis. The fower plications of the former, however, will usually distiugnish it from the latter speries. This tendency to fewer plications is more marked in the Hamilton formation and attains its climax in the Chemung, where the species is known as A. hystrix.

Atrypa subtrigonalis Hall=Rliynelonella subtrigonalis.

Atrypa sulcata Vanuxem = Whitfieldella sulcata.

Atrypa tenuilineata Hall=Dalmanella tenuilineata.

Atrypa tribulis $\mathrm{Hall}=\mathrm{A}$. reticularis.

Atrypa unguiformis Hall=Hipparionyx proximus.

Atrypa unisulcata Conrad=Pentagonia misuleata.

ATRYPINA Hall and Clarke. Genotype Leptocelia imbricata Hall.

Atrypiua Hall and Clarke, Pal. New York, VIII, Pt. II, 1893, p. 161, 1ig. 152 ;Thirteenth Anu. Rep. New York State Geologist, 1895, p. 815.

Atrypina clintoni Hall and Clarke.

Clinton (Sil.).

Atrypina elintoni Hall and Clarke, Pal. New York, YIII, Pt. II, 1893, p. 162, pl. 53 , figs. $7,17-19 ;$ pl. 83 , tig. 6 .

Loc. Orleans County, New York.

Atrypina disparilis (Hall).

Niagara (Sil.).

Atrypa disparilis Hall, Pal. New York, II, 1852, p. 277, pl. 57, fig. 6.-Hall and Clarke, Pal. New York, VIII, Pt. [1, 1895, pl.53, figs. 1-4.

Leptocolia disparilis Hall, Twelfth Rep. New York State Cab. Nat. Hist., 1859, p. 77 .

Trematospira? disparilis Hall, Sixteenth Rep., Ibidem, 1863, p. 60;-Trans. Albany Institute, IV, 1863, p. 146.

Cœlospira disparilis Hall, Twenty-eighth Rep. New York State Mus. Nat. Hist., 1879, p. 162, pl. 25, figs. 39-43;-Eleventh Rep. State Geol. Indiana, 1882, p. 363, pl. 25, figs. 39-43.-Beecher and Clarke, Mem. New York State Mus. Nat. Hist., I, 1889, p. 64, pl. 5, figs. 17-23.

Loc. Wolcott, New York; Waldron, Indiana.

Obs. Davidson in 1882 regarded this species the same as Atrypa barrandei of Europe. 
Atrypina imbricata Hall.

Lower Helderberg (Dev.).

Leptocolia imbricata Hall, Tenth Rep. New York State Cab. Nat. Hist., 1857, p. 108;-Pal. New York, III, 1859, p. 246, pl. 38, figs. 8-13.-Billings, Geol. Canada, 1863, p. 957, fig. 452.

Trematospira imbricata Hall, Sixteenth Rep. New York State Cab. Nat. Hist., 1863 , 1. 60 ;-Trans. Albany Institute, IV, 1863, p. 146.-Keyes, Geol. Survey Missouri, V, 1895, p. 96.

Trematospira ? imbricata Meek and Worthen, Geol. Survey Illinois, III, 1868, p. 381 , pl. 7, fig. 2.

Atrypina imbricata Hall and Clarke, Pal. New York, YIII, Pt. II, 1895, pl. 53, tigs. 5, 6, 8-10.

Loc. Albany and Schoharie counties, New York; Perry County, Missouri.

Atrypina intermedia (Hall).

Arisaig (Sil.).

Leptocolia intermedia Hall, Canadian Nat. Geol., V, 1860, p. 147, fig. 5.-Dawson, Acadian Geology, 3d ed., 1878, p. 598, tig. 202.

Loc. Arisaig, Nova Scotia.

Avicula desquamata Hall=Obolella crassa.

AULACORHYNCHUS Dittmar.

Genotype A. pachti Dittmar.

Aulicorhyuchus Dittmar, Verhand. Kais. Mineral. Gessel. St. Petersburg, „d ser., VII, 1871, p. 1, pl. 1, figs. 1-13.-Hall and Clarke, Pal. New York, VIII, Pt. II, 1893, p. 311;-Thirteenth Ann. Rep. New York State Geologist, 1895, 1. 904.

Isogramma Meek and Worthen, Geol. Survey Illinois, V, 1873, p. 568.

Aulacorhynchus millipunctatum (Meek and Worthen). Up. Coal Meas. Chonetes?? millipunctata Meek and Worthen, Proc. Acad. Nat. Sci. Philadelphia, 1870, p. 35 ;-Geol. Survey Illinois, T, 1873, p. 566, pl. 25, fig. 3.

Isogramma millipunctata Meek and Worthen, Ibidem, 1873, p. 568.

Aulacorhynchus millipunctatus Hall and Clarke, Pal. New York, VIII, Pt. II, 1893 , p. 312 , pl. 83, figs. 14, 15.

Chonetes millipunetatus Keyes, Geol. Survey Missouri, Y, p. 54.

Lnc. Marion County, Illinois; Kansas City, Missouri.

Aulosteges guadalupensis Shumard = Strophalosia guadalupensis. Aulosteges spondyliformis White and St. John=Strophalosia spondyliformis.

Barrandella Hall and Clarke=Clorinda.

BARROISELLA Hall and Clarke.

Genotype Lingula subspatulata

Meek and Worthen (non Ball and Meek).

Barroisella Hall and Clarke, Pal. New York, Extract, VIII, Pt. I, 1890, p. 62;Pal. New York, VIII, Pt. 1, 1892, pp. 62, 64;-Eleveuth Ann. Rep. New York State Geologist, 1894, n. 230.

Barroisella subspatulata (Meek and Worthen).

Black Slate (Dev.).

Lingula subspatulita Meek and Worthen (non Hall and Meek), Geol. Survey

Illinois, III, 1868, p. 437, pl. 13, tig. 1.

Lingula subspatulata? A. Winchell, Proc. American Phil. Soc., XI, 1870, p. 248.

Barroisella subspatulata Hall aud Clarke, Pal. New York, VIII, I’t. I, 1892, p. 63 , pl. 2, figs, $14-16$ and p. 164.

Loc. Jonesboro, Illinois; Louisville and Lebanon, Kentucky; Rockford, Iudiana.

BEACHIA Hall and Clarke.

Genotype Meganteris suessana Hall.

Beachia Hall and Clarke, Pal. New York, VIII, Pt. II, 1893, p. 260;-Thirteenth

Ann. Rep. New York State Geologist, 1895, p. 850. 
Beachia suessana Hall.

Oriskany (Dov.).

Meganteris smessana Hall, Teuth liep. New York State Cah. Nat. Hist., 1857, 1. I00.

lienssolie ria snessana Hall, PaI. Now York, III, 1859, p. 459, pI. 107, ligs. 1-15.

beachia smessana Hall and Clarke, Ibiclem, VIII, Pt. II, 1893, 1. 260, 19.. 77, tigs. 1-11.

Lov. Cumberland, Maryland; near Rondont, Now York.

BEECHERIA Hall and Clarke. Genotype B. davidsoni Hall and Clarke. Beechoria IIall and Clarke, PaI. New York, VIIl, Pt. II, 18!3, 1.300;-Thurteenth Ami. Rep. New York State Geologist, 1895, p. 866.

Beecheria davidsoni Hall and Clarke.

Uprer Carboniferons.

Beecheria davidsoni Hall and Clarke, l'al. New York, VIII, I't. II, 1893, 1. 300, lig. 224, pl. 79, ligs. 33-36.

Loc. Windsor, Nova ścotia.

\section{BILLINGSELLA IIall and Clarke.}

Genotype Orthis pepina Hall=O, coloranoensis Shumard.

Billingrsella and Protorthis Hall and Clarke, Pal. Now York, VIII, P't. I, 18:12, p1. 230,231 ;-Eleventh Ann. Rep. New York State Geologist, 1894, p. 273.

Ob8. Protorthis was fonded on Orthis billingsi Hartt, a species rarely found in good preservation. The diagnostic character was sulposed to be the presence of a rudimentary spondylimm and the absence of a deltidium. In the National Musenm eollection, however, there are two artificial casts of the ventral valve made from llartt's original specimens and other material collected hy Mr. Walcott, showing O. billingsi to be withont a spondylimm. The rostral plate is the deltidium distorted lyy giressure to which these shells have been suljeeted. The only eharacter of generic importance is that the geologieally older species of Billingsella have a more rulimentary or nearly obsolete carlinal process than the typo species. This difference, however, hardly justifies the retention of Protorthis.

Billingsella alberta (Walcott).

Mildle Cambrian.

Orthisina alberta Walcott, Proc. U. S. National Mus., XI, 1888, p. 442.

Loc. Mount Stephan, British Columbia.

Billingsella billingsi (Hartt).

Midnle Cambrian.

Orthis bllhngsi l Iartt, Dawson's Acadian Geology, 2d ed., 1868, 1. 644, fig. 223.-

Walcott, Bull. U. S. Geol. Snrvey, 10, 1881, p. 17, pl. 1, fig. 1.-Mathew,

Trans. Royal soe. Camala, III, 1886, p. 43.

Orthis? billingsi Nlatthew, Iludem, VIII, 1891, p. 131.

Protortbis billingsi Hall and Clarke, I'al. New York, VIII, Pt. I, 18.2, 1']. 219, 232, pl. 7A, tiers. 14-20.

Loc. St. John, Now Bruuswick.

Billingsella coloradoensis (Shumard).

Upper Cambrian.

(Irthis coloradoensis Shumard, Trans. St. Jonis Acad. Sei., I, 1860, 1'. 627.

(Irthis pepina IIsll, Sixteenth Rep. New York State Cab. Nat. IList., IS63, p. 134, 11. 6, figs. 23-27;-C'Trans. Albany Institute, V, 1867, I. 113.-Whittield, Geol. Wiseousin, IV, 1882, 1). 170, pl. 1, figs. 4, 5 .

Orthis? (Orthisina?) pepina Ilall, Second Ann. Rep. New York Stato foologist, 1883, pl. 37, figs. 16-19.

Billingsella pepina Hall and Clarke, Pal. New York, VIII, I't. I, 1892, 1. 230, pl. 7, figs. $16-19$; pl. 7A, figs. 7-9.

Orthis (Billingsella) pepina Sardeson, Bnll. Minnesota Acatl. Nat. Sci., IV, 1896, 1. 96.

J.oc. Burnett Comty, 'Texas; Lake Pepin, Minnesota; St. Croix River and Berlin, Wisconsin. 
Billingsella festinata (Billings).

Lower Cambrian.

Orthisina festinata Billiugs, Pal. Fossils, I, 1861, p. 10, figs. 11, 12;-Geol. Vermout, II, 1861, p. 949, figs. 350-352;-Ameriean Jour. Sei., 2d ser., XXXIII, 1862, p. 105 ;-Geology Canada, 1863, p. 284, fig. 289.-Walcott, Bull. U. S. Geol. Survey, 30, 1886, p. 120, pl. 7, fig. 7;-Tenth Ann. Rep. U. S. Geol. Survey, 1891, p. 613, pl. 72, fig. 7.

IBillingsella festinata Hall and Clarke, Pal. New York, VIII, Pt. I, 1892, p. 230. Loc. Swanton, Vermont; York, Pennsylvania.

Billingsella (?) grandæva (Billings).

Calciferons (Ord.).

Orthisina grandeva Billıngs, Canadian Nat. Geol., IV, 1859, 1. 349, fig. 1;Geology Canada, 1863, p. 113, fig. 21.

Jillingsella? grandeva Hall and ('larke, Pal. New York, VIII, J't. I, 1892, p. 231. Loc. Mingan Island, Gulf of St. Lawrence.

Billingsella latourensis (Matthew).

Mirllle Cambrian.

Kutorgina latourensis Natthew, 'l'rans. Royal Soe. Canadi, III, 1886, 1. 42, pl.5, lig. 18.-Hall as.' Clarke, Pal. New York, VIII, Pt. I, 1892, 1p. 93, 95, 233, pl. 4, figs. 18-20.

Loc. Portlant, New Brnuswick.

Billingsella (?) laurentina (Billings).

Anticosti (Sil.).

Orthis laurentina Billings, (feol. Survey Canala; Rep. for 1856, 1857, p. 247 ;-Pal. Fossils, I, 1862, p. 138, fig. 115 .

Billingsella? laurentuna IIall and Clarke, Pal. New York, VIII, Pt, I, 1892, pp. 194, 231, 238, pl. 7A, figs. 1-6.

Loc. Anticosti.

Billingsella orientalis (Whitfield).

Lower Cambrian.

Orthisina orientalis Whitfield, Bull. American Mus. Nat. llist., I, 1884, 1. 144, pl. 14, fig. 6.-Walcott, 13ull. U. S. Geol. Survey, 30, 1886, 1. 120, pl. 7, fig. 6 ; - Tenth Ann. Rep. U. S. Geol. Survey, 1891, p. 613, pl. 72, 1ig. 8.

Billingsella orientalis Hall and Clarke, Pal. New York, VIIt, Pt. I, 1892, p. 230. Loc. Georgia and Swanton, Vermont.

Billingsella (?) primordialis (Whitfield).

Calciferous (Ord.).

Streptorlıyehns? primordiale Whutfiel,, Bnll. American Mus. Nat. Ilist., I, 1886,

1. 301 , pl. 24, fig. 7.

Billiugsella? primordiale Ilall and Clarke, Pal. New York, VIII, Pt. I, 1892, p. 231. Lor. Fort Cassin, Vermont.

Billingsella quacoensis (Matthew).

Middle Cambrian.

Orthis qnacoensis Matthew, Trans. Royal soc. Canada, II], 1886, p. 43, pl. 5, lig. 20.

Orthis? quacoensis Matthew, Ibiclem, VIII, 1891, p. 131.

Protorthis quacoensis Hall and Clarke, Pal. Now York, VIII, P't. I, 1892, 1'. 232, pl. $7 \mathrm{~A}$, fig. 21.

Loe. Portland and St. Martins, Now Brunswick.

Billingsella transversa (Walcott).

Lower Cambrian.

Orthisina? transversa Walcott, Bull. U. S. Geol. Survey, 30, 1886, p. 121, pl.

7, fig. 5;-Tenth Ann. Rej. IT. S. Geol. Surrey, 1891, p. 613, pl. 72, lig. 9.

Billingsella transversa Hall and Clarke, Pal. New York, VIII, l't. 1, 1892, p. 230. Loe. Georgia, Vermont.

Billingsella whitfieldi (Walentt).

Lower Cambrian.

Kntorgina whitfielıli Walcott, M1on. 1T. S. Geol. Survey, VIII, 1884, p. 18, pl.

9, fig. 4 .

Loc. Enreka district, Nevada.

Billingsia Ford (non de Koninck, 1876)=Elkania. 
BILOBITES Limmens.

Genotype Anomia biloba Linnens. Bilohites Linuirus, Systema Nature, orl. Muller, VI, 1775, D. 325.-Hall, Jull. Geol. Soe. America, I, 1889, 1). 21.-Beecher, American Jonr. Sri., 3d ser., XLII, 1891, 1. 51.-Hall and Clarke, Pal. New York, VIII, Pt. I, 1892, pp. 204, 223;-Eleventh Am. Rep. New York State Geologist, 1894, p. 269.

Dienlosia King, Mou. Permian Fossils lingland, I'al. Soc., 1850, p. 106.

Bilobites acutilobus (Ringneberg).

Niagara (Sil.).

Orthis acutiloba Rumneberg, Proc. Aeal. Nat. Sci. Philadelphia, 1888, p. 134, pl. 7 , fig. 5.

Bilobites acntilobus Beecher, American Jour. Sci., $3 d$ ser., XLII, 1891, p. 52, pi. 1, fig. 1.

Loc. Lockport, New York.

Bilobites bilobus (Limnsens).

Niagara (Sil.).

Anomia Jiloba Linn:HIs, Systema Naturæ, ed. XII, 1767, p. 1154.

Delthyris simuatus Hall, Geol. New York; Rep. Fonrth Dist., 1813, 1. 105, fig. 8. Apirifer bilobns Hall, American Jonr. Sci., 21 ser., XX, 1819, p. 228;-Pal. New York, IV, 1852, p. 260, pl. 54, 1ig. 1.

Orthis biloba Hall, Twelftl Rep. New York State Cab. Nat. Hist., 1859, p. 85 ;-Eleventh Ren. State Geol. Indiana, 1882, p. 286, pl. 27, fig. 16.

Bilobites bilobus Beecher, American Jour. Sci., 3d ser., XLII, 1891, p. 52, pl. 1, fig. 28 .

Bilobites biloba Hall and Clarke, Pal. New York, VIII, Pt. I, 1892, pp. 190, 204, 205, 223, pl. 5B, tigs. 11-14.

Loc. Lockport, New York; Waldron, Indiana; Wisconsin.

Bilobites varicus (Conrad).

Lower Helderberg' (Dev.).

Delthyris bilobata Conrar (not Orthis bilobata Sowerby), Second Ann. Rep. New York Geol. Surves, 1838, p1). 112, 118.

Delthyris varica Conrıd, Jour Acad. Nat. Sci. Philadelphia, VIII, 1842, 1. 262, pl. 14, fig. 20.

Orthis varica Hall, Pal. New York, III, 1859, p. 179, pl. 24, fig. 1.

Orthis (Dicclosia) varica llall, Second Ann. Rep. New York State Geol., 1883, pl. 35, figs. 38-12.

Bilobites varicus Beecher, American Jour. Sei., 3d ser., XLII, 1891, p. 52, pl. 1, figs. 3-27.-Hall and Clarke, Pal. New York, VIII, Pt. I, 1892, pp. 204, 223, 11. 5B, figs. 15-19.

Loc. Albany and Scholıarie counties, New York; Decatur County, Tennessee; St. Blandine, New Brunswick.

BOTSFORDIA Matthew.

Genotype Obolus pulcher Matther.

Obolus (Botsfordia) Matthew, Trans. Royal Soc. Canada, VIII, 1891, p. 148; X, p. 90.

Botsfordia pulchra Matthew.

Middle Cambrian.

Obolns pulcher Matthew, Canadian Record of Science, III, 1889, p. 306;-Traus. Royal Soc. Canada, VII, 1890, p. 151, pl. 8, figs. 1, 2.

Olsolus (Botsfordia) pulcher Nattlew, Trans. Royal Soe. of Canada, VIII, 189I, p. 148 .

Obolus? pulcher Hall and Clarke, Pal. New York, VIII, Pt. I, 1892, pp. 81, 183, pl. $4 \mathrm{~K}$, fig. 22.

Obolus (Botsfordia) pulchra Matthew, Trans. lioyal Soc. Canada, X, 1891, p. 90 , pl. 16 , fig. 3 .

Botsfordia pulchra Iatthew, Trans. New York Acad. Sei., XIV, 1895, 1. 115, pl. 3. Loe. Canton Island, New Brunswick.

Brachymerus Shaler (non Dejean, 1834)=Anastrophia.

Brachymerus reversus Shaler $=$ Parastrophia reversa. 
Brachyprion Shaler =Stropheodonta.

Brachyprion geniculatum Shaler =Stropheodonta geniculata.

Brachyprion leda Shaler=Rafinesquina leda.

Brachyprion ventricosum Shaler $=$ Stropheodonta ventricosa.

CAMARELLA Billings. Genotype C. volborthi Billings.

Camarella Billings, Canadian Nat. Geol., IV, 1859, p. 301 ;-Iloidem, VI, 1861, p. 316.-Walcott, Bull. U. S. Geol. Survey, 30, 1886, 1. 122.-Nettelroth, lientneky Fossil Shells, Mem. Kentueky Geol. Survey, 188:1, p. 48.-Hall and Clarke, Pal. New York, VI1l, l’t. 11, 1893, p. 219:-Thirteeuth Aun. Rep. New York State Geologist, $1895, \mathrm{p}, 838$.

Camarella ambigua (Hall).

Trenton (Ord.).

Atrypa ambigua Hall, Pal. New York, 1, 1847, p. 143, pl. 33, figs. 8, 9.

Triplesia? ambigna Hall, Twelfth Rep. New York State Cal. Nat. Hist., 1859, p. 65. Camarella ambigna Miller, American Pal. Foss., 1879, p. 107.

Loc. Midlleville, New York.

Camarella antiquata Billings=Protorhyncha antiquata.

Camarella bisulcata Emmons=Cyclospira bisulcata.

Camäella bernensis Sardeson=Parastrophia hemiplicata.

Camarella breviplicata Billings. Calciferous (Ord.).

Camarella lroviplieata Billings, Pal. Fossils, I, 1865, 1). 304, fig. 295.

Loc. Stanlıridge, Quebec, Camala.

Camarella calcifera Billings=Syntrophia calcifera.

Camarella cireularis Miller= P'arastrophia hemiplicata.

Camarella(?) costata Billings.

Calciferous (Oril.).

Camarella? eostata lbillings, Pal. Fossils, I, 1865, p. 305, fig. 296.

Loc. Staubridge, Quebee, Canada.

Camarella lemiplicata Billings=Parastrophia hemiplicata.

Camarella lenticularis Billings.

Anticosti (Sil.).

Camarella lentieularis Billings, Catalogne Sil. Foss. Anticosti, 1866, p. 45.

Loc. Antieosti.

Camarella longirostris Billings.

Ohazy (Ord.).

Camarella longirostra Billings, Canadian Nat. Geol., IT, 1859, p. 302; p. 445, fig. $23 ;--$ Geol. Canada, 1863, p. 127, fig. 53.

Loc. Mingen Islands, Gulf of St. Lawrenre.

Camarella minor Walcott $=$ Protorhyncha minor.

Camarellai ops Billings=Parastrophia ops.

Camarella owatonnensis Sardeson=Cyelospira bisulcata.

Camarella panderi Billings.

Black River (Ord.).

Camarella panderi Billings, Canadian Nat. Geol., IV , 1859, p. 302 ;-Geol. Canada, 1863, p. 143, fig. 78.-Hall and C'larke, Pal. New York, VIII, Pt. II, 1893, p. 220, p]. 62 , figs. $19-23$.

Loc. Panquettes Rapids, Canala; Curdsville, Kentneky.

Camarella parva Billings.

Calciferous (Ord.).

Camarella parva Billings, Pal. Fosisils, I, 1865, p. 219.

Camarella parva? Matthew, Trans. Royal Soe. Canada, XI, 1893, ]. 103, pl. 7 , fig. 9.

Loc. Table Head and Portland Creek, Newfoundland; near St. John, New l3runswiek.

Bull. $87-11$ 
Camarella polita Billings.

Calciferous (()rol.).

Camarella polita libllings, I'aJ. Fossils, 1, 1865, p. 305, fig. 297 on p. 304.

Lor. Staubrilge, (pueber, Camad:1.

Camalella reversa Billings= Anastrophia reversa.

Camarella varians lillings. Calciferous-Chazy (Ort.).

('amarellit varians I3illings, Canatlan Nat. Geol., IV, 1859, p. 445, fig. 24 ;-Geol. Cinatli, 186:3, p. 127, fig. 52;-Cal. Fossils, I, 1865, p. 220.

Loc. Mingan Islands, Gnlf of St. Lawrence; Table Head and Portland creek, Newfondlanel; Chazy, New York.

Camarella volborthi Billings.

Black River (Orrl.).

Camarella rolhorthi libllings, Canadian Nat. Geol., IV, 1859, 1. 301;-Cieol. Canala, 1863, p. 143, fig. 77.-Hall and Clarke, Pal. New York, VIII, J't. II, 1893, 1. 220, pl. 62, figs. 11-18; pl. 84, fig. 42.

Loc. Pancultes Rapids, Ontario, Canada.

Camarium Irall= Merista.

Camarium elongatum Hall= Merista typus.

Camarim meeki Hall= Meristella meeki.

Camarium princeps $\mathrm{H}$ all = Meristella princeps.

Camarimm typus Hall= Merista typus.

CAMAROPHORELLA Hall and Clarke.

Genotype Pentamerus lenticularis White and Whitfield.

('amarophorella Hall and Clarke, Pal. New York, VIII, Pt. II, 1893, P. 215;Thirteenth Ann. Rep. New York State Gcologist, 1895, p. 838.

Camarophorella lenticularis (White and Whitfield).

Burlington (L. Carb.).

Pentamerns lentienlaris White and Whitfield, Jonr. Boston Soe. Nat. Hist., VIII, 1862, p. 295.

Camarophor.lla lenticularis Hall and Clarke, Pal. New York, VII, I't. II, 1893, p. 215, pl. 62 , figs. $46-18$.

Loc. Burlington, Jowa.

CAMAROPHORIA King. Genotype Terebratula schlotheimi von Bucb. Camarophoria King, Ann. Mag. Nat. IIist., XVHI, 1816, 1). 89;-Mon. Permian Foss. England, Pal. Soc., 1850, p. 113.-Hall, Pal. New York, IV, 1867, p. 435.--Hall and Clarke, Pal. Yew York, VIII, Pt. II, 1893, 1. 212;-Thirteenth Ann. Rep. New York State Ceologist, 1895, p. 837.

Stenoehisma (Ehlert (non Conral), Fiseher's Mannel Con'hylıologie, 1887, p. 1309.

Camarophoria(?) bisulcata Shumard.

Cpper Carboniferons.

Camarophoria(?) lisulenta Shumard, Trans. St. Lonis Acad. Sci., I, 1858, p. 296, pl. 11, fig. 2.

Loc. Gualalupe Momntains of New Mexieo and Texas.

Camarophoria caput-testudinis (White). Burlington (L. Carb.). Rhynchonella eaput-testnclinis White, Proe. Boston Soe. Nat. Ilist., IX, 1862, p. 23.

Cammrophoria calunt-festulinis Ifall and Clarke, Pal. New York, VIII, Pt. II, $1893,1.215$.

Loc. liurlington, Iowa.

Obs. P'robahly identical with C. ringens Swallow.

Camarophoria encharis Hall=Camarospira encharis.

Camarophoria explanata (McChesney).

Kaskaskia (L. Carb.).

Rhynchomellit 'xjlimata McChesney, Descriptions New Pal. Foss., 1860, p. 50;-

Trans. Chicago Acall. Sei., I, 1868, p. 30, pl. 6, fig. 7. 


\section{Camarophoria explanata (Mc.Chesney)-Continued.}

Pugnax explanatus Hail and Clarke, I’al. New York, VIII, Pt, II, 1895, pi. 60, figs. 43-.15.

Loc. Chester, Illinois; Princeton, Kentucky.

Obs. Specimens of this species in Mr. Ulrich's collestion prove it to be a Camarophoria.

Camarophoria giffordi Worthen=Enteletes hemiplicatus.

Canarophoria globulina Geinit\% (non Phillips)=Pugnax utah.

Camirophoria globulina Davidson=Pugnax globulina.

Camarophoria occidentalis Miller.

Burlington (L. Carb.).

Camarophoria occillentalis Miller, Jonr, Ciuriunati soc. Nat. Hist., IV, Is8I, p. 8, 13. 7 , fig. 7.

Loc. Lake Valley district, New Mexico.

Camarophoria osagensis Swallow = Pugnax utah.

Camarophoria ringens (Swallow).

Ḱcokuk (L. (arb.).

Ryuchonella ringens Swallow, Trans. St. Louis Acasl. Sci., I, 1860, p. 653.Keyes, Geol. Survey Missouri, V, 1895, 1. 102.

Camarophoria ringens Hall and Clanke, Pal. New lork, V111, Pt. II, 1893, 1. 214.

Loc. Callaway C'ounty, Missomi.

Obs. Compare with C. "apnt-testullinis and Rhynchonella striata. The writer has seen specimons of R. ringens from Callaway Count 5 , Missomri, Swallow's original locality.

Camarophoria rhomboidalis Hall and Clarke. Corniferous (Dev.). Camarophoria rhomboitalis Hall and Clarke, l'al. New York, VIII, Pt. II, 1895, 1. 366, pl. 62, figs. $25-29$.

Loc. Cass County, Incliana.

\section{Camarophoria subcuneata Hall.}

St. Lonis (L. Carb.).

Rhynchonclla subcuneata Hall, Trans. Albany Institute, IV, 1858, 1. 11 ;-Geol. Survey Iow:1, I, Pt. II, 1858, p. 658, p1. 23, fig. 3.-Whitfield, Bull. Ameriean Mits. Nat. 11ist., I, 1882, p. 5I, pl. 6, figs. 47-49.-Hall, Twelfth Rep. State Geol. Indiana, 1883, p. 333, pd. 29, figs. 47-49.-Herrick, Bull. Denison Iniv., III, 1888, p. 39, pl. 7, fig. 23.-Keyes, Geol. Snrvey Missouri, V, 189., p. 102.

Camarophoria subenneata Hall and Clarke, Pal. New York, VIII, Pt. II, 1893, pl. 62 , figs. $3 t-37$.

Loc. Spergen llill aud Bloomington, Indiana. In the IVaverly at Granville, Ohio, according to Herrick.

Obs. See Rhynchonella arctirostrata.

Camarophoria subtrigona Meek and Worthen. Keokuk (L. Carb.). Rhynchonella subtrigona Meek and Worthen, Proc. Acad. Nat. Sci., Philadelphia, 1860, p. 451.-Keyes, Geol. Snrvey Missonri, V, 1895, 1. 102.

Rhynchonella parviui McChesney, Deseriptions New Pal. Foss., 1861, p. 83;Ibidem, 1865, pl. 6, tig. '2.

Camarophoria subtrigona Meek aud Worthen, Geol. Survey Illinois, 'II, 1866, p. 251, pl. 18, tig. 7.-McChesiuy, Trans. Chicago Acail. Sci., I, 1868, p. 31, pl. 6, fig. 2.-Hall and Clarke, Pal. New York, VIII, Pt. II, 1893, p. 214, pl. 62, figs. $38-43$.

Camarophoria ringens Hall and Clarke (non swallow), Ibiden, 1893, pl. 84, fig. 5.

Loc. Keokuk, Lowa; Nauroo and Warsaw, Illinois.

Camarophoria swallovana Slumard=Pugnax swallovana.

Camarophoria thera (Walcott). Lower Carboniferous.

Rhyuchonclla thera Walcott, Mon. U. S. Geol. Snrvey, VIII, 1884, 1. 223, 11. 7, fig. 6.

Loc. Eureka district, Nevada. 
Camarophoria(?) wortheni (1Iall).

Warsaw (1. Carb.).

Rhynchonella wortheni Hall, Trans. Albany lustitute, IV, 1858, 1. 11.

Camarophoria? wortheni Whitfeld, Bull. American Mus. Nat. Hist., I, 1882, p. 51, pl. 6, tigs. 35-39.-1 - Iali, Twelftı Iiep. Stato Geol. Incliana, 1883, 1. 334, p1. 29, tigs. 35-39.

Camarophoria wortheni Hall and Clarke, Pal. New York, VII, Pt. II, 1893, p. 214.

Loc. Alton, Illinois.

CAMAROSPIRA Hall and Clarke.

Genotype Camarophoria encharis Hall.

Camarospira Hall and Clarke, Pal. New York, VIII, Pt. II, 1893, p. 82;-Thirteenth Ann. Rep. New York State Geologist, 1895, p. 776 .

\section{Camarospira eucharis Hall.}

Corniferous (Dev.).

Camarophoria encharis Hall, Pal. New York, IV, 1867, p. 368, pl. 57, figs.40-15.

Camarospira encharis Hall and Clarke, Ibidem, VIII, Pt. II, 1893, p. 82, pl. 50, figs. 46-52.

Loc. Ontario, Canada; Cass County, Indiana.

CAMAROTCECHIA Hall and Clarke.

Genotype Atrypa congregata Conrad.

Camarotechia Hall and Clarke, Pal. New Jork, VIII, Pt. II, 1893, p. 189;Thirteenth Ann. Rep. New York State Geologist, 1895, p. 826.

Camarotœchia(?) acinus Hall.

Niagara (Sil.).

Rhynchonella acinus Hall, Trans. Albany Institute, IV, 1863, p. 215;-Twentyeighth Rep. New York State Mus. Nat. Hist, 1879, p. 163, pl. 26, figs. 7-11;Eleventh Rep. State Geol. Indiana, 1882, p. 306, pl. 26, figs. 7-11.-Nettelroth, Kentucky Fossil Shells, Mem. Kentucky Geol. Survey, 1889, p. 73, pl. 26, figs. $6,13,14$, and pl. 32, figs. 13-16.--Beecher and Clarke, Mem. New York Stato Mus., I, 1889, p. 35, pl. 1, figs. 9-11.

Camarotwehia? acinus Hall and Clarke, T'al. New York, VIII, Pt. II, 1893, p. 190. Loc. Waldron, Indiana; Louisville, Kentucky.

Camarotœchia(?) acinus convexa (Foerste).

Clinton (Sil.).

Rhynchonella acinus var. convexa Foerste, Proc. Boston soc. Nat. Hist., XXIV, 1890, p. 318, pl. 6, fig. 13 ;-Geol. Ohio, VII, 1895, p. 593, pl. 31, fig. 13.

Loc. Hanover, Indiaua.

vamarotøechia æquiradiata Hall.

Clinton (Sil.).

Atrypa equiradiata Hall, Pal. New York, II, 1852, p. 70, pl. 23, tig. 5.

Rhynchospira? equiradiata Hall, Twelfth Rep. New York State Cab. Nat. Hist., 1859, p. 77.

Rhynchonella :equiradiata Miller, N. American Geol. Pal., 1889, p. 36 T.

Camarotochia dequiradiata Hall and Clarke, Pal. New York, VIII, Pt. II, 1893, p. 190.

Protorhyncha iequiradiata Hall and Clarke, Ibidem, 1895, pl. 56, tigs. 7-9.

Loc. Oneida County, New York; Arisaig, Nova Scotia.

Camarotochia (Plethorhyncha) barrandei Hall. Oriskany (Dev.). Rhynchonella barrandi Hall, Tenth Rep. New York State Cab. Nat. Hist., 1857, p. 82, figs. 1-3; p. 84, fig. 4 ;-Pal. New York, III, 1859, p. 442, pl. 103, figs. 3-8. Plethorhyncha barramli Hall and Clarke, Ibidem, VIII, Pt. II, 1893, p. 191.

Loc. Albany and Schoharie counties, New York.

Camarntœchia billingsi Hall.

Corniferous (Dev.).

Rhynchonella thalia Billings (non d'Orbigny, 1847), Canadian Jour., V, 1860 , p. 272, figs. 23-25:-Gieol. Canada, 1863, p. 370, fig. 386.

hhynchonella (Stenocisma) billingsi Hall, Pal. New York, IV, 1867, p. 336, pl. 54, figs. 9-13. 


\section{Camarotœchia billingsi Hall-Continued.}

Canarotøehia billingsi Hall and Clarke, Ibidem, VIII, Pt. II, 1893, p. 192, pl. 57 , fig. 3.

Loc. New York; Columbus, Ohio; Ontario.

\section{Camarotœchia carica Hall.} Rhyuchonella (Stenocisma) carica Hall, Pal. New York, IV, 1867, p. 344, pl. 54A, figs. 21-23.

Camarotechia carica Hall and Clarke, Ibidem, VIII, Pt. II, 1893, p. 192.

Loc. Hamilton, Madison County, New York.

Camarotœchia carolina Hall.

Rhynchonella (Stenocisma) carolina Hall, Pal. New York, IT, 1867, p. 337, pl. 34, figs. 14-19.

Rhynchonella carolina Meek, Pal. Ohio, I, 1873, p. 196, pl. 18, fig. 8.-Nettelroth, Kentucky Fossil Shells, Mem. Kentucky Geol. Surves, 1889, p. 75, pl. 13, figs.

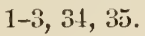

Camarotechia carolina Hall and Clarke, Pal. New York, VIII, Pt. Il, 1893, p. 192 , pl. 57, figs. $4-6$.

Loc. Columbus and Sandusky, Ohio; Falls of Ohio.

Camarotœchia congregata (Courad).

Hamilton (Der.).

Atryla congregat: Conrad, Fifth Ann. Rep. New York Geol. Surrey, 1841, p. 55. Rhynehonella (Stenocisma) congregata Hall, Pal. New York, IY , 1867, p. 341, pl. 54, figs. 44-59.

Camarotiechia congregata Hall and Clarke, Ibidem, VIII, Pt. II, 1893, 1. 192, 1]. 57, figs. $15-27$.

Loc. Fultonhan, Summit, Onondaga, and Tinkers Falls, New York.

Camarotøchia contracta Hall.

Portage-Waverly (I)ev.-I. Carb.). Atrylla contracta IIall, Geol. New York; Rep. Fourth Dist., 1813, tab, 66, figs. $2,3$.

Atrypa laticostata IIall (non Phillips), Ibidem, 1843, tab. 66, fig. 1.

Rhynchonella (Stenocisma) contracta Hall, Pal. New York, IV, 1867, p. 351, pl. 55, figs. 26-39.

Rhynchonella contracta Herrick, Bull. Denison Univ., III, 1887, 1. 39, pl. 10, fig. 9;-Ibidem, IV, 1888, p. 23, pl. 11, fig. 21.

Camarotœehia contracta Hall and Clarke, Pal. New York, VIII, 1’t. II, 1893, p. 192, pl. 57, figs. 28-32, 49.

Loc. New York; Meadville and Bradford, Pennsylrania; Licking Count5, Ohio. Camarotœchia contracta saxatilis (Hall). Hamilton (Dev.). Rhynchouella (Stenocisma) saxatilis Hall, Pal. New York, IV, 1867, p. 417, pl. 54 A, figs. 44-51.

Loc. Rockford, Iowa.

Camarotœchia dotis Hall.

Marcellus and Hamilton (Dev.). Rhyuchonella (Stenocisıa) dotis Hall, Pal. New York, IV, 186ī, p. 344, pl. 54A, figs. 11-20.-Rathbun, Bull. Bufialo Soc. Nat. Sci., I, 1874, p. 246, pl. 8, figs. 10, 12 ;-Proc. Boston Soc. Nat. Hist., XX, 1879, p. 33.

Camarotochia dotis Hall and Clarke, Pal. New York, VIII, Pt. II, 1893, p. 192, pl. 57, figs. 40,41 .

Loc. Geneseo and York, New York; Columbus, Ohio; Rio Maecuru and Rio Curua aud Erere, Brazil.

Camarotœchia(?) duplicata Hall.

Chemung (Dev.).

Atrypa duplicata Hall, Geol. New York; Rep. Fourth Dist., 1843, tab. 67, fig. 2. Rhynchonella (Stenocisma) duplicata Hall, Pal. New York, IV, 1867, p. 350, pi. 55 , figs. $17-25$. 
Camarotœchia ? duplicata Hall-Continued.

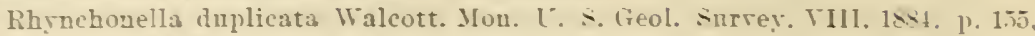
pl. 1 , fig.:

Camarotechia (?) Inplieata Hall ancl Clarke. Pal, New York. VIII. I't. II. 1 Na3, p. 192, pl. 57 , tigs. $36-39$.

Loc. New Tork; Eureka district, Nerada.

Camarotœchia (Plethorhyncha) endlichi (Meek).

? Deronian.

Rhrnchonella endlichi Meek. Bnll. T. \&. Geol. Snrvey Terr., 2t str.. 1. 15is.

11. 46. -White, Twelfth Ann. Rep. L. S. Geol. survey Terr., 1:\$3. p. 133, yl.

$3 \mathrm{~B}^{2}$, tig. :2: pl. 33 . tig. 4 .

Loc, East of Animas River, Colorado.

16s. This trpe of Rhrnchonella occurs in eastern North America only in the Lower Devonian. It therefore seems probable that Jeek's provisional reference to the Deronian is nearer correct than White's to the Lower Carboniferons.

Camarotœchia eximia Hall.

Portage-Cheiung (Der.).

Atrrna esimia Hall. Geol. Jew lork; Rep. Fourth Dist.. 1s43, tab. bb. tig.4.Rogers, Geol. Penusylrania, II. Pt. II, 1858, p. 829, fig. 682.

Rhynchonella (stenocisna eximia Hall, Pal. New York, IT, 1s67, p. 348, pl. 55. tigs. 1-8.-Kindle. Bnll. American Pal.. 6. 15983. 1. 300.

Camarotwechia eximia Hall and Clarke, Pal. New York, VIII, Pt. II, 1893, p. 192, pl. 57. figs, 44.45.

Loe. Ithaca. New Tork: Pennsrirania.

Camarotcechia fringilla (Billings).

Anticosti (Sil.).

Rhrnchnnella fringilla Billings. Pal. Fossils. I, 1862. p. 141, fier. 118.

['amarotechia fringilla Hall and clarke. Pal. Nen York, VIII, Pt. II, 1s93, p. 190. pl. in, figs. 2ะ-30.

Loe. Anticosti.

\section{Camarotæchia glacialis (Billings).}

Anticosti (Sil.).

Phynehonella glacialis Billings. Pal. Fossils, I, 1\&62, p. 143. fig. 120.

Camarntrechia glacialis Hall and Clarke. Pil. Yew lork. VIII. Pt. II, 1593. p. 190. Loc. Anticosti.

Camarotœchia horsfordi Hall.

Marcellus and Hamilton (Der.).

Rhsnchonella horsfordi Hall. Thirteenth Pep. Nem York State Cab. Nat. Hist.

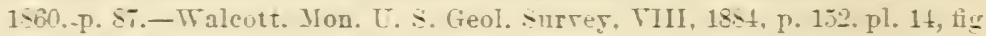

3 ; pl. 15. fig. 6 .

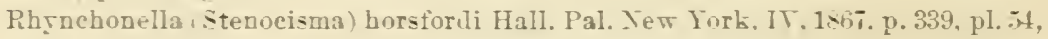
tigs. 21-32.

Camarotechia horsfordi, Hall and Clarke. Pal. New Iork, MIII. Pt. II. 1893, p. 19.2. pI. 5i, figs. $i-9$.

Loc. Moscom, York. Geneseo, and Aron, Nem York; Enreka district, Lerarla.

Camarotœchia? indianensis (Hall).

Niagara (Sil.).

Rhynchonella indianensis Hall, Trans. Albany Institute. IT, 1\$63, p. 215:-

Twentr-eighth Rep. Nen York state Mus. Nat. Hint. 18i9, p. 163. pl. 26, tigs. 12-22:-Elerenth Pep. State Geol. Indiana, 18x-2. p. 306. pl. 26. tigs. 1223: pl. 2T, figs, 4-6.-1ettelroth, Kentucky Fossil -hells, Mem, Kentucky Genl. -nrrer, 1889. p. iỏ, pl. 33. figs. 18-20.-Beecher anil Clarke, Yem. New Tork Ftate Mas. I, 1889, p. 42, pl. 3, figs. 17-2x.

Loc. Waldron. Indiana; Lonisrille, Kentuckr.

Camarotcechia marshallensis (A. Winchell).

Marshall (L. Carb.)

lihynchonella marshallensis A. Winchell. Proc. Acad. Tat. Sci. Philarlelpbia. 1562, p. 40.,-Herrick. Bull. Denison Univ, III, 18x, p. 40 ; IV, p. 23;Genl. Whis, VII, 1895. pl. 23, tig. 14 . 
Camarotœchia marsnallensis (A. Wincliell)-C'ontinued.

Camarotechia marshallensis Hall and Clarke, Pal, Jew York. VIII, Pt. II, 1893, p. 192.

Loc. Marshall, Michigan; Graurille, ett., Ohio.

Camarotcechia(?) neglecta Hall.

Clinton and Niagara (Sil.).

Atrypa neglecta Hall, Pal. New York, II, 1852, p. 70, pl. 23, fig. 4: p. 27t. pl.57, tig. 1.-Billings, Canadian Nat. Geol., I, 1856, p. 138, pl. 2. figs. 11, 12.

Rhyuchonella neglecta Hall, Twelfth Rep. Nem York State Cab. Nat. Hist., 1×59, 1. 78.-Billings, Geology Canada. 1863, p. 315. fig. 325.-Meek. Pal. Ohio, 1, 1>73, p. 179, n1. 15. 1ig. 3.-Hall and Whittield, Ibidem, II, 1:75, P. 134,

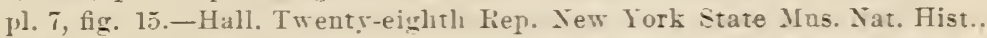
1879. 1\% 16:, I1. 26, figs. 1-6:-Elerenth Rep. State Geol. Indiana. 1852. p. 305, I1. 26, tigs. 1-6: 11. 27. tig. 3,-Beecher and Clarke, Mem. Yew York state Mns., I, 1s89. I'. 37, pl. 4, tigs. 3, 6-8.-Foerste, Proc. Boston Soc. Nat. Hist., XIIT, 1s.90, p. 317, pl. 6, fig. 12 .

Iihynehonella meglecta var. scolbina Meek, American Jour. Sci., :3d ser.. IV. 15i:, 1. $27 \%$.

lihynchonella cobiua Hall and Whittield, Pal, Ohio, II. 14i5. p. 116.-Foerste, Geol. Ohio, VII. 1895, 11. 5:12?.

Camarotochia? nerlecta Hall aud Clarke, Pal. New York. VIII, Pt. II, 1893. p. 190. Luc. Reruales Basin. Lockport, etc.. Vew lork: Hamilton, Ontario: Daston aud Cedarville, Ohjo; Hanover. Indiana; Wisconsin: Arisaig, Yora Scotia.

Camarotæchia obtusiplicata Hall.

Niagara (sil.).

Atrypa obtusiplicata Hall, Pal. Jew York, II, 1852, p. 2i9, pl. 2\&, tig. 2.

Rhrnchonella obtusiplicata Hall, Trelfth Rep. Yen York State Cab. Yat. Hist., 1859, p. 7.

Camarotechia obtusiplicata Hall aud Clarke, Pal. New York. VIII. Pt. II, Is93, p. 190.

Loc. Lockport, Jew York.

Camarotœchia orbicularis Hall.

Chemung (Der.).

Rhrnchonella orbicularis Hall, Thirteenth Rep. Yerr York state Cab. Nat. Hi=t., $1860,1 \% .88$.

Rhruchonella (Stenocisma) orbicularis Hall. Pal. Jew lork. IT, 1867, p. 353, pl. 5i, figs. $40-16$.

Camarotechia orbicularis Hall and Clarke, Pal, Jew York, VIII. Pt. II, 1s.3, p. $102,1,37$, figs. $46-48,50$.

Loc. Chautaunua County, New lork: Meadrille. Pennsyrania.

Camarotœchia plena Hall.

Chazy (Ord.).

Atrypal plena IIall. Pal. New York, I, 1247. p. 21. pl. 4 bis, fig. T.-Billiugs. Canadian lat. Geol., I, 1 556 , p. 207, figs. 17-19.-Rogers. Geul. 1'ennsylvauia, II, Pt. II. 1>5, 1. 17 . fig. 59:2.

Atrgpa plicifera Hall, l'al. Yen York, I, 14i, p. ‘2, pl. 1 bis, tig. \&.

Arry altilis Hall, Ihidem, 18ti, p. 28, pl. 4 bis. fig..

Rhruchonella plena, plicifera, aul altilis Hall, Trelfth Rep. Vew lork state Cab. Yat. Hist., 1859, p1.65, 66.

Rhyuchonella plena Billings, C'auadian Yat. Geol.. II", 1059. p. 414. fig. 20?:(ieul. C'anada, 1863, 1) 1:6, fig. 50.

Camarotcchia plena and altilis Hall and Clarke, Pal. Jem York, VIII, Pt. II, 1893, 1. 190.

Luc. Chazy, New York; Montreal and Ottawa, Cauada.

Camarotœchia (Plethorhyncha) pleiopleura (Conrad).

Oriskany (Der.).

Atrrpa pleioplenra Conrad. Fifth Ann. Rep, Geol. Surres Net lork, 1\&41, p. as. Rbynchonella pleiopleura Hall. Tenth Rep. Jew York state Cab. Nat. Hist.. 15-5, p. \$6, figs. 1-1:-Pal. New York. III, 1559, p. 410, pl. 10:2, tigs. 3, 4,-Billiugs, Pal. Fossils, II, 1sit, p. 3s, tigs $19,20$. 


\section{Camarotøechia (Plethorhyncha) pleiopleura (Conrad)-Continued.}

Plethorhyneha pliopleura Hall and Clarke, Pal. New York, VIll, I't. II, 1893, 1. 191.

Loc. Albany and sehoharie counties, Now York; Indian Cove, Gaspé.

\section{Camarotœchia prolifica Hall.}

Marcellus and Hamilton (Dev.).

Rhynchonella (Stenocisma) prolifica Hall, Pal. New York, IV, 1867, p. 343, pl. $5+4$, figs. $1-10$.

Rlỳnchonella prolifica Tschernyschew, Mém. du Comité Géol. St. Petersburg, III, 1887, 1. 89, pl. 14, fig. 6.

Camarotechia prolifica Hall and Clarke, Pal. New York, VIII, Pt. II, 1893, p. 192, pl. 57, figs. 42,43 .

Loc. Fultonham and Cooperstown, New York; Russia.

Camarotcehia sageriana (A. Winchell).

Marshall (L. Carb.).

Rhynchonella sageriana $A$. Winchell, Proc. Acad. Nat. Sci. Philadelphia, 1862, p. 407 ; -Ibiılem, 1865, p. 122.-Herrick, Bull. Denison Unir., III, 1888, p. 39.

Camarotrechia sageriana Hall and Clarke, Pal. New York, VIII, Pt. II, 1893, p. 192.

Loc. Marshall, Michigan; Weymouth, Ashland, Sciotoville, and Nowark, Uhio; Hickman County, Tennessee.

Camarotochia sappho Hall.

Marcellus-Waverly (Dev.-I. Carb.).

Rhynchonella salpho Hall, Thirteenth Rep. New York State Cab. Nat. Ilist., 1860, 1. 87.--Herrick, Bull. Denison Unis., III, 1888, p. 40, pl. 5, fig. 1; pl. 7, fig. 25;-Geol. Ohio, VII, 1895, pl. 21, fig. 1.

Rhynchonella (Stenocisina) sapplo Hall, Pal. New York, IV, 1867, p. 340, pl. 54, figs. $33-43$; valr. pl. 55, figs. $47-52$.

Camarotechia sappho Hall and Clarke, Pal. Now York, VIII, I't. II, 1893, p. 192 , pl. 57, figs. 10-14.

Loc. Leroy, Geneseo, and York, New York; Licking County, Ohio.

Camarotøechia (Plethorhyncha) speciosa (Hall). Oriskany (Dev.). Rhynchonella speciosa Hall, Tenth Rep. New York State Ca!. Nat. Hist., 1857, p. 81 ;-l'al. New York, III, 1859, p. 44., pl. 103A, figs. 1-6.-1Ieek and Worthen, Geol. Survey Illinois, III, 1868, p. 394, pl. 8, fig. 9.

Rhynchotrema speciosa Waagen, I'alwontologica Indica, Ser. XIII, I, 1883, p. 411. Plethorhyncha speciosa Hall and Clarke, Pal. New York, VIII, Pt. II, 1893, p. 191, pl. 58, figs. 29-37.

Loc. Cumberland, Maryland; Jackson County, Illinois.

Camarotœchia stephani Hall.

Portage and Chemung' (Der.).

Rhynchonella (Stenocisma) stephani Hall, Pal. Now Fork, IV, 1867, p. 349, pl. 55 , figs. 9-16.

Camarotechia stephani Hall and Clarke, Pal. New York, VIII, Pt. Il, 1s93, p. 192 ;-Ibiden, 1895, pl. 57, figs. 33-35.

Loc. Ithaca and Phillipsburg, New York; Bradforı, Pennsylvania.

Camarotœchia tethys (Billings).

Coruiferous (Her.).

Rhynchonella? tethys Billings, Canadian Jomr., V, 1860, p. 270, figs. 20-22.

Rhynchonellat tethys Billings, (ieol. Canada, 1863, p. 370, fig. 3×7.-Walcott, Mon. U. S. Geol. Survey, VIH, 1881, p. 152.-Nettelroth, Kentucky Fussil Shells, Mem. Kentucky Geol. Survey, 1889, p. 83, pl. 13, figs. 25-33; pl. 31, tims. $22-25$.

Ihhychonella (Stenocisma) tethys Hall, Pal. New York, IV, 1867, p. 335, pl. 54, figs. 1-8.

Camarotechia tethys Hall and Clarke, Pal. Now York, VIII, Pt. II, 1893, p. 192, pl. 57, figs. 1, 2 .

Loc. County of Haldimand, Ontario; Stafford and Williamsville, Now Jork; Columbus, Ohio; Falls of Ohio; Eureka district, Nevada. 
Camarotœchia ventricosa Hall.

Lower Helderber'g (Dev.).

Rhynchonella ventricosa Hall, Tenth Rep. New York State Cab. Nat. Hist., 1857, p. 78 , figs. 1-6;-Pal. New York, III, 1859, p. 238, pl. 43, fig. 1.

Camarotwehia ventricosa Hall ant Clarke, Ibidem, VIII, Pt. II, 1893, p. 191.

Wilsonia ventricosa Hall and Clarke, Pal. New York, VIII, Pt. II, 1895, 1). 58, figs. 13,14 .

Loc. Schoharie, Carlisle, and Cherry Valley, New York.

\section{Camarotœchia whitei Hall.}

Niagara (Sil.).

Rhynchonella whitii Hall (non A. Winchell), Trans. Albany Institute, IT, 1863,

p. 216.

Rhpnchonella whitii Hall, Twenty-eighth Rep. New York State Mns. Nat. Hist, 1879, p. 164, pl. 26, figs. 23-33;-Eleventh Rep. Stato Geol. Indiana, 1882, p. 307, pI. 26, figs. 23-33.-Beecher and Clarke, Mem. New York Stato Mns., I, 1889 , p. 39 , pl. 4 , figs. $1,2,4,5$.

Rhynchonella whitiana Miller, American Pal. Fossils, $2 d$ ed., 1883, p. 297.

Camarotøchia? whitii Hall and Clarke, Pal. New York, VIII, Pt. II, 1893, p. 190.

Loc. Waldron and Osgood, Indiana.

Cupulus lugubris Conrad= Discinisea lugubris.

CAPELLINIA Hall and Clarke.

Genotype C. mira H, and C.

Capellinia Hall and Clarke, Pal. New York, VIII, Pt. II, 1893, p. 248, pl. 70, figs. 6-14;-Thirteenth Ann. Rep. New York State Geologist, 1895, 1. 847.

Capellinia mira Hall and Clarke.

Niagara (Sil.).

Capellinia mira Hall and Clarke, Pal. New York, VIII, Pt. II, 1893, p. 249, pl. 70, figs. 6-14.

Loc. Vicinity of Milwankee, Wisconsin.

CATAZYGA Hall and Clarke.

Genotype Athyris headi Billings.

Catazyga IIall aud Clarke, Pal. New York, VIII, Pt. II, 1893, p. 157, tig. 151;-

Thirtcenth Ann. Rep. New York Stato Geologist, 1895, p. 803.

Catazyga erratica Hall.

Lorraine (Ord.).

Orthis? erratica Hall, Pal. New York, I, 1847, p. 288, pl. 79, fig.5.

Athyris headi var. anticostiensis Billings, Pal. Fossils, I, 1862, p. 147, fig. 127.

Athyris headi var. borealis, Billings, Ibidem, 1862, p. 147, fig. 126.

Athyris borealis Billings, Geol. Canala, 1863, p. 212, fig. 216.

Athyris anticostiensis Billings, Ibidem, 1863, p. 212, fig. 215.

Zygospira anticostiensis Davidson, Suppl. British Sil. Brach., Palirontographical

Soc., 1882, p. 127.

Zygospira erratica Datvidson, Ibidem, 1882, p. 126.

Orthis erratica, var. Keesow, Ueber Sil. u. Devon. geschiebe Westprenssens, 188t, p. 246, 1l. 2, fig. 10.

Catazyga headi vars. borealis and anticostiensis Hall and Clarke, Pal. New York, VIII, Pt. II, 1895, pl. 54, figs. 27, 31-34.

Catazyga erratica Hall and Clarke, Pal. New York, VIII, Pt. II, 1893, p. 158, pl. 5t, figs. 17-23.

Loc. Oswego Conuty, New York; River Saguenay, Lake St. John, Canarla; Inticosti; "Wesenberg Schict," Prussia.

Catazyga headi (Billings).

Lorraine (Ord.).

Athyris leadi Billings, Pal. Fossils, I, 1862, p. 147, fig. 125;-Geol. Canada, 1863, 1. 212, fig. 214 .

Zygospira hoadi Hall, Twenty-third Rep. New York State Cab. Nat. Hist., 1872, pl. 13, figs. 23-25 (extract pub. 1871).-Meek, Pal. Ohio, I, 1873, 1. 127, pl. 11, fig.1.-Miller, Cincinnati Quart. Jour. Sci., II, 1875, p. 59.-Davidson, Suppl.

British Sil. Brach., Palieontographical Soc., 1882, p. 125.

Glassia schuchertana Ulrich, American Geologist, I, 1888, 1. 186.

Glassia headi Miller, N. American Gool. Pal., 1889, p. 346. 
Catazyga headi (Billings)-Continued.

Catazyga headi llall and Clarke, Pal. New York, V'1II, Pt. 11, 1893, p. 158, lig.

$151 ;$ pl. 54, figs. 24-26, 30.

Loc. St. Lawrence liver, opposite Three livers; noar St. Nicholas, St. Croix, and Becaneonr River, Quelec, Canada; Waynesville, ete., Ohio; Richmoml and Versailles, Indiana. According to Mr. Ami, also in the Utica slate at Ortawa, Canada.

Catazyga uphami (Winchell and Sehuchert).

Trenton (Ord.).

Zygospira "phami Winchell and Schuchert. American GeoI., 1X, 1892, p. 291;-

Minnesota Geol. Survey, III, p. 468, pl. 34, ligss. 45-18.

Loc. Near Spring Valley and Wykoff; Minnesoti.

CENTRONELLA Billiugs. Geuotype Rhyuchonella glansfagea Hall.

Centronella Billings, Canadian Nat Geol., IV, 1859, 1. 131, figs. 1-5;-Canadian

Jour., VI, 186I, p. 271.-IIall, Sixteenth lep. New York State Cab. Nat.

IIist., 1863, p. 45, ligs. 13-17 ;-Amorican Jour. Sci., 2.l ser., XXXV, 1863, p. 396.-Billings, Ibidem, XXXVI, 1863, p. 237.-Dall, Trans. Albany Institute, IV, 1863, pp. 131, 148.-A. Winchell, Proc. Aead. Nat. Sci. Philadelphia, 1865, p. 122.-Hall, Pal. Now York, IV, 1867, p. 399.-Hall ant Clarke, Ibidem, VIII, Pt. II, 1893, p. 265;-Thirteenth Ann. Rep. New York State Geologist, 1895, p. 853.

Centronella(?) allei A. Winchell.

Waverly (L. Carb.).

Centronella allii A. Winchell, Proc. Acad. Nat. Sci. Philadelphia, 1865, 1. 123. Cryptouella? allei Hall and Clarke, Pal. New York, VIII, Pt. II, 1893, p. 290.

Loc. Burlington, Iowa; Hamburg, Illinois; Snmuit County, Ohio.

Centronella alveata Hall.

Onondaga (Dev.).

Rhynchonella? alveata Hall, Tenth Rep. New York State Cab. Nat. Hist., 1857, p. 124.

Centronella hecate Billings, Canadian Jour., VI, (May) 1861, p. 272, fig. 99;Geol. Canadi, 1863, p. 374, fig. 403.-Hall, Pal. Now York, IV, 1867, p. 420, pl. 61A, figs. 27-29.-Ibidem, VIII, Pt. II, 1895, pl. 79, fig. 15.

Centronella alveata Hall, Pal. New York, IV, 1867, p. 401, pl. 61A, figs. 22-24.Hall and Clarke, Ibidem, VIII, Pt. II, 1893, p. 268, pl. 79, tigs. 22-24.

Loc. New York; Cayuga, Ontario.

Obs. See C. impressa Hall.

Centronella anma Hartt=Harttina anna.

Centronella(?) arcei A. Ulrich.

Devonian.

Centronella? arcei Ulrich, N. Yahrb. f. Mineral, Beilagehand, VIII, 1892, p. 53, pl. 5, figs. 5-9.

Loc. Icla, and near Pulquina, Bolivia.

Centronella billingsiana Meek and Worthen= Whitfieldella hillings. iana.

Centronella(??) crassicardinalis Whitfield.

Warsaw (L. Carb.).

Centronella crassicardinalis Whitfield, Bull. American Mns. Nat. Hist., I, 1882, p. 55, pl. 6, figs. 50-52.-Hall, Twelfth Rep. State Geol. Indiana, XIIX, 1883, figs. $50-52$.

Loc. Spergen Hill, Indiana.

Obs. 'This species is not well estahlished and is based upon a single ventral valve. Compare witl Athyris densa.

Centronella(?) flora A. Winchell.

Waverly (L. Carb.).

Centronella? Hora A. Winchell, Proc. American Phil. Soc., XII, 1870, p. 25.

Loe. Sciotorille, Uhio. 
Centronella glansfagea Hall.

Oriskany-Corniferous (Dev.). Rhynchonella glansfagea Hall, Tenth Rep. New York State Cab. Nat. Hist., 1857 , p. 125 , figs. $1-6$.

Ceutronelliı glansfagea Billings, Canadian Nat. Geol., IV, 1859, p. 132, figs. 1-5;-Canadian Jour., VI, 1861, p. 271, fig. 97;-Geol. Canada, 1863, p. 374, fig. 405.- Hall, Sixteenth Rep. Now York State Cab. Nat. Hist., 1863, pll. $4 \overline{1}-47$; - Pal. New York, IV, 1867, p. 399, pl. 61A, figs. 1-21, 25, 26. - Nettel roth, kentucky Fossil Shells, Mem. Kentneky Gool. Survey, 1889, p. 153, pl. 31, figs. 14-17.-Hall and Clarke, Pal. New York, VIII, Pt. II, 1893, p. 268, fig. 180; 180 ; pI. 79, figs. 1-14, 17, 21.

Loc. Albany and Schoharie counties, New York; Cayuga, Ontario; Falls of Ohio; Michigan.

Ohs. In the American Mnsenm of Natural History this species is labeled Atrypa naviculoides Conrad. The writer has not been alle to tind this description. It may be one of Conral's manuscript names.

Centronella glaucia Hall.

Hamilton (Dev.).

Centronella glancia Hall, Pal. New York, IV, 1867, p. 403, pl. 61A, figs. 39, 40.Hall and Clarke, Ibidem, VIII, Pt. II, I893, p. 269.

Loc. Schoharie, New York.

Centronella hecate Billings $=\mathrm{C}$. alveata.

Centronella impressa Hall.

Haimilton (Dev.).

Centronclla impressa Hall, Fourteenth Rep. New York State Cab. Nat. Hist., (July or August) 1861, p. 102 ;-Fifteenth Rep., Ibidem, 1862, pl. 3, figs. 1-5.-Billings, Canadian Nat. Geol., VII, 1862, p. 392.-Hall, Pal. New York, IV, 1867, p. 402, pl. 61A, figs. 30-38.- Hall and Clarke, P’al. New York, VIII, P’t. II, 1893, p. 269 , pl, 79 , figs. $16,18-20$.

Loc. Bellona, York, Pavilion, and Hamburg, New York.

Obs. Billings says this species is the same as C. lecate (=C. alveata).

Centronella julia A. Winchell= Romingerina julia.

Centronella margarida Derby =Trigeria margarida. Centronella (?) navicella Hall.

Chemung (Dev.).

Terebratnla navicella Hall, Pal. New York, IV, 1867, p. 391, pl. 60, ligs. 38-44.

Centronella (?) navicella Hall and C'larke, Ibidem, VIII, Pt. II, 1895, pl. 79, figs. 40-42.

Loc. Rockford, Iowa.

Centronella ovata Hall.

Upper Helderberg (Dev.).

Centronella ovata IIall, Pal. New York, IV, 1867, p. 419, pl. 61A, tigs. 47-49.

Loc. Cayuga, Ontario.

Centronella(?) silvetii A. Ulrich.

Devonian.

Centronella silvetii A. Ulrich, N. Jahrh. f. Mineral., lieilageband, VIII, 1892, p. 51, pl. 4, figs. 15a-15d.

Lor. Chahnarani, Bolivia.

Centronella tunida Billiugs.

Uriskany and Corniferous (Dev.).

Centronella tumida Billings, Canadian Jour., VI, 1861, p. 272, fig. 98;-Geol. Canadil, 1863, p. 374, fig. 404.

Loc. Caynga and Port Colbourne, Ontario.

\section{CHARIONELLA Billings.}

Genotype Atrypa scitula Hall.

Charionella Billings, Canadian Jour., VI, 1s61, pp. 148, 274, figs. 101, 102.-Hall, Sixteenth Rep. New York State Cab. Nat Hist., 1863, p. 40;-American Jonr. Sci., n. ser., XXXV, 1863, p. 39ti.-Hall and Clarke, Pal. New York, VIII, Pt. 11, 18!3, p. 78;-Thirteenth Rep. New York State Geologist, 1895, p. 775. 
Clıarionella circe Billings $=$ C. scitula.

Charionella doris Billings = Mleristella doris.

Charionella hyale Billings = Whitfieldella hyale.

Charionella rostrata Billings $=$ Meristella mostrata.

Charionella scitula Hall.

Corniferous (llev.).

Atrypa scitula liall, Geol. New York; liep. Fourth Dist, 1813, p. 171, fig. 1.

Athyris? scitula Billings, Canadian Jour., V, 1860, p. 278, figs. 35-38.

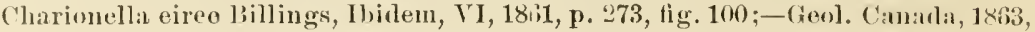
p. 37., fig. 100 .

Meristella scitula Hall, Pa1. New York, IV, 1867, p. 302, p]. 47, figs. 31-ix.

Meristella rirce Miller, N. American Geol. Pal., 188!, 1. 35.4.

Charionella scitula Hall aud Clarke, l'al. New York, VIII, Pt, II, 18113, p. 78, pl. 42, figs. 17-19.

Lne. Williansville aud Clarence Hollow, New Tork; Coinmbns, (Thio (Whitfield); county of Haldimand, Ontario.

CHONETES Fiseher de Waldheim. Genotype Orthis striatella Dalman.

Chonetes Fischer de Wallheim, Gryctographie dı Gouvernement do Moscow, I't. 11, 1837, p. 134.-Hall, l'al. New York, 11, 1852, p. 64.-Billings, Canadiau Jomr., VI, 1861, 1.319.-Meek and Hayden, Pal. Upper Missomri, Smithsonian ('onl. Knowl., 17', 186.1, p. 2'.-Hall, Twentioth Rej. New York State Cab. Nat. Hist., 1867, p. 212;--Pal. New York, IV. 1867, p. 115.-Walcott, Nom. 1T. S. Geol. Survey, VIII, 1884, p. 122.-Nettelroth, Kentucky Fossil Shells, Mem. Kentucky Geol. Survey, 1886, p. 66.--1lall and Clarke, Pal. New York, VIII, Pt. I, 1892, p. 303;-Eleventh Ann. Rep. New York State Grologist, 1894, p. 292.

Chonetes acutiradiatus Hall.

Corniferous (Dev.).

Strophomena aeuturadiata Hall, Geol. New York; Rep. Fonrth Dist., 1843, p. 171, fig. 3.

Chonetes acntiradiata Hall, Tenth Rep. New York State Cab. Nat. Hist., 1857, p. 117;-Pal. New York, IV, 1867, p. 120, pl. 20, fig. 5;-Second Anu. Rep. New York State Geol., 1883, pl. 47, fig. 8.-Nettelrotll, Kentucky Fossil SLells, Mem. Kentueky Geol. Survey, 1889, p. 66, pl. 18, figs. 18-20.-Hall and Clarke, Pal. New York, VIII, Pt. I, 1892, pl. 16, fig. 8.

Loc. Wılliamsville, Stafford, etc., New York; Columbns, Ohio; Falls of Ohio.

Chonetes amazonicus Derby.

Upper Carboniferons.

Chonetes amazonica Dcrby, Bull. Cornell Univ., I, 1874, p. 41, pl. 6, figs. 3, 12, 19 ; pl. 9, figs. 8, 9.-Hall aud Clarke, Pal. New York, VIII, Pt. I, 18.22, pl.15B, fig. 13 .

Loc. Itaituha, Brazil.

Chonetes antiope Billings.

Lower Devonian.

Chonetes anitope liillings, Pal. Fossils, II, 1874, 1. 19.

Loc. Monnt Jolli and Percé, Nova Scotia.

Chonetes arcei A. Ulrich.

Middle Devonian.

Chonetes arcei A. Ulrich, N. Jahrb. f. Mineral., Beilageband VIII, 1892, p. 77, pl. 4 , figs. 35,36 .

Loc. Chahuarani, Icla, and Tarabuco, Bolivia.

Chonetes arcuatus Hall.

Cormiferous (Dev.).

Chonetes arenata 1lall, Teuth Rep. New York State Cab. Nat. Hist., 1857, ). 116 ;-Pal. New York, IV, 1867, p. 119, pl. 20, fig. 7;-Second Ann. Rep. New lork State Geol, 1883, pl. 47, figs. 15, 35, 36.-Hall and Clarke, Pal. Now York, VIII, Pt. I, 1892, pl. 16, figs. 15, 35, 36.

Loc. Williamsville, Clarence Hollow, ete., New York; Columbus, Ohio. 
Chonetes armata Norwood and Pratten (non Bouchard)=C. pusilus. Chonetes canadensis Billings.

Lower Devonian. Chonetes cantulensis Billings, Pal. Fossils, II, 1874, p. 17, fig. 7.

Loc. Percé, Nova Scotia.

Chonetes complanata Hall=Chonostrophia complanata.

Chonetes comstockei Rathbun.

Middle Devonian.

Clonetes comstockii Rathbun, Bull. Buffalo Soc. Nat. Sei., 1, 1874, 1. 250, 11. 9, figs. 5, 14, 18, 19, 31;-Proc. Boston Soc. Nat. Hist., XX, 1879, p. 18.

Loc. Province of Para, Brazil.

Chonetes cornutus (Hall).

Clinton (Sil.).

Strophomena cornuta Hall, Geol. New Yo:k; Rep. Fourth Dist., 1843, p. 73, fig. 3.

Chonetes cornuta de Koninck, Recher. Animaux Foss., Pt. I, 18+7, p. 200, pl. 20, fig. 3.-Hall, Pal. New York, II, 1852, p. 64, pl. 21, fig. 10;-Second Aun. Rep. New York State Geol., 1883, pl. 47, fig. 1.-Hall and Clarke, Pal. New York, VIII, Pt. I, 1892, pl. 16, fig. 1.

Loc. Wayne County, New York.

Chonetes coronatus (Courad).

Hamilton (Der.)

Strophomena carinata Conrad, Jonr. Acad. Nat. Sci. Philadelphia, VIII, 1842, p. 257 , pl. 14, fig. 13.

Strophomena syrtalis Courad, Ibidem, 1842, p. 253, pl. 14, fig. 1.

Chonetes littoni Norwood and Pratten, Jour. Acad. Nat. Sci. Philidelphia, 1II, 1854, p. 25, pl. 2, fig. 4 .

Chonetes maclurea Norwood and Pratten, Ibidem, 1854, p. 28, pl. 2, fig. 8.

Chonetes tuomyi Norwood and Pratten, Ibidem, 1854, p. 28, pl. 2, fig. 9.

Clionetes martini Norwood and Pratten, Ibidem, 1854, p. 29, pl. 2, fig. 10.

Chonetes coronata Hall, Tenth Rep. New York State Cab. Nat. Hist., 1857, p. 146, figs. 1, 2;-Pal. New York, IV, 1867, 1) 133, pl. 21, figs. 9-12.-Whitfield, Geol. Wiscousin, IV, 1882, p. 327, pl. 25, fig. 16.-Hall, Second Ann. Rep. New York State Geol., 1883, pl. 47, figs. 10, 11, 24, 26, 33, 39, 41, 43.-Hall and Clarke, Pal. New York, VilI, Pt. I, 1892, pl. 16, figs. 10, 11, 24, 26, 33, $39,41,43$.

Loc. New York; Pemsylvania; near Arkona, Ontario; Bakeoven, Illinois; Milwaukee, Wisconsin.

Obs. In the Illiuois State collection there are specimens of C. maclurea aud C. littoni which are not specifically distinct from C. coronatus Conrad. In the American Museum of Natural History the writer has seen specimens of $\mathrm{C}$. tnomyi and C. martini labeled as varieties of C. coronatns.

Chonetes curuaensis liathbun.

Middle Devonian.

Chonetes curuaeusis Rathlun, P'roe. Boston Soc. Nat. Sei., XX, 1879, p. 21.

Loc. Province of Para, Brazil.

Chonetes dawsoni Billings=Chonostrophia dawsoni.

Chonetes deflecta Hall $=$ C. vicinus.

Chonetes emmetensis A. Winchell.

Hamilton (Dev.).

Chonetes emmetensis A. Winchell, Rep. Lower Peniusula Nlichigan, 1866, 1. !2.

Loc. Grand Traverse Region, Michigan.

Chonetes falklandicus Morris and Sharpe.

Lower Devonian.

Chonetes falklandica Morris and Sharpe, Quart. Jour. Geol. Soc. London, II, 1846, p. 274, pl. 10, fig. 4.-De Koninck, Recher. Animallx Foss., Pt. I, 1847, p. 204, pl. 20, fig. 4.-Ton Ammon, Zeits. d. Gessels. fïr Erdk., Berlin, XXVIII, 1893, p. 360, fig. 5 .

Loc. Falkland Islands; Taquarassu, Matto Grosso, Brazil. 
Chonetes filistriatus Walcott.

Lower Devonian.

Chonetes tilistriata Walcott, Mon. U. S. Cieol. Nurvoy, VII1, 1881, 1. 127, 1)1. 13, tig. 15 .

Loc. Euroka clistrict, Novala.

Chonetes fischeri Hall=Chonopeetus tischeri.

Chonetes Hemingi Norwood amd Pratten=C. variolatus.

Chonetes freitassii Rithbun.

Middle Devonianl.

Chonotes species Rathbun, liull. Buffalo soo. Nat. Si:i., 1, 1874, p. 253.

Chonetes freitassii Rathbm, l'roe. Boston Soe. Nitt. llist., XX, 1879, p. 18.

Lor. Province of Para, Brazil.

Chonetes geinitziana Wagen, and Miller=0. glaber.

Chonetes geniculatus White.

Kinderhook (I. (a)lo.).

Chonetes genicnlata White, l'roc. Boston Soc. Nat, llist., IX, 1862, p. 29.-A.

Winchell, Proc. Acad. Nat. Sei. Philadelphia, 1865, p. 116;-Proc. Amrican Phil. Soc., XI, 1870, p. 250.

Chonetes genienlatus Kejes, Geol. snrvey Missonri, V, 1895, p. 53, pl. 38, fig. 3.

Loc. Ilauburg, Illinois; Clarksville, Missouri; Rockfort, Indiana; Rockville, Ohio.

Obs. Compare with C. ornatus Shmmard.

Chonetes gibbosa Hall $=\mathrm{C}$. vicinus.

Chonetes glabra Hall (nou Geinitz) $=$ C. lineatus.

Chonetes glaber Geinitz.

Upper Carboniferons.

Chonetes glabra Geinitz, Carbon u. Dyas in Nebraska, 1866, p. 60, pl. 4, figs. 1.)-18. -Tonla, Sitzb. der Kais. A kad. der Wissensch., Wien, LIX, 1869, 1. 10.Meek, Hinal Rep. U. S. Geol. Survey Nebraska, 1872, p. 171, pl. 4, fig. 10; pl. 8, fig. 8.-Derby, Bull. Cornell Univ., I, 187t, p. 43, pl.8, figs. 11, 14, 15, 19 ;I3nll. Mus. Comp. Zool., III, 1876, 1. 280.

Chonetes geinitziana Wangren, Palientologica Indica, Ser. XIII, I, 1884, p. 621. Chometes lavis lieyes, Proc. Acad. Nat. Sci. Philadelphia, 1888, p. 229, pl. 12, fig. 3;-Geol. Survey Missonri, V, 1895, p. 55, pl. 37, fig. 5.

Chonetes geinitzianus Miller, N. American Geol. Pal., 1889, p. 339.

Loc. Nebraska City, Nebraska; Kansas; Iowa; Illinois; Bomjardin and Itaituba, Brazil; Yampopata and Cochabamba, Bolivia.

Chonetes granulifer Owell.

Upper Carboniferous.

C'houtes granulifera Owen, Geol. Rep. Iowa, Wisconsin, Minuesota, 1852, p. 583, 1)1. 5, fig. 12.-Norwood and Pratten, Jour. Acad. Nat. Sci. Philadelphia, III, 1854, p. 24.-Neek, linal Rep. U. S. Geol. Survey Nebraska, 1872, p. 170, pl. 1, fig. 9 ; pl. 6, fig. 10; pl. 8, fig. 7.-White, Wheeler's Geogr. Geol. Survey west 100 Merid., 1875, p. 122, pl. 9, fig. 8. -Keyes, Geol. Survey Missouri, V, 1895, p. 56.

Chonetes smithii Norwood aud l'ratten, Jour. Acad. Nat. Sei. Philadelphia, III, 1854, p. 24, pl. 2, fig. 2.-Meek and Worthen, Geol. Survey Illinois, V, 1873, p. 570, pl. 25, fig. 11.-Hall and Clarke, Pal. New York, VIII, Pt. I, 1892, pl. $15 \mathrm{~B}, \mathrm{fig} .12$.

Chonetes mucronata Meek and Hayden, Proc. Acad. Nat. Sci. Philadelphia, 1858, p. 262;-Pal. Upper Missouri, Smithsonian Cont. to Knowl., 172, 1864, p. 22, pl. 1, fig. 5.-Geinitz, Carbon u. Dyas in Nebraska, 1866, p. 58, pl. 4, tigs. 12-14.-Tonla, Sitzungsb. der Kais. Akad. der Wissenseh., Wein, LIX, 1869, p. 10 .

Chonetes granuliferus Beecher, American Jour. Sci., 3I ser., XLI, 1891, p. 357, pl. 17 , fig. 15 .

Loc. Mouth of Keg Creek, Iowa; Illinois; Kansils; Missonri ; Alıbama; Kaurab Canyon, Arizona; Cochabamba, Bolivia. 
Chonetes hemisphericus Hall.

Upper Helderberg (Dev.).

Chonetes hemispherica Hall, Tenth Rep. New York State Cab. Nat. Hist., 1857, p. 116, figs. 1-3.-Billings, Canadian Jour., VI, 1861, p. 349, figs. 121-123; Geol. Canalda, 1863, 1). 368, fig. 380.-Hall, Pal. New York, IV, 1867, 1. 118, pl. 20, fig. 6.-Nicholson, Pal. Prov. Ontario, 1873, p. 75.-Walcott, Mon. I. S. Geol. Survey, VIII, 1884, 1. 123.-Hall and Clarke, Pal. New York, VIII, Pt. I, 1892, pl. 16, fig. 14.

Loc. Schoharie, etc., New York; Eureka ilistrict, Novada; Ontario, Canada.

Chonetes herbert-smithi Rathbun.

Middle Devonian.

Clonetes herbert-smithi (Hartt MS.) Rathbun, Bull. Buffalo Soc. Nat. Aci., I, 1874, p. 251, pl. 10, figs. 39-42, 44-47;-Proc. Boston Soc. Nat. Hist., XX, 1879, p. 20.

Loc. Province of Para, Brazil.

\section{Chonetes illinoisensis Worthen.}

Burlington (L. Carb.).

Chonetes logani HaIl (non N. and P.), Geol. Survey Iowa, I, Pt. II, 1858, p. 59٪, lyl. 12, figs. $1,2$.

Chonetes illinoiensis Worthen, Trans. St. Lonis Acal. Sei., I, 1860, p. 571.-A. Winchell, Proc. Acad. Nat. Sci. Philadelphia, 1863, p. 5 ;-lbidem, 1865, p. 116.-Meek and Worthen, Geol. Survey Illinois, III, 186.3, 1. 505, pl. 15, fig. 8.-Herrick, Bull. Denison Univ., III, 1888, p. 35, pl. 3, tig. 21.

Loc. Burlington, Iowa; Jersey County, Illinois; Rockford, Indiana; Licking County, Ohio.

Chonetes iowensis Owen = Pholidostrophia iowensis.

Chonetes koninckianus Norwood and Pratten.

Midlle Devonian.

Chonetes koninckiana Norwood and Pratten, Jonr. Acad. Nat. Sci. Philadelphia, III, 1854, p. 30, pl. 2, fig. 11.

Loc. Jonesboro, Union Comty, Illinois.

Chonetes levis Keyes=C. glaber Geinitz.

Chonetes laticosta Hall =C. mucronatus.

Chonetes lepidus Hall.

Marcellus-Chemung (Dev.).

Chonetes lepicla Hall, 'Tenth Rep. New York State Cab. Nat. Hist., 1857, p. 148;Pal. New York, IY, 1867, p. 142, pl. 22, tigs. 12, 13.-Clarke, Bull. U. \&. Geol. Survey, 16, 1885, 11). 24, 32.

Loc. Cayuga Lake, etc., New York; Meadville, Peunsylvania.

Chonetes lineatus (Conrad).

Corniferous (Dev.).

Strophomea lineata Conrad, Third Anu. Rep. Geol. Survey Now York, 1839, p. 61.-Vanuxem, Geol. New York; Rel. Third I)ist., 1842, p. 139, tig. 6 (should lhe 5a).-Hall, Geol. New York; Rep. Fourth Dist., 1813, p. 175, tig. 8.

Chonetes glabra IIall, Tenth Rep. New York State Cab. Nat. Hist., 1857, 1) 117, ligs. 1-8.

Chonetes lineata Hall, Pal. New York, IV, 1867, p. 121, pl. 20, fig. 3;-Secoul Amm. Rep. New York State Geol., 1883, pl. 47, fig. 34.-Hall and Cliure, l'al. New York, VIII, Pt. I, 1892, pl. 16, tig. 34.

Loc. Cayuga Lake, etc., New York.

Chonetes littoni Norwood and Pratten $=$ C. coronatus. (lionetes logani Hall (non Nor. and Prat.)=C. illinoisensis.

Chonetes logani Nor wood aud Pratten. Kinderhook-Burlington ( $\mathrm{L}_{\text {. Carb.). }}$

Chonetes logani Norwood and Pratten, Jour. Acul. Nat. Sci. Philadelphia, III, 185.t, p. 30, pl. 2, fig. 12.-A. Winchell, Proc. Acad. Nat. Sei. Philadelphia, 1865, p. 116.-Hall, Pal. New York, IV, 1867, pl. 22, figs. 23, 26-28;-Seconıl Aun. Rep. New York State Geol., 1883, pl. 47, tig. 25.-Herrick, Bn11. Denison Univ., III, 1888, [1. 35, pl. 3, fig. 12; pl. 7, fig. 22.-Hall and Clarke, Pal. New York, VIII, l't. I, 1892, pl. 16, fig. 25:

Loc. Burlington, lowa; Qnincy, Illinois; Licking C'onnty, Ohio. 
Chonetes logani aurora Hall.

Tully-Burlington (1)ev.-L. Carb.).

Chonetes logani var. aurora 1Fall, Pal. New York, IV, 186i7, 1) 137, 11. 22, figs. 16-18;-Secoud Ann. Rep. New York State freol., 1883, pl, 47, tigs. 9, 1గ.Whiteaves, Cont. to Canadian Pal., I, 1891, p. 215, pl. 29, fing. 2.-11all :mel Clarke, Pal. Now York, VIII, Pt. I, 1892, pl. 16, figs. 9, 18.

Chonotes aurora Williams, Bull. Gool. Soe. Ameriea, 1, 1890, p. 491, pl. 1ㄹ, ligs. $10,11$.

Loc. Tully and Dernyter, New York; Athabasea, Mackenzie, and Red beer rivers, Northwest 'Ferritory, Canada; Cuyshoga and Licking comules, Ohio; Burlington, Iowa.

Chonetes loganensis Hall and Whitfield.

Kinderhook (I. Carh).).

Chonetes loganensis Hall and Whitfield, King's Geol. Expl, 40th Paral, IT, 187T, p. 253, pl. 4, fig. 9.

Loc. Logan Canyon, Wahsatch Range, Utah.

Chonetes maclurea Norwood and Pratten=C. coronatus.

Chonetes macrostriata Walcott=Stropheodonta macrostriata.

Chonetes manitobensis Whiteaves.

Upuer Deromian.

Chonetes manitobensis Whiteaves, Cont. to Canadian Pal., I, 1892, p. 281, pl. 37, figs. $1,2$.

Loc. Manitoba Islaud, Lake Manitoba, Canada.

Chonetes nartini Norwood and Pratten $=$ C. coronatus.

\section{Chonetes melonicus Billings.}

Oriskauy (Der.).

Chonetes melonica Billings, Pal. Fossils, II, 1874, p. 15, fig. 6.

Loc. Little Gaspé, Queluec, Canada.

Chonetes mesolobus Norwood and Pratten.

Upper Carboniferous.

Chonetes mesoloba Nor. and Prat., Jour. Aead. Nat. Sei. Philadelphia, III, 1854, p. 27, pl. 2, fig. 7.-White, Wheeler's Geogr. Geol. Expl. Survey west 100 Merid., 1875, p. 123, p\}. 9; fig. 7.-Hall, Second Ann. Rep. New York State Geol., 1883, 11. 47, fig. 22.-Keyes, Proc. Acad. Nat. Sci. Philadelphia, 188?, p. 228.-Hall and Clarke, Pal. New York, VIII, Pt. I, 1892, pl. 16, fig. 22.

Loc. Belleville, Illinois; Charboniere, Missonri; Flint Ridge, Ohio; New Mexiro; Arizona.

Chonetes michiganensis Stevens.

Upper Carboniferous.

Chonetes michiganensis Stevens, American Jour. Sci., 2 d ser., XXV, 1858, 1. 263.

Loc. Battle Creek, Michigan.

Chonetes millipunctata Meek and Worthen=Aulacorhynchus millipunctatum.

Chonetes minima Hall (non Sowerby)=C. undulatus.

Chonetes mneronata Meek and Hayden (non Hall) = C. grannlifer.

\section{Chonetes mucronatus Hall.}

Oriskany-Hamilton (Dev.).

Strophomena mucronata Hall, Geol. New York; Rep. Fourth Dist., 1843, p. 180, fig. 3.

Chonetes laticosta Hall, Tenth Rep. New York State Cab. Nat. Hist., 1857, p. 119.-Billings, Pal. Fossils, II, 1874, p. 20.

Chonetes mucronata Hall, Pal. New York, IV, 1867, p. 124, pl. 20, fig. 1; pl. 21, fig. 1.-Nicholson, Pa!. Prov. Outario, 1873, p. 74.-Iall, Second Ann. Rep. New York State Geol., 1883, pl. 47, figs. 6, 7.-Hall and Clarke, Pal. New York, VIII, l't. I, 1892, pl. 16, figs. 6, 7.

Chonetes mucronata? Walcott, Mon. U. S. Geol. Survey, VIII, 1884, p. 124.

Loc. New York; Caynga, Ontario; Gaspé; Euroka district, Nevara.

Obs. See C. stiibeli. 
Chonetes multicosta A. Winchell. Kinderhook and Burlington (L. Carb.). Chonetes multicosta A Winchell, Proc. Acad. Nat. Sci. Philalelphia, 1863, p. 5;Proc. American Phil. Soc., XII, 1870, p. 250.

Loc. Burlingtou, Iowa; Hickman and Nlaury counties. Temnessee.

Chonetes murieata Hall=Strophalosia muricata.

Chonetes nana Norwood and Pratten (non de Verneuil)=C. yandellanus. Chonetes novascoticus Hall.

Arisaig and Niagara (Sil.).

Chonetes norascotica Hall, Canadian Nat. Geol., V, 1860, p. 144, fig. 2.-Dawson, Acadian Geol., 3 il ed.. 1878, p. 595, fig. 199.-Hall, Twenty-eighth Rep. New York State IIus. Nat. Hist., 1879, p. 155, pl. 22, figs. 11-14;-Eleverth Rep. State Geol: Indiana, 1882, p. 293, pl. 22, figs. 11-14.

Loc. Arisaig, Nova Scotia; Waldron, Indiana.

Chonetes onettianus Rathbu1.

Middle Devonian.

Chonetes onettiana Rathbun, Bull. Buffalo Soc. Nat. Sci., I, 1874, p. 253, pl. 10, figs. $43,48$.

Loc. Province of Para, Brazil.

Chonetes ornatus Shumard.

Chouteau (L. Carb.).

Chonetes ornata Shumard, Geol. Rep. Missouri, 1£55, p. 202, Pl. C, fig. 1.-Keyes, Geol. Survey Missouri, V, 1895, p. 53, pl. 38, fig. 2.

Loc. Louisiana and Hannibal, Missouri.

Obs. See C. geniculatus White.

Chonetes parvus Shumard.

Upper Carboniferous.

Chonetes parva Shumarl, Geol. Rep. Missouri, 1855, p. 201.

Loc. Boone County, Missouri.

Obs. Keyes says this species is a synonym for $\mathrm{C}$. flemingi $=\mathrm{C}$. variolatns.

Chonetes permianus Shumarl.

Upper Carboniferous.

Chonetes permiana Shumard, Trans. St. Louis Acad. Sci., I, 1859, p. 390.

Loc. Mouth of Delaware Creek, Texas.

Chonetes planumbonus Meek and Worthen.

Keokuk (I. Carb.).

Chonetes planumbona $\$ leek and Worthen, Proc. Acad. Nat. Sci. Philadelibia, 1860 , p. 450 ;-Geol. Survey Illinois, II, 1866, 1. 253, pl. 18, fig. 1.

Loc. Monroe County, Illinois; Crawfordsville, Indiana; Kings Monntain, Kentucky.

Chonetes platynotus White.

Upper Carboniferous.

Chonetes platynota White, Wheeler's Geogr. Geol. Expl. Survey west 100 Merid., Prel. Rep., 1874, p. 19 ;-Ibidem, Final Rep., IV', 1875, p. 121, pl. 9, fig. 6.

Loc. Santa Fe, New Mexien; near Salt Lake, Utah.

Chonetes pulchellus A. Winchell.

Waverly (I. Carb.).

Chonetes pulchella A. Winchell, Proc. Acarl. Nat. Sci. Philadelphia, 1862, p. 410 ;-Ibidem, 1865, p. 115;--Proc. American Phil. Soc., XII, 1870, 11. 250.Herrick, Bull. Denison Univ., III, 1888, p. 37, pl. 3, fig. 14.

Loc. Moscow, Hillsdale County, Michigan; Trumbull, Snmmit, and Licking connties, Ohio; Shafers, Pennsylvania; Hickman County, Tennessee.

Chonetes punctatus Simpson.

Lower Helderber'g (Dev.).

Chonetes punctata Simpson, Trans. American Phil. Soc., n. ser., XVI, 1889, p. 438 , fig. 3 .

Loc. Hazardville, Carbon County, Pennsylvania.

Chonetes pusillus Hall.

Hamilton (Dev.).

Chonetes armata Norwood and I'ritten (nou Bouchard), Jour. Acad. Nat. Sci.

Philadelphia, III, 1854, p. 28.

Bull. 87-12 
Chonetes pusillus Hall-Continued.

Chonetes pusilla IIall, Tenth Rep. New York State Cal. Nat. Hist., 1857, p. 149;-Pal. Now York, IV, 1867, 1. 128, pl. 21, lig. 6.-Meck, Trans. Chieago Acad. Sci., I, 1868, p. 93, pl. 13, fị.. 2.

Loc. liakeoven, Illinois; Fort Resolution, Great slave Lake, British America.

Obs. In the Illinois State collection there is a specimen of C. armatus N. and I'. with an old label attached. This speeimen is identical with C. pusillus Hall.

Chonetes reversa Whitfield=Cinonostrophia reversa.

Chonetes rücki $A$. Ulrich.

Middle Devonian.

Chonetes riicki A. Ulrieh, N. Jahrb. f. Mineral., Beilageband, VIII, 1892, p. 79, pl. 5 , tigs. 1,2 .

Loc. Chahmarani, Icla, and Tarabuco, Bolivia.

Chonetes sarcinulatus Norwood and Pratten.

Chonetes sarcinulata Norwood and Pratten (non Schlotheim), Jour. Acad. Nat. Sci. Philadelphia, IIl, 1854, p. 28.

Obs. It is impessible to point out the American representative intended by these anthors for this species.

Chonetes scitulus Hall.

Marcellus-Chemung (Dev.).

Chenetes scitnla Hall, Tenth Rep. New York State Cab. Nat. Hist., 1857, p. 147 ;Pal. New York, IY, 1867, p. 130, pl. 21, fig. 4;-Second Ann. Rep. New York State Geel., 1883, pl. 47, figs. 3, 4, 27, 32, 40, 44.-Herrick, Bnll. Denison Univ., III, 1888, p. 36, pl. 1, fig. 4.-Whitfield, Annals New York Acad. Sci., Y, 1891 , p. 518, pl. 11, fig. 10.-Hall and Clarke, Pal. New York, YIII, P't. I, 1892, pl. 16, tigs. 3, 4, 27, 32, 40, 44.-Whitfield, Geel. Ohio, VII, 1895, p. 443, pl. 7, fig. 10.-Kindle, Bull. American Pal., 6, 1896, p. 37.

Chonetes scitulns Beecher, American Jour. Sci., XLI, 1891, p. 35\%, pl. 17, fig. 14.

Loc. Moscow, Hamburg, etc., New York; Meadville, Penusylvanial Delaware and Licking connties, Ohio.

Chonetes setigerus (Hall).

Marcellus-Waverly (Dev.-L. Carb.).

Strophomena setigera Hall, Geol. New York; Rop. Fourth Dist., 1813, p. 180, fig. 2 ; p. 222, fig. 3.

Chonetes setigera de Koninck, Recher. Animaux Foss., I, 1847, p. 215, pl. 20, fig. 7.-Hall, Tenth Rep. New York State Cab. Nat. Hist., 1857, p. 150;-Pal. Now York, IV, 1867, p. 129, pl. 21, fig. 2; p. 142, pl. 22, figs. 1-5;-Second Ann. Rep. New York State Geol., 1883, pl. 47, figs. 2, 5, 19.-Walcott, Mon. U. S. Geol. Survey, VIII, 1884, p. 125.-Clarke, Bull. U. S. Geol. Survey, 16, 1885, p. 24.-Hall and Clarke, Pal. New York, VIII, Pt. I, 1892, pl. 16, tigs. $2,5,19$.

Chonetes setigera? A. Winchell, Proe. Acad. Nat. Sei. Philadelphia, 1862, p. 411.

Loc. New York; Meadville, Pennsylvania; Ohio; Union City, Branch County, Michigan; Enreka district, Nevada.

Chonetes shumardianus de Koninck.

Keokuk (L. Carb.).

Chonetes shumarłliana de Koninck, Recher. Animaux Foss., Pt. I, 1817, p. 192, pl. 20, fig. 1.-Norwood and Pratten, Jour. Acad. Nat. Sei. Philadelphia, III, 1854 , p. 24.

Loc. The Knobs, Jefferson Connty, Kentucky.

Chonetes smithii Norwood and Pratten=C. granulifer.

Chonetes striatellus (Dalman).

Silurian.

Orthis striatella Dalman, Kgl. Svens. Vetens.-Akad. Handl., 1828, p. 111, pl. 1, fig. 5.

Chonetes striatella Etheridge, Quart. Jour. Geol. Soc. London, XXXIY, 1878, p. 595 .

Loc. Europe; Cape Louis Napoleon, lat. $79^{\circ} 38^{\prime}$. 
Chonetes stübeli A. Ulrich.

Middle Devonian.

Chonetes stiibeli A. U1rich, N. Jalırb. f. Mineral., Beilagebaud, VIII, 1892, p. 80, pl. 5 , figs. 3,4 .

Loc. Rio Sicasica, Bolivia.

Obs. Probably the same as C. mneronatus.

Chonetes subquadratus Nettelroth.

Hamilton (Dev.).

Chonetes subchadrata Nettelroth, Kentucky lossil Shells, Mem. Kentucky Geol.

Survey, 1889, p. 67.

Loc. Falls of Ohio.

Chonetes tenuistriatus Hall.

Arisaig (Sil.).

Chonetes tenuistriata Hall, Canadian Nat. Geol., V, 1860, p. 145, tig. 3.-Dawson, Acadian Geol., 3d ed., 1878, 1. 596, fig. 200.

Loc. East River, Nova Scotia.

Chonetes tumidus Herrick.

Waverly (L. Carb.).

Chonetes tumidus Herrick, Bnll. Denison Inniv., III, 1888, p. 36, p1. 2, tig. 21.

Loc. Moots Run, Licking County, Ohio.

Chonetes tuomyi Norwood and Pratten $=$ C. coronatus.

Chonetes undulatus Hall.

Niagara (Sil.).

Chonetes minima Hall (non Sowerby), Twenty-eighth Rep. New York State Mus. Nat. Hist., Doc. eil., 1876, pl. 22, fig. 15.

Chonetes undulata Hall, Ibidem, 1879, p. 155, pl. 22, fig. 15;-Eleventh Rep. State Geol. Indiana, 1882, p. 294, pl. 22, fig. 15.

Loc. Waldron, Indiana.

Chonetes variolatus (d'Orbigny).

Upper Carboniferous.

Leptena variolata d’Orbigny, Voyage dans l'Amérique Meridionale; Paléontologie, 1842, p. 49.

Productus variolata d'Orbigny, Ibidem, 1842, pl. 4, figs. 10, 11.

Chonetes variolata de Koninck, Recher. Animaux Foss., Pt. I, 1847, p. 206, pl. 20, fig. 2.-IIall, Stansbury's Expl. Great Salt Lake, 1852, p. 410, pl. 3, fig. 1.Norwood and Pratten, Jour. Acad. Nat. Sci. Philadelphia, III, 1854, 1. 28.

Chonetes flemingi Norwood and Pratten, Ibidem, 1854, p. 26, pl. 2, fig. 5.Geinitz, Carbon 11. Dyas in Nebraska, 1866, p. 59.-Hall and Clarke, Pal. New York, VIII, Pt. I, 1892, pl. 15B, fig. 11.-Keyes, Geol. Survey Missouri, V, 1895, p. 54, p1. 38, fig. 6 .

Loc. Yarbichambi, Bolivia; Guernsey, etc., Ohio; Illinois; Missouri ; Kansas; Nebraska.

Obs. Compare with C. parvus.

Chonetes verneuilianus Norwood and Pratten.

Upper Carboniferous.

Chonetes verneniliana Norwood and Pratten, Jour. Acad. Nat. Sci. Philadelphia, III, 185t, p. 26, pl. 2, fig. 6.-Newberry, Ives' Rep. Colorato River of the West, 1861, p. 128.-Meek, Final Rep. U. S. Geol. Survey Nehraska, 1872, p. 170, pl. 1, fig. 10.-Hali, Second Rep. New York State Geol., 1883, pl. 47, figs. 20, 21.-White, Thirteenth Rep. State Geol. Indiana, 1881, p. 128, pl. 25, figs. 7, 8. - Hall and Clarke, Pal. New York, VIII, Pt. I, 189:2, pl. 16, figs. 20, 21.

Loc. Carboniero, Missouri; Indiana; Illinois; Missonri; Kansas; Nebraska; banks of Colorado River.

Chonetes verneuilianus utahensis Meek.

Upper Carboniferous.

Chonetes verneniliana var. ntahensis Meek, Simpson's Rep. Expl. Great Basin, Ter. Utah, 1876, p. 348, pl. 2, fig. 2.

Loc. Near Humboldt Mountains, Utah. 
Chonetes vicinus (Castelnau).

Hamilton (Dev.).

Leptarna vicina Castelnan, Systeme Sil. l'Amórique Septentrionale, 1813, p. 39, pl. 14, fig. 9.

Chonetes vicina de Koninck, Reeher. Animanx loss., I't. I, 1847, p. 203.

Chonetes deflecta Hall, Tenth Rep. Now York State Cah. Nat. Hist., 1857, p. 149 ;-Pal. Now York, IV, 1867, p. 126, pl. 21, tigs. 7, 8;-Second Ann. Rep. N. Y. State Geol., 1883, pl. 47, fig. 28.-Walcott, Mon. U. S. Geol. Survey, VIII, 1884, p. 24, pl. 2, fig. 8.- Hall and Clarke, Pal. New York, VIII, Pt. I, 1892, pl. 16, fig. 28.

Chonetes gilobosa Hall, Tenth Rep. New York State Cah. Nat. Hist., 1857, p. 145.

Loc. Ontario County, New York; Columbus, Ohio; Wisconsin; Eureka district, Nevada.

Obs. Castelnan's specimens are from "Ontario Connty, New York." II is figures are good and can not be compared with any other species than the wellkuown C. deflectus Hall, a species occurring abuudantly in Ontario County.

Chonetes yandellanus Hall.

Corniferous (Dev.).

Chonetes nana de Koninck (non de Vernenil), Recher. Animaux Foss., Pt. I, 1847, p. 213.-Norwood and Pratten (non de Vernenil), Jonr. Acad. Nat. Sci. Philadelphia, III, 1854, p. 28.

Chonetes yandellana Hall, Tenth Rep. New York State Cab. Nat. Hist., 1857, p. 118;-Pal. New York, IV, 1867, p. 123, pl. 20, fig. 4.-Nettelroth, Kenticky Fossil Shells, Mem. Kentucky Geol. Snrvey, 1889, p. 68, pl. 17, figs. 16-19; pl. 31 , figs. $20,30$.

Loc. Falls of Ohio; Columbus, Ohio.

CHONOPECTUS Hall and Clarke. Genotype Chonetes fischeri N. and P. Chonopectus Hall and Clarke, Pal. New York, VIII, Pt. I, 1892, p. 312 ;-Elerenth Ann. Rep. New York State Geologist, 1894, p. 295.

Chonopectus fischeri (Norwood and Pratten).

Kinderhook and Burlington (L. Carb.).

Chonetes fischeri Norwood and Pratten, Jour. Acarl. Nat. Sci. Philadelphia, III, 1854, p. 25, pl. 2, fig. 3.-Hall, Geol. Survey Iowa, I, Pt. II, 1858, p. 517, pl. 7, fig. 1; -Second Ann. Rep. New York State Geol., 1883, pl. 47, figs. 17, 31.

Chonopectus fischeri Hall and Clarke, Pal. New York, VIII, Pt. I, 1892, p. 312, pl. 15B, figs. 20-23: pl. 16 , figs. 17,31 .

Loc. Burlington, Iowa; Warren, Pennsylvania.

CHONOSTROPHIA Hall and Clarke.

Genotype Chonetes reversa Whitfield. Chonostrophia Hall and Clarke, Pal. New York, VIII, Pt. I, 1892, p. 310;Eleventh Ann. Rep. New York State Geologist, 1894, p. 294.

Chonostrophia complanata Hall.

Oriskauy (Dev.).

Chonetes complanata Hall, Tenth Rep. New York State Cab. Nat. Hist., 1857, p. 56 ;-Pal. New York, III, 1859, p. 418, pl. 93, fig. 1 ; - Second Ann. Rep. Now York State Geol., 1883, pl. 47, figs. 13, 29.

Chonostrophia complanata Hall and Clarke, Pal. New York, YIII, Pt. I, 1892, p. 311 , pl. 16, tigs. $13,29$.

iStrophomena sp. A, A. Ulrich, N. Jahrb. f. Mineral., Beilageband, V1II, 18:2, p. 70, pl. 14, fig. 24 ( $\$ 23)$.

Loc. Albany and Schoharie counties, New York; Cayuga, Ontario ; Cumberland, Maryland; ? Bolivia.

Chonostrophia dawsoni (Billings).

Lower Devonian.

Chonetes dawsoni Billings, Pal. Fossils, II, 1874, p. 18, fig. 8.

Chonostrophit dawsoni Hall and Clarke, Pal. New York, VIII, Pt. 1, 1892, p. 311 .

Loc. Gaspé and Percé, Quebec, Canada. 
Chonostrophia nelderbergiæ Hall.

Lower Helderberg (Dev.). Chonostrophi: helderbergia Hall and Clarke, Pal. New York, VIII, Pt. I, 1892, pl. 311,353 , pl. 15B, fig. 14.

Loc. Albany County, New York.

Chonostrophia reversa (Whitfield).

Corniferous (Dev.).

Chonetes reversa Whitfield, Annals New York Acad. Sci., II, 1882, P. 213; lbidem, V, 1891, p. 549, pl. 11, tigs. 8, 9;-Geol. OLio, VII, 1895, 1. 443, pl.7, figs. 8,9 .

Chonostrophia reversa Hall and Clarke, Pal. New York, VIII, Pt. I, 1892, p. 311, pl. 15B, figs. 15-19;-'Thirteenth Ann. Rep. New York State Geologist, 1895, p. 176, pl. 4 , fig. 5 .

Loc. Columbus and Delaware, Ohio; Union Springs, New York; Cayuga, Ontario.

CHRISTIANIA Hall and Clarke. Genotype Leptrena subquadrata Hall. Christiania Hall and Clarke, Pal. New York, VIII, Pt. I, 1892, 1). 298;-Eleventh Ann. Rep. New York State Geologist, 1894, 1. 290.

Christiania subquadrata Hall.

Lower Zellerberg (Dev.).

Leptiena subquadrata Hall, Second Amn. Rep. New York State Geol., 1883, pl. 46, figs. 32,33 .

Christiania subquadrata Hall and Clarke, Pal. New York, VIII, Pt. I, 1892, pp. 298, 351 , pl. 15 , figs. 32 , 33 ; pl. $15 \mathrm{~A}$, fig. 36 ; pl. 20, figs. $18-20$.

Loc. Perry and Blount comnties, Tennessee.

CISTELLA Gray.

Genotype Terebratula cuneata Risso.

Cistella Gray, Brit. Mus. Cat. Brach., p. 114.

Cistella beecheri Clark.

Upper Cretaceous.

Cistella beecheri Clark, Johns Hopkins Univ. Cire., XV, 121, 1896, p. 3.

Loc. Viucentown, New Jerses.

Cistella plicatilis Clark.

Upper Cretaceous.

Cistella plicatilis Clark, Johns Hopkins Unir. Cire., XV, 121, 1896, 1. 3.

Loc. Vincentown, New Jersey.

\section{CLEIOTHYRIS King.}

Genotype Atrypa pectinifera J. de C. Sowerby=Spirifer roissyi L'Eveillé=A thyris roissyi of authors.

Cleiothyris King (von Phillips), Mon. Pemian Fossils, Pal. Soc., 1850, p. 137.Hall and Clarke, Pal. New York, VIII, Pt. II, 1893, p. 90;-Thirteenth Ann. Rep. New York State Geologist, 1895, p. 779.

Cleiothyris clintonensis (Swallow).

Kaskaskia (L. Carb.). Spirigera clintonensis Swallow, Truns. St. Louis Acad. Sci., II, 1863, p. 89.

Loc. Chester, Illinois; St. Genevieve and Cooper counties, Missouri.

Obs. Compare with C. roissy. Regarded by Keyes as a synonym for Seminula subquadrata. However, this species does not appear to be a Seminula.

Cleiothyris crassicardinalis (White).

Kinderhook (L. Carb.). Athyris crassicardinalis White, Jour. Boston Soc. Nat. Hist., VII, 1860, p. 229.

Loc. Burlington, Iowa.

Cleiothyris hirsuta Hall.

St. Louis and Kaskaskia (L. Carb.). Spirigera (Athyris) hirsuta Hall, Trans. Albany Lustitute, IV, 1858, 1. 8.

Athyris hirsuta Whitfield, Bull. American Mus. Nat. Hist., I, 1882, p. 19, pl. 6, figs. 18-21.-Hall, Twelfth Rep. State Geol. Indiana, 1883, p. 328, pl. 29, figs. $18-21$. 
Cleiothyris hirsuta Hall-Continued.

Cliothyris hirsuta IIall and Clarke, 1'al. New York, VIlI, 1’t. II, 1895, 11. 46, ligs. $25-28$.

Loc. Spergen Hill, Indiana; Alton and Chester, Illinois; Princeton, Kentucky; Montana.

Cleiothyris missouriensis (Swallow).

Upper Carboniferous.

Spirigera nissonriensis Swallow, Trans. St. Lonis Acad. Sei., 1, 1860, 1) 650.

Loc. Montgomery and Chariton comnties, Missonri.

Cleiothyris obmaxima (McChesney).

Keokuk (L. Carb.).

Athyris obmaxima MeChesney, Descriptions New Pal. Foss., 1861, p. 80.

ISpirigera obmaxima White, Wheeler's Expl. Survey west 100 Meril., IV, 1875, p. 92, pl. 5 , fig. 12.

Loc. Nanvoo anıl Warsaw, Illinois; Keokuk, Iowa; Mountain Spring, Nevada; Ophir City, Utah.

Obs. The specimen figured by White may be Athyris incrassata Hall.

\section{Cleiothyris obvia (MeChesney).}

Kaskaskia (1. Carb).

Athyris obvia McChesn'y, Descriptions New Pal. Foss., 1861, p. 81.

Loc. Kaskaskia, Illinois.

Obs. Probably a synonym for C. roissyi.

\section{Cleiothyris orbicularis (McChesney).}

Upper Carboniferons.

Athyris orbicularis McChesney, Deseriptions New Pal. Foss., 1860, p. 47.

Loc. "Extensively distribnted in the Western States."

Obs. Specimens of this species in the United States National Museum donated by Professor Worthen show it to be a Cleiothyris.

Cleiothyris reflexa (Swallow)..

Warsaw (1. Carb.).

Spirigera reflexa Swallow, Trans. St. Louis Acad. Sei., II, 1863, p. 88.

Loc. Barretts Station, St. Lonis County, Missouri.

Obs. Should be compared with C. roissyi. Regarded by Keyes as a synonyu for

Seminula trinuclea. Swallow's species, however, does not appear to he a Seminnla.

Cleiothyris roissyi (L'T́̀veillé).

Keokuk-Kaskaskia (1.. Carb.).

Spirifer de roissyi L’Éveillé, Hémoires Soe. Géol. de France, II, 1835, 1’. 39, 11. 2, figs. $18-20$.

Terebratula royssii Marcou, Geol. North America, 1858, p. 51, pl. 6, fig. 10.

Athyris sublamellosa Hall, Geol. Survey Iowa, I, Pt. II, 1858, p. 702, pl. 27, fig. 1.-Derby, Bull. Cornell Univ., I, 1874, p. 10, pl. 2, tigs. 9-12; pl. 3, figs. $15-21,29$; pl. 6 , fig. 16 ; pl. 9 , figs. 5,6 .

Athyris parvirostris Meek and Worthen, Proc. Acad. Nat. Sci. Philadelphia, 1860, p. 451 .

Spirigera americana Swallow, Trans. St. Lowis Acad. Sci., II, 1863, p. 89. Spirigera pectinifera Swallow (non Sowerby), Ibidem, 1863, p. 88.

Athyris planosuleata Geinitz (non Phillips), Carbon u. Dyas in Nebraska, 1866, p. 42.-Meek and Worthen, Geol. Survey Illinois, Il, 1866, p. 254, pl. 18, fig. 8 .

Spirigera planosulcata? White, Wheeler's Rep. Geogr. Geol. Expl. Survey west 100 Merid., IV, 1875, p. 143, 1). 10, fig. 5.

Athyris planosnleata? Hall and Whittield, King's [T. S. Geol. Expl. 40th Parl., IV, 1877 , p. 257 , pl. 4, figss. 10, 11.

?Athyris roissyi Neek, Ibidem, 1877, p. 82, pl. 9, fig. 3 .

Athyris hirsuta Walcott, MIon. U. S. Geol. Survey, VIII, 1884, p. 222, pl. 18, fig. 5. Cliothyris roysii IIall and Clarke, Pul. Now York, VIIl, Pt. 1I, 1893, p. 91, pl. 46 , figs. 23,$24 ;$ pl. 84 , fig. 32 . 
Cleiothyris roissyi (L'Éveillé)—Contiuued.

Cliothyris sublamellosa Hall and Clarke, Ibiclem, 1893, p. 91.

Loc. Europe; Mississippi Valley; White Pine and Eureka districts, Nevada; Salt Lake City, etc., Utah; Lake Valley mining district, etc., New Mexico; Lake County, Colorado; Guatemala; Bomjardin and Itaituba, Brazil.

Obs. American specimens nsually referred to this species are constantly smaller and are often without sinus or folıl. If these differences are regarded as of sufficient importance to distinguish American specimens from typical C. roissyi then this species will be known as C. sublamellosa Hall. Of Spirigera americana Swallow, authentic specimens have been seen by the writer in Professor Hall's collection. These are identical with Athyris sublamellosa.

Meek's Athyris roissyi (1877) will probably prove to be a new species of Seminula.

See C. clintonensis, C. reflexa Swallow, and C. obvia McChesnes.

Cleiothyris squamosa (Worthen).

St. Louis (L. Carb.).

Athyris squamosa Worthen, Bull. Illinois State Mus. Nat. Hist., 2, 1884, p. 24;Geol. Survey Illinois, VIII, 1890, p. 103, pl. 11, fig. 2.

Loc. Monroe County, Illinois.

CLINTONELLA Hall and clarke.

Genotype C. vagabunda Hall and Clarke.

Clintonella Hall and Clarke, Pal. New York, VIII, Pt. II, 1893, p. 159:-Thirteenth Ann. Rep. New York State Geologist, 1895, p. 814.

Clintonella vagabunda Hall and Clarke.

Clinton (Sil.).

Clintonella vagabunda Hall and Clarke, Pal. New York, VIII, Pt. II, 1893, p. 160, 1). 52, figs. 1-11.

Loc. ?Orleans County, New York.

CLITAMBONITES Pander.

Genotype Pronites adscendens Pander.

Klitambonites Pander, Beitrage zur Geognosic des Russischen Reiches, 1830, 1. 70 , pl. 3, fig. 14; pl. 28, figs. 16,17 .

Clitambonites Ehlert, Fischer's Mannel de Conchyliologie, 1887, p. 1289, fig. 1059.-Hall and Clarke, Pal. New York, VIII, Pt. I, 1892, p. 233.-Winchell and Sehuchert, Minuesota Geol. Survey, III, 1893, p. 377.-Hall and Clarke, Eleventh Ann. Rep. New York State Geologist, 1891, p. 274.

Clitambonites adscendens (? Pander).

Ordovician.

Orthisina adscendens (Pander) Kayser, Paleontographica, Snppl., III, 1876, p. 20, pl. 2, figs. 9-11.

Loc. Europe; Juan l'obre and Laja, Cordillere San Jnan, Argentine Rejublic. Obs. This identification is probably erroneous.

Clitambonites(?) borealis (Castelnau).

"Magnesian limestone" = ? Galena (Ord.).

Tereloratula borealis Castelnau, Essai Syst. Sil. l'Amériłne Septentrionale, 1843, p. $40, \mathrm{pl} .14$, fig. 14 .

Terebratula turpis de Verneuil, Ibilem, 1843, p. 40, footnote.

Loc. "Magnesian limestone of Green Bay, Wisconsin."

Obs. The figure is not satisfactory. The species seems to be related to C. dirersus Shaler.

Clitambonites diversus (Shaler).

Trenton-Lorraine (Ord.).

Orthisina diversa Shaler, Bull. Mus. Comp. Zool., 4, 1865, p. 67.

Orthisina renenili Billings (non Eichwald), Catalogue Sil. Foss. Anticosti, 1866, pp. 43,74 .

Ilemipronites americanus Whitfield, Ann. Rep. Geol. Survey Wisconsin, 1877, p. 72;-Geol. Wisconsin, IV, 1882, p. 243, pl. 10, figs. 15-17. 
Clitambonites diversus (Slıaler)-Contimucl.

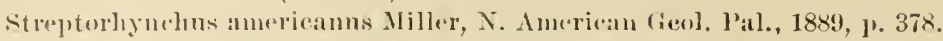

('litimbonites americanus Hall and ('larke, Pal. Xew lork, V'lll, 1’t. 1, 1892, 1. 23s, 11. 1.is, figs. 1-8.

Clitambonites diversa Winchell and Sehnehert, Minnesota Geol. Survey, III, 1893, 1. 378, 11. 30, figrs. 11-17.-. Whiteaves, Pal. Fos., III, I’t. III, 1897, ]. 166 .

Loc. Anticosti; Cannom Falls, Kenyon, ete., Minuesota; Oshkush, Wisconsin; Ottawa and Lake Wimipeg, Canala.

(obs. See C. borealis.

Clitambonites diversus altissimus Winclıell and Sehnchert. 'Trenton (Ord.).

Clitamhonites americamus var. Hall and Clarke, Pal. New York, VIII, l’t. I, 1892, pl. $15 \mathrm{~A}$, figs. 7,8 .

Clitambonites diversa var. altissima Wimehell and Schuchert, Minuesota Geol. Survey, III, 1893, p. 381, pl. 30, figs 18, 19.

Loc. Near Camon Falls, Minuesota.

Clitambonites (?) johannensis Matthew.

Upper Uambrian.

Orthisina johaunensis Matthew, Traus. Royal Soc. Canala, IX, 1892, 11. 49, pl. 12, figs. $13 \mathrm{a}-13 \mathrm{e}$.

Loc. Near St. John, New Brunswiek.

Clitambonites planus retroflexus (de V'ernenil).

Lower Ordovicianl.

Gonambonites plana var. retroflexi de Vernenil, Beitrage zur Geoguosie des Russisehen Reiches, 1830, p. 77, pl. 25, figs. 1, 2.

Clitambonites (Gonambonites) plaua var. retrotlexa Matthew, Traus. Roy. Sor. Canada, 21 ser., 1, 1896, 1. 266, 1, 1. 2, tigs. 1a-1c.

Loc. Mc. Feei, Cape Breton, Nova Scotia.

CLORINDA Barrande.

Genotype C. armata Barrande.

Clorinda Barrancle, Systime Silurien Bohème, V, 1879.

Barrandella IJall and Clarke, Pal. New York, VIII, Pt. 1I, 1893, pp. 241, 243;Thirteenth Ann. Rep. New York State Creologist, 1895, p. 814.

Clorinda arcuosa (McChesney).

Niagara (Sil.).

Pentamerus arenosus 11 chesney, Deseriptions New Pal. Foss, 1861, p. 87.

Loc. Nilwankee, Wisconsin.

Clorinda areyi (Hall and Clarke).

Clinton (Sil.).

Barrandella areyi Hall and Clarke, Pal. New York, VIII, Pt. II, 1895, pl. 242, 368 , pl. 71, figs. 11-16.

Loc. Rochester, New lork.

Clorinda barrandei (Billings).

Anticosti (Sil.).

Pentamerus barrandi Billings, Geol. Survey Canada; Rep. l'rogress for 1856, 1857 , 1. 296;-Geol. Canada, 1863, p. 316, fig. 327.

Barraudella barrandii Itall and Clarke, Pal. New York, VIll, Pt. Il, 1893, p. 243, fig. $174 ;$ pl. 71 , figs. $17-20$.

Loc. Anticosti.

Clorinda fornicata (Hall).

Clinton and Niagara (Sil.).

Pentamerus fornicatus Hall, Pal. New lork, II, 1852, 1. 81, pl. 24, fig. 7.

Jentamerus fornicatus var. I Iall, Descrip. u. sp. Fossils, Waldron, Indiana, 1879, 1. 16;-Eleventh Rep. State Geol. Indiana, 1882, p. 299, pl. 27, fig. 15;Trans. Albany Institute, X, 1883, p. 72.

Barrandella fornicata Hall and Clarke, Pal. New York, VIII, l’t. 1I, 18413, 1'.243, 11. 70, figs. 11-13.

Loc. Lockport, New lork; Waldron, Indiana; Wisconsin. 
Clorinda ventricosa ( $\left.\mathrm{H}_{\mathrm{al}} \mathrm{ll}\right)$.

Niagara (Sil.).

Jentamerus ventricosa Hall, Geol. Survey Wisconsin; Rep. Progress, 1860, p. 2.Whitfield, Geol. Wisconsin, IV, 1882, p. 291, pl. 17, figs. 11-13.-Nettelruth, Kentucky Fossil Shells, Mem. Kentucky Survey, 1889, [’. 64, pl. 33, figs. 12-14.

Pentamerus chicagoensis Winchell and Marcy, Mem. Boston Soe. Nat. Hist., I, 1865, 1. 94, pl. 2, fig. 11.-Hall, 'Twentieth Rep. New York State Cab. Nat. Hist., 1868 , p. 392.

Pentamerus (Pentamerella?) ventricosa Hall, Twentieth Rep. New York State Cab. Nat. Hist., 1868, p. 374, pl. 13, figs. 18-21.

Pentamerus (Pentamerella) ventricosns Hall and Whitield, PaI. Ohio, II, 1875, p. 138, pl. 7 , figs. 7,8 .

Barrandella ventricosa Hall and Clarke, Pal. New York, VIII, Pt. II, 1893, p. 243 , pl. 71 , tigs. $4-10$; pl. 84 , fig. 46.

Loc. Waukesha, Wisconsin; Bridgeport, Illinois; Lonisville, Kentucky; Ohio.

Caelospira Hall=Anoplotheca.

Cœlospira concava Hall 1867 (not 1863)=Anoplotheca camilla.

Cœlospira disparilis Hall=Atrypina disparilis.

CONCHIDIUM Linné.

Genotype C. biloculare Linné.

Conchidium Linné, Museum Tessinianum, 1753, p. 90 ;-Systema Nature, erI. xi, II, 1760, p. 163.-CEhlert, Fischer's Manuel de Conchyliologie, 1887, p. 1311.-Hall and Clarke, Pal. New York, VIII, Pt. II, 1893, p. 231 ;-Thirteenth Ann. Rep. New York State Geologist, 1895, p. 842.

Helmintholitus Linné, Systema Natura, ed. xii, [V, 1766, ]. 163.

Pentamerns Sowerby (non Pentamera Dumeril, 1806), Mineral Conchology, I, 1813 , p. 73.

Gypidia Dalman, Kongl. Svenska Vet.-Akad. Handl., für 1827, 1828, pp. 93, 100. Pentamerus Billings, Canadian Jour., VI, 1861, p. 269.-Hall, Twentieth Rep. New York State Cab. Nat. II ist., 1867, 1. 163;-Pal. New York, IV, 1867, l'l. 369, 373.-Nettelroth, Kentucky Fossil Shells, Mem. Kentucky Geol. Survey, 1889 , p. 52.

Antirhynchonella Quenstedt, Petref. Deutschlands, Brach., 1871, 1. 231.

Zdimir Barrande, Système Silurien Bohème, VI, 1881, p. 171.

Conchidium biloculare Linné.

Silurian.

Conchidium biloculare Linne, Systema Natura, ed. xi, II, 1760, p. 163.-Hall and Clarke, Pal. New York, VIII, l’t. II, 1893, p. 233, pl. 6, figs. 11-14.

Pentamerus couchidium Emmerson, Geol. Frobischer bay; Nourses Narr. Ilall's Aretic Exped., 1879, p. 578.

Loc. Europe; Rescue Harbor, Arctic America.

Conchidium colletti (Miller).

Waterlime (Sil.).

Petamerus colletti Miller, Seventeenth Rep. State Geol. Indiana, 1891, p. 77, pl. 13 , figs. 5,6 .

Conchidinm colletti Hall aud Clarke, Pal. New York, V'III, Pt. II, 1893, p. 235, pl. 66 , figs. 16,17 .

Loc. Kokomo, Indiana.

Obs. Compare with C. laqueatum Courad.

Conchidium crassiplica Hall and Clarke.

Niagara (Sil.).

Conchidium crassiplica Hall and Clarke, Pal. New York, VIIl, Pt. II, 1895, pp. 235,369 , pl. 66 , figs. $24,25$.

Loc. ?Near Louisville, Kentucky.

Conchidium crassiradiatum (McChesney).

Niagara (Sil.).

Pentamerus crassoradius McChesney, Descriptions New Pal. Foss., 1861, p. 87.

Loc. Milwaukee, Wisconsin. 
Conchidium decussatum (Whiteaves).

Silnrian.

Pentanerus decussatus Whiteaves, Cinulian hecord of Science, 1891, p. 295, pl. 3, figs. 3, 1.-Calvin, Bnll. Lal. Nat. Hist. State Univ. Iowa, XI, 1892, p. 164, pl. 11, figs. 1-3; pl. 12, tig. 2.

Conchidinm decussatum Ilall aud Clarke, I'al. New York, V'III, I't. II, 1893, p. 235 , pl. 65, figs. 1, 2; pl. 66, fig. 15.

Loc. Graul Rapids of the Saskatchewan, ete., Caurda.

Conchidium exponeum Hall and Clarke.

Niagara (Sil.).

Conchilium exponeus Ifall and Clarke, Pal. Now York, VIII, Pt. II, 1895, 11. 66, figs. $6-9$.

Loc. Louisville, Kentucky.

Conchidium georgiæ Hall and Clarke.

Clinton (Sil.).

Conchillium georgi: IIall and Clarke, Pal. New York, VIII, Pt. II, 1895, 1). 369, pl. 66 , figs. $18,19$.

Loc. Trenton, Georgia.

Conchidium greenei Hall and Clarke.

Niagara (Sil.).

Conchidium greenii Hall and Clarke, Pal. New York, VIII, Pt. II, 1895, pp. 235, 368 , pl. 66, figs. 20-22.

Loc. Near Milwaukee, Wisconsin.

Conchidium knappi (Hall and Whitfield).

Niagara (Sil.).

Pentamerus knappi Hall and Whitfiell, Twenty-fourth Rep. New York State Cab. Nat. Hist., 1872, p. 184.-Nettelroth, Kentucky Fossil Shells, Mem. Kentucky Geol. Survey, 1889, p. 55, pl. 28, figs. 1-4.

Pentamerns? knappi Hall and Whitfield, Twenty-seventh Rep. New York State Cab. Nat. Hist., 1875, pl. 10, figs. 10-12.

Conchidium knappi Hall and Clarke, Pal. New York, VIII, Pt. 11, 1893, p. 235, pl. 64, figs. 11-13.

Loc. Louisville, Kentucky

Conchidium knighti (Nettelroth).

? Corniferous (Dev.).

Pentamerus knighti Nettelroth (nou Sowerby), Kentucky Fossil Shells, Men. Kentucky Geol. Survey, 1889, p. 57, pl. 29, figs. 1, 2, 17.

Conchidinm nettelrothi Hall anl Clarke, Pal. New York, VIII, Pt. II, 1893, p. 234, pl. 64, figs. 14-16.

Loc. Louisville, Kentueky.

Obs. This species is very much like C. nysins and may be identical with it (Ami says that C. knighti occurs in the Upper Silurian at Arisaig, Nova Scotia).

Conchidium laqueatum (Conrad).

Niagara (Sil.).

Pentamerus laqueatns Conrad, Proc. Acad. Nat. Sci. Philadelphia, VII, 1855, p. 441.

Pentamerus wobilis Emmons, Maunal of Geol., 1860, p. 107, figure.

Conchidium laqueatus Hall and Clarke, Pal. New York, VIlI, Pt. II, 1893, p. 232, fig. 168 ; p. 23เ, pl. 65, figs. 3-9.

Loc. Delphi, Indiana.

Conchidium littoni Hall.

Niagara (Sil.).

Pentamerus littoni Hall, Pal. New York, III, 1859, p. 262.-Hall and Whitfield, Twenty-fourth Rep. New York State Cab. Nat. IIist., 1872, p. 186 ;-Twentyseventh Rep. Ibidem, 1875, pl. 10, figs. 8, 9.-Nettelroth, Kentucky Fossil Shells, Mem. Kentucky Geol. Surves, 1889, p. 5९, pl. 27, figs. 12, 13.

Conchidium littoni Hall and Clarke, Pal. New York, VIII, Pt. II, 1895, pl. 64, figs. $9,10$.

Loc. Hardin County, Tennesser; Louisville, Kentucky. 
Conchidium multicostatum IIall.

Pentamerus multicostatus IIall, Geol. Survey Wiscousin; Rep. Progress, 1860, p. 1;-Twentieth Rep. New York State Cab. Nat. Hist., 1867, p. 373, pl. 13, figs. 22-24.

Conchidium multicostatum Hall and Clarke, Pal. New York, VIIl, I’t. II, 1895, pl. 64 , fig. 6 ; 11. 66 , fig. 10 .

Loc. Wanwatosa and Wankesha, Wisconsin.

Conchidium nettelrothi Hall and Clarke=C. knighti.

Conchidium nysius (Hall and Whitfield).

Niagara (Sil.).

Pentamerus nysius var. crassicosta Hall and Thitfield, Twenty-fourth Rep. New

York State Cab. Nat. Hist., 1872, 1. 184;-Twenty-seventh Rep. Ibidem, 1875, pl. 10, figs, 4-7.-Nettelroth, Kentucky Fossil Shells, Mem. Ǩentucky

Geol. Survey, $18 \times 9$, p. 60, pl. 28 , figs. $5-8$.

Pentamerus nysius var, tenuicostatus Nettelroth, Ibide_a, 1889, p. 60.

Conchidium nysius Hall and Clarke, Pal. New York, VIII, Pt. II, 1893, 1. 235, 1. 61 , figs. $1,8,27$.

Loc. Lonisville, Kentucky.

Obs. See C. tenuicostatum.

Conchidium obsoletum Hall aud Clarke.

Niagara (Sil.).

Conchidium obsoletum Hall and Clarke, Pal. Now York, VIII, I't. II, 1895, pl. 67 , figs. 8,9 .

Loc. Genoa, Ottawa County, Ohio.

Conchidium occidentale Hall.

Guelph (Sil.).

Pentamerus occidentalis IIall, Pal. New York, II, 1852, p. 341, pl. 79, figs. 1, 2.Billings, Geol. Canada, 1863, 1. 337, fig. 3+1.-Nicholson, Pal. Prov. Ontario, 1875, p. 67, fig. 35. - Whitfield, Geol. Wisconsin, IT, 1882, p. 314, pl. 17, fig. 10 ; pl. 23, figs. 1, 2.-Hall and Clarke, Pal. New York, YIII, Pt. II, 1893, p. 239.

Conchidium(?) occidentalis Hall and Clarke, Ibidem, 1895, pl. 67, figs, 1-5.

Loc. Gault and Guelph, Ontario; Point St. Vital, Lake Hurou; Williamstown, Wisconsin.

Conchidium(?) salinense (Swallow).

"Base of Chemung" (Dev.).

Pentamerus salinensis Swallow, Traus. St. Louis Acad. Sci., I, 1860, 1. 652.Keyes, Geol. Survey Missouri, 'V, 1895, p. 104.

Loc. Moniteau County, Missouri.

Obs. The geological horizon is probably Corniferous or Hanilton.

Conchidium scoparium Hall and Clarke.

Guelph (Sil.).

Conchidium scoparinm Hall and Clarke, Pal. Now York, VIII, Pt. II, 1895, pl. 67 , figs. 6,7 .

Loc. Durham, Ontario.

Conchidium tenuicostatum (Hall and Whitfield).

Niagara (Sil.).

Pentamerus nysius var. tenuicosta Hall and Whitfield, Twenty-fourth Rep. New York State Cab. Nat. Hist., 1872, 1. 184;-Twenty-seventh Rep. Ibidem, 1875, pl. 10, figs. 1-3.

Pentamerus complanatus Nettelroth, Kentucky Fossil Shells, Mem. Kentncky Geol. Survey, 1889, p. 53, pl. 27, figs. 14-16.

Conchidium tenuicostatns Hall and Clarke, I'al. New York, VIlI, I't. Ii, 1893, p. 235, pl. 64 , figs. $3-5$.

Loc. Louisville, Kentucky.

Obs. P. nysins is described as consisting of two varieties. If these varieties are species, as pointed out by Nettelroth, then P. nysius will be based upon and supplant variety crassicosta, while variety tenuicosta must be elevated to specifie rank. 1. complanatus Nettelroth, therefore, becomes a synonym for C. tenuicostatum, as both are established upon the same specimens. 
Conchidium unguiforme (Ulrich).

Niagara (Sil.).

(ivjidlia nugniformis Ulrich, Contrib. Amerienu Pal., 1×86, p. 228, pl, 3, fig. 2.

Gypidula unguiformis Miller, N. Ameriwan (ieol. Pal., 1859, p. 346.

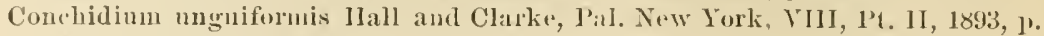
235, 11. 66, figs. 1-4.

Loc. Lonisville, Kenturky.

CONOTRETA Walcott.

Geuotype C. rusti Walcott.

('onotreta Walcott, I'roe. I\% S. Nat. Mus., XII, 1890, 1. 365 (extract 1889).Hall and Clarke, P'al. New York, VIII, Pt. I, 1892, p1. 104, 167;-Eleventh Ann. Rep. New York State Geologist, 1891, 1. 250.

Conotreta rusti Walcot $t$

Trenton (Ord.).

Conotreta rusti Waleott, Proc. U. S. Nat. Mus., XII, 1890, 1. 365, figs. 1-4 (extract 1889). - Hall and Clarke, Pal. New York, VIII, Pt. I, 1892, p. 104, pl. 4K, figs. 16-21.

Loc. Trenton Falls, New York; Covington, Kentucky.

Conradia Hall and Clarke (non Adams)=Dinobolus.

CRAN ÆNA Hall and Clarke. Genotype Terebratula romingeri Hall.

Cranæena Hall and Clarke, Pal. New York, VIII, Pt. 1I, 1893, 1. 297; - Thirteenth Ann. Rep. New York State Geologist, 1895, p. 865.

Cranæna iowensis (Calvin).

Middle Deronian.

Terebratula (Cryptonella) iowensis Calvin, Bull. Lak. Nat. Hist. Univ. Iowa, I, 1890, p. 174 , pl 3, fig. 4 .

Cranzena iowensis Hall and Clarke, Pal. New York, VIII, Pt. II, 1893, p. 297, pl. 80 , figs. $36-39$; pl. 83 , tig. 10.

Loc. Fayette, Iowa; Fulton, Missouri.

Cranæna romingeri Пlall.

Hamilton (Dev.).

Terebratula romingeri Hall, Sixteenth Rep. New York State Cah. Nat. Hist.: 1863, 1. 48, figs. 22, 23;-Yal. New York, IV, 1867, p. 389, pl. 60, figs. 17-25, 66, 67.-Nettelroth, Kentueky Fossil shells, Mem. Kentucky Geol. Survey, 1889 , p. 155, pl. 16, tigs. 20-22.

Crantena romingeri Hall and Clarke, Pal. New York, TIII, Pt. 11, 1893, p. 297, tig. 215 ; pl. 80, figs. 13-19.

Loc. Thunder Bay, Michigan; Waterloo, Inwa; York aud Hamburg, New York; Clarke County, Indiana.

CRANIA Retzius.

Genotype Anomia craniolaris Linné.

Crania Retzius, Schrift. Ges. Naturf. Freuude, Berlin; II, 1781, 1. 7?.-Dall, Bı11. Mns. Comp. Zool., III, 1871, p. 27 ;-Bull. U. S. Nat. Mns., 8, 1877, p.21.Nettelroth, Kentucky Fossil Shells, Mem. Kentucky Geol. Snres, 1889, p. 31.-Hall and Clarke, I'al. New York, VIII, Pt. I, 1892, pp. 145, 169.-Winehell and Schnehert, Minnesota Geol. Surver, III, 1893, p. 372.-IFall and Clarke, Eleventh Auн. Rep. New York State Geologist, 1894, p. 260.

Crania acadiensis IIall.

Arisaig (Sil.).

Crania aeadiensis Hall, Canadian Nat. Geol., V, 1860, p. 144, fig 1.-Dawson, Acadian Geol., $3 d$ ed., 1878, p. 595, fig. 198.

Loc. Last River, Nova Scotia.

Crania agaricina Hall and Clarke.

Lower Helderberg (Dev.).

Crania agaricina Hall and Clarke, Pal. New York, VIII, Pt. I, 1892, p. 180, pl. $4 \mathrm{H}$, fig. 2.

Loc. Albany County, New York; Decatur County, Teunessee.

Crania albersi Miller and Faber.

Utica (Orl.).

Crania albersi Miller aud Faber, Jour. Cincinnati Soc. Nat. Hist., XVII, 1894, p. 154, pl. 8, figs. 17-19.

Loc. Cincinnati, Uhio. 
Crania alternata James $=$ C. scabiosa.

Crania anna Spencer.

Niagara (Sil.).

Crania anua Spencer, Bull. Univ. Missouri, I, 1884, p. 57;-Trans. St. Louis Acad. Sci., IV, 1886, p. 607, pl. 8, fig. 4.

Loc. Hanilton, Ontario.

Crania asperula James $=$ C. seabiosa.

Crania aurora Hall.

Schoharie Grit (Dev.).

Crania anrora Hall, Sixteenth Rep. New York State Cab. Nat. Hist., 1863, p. 30 ;-Pal. New York, IV, 1867, p. 27, pl. 3, fig. 12.

Loc. Knox, Albany County, New York.

Crania bella Billings.

No. 5 Gaspé Series (?Dev.). Crania bella Billings, Pal. Fossils, II, 1874, p. 15, fig. 5 .

Loe. Cape Bon Ami, Gaspé, Canada.

Crania blairi Miller $=$ C. rowleyi.

Crania bordeni Hall and Whitfield $=$ C. sheldoni.

Crania carbonaria Whitfield $=\mathrm{C}$. modesta.

Crania centralis Hall.

Portage (Dev.).

Crania centralis Iall, Pal. Now York, V, Pt. II, 1879, pl. 88, fig. 2.

Loc. Watkins, New York.

Crania chesterensis Miller and Gurley.

Kaskaskia (L. Carb.).

Crania chesterensis Miller and Gurley, 1311l. Illinois State Mus. Nat. Hist., 12, 1897, p. 47, pl. 3, figs. 24-26.

Loc. Chester, Illinois.

Crania(?) columbiana Walcott.

Middle Cambrian.

Crania? columbiana Wralcott, Proc. U. S. Nat. Mus., XI, 1888, p. 441.-Hall and Clarke, Pal. New York, VIII, Pt. I, 1892, p. 150.

Loc. Mount Stephan, British Columbia.

Obs. Probably a species of Acrotreta.

Crania costata James $=$ C. scabiosal.

Crania crenistriata Hall.

Corniferous and Hamilton (Dev.).

Crania crenistria 1Iall, Thirteenth Rep. New York State Cal. Nat. Hist., 1860, 1. 78, fig. 6, on P. 76 ; - Pal. New York, IV, 1867, 1. 28, pl. 3, figs. 13-16.-Hall and Clarke, Ibidem, VIII, Pt. I, 18!2, pl. 4H, figs. 6-12.

Loc. Alexander, etc., New York; Columbus, Ohio; Louisrille, Kentucky; Alpena, Michigan.

Obs. See C. sheldoni White.

Crania(?) deformata (Hall).

Chazy (Ord ).

Orbicula? deformata Hall, Pal. New York, I, 1817, p. 23, pl. 4 bis, fig. 10.

Crania q deformata Miller, N. American feol. Pal., 1889, p. 341.-Hall and Clarke,

Pal. New York, YIII, Pt. I, 1892, 1) 150.

Loc. Chazy, New York.

Obs. This species is not well establisherl and harl better be lropped since the type specimen does not preserve the generic or specific characters.

Crania dentata Ringueberg.

Niagara (Sil.).

Crania dentata Ringueberg, Bull. Buftalo Soc. Nat. Sei., V, 1886, 1. 16, pl. 2, fig. 6.

Lor. Loekport, New York.

? Crania dubia Foerste.

Clinton (Sil.).

? Crania dubia Foerste, GeoI. Ohio, VII, 1895, p. 565, pl. 37, fig. 17.

Loc. Dayton, Ohio.

Obs. May not be a brachiopod. 
Crania dyeri Miller.

Utica (Ord.).

Crania dyeri Mliller, Cincinnati Qnart. Jour. Sei., II, 1875, p. 13, fig. 3.

Loc. Cincinnati, Ohio.

Crania famelica Hall and Whitfield.

Hamilton (Dev.).

Crania famelica llall and Whitfield, Deseriptions n. 8p. Fossils, 1872, p. 17, pl.

11, fims. 6, 7;-Twenty-thirl Rop. Now York State Cab. Nat. Hist., 1873, p. 236 , pl. 11 , tigs. 6,7 .

Loc. Cerro Gorlo, Iowa; Callaway County, Missouri.

Obs. Compare with Craniclla hamiltonise Hall.

Crania favincola Hall and Clarke.

Middle Devonian.

Crania favincola Hall and Clarke, Pal. New iork, VIII, Pt. I, 1892, p. 180, pl.4H, fig. 33.

Loc. Crab Orchard, Kentucky.

Crania gracilis Ringueberg.

Niagara (Sil.).

Crania gracilis Ringneberg, Bull. Buffalo Soc. Nat. Sci. V, 1886, p. 17, pl. 2, fig. 7. Crania pannosa Ringueberg, Ibidem, 1886, p. 17, pl. 2, fig. 8 .

Loc. Lockport, Niew York.

Obs. Species of Crania are rery variable in shape, and since both forms are attached to one Orthoceras, it is probable that bnt a siugle species is here represented.

Crania granosa Hall and Clarke.

Hamilton (Dev.).

Crania granosa Hall and Clarke, Pal. New York, VIll, Pt. I, 1892, p. 180, pl. 4H, figs. $19,20$.

Loc. Centerfield, New York.

Crania granulosa N. H. Winchell.

Trenton (Ord.).

Crania grannlosa N. H. Winchell, Eighth Aun. Rep. Geol. Nat. Hist. Survey

Minnesota, 1880, 1. 63.-Winchell and Schuchert, Minnesota Geol. Snrvey, I11, 1893, p. 373, pl. 29, figs. 34, 35.

Loc. Minneapolis, Minnesota.

Crania gregaria Hall=Craniella hamiltonia.

Crania greenei Miller.

Upper Helderberg (Dev.).

Crania greenii Miller, Eighteenth Ann. Rep. Geol. Survey Indiana, 1894, p. 310, pl. 9 , fig. 7 .

Loc. Falls of Ohio.

Obs. Probably the same as Craniella hamiltonia.

Crania halli Sardeson=Craniella ulrichi.

Crania hamiltonìe Hall=Craniella hamiltonia.

Crania lælia Hall.

Utica and Lorraine (Ord.).

Crania lelia Hall, Deseriptions n. sp. Crinoidea and other Fossils, 1866, p. 13;Twenty-fourth Rep. New York State Cab. Nit. Hist., 1872, p. 220, pl. 7, fig. 16.-Miller, Cincinnati Quart. Jour. Sci., II, 1875, p. 12.-Hall and Whitfield, Pal. Ohio, II, 1875, p. 75, pl. 1, fig. 16.-Hall and Clarke, Pal. New York, VIII, Pt. I, 1892, pl. 4H, fig. 1.

Loc. Cincinnati and Oxford, Ohio; Richmond, Incliana.

Crania lævis Keyes.

Chonteau (L. Carb.).

Crania lievis Keyes, Geol. Survey Missouri, V, 1895, p. 40.

Loc. Lonisiana, Missonri.

Crania leoni Hall.

Portage and Chemung (Dev.).

Crania leoni IIall, Thirteenth Rep. New York State Cab. Nat. Hist., 1860, p. 78,

figs. 7,8 on p. 76 ;-Pal. New York, IV, 1867, p. 30, pl. 3, figs. 27-30, (925, 26).-

Hall and Clarke, Ibidem, VIII, Pt. I, 1892, pl. 4H, figs. 34, 35.

Loc. Leon, New York. Portage of Ontario County, New York (Clarke). 
Crania modesta White and St. John.

Upper Carboniferous.

Crania modesta White and St. John, Trans. Chicago Acad. Sci., I, 1868, p. 118.-

White, Thirteenth Rep. State Geol. Indiana, 1884, p. 121, pl. 35, fig. 9; pl. 36, fig. 5.

Crania carbonaria Whitfield, Annals New York Acarl. Sci., II, 1882, p. 229;Ibidem, V, 1891, p. 599, pl. 15, figs. 11, 12 ;-Geol. Ohio, VII, 1895, p. 484, pl. 11, figs. $11,12$.

Loc. Fremont County, Iowa; Vermilion and Sullivan counties, Indiana; Carbon Hill, Ohio; Manhattan, Kansas.

Crania multipunctata Milier $=$ C. scabiosa.

Crania pannosa Ringueberg $=$ C. gracilis.

Crania parallela Ulrich $=\mathrm{C}$. seabiosa.

Crania percarinata Ulrich $=$ C. scabiosa.

Crania(?) permiana Shumard.

Upper Carboniferous.

Crania permiana Shumard, Trans. St. Louis Acad. Sci., I, 1859, p. 395.

Loc. Guadalupe Monntains, New Mexico.

Obs. Probably not a Crania.

Crania pulchella Hall and Clarke.

Lower Helderberg (Dev.).

Crania pulchella Hall and Clarke, Pal. New York, VIII, Pt. I, 1892, p. 180, pl. $4 \mathrm{H}$, fig. 3.

Loc. Albany County, New York.

Crania radicans A. Winchell=Strophalosia radicans.

Crania reposita White.

Burlington (L. Carb.).

Crania reposita White, Proc. Boston Soc. Nat. Hist., IX, 1862, p. 30.

Loc. Burlington, Iowa.

Crania reticularis Miller $=$ Trematis reticularis.

Crania(?) reversa Sardeson.

St. Peter (Ord.).

Crania(?) reversa Sardeson, Bull. Minnesota Acad. Nat. Sci., IV, 1896, p. 77, pl. 3 , figs. 6,7 .

Loc. St. Paul, Minnesota.

Crania rowleyi Gurley.

Chouteau (L. Carb.).

Crania rowleyi Gurley, New Carb. Fossils, 1, 1883, p. 3.-Hall and Clarke, Pal. New York, VIII, Pt. I, 1892, pl. 4H, fig. 13.

Crania blairi Miller, Eighteenth Ann. Rep. Geol. Survey Indiana, 1894, p. 310, pl. 9, figs. 5,6 .

Loc. Pike County and Sedalia, Missouri.

Crania scabiosa Hall.

Utica and Lorraine (Ord.).

Crania scabiosa Hall, Descriptions 11. sp. Crinoidea and other Foss., 1866, p. 13 ; Twenty-fourth Rep. New York State Cab. Nat. Hist., 1872, p. 220, pl. 7, fig. 15.-Hall and Whitfield, Pal. Olío, II, 1875, p. 74, pl. 1, fig. 17.-Miller, Cincinnati Quart. Jour. Sci., II, 1875, p. 12.-Hall and Clarke, Pal. New York, VIII, Pt. Y, 1892, p. 148, pl. 4 H, figs. 23-28, 30, 31.

Crania multipunetata Miller, Cincinnati Quart. Jour. Sci., II, 1875, p. 13, fig. 4. Crania percarinata Ulrich, Jour. Cincinuati Soc. Nat. Hist., I, 1878, p. 98, pl. 4, fig. 12.

Crania parallela Ulrich, Ibidem, 1878, p. 98, pl. 4, fig. 13.

Crania asperula James, The Palieontologist, 3, 1879, p. 22.

Crania costata James, Ibidem, 1879, p. 22.

Crania alternata James, Ibiden, 1879, p. 23.

Loc. Cincinnati, etc., Ohio; Indiana; Illinois; Wisconsin.

Obs. The shells of Crania are adapted to theobjects upon which they are cemented. 


\section{Crania scabiosa Hall-Coutinued.}

C. scabiosa has bcen fond growing on Rafinesquina, Strophomena, Rhyn"lonelli, l'leurotomaria, and Mouticulipora. In nearly all cases this species partakes more or less of the ornamentation of its lust. The rariation pointed out by authors is accidental and has no specilic value.

Crania setifera Hall.

Niagara (Sil.).

Crania setifera Hall, 'Trans. Albany Institute, IV, 1863, p. 209 (non Hall, 1866);-

Twenty-eightlı Rep. New York State Mus. Nat. Hist., Doc. ed., 1876, pl. 21, figs. 8-10;-Ibidem, 1879, p. 148, pl. 21, 1igs. 8-10;-Eleventh Rep. State Geol. Indiana, 1882, p. 283, pl. 21, figs. 8-10.-Hall and Clarke, Pal. New York, VIII, Pt. I, 1892, fl. 4H, fig. 18.

Loc. Waldron, Indiana.

Crania setigera Hall.

Trenton and Lorraine (Ord.).

Crania setigera 1lall, Descriptions n. sp. C'rinoidea and other Fossils, 1866, p. 12 ;- Twenty-fourth Rep. New York State Cab. Nat. Hist., 1872, p. 220, pl. 7, fig. 15.-Hall and Clarke, Pal. New York, VIII, Pt. I, 1892, pl. 4H, figs. 11-16.-Winchell and Schuchert, Minnesota Geol. Survey, III, 1893, p. 372, pl. 29, figs. 32,33 .

Loc. Mineral Point and Beloit, Wisconsin; Decorah, Iowa; Minneapolis, Cannon Falls, etc., Minuesota; Wilmington, Illinois.

Crania sheldoni White.

Hamilton (Dev.).

Crania sheldoni White, Proc. Boston Soc. Nat. Hist., IX, 1862, p. 29.

Crania bordeni Hall and Whittield, Twenty-fourth Rep. New York State Cab. Nat. Ilist., 1872, p. 187;-Twenty-seventh Rep. Ibidem, 1875, pl. 9, figs. 36, 37.-Nettelroth, Kentucky Fossil Shells, Mem. Kentucky Geol. Survey, 1889, p. 32, pl. 2, fig. 14.-Hall and Clarke, Pal. New York, VIII, Pt. I, 1892, pl.4H, iigs. 4,5 .

Loc. New Buffalo and Iowa City, Iowa; Falls of Ohio.

Obs. This species may not be distinct from C. crenistria.

Crania siluriana Hall.

Niagara (Sil.).

Crania siluriana Hall, Trans. Albany Institute, IV, 1863, p. 208 ;-Twenty-eighth

Rep. New York State Mus. Nat. Hist., 1879, p. 148, pl. 21, figs. 3-7;-Eleventh

Rep. State Geol. Indiana, 1882, p. 282, pl. 21, figs. 3-7.--Beecher and Clarke, Mem. New York state Mus., I, 1889, p. 13, pl. 1, figs. 1, 2.

Loc. Waldron, Indiana.

Crania socialis Ulrich.

Utica (Ord.). Crania soeialis Ulrich, Jour. Ciucinnati Soc. Nat. Hist., I, 1878, p. 98, pl. 4, fig. 14.-Hall and Clarke, Pal. Now York, VIII, Pt. I, 1892, pl. 4H, fig. 29.

Loc. Cinciunati, Ohio.

Crania spinigera Hall.

Niagara (Sil.).

Crania spinigera Hall, Descriptions u. sp. Foss. Waldron, Indiana, 1879, p. 13 ;-

Eleventh Rep. State Geol. Indiaua, 1882, p. 283, pl. 27, fig. 1;-Trans. Albany Institute, X, 1883, p. 69.-Hall and Clarke, Pal. New York, VIII, Pt. I, 1892, pl. $4 \mathrm{H}, \mathrm{fig} .17$.

Loc. Waldron, Indiana.

Crania trentonensis Hall.

Trenton (Ord.).

Crania trentonensis Hall, Descriptions n. sp. Crinoidea and other Fossils, 1866, p. 12;-Twenty-fourth Rep. New York State Cab. Nat. Hist., 1872, p. 219, pl. 7, figs. 11, 12.-Hall and Clarke, Pal. New York, VIII, Pt. I, 1892, pl.4H, figs. 21, 22.-Winchell and Schuchert, Minuesota Geol. Survey, III, 1893, p. 374 , pl. 29 , figs. 36,37 .

Loc. Middleville, New York; Cannon Falls, Minwesota; Janesville, Wisconsin; Dixon, Illinois. 
CRANIELLA Ehlert.

Genotype C. meduanensis Ehlert.

Craniella Ehlert, Bull. Soc. Etules Scientif. d'Angers, 1888, p. 37.-Hall and Clarke, Pal. New York, VIII, Pt. I, 1892, p1. 153, 170.-Winchell and Schnchert, Mimnesota Gcol. Survey, III, 1893, 1\% 374.- Hall and Clarke, Eleventh Ann. Rep. New York State Geologist, 1894, p. 262.

Craniella(?) clintonensis Foerste.

Clinton (Sil.).

Craniella? clintonensis Foerste, Geol. Ohio, VII, 1895, p. 565, pl. 37, figs. 3a, 3b.

Loc. 'Todds Fork, Ohio.

Craniella hamiltoniæ Hall.

Hanilton (Dev.).

Crania hamiltonise Hall, Thirteenth Rep. New York State Cab. Nat. Hist., 1860, p. 77, figs. 4, 5, on p. 76 ;-Pal. New York, IV, 1867, p. 27, pl. 3, figs. 17-23.Whiteaves, Cont. Canadian Pal., I, 1891, P. 214.

? Crania hamiltonize? Herrick, Bull. Deuison Unir., III, 1888, p. 31, pl. 12, fig. 10. Crania gregaria Hall, Sixteenth Rep. New York State Cab. Nat. Hist., 1863, p. 31 ;-Pal. New York, IV, 1867, p. 29, pl. 3, fig. 24.

Craniella hamiltonice Hall and Clarke, Pal. New York, VIII, Pt. I, 1892, pp. 148, 153 , pl. 41 , figs. $3-16$.

Loc. Cazenovia, Hamilton, etc., New York; Hay and Athabasca rivers, Canada. (Waverly group, Moote Run, Licking County, Obio, according to Herrick.)

obs. See Crania greenei Miller.

Craniella(?) ulrichi Hall and Clarke.

Trenton (Ord.).

Craniella ulrichi Hall and Clarke, Pal. New York, VIII, Pt. I, 1892, pp. 153, 181, pl. 4, figs. 1, 2.

Crania halli Sardeson, Bull. Minnesota Acad. Nat. Sci., III, 1892, p. 328, pl. 4, figs. 8-10.

Craniella? nlrichi Winchell and Schnchert, Minnesota Geol. Survey, III, 1893, p. 375 , pl. 29, figs. 38,39 .

Loc. Minneapolis, St. Paul, and Fountain, Minnesota.

Craniops Hall=Pholidops.

CRYPTACANTHIA White and St. John.

Genotype Waldheimia? compacta White and St. John.

Cryptacanthia White and St. John, Trans. Chicago Acad. Sci., I, 1868, p. 119.Dall, American Jour. Conch., VI, 1870, p. 114.-Hall and Clarke, Pal. New York, VIII, Pt. II, 1893, p. 300 ;-Thirteenth Ann. Rep. New York State Geologist, 1895, p. 867.

Cryptacanthia compacta White and St. John. Upper Carboniferons.

Waldhoimia? (Cryptacantlia) compacta White and St. John, Traus. Chicago Acad. Sci., I, 1868, p. 119, fig. 3.

Cryptacanthia compacta Hall and Clarke, Pal. New York, VIII, Pt. II, 1893, 1. 301, fig. 225 .

Loc. Madison County, Missonri.

CRYPTONELLA Hall, 1867. Genotype Terebratula rectirostra Hall.

q Cryptonella Hall, Fourteenth Rep. Now York State Cab. Nat. Hist., 1861, pp. 101, 102;-Fifteenth Rep. Ibidem, 1862, p. 160, pl. 3, figs. 8, 9.-Billings, Canadian Nat. Geol,,VII, 1862, p. 392.-Hall, Sixteeuth Rep. New York State Cab. Nat. Hist., 1863, p. 43, figs. 1-7 on p. 42 ;-American Jour. Sci., 2d ser., XXXV, 1863, p. 396.-Billings, Ibiclem, XXXVI, 1863, p. 238.-Hall, Trans. Albany Institute, IV, 1863, pp. 132, 148.

Centronella (partim) A. Winchell, Proc. Acarl. Nat. Sci. Philadelphia, 1865, p. 123. Cryptonella Hall, Twentieth Rep. New York State Cab. Nat. Hist., 1867, p. 161; Pal. New York, IV, 1867, p. 392.-Hall and Clarke, Pal. New York, VIII, Pt. II, 1893, p. 286 ;-Thirteenth Ann. Rep. New York State Geologist, 1895, p. 860.

Obs. This genus can not be considered as established before 1867 .

Bull. $87-13$ 
Cryjotonella calvini IIall and Whitfield= Diclasma ealvini.

Cryptonella(?) circulus Walcott.

Devonian.

Cryptonellat? eireula Wakott, Mon. U. S. Geol. Survey, VIII, 1884, p. 163, pl. 15, fig. 2.

Loc. Lone Momtain, Nevada.

Obs. Adlitional material shows that this species attained a length of 1 inch.

Cryptonella eudora Hall and Whitfield, 1S73=Dielasma calvini.

Cryptonella(?) eudora Hall. Chemung-Waverly (Dev.-L. Carb.).

Cryptonella ('Terebratula) eudora Hall, Pal. New York, 1V, 1867, p. 398, pl. 61, figs. 31-11.

Cryptonella eudora Herriek, Bull. Denison Univ., III, 1888, p. 48, pl. 5, fig. 10 ;Geol. Ohio, VII, 1895, pl. 21, fig. 10.

Loc. Ithaca, New York; Licking Connty, Ohio.

Cryptonella(?) eximia IIall.

Lower Helderber' (Dev.).

Cryptonella eximia Hall, Fifteenth Rep. Now York State Cab. Nat. I [ist., 1862, p. 160, pl. 3, tigs. 6, 7; - Sixteenth Rep. Ibilem, 1863, p. 13, figs. 10, 11.--Hall and Clirke, l'al. New York, VIII, Pt. 11, 1895, pl. 80, figs. 11, 12.

Loc. Not given.

Cryptonella(?) inconstans (Herrick).

Waverly (L. Carb.).

Terebratula? inconstaus Herrick, Bull. Denison Univ., IV, 1888, p. 24, pl. 3, figs. 8,9 ; pl. 11, tig. 18 .

Cryptonella(?) inconstans Hall and Clarke, Pal. New York, VIII, Pt. II, 1895, pl. 79 , figs. 31,32 .

Terebratula inconstans Herrick, Geol. Ohio, VII, 1895, pl. 23, fig. 17.

Loc. Ashland County and Lodi, Ohio.

Cryptonella iowensis Calvin=Cranana iowaensis.

Cryptonella iphis Hall.

Cor'uiferous (Dev.).

Cryptonella iphis Hall, Pal. New York, IV, 1867, p. 396, pl. 61, figs. 26-28.

Loc. Cayuga, Ontario.

Cryptonella lens Hall.

Corniferous (Dev.).

Terebratula lens IIall, Thirteenth Rep. New York State Cab. Nat. Hist., 1860, p. $89 ;-$ Pal. New York, IV, 1867, p. 386, pl. 60, figs. 1-4.

Cryptonella lens Hall and Whitfield, Twenty-fourth hep. Now York State Cab. Nat. Hist., 1872, 1. 199.

Loc. Clarence Hollow, New York; Falls of Ohio.

Cryptonella lineklieni Hall=Eunella lineklæui.

Cryptonella ovalis Miller.

Hamilton (Dev.).

Cryptonella ovalis Miller, Seventeenth Rep. State Geol. Indiana, 1891, p. 76, pl. 13 , figs. $1,2$.

Loc. Bunker Hill, Indiana.

Cryptonella pinonensis Waleott.

Upper Devonian.

Cryptonella pinonensis Waleott, Mon. U. S. Geol. Survey, VIII, 1884, p. 163, pl. 4, tig. 4.

Loc. Pinon Range, Nevada.

Cryptonella planirostris Hall.

Mareellus, Hamilton (Dev.).

Terebratula planirostra 11all, Thirteenth Rep. New York State Cab. Nat. Hist., 1860, p. 89.

Cryptonella planirostra IIrll, Fourteenth Rep. New York State Cab. Nat. IIist., 1861, p. 101 ;-Sixteenth Rep. Soilem, 1863, p. 44;-Pal. New York, IV, 1867, 1. 395, pl. 61, figs. 9-27.-Hall and Clarke, Ibidem, V1I1, Pt. II, 1893, 1. 287, fig. 208 ; pl. 80, tigs. 5-10.

Loc. Seneca and Canandaigua lakes, New York. 


\section{Cryptonella rectirostris Hall.}

Hamilton (Dev.).

Terebratula rectirostra IIall, Whirteenth Rep. New York state Cab. Nat. Hist., $1860,1) .88$.

Cryptonella rectirostra Hall, Fourteenth Rep. New York State Cab. Nat. Hist., 1861, p. 101; - Sixtcenth Rep. Ibidem, 1863, p. 44;-l’al. New York, IV, 1867, p. 394, p]. 61, figs. 1-8.-Hall and Clarke, Ilidem, VIII, Pt. II, 1893, p. 286, pl. 80, figs. 1-4.

Loc. Bellona, York, Moscow, etc., New York; Falls of Ohio.

Cryptonella subelliptica Hall and Clarke.

Waverly (L. Carb.).

Cryptonella subelliptica Hall and Clarke, Pal. New York, V'III, Pt. II, 1895, p]. 81 , figs. 41-43.

Loc. Sciotoville, Ohio.

CYCLORHINA Hall and Clarke. Genotype Rhynchospira nobilis Hall.

Cyclorhina Hall ant Clarke, Pal. Now York, VIII, Pt. II, 1893, p. 206 ;-Thirteenth Aun. Rep. New York State Geologist, 1895, p. 830.

Cyclorhina nobilis Hall.

Hamilton (Dev.).

Rhynchospira nobilis Hall, Thirteenth Rep. New York State Cab. Nat. Hist., 1860, p. 83.

Rhynchospira and Trematospira? nobilis Hall, Pal. New York, IV, 1867, pp. 277, 412 , pl. 63, figs. 33-36.

Retzia (Trematospira) nobilis Whiteaves, Cont. Canadian Pal., I, 1889, p. 116.

Cyclorhina nobilis Hall and Clarke, Pal. New York, VIII, Pt. II, 1893, 1. 207, pl. 61, figs. 1-12.

Loc. Darien, New York; Thedforrl, Ontario.

CYCLOSPIRA Hall and Clarke. Genotype Orthis bisulcata Emmons. Cyclospira IIall and Clarke, Pal. New York, VIII, Pt. II, 1893, p. 146.-Wiuchell and Schuchert, Minuesota Geol. Survey, III, 1893, p. 469.-Hall and Clarke, Thirteenth Ann. Rep. New York State Geologist, 1895, 1. 808.

Cyclospira bisulcata (Eımons).

Trenton (Ord.).

Orthis bisnleata Emmons, Geol. New York; Rep. Second Dist., 1842, p. 396, fig. 4.

Atrypa bisulcata Ilall, Pal. New York, I, 1847, p. 139, pl. 33, tig. 3.

Genus? bisnlcata Ilall, Twelfth Rep. New York State Cab. Nat. Hist., 1859, p. 65.

Camarella bisulcata Miller, Americau Pal. Foss., 1877, p. 107.

Camarella owatonnensis Sardeson, Bnll. Ifinnesota Acad. Nat. Sci., III, 1892, p. 328 , pl. 4 , figs. $1-3$.

Cyclospira bisulcata? Winchell and Schuchert, Minnesota Geol. Sncvey, III, 1893, 1. 470, pl. 34, figs. $49-54$.

Cyelospira bisuleata Hall and Clarke, Pal. New York, VIII, Pt. II, 1893, 1. 147, figs. 133-136; pl. 54, figs. 38-40;-Whiteaves, Pal. Foss., III, Pt. III, 1897, p. 180.

Loc. Adams, Jefferson County, New York; Ottawa, Canada; Cannon Falls, etc., Minnesota; Lake Winnipeg, Manitoba.

Cyclospira(?) sparsiplica Foerste.

Clinton (Sil.).

Cyclospira? sparsipliea Foerste, Geol. Ohio, VII, 1895, 1. 593, pl. 37A, fig. 18.

Loc. Dayton, Ohio.

Obs. May be a species of Parastrophia or a rhynchonelloid.

CYRTIA Dalman.

Genotype Anomites exporrectus Wahlenberg.

Cyrtia Dalman, Kongl. Svenska Vet.-Akad. Ilandl., för 1827, 1828, pp. 93, 97.Billings, Canadian Jour., VI, 1861, 1. 262.-Nêttelroth, Kentucky Fossil Shells, Nem. Kentueky Geol. Survey, 1889, p. 93.-Hall and Clarke, Pal. New York, VIII, Pt. II, 1893, 1’.40;-Thirteentl Anu. Rep. New York State Geologist, 1895, p. 759 .

Cyrtia acutirostris Shumard = Cyrtina acutirostris. 
Cyrtia alta Hall.

Waverly (L. Carb.).

Spirifer alta Hall, Proc. American Phil. Soc., X, 1866, p. 216;-Pal. New York, IV, 1867, p. 248, pl. 43, figs. 1-7.

Syringothyris alta Schnchert, Ninth Ann. Rep. New York State Geol., 1890, p. 35.

Cyrtia alta IIall and Clarke, Pal. New York, VIII, I't. II, 1893, p. 42, pl. 26, tigs. $1-5$; pl. 39 , figs. $37,38$.

Loc. Mealville, Pennsylvania; Beciford, Ohio.

Cyrtia biplicata Mall=Cyrtina biplicata.

Cyrtia curvilineata White=Cyrtiua curvilineata.

Cyrtia cyrtiniformis (Hall and Whitfield).

Chemung (Dev.).

Spirifera cyrtinaformis Hall and Whitfield, Twenty-third Rep. New York State

Cab. Nat. Hist., 1872, p. 238, pl. 11, figs. 21-24;-Extract, 1872, p. 19, pl. 11, figs. 21-24.-Whiteares, Cont, to Canalian Pal, I, 1891, n. 222.

Cyrtia cyrtiniformis Hall and Clarke, Pal. New York, VIII, Pt. II, 1893, p. 42, pl. 25, figs. 26-32.

Loc. Rockford, Iowa; Hay River, Canada.

Obs. Compare with C. norwoodi Meek.

Cyrtia dalmani Hall=Cyrtina dalmani.

Cyrtia exporrecta (Wahlenberg).

Niagara (Sil.).

Anomites exporrectus Wahlenberg, Nova Acta Regias Soc. Scient. Upsal, VIII, 1821, p. 64 .

Spirifera (Cyrtia) trapezoidalis Hall and Whitfield, Twenty-fourth Rep. New York State Cab. Nat. Hist., 1872, 1. 183.

Crrtia trapezoillalis Hall and Whitfield, Twenty-seventh Rep. Ibidem, 1875, pl. 9 , figs. 19-21.

Cyrtia exporrecta Nettelroth, Kentucky Fossil Shells, Mem. Kentucky Geol. Snrvey, 1889 , p. 93, pl. 27, figs. 6-8, 20.-Hall and Clarke, Pal. New York, V1II, Pt. II, 1893, p. 42, pl. 28, figs. $1,48,49,51$.

Loc. Enrope; Lonisville, Kentucky.

Cyrtia exporrecta arrecta Hall and Whitfield=C. myrtea.

Cyrtia gigas Troost=Syringothyris gigas.

Cyrtia hamiltonensis Hall=Cyrtina hamiltonensis.

Cyrtia meta (Hall). Clinton and Niagara (Sil.).

Spirifer ralliatus (pars) Hall, Pal, New York, II, 1852, p. 66, pl. 22, figs. 2a-2e, 2 t.

Spirifera meta Hall, Twentieth Rep. New York State Cab. Nat. Hist., 1867, p. 372, pl. 13 , figs. 12,13 .

Cyrtia radians Hall and Clarke, Pal. New York, VIII, Pt. II, 1893, pp. 42, 362 , pl. 28 , figs. $4,5,50,52 ;$ pl. 39 , fig. 33 .

Loc. Lockport and Roehester, New York; Milwaukee, Wisconsin.

Cyrtia missonriensis Swallow $=$ Cyrtina missonriensis.

Cyrtia myrtia Billings.

Anticosti and Niagara (Sil.).

Cyrtia myrtia Billings, Pal. Fossils, I, 1862, p. 165, fig. 149.-Hall and Clarke,

Pal. New York, VIII, Pt. II, 1893, p. 42.

Cyrtia trapezoidalis var. arrecta Hall and Whitfield, Twenty-fonrth Rep. New York State Cab. Nat. Hist., 1872, p. 183.

Cyrtia exporrecta Hall and Whitfiell, Twenty-seventh Fep. Ibidem, 1875, pl. 9, figs. $22,23$.

Cyrtia exporrecta var. arrecta Nettelroth, Kentncky Fossil Shells, Mem. Kentucky Geol. Survey, 1889, p. 94, pl. 27, fig. 21; pl. 34, fig. 35; pl. 37, figi. 60, 61.Hall and Clarke, Pal. New York, VIII, Pt. II, 1895, pl. 28, figs. 2, 3; 1l. 39, fig. 32 .

Loc. Anticosti; Louisville, Kentucky. 
Cyrtia norwoodi (Meek).

Middle Devonian.

Spirifera norwoodi Meek, Proc. Acad. Nat. Sci. Philadelphia, 186C, 1. 308.

Spirifera utahensis Meek, note appended to extra copies of the above-cited paper, 1860 ;-Simpson's Rep. Expl. Great Basin Terr. Utah, 1876, p. 345, pl. 1, fig. 4 ;-King's U. S. Geol. Expl. 40th Parl., IN, 1877, 1. 39, pl, 3, fig. 1.

Loc. Buell Valley, Utah.

Obs. Compare with C. erytiniformis Hall and Whitfield.

Cyrtia occidentalis Swallow = Cyrtina occidentalis.

Cyrtia radians Hall and Clarke $=\mathrm{C}$. meta.

Cyrtia rostrata Hall= Oyrtina rostrata.

Cyrtia trapezoidalis Hisinger $=\mathrm{O}$. exporreeta.

Cyrtia trapezoidalis arrecta Hall and Whitfield=C. myrtia.

C'yrtia triquetra Hall=Cyrtina triquetra.

Cyrtia umbonata Hall= Cyrtina umbonata.

CYRTINA Davidson. Genotype Cyrtia heteroclita Defrance.

Cyrtina Davidson, Mon. British Carl. Brachiopoda, Pal. Soc., 1858, p. 66.-Hall,

Pal. New York, IV, 1867, p. 263;-Twentieth Rep. New York State Cal. Nat.

Hist., 1867, p. 251.-Herrick, Bull. Dennison Univ., IV , 1888, p. 11.-Nettelroth,

Kentucky Fossil Shells, Mem. Kentucky Geol. Survey, 1889, p. 95.-Hall and

Clarke, Pal. New York, VIII, Pt. II, 1893, p. 43 ;-Thirteeuth Aun. Rep. New

York State Geologist, 1895, p. 763.

Cyrtina acutirostris (Shumard).

Chouteau (L. Carb.).

Cyrtia acutirostris Shumard, Geol, Rep. Missouri, 1855, p. 204, pl. C, fig. 3.

Cyrtina acutirostris Miller, N. American Geol. Pal., 1889, 1. 342.-Hall and Clarke, Pal. New York, VIII, Pt. II, 1895, pl. 28, figs. 38-12, 44, 54.-Keyes Geol. Survey Missouri, V, 1895, p. 89, pl. 39, fig. 10.

Loc. Hannibal and Louisiana, Missouri.

Cyrtina affinis Billings.

Oriskany (Dev.)

Cyrtina dalmani Billings, Canadian Nat. Geol., VIII, 1863, p. 37.

Cyrtina affinis Billings, Pal. Fossils, II, 1874, p. 49, pl. 3A, fig. 6 .

Loc. Grand Greve, Gaspé.

Cyrțina billingsi Meek.

Hamilton (Dev.).

Cyrtina billingsi Mleek, Trans. Chicago Acad. Sei., I, 1868, 1. 97, pl. 14, fig. 6.Whiteares, Cout. to Canadian Pal, I, 1891, p. 227.

Loc. Clearwater and Athabasca rivers, British America.

Cyrtina biplicata Hall.

Upper Helderberg (Dev.).

Cyrtia biplicata Hall, Tenth Rep. New York State Cab. Nat. Hist., 1857, 1. 165.

Cyrtina biplicata Hall, Pal. New York, IY, 1867, p. 266, pl. 27, figs. 5-10.-Hall and Clarke, Pal. New York, VIII, Pt. II, 1895, pl. 28, figs. 7-10.

Loc. Albany and Schoharie counties, ete., New York; Michigan.

Cyrtina burlingtonensis Rowley.

Burlington (L. Carb.).

Cyrtina burlingtonensis Rowley, American Geologist, XII, 1893, p. 308, pl. 14, figs. 15-17.

Loc. Louisiana, Missouri.

Obs. Compare with C. neogenes.

Cyrtina crassa Hall.

Corniferous (Dev.).

Cyrtiua crassa Hall, Pal. New York, IV, 1867, p. 267, pl. 27, figs. 11, 12.-Hall and Whitfield, Twenty-seventh Rep. New York State Cab. Nat. Hist., 1875, pl. 9, figs. 14-16. - Nettelroth, Kentucky Fossil Shells, Mem. Kentucky Geol. Survey, 1889, p. 95, pl. 13, figs. 21-24.-Hall and Clarke, Pal. New York, VIII, Pt. II, 1895, pl. 28, tigs. 13-15.

Loc. Vienua, Now York; Falls of Ohio. 
Cyrtina(?) curupira Rathbun.

Midkle Devonian.

Cyrtina(?) curupira Ratbun, 13ull. Buflalo Soe. Nat. Sci., I, 1874, p. 212, pl. 10, figs $1,6$.

Loc. Erere, Province of Para, Brazil.

Cyrtina curvilineata White.

Hamilton (Dev.).

Crrtia curvilineata White, Proc. Boston Soc. Nat. Hist., IX, 186i2, 1. 25.

C'yrtina eurvilineata? Hall, Pal. New York, IT, 1867, 1. 270, 1]. 4t, figs. 53-55.

(yrtina curvilineata IIall and Clarke, lbislem, VIII, Pt. II, 1895, pl. 28, figs. 11, 12

Loc. Iowa City, Iowa.

Cyrtina dalmani Billings (non Hall)=C. aftinis.

Cyrtina dalmani (Hall).

Lower Helderberg (Der.).

Cyrtia dalınani Hall, Tenth Rep. New York State Cab. Nat. Hist., 1857, p. 61; l'al. New York, III, 1859, I. 206, pl. 24, fig. 1.

Cyrtina dalmani Meek and Worthen, Geol. Survey Illinois, III, 1868, p. 383, pl. 7 , fig. 3.

Loc. Albany and Schoharie counties, New York; Perry County, Missouri; Decatur Connty, Tennessee; Dalhousie, New Bruuswick.

\section{Cyrtina davidsoni Walcott.}

Midrle and Upper Devonian.

Cyrtina davidsoni Walcott, Mon. U. S. Geol. Survey, VIII, 1884, p. 146, pl. 3, fig. 2.

Loc. White Pine district, Nevada.

Cyrtina hamiltonensis Hall.

Up. Helderberg, Ham., and Port. (Dev.).

Cyrtia hamiltonensis Hall, Tenth Rep. New York State Cab. Nat. Hist., 1857, p. 166.-Billings, Canadian Jour., VI, 1861, p. 262, figs. 80-82;-Geol. Canada, 1863, 1. 384, fig. 415.

Cyrtina lamiltonensis Hall, Pal. New York, IV, 1867, p. 268, pl. 27, figs. 1-4; pl. 44, figs. 26-33, 38-52.-Meek, Trans. Chicago Acad. Sci., I, 1868, p. 99, pl. 14, figs. 5, 7, 10.-Nicholson, Pal. Prov. Ontario, 1874, p. 83.-Walcott, Mon. U. S. Geol. Survey, VIII, 1884, p. 147.-Nettelroth, Kentucky Fossil Shells, Mem. Kentucky Geol. Survey, 1889, p. 96, pl. 13, tigs. 4-12. - Whiteaves, Cont. to Canadian Pal., I, 1891, pl. 226, 288.-Hall anıl Clarke, Pal. New York, VIll, Pt. II, 1895, pl. 28, figs. 23-33, 43, 45, 46, 53.-Kindle, Bull. American Pal., 6, 1896, 1. 35.

Cyrtina panda Meek, Trans. Chicago Acarl. Sci., 1, 1868, p. 100, pl. 14, fig. 8.

Loc. New York; Pennsylvania; Maryland; Cayuga and Thedford, Ontario ; Lonisville, Kentucky; Indepentence, Iowa; Eureka district, Nevada; Mackenzio and Athabasca rivers, and lakes Manitoba and Winnipegosis, British America.

Obs. C. panda is a variation of this species with a higher ventral area.

Cyrtina hamiltonensis recta Hall.

Hamilton and Chemung (Dev.).

Cyrtina hamiltonensis var. recta Hall, Pal. New York, IV, 1867, 1. 270, pl. 44, figs. 34-37.- - Yettelroth, Kentucky Fossil Shells, Mem. Kentucky Gool. Survey, 1889 , p. 97, pl. 13, figs. 13-16.-Hall and Clarke, Pal. New York, VIII, Pt. II, 1895, pl. 28, figs. 21, 22.

Loc. Allegany Couty, New York; Falls of Ohio.

Cyrtina lachrymosa Hall aud Clarke.

Waverly (L. Carb.).

Cyrtina lachrymosa Hall and Clarke, Pal. New York, VIII, Pt. II, 1895, pp. 46, 362 , pl. 28, figs. $36,37,47$.

Loc. Riclifield, Ohio.

Cyrtina missouriensis (Swallow).

Hamilton (Dev.).

Cyrtia missonriensis Swallow, Trans. St. Louis Acad. Sci., I, 1860, p. 647.

Cyrtina missonriensis Miller, N. American Gool. Pal., 1889, p. 343.

Loc. Callaway County, Missouri.

Obs. Regardod by Keyes as a synonyu for C. umbonata. 
Cyrtina neogenes Hall and Clarke.

Burlington (L. Carb.).

Cyrtina neogeues Hall and Clarke, Pal. New York, VIII, l’t. II, 1895, pl. 84, fig. 41.

Loc. Burlington, Iowa.

Obs. Compare with C. burlingtonensis.

Cyrtina(?) occidentalis (Swallow).

Hamilton (Dev.).

Cyrtia occilentalis Swallow, Trans. St. Louis Acal. Sei., I, 1860, p. 648.

Cyrtina? occilentalis Miller, N. American Geol. Pal., 1889, p. 343.

Syringothyris occilentalis Keyes, Geol. Survey Missouri, V, 1889, p. 86.

Loc. Callaway County, Missouri.

Obs. This is probably a Spirifer with a high area as in S. asperus, or it is a Cyrtia.

Cyrtina panda Meek $=$ C. hamiltonensis.

Cyrtina pyramidalis (Hall).

Niagara (Sil.).

Spirifer pyramidalis Hall, Pal. New York, II, 1852. p. 266, pl. 54, fig. 7.

Cyrtiua pyramidalis Miller, N. American Geol. Pal., 1889, 1. 3.43.

Loc. Lewiston, New York.

Cyrtina rostrata Hall.

Oriskany and Corniferous (Dev.).

Cyrtia rostrata Hall, Tenth Rep. New York State Cab. Nat. Hist., 1857, p. 64;-

Pal. New York, III, 1859, p. 429, pl. 96, figs. 1-6; pl. 98, fig. 8.-Billings, Canadian Jour., VI, 1861, p. 263.

Cyrtina rostrata Hall and Clarke, Pal. New York, VIII, Pt. II, 1895, pl. 25, figs. $1-8 ;$ pl. 28 , fig. 6.

Loc. Albany Connty, New York; Cumberlaut, Maryland; Caynga, Ontario.

Cyrtina triplicata Simpson.

Waverly (L. Carb.).

Cyrtina triplicata Simpson, Trans. Americau Phil. Soc., 11. ser., XVI, 1889, 1.439,

fig. 4.

Loe., Warren, Peunsylvania.

Cyrtina triquetra (Hall).

Hamilton (Dev.).

Cyrtia triquetra Hall, Geol. Survey Iowa, I, I't. II, 1858, p. 513.

Cyrtina triquetra Meek, Trans. Chicago Acarl. Sci., I, 1868, p. 99.-Meek and Worthen, Geol. Survey Illinois, III, 1868, 1. 436, pl. 13, fig.4.-Hall and Clarke, Pal. New York, VIII, Pt. II, 1895, pl. 28, figs. 14, 35.

Loc. Rock Island, Illinois.

Cyrtina umbonata (Hall).

Hamiltou (Dev.).

Cyrtia umbonata Hall, Geol. Survey Iowa, I, Pt. II, 1858, p. 512, pl. 5, fig. 2.

Cyrtina umbonata Miller, N. Ameriean Geol. Pal., 1889, p. 313.-Keyes, Geol. Survey Missouri, V, 1895, p. 90.

Loc. Buffalo, Lowa; Rock Island, Illinois; Callaway County, Missouri.

Obs. See C. missouriensis.

Cyrtina umbonata alpenaensis Hall and Clarke.

Hamilton (Dev.).

Cyrtina umbonata var. alpenensis Hall and Clarke, Pal. New York, VIII, Pt. II, 1895 , p. 362, pl. 28, figs. 16-20.

Loc. Alpena, Michigan.

DALMANELLA Hall and Clarke.

Genotype Orthis testudinaria Dalman. Orthis (group of O. testudinaria) Ifall, Bull. Geol. Soc. America, I, 1889, p. 21. Dalmanella Hall aud Clarke, Pal. New York, VIII, Pt. I, 1892, pp. 205, 223.Winchell and Schuchert, Miunesota Geol. Survey, III, 1893, 1). 439.-Hall and Clarke, Eleventh Anu. Rep. New York State Geologist, 1894, p. 170. 
Dalmanella amœna N. H. Winchell.

'Trenton (Ord.).

Orthis amona Winchell, Eighth Am1. Rep. (iool. Nat. Hist. Survey Minnesota, $1880,1.65$.

(rothis (1).) anmena Winchell and schuchert, Minnesota Geol. Survey, MI, 1893, p. $453,11.33$, figs. $48-50$.

Loc. Fpring Valley, Minnesota.

Dalmanella arcuaria Hall and Clarke.

Niagara (Sil.).

1)almanella arenaria Hall and Clarke, Pal. New York, VIII, Pt. I, 1892, P'P. 2024, 341, pl. $5 \mathrm{C}$, figs. 20,2 .

Loc. l'erry C'ounty, Temuesse's.

Dalmanella bellula (Meek).

Lorraine (Ord.).

Orthis bellula (.James MS.) Meek, Pal. Ohio, I, 1873, 1. 103, pl. 8, fig. 5; Miller,

Ciuciunati Quart. Jour. Sei., I1, 1875, 1. 31.

Dalmanella bellula Ilall and Clarke, Pal. New York, VIII, Pt. I, 1892, 1. 224.

Loc, Cincinuati, Ohio.

Dalmanella concinna Hall.

Lower Helderberg (Dev.).

Orthis concinua Iall, Pal. New York, III, 1859, p. 172, pl. 13, figs. 1-3.

Dalmanella concinna Hall and Clarke, Pal. New York, YIII, It. I, 1892, 1P. $207,224$.

Loc. Cumberlaud, Maryland.

Dalmanella crispata (Emmons).

Lorraine (Ord.).

Orthis crispata Emmons, Geol. Now York; Rep. Second Dist., 1812, p. 404, fig. 5. Dalnanella crisjuata Hall and Clarke, Pal. New York, VIII, Pt. I, 1892, p. 224.

Loc. Lorraine, New Iork.

Dalmanella devonica (Walcott).

Lower Devonian.

Skenidium deronicum Walcott, Mon. U. S. Geol. Survey, VIII, 1884, 1. 116, pl. 13, fig. 4 .

Loc. Eureka district, Nevada.

Obs. "The type specimen has no spondylium and therefore is no Scenidinm.

Dalmanella electra (Billings).

Calciferous (Ord.).

Orthis electra Billiug8, Pal. Fossils, I, 1862, p. 79, fig. 72; 1. 217;-Gool. Canada, 1863, p. 231, fig. 246.

Orthis electra? White, Wheeler's Rep. Geol. Geogx. Expl. west 100 Merid., IV, 1875,1 . 55.

Dalmanella electra Hall and Clarke, Pal. Now York, VIII, Pt. I, 1892, p. 223.

Loc. Point Levis aud St. John, Canada; Newfoundland; House Range, Utah.

Dalmanella electra major (Matthew).

Calciferous (Ord.).

Orthis electra var. major Matthew, Trans. Royal Soc. Canada, X, 1893, p. 100, pl. 7 , fig. 3.

Loc. Near St. John, New Brunswick.

Dalmanella electra lævis (Matthew).

Calciferous (Urd.).

Orthis electra rar. levis Matthew, Trans. Royal Soe. Canada, X, 1893, p. 100.

Loc. Near St. John, Now Brunswick.

Dalmanella elegantula (Dalmau).

Clinton and Niagara (Sil.).

Orthis elegantula Dalman, Kongl. Svenska Vet.-Akad. Handl., för 18:7, 1828, p. 117, pl. 2, fig. 6.-Hall, Pal. Now York, II, 1852, p. 252, pl. 52, fig. 3.Billings, Canadian Nat. Geol., I, 1856, p. 136, pl. 2, fig. 5.-Roemer, sil. Fauna west. 'Tennessee, 1860, p. 62, pl. 5, fig. 7.-Billings, Geol. Canada, 1863, p. 312, fig. 320.-Hall, Twenty-eighth Rep. New York State Mus. Nat. Hist., 1879, 1. 150, pl. 21, figs. 11-17;-Eleventh Rep. State Geol. Indiana, 1882, p. 285, pl.21, figs.11-17;-Second Amı. Rep. Now York State Geol., 1883, 
Dalmanella elegantula (Dalman)-Continued.

pl. 35, figs. 34-37.-Foerste, Bull. Denisou Univ., I, 1885, 1. 84, pl. 13, fig. 1.-Nettelroth, Kentucky Fossil Shells, Mem. Kentucky Geol. Survey, 1889, p. 37, pl. 32, figs. 52-57.-Beecher and Clarke, Mem. New York State Mus., I, 1889, p. 14, pl. 1, figs. 3-12.-Foerste, Proc. Boston Soe. Nat. Hist., XXIV, 1890, p. 307.

Orthis canalis Hall, Geol. New York; Rep. Fourth Dist., 1843, p. 105, fig. 6.

Orthis olegantula? var. Hall, Pal. New York, II, 1852, 1. 57, 1.l. 20, fig. 7.

Dalmanella elegantula Hall and Clarke, Pal. New York, VIII, Pt. I, 1892, pp. 207,224 , pl. 5C, figs. 15-19.

Orthis (Dalmanella) elegautula Foerste, Geol. Ohio, VII, 1895, 1, 581, 11. 25, figs. 11,17 .

Loc. Europe; New York; Ohio; Indiana; Kentucky; 'Tennessee; Missouri; Ontario and Nova Scotia, Canada; Collinsville, Alabama.

\section{Dalmanella elegantula parva (Foerste).}

Clinton (Sil.).

Orthis elegantula var. parva Foerste, Bull. Denison Univ., I, 1885, 1. 85, 11. 13, fig. 17.

Dalmanella elegantula var. parva Hall and Clarke, Pal. New York, VIII, Pt. I, 1892, p. 224.

Loc. Dayton, Ohio.

Dalmanella(?) evadne (Billings).

Calciferous (Ord.).

Orthis evadne Billings, Pal. Fossils, I, 1862, p. 81, fig. 74; 1). 79.-Whitfield, Bull. American Mus. Nat. Hist., I, 1886, p. 300, pl. 24, fig. 8.

Dalmanella? evadne Hall and Clarke, Pal. New York, VIII, Pt. I, 1892, P. 223, pl. 5B, figs. $25,26$.

Loc. Point Levis, Canada; Fort Cassin, Vermont.

Dalmanella hamburgensis (Walcott). Pogonip and Trenton (Ord.).

Orth is hamburgensis Walcott, Mon. U. S. Geol. Survey, VIII, 1884, p. 73, pl. 2, fig. 5 .

Orthis (Dalmanella) hamburgensis? Winchell and Schuchert, Mimnesota Geol. Survey, III, 1893, 1. 440, pl. 33, figs. 14-16.

Loc. Pogonip group, Eureka district, Nevada. In the Trenton at St. Paul, Canwon Falls, etc., Miunesota; Highbridge, Kentucky.

Dalmanella infera (Calvin).

Chemung (Dev.).

Orthis infera Calvin, Bull. U. S. Geol. Survey Terr., IV, 1878, 1'. 728.

Dalmanella infera Hall and Clarke, Pal. New York, YIII, Pt. I, 1892, 1. 224.

Loc. Independence, Iowa; Naples, New York.

Dalmanella lenticularis (Vanuxem).

Corniferous (Dev.).

Orthis lenticularis Vanuxem (non Wahlenberg), Geol. New York; Rep. Third Dist., 1842, 1. 139, fig. 4.-Hall, Pal. New lork, IV, 1867, p. 35, pl. 5, figs. 1, 2. Orthis lenticularis and O. lentiformis Hall, Geol. New York; Rep. Fourth Dist., 1843 , p. 175 , fig. 4.

Orthis eboracensis Miller, N. American Geol. Pal., 1889, 1. 357.

Dalmanella lenticularis Hall and Clarke, Pal. New York, VIII, Yt. I, 1892, pp. $207,224,11.5 \mathrm{C}$, figs. $36-41$.

Loc. Leroy, Caledonia, etc., New York.

Dalmanella lepida Hall.

Hamilton (Dev.).

Orthis lepidus Hall, Thirteenth Rep. New York State Cab. Nat. Hist., 1860, p.

78 ;-Pal. New York, IV, 1867, p. 46, pl. 6, fig. 1.

Dalmanella lepida Hall and Clarke, Pal. New York, VIII, Pt. I, 1892, pp. 207,224.

Loc. Outario County, New York. 
Dalmanella macleodi (Whitfield).

Calciferous (Ord.).

Orthis macleodi Whitfold, BuIl. American Mus. Nat. IIist., II, 1889, 1). 43, 11. 7, figs. 1-4.

Dalmanella macloodi Ilall and Clarke, Pal. New York, VII, Pt. I, 1892, 1. 224.

Loc. Beekmantown, New Jork.

Dalmanella melita (Hall and Whitfield).

Upper Cambrian.

Loptipna melita Hall and Thitfield, King's U. S. Geol. Survey, 40tl Parl., 1V, 1877, p. 208, pl. 1, figs. 13, 14.-Walcott, Mnn. U. S. Geol. Survey, VIII, 1884, p. 22 .

Loc. Enreka district, Nevada.

$O b s$. This species is related to D. evadne (Billings).

Dalmanella(?) nettoana (Rathbun).

Middle Devonian.

Orthis nettoana Rathbun, Bull. Buffalo Soc. Nat. Sci., I, 1874, p. 247, pl. 10, figs.

7, 10, 13;-Y'roc. Boston Soc. Nat. Hist., XX, 1879, 1. 22.

Loc. Province of Para, Brazil.

Dalmanella parva (de Verneuil).

Anticosti (Sil.).

Orthis parva (Pander) de Vernenil, Geology of Russia and the Ural Mountains, 1845, p. 188, pl. 13, fig. 3.-Billings, Cat. Sil. Foss. Anticosti, 1866, p. 41.

Loc. Europe; Anticosti.

Dalmanella perelegans Hall.

Lower Helderberg (Dev.).

Orthis perelegans Hall, Tenth Rep. New York State Cal. Nat. Hist., 1857, p. 44, fig. 1;-Pal. New York, III, 1859, p. 171, pl. 13, tigs. 4-12;-Second Ann. Rep. New York State Geol., 1883, pl. 35, figs. 32, 33.

Dalmanella perelegans Hall and Clarke, Pal. New York, VIII, Pt. I, 1892, pp. 207, 224 , pl. 5C, figs. 34,35 .

Loc. Albany and Schoharie counties, New York; Decatur County, Tennessee.

Dalmanella planiconvexa Hall. Lower Helderberg and Oriskany (Dev.). Orthis planoconvexa IIall, Pal. New York, III, 1859, p. 168, pl. 12, figs. 1-6.

Dalmanella planoconvexa Hall and Clarke, Pal. New York, VIII, Pt. I, 1892, pp. $207,221$.

Loc. Albany County, New York; Cumberland, Maryland.

Dalmanella(?) plicifera (Hall).

Chazy (Ord.).

Leptrena plicifera Hall, Pal. New York, I, 1847, p. 19, pl. 4 bis, fig. 1.

Strophomena plicifera Hall, Twelfth Rep. New York State Cab. Nat. Hist., 1859, 1). 70 .

Loc. Chazy, New York.

Dalmanella pogonipensis (Hall and Whitfield).

Pogonip (Ord.). Orthis pogonipensis Hall and Whitfield, King's U. S. Geol. Expl. 40th Parl., IV, 1877, p. 232, pl. 1, figs. 9, 10.

Strophomena nemea H. and W., Ibidem, 1877, p. 233, pl. 1, fig. 15. - Walcott, Mon. U. S. Geol. Survey, VIII, 1884, 1. 71.

Loc. White Pine and Eureka districts, Nevala.

Obs. These are shells of the D. perveta group. S. nemea is based on a dorsal valve of $O$. pogonipensis.

Dalmanella quadrans Hall.

Lower Helderberg (Dev.).

Orthis quadrans Hall, Pal. New York, III ; Corrigenda in vol. with plates, 1861, pl. 12, figs. 9-12.

Dalmanella quadrans Hall and Clarke, Ibidem, VIII, Pt. I, 1892, p. 224.

Loc. Catskill and Schoharie, New York. 
Dalmanella stonensis (Saffor $(1)$. Trenton (Ord.).

Orthis stonensis Safford, Geol. Tennessee, 1869, p. 286.

Dalmanella stonensis Hall and Clarke, Pal. New York, VIII, Pt. I, 1892, p. 224, pl. $5 \mathrm{C}$, figs. $4,5$.

Loc. Near Nashville, Tennessee.

Dalmanella subæquata (Conrad).

Trenton (Ord.).

Orthis subrequata Courad, Proc. Acad. Nat. Sci. Philadelphia, I, 1813, 1. 333.Hall, Pal. New York, I, 1847, p. 118, 11. 32, fig. 2;-Geol Wisconsin, I, 1862, p. 42, figs. 1-3, and p. 436 ; - Second Ann. Rep. New York State Geol., 1883, pl. 31 , figs. 19-24.

Orthis minneapolis N. H. Winchell, Eighth Ann. Rep. Geol. Nat. Hist. Survey Minnesota, 1880, p. 63.

Orthis perveta Hall, Second Ann. Rep. New York State Geol., 1883, pl. 34, figs. $17,18($ (?16).

Dalmanella subiequata Hall and Clarke, Pal. Now York, YIII, Pt: I, 1892, pp. I94, 207, 224, pl. 5C, figs. 6-11.

Dalmanella perveta Hall and Clarke, Ibidem, 1892 , p. 224, pl. 5C, figs. 13, 14.

Orthis (D.) subaruata Winchell and Schnchert, Minnesota Geol. Surves, III, 1893, p. 446 , pl. 33 , figs. $30-36$.

Loc. Mineral Point, Wisconsin; Minneapolis, St. Paul, Cannon Falls, Fountain, etc., Minnesota; Decorah and McGregor, Iowa; Auburn, Lincoln County, Missouri ; Montreal, Canada.

Dalmanella subæquata circularis N. H. Winchell.

Trenton (Ord.).

Orthis cireularis N. H. Winchell, Eighth Anu. Re1\% Geol. Nat. Hist. Survey Minnesota, 1880, 1. 66 .

Orthis (D.) subequata var circularis Winchell aud Schnchert, Minnesota Geol. Survey, III, 1893, 1. 452, pl. 33, figs. 46, 47.

Loc. Minneapolis, Cannon Falls, etc., Minnesota; Highbridge, Kentucky; Lebanon, Tenuesseo.

Dalmanella subæquata conradi N. H. Winchell.

Trenton (Ord.).

Orthis conradi N. H. Wincliell, Eighth Ann. Rep. Geol. Nat. Hist. Survey Minnesota, 1880, p. 68.

Orthis (D.) subiequata var. conradi Winchell and Schuchert, Minnesota Geol. Survey, III, 1893, p. 449, pl. 33, figs. 37-39.

Loc. Minneapolis, Minnesota; Vecorah, Iowa; Janesville and Beloit, Wisconsin; Montreal, Canada; ?Eureka district, Nevada.

Dalmanella subæquata gibbosa (Billings).

Chazy-Trenton (Ord.). Orthis gibbosa Billings, Geol. Survey Canada; Rep. Progress for 1856, 1857, p. 296 ;-Canadian Nat. Geol., IT, 1859, p. 434.

Dalmanella gibbosa Hall and Clarke, Pal. Now York, VIII, Pt. I, 1892, p. 224.

Orthis (D.) subequata var. gibbosa Winchell and Schuchert, Minnesota Geol. Survey, III, 1893, p. 451, pl. 33, figs. 43-45.

Loc. Near Ottawa and Bellville, Canada; Minneapolis, Cannon Falls, ete., Minnesota; Decorah, Iowa; Mineral Point, Wiscousin; in the Chazy, Island of Montreal, and Pallideau Islauds, Lake Huron.

Dalmanella subæquata pervetus (Conrad).

Trenton (Ord.).

Orthis perveta Courad, Proc. Acad. Nat. Sci. Philadelphia, I, 1843, p. 333.Hall, Pal. New York, I, 1847, p. 120, pl. 32, tig. 5.-Billings, Canadian Nat. Geol., IV, 1859, 1. 434, fig. 10.-Hall, Geol. Wisconsin, I, 1862, p. 42, fig. 7.Billings, Geol. Canada, 1863, p. 130, fig. 57.

Orthis media N. H. Winchell, Eighth Ann. Rep. Geol. Nat. Hist. Survey Minuesota, 1880, p. 64 . 
Dalmanella subæquata pervetus (Conrad)-Continued.

Orthis kassuba' N. H. Winchell, Ibiden, 1880, 1. 65.

OOrthis perveta Walcott, Mon. U. S. Geol. Snrvey, V111, 1881, 1. 72, pl. 11, fig. 3.

Dalnanelliı perveta Hall and Clarke, l'al. New York, V'II, l't. I, 1892, pl. 5C, fig. 12.

Orthis (D.) subaeguata var. perveta Winchell and Schuchert, Minnesota Geol. Survey, II1, 1893, 1). 550, pl. 33, figs. 40-42.

Loc. Mineral Point, Beloit, etc., IV isconsin; Minneapolis, St. Paul, Cannon Falls, etc., Minnesota; Decorah, lowa; Dixon, Illinois; Tennessec.

Dalmanella subcarinata Hall.

Lower Helderberg (Dev.).

Orthis subcarinata IIall, Tentl Rep. New York State Cab. Nat. Hist., 1857, p. 43, figs. 1, 2;-Pal. New York, III, 1859, p. 169, pl. 12, tigs. 7, 8, 13-21 (not figs. 9-12=D. (quadrans).-Meek and Worthen, Geol. Survey Illinois, III, 1868, p. 373, pl. 7, fig. 6.-Whitfield, Geol. Wisconsin, IV, 1882, 1. 320, 14. 25, figs. 3, 4.-Hall, Second Ann. Rep. New York State Geol., 1883, pl. 35, figs. 23-31.

POrthis subearinata Tseherneysehew, Fauna Untern Devon des Urals, Mem. Com. Géol., Russia, IV, 1885, 1.57, pl. 7, fig. 97.

Dalmanella subcarinata Hall and Clarke, Pal. New York, VIII, Pt. I, 1892, pp. 207, 224, 1). 5C, figs. 25-33.

Loc. Catskill, Schoharie, ete., New York; Perry and Pike countics, Missouri; Decatur County, Tonnessee; Waubakee, Wisconsin; Arisaig, Nova Scotia (Ani); Russia.

Dalmanella superstes Hall and Clarke.

Chemung (Der.).

Dalınanella superstes Hall and Clarke, Pal. New York, VIII, Pt. I, 1892, P1. 207, 224,342 , pl. $5 \mathrm{C}$, figs. 44-47.

Loc. Near Howard, Steuben County, New York.

Dalmanella tenuilineata (Hall).

Chemung (Dev.).

Atrypa? tenuilineata Hall, Geol. New York; Rep. Fourth 1Dist., 1813, p. 271, fig. 4 .

Orthis leoneusis Hall, Pal. New York, IV , 1867, p. 62, pl. 8, figs. 3-8.

Dalmanella leonensis Hall and Clarke, Ibidem, VIII, I't. I, 1892, 1. 22. pl. 5C, tigs. 42,43 .

Loc. Leon, Conewango, etc., Now York.

Dalmanella tersa (Sardeson).

Lorraine (Ord.).

Orthis tersus Sardeson, Bull. Minnesota Acad. Nat. Sci., Ill, 1892, p. 331, pl. 5, figs. 11-13;-American Geol., XIX, 1897, 1. 100, pl. 5, figs. 8-13.

Loc. Wilmington, Illiwois; Nye, Wisconsin.

Dalmanella testudinaria (Dalman).

Chazy-Lorraine (Ord.).

Orthis testudinaria Dalman, Kongl. Svenska Vet.-Akad. Handl., för 1827, 18:8, 1. 115, pl. 2, fig. 4.-Courad, Awn. Rep. Geol. Survey New Tork, 1839, p. 63.Hall, Pal. Now York, I, 1847, p. 117, 11. 32, fig. 1 ; p. 288, pl. 79, fig. 4.-Billings, Canadian Nat. Geol., I, 1856, p. 40, fig. 1.-Rogers, Geol. Pennsylvania, I1, Pt. II, 1858, 1. 818, fig. 601.-Billings, Geol. Canada, 1863, p. 165, fig. 144.-Miller, Cincinuati Quart. Jour. Sci., II, 1875, 1. 20.-Whitficld, Geol. Wisconsin, IV, 1882, 1. 258, 11. 12, figs. 5-7.-Hall, Second Aun. Rep. New York State Geol., 1883, pl. 34, figs. 1-4, 6-13.-Walcott, Mon. U. S. Geol. Survey, VIII, 1884, 1. 72, pl. 11, fig. 10.-Sardeson, Americau Geol., IIX, 1897, p. 92.

Orthis striatula Emmons, Geol. New York; Rep. Second Dist., 1842, p. 394, fig. 3. Orthis testudinaria? Emmons, Ibidem, 1842, 1. 404, fig. 4.-White, Wheeler's Expl. Survey west 100 Merid., IV, 1875, p. 72.

Orthis disparilis Owen (nou Conrad), Geol. Survey Wisconsin, Iowa, Minnesota, 1852, pl. 2B, tig. 23 (see specimeus U. S. Nat. Mus., Cat. Invert. Foss., 17887). 
Dalmanella testudinaria (Dalman)-Continued.

Dalmanella testudinaria Hall and Clarke, Pal. New York, VIII, Pt. I, 1892, pp. 190, 206, 218, 224, pl. 5B, figs. 27-39.

Orthis rogata Sardeson, Bull. Minnesota Acad. Nat. Sci., 1II, 1892, 1. 331, pl. 5, figs. 1-4;-American Geol., XIX, 1897, p. 95, pl. 4, figs. 1-10.

Orthis (Dalmanella) testudinaria Winchell and Schuchert, Minnesota Geol. Survey, III, 1893, p. 441, pl. 33, figs. 17-22.- Whiteaves, Pal. Foss., III, Pt. III, 1897 , pp. $177,241$.

Loc. Enrope; throughout the extent of the formations in America.

Dalmanella testudinaria emacerata Hall.

Utica (Ord.).

Orthis emacerata Hall, Thirteenth Rep. New York State Cab. Nat. Hist., 1860, p. 121 ;-Fifteenth Rep. Ibidem, 1862, pl. 2, figs. 1-3.-Billings, Canadian Nat. Geol., VII, 1862, p. 393.-Miller, Cincinnati Quart. Jour. Sci., II, 1875, p. 24.-Hall, Second Ann. Rep. New York State Geol., 1883, pl. 34, figs. 14, 15.-Kejes, Geol. Survey Missonri, V, 1895, p. 58.-Sardeson, American Geol., XIX, 1897, p. 102, pl. 5, figs. 14, 18, 28.

Orthis cyclus James, Cincinnati Quart. Jour. Sci., I, 1874, p. 19.

Dalmanella emacerata Hall and Clarke, Pal. New York, VIII, Pt. I, 1892, pp. 207, 224, pl. 5C, figs. 1, 2.

Orthis macrior Sardeson, Bnll. Minmesota Acad. Nat. Sci., III, 1892, p. 330, pl. 5, figs. 5-7.

Orthis (D.) testudinaria var. emacerata Winchell and Schnchert, Minnesota Geol. Survey, III, 1893, p. 445, Il. 33, figs. 23, 24.

Loc. Cincinuati, Ohio; Spring Valley and Granger, Minnesota; Cape Girardeau, Missonri; St. Croix, Qnelrec, Canada.

Dalmanella testudinaria futilis (Sarteson).

Trenton (Ord.).

Orthis futilis Sarleson, American Geol., XIX, 1897, p. 104, pl. 5, figs. 25-27.

Loc. Near Granger and Wykoff, Minnesota.

Dalmanella testudinaria ignota (Sardeson).

Lorraine (Orl.). Orthis ignota Sardeson, American Geol., XIX, 1897, p. 99, pI. 5, figs. 1-7.

Lor. Near Spring Valley, Minuesota.

Dalmanella testudinaria meeki (Miller).

Lorraine (Ord.).

Orthis emacerata Ncek (non IIall), Pal. Ohio, I, 1873, p. 109, pI. 8, figs. 1, 2

Orthis meeki Miller, Cincinnati Qnart. Jonr. Sci., II, 1875, p. 20.-Sardeson, American Geol., XIX, 1897, p. 98, pl. 4, figs. 24-29.

Ortlis jugosa James, The Palieontologist, 4, 1879, p. 31.

Dalmanella meeki Hall and Clarke, Pal. New York, VIII, Pt. I, 1892, 11. 206, 224, pl. 5C, fig. 3 .

Orthis corpnlenta Sardeson, Bull. Minnesota Acarl. Nat. Sci., III, 1892, p. 330, pl. 5, figs. 8-10;-American Geol., XIX, 1897, 1. 101, pl. 4, figs. 11-19.

Orthis (D.) testudinaria var. meeki Winchell and Sehnchert, Minnesota Geol. Survey, III, 1893, p. 445, pl. 33, figs. 25-29.

Loc. Oxford, ete, Ohio; Spring Valley, Minnesota.

Dalmanella testudinaria multisecta (Mrek).

Utica (Ord.).

Orthis emacerata rar. multisecta (James IS.) Meek, Pal. Ohio, J, 1873, p. 112, pl. 8, fig. 3.-Miller, Cincinnati Quart. Jonr. Sci., II, 1875, p. 22.

Orthis multisecta Sarleson, American Geol., X1X, 1897, p. 97, pl. 4, figs. 20-23.

Dalmanella multisecta Hall and Clarke, Pal. New York, VIII, Pt. I, 1892, pp. $207,224$.

Loc. Cincinnati, Obio.

Dalmanella testudinaria porrecta (Sarleson).

Trenton (Ord.).

Orthis porrecta Sardeson, American Geol., XIX, 1897, p. 104, pl. 5, figs. 19-24.

Loc. Near Granger, Minnesota. 
DELTHYRIS Dalman.

Genotype Delthyris elevata Dalman.

Dolthyris Dalman, Kongl. Svenska Vet.-Akal. Handl., för 1827, 1828, pp. 93, 99.—

Dall, American Jour. Couch., V1, 1870, p. 116.-Ifall and Clarke, Pal. Now York, V111, l't. I1, 1\$93, pp. 9 and 16 under caption Soptati (non p. 19).

Spirifera "lanellosa" Hall, Ninth Ann. Rep. New York Stato Geol., 1890, p. 11. Obs. Specimens of D. elevata examined by the writer show a distinct median septum in the ventral valve.

Delthyris acanthoptera Conrad = Spirifer aeanthopterus.

Delthyris acanthota Hall=Spirifer disjunctus.

Delthyris acuminata Conrad = Spirifer acuminatus.

Delthyris aenminata Hall (non Conral) $=\mathrm{D}$. mesicostalis.

Delthyris acntilirata Conrad=Platystrophia acutilirata.

Delthyris arenaria Vanuxem $=$ Spirifer arenosus.

Delthyris arenosa Conrad $=$ Spirifer arenosus.

Delthyris audacula Conrad= Spirifer audaeulus.

Delthyris bialveata Conrad $=$ Spirifer radiatus.

Delthyris biloba Conrad $=$ Bilobites varicus.

Delthyris brachynota Hall=Platystrophia biforata.

Delthyris ehemungensis Conrad=Spirifer disjunctus.

Delthyris eongesta Hall=Spirifer granulosus.

Delthyris consobrina (d'Orbigny).

Hamilton (Dev.).

Delthyris ziczac Hall (non Roemer), Geol. New York; Rep. Fourth Dist., 1843, p. 200 , fig. 5.

Spirifera consebrina d'Orbigny, Prodrome Pal., I, 1850, p. 98.-Miller, N. Ámerican Geol. Pal., 1889, p. 372.

Spirifer clio Hall, Thirteenth Rep. New York State Cab. Nat. Hist., 1860, p. 94.

Spirifera ziczac Hall, Pal. New York, IV, 1867, p. 222, pl. 35, figs. 15-23;-Second Ann. Rep. New York State Geol., 1883, pl. 59, fig. 9; pl. 60, fig. 18.-Whitfield, Annals Now York Acal. Sci., V, 1891, 1. 554, pl. 11, fig. 13;-Geol. Olio, VIl, 1895, p. 448, pl. 7, fig. 13.

Spiriferina? ziczac Whitfield, Geol. Wiscousin, IV, 1882, p. 332, pl. 25, figs. $23,24$.

Spirifer consobrinus Hall and Clarke, Pal. New York, VIII, l’t. II, 1895, pl. 34 , figs. 9,18 ; pl. 37, figs. $9,10$.

Loc. Noscew, York, Darien, ete., New York; Columbus, Ohio ; Nilwankee, Wisconsin; Louisville, Kentucky.

Delthyris cuspidata Hall=Spirifer disjunetus.

Delthyris decemplicatus Hall=D. suleata.

Delthyris disjuncta Hall=Spirifer disjunctus.

Delthyris duodenaria Hall=Spirifer duolenarius.

Delthyris duplicata Conrad=Spirifer duplicatus.

Delthyris euruteines Owen=Spirifer euruteines.

Delthyris expansa Owen=Pterotheca expansa, a P'teropod.

Delthyris fimbriata Conrad=Reticnlaria fimbriata.

Delthyris granulifera Hall=Spirifer granulosus.

Delthyris grantosa Conrad=Spirifer granulosus.

Delthyris inermis IIall=Spirifer lisjnnetus.

Delthyris levis Hall=Retieularia lievis.

Delthyris lynx Hall=Platystrophia lynx and biforata.

Delthyris macronota Hall=Spirifer maeronotus. 
Delthyris macropleura Conrad $=$ Spirifer maeropleura.

Delthyris medialis Hall=Spirifer audaculus.

Delthyris mesicostalis Hall.

Ithaca and Chemung (Dev.).

Delthyris mesacostalis Hall, Geol. New York; Rep. Fourth Dist., 1843, p. 269, fig. 9.

Delthyris acuminata Hall (non Conrad), Ibidem, 1843, p. 270, fig. 5 .

Spirifera mesacostalis Hall, Pal. New York, IV, 1867, p. 240, pl. 40, figs. 1-3.

Spirifera mesacostalis? Hall, Second Ann. Rep. New York State Geol., 1883, pl.59, figs. 32-34.

Spirifera mesacostalis var. acuminata Hall, Ibidem, 1883, figs. 27-31.

Spirifer mesacostalis Hall and Clarke, Pal. New York, VIII, Pt. II, 1895, pl. 34, figs. 32-34.-Kindle, Bull. Ameriean Pal., 6, 1896, p. 35.

Loc. Ithaca, Philipsburg, Olean, etc., New York.

Delthyris mesastrialis Hall=Spirifer mesistrialis.

Delthyris mueronata Conrad=Spirifer pennatus.

Delthyris niagartnsis Conrad=Spirifer niagaraensis.

Delthyris perlamellosa (Hall).

Lower Helderberg (Dev.).

Spirifer perlamellosa Hall, 'Tenth Rep. New York State Cal. Nat. Hist., 1857, p. 57, figs. 1-5 on p. 58;-Pal. Now York, III, 1859, p. 201, pI. 26, figs. 1, 2.Billings, Geol. Canada, 1863, p. 957, fig. 455.-Hall and Clarke, Pal. New York, VIII, Pt. II, 1895, pl. 35, figs. 7-13.

Delthyris macropleura Rogers (non Conrad), Geol. Pennsylvania, I1, Pt. II, 1858, p. 825 , fig. $6+3$.

Spirifera perlamellosa Meek and Worthen, Geol. Survey Illinois, III, 1868, p.384, pl. 7, fig. 9.-Hall, Second Ann. Rep. New York State Geol., 1883, pl. 60, figs. 5-13.

Spirifera perlamellosa? Keyes, Geol. Survey Missouri, V, 1895, p. 7 .

Loc. Schobarie, Carlisle, etc., New York; Cumberland, Maryland ; Pennsylvania; Square Lake, Maine; Perry County, Missouri ; Decatur County, Tennessee.

Delthyris perlatus Conrad $=$ Spirifer disjunetus.

Delthyris prolata Vanuxem=Spirifer disjunctus.

Delthyris prora Conrad $=$ Spirifer acuminatus.

Delthyris radiatus Hall= Spirifer radiatus.

Delthyris raricosta Conrad.

Upper Helderberg (Dev.).

Delthyris raricosta Conrad, Jour. Acad. Nat. Sei. Philadelphia, VIII, 1842, 1. 262, pl. 14, fig. 18.

Delthyris undulatus Vanuxen, Geol. New York; Rep. Third Dist., 1842, p. 132, fig. 3.

Spirifer raricosta Billings, Canadian Jour., VT, 1861, p 258, figs. $71-73$ on p. 259 ;Geol. Canada, 1863, p. 372, fig. 392.-Walcott, Mon. U. S. Geol. Survey, VIII, 1884, p. 135, pl. 4, fig. 2; pl. 14, fig. 12.-Hall and Clarke, Pal. New York, VIII, Pt. II, 1895, pl. 35, figs. 5, 6, 14-17.

ISpirifer hesione Billings, Proc. Portland Soc. Nat. Hist., 1863, p. 117, pl. 3, fig. 17.

Spirifera raricosta Hall, Pal. New York, IV, 1867, p. 192, pl. 27, figs. 30-34; pl. 30, figs. 1-9.-Nicholson, Pal. Prov. Ontario, 1873, p. 82.-Billings, Pal. Fossils, II, 1874, p. 47, pl. 3A, fig. 5.-Hall, Second Ann. Rep. New York State Geol., 1883, pl. 60, figs. 14-17. - Nettelroth, Kentucky Fossil Shells, Mem. Kentucky Geol. Survey, 1889, p. 128, pl. 17, figs. 38-42.

Loc. Schoharie, Caledonia, ete., New York; Colnmbus, Ohio; Falls of (Olin; Eureka distriet, Nevada; Port Colborne, Ontario; Square Lake, Maine; Grand Greve, Gaspé. 
Delthyris rugatina Conrarl=D. suleata.

Delthyris(?) rugicosta (Hall).

Arisaig (Sil.).

Spirifera rugaceosta IIall, Canadian Nat. Geol., V, 1860, p. 145.-Dawson, Acadian Geol., 3il eel., 1878, p. 596.

Loc. Arisaig, Nova Scotia.

Delthyris sculptilis Hall.

Hamilton (Dev.).

Delthyris sculptilis IIall, Geol. New York; Rep. Fourth Dist., 1843, p. 202.

Spirifera sculptilis? Billings, Canadian Jour., VI, 1861, p. 262, fig. 79.

Spirifera sculptilis Billings, Geol. Canada, 1863, p. 386, fig. 423.-Hall, Pal. New York, IV, 1867, p. 221, pl.35, figs. 10-14.-Nettelroth, Kentucky Fossil Shells, Nem. Kentucky Geol. Survey, 1889, p. 132, pl. 31, fig. 13.

Spirifer sculptilis Hall and Clarke, Pal. New York, VIII, Pt. II, 1895, I1. 37, fig. 8 .

Loc. Ludlowrille, York, etc., New York; Mouroe County, Pennsylvania; Bosanquet, Ontario; Falls of Ohio.

Delthyris sinuatus Hall=Bilobites bilobus.

Delthyris staminea Hall=Spirifer crispus.

Delthyris sulcata Hisinger.

Niagara (Sil.).

Delthyris sulcata Hisinger, Petref. Suecica, 1837 , p. 73 , pl. 21, fig. 8.

Delthyris rugatina Conrad, Jonr. Acad. Nat. Sci. Philadelphia, VIII, 1842, p. 261.

Delthyris decemplicatus Hall, Geol. New York; Rep. Fourth Dist., 1843, p. 105, fig. 4 .

Spirifer sulcatus Hall, American Jour. Sci., XX, 1849, p. 228 ;-Pal. New York, II, 1852, p. 261, pl. 54, fig. 2.-Billings, Canadian Nat. Geol., I, 1856, p. 137, pl. 2, fig. 7.-Hall, Second Ann. Rep. New York State Geol., 1883, pl. 60, figs. 1-4.-Hall and Clarke, Pal. New York, VIII, Pt. II, 1895, pl.35, figs. 1-4.

Loc. Europe; Lockport, Rochester, etc., New York; Hamilton, Ontario.

Obs. Davidson regards this species as synonymons with D. elevata Dalman, 1828.

Delthyris undulatus Vanuxem $=$ D. raricosta.

Delthyris varica Conrarl=Bilobites varicus.

Delthyris ziczac Hall=D. consobrina.

DERBYA Waagen.

Genotype Derbya regularis Waagen.

Derbyia Waagen, Palæontologica Indica, Ser. XIII, I, 1884, pp. 576, 591.

Derbya Hall and Clarke, Pal. New York, VIII, Pt. I, 1892, p. 261 ;-Eleventh Ann. Rep. New York State Geologist, 1894, p. 286.

Derbya affinis Hall and Clarke.

Upper Carboniferons.

Derbya affinis Hall and Clarke, Pal. New York, VIII, Pt. I, 1892, p. 349, pl. 11B, figs. 4,5 .

Loc. Near Kansas City, Missouri.

Derbya bennetti Hall and Clarke.

Upper Carboniferous.

Derbya bennetti IIall anl Clarke, Pal. New York, VIII, Pt. I, 1892, pp. 263, 348, pl. $11 \mathrm{~A}$, figs. $34-39$.

Loc. Near Kansas City, Missouri.

Derbya biloba Hall.

Upper Carboniferous.

Streptorhynchus biloba Hall, Second Ann. Rep. New York State Geol., 1883, pl. 41, figs. 4, 5 .

Derbya biloba Hall antl Clarke, Pal. New York, VIII, Pt. I, 1892, p. 350, pI. 11, figs. 4,5 .

Loc. Winterset, lowa. 
Derbya broadheadi Hall and Clarke.

Upper Carboniferous.

Derbya broadheadi Hall aud Clarke, Pal. New York, VIII, Pt. I, 1892, pp. 263, 347 , pl. 11A, tigs. 23, 24.

Loc. Near Kansas City, Missouri.

Derbya correanus (Derby).

Upper Carboniferous.

Streptorhymehus correanus Derby, Bull. Cornell Univ., I, 187.t, p. 32, pl. 6, tig. 11; pl. 7, figs. 1-4, 8, 10, 11-14, 17.-Hall, Second Anu. Rep. New York State Geol., 1883, pl. 41, figs. 18-22.

Derbya correanus Waagen, Palarontologica Indica, Ser. XIII, 1, 1884, p. 592.

Derbsa correana Hall and Clarke, Pal. New York, VIII, Pt. I, 1892, p. 262, pl. 11, tigs. 18-22; pl. 20, tigs. $10,11$.

Loc. Itaituba, Brazil.

Derbya(?) costatula Hall anci Clarke.

Kaskaskia (L. Carb.).

Derliya? costatula Hall aud Clarke, Pal. New York, VIIl, Pt. I, 1892, p. 346, pl. 11B, tigs. 16, 17.

Loc. Crittenden Conuty, Kentucky.

Derbya crassa (Meek and Hayden).

Upper Carboniferous.

Orthis arachnoides Roener (uon P'hillips), Kreilebilduug Texas, 1852, 1). 89, pl.

11, fig. 9.-Hall, Mexican bound. Survey, 1857, pl. 20, fig. 3.

Orthisina crassa Meek and Itaydeu, Proc. Acad. Nat. Sci. Philadelphia, 1858, 1. 261.

Orthis lasallensis Mcchesney, Descriptions New I'al. Fossils, 1860, p. 32;Iloidem, 1865 , pl. 1, lig. 6.

Orthis richmonta MeChesney, Deseriptions New Pal. Foss., 1860, p.32;-Ibidem, 1865, pl. 1, fig. 5.

Hemipronites crassus Meek and IIayden, Pal. Upper Missonri, Smithsonian Cont. Knowl., XIV, 172, 1864, p. 26, pl. 1, fig. 7.-Neek, Final Rep. U. S. Geol. Survey Nebraska, 1872, 1. 171, p1. 5, fig. 10; 1,1. \&, fig. 1.-Neek and Worthen, Gcol. Survey lllinois, V, 1873, 1. 570, pl. 25, fig. 12.-Herrick, 13ull. Deuison Tniv., II, 1887, 1. 50, pl. 2, tig. 19.

Orthis crenistria Geinitz (nou I'hillips), Carbon u. Dyas in Nobraska, 1866, p. 16, 1l. 3, tigs. 20, 21.

Hemipronites lasallensis NeClısney, Trans. Chicago Acal. Sci., 1, 1868, 1. 28, pl. 1 , lig. 6.

Hemipronites richmomlin IdChesney, Trans. Chicigo Acad. Sci., 1, 1868, 1. 28, 1). 1 , fig. 5 .

Iemipronites crenistria White, Wheeler's Expl. Survey west 100 Merid., IV, $187 .$, 1). 124, pl. 10, fig. 9

Streptorhyuchus richmoudi Ilall, Second Ann. Rep. New York State Gool., 1883, pl. 10, figs. $10,11$.

llemipronites crassa White, Thirtesuth Rep. State Geol. Indiana, 1884, 1. 129, pl. 26, tigs. 4-11.

Verbyia crassa Waagen, Paliontologica Indica, Ser. XIII, I, 1884, p. 592.- HaIl aud Clarke, Pal. New York, VIII, Pt. I, 1892, p. 262, pl. 10, figs. 10, 11 ; pl. 11A, figs. 28-33; pl. 1113, tigs. 23, 21; 1). 20, tigs. 12, 13.-Smith, Proc. American 1'hil. Soc., XXXV, 1897, 1, 28 (extract).

Streptorhyuchus crenistria lieyes, Proc. Acad. Nat. Sci. Philatlel phia, 1888, p. 229 ;-Geol. Survey Missouri, Y, 1895, 1. 67, pl. 38, tig. 8 .

Streptorhynchus crassum Miller, N. American Geol. Pal., 1889, p. 378.

?Streptorhynchus crassum Whittield, Annals New York Acad. Sei., V, 1891, P. 580, pl. 13, figs. 11, 12;-Geol. Ohio, VII, 1893, 1. 468, pl. 9, tigs. 11, 12.

Loc. Leavenworth, Kansas; Nebraska City, Nebraska; Illinois; Missouri; Iowa; Ohio; Arkansas; Utah; Nevada; northern Now Jexico; San Saba Valley, Texas.

Bull. $87-14$ 
Derbya cymbula Ilall and Clarke.

Upper Canbonilerous.

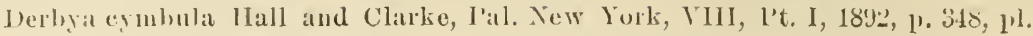
111 , tigs. :2, :3.

Lor. Near Kinsas City, Missouri.

Derbya kaskaskiaensis (MeChexney).

Kaskaskia (L. Carb.).

(rthis kiskiılicusis MeChesuey. I)escriptions New Pal. Fuss., 1860), 1. 31.

Derby'a kiskaskiensis Hall and Clarke, I'al. New lork, VI1I, P’t. I, 1892, J1. 111 , fị. 6.

Loc. Kaskaskia, Chester, aud ('ritteuden, 1lliuois.

Derbya keokuk Ilall.

Knobstone-Keokuk (l., Curb.)

Orthis erenistria Yandell and Shmuare, Cont. (ieol. Kentucky, 18i7, Pl. 19, 21.

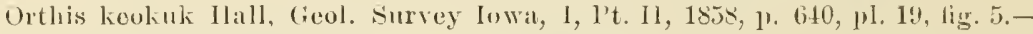
lieyes, Geol. simvey Missumri, V, 1895, 1' li3.

Streptorhyuchus keokuk Hall, Second Anu. Tep. New York State Geol., 1883, pl. 11, figs. $1-3$.

Streptorhynchus crenistria Walcott, Mon. U. S. (ieol. Nurvey, VIII, 1884, p. 279 1). 18 , iig. 14 .

1)erbya keokuk 1 Iall and Clarke. P'al. New York, VII1, Pt. 1, 1892, 1'. 26-, 11. 11 figs. 1-3.

Loc. Keokuk, Iowa; Warsaw and Nanvoo, Illinois; New Providence, Indiana Clark Comnty, Missonri; Tevada.

Derbya pratteni (MeCliesuey).

Uprer Carboniferous

Orthis pratteni Mechesney, Descriptions New Pal. Foss., 1860. 1. 3.3.

Loc. Charbonier. Missonri.

Derbya robusta (Hall).

Upher Cirboniferous

Orthis ambraculum? Owen (non Schloth. , Geol. Survey Wisconsin, low: Min nesotil, 185:, 11. 5, fig. 11 (see specimens in U. S. Yat. Ilus., ('at. Invert Foss., 17915).

Orthis rolusta 11a11. Geol. Smrvey lowa, 1, I't. 11, 1858, 1'. 743, 111. 2x, tig. 5.

streptorhynehus robusta Hall, second Anu. Rep. New York statc Geol., 18צ:3 1). 40, figs. 12-17.

Derbyia robusta Waagen, Paloontologica Iudiea, Ses. XIII, 1, 18צ4, p. 592.-Hal aud Clarke, Pal. New York, VIII, I't. I, 1892, 1'. 262, 11. 10, figgs. 12-17; pl 111 , figs, 7,8 .

Loc. St. Clair Comnty, Illinois.

Derbya ruginosa Hall and Clarke.

Keokuk (L. Carb.)

Derlya ruginosi Hall and Clarke, Pal. New York, VIIl, Pt. I, 1892, I. 346, pl $11 \mathrm{~A}$, figs. $25-27$.

Loc. New Providence, Intiana.

Dicellomus Hall=Obolella.

Dicellomus crassa Hall=Obolella crassa.

Dicellomus polita Hall=obolella polita.

Dicelosia King=Bilobites.

Dicranisens Meek=Triplecia.

I) icraniscus ortoni Meek =Triplecia ortoni.

DICTYONELLA Hall.

Genotype Rhynehonella? retieulata Hall

Jiet onella Hall, Twentieth liej. New York State Cab. Nat. Hist., 1867, 1. $27 t$

Eichwaldia Hall, Hbiclem, 1867, pl. 274-277, with figs-Dall, American Jour Conch., VI, 1870, 1. 98.- Hall ant Clarke, Pal. New York, VIIl, Pt. il, 1893 p. 307; -Thirteentl Ann. Rep. New York State Geologist, 1895, p. 903. 
Dictyonella anticostiensis (Billings).

Anticosti (Sil.).

Eichwaldia anticostiensis Billings, Catalogue Sil. Foss. Anticosti, 1866, p. 10.

Loc. Anticosti.

Dictyonella concinna Hall.

?Niagara (Sil.).

Eichwaldia concinna Hall, Twentieth Rep. New York State Cab. Nat. Hist., 1867, p. 278.-Hall and Clarke, Pal. New York, V1II, Pt. II, 1895, pl. 83, fig. 5.

Loc. Perry and Decatur counties, 'Tennessee.

Dictyonella corallifera Hall.

Niagara (Sil.).

Atrypa corallifera Ilall, Pal. New York, II, 1852, p. 281, pl. 58, fig. 5.

Eichwaldia corallifera Hall, Twentieth Rep. New York State Cab. Nat. Hist., 1867, p. 278

Loc. Lockport and Rochester, New York.

Dictyonella gibbosa Hall.

Niagara (Sil.).

Eichwaldia gibbosa Hall, Twentieth Rep. New York State Cab. Nat. Ilist., 1867, p. 278.-Hall and Clarke, Pal. New York, VIII, Pt. II, 1895, pl. 83, figs. 6, 7. Loc. Perry and Decatur counties, Tennessee.

Dictyonella reticulata Hall.

Niagara (Sil.).

Rhyuchonella? reticulata Hall, Trans. Albany Institute, IV, 1863, p. 217.

Eichwaldia reticulata Hall, Twenticth Rep. New York State Cab. Nat. Hist., 1867, pp. 275-277, figs. 1-7;-Twenty-eighth Rep. Ibiclem, 1879, p. 169, pl. 26, figs. 50-54;-Eleveuth Rep. State Geol. Indiana, 1882, p. 312, pl. 26, figs. 50-54.-Foerste, Bull. Denison Univ., 1, 1885, p. 91, pl. 13, fig. 4.-Beecher and Clarke, Mem. New York State Mus., I, 1889, p. 31, pl. 3, figs. 11 -13.-IIall and Clarke, Pal. New York, VIII, Pt. II, 1893, p. 308, figs. 229-235; pl. 83, figs. 8-13.-Foerste, Geol. Ohio, VII, 1895, 1. 594, 11. 25, fig. 4.

Loc. Waldron, Iudiana; Dayton, Ohio; Wisconsin.

DIELASMA King. Genotype Terebratulites elongatus Schlotheim. Epithyris King (non Phillips), Mon. Permian Foss., Pal. Soc., 1850, 1. 46.-Dall, American Jour. Conch., VI, 1870, p. 103.

Dielasma King, I'roe. Dublin Univ. Zool. Bot. Assoe., I, 1859, 1. 260.-Beecher and Schuchert, Biol. Soc. Washingtou, VII, 1893, pp. 71-82.-Hall and Clarke, Pal. New York, VIII, Pt. II, 1893, 1. 293 ;-Thirteenth Ann. Rep. New York State Geologist, 1895, 1. 863.

Dielasma bovidens (Morton).

Upler Carboniferoms.

T'erebratula bovidens Morton, American Jour. Sci., XXIX, 1\&36, p. 150, pl. 2, fig. 4.-Meek, Final Rep. U. A. (ieol. Survey, Nebraska, 1872, p. 187, 11. 1, fig.7; pl. 2, fig. 4.-Meck and Worthen, Geol. Survey Illinois, V, 1873, p. 572, pl. 25, fig. 15. - White, Thirteenth Rep. State Geol. Indiani, 1884, p. 137, pl. 32, figs. 17-19.-Keyes, Geol. Sulvey Missouri, V, 1895, p. 105.

Terebratula bovidens? I Iall, Geol. Survey Iowa, I, Pt. I1, 1858, p. 711.-MeChesney, Trans. Chicago Acal. Sci., I, 1869, p. 37, pl. 1, tig. 2.

Terebratula millipunctata Hall, Expl. Surveys R. R. Ronte Miss. River, Pacitic Ocean, III, 1856, 1. 101, 13. 2, tigs. 1, 2;-Trans. Allany Institute, IV, 1858, p. 35.-Meek and Hayden, Proc. Acad. Nat. Sci. P'hiladelphia, 1859, p. 26.White and St. John, Trans. Chicago Acad. Sci., I, 1868, p. 119.

Terebratula clongata Shmmard (non Schlotheim), Trans. St. Louis Acad. Sci., I, 1859, 1. 392.

Terebratula geniculosa MeChesuey, Uescriptions New Pal. Foss., 1861, 1. 82 ;Ibitlem, 1865, pl. 1, tig. 2.

Dielasma? hovidens White, Wheeler's Expl. Survey west 100 Merid., Prel. Rej., 1874, p. 21. 
Dielasma bovidens (Morton)-Continued.

Trebratula (Dielasma) bovidens White, Lbillem, rinal Rep., IV, 1875, 1. 141, il. 11, lig. 10.

Tereliatula hastata Walcott (non Sowerby), Mon. U. S. Ceol. Surrey, VIII, 1881, 1. 224.-Smith, l'roc. Ameriean Phil. Soc., XXXV, 18!17, 1. 30.

1)ielasula bovidens Hall and Clarke, l'al. New York, VIII, l't. II, 1893, pI. 295, 296 , fig. $213 ;$ jl. 81 , ligs. 29-35.

Loc. Pntuan Ilill, (hhio; Indiana; Illinois; Missonri; Iowa; Neloraska; Arkansals; New Mexico; Enreka district, Nevala; Gualalupe Momutains, Trxas.

\section{Dielasma burlingtonense White.}

Kinderhook (L. Carb.).

Terebratula burlingtonensil White, Jour. Boston Soc. Nat. Ilist., VIl, 1860, p. 228.

Tereloratula (I)ielasma) burlingtonensis White, Wheeler's Expl. Survey west 100 Merid., 1 Y 1875, p. 93.

Dielasma burlingtonensis IIall ant Clarke, Pal. New York, VII, Pt. II, 1893, p. 296 , pl. 81, figs. 9-11.

Loc. Burlington, Iowa; Monntain Spring, Nevada.

Dielasma calvini (Hall and Whitfield).

Chemuug (Dev.).

Crpytonella endora llall and Whitfield (non Hall, 1867), Twenty-third Rep. New York State Cab. Nat. Ilist., 1873, 1. 225.

Cryptonella ealvini Ilall and Whitfield, Ibidem, 1873, p. 239.

?Cryptonella calvini Whiteaves, Cout. Canadian Pal., I, 1891, p. 235.

Dielasma calvini Hall and Clarke, Pal. New York, VIII, Pt. II, 1893, p. 296, pl. 80 , figs. 20-22.

Loc. Hackberry Grove, lowa; Mackenzie and Peace rivers, Canalla.

Dielasma formosum Hall.

Warsaw (L. Carb.).

Terebratula formosa Hall, Trans. Albany Institute, IV, 185x, p. 7.-Whitlielı,

Bull. American Mus. Nit. Hist., I, 1882, p. 55, pl. 6, figs. 59-64.-White, Eleventh Rep. State Geol. Indiana, 1882, ए. 361, pl. 39, figs, 6-8.-Hall, Twelfth Rep. Ibidem, 1883, p. 337, pl. 29, figs. 59-64.

Dielasma formosa Hall and Clarke, Pal. New York, VIII, Pt. II, 1893, p. $296, \mathrm{pl}$. 81 , tigss. 12-26.

Loc. Bloomington aud spergen Hill, Indiana; Alton and Warsaw, Illinois; Caldwell County, lientucky.

Dielasma gorbyi (Miller).

Keokuk (L. Carb.)

Terebratula gorbyi Miller, Seventeenth Rep. State Geol. Indiana, 1891, p. 77, pl. 13 , figs. 3,4 .

Loc. Edwardsville and Crawfordsville, Indiana.

Dielasma hochstetteri (Toula).

Upper Carboniferous.

'Terebratula hochstetteri Tonla, Sitzb. der k. k. Akad. der Wissensch. zu Wien,

LIX, 1869, p. 1, pl. 1, fig, 1.-Derby, Bull. Cormell Univ., I, 1874, p. 63.

Loc. Near Cochabamba, Bolivia.

Obs. Probably synonymous with D. bovirlens (Morton).

Dielasma itaitubaense (Derby).

Upper Carboniferous.

Terebratula itaitubensis Derby, Bull. Cornell Coiv., I, 1874, p. 1, pl. 2, figs. 1,3, 8, 16 ; pl. 3, fig. 24; pl. 6, tig. 15.

Dielasma itaitnbensis Waigen, Palirontologica Indica, Ser. XIII, I, 1882, 1' 348.--le Koninck, Aunales du Musée Royal d'Histoire Nuturelle de Belgi(1ue, XlV, 1887, 1. 26, pl. 5, tigs. 1-10, 45, 50.

Loc. Beach at Itaituba, Brazil; Belgium. 
Dielasma ohovata Hall aud Clarke, Pal. New York, VIII, Pt. II, 1895, pl. 81, figs. $38-40$.

Loc. Kéntueky.

Dielasma occidentale (Miller).

Chonteau (L. Carb.).

'Terebratula oeciclentalis Miller, Eighteentlı Ann. Rep. Geol. Survey Indiana, 1894, 1. 313, pl. 9, figs. 10-13.

Loc. Aerdalia, Missonri.

Dielasma(?) rowleyi (Worthen).

Burlington (L. Carb.).

Terebratula rowleyi Worthen, Bull. Illinois State Mns. Nat. Hist., 2, 1884, p. 23;Geol. Survey Illinois, VIII, 1890, 1. 102, pl. 11, fig. 6.-Keyes, Feol. Survey Missonri, V, 1895, p. 105, pl. 40, fig. 15.

Dielasma rowleyi Hall and Clarke, Pal. New York, VIII, J't. II, 1893, 1. 296, pl. 81 , figs. $27,28$.

Loc. Pike C'ounty, Missouri.

Dielasma sacculus (Martin).

Upper Carboniferous.

Conchyliolithus auomites sacculus Martin, Petref. Derbesiana, 1804, tab. 46, figs. 1,2 .

T'erebratula sacenlus Dawson, Aeadian Geol., 1855, p. 219, fig. 27.-Davidson, Quart. Jour. (reol. Soe. London, XIX, 1863, p. 169, pl. 9, higs. 1-3.-1):iwson, Acurlian Geol., 3i ed., 1878, 1. 2\$9, fig. 87.

Loc. Europe; Winilsor, Nova Seotia.

Dielasna shumardianum (Miller).

Kaskaskia (I. Carb.).

Terebratula areuata Swallow (nou Roemer, 1840), Trans. St. Louis Aead. Sri., II, 1863, p. 83.-Neek, Sixtl Ann. Rep. U. S. Geol. Survey Terr., 1872, p. 470.

'Tereloratula shumardana Miller, Americau Pal. Foss., 2il erl., 1883, p. 299.

Loc. St. Genevieve Connty, Missouri; Chester, Illinois; near Virginia City, Montana.

Obs. Regadded hy Meek and White as probably synonymons with 1), bovidens (Morton).

\section{Dielasma turgidum (Hall).}

Warsaw and St. Louis (L. Carb.).

Terebritula turgicla Hall, Trans. Albany Institnte, 1V, 1858, 1. 6.-Whitfield, Bull. Ameriean Mus. Nat. Hist., I, I882, p.54, pl.6, tigs. 53-58.-Hall, Twelfth Rep. State Geol. Indian:ı, 1883, p. 336, pl. 29, figs. 53-58.-Whitfielı, Anuals New York Acul. Sei., V, 1891, p.586, pl. 13, figs. 21, 22);-Gool. (Hio, VII, 1895, p. 473, pl. 9, figs. 2I, 22.

Dielasma turgirla lieecher and Schuchert, Proc. Biol. Soc. Washington, VIII, 1893, p. 73, pl. I0, figs. 1-6.-Hall and Clarke, Pal. New York, VII, l’t. II, [893, p. 296, pl. 81, figs. $1-8$.

Loc. Bloomington and Spergen Hill, Indiana; Crittenden Connty, Kentueky; Maxville and Newtonville, Ohio; Alton and Warsaw, lllinois; Pella, lowa; Boonville, Missouri.

\section{DIGNOMIA Hall.}

Genotype Lingula alveata Hall.

Dignonia Hall, Notes on some New or Imperfeetly Kuown Forms among the Brach., 1872, p. 2, pl. 13, fig. 3;-Twenty-third Rep. New York State Cab. Nat. Hist., 1873, p. 245, pl. 13, fig. 3.-Hall and Clarke, Pal. New York, VIII, Pt. I, 1892, 1p. 14, 163 ;-Eleventh Anu. Rep. New York State Geologist, 1894, p. 230.

\section{Dignomia alveata Hall.} 23 ;-Pal. New York, IV, 1867, 1. 12, pl. 2, figs. 14, 15. 


\section{Dignomia alveata IIall-Continuerl.}

1)ignomia alvoata IIall, Notes on some Now an Imperfectly known lorms anong the 13rach., 1872, 1. 2, pl. 13, fig. 3;-'Twenty-thiril Rop. New York State Cab. Nat. llist., 1873, pl. 13, fig. 3.-Hall and Clarke. Pal. Now York, VII, Pt. I, 1892, p. 1.1, pl. 1, ligs. 24, 25.-Clarke, Thirteenth Amn. Rep. New York State Ceologist, 1895, p. 187, pl, f, fig. 1.

Lor. Canandaigna Lake, ete., New York.

\section{DINOBOLUS Hall.}

Crenotype Obolus conradi Hall.

Dinobulns Hall, Notes on some New or Imperfectly Known forms among the Braclı., (March) 1871, p. 4;-Ibilem, 1872, p. 4;-Twonty-thirl Rep. New York state Cah. Nat. Hist., 1873, p. 247.-Fall and Whitficld, Pal. (Hio, II, 1873, 1. 130. - IIall and Clarke, Pal. Now York, VIII, Pt. I, 1892, pp. 36, 46, 164;-Eleventh Aun. Rep. New York State Geologist, 1894, 1. 2:37. Obolellina libllings, ('anadian Nat. Geol., VI (December) 1871, 1. 222; - Ibidem, VI, 1872, 1. 326, figs. 1, 2;-American Jour. Sci., 31 ser., III, 1872, 1. 270.

Conradia IIall (non Adams), Twenty-third Rep. New York State Cak. Nat. Ilist, 1873, p. 250.-Davidson and King, Quart. Jonr. Geol. Soc. London, XXX, 1874 , p. 159 .

\section{Dinobolus canadaensis (Billings).}

Black River and Trenton (Ord.).

Oholus canadensis Billings, Canadian Nat. Geol., II, 1858, p. 441, fig. 20-23 (non fig. $19=$ D. magnificus);-Geol. smrey Canata; Rep. Prog. for 1857, 1858, 1. 189, fiщs. 20-23 (non fig. 19);-Geol. Canala, 1863, p. 142, figs. 75.

Obolellina canadensis lillings, Canadian Nat. Ceol., VI, 1871, p. 222;-Ibilem, 1872, 1, 326, fig. 15 ; fig. 6, p. 329 .

Dinobolus canadensis Davidson and King, (Ynart. Jonr. Geol. Soc. London, XXX, 187, p. 162, pl. 19, fig. T.

Lor. Panquette Rapisls, ete., Canala.

\section{Dinobolus conradi IIall.}

Niagara (Sil.).

Oholus conradi Hall, Twentieth Rep. New York State Cab. Nat. Hist., 1868, p. 368, pl. 13, figs. $1,2$.

Obolus ('Trimerella?) conradi Meek and Worthen, Geol. Survey Illinois, 1II, 1868, 1. 351, pl. 5, fig. 7.

Trimerella conradi Dall, Ameriean Jour. Conch., VII, 1871, p. 83.

Dinobolus conradi IIall, Twenty-thirl Rep. New York State Cab. Nat. Hist., 1873, p. 247 (also extracts 1871, 1872).Davidson and King, Quart. Jonr. Geol. Soc. London, XXX, 187.1, p. 160, pl. 18, figs. 1-5.-Hall and Whittield, Pal. Ohio, II, 1875, p. 130, pl. 7, figs. 3, 4.-IIall anl Clarke, Pal. New York, VIII, Pt. I, 1892, p. 38, pl. 4B, figs. 13-24.

Loc. Port Byron, Illinois; Leclaire, Iowa; Racine and firafton, Wisconsin; Crawford, Ohio; England; Gotland.

\section{Dinobolus magnificus (Billings).}

Black River-Trenton (Ord.).

()bolns canadensis Billings (partim), Geol. Snrr. Canada, Rep. Prog. for 1857, 1858, p. 189, fig. 19 (non 20-23);-Canadian Nat. Geol., 1II, 18\%8, p. H11, fig. 19 (non figs. $20-23=$ D. canadensis).

Ololellina magnificus Billings, Ihidem, n. ser., VI, 1872, p. 329, fig. 7 .

Dinobolıs magnificus Davilson and King, Quart. Jonr. Geol. Soc. London, XXX, 187t, p. 16t, pl. 19, fig. 8.-Nicholson, Pal. Prov. Ontario, 1875, p. 17, fig. 6.

Loc. Panrnette' Rapiıls, etc., Canada.

Dinobolus(?) parvus Whitfield.

Galena (Ord.).

Dinobolns? parvns Whitfield, Geol. Wisconsin, IV, 1882, p. 347, pl. 27, figs. 8-10.-Wincholl and Schmehert, Minnesot: Geol. Snrvey, III, 1893, p. 356, liw. 27.-Whiteaves, P'al. Foss., III, l't. JII, 1897, p. 166.

Loc. Whitewater, Wisconsin; Wykoti, Minnesota; Lake Winnipeg, Canada. 
DIEORTHIS Hall and Clarke. Genotype Orthis pectinella Emmons. Dinorthis Hall and Clarke, P'il. New York, ViII, Pt. I, 1892, pp. 195, 222.-Winchell and sidhuchert, Mimesota Geol. Survey, III, 1893, I. 420.

Pliesiomys Ilall ant Clarke, Pal. New Iork, V'III, Pt. I, 1892, p. 196.

linorthis and I'lixsinmys Hall and ('larke, Eleventh Amn. Rep. New York State Geologist, 1894, p. 266 .

\section{Dinorthis deflecta (Conrarl.)}

Trenton (Orl.).

Strophomena deflecta Conrad, Proc. Acarl. Nat Sci. Philadelphia, I, 1843, p. 332.-1Iall, Twelfth Rep. New York Ntate Cab. Nat. 1list., 1859, p. 70.

Strophomena recta Conrat, Proe. Acarl. Nat. Sci. Philadelphia, I, 1843, 1. 332.Hall, Twelfth Rep. New York state Cal. Nat. Hist., 1859, 1. 70.

Leptirna deflecta Hall, l'al. New York, I, 1817, p. 113, pl. 311, fig. 5.

Leptena recta IIall, Ibidem, 184i, p. 113, pl.31B, fig. 6 .

Streptorhynchus rectus Miller, American Pal. Foss., 1877, p. 134.

Streptorhyuchus deflectum Miller, N. American Geol, and Pal., 1889, p. 378.

Plasimys deflecta Hall and Clirke, Pal. New York, VIII, Pt. I, 1892, 1p. 197, 222, pl. $5 \mathrm{~A}$, 1igs. 28-34.

Pliesiomy's recta Hall and Clarke, Ihiłlem, 1892, pp. 197, 222.

Plarsiomys loricula Hall and Clarke, Ilvidem, 1892, pp. 197, 341, pl. 5A, figs. 31-34. Orthis (Dinorthis) deflerta Winchell and Schnchert, Jinnesota Geol. Surves, III, 1893, p. 422, 11. 32, figs. 24-30.

Lor. Mineral Point, lieloit, Janesville, Wisconsin; Dixon, Illinois; Minueapolis, st. Paul, ete.. Minnesota; McGregor, Iowa; central Temnessee; Highbrilge, Kentucky.

Dinorthis fontinalis (White).

Calciferous (Ord.).

Strophomena fontinalis White, Wherler's Expl, and Snrvey west 100th Merid. IV, 1875, p. 51, pl. 3, fig. 4 ;-l'lelim. Rep., 1. 10, $187 t$.

Lor. Jish spring, Honse Range, I’tals.

Obs. Pelated to D. reflecta (Conrad).

Dinorthis iphigenia (Billings).

Trenton (Ord.).

Orthis iphigenia Billings, Pal. Fossils, I, 1862, p. 133, pl. 110.

Plitsionyc iphigenial Hall and C'larke, Pal. Now York, VIII, Pt. I, 1892, p. 222.

Loc. Ottawa, Camada.

Dinorthis meedsi Winchell and Schuchert.

Trenton (Ord.).

Orthis meelsi Winchell and Schurhert, Ameriean (ienl, IX, April 1, 1892, 1. 289.

Orthis mimesotrnsis Sarreson, Bull. Minnesota Acal. Nat. Sci., III, April 9, 1892, 1. 332, 11. 5, figs. $14-17$.

Orthis (Diuorthis) meedsi Winchell and sichohert, Minnesota Geol. Survey, III, 1893, p. 427, p]. 32, figs. 39-4ㄱ.

Lor, Camnon Falls, Kenyon, Preston, ote., Minnesota; llecorah and McGrogor, lowa; Yeunh and Oshkosh, W iseonsin.

Dinorthis meedsi germana Winchell and Schuchert.

Trenton (Ord.).

Orthis meelsi var. germana Winchell and schuchert, Ameriean Geol., IX, 1892, 1. 290.

Orthis (1).) meedsi var. germana Winchell and schnchert, Minnesota Geol. Surrey, III, 1893 , p. 428, pl. 32, figs. $43-15$.

Loc. Cannon Falls, Kenyou, and Fountain, Mlinnesota.

Dinorthis pectinella (Emmons).

Trenton (Ord.).

Orthis pectinella Emmons, Geol. New York; Rep. Second Dist., 1842, p. 394, fig. 2.-Hall, Pal. New York, I, 18.7, p. 128, pl. 32, fig. 10.-Billings, Cauadiau Nat. Geol., I, 1856, p. 205, fig. 5-liogers, Geol. Pennsylvania, II, Pt. II, 
Dinorthis pectinella (Emmons)-Continued.

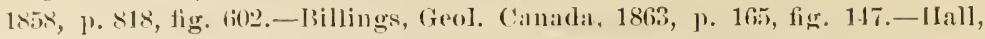
Siseoml Am liep. New Jork Stato Geol., 1:8:3, pl. 31, tigs. 3!), 40.

Orthis pectinella var. semioralis Hall, l’al. New York, 1, 18.17, 1. 121, pl.32, lig. 11.-Miller, N. American Geol. J'al., 1889, p. 359.

Orthis clarlott: N. II. Winchell, Eightl Rej. (irol. Nat. Hist. Snrvey Minnesota, 1880, 1). 67.

Dinorthis pectinella IJall and Clarke, I'al. New York, VIII, Pt. I, 1892, pp. 195, 292, 228, pl, 5, figs. 27-33.

(ortlis (Diuorthis) pectinella Winchell and scluchcrt, Minmesota Geol. Survey, 1[1, 1893, 1. 424. p]. 32, figs. 31-31.-Whuteaves, J'al. Foss., III, P't. I1 I. 18!r, ). 175.

Lor. Middlerille, Trenton Falls, ete., New Jork; Jennsylvania; Mercer Comnts, Kentucky; Onturio, Canada; Decorah, Iowa; St. Panl, Minueapolis, and Cannou Falls, Minuesota; Lake Winnipeg, C'anala.

Dinorthis pectinella sweeneyi N. H. Winchell.

Trenton (Ord.).

Orthis sweeneyi N. H. Winchell, Nintl Rep. Geol. Nat. Mist. Survey Minnesota, $18 \times 1$, p. 11\%.

Dinorthis sweeneyi llall and Clarke, Pal. New Iork, VIII, Pt. I, 1892, pp. 196, $222,2.28,1)$. 5 , figs. $34-36$.

Orthis (Dinorthis) pectinella var. sweenesi Winchell and Schuchert, Minnesota Geol. Survey, III, 1893, p. 426, pl. 32, ligs. 35-38.

Loc. St. Paul, Cammon Falls, ete., Minnesota; llecomah and Mefiregor, Iowa.

Dinorthis platys (Billings).

Chazy (Ord.).

Orthis platys Billings, Cunadian Nat. Geol., IV, 1859, 1. 438, tig. 1.5;-Cieol. Camala, 1863, l. 12!), fig. 54.-IIall and Clarke, Pal. Now York. V1I, Pt. I, 1892, p. 218.

Loo. Islaud of Montreal, Canala.

Dinorthis porcata (MeCoy).

Trenton and Lorraine (Ord.).

Orthis porrata MeCoy, Silurian Foss. of Ircland, 18.16. p. 32, pl. 3, fig. 14.-13illings, Pal. Fossils, I, 186?, p. 135, fig. 111;-Geol. Canata, 1863, p. 312, fig. 319.

Orthis anticostiensis Shaler, Fossil Brachiopoda of the ()hio Valley, 1887, p. 19, 1). 6.

Plesiomys porcata Hall and Clarke, Pal. New York, VII. Pt. I, 1892, PJ. 197, 222, 1). $5 \mathrm{~A}$, figs. $20,21$.

Lor. Ireland: Ottawa, Canadia; Anticosti.

Dinorthis proavita Winchell and Schnchert.

Lorraine (Ord.). Orthis proavita WincluelJ and Schucluert, American Geol., IX, April 1, 1892, 1. 290.

Orthis petra Sardeson, linll. Minnesota Acal. Nat. Sei., III, April 9, 1892, P. 332, pl. 5, figs. $18-21$.

Orthis (Dinorthis) proavita Winchell and schuchert, Minnesota Geol. Snrves, IIl, 1893, p. 43I, ,l. 32, figrs. 51-57.-? IVliteaves, Pal. Foss., III, Pt. III. $18(17,1) .176$.

Loc. Spring Valley, Mimesota; Wilmington, Illinois; Lake Winnipeg, Canada. Dinorthis retrorsa (Salter).

Trenton and Lorraine (Ord.).

Orthis retrorsa Salter, Mem. Geol. Survey Great Britain, II, 1858, p. 373. 11. 27. ligs. 3, 4.-Billings, Pal. Fossils, I, 1862, p. 136, tigs. 112, 113._Mcek, Pal. Olnio, I, 1873. p. 92, pl. 11, tig. 7.-Miller, Cincinnati Quart. Jonr. Sci., II. 1875, p. 37.

Orthis carleyi IIall, Thirteenth Rep. New York State Cal. Nat. Ilist., 1860, p. 120,

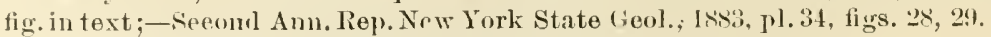
Orthis kennicotti MeChesney, New Pal. Fossils, 1861, p. Ts. 
Dinorthis retrorsa (Salter)-Contimnerl.

Pliesiomys retrorsa Hall ancl Clarke, l'al. New York, VIII, Pt. I, 1892, 11. 197, 222, pl. 5A, figs. 14-16.

Loe. England; Oxford, etc., Olico; Ottawa, Camada.

Dinorthis subquadrata (Hall).

Lorraine (Ord.).

Orthis subquadrata Hall, Pal. New York, I, 1847, p. 126, pl. 32 А, fig. 1;-Cieol. Wisconsin, I, 1862, p. 54, figs. 1, 2.-Neek, Pal. Ohio, I, 1873, p. 94, pl. 9, fig. 2.-Miller, Cincinnati Qnart. Jonr. Sei., II, 1875, p. 38.-White, Second Ann. Rep. Intlana Burean of Statistics and Geol., 1880, p. 481, pl. 1, figs. 3-5;-Tenth Rep. State Geol. Indiana, 1881, p. 116, pl. 1, figs. 3-5.-Shaler, Foss. Brachiopoda of the Ohio Yalley, 1887, p. 22, pl. 7.-Feyes, Geol. Survey Missouri, V, 1895 , p. 60.

QOrthis suloquatrata Billings, Geol. Canata, 1863, p. 165, fig. 146.

Plirsiomy's subquadrata Hall and Clarke, Pal. New York, VIII, Pt. I, 1892, pp. 191. 1!ki, 222, pl. 5A, figs. 17-19.

Orthis (linorthis) subruadrata Winehell and Sehnehert, Minnesota Geol, Survey, III, 1893, p. 428, pl. 32, figs. 46-50.--Whiteaves, P'ul. Foss., III, Pt. III, 1897, p. 176.

Loc. Ohio Valley; Spring Valley, Minnesota; Wilınington, Illiuois; Warren and Jefferson counties, Missouri; Jattners, Iow: ; Iron Rirlge, Wiseonsin; Lake Winnipeg, Canada; Anticosti.

Discina of authors (non Lamarek) = Orbicnloidea.

Discina agadica Hartt-= Parmophorella actadica, a gastropod.

Discina alleghania Hall - Orbiculoidea alleghania.

Discina ampla Hall =Orbienloidea ampla.

Discina capax White -- Orbiculoidea capax.

Discina capnliformis McChesney - Orbicnloidea capuliformis.

Discina ciree Billings = Orbienloirlea lamellosa.

Discina clara Spencer =-Schizotreta tenuilamellata.

Discina eoncordensis Sardeson :-- Schizotreta pelopea.

Discina eonnata Walcott=Lingnlodiscina ronnata.

Diseina conrarli Hall=Opbicnloidea conradi.

Discina convexa Slummard=Orbicnloidea convexa.

Discina diseus Hall=Orbiculoidea discus.

Discina doria Hall=Orbienloidea doria.

Discina chira Hall=Orbiculoidea elnira.

Discina forbesi Ni $\cdot h o l s o n=$ Schizotreta tenuilamellata.

Discina gallaheri Winchell=Orbiculoidea gallaheri.

Discina grandis Vannxem $=$ Romerella grandis.

Diseina grandis Hall=Orlbiendoidea ampla.

Discina lumilis Ifall=Orbiendeilea Immilis.

? Discina inutilis Hall.

Upper Cambrian.

Discina inntilis Ifall, Sixteentl Rep. New York State Cal, Nat. Hist., 1863, p. 130, pl. 6, fig. 11 ; -Trans. Alluany Institute, V, I867, p. 108.

Loc. Mazomanie, TViseonsin.

Obs. Itudeterminable.

Discinn illinoisensis Miller and Gurley=Orbienloirlea illinoisensis.

Discina jervensis Barret $=$ Orbicnloidea jervisensis. 
- Discina keokuk Gurley=orbienloirlea keokuk.

Discina lodensis 11 all=Orbiculoidea lodiensis.

Discina magnifica Herrick=Orbiculoidea magnitioa.

Discina manhattensis Meekand Hayden= Orbiculoidea manhattanemsis.

Discina marginalis Whitfield=Orbiculoidea marginalis.

Discina media IIall=Orbiculoidea lodiensis media.

Discina meekana Whitheld=Orbiculoidea missonriensis.

Discina microseopicas Shmmard = Acrotreta microscopica.

Discina minnta Hall=Orbiculoidea minuta.

Diseina missonriensis Shumard=Orbiculoidea missouriensis.

Discina munda Hiller and Gurley=Orbiculoidea munda.

Discina neglecta Hall=orbiculoidea neglecta.

Discina newberryi Hall=Lingulocliscina newberryi.

Discina nitida Meek and Worthen=Orbicnloidea missouriensis.

Diseina nitida=Orbicnloidea nitirla.

Discina patellaris Winchell=Orbiculoilea patellaris.

Discina pelopea Billings=Schizotreta pelopea.

Discina(?) pileolus Whiteaves.

? Lower Cretaceons.

Discina pileolus Whiteaves, Cont. Canadian Pal, I, 1889, p. 159, pl. 21, fig.:3.

Loc. Rink Rapirls on Lewis liver, British America.

Obs. "l'rofessor Ifyatt thinks that the fossils from this locality are Jurassic" (Stanton).

Discina pleurites Meek=Lingulodiscina plenrites.

Discina ramballi Hall = Orbienloidea rancilalli.

Discina saffordi Winclıell=Orbicnloidea saffordi.

Discina sampsoni Miller=Orbiculoidea sampsoni.

Discina(?) semipolita Whiteaves.

Cretaceons.

'Discina senipolita Whiteaves, Mesozoic Fossits, I, Geol. survey Canada, 1884, p. 252, pl. 33 , fig. 9 .

Loc. Queen Charlotte Island.

Discina seneca IIall=Orbicnloidea seneca.

Diseina solitaria Ringmeberg=Schizotreta teunilamellata.

?Discina sublamellosa Trich.

Lorraine (Oril.).

Diseina snblamellosa Ulrieh, Jonr. Ciucinnati, Soe. Nat. Hist., I, 1878, p. 97, pl. 4, fig. 11.-Miller, N. American Geö. Pall, 1889, p. 344.

Loc. Covington, Kentueky.

obs. Probably not a brachiopod.

Disciua subtrigonalis McChesney =Orbienloiclea subtrigonalis.

Discina tenuilamellata var. subplana Hall=Orbiculoidea subplana.

Discina tennilineata Meek and Hayclen=Orbiculoidea tenuilineata.

Discina tennistriata Ulrich=Orbiculoidea temuistriata.

Discina trigonalis McChesney =Orbiculoirlea subtrigonalis.

1)iscina trumeata Hall = Schizobolus concentricus.

Diseina truncata Emmons= Crbiculoidea lamellosa.

Discina tullia Hall=Orbiculoidea tullia.

Discina utahensis Meek=Orbiculoidea utahensis. 
Discina(?) vancouverensis Whiteaves.

Cretaceons.

Discina vancouverensis Whiteaves, Mesozoic Fossils, I, (ieol. Survey Canada, 1879, 1. 177, pl. 20 , fìg. 6.

Lor. Admiralty Island.

Discina vannxemi Hall=Orbiculoidea vanuxemi.

Discina varsoviensis Worthen=Orbicnloidea varsaviensis.

Discinella Hall=Operculum of P'teropod.

DISCINISCA Dall.

Genotype Discina lamellosa Broderip.

Discinisea Dall, Bull. Mus. Comp. Zoology, III. 1871. p. 37.

Discinisca lugubris (Conrad).

Miocene and Pliocene.

Capulus lngubris Conrad, Jour. Acad. Nat. Sci. Philarlelphia, VII, 1834, p. 143.

Orlicula lngubris Conrad, Fossils Merlial Tertiary For. U. S., 1845, p. 75, pl.43,

tig. 2.-Tuomey and Holmes, Foss. Sonth Carolina, 1855, p. 17, pl. 5, fig. 1.-

Dall, Republication of Conrad's Foss. Medial Tert. For. U. S., 1893, p. 101, pl. 43 , fig. 2.

Diseina lugnbris, Whitfield, MLon. U. S. Geol. Snrvey, XXIV, 1894, p. 23, pl. 1, figs. 1-3.

Loc. St. Marys County, Maryland; Petersburg, Virginia: Peedee River, South Carolina; Atlantic City, Shiloh, aud Bridgeton, New Jersey.

Obs. Referred to Discinisea on authority of Dr. W. 1I. Dall.

Discinisca multilineata (Conrad).

Miocene.

Orbicula multilineata Conrat, Fossils Medial Tertiary For. L. S., 1815, p. 75, pl.

43, fig. 3.-Tuomey and Holmes, Foss. South Carolina, 1855, p. 18, pl. 5, fig. 2.-

Dall, Republication of Conrad's Foss. Mrdial Tert. For. U. S., 1893, p. 101, pl. 43, fig. 3.

Loc. City Point, Virginia; Pedee River, Sonth Caroliua.

Obs. Probably a less worn variety of 1). lugubris (Dall).

DISCINOPSIS Matthew.

Genotype Acrotreta? gnlielmi Matthew.

Discinopsis (Matthew MS.) Hall and Clarke, l'al. New York, VIII, l’t. I, 1892, pp. 105, 167;-Eleventh Ann. Rep. New York State Geologist, 1894, p. 250.

Discinopsis gulielmi Matthew.

Middle Cambrian.

Acrotreta? gnilelmi IIatthew, Trans. Royal Soc. Canacla, 1886, p. 37, pl.5, tig. 14.

Discinopsis gnlielmi Hall ant Clarke, Pal. New York, VIII, Pt. I, 1892, p. 105, pl. 3, figs. 20-24.

Loc. l'ortland, New Brunswick.

EATONIA Hall.

Genotype Atrypa pecnliaris Conrad.

Latonia Hall, Tenth Rep. New York State Call. Nat. Hist., 1857, p. 90;-Twelfth Rep. Ibidem, 1859, p. 35 ;-Pal. New York, III, 1859, p. 432.-Millings, Proc. Portland Soc. Nat. Hist., 1863, p. 111.-Hall and Clarke, Pal. New York, VIII, Pt. II, 1893, p. 205;-Thirteenth An1. Rep. New York State Geologist, 1895, p. 829.

Eatonia coulteri Miller and Gurley.

Oriskany (Dev.).

Eatonia coulteri Niller and Gurley, Bull. Illinois State Mus. Nat. Hist., 3, 1893, p. 72 , pl. 7 , figs. $8-11$.

Loc. Jackson County, Illinois.

Eatonia eminens Hall.

Lower Helderberg (Dev.).

Eatonia eminens Hall, Tenth Rep. New York State Cab. Nat. Hist., 1857, p. 92;Pal. Now York, IlI, 1859, p. 242, pl. 37, tig. 2.-Hall and Clarke, Pal. New York, VIII, Pt. II, 1893, p. 206.

Loc. Decatnr County, Tennessec. 
Eatonia medialis ( $\mathrm{V}$ anuxem).

Lower Hellerberg (Dev.).

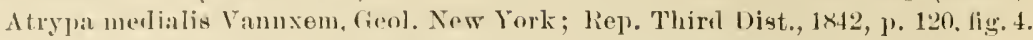

Gatonia medialis Jlall, 'Tentl liej. New York State Cab. Nat. Hist., 1857, p. 90, tigs. 1-7;-I'il. New York, J11, 1859, 1. 241. pl. 37, fig. 1.—Billings; l’rue. Portland Soc. Nat. llist., 1863, p. 111, pl. 3, lig. 7.-11:all and Clarke, I'al. New York, VIII, 1't. 11, 1893, 1. 206, pl. 61, tigs. 29-35.

Loe. Schoharie, Carlisle, Catskill, ete., New York; Sipuare Lake, Maine.

Eatonia peculiaris (Commd). Lower Helderberg and Oriskany (Dev.).

Atrypa peenliaris Conrad, Fifth Ann. Rep. Geol. snrvey New York, 1841, p. 56.-

Vamxem, Geol. New York; Rep. Third Dist., 1812, p. 123, fig. 3.-Hall, Ibirlen, liep. Fonrtlı 1)ist, 1813, 1. 148, lig. 3.-Rogers, Geol. Penusylvania, II, Pt. II, 1858, p. 825, fig. 640.

Atryja? unstella Castelnan, Essai Syst. Sil. I'Amárique Septentrionale, 1843, p. 39, pl, 14, fig. 3.

Latonia jeenliaris IIall, Twelfth Rep. New York State Cab. Nat. Hist, 1859, p. 37, ligs. 1-7;-Pal. New York, 1II, 1859, p. 244, pl. 38, tigs. 21-26; p1. 51, fic. $2 ;$ p. 436, pl. 101, fig. 2; pl. 101 A, fig. 1;-Fifteenth Rep. New York State Cal. Nat. Hist., 1862, pl. 11.-Billings, Geol. Canads, 1863, p. 957, fig. 450.Meek and Worthen, freol. Snrvey Illinois, III, 1868, 1. 395, pl. 8, fig. 2.Billings, l'al. Fossils, II, 187, 1. 40, pl. 3A, tig. 2.-. Hall and Clarke, Pal. New lork, VIII, Pt. II, 1893, p. 206, pl. 6i1, ligs. 17-26.

Eatonia prenliaris? Keyes, Geol. Survey Missonri, V, 1895, p. 104.

Lor. Scholarie, ete., New York; I'ennsylvania; Cumberland, Iaryand; Jackson and Perry connties, Missonri: Gaspé.

Eatonia pumila Hall.

Oriskany (Dev.).

Eatouia pumila Hall, Pal. New York, III, 1859, p. 437, pl. 101, fig. 1.-Hall and Clarke, l'al. New York, YIII, Pt. 1], 1893, 1. 206.

Loe. Albany County, New York.

Eatonia singularis (Vam11xem).

Lower Helderberg (Dev.).

Atrrpa singularis Vamxem, Geol. New York; Rep. Third Dist., 1842, p. 120, fig 3. Eatonia singularis Hall, P'al. New York, III, 1859, p. 242, pl. 28, figs. 14-20.IIall and Clarke, Ibiclem, VIII, l’t. II, 1893, p. 206, pl. 61, figs. 13-16.

Loc. Sehoharie, ete., New York.

Eatonia sinuata Mall.

Oriskany (Dev.).

Eatonia siuuata Ilall, Tenth Rep. New York State Cab. Nat. Hist.. 1857, p. 11; Pal. N'ew York, II], 1859, p. 138, pl. 101A, figs. 3-6.-Hall and Clarke, Ibidem,

VIII. Pt. II, 1893, p. 206, pl. 61, fiuss. 36-38.

Loc. Cumberland, Maryland.

Eatonia(?) variabilis Whiteaves.

Haniilton (Dev.).

Eatonia variabilis Whiteaves, Cont. to Canalian Pal., I, 1891, p. 233, pl. 29, figs. 6-9.

Loc. Hay River, Canala.

Eatonia whitfieldi Hall.

Oriskany (Dev.).

Eatonia whitfieldi 1lall, Pal. New Y*ork, III, 1859, p. 437, pl. 101A, fig. 2.--Hall and Clarke, Ibiclem, VIII, Pt. 11, 1893, p. 206, pl. 61, figs. 27, 28.

Loc. Cumberland, Maryland.

EICHWALDIA Billings. Genotype Eichwallia sulttrigonalis Billings.

liehwaldia Iiillings, Geol. Snrvey Canaula; liep. Progress for 1857, 1858, p. 190 ;Canadian Nat. Geol., III, 18.58, p. 412.

Eichwaldia of other anthors= Dictyonella. 
Eichwaldia subtrigonalis Billings.

Trenton (Ord.).

Eichwaldia subtrigonalis Billiugs, Geol. Survey Canata; Rep. Progress for 1857, 1858, p. 192, fig. 24;-Canadian Nat. Geol., III, 1858, 1. 413, fig. 21;-Cieol. Canada, 1863, p. 142, fig. 76.-Hall and Clarke, Pal. New York, VII, Pt. II, 1893, p. 310, figs. 241, 242; pl. 83, figs. $1-1$.

Loc. Panquette Rapids, Canada.

ELKANIA Ford.

Genotype Obolella desiderata Billings.

Billingsia Ford (nou de Koninck, 1876), American Jour. Sei., 3d ser., XXXI, 1885, p. 466.

Elkania Forl, American Jour. Sei., 3d ser., XXXII, 1886, p. 325.--Hall and C'larke, Pal. New York, VIII, Pt. I, 1892, p1. 75, 165;-Eleventh Anll. Rep. New York State Geologist, 1894, p. 211.

Elkania ambigua (Walcott).

Pogonip (base of ()ril.). Obolella? ambigua Walcutt, Mon. U. S. Geol. Survey, VIll, 1884, 1. 67, pI. 1, fig. 2. Elkania ambigua Hall aud Clarke, Pal. New York, YIlI, Pt. I, 1892, p. 78.

Loc. Eureka district, Nevada.

Elkania desiderata (Billings).

Epper Cambrian.

Obolella desiderata Billing's, Pal. Fossils, I, 1862, p. 69, fig. 62 o11 1. 68.

Oholella? desiderata Walcott, Bull. U. s. Geol. Snrvey, 30, 1886, I. 111.

Billingsia desiderata Forl, American Jour. Sci., 3i ser., XXXI, 1886, 1. 466, ligs. 1, 2.

Elkania desiderata Hall and cliarke, Pal. New York, VIII, I't. I, 1892, 1. 77, pl. 3, figs. $15-19$.

Loc. Point Levis, Canada.

ENTELETES Fischer de Waldheim. Genotype Orthis lamareki Fisch.

Enteletes Fischer de Waldheim, Oryet. Gour. Moseou, 1830, P. 193, tab. 26, figs. 6, 7.-Waagen, Palceontologica Indica, Ser. XIII, I, I884, P. 550.-Hall and Clarke, Pal. New York, VIII, Pt. I, 1892, pp. 185, 214;-Eleveuth Aun. Rep. New York State Geologist, 1894, 1, 272.

Syntrielasma Meek and Worthen, Proe. Acad. Nat. Sei. Philadelphia, 1865, p. 277 ;-Geol. Survey Illinois, II, 1866, 1. 321, tig. 36.

Enteletes andii (d'Orbigny).

Upper C'arboniferons.

Terebratula audii d'Orbiguy, Voyage dans l'Amérique Mérilionale, I’al., 1812, 1. 45, pl. 3, figs. 14,15 .

Orthis andii Salter, Qnart. Jour. Geol. Soc. London, XYII, 1861, I. 64, pl. 4, fig. 3 .

Syutrielasma andii Derby, Bull. Cornell Unir., I, 1874, p. 62.

Rhynehonella audii Gabb, Jour. Acad. Nat. Sei. I'hiladelphia, 2d ser., VIII, 1881, p. 302.

Enteletes andii Hall and Clarke, Pal. New York, VIII, Pt. I, 1892, 1. 217.

Loc. Yarbichambi anıl Lake Titicaca, Bolivia; Santa Cruz.

Enteletes gaudryi (d'Orbigny).

Upper Carboniferons.

Terebratula gaudryi d’Orbigny, Voyage daus l'Amérique Mériclionale, Pal., 1842 , p. 45.

Terebratula antissiensis l'Orbigny, Ibidem, 1812, pI. 3, fig. 16 (non pl. 2).

Syntrielasma gaudryi Derb5, Bull. Cornell Iniv., I, 1874, 1.62.

Enteletes gandryi Hall and Clarke, I'al. New York, VIII, Pt. I, 1892, 1. 217.

Loc. Yarbichambi, Rolivia.

Enteletes hemiplicata Hall.

Uper Carboniferous.

Spirifer hemiplicata Hall, Stausbury's Exped. Cireat Salt Lake, 1852, 1. 409, pl.

4, fig. 3. 


\section{Enteletes hemiplicata Hall-Continued.}

lihynchonellat angulata Geinitz (non Limué), Carbon u. Dyas Nebraska, 1866, p. 37, pl. 3, figs. 1-4.

Sisntrielasma hemiplicata Moek and Worthen, Geol. Snrvey Illinois, I1, 1866, p. 323 , fig. $36 ;$ 1. 322 I, fig. 37.-Meek, Final Riep. I. S. Geol. Survey Nebraska,

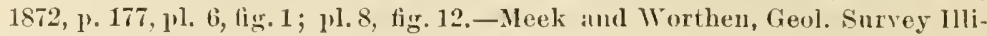
nois, V, 1873, 1. 571, pl. 26, fig. 20.-Kayser, Riehthofens China, IV, 1883, p. 179, [1. 24, figs. 2, 3.-White, Thirteenth Rep. State Geol. Indiana, 1881, p. 131, pl. 26, figs. 15-18.-Keyes, Geol. Survey Missonri, V, p. 75, pl. 39, fig. 8.

Camerophoria gifiordi Worthen, Bull. Illinois State Mus., 1, 1882, p. 39;-Geol. Survey Illinois, VII, 1883, p. 318, figs, a-c.

Enteletes hemiplieata 1 iall and Clarke, Pal. New York, VIII, Pt. I, 1892, pJ. 215, 226, pl. 7A, figs. 44-52.

Loc. Weston, l'latte County, Missouri; Vandalia and Alta, Illinois; Steunett, Iowa; Kansas Citỵ, Missouri; Nebraska City, Nobraska; Lo Ping, China.

\section{EUMETRIA Hall.}

Genotype Retzia verneuliama Hall=T'erebratula mareyi Shumard.

Eumetria Hall, Sixteenth Rep. New York State Cab. Nat. Hist., 1863, 1. 59.Waagen, Palirontologiea Indica, Ser. XIII, I, 1883, p. 487.-IH1l and Clarke, Pal. New York, VIII, Pt. II, 1893, 1. 115, figs. 104, 105;-Thirteenth Ann. Rep. New York State Grool., 1895, I. 795.

Eumetria(?) altirostris (White).

Kinderhook (L. Carb.).

Retzia (Acambona?) altirostris White, Proc. Bostun Soc. Yat. Hiat., IX, 1862, 1. 28.

Loc. Burlington, Iowa.

\section{Eumetria marcyi (Shumard).}

St. Lonis and Kaskaskia (I. Carb.).

Terehratula serpentina? Owen (non de Koninck), Geol. Survey Wisconsin. Iowa, Minnesota, 1852, 11. 3A, fig. 13 (see speeimens in U. S. Nat. Mus., Cat. Invert. Foss., 17955).

Terebratula mareyi Shmmard, Marey's Rep. U. S. Expl. Red River of Lonisiana, 1854 , p. 177 , pl. 1, fig. 4 .

Retzia verneuiliaua IIall, Geol. Survey Iowa, I, I’t. II, 1858, p. 657, 11. 23, fig. 1 ; - Traus. Alliny Institute, IV, 1858, 1.9.

Retzia vera IIall, Geol. Survey Iowa, I, Pt. II, 1858, p. 704, pl. 27, tigg. 3.

Enmetria vera Hall, Sixteenth Rep. New York state Cab. Nat. Hist., 1863, p. 5 , figs. 1-3, and p. 59.

Eumetria rerneniliana IIall, Ibidem, 1803, p.55, fig. 2.-Whitfielı, Bull. American Mus. Nat. Hist., 1882, 1. 50, pl. 6, figs. 28-30.-Hall, Twelfu Rep. State Geol. Indiana, 1883 , p. 335, pl. 29, figs. 28-30.

Retzia radialis Walcott (110n Phillips), Mon. U. S. Geol. Survey, VII1, 188.t, l. 220, pl. 7, figs. 5 , 5a (5b?).

Retzia mareyi Miller, N. Ameriean Geol. Pal., 1889, p. 366.

Eumetria verneniliana and vera IIall and Clarke, Pal. New York, VIIl, Pt. II, 1893, p. 117, figs. 104, 105, pl. 50, tigs. 13-26, 31, 37; pl. 83, figs. 26, 27.

Loc. Washington and ('rawford counties, Arkansas; Floyd County ans elsewhere in Indiana; Alton, Illinois; Greene County, Missouri; Iowa; Cumberland Mountain, Tennessee.

Obs. Hall autl Clarke (1893), in treating of the American speeies of Eumetria (E. vera and var. costata, and E. verneuiliana), say they "are, perhaps, all representatives of the same sprecies." The writer regards thrm as one speeies, varying in different localities in size and number of striations. Owen was the first to observe this form and identified it provisionally with ' $T$. serpentina de lioninek. Shumard, however, believed it to be distinct from that species, and gave the name 'T. mareyi four years prior to that of Hall. 
Eumetria marcyi costata Hall.

Kaskaskia (L. Carb.).

Retzia vera var. costata Ilall, Geol. Survey lowa, I, Pt. 1I, 1858, 1. 704, 1]. 27, tig. 3.

Eumetria vela var. costata Hall and Clarke, Pal. New York, VIII, Pt. II, I895, pl. 51 , figrs. $27-33$.

Loc. Chester, Illinois; Crittenden Connty, Kentucky.

Eumetria vera Hall = E. mareyi.

Eumetria vermeniliana Hall = E. maleyi.

Eumetria woosteri (Wlite).

? Upper C'arboniferous.

Retzia woosteri White, Bull. U. S. Geol. Survey Terr., V, 1879, r. 215;-T'welfth Ank. Rep. U. s. Geol. Survey Terr., 1883, p. 134, pl. 34, fig. 8.

Loc. Near Greeley, Colorato.

Obs. Closely related with E. mareyi of the Lower Carboniferons.

EUNELCA Hall and Clatke. Genotype Terebratula sullivanti Hall.

Eunella Ifall and Clarke, Pal. New York, VIII, Pt. II, 1893, 1. 290 ;-Thirteenth Ann. Rep. New York State (ieol., 1895, 1. 861.

Eunella harmonia Hall.

Corniferouss (Dev.).

Terebratula harmonia Ilall, l’al. New York, IV, 1867, 1. 388, pl. 60, figs. 11-16.Nettelrotl, Kentucky Fossil Shells. Mem. Kentucky Geol. Survey, 1889, p. 151, 11. 17, figs. 1-4.

Eumelli harmonia Hall and Clarke, Pal. New York, V11, Pt. II, I893, p. 290, pl. 80, figs. 33-35.

Loc. Falls of Ohio; Ontario, Canala.

Eunella lincklæni Hall.

Iarcellus and Hamilton (Dev.).

Terebratula linekleni Hall, Thirteenth Rep. New York State Cab. Nat. Hist., 1860, 1. 88;-P'al. New York, IV, 1867, corrigenda.-Nettelroth, Kentucky Fossil Shells, Nem. Kentueky Geol. Survey, 1889, p. 155, pl. 17, figs. 22-24.

Cryptomella linckleni Hall, Fourteenth kep. New York State Cal. Nat. Hist., 1861, 1. 101 ; - Sixteenth Rep. Ibidem, 1863, P. 44.

Crsptonella? lincklieni Hall, Pal. New York, IV, 1867, p. 397, pl. 60, figs. 49-65.

Terebratula lincklieni var. Hall, Ibilem, 1867, p. 418, pl. 60, fïs. 32-37.

Ennella lineklieni Hall and Clarke, Pal. New York, VIII, Pt. II, I893, 1. 290, pl. 80 , figs. $28-32$.

Ioc. Clarke County, Indlana; Hanilton and Canandaiguil Lake, New York; Thunder Bay, Miehigan.

Eunella simulator Hall.

Hamilton (Dev.).

Terebratula simulator Hall, Pal. New York, IV, 1867, p. 391, pl. 60, tigs. 69, 70.

Eunella simnlator IIall and Clarke, Pal. New York, VIIl, I't. II, 1893, p. 290, pl. 80 , fig. 27.

Loc. Thedforl, Ontario.

Eunella sullivanti Hall.

Corniferous (Dev.).

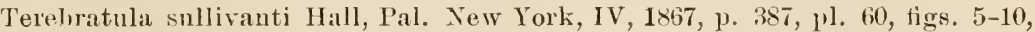
68.-Whiteaves, Cont. Canatlian Pal., I, 1892, 1. 291, pl. 37, figs. 9, 10.

Enmella snllivanti Hall and C'larke, Pal. N sw York, VIII, Pt. II, 1893, p. 290, fig. 210, pl. 80, tigs. 23-26.

Loc. Columbus anıl siundusky, Ohio; near Cayuga, Ontario, and Lakes Manitoba, and Winnipegosis, Canalla.

GLASSIA Davirlson.

Genotype Atrypa obovata Sowerby.

Glassia Davidson, Geol. Mag., n. ser., VIII, 1881, p. 11;-Snp. British Devonian ancl silıriın Brach., Pal. Soe., 1882, w. 38.-Hall anıl Clark», Pal. New York, VIII, Pt. II, 1893, 1. 152, figs. 142-145;-Thirteenth Ann. Rep. New York State Geologist, 1895, p. 811. 
Glassia romingeri Hall and Clarke.

'Trenton (Or'l.).

Glassia romingeri llall and C'larke, l'al. Now York, VIII, I't. II, 1893, 1. 153, 11. 83, ti ins. 32-35.

Loc. Drift near $\Lambda$ un Arbor, Michigan.

Glassia sclucherti Ulrich= Catazyga headi.

GLOSSINA P'hillips.

Genotyle Lingula attemata Sowerby.

Glossina I'hillips, Mem. Geol. Survey Great Britain, 11, l’t. 11, 18.1\%, 1. 370.-1)ill, Bull. I. S. Nat. Mns., 8. 1877, Ir. 29.-1lall and Clarke, l'al. New York, VIII, Pt. I, 1892, pp. 15, 164;-Eleventh Ann. Rep. New York state Geologist, 1891, 1. 230.

Glossina acuminata Hall and Clarke=Lingulepis acuminati.

Glossina crassa (Ilall).

Trenton (Ord.).

Lingula crissa Ilall, Pal, New York, 1, 1817, 1. 98, pl. 30, fig. 8.

Loc. Niddleville and Lake ('hamplain, New York.

Glossina cyane (Billing's).

Lingula eyaue Billings, Pal. Fossils, I, 1865, p. 216, fig. 200.

Loc. Near Portland Creek, Newfoundland.

Glossina deflecta Winchell and Schuchert. Trenton and Lorraine (Orl.).

Lingula (Glossina) dellecta Winehell and sehnehert, American Geol., IX, 1842, 1. 281;-Minnesota Geol. Survey, III. 1893, 1. 318, [1. 29, figs, 15-18.

Loc. Near Fountain and spring Valley, Miunesota.

Glossina dubia ( l'Orbig'ny).

Ordovician.

Lingula dubia d'Orbigny, Voyage dans l'Amérinue Méridionale, 18t2, p. 29, pl. 2 , fig. 7 .

Loc. Taeopaya, Bolivia.

Glossina flabellula Hall and Clarke.

Waverly (L. Carb.).

Lingula (Glossina) flabellula Hlall aud Clarke, Pal. New York, VII, Pt. 1, 1892, pp. 15, 172, pl. 1, figs. 33,31 .

Loc. Seiotoville, Ohio.

Glossina hurlbuti N. H. Winchell.

Trenton (Oril.).

Lingula hurlbnti N. H. Wiuehell, Eighth Aun. Fe]1. Geol. Nat. llist., Survey Ninnesuta, 1880, 1, 62.

Lingula (Glossina) hurlouti Winehell aud schuchert, Minuesota Geol. Survey, III, 1893, 1. 347, pI. 29, figs. 13, 14 .

Loc. Mantorville and near spring Valley, Miumesota.

Glossina leana (Hall).

Hamilton (Dev.).

Lingula leani 11alI, Sixteentl Rep. New York State Can. Nat. Hist., 1863, 1. 20;-Pal. New Tork, IV, 1867, 1. 9, pl. 2, fig. 12.-Waleott, Mon. U. S. Geol. Survey, VHIT, 1881, p. 106. 11. 13, fig. ‥

Loc. Bristol, New York; Lone Mountain, Nevadia.

Glossina nebraskaensis (Meek).

Lpper Carboniferous.

Lingula seotiea var. nebraskensis Neek, Fiual Rep. U. S. Geol. Survey Nebraska, 1872, p. 158 , pl. 8, fig. 3.

Lingula nebraskensis Miller, N. Aueriean Geol. Pal., 1889, p. 350.

Loc. Nebraska City, Nebraska.

Glossina perovata (Hall).

Clinton (Sil.).

Liugula perovata Hall, Pal. New York, 11, 1852, p. 55, pl. 20, fig. 3.

Loc. Rochester, Now York. 
Lingula sedaliensis Miller, Eighteenth Ann. Rep. Geol. Survey Indiana, 1894, 1. 308, pl. 9, fig. ?.

Loc. Sedalia, Missouri.

$O b s$. This species is probably the same as (i. waverlyensis.

Glossina spatiosa (Hall).

Lower Helderberg (Dev.).

Lingula spatiosa 1Lall, Pal. New lork, 1II, 1859, p. 158, pI. 9, fig. 10.

Loc. Near Hudson, New York.

Glossina trentonensis (Courad).

Trenton and Utica (Ord.).

Lingula trentonensis Conrad, Jour. Acarl. Nat. Sei. Philadelphia, VII, 1812, p. 266, pl. 15, fig. 11.-Vanuxem, Geol. Now York; Rep. 'Third Dist., 1812, p. 48.

Lingula attenuata? Hall (non Sowerby), Pal. New York, I, 1847, p. 94, pl. 30, fig. 1 .

Lingula daphne Billings, Pal. Fossils, I, 1862, p. 50.

?Lingula attenuata A. Ulrich, N. Yahrb. f. Mineral, Beilageband, VIII, 1892, p. 7, pl. 1 , fig. 3 .

Loc. (iIens Falls, Trenton Falls, Middleville, New York; Wisconsin: Montreal aud Ottawa, Canala; ?near Vacas, Bolivia.

Glossina triangulata (Nettelroth).

Ilamilton (Dev.).

Lingula triangulata Nettelroth, lientueky Fussil Shells, Mem. Lentucky Geol. Survey, 1889, p. 34, pl. 26, fig. 1.

Loc. Falls of Ohio.

\section{Glossina waverlyensis (Herrick).}

Waverly (L. Carb.).

Lingula seotica?? Meek, Pal. Ohio, II, 1875, 1. 2766, 11. 14, fig. 9.

Lingula waverlyensis Herrick, Bull. Denison Lniv., IV, 1888, pp. 12, 18, pl. 3, fig. 1.-Hall and Clarke, Pal. New York, VIII, Pt. I, 1892, P. 9, 11. 4 K, fig. 7.

Lingula (scotica var.) waverlyensis Herrick, (ieol. Ohio, V1I, 1895, pl. 22, fig. 1. Loc. Berea and Newark, Ohio; Oil City, D'ennsylvania.

Obs. See G. serlaliaensis (Miller).

Goniocalia Hall= Pentagonia.

Goniocelia miangulata Hall= Pentagonia unisulcata.

Gotlandia Dall=Trimerella.

Gypidia Dalman=Conchidinm.

Gypidia unguiformis Ulrich=Conchidinn unguiformis.

GYPIDULA Hall.

Genotype Pentamerus occidentalis Hall.

Gypidula Inall, Twutieth Rep. New rork State Cab. Nat. Hist., 1867, p. 163;Pal. New lork, IV, 1867, pp. 373, 380.-Walcott, Mon. U. S. Geol. Survey, VIII, 1884, p. 161.

Sieberella (Ehlert, Fischer's Mannel de Conchyliologie, 1887, 1. 1311.

Gypidula and Sieberella Hall and Clarke, Pal. New York, VIII, Pt. II, 1893, p. 245 ;-Thirteenth Ann. Rep. New York state Geol., 1895, p1. 815, 816.

Atrypa comis Owen, Geol. Rep. Wiscousin, Iowa, Mimnesota, 1852, p. 583, pl. 3A, fig. 4 (nee specimens in U.S. Nat. Mus., Cat. Invert. Foss., 17928).

Pentanerus (11. sp. ?) Owen. Ibidem, 1852, pl. 3A, fic. 11 (Ibiden, Cat., 17929).

Pentamerus oceidentalis Hall, Geol. Survey Iowa, I, Pt. II, 1858, 1.5I4, pl. 6, fig. 2 (non Pentamerus occidentalis IIall, 1852).

Pentamerus galeatiformis Mrek and Worthen, Geol. Survey, Illinois, II, 1866, p. 325.

Gspidula oceidentalis Hall, Pal. New ,York, IV, 1867, 1. 380, I1. 58 A, figs. 1-8.

Bull. $87-15$ 


\section{Gypidula comis (()wеu)-Contimmed.}

I'ontamerns eomis Meek and Worthen, Geol. Survey lllinois, Ill, 1s68, p. 428, pl. 13, fig. 6.-Whitaves, Cont. Camalian l'al., I, 1892, 1. 2410.

Pentamerns (Gypirlula) couis Walcott, Mon. U. S. Geol. Surver, VIII, 1881, P. 159, pl. 3, tigs. 1. 7; pl. 14, tig. 15; pl. 15, tim. 5.

Gypidula rom is Ifall and Clarke, l'all. New York, VIll, Pt. 11, 1893, 1. 247, fig. 177; 1). 72 , figs. $15-24$.

Loc. Independence and J)itvenport, lowa; Rock Island, Llinois; Eureka district, Nevada; lakes Manitolia aud Winnipergosis, C'anadia.

Gypidula coppingeri (Etheridge).

Siluriau.

Pentamerus coppingeri Etherilge, Quirt. four. Geol. Soe. Londou, XXXIV, 1878, p. 594, pl. 25, fign. $2,3$.

Loc. Oftley Island, lat. $81^{\circ} 16^{\prime}$.

Gypidula galeata (Dahman). Lower Helderberg and Midlle Devonian.

Atrypa galeata Dalmau, Kongl. Svenska, Vet.-Akal. Ilaudl., fïr 1827. 1828, 1. 16, pl. 5, fig. 4.-Troost, Sixth (ieol. Rep. Tennessee, 1811. p. 15.-Vanuxem, (ieol. New York; Rep. Third Dist., 1812, p. 117, fig. 1.-Casteluan. Essai śsst. sil. l'Amérique Septentrionale, 18.13, p. 39, pl.11, fig. .l.

Pentamerus galeatus Hall, Teuth Rep. New. York State Cab. Nat. Hist., 1857, p. 105, figs. 1-3.-Rogers, Geol. Pennsylvania, II, P’. II. 1858, p. 825, tiщ. 646.Hall, Pal. New York, III, 1859 , p. 257, pl. 46, fig. 1; pl. 47, 1ì. 1.-13illing;, Geol. Cauada, 1863, p. 957 , tig. 454.

Pentamerus galeatus var. Whiteares, Cont. to ('analian Pal, I, 1891, 1) 231.

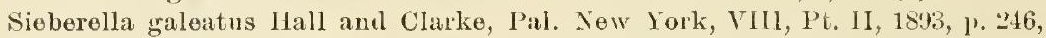
fig. $175 ;$ pl. 72 , figs. $7-13$.

Loc. Europe; Albany and Schoharie comnties, New Yurk; Cumberland, Maryland; Pennsylvania; st. Blandine, New Brunswick; Mackenzie River, Candua.

Gypidula globulosa (Nett(lroth).

Niagara (Sil.).

Pentamerus globulosus Nettelroth, Kentucky Fossil Shells, Mem. Kentucky Geol. Survey, 1889, 1. 51.

Loc. Louisville, Kentucky.

Gypidula knotti (Nettelroth).

Niagara (Sil.).

Pentamerus knotti Nettelroth, Kentucky Fossil Shells, Mem. Kientucky Geol. Survey, 1889, p. 56, I1. 32, figs. 9-12.

Loc. Louisrille, Kentucky.

Gypidula læviuscula Hall.

Middle Deronian.

Grpidula leviuseula IIall, Pal. New York, IV, 1867, p. 381, pl. 58, tigs. 22, 28.-

Hall and Clarke, Pal. Now York, VIIl, Pt. II, 1893, p. 248, pl. 72, figs. $25,26$.

Loc. IVaterloo, Iowa.

Gypidula lotis (Waleott).

Upper Devonian.

Pentamerus lotis Walcott, IIon. U. S. Ceol. Survey, VIII, 188t, p. 161, pl.3, fig. \&. Gypidnla lotis Hall and Clarke, Pal. New York, VIlI, Pt. II, 1893, p. 248.

Loc. White Pine mining distriet, Nevadia.

Gypidula munda Calvin.

Middle Devonian.

Gypidula munda Calvin, Bull. L. S. Geol. Geogr. Surves Terr., IV, 1878, p. 730.

Gypidula mundula Hall and Clarke, Pal. Now York, V'III, P't. II, 1893, p. 248.

Loc. Independence, Iowa.

Gypidula nucleus (Hall and Whitfield).

? Clinton (Sil.).

Pentamerus galeatus Hall aur Whitlield, Twenty-fourth Rep. New York State Cab. Nat. Hist., 1872, J1. 197, 200a.

Pentamerus nucleus Hall and Whitfield, Twenty-serenth Rep. New York State Cab. Nat. Hist., 1875, pl.9, lig-.30-32.-Nettelroth, Kentucky lossil shells, Mem. Kentucky Geol. Survey, 1889, 1. 59, pl. 27, higs. 25-27; 11.33, figs.27-33. 


\section{Gypidula nucleus (Hall and Whitfield)-Continned.}

Sieberella nuclens Hall and Clarke, l'al. Now York, VIII, Pt. II, 1893, p. 247, pl. 72, figs. 1-3.

Loc. Lonisville, Kentueky.

Gypidulia occidentalis Hall=G. comis.

Gypidula pseudogaleata (Hall).

Lower Helderberg (Dev.).

Pentamerus psendogaleatus Hall, Tenth Rep. New York State Cab. Nat. Hist., 18:7, p. 106, figs. 1-6;-Pal. New York, I11, 1859, p. 259, pl. 46, fig. 2.

Sieberellit psendogaleata Hall and Clarke, Pal. New York, VIII, Pt. II, 1893, p. 242, 1). 72 , fig. 14 .

Loc. Sehoharie and Carlisle, New York.

Gypidula romeri (Hall and Clarke).

Silurian.

Pentamerns galeatus Roemer (not Dalman), Sil. Fa una west. 'Tennessee, 1860, p. 73, pl. 5, fig. 14 .

Sieberella remeri Hall and Clarke, Pal. New York, VIII, Pt. II, 1893, p. 247, pl. 72 , fig. 6.

Loc. Decatur County, Temnessee.

Gypidula romingeri Hall and Clarke.

Hamilton (Dev.).

Gypidıia romingeri Hall and Clarke, Pal. New York, VIII, Pt. II, 1893, 1. 248, pl. 72, figs. $27-33$.

Loc. Alpena, Michigan.

Gypidula subglobosa (Meek and Worthen).

Hamilton (1)ev.).

Pentamerus sulgglolosus Meek and Worthen, Geol. Snrvey lllinois. III, I868, p. 429, pl. 13, fig. 5.

Gypidula subglobosa Hall and Clarke, Pal. New York, VIII, It. II, 1893, p. 248.

Loc. Rock Island, Illinois.

\section{Gypidula uniplicata (Nettelrotli).}

Niagara (Sil.).

Pentanerus uniplicatus Nettelroth, Kentucky Fossil Shells, Mem. Kentueky Geol. Survey, 1889, p. 63, pl. 33, figs. 25, 26.

Sieberella miplieata Hall and Clarke, Pal. New York, VIII, Pt. II, 1893, P. 247. Loe. L.onisvillo, Kentueky.

HARTTINA Hall and Clarke.

Genotype Centronella anna Hartt.

Harttina Hall and Clarke, Pal. New York, VIII, Pt. II, 1893, 1. 292;-Thirteenth Ann. Rep. New York State Geologist, 1895, p. 862.

\section{Harttina coutinhoana (Derby).}

Upper Carboniferous.

Walcheimia eoutivhoana Derby, Bull. Cornell Univ., I, 1874, 1. 3, pl. 3, fig. 22; pl. 8, fig. 6 ; ll. 9 , figs. 1,2 .

Harttina continhoana Hall and Clarke, Pal. New York, VIII, Pt. II, 1893, p. 292. Loc. Bomjardim, Brazil.

\section{Harttina anna (Hartt).}

Upper Carboniferous.

Centronella anna Hartt, Dawson's Acarlian Geol., 3d ed., 1878, p. 300, fig. 9!.

Harttina anna Hall and Clarke, Pal. New York, VIII, Pt. II, 1893, 1. 292, figs. 211,$212 ;$ pl. 79, tigs. $37-39$.

Loc. Windsor, Nova Seotia.

Hallina Winchell and schuchert=Zygospira.

HEBERTELLA Hall and Clarke. Genotype Orthis simuata Hall.

Gronp of Orthis occidentalis Hall, Bull. Geol. Soc. America, I, 1889, 1. 20.

Hebertella Hall and Clarke, Pal. New York, ViII, Pt. I, 1892, 1P. 198, 229.Winchell and Schuchert, Minuesota Geol. Survey, III, 1893, p. 132.-1 Hall and Clarke, Eleventh Ann. Rep. New York State Geologist, 1894, 1. 266. 
Hebertella battis (Billings).

Calciferous (Ord.).

Orthis battis Billings, Pal. Fossils, I, 1865, 1. 185.

Hobertella Hall aucl Clarke, Pal. New York, VIII, Pt. I, Ixi2, 1. 22.2.

Loc. I'oint Levis, Canalis.

Hebertella bellirugosa (Conrad).

Trenton (Orrl.).

Orthis bellarugosa Comrat, Proc. Acal. Nat. Sri. Philadelplia, I, 1843, p. 333.IIall, Pal. New York, 1, 1847, j. 118, pl. 32, tig. 3.

Hehertella hollarmgosa IIall ant Clarke, Pal. New York, V1I1, Pt. 1, 1892, p. 222. Orthis (Hehertella?) bellarugosa Wiuchell and Schuchert, Minuesota Geol. Sur-

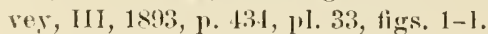

Loc. Mineral Point, Janesville, Neenali, ete., Wisconsin; Minneapolis, St. Paul, Canuon Falls, cte.. Minnesota; Decoral and MeGregor, Lowa; Curdsville, Kentucky; Rutlierforl County, Tenuessee.

Hebertella borealis (Billings).

Chazy-Trenton (Ord.).

Orthis borealis liillings, Canadian Nat. Geol., IV, 1859, P. 436, fig. 14;-Geol.

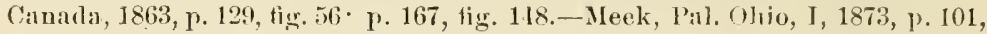
pl. 8, fig.4.-Miller, Ciuciunati Quart. Jour. Sei., II. 1875, 1. 28. -Nettelroth, Kentucky Fossil Shells; Mem. Kentneky Geol. Survey, 1889, p. 36, pl.34, figs. $14-20$.

Hebertella borealis Hall aud Clarke, Pal. New York, VIIl, Pt. I, 1892, 1. 222.

Orthis (Hebertella) borealis Wincliell ancl Sebuchert, Minuesota Geol. Survey, III, 1893, p. 433 , fig. 33.

Loc. Canglinawaya, St. Genevieve, Isle Bizard, and Cornwall, Canala; Frankfort, Kentucks; Nashville, Tennessee; Cannon Falls, etc., Minuesota; Wiscousin (Whitfield).

Hebertella daytonensis (Foerste).

Clinton (Sil.).

Orthis daytonensis Foerste, Bull. Denisou Univ., I, 1885, P. 87, pl. 13, figs. 13, $20,21$.

Hehertella daytonensis Hail and Clarke, Pal. Now York, VIII, Pt. 1, 1892, 1. 222. Orthis (Hebertella) daytoneusis Foerste, Geol. Olio, V11, 1895, p. 575, pl. 23, figs. 13, 20, 21.

Loc. Dayton, Ohio.

Hebertella fausta (Foerste).

Clinton (Sil.).

Orthis fausta Foerste, Bull. Denison Univ., I, 1885, p. 85, pl. 13, tigs. 15, 16.

Helertella fausta Hall and Clarke, Pal. New York, VIII, I't. I, 1892, p. 222.

Orthis (Hebertella) fausta and var. sruamosa Foerste, fifol. Ohio, VII, 1895, Pp. 573,57 , 1. 1.25 , figs. $15 \mathrm{a}-15 \mathrm{~d}, 16 \mathrm{a}, 16 \mathrm{~b} ; \mathrm{l} 1.37 \mathrm{~A}$, figs. $19 \mathrm{a}, 19 \mathrm{~b}$.

Loc. I)ayton, Ohio.

Hebertella imperator (Billings).

Chazy (Ord.).

Orthis imperator Billings, Canadian Nat. Gool., IV, 1859, 1. 435, figs. 11-13;Geol. Canada, 1863, p. 129, fig. 55.

Hebertella imperator IIall and Clarke, PaI. New York, VIII, I’t. 1, 1892, p. 222.

Loc. Hawkesbury aud Cornwall, Cauada.

Hebertella insculpta Hall.

Lorraine (Ord.).

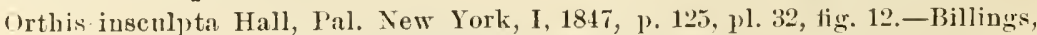
Geol. Canara, 1863, 1. 167, fig. 150.-Meek, Pal. Ohio, I, 1873, p. 99, pl. 9, fir. 1.-Miller, Cineinuti Quart. Jonr. Sci., II, 1875, r. 40.

Orthis hellarugosa Hall (now Conrad), Second Ann. Rep. New York State f́eol., $1883, \mathrm{p} 1.3 \mathrm{~s}, \mathrm{tig} .22$.

Hehertelli iuscnlpta IIall and C'arke, Pal. New York, VIII, Pt. I, 1892, 1. 222, pl, $5 \mathrm{~A}$, fig. 13. 
Hebertella insculpta Hall-Continnerl.

Orthis (Hebertella) insculpta Winchell and Schuchert, Minnesota feol. Survey, III, 1893, p. 435 .

Loc. Oxford, etc., Ohio; Richmond, Indiana; Wilmington, Illinois; Iron Riılge, Wisconsin; Lattners, Iowa.

Hebertella lonensis (Walcott).

Pogonip (Ord.). Orthis lonensis Walcott, Mon. U. S. Geol. Snrvey, VIII, 1884, p. 74, pl. 11, fig. 6. Hebertella lonensis Hall and Clarke, Pal. New York, VIII, Pt. I, 1892, p. 222.

Loc. Enreka district, Nevala.

Hebertella maria (Billings).

Orthis marial Billings, Pal. Fossils, J, 1862, i. 137, fig. 114.

Iorraine (Orl.).

Hebertella simnta or maria? Hall and Clarke, Pill. New York, VIll, Pt. 1. 1892, 1. 2.2, , 1. $5 \mathrm{~A}$, figs. $9,10$.

Loc. Anticosti; Colby, Kentucky.

Hebertella occidentalis Hall.

Lorraine (Ord.).

Orthis occiclentalis Hall, Pal. New York, I, 1847, p. 127, pl. 32A, 1ig. 2; pl. 32B, fig. 1 ;-Twelfth Rep. New York State Cab. Nat. Hist., 1859, p. 72.-Billings, Geol. Canala, 1863, p. 210, fig. 210.-Week, Pal. Ohio, 1, 1873, p. 96, pl. 9, fig. 3.-White, Wheeler's Expl. Survey west 100th Merid., IV, 1875, p. 70, pl. 4, fig. 11.-Miller, Cincinnati Quart. Jour. Sei., II, 1875, p. 34.-White, Second Ann. Rep. Indiana Burean Statistics and Geol., 1880, p. 485, pl. 2, figs. 10-12;--Tentlı Rep. Stato Geol. Indiana, 1881, 1. 117, pl, 2, tigs. 10-12.-Whitheld, Geol. Wisconsin, IV, 1882, 1. 260, pl. 12, figs. 17, 18.-Hall, Seconel Ann. Rep. Now York State Geol., 1883, pl. 34, figs. 31-34; pl. 35, figs. 16-21.

Orthis subjugata II:ıll, I’al. New York, I, 1817, p. 129, pl. 32C, fig. 1.

Orthis subjugata(?) Owen, Geol. Survey Wisconsin, Iowa, Minuesota, 1852, pl. 213, figs. 4, 5 (see specimens in U. S. Nat. Mus.. Cat. Invert. Foss., 17885).

Hebertella occidentalis Hall and Clarke, Pal. New York, VIIl, l’t. I, 1892, 1).222, pl. 万A, figs. 11, 12.

Loc. Cinciunati, Oxford, ete., Ohio; Richmond, Indiana; Saranna, Illinois; Cape Girardean, Missonri; Delafiell, Wiscousin; Silver City, New Mexico.

Hebertella occidentalis sinuata Hall.

Lorlaine (Ord.).

Orthis sinnata IIall, Pal. Now York, I, 1847, p. 128, pl. 32li, fig. 2.-Miller, Cinciunati Quart. Jour. Sci., II, 1875. p. 36.-Shaler. Fossil Brachioporla Ohio Valley, 1887, pl. 8.

Orthis occidentalis var. simuata Neek, I'al. Ohio, I, 1873, p. 98.

Hebertella sinuata Hall and Clarke, Pal, New York, VII I, 1’t. I, 1892, 1. 22:2, pl. $5 \mathrm{~A}$, fig's. 1-8.

Loc. Cincinnati, Ohio.

Hebertella scovilli (Miller).

Lorraine (Orl.).

Orthis scovilli Hiller, Jonr. Cincinnati Soc. Nat. IHist., V, 1882, 1. 40, pl. 1, fig. 5. Hebertella scovilli Hall and Clarke, Pal. New lork, VIII, Pt. I, 1892, 1. 222.

Loc. Lebanon, Ohio.

Hemipronites americanus Whitfield=Clitambonites diversus.

Hemipronites apicalis Whitfield = Polytochia apicalis.

Hemipronites crassus McClıesney= Derbya crassa.

Hemipronites crenistria White (non Meek or Plillips) = Derbya crassa. Hemipronites crenistria Meek, and Herrick=Orthothetes crenistria. Hemipronites propinquus Meek and Worthen=Orthothetes subplauus. 
Hemithyris psittacea (Chemnitz).

Pliocene and liecent.

Auomia rostrum psittaeca Chemuitz, Neues syst. Conch.-Cab., VIIl, 1785, pl. $7 \times$, tig. 713 .

lihyohonella psittacea lhaidson, 'Trans. Linniran Sor. London, IV, 1887, p. I63, 1)I. 24, ligs. 1-11.

loc. Fossil. fulf of tit, latwence, chuarla.

HETERORTHIS Hall and Clarke.

Genotype Orthis elytie Hall.

Heterorthis Hall and Clarke, l'al. New York, VIII, l’t. I, 1892, pl. 207, 223;Eleventl Anu. Rep. Now York State (ieologist, 1894, 1. 268.

Heterorthis clytie II:all.

Trenton (Ord.).

Orthis elgtie Inall, Fourteenth liẹp Now York State Cab. Nat. Hist., 1861, 1. :10;-

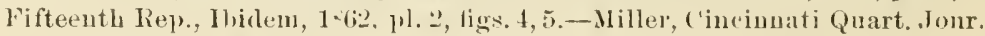
Sei., 1I, 1875, 11. 34.-Hall and Whitfield, Pal. Ohio, II, [875, p. 75, p]. I, figs. $18,19$.

IIeterorthis clytie Ifall aud Clarke, Pal. New York, VIIl, Pt. 1, 1892, pl. 202, 22:3, pl. 513 , figs $20-24$.

Loc. Frankfort and Paris, Kentneky.

HIN DELLA Davidson.

Genotype Athyris umbonata Billings.

Hiudelı Davidson, Snppl. Jrilish sil. Brach., Pal. Soe., 1882, p. 130.-Hall aurl Clarke, Pal. New York, VIII, I't. II, 1893, p. 63, ligs. 46-51;-Thirteenth Ann. Rep. New York Stitte Geologist, 1895, p. 769.

Hindella prinstana (Billings).

Anticosti (Sil.).

Athyris prinstana Billings, l'al. Tossils, 1, 1862, p. 145, fig. 122.

Meristella prinstana Miller, X. American Geol. Pal., 1889, p. 354.

Hindella prinstana lIall and Clarke, Pal. New York, VIIl, Pt. II, 1893, p. 61, pl. 41, fig. 28; pl. 49, fig. 1 .

Loc. Antieosti.

Hindella umbonata (Billings).

Anticosti (Sil.).

Athyris umbonata Billings, Pal. Fossils, I, 1862, p.114, fig. 121;-Geol. Cunada, 1863. p. 317, fig. 331 .

Hindella nmbonata Davirlson, Suppl. British Sil. Brach., Pal. Soe., 1882, p. 130, fig. in text,-liall anl Clarke, Pal. New York, VIlI, P't. 1I, 1893, p. 64, figg. $46-51$; jl. 41, figs. $26,27,29,30$.

Meristella umbonatit Forste, Bull. Denison Univ., I, 1885, p. 88, pl. 13, fig. 2;Geol. Olıio, VII, 1895, p. 590, p]. 225, fig. 2.

Loc. Anticosti; Dayton, Ohio (Ferste).

\section{HIPPARIONYX VanmXem.}

Genotype Hipparionyx proximus Vanuxem.

Hipparionyx Vamxem, (feol. New York; Rep. Third Dist., 1842, p. 124, fig. 4.-Hall and Claske, l'al. New York, VIII, I't. 1, 1892, p. 257;-Eleventh Ann. Rep. Xew York State Geologist, 1891, 1. 281.

Hipparionyx ronsimilaris Vamxem=Atrypa reticnlaris.

Hipparionyx proximus Vanuxem.

Oriskany (Dev.).

Hipparionyx proximus Vauncem, Geol. New York; Rep. Third Dist., 1812, p. 124, fig. 29, No. 4.- Hall and Clarke, Pal. New lork, VIlI, I’t. I, 1892, p. 25i, 11.9, figs. $33-36 ;$ pl. 15.t, ligs.s. 9-11.

Atrypa mngriformis (Conlad) Ilall, fieol. Now York; Rep. Fourth Dist., 18 13, 1. 149. fig.4.-Rogers, fieol. l'ennsylyania, If, Pt. II. 1858, p. 826, lig. 651

Orthis conadi Casteluan, Essai sist. Sil. l'Amérique Septentrionale, 1843, p. 37, pl. 15, fig. 4 .

Orthis unguiformis C'asteluan, Ibirlem, 1813, 1. 37, pl. 15, fig. 3.-Ennons, Mannal Geol., 1860, 1. 129, fig. 115. 


\section{Hipparionyx proximu; I aunxem-Continued.}

Orthis hipparionyx Hall, Pal. New York, IlI, 1859, p. 407, pl. 89, figs. 1-4; pl.90, figs. 1-7; pl.91, figs. 4,5; pl.94, 1ig.4.

Strophodonta intermedia llall, l'il. New York, III, 1859, p. 482, pl. 95A, figs. 13,14 .

Streptorhynchus hipparionyx Ilall, Second Amn. Rep. New York State Geol., 1883, pl. 39, iims. 33-36.

Loc. Schoharie and Albauy connties, New York; Frankstown, Pennsylvania; Cumberland, Maryland; Caynga, Ontario.

Obs. Thus speciesdoes not occur in Germany according to Kayser.

\section{HOMEOSPIRA Hall and Clarke. Genotype Rhynchospira evax Hall.}

Honneospira Hall and Clarke, Pal. New Yock, VIII, P'. II, 1893, p. 112;-Thirteeuth Ann. Rep. New York State Geologist, 1895, p. 792.

Homœospira apriniformis Hall.

Niagara (Sil.).

Atrypa aprinis 1 all (non de Vernenil), I'al. New York, II, 1852, 1. 280, pl. 57, fig. 7.

Rhynchospira? aprinis Ilall, Twelfth Rep. New York State Cab. Nat. Hist., 1859, p. 77.

Rhynchospira apriniformis IIall, Pal. New York, III, 1859, p. 485.

Rhynchonella aprinis Miller, N. American Geol. Pal., 1889, 1. 367.

Homosospira apriniformis IIall and Clarke, Pal. New York, VIII, Pt. II, 1893, p. 111 , pl. 83 , figs. $24,25$.

Loc. Lockport, New York.

\section{Homœospira evax Hall.}

Rhyuchospira evax Hall, Trans. Albany Institute, IY, 1863, p. 213.

Retzia evax Ilall, Twenty-eighth Rep. New York State Mus. Nat. Hist., 1879, p. 160, pl. 25, figs. 13-21;-Eleventlı Rep. State Geol. Indiana, 1882, p. 302, pl. 25, tigs. 13-21.-Beecher and Clarke, Mem. New York State Mus., I, 1889, p. 55, pl. 5, figs. $1-9$.

Homoospira evax Hall and Clarke, Pal. New York, VIII, Pt. II, 1893, p. 112, pl. 50 , iigs. $15-20(? 32-35)$.

Loc. Waldron, Indiana; ?Perry County, Tennessee.

Homœospira sobrina (Beecher and Clarke).

Niagara (Sil.).

Retzia sobrina Becher and Clarke. Mem. New York State Mus., I, 1889, p. 61, pl. 5, tigs. 10-16.

Homreospira sobrina Hall and Clarke, Pal. New York, VIII, Pt. II, 1893, p. 112, pl. 50 , tigs. 26-28.

Loc. Waldrou, Indiana.

HUSTEDIA Ilall anı Clarke. Genotype Terebratula mormoni Marcon.

IInstedia Ifall aud Clarke, Pal. New York, VIII, Pt. II, 1893, p. 120;-Thirteenth Am. Rep. New York State Geologist. 1895, p. 797.

Hustedia(?) meakana (Shmmald).

Upper Carboniferous.

Retzia(?) meekana Shumarl, Trans. St. Lonis Acarl. Sci., I, 1858, p. 295, pl. 11, fig. 7 .

Loc. Gnadalnpe Monutains, New Mexico.

Hustedia mormoni (Marcou).

Upper Carboniferous.

Terebratula mormoni Marcon, Geol. N. America, February, 1858, p. 51, pl. 6, fig. 11 ;-Trans. St. Lonis Acul. Sri., III, 1875, p. 252.

Retzia pmuctnlifera Shunard, Trans. At. Lon is Acad. Sei., I, June, 1858, p. 220.McChesney, Trans. Chicago Aeal. Sci., l, 1868, p. 32, pl. 1, iig. 1.-Meek, Final liep. U. S. Geol. Survey Nebraska, 1872, p. 181, pl. 1, tig. 13; pl. 5, fig. 7 . 


\section{Hustedia mormoni (Marcou)-Continned.}

Ketzia mormoni Meck and Haylen, Proc. Acad. Nat. Sci. Mhiladelphia, 1859, 1). 27.-Geinitz, Carl. 1. Wyas Neluaska, 1866, 1. 39, pl. 3, tig. 6.-White, Wheeler's lixpl. Survey west 100th Merid., IV, 1875, P. 111, j1. 10, lig. 7; Thirteenth Reje. Stato (ieol. Indiana, 1884, ]. 136, pl. 35, figs. 10-12.-Keyes, Proe. Acal. Nit. Sei. Ihiladelplia, 1888, p. 231;-Geol. Survey Missonri, I, 1895, p. 95, pl. 11 , fig. 2.

Retzia snbglobosa IIcCliesney, Irescriptions New Pal. Foss., 1860, p. 45;-Ibidem, 1865, pl. 1, lig. 1.

Retzia compressa Neek, (icol. Snrres California, I, 1864, p. 14, pl. 2, fig. 7.Kayser, Richtholens China, IV, 1883, p. 176, pl, 22, tigs. 1-1.

Enmetria punctulifera Derlyy, Bull. Cornell Univ., I, 1874, p. 4, pl. 8, figs, 4, 5, 7, 8, $10 ;$ pl. 9, tig. 3 .

Retzia radialis Waleott (non Phillips), Mon. U. S. Ceol. Survey, VIII, 1884, p. 220, pl 7, figs. 5d-ih..., suith, Proe. American Plil. Soe, XXXV, 1897, F. 31.

Hnstedia mormoni Hall and C'larke, I’al. New York, VIlI, Pt. II, 1893, p. 120, fig. $106 ;$ pl. 51, ligs. 1-!).

Loc. Salt Lake City, Itah; Santa Fe, New Mexico; Nevada; Shasta County, California; Nohraska; Kansas; Arkansas; Nlissouri; Iowa ; Illinois; Indiana; Bomjartim and Itaituba, Brazil; Lo Ping, China.

\section{Hustedia(?) papillata (Slımmard).}

Upper Carboniferous.

Retzia papillata Shmmard, 'Trans. St. Lonis Acarl. Sci., I, 1858, p. 294, pl. 11, fig. 9.

Loc. Guadalupe Momntains, New Nexico.

Obs. Compare with H. mormoni.

Hustedia(?) triangularis (Miller).

Chontean (L. Carb.).

Retzia triangularis Miller, Eighteenth Ann. Rep. Geol. Survey Indiana, 1894, p. 315, pl. 9, tigs. 25, 26.

Loe. Sellalia, Missouri.

HYTTELLA Hall and Clarke. Genotype Atrypa congesta Conrad.

Hyattella Ifall and Clarke, Pal. New York, VII, Pt. II, 1893, p. 61, fig. 45;--Thirteenth Amm. Rep. New York State Geologist, 1895, p. 767.

Hyattella congesta (Conrarl).

Clinton (Sil.).

Atrypa congesta Conrad, Jour. Acad. Nat. Sci. Pliladelplia, VIII, 1842, p. 265, pl. 16, tig. 18.-Hall, (icol. New York; Rej. Fonrth 1)ist., 1843, p. 71, lig. 2;Pal. New York, II, 1852, 1. 67, pl. 28, fig. 1.-lBillings, Canadian Nat. Geol., I, 1856, p. 136, pl. 2, fig. 4.-Rougers, Geol. Pennsylvania, II, I’t. II, 1858, p. 823, tig. 632.

Atry]a quadŗicostata I\}all, Pal. New York, II, 1852, p. 68, p]. 23, fig. 2.

'Triplesia? congesta Ilall. Twelfth Rep. New York state Cab. Nat. Ilist., 1859, p. 77.

Triplesia? qualricostata 1Iall, Jhidem, 1859, p. 78.

Rhynchonella quadricostata Miller, N. American Geol. Pal., 1889, p. 369.

Camerella congesta Nettelroth, Kentucky Fossil Shells, Neus. Kentueky Geol. survey, 1889, p. $4 x$.

Ifyattella congesta 11 ill anil Clarke, Pal. New York, VIII, Pt. II, 1893, p. 61, fig. $45 ; \mathrm{pl} .40$, ligs. 23-28; pl. 81, ligs. 26-28.

Loc. Rochester, Reynales Basin, ctc., New York; Flamborough Heal, Ontario; Pennsylvania; Lonisville, Kentucky.

Hyattella junia (Billings).

Anticosti (Sil.).

Atlỵris junia Billings, Catalogne Sil. Foss. Anticosti, 1866, p. 46.

Hyattella junia Hall and Clarke, Pal. New York, V1II, Pt. 11, 1893, p. 62, pl. 40, figs. 29-3I.

Loc. Anticosti. 
Hypothyris King (non Phillips), Ann. Mag. Nat. IIist., XVIII, 1846, p. 28;-Mon. Permian Foss., Pal. Soc., 1850, pp. 81, 100, 111.-Hall and Clarke, Pal. New York, Y1II, Pt. II, 1893, p. 200 ;-Thirteentl Amn. Rep. New York State Geologist, 1895, 1. 828.

\section{Hypothyris castanea (Meek).}

Midıle Devonian.

Rhynchouella castanea Meek, 'Trans. Chicago Acad. Sci., I, 1868, p. 93, pl. 13, fig. 9.-Walleott, Mon. U. S. Geol. Survey, VIII, 1884, P. 153, pl. 15, figs. 1, 4.-Whiteaves, Cont. to Canadian Pal., I, 1891, 1. 232.

Liorhỵchus castanens Hall and Clarke, Pal. New' York, VIII, Pt. II, 1895, pl. 59, figs. $28,29$.

Loc. Lockhart and Mackenzie River, Canada; Eureka district, Nerarla.

\section{Hypothyris cuboides (Sowerby).}

Tully (Dev.).

Atrypa cuboides Sowerby, 'Trans. Geological Soc., 2d ser., V, 1840, pl. 6, fig. 24.Vanuxem, Geol. New York; Rep. Third Dist., 1842, p. 163, fig. 1.-Hall, Ibidem, Rep. Fomrth 1)ist., 1843, pp. 215, 216, fig. 1.

Rhynchonella venustula Hall, Pal. New York, IV, 1867, p. 345, pl. 54A, figs. 2443.-Willians, lmll. Geol. Soc. America, I. 1890, p. 493, pl. 13, figs. 4, 8, 14, $23,24,27,29,31-34$.

Hypothyris cuboides and veuustmla Hall and ('larke, Pal. New York, VIII, Pt. II, 1893, p. 200, pl. 60 , figs. 49-55.

Loe. Europe; Tully, Ovid, Penn Yan, ete., New York.

Hypothyris emmonsi (Hall and Whitfielı).

Rlyynehonella emmonsi Hall and Whitfield, King's U. S. Geol. Expl. 40th Parl., $1 \mathrm{~V}, 1877$, p. 247, pl. 3, figs. 4-8.-Walcott, Mon. I. S. Geol. Survey, VIII, 1884, p. 157.

Rhynchonellin intermedia liarris, Proc. Davenport Acad. Nat. Sci, II, 1878, p. 285, pl. 11, figs. 5, 6.

Rhyuchonella cuboides Whiteaves, Cont. to Canadian Pal., I, 1891, p. 231.

Hypothyris emmonsi and intermedia Hall and CJarke, Pal. New York, VIII, l't. II, 1893, 1). 200.

Loc. White l'ine district, Nevarla; Davenport, Iowa; Hay am Peace rivers, Canarla.

\section{IPHIDEA Billings.}

Iphidea Billings, Canadian Nat. Geol., n. ser., Y'I, 1872, 1. 477;-Pal. Fossils, II, 187., p. 76.-Walcott, Bull. U. S. Geol. Survey, 30, 1886, p. 100.-IIall aul Clarke, Pal. New York, VilI, Pt. I, 1892, 11]. 97, 166;-Eleventh Ann. Rep. New York State Geologist, 1894, ]. 249.-Walcott, Proc. U. S. National Mus., XIX, $1897,17.707$.

Micromitra Meck, Sixth Ann. Rep. U. S. Geol. Snrvey Terr., 1873, p. 479.

Kutorgina (pars) Dall, Bull. U. S. National Mus., 8, 1877, p. \&0._Waleott, Bull. 1T. S. Geol. Survey, 30, 1886, 1\%. 101.-Ilall and Clarke, Pal. New York, VIII, Pt. 1, 1892, 1. 90.

Paterina Beechrr, American Jour. Science, 31 ser., XLI, 1891, p. 345.-Hall and Clarke, Eleventh Rep. N. Y. State (ieologist, 1894, p. 247.

Iphidea alabamaensis Walcott.

Niddle Cambrian.

Iphirlea alabamansis Walcott, Proe. U.S. National Mus., X1X, 1897, 1. 713, pl. 59, tigs. 5. 5a.

Loc. Coosa Valley, Cherokeo County, Alabama; near Rogersville. Tenmessec.

\section{Iphidea bella Billings.}

Lower Cambrian.

Iphidea bella billings, Canadian Nat. Geol., n, ser.. VI, 1872, 1. 447, tig. 13;Pal. Fossils, II, 187t, p. 76, fig. 44.-Walcott, Bnll, U. S. Geol. Survey, 30, 1886, 
Iphidea bella Billings-C'ontinnerl.

1. 100, pl. 7, fig. 4;-Tenth Anu. Re]. U. S. Geol. Survey, 1891, p. 608, pl. 67, fig. 6. - IIall and Clarke, Pal. New York, VII, P't. I, 1892, 1. 98, lig. 54, pl.4, tigss. $8,9$.

Loc. Trois l'istoles, below Qneber, Canada; Anse au Lonp, Labralor.

Iphidea crenistria Walcott.

Middle Cambrian.

Iphidea crenistria Walcott, I'roc. U. S. National Mus., XIX, 18!17, p. 713, pl. 59, figs. $4-4 b$.

Loc. Grand Canyon of the Colorado.

Iphidea labradorica (Billings).

Lower Cambrian.

Obolus labratoricus Billings, Geol. Vermont, II, 1861, p. 946, fig. 345;-Pal. Fossils, I, 1861, 1. 6, fig. 6;-Geol. of Canada, 1863, 1). 284, fig. 291.

Kutorgina labradorica Walcott, Bull. U. S. Geol. Survey, 30, 1886, p. 104, pl. 9, fig. 2;-Tenth Anu. Rep. U. S. Geol. Survey, 1891, 1. 609, pl. 69, fig. 3.

Paterina labradorica Beecher, Anerican Jour. Sei., 31 ser., XLI, 1891, I'p. 345, 356 , pl. 17, figs. 1, 2.

Loc. Ause an Lonp, Straits of Belle Isle, Labrador; Conception Iay, Newfoundland.

Iphidea labradorica swantonensis Walcott.

Lower Cambrian.

Knntorgiua labradorica var. swantonensis Wal'ott, Proc. U. S. Nat. Mus., XII, 1889, p. 36 ;-Tenth Ann. Rep. U. S. Geol. Survey, 1891, p. 609, pl.69, lig.2.

Loc. East of Swanton and Highgate Springs, Vermont.

Iphidea logani Walcott.

Middle Cambrian.

Ipliidea logani Walcott, Proc. U. S. National Mns., XIX, 1897, p.711, pl.59, figs. 2-2l).

Loc. Trois Pistoles, Qnebec, Canada.

I phidea ornatella Hall and ('larke=I. superba.

Iphidea pannulus (White).

Lower and Middle Cambrian.

Trematis pannulus White, Wheeler's Expl. Survey west 100th Merid., Prel. Rep., 1874, p. 6.

Trematis? pannulus White, Ibidem, Final Rep., IV, 1875, p. 36, pl. 1, fig. 4.

Ḱntorgina paunula Walcott, Bull. U. S. Geol. Survey, 30, 1886, 1. 105, pl. 7, tig. 3; 1)l. 8, fig. 2;-American Jonr. Sci., 3ıl ser., XXXIT, 1887, p. 190, pl. 1, tig. 14;Tenth Ann. Rej. U. S. Geol. Survey, 1891, p. 609, pl. 69, tig. 5.

Loc. Pioche, Nevada; Wasatch Mountains, Utah; Mount Stephan anıl Castle Mountain, Britisb Columbia; Waslington County, New York; Island of Orleans in the Sillery conglomerate.

Iphidea pealei Walcott.

Middle Cambrian.

Iphidea pealei Walcott, Proc. U. S. National Mus., XIX, 1897, p. 712, pl.59, figs. $3-3 \mathrm{c}$.

Loc. Near Hillsilale, Nontana.

Iphidea prospectensis Walcott.

Lower Cambrian.

Kutorgina prospectensis Walcott, Mon. U. S. Geol. Snrves, VIII, 1884, p. 19, p1.9, fig. 1;--Bull. U. S. Geol. Survey, 30, 1886, p. 106, pl. 9, fig. 3;-Tentlı Ann. Rep. I. S. Geol. Smvey, 1891, p. 610, pl. 69, fig. 4.

Loc. Eureka district, Nevada.

Iphidea sculptilis Meek.

Upper ('ambrian.

Iphidea (??) sculptilis Meck, Sixth Ann. Rep. U. S. Geol. Survey Territories; 1873, p. 479.

Micromitra sculptilis Meck, Ibidem, 1873, p. 479.

Ĺutorgina minutissima Hall and Whitfield, King's U. S. Geol. Expl, 40th Parl., IV, 1877, p. 207, pl. 1, tigs. 11, l2. 


\section{Iphidea sculptilis Meek-Continned.}

Kutorgina sculptilis Walcott, Mou. U. S. Geol. Survey, VIII, 1884, p. 20, pl. 1, fig. 7; pl. 9, fig. 7.

Loc. Gallatin City, Montana; Enreka district, Nevada.

Obs. The ventrai pedicle foramen in this species, the genotype of Micromitra, is partially closed posteriorly, hut otherwise does not stem to differ generically from Iphidea.

\section{Iphidea stissingensis (Dwight).}

Middle Cambrian.

Kutorgina stissingensis Dwight, American Jour. Sci., 3d ser., XXXVIII, 1889, p. 145, pl. 6. figs. 5-8;-Traus. Vassar Brothers' Inst., V, 1891, p. 105, 11. 1, figs. $5-8$.

Loc. Stissing Monntain, Duchess County, New York.

\section{Iphidea superba Waleott.}

Iphidea cnf.? ornatella IIall and Clarke, Pal. New York, VIII, I't. I, 1892, pl. 4, figss. 6,7 .

Iphisea superba Waleott, Proc. U. S. National Mns., XIX, 1897, 1. 711, 11. 59, figs. 1-1e.

Lor. Grand Canyon of the Coloralo.

Isogramma Meek and Worthen= \nlacorliynchus.

Isogramma millipuctata Meek and Worthen=Anlacorhynchus millipuuctatum.

\section{KINGENA Davidson.}

Genotype Terebratula lima Defrance.

Kingena Davidson, Mon. British Cret. Brach., Pal. Soc., I, 1853, 1. 4?.

\section{Kingena leonensis (Conrad).}

Washita (Lower Cret.).

Terebratula leonensis Conrad, Lnory's Rep. I. S. and Mexican Bound. Anrvey, I, 1857, 1. 164, pl. 21, fig. 2.-Gabb, Proc. Acad. Nat. Sci. Philadelphia, 1861, 1. 18.

Loc. Leon Springs, Texas; also Denison, Texis (Hill).

\section{Kingena wacoensis (Roemer).}

Washita (Lower Cret.).

Terebratula s]. undet. Roemer, Texas, 1849, p. 408.

'Terebratula wacoensis Roemer, Kíreilebildung ron Texas, 1852, 1. 81, pl. ti, fig. 2.Gabb, Proe. Acad. Nat. Sci. Philadelphia, 1861, 1. 18.

Terebratula choctawensis Shumard, Iarey': Rep. Red River Lonisiana, 1854, p. 195, 1,l. 2, tig. 3.—Gabl, Proc. Acad. Nat. Sci. Philadelphia, 1861, 11. 19.

?Terebratula wacoensis Whiteaves, Mesozoic Foss., Geol. Surv. Canarla, 1, 1879, 1. 177.

Loc. Near New Brannfels, Texas; Trent River, Vancourer Island. "I have traced its continnity from the Red River to the Rio Grande" (Hill).

Obs. Gabl, is correct in regarding $T$. choctawensis as a synonym for ' $T$. wacoensis. "The Vancouver specimens are doulitful" (Stanton).

Klitambonites Pander=Clitambonites.

Koninckiana americana Swallow= Productus swallovi.

\section{KUTORGINA Billings.}

Fenotype Obolella cingulata Billings.

Kintorgina Billings (partim), Geol. Vrrmont, 11, 1861, 1. 948, 1igs. 347-349.-l3illings (partim), Pal. Fossils, I, 1861, 1.9, figs. 8-10. - 1)all, Bnll. U. S. Nat. Mus., 8, 1877, 1). 40.-Walcott (1rartiu), Bull. 1. S. Geol. Surver, 30, 18r6, p. 101.Beecher, Ameriean Jour. Sci., 31 ser., XLI, 1×91, p. 345.-Hall and Clarke, Pal. New York, VIII, Pt. I, 1892, p1. 90, 166, 183;-Eleventh Anu. Rep. New York State Geologist, 1894, 1. 247. 
Kutorgina cingulata Billings.

Lower Cambrian.

()holellit (Kutorgina) cingulata liblings, Geol. Vermonf, 11, 1861, 1. 9.jx, figs. $317-819 ;-1$; 1. liossils, 1,1861, ]. 8 , figs. $8-10$.

Obolella cingulata IBllings, (ieol. Cauala, 1863, 1. 2א4, fig. $2 \times 7$.

Kutorginal ciugulata Walcott, Bull. T. S. Geol. Survey, 30, 1886, p. 102, pl.9,

fig. 1.-Deccher, American .Jour. Sci., 31 ser., XLI, 1841, 1. 345.-Winleott,

'Tenth Anu. Ri('). U. S. (ieol. Survey, 1891, p. 609, pl. 69, fig. 1.-Hall and Clarkc,

Pal. New Jork, VIII, l't. I, 1892, p. 92, tigs. $47-49$; pl. 4, figs. 10-17.

Loc. Anse an Loup, Labrador; Swanton and Georgia, Vermont; Malvern Hills,

Eugland; Island of Bornholm, Sweden.

Kintorgina labralorica Walcott $=$ Iphidea labradorica.

Kintorgina labradorica var. swantonensis Walcott $=I$ phidea labradorica swantonensis.

Kntorgina latonrensis Matthew=Billingsella latourensis.

Kntorgina minutissima Hall and Whitfield=Iphidea seulptilis.

Kutorgina pammula White $=$ Iphidea paunulus.

Kintorgina prospectensis Walcott = Iphidea prospectensis.

?Kutorgina pterineoides Matthew.

Middle Cambrian.

Kintorgina? pterineoides Natthew, Trans. Royal Soc. Cimada, III, 1886, 1. 43, pl. 5 , fig. 19.

Loc. Ilanford Brook and St. Martins, New Brunswick.

Obs. It is not certain that this species is a lorachiopor. May he the opereulum of a pteropod.

Kntorgina sculptilis Walcott $=$ Iphidea senlptilis.

Kntorgina stissingensis Dwight = Iphillea stissingensis.

Kutorgina whitfieldi Waleott=Billingsella whitfieldi.

LEIORHYNCHUS Hall. Genotype Orthis quadricostata Vanuxem.

Leiorhynchus Hall, 'Thirteenth Rep. New York state Call. Nat. Hist., 1866, p. 75;-Twentieth Rep. Ibidem, 1867, p. 272 ;-Pal. New York, IV, 1867, p. 355.Waagen, Palieontologica Indica, Ser. XIII, I, 1883, p. 411.

Liorlynehus 11 all and Clarke, Pal. New York, V1II, Pt. II, 1893, p. 193;Thirteenth Anu. Rep. New York State Geologist, 1895, p. 827.

Obs. A sub renus of Cum ruterehia, differing only in exterior ornanentation.

Leiorhynchus boonense (Shumard).

Burlingto: (L. Carb.).

Rhynchonella boonensis shnmard, Geol. Rep. Misionri, 1855, p. 205, pl, C, fig. 6.--Keses, feol. Survey Missouri, V, 1895, 1. 101.

Liorhychus boonensis Hall and Clarke, Pal. New York, VIII, P4. II, 1893, p. 194, , l. 60, fig. 3\%).

Loc. Columbia, Boone County, and Cooper County, Missouri.

Leiorhynchus dubium Hall.

Mareellus (Dev.).

Leiorhynehus dubins 1Iall, Pal. New York, IV, 1867, p. 364, pl. 56, figs. 22-25.-

Ilall aud Clarke, Pal. New lork, VIII, T't. 1I, 18:5, pl. 59, tigs. 6, 7.

lihynchonella dubia Tschernyselıow, Méu. Connité Grologique de St. Peterslurg, III, 3, 1887, p. 90, pl. 14, fig. 7.

Loc. New Jork; Irals of Rusia.

Leiorhynchus globuliforme (Vanuxem).

Chemung (Der.).

Atrypa glohnliformis Vannxm, Geol. New York; Rep. Third Dist., 1842, p. 1×2, fig. 2.

Leiorhynehus glohuliformis Hall, Pal. New York, IV, 1867, p. 364, pl. 57, figs. 26-29. - Hall and Clarke, Pal. New York, VIll, Pt. II, 1893, p. 194, pl. 59, ligs. $23-27$.

Loc. Otsego County, New York. 
Leiorhynchus greeneanum (Ulrich).

Waverly (L. Carb.).

Rhynchonella greenana Ulrich, Cont. American I'al., I, 1886, p. 26, pl. 3, fig. 1.

Liorhynchus greeniauts Hall and Clarke, Pal. New Tork, VIII, Pt. II, 1893, p. 194.

Pngmax greenianus Hall and C'arke, Ibidem, 1895, Il. 60, figs. 36-38.

Loc. Near New Mlhany, Indiana.

Leiorhynchus (?) hecate Clarke.

Genesee (Dev.).

Leiorhynchus(?) hecate Clarke, Bull. U. S. Geol. Survey, 16, 1885, 1. 31, 11. 3, fig. 4.

Loc. Ontario County, New York.

Obs. I'robably the same as spirifer pluto Clarke.

Leiorhynchus iris Hall.

Chemung (Dev.).

Leiorhynchus iris Hall, I'al. New York, IV, 1867, p. 360, pl. 56, tigs. 41-13.

Loc. Rockforl, Iowa.

Leiorhynchus kelloggi Hall.

Hamilton (1)ev.).

Leiorhynchus kelloggi Hall, Pal. New York, IV, 1867, p. 361, pl. 57, figs. 1-12.Hall and Clarke, Pal. New York, VIII, Pt. II, 1893, P. 194, 11. 59. figs. $18-20,32,33$.

Leiorhynclus kelloggi? Whitficld, Geol. Wisconsin, IV, 18×2, p. 334, pl, 26, lig. 9. Rhỹuchonella kelloggi Tschernyschew, Mém. Comité Géologịnue de st. Petersburg, III, 3, 1887, p. 91, pl. 14, tig. 14.

Loc. Ohio; New York; Milwatkee, Wiscousin; Urals of Rıssia.

Leiorhynchus laura (Billings).

Marcellus-Hamilton (Dev.).

Rhynchonella? laura Billings, Canarlian Jour, V, May, 1860, p. 278, figs. 26-28;Geol. Canada, 1863, p. 384, tim. 418.

Leiorhynchus multicosta Iall, Thirteenth Rep. New York State Cab. Nat. Hist, December, 1860 , p. 85, figs. 14, 15, on 1. 94;-Pal. New lork, $1 \mathrm{~V}, 1867,1$. 358, pl. 56, figs. 26-40.

Leiorhyuchus laura Billings, Canalian Nat. (icol., 11. ser., VII, 1874, 1. 240.

Rhynchonella (Leiorlyuchus) lania Walcott, Mou. U. S. Geol. Survey, VIII, 1884 , p. 159.

? Rhynchonella multicosta Tscheruyschew, Devon, in Donetz Becken, 1886, pl. 15, figs. 1-3;-Mém. Comitó Cí́ologiquo de st. Petersburg, 111, 3, 1887, p. 92.

Liorhynelus multicosta and lanra IIall and clarke, I'al. New Yurk, VIIl, Pt. II, 1893, p. 194, 11]. 59, figs. 8-10, 13-17.

Loc. Thedford and Bosanquet, Ontario; New York; Eureka district, Nevada; ? Russia.

\section{Leiorhynchus lesleyi Hall and Clirke.}

Upper Devomian.

Liorhynchus lesleyi Hall.and Clarke, Pal. New York, VIII, Pt. II, 1895, 1. 368, 1l. 59, figs. 34-36.

Loc. "Pennsylvania."

\section{Leiorhynchus limitare (Vannxem).}

Marcellus (Dev.).

Orthis limitaris Vanuxem. Geol. New York; Rep. Third Dist., 1842, 1. 146, tig. 3. Atrspa limitaris Hall, Ibidem, Rep. Fourth Inist., 1845, p. 182, fig. 11.

Leiorhynchus linitaris Hall, Thirteenth liep. New York State Cal, Nat llist., 1860, p. 85 ;-Pal. New York, IV, 1867, 1. 356, pl. 56, figs. 6-21.-Whitfield, Annals New York Acad. Sci., V, 1891, 1. 550, pl. 11, fig. 11;-Geol. Ohio, VII, 1895 , p. 444 , pl. 7 , fig. 11.

Rhynchonella limitaris Tschernyschew, Mémoires ‘u comité Gélogique de St. P'eterslıurg, 1887, III, 3, pl. 14, fig. 5.

Liorhynchus limitaris Hall and Clarke, Pal. New York, VIII, I’t. II, 1893, p. 194, pl. 59, figs. 12, 35.

Loc. Schoharie, Marcellus, Avou, ete., New York; Delaware Conuty, Ohio (Whitfield); Urals of Russia. 
Leiorhynchus mesicostale Hall.

l'ortage-Chemung (1)ev.).

Atrypa mesacostalis Hall, Geol. Now York; Rep. Fourth Dist., 1843, Tables Organic Remains, 64, tig. 1.

Leiorhynchus mesacostalis llall, Thirteenth Rep. Now York State Cal, Nat. Hist., 1860, 1. 86, fig. 1;-Pal. Now York, IV, 1867, p. 362, pl. 67, figs. 18-25.-Kiudle, linll. American Pal., 6, 1896, 1. 37.

Rhynchonella mesacostalis Tsehernyschew, Mémoires du Comité fréologígue de St. P'etersburar, 1887, p. 91, pl. 14, figs. $3,4$.

Liorhynchus mesacostalis Hall and Clarke, Pal. New York, VI1L, Pt. 11, 18!3, p. 194, pl. 59, lims. 11, 12.

Loc. Ithaca, EImira, liath, ete., New York; Urals of Russia.

Leiorhynchus multicosta Hall=L. latura.

Leiorhynchus mysia Hall.

Marcellus (Dev.).

Leiorhynchus mysia I1all, Pal. New York, IV, 1867, p. 357, pl. 56, figs. 1-5.

Loc. Schoharie, New York.

Leiorhynchus nevadaense Walcott.

Middle Devonian.

Rhynchonella (Leiorhynchus) nevadensis Walcott, Mon. U. S. Geol. Surrey, VIII, 1884, 1. 157, p]. 14, fig. 9.

Loc. Eureka district, Nevada.

Leiorhynchus newberryi Hall.

Waverly (L. Carb.).

Lelorhynchus nowberryi Hall, Twenty-third Rep. Now York State Cab. Nat. Hist., 1873, p. 240, pl. 11, figs. 25-27.

Liorhynchus newheryi Hall and̄ Clarke, Pal. New York, VIII, Pt. II, 1893, p. 191, pl. 59, figs. 37,38 .

Loc. Kelloggsville, Ashtabula County, Ohio.

Leiorhynchus quadricostatum (Vanuxem).

Genesee (Dev.).

Orthis quadricostata Vanuxem, Geol. New York; Rep. Third Dist., 1842, 1. 168, fig. 2 .

Atrypa (Orthis) quadricostata Hall, Ibidem, Rep. Fourth Dist., 1843, p. 223, fig. 2.

Leiorhynchus quadricostata Hall, Thirteenth Rep. New York State Calb. Nat. Hist., 1860, 1. 86;-Pal. New York, IV, 1867, p. 357, pl. 56, tigs. 11-49.Clarke, Bull. I. S. Geol. Survey, 16, 1885, p. 24.-Nettelroth, Kentucky Fossil Shells, Mem. Kentucky Geol. Survey, 1889, 1. 71.

Leiorhynchns quadricustata? Meek, King's U.S. Geol. Expl. 10th Pari., IV, 1877, p. $79, \mathrm{pl} .3$, fig. 9.

Liorhynchus quadricostatus Hall and Clarke, Pal. New York, VIII, Pt. II, 1893, p. 193, pl. 59, figs. 21, 22.

Loc. Ithaca, Seneca Lake, Cayuga Lake, New York; Falls of Ohio; White Pine district, Nevada.

Leiorhynchus robustum Hall and Clarke.

Chemung (Dev.).

Liorhynchus robustus Hall and Clarke, Pal. New York, VIII, I't. II, 1893, pl.59, figs. 30,31 .

Loc. Steuben Connty, New York.

Leiorhynchus sesquiplicatum A. Winchell.

Hamilton (1)ev.).

Leiorhyuchus sesquiplicatus A. Winchell, Rep. Lower Peninsula Michigan, 1866, p. 9 .

Loc. Grand Traverse district, Michigan.

Leiorhynchus sinuatum Hall.

(hemung (Dev.).

Leiorhynchus sinuatns Hall, Pal. New York, IV, 1867, p. 362, pl. 57, figs. 13-17.

Rhyuchonella (Leiorhynehus) sinuatus Walcott, Mon. U. S. Geol. Survey, VIII, 1881, p. 158 , pl. 14, fig. 5.

Liorbynchus sinuatus Hall aud Clarke, Pal. New York, VIII, Pt. II, 18: 3, 1. 194.

Loc. Ithaca and Chemnng Narrows, New York; Eurckid district, Nevada. 
LEPT \&NA Dalman.

Genotype Productus rugosa Hisiuger =Couchita rhomboidalis Wilckens.

Leptiena Dalman, Kongl. Svenska Vet.-Akaג. Handl., för 1827, 1828, pp. 93, 94.King, Mon. Permian Foss., Pal. Soc., 1850, p. 104.-Hall aud Clarke, Pal. New York, V11I, Pt. I, 1892, p. 276.- Winchell and Schuchert, Minmesota Geol. Survey, III, 1893, p. 409.- HaIl and Clarke, Eleventh Ann. Rep. New York State Geologist, 1894, p. 277.

Leptagonia McCoy, Carb. Foss. Ireland, 1844, p. 116.

Plectambonites Ehlert, Fischer's Manuel Conchyliologie, 1887, 1. 1283.

Leptena alternata Conrad = Rafinesquina alternata.

Leptiena alternistriata Hall= Rafinesquina alternata alternistriata.

Leptiena barabuensis Whitfield=Syntrophia barabnensis.

Leptiena bipartita Hall=Strophomena bipartita.

Leptiena camerata Hall=Rafinesquina camerata.

Leptæna charlottæ Winchell and scluuchert.

Trenton (Ord.).

Leptena charlott: Winchell and schuchert, American Geol., 1X, April 1, 1892,

p. 288;-Minnesota Geol. Nurvey, III, 1893, p. 410, pl. 32, figs. 1-5.

Strophomena halli Sarlesou, Bull. Minnesota Acad. Nat. Sci., III, April 9, 1892, p. 334, pl. 4, figs. 36-32.

Loc. Minneapolis and St. Panl, Minnesota.

Leptrena concava Hall=Leptenisea concava.

Leptiena corrugata Hall=Strophomena corrugata.

Leptiena decipiens Billings=Leptella decipiens.

Leptena deflecta Hall=Dinorthis deflecta.

Leptrena deltoidea=Rafinesquina deltoidea and R. minnesotaensis.

Leptiena depressa Hall=L. rhomboidalis.

Leptrua fasciata Hall=Rafinesquina fasciata.

Leptrena incrassata Hall=Rafinesquina incrassata.

Ieptrena indenta Conrad = Stropheodonta inclenta.

Leptrena julia Shaler $=$ Stroplomena ,julia.

Leptena laticosta de Verneuil=Tropidoleptus carinatus.

Leptiena melita Hall and Whitfield=Dalmanella melita.

Leptrena mesacosta Slıumard=Rafinesquiua mesicosta.

Leptæna minnesotensis Sarleson=Plectambonites sericens.

Leptrena nucleata Hall=Anoplia meleata.

Leptrena obscura Hall=Rafinesquina obsen'a.

Leptrena orthididea Hall=Strophonella orthididea.

Leptrena patenta Hall=Strophonella patenta.

Leptana planoconvexa Hall=Strophomena planiconvexa.

Leptana planumbona Hall=Strophomena rugosa.

Leptrena plicatella Ulrich = Plect:umbonites plicatellus.

Lept:ena plieifera Hall=Dalmanella? plicifera.

Leptena precosis Sardeson= Plectambonites sericeus.

Leptena profunda Hall=Stropheodonta profunda.

Leptrena prolongata Foerste=Plectambonites transversalis prolongatus.

Leptrena punetulifera Conrad=Strophonella punctulifera. 
Lept:ena qualrilatera Shaler $=$ L. rhomboiclalis.

leptirna recelens Sardesou= Plectambonites sericens. leptina recta $H_{a l l}=$ Dinorthis deflecta.

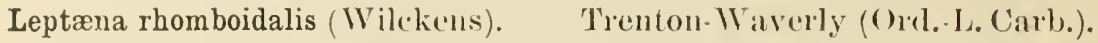

('on'hita rlomboidalis Wilckens, Xachrict ron selten Versteinerungen, 1769, p. $77,1,1.8$, figs. $13,41$.

Strophomena undulosa ('onrarl, Fifth Ann. Rep. Geol. Survey lew York, 1841, 1.5. 54.

Strophomena depressa Vamxem, Geol. New York; liep. Thiol l)ist., 1812, 11. 79, tig. 5.-Hall, Ibidem, liep. Fonth 1)ist., 1843, 1) 77, lig. 5; 1). 104, tig. 2.Billings, Canalian Nat. Geol., 1, 1856, p. 59, pl, 1, fig. 5.-lioemer, Sil. Fanna west. Tennessee, 1860,1 . 65. pl. 5, fig. 2.

Strophomena undulatus Vanuxem, (ieol. New York; Rep. Third Dist., 184:2, p. 139, lig. :3.

Strophomena undulata lall, Ibinem, Rej. Fourth 1)ist., 1813, P. 175, fig. 3.Yandell and Shnmard, Cont. Geol. Kontucks, 18.17, 1) 11.

Prodnctus? suleatus Casteluau. Essai syst. Sil. l'Anérique Septentrionale, 1843, p. 39, pl. 13, fig. 7 .

Productus snleifer de Vernenil, lbident, 1843, p. 39.

Leptarna tenuistriata Hall, l'al. New York, I, 1847, p. 108, pl. 31 A, fig. 4.-Ilall and Ciarke, Pal. New York, YIII, Pt. I, 1892, pl. 8, tigs. 12-16.

Leptiena depressa Hall, Pal. New York, II, 1852, 1. 62, pl. 21, fig. 8; 1. 257, pl. 53, fig. 6.-Rogers, Gool. Penusylvaniiı, II, P't. II, 1858, p. 823, tig. 630.

Strophomena rilgosa IIall, Pal. New York, IIl, 18.59, 11. 195, pl. 19, fig. 1.

Stroplomeua rhomboidalis IBillings, Canarlian Jour., V'1, 1861, 1) 336, figs. 111, 112;-Geol. Canada, 1863, p. 311, fig. 314; p. 367, fig. 373;--Proc. I'ortland Soc. Nat. Hist., 1863, p. 107, pl. 3, fig. 1.-Hall, Pal. New York, IV, 1867, p. 76, 11. 12, tigs. 16-18; 1. 414, pl. 15, ligs. 15, 16.-Neek and Trorthen, Geol. Anrvey Illinois, III, 1868. 1. 426, 11. 10, tig. 7.-Neek, Pal. (1)io, I, 1573, 1. 75, pl.5, tig.6.-Billings, Pal. Foss., II, 1874, p. 27.-White, Wheeler's Expl. Survey west 100th Merid., $1 \mathrm{~T}, 1875$, 1. 85, pl. 5, fig. 5 - Hall and Whitfield, King's 1. S. Geol. Expl. 40th Parl., IY, 1877, 1'. 253, jl. 4, tig. 4.-Hall, Twenty-eighth Rep. New York state Mus. Nat. 1list., 1879. 1. 151, pl. 22, figs. 4-10.-Miller, Jour. C'incimuti soc. Nat. Hist, IY, 1881, 1. 1.-Hall, Eleventh Rep. State Geol. Indiana, 1842, p. 288, pl. 22, figs. 4-10;-Second Ann. Rep. New York State Geol., 1883, pl. 38, tigs. 17-31.-Waleott, Mon. U. S. Geol. Survey, V1I, 1884, 1, 118.-Beecher and Clarke, Mem. New lork State Mrus., I, 1889, p. 18, pl. 2, tigs. 1-13.-Nettelrotl, Kentueky Fossil Shells, Mem. Kentucky Grol. Kurvey, 1889. p. 150, 11. 18, 1igs. 1-3.-Foerste, I'roe. Poston soe. Nat. Ilist., XXIT, 1890, p. 298.-Beeeher, American Jomr. s.i., 34 ser., XLI, 1891, 11. 357, 11. 17, figs. 18-2I.-Herrick, Geol. Ohio, VII, 1895, pl. 20 , tig. 6 .

Strophomena analoga l)avislson, Qunrt. Jonr. Geol. Soe. Loudon, XIX, 1863, p. 173, pl. 9, fig. 18. -Dawson, Acallian (icol., 3d ed., 1878, 1. 295, tig. 95.

Leptonn qualrilatera Slater, Bull. Mus. ('omp. Zool, 4, 1865, p. 65.

Strophomena gibbosa James, Cincinnati (puart. Jour. Sci, I, 1874, p. 333.

Strophomena tenuistriata Miller, 1 bidem, II, 1875, p. 55.-11all, Second Ann. Rep. New York State Geol., 1883, pl. 3×, figs. 12-16.

Leptena rhomboidalis IIall and Clarke, Pul. New York, VIII, l't. I, 1892, 1. 279, 11. 8, tigs. 17-31; pI. 15. tigs. 40-12; pl. 20, figs. 21-21.-Foerste, Cieol. Ohio, III, 1895, p. 566 .

Leptirna (Strophomena) rhomboidalis, Beceher, American Jour. Aci., 3d ser., XLIV, 1892, p. 150, pl. 1, figs. 7-9.

Plectambonites rhomboilalis Keyes, Geol. Survey Missouri, V, 1s.5, p. 70, fig. 6.

Loc. Annerally distributed in the above-given formations througlout Ameriea ancl Euroje. 
Strophomena depressa var. ventricosa Hall, Tenth Rep. New York State Cab. Nat. Hist., 1857, p. 55.

Strophomena rugosa var. ventricosa Hall, Pal. New York, III, 1859, p. 417, pl. 94, figs. 2, 3 .

Leptæna rhomboidalis var. ventricosa Hall and Clarke, Pal. New York, VIII, Pt. I, 1892, pl. $15 \mathrm{~A}$, fig. 43.

Loc. Albany and Schoharie counties, New York; Cumberland, Mlaryland ; Cayuga, Ontario.

Leptæua rugosa $=\mathrm{L}$, rhomboidalis.

Leptrna saxea Sardeson=Plectambonites sericeus.

Leptina sericea Sowerby =Plectambonites sericeus.

Leptrena sordida Billings = Leptella sordida.

Leptæna(?) stelzneri Kayser.

Ordovician.

Leptæna stelzneri Kayser, Palæontographica, Suppl., III, 1876, p. 21, pl. 3, fig. 21.

Loc. Guaco, Argentine Republic.

Obs. Since this species has a high ventral area and a perforated deltidinm it is probably a Clitambonites.

Leptiena striata Hall=Strophonella striata.

Leptrena subplana Hall=Orthothetes subplanus.

Leptrena subquadrata Hall=Christiania subquadrata.

Leptrena subtenta Hall=Strophomena trentonensis or S. rugosa sub. tenta.

Leptrena sulcata de Vernenil=Strophomena sulcata.

Leptrena tenuilineata Hall=Rafinesquina tenuilineata.

Leptrena tenuistriata Hall=L. rhomboidalis.

Leptæna transversalis = Plectambonites transversalis.

Leptrena transversalis var. alabamaensis Foerste = Plectambonites transversalis alabamaensis.

Leptæna trilobata Owen=Strophomena trilobata.

Leptæna unicostata Meek arrd Worthen.

Lorraine (Ord.).

Leptena (n. sp. ?) Owen, Geol. Survey Wisconsin, Iowa, Minnesuta, 1852, pl. 2B, fig. 3. [See specimen in U. S. Nat. Mus., Cat. Invert. Foss., 17908.]

Strophomena unicostata Meek and Worthen, Geol. Survey Illinois, III, 1868, p. 335, pl. 4, fig. 11.-Whitfield, Geol. Wisconsin, IV, 1882, p. 262, pl. 12, fig. 14.

Rafinesquina nnicostata Hall and Clarke, Pal. New York, VIII, Pt. I, 1892, pl. $15 \mathrm{~A}$, fig. 39 ; pl. 20 , fig. 25.

Leptiena unicostata Winchell and Schnchert, Minnesota Geol. Survey, III, 1893, p. 411, pl. 32, figs. 6-9. -Whiteaves, Pal. Foss., III, Pt. III, 1897, p. 174.

Loc. Saranna and Wilmington, Illinois; Delafield and Iron Ridge, Wisconsin; Spring Valley and Granger, Minnesota; Lattners, Iowa; Rapids of the Nelson River, Lake Winnipeg, Manitoba.

Leptæena variolata d'Orbigny $=$ Chonetes variolatus.

Leptrua vicina Castelnau $=$ Chonetes vicinus.

LEPT ENISCA Beecher.

Genotype Leptrena concava Hall.

Leptrenisca Beecher, Anerican Jour. Sci., 3d ser., XL, 1890, p. 239, pl.9, figs. 1-5.Hall and Clarke, Pal. New York, VIII, Pt. I, 1892, p. 3 n; -Eleventh Aun. Rep. New York State Geologist, 1894, p. 291.

Bull. $87-16$ 
Leptænısca adnascens Hall and Clarke.

Lower Helderberg (Dev.).

Leptarnisea alnascens IIall and Clarke, Pal. New York, VHI, l’t. I, 1892, pp. 301, 352 , pl. 15 A, fi.gs. 22, 23.

Loc. Near Clarksville, New York.

Leptænisca concava Hall.

Lower Helderberg (Dev.).

Leptrna coucava Hall, Tenth Rep. New York State Cab. Nat. Hist., 1857, 1. 17;-I’al. New York, III, 1859, p. 197, pl. 18, fig. 2.

Loptirna? (sıbgenus?) concava Hall, Second Ann. Rep. New York State Geol., 1883 , pl. 46 , figs. 30,31 .

Leptenisca concava Beecher, American Jour. Sici., 3d ser., XL, 1890, p. 238, pl. 9, figs. 1-5.-Hall and Clarke, Pal. New York, VIII, I't. I, 1892, p. 300, pl. 15, figs. 30, 31; pl. 15A, figs. 19-21.

Loc. Albany County, New York; Decatur County, Tonnessee.

Leptænisca tangens Hall and Clarke.

Lower Helderberg (1)ev.).

Leptrenisca tangens Hall and Clarke, Pal. New York, VIII, Pt. I, 1892, pp. 301, 352 , pl. $15 \mathrm{~A}$, figs. $24-30$.

Loc. Near Clarksville, New York.

LEPTELLA Hall and Clarke.

Genotype Leptrena sordida Billings.

Leptella Hall and Clarke, Pal. New York, VIII, Pt. I, 1892, p. 293;-Eleventh Ann. Rep. New York State Geologist, 1894, p. 277.

Leptella decipiens (Billings).

Calciferous (Ord.).

Leptæna decipiens Billings, Pal. Fossils, I, 1862, p. 74, fig. 67; p. 219;-Geol. Canada, 1863, p. 231, fig. 243.

Leptella decipiens Hall and Clarke, Pal. New York, VIII, Pt. 1, 1892, p. 294.

Loc. Point Levis, Canada; Portland Creek, Newfoundland.

Leptella sordida (Billings).

Calcif'erous (Ord.).

Leptæna sordida Billings, Pal. Fossils, I, 1862, p. 73, fig.66;--Geol. Canada, 1863, p. 231, fig. 242.

Leptella sordida Hall and Clarke, Pal. New York, VIII, Pt. i, 1892, p. 293, pl. $15 \mathrm{~A}$, figs. $12-16$.

Loc. Point Leris, Canada.

LEPTOBOLUS Hall.

Geuotype L. lepis Hall.

Leptobolus Hall, Description n. sp. Foss. from Hndson River Group, 1871, p. 3 ;Twenty-fourth Rep. New York State Cab. Nat. Hist., 1872, p. 226.-Hall and Clarke, Pal. New York, VIII, Pt. I, 1892, pp. 73, 165;-Elerenth Ann. Rep. New York State Geologist, 1894, p. 211.

Leptobolus grandis Matthew.

Lowest Ordovician.

Leptololus grandis Mattlew, Trans. Royal Soc. Canada, X, 1874, p. 91, pl. 16, fig. 7.

Loc. Hardingville, New Brunswick.

Leptobolus insignis Hall.

Utica (Ord.).

Leptobolus insignis Hall, Descrip. n. sp. Foss. from Hudson River Group, 1871, p. 3, pl. 3, fig. 17;-Twenty-fourth Rep. New York State Cab. Nat. Hist., 1872, p. 227, pl. 7, fig. 17.-Nicholsou, Pal. Province Ontario, 1875, p. 85.Hall and Clarke, Pal. Now York, VIII, Pt. I, 1892, 1. 74, pl. 3, figs. 1-6.

Loc. Middleville, Utica, etc., New York; Ottawa, Canada; Cincinnati, Ohio.

Leptobolus lepis Hall.

Utica (Ord.).

Lepiowonts lepis Hall, Description n. sp. Foss. from Hulson River Group, 1871, p. 3, pl. 3, figs. 19, 20 ;-Twenty-fourth Rep. New York State Cab. Nat. Hist., 1872, p. 226, pl. 7, figs. 19, 20.-Hall and Whitfield, Pal. Ohio, II, 1875, 1. 69, pl. 1, figs. 10, 11.-Miller, Cincinnati Quart. Jour. Sci., II, 1875, p. 11.-IIall and Clarke, Pal. New York, VIII, Pt. I, 1892, P. 7t, pl. 3, figs. 8-10.

Loc. Cincinnati, Ohio. 
Leptobolus occidentalis Hall.

Maquoketa (Ord.).

Leptobolus occidentalis Hall, Pescription n. sp. Foss. from Hudson River Group, 1871, p. 3, pl. 3, fig. 18;-Twenty-fourth Rep. New York State Cab. Nat. Hist., 1872, p. 227, pl. 7, fig. 18.-Hall and Clarke, Pal. New York, VIII, Pt. I, 1892, pl. 3, fig. 7 .

Loc. Hawleys Mills, Iowa; Platteville, Wisconsin; Ottawa, Canada (Ami).

Leptocœlia Hall = Anoplotheca.

Leptoccelia propria Hall=Anoplotheca flabellites.

Leptocolia disparilis Hall=Atrypina clisparilis.

Leptocelia imbricata Hall=Atrypina imbricata.

LEPTOSTROPHIA Hall and Clarke.

Genotype Stropheodonta magnifica Hall.

Leptostrophia Hall and Clarke, Pai. New York, VIII, Pt. I, 1892, p. 288;-Eleventh Anu. Rep. New York State Geologist, 1894, p. 281.

Obs. This is a subdivision of Stropheodonta. The following species have been referred to it: S. magnifica, S. perplana, S. textilis, S. beckei, S. magniventra, S. junia, S. irene, S. blainvillei, and $S$. tullia.

LINDSTREMELLA Hall and Clarke. Genotype L. aspidium H. and C.

Lindstrœmella Hall and Clarke, Extract Pal. New York, V'lII, 1890, p. 134;-1'al. New York, VIII, Pt. I, 1892, p. 134 ;-Eleventh Ann. Rep. New York State Geologist, 1894, 1'. 257.

Lindstrœmella aspidium Hall and Clarke.

Hamilton (Dev.).

Liudstrœmella aspidium Hall and Clarke, Extract Pal. New York, VIII, 1890, p. 134, pl.4E, figs. 25-28;-Pal. New York, VIII, Pt. I, 1892, pp. 134, 178, pl.4E, figs. 25-28.

Loc. Leonardsville, Hamilton, Darien, etc., New York.

LINGULA Bruguière.

Genotype Lingula anatina Lamarck.

Lingula Bruguiere, Encyclopédie Méthodique, I, 1792, pl. 250.-Meek and Haydeu, Pal. Upper Missouri, Sunithsonian Cont. to Knowl., XIV, 172, 1864, p. 68.-Hall, Pal. New York, [V, 1867, p. 5.-Dall, American Jour. Conch., VI, 1870, pp. 153, 154.-Meek, Hayden's U. S. Geol. Survey Terr., IX, 1876, p. 7.Dall, Bull. U. S. Nat. Museum, 8, 1877, 1. 43.-Hall and Clarke, Pul. New York, VIIl, Pt. I, 1892, pp. 2, 161.-Winchell and Schuchert, Minnesota Geol. Survey, III, 1893, p. 338.- Hall and Clarke, Eleventl Ann. Rep. New York State Geologist, 1894, p. 226.

Lingula acuminata Hall=Lingulepis acuminata.

Lingula acutangula Roemer=Lingulepis acntangulus.

Lingula acutirostris Hall.

Clinton (Sil.).

Lingula acutirostra Hall, Geol. New York; Rep. Fourth Dist., 1813, p. 77, fig. 9 on p. 76 ;-Pal. New York, II, 1852, p. 56, pl. 20, fig. 5.

Loc. Wolcott, New York.

Obs. Based upon a single specimen now lost.

Lingula æqualis Hall.

Trenton (Ord.).

Lingula sequalis Hall, Pal. New York, I, 1847, p. 95, pl. 30, fig. 3.-Walcott, Proc. U. S. Nat. Mus., XI, 1888, p. 480, fig. 3.-Ilall and Clarke, P'al. New York, VIII, Pt. X, 1892, p. 9, fig. 4.

Loc. Middleville, Trenton Falls, and Rome, New York.

Lingula alba-pinensis Walcott.

Upper Devonian.

Lingula albapinensis Walcott, Mon. U. S. Geol. Survey, VIIl, 1884, p. 108, pl. 2, fig. 1.

Loc. White Pine district, Nerada. 
lingula alveata $H_{i l l}=$ Dignomia alveata.

Lingula ampla Owen=Lingulella ampla.

Lingulin antigna Emmons=Lingulepis acuminata.

Lingula antiqua Hall, 1S51, 1862, Hayden, 1863 (non Hall, 1847)=Lingulepis pinniformis.

Lingula antiquat: Enmons=Lingulepis acuminata.

Lingula artemis Billings.

Gaspé No. 5 (L. Dev.).

Lingula artemis Billings, Pal. Fossils, II, 1874, p. 14, fig. 4.

Loc. Gaspé, Cape Bou Ami.

Lingula atra II errick.

Waverly (L. Carb.).

Lingula atra Herrick, Bull. Denison Univ., IV, 1888, pl. 13, 16, pl. 10, fig. 30;Geol. Ohio, VII, 1895, pl. 22, figs. 5, 6 .

Loc. Cuyahoga River, Ohio.

Liugula attenuata Hall=Glossina trentonensis.

Lingula aurora Hall=Lingulella aurora.

Lingula aurora var. Hall=Lingulella stoneana.

Lingula belli Billings.

Chazy (Ord.).

Lingula belli Billings, Canadian Nat. Geol., IV, 1859, p. 431, tigs. 7, 8; -Geol. Canarla, 1863, p. 124, fig. 47.

Loc. Island of Montreal, Allumette Island, Canada.

Lingula beltrami Winchell and Schuchert.

Lorraine (Ord.).

Lingula beltrami Winchell and Schuchert, Minnesota Geol. Survey, III, 1893, p. 351 , figs. $25 \mathrm{a}, 25 \mathrm{~b}$.

Loc. Spring Valley, Minnesota.

Lingula bicarinata Ringneberg.

Niagara (Sil.).

Lingula bicarinata Ringueberg, Proc. Acarl. Nat. Sci. Philadelphia, 1884, p. 149, pl. 3, fig. 8.--Miller, N. American Geol. Pal., 1889, p. 349.

Loc. Lockport, New York.

Lingula billingsana Whitcaves=Lingulella billingsana.

Lingula bisulcata Ulrich.

Utica (Ord.).

Lingula bisuleata Ulrich, American Geologist, IJI, 1889, p. 380, fig. 2, on p. 378.

loc. Ludlow, Kentucky.

Lingula brevirostris Meek and Hayden.

Jurassic.

Lingula brevirostris Meek and Iaydeu, Proc. Acar. Nat. Sçi. Philadelphia, 1858, p. 50 ;-Ihidem, 1860 , p. 419;-Pal. Upper Missonri, Snithsonian Cont. to Knowl., XIV, 172, 1865, 1. 69, pl. 3, fig. 3.-Whitfield, Powell's Geol. Geogr. Survey Rocky Mt. Region, 1880, p. 346, pl.3, figs. 4, 5 .

Loc. Black Hills, Dakota.

Lingula briseis Billings.

Trenton (Ord.).

Lingula briseis Billings, Pal. Fossils, I, 1862, 1. 48, fig. 52;-Geol. Canada, 1863, p. 161, fig. 136.

Loc. Bayonne River, Canada.

Lingula (??) calumet N. H. Winchell.

? Cambrian.

Lingula calnmet N. H. Winchell, Thirteenth Ann. Rep. Geol. Nat. Hist. Survey

Minnesota, 1885, 1. 65.-Miller, N. American Geol. Pal., 1889, p. 349.

Loc. l'ipestone, Miunesota.

Obs. It is not certain that these specimens are organic. 
Lingula(?) canadaensis Billings.

Trenton and Lorraine (Ord.).

Lingula eanadensis Billings, Pal. Fossils, I, 1862, p. 114, fig. 95;-Geol. Canada, 1863, p. 210, fig. 209.-Hall and Clarke, Pal. New York, VIII, Pt. I, 1892, p. 27.-Winchell and Schuchert, Minnesota Geol. Survey, III, 1893, p. 35̃2, fig. 26. Loe. Anticosti; in the Galena at Mantorville and Hader, Mimnesota.

Lingula carbonaria Shumard.

Upper Carboniferous.

Lingula carbonaria Shumard, Trans. St. Louis Acad. Sci., I, 1858, p. 215.

Loc. Clarke County, Missouri.

Lingula centrilineata Hall.

Lower Hellerberg (Dev.).

Lingula centrilineata Hall, Pal. New York, III, 1859, p. 155, pl. 9, figs. 1, 2.Hall and Clarke, Pal. New York, VIII, Pt. I, 1892, p. 15.

Loc. Albany County, New York.

Lingula ceryx Hall.

Schoharie (Dev.).

Lingula ceryx Hall, Sixteenth Rep. New York State Cab. Nat. Hist., 1863, p. 19 ;-Pal. New York, IV, 1867, p. 5, pl. 2, fig. 1.

Loc. Clark esville, New York.

Lingula cincinnatiensis Hall and Whitfield.

Lorraine (Ord.).

Lingulella (Dignomia) eincinnatieusis 1 Hall and Whitfield, Pal. Ohio, II, 1875, p. 67, pl. 1, figs. 2,3 .

Lingulella cincinnatiensis Miller, American Pal. Foss., 1877, p. 115.

Loc. Cincinnati, Ohio.

Lingula clathrata Winchell and Schuchert.

Trenton (Ord.).

Lingula clathrata Winchell and Schuchert, Iinnesota Geol. Survey, III, 1893, p. 345 , pl. 29, fig. 42.

Loc. St. Paul, Minuesota.

tingula clintoni Vanuxem.

Clinton (Sil.).

Lingula oblouga Conrad (non Eichwald), Third Ann. Rep. Geol. Snrvey New York, 1839, 1. 65.-Hall, Geol. New York; Rej. Fourth Dist., 1813, p. 77, fig. 4 ;-Pal. New York, II, 1852, p. 54, pl. 20, fig. 1.-Rogers, Geol. Ponnsylvania, II, Pt. II, 1858, p. 823, fig. 629.

Lingula clintoni Vanuxem, Geol. New York; Rep. Third Dist., 1842, p. 79, fig. 4. Lingula suboblonga d'Orbigny, Prodrome Pal. Stratig., 1850, p. 34.

Loc. Cayuga County, New York; Pennsylvania; Hamilton, Ontario; Arisaig, Nova Scotia (Honeyman and Ami).

Lingula cobourgensis Billings.

Trenton (Ord.).

Lingula cobourgensis Billings, Pal. Fossils, I, 1862, p. 50, fig. 54;-Geol. Canala, 1863, p. 161, fig. 132.

Lingula cobourgensis? Winchell and Schnchert, Minnesota (ieol. Surver, III, 1893, p. 346, pl. 29, fig. 12.

Loc. Cobourg and Colingwood, Canada; ?Minneapolis, Minnesota; in the Utica at Ottawa, Canada (Ami).

Lingula coheni A. Ulrich.

Middle Devonian.

Liugula coheni A. Ulrich, N. Yahrb. f. Mineral., Beilageband, VIII, 189:2, p. 82, ll. 5, fig. 11.

Loc. Near Pulquina, Bolivia.

Lingula complanata Williams.

Hamilton-Ithaca (Dev.).

Lingula nuda Hall, Pal. New York, IV, 1867, pl. 2, fig. 4 (not figs. 5, 6).

Lingula complanata Williams, Proc. American Ass. Adv. Sci., XXX, 1882, p. 188; -

Bull. U. S. Geol. Survey, 3, 1884, pp. 14, 15, 20, 22.-Hall and Clarke, Pul.

New York, VIII, Pt. I, 1892, pl. 1, fig. 1\%.

Loc. Ithaca and Canandaigua Lake, New York. 
Lingula compta Hall and Clarke.

Hamilton (Dev.).

Lingulat compta Itall and Clarke, Pull. New York, V111, l’t. I, 1892, p. 171, pl. 1, fig. 16.

Loc. Canandaigna Lake, New York.

Lingula concentrica Vanuxem =Schizobolus concentricus.

Lingula concentrica Conrad.

? Corniferous (Dev.).

Lingula concentrica Conrad, Third Ann. Rep. Geol. Survey New York, 1839, p 64.

Loc. "Helderberg Mountains," New York.

(1)bs. Insufficiently defined to be recognized.

Lingula covingtonensis Hall and Whitfield.

Utica (Ord.).

Lingula covingtonensis Hall and Whitfield, Pal. Ohio, II, 1875, p. 67, pl. 1, fig.

1. - Hall and Clarke, Pal. New York, VIII, Pt. 1, 1892, p. 8.

Loc. Corington, Kentucky.

Lingula crassa Hall=Glossina crassa.

Lingula crawfordsvillensis Gurley.

Keokuk (L. Carb.).

Lingula craw fordsvillensis Gurley, New Carboniferous Foss., l, 1883, p. 2.-Mil-

ler, N. American Geol. Pal., 1889, 1. 350.

Loc. Crawfordsville, Iudiana.

Obs. Should be compared with L. varsaviensis.

Lingula cuneata Conrad.

Medina (Sil.).

Lingula enueata Conrad, Third Amn. Rep. Geol. Survey New York, 1839, pp. 63, 64.-Wall, Geol. New York; Rep. Fourth 1)ist., 1843, p. 48, fig. 5;-Pal. New York, II, 1852, p. 8, pl. 4, fig. 2.-Hall and Clarke, Pal. New York, VIII Pt. I, 1892, ]. 12, pl. 1, figs. 11, 12; pl. 4K, fig. 9 .

Lingulella enueata Miller, N. American Geol. Pal., 1889, p. 352.

Loc. Medina and Lockport, New York.

Lingula curta Conrad.

Trenton-Utica (Ord.).

Lingula curta Conrad, Jour. Acad. Nat. Sci. Philadelphia, V111, 1842, p. 266, pl. 15, fig. 12.-Hall, Pal. New York, l, 1847, p. 97, pl. 30, fig. 6.-Rogers, Geol. Pennsylvania, II, Pt. II, 1858, p. 818, fig. 604.-13illings, Geol. Canada, 1863, p. 161, fig. 138; p. 201, fig. 197.-Emerson, 'Geol. Frobischer Bay; Nonrse's Narr. Hall's Arctic Exped., App., JII, 1879, p. 578.

Loc. East Canada Creek and Midlleville, New York; Carlisle, etc., Pennsylvania; Montmorency Falls, Canada; Frobischer Bay.

Lingula cuyahoga Hall.

Chemung. Waverly (Dev.-L. Carb.).

Lingula cuyahoga Hall, Sixteenth Rep. New York State Cab. Nat. Hist., 1863, p. 24 ;-Pal. New York, IV, 1867, p. 15, pl. 1, fig. 5.-Herrick, Bull. Denison Univ., IV, 1888, p. 13 ;-Geol. Ohio, VII, 1895, pl. 22, fig. 9.

Lingula cuyahoga? Hall and Clarke, Pal. New York, VIII, Pt. I, 1892, pl. 1, fig. 18.

Loc. Akrou and Cuyahoga Falls, Ohio; Chemung group, Panama, New York.

Lingula cyane Billings=Glossina cyane.

Lingula daphue Billings=Glossina trentonensis.

Lingnla dawsoni Matthew =Lingulella dawsoni.

Lingula delia Hall.

Hamilton (Dev.).

Lingula deiia Hall, Sixteenth Rep. New York State Cab. Nat. 11 ist., 1863, p. 22;Pal. New York, IV, 1867, p. 12, pl. 2, fig. 9.-Hall and Clarke, Pal. New York,

VIII, Pt. I, 1892, p. 15, pl. 1, fig. 29.

Loc. Canandaigua Lake, Now York.

Lingula densa Hall.

Hamilton (Dev.).

Lingula densa Ifall, Sixteenth Rep. New York State Cab. Nat. Hist., 1863, p. 22; -

Pal. New York, IV, 1867, p. 11, pl. 2, tigs. 10, 11. 


\section{Lingula densa Mall-Continued.}

Lingula densa? Hall and Clarke, Pal. New York, VIII, Pt. I, 1892, p. 15, pl. 1, fig. 23.

Loc. Summit and Centerfield, New York.

Lingula desiderata Hall.

Corniferous (Dev.).

Lingula desiderata Hall, Sixteenth Rep. New York State Cab. Nat. Hist., 1863, p. 19 ;-Pal. New York, IV, 1867, p. 6, pl. 2, fig. 2.

Loc. Ontario County, New York.

Lingula(?) dolata Sardeson.

Calciferous (Ord.).

Lingula dolata Sardeson, Bull. Minnesota Acad. Nat. Sci., IV, 1896, pl. 6, fig. 12.

Loc. Stillwater, Minnesota.

Lingula dnbia d'Orbigny=Glossina clubia.

Lingula elderi Whitfield.

Trenton and Lorraine (Ord.).

Lingula elderi Whitfield, American Jour. Sci., 3d ser, XIX, June, 1880, p. 472, figs. 1, 2;-Geol. Wisconsin, IV, 1882, p. 345, pl. 27, figs. 1-5.-Hall and Clarke, Pal. New York, VIII, Pt. I, 1892, p.11, pl.1, figs.21, 22.-Winchell and Schuchert, Minnesota Geol. Survey, III, 1893, p. 339, pl. 29, figs. 1-1.

Lingula minnesotensis N. H. Winchell, Eighth Ann. Rep. Geol. Nat. Hist. Survey Minuesota, July, 1880, p. 61.

Loc. Rochester, Minneapolis, etc., Minnesota; Beloit, Wisconsin; Cincinnati, Ohio.

Lingula elegantula Shaler $=$ L. rectilateralis.

Lingula elliptica Hall (non Phillips)=L. subelliptica.

Lingula(?) elliptica Emmons.

Cambrian.

Lingula elliptica Emmons (nou Phillips, 1836), American Geology, Pt. II, 1855, 1. 112.

Loc. Augusta County, Virginia.

Obs. This species belongs to another genus. The specific name will therefore not conflict with that of Phillips.

Lingula elongata Hall.

Trenton (Orrl.).

Lingula elongata Hall, Pal. Now York, I, 1847, p. 97, pl. 30, fig.5.-Billings, Geol. Canada, 1863, p. 161, fig. 135.-Whiteaves, Pal, Foss., III, Pt. III, 1897, p. 165.

Loc. Lewis County, New York; Lake Winnipeg, Manitoba; Ottawa, Canada, in the Utica terrane (Ami).

Lingula ererensis Rathbun.

Middle Devonian.

Lingula ererensis Rathbuu, Proc. Boston Soc. Nat. Hist., XX, 1879, p. 16.

Loc. Erere, Province of Para, Brazil.

Lingula exilis Hall=Lingulodiscina exilis.

Lingula eva Billings.

Black River (Ord.).

Lingula eva Billings, Canadian Nat. Geol., VI, 1861, p. 150;-Geol. Canada, 1863, p. 111, fig. 73.-Winchell and Schuchert, Minnesota Geol. Survey, III, 1893, p. 341 , pl. 29 , figs. 5,6 .

Loc. Murray Bay, Canada; Fremont, Winona County, Minnesota.

Lingula forbesi Billings.

Lorraine (Ord.).

Lingula forbesi Billings, Pal. Fossils, I, 1862, p. 115, fig. 96.

Loc. Anticosti.

Lingula gannensis Herrick.

Waverly (L. Carb.).

Lingula gannensis Herrick, Bull. Denison Univ., IV, 1888, pp. 12, 17, pl. 3, tigs. 2, 3;-Geol. Ohio, VII, 1895, pl. 22, figs. 2, 3.

Loc. Gann, Knox County, Ohio. 
Lingula gibbosa Hall.

Niagara (Sil.).

Lingula gibbosa 1Iall, Description n. sp. Foss. Waldron, Indiana, 1879, p. 13 ;Eleventh Rep. State Geol. Indiana, 1882, p. 284, pl. 27, tig. 2;-Trans. Albany Institute, X, 1883, p. 69.

Loc. Waldron, Indiana.

Lingula gorbyi Miller.

Choutean (L. Carb.).

Lingula gorbyi Miller, Eighteenth Ann. Rep. Geol. Survey Indiana, 1894, ן. 309 , pI. 9, figs. 3,4 .

Loc. Serlalia, Missouri.

Lingula gracana Rathbun.

Middle Devonian.

Lingula gracana Rathbun, Bull. Buffalo Soc. Nat. Sci., I, 1874, p. 259, fig. 2.

Loc. Erere, Province of Para, Brazil.

Lingula halli White.

Burlington (L. Carb.).

Lingula halli White, Proc. Boston Soc. Nat. Hist., IX, 1862, p. 30.

Loc. Burlington, Iowa.

Lingula howleyi Matthew.

Lower Ordovician.

Lingula howleyi Matthew, Trans. Royal Soc. Canada, 2d ser., I, 1896, p. 259, pl. 1 , fig. 3.

Loc. Kelleys Island, Conception Bay, Newfoundland.

Obs. Appears to be a synonym for L. murrayi Billings.

Lingula hurlbuti N. H. Winchell = Glossina hurlbuti.

Lingula huronensis Billings.

Chazy (Ord.).

Lingula huronensis Billings, Canadian Nat. Geol., IV, 1859, p. 133, fig. 9;--Geol. Canada, 1863, p. 124, fig. 48.

Loc. St. Joseph Island, Lake Huron.

Lingula indianaensis Miller and Gurley.

Keokuk (L. Carb.).

Lingula indianensis Miller and Gurley, Bull. Illinois State Mus. Nat. Hist., 3, 1893, p. 69, pl. 7, fig. 1 .

Loc. Craw fordsville, Indiana.

Lingula ingens Spencer.

Niagara (Sil.).

Lingula ingens Spencer, Bull. Unir. State Missouri, 1881, p. 56;-Trans. St. Lonis Acarl. Sci., IV, 1886, p. 606, pl. 8, fig. 6.

Loc. Hamilton, Ontario.

Lingula insularis Billings.

Anticosti (Sil.).

Lingula insularis Billiugs, Catalogue Sil. Foss. Anticosti, 1866, p. 40.

Loc. Anticosti.

Lingula iole Billings.

Calciferous (Ord.).

Lingula iole Billings, Pal. Fossils, I, 1865, p. 215, fig. 199.

Loc. Near Portland Creek, Newfonndland.

Lingula iowaensis Owen.

Galena (Ord.).

Lingula iowensis Owen, Geol. Rep. Iowa, Wisconsin, and Illınois, 1844, p. 70, pl. 15, fig. 1.-Hall and Clarke, Pal. New York, VIII, Pt. I, 1892, p. 8, pl. 1,

fig. 14.-Winchell and Schuchert, Minnesota Geol. Survey, III, 1893, p. 349, pI. 29, figs. 19-22.--Whiteaves, Pal. Foss., III, Pt. III, 1897, P. 164.

Lingula quadrata? Owen (not Eich.), Geol. Rep. Wisconsin, Iowa, and Minnesota, 1851, pl. 2B, fig. 8. [See specimens in U. S. Nat. Mus., Cat. Invert. Foss., 17873.]

Lingula quadrata HaIl, Geol. Wisconsin, 1, 1862, p. 46, fig. 1, and p. 435.-Meek and Worthen, Geol. Survey Illinois, III, 1868, p. 305, pI. 2, fig. 4.

Lingulella iowensis Whitfield, Geol. Wisconsin, IV, 1882, p. 242, pl. 9, fig. 1.

Loc. Wisconsin; Iowa; Minnesota; Illinois; Lake Winnipeg, Manitoba. 
Lingula irene Billings=Lingulella irene.

Lingula iris Billings.

Lingula iris Billings, Pal. Fossils, I, 1865, p. 301, tig. 290.

Loc. Point Levis, Canada.

Lingula kingstonensis Billings.

Black River (Ord.).

Lingula kingstonensis Billings, Pal. Fossils, I, 1862, p. 48, fig. 51;-Geol. Canala, 1863 , p. 141, fig. 74 .

Loc. Loug Island, near Kingston, Canada.

Lingula lamellata Hall, 1852 (partim, non Hall, 1843)=L. treniola.

Lingula lamellata Hall.

Niagara (Sil.).

Lingula lamellata Hall, Geol. New York; Rep. Fourth Dist., 1843, p. 108, fig. 2;-Pal. New York, II, 1852, p. 249, pl. 53, figs. 1, 2 (non p. 55, pl. 20, fig. $4=$ L. teniola).-Hall and Clarke, Pal. New York, VIII, Pt. I, 1892, p. 16, pl. 1 , figs. 9,$10 ; \mathrm{pl} .4 \mathrm{~K}$, figs. $10-13$.

Loc. Lockport and Rochester, New York; Hamilton, Ontario.

Lingula leana Hall=Glossina leana.

Lingula ligea Hall.

Hamilton-Portage (Dev.).

Lingula ligea Hall, Thirteenth Rep. New York State Cab. Nat. Hist., 1860, p. 76 ;-Pal. New York, IV, 1867, p. 7, pl. 1, fig. 2.-Walcott, Mon. U. S. Geol. Survey, VIII, 1884, p. 107, pl. 2, tig. 2.-Clarke, Bull. I. S. Geol. Survey, 16, 1885, p. 62.

Lingula ligea var. Hall, Pal. New York, IV, 1867, p. 8, pl. 2, fig. 8.

Lingula ligea? Whitfield, Annals New York Acad. Sci., T, 1891, pp. 547, 573, pl. 11, 1igs. 3, 4;-Geol. Ohio, VII, 1895, p. 441, pl. 7, figs. 3, 4; p. 462.

Loc. Seneca Lake, Ithaca, etc., New York; Thedford, Ontario (Whiteaves); Delaware County, Ohio (Whitfield); Eureka district, Nevada.

Lingula ligea nevadaensis Walcott.

Lower Devonian.

Lingula ligea var, nevadensis Walcott, Mon. U. S. Geol. Survey, VIII, 1884, p. 107, pl. 2, fig. 3 .

Loc. Eureka distriet, Nevada.

Lingula lingulata Hall and Clarke.

Clintou (Sil.).

Lingula lingulata Hall and Clarke, Pal. New York, VIII, Pt. 1, 1892, p. 173, pl. $4 \mathrm{~K}$, fig. 5 .

Loc. Hamilton, Ontario.

Lingula lonensis Walcott.

Lower Devonian.

Lingula lonensis Walcott, Mon. U. S. Geol. Survey, VIII, 1४४4, p. 108, pl. 13, fig. 1.

Loc. Lone Mountain, Nevada.

Lingula lucretia Billings.

Gaspí No. 5 (Dev.).

Lingula lucretia Billings, Pal. Fossils, 1I, 1874, p. 14, fig. 3.

Loc. Cape Bon Ami, Gaspé.

Lingula lyelli Billings.

Chazy (Ord.).

Liugula lyelli Billings, Canadian Nat. Geol., IV, 1859, p. 348, fig. 1 ; 1. 431 ;-Geol. Canada, 1863, p. 124, fig. 49.

Loc. Alumette Island.

Lingula maida Hall.

Hamilton (Dev.).

Lingula maida Hall, Sixteenth Rep. New York State Cab. Nat. Hist., 1863, p. 20 ;-

Pal. New York, IV, 1867, p. 9, pl. 2, fig. 13.

Loc. Moseow, New York. 
Lingula manni Hall.

Corniferous (Dev.).

lingula manni Ilall, Nixteenth Rep. New York State Calb. Nat. Hist., 1863, p. 20 ;-Pal. Now York, IY, 1867, p. 6, pl. 2, fig.3.-Whitfield, Annals Now York Acad. Sci., V, 1891, 1. 546, pl. 11, figs. 1, 2;-Geol. Olıio, VII, 1895, 1. 441, pl. 7 , figs. $1,2$.

Loc. Delaware Conuty, Ohio.

Lingula mantelli Billings.

Calciferous (Ord.).

lingula mantelli Billings, Canadian Nat. Geol., IV, 1859, p. 34!, figs. 1e-1f;Geol. Canada, 1863, 1. 113, fig. 20.

Loe. St. Enstache, Canada.

Lingula (?) manticula Wlite.

Upjer Cambrian.

Liugula? nuanticula White, Wheeler's Expl. Survey west 100 Mericl., Prel. Rep., 1874, p. 9;-Ibidem, Final Rep., IV, 1875, p. 52, pl. 3, fig. 2.-Walcott, Mon. U. S. Geol. Survey, VIII, 1884, p. 13, pl. !, tig. 3; pl. 11, fig. 2.

Loc. Schell Creek Range, Nevada.

Lingula marginata d'Orbigny (non Phillips)=L, submarginata.

Lingula matthewi Hartt = Acrothele matthewi.

Lingula meeki Herrick.

Waverly (L. Carb.).

Lingula meeki Herrick, Bull. Denison Univ., IN, 1888, 1p. 13, 18, pl. 10, fig. 31 ;-Geol. Ohio, VII, 1895, pl. 22, figs. 7, 8.

Loc. Cuyahoga Valley, Ohio.

Lingula melie Hall.

Waverly (L. Carb.).

Lingula melie Hall, Sixteenth Rep. New York State Cab. Nat. Hist., 1863, 1. 24;-Pal. New York, IV, 1867, p. 14, pl. 1, tigs. 3, 4.-Meek, Pal. Ohio, II, 1875, 1. 276, pl, 14, fig. 3.-Herrick, Bull. Denison Univ., IV, 1888, p. 13.Hall and Clarke, Pal. New York, VIII, Pt. I, 1892, p. 12, fig. 9; pl. 1, fig. 32.-Herrick, Geol. Ohio, VII, 1895, pl. 20, fig. 1; pl. 22, fig. 10.

Loc. Chagrin Falls and Berea, Ohio.

Lingula membranacea Winchell.

Waverly (L. Carb.).

Lingula membranacea A. Wiuchell, Proc. Acad. Nat. Sci. Plilarlelphia, 1863, y. 3.-Herrick, Bull. Denisen Univ., IV, 1888, pp. 12, 17, pl. 3, fig. 4;-Geol. Ohio, VII, 1895, pl. 22, fig. 4.

Lingula (Lingulella?) membranacea Meok, Pal. Ohio, II, 1875, p. 275, pl. 14, fig. 4.

Loc. Burlington, Iowa; Harts Grove and Loudonville, Ohio; Shafers, Penusylvania.

Lingula metensis Terquem?

Lower Lias (Jurassic).

Lingula ef. metensis (Terquem) Möricke, Nenes Jahrbuch f. Mlinerı., Beilageband, IX, 1894, p. 58, pl. 5, fig. 10.

Loc. Sierra de la Ternera; Mine Amolaues, Chile.

Lingula minnesotensis N. H. Winchell=L. elderi.

Lingula minuta Meek.

Hamiltou (Dev.).

Lingula minuta Meek, Trans. Chicago Acad. Sci., I, 1868, p. 87, pl. 13, fig. 1.

Loc. Near Fort Resolution, Great Slave Lake, British America.

Lingula modesta E. O. Ulrich.

Trenton-Lorraine (Ord.).

Lingula modesta Ulrich, Amerieau Geologist, III, 1889, p. 382, fig. 4 on p. 378.-

Winchell and Schuchert, Mimuesota Geol. Survey, III, 1893, p. 344, pl. 29, fig. 41.

Lingula vanhorni Hall and Clarke (non Miller), Pal. New York, VIII, Pt. I, 1892, pl. 1 , fig. 4.

Loc. Covington and Frankfort, Kentucky; Lattners, Iowa; Granger and Wykofi;, Ninnesota. 
Lingula morsei (N. H. Winchell).

St. Peters (Ord.).

Lingulepis morsensis N. H. Winchell, Fourth Ann. Rep. Geol. Nat. Hist. Survey Minnesota, 1876, p. 4I, fig. 6.

Lingulepis morsii Miller, N. American Geol. Pal., 1889, p. 352.

Lingula morsii Hall and Clarke, Pal. New York, VIII, Pt. I, 1892, p. 62.- Sardeson, Bull. Minnesota Acad. Nat. Sci., IV, 1896, p. 77, pl. 4, figs. $2,3$.

Loc. Near Fountain, Minnesota.

Lingula mosia Hall.

Upper Cambrian.

Lingula mosia Hall, Sixteenth Rep. New York State Cab. Nat. Hist., 1863, p. 126, pl. 6, figs. 1-3;--Trans. Albany Institute, V, 1867, p. 102.-Sardeson, Bull. Minnesota Acad. Nat. Sci., 1V, 1896, p. 95.

Loc. Lagrange Monntain, Minnesota; Mazomanie, Wisconsin.

Lingula münsteri d'Orbigny.

Ordovician.

Lingula miinsterii d'Orbigny, Voyage dans l'Amérique Méridionale, Pal., 1812, p. 29 , pl. 2 , fig. 6 .

Lingula miinsteri A. Ulrich, N. Jahrb. f. Mineral., Beilageband, VIII, 1892, p. 7. Loc. Tacopaya, etc., Bolivia.

Lingula(?) murrayi Billings.

Upper Cambrian.

Lingula murrayi Billings, Canadian Nat. Geol., n. ser., VI, 1872, p. 467, fig. 3 ;-

Pal. Fossils, II, 1874, 1). 66, fig. 34 .

Loc. Bell Island, Conception Bay, Newfoundland.

Obs. See Lingu la howleyi.

Lingula mytiloides Sowerby.

Upper Carboniferous.

Lingula mytiloides Sowerby, Mineral Conchology, I, 1813, p. 55, tal). 19, figs. 1,

2.- Meek and Worthen, Geol. Survey Illinois, V, 1873, p. 572, pl. 25, fig. 2.

Loc. Illinois.

Lingula nitida Meek and Hayden.

Upper Cretaceous.

Lingula nitida lleek and Ilayden, Proc. Acad. Nat. Sci. Philadelphia, 1861, 1. 443.-Meek, Rep. U. S. Geol. Survey Terr., IX, 1876, p. 9, pl. 28, fig. 18.White, Eleventh Rep. U. S. Geol. Survey Terr., 1879, p. 205.-Whiteaves, Cont. Cauadian Pal., I, 1885, p. 29.

Loc. Mouth of Big Horn River, Nebraska; Sage Creek, Colorado; Near Irvine Station, Canadian Pacific Railroad, Canada.

Lingula norwoodi James=Lingulops norwoodi.

Lingula nuda Hall (partim)=L. complanata.

Lingula nuda Hall.

Hamilton (Dev.).

Lingula nuda Hall, Sixteenth Rep. New York State Cab. Nat. Hist., 1863, p. 22; -

Pal. New York, IV, 1867, p. 10, pl.2, fig8. 5, 6 (non fig. 4=L. complanata).

Loc. Canandaigua Lake, Now York.

Lingula nympha Billings.

Lingula nympha Billings, Pal. Fossils, I, 1865, p. 214, fig. 198.

Loc. Table Head, Newfoundland.

Lingula oblata Hall.

Clinton (Sil.).

Lingula oblata Hall, Geol. New York; Rep. Fonrth Dist., 1843, p. 77, fig. 8 on p. 76 ;-Pal. New York, II, 1852, p. 54, pl. 20, fig. 2.

Loc. Sodus and Wolcott, New York.

Lingula oblonga Conrad (non Eichwald) $=$ L. clintoni.

Lingula obtusa Hall.

Trenton-Utica (Ord.).

Lingula obtusa Hall, Pal. New York, I, 1817, p. 98, pl. 30, fig. 7.-Billings, Geol.

Canada, 1863, p. 16I, fig. 137.-Whiteares, Pal. Foss., III, Pt. III, 1897, p. 165.

Loc. Middleville, New York; Lake Winnipeg and Ottawa, Canada. 
Lingula paliformis Hall = Lingulella paliformis.

Lingula papillosa limmons.

Trenton (Orl.).

Lingula papillosa Emmons, American Geology, l't. II, 185i, 1. 202, fig. 64;Manual Geol., 1860, p. 99, fig. in text.

Loc. Unknown.

Lingula paracletus Hall and Clarke.

Waverly (L. Carb.).

Lingula paracletus 1 lall and Clarke, Pal. New York, VIII, Pt. I, 1892, pp. 10, 12, fig. $8 ;$ p. 172.

Loc. Chardon, Ohio.

Lingula parrishi Miller.

Upper Carboniferons.

Lingula parrishi Miller, Eighteenth Aun. Rep. Geol. Survey Indiana, 1894, p. 307 , pl. 8 , fig. 2 ; pl. 9, fig. 1 .

Loc. Kansas City, Missouri.

Lingula perlata Hall.

Lower Helderberg (Dev.).

Lingula perlata Hall, Pal. New York, III, 1859, p. 156, pl. 9, figs. 3-5.

Loc. Albany and Schoharie counties, New York.

Lingula perovata Hall=Glossina perovata .

Lingula perplexa Hall=L. subelliptica.

Lingula perryi Billings.

? Chazy (Ord.).

Lingula perryi Billings, Pal. Fossils, I, 1861, p. 20, fig. 23;-Geol. Vermont, II, 1861, p. 957, fig. 363;-Geol. Canada, 1863, p. 274, fig. 278.

Loc. Highgate Spring, Vermont.

Lingula philomela Billings.

Trenton and Lorraine (Ord.).

Lingula philomela Billings, Pal. Fossils, I, 1862, p. 49, fig. 53;-Geol. Canada, 1863, p. 161, tig. 133.-Hall and Clarke, Pal. New York, VIII, Pt. I, 1892, pl.1, fig. 8.-Winchell and Sehuchert, Minuesota Geol. Survey, III, 1893, p. 342, pl. 29, figs. 7,8 .

Loc. Montmorency Falls, Ottawa, etc., Canada; Florencerille, Iowa.

Lingula plagemanni Möricke.

Jnrassic.

Lingula plagemanni Möricke, Neues Jahrbuch f. Mineral., Beilagelaud, IX, 1894, p. 59 , pl. 5 , fig. 9.

Loc. Canales and Caracoles, Bolivia.

Lingula pinnaformis Hall = Liugulepis piuniformis.

Lingula polita Hall=Obolella polita.

Lingula jrima Hall =Lingulepis prima.

Lingula procteri Ulrich $=\mathrm{L}$. vauhorni.

Lingula progne Billings.

Trenton-Utica (Ord.).

Lingnla progne Billings, Pal. Fossils, I, 1862, p. 47, fig. 50;-Geol. Canada, 1863, p. 161, fig. 134; 1. 201, fig. 196.

Loc. Montreal, Collingwood, Ottawa, etc., Canada.

Lingula punctata Hall.

Hamilton and Ithaca (Dev.).

Lingula punctata Hall, Sixteenth Rep. New York State Cal. Nat. IIist., 1863, p. 21 ;-Pal. New York, IV, 1867, p. 10, pl. 1, fig. 6.-Hall and Clarke, Pal. New York, VIII, Pt. I, 1892, pp. 11, 17, pl. 1, figs. 26-28.

Loc. Canandaigua Lake and Summit, New York; Portage group at Ithaca (Williams).

Lingula quadrata, American anthor's $=\mathrm{L}$. rectilateralis and I. iowaensis. 
Lingula quebecensis Billings.

Upper Cambrian and Calciferous.

Lingnla quebecensis Billings, Pal. Fossils, I, 1862, p. 72, fig. 65; pp. 72, 216;Geol. Canada, 1863, p. 230, fig. 241.

Loc. Point Levis, Sillery, etc., Canada; Cow Head, Newfoundland.

Lingula rectilatera Hall.

Lower Helderberg (Dev.).

Lingula rectilatera Hall, Pal. New York, III, 18599, p. 15̌6, pl. 9, figs 6-8.

Loc. Albany and Schoharie counties, New York; Arisaig, Nova Scotia (Ami).

Lingula rectilateralis Emmons.

Trenton-Lorraine (Ord.).

Lingula rectilateralis Emmons, Geol. New York; Rep. Second Dist., 1812, p. 399 , fig. 6 .

Lingula rquadrata Hall (non Eichwald), Pal. New York, I, 1847, p. 96, pl. 30, fig. 4; p. 285, pl. 79, fig. 1.-Billings, Canadian Nat. Geol., I, 1856, p. 319, fig. 8.--Rogers, Geol. Penusylvania, II, Pt. II, 1858, p. 820, fiğ. 615.-Billings, Geol. Cauada, 1863, p. 161, fig. 131;-Catalogue Sil. Foss. Anticosti, 1866, p. 10.-Hall and Clarke, Pal. Now York, VIII, Pt. I, 1892, pl, 1, fig. 13.

Lingula elegantula Shaler, Bull. Mus. Comp. Zool., 4, 1865, p. 61.

?Lingula quadrata Viller, Cincinnati Quart. Jour Sci., II, 1875, p. 9.

Loc. Rodnan, Lorraine, Niddleville, Trenton Falls, etc., New York; Ottawa etc., Canada; Anticosti.

Obs. This species is more elosely related to L. iowaensis than to L. quadrata Eichwald.

Lingula riciniformis Hall.

Trenton (Ord.).

Lingula riciniformis Hall, Pal. New York, I, 1817, p. 95, pl. 30, fig. 2.-Winchell and Schnchert, Minnesota Geol. Survey, III, 1893, p. 343, fig. 24; pl. 29, fig 9.

Lingula (Glossina) riciniformis Hall and Clarke, Pal. New York, VIII, Pt. I, 1892, pl, 1, fig. 3.

Loc. Middleville, New York; Charlesbonrg, Canada; St. Panl, Minnesota.

Lingula riciniformis galenaensis Winchell and Schuchert. Trenton (Ord.).

Lingula riciniformis var. galenensis Winchell and Schuchert, American Grol., IX, 1892, p. 284 ;-Minnesota Geol. Survey, III, 1893, p. 344, pl. 29, figs. 10, 11.

Loc. Near Kenyon and Fonntain, Minnesota; Neenah and Oshkosh, Wisconsin.

Lingula rodriguezii Rathbun.

Middle Devonian.

Lingula rodriguezii Rathbun, Bull. Buffalo Soc. Nat. Sci., I, 1874, 1’. 260.

Loc. Erere, Province of Para, Brazil.

Lingula scotica Meek (non Davidson)=Glossina waverlyensis.

Lingula scotica var. nebraskensis Meck=Glossina nebraskensis.

Lingula scutella Hall and Clarke.

Chemung (Dev.).

Lingula scutella Hall and Clarke, Pal. New York, VIII, Pt. I, 1892, p. 171, pl. 1, fig. 30 .

Loc. Alleghany County, New York.

Lingula shumardi Cragin.

Lower Cretaceous.

Lingula shumardi Cragin, Geol. Survey Texas; Fourth Ann. Rep., 1893, p. 166.

Loc. Bonlam-Sherman road, Fannin County, Texas.

Lingula spathata Hall.

Lower Helderberg (Dev.).

Lingula spathata Hall, Pal. New York, III, 1859, p. 157, pl. 9, figs. 7, 9,11.

Loc. Albany and Schoharie counties, New York; Arisaig, Nova scotia (Ami).

Lingula spatiosa Hall=Glossina spatiosa.

Lingula spatulata Vanuxem.

Genesee and Portage (Dev.).

Lingula spatulata Vanuxem, Geol. New York; Rep. Third Dist., 1842, p. 168, fig. 3.- Hall, Ibidem, Rep. Fourth Dist., 1843, p. 223, fig. 3;-Pal. New York, IV, 1867, p. 13, pl. 1, fig. 1.-Clarke, Bull. U. S. Geol. Survey, 16, 1885, p. 25.- 


\section{Lingula spatulata Vamnem-Continued.}

Tsehernyschew, Mémoires dn Comité Géologiqne de St. Pétershourg, 1887, 1. 116, pl.14, fig. 29._Hall and Clarke, Pal. New York, VIII, Pt. I, Is!12, pl. 1, fig. 15 .

Lingula spatulata? Rathlun, Bull. Buffalo Soc. Nat. Sci., I, 1874, p. 258, lig. 1 ; Proc. Boston Soe. Nat. Hist., XX, 1879, p. 16.

Loc. Lodi, Seneca Lake, rete., New York; Portage group at Ithaca, Now York

(Williaus); Erere, Province of Para, Brazil; Urals of Russia.

Lingula stautoniana Rathbun.

Middle Devonian.

Lingula stantoniana Rathbun, Bull. Buffalo Soc. Nat. Sei., 1, 1874, 1. 259, fig. 3.

Loc. Erere, Province of Para, Brazil.

Lingula(?) striata Enmons.

Cambrian.

Lingula striata Emmons, American (ieology, l't. II, 185., p. 112, 11. 1, fig. 17;Manual Geol., 1860, p. 88, fig. 7 t.

Loc. Angusta County, Virginia.

Lingula subelliptica d'Orbigny.

Clintou (Sil.).

Lingula elliptica Hall (non Phillips), Gool. New York; Rep. Fonrth Dist., 1813, p. 76 , fig. 7 .

Lingula subelliptica d'Orbigny, Prodrome de I'al., 1, 1850, p. 34.

Lingula perplexa Hall, Miller's American Pal. Fossils, 1877, p. 244.

Loc. Wolcott, New York.

Lingula submarginata d'Orbigny.

Ordovician.

Lingula marginata d'Orbigny, Voyage dans l’Anúriłue Meriıliouale, P’al., 1842, p. 28 , pl. 2 , fig. 5 .

Lingula snbmarginata d'Orbigny, Prodrone de Pal., I, 1850, p. 11.

Loc. 'Tacopaya, Bolivia.

Lingula suboblonga d'Orbigny $=\mathrm{L}$. clintoni.

Lingula subspatulata Meek and Worthen (non Hall and Meek)=Barroisella subspatulata.

Lingula subspatulata Hall aud Meek.

Upper Cretaceons.

Lingula subspatnlata Iall and Meek, Mem. American Acar. Arts Science, n. ser., Y, 1854-1856, 1. 380, pl. 1, fig. 2.-White, Rep. Gengr. Geol. Survey west 100th Merid., IV, 1875, p. 169, pl. 15, fig. 4.

Lingula subspatulata? Whiteaves, Cont. Canalian Pal., I, 1889, p. 185.

Loc. Near Red Cedar Island, Nebraska; near old Fort Wingate, Now Mexico; Rollingr River, Manitoba.

Lingula tæniola Hall and Clarke.

Clinton (Sil.).

Lingula lamellata Hall (partim), Pal. New York, II, 1852, p. 55, pl. 20, fig. t.

Lingula teniola Hall and Clarke, Ibiclem, VIII, Pt. I, 1892, pp. 18, 173, pl. 4K, fig. 8 .

Loc. Clinton, New York; Hamilton, Ontario.

Lingula thedfordensis Whiteaves.

Hamilton (Dev.).

Lingula thedfordensis Whiteaves, Extract Cont. Canadian Pal., I, 1887, 1. 3, pl. 15, fig. 1 ;-Cont. Canadiau Pal., 1, 1889, p. 111, pl. 15, fig. 1.

Loc. Thedford, Ontario.

Lingula tighti Herrick.

Upper Carboniferous.

Lingula tighti Herrick, Bull. Denison Unir., II, I887, p. 43, pl.4, fig. 5.

Loc. Newark, Ohio.

Lingula trentoneusis Conrad=Glossina trentonensis.

Lingula triangulata Nettelroth $=$ Glossina triangulata. 
Lingula triquetra Clarke.

Portage (Dev.).

Lingula triquetra Clarke, Bull. U. S. Geol. Survey, 16, 1885, p. 62, pl. 3, fig. 11.

Loc. Ontario County, New York.

Lingula truncata Sowerby.

Neocomian (Cret.).

Lingula truncata Sowerby, Trans. Geol. Soc. London, IV, 1836, pl. 14, fig. 15.-

Davidson, British Cret. Brach., Pal. Soc., 1852, p. 6, pl. 1, figs. 27, 28, 31.-

Behrendsen, Zeit. der Deutschen Geol. Gessel., XLIV, 1892, p. 27.

Loc. Europe; Arrogo, Triugnico, Argentine Republic.

Lingula umbonata Cox.

Upper Carboniferous.

Lingula unbonata Cox, Owen's Geol. Survey Kentucky, III, 1857, p. 576, pl. 10, fig. 4.-Wlite, Thirteenth Rep. State Geol. Indiana, 1884, p. 120, pl. 25, fig. 14.-Herrick, Bull. Denison Univ., II, 1887, p. 144, pl. 14, fig. 2.-Keyes, Proc. Acad. Nat. Sci. Philadelphia, 1888, p. 226;-Geol. Survey Missouri, V, 1895 , p. 38 , pl. 35 , fig. 4 .

Loc. Crittenden, Union, and Hancock counties, Kentucky; Newark, Ohio; Des Moines, Iowa; Clinton and liansas City, Missouri.

Lingula vanhorni Hall and Clarke (partim) =L. modesta.

Lingula vanhorni Miller.

Trenton and Lorraine (()rll.).

Lingula vanhorni Miller, Cincinuati Quart. Jour. Sci., II, 1875, p. 9, fig. 1;Eighteenth Rep. Geol. Survey Indiana, 1894, p. 309.

Lingula procteri Ulrich, American Geologist, III, 1889, 1. 377, tig. 1.-Hall and Clarke, Pal. New York, VIII, Pt. I, 1892, p. 12, pl. 1, figs. 5- 7 .

Loc. Versailles, Indiana; Covington and Burgin, Kentucky.

Obs. An examination of the type specimen led to the above synouymy.

Lingula varsaviensis Worthen.

Warsaw (L. Carb.).

Lingula rarsoviense Worthen, Bull. Illinois State Mus. Nat. Hist., 2, 1884, p. 24;-Geol. Survey Illinois, VIII, 1890, p. 104, pl. 11, tig. 8.

Loc. Warsaw and Hamilton, Illinois.

Lingula waverlyensis Herrick=Glossina waverlyensis.

Lingula whitfieldi Ulrich.

Lorraine (Ord.).

Lingula whitfieldi Ulrich, American feologist, III, 1889, p. 381, fig. 3 on 1. 378.

Loc. Covington, Kentucky.

Lingula whitei Waleott.

Lower Devonian.

Lingula whitii Walcott, Mnn. U. S. Geol. Survey, VIII, 1884, p. 109, pl. 13, fig. 3.Hall aud Clarke, Pal. New York, VII1, Pt. I, 1892, p. 11, 11. 1, fig. 31.

Loc. Eureka district, Nevada.

Lingula winona Hall=Lingulella winona.

LINGULASMA E. O. Ulrich.

Genotype L. sehucherti Ulrich.

Lingulasma Ulrich, American Geologist, III, 1889. p. 383.-Hall and Clarke, Pal.

New York, VIII, Pt. I, 1892, p1. 21, 46, 163.-Winchell and Sehuchert, Minnesota Geol. Survey, III, 1893, p. 353.- Hall and Clarke, Eleventh Ann. Rep. New York State Geologist, 1894, p. 33j.

Lingulelasma Miller, N. American Geol. Pal., 1889, p. 351.

\section{Lingulasma galenaense Winchell and Schuchert.}

Galena (Ord.).

Lingulasma galenensis Winchell and Schuchert, American Geol.. IX, 1892, p. 285 ;-Minnesota Geol. Survey, III, 1893, 1. 354, 1, l. 30, figs. 1-4.

Loc. Fillmore and Goodhue counties, Miunesota; Decorah, Iowa; Neenah and Oshkosh, Wiseonsin. 
Lingulasma schucherti Ulrich.

Lorraine (Ord.).

Lingulasma schncherti Ulrich, Ameriean Geologist, III, 1889, p. 389, fig. 5 on p. 378.- IIall and Clarke, P'al. Now York, VIII, Pt. I, 1892, p. 24, pl. 2, figs. [7-23.

Lingulelasma schucherti Miller, N. American Ceol. Pal., 1889, p. 351.

Loc. Wilmiugton and Savannal, Illinois.

LINGULELLA Salter.

Genotype Lingula davisi MeCoy.

Lingulella Salter, Men. Geol. Survey Great Britain, III, 1866, p. 333.-Hall and Clarko, Pal. Now York, VIII, Pt. I, 1892, 11). 55, 163;-Eleventh Aun. Rep. New York State Geologist, 1894, p. 232.

Lingulella affinis Billings $=$ Lingulobolus affinis.

Lingulella ampla (Owen).

Middle Cambrian.

Lingula ampla Owen, Geol. Rep. Wisconsin, Iowa, and Miunesota, 1852, p. 583, pl. 1B, fig. 5.-Hall, Sixteenth Rep. New York State Cab. Nat. Hist., 1863, p. 125 , pl. 6, fig. 10 ;-Trans. Albany Institute, V, 1867, p. 101.

Loc. Trempealean, Wisconsin; Winona, Minnesota.

Lingulella aurora Hall.

Upper Cambrian.

Lingula aurora Hall, Ann. Geol. Rep. Wisconsin, 1861, p. 24 ;-Geol. Surv. Wisconsin, I, 1862, p. 21, fig. 4 ; p. 435 ; - Sixteenth Rep. New York State Cab. Nat. Hist., 1863, p. 126, pl. 6, figs. 4, 5;-Trans. Albany Institute, V, 1867, P. 103.

Lingulella aurora Hall, Twenty-third Rep. New York State Cab. Nat. Hist., 1873, p. 244.-Hall and Clarke, Pal. New York, VIII, Pt. I, 1892, pl. 2, figs. $12,13$.

Loc. Mazomanie, Wisconsin; Osceola, Wisconsin, and Otisville, Minnesota (Sardeson).

Lingulella(?) billingsana (Whiteaves).

Upper Cambrian.

Lingula billingsana Whiteaves, American Jour. Sci., 3d ser., XVI, 1878, p. 226.

Lingula efr. billingsiana Matthew, Trans. Royal Soc. Canada, X, 1894, p. 93, pla 16, fig. 6.

Loc. Conception Bay, Newfoundland.

Lingulella cælata (Hall).

Lower Cambrian.

Orbicula cxlata Hall, Pal. New York, I, 1847, p. 290, pl. 79, tig. 9.

Obolella crelata Billings, Canadian Nat. Geol., 2 d ser., VI, 1871, p. 218.

Obolella (Obolus) celata Ford, American Jour. Sci., 3d ser., II, 1871, p. 33.

Lingulella cielata Ford, Ibillem, XV, 1878, p. 127.-Walcott, Bull. U. S. Geol. Survey, 30, 1886, p. 95, pl. 7, fig. 1;-Tentl Ann. Rep. U. S. Geol. Surrer, 1891, p. 607, pl. 67, fig. 1.-Hall and Clarke, Pal. New York, VIII, Pt. I, 1892, p. 57 , pl. 2 , figs. $1-4$.

Lingula ? cielata Matthew, Trans. New York Acad. Sci., XIV, 1895, p. 126.

Loc. Troy and Schodack Landing, New York; New Brunswick.

Lingulella cincinnatiensis Hall and Whitfield = Lingula cincinnatiensis.

Lingulella(?) cuneata Matthew.

Lowest Ordovician.

Lingulella(?) cuneata Matthew, Trans. Royal Soc. Canada, X, 1894, p 92, pl. 16, fig. 5.

Loe. Harlingville, New Brunswick.

Lingulella dawsoni Matthew.

Midlle Cambrian.

Lingula? dawsoni (Matthew MS.) Walcott, Bull. U. S. Geol. Survey, 10, 1884, p. $15, \mathrm{pl} .5$, fig. 8 .

Lingulella dawsoni Matthew, Trans. Royal Soc. Canada, III, 1886, p. 33, pl. 5, ficr. 9.-IFall and Clarke, l'al. New York, VIII, Pt. I, 1892, p. 58, pl. 2, fig. 5.

Loc. Portland, etc., New Brunswick. 
Lingulella ella (Hall and Whitfield). Lower and Middle Cambrian.

Lingulepis ella Hall and Whitfield, King's U. S. Geol. Expl. 40th Parl., IV, 1877 , p. 232, pl. 1, fig. 8 .

Lingulella ella Walcott, Bull. U. S. Geol. Survey, 30, 1886, p. 97, pl. 7, fig. 2 ; pl. 8, fig. 4;-Tenth Ann. Rep. U. S. Geol. Survey, 1891, p. 607, pl. 67, fig. 2.Hall and Clarke, Pal. New York, VIII, Pt. I, 1892, p. 58, figs, 19-21.

Loc. Wasatch Range, Utah; near Pioche, Nevada.

Lingulella granvillensis Walcott.

Lower Cambrian.

Lingulella grauvillensis Walcott, American Jour. Sci., 3d ser., XXXIV, 1887, p. 188, pl. 1, fig, 15;-Tenth Aun. Rep. U. S. Geol. Survey, 1891, p. 607, pl. 67, tig. 4.-Hall and Clarke, Pal. New York, VIII, Pt. I, 1892, p. 58.

Lingulella efr. granvillensis Matthew, Trans. New York Acad. Sci., XIV, 1895, p. 114.

Loc. North Granville, New York; ? New Bruuswick.

Lingulella(?) inflata Matthew.

Middle Cambrian.

Lingulella? intlata Matthew, Trans. Royal Soc. Canada, III, 1886, p. 33, pl. 5, fig. 7;-Trans. New York Acad. Sci., XIV, 1895, p. 127, pl. 5, fig. 3.

Loc. Hanford Brook, St. Martins, New Brunswick.

Lingulella inflata ovalis Matthew.

? Middle Cambrian.

Lingulella inflata var. ovalis Matthew, Trans. New York Acad. Sci., XIV, 1895, p. 127 , pl. 5 , fig. 4 .

Loc. Hanford Brook, New Brunswick.

Lingulella irene (Billings).

Upper Cambrian and Calciferous.

Lingula irene Billings, Pal. Fossils, I, 1862, p. 71, fig. 64;-Geol. Canada, 1863, p. 230, fig. 240 .

Loc. Point Levis, Canada.

Lingulella lævis Matthew.

Upper Cambrialı.

Lingulella lævis Matthew, Trans. Royal Soc. Canada, IX, 1892, p. 39, pl.12, figs. $4 \mathrm{a}, 4 \mathrm{~b}$.

Loc. Near St. John, New Brunswick.

Lingulella lamborni Meek.

?Upper Cambrian.

Lingulella lamborni Meek, Proc. Acad. Nat. Sci. Philadelphia, 1871, p. 185, fiy. 1.-Keyes, Geol. Survey Missonri, V, 1895, p. 38, pl. 35, fig. 5 .

Loc. Madison County, Missouri.

Lingulella linguloides Matthew.

Middle Cambrian.

Lingulella linguloides Mattherw, Trans. Royal Soc. Canada, III, 1886, p. 34, pl.5, fig. 8 .

Loc. Porters Brook, St. Martins, New Brunswick.

Lingulella macconelli Walcott.

Middle Cambrian.

Lingulella macconelli Walcott, Proc. U. S. Nat. Musenm, XI, 1888, p. 441.

Loc. Mt. Stephens, British Columbia.

Iingulella martinensis Matthew.

Middle Cambrian.

Lingulella martinensis Matthew, Trans. Royal Soc. Canada, IV, 1890, p. 155, pl.

8, fig. 4 ;-Trans. New York Acad. Sci., XIV, 1895, p. 113, pl. 2, fig. 6.

Loc. Hanford Brook, New Brunswick.

Lingulella minuta Hall and Whitfield. Up. Camb. and Pogonip (Ord.).

Lingulella? minuta Ha'l and Whitfield, King's U. S. Geol. Expl. 40th Parl., IV, 1877, p. 206, pl. 1, tigs. 3, 4.-Walcott, Mon. U. S. Geol. Survey, VIII, 1884, p. 13.

Loc. Eureka district, Nevada.

Bull. $87-17$ 
Lingulella(?) paliformis Halll.

Hamilton (1)er.).

lingula paliformis Hall, Thinteenth Rep. New York State Cab. Nat. Hist., 1N60, 1. 76 , fig. 1.

Lingula pala formis IIall, Pal. New York, $1 \mathrm{~V}, 1867$, p. 8, pl. 1, fig. 7.-Whitfield, Geol. Wisconsin, IV, 1882, 1. 324, pl. 25, fig. 10.

Lingulella? palaformis Hall aud Clarke, Pal. New York, VIII, Jt. I, 1892, pl). 59,61 , pl. 2, figs. $6-8$.

Loc. Cayura Lake, New York; Milwankee, Wisconsin.

Lingulella radula Matthew.

Middle Cambrian.

Lingulella radula Matthew, Trans. Royal Soc. Canada, VIII, 1891, p. 147, 11. 15, figs. 7,8 .

Loc. St. John, New Brunswick.

Lingulella roberti Matthew.

Lower Ordovician.

Lingulella roberti Matthew, Trans. Royal Soc. Canada, 2d ser., I, 1896, p. 256, pl. 1, fig. 2.

Loc. Cape Breton, Nova Scotia.

Lingulella selwyni Matthew.

Lower Ordovician.

Lingulella selwyni Matthew, Trans. Royal Soc. Canada, 2d ser., I, 1896, p. 255, pl. 1, fig. 1.

Loc. Cape Breton, Nova Scotia.

Lingulella? spissa = Sphrerobolus spissus.

Lingulella starri Matthew.

Middle Cambrian.

Lingulella starri Matthew, Trans. Royal Soc. Canada, VIII, 1891, p. 146, pl. 15, figs. 5,6 .

Loc. St. Johns, New Brunswick.

Lingulella starri minor Matthew.

Upper Cambrian.

Lingulella starri var. minor Matthew, Trans. Royal Soe. Canada, IX, 1892, 1. 58.

Loc. Near St. John, New Brinnswick.

Lingulella stoneana Whitfield.

Upper Cambrian.

Lingula aurora var. Hall, Sixteenth Rep. New York State Cab. Nat. Hist., 1863, p. 127, pl. 6, figs. 6-8;-Trans. Albany Institute, V, 1867, p. 104;-Twentythird Rep. New York State Cab. Nat. Hist., 1873, pl. 13, fig. 5.

Hingulella stoneana Whitfield, Geol. Wisconsin, IV, 1882, p. 334, pl. 27, figs. 6, 7.-Hall and Clarke, Pal. New York, VIII, Pt. I, 1892, pl. 2, figs. 9-11.

Loc. Prairie du Sac and Mazomanie, Wisconsin.

Lingulella winona (Hall).

Middle Cambrian.

Lingula winona Hall, Sixteenth Rep. New York State Cab. Nat. Hist., 1863, p. 126, pl. 6, fig. 9;-Trans. Albany Institute, V, 1867, p. 102.-Sardeson, Bull. Minnesota Acad. Nat. Sci., IV, 1896, p. 96.

Loc. Lansing, Iowa; Wisconsin.

LINGULEPIS Hall.

Genotype Lingula pinniformis Oren.

Lingulepis Hall, Sixteenth Rep. New York State Cab. Nat. Hist., 1863, p. 129.Meek and Hayden, Pal. Upper Missouri, Smithsonian Cout. to Knowl., XlV, 172, 1861, p.1.-Hall, Trans. Albany Institute, V, 1867, p. 106.-Hall and Clarke, Pal. New York, VIII, Pt. I, 1892, pp. 59, 163;-Eleventh Ann..Rep. New York State Geologist, 1894, p. 231.

Obs. The essential difference between Lingulepis and Lingulella is that the ventral beak of the former is often much attenuated. The amount of attenuation, however, is often a very ehangeable feature in specimens of a species from a locality. It is this variation and the want of large collections that has lead to the makıng of too many species of Lingulepis. 
Lingulepis acuminata (Conrad).

Upper Cambrian.

Lingula acnminata Conrad, Third. Aun. Rep. New York Geol. Survey, 1839, p. 64.-Hall, Pal. New York, I, 1847, p. 9, with fig.-Billings, Geol. Canarla, 1863, p. 102, fig. 8. -Matthew, Trans. Royal Soc. Canada, 2d ser., I, 1896, p. 257, pl. 2 , fig. 5 .

Lingula antiqua Emmons, Geol. Now York; Rej. Second Dist., 1842, p. 268, fig. 68.-Hall, Pal. New York, I, 1847, p. 3, pl. 1, tig. 3.-Emmons, Amerieall Geolog 5 , Pt. II, 1855, p. 202, pl. 4, fig. 7.

Glossina acuninatal Hall and Clarke, Pal. New York, VIII, Pt. I, 1892, pl. 1, figs. 1,2 .

Loc. Saratoga and Franklin counties, etc., New York; Lansdowne, Bastarl, anıl Beverly, Canada.

Obs. The material of this species in the collection of the U. S. Geological Snrvey has specimens which are difficult to separate from L. pinniformis and L. dakotensis, and there is every gradation between these and L. acuminata. See L. pinniformis.

Lingulepis acutangulus (Roemer).

Upper Cambrian.

Lingula acutangula Roemer, Texas, 1849, p. 420;-Kreidebildung Texals, 1852, p. 90 , pl. 11, fig. 10.

Loc. Burnett and Llano counties, Texas.

Lingulepis aftinis = Lingulobolus affinis.

Lingulepis cuneolus Whitfield.

Upper Cambrian.

Lingulepis cuneolus Whitfield, Powell's Geol. Geogr. Surrey Rocky Mountain Region, Prel. Rep., 1877, p. 8;-Ibi^lem, Final Rep., 1880, 1. 336, 11. 2, figs, 5,6 .

Lingulepis perattenuatus Whitfield, Ibidem, Prel. Rep., 1877, p. 9;-Final Rep., 1880 , p. 337 , pl. 2, figs. $7-9$.

Loc. Red Canyon Creek, Black Hills, South Dakota.

Lingulepis dakotensis Meek and Hayden $=\mathrm{L}$. pinniformis.

Lingulepis ella Hall and Whitfield=Lingulella ella.

Lingulepis(?) mæra Hall and Whitfield. Up. Camb. and Pogonip (Ord.).

Lingulepis mæra Hall and Whitfield, King's U. S. Geol. Expl.40th P'arl., IV , 187T, p. 206, pl. 1, figs. 5-7.-Walcott, MIon. U. S. Geol. Survey, V'III, 1884, p. 12. Lingulepis? mæra Hall and Clarke, Pal. New York, VIII, Pt. I, 1892, p. 61.

Loc. Secret Canyon, Ruby Hill, and Eureka distriet, Nevada.

Lingulepis matinalis Hall.

Upper Cambrian.

Lingulepis pinnaformis Hall, Sixteenth Rep. New York State Cab. Nat. Hist., 1863, p. 130 ;-Ibidem, 1863, p. 130, pl. 6, figs. 12, 13.

Obs. A distinct species occurring in numbers in a blue shale just above the trap at St. Croix Falls, Wisconsin.

Lingulepis minima Whitfield $=\mathrm{L}$. prima.

Lingulepis minuta Hall and Whitfield=Obolella whitieldi.

Lingulepis morsensis N. H. Winchell=Lingula morsei.

Lingulepis perattenuata Whitfield $=\mathrm{L}$. cuneolus.

Lingulepis pinniformis (Owen).

Upper Cambrian.

Lingula antiqua and prima (non Emmons, Hall, 1847) Foster and Whitney, Geol.

Rep. Lake Superior Dist., II, 1851, p. 204, pl. 23, figs. 1, 2.-Hall, Geol. Wisconsin, I, 1862, p. 21, fig. 3.-Hayden, American Jour. Sci., 2d ser., XXXIII, 1863 , p. 73.

Lingula pinnaformis Owen, Geol. Survey Wiscousin, Iowa, Minnesota, 1852, p. 583, pl. 1B, figs. 4, 6, 8.-Hall, Geol. Wisconsin, I, 1862, pp. 21, 435, fig. 3. 


\section{Lingulepis pinniformis (Owen)-Continued.}

Orbicula prima Owen, Geol. Survey Wisconsin, Iowa, Minnesota, 1852, figs. 17, 1!). Lingrulepis pinnaformis Hall, Sixteenth Rep. New York State Cab. Nat. Hist., 1863, 1. 129, pl. 6, figs. 14-16;-Trans. Albany Institute, V, 1867, p. 107.Whitfield, Powell's Geol. Geogr. Survey Rucky Mountain Region, 1880, 1\%. 335, pl. 2, figs. 1-1;-Geol. Wisconsin, IV, 1882, p. 169, pl. 1, figs. 2, 3.

Lingulep is pinniformis and dakotensis Meek and Iayden, Pal. Upjer Missomri, Smithsonian Cont. to Knowl., XIV, 172, 1864, pp. 2, 3, pl. 1, fig. 1.

Lingnlepis dakotensis Whittield, Powell's Geol. Googr. Survey Rocky Mountain Region, 1880, p. 337, pl. 2, figs. 10, 11.

Lingulepis pinniformis Hall and Clarke, Pal. New York, VIII, Pt. I, 1892, p. 60, figs. 22,$23 ;$ pl. 1 , figs. 35,36 .

Loc. Falls of St. Croix, Hudson, etc., Wisconsin; Black Hills, Sonth Dakota.

Obs. This speeies also occurs at Ausable Chasm and Whitehall, New York, and are there regarded as $L$, aeuminata. It may be advisable to refer Owen's species to L. acuminata (Conrad).

Lingulepis prima Meek and Hayden=Obolella polita.

Lingulepis prima (Hall).

Upper Cambrian.

Lingula orata Emmons, Geol. New York; Rep. Second Dist., 1842, p. 105 (undefined).

Lingula prima (Conrad MS.) Hall, Pal. New York, 1, 1847, p. 3, pl. 1, fig. 2.Emmons, Aweriean Geology, Pt. II, 1855, p. 202.

Obolella prima Whittield, Bull. Anerican Mus. Nat. Hist., I, 1884, p. 142, pl. 14, figs. $3-5$.

Lingulepris minima Whitfield, Thidem, 1884, p. 141, pl. 14, figs. 1, 2.

Lingnlella? prima Hall and Clarke, Pal. New York, VIII, Pt. I, 1892, p. 69.

Loc. Keeseville, Essex, etc., New York; ?Black Hills, Sonth Dakota.

Lingulepis primiformis Whitfield.

Upper Cambrian.

Lingulepis primeformis Whitfield, Ludlow's Rep. Reconn. Black Hills South Dakota, 1875 , p. 103, pl. 1, fig. 4.

Loc. Black Hills, South Dakota.

LINGULOBOLUS Matthew.

Genotype Lingulella(?) aftinis Billings.

Lingulobolus Matthew, Traus. Royal Soc. Camala, 2(L ser., I, 189i, 1. 260.

Lingulobolus affinis (Billings).

Lower Ordovician.

Lingulella? affinis Billings, Canadian Nat. Geol., n. ser., VI, 18i2, p. 468, fig. 4:-Pal. Fossils, II, 1874, p. 67, fig. 35.

Lingulepis affiuis Walcott, American Jour. Sci., 3d ser., XXXVII, 1889, p. 381.

Lingulobolus affinis Matthew, Trans. Royal Soc. Canada, 2d ser., 1., 1896, p. 261, pl. 1, fig. 4.

Loc. Bell Island, Newfoundland.

Lingulobolus affinis cuneata Matthew.

Lower Ordovician.

Lingulobolns affinis var. cuneata Matthew, Trans. Rojal Soc. Canada, 2d ser., I, 1896, p. 262, pl. 1, figs. 4e, 4 d.

Loc. Great Bell Island, Conception Bay, Newfoundland.

\section{LINGULODISCINA Whitfield.}

Genotype Lingula exilis Hall.

Lingulodiscina Whitfield, Bull. American Mus. Nat. Hist., III, 1890, p. 122, figs. 1-8.

CEhlertella Hall and Clarke, Pal. New York, VIII, Pt. I, 1890, plı. 133, 168;-Eleventh Ann. Rep. N. Y. State Geologist, 1894, p. 257.

Lingulodiscina(?) connata (Waleott).

Lower Carboniferous.

Discina eonuata Walcott, IIon. U. S. Geol. Survey, VIII, 1884, p. 214, pl. 7, lig. 3.

Loc. Eureka district, Nevada. 
Lingulodiscina exilis (Hall).

Marcellus (Dev.).

Lingula exilis IIall, Thirteenth Rep. N. Y. State Cal. Nat. Hist., 1860, p. 77, fig. 2 ;-Pal. New York, IV, 1867, 1. 7, pl. 1, figs. 8, 9.

Lingulodiscina exilis Whitfield, Bull. American Mus. Nat. Ilist., III, 1890, 1. 122, figs. 1-8.

Loc. Schoharie County, New York.

Lingulodiscina newberryi (Hall).

Waverly (L. Carb.).

Discina newberryi Hall, Sixteenth Rep. N. Y. State Cab. Nat. Hist., 1863, 1, 30;-Pal. New York, IV, 1867, p. 25, pl. 1, figs. 10, 11.

Discina (Orbiculoidea) newberryi Meek, Pal. Ohio, II, 1875, p. 277, pl. 14, fig. 1.

Discina newberryi Walcott, Mon. U. S. Geol. Surves, VIII, 1884, p. 213, p1. 18, fig. 3.-Keyes, Geol. Survey Missouri, V, 1895, p. 40.

Orbiculoidea newberryi Herrick, Bull. Denison Univ., IV, 1888, I'. 12;--íeol. Ohio, VII, 1895, pl. 22, figs. 11, 13.

CEhlertella newberryi Hall and Clarke, Pal. New York, VIII, I’t. I, 1892, 1). 132, pl. $4 \mathrm{~F}$, fig. 18.

Loc. Curahoga Falls, Akron, and Farmington, Ohio; Eureka district, Nerarla.

Obs. This species should be compared with Orbiculoidea(?) capax (White.)

Lingulodiscina pleurites (Meek).

Waverly (L. Carb.).

Discina (Orbiculoidea?) pleurites Meek, Pal. Ohio, II, 1875, p. 278, pl. 14, fig. 2.

Orbiculoidea pleurites Herrick, Bull. Denison Univ., IV, 1888, pl. 12, 19, 11. 3, fig. 5 ;-Geol. Ohio, VII, 1895, pl. 22, fig. 12.

Ehlertella pleurites Hall and Clarke, Pal. New York, VIII, Pt. I, 1892, 1. 132, pl. $4 \mathrm{E}$, figs. $21-24 ;$ pl. $4 \mathrm{~F}$, figs. $19,20$.

Loc. Nowark and Gann, Knox County, Ohio.

\section{LINGULOPS Hall.}

Genotype L. whitfieldi I Iall.

Lingulops Hall, Notes on some New or Imperfectly Known Forms anong the Brachiopoda, 1871, p. 2;-Ibidem, 1872, p. 2, pl. 13, figs. 1, 2;-Twenty-third Rep. N. Y. State Cab. Nat. Hist., 1873, p.214, pl.13, figs. 1, 2.-Davidson and King, Quart. Jour. Gool. Soc. London, XXX, 1874, p. 164.-Hall and Clarke, Pal. New York, VIII, Pt. 1, 1892, pp. 18, 46, 163;-Eleventh Ann. Rep. N. Y. State Geologist, 1894, p. 233.

Lingulops granti Hall and Clarke.

Niagara (Sil.).

Lingulops granti Hall and Clarke, Pal. New York, VIII, Pt. I, 1892, p1. 19, 173, pl. 4 K, figs. 14, 15.

Loc. Hamilton, Ontario.

Lingulops norwoodi (James).

Utica (Oril.).

Lingula norwoodi James, Cincinnati Quart. Jour. Sei., II, 1875, p. 10, fig. 2; Jour. Cincinnati Soc. Nat. Hist., VI, 1883, 1. 235, pl. 10, fig. 1.

Lingulops norwoodi Hall and Clarke, Pal. New York, VIII, Pt. I, 1892, 1. 19, pl. 2, figs. 24-26.

Loc. Covington, Kentucky.

Lingulops whitfieldi Hall.

Maquoketa (Orl.).

Lingulops whitfieldi Hall, Notes on some Nen or Imperfectly Known Forms among the Brachiopoda, 1872, p. 2, pl. 13, fig. 12;-Twenty-thirl Rep. N. Y. State Cab. Nat. Hist., 1873, pl.13, figs. 1, 2.-Davidson and King, Quart. Jour. Geol. Soc. London, XXX, 1874, p. 161, pl. 19, fig. 9.-IIall and Clarke, Pal. New York, VIII, Pt. I, 1892, p. 19, pl. 2, figs. 27-30.

Loc. Near Lattners, Dubuque Connty, Iowa.

Linuarssonia Walcott, American Jour. Sci., 3d ser., XXIX, 1885, p. 115; XXX, p. 21.-Matthew: Trans. Royal Soc. Canada, III, 1886, 1. 35.-Hall atud 
LINNARSSONIA Waleott-Continued.

Clarko, l'al. New York, VIII, l't. I, 1892, p p. 107, 167 ;-Eleventh Ann. Rep. N. Y. State Grologist, 1894, p. 251.-Matthew, Trans. Royal Soc. Canada, IX, $1892,1.42$.

Linnarssonia belti Davirlson.

Upper Cambrian.

Linnarsonia belti \& Matthew, Trans. Royal Soc. Canada, IX, 1892, p. 42, pl. 12, figs. $7: 1-7 c$.

Loc. Near St. Johu, New Brunswick.

Linnarssonia misera (Billings).

Middle Cambrian.

Obolella? misera Billings, Cauadian Nat. Geol., n. ser., VI, 1872, p. 470.

Linnarsson ia misera Matthew, Trans. Royal Soc. Canada, III, 1886, p. 35, fig. 12.Hall and Clarke, Pal. New York, VIII, I't. I, 1892, p. 108, pl.8, figs. 35-37.

Loc. Trinity Bay, Newfoundland; St. Martins, Now Brunswick.

Linnarssonia pretiosa (Billings).

Upper Cambrian.

Obolella pretiosa lBillings, Pal. Fossils, I, 1862, p. 68, fig. 61;-Geol. Cauada, 1863, p. 230 , fig. 239.

Obolella? pretiosa Walcott, Inull. U. S. Geol. Survey, 30, 1886, p. 111.

Linuarssonia pretiosa Dawson, Trans. Royal Soc. Cunala, VII, 1889, p. 5., fig. 26.-IIall and Clarke, Pal. New York, VIII, Pt. I, 1892, p. 70, pl. 3, figs. $43,44$.

Loe. Bridge of the Grand Trunk Railroad across the Chandiere River; Cape Rouge; Little Metis; Sillers and Point Levis, Canada.

Linnarssonia sagittalis taconica Walcott. Lower and Middle Cambrian.

Linnarssonia taconica Waleott, American Jonr. Sci., 3d ser., XXXIV, 1887, 1’. 189, pl. 1, fig. 18.-Hall and Clarke, Pal. New York, VIII, Pt. I, 1892, p. 106.

Linnarssonia sagittalis Waleott, Proc. U. S. Nat. Mus., XI, 1888, p. 442.

Linnarssonia sagittalis var, taconica Waleott, Ameriean Jonr. Sci., 3 d ser. XXXYII, 1889, 1. 36;-Tenth Ann. Rep. U. S. Geol. Survey, 1891, p. 610, pl. 68 , fig. 1.

Loc. Washington Connty, New York; Monnt Stejlıan, British Columbia.

Linuarssonia taconica Walcott $=\mathrm{L}$. sagittalis taconica.

Linnarsonia transversa (Hartt).

Middle Cambrian.

Obolella transversa Hartt, Dawson, Acadian Geol., 2l ed., 1868, p. 644.-Walcott, Bull. U. S. Geol. Survey, 10, 1881, ]. 16, ㄲl. 1, fig. 5.

Linnarssonia transversa Walcott, American Jour. Sci., 3d ser., XXIX, 1885, p. 116, figs. 3, 4, 6.-Hatthew, Trans. Royal Soc. Canada, III, 1886, p. 35, pl. 5, fig. 11.-Hall and Clarke, Pal. New York, VIII, P't. 1, 1892, 1. 108, pl. 3, figs. 38-42.-Matthew, Trans. N. Y. Acad. Sci., XIV, 1895, p. 125, pl. 5, tigs. 1, 2. Loc. St. John, New Brunswick.

LISSOPLEURA Whitfield. Genotype Rhynchonella requivalvis Hall. Lissopleura Whitfield, Bull. Am. Mus. Nat. Ifist., VIII, 1896, p. 232.

Lissopleura æquivalvis (Hall).

Lower Helderberg (Dev.).

Rlyyuchonella equnivalvis Hall, Tenth Rep. N. Y. State Cab. Nat. Hist., 1857, p. 66 ;-Pal. New York, III, 1859, p. 224, p]. 29, pp. 2, 3.

Lissopleura aquivalvis Whitfield, Bull. Am. Mus. Nat. Hist., VIII, 1896, p. 232, figs, 1-5.

Loc. Helderberg Mountains, New York.

MARTINIA MeCoy.

Genotype Anomites glabra Martiı.

Martinia McCoy, Carboniferous Fossils Ireland, 1814, 1. 128, fig. 18; 1. 139, fig. 132.-King, Mon. Permian Fossils, Pal. Soc., 1850, pp. 81, 134.-Meek and Hayden, Pal. Upper Missouri, Smithsonian Cont. to Linowl., XIY, 172, 1861, p. 19.-Waagen, Palieontologica Indica, Ser. XIII, I, 1883, p. 528.-Herrick, Bull. Denison Univ., IV, 1888, p. 14.-Hall and Clarke, Pal. New York, VIII, Pt. II, 1893, pl. 9, 32, 40. 
Martinia athyroides A. Winchell.

Hamilton (Dev.).

Martinia athyroides A. Winchell, Rep. Lower Peninsula Michigan, 1866, p. 94.

Loc. Grand Traverse region, Michigan.

Martinia glabra (Martin).

Upper Carboniferous.

Anomites glabra Martin, Petrefacta Derbiensia, 1809, pl. 48, figs. 9, 10.

Spirifera glabra Davidson, Quart. Jour. Geol. Soc. London, XIX, 1863, p. 170, pl. 9, figs. 9, 10.-Dawson, Acadian Geology, 3d ed., 1878, p. 291, fig. 89.

Loc. Europe; Picton, Windsor, etc., Nova Scotia.

Martinia glabra contracta (Meek and Worthen). Kaskaskia (L. Carb.).

Spirifera glabra var. contracta Meek and Worthen, Proc. Acad. Nat. Sci. Philadelphia, 1861, p. 143;-Geol. Survey Illinois, II, 1866, p. 298, pl. 23, fig. 5.White, Wheeler's Expl. Survey west 100th Merid., IV, 1875, p. 136, pl. 10, fig. 2.

Spirifera (Martinia) contractus Whitfield, Anuals N. Y. Acad. Sci., V, 1891, p. 583 , pl. 13, figs. 17-19.

Spirifera (Martinia) contracta Whitfield, Geol. Ohio, VII, 1895, 1. 471, pl. 9), figs. $17-19$.

Loc. Chester, Illinois; Newtonville, Ohio; Lincoln County, Nevada.

Martinia glanscerasi (White).

Hamilton (Dev.).

Spirifera glanscerasi White, Proc. Bostou soc. Nat. Hist., IX, 1862, p. 24.

Loc. Iowa City, Iowa.

Martinia(?) insolita A. Winchell.

Huron (Dev.).

Spirifera? insolita A. Winchell, Proc. Acal. Nat. Sci. Philadelphia, 1862, p. 406.

Loc. Port aux Barques, Michigan.

Martinia lævigata (Swallow).

Keokuk (L. Carb.).

Spirifera lievigata Swallow, 'Trans. St. Lonis Acad. Sci., II, 1863, 1. 86.

Loc. Iowa and Missonri.

Obs. Regarded by Keyes as a synonym for Spirifer logani.

Martinia maia (Billings). Corniferous (Dev.).

Athyris maia Billings, Canadian Jonr. Sei., V, 1860, p. 276, figs. 33, 34;-Geol. Canada, 1863, p. 373, fig. 398.

Athyris? maia Nicholson, Pal. Prov. Ontario, 1874, p. 88.

Spirifera maia Hall, Pal. New York, IV, 1867, p. 116, pl. 63, figs. 6-13.-Davidson, Suppl. British Sil. Brach., Paleontographical Soc., 1882, p. 122.-Whitfield, Annals N. Y. Acad. Sci., V, 1891, p. 549, pl. 11, fig. 14.-Hall and Clarke, Pal. New York, VIII, Pt. II, 1895, pl. 38, figs. 5, 6.-Whitfiell, Geol. Ohio, VII, 1895 , p. 444, pl. 7 , fig. 14 .

Spirifera (Martinia) maia Walcott, Mon. U. S. Geol. Survey, VIII, 1884, p. 141, pl. 14, fig. 13 (?pl. 3, fig. 1).

Loc. St. Marys, Township of Blanchard, Ontario; Columbns and Delaware, Ohio; Eureka distriet, Nevala.

Martinia meristoides Meek.

Middle Devonian.

Spirifera (Martinia) meristoides Meek, Trans. Chicago Acad. Sci, I, 1868, p. 106, pl. 14, fig. 3.-Walcott, Mon. U. S. Geol. Survey, VIII, 1884, p. 142.Whiteaves, Cont. Canadian Pal., I, 1891, p. 226.

Loc. Mackenzie River Basin, British America.

Martinia planoconvexa Meek and Hayden=Ambocœlia planiconvexa.

Martinia sublineata Meek.

Middle Devonian.

Spirifera (Martinia) sublineata Meek, 'Trans. Chicago Acar. Sci., I, 1868, I'. 103, pl. 14, fig. 1.

Loc. Great Slave Lake, British America. 
Martinia subumbona (Hall).

Hamilton-Portage (Dev.).

Ortluis subumbona Hall, Tenth Rep. N. Y. State Cab. Nat. Hist., 1857, 1) 168.

Ambocolia subumbona Hall, Thirteenth Rep. Ibidem, 1860, 1. 71.

Spirifera subumbona IFall, Pal. New York, IV, 1867, p. 234, 1l. 33, figs. 22-30.

Martinia subumboua Millor, N. American Geol. Pal., 1889, 1. 352.

Spirifer subumbona Hall and Clarke, Pal, New York, VIII, Pt. II, 1895, pl. 29, fig. 14.

Loc. Slore of Lake Erie, Tully, and Mckinneys Station, New York.

Obs. Professor Williams says this species is a synonym for Ambocelia gregaria.

MEEKELLA White and St. J. Genotype Plicatula striatocostata Cox. Meekella White and St. John, Trans. Chicago Acad. Sci., I, 1868, p. 120, figs. 4-6.-

Meek, Final Rep. U. S. Geol. Survey Nebraska, 1872, p.175.-Waagen, Palseontologica Indica, Ser. XIII, I, 1884, p. 576.--Hall and Clarke, Pal. New York, VIII, Pt. I, 1892, p. 264 ;-Eleventh Am. Rep. N. Y. State Geologist, 1894, p. 287.

Meekella occidentalis (Newberry).

Upper Carboniferous. Streptorhynchus occidentalis Newberry, Ives's Rep. Colorallo River of the West, 1861, p. 126, pl. 1, fig. 5.

Meekella occidentalis Hall and Clarke, Pal. New York, VIII, Pt. I, 1892, 1. 266, pl. 11B, figs. 18, 19.

Loc. Canyon of Cascade River.

Obs. See Meekella pyramidalis.

Meekella(?) occidentalis (Swallow).

Upper Carboniferous.

Orthisina occidentalis Swallow, Trans. St. Louis Acad. Sei., II, 1863, p. 82.

Loc. Callwell County, Missouri.

Obs. If a Meekella it slould be compared with M. striaticostata. Regariled liy Keyes as a synonym for M. striaticostata.

Meekella pyramidalis (Newberry).

Upper Carboniferous.

Streptorhynchus pyramidalis Newberry, Ives's Rep. Colorado River of the West, 1861, p. 126, pl. 2, figs. 11-13.

Meekella pyramidalis Hall and Clarke, Pal. Now York, VIII, Pt. I, 1892, p. 266.

Loc. Colorado River.

Obs. This species is quite distinct from M. striatieostata Cox, with which it has been confounded. M. occidentalis Newberry, however, may prove to be but a large individual of M. pyramidalis.

Meekella striaticostata (Cox).

Upper Carboniferous.

Plicatula striatocostata Cox, Owen's Geol. Survey Kentucky, III, 1857, 1. 568, pl. 8 , fig. 7.

Orthisina shumardianus Swallow, Trans. St. Louis Acad. Sci., I, 1858, 1. 183.

Orthisina missouriensis Swallow, Ibidem, 1858, p. 219.-Meek and Hayden, Proc. Acad. Nat. Sci. Philadelphia, III, 1859, p. 26.

Orthisina shumardiana Meek and Hayden, Ihidem, 1859, p. 26.

Orthis striatocosta Geinitz, Carbon und Dyas in Nebraska, 1866, p. 48, pl. 3, figs. 22-24.

Meekella striatocostata White and St. Jolın, Trans. Chicago Acad. Sci., I, 1868, pp. 120, 122, figs. 4-6. -Meek, Fiual Rep. U. S. Geol. Survey Nebraska, 1872, p. 175, pl. 5, fig. 12.-Meek and Worthen, Geol. Survey Illinois, V, 1873, p. 571, pl. 26, fig. 21. - White, Wheeler's Expl. Survey west 1C0th Merid., IV, 1875, p. 26, pl. 9, fig. 4.-Kayser, Richthofen's China, IV, 1883, p. 178, pl. 23, fig. 8. - White, Thirteenth Rep. State Geol. Indiana, 1884, p. 130, pl. 26, figs. 12-14.-Hall and Clarke, Pal. New York, VII I, Pt. I, 1892, p. 265, pl. 10, figs. 18-23; pl. 1113, figs. 20-22.-Keyes, Geol. Survey Missouri, V, 1895, p. 68, pl. 39 , fig. 1 . 
Meekella striaticostata (Cox)-Continued.

Streptorhynchus (Meekella) striatocostata Hall, Second Ann. Rep. New York State Geol., 1883, pl. 40, figs. 18-23.

Loc. Hopkins County, Kentucky ; Indiana ; Illinois ; Missouri ; Iowa ; Nebraska; New Mexico; Nevada; Utah; ?China.

Obs. See M. occidentalis (Swallow).

MEGALANTERIS Chlert. Genotyje Terebratula archiaci de Verneuil. Moganteris Suess, Sitz. der k. k. Akad. der Wissensch. zu IVien, XVIII, 1855, p. 51. Megalanteris Ehlert, Fischer's Manuel de Conchyliologie, 1887, p. 1319.-Hall and Clarke, Pal. New York, VIII, Pt. II, 1893, p. 277 ; - Thirteenth Anu. Rep. N. I. State Geologist, 1895, p. 859.

Megalanteris condoni (MeChesney).

Oriskany (Dev.).

Rensseleria condoni McChesney, New Pal. Fossils, 1861, p. 85 ;-Trans. Chicago Acad. Sci., I, 1868, p. 36, pl. 7, fig. 2.-Meek and Worthen, Geol. Survey Illinois, III, 1868 , p. 401, pl. 8 , fig. 4.

Newberria? condoni Hall, Tenth Ann. Rep. N. Y. State Geol., 1891, 1. 7 of extract. Megalanteris condoni Hall and Clarke, Pal. New York, VIII, Pt. II, 1893, p. 280. Loc. West of Jonesboro, Union County, Illinois.

Megalanteris ovalis Ball.

Oriskany (Dev.).

Meganteris ovalis Hall, Tenth Rep. N. Y. State Cab. Nat. Hist., 1857, p. 101.

Rensselæria ovalis Hall, Pal. N. Y., III, 1859, p. 458, pl. 106, tig. 2.-Billings, Geol. Canada, 1863, p. 962, fig. 471.

Megalanteris ovalis Hall and Clarke, Pal. New York, VIII, Pt. 1I, 1893, 1. 280, pl. 77, figs. 12-22.

Loc. Albany and Schoharie counties, New York.

Meganteris æquiradiata Hall=Rensselæria æquiradiata.

Meganteris cumberlandia Hall = Rensselæria cumberlandie.

Meganteris elliptica Hall=Rensselwria elliptica.

Meganteris elongata $\mathrm{Hall}=$ Amphigenia elongata

Meganteris levis Hall=Meristella lievis.

Meganteris mutabilis Hall=Rensselieria mutabilis.

Meganteris ovalis Hall= Megalanteris ovalis.

Meganteris ovoides Hall=Rensselæria ovoides.

Meganteris subtrigonalis Hall=Amphigenia elongata subtrigonalis.

Meganteris suessana Hall=Beachia suessana.

Megerlia dubitanda Cooper =Terebratella(?) dubitanda.

MERISTA Suess.

Genotype Atrypa herculea Barrande.

Merista Suess, Jalırbnch Köngl. Kais. Geol. Reichs., I1, 1851, p1). 150, 160._-11all, Thirteenth Rep. N. Y. State Cab. Nat. Hist., 1860, p. 73;-Twentietlı Rep. N. Y. State Cab. Nat. Hist., 1867, p. 258.-Dall, Bull. U. S. Nat. Mus., 8, 1877, p. 47.-Hall and Clarke, Pal. New York, VIII, Pt. II, 1893, p. 70, fig. 54;Thirteenth Anu. Rep. N. Y. State Geologist, 1895, 1. 771.

Camarium Hall, Twelfth Rep. N. Y. State Cab. Nat. Hist., 1859, p. 42;-Pal. New York, III, 1859, p. 486;-Fifteenth Rep. N. Y. State Cab. Nat. Hist., 1862, p. 176 .

Merista areuata $\mathrm{Hall}=$ Meristella arcuata.

Merista bella Hall= Meristella bella.

Merista bisulcata Hall=Whitfieldella bisuleata.

Merista crassirostra Hall = Whitfieldella cylindriea.

Merista cylindrica Hall $=$ Whittieldella cylindrica. 
Merista elongata (Hall).

Lower Hellerberg (I)ev.).

Cimarium olongatum Ilall, Pal. New York, I11, 1859, p. 488, pl. 95A, lig. 4.

Loc. Cumberland, Marylaud.

Ohs. Probably only a variety of M. typa.

Merista loughtoni Winchell=Meristella houghtoni.

Merista lavis Hall = Meristella lavis.

Merista lata Hall=Meristella lata.

Merista lens Hall = Meristella lens.

Merista meeki Jall = Meristella meeki.

Merista princeps Hall = Meristella princeps.

Merista subquadrata Hall= Meristella subquadrata.

Merista tennesseensis Hall and Clarke. Lower Hellerberg (Dev.).

Merista temuesseensis Hall and Clarke, Pal. New York, VIII, Pt. II, 1895, pp. 71, 365 , pl. 42, figs. $1-6$.

Loc. Perry County, Tennessee.

Merista typus Hall.

Lower Helderberg (Dev.).

Camarium typum Hall, Pal. New York, 1II, 1859, p. 187, pl.95A, figs. 2a, 3, 5, 6.

Merista typum Hall, Thirteenth Rep. N. Y. State Cab. Nat. Hist., 1860, p. 93, figs. 10-13.

Merista typa Hall and Clarke, Pal. New York, VIII, Pt. II, 1895, pl. 42, figs. 7-12.

Loc. Cumberland, Maryland.

MERISTELLA IIall, 1860.

Genotype Merista arcuata Hall.

?.Meristella Hall, Twelfth Rep. N. Y. State Cab. Nat. Hist., 1859, p. 78.

Meristella Hall, Thirteenth Rep. Ibidem, 1860, pp. 74, 93 ;-Sixteenth Rep. Ibidem, 1863 , p. 50, figs. 27-34;-Trans. Albany Iustitute, IV, 1863, p. 139 ;-American Jour. Sci., 2d ser., XXXV 1863, p. 396; XXXV1, p. 11;-'T'wentieth Rep. N. Y. State Cab. Nat. Hist., 1867, pp. 155, 258;-Pal. New York, IV, 1867, p. 295.Nettelroth, Kétueky Fossil Shells, Mem. Kentucky Geol. Survey, 1889, p. 97.-Hall and Clarke, Pal. New York, VIII, l’t. II, 1893, p. 73, figs. 55, 56 ; Thirteenth Aun. Rep. N. Y. State Geologist, 1895, 1. 773.

Athyris Billings, Proc. Portland Soc. Nat. Hist., 1863, p. 115.

Meristella arcuata Hall.

Lower Helderberg (Dev.).

Merista arcuata Hall, Tenth Rep. N. Y. State Cab. Nat. Hist., 1857, p. 95, figs. 1-4;-Pal. New York, III, 1859, 1. 249, pl, 41, fig. I (?2).

Meristella arcuata Hall, Ibilem, IV, 1867, P. 298, figs. 1, 2.-Hall and Clarke, Ibidem, VIII, Pt. II, 1895, pl. 43, figs. 1, 2; pl 44, fig. 5.

Loc. Albany and Schoharie counties, New York; St. Blandine, New Brunswick.

Meristella barrisi Hall.

Marcellus-Hamilton (Dev.).

Meristella barrisi Hall, Thirteenth Rep. N. Y. State Cab. Nat. Hist,, 1860, p. 84;-Pal. New York, IV, 1867, p. 304, pl. 49, figs. 5-22.-? Tsehernyschew, Mémoires In Comité Géologique de St. Pétersbourg, fII, 3, 1887, 1. 55, pl. 9, figs. 12, 15; pl. 13, figs. 1, 2.-Hall and Clarke, Pal. New York, VIII, l't. II, 1895 , pl. 43 , figs. 25,26 ; pl. 44 , figs. $27-30$.

Loc. York and Leroy, New York; Urals of Russia.

Meristella bella (Hall).

Lower Helderberg (Dev.).

Merista bella Hall, Tenth Rep. N. Y. State Cab. Nat. Hist., 1857, p. 92, figs. 1-7;Pal. New York, III, 1859, p. 248, pl. 40, fig. 1.

Meristella bella Whitfield, Annals N. Y. Acad. Sci., V, 1891, p. 510, pl. 5, figs. 8-10.-Hall and Clarke, Pal. New York, VIII, Pt. II, 1895, pl. 43, tigs. 7-9; pl. 41, figs. 1-3.-Whitfield, Geol. Ohio, VII, 1895, p. 412, pl. 1, tigs. 8-10.

Loc. Albany aud Schoharie counties, New York; Greenfield, Ohio; Lake Temiseolita, New Brunswick. 
Meristella(?) blancha (Billings).

Lower Helderberg (Dev.).

Athyris blancha Billings, Proc. Portland Soc. Nat. Hist., 1863, p. 115, pl. 3, figr. 13.

Meristina (?) blancha Hall and Clarke, Pal. New York, VIII, Pt. II, 1893, p. 68, pl. 41, figs. 22, 23.

Loc. Square Lake, Maine.

Obs. Compare with Meristella arcuata.

Meristella clusia (Billings).

Corniferous (Dev.).

Athyris? clusia Billings, Canadian Jour. Sci., V, 1860, p. 279.

Loc. Cayuga, Ontario.

Meristella doris Hall.

Upper Helderberg (Dev.).

Meristella doris Hall, Thirteenth Rep. N. Y. State Cal. Nat. Hist., 1860, p. 81:-

Pal. New York, IV, 1867, p. 303, pl.50, figs. 1-12.-Hall and Clarke, Pal. New

York, VIII, Pt. II, 1895, pl. 43, figs. 21, 22.

Charionella doris Billings, Geol. Canada, 1863, p. 374, figs.400E, 401a, b.

Loc. Schoharie and Williamsville, New York; Cayuga, Ontario.

Meristella elissa Hall=Meristella nasuta.

Meristella haskinsi Hall.

Hamilton (Dev.).

Meristella haskinsi Hall, Thirteenth Rep. N. Y. State Cab. Nat. Hist., 1860, p. 84 ;-Pal. New York, IV, 1867, p. 306, pl. 49, figs. 23-35.-Hall and Clarke,

Ibidem, ViII, Pt. II, 1895, pl. 43, figs. 23, 24 ; pl. 44, fig. 31.

Loc. Seneca Lake,"York, Moscow, etc., Now York; Thedford, Ontario.

Meristella (?) houghtoni (A. Winchell).

Huron (Dev.).

Merista koughtoni Winchell, Proc. Acad. Nat. Sci. Philudelphia, 1862, p. 407. Meristella (?) houghtoni Hall aud Clarke, Pal. New York, VIII, Pt. II, 1893, p. 78. Loc. Port aux Barques, Michigan.

Meristella (?) incerta Simpson.

Waverly (L. Carb.).

Meristella incerta Simpson, Trans. American Philosophical Soc., n. ser., XVI, 1889, p. 442, fig. 7.

Loc. Warren, Pennsylvania.

Obs. Based upon a crushed aud broken specimen.

Meristella lævis (Vanuxem).

Lower Helderberg (Dev.).

Atrypa lavis Vanuxem, Geol. Now York; Rep. Third List., 1842, p. 120, fig. 2.Rogers, Geol. Pennsylvania, I1, Pt. II, 1858, p. 825, fig. 642.

Merista levis Hall, Tenth Rep. N. Y. State Cab. Nat. Hist., 1857, p. 94, figs. 1-6 ;-Pal. New York, III, 1859, p. 247, pl. 39, figs. 3, 4.- Ileek and Worthen, Geol. Survey Illiuois, III, 1868, p. 376 , pl. 7 , fig. 8.

Meristella lavis Whitfield, Anuals N. Y. Acad. Sci., Y, 1891, p. 510, pl. 5, firs. 6, 7.- Hall and Clarke, Pal. New York, VIII, Pt. II, 1895, pl. 43, figs. 3-6 ; pl. 44, fig. 4.-Whitfield, Geol. Ohio, VII, 1895, p. 411, pl. 1, figs. 6, 7.

Loc. Albauy aud Schoharie counties, New York; Greenfield, Ohio; l'erry County, Missouri ; Pennsylvania; Square Lake, Naine; St. Blaudine, New Brunswick.

Meristella (?) lævis (Hall).

Lower Helderberg (Dev.).

Megauteris lavis Hall (non Vauuxem), Tenth liep. N. Y. State Cab. Nat. IIist., 1857, p. 99.

Reusselæria lievis Hall, Pal. New York, III, 1859, p. 256, pl. 40, fig. 2.

Loc. Albany County, New York.

Meristella lata Hall.

Oriskany (Dev.).

Merista lata Hall, Pal. Now York, III, 1859, p. 431, pl. 101, fig. 3.

Meristella lata Hall and Clarke, Pal. New York, VIII, Pt. II, 1893, p. 78, pl. 41, fig. 12.

Loc. Albany and Schoharie comnties, New York; Cayuga, Untario. 
Meristella lens ( $\Lambda$. W'inelıell).

Hamilton (Dev.).

Morista lens A. Winchell, Rep. Lower Peninsula Michigan, 1866, p. (4.

Meristella lens IIall and Clarke, Pal. New York, VIII, Pt. II, 1893, p. 78.

L.oc. Grand Traverse region, Michigan.

Meristella lenta Hall.

Oriskany (Dev.).

Meristella lenta IIall, Pal. Now York, IV, 1867, p. 420, pl. 63, figs. 19-22._-Hall and Clarke, Ibirlem, VIII, Pt. II, 1895, pl. 44, figs. 15-18.

Loc. Caynga, Ontario.

Meristella maria Hall= Meristiua maria.

Meristella meeki Hall.

Lower Helderberg (Dev.).

Nerista meeki Hall, Tenth Rep. N. Y. Stato Cab. Nat. Hist, 1857, 1. 97;-Pal.

New York, III, 1859, p. 252, pl. 44, fig. 6 .

Camarium meeki Hall, Ibidem, III, 1859, p. 486.

Meristella meeki IIall and Clarke, Pal. New York, VIII, Pt. II, 1893, 1. 78.

Loc. Perry County, Tennessee.

Meristella meta Hall.

Hamilton (1)er.).

Meristella meta IIall, Pal. New York, IT, 1867, p. 308, pl. 49, tiuss. 1-1.-Hall and Clarke, Ibidem, VIII, Pt. II, 1895, pl. 43, figs. 29, 30.

Loc. Delphi, New York.

Meristella nasuta (Conrad).

Upper Helderberg (Dev.).

Atrypa nasuta Courad, Jour. Acad. Nat. Sci. Philadelphia, VIII, 1842, p. 265.

Terebratula valenciennii Castelnau, Essai syst. Sil. l'Amérique Septeutrionale, 1843, 1. 39, pl. 13, fig. 6 .

Meristella nasuta Hall, Thirteenth Rep. N. Y. State Cab. Nat. Hist., 1860, p. 93, figs. 8, 9; -Fifteenth Rep. Ibidem, 1862, p. 160, figs. 17-22 on p. 161;-Pal. New York, IV, 1867, p. 299, pl. 48, figs. 1-25.-Nettelroth, Kentucky Fossil Shells, Mem. Kentucky Geol. Survey, 1889, p. 98, j]. 15, figs. 2-8.-Hall and Clarke, Pal. New York, VIII, Pt. II, 1895, pl. 43, figs. 18-20; pl. 44, figs. 13, $14,19-26$.

Athyris clara Billings, Canadian Jour. Sei., V, 1860, p. 274, figs. 29-32;-Geol. Canada, 1863, p. 373, fig. 397 ;-Canadian Nat. Geol., n. ser.. V1I, 1874, p. 240.

Meristella elissa Hall, Fonrteenth Rep. N. Y. State Cab. Nat. Hist., 1861, p. 100 ;Fifteenth Rep. Ibiclem, 1862, 11. 3, figs. 21, 22.

Athyris masuta Niclolson, Pal. Prov. Ontario, 1874, p 86.

Meristella (Whitfieldia) nasuta Walcott, Mon. U. S. Geol. Survey, VIII, 1884, 1). 148, pl. 3 , fig. 8 .

Loc. Schoharie, Clarence, Williamsville, etc., New York; Cayuga. Ontario; C'olumbus and Dublin, Ohio; Falls of Ohio; Lone Mountain, Nevada.

Meristella nueleolata Whitfield $=$ Whitfieldella nucleolata.

Meristella princeps Hall. Lower IIelderberg (Dev.).

Merista princeps Hall, Tenth Rep. N. Y. State Cab. Nat. Hist., 1857, p. 95, figs. 1-5;-Pal. New York, III, 1859, p. 251, pl. 44, figs 1-5.

Camarium princeps Hall, Ibidem, III, 1859, 1. 486.

Meristella princeps Hall, Thirteenth Rep. X. Y. State Cab. Nat. Hist., 1860, p. 93, figs. 5-7.-Hall and Clarke, Pal. New York, VIII, Pt. II, 1895, pl. 43, figs. 10-13.

Loc. Carlisle and Schoharie, New York; St. Blandine, New Brunswick.

Meristella rectirostra $\mathrm{Hall}=$ Meristina rectirostris.

Meristella riskowskyi $\mathrm{A}$. Ulrich.

Mitdle Devonian.

Meristella riskowskyi A. Ulrich, X. Jahrb. f. Mineral., Beilageband, VIII, 1892, p. 64, pl. 4, figs. 16-18.

Loc. Chahnarani and near Oeoni, Bolivia. 
Meristella rostrata Hall.

Hamilton (Dev.).

Atrypa rostrata Hall, Geol. New York; Rep. Foürth Dist., 1843, p. 202, fig. 2. Athyris? rostrata Billings, Canadian Jonr. Sci., V, 1860, p. 281, figs. 43, 44.

Charionella rostrata Billings, Geol. Canada, 1863, p. 385, fig. 420.

Meristella rostrata Hall, Pal. New York, IV, 1867, p. 307, pl. 50, figs. 13-17.Hall and Clarke, Ibidem, Vol. VIII, Pt. II, 1895, pl. 43, figs. 27, 28.

Loc. Eighteen Mile Creek, etc., New York; Bosanquet, Ontario.

Meristella subquadrata Hall.

Lower Helderberg (Dev.)

Merista subquadrata Hall, Tenth Rep. N. Y. State Cab. Nat. Hist., 1857, p. 93;Pal. New York, III, 1859, p. 249, pl. 40, fig. 3.

Meristella subquadrata Hall and Clarke, Ibidem, VIII, Pt. II, 1893, p. 78, pl. 43, figs. 14, 15.

Loc. Schoharie and Carlisle, New York.

Meristella unisulcata IIall=Pentagonia unisulcata.

Meristella unisulcata biplicata Hall=Pentagonia unisulcata biplicata. Meristella unisulcata uniplicata Hall= Pentagonia unisulcata miplicata.

Meristella walcotti Hall and Clarke. Oriskany (Dev.).

Meristella walcotti Hall and Clarke, Pal. Ner York, VIII, Pt. II, 1895, pl. 77, 365 , figs. 55,56 , pl. 43 , figs. 16,17 ; pl. 44, figs. $6-11,23,32$.

Loc. Cayuga, Ontario.

MERISTINA Hall.

Genotype Meristella maria Hall.

Meristina Hall, Twentieth Rep. N. Y. State Cab. Nat. Hist., 1867, p. 157;-Pal. New York, IV, 1867, p. 299. - Nettelroth (partim), Kentucky Fossil Shells, Mem. Kentucky Geol. Survey, 1889, p. 101.- Hall and Clarke, Pal. New York, VIII, Pt. II, 1893, p. 65; - Thirteenth Ann. Rep. N. Y. State Geologist, 1895, p. 770. Whitfieldia Davidson, Supplement British Sil. Brach., Paleontographical Soc., 1882, p. 107.-Beecher and Clarke, Mem. New York State Mus., I, 1889, p. 73.

Meristina maria Hall.

Niagara (Sil.).

Athyris tumida Roemer, Sil. Fauna west. Tennessee, 1860, p. 70, 11. 5, fig. 12.

Meristella maria Hall, Trans. Albany Instituto, IV, 1863, p. 212.-Hall and Whitfield, Twenty-fourth Rep. N. Y. State Cab. Nat. Hist., 1872, p. 196.

Meristina maria Hall, Twentieth Rep. N. Y. State Cab. Nat. Hist., 1867, p. 157 ;Pal. New York, IV, 1867, p. 299.-Hall and Whitfield, Pal. Ohio, II, 1875, p. 132, 1)1. 7, figs. 5, 6.-Nettelroth, Kentucky Fossil Shells, Mem. Kentucky Geol. Survey, 1889, p. 101, pl. 29, figs. 7-10.-Hall and Clarke, Pal. New York, VIII, Pt. II, 1893, p. 67, pl. 41, figs. 1-17.

Meristella tumida Etheridge, Quart. Jour. Geol. Soc. London, XXXIV, 1878, p. 597.

Meristella (Meristina) maria Hall, Twenty-eighth Rep. N. Y. State Mus. Nat. Hist., 1879, p. 159, pl. 25, figs. 8-12;-Eleventh Rep. State Geol. Indiana, 1882 , p. 299 , pl. 25 , figs. 8-12.

Whitfieldia maria Beecher and Clarke, Mem. N. Y. State Mus., I, 1889, p. 73, pl. 7, figs. 1-3.

Loc. Waldron, Indiana ; Springfield, Ohio ; Louisville, Kentncky ; Perry County, Tennessee; Bridgeport, Illinois; Racine, Wisconsin; Bessels Bay, $81^{\circ} 6^{\prime}$.

Obs. This species is not identical with M. tunida Dalman.

Meristina nitida Hall= Whitfieldella nitida.

Meristina rectirostris Hall.

Niagara (Sil.).

Meristella rectirostra Hall, Descriptions n. sp. Fossils from Waldron, Indiana, 1879, p. 15 ;-Eleventh Rep. State Geol. Indiana, 1882, p. 301, pl. 27, figs. 10 14 ;- Trans. Albany Institute, X, 1883, p. 71.-Beecher and Clarke, Mem. N. Y. State Ius., I, 1889, p. 67, pl. 7, figs. 4, 5, 11-13. 
Meristina rectirostris Hall-Continued.

Meristin: rectirostra II:ll and Clarko, Pal. Now York, VIII, Pt. II, 1893, p. 68, figs. 52,53 , pl. 41, figs. 18-21.

Loc. Waldrou, Indiana.

Meristina trisinuata (McChesuey).

Niagara (Sil.).

Pentamerus trisimatus MeChesney, Descriptions New Pal. Fossils, 1861, p. 86 .

Athyris? trisimnatns McChesney, Trans. Chicago Acad. Sei., I, 1868, p. 33, pl. 8, fig. 2.

Loc. Milwankee, Wisconsin.

()hs. Probabls spnontrmons with Meristina maria.

METAPLASIA Hall and Clarke. Genotype Spirifer pyxidata Hall. Metaplasia Hall and Clarke, Pal. New York, VIII, Pt. II, 1893, p. 56;-Thirteenth Ann. Rep. N. Y. State Geologist, 1895, p. 762.

Metaplasia disparilis (Hall).

Corniferous (Dev.).

Spirifer disparilis Hall, Tenth Rep. N. Y. State Cab. Nat. Hist., 1857, p. 134.

Spirifera disparilis IIall, Pal. New York, IV, 1867, p. 204, pl. 30, figs. 10-15.

Metaplasia pyxidata Hall and Clarke, Ibidem, VIII, Pt. II, 1895, pl. 39, figs. $19-22$.

Loc. Williamsville and Clarence Hollow, New York.

Metaplasia pyxidata Hall.

Oriskany (Dev.).

Spirifer pyxidata Hall, Pal. Now York, III, 1859, p. 428, pl. 100, figs. 9-12.

Metaplasia pyxidata Hall and Clarke, Pal. New York, VIII, Pt. II, 1893, p. 56.

Loc. Albany and Schoharie counties, New York; Cumberland, Maryland; Caynga, Ontario.

Micromitra Meek=Iphidea.

MIMULUS Barrande.

Genotype M. perversus Barrande.

Mimulus Barrande, Système Silurien du Centre de la Bohème, V, 1879, 1. 109.--

Hall and Clarke, Pal. New York, VIII, Pt. I, 1892, p. 272 ;-Eleventh Ann. Rep. N. Y. State Geologist, 1894, p. 289.

Mimulus waldronensis (Miller and Dyer).

Niagara (Sil.).

Spiriferia (?) waldronensis Miller and Dyer, Jonr. Cincinnati Soc. Nat. Hist., I, 1878, p. 37, pl. 2, fig. 3 .

Triplesia putillus Hall, Descriptions n. sp. Fossils Walulron, Indiana, 1879, p. 16;Eleventh Rep. State Geol. Indiana, 1882, p. 298. pl. 27, figs. 19-22;-Trans.

Albany Institute, X, 1883, p. 72.

Streptis waldronensis Beecher and Clarke, Mem. New York State Mus., I, 1889, p. 30 , pl. 3, figs. 9, 10.

Mimulus waldronensis Hall and Clarke, Pal. New York, VIII, Pt. I, 1892, p. 273 , pl. $11 \mathrm{C}$, figs. $23-28$.

Loc. Waldron, Indiana.

MONOMORELLA Billings.

Genotype M. prisca Billings.

Monomorella Billings, Canadian Nat. Geol., n. ser., VI, 1871, p. 220;-American Jour. Sci., 31 ser., III, 1872, p. 358.-Davidson and King, Quart. Jour. Geol. Soc. London, XXX, 187t, p. 155.-Hall and Clarke, Pal. New York, VIII, Pt. I, 1892, jp. 40, 46;-Eleventh Ann. Rep. N. Y. State Geologist, 1894, p. 238.

Monomorella egani Hall and Clarke.

Niagara (Sil.).

Monomorella egani Hall and Clarke, Pal. New York, VIII, Pt. I, 1892, pp. 42, 175, pl. 4C, fig. 16.

Loc. Near Grafton, Wisconsin. 
Monomorella greenei Hall and Clarke.

Niagara (Sil.).

Monomorella greenii Hall and Clarke, PaI. New York, VIII, Pt. I, 1892, pp. 42, 174, pl. 4D, figs. 5-10.

Loc. Near Grafton, Wiseonsin; Risingsun, Ohio.

Monomorella kingi Hall and Clarke.

Niagara (Sil.).

Monomorella kingi Hall and Clarke, Pal. New York, VIII, Pt. I, 1892, pp. 42, 174, pl. 4D, figs. $1,2$.

Loc. Near Cedarburg, Wisconsin; Hawthorne, Illinois.

Monomorella newberryi Hall and Whitfield.

Niagara (Sil.).

Monomorella newberryi Hall aud Whitfield, Pal, Ohio, II, 1875, p. 131, pl. 7, figs. 1, 2.-Hall and Clarke, Pal. Now York, VIII, Pt. I, 1892, pl.4C, figs. 1, 2. Loc. Genoa, Ohio.

Monomorella orbicularis Billings.

Guelph (Sil.).

Monomorella orbicularis Billings, Canadian Nat. Geol., n. ser., VI, 1871, p. 221;Ameriean Jour. Sei., 3d ser., III, 1872, p. 359.-Davidson and King, Quart. Jour. Geol. Soc. London, XXX, 1874, 1. 158, pI. 17, fig. 10.

Monomorella enf. orbieularis Hall and Clarke, Pal. New York, VIII, Pt. I, 1892, pl. $4 \mathrm{C}$, figs. 3-5.

Loc. Ilespelar, Ontario; near Grafton, Wisconsin.

Monomorella ortoni Hall and Clarke.

Niagara (Sil.).

Monomorella ortoni Hall aud Clarke, Pal. New York, VIII, Pt. I, 1892, pp. 42, 175, pl. 4C, figs. 14, 15.

Loc. Risingsun, Wood County, Ohio.

Monomorella ovata Whiteaves.

Guelph (Sil.).

Monomorella ovata Whiteaves, Pal. Fossils, III, 1884, p. 5, pl. 2, fig. 1; pl. 8, fig. 1.-Hall and Clarke, Pal. New York, VIII, Pt. I, 1892, p. 42, pl. 4D, figs. 13-15.

Loc. Durham, Ontario.

Monomorella ovata lata Whiteaves.

Guelph (Sil.).

Monomorella ovata var. lata Whiteaves, Pal. Fossils, III, 1884, p. 6, pl. 2, fig. 2 ; pl.8, fig. 2.-Hall and Clarke, Pal. New York, VIII, Pt. I, 1892, pl. 4, figs. 11,12 ; pl. 4 C, figs. $17,18$.

Loc. Durham, Ontario; Haw thorne, Illinois.

Monomorella prisca Billings.

Guelph (Sil.).

Mouomorella prisca Billings, Canadian Nat. Geol, n. ser., VI, 1871, I. 221 ; - Ameriean Jour. Sei., 3d ser., III, 1872, p. 359.-Davidson and King, Quart. Jour. Geol. Soe. London, XXX, 1874, p. 156, pl. 17, figs. 5-8.-Nicholson, Pal. Prov. Ontario, 1875, p. 68, fig. 38.-Hall and Clarke, Pal. New York, VIII, Pt. I, 1892, pl. 4C, figs. 6-13.

Loc. Hespelar and Elora, Ontario; Risingsun, Wood County, Ohio ; Hawthorne, Port Byron, and Cicero, Illinois. .

NEWBERRYA Hall.

Genotype Rensselieria? johauni Hall.

Rensselandia Hall, Pal. New York, IV, 1867, p. 385.

Newberria Hall, Cont. Canadian Pal., I, 1891, p. 236 ;-Tenth Ann. Rep. N. Y. State Geol., 1891, p. 91 (extract, 1).4).-Hall and Clarke, Pal. New York, VIII, Pt. II, 1893, p. 261 ;-Thirteenth Ann. Rep. N. Y. state Geologist, 1895, p. 851.

Obs. It is unfortunate that Rensselieria johami is the type for two generie names. Adhering strictly to the rules of nomenclature Rensselandia will take precedence over Newberrya. The first term is, however, improperly constructed and is without meaning. 
Newberrya claypolei Hall.

Hamilton (Dev.).

Rensselaria marylaulica? Claypole, l'roc. American Phil. Soc., 1883, p. 235.

Newberria claypolii IIall, Tenth Ann. Rep. N. Y. State Geol., 1891, p. 9, extract, pl. 5, figs. 1-9.-Hall and Clarke, Pal. New York, VIII, Pt. II, 1893, p. 263, pl. 78, figs. 1-9.

Loe. Perry County, Pennsylvania.

Newberria? condoni McChesney = Megalanteris condoni.

Newberrya johannis Hall.

Middle Devonian.

Rensselæria? johanni Hall, Pal. New York, IV, 1867, 1. 385, pl. 58A, tigs. 9-20.

Rensselandia johanni Hall, Ibidem, 1867, at end of description.

Newberria johanni Hall, Cont. Canadian Pal., I, 1891, p. 237.

Newberria johannis Hall, Tenth Ann. Rep. N. Y. State Geol., 1891, p. 8, extract, pl. 6, figs. 1-11.-Hall and Clarke, Pal. New York, VIII, Pt. II, 1893, p. 262, pl. 78 , figs. 10-16.

Loc. Waterloo, Iowa.

Newberrya lævis (Meek).

Middle Devonian.

Rensselæria levis Meek, Trans. Chicago Acad. Sci., I, 1868, p. 108, pl. 13, fig. 8; pl. 14, fig. 4.

Newberria lævis Hall, Cont. Canadian Pal., I, 1891, p. 237, pl. 30, figs. 3, 4 .

Newberria levis Hall, Tenth Ann. Rep. N. Y. State Geol., 1891, p. 7, extract, pl. 6, figs. 12-15.-Hall and Clarke, Pal. New York, VIII, Pt. II, 1893, p. 264, pl. 78, figs. 17-20.

Loc. Mackenzie, Onion, and Lockhart rivers, Canada.

Newberrya missouriensis Swallow.

Hamilton (Dev.).

Newberria missouriensis (Swallow MS.) Hall, Tenth Ann. Rep. N. Y. State Geol., 1891, p. 9, extract, pl. 5, figs. 10-12.-Hall and Clarke, Pal. New York, VIII, Pt. II, 1893, p. 263, pl. 78, figs. 21-23.

Loc. Moniteau County, Missouri.

NOTOTHYRIS Waagen. Genotype Terebratula subvesicnlaris David.

Notothyris Waagen, Palieontologica Indica, Ser. XIII, I, 1882, p. 375.-Hall aud Clarke, Pal. New York, VIII, Pt. II, 1893, p. 274;-Thirteenth Ann. Rep. N. Y. State Geologist, 1895, p. 857.

Notothyris (?) smithii Derby.

Middle Devouian.

Notothyris (?) smithii Derby, Archivos do Museu Nacional do Rio De Janeiro,

IX, 1890, p. 81.-Hall and Clarke, Pal. New York, VIII, Pt. II, 1893, pp. 267, 275 .

Loc. Head of the Paraguay in Matto-Grosso, Brazil.

NUCLEOSPIRA Hall.

Genotype Spirifer ventricosa Hall.

Nucleospira Hall, Twelfth Rep. N. Y. State Cab. Nat. Hist., 1859, p. 24 ;-Yal. New York, III, 1859, p. 219 ;-Ibidem, IV, 1867, p. 278.-Nettelroth, Kentucky Fossil Shells, Mem. Kentucky Geol. Survey, 1889, p. 103.-Hall aud Clarke, Pal. New York, VIII, Pt. II, 1893, p. 142 ;-Thirteenth Anu. Rep. N. Y. State Geologist, 1895 , p. 806.

Nucleospira barrisi White.

Kinderhook (L. Carb.).

Nucleospira barrisi White, Jour. Boston Soc. Nat. Hist., VIII, 1860, p. 227.

Loc. Burlington, Iowa.

Nucleospira concentrica Hall.

Lower Helderberg (Dev.).

Nucleospira concentrica Hall, Pal. New York, III, 1859, p. 223, pl. 28B, figs. 1519.-Hall and Clarke, Ibidem, VIII, Pt. II, 1895, pl. 48, fig. 7.

Loc. Decatur County, Tennessee. 
Nucleospira concinna Hall.

Corniferous-Hamilton (Dev.).

Atrypa concinna Hall, Geol. N. Y.; Rep. Fourth Dist., 1843, p. 200, fig. 3.

Nueleospira concinna Hall, Twelfth Rep. N. Y. State Cal,. Nat. Hist., 1859, pp. 25, 26;-Pal. New York, 1V, 1867, p. 279, pl. 45, tigs.33-57.-Davidson, Suppl. British Silurian Brach., Pal:eontographical Society, 1882, p. 121.-Walcott, Mon. U. S. Geol. Snrvey, VIII, 1884, P. 147.-Nettelroth, Kentucky Fossil Shells, Mem. Kentucky Geol. Survey, 1889, p. 103, pl. 32, figs.1-4.-Hall and Clarke, Pal. New York, VIII, Pt. II, 1893, p. 115, fig. 131; pl. 48, figs. 12-17, 19-34; pl. 84, fig. 38.

Loc. Moscow, Darien, ete., New York; Monroe Connty, Pennsylvania; Thedford, Ontario; IIardy County, Virginia; Columbus, Ohio; Falls of Ohio; Lone Mountain, Nevalla.

Nucleospira elegans Hall. ? Niagara and L. Helderberg (Sil. and Dev.).

Nucleospira elegans Hall, Pal. Now York, III, 1859, p. 222, pl. 28B, figs. 10-15.Nettelroth, Kentucky Fossil Sliells, Mem. Kentucky Geol. Survey, 1889, p. 104.-Hall and Clarke, Pal. New York, VIII, Pt. II, 1895, pl. 48, figs. 8-11.

Loc. Cherry Valley, New York; Cumberland, Maryland. In the Niagara near Louisville, Kentucky (Nettelroth).

Nucleospira indianensis Miller=Parazyga hirsuta.

Nucleospira pisiformis IIall.

Niagara (Sil.).

Orthis pisum Hall (non Sowerby), Pal. New York, II, 1852, p. 250, pl. 2, fig. 1.

Nucleospira pisiformis Hall, Pal. New York, III, 1859, pl. 28I3;-Trans. Albany Institute, IV , 1863, p. 2:6 ;-Twenty-eighth Rep. N. Y. State Mus. Nat. I ist., 1879, p. 160, pl. 25, figs. 22-28;-Eleventh Rep. State Geol. Indiana, 1882, 1. 301, pl. 25, figs. 22-28.-Kayser, Richthofens China, IV, 1883, 1) 47, pl. 4, figs. 9-11.-Nettelroth, Kentucky Fossil Shells, Mem. Kentucky Geol. Surviy, 1889, p. 104, pl. 33, figs. 7-9.-Keyes, Geol. Survey MIissouri, V, 1895, p. 94, pl. 41, fig. 5.

Loc. Wolcott, New York; Waldron, Indiana; Lonisville, Kentucky; Pike County, Missouri; Tshan-Tien, China.

Nucleospira rotundata Whitfield.

Waterlime (Sil.).

Nucleospira rotundata Whitfield, Ann. Now York Acal. Sci., II, 1882, p. 194;Ibiden, V, 1891, p. 511, 11. 5, figs. 11-14;-Geol. Olrio, VII, 1895, p. 413, pl.1, figs. 11-14.

Loc. Greenfield, Ohio.

\section{Nucleospira ventricosa Hall.}

Lower Helderberg (Dev.).

Spirifer ventriıosa Hall, Tenth Rep. N. Y. State Cab. Nat. Hist., 1857, 1. 57.

Nncleospira ventricosa Hall, Pal. New York, III, 1859, p. 220, pl. 14, fig. 1; pl. 28B, figs. 2-9.-Hall and Clarke, Pal. New York, VIII, Pt. II, 1893, p. 145, figs. $128-130$; pl. 48 , figs. $2-6,18$; pl. 84, ligs. 39, 40.

Loc. Scholnarie, Clierry Valley, ote., New York; Cumberland, Maryland.

OBOLELLA Billings.

Genotype $O$. chromatica Billings.

Obolella Billings, Geol. Vermont, II, 1861, 1. 946;-Pal. Fossils, I, 1861, p. 7.Hall, Sixtrentl Rep. N. Y. State Cab. Nat. Hist., 1863, 1) 131.-Meek and Hayden, Smithsonian Cont. to Knowledge, XIV, 172, 1861, p. 3.-Hall, Trans. Albany Institute, V', $186 \overline{7}$, J. 108.-Dall, American Jonr. Conchology, VI, 1870, pp. 162, 164.-Billings, Camalian Nat. Geol., n. ser., VI, 1871, p. 217, figs. 5, 6;-American Jour. Sei., 31 ser., III, 1872, p. 355, figs. 5-7;-Ihidem, 3d ser., XI, 1876, p. 176.-Forł, Jbillem, 3d s'r., XXI, 1881, 1. 131.-Walcott, Bull. U. S. Geol. Snrvey, 30, 18c6, 1). 109.-Hall and Clarke, Pal. New York, VIII, Pt. I, 1892, pp. 66, 164 ;-Eleventh Ann. Rep. N. Y. State Geologist, 1894, Bull. 87-18 


\section{OBOLELLA Billings-Continued.}

P. 210.-Mathow, 'T'rus. Royal Soe. Canala, IX, 1892, p. 39.-Mickwitz,

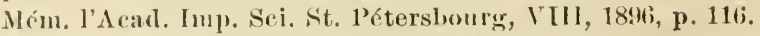

Dicellomus Hall, Twenty-third liep. N. Y. State Cab. Nat Il ist., 1873, p. 246.

Obolella ambigua Walcott= Elkania ambigua.

Obolella atlantica Walcott.

Lower Cambrian.

Wholella : Itlantica Walcott, Proc. IT. S. Nat. Mns., XII, 1889, 1. 36;-T'enth Ann.

Rep. IT. S. Geel. Survey, 1891, 1. (i11, pl. 71, fig. 1.

Loc. Conception lay, Nowfommlind; Attlehoro, Massachusetls.

Obolella cirlata Billings=- Lingulella cerata.

Obolella chromatica Billings.

Lower Cambrian.

Obolellar eliromatica Billings, Geol. Vermont, 11, 1861, p. 947, fig. 3.16;-Pal.

Fossils, I, 1861, p. 7, fig. 7;-Geol. Canada, 1863, p. 284, fig. 288.-Hall,

Trans. Albany lustitute, V, 1867, p. 110.-Billings, Ameriean. Jour. Sei., 3، ser., XI, 187t, p. 176, tigs. 1-4.-Ford, Ibidem, 3九l ser., XXI, 1881, p. 133, figrs. 3, 1, 5.-Walcott, Bull. U. S. Geol. Survey, 30, 1886, p. 112, p1. 11, fig. I ;-Tenth Anu. Kep. U.S. cieol. Survey, 1. 611, p1.71, fig. 2.-1lall aud Clarlse, Pal. New York, VIIl, Pt. I, 1892, p. 70.

Loc. Anse an Loup, Canala.

Obolella eingulata Billings=Kntorgina cingulata.

Obolella circe Billings.

Lower Cambrian.

Obolella circe Iillings, Canadian Nat. Geol., u. ser., 1V, 1871, p. 218;-American Jour. Sei., III, 1872, p. 357.- Walcott, Bull. U. S. Geol. Surrey, 30, 1886, p. 118, pl. 10, fig. 3 ;-Tenth Anu. Rep. U. S. Geol. Survey, 1891, P. 611, pl. 71, fig. 3.

Loc. Trois Pistoles, Canada.

Obolella crassa (1 Iall).

Lower Cambrian.

Orbicula? crassa Hall, Pal. New York, I, 1847, p. 290, pl. 79, fig. 8.

Avicula? desinamata Hall, Ibidem, 1847, p. 292, pl. 80, fig. 2.

Obolella crassa Billings, Canadian Nat. Geol., n. ser., VI, 1871, p. 218.-Ford, Amer. Jour. Sei., 3d ser., X V , 1878, p. 128;-Ibidem, 31 ser., XXI, 1881, p. 131, figs. 1, 2.-Walcott, Bull. U. S. Geol. Survey, 30, 1886, p. 114, pl. 10, fig. 1.Shaler aud Foerste, Bull. Mns. Comp. Zool., XVI, 1888, p. 27, pl. 1, fig. 1.Waleott, Tentl Aun. Rep. U. S. Geol. Survey, 1891, p. 612, pl. 71, fig. 4.Hall aml Clarke, Pal. New York, VIII, Pt. I, 1892, p. 70, pl. 2, figs. 31-36.

Obolella dlestnanata lillings, Canadian Nat. Geol., 11. ser., VI, 1871, p. 217, tig. 6;-American Jonr. Sci., 3d ser., III, 1872, p. 355, fig. 6.

Obolella (Orbienla?) crassa Ford, American Jonr. Sci., 31 ser., II, 1871, p. 33.

Dieellomms erassa IIall, Twenty-third Rep. N. Y. Stato Cab. Nat. Hist., 1873, p. 246, 1). 13, figs. 6-9.

Obolella cliromatica (lap. crassa) Walcott, American Jonr. Sci., 3d ser., XXIX, 1885, p. 116, figs. 1, 2;-Ibidem, XXX, 1890, p. 21.

Loc. Troy and Schodaek Landing, New York; North Attleboro, Massachusetts; St. Simon and Bic IIarbor, below Quebec, Canada.

Obolella desiderata Billings=Elkania desiderata.

Obolella descyumata Billings=Obolella erassa.

Obolella (?) discoidea Hall and Whitfield. Up. Camb. and Pogonip (Orl.).

Obolella discoidea Hall and Wh hitfield, King's U. S. Geol. Expl. 40th Parl., IT, 1877, p. 203 , pl. 1, figs. 1, 2.-Walcott, Mlou. U. S. Geol. Survey, VIII, 1884, P. 14.

Obolella? discoidea Walcott, Bull. U. S. Geol. Survey, 30, 1826, p. 111.-Hall and Clarke, Pal. New York, VIII, Pt. I, 1892, 1. 69.

Loc. Eureka district, Nevada. 
Obolella gemma Billing's.

Lower Cambrian.

Obolella gemma Billings, Canadian Nat. Geol., n. ser., VI, 1871, p. 217, fig.5;American Jour. Sei., 3 d ser., III, 1872. p. 357, fig. 5.-Walcott, Bull. U. S. Geol. Surrey, 30, 1886, p. 116, pl. 10, tig. 2;-Tenth Ann. Rep. T. S. Geol. Survey, 1891, p. 612 , 11. 71, fig. 5 ; pl. 72, tig. 2.-Hall and Clarke, Pal. New York, VuI, Pt. I, 1892, p. 71, fig. 30 ; pl. 2, tigs. 42-44.

Lor. Bie and St. Simon harbors, helow Quebec, Canala; Tros, Now York.

Obolella (?) gemmula Matthew.

Upper Cambrian.

Obolella (?) gemula Matthew, Trans. lioyal Soc. Canada, IX, 1892, 1. 11, pl. 12, tigs. Sil-8c.

Loc. Near St. John, New Brunswick.

Obolella (?) ida Billings.

Upper Cambrian and Calciferous (Ord.).

Obolella ida Billings, Pal. Fossils, I, 1862, p. 71, fig. 63, on 1. 68.

Obolella ? ida Walcott, Bull. U. S. Geol. Survey, 30, 1886, p. 111.

Loc. Point Levis, Canada.

Obolella misera Billings=Limnarssonia misera.

Obolella minuta (Hall and Whitfield).

Upper C'ambrian.

Lingulepis ? minuta Hall and Whitfielel, Rep. Geol. Expl. 40th Farl., 1V, 1877, p. 206, pl. 1, figs. 3, 4.-Walcott, Mon. U. S. Geol. Survey, VIII, 1884, 1. 13. Loc. Eureka district, Nevada.

Obolella nana Meek and Hayden.

Middle Cambrian.

Obolella nana Meek and Hayden, Proc. Acad. Nat. Sci. Philaelelphia, 1861, p. 435.-Billings, Pal. Fossils, I, 1862, p. 67.-Lllayden, American Jour. Sci., 21 ser., XXXIII, 1863, 1. 73. - Neek and Hayden, Smithsonian Cont. to Knowledge, XIV, 172, 1864, 1. 4, pl. 1, fig. 3.-Whitfield, Powell's (ieol. Geogr. Sur= vey Rocky Mountain Region, 1880, 1. 340, pl. 2, figs. 14-17.-Hall and Clarke, Pal. New York, VIII, Pt. I, 1892, 1. 69.

Loc. Black Hills, South Dakota.

Obolella nitida Ford.

Lower Cambrian.

Obolella nitida Ford, American Jour. Sei., 3d ser., V, 1873, p. 213.—Waleott, Bull. U. S. Geol. Survey, 30, 1886, p. 118, pl. 11, fig. 2;-Tenth Ann. Rep. U. S. Geol. Survey, 1891, p. 612, pl. 72, fig. 1.-Ilall and Clarke, Pal. New York, VIII, Pt. I, 1892, Pp. 69, 70.—? Matthew, Trans. N. Y. Acad. Sei., NIV, 1895, p. 12i, pl. 2, fig. 8 .

Loc. Troy, and Washington County, New York; Hanford Brook, New Bruswick.

Obolella pectenoides (Whitfield).

Upper Cambrian.

Obolus pectenoidles Whitfield, Ludlow's Rep. lieconn. Plack Hills, Dakota, 1875, p. 103, figs. 1-3.

Oholus? pectenoides Whitfield, Powell's Geol. Geogr. Survey Rocky Mountain Region, 1880, p. 338, pl. 2, figs. 18, 19.

Loc. Black Hills, South Dakota.

Obolella polita Hall.

Middle Cambrian.

Obolus appolinus Owen (non Eichwald), Geol. Survey Wisconsin, Iowa, Minnesota, 1852, pl. 1B, figs. $9,11,15,20$.

Lingula? polita Hall, Ann. Rep. Geol. Survey Wisconsin, 1861, p. 24;-Geol. Rep. Wisconsin, I, 1862, pp. 21, 435 .

Obolella ? polita Hall, Sixteenth Rep. N. Y. State Cab. Nat. Hist., 1863, 1. 133, 1]. 6, figs. 17-21;-Trans. Albany Institute, V, 1867, P. 112.

Lingulepis prima Meek and Hayden, Smithsonian Cont. to Knowl., XIV, 172, 1864, 1. 3 , pl. 1, fig. 2.

Dicellomus polita Hall, Twenty-third Rep. N, Y. State Cab, Nat. Hist., 1873, p. 246. 
Obolella polita Hall-Continuer.

Obolella polita Whitfield, l'owell’s Geol. Geogr. Survey Rocky Morntain Regrion, 1880, T. 339, pl. "2, figs, 12, 13.-Walcott, Bull. U. S. (ieol. Survey, 30, 1886, 1. 111.-Hall and Clarke, Pal. New York, V'III, Pt. I, 1892, pl. 2, figs. 37-41.

Lor. Trmpealean, Wisconsin; Blick Hills, South Dakota.

Obolella pretiosa Billings=Liunarssonia pretiosa.

Obolella prima Whitfield=Lingulepis prima.

Obolella transversa Hartt=Limarssonia transversa.

Obolellina Billings= Dinobolus.

Obolellina canadensis Billings=1)inobolus canadaensis.

Obolellina galtensis Billings= Rlıinobolus galtensis.

Obolellina magnifica Billings=Dinobolus magnificus.

oBOLUS Eichwald.

Genotype Obolus appolinus Eichrald.

Obolus Eichwald, Zoologia Specialis, I, 1829, p. 274.--Iall and Clarke, Pal. Now York, VIII, I't. I, 1892, p. 80, figs. 33, 34; pp. 164, 337.-Matthow, Trans. Royal Soc. Canada, IX, 1892, p. 43.-Mickwitz, Mém. l'Acarl. Inip. Sci. St. Pétersbouris, VIII, 18!16, pp. 25, 126.

Enobolus Mickwitz, Hém. l'Acad. Imp. Sei. St. Pétersbourg, VIII, 1896, pp. 25, $129,133$.

Obs. Both Enobolus aud Obolus are hased npon the same species.

Obolus appoliuus Owen (non Eichwald)= Obolclla polita.

Obolus canadensis Billings, 1858=Dinobolus magnificus.

Obolus canadensis Billings = Dinobolus canadaensis.

Obolus conradi Hall=Dinobolus conradi.

Obolus galtensis Billings=Rhinobolus galtensis.

Obolus labradoricus Billings $=\mathrm{I}_{\mathrm{p}}$ hidea Jabradorica.

Obolus (?) major Matthew.

Lower Cambrian.

Obolus? major Matthew, Trans. Royal Soc. Cauada, IV, 1890, p. 155, pl. 8, fig. 3.

Mickwitzia (?) major Mickwitz, Mém. l'Acal. Imp. Sci. St. P'étersbourg, VIII, 1896, p. 23.

Loc. Near St. John, New Brunswiek.

Obolus (?) murrayi Billings.

Cambrian.

Obolus? murrayi Billings, Pal. Fossils, 1, 1865, I. 362.

Loc. Hare Bay, Newfoundland.

Obolus ? pectenoides Whitfield=Obolella pectinoides.

Obolus pulcher Matthew=Botsfordia pulchra.

Obolus pristinus Matthew.

? Midllle Cambrian.

Obolus pristinus Natthew, Trans. N. Y. Acad. Sei., XIV, 1895, p. 121, pl. 4, fig. 1.

Loc. Hanford Brook, New Brunswick.

Obolus (?) refulgens Matthew.

Middle Cambrian.

Obolus refulgens Matthew, Trans. Royal Soc. Canada, IX, 1892, p. 44, pl. 12, figs. 6a-6d.

Ololus (?) refulgens Mick witz, Mlém. l'Acad. Imp. Sci. St. P'étersbourg, VIII, 1896, p. 23.

Loc. Near St. John, New Brunswick.

Ehlertella Hall and Clarke=Linguloriscina.

Orbicula Cuvier $=$ Crania .

Orbieula Sowerby, $\mathbf{1 8 3 0}=$ Discina.

Orbicula cælata Hall=Lingulella celata, 
Orbicula corrugata Hall=Lichenalia, a bryozoan.

Orbicula crassa Hall=Obolella crassa.

Orbicula deformata Hall=Crania deformata.

?Orbicula excentrica Emmons.

Cambrian.

Orbicula excentrica Emınons, Amcrican Geology, Pt. II, 1855, p. 112, pl. 1, fìg. 4.

Crania excentrica Miller, N. American Geol. Pal., 1889, p. 341.

Loc. Angusta Comnty, Virginia.

Obs. Proluably a gastroporl.

Orbicula filosa Hall=Sehizocrania filosa.

Orbicula grandis Vannem = Romerella grandis.

Orbicula lamellosa IIall (non Broderip) =Orbiculoidea lamellosa.

Orbicnla lodensis Vannxem=Orbicnloidea lodiensis.

Orbicula lugubris Conrad= Discinisea lugubris.

Orbicula minuta Hall=Orbiculoidea minuta.

Orbicula multilineata Conrad=Discinisca multilineata.

Orbicula parmulata Hall=Orbiculoidea parmulata.

Orbicula prima Owen = Lingulepis pinniformis.

Orbicula squamiformis Hall=Pholidops squamiformis.

Orbicula subtruncata $\mathrm{Hall}=$ Plolidops snbtruncata.

Orbicula tenuilamellata Hall=Schizotreta tenuilamellata.

Orbicula terminalis Emmons=Trematis terminalis.

Orbicula truncata Emmons=Orbiculoidea lamellosa.

ORBICULOIDEA d'Orbigny. Genotype Orbicula morrisi Davidson.

Orbiculoilea d’Orbigny, Prodrome de Paléontologie stratigraphique, I, 1850, p. 44.-Dall, Bull. Mus. Comp. Zool., III, 1871, p. 37 ;-American Jour. Conch., VII, 1871, p. 74.-Herrick, Bnll. Denison Univ., IV, 1888, p. 12.-Hall and Clarke, Pal. New York, VIII, l't. I, 1892, p. 125, fig. 64; p. 128, fig. 160 and pp. 160, 168.-Winchell and Schuchert, Minnesota Geol. Survey, III, 1893, p. 363.-Hall and Clarke, Eleventh Ann. Rep. N. Y. State Geologist, 1894, p. 256 .

Discina Hall (non Lamarck), Pal. New York, III, 1859, p. 159;-Sixteenth Rep. N. Y. State Cab. Nat. Hist., 1863, p. 130;-Pal. New York, IV, 1867, p. 15.

Orbiculoidea alleghania (Hall). Chemung (Dev.).

Discina alleghania Hall, Thirteenth Rep. N. Y. State Cab. Nat. Hist., 1860, p. 77, figs. 1, 2;-Pal. New York, IV, 1867, p. 25, tig. 1, pl. 1, fig. 17.

Loc. Hobbieville, Alleghany County, New York.

Orbiculoidea ampla Hall.

Oriskany (Dev.).

Discina, grandis Hall (non Vanuxem, 1842), Pal. New York, IIL, 1859, p. 406, pl. 92 , tig. 1.

Discina ampla Hall, Ibidem, corrigenla in volume with plates, 1859.

Orbiculoidea ampla Hall and Clarke, Pal. Now York, VIII, Pt. I, 1892, p. 127.

Loc. Albany County, New York; Cayuga, Ontario.

Orbiculoidea baini (Morris and Sharpe.)

Middle Devonian.

Orbicula haini Morris and Sharpe, Quart. Jour. Geol. Soc. London, II, 1846, p. 277, pl. 10, fig. 5.-Sharpe and Salter, Trans. Geol. Soc. London, 2d ser., VII, 1856 , p. 210 , pl. 26 , tigs. $20-23$.

Discina baini von Ammon, Zeits. Gessels. fiir Ertk., Berlin, XXVIII, 1893, p. 359 , fig. 4 .

Loc. Falkland Islands; Taquarassu, Matto.Grosso, Brazil; South Africa. 
Orbiculoidea (?) capax (W'hite).

Kinderhook (L. Carko).

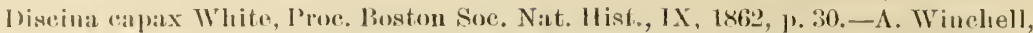
Proc. Acad. Nat. sci, l'hilade]phia, 1865, p. 112;-Proe. Ameriean P'hil, Soc, XII, I870, 1., 2.19.

loe. Burlington, Iowa; (rirard and Roekville, Ohtio (A. Winchell).

Ohs. 'This speeies should lw eompared with Lingulodiseina newherryi Hall.

Orbiculoidea capuliformis (MeChesney).

Upper Carboniferous.

Discina eapuliforma McChesueg, New Pal. Fossils, I8to, p. 72;-Trans. Chicago Arad. Sci., I, 1868, p. 73, pl. 2, fig. 20.

loc. springfield, Illinois.

Obs. Compare with (1, 'ouvexal Shumard.

Orbiculoidea conica Dwight=Schizotreta cuniea.

Orbiculoidea conradi (Hall).

Lower Heliterberg (Dev.).

1)iscina conrali 1Iall, Hal. New York, II, 1859, 1.161, pl.9, figs. 16, 17; 1. 10A, fig. 2.

Loc. Near IIndson, New York.

\section{Orbiculoidea convexa (Shmmard).}

Upper Carboniferous.

Hiscina convexa Shmuard, Trans. St. Loins Acad. Sei., I, 1858, p. 221.-White, Thirtecuth Rep. State Geol. Indiana, 1881, p. 121, pl. 25, fig.9.-Herrick, Bull. Denison Inir., I, 1887. pl.3, fig. 19.-Keyes, Geol. Snrvey Missonri, V, 1895, p. 40 , 1) 1. 35, fig. 7 .

Loc. Valley of' Verligris River, Kansas: Kansas City, Missonri; Vermilion County, Indiana; Newark, Ohio.

obs. See Orbiculuidea capuliformis Mcchesney.

Orbiculoidea discus Itall.

Lower Helderberg (Dev.).

Uiscina riscus Hall, Pal. New York, III, 1859, p. 159, pl. 9, figs. 13-15.

Schizocrania (?) diseus Hall and Clarke, Pal. New York, VIII, Pt. I, 189:, p. 132. Orhiculoidea discus Hall and Clarke, Ibidem, 1892, pl. 4E, fig. 13.

Loc. Near Hudson and Albany counties, New York.

Orbiculoidea doria (Hall).

Hamilton (Dev.).

Discina doria Hall, Sixteenth Ren. N. Y. State Cah. Nat. Hist., 1863, 1. 26;-Pal.

New York, IV, 1867, 1. 19, pl. 2, ligs. 19-22, 31 (930).-Nettelroth, Kentucky Fossil shells, Mem. Kentucky (ieol. Survey, 1889, 1. 32.

Loc. Madison County, New York; Thedford, Ontario; Clark County, Indiana.

Orbiculoidea elmira (Hall).

Chemung (Dev.).

liscina elmira Hall, Sixteenth Rep. N. Y. State Cab. Nat. Hist., 1863, p. 29 ; Pal. New York, IV, 1867, p. 24, pl. 2, figs. 38, 39.

Loc. Elmira, New York; Wellsboro, Pennsylvania.

Orbiculoidea gallaheri (A. Winchell).

Marshall (L. Carb.).

Discina gallaheri A. Winchell, Proc. Acarl. Nat. Sci. Philadelphia, 1865, p, 112;-

Proc. Ameriwan Philosophical Soc., XII, 1870, p. 249.

Loe. Hillsdale, Michigan; Granville, Ohio; Shafers, Pennsylvania.

Orbiculoidea herzeri Hall and Clarke. Waverly (L. Carb.).

Orhicnloidea herzeri Hall and Clarke, Ial. Now York, VIII, Pt. I, 1892, p]). $126,127,178$

Orbienloidea pmlehra IIall and Clarke, Ibulem, 1892, pl. 4E, fig. 19; pl. 4F, figs. $9-13,30,(? 14-16)$.

Loc. Berea aud Baconsburg, Ohio; Mealville, Pemsylvania.

Orbiculoidea humilis (Hall).

Marcellus and Hamilton (Dev.).

Discima humilis Ifall, Sixteenth Rep. N. Y. State Cab. Nat. Hist., 1863, p. 25;Pal. New York, IV, 1867, p. 16, pl. 2, fig. 18.-Whitfield, Annals N. Y. Acad. Sei., V, 1891, p. 560;-Geol. (1hio, V1I, 1895, p. 452, pl. 8, figs. 1, 2.

Lor. Bridgewater, Canandaigna Lake, ete., New York; Leroy, Ohjo. 
Orbiculoidea illinoisensis (Miller and Gurley).

Upper Carboniterous.

Discina illinoiensis Miller aud Gurley, Bull. Illinois State Mus. Nat. Hist., 3, 1893, p. 70, pl. 7, figs. 2-5.

Loe. Luox and Peoria comnties, Illinois.

Obs. Closely related to O. convexia.

Orbiculoidea jervisensis (Barrett).

Oriskany (Dev.).

Discina jervensis Barrett, Annals N. Y. Aead. Sei., I, 1878, p. 121.

Loc. Port Jervis, New York.

Orbiculoidea keokuk (Grurley).

Keokuk (L. Uarb.).

Discina keokuk Gurley, New Carb. Fossils, 1884, p. 6.

Loc. Craw fordsville, Indliana.

Orbiculoidea lamellosa Hal].

Treuton and Lorraine (Ord.).

Orbicula lamellosa Hall (non Broderip, 1833), Pal. New York, 1, 1847, p. 99, pl. 30 , fig. 10.

Orbicula truncata Emmons, Americun Geologs, Pt. I1, 1855, ]'. 200, fig. 62.

Diseina truneata Emmous, Manual of Geol., 1860, ]". 99.

Orbiculoirlea lamellosa? Winchell and Sehuchert, Minnesota Geol. Survey, III, 1893, p. 364, pl. 29, fig. 25.

Orbiculoidea lamellosi Hall and Clarke, Pal. New York, VIII, Pt. 1, 1892, pí. $1 \mathrm{E}$, fig. 12.

Discina circe Billings, Pal. Fossils, I, 1862, p. 51, fig. 55;-Geol. Canala, 1863, 1. 159 , fig. 125 .

Loc. Middleville and Lowville, New York; Bellville and (ottawa, Cauala; Spring Valles, Minnesota.

()bs. Orbienla lamellosa Broderip, is the type species of liscinisea, and Ilall's name will therefore stand.

Orbiculoidea lodiensis (Vanuxem).

Genesee (Tev.).

Orbieula lorlensis Vamnem, Geol. N. X.; Rep. Third Dist., 1842, p. 168, fig. 1.11:11, Ibidem, Rep. Fonrth Dist., 1843, p. 223, fig. 1.

Diseina loclensis Hall, Pal. New York, IV, 1867, 1. 22, 1) 1. 1, fig. 14; pl. 2, fig. 35.Rathlun, 13ull. Buftalo Soc. Nat. Sci., I, 1874, 1. 257;-Proc. Boston Soe. Nat. Ilist., XX, 1879, P. 17.-Walcott, Mon. U. S. Geol. Survey, YIII, 1881, 1. 112, pl. 2, fig. 5.-Clarke, 13u11. 1T. S. Geol. Surves, 16, 1885, 1. 21.-Whitfielı, Annals N. Y. Aead. Sei., V, 1891, 1. 517, pl. 11, fig. 7;-Geol. (Hio, VII, 1895, 1. $442, \mathrm{pl} .7, \mathrm{fi} g .7$.

Discina sp. a A. Ulrich, N. Jahrb. fiir Mineral., Beilageband, VIII, 1892, n. 81, pl. 5 , fig. 10 .

Orhiculoidea lodensis Hall and Clarke, Pal. New York, VIII, Pt. I. 1892, pl. 1F, fing. 21.

Loc. Lodi, ete., New York; White I'ine listrict, Nevala; Erere, I'rovinceuf l'ara, Brazil; C'haluarani, Bolivia. In the Mareellus shale of Delaware County, Ohio (Whitfield).

Orbiculoidea lodiensis media Hall.

Marcellus-Chemung (Dev.).

Discina media Ilall, Sixteenth Rep. N. Y. State Cal. Nat. IIist., 1s63, 1). 27;Pal. New York, IV, 1867, 1. 20, 11. 2, tigs. 25-29.-Walcott, Mon. U. S. Geol. Survey, V1IJ, 1884, p. 113.

Orbieuloidea media 11 all and Clarke, Pal. New York, VII, Pt. I, 1892, pl. 4E, figs. 15-17.

Loc. Seneca and Canandaigua lakes, New York; Chemung group, Troupsburg, New York.

Orbiculoidea magnifica (Herrick).

Waverly (L. Carb.).

Discina magnifica Herriek, Bull. Goul. Soc. America, II, 1891, p. 46, pl. 1, lig. 17.

Loc. Wooster, and Ashland County, Ohio. 
Orbiculoidea manhattanensis (Meek and Hayden). Upper Carboniferous.

1)iscina mamhattemsis Meek and llayclen, P'roc. Acad. Nat. Sci. Plibadelphia, 1859,1 . 25.

loc. Near Manlattan, Kansas.

Orbiculoidea marginalis (Whitticld).

Hamilton (Dev.).

Discina narginalis Whittelt, Ann. Rep. Geol. Survey Wisconsin, 1880, p. 70;Geol. snrvey Wisconsin, IV, 1882, p. 325, pl. 25, tig. 11.

(Trbiculoidea marginalis IIall and Clarke, Pal. New York, VIII, Pt. I, 1892, P. 127, J). 4 F, fig. 17.

Loc. Milwaukee, Wiscousiu.

Orbiculoidea minuta (Hall).

Marcellus-Hamilton (Dev.).

Orbicula minuta Hall, Geol. N. Y. ; liep. Fourth Dist., 1843, p. 180, fig. 9.

Discina minuta Hall, Pal. New York, IV, 1867, p. 16, pl. 1, fig. 16.-Walcott, MLon. U. S. Geol. Survey, VIII, 1884, [. 112, pl. 13, fig. 5.-Whitfield, Aunals N. Y. Acad. Sci., V, 1891, p. 547, pl. 11, figs. 5, 6;-Geol. OLio, VII, 1895, p. 442, pl. 7 , figs. $5,6$.

Orbiculoidea minuta Beecher, American Jour. Sci., 3d ser., XLI, 1891, p. 356, pl. 17, figs. 5-7;-Americau Jour. Sci., 3il ser., XLIV, 1892, p. 150, pl. 1, figs. 4-6.

Loc. Avon, New York; Delaware Connty, Ohio; near Eureka, Nevada.

Orbiculoidea missouriensis (Shumard).

Upper Carboniferous.

Discina misson riensis Shumari, Trans. St. Louis Acad. Sci., I, 1858, p. 221.

Discina nitida? Meek and Worthen (nou Phillips), Geol. Survey Illinois, V, 1873, p. 572, pl. 25 , fig. 1 .

Discina nitida White, Thirtecuth Rep. State Geologist Indiana, 1881, p. 121, pl. 25, fig. 10.-Keyes, Proc. Acad. Nat. Sci. Philadelphia, 1888, 1. 226.-Hall and Clarke, Pal. New York, VIII, Pt. I, 1892, 1. 131, pl. 4F, figs. 23-28.-Keyes, Geol. Survey Missouri, V, 1895, p. 39, pl. 35, fig. 6.

Discina meekana Whitfield, Annals N. Y. Acarl. Sci., II, 1882, 1. 228.-Herrick, Bull. Denisou Univ., II, 1887, p. 145, pl. 2, tig. 8.- Whitfield, Annals N. Y. Acad. Sci., V, 1891, p. 598, pl. 15, figs. 1-3;-Geol. Ohio, VII, 1895, 1. 483, pl. 11, figs. 1-3.

Loc. Lexington, Missouri; Illinois; Carbou Hill and Fliut Ridge, Ohio; Des Moines, Iowa; Vermilion County, Indiana.

Obs. This species is not D. nitida Phillips. It differs from it in form and in the wuscular scars.

Orbiculoidea (?) munda (Miller and Gurley).

Upper Carboniferons.

Discina munda Miller and Gurley, Bull. Illinois State Mus. Nat. Hist., 3, 1893, 1. 71, pl. 7, figs. 6,7 .

Loc. Kansas City, Missouri.

Obs. This species may be a Lingulodiscina, but since the ventral valve is unknown satisfactory generic reference can not be made.

Orbiculoidea neglecta (IIall).

Chemung (Dev.).

Discina neglecta IIall, Sixtcenth Rep. N. Y. State Cab. Nat. Hist., 1863, r. 29;Pal. New York, IV, 1867, p. 24, pl. 1, figs. 12, 13.

Loc. Ithaca, New York.

Urbienloidea newberryi Meek=Lingulodiscina newberryi.

Orbiculoidea nitida (Phillips).

Upper Carboniferous.

Orbicnla nitida Phillips, Geol. Yorkshire, II, 1836, p. 221, pl. 9, 1igs. 10-13.

? Discina nitida Walcott, Mon. U. S. Geol. Survey, VIII, 1884, p. 213, pl. 7, fig. 4.

Loc. England; White l'ine district, Nevada. 
Orbiculoidea numulus Hall and Clarke.

Waterlime (Sil.).

Orbiculoidea numulus Hall and Clarke, Pal. New York, VIII, Pt. I, 1892, p. 178, pl. $4 \mathrm{E}$, fig. 14.

Loc. Marshall, New York.

Orbiculoidea parmulata (Hall).

Orbicula parmulata Hall, Geol. New York; Rep. Fourth Dist., 1843, p. 48, fig. 4;Pal. New York, II, 1852, pl. 4, fig. 3.

Loc. Međina and Lockport, New York.

Orbiculoidea patellaris (A. Winchell).

Kinderhook (L. Carb.). Discina patellaris $\Lambda$. Winchell, Proc. Acad. Nat. Sci. Philadelphia, 1863, p. 4.

Loc. Burlington, lowa.

Orbiculoidea pleurites Meek=Lingulodiscina pleurites.

Orbiculoidea pulehra Hall=Orbieuloidea hertzeri.

Orbiculoidea randalli Hall.

Hamilton (Lev.).

Discina randalli Hall, Sixteenth Rep. N. Y. State Cab. Nat. Hist., 1863, 1. 25;Pal. Now York, IV, 1867, p. 18, pl. 2, fig. 34.

Orbiculoidea randalli Hall and Clarke, Pal. New York, VIII, Pt. 1, 1892, pl. 4E, tig. 18.

Loc. Schoharic, Now York.

Orbiculoidea saffordi (A. Winchell).

Lower Carboniferous.

Discina saffordi A. Winchell, Geol. Tennessce, 1869, p. 443;-Proc. American Philosophical Soc., XI1, 1870, p. 248.

Loc. "Just above Black Slate," Hickman County, Tennessee.

Orbiculoidea sampsoni (Miller).

Chouteau (L. Carb.).

Discina sampsoni Miller, Seventeenth liej. State Geol. Indiana, 1891, 1. 80, pl. 13, figs. $10-12$.

Loc. Sedalia, Missouri.

Orbiculoidea seneca (Hall).

Hamilton (Dev.).

Discina seneca IIall, Sixteenth Rep. N. Y. State Cab. Nat. IIist., 1863, 1. 26;Pal. New York, IV, 1867, p. 20, jl. 2, figs. 23, 24.

Loc. East shore of Sencea Lake, New York.

Orbiculoidea subplana (Hall).

Arisaig (Sil.).

Discina tenuilamellata var. subplana 11all, Canadian Nat. Geol., V, 1860, 1. 114.Darvson, Acadian Geol., 3d ed., 1878, p. 595.

Loc. Arisaig, Nova Scotia.

Orbiculoidea subtrigonalis (McChesney).

Upper Carboniferons.

Discina subtrigonalis McChesney, New Pal. Fossils, 1865, 1. 97.

Discina trigonalis McChesney, Ibidem, 1865, pl. 2, fig. 19;-Trans. Chicago Acad. Sci., 1, 1868, p. 24, pl. 2, fig. 19.

Loc. Lasalle, Lllinois.

Orbiculoidea tenuilineata (Meek and Hayclen). Upper Carboniferous.

Discina tenuilineata Heek and Hayden, l'roc. Acal. Nat. Sci. Philadelphia, 1859, p. 25.

Loc. Cottourwood Creek, Kansas.

Orbiculoidea tenuistriata (Ulrich).

Utica (Ord.).

Discina tenuistriata Ulrich, Jour. Cincinnati Soc. Nat. Hist., I, 1878, 1. 96, pl. 4, fig. 10.

Loc. Covington, Kentucky. 
Orbiculoidea tullia (Hall).

'T'ully (1)ev.).

Discina tullia Hall, Sixteontl Rep. N. Y. State Cab. Nat. Hist., 1863, 1. 28;-1'al. New York, IV, 1867, 1. 22, pl. 2, tigs. 16, 17.

Loc. Sencea Lake, New Jork.

Orbiculoidea utahensis (Meek).

Upher Carboniferous.

Diseina sp. nndet., Meek, King's T. S. Geol. Fxpl. 40th Parl., IV, 1877, 1. 99, 11. 10, fig. 3 .

Disciua utahensis Meek, Ibidem, 1877, 1. 99 (also see lootnote, p. 9).

L.oc. Weber Canyon, Wasateh Range, Utal.

Orbiculoidea vanuxemi (Hall).

Arisaig and Waterlime (Sil.).

Discina vanmxemi IIall, Pal. Now York, III, 1859, p. 162, pl. 8, dig. 1.

Loc. Manlius-square; New York; Arisaig, Nova Seotia (Ami).

Orbiculoidea varsaviensis (Worthen).

Keoknk (L. Carb).).

Diseina varsoviensis Worthen, 13ull. Illinois State Mus. Nat. Hist., 2, 1881, p. 23 ;-Geol. Survey Illinois, VIII, 1890, p. 102, pl. 1i, fig. 7.

Loc. Warsaw, Illinois.

ORISKANIA Hall and Clarke.

Genotype O. navicella 11. and C.

Oriskania Hall and Clirke, Pal. New York, VIII, Pt. 1I, 1893, p. 270;-Thirteenth Ann. Rep. N. Y. State Geologist, 1895, p. 85.1.

Oriskania navicella Hall and Clarke.

Oriskany (Dev.).

Oriskania navicella Hall and Clarke, Pal. New York, V1II, Pt. 1I, 1893, p. 269, figs. 181-183, pl. 79, figs. 25-27.

Loc. Near Hudson, New York.

ORTHIDIUM Hall and Clarke. Genotype Orthis gemmicula Billings.

Orthidium Hall and Clarke, Pal. New York, V1Il, Pt. I, 1892, p. 244 ;-Eleventh Ann. Rep. N. Y. State Geologist, 1894, p. 276.

Orthidium gemmicula (Billings).

Orthis gemmicnla Ballings, Pal, Fossils, I, 1862, p. 75, tig. 68.

Orthidium gemmicula IIall and Clarke, Pal. New York, VI1I, Pt. 1, 1892, pp. $217,24 .$, pl. $7 \mathrm{~A}$, figs. 22-25.

Loc. Point Levis, Canada.

\section{Orthis of authors.}

Orthis Hall, Pal. New York, IV, 1867, p. 33. - Shaler, Fossil Brachiopodit of the Ohio Valley, 1887, p. 18.-Herrick, Bull. Denison University, IV, 1888, p. 14.-Nettelroth, Kentueky Fossil Shells, Mem. Kentucky Geol. Survey, 1889, p. 34.-Hall, Bull. Geol. Soe. America, I, 1889, p. 19.-Hall and Clarke, Pal. New York, VIIl, I't. I, 1892, 11). 185, 186;-Eleventh Ann. Rep. N. Y. State Geologist, 1894, 1. 264.

ORTHIS Dalman (emend Hall and Clarke).

Genotype Orthis ealligramma Dalman.

Orthis Dalnan, Kongl. Svenska Yet.-Akarl. IIandl., fïr 1827, 1828, pl. 93, 96.-11all and Clarke, Pal. New Yurk, VHI, 1’t. 1, 1892, 1. 192.-Winchell and Schuchert, Minnesota Geol. Survey, 11I, 1893, p. 417.- Hall and Clarke, Eleventh Ann. Rej. State Goologist, 1894, 1). 265.

Orthis aequivalvis Hall, $1847=$ Plectorthis aequivalvis.

Orthis arquivalvis Hall, 1857 (nou 1847)=Orthis eryna.

Orthis aquivalvis Shaler (non Hall)=Rhipidomella uberis.

Orthis (?) acuminata Billings.

Chazy (Ord.).

Orthis ? acuminata Billingrs, Canadian Nat. Geol., IV, 1859, 1. 410, fig. 19.

Orthis aenminata Billings, Gool. Canadi, 1863, p. 130, tig. 59.

Loc. Caughuawaga, Canadi. 
Orthis acntilirata Meek=Platystrophia acutilirata.

Orthis acntiloba Ringueberg=Bilobites acutilobus.

Orthis alata Shaler $=$ Orthis davidsoni.

Orthis alsus Hall= Rhipidomella alsa.

Orthis (?) alternans Castelnau.

Formation.?

Orthis alternans Castelnau, Essai Syst. Sil. l'Amérique Septentrionale, 1843, p. 38 , pl. 14, fig. 2.

Loc. "Fron an erratic hlock, Lake of the IVoots." Undetermimable.

Orthis amona N. H. Winchell=Dahmanella amcua.

Orthis anticostiensis Shaler $=$ Dinorthis porcat:.

Orthis (?) apicalis Billings.

? Upper Cambrian.

Orthis? apicalis lBillings, Pal. Fossils, I, 1865, p. 301, tig. 291.-Hall anl Clarke, l’al. New York, VIII, Pt. I, 1892, p. 217.

Loc. Point Levis and west end of Island of Orleans, Canada.

Orthis arachnoides Roemer and Hall (non Phillips)=Derbya crassa.

Orthis armanda Billings=Syntrophia armanda.

Orthis assimilis Hall=Rhipidomella assimilis.

Orthis aurelia Billings=Plectorthis amrelia.

Orthis aymara Salter $=$ Anoplotheca tlabellites.

Orthis barabnensis Winchell=Syntrophia barabnensis.

Orthis battis Billings= Hebertella battis.

Orthis bellarugosa Courad = Hebertella bellirugosa.

Orthis bellarugosa Hall, 1853= Hebertella insculpta.

Orthis bellula Meek= Dalmanella bellula.

Orthis benedicti Miller.

Orthis benedicti lliller, Seventeenth Rep. State Geol. Indiana, 1891, p. 78, pl. 13 , figs. $7-9$.

Loc. Hartsville, Indiana.

Orthis bicostatus Vanuxem=Reticularia bieostata.

Orthis biforata of authors=Platystrophia biforata.

Orthis biforata acutilirata White= Platystrophia acutilirata.

Orthis billingsi Hartt=Billingsella billingsi.

Orthis biloba Hall= Bilobites bilobus.

Orthis bisuleata Emmons=Cyelospira bisulcata.

Orthis borealis Billings= Hebertella horealis.

Orthis(?) buchi d'Orbigny.

Upper Carboniferous.

Orthis bnchi d’Orbigny, Voyage rlans l'Amérique Méridionale, Pal., 1842, p. 49.

Productus andii d'Orbigny, lbilem, p. 54, pl. 5, tigs. 1-3,-de Koninck, Recher. Animaux Foss., Pt. I, 1847, p. 238.

Loc. Yarlichambi, Bolivia.

Orthis calligranma Foerste (non Dalman)=Orthis flabellites.

Orthis calligramma davidsoni Nicholson and Hinde=Orthis davidsoni.

Orthis calligramma Kayser.

Lower Ordovieian.

Orthis calligramma Kayser (non Daviılson), Palrontographica, Suppl., III, 1876, pp. 18, 26, pl. 3, figs. 9-18.

Loc. Corllillere San Juan, Argentine Republie.

Obs. These shells appear to he more closely related to O. plicatella than to $O$. ealligramua. 
Orthis canalis Hall= Dalmanella elegantula.

Orthis carbonaria Swallow=Rlipirlomella pecosi.

Orthis carinata Hall=Srhizophoria earinata.

Orthis carleyi Hall=Dinorthis retrorsa.

Orthis caransii Salter.

Calciferoms (Oril.).

Orthis carausii (Salter, MS.) Davidsou, Geol. Mag. London, V, 1868, p. 315, pl. 16 , fig. 23.

Orthis carausii ? Matthew, Trans. Royal Soc. Canarla, X, 1893, p. 102, pl. 7, tig. 7.

Loc. Englanı; near St. John, New Brunswick.

Orthis (?) centrilineata Hall.

Lorraine (Ord.).

Orth is centrilineata Hall, Pal. New York, 1, 1817, 1. 289, pl. 79, fig. $5 *$.

Loc. Lorraine and Turin, New York.

Orthis centrosa Miller = Platystrophia crassa.

Orthis charlotte Winchell=Dinorthis pectinella.

Orthis cincinuatiensis Miller=Orthis? pumili.

Orthis (?) circularis N. H. Winchell= Dalmanella subsequata circularis.

Orthis circulus IIall= Rhipidomella cireulus.

Orthis clarkensis Swallow = Rhipidomella clarkensis.

Orthis cleobis Hall=Rhipidomella cleobis.

Orthis clytie Hall=Heterorthis clytie.

Urthis colorarloensis Meek, $1870=$ Orthis ? desmoplenra.

Orthis coloradoensis Shumard=Billingsella coloradoensis.

Orthis concinna Hall= Dalmanella concinna.

Orthis (?) concinna Morris and Sharpe.

Lower Devonian.

Orthis concinna Morris and Sharpe, Quart. Jour, Geol. Soc. London, II, 1846, p. 275 , pl. 10, tig. 2 .

Loc. Falkland Islands.

Obs. Probably a species of Orthothetes.

Orthis conradi Castelna $\mathrm{u}=$ Hipparionyx proximus.

Orthis conradi N. H. Winchell=Dalmanella subaequata comradi.

Orthis cooperensis Swallow= Rhipiclomella dubia.

Orthis cora d'Orbigny= Schizophoria cora.

Orthis corinna Billings.

Orthis corinna Billings, Pal. Fossils, I, 1865, p. 302, fig. 292.

Orthis ? corinna Hall and Clarke, Pal. New York, VIII, Pt. I, 1892, 1. 217.

Loc. Stanbridge, Quebec, Canada.

Orthis corpulenta Sardeson=Dalmanella testudinaria meeki.

Orthis costalis Hall.

Chazy (Ord.).

Orthis costalis Hall, Pal. New York, I, 1817, p. 20, pl, 4 bis, fig. 4;--Second Ann. Rep. N. Y. State Geol., 1883, pl. 34, tigs. 35-38.-Hall aud Clarke, Pal. New York, VIII, Pt. I, 1892, pp. 221, 228, pl. 5, figs. 15-17.

Loc. Chazy, New York.

Orthis costata Hall (non Sowerby)=Orthis pumila.

Orthis crassa James=Platystroplia crassa.

Orthis crenistria Geinitz=Derbya crassa.

Orthis crispata Limmons=Dalmanella erispata.

Orthis cumberlandia IIall=Rhipidomella cumberlandia.

Orthis cumeata Owen=Rhipidomella cmeata. 
Orthis cyclas Hall=Rhipidomella cyclas.

Orthis cyclus James=Dalmanella testudiuaria emacerata.

Orthis cypha James=Platystrophia laticosta.

Orthis dalyana Miller=Rhipidomella dalyana.

Orthis davidsoni de Verneuil.

Anticosti and Niagara (Sil.).

Orthis davidsoni de Verneuil, Bull. Soc. Géol, de France, 2d ser., V, 1848, 1. 341, pl. 4, fig. 9.-13illings, Geol. Canada, 1863, p. 312, fig. 318. - Hall and Clarke,

Pal. Now York, V1II, Pt. I, 1892, pp. 192, 193, 221, 228, pl. 5, figs. 5-8.

Orthis alata Shaler, Bull. Mus. Comp. Zool., 4, 1865, p. 66.

Orth is calligramma var. davidsoni Nicholson and Finde, Canadian Jour., n. ser.,

XIV, 1874, p. 144.-Nicholson, Pal. Prov. Ontario, 1875, p. 47, fig. 21g.

Loc. Europe; Anticosti; Dundas, Ontario.

Orthis daytonensis Foerste $=$ Hebertella daytonensis.

Orthis deformis Hall=Orthothetes deformis.

Orthis (?) delicatula Billings.

? Calciferous (Ord.).

Orthis delicatula Jillings, Pal. Fossils, I, 1865, p. 217.

Loc. Pistolet Bay and near Portland Creek, Newfoundland.

Orthis dentata Meek (nou Pander)=Platystrophia crassa.

Orthis (?) desmopleura Meek.

Calciferous (Ord.).

Orthis coloradoensis Meek (non Shumard), I'roc. American Phil. Soc., II, 1870, p. 425 .

Orthis desmopleura Meek, Hayden's U. S. Geol. Survey Wyoming, 1872, 1. 295.

Loc. Colorado City and Maniton, Colorado.

Orthis dichotoma Hall=Plectorthis dichotoma.

Orthis diseus Hall=Rhipidomella diseus.

Orthis disparilis Courad=Orthis tricenaria.

Orthis disparilis $\mathrm{O}$ wen=Dalmanella testudinaria.

Orthis disparilis Kayser.

Ordovician.

Orthis disparilis Kayser (non Conrad), Palieontographica, Suppl., 111, 1876, p. 26 , pl. 3, figs. 4-8.

Loc. Potrero de los Angulos, ete., Argentine Republic.

Obs. Probably a new species.

Orthis dubia Hall=Rhipidomella dıbia.

Orthis eboracensis Miller=Dalmanella lenticularis.

Orthis electra Billings=Dalmanella electra.

Orthis elegantula Dalman=Dalmanella elegantula.

Orthis elegantula parva Foerste $=$ Dalmanella elegantula parva.

Orthis ella Hall= Plectorthis ella.

Orthis emacerata Hall=Dalmanella testudinaria emacerata.

Orthis emacerata Meek (non Hall)=Dalmanella testudinaria neeki.

Orthis emarginata Hall=Rhipirlomella oblata emarginata.

Orthis eminens Hall=Rhipidomella eminens.

Orthis erratica Hall=Catazyga erratica.

Orthis (?) eryna Hall.

Corniferous (Dev.).

Orthis aequivalvis Hall (non Hall, 1847), Tenth Rep. New York State Cab. Nat. Hist., 1857, p. 109.

Orthis eryna Hall, Sixtcenth Rep. Ibidem, 1863, p. 35;-Pal. New York, IV, 1867, corrigenda.

Orthis idlas Hall, Pal. New York, IV, 1867, 1. 42, pl. 5, fig. 11.

Loc. Williamsville, New York.

Obs. Possibly a species of Hipparionyx. 
Orthis (?) eudocia Billings.

Calciferous (Ord.).

Orthis endocia lillings, ['al. Fossils, 1, 18ti2, 1. 83, fig. 7i.

Loc. Point Lovis, C'anala.

Orthis (?) eurekaensis Wilcott.

Upper Cambrian.

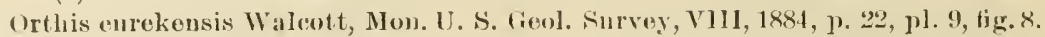
Protorthis? enrekensis Hall and Clarke, Pal. New York, VII1, 1't. I, 1s!2, 1'.232. Loc. Fureka district, Novada.

Orthis euryone Billings.

Calciferons (1) rel.).

Orthis euryoue Billings, Pal. Fossils, I, 1862, 1. 78, fig. 71.-Hall and Clarke, Pal.

New Jork, VI11, P1. I, 1892, pl. 221, 2.28, pl.5, fig. 4.

Orthis euryone? Mattlew, Trans. Royal Soc. Cunada, 1893, 1. 101, pl. 7, fig. 5.

Loc. Point Levis, Canala; near St. John, New Brunswick.

Orthis evatue Billings= Dalmanella evadne.

Orthis fasciata Hall=Orthostrophia fasciata.

Orthis fausta Focrste=Hebertella fausta.

Orthis tissicosta Meek, and Miller=Plectorthis dichotoma.

Orthis fissicosta Hall=Plectorthis tissicosta.

Orthis (?) fissiplica Roemer.

Niagara (Sil.).

Orthis fissiplica Roemer, Die silurisehe Fauna des west. Tennessee, 1860, p. 64, I) $1.5, \mathrm{fig} .5$.

Loc. Perry County, Tenuessee.

Orthis flabella Hall=Orthis flabellites.

Orthis flabellites Foerste.

(linton and Niagara (Sil.).

Orthis flabellulum? Hall (non Sowerby), feol. N. I.; Rep. Fourth Dist., 1843, p. 105, fig. 5 .

Orthis flabellulum var. Hall, Pal. New York, II, 1852, pp. 254, 255, pl. 52, figs. 6, 7.

Orth is flabellulum Jillings, Canadian Nat. (feol., 1, 1856, 1. 136, pl. 2, fig. 6.Nettelroth, Keutucky Fossil Shells, Mem. Kentucky Geol. Survey, 1889, p. 38, pl. 34, fig. 30 .

Orthis flabella Hall, Second Anu. Rep. N. Y. State Gool., 1883, pl. 34, figs. 41, 42; pl. 35, figs. 6-8.-Foerste, Bull. Denisou Univ., I, 1885, p. 82, pl. 13, fig. 12.

Orthis calligramma Foerste (non Dalman), Proc. Foston soe. Nat. Hist., XXIV, 1890, 1. 308, pl. 6 , figs. $4,5$.

Orthis flabellites Foerste, Ibiclew, 1890, p. 311.-Hall aud Clarke, Pal. Now York, VIII, Pt. I, 1892, p]. 221, 227, pl. 5, figrs. 37-41; pl. 20, fig. 1.

Orthis (Dinorthis) calligramma Focrste, Geol. Ohio, V11, 1895, p. 570, pl. 25, figs. $12 \mathrm{a}, 12 \mathrm{~h} ;$ pl. 31, figs. 4, 5 ; pl. 37A, fig. 20.

Loc. Lockport, Rochester, etc., New Jork; I)ayton, Ohio; Osgood, indiana; Lonisville, Kentucky; Milwaukee, Wiseonsin; Duudas, Ontario.

Orthis flabellites spania Hall and Clarke.

Niagara (Sil.).

Orthis flubellites var. spania Hall and Clarke, Pal. Now York, VIII, I't. II, 1895, pl. 84 , figs. 10 .

Loc. Near Milwankce, Wisconsin.

Orthis flabellulum Hall (non Sowerby)=Orthis flabellites.

Orthis (?) flava A. Winchell.

Kinderhook (L. Carb.).

Orthis flava A. Wiuchell, Proc. Acad. Nat. Sei. Philadelphia, 1865, p. 117.

Loc. Burlington, Iowa.

Orthis futilis Sardeson $=$ Dalmanella testudinaria futilis.

Orthis gemmicula Billings=Orthidium gemmicula.

Orthis gibbosa Billings=Dalmanella subieruata gibbosa.

Orthis goodwini Nettelroth=Rhipidomella goodwini, 
Orthis (?) glypta Hall and Clarke.

Niagara (Sil.).

Ortlis ? glypta IIall and Clarke, Pal. New York, VIII, Pt. II, 1895, p. 359, pl. 84, figs. 8, 9.

Loc. Near Milwaukee, Wisconsin.

Orthis halli Safford=Orthostrophia strophomenoides.

Orthis hambnrgensis Walcott=Dalmanella hamburgensis.

Orthis harttii Rathbun=Rhipidomella hartti.

Orthis (?) highlandensis Walcott.

Lower Cambrian.

Orthis(?) highlandensis Walcott, Bull. U. S. Geol. Survey, 30, 1886, p. 119, pl. 8, fig. 3.

Orthis highlandensis Walcott, Tenth An1. Rep. U. S. Geol. Survey, 1891, p. 612, pl. $7 \ddot{2}, \mathrm{fig} .5$.

Loc. Pioche and Highland Range, Nevadi.

Orthis hipparionyx llall - Hiplarionyx proximus.

Orthis hippolyte Billings.

Calciferons (Ord.).

Orthis hippolyte Billings, Pal. Fossils, I, 1862, 1. 81, fig. 73; 1. 218.-Hall and Clarke, Pal. New York, VIII, Pt. I, 1892, p1. 217, 221, 228.

Orthis hippolyte? Meek, Sixtl Anu. Rep. U. S. Geol. Survey Terr., 1873, p. 464.

Loc. Point Levis aud Phillipslunrg, Canada; Cow Head, Newfousdland; near Malade City, Utal.

Orthis (?) holstoni Safforrl.

Trenton (Ord.).

Orthis? holstoni (Safỉord MS.) Hall and (larke, Pal. New York, VIII, Pt. I, 1892, Pp. 218, 340, pl. 5A, figs. 35-37.

Loc. Near Nashville, Tennessee.

Orthis humboldti d'Orbigny.

Silurian.

Orthis humboldtii d'Orbigny, Voyage dans l'Amérique Méridiouale, Pal., 1842, p. 27.

Spirifer humbolıtii d'Orligigny, Ihidem, pl. 2, figs. 16-20.

Loc. Bolivia.

Orthis huroniensis Castlenan=Rafinesquina alternata.

Orthis hybrida Sowerby=Rhipidomella hybrida.

Orthis idas Hall=Orthis eryna.

Orthis idonea Hall=Tihipidomella idonea.

Orthis ignota Sardeson=Dalmanella testudinaria ignota.

Orthis imperator Billings=Hebertella imperator.

Orthis impressa Hall=Schizophoria striatnla.

Orthis ineqnalis Hall=Orthothetes inerpualis.

Orthis inca d'Orbigny = Rhipidomella inca.

Orthis infera Calvin=Dalmanella infera.

Orthis insenlpta Hall=Hebertella insculpta.

Orthis insignis Hall=Scenidinm insignis.

Orthis interlineata Hall (non Sowerby)=Sehizophoria tioga.

Orthis interstriata Hall=Orthothetes interstriatus.

Orthis iowensis Hall=Schizophoria striatula.

Orthis iowensis furnarius Hall=Sehizophoria striatulı.

Orthis iphigenia Billings=Dinorthis iphigenia.

Orthis jamesi Hall=Plectorthis jamesi.

Orthis jugosa .James=Dalmauella testudinaria meeki.

Orthis kankakensis McChesney=Plectorthis kankakiensis. 
Orthis kaskaskiensis McChesuey= Jerbya kaskaskiaensis.

Orthis kassuba Wincliell=Dalmanella subarpuata pervetus.

Orthis kennicotti McChesney=Dinorthis retrorsa.

Orthis keokuk Hall= Derbya keokuk.

Orthis lasallensis MeChesney=Derbya crassa.

Orthis laticosta Meck = Platystrophia laticosta.

Orthis (?) laticostata d'Orbigny.

Devonian.

Orthis lacticostata d'Orbigny, Vopage dans l'Amériøne Méridionale, Pal., 1842, p. 39 .

Lor. ? Bolivia.

Orthis lanrentina Billings=Billingsella? lanrentina.

Orthis lenticularis Wahlenberg?.

Upper Cambrian.

Orthis lenticularis (Wahl.) Kayser, Palipontographica, Suppl., IlI, 1876, p. 9, pl. 1, figs. 11, 12.-Natthew, Trans. Royal Soc. Canala, IX, 1892, 11. 46, pl. 12, figs. 9a-9d.

Loc. Province Salta and Jujuy, Argentine Republie; near St. John, New Brunswick.

Orthis lenticularis atrypoides Matthew.

Upper Cambrian.

Orthis lenticnlaris var, atrypoides Matthew, Trans. Soyal Soc. Canada, IX, 1892, p. 48 , pl. 12, tigs. $11 \mathrm{a}, 11 \mathrm{~b}$.

Loc. Near St. John, New Brunswick.

Orthis lenticularis lyncioides Matthew.

Upper Cambrian.

Orthis lenticnlaris var. lyncioides Matthew, Trans. Royal Soc. Canada, iX, 1892, p. 49 , pl. 12, figs. 10a-10c.

Loc. Near St. John, New Brunswick.

Orthis lenticularis strophomenoides Matthew.

Upper Cambrian.

Orthis lenticnlaris var. strophomenoides Mattlew, Trans. Royal Soc. Canada, IX, 1892 , p. 49 , pl. 12, figs. 12a, $12 \mathrm{~b}$.

Loc. Near St. John, New Brunswick.

Orthis lenticularis Vanuxem=Dalmanella lenticularis.

Orthis lentiformis Hall= Dalmanella lenticularis.

Orthis lentiformis Owen=Sehizophoria striatula.

Orthis leonensis Hall=Dalmanella tenuilineata.

Orthis lepirla Hall=Dalmanella lepida.

Orthis (?) leptænoides Emmons.

Trenton (Ori.).

Orthis leptinnoides Emmons, Geol. N. Y.; Rep. Fonrth Dist., 1812, p. 396, fig. 1.

Loc. New York.

Obs. Undefined and figure too poor for identification.

Orthis leucosia Hall=Rhipidomella lencosia.

Orthis limitaris Vanuxem=Leiorhynchus limitare.

Orthis linneyi James=Orthorhynchnla limneyi.

Orthis livia Billings=Rhipidomella livia.

Orthis lonensis Walcott $=$ Hebertella lonensis.

Orthis loricnla Hall=Dinorthis deflecta.

Orthis Incia Billings= Rhipiclomella lncia.

Orthis lyux Eichwald= Platystrophia lyux and P. biforata.

Orthis maria Billings=Hebertella maria.

Orthis mactarlanii Meek=Schizophoria mactarlanii. 
Orthis maeleodi Whitfield=Dalmanella maeleodi.

Orthis maerior Sardeson=Dalmanella testudinaria emacerata.

Orthis media Shaler=Rhipidomella media.

Orthis media N. H. Winehell=Dalmanella subiequata pervetus.

Orthis meeki Miller=Dalmanella testudinaria meeki.

Orthis menapiæ Hicks.

Oalciferous (Ord.).

Orthis menapice (Hicks MS.) Daridson, Geol. Mag. Lonılon, V, 1868, p. 314, pl. 16, figs. 24-28.-Matthew, Trans. Royal Soc. Canala, X, 1893, 1. 101, pl. 7, figs. 2-6.

Loc. England; near St. Johns, Now Brunswick.

Orthis merope Billings=Scenidium merope.

Orthis michelini L'Eveille= Rhipidomella miehelini.

Orthis michelini Meek, $1577=$ Rhipidomella nevadaensis.

Ortlis michelini burlingtonensis Hall=Rhipidomella burlingtonensis.

Orthis (?) minna Billings. Calciferous (Ord.).

Orthis minna Billings, Pal. Fossils, I, 1865, p. 303, fig. 294.

Loc. Stanbridge, Qnehec, Canada.

Orthis mimeapolis N. H. Winchell=Dalmanella subierquata.

Orthis minnesotensis Sardeson=Dinorthis meedsi.

Orthis missouriensis Shumard. Cape Girardeall Limestone (Sil.).

Orthis missouriensis Shumarl, Geol. Rep. Missouri, 1855, 1. 205, pl. C, fig. 9.Keyes, Geol. Survey Missouri, V, 1895, p. 60.

Loc. T'wo miles above Cape Girardean, Missouri.

Orthis missourieusis Swallow (non Shumard)=Rhipiłomella missonriensis.

Orthis mitis Hall=Rhipidomella mitis.

Orthis morganiana Derby=Orthotichia morganiana.

Orthis (?) morrowensis James.

Lorraine (Ord.).

Orthis (?) morrowensis James, Cincinnati Qnart. Jonr. Sei., I, 1874, 1. 21.

Lor. Warren County, Ohio.

Orthis multiseeta (James) Meek = Dalmanella multisecta.

Orthis multistriata Hall=Sehizophoria multistriata.

Orthis museulosa Hall=Rhipidomella museulosa.

Orthis (?) mycale Billings.

Calciferous (Oril.).

Orthis mycale Billings, Pal. Fossils, I, 1862, p. 82, fig. 7...-Hall and Clarke, Pal.

New York, VIII, Pt. I, 1892. p. 217, pl. 7A, figs. 10, 11.

Loc. Point Levis, Canada.

Orthis neglecta James=Pleetorthis dichotoma.

Orthis nettoana Rathbun=Dalmanella nettoaua.

Orthis nevarlensis Meek=Rhipidomella nevadaensis.

Orthis (?) nisis Hall and Whitfield.

Niagara (Sil.).

Orthis nisis Hall and Whitfield, Twenty-fourth Rep. N. Y. State Cah. Nat. Hist., 1872, p. 181 ;-Twenty-seventh Rep. Ibiclem, 1875, pI. 9, figs. 4-8.-Nettelroth, Kentucky Fossil Shells, Mem. Kentucky Geol. Survey, 1889, p. 42, pl. 27, figs. 4, 5.-Hall and Clarke, Pal. New York, VIII, Pt. I, 1892, p. 217.

Lor. Lonisville, Kentucky.

Ortinis nucleus Hall=Aubocolia umbonata.

Orthis oblata Hall=Rhipidomella oblata.

Bull. 87- 19 
Orthis ollata emarginata Hall=Rhipidomella oblata emarginata.

Orthis obtusa Pancler.

Ordovician.

Orthis obtus:l (l'auler) kayser, l'alieontographica, Suppl., III, 1876, p. 19, pl. 3, figs. $1,2$.

Loc. Furope; Cordillere San Juan, Argentine Republic.

Orthis oceasus Hall=Rhipidomella oceasus.

Orthis oceidentalis Hall=Hebertella occidentalis.

Ortlis ortlıambonites Billings=O. panderiana.

Orthis palmata Sharpe and Salter=Anoplotheca Habellites.

Orthis panderiana Hall and Clarke.

Calciferous (Ord.).

Urthis orthambonites Billings (non Murchison and de Verneuil), Pal. Fossils, I, 1862 , p. 77, fig. 70 ;-Geol. Canula, 1863, p. 231, fig. 245.-Sehnchert, Ninth Amm. Rep. N. Y. State Geol., 1890, 1. 43.-Hall and Clarke, Pal. New York, V1II, Pt. I, 1892, 1p. 221, 228, pl. 5, figs. 1-3.-Matthew, Trans, Royal Soc. Canarla, X, 1893, p. 101, pl. 7, fig. 4.

Orthis panderiana Hall and Clarke, Pal. New York, VIlI, I’t. I, 1892, pl. 5, footuote.

Loc. Point Levis and St. Johu, Canada.

Orthis parva de Vernenil=Dahnanella elegantula.

Orthis pecosi Mareou=Rhipilomella pecosi.

Orthis (?) pectinata d'Orbigny.

Devouian.

Orthis pectinatus d'Orbigny, Voyage dlans l'Amérique Méridionale, Pal., 1842, p. 39.

Spirifer pectinatus d'Orbigny, Ibidem, 1842, pl. 2, tigs. 13-15.

Loc. Lake Titicaca, Bolivia.

Obs. Probably a species of Orthothetes.

Orthis pectinella Emmons=Dinorthis peetinella.

Orthis pectinella Whitfield, 1SS2=Plectorthis whitfieldi.

Orthis peetinella semiovalis Hall=Dinorthis pectinella.

Orthis pedunenlaris Hall=Schizophoria peduneularis.

Orthis peloris $\mathrm{Hall}=$ Rhipidomella peloris.

Orthis penelope Hall=Rhipidomella penelope.

Orthis penniana Derby = Rhipidomella pemiana.

Orthis pennsylvanica Simpson=Rhipidomella pennsylvaniea.

Orthis pepina Hall= Billingsella eoloradoensis.

Orthis perelegans Hall=Dalmanella perelegans.

Orthis perversa Hall=Orthothetes chemungensis perversus.

Orthis perveta Conrad=Dalmanella subequata pervetus.

Orthis perveta Hall, $1883=$ Dalmanella subrequata.

Orthis petre Sardeson=Dinorthis proavita.

Orthis (?) pigra Billings.

Chazy (Ord.).

Orthis piger Billings, Canadian Nat. Geol., IV, 1859, p. 442.

Loc. Mingan Island.

Obs. This species is probably congenerie with Billingsella grandæeva.

Orthis pisum Hall (non Murchison)= Nucleospira pisiformis.

Orthis plana Castelnau (non Pander)=Rafinesquina alternata.

Orthis planoconvexa Hall= Dalmanella planiconvexa.

Orthis platys Billings=Dinorthis platys.

Orthis plicata Vanuxem =Spirifer vamuemi. 
Orthis plicatella White (nom Hall)=Orthis tricenaria.

Orthis plicatella Hall=Plectorthis plicatella.

Orthis pogonipensis Hall and Whitfield=Dalmanella pogonipensis.

Orthis porcata McCoy=Dinorthis porcata.

Orthis (?) porcia Billings.

Chazy (Ord.).

Orthis porcia Billings, Canalian Nat. Geol., IV, 1859, 1. 439, tigs. 16-18;-Geol. Canarla, 1863, p. 130, fig. 58.

Loc. Near Montreal, Canada.

Orthis porrecta Sardeson=Dalmanella testudiuaria porrecta.

Orthis pranmbona Hall=Amboecelia pr:eumbona.

Orthis pratteni McChesney= Derbya pratteni.

Orthis pravus Hall=Orthothetes pravus.

Orthis propinqua Hall=Schizophoria propinqua.

Orthis propinqua Nettelroth=Schizophoria striatula.

Orthis (?) pumila Ulrich.

Lorraine (Ord.).

Orthis costata (non Sowerby) Hall, American Jour. Sci., XLVIII, 1845, p. 295.-

Miller, Cincinnati Quart. Jonr. Sci., II, 1875, p. 33.

Orthis pumila Ulrich, Catalogue Cincinnati Fossils, 1880, p. 14.

Orthis cincimnatiensis Miller, American I'al. Fossils, 2d ed., 1883, p. 296.

Loc. Cincinnati, Ohio.

Orthis (?) punctostriata IIall.

Niagara (Sil.).

Orthis punctostriata Hall, Pal. New York, 1I, 1852, p. 254, pl. 52, fig. 5.

Orthis? punctostriata Hall and Clarke, Ibilem, VIII, Pt. I, 1892, p. 217, pl. 20, figs. 2-4.

Loc. Lockport, New York.

Orthis pyramidalis Hall=Scenidium pyramidalis.

Orthis quacoensis Matthew=Billingsella quacoensis.

Orthis quadrans Hall=Dalmanella quadrans.

Orthis quadricostata Vannxem=Leiorhynchus quadricostatum.

Orthis(?) remnicha N. H. Winchell. Upper Cambrian.

Orthis remnicha N. H. Winchell, Fonrteenth Ann. Rep. Geol. Nat. Hist. Survey of Minnesota, 1886, p. 317, pl. 2, fig. 7.

Loc. Red Wing, Minnesota; Cold Creek Canyon, Burnett County, Texas.

Orthis resupinata Hall, 1813 (non Martin)=Schizophoria tulliensis.

Orthis resupinata Martin $=$ Schizophoria resupinata.

Orthis resupinata latirostrata Toula=Schizophoria cora.

Orthis resupinoides Cox $=$ Schizophoria resupinoides.

Orthis retrorsa Salter $=$ Dinorthis retrorsa.

Orthis rhynchonelliformis Shaler = Rhipidomella rhynchonelliformis.

Orthis richmonda McChesney= Derbya crassa.

Orthis robusta Hall=Derbya robusta.

Orthis rogata Sardeson=Dalmanella testudinaria.

Orthis (?) rugiplicata Hall and Whitfield.

Niagara (Sil.).

Orthis rugreplicata Hall and Whitfield, Twenty-fourth Rep. N. Y. State Cab. Nat.

Hist., 1872, p. 182 ;-Twenty-serenth Rep. Iloidem, 1875, pl. 9, figs. 1-3.-

Hall, Second Ann. Rep. N. Y. State Geol., 1883, pl. 34, tigs. 25-27.-Nettelroth, Kentucky Fossil Shells, Mem. Kentucky Geol. Survey, 1889, p. 44, pl. 27, figs. 1-3.

Orthis rugiplicata, Hall and Clarke, Pal. New York, VIII, Pt. I, 1892, p. 217.

Loc. Louisville, Kentucky. 
Orthis (?) ruida Billiugs.

Anticosti (Sil.).

Orthis railit Billings, Catalogne Silurian Fossils of Anticosti, 1866, 1) 42.

Loc. Inticosti.

Orthis (?) saffordi Hall and Clarke.

Trenton (Ord.).

(1)this ? sifforll, Hall and Clarke, Hal. New York, VIII, I't. I, 1892, 1'). 218, 310, 1]. 5A, figs. 38-10.

Loc. "East Temnessce."

Orthis (?) salemensis Walcott.

Jower Cambrian.

Orthis salemensis Walcott, Anerican Jomr. Sici, 3t ser., XXXIV, 1887, 1. 190, pl. 1, fig. 17;-Tenth Ann. Rep. U. S. Geol. Survey, 1891, 1. 612, pl. 72, fig. 6.

Loc. Washington Comnty. New York; near Quebec, Canada.

Orthis saltensis Kayser.

Upper Cambrian. ()rthis saltensis Kayser, Palinontographica, Suppl., IIí, 1876, p. 8, pl. 1, fig. 16. Loc. Provinee Salta and Jujuy, Argentine Republuc.

Orthis (??) sandbergeri N. H. Winchell.

Upper Cambrian.

Orthis sandbergeri N. II. Winchell, Fourteenth $A \mathrm{~nm}$. Rep. Geol. Nat. Hist., Surrey of Minnesota, 1886, J. 318, pl. 2, figs. 8, 9.

Loc. Red Wing, Mimesota.

Orthis sehohariensis Castelnau=Strophonella schohariensis.

Orthis scovilli Miller = Hebertella scovilli.

Orthis sectostriata Ulrich=Plectorthis sectistriata.

Orthis semele Hall= Rhipidomella semele.

Orthis simuata Hall=Hebertella sinuata.

Orthis (?) sola Billings.

Lorraine (Oril.).

Orthis sola Billings, Catalogue Silurian Fossils of Anticosti, 1866, p. 12.

Loc. Anticosti.

Orthis solitaria Mall= Rhipiclomella solitaria.

Orthis stonensis Safford = Dalmanella stomensis.

Orthis striatocostata Geinitz= Meckella striaticostata.

Orthis striatula Emmons (non Schlotheim)= Dalmanella testudinaria.

Orthis striatula of anthors= Schizoploria striatula.

Orthis strophomenoides Hall=Orthostrophia strophomenoides.

Orthis subiequata Comrad=Dalmanella subiecpuata.

Orthis subcarinata Hall= Dalmanella subcarinata.

Orthis subcircula Simpson= Rhipidomella subcirculus.

Orthis subelliptica White and Whitfield=Rlipidomella subelliptica.

Orthis subjugata Hall= Hebertella oeciclentalis.

Orthis (?) subnodosa \#all.

Niagara (Sil.).

Orth is subnodosa Hall, Descriptions of 11. sp. Fossils from Waluron, Indiana, 1879,

p. 14;-Eleventh Rep. State Geol. Indiana, 1882, p. 286, pl. 27, fig. 17;-

Trans. Albany Institute, X, 1883, p. 70.-Nettelroth, Kentucky Fossil Shells,

Mem., Kentueky Geol. Survey, 1889, p. 44.

Loc. Waldron, Indiana; Lonisville, Kentucky.

Orthis suborbicularis Hall= Rhipiclomella suborbicularis.

Orthis subquadrata Hall=Dinorthis subquadrata.

Orthis subumbona Iall=Martinia subumbona. 
Orthis (?) sulivanti Morris and Sharpe.

Lower Devonian.

Orthis sulivanti Morris and Sharpe, Quart. Jour. Geol. Soc. Londou, II, 1846, p. 275 , pl. 10, fig. 1.

Loc. Filkland Islands; Sonth Africa.

Orthis swallovi Hall=Sehizophoria swallovi.

Orthis sweeneyi Winchell=Dinorthis pectinella sweeneyi.

Orthis (?) tenuidens Hall.

Clinton (Sil.).

Orthis tenuidens Hall, Pal. New York, II, 1852, p. 58, pl. 20, tig. 9.

Loc. Oneida County, New York.

Obs. May be a species of Orthothetes.

Orthis (?) tenuis Morris and Sharpe.

Lower Devonian.

Orthis tenuis Morris and Sharpe, Quart. Jour. Geol. Soc. London, II, 1816, 1. 275, pl. 10, fig. 4 ; pl. 11, fig. 4 .

Loc. Falkland Islands.

Obs. Similar to Chonostrophia complanata Hall.

Orthis (??) tenuistriata Hall.

Portage (Dev.).

Orthis tenuistriata Hall, Geol. N. Y.; Rep. Fourth Dist., 1843, p. 245, fig. 3.

Loc. Shores of Crooked Lake, New York.

obs. This is not an Orthis; probably a pelecypod.

Orthis tersus Sardeson=Dalmanella tersa.

Orthis testudinaria Dalman=Dalmanella testudinaria.

Orthis testudinaria Owen, $1844=0$. tricenaria.

Orthis thiemii White=Rhipidomella thienei.

Orthis tioga Hall=Schizophoria tioga.

Orthis tricenaria Conrad.

Trenton (Ord.).

Orthis tricenaria Conral, Proc. Acal. Nat. Sci. Philadelphia, I, 1843, p. 333.Hall, Pal. New York, I, 1847, p. 121, 1)l. 32, fig. 8.-Salter, Canalian Organic Remains, Decade 1, 1859, p. 39, pl. !, figs. 1-4.-Iall, Geol. Wisconsin, I, 1862, p. 42, figs. 8-11.-Billings, Geol. Canada, 1863, p. 167, fig. 151.-IIall, Second Ann. Rep. N. Y. State Geol., 1883, pl. 35, figs. 1-5. - ? Walcott, Mon. U. S. Geol. Survey, VIII, 1884, p. 74, pl. 11, fig. 4.-Hall and Clarke, Pal. New York, VIII, Pt. I, 1892, pp. 191, 193, 221, 228, pl. 5, figs. 9-14.-Winchell and Sehnchert, Minnesota Geol. Survey, III, 1893, 1. 418, pl. 32, figs. 18-23.-Keyes, Geol. Survey Missouri, V, 1895, 1. 60, pl. 39, fig. 4.-Whiteaves, Pal. Foss., III, Pt. III, 1897, p. 175 .

Orthis disparilis Conrad, Proc. Acad. Nal. Sci. Philadelphia, I, 1843, p. 333.Hall, Pal. New York, I, 1817, p. 119, pl. 32, fig. 4.-Billings, Canadian Nat. Geol., IV, 1859, 1. 440, fig. 20.-Hall, Geol. Wisconsin, J, 1862, p. 435.-Billings, Geol. Canada, 1863, p. 130, fig. 60.-Hall and Clarke, Pal. New York, VIII, Pt. I, 1892, pp. 191, 221, 228.

Orthis testulinaria? Owen, Geol. Expl. Iowa, Wiscousin, and Illinois, 184t, pl. 15 , fig. 11.

?Orthis plicatella White (non Hall), Wheeler's Expl. and Survey west 100th Merid., IV, 1875, p. 72, pl. 4, fig. 10.

Loc. Mineral Point, Wiscousin; Midlleville, etc., New York; Kentucky; Teunessee; near Ottawa and Montreal, Canada; Mingan Islands; Lake Winnipeg, Manitoba; White Pine and Eureka districts, Nevada; Minneapolis, etc., Minnesota; Pike Connty, Missonri.

Obs. O. plicatella White and $O$. tricenaria Walcott may prove to be distinct from $O$. tricenaria Conrad. 
Orthis (?) trinucleus Hall.

Clinton (Sil.).

Orthis triuuclens Ifall, Pal. New York, II, 1852, p. 58, pl. 20, fig. \&.

Loc. Wayne County, New York.

Orthis triplicatella Meek=Plectorthis triplicatella.

Orthis (?) tritonia Billings.

Calciferous (Ord.).

Orthis tritonia 13illings, Pal. Fossils, I, 1862, J. 76, fig. 69;-Geol. Canada, 186:, 1. 231, fig. 244.-Hall :1nd Clarke, l':1. Now York, VIII, Pt. I, 1892, p. 217, pl. 7 A, ligs. 12, 13.

Loc. Point Leris, Canala.

Orthis tubulostriata Hall= Rhipidomella tululistriata.

Orthis tulliensis Vanuxem=Schizophoria tullieusis.

Orthis uberis Billings=Rhipidomella nberis.

Orthis umbonata Conrad=Ambocelia nmbonata.

Orthis umbraculum Owen (nou von Buch)= Derbya rolusta.

Orthis umbraculum Hall, 185:, Newberry, 1861=Orthothetes umbracılım.

Orthis unguieulus Hall, 1843 (non Phillips) = Ambocelia gregaria.

Orthis unguformis Castelnan, and Emmons=Hipparionyx proximus.

Orthis vamuemi Hall=Rhipidomella vanuxemi.

Orthis vanuxemi pulchella Herrick=Rhipidomella vanuxemi pulchella. Orthis varica Conrad = Bilobites varicus.

Orthis vespertilio Sowerby.

Ordovician.

Orthis vespertılio (Sowerhy) Kayser, Palæontographica, Snppl., I11, 1876, p. 27, pl. 3, figs. 22, 23.

Loc. Europe; Potrero de los Angulos, etc., Argentine Republic.

Orthis whitfieldi N. H. Winchell=Plectorthis whitfieldi.

Orthisina d'Orbigny=Clitambonites.

Orthisina alberta Walcott=Billingsella alberta.

Orthisina alternata Hall=Orthothetes chemm gensis perversus.

Orthisina americana Whitfield=Clitambonites dirersus.

Orthisina arctostriata Hall=Orthothetes ehemmgensis aretistriatus.

Orthisina crassa Meek and Hayden=Derbya crassa.

Orthisina diversa Shaler = Clitambonites diversus.

Orthisina festinata Billings= Billingsella festinata.

Orthisina grandieva Billings=Billingsella grandieva.

Orthisina missouriensis Swallow= Meekella striaticostata.

Orthisina transversa Walcott $=$ Billingsella transversa.

Orthisina vernenili Billings=Clitambonites diversus.

ORTHORHYNCHULA Hall and C. Genotype Ortlis (?) linneyi James.

Orthorhynchula Hall and Clarke, Pal. New York, VIII, Pt. II, 1893, p. 181;-Thirteenth Ann. Rep. N. Y. State Geologist, 1895, 1. 824.

Orthorhynchula linneyi (James).

Lorraine (Ord.).

Orthis (?) linueyi James, The Paleontologist, 5, 1881, p. 41.

Orthis linueyi Nettelroth, Kentucky Fossil Shells, Mem. Kentucky Geol. Survey, 1889, p. 41, pi. 34, figs. $7-18$; errata, p. 1.

Orthorhynchula linneyi Hall and Clarke, Pal. New York, VIII, Pt. II, 1893, p. 181, pl. 56, figs. 10-13, 19.

Loc. Near Dauville, otc., Kentucky; Cincinnati, Ohio; Nashville, Tenuessee. 
ORTHOSTROPHIA Hall.

Genotype Orthis strophomenoides Hall.

Orthostrophia Hall, Second Ann. Rep. N. Y. State Geol., 1883, pl. 36, figs. 32-34.-Hall and Clarke, Pal. New York, VIlI, Pt. 1, 1892, pp. 199, 223, 253;-Eleventh Ann. Rep. N. Y. State Geologist, 1894, P. 267.

Orthostrophia (?) fasciata Hall.

Niagara (Sil.).

Orthis fasciata Hall, Pal. New York. II, 1852, p. 255, pl. 52, fig. 8.

Orthostrophia ? fasciata Hall and Clarke, Pal. New York, VIII, Pt. I, 1892, pp. $200,223$.

Loc. Rochester and Lockport, New York.

Orthostrophia strophomenoides Hall.

Lower Helderberg (Dev.).

Orthis strophomenoides Hall, Tenth Rep. N. Y. State Cal. Nat. Hist., 1857, p. 46 ;-Pal. New York, IIl, 1859, P. 177, pl. 14, fig. 2.

Orthis halli Safford, Geol. Tennessee, 1869, pl. 328, 533.

Orthostrophia strophomenoides Hall, Second Ann. Rep. N. Y. State Geol., 1883, pl. 36, figs. 32-34.- Hall and Clarke, Pal. New York, VIII, Pt. I, 1892, pp. 200,223 , pl. 5A, figs. $24-27$; pl. 6 , figs. 32-34.

Orthostrophia halli Hall and Clarke, Pal. New York, VIII, Pt. 1, 1892, 11. 5A, figs. 22, 23.

Loc. Albany and Schoharie counties, New York; Square Lake, Maine; Perry County, 'Tennessee.

ORTHOTHETES Fischer de Wald. Genotype Spirifera erenistria Phil.

Orthothetes Fischer de Waldheim, Oryetographio in Gouvernement de Moscou, 1837, p. 133.-Waagen, Palæontologica Inclica, Ser. X111, I, p. 607, 1884.Hall and Clarke, Pal. New York, VIII, Pt. I, 1892, 1. 253;-Eleventh Ann. Rep. N. Y. State Geologist, 1894, 1. 284.

Streptorhynchus Hall (non King), Sixteeuth Rep. N. Y. State Ca1l. Nat. Hist., 1863, p. 61, figs. 1-6;-Pal. New York, IV, 1867, p. 64.-Nettelroth, Kentucky Fossil Shells, Mem. Kentucky Geol. Survey, 1889, r. 139.

\section{Orthothetes agassizi (Ratlibun).}

Middle Devonian.

Streptorhyuchus agassizi (Hurtt) Rathlun, Bull. Buffalo Soc. Nat. Sci., I, 1874, p. 248 , pl. 9, figs. $3,4,10,16,17,23,25,26,28-30$;-Proc. Boston Soc. Nat. llist., XX, 1879, p. 24.

Loc. Erere, Province of Para, Brizil.

Orthothetes anomalus (A. Winchell).

Hamilton (Dev.).

Crania (l'seudocrania) anomalid A. Winchell, Geol. Rep. Lower Peninsula Michigan, 1866, p. 92 .

Streptorhynchus anomala IIall and Clarke, Pal. New York, VIII, P't. 1, 1892, p. 152.

Loc. Grand 'Traverse region, Michigan.

Orthothetes bellulus Clarke.

Marcellus (Dev.).

Orthothetes bellulus Clarke, Thirteenth Ann. Rep. N. Y. State Geologist, 1895, Pl. 176, 187, pl. 4, figs. 2-4.

Loc. Livonia salt shaft, Livonia, New York.

Orthothetes chemungensis (Conrad).

Chemung (Dev.).

Strophomena chemungensis Conrad, Jour. Acad. Nat. Sei. Philadelphia, VIII, 1842, p. 257, pl. 14, fig. 12 .

Strophomena bifurcata Hall, Geol. N. Y.; Rep. Fourth Dist., 1813, p. 266, tig. 2. Strophomena pectinacea Hall, Ibidem, 1א43, 1. 266, fig. 4.

Streptorhynchus chemungensis Hall, Pall. New York, IV, 1867, 1. 67;-Second Ann. Rep. N. Y. State Geol., 1883, pl. 40, tig. 9.-Walcott, Mon. U. S. Geol. Survey, VIll, 1884, P. 117, pl. 13, fig. 16.

Streptorhynchus chemungensis var. pectinacea Hall, Pal. New York, IV, 1867, p. 73, pl. 10, fig. 6 . 


\section{Orthothetes chemungensis (Conrad)-Continued.}

Orthothetes chemungensis Hall and Clarke, l'al. Now York, VIII, I’t. I, 18!2, p. 255, pl. 10, fig. 9; pl. IIA, fig. 14.-Whiteaves, Cont. Canadian Pal., I, 1892, p. 28.5.

Loc. New York and P'ennsylvania; Eureka district, Nevada; Lake Winnpegosis, Caunda; Waverly group of Ohio.

Orthothetes chemungensis arctistriatus Hall.

Hamilton (Dev.).

Strophomena aretostriata Hall, Geol. N. Y.; Rep. Fourth Dist., 18.13, 1. 266, fig. 3.

Orthisina aretostriata 1lall, Thirteenth Kep. N. Y. State Cab. Nat. Ihst., 1860, Pl). 80,81 , figs. 1,$2 ;$ p. 112 .

Streptorhyuchus chemungensis var. aretostriata Hall, Pal. New York, IV, 1867, 1. 71, pl. 9, figs. 1-12;-Seeond Ann. Rep. N. Y. State Geol., 1883, pl. 40, fig. 8 .

llemipronites chemungensis var, aretostriata Mleek, King's U. S. Geol. Expl. 40th Parl., IV, 1×77, p. 35, pl. 3, fig. 2.

Streptorhynchus aretostriata Walcott, Mon. U. S. Geol. Surveg, VIII, 1884, p. 117, pl. 13, tig. 7.-Nettelroth, Kentucky Fussil Shells, Mem. Kentucky Geol. Survey, 18:9, p. 140, pl. 31, figs. 31-33.

Orthothetes chenumgensis var. aretostriata 11 all and Clarke, Pal. New York, VIII, Pt. I, 1892, pl. 10, fig. 8.

Loc. New York; Falls of Ohio; Eureka district, Nevada.

Orthothetes chemungensis perversus (Hall).

Cornif. and Ham. (Dev.).

Orthis perversa Hall, 'Tenth Rep. N. I. Stato Cab. Nat. Hist., 1857, p. 137.

Orthisina alternata Hall, Thirteenth Rep. N. Y. State Cab. Nat. 11ist., 1860, p. 81 , figs. 1,$2 ;$ p. 112.

itreptorhyuchus chemungensis var. perversus Hall, I'al. New York, 1T, 1867, p. 72, pl. 9, figs. 13-17, 26.

Streptorhyuchus chemungeusis var. alternata Hall, SeconI Ann. Rep. N. Y. State Geol., 1883, pl. 40, fig. 7.

Orthothetes chemungensis var, alteruata Hall and Clarke, Pal. New York, VIII, Pt. I, 1892, pl. 10, fig. 7.

Loc. New York; Bosanquet, Ontario; Eureka district, Nevada.

Orthothetes crenistria (Plillips?).

Lower Carboniferous.

Streptorhyuchus crenistria? A. Winchell, Proc. Acad. Nat. Sei. Philadelphia, 1862, p. 410.

Streptorhynehus erenistria Davidson, Quart. Jour. Geol. Soc. London, XIX, 1863, 1). 173, pl. 9, fig. 19.-Dawson, Aeaủian Geology, 31 ed., 1878, 11. 296, fig. 96.Ltheridge, Quart. Jour. Geol. Soc. London, XXXIT, 1878, p. 362.

Hemipronites crenistria? Meek, l'al. Ohio, 1I, 1875, p. 279, pl. 10, fig. 5.

Hemipronites crenistria Meek, King's I. S. Geol. Expl. 40th Parl., IV, 1877, p.

pl. 7, fìg. 2.-Herrick, Bull. Denison Univ., III, 1888, p. 37, pl. 5, fig. 14; pl. 3, fig. 24; pl. 6, fig. 8; pl. 9, fig. 21; IV, p. 24, pl. 2, figs. 1,5;-Geol. Ohio, VII, 1895, pl. 15, fig. 1 ; pl. 21, fig. 14.

Orthothetes crenistria Hall and Clarke, Pal. New York, VIII, I’t. I, 1892, p. 25\%, pl. $11 \mathrm{~A}$, fig. 15 .

Loc. Medina and Granville, Ohio; Port aux Barques, Michigan; East River and Shubenacadie, Nova Scotia; Feilden Isthmus, lat. $82043^{\prime}$; White Pine district, Nevada.

Obs. These references are unsatisfactory ideutifications of Phillips's species. It may prove that more than a single species is here included.

Orthothetes deformis Hall.

Lower Helderberg (Dev.).

Orthis deformis IIall, 'Tenth Rep. N. Y. State Cah. Nat. Hist., 1857, p. 44;-Pal. New York, III, 1859, p. 174, pl. I0A, fig. 13; pl. 15, fig. 3. 


\section{Orthothetes deformis Hall-Continued.}

Streptorhynchus deformis IIall, Second Ann. Rep. N. Y. StateGeol., 1883, pl. 39, fig. 32.

Orthothetes deformis Hall and Clarke, Pal. New York, VIII, Pt. I, 1892, 1. 255, pl. 9, fig. 32 .

Loc. Albany County, New York; Cumberland, Maryland.

Orthothetes deformis sinuatus Hall and Clarke. Lower Hellerberg (Dev.).

Orthothetes deformis var. sinuata Hall and Clarke, l'al. New York, VIII, I't. 1, 1892, pl. 20, figs. 8,9 .

Loc. Cumberland, Maryland.

Orthothetes desideratus Hall and Clarke.

Waverly (L. Carb.).

Orthothetes desideratus Hall and Clarke, Pal. New York, VIII, Pt. I, 1892, p. $345, \mathrm{pI} .9 \mathrm{~A}$, figs. $26,27$.

Loc. Medina County, Ohio.

Orthothetes flabellum (Whitfield).

Corniferous (Dev.)

Streptorhynchus flabellum Whitield, Aumals N. Y. Acad. Sci., II, 1882, p. 200;Ibidem, V, 1891, p. 521, pl. 6, figs. 7, 9;-Geol. Ohio, VII, 1895, 1. 421, pl. 2, figs. $7,9$.

Loc. Columbus, Ohio.

Orthothetes hydraulicus (Whitfield).

Waterlime (Sil.).

Streptorhynchus hydraulicum Whitielı, Aunals N. Y. Acal. Sci., II, 1882, 1). 193;--Ibideu, V, 1891, p. 508, pl. 5, figs. 1-3;-Geol. Ohio, VIl, 1895, 1. 410, pl. 1, figs. 1-3.

Loc. Bellville and Greentield, Ohio.

Orthothetes inæqualis Hall.

Kinclerhook (L. Carb.).

Orthis inequalis Hall, Geol. Survey Iowa, I, Pt. II, 1858, 1. 490, pl. 2, fig. 6.

Streptorhynchus inequalis A. Winchell, Proc. Acad. Nat. Aci. Philadelphia, 1865, p. 117.

Streptorhynchus equivalvis Hall and Whittield, King's U. S. Geol. Expl. 10th Parl., IV, 1877, p. 252, pl. 4, figs. 1, 2.

Streptorhynchus equivalvis liall, Second Ann. Rep. N. Y. State Geol., 1883, pl. 42 , figs. $20-23$.

Orthothetes in:equalis Hall and Clarke, l'al. Now York, VIII, Pt. I, 1892, pl. 9A, figs. 20-23.

Loc. Burlington, Iowa; Newark and Granville, Ohio: Shafers, Pennsylvania; Wasatch Range, Utah.

Orthothetes inflatus (White and Whitfield). Kinderhook (L. Carb.).

Streptorhynchus inflatus White aud Whitfield, Proc. Boston Soc. Nat. Iist., VIII, 1862, p. 293.-Hall aud Whitlield, King's IT. S. Geol. Expl. 40 Parl., IV, 1877, p. 252, pl. 4, fig. 3.-Hall, second Ann. Rep. N. Y. State Geol., 1883, pl. 42 , ligs. 24,25 .

Orthothetes inflatus Hall and Clarke, Pal. New York, VIII, Pt. 1, 1892, pl. 9A, figs. $24,25$.

Loc. Burlington, Iowa; Ury Canyon, Ofuirrh Monntains, Utah; Montana.

Orthothetes interstriatus (Hall).

Coralline (Sil.).

Orthis interstriata Hall, Pal. New York, II, 1852, 1). 326, pl. 74, figs. 1, 2.

Loc. Schoharie, New York.

Orthothetes lens (White).

Kinderhook (L. Carb.).

Streptorhynchus leus White, Proc. liostou Soc. Nat. Ilist., IX, 1862, p. 28.Keyes, Geol. Survey Missouri, V, 1895, p. 67, 11. 39, fig. 2.

Streptorhynchus lens? A. Winchell, Proc. Acad. Nat. Sci. Philadelphia, 1865, p. 117. 
Orthothetes lens (White)_Contimed.

Orthothetes lens IIall and Clarke, Pal. New York, VIII, Pt. I, 1X92, p. 256, pl. 11A, figr. 16-22.

Loc. Clarksville, etc., Missonri; Jlauburg, Illinois; Medina Connty, ()hio (Winchell).

Orthothetes pandora (Billings).

Upper Hellerberg (Dev.).

Stroptorlyzuchus pandora Billings, Canadian Jonr., V, 1860, p. 226, figs. 12, 13;Creol. Canarla, 1863, 1. 369, fig. 381.-Nieholson, l’al. Prov. Ontavio, 1874, p. 70.

Streptorhynchus chemungensis var. pandora Hall, Pal. New York, IV, 1867, p. 6r, pl. 4, figs. 11-19; pl. 9, figs. 18-25, 27;-Second Ann. Rep. N. Y. State Geol., 1883, pl. 40, figs. 1-6.

Orthothetes chemungensis var. pandora 1 Iall and Clarke, Pal. New York, VIII, Pt. I, 1892, 1. 255, pl. 9, fig. 30; pl. 10, figs. 1-6.

Loc. Scholırie, Kuoxville, Clarksville, ete., New York; Cayuga, Ontario; Colnmlus, Ohio (Whitfield); Eureka district, Nevarla.

\section{Orthothetes pravus Hall.}

(?Upper) Devonian.

(1rthis piava Hall, Geol. Surves Iowa, I, Pt. II, 1858, 1) 190.

Orthothetes prava Hall and Clarke, Pal. New York, VIII, Pt. I, 1892, p. 255 , pl. $11 \mathrm{~A}$, fig. 13.

Loc. Lime Creek, Worth County, Iowa.

Orthothetes subplanus (Conrad). Niagara and L. Held. (Sil. and Dev.).

Strophomena subplana Conrad, Jonr. Acad. Nat. Sci., I'hiladelphia, VIII, 1842, 1. 258.-11all, Geol. N. Y.; Rep. Funrth Dist., 1813, p. 104, fig. 1;-Twelfth liej. N. Y. State Cab. Nat. Hist., 185!, p. 82.

Leptiena subplana Hall, Pal. New York, II, 1852, p. 259, pl. 53, figs. 8-10.-Billings, Canadian Nat. Geol., 1, 1856, p. 138, pl. 2, figs. 16. 17.

Strophomena pecten Roemer, Die Kil. Famna west. Tennessee, 1860, p. 67, pl.5, fig. 4.-Billings, Geol. Canada, 1863, p. 311, fig. 315;-Catalogue Silurian Fossils of Anticosti, 1866, T. 40.

Streptorhynehus (Strophodonta) subplanns IIall, Geol. Surrey Wisconsin, I, $1862,1 \% 436$.

Streptorbynelus subplanus Hall, Trans. Albany Institute, IV, 1863, p. 226;sixteenth Rep. N. Y. State Cal,. Nat. Iist., 18ti3, 1). 63, figs. 1, 2;-Tweutyeighth Rep. N. Y. State Mus. Nat. Hist., 1879, 1. 151, pl. 21, figs. 26-33;Eleventh Rep. State Geol. Indiaua, 1882, p. 288, pl. 21, figs. 26-33;-Secoml Ann. Rep. N. Y. Stat Geol., 1883, pl. 39. figs. 21-24; pl. 42, fig. 19.-Nettelroth, Kentucky Fossil Shells, Mem. Kentucky Geol. Survey, 1889, p. 111, pl. 29, figs. 11, 12.-Beocher aud Clarke, Mem. N. Y. State Mus., I, 1889, p. 23, pl. 2, fins. 14-20.

Streptorlynchus lieniaster Winchell and Marey, Mem. Boston Soe. Nat. Hist., I, 1865, p. 93, 1). 2, fig. 10.-Hall, Twentieth Rej. N. Y. State Cal.. Nat. Hist., 1867, p. 392.

Hemipronites subplanus Meek and Worthen, Geol. Sirvey Illinois, III, 1868, 1. 349.

Hemipronites propinıums Meek and Worthen, Ihiclem, 111, 1868, p. 351, pl. 6, fig.6. Orthothetes subplana IIall and Clarke, Pal. New Vork, VIII, Pt. 1, 1892, p. 255 , pl. 9, figs. 21-24; pl. 9A, fig. 19; pl. 11A, figs. 9-12.

Loc. Lockport, Rochester, etc., New York; Thorold, Ontario; Waldron, Indiana; Lomisville, Kentucky; 'Thebes, Alexander County, and Bridgeport, Illinois; Pike Comnty, Missouri; Decatur County, Tennessee; Arisaig, Nova Scotia (Ami); Anticosti.

Orthothetes tapajotensis (Derby).

Upper Carboniferous.

Streptorhymchus tapajoteusis Derby, Bull. ('ornell Uwiv., 1, 1874, 1. 37, pl. 5, figs. $3,6,7,9,10 ;$ pl. 8 . fig. 9 . 


\section{Orthothetes tapajotensis (Derby)-Continued.}

Orthothetes tapajotensis Waagen, Palieontologica Indiea, Ser. XIII, I, 1884, pp. 607, 608.

Loc. Bomjardim and Itaitula, Brazil.

\section{Orthothetes tenuis Hall.}

Streptorhynchus tenuis Hall, Trans. Albany Institute, IV, 1863, p. 210 ;-Twentyeighth Rep. N. Y. State Mus. Nat. Hist., 1879, p. 150, pl. 23, figs. 11-13;Elerenth Rep. State Geol. Indiana, 1882, p. 287, pl. 23, figs. 11-13.-Foerste, Bull. Denison Iuiv., II, 1887, p. 105, pl. 8, tigs. 31, 32, 38.-Nettelroth, Kentucky Fossil Shells, Mem. Kentueky fieol. Survey, 1889, p. 142.

Orthothetes teunis Hall and Clarke, Pal. New Tork, VIII, Pt. I, 1892, 1. 255.

Strophomena (Orthothetes) temis Foerste, Ceol. Ohio, VII, 1895, 1. 568, pI. 27, tigs. $31,32,38$.

Loc. Waldron, Indiana; near Lonistille, Kentucky; Dayton, Ohio.

Orthothetes umbraculum of anthors (non von Bnch). L. and Up. Carb.

Orthis nmbraculnm Iall, Stansbury's Expl. Survey Valley Great Salt Lako, Utali, 1852, p. 412, pl. 3, tig. 6.-Newberry, Ives's Rep. Colorarko River of the Vest, 1861, p. 12:.

Streptorhynchus nubraculum? A. Winchell, Proc. Acad. Nat. Sci. Philadelphia, 1865, p. 117.

Hemipronites unlıraculuı? A. Winchell, Proc. Anerican Philosophical Soc., XII, 1870 , p. 251.

Orthothetes nmbraenlum Hall and Clarke, Pal. New York, VIII, Pt. I, 1892, 1. 256.

Loc. Waverly group, Newark, Sciotoville, Warren, etc., Ohio; Up. Carb., Leavenworth, Kansas.

Orthothetes woolworthanus Hall.

Lower Helderberg (Dev.).

Strophomena woolworthana Hall, Tenth. Rep. N. Y. State Cab. Nat. Hist., 1857, p. 48, tigs. 1, 2;-Hall, Pal. Now York, III, 1859, p. 192, pl. 17, figs. 1, 2.

Streptorhynchus woolworthana Billings, Geol. Canada, 1863, p. 957, fig. 449.Hall, Second Aun. Rep. N. Y. State Geol., 1883, pl. 39, tigs. 25-31.

Orthothetes woolworthana Hall and Clarke, P'al. New York, VIII, Pt. I, 1892, p. 255 , pl. 9, figs. 25-31.

Loc. Schoharie, Carlisle, Clarksville, and Huitson, New York.

ORTHOTICHIA Hall and C.

Genotype Orthis? mor waniana Derby.

Orthotichia Hall and Clarke, Pal. New York, VII, Pt. I, 1892, 1. 213;-Eleventh Ann. Rep. N. Y. State Geologist, 1894, p. 272.

Orthotichia morganiana (Derby).

Upper Carboniferous.

Orthis? morganiana Derby, Bull. Cornell I'niversity, I, 1874, p. 29, pl. 3, tigs. $1-9,11,34 ;$ pl. 4 , figs. $6,14,15$.

Orthis morganiana Waagen, Paleontologica Indica, Ser. XIII, I, 1884, p. 564.

Orthotichia? morganiana Hall and Clarke, Pal. Now York, V1lI, Pt. I, 1892, pp. 213,226 , pl. 7 , figs. 11-15.

Loc. Bomjardim and Itaituba, Brazil.

ORTHOTROPIA Hall and Clarke.

Genotype O. dolomitica H. and C.

Orthotropia Hall and Clarke, Pal. New York, VIII, Pt. II, 1895, explanation sheet to pl. 84, figs. 3-7.-Thirteenth Ann. Rep. N. Y. State Geol., 1895, p. 913.

Orthotropia dolomitica Hall and Clarke.

Orthotropia dolomitica Hall and Clarke, Pal. New York, VIII, l't. II, 1895, pl. 81, figs. 3-7.

Loc. Near Milwaukee, W'isconsin. 
PARASTROPHIA IIall and C. Genotype Atrypa hemiplicata Hall. T'arastrophia IIall and Clarke, P'al. New York, VIlI, Pt. Il, 1893, 1. 221;-Thirtwenth Anu. liep. N. Y. State Geologist, 1895, p. 839.

Parastrophia divergens Hall and Clarke.

Lorraine (Ord.).

Parastrophia divergens 1 lall and Clarke, Pal. New lork. VIII, P't. II, 1895, pp. 222, 36ti, pi. 63, figs. 4-7.

Loc. Wilmington, Illinois.

Parastrophia greenei Hall and Clarke.

Niagara (Sil.).

Parastrophia greenii Hall and Clarke, Pal. New York, VIII, Pt. II, 1895, pp. 222, 367 , pl. 63, figs. 17-20, 22.

Loc. Milwaukee, Wisconsin.

Parastrophia hemiplicata Hall.

Trenton (Ord.).

Atrypa hemiplicata Hall, l’al. New York, I, 1847, p. 144, pl. 33, fig. 10.-Billings, Canadian Nat. Geol., I, 185̄6, p. 208, figs. 20-23.

Atrypa eirenlus Hall, Pal. New York, I, 1847, p. 142, pl. 33, fig. 7;-Twelfth Rep.

N. Y. State Cab. Nat. Fist., 185!, p. 65.

Pentamerus hemiplicatus Hall, Twelfth Rej. N. Y. State Cab. Nat. Hist., 1859, p. 66.-Billings, Canidian Jonr., IV, 1859, p. 316.

Camarella hemiplicata Billings, Geol. Canara, 1863, p. 168, fig. 151.

Camarella cireulns Miller, American Pal. Fossils, 1877, p. 107.

Camarella hernensis Sardeson, Bull. Minnesota Acad. Nat. Sei., III, 1892, p. 328, pl. 4, figs. 4-6.

Anastrophia ? hemiplieata Winchell and Sehuchert, Minnesota Geol. Survey, III, 1893, p. 382, pl. 30, figs. 29-31.-Whiteaves, Pal. Foss., III, Pt. III, 1897, P. 167.

Parastrophia hemiphicata Hall and Clarke, Pal. New York, VIII, Pt. II, 1893, p. 221 , pl. 63, figs. $1-3$.

Loc. Middleville, Watertown, ete., New York; Center County, Pennsylvania; Wisconsin; Minnesota; Ottawa and Lake Winnipeg, Canada.

Parastrophia hemiplicata rotunda (Winchell and Schu.). Trenton (Ord.).

Anastrophia ? hemiplicata var. rotumda W. and S., Minuesota Geol. Survey, III, 1893, p. 383, pl. 30, figs. 32-35.

Loc. Cannon Falls, Minnesota; Decoralı, lowa.

Parastrophia latiplicata Hall and Clarke.

Niagara (Sil.).

Parastrophia latiplieata Hall and Clarke, Pal. New York, VIII, Pt. II, 1895, pp. 222, 368, 11. 63, figs. 23-27.

Lnc. Milwankee, IVisconsin.

Parastrophia multiplicata Hall and Clarke.

Niagara (Sil.).

Parastrophia multiplicata Hall and Clarke, Pal. New York, VIII, Pt. II, 1895, pp. 222, 367, pl. 63, figs. 15, 16, 21.

Loc. Milwankee, Wiscousin.

Parastrophia (?) obscura (Hall and Whitfield).

Pogonip (Ord.).

l'oramlonites obseurus Hall and Whitfield, King's U. S. Geol. Expl. 40th Parl., IV, 1877, p. 234, pl. 1, fig. 16.

Porambonites? oloseurus Hall and Clarke, Pal. New York, VIII, Pt. II, 1893, p. 228.

Loc. White Pine district, Nevala.

Obs. Based upon a single ventral valve which is insufficient to determine whether it belongs to Parastrophia or some rhynchonelloid. It is not a Porambonites. 
Parastrophia ops (Billings).

Camarella ops Billings, Pal. Fossils, I, 1862, p. 148, figr. 128.

Loc. Anticosti.

Obs. May be only a variety of $\mathrm{P}$. reversa.

Parastrophia reversa (Billings).

Anticosti (Sil.).

Pentamerus reversus Billings, Geol. Survey Canada; Rep. Progress for 1856 , 1857, p. 295 ;-Canadian Jour., IV, 1859, p. 316.

Brachymerns reversus Shaler, Bull. Mus. Comp. Zool., 4, 1865, p. 69.

Anastrophia reversa Miller, American I'al. Foss., 1877, p. 104.

Parastrophia reversa Hall and Clarke, Pal. New York, VIII, Pt. II, 18:5, pl. 63, figs. 8-14.

Loc. Anticosti.

Obs. Billings says this species is a large P. hemiplicata Hall. It appears, however, to be distinct. See P. ops Billings.

Parastrophia scofieldi (Winchell and Sehnehert).

Trenton (Ord.).

Anastrophia ? scofieldi W. anıl S., Minnesota Geol. Survey, 111, 1893, p. 383, pl. 30 , figs. 24-28.

Loc. Near Cannon Falls, Minnesota.

PARAZYGA Hall and Olarke.

Genotype Atrypa hirsuta Hall.

Parazyga Hall and Clarke, Pal. New York, VIII, Pt. II, 1893, 1. 127 ;-Thirteenth Ann. Rep. N. Y. State Geologist, 1895, 1. 800.

Parazyga deweyi IIall.

Lower Helderberg (1)v.).

Waldheimia deweyi Hall, Tenth Rep. N. Y. State Cab. Nat. IIist., 1857, p. 89.

Trematospira (Rhynchospira) deweyi Hall, Pal. New York, III, 1889, 1. 216, pl. 36 , fig. 3 .

Parazy ga deweyi Hall and Clarke, Ibillem, VIII, I't. II, 1893, 1. 128, fig. 112, pl. 49 , figs. $40-46$.

Loc. Albany and Schoharie counties, New York.

\section{Parazyga hirsuta Hall.}

Corniferous and Hamilton (Dev.).

Atryla hirsuta Hall, Tenth Rep. N. Y. State Cab. Nat. Hist., 1857, p. 168.

Trematospira hirsuta Hall, Thirteenth Rep. Ibidem, 1860, p. 101;-Fourteenth

Rep. Ibidem, 1861, p. 101 ;-Fiftcenth Rep. Ibidem, 1862, pl. 2. figs. 11-16;-

Pal. New York, IV, 1867, p. 274, pl. 45, figs. I6-32.-Nettelroth, Kentucky

Fossil Shells, Mem. Kentucky Geol. Nurvey, 1889, p. 136, pl. 16, figs. 15-19.

Athyris ? chloe Billings, Canadian Jonr., n. ser., V, 1860, p. 282, figs. 45-47.

Retzia chlne Billings, Geol. Canada, 1863, p. 385, fị. 419.

Nucleospira indiamensis Miller, Serenteenth Rep. State Geol. Indiaua, 1892, p. 79, pl. 13, figs. 13-15.

Parazyga hirsuta Hall and Clarke, Pal. Now York, VIII, Pt. II, 1895, p. 128, fig. 111 ; pl. 49, figs. 28-39.

Loc. New York; Thedford, Canada; Falls of Ohio; Bunker Hill, Indiana.

Paterina Beecher $=$ Iphidea.

PATERULA Barrande.

Genotype Paterula bohemica Barrande.

Paterula Barrande, Système Sil. du Centre de la Bohéme, V, 1879, p. 110.-1lall and Clarke, Pal. New York, VIII, Pt. I, 1892, l1). 78, 165;-Elerenth Ann. Rep. N. Y. State Geologist, 1894, p. 242.

Paterula amii n. sp.

Caleiferous (Ord.).

Paterula species Hall and clarke, VIII, Pt. I, p. 78, pl. 4k, fig. 1.

Loc. Quebec, Canada. 


\section{PENTAgONIA Cozzens. Genotype Pentagonia peersii Comzens=} Atrypa nuisuleata Conrad.

Pentagonia Cozzens, Ammals Lyeoum Nat. Jist. N. Y., IV, 1846, p. 158.-Meek :ud IIaydon, Smitlisonian Cont. Knowledgo, XIV, 172, 1861, p. 16.-1Iall and Clarke, Pal. New York, V1II, P't. 11, 1895, 11. 80;-Thirteenth Am. Rej. N. Y. State Geologist, 1895, 1. 775.

Goniocelia Hall, Fonrteenth Rep. X. Y. State Cal. Nat. IIist., 1861, p. 101.

Pentagonia peersii Cozzens= Pentagonia misulcata.

\section{Pentagonia unisulcata (Comrad). Oriskany to Hamilton (Dev.).}

Atrypa unisuleata Conrad, Fifth Ann. Rep. Geol. Survey of N. Y., 1841, p. 56.Ulall, Fifteenth Rep. N. Y. State Cab. Nat. Hist., 1862, pl. 11, fig. 10.

Pentagonia peersii Cozzens, Annals Lycenm Nat. Hist. N. Y., IV, 1846, p. 158, pl. 10, fig. 3.

Rhỹchouella unisulcata Hall, Tenth Rep. N. Y. State Cab. Nat. Hist., 1857, p. 125 .

Athyris? unisuleata Billings, Canadian Journal, V, 1860, p. 279, figs. 39-42.

Goniocœlia uniangulata Hall, Fourteenth Rep. N. Y. State Cab. Nat. Hist., 1861. P. 101.

Meristella? unisulcata Hall, Fifteenth Rep. Ibirlem, 1862, pl. 2, figs. 17-25.

Athyris unisulcata Billings, Geol. Canada, 1863, p. 373, fig. 396.

Meristella (Pentagonia) unisuleata varieties liplicata aud uniplicata Hali, Pal. New York, IV, 1867, p. 309, pl. 50, figs. 18-35.

Meristella nuisulcata Nettelroth, Kentucky Fossil Shella, Mem. Kentucky Geol. Survey, 1889, p. 99, pl. 15, figs. 9-16.

Pentagonia unisulcata Hall and Clarke, Pal. New York, VIII, Pt. II, 1895, p. 80, pl. 42, figs. 22-32.

Loc. New York; county of Haldimand and Bosanquet, Ontario; Falls of Ohio.

\section{PENTAMERELLA Hall.}

Genotype Atrypa arata Conrad.

Pentamerella Hall, Twentieth Rep. N. Y. State Cab. Nat. Hist., 1867, p. 163;Pal. New York, 1V, 1867, pp. 373, 375. - Nettelroth, Kentucky Fossil Shells, Nem. Kentucky Geol. Survey, 1889, p. 49.-Hall and Clarke, Pal. New York, VIII, Pt. II, 1893, p. 245;-Thirteenth Ann. Rep. N. Y. State Geologist, 1895, p. 845 .

Pentamerella arata (Courad).

Upper Helderberg (Dev.). Atrypa arata Conrad, Fifth Ann. Rep. Geol. Survey N. Y., 1811, p. 55.

Atrypa octocostatil Conrad, Ibidem, 1841, p. 55.

Pentamerus aratus Hall, Tenth Rep. N. Y. State Cah. Nat. Hist., 1857, p. 120, figs. 1-10.-Billings, Canatian Journal, VI, 1861, p. 269, figs. 93-96;-Geol. Canada, 1863, p. 370, fieg. 389.

Pentamerella arata Hall, Pal. New York, IV, 1867, p. 375, pl. 58, figs. 1-21.Nettelroth, Kentucky Fossil Shells, Mem. Kenturky Geol. Survey, 1889, p. 49, pl. 13, figs. 17-20.-Hall and Clarke, Pal. New York, VIIl, Pt. II, 1893, p. 245 , pl. 71, figs. 21-29.

q Pentamerus aratus Tschernyschew, Mém. Comité Géologique ‘le st. Pétersbourg, III, 1887, p. 101, pl. 4, figs. 18, 19.

Loc. New York; Cayuga, etc., Ontario; Columbus, Ohio; Falls of Ohio; ? Urals of Russia.

Pentamerella borealis (Meek).

Hamilton (Dev.).

Pentamerus borealis Neek, Trans. Chicego Acad. Sci., I, 1868, p. 95, pl. 13, fig. 11. Loc. Anderson River, British America.

Pentamerella (?) compressa Ringueberg.

Niagara (Sil.).

Pentamerolla compressa Ringuoberg, Bull. Buffalo Soc. Nat. Sci., V, 1886, p. 15, pl. 2 , fig. 4. 
Pentamerella (?) compressa Ringueberg - Continued.

Loc. Lockport, New Yoek.

Obs. May be a pathologic or compressed specimen of Spirifer crispus or S. sulcatus.

Pentamerella dubia Hall.

? Hamiltoll (Dev.).

Atrypa (u. sp.?) Owen, Geol. Survey Wisconsin, Iowa, Minuesota, 1852, p]. 3A,

tig. 1. [See speeimen in L. S. Nat. Mns., Cat., Invert. Foss., 17927.]

Spirifer dubius Ilall, Thirteenth Rep. N. Y. State Cab. Nat. Hist., 1860, p. 90.

Pentanerella dubia Hall, Pal. New York, IV, 1867, p. 379, pl. 58, tigs. 38-43.Hall and Clarke, Ibileu, VIII, Pt. II, 1893, p. 245, pl. 71, figs. 32-38.

Loc. Iowa City, Iowa.

Obs. See Pentamerella micula Hall.

Pentamerella intralineata (A. WinchelI).

Ilamilton (Dev.).

Pentamerus intralineatus A. Winchell, Geol. Rep. Lower Pcninsula of Michigan, 1866, p. 94.

Loc. Grand Traverse region, Michigan.

Pentamerella micula Hall.

? Hamilton (Dev.).

I'entamerella nienla Hall, Pal. New York, IV, 1867, 1. 378, pI. 58, figs. 26, 27.Hall and Clarke, Ibidem, VII, P't. II, 1893, 1. '245.

Loc. Iowa City, Iowa.

Obs. Compare with Pentamerella duhia Hall.

Pentamerella obsolescens Hall.

? Hamilton (Dev.).

Pentamerella obsolescens Hall, Pal. New York, IV, 1867, p. 379, 11. 58, figs. 24, 25.-Hall and Clarke, Ibidem, VIII, P't. II, 1893, 1\%. 245.

Loc. Waterloo, Iowa.

Pentamerella pavilionensis Hall.

Hamilton (Dev.).

Pentamerus papilionensis Hall, Thirteenth Rep. N. Y. State Cals. Nat. Hist., 1860, p. 86.

Pentamerella papilionensis Hall, Pal. New York, IV, 1867, 1. 377, pl. 58, tigs. 2837.-Nettelroth, Kéntucky Fossil Shells, Mem. Kentucky Geol. Survey, 1889, p. 50 .

Pentamerella pavilioneusis Hall and Clarke, Pal. New York, VIII, Pt. II, I893, p. 2.5 , pl. 71 , figs. 30,31 .

Loc. Seneca and Canandaigua lakes, etc., New York; Falls of Ohio.

Pentamerella thusnelda Nettelroth.

Corniferous (Dev.).

Pentamerella thusneldir Nottelroth, Kentucky Fossil Shells, Mem. Kentucky Geol. Survey, 1889, p. 51, pl. 31, tigs. 26-28.

Loc. Near Louisville, Kentucky.

Pentamerella ventricosa $\mathrm{Hall}=$ Clorinda ventricosa.

PENTAMERUS Sowerby.

Genotype P. lavis Sowerby.

Pentamerus Sowerby, Mincral Conchology, I, 1813, 1. 76.-Hall aud Clarke, Pal.

New York, VIII, Pt. II, 1895, p. 236;-Thirteenth Ann. Rep. N. Y. State. Geologist, 1895, p. 844.

Pentamerus arenosus McChesney=Clorinda arenosa.

Pentamerus aratus= Pentamerella arata.

Pentamerus barandi Billings=Clorinda barrandei.

Pentamerus beaumonti Castelnan $=$ P. oblongus.

Pentamerus bisinuatus MeChesney $=\mathrm{P}$. oblongus.

Pentamerus borealis Meek=Pentamerella borealis.

Pentamerus brevirostris Hall=Anastrophia brevirostris. 
Pentamerus chieagoensis Winchell and Marcy=Clorinda ventricosa.

Pentameris colletti Miller = Conchidium colletti.

Pentamerns comis Meek and Worthen=Gypidala comis.

P'ntamerns complanatus Nettelroth=Conchidium tennicostatum.

I'entanerus 'onchidium=Conchidium biloculare.

P'entamerus coppingeri Etheridge= Gypidula coppingeri.

Pentamerus crassoradius MaChesney=Conchidium erassiradiat $\mathrm{nm}$.

Pentamerus decussatus Whiteaves=Conchidium decussatum.

Pentamerus deshayessii Castelnan=Rensseliria ovoides.

Pentamerus elongatus Vanuxem=Amphigenia elongata.

Pentamerus fornicatus Hall=Clorinda fornicata.

Pentamerus galeatiformis Meek and Worthen=Gypidula comis.

Pentamerus galeatus $\Pi$ all=Gypidula galeata.

Pentamerus galeatus Hall and Whitfield=Gypidula nneleus.

Pentamerus galeatus Roemer $=$ Gypidula remeri.

Pentamerus globulosus Nettelroth=Gypidula globulosa.

Pentamerus hemiplicatus Billings = Parastrophia hemiplicata.

Pentamerus interplicatns Hall=Anastrophia interplicata.

Pentamerus intralineatus Winchell=Pentamerella intralineata.

Pentamerus knappi Hall and Whitfield=Conehidinm knappi.

Pentamerus knighti Sowerby = Conchidium knighti.

Pentamerus knotti Nettelroth=Gypidula knotti.

Pentamerus laqueatus Conrad=Conchidium laqueatum.

Pentamerus lenticularis White and Whitfield=Camarophorella lenticularis.

Pentamerus littoni Iall=Conchidium littoni.

Pentamerus lotis Waleott $=$ Gypidula lotis.

Pentamerus multicostatus=Conchidium multicostatum.

Pentamerus nobilis Emmons=Conchidium laqueatum.

Pentamerns nucleus Hall and Whittield = Gypidula nueleus.

Pentamerus nysins var. crassicosta Hall=Conchidium nysius.

Pentamerus uysius var. tenuicostatus Nettelroth $=$ Conchidium nysius. Pentamerus nysius var. tenuicosta Hall=Conchidium tenuicosta.

Pentamerus oblongus Sowerby.

Clinton and Niagara (Sil.).

Pentamerns oblongus Sowerby, Murchison's Silurian System, 1839, p. 641, pl. 19, fig. 10.-Hall, Geol. N. Y.; Rep. Fourth Dist., 1843, 1. 70, figs. 1-5.Owen, Geol. Expl. Iowa, Wisconsin and Illinois, 1844, pl. 14, fig. 10.-Hall, Ameriean Jour. Sici., 2d ser., XX, 1849, p. 227 ;-Pal. New York, II, 1852, p. 79, l. 25, fig. 1 ; pl. 26, fig. 1.-Billings, Canatlian Nat. Geol., I, 1856, 1. 58, pl. 1, figs. 2, 3;-Geol. ('anadit, 1863, p. 316, fig. 326.-Hall and Whitfiel, Twenty-fourth Rej, N. Y. State Cah. Nat. Hist., 1872, 1. 183 ;-Geol. Survey Ohio, Pal., II, 1875, p. 137, fl. 7, tig. 9.-Whitfield, Geol. Wisconsin, IV, 1882, p. 288, pl. 17, figs. 4-9. - Nettelroth, Kentucky Fossil Shells, Mem. Kentucky Geol. Survey, 1889, p. 60, pl. 33, figs. 15-17.-Hall and Clarke, Pal. New York, VIII, Pt. II, 1895, p. 237, figs. 169-171; pl. 67, fig. 20; pl.68, figs. 1-5; pl. 69, figs. 1, 4-7, 13, 14; pl. 70, tigs. 1-4.

Pentamerus beaumonti Castelnau, Essai syst. Sil. l'Amérique Septentrionale, 1843, 1. $38, \mathrm{pl} .13$, fig. 9. 
Pentamerus oblongus Sowerby-Continued.

Pentamerus bisinnatus MeChesney, Deseriptions New Pal. Foss., 1861, p. 85;Trans. Chicago Acad. Sci., I, 1868, pl. 9, fig. 1.-Whitfield, Geol. Wisconsin, IV, 1882, p. 290, pl. 17, fig. 3.

Loc. England; New York; Ohio; Indiana; Kentucky; Illinois; Iowa; Wisconsin; Thorold, Ontario; Anticosti.

Pentamerus oblongus cylindricus Hall and Whitfield.

Niagara (Sil.).

Pentamerus oblongns var. cylindrica Hall and Whitfield, Twenty-fourth Rep. N. Y. State Cab. Nat. Hist., 1872, p. 183;-Twenty-seventl Rep. Ibidem, 1875, pl. 10, figs. 13, 14.-Nettelroth, Kentucky Fossil Shells, Mem. Kentneky Geol. Survey, 1889, p. 61, pl. 30, figs. 2-4.-Hall and Clarke, Pal. New York, VIII, Pt. II, 1893, p. 237, fig. 172; pl. 68, figs. 7, 8; pl. 69, figs. 11, 12. Loc. Lonisville, Kientucky.

Pentamerus oblongus maquoketa Hall and Clarke.

Niagara (Sil.).

Pentamerus oblongns (partim) Whitfield, Geol. Wisconsin, $1 V$, 1882, pl. 288, 291, pl. 17 , figs. 8,9 .

Pentamerus oblongus var. maquoketa Hall and Clarke, Pal. New York, VIII, PI. II, 1893 , p. 239, pl. 67 , figs. 11-13.

Loc. Ashford, Wisconsin; near Dubuque and Hopkinton, Iowa.

Pentamerus oblongus subrectus Hall and Clarke.

Niagara (Sil.).

Pentamerus oblongus var. subrectus Hall and Clarke, Pal. New York, VIII, Pt. II, 1893 , pp. 238,239 , pl. 68 , fig. 6 ; pl. 69, figs. $2,3,8-10$; pl. 70 , fig. 5 .

Loc. Earlville, Iowa; Wisconsin.

Pentamerus occidentalis Hall, 1858 (non 1852)=Gypidula comis. Pentamerus occidentalis Hall, $1852=$ Conchidinm occidentale.

\section{Pentamerus ovalis IIall.}

Clinton (Sil.).

Pentamerus ovalis Hall, Pal. New York, II, 1852, p. 103, pl. 31, fig. 1.-Foerste, Proc. Boston Soc. Nat. IIist., XXIV, 1890, p. 324, pl. 5, figs. 17, 18.

Loc. New Hartford, Oneida Comnty, New York; Cumberland Gap, Tennessee; Collinsville, Alahama.

Obs. Compare with P. oblongus.

Pentamerus papilionensis Hall = Pentamerella pavilionensis.

Pentamerus pergibbosus Hall and Whitfield. Niagara (Sil.).

Pentamerus pergibbosus Hall and Whittield, Pal. Ohio, 1I, 1875, 1. 139, pl. 7, figs.

10, 11.-Nettelroth, Kentucky Fossil Shells, Mem. Keutucky Geol. Survey, 1889, p. 162 -Hall and Clarke, Pal. New York, VIII, Pt. II, 1893, p. 239, pl. 67, figs. 10, 14-19.

Loc. Greenfield, Ohio; Lonisville, Kentucky; Wisconsin (Whitfield).

Pentamerus pesovis Whitfield.

Waterlime (Sil.).

Pentamerns pesovis Whitfield, Annals N. Y. Acacl. Sci., II, 1882, p. 195;-Ibidem, V, 1891, p. 513, pl. 5, figs. 11-22;-Geol. Ohio, VII, 1895, p. 414, pl. 1, figs. 18-22.

Loc. Greentield, Ohio; Louisville, Kentucky; Wisconsin (Whittield).

Pentamerus pseudogaleatus Hall=Gypidnla pscudogaleata.

Pentamerus reversus Billings=Parastrophia reversa.

Pentamerus salinensis Swallow = Conehidium saliense.

Pentamerus subglobosns Meek and Worthen=Gypidula subglobosa.

Pentamerus trisinuatus McChesney= Meristina trisinuata.

Pentamerus uniplicatus Nettelroth=Gypidula uniplicata.

Pentamerus ventricosus Hall=Clorindi ventricosa.

Bull. S7 $-20$ 
Pentamerus vernenili I Iall = Anastrophia vernenili

PHOLIDOPS Hall.

Genotype Orbienla squamiformis Hall.

l'holiclops IIall, Pal. Now York, III, 185!', p. 489;-Thirteenth Rep., N. Y. State Calb. Nat. Hist., 1860, 1. 92;-Fifteonth Rep. Ibirlem, 1862, 1. 195;-Pal. New York, IV, 18ti7, p1). 31, 413.-Dall, Bull. Mus. Comp., Zool., III, 1871, 1. 27.Ifall and Clarke, Pal. Now York, VIII, Pt. I, 1892, 1. 155.-IVinchell and Srhuchert, Mimmesota Gool. Survey, III, 1893, 1. 376.-1Iall and Clarke, Eleventl, Rep. N. Y. State Geologist, 1894, p. 262.

Craniops Hall, Twolfth Rep. N. Y. State Cah. Nat. Hist., 1859, 1. 84.-Gillelt, Fischer's Manuel de Conchyliologie, 1887, p. 1272.

Pholidops arenaria Hall.

Oriskany (Dev.).

Pholidops arenaria IIall, Jal. Now York, IV, 1867, p. 413, pl. 3, fig. 10.-Hall anl Clarke, Ihidem, VIII, Pt. I, 1892, pl. 4I, fig. 24.

Loc. Albany Comnty aurl IIndson, New York.

Pholidops areolata Hall.

Scholarie (Der.).

Pholidops a reolata Hall, Sixteenth Rep. N. Y. State Cal. Nat. IIist., 1863, p. 31 ; -

Pal. Now York, IV, 1867, p. 31, pl. 3, figs. 1, 5.-Ilall and Clarke, Pal. Now York, VIII, Pt. I, 1892, pl. 4I, figs. 25, 26.

Loc. Clarksville and Knox, New York.

Pholidops bellula Waleott.

Lower Devonian.

Pholidops belłnla Walcott, Mon. U. S. Geol Survey, VIII, 1884, p. 113, pl. 2, fig. 6.-Hall and Clarke, Pal. New York, VIII, Pt. I, 1892, p. 157.

Loc. Eureka district, Nevala.

Pholidops calceola Hall and Clarke.

Cornifermus (Dev.).

Pholidops calceola Hall and Clarke, I'al. New York, VIII, Pt. I, 1892, 1P. 157, 182, pl. 4I, fig. 30 .

Loc. Falls of Ohio.

Pholidops cincinnatiensis Hall.

Lorraine (Ord.).

Pholidops cincimuatiensis Hall, Twenty-fourth Rep. N. Y. State Cab. Nat. Hist., 1872, pl. 7, fig. 10;-Pal. Obio, I, 1873, p. 130, pl. 5, fig. 2.-Miller, Cineinmati Quart. Jour. Seience, II, 1875, p. 14 ;-Jonr. Cineinnati Soc. Nat. Hist., I, 1878, p. 107.-Hall and Clarke, Pal. New York, VIII, Pt. I, 1892, p. 157, ]l. $\{$ I, fig. 18.

Loc. Cincinmati, ete., Ohio.

Pholidops greenei Mliller and Gurley.

Hamilton (Dev.)

Pholidops greenei Miller and Gurley, Bull. Illinois state Mus. Nat. Hist., 12, 1897, p. 48 , pl. 3, tigs. 16-21.

Loc. Falls of Ohio.

Pholidops hamiltoniæ Hall.

Hamilton (Der.).

Pholidops haniltonise 1Tall, Thirtcenth Rep. N. Y. State Cah. Nat. Hist., 1860 , 1. 92 ;-Pal. New York, IV , 1867, 1. 32, jl. 3, figs. 6-9.-Hall and Clarke, Pal. New York, VIII, Pt. I, 1892, p. 157, pl. 4I, figs. 31-34 (37?).

Loc. Darien, Moscow, Canandaigua Lake, etc., Now York.

Pholidops lamellosa Hall = Pholidops oblata.

Pholidops lepis Hall and Clarke.

Corniferous (Dev.)

Plolidops lepis Hall and Clarke, Pal. New York, VIII, P't. I, 1892, p. 157.

Loc. Not given.

Obs. A nomina nudum.

Pholidops linguloides Hall=Pholidops oblata. 
Pholidops oblata Hall.

Hamilton (Dev.).

Pholidops oblata Hall, Pal. New York, IV, 1867, p. 414, pl. 3, fig. 10.

I'holidops (?) linguloides IIall, Ibirlem, 1867, p. 414.

Pholidops Iantellosa Hall, Ibidem, 1867, pi. 3, tig. 11.

Pholidops linguloides and oblita Itall and Clarke, P'al. New York, VIII, I't. I, 1892, p. 157, pl. 41, tigs. $35,36$.

Loc. Aurora and Canandaigua Lake, Now York.

\section{Pholidops ovalis Hall.}

Pholidops ovalis Hall, Trans. Albany Institute, IV, 1863, p. 209;-Pal. New York, IV, 1867, pl. 3, figs. 1, 2;-l'wenty-eighth Rep. N. Y. State Mus. Nat. Hist., 1879, 1. 149, 11. 21, figs. 1, 2;-Eleventh liep. State Geol. Indiana, 1882, p. 284, pl. 21, figs. 1, 2.- Hall and Clarke, Pal. New York, VIII, Pt. I, 1892, p. 157, pl. 4I, tig. 26.

Loc. Waldron, Indiana: Arisaig, Nova Seotia (Ami).

Obs. This specios and P. suluamiformis are probably identieal with $\mathrm{P}$. implicata Sowerloy.

\section{Pholidops ovata Hall.}

Lower Helderberg (Dev.).

Pholidops ovatus Hall, Pal. New York, III, 1859, p. 490, pl. 103B, iig. 7.

Pholidops ovata Iall and Clarke, Pal. New York, VIII, Pt. I, 1892, p. 157, pl. 4I, figs. 22, 23.

Loc. Albany County, New York; ? Square Lake, Maine.

Pholidops patina Hall and Clarke.

Corniferous (Dev.).

Pholidops patina Hall and Clarke, Pal. New York, VIII, Pt. 1, 1892, p. 182, pl. 4I, figs. 27-29.

Loc. De Ceuville, Ontario.

? Pholidops quadrangularis Walcott.

Lower 1)ezonian.

Pholidops quadrangularis Walcott, Mon. U. S. Geol. Survey, VIII, 1884, 1. 114, pl. 2 , tig. 7 .

Loc. Lone Mountain, Nevalla.

Obs. Apparently a plate of a crinoid.

Pholidops squamiformis Hall.

Niagara (Sil.).

Orbicula ? squamiformis Hall, Geol. N. Y.; Rep. Fourth Dist., 1843, p. 108, fig. 1 ;-Pa1. New York, 11, 1852, p. 250, pl. 53, tig. 4.

Craniops squami fornis Hall, Twelfth Rej. N. Y. State Cab. Nat. Hist., 1859, p. 84. Pholidops squaniformis Hall, Pal. Now York, III, 1859, p.490, pl. 103B, tig. 6.Hall and Clarke, Pal. New York, VIII, Pt. I, 1892, p. 156, pl. 1I, tig. 21.

Loc. Lockport, Rochester, etc., New York.

Obs. See Pholidops ovalis Hall.

Pholidops subtruncata Hall.

Lorraine (Ord.).

Orbicula? subtruneata Hall, Pal. Now York, I, 1847, p. 290, pl. 79, fig. 7.

Pholidops subtruncata Hall, Descrip. n. sp. of Crinoidea and other Fossils, 1866, p. 14 ; -Twenty-fourth Rep. N. Y. State Cab. Nat. IIist., 1872, p. 221, pl. 7, fig. 9.-Hall and Clarke, Pal. New York, VIII, Pt. I, 1892, pl. 4I, fig. 19.

Loc. Lorraine and Turin, New York. In the Trenton at Ottawa, Canada (Ami).

Pholidops terminalis Hall.

Oriskany (Dev.).

Pholidops terminalis Hall, Pal. New York, III, 1859, p. 490, pl. 103B, fig. ४.Hall and Clarke, lbidem, VIII, Pt. I, 1892, p. 157.

Loc. Cumberland, Maryland.

Pholidops trentonensis Hall.

Trenton (Ord.).

Pholidop trentonensis Hall, Descrip. n. sp. of Crinoidea and other Fossils, 1866, p. 14;-Twenty-fourth Rep. N. Y. State Cab. Nat. IIist., 1872, p. 221, pl. 7, fig. 8.-Hall and Clarke, Pal. Now York, VIII, Pt. I, 1892, 1. 157, pl. 4I, fig. 17.

Loc. Middleville, Now York. 
Pholidops trentonensis minor Wincliell and Schuchert. Trenton (Ord.).

Plolidops trentonensis var. minor Winchell aud Schuchert, Minuesota Geol. Snrvey, 111, 1893, p. 376, pl. 29), fig. 40 .

loc. St. Pinl and Canuon Falls, Minnesota.

PHOLIDOSTROPHIA Hall and Clarke. (ienotype Strophodonta nacrea Hall=Chonetes (?) iowensis Owen.

Pholidostroplia IIall and Clarke, Pal. New York, V111, l't. 1, 1892, 1. 287;Eleventh Ann. Rep. N. Y. State Geologist, 1891, 1. 281.

Pholidostrophia iowaensis (Cwen). Corniferous and Ilamilton (I)ev.).

Chonetes (?) iowensis (1wen, Geol. Snrvey Wisconsin, lowa, Minnesotie, 1852, p. 584, 13. 3A, tig. 7. [See specinens in T. S. Nat. Mus., Cat. Invert. Foss., 17912.]

Chonetes sp. undet. Owen, 1bidem, 1852, pl. 3A, lig. 17. [See sperimens in U.S. Nat. Mus., Cat. Invert. Foss., 17916.]

Strophomena (Strophodonta) nacrea 11all, Tenth Rep. N. Y. State Cab. Nat. Hist., $1857, \mathrm{~T} \cdot 141$.

Strophomena lepida Hall, Geol. Iowa, 1, 1858, p. 493, pl. 3, Jig. 3.-Billings, Canadian Jonr. Sei. Arts, V1, $1 \times 61$, p. 344.

Strophodonta nacrea Hall, Pal. New York, IV, 1867, p. 104, pl. 18, fig. 1; - Second Ann. Rep. N. Y. State Cieol., 1883, pl. 46, ligs. 20-24.-Nettelroth, Kentucky Fussil Shells, Mem. Kentncky Geol. Survey, 1889, p. 146.

Stropheodonta (Pholidostrophia) nacrea Hall and Clarke, Pal. New York, VIII, Pt. I, 1892, p. 287, 11. 15, figs. 20-24; Pt. 11, 1895, 11. 84, lig. 11.

Loc. Iowa City, Iowa; western New York; Columbus, Ohio; Falls of Ohio; Rock Island, Illinois: Alpena, Miehigan; Ontario, Canada.

Obs. Owen's type specimens preserved in the United States National Museum prove to be identical with Strophomena lepida, which Hall in 1867 said is a synongun for Stropheodonta nacrea.

Plæsiomys Hall and Clarke=Dinorthis.

PLATYSTROPHIA King. Genotype Terebratulites biforata Schlotheim.

Platystrophia King, Mon. P'ermian Fossils of England, Pal. Soc., 1850, p. 116.Hall, Geol. Soe. America, 1, 1889, pp. 19, 20.--Hall and Clarke, Pal. Now York, VIII, Pt. I, 1892, 1. 200.-Winchell and sehnchert, Minnesota Geol. Survey, III, 1893, p. 454.-Hall and Clarke, Eleventh Amm. Rep. N. Y. State Geologist, 1894, p. 268.

Obs. It is doubtful whether all the various forms of Platystrophia can he regarded as species. This genus is nearly always abundantly represented by one or more forms throughont the American Ordovician and Silurian systems. When individuals of the same region or of widely separated. loealities are compared with each other it is apparent that the specitic eharacters ar. very inconstant. Individuals of a stratnm, however, are fairly constant in form, size, and plications, and it is this linited constancy that has served in many of the following species.

Platystrophia acuminata James.

Lorraine (Ord.). Orthis (Platystrophia) acuminata James, The Palientologist, 1, 1878, 1. 7.

Loc. Cinciunati, Ohio.

Platystrophia acutilirata (Conrad).

Lorraine (Ord.). Delthyris acutilirata Conrad, Jour. Acad. Nat. Sci. Philodelphia, VIII, 1842, 1'. 260, pl. 14, fis. 15.

Orthis (Plaţ̦stropliia) acıtilirata Meck, Pal. Ohio, I, 1873, p. 119, pl. 10, lig. 5. Orthis acutilirata Miller, Cinciunati Quart. Jour, sei., II, 1875, p. ㄹ. 


\section{Platystrophia acutilirata (Conrad)-Continned.}

Orthis biforata var. acutilirata White, Second Ann. Rep. Indiana Bureau of Statisties and (ieol., 1880, p. 487, pl. 2, tigs. 5-9;-Tenth Rep. State Geol. Indiana, 1881, p. 119, pl. 2, tigs. 5-9.

Platystrophia acutilirata Hall and Clarke, Pal. New York, VIII, Pt. I, 1892, p. 223. Loc. Richmond, Indiana; Oxford, Ohio ; Lonisiana, Missouri (Keyes).

\section{Platystrophia biforata (Schlotheim). Chazy-Niagara(Ord. and Sil.).}

Terebratulites biforatus Schlotheim, Petrefactenkmule, 1820, 1. 265.

Spirifer sheppardi Castelnan, Essai Syst. Sil. l'Amérique Septentrionale, 1813, p. 42, pl. 14, tig. 15 .

Delthyris brachynota Hall, Geol. New York; Rep. Fonrth Dist., 1843, p. 70, fig. 6. Orthis and Delthyris Owen, Geol. Expl. Iowa, Wisconsin, Illinois, 1844, pl. 15, figs, 3,7 .

Delthyris lynx Hall (partim; non Eichwald), Pal. New York, I, 18.7, p. 133, pl. $32 \mathrm{D}$, fig. 1.

Spirifer liforata var. lynx Hall, Ibidem, II, 1852, p. 65, pl. 22, fig. 1.

Orthis liforatns Billings, Cauadian Nat. Geol., I, 1856, 1. 206, figs. 6-10.-Nicholsom and Hinde, Canadian .Jour., XIV, 187.1, p. 158.-White, Rep. U. S. Geogr. Geol. Survey west 100th Meridian, IV, 1874, p. 74, pl.4, fig. 9.--Nettelroth, Kentucky Fossil Shells, Mem. Kentucky Geol. Survey, 1889, p. 35, p]. 29, figs. 18-29.--Foerste, Proc. Boston Soc. Nat. Hist., XXIV, 1890, p. 312.

Orthis lynx Billings, Geol. Canada, 1863, p. 167, lig. 149._Miller (partim), Cincinnati Quart. Jour. Sci., II, 1875, p. 25.

Platêstrophia regularis Shaler, Bull. Mns. Comp. Zool., 4, 186\%, p. 67.

Orthis (Platystroplia) hiforata Meek, Pal. Ohio, I, 1873, p. 112.-Foerste, Geol. Ohio, ViI, 1895, 1. 579, pl. 25, tigs. 7, 8.

Orthis (Platystrophia) biforata var. lynx Hall, Second Ann. Rep. N. Y. State Geologist, 1883, pl. 35, figs. 11-11 (non figs. 9, 10, 15 of pl. 35 and fig. 30, pl. $34=1$. biforata lynx).

Orthis biforata var. lynx forma reversata and daytonensis Foerste, Bull. Denison Univ., I, 188., p1. 81, 82, pl. 13, figs. 7,8 .

Platystrophia lynx Hall and Clarke, Pal. New York, VIII, Pt. I, 1892, pl. 202, 223, pl. 5B, fig. 10.-Keyes, Geol. Survey Missouri, V, 1895, p. 61, pl. 39, tig. 5.

Platystrophia bifurata Winchell and Schuchert, Minnesota Ceol. Survey, III, 1893, 1. 455, pl. 33, figs. 5I-54.-Whiteaves, Pal. Foss., III, Pt. III, 1897, p. 177.

Loc. Thronghont the horizons mentioned above in North America; also in Euglaud, Scotland, Irelaut, Crotland, Scaudinavia, Oeland, and Russia.

\section{Platystrophia crassa James.}

Lorraine (Ord.).

Orthis (Platystroplia) dentata?? Meek (non Pander), Pal. Ohio, I, 1873, p. 117, 1). 10, fig. 3 .

Orthis (Platystrophia) erassa James, Cincinnati Quart. Jour. Nei, I, 1874, p. 20. Orthis dentata Miller, Ibiclem, II, 1875, P. 27.

Orthis centrosa Miller, North American (ieol. Pal., 1889, p. 356.

Platystrophia crassa Hall and Clarke, Pal. New York, V1II, Pt. I, 1892, 1. 223.

Platystrophia liforata var. crassa Winchell and Schuchert, Geol. Survey Minnesota, III, 1893, p. 458, pl. 33, figs. 55, 56.-Whiteaves, Pal. F'oss., III, l’t. III, 1897, p. 178.

Loc. Cincinnati, Ohio; Apring Valley, Minnesota; Lake Wimnipeg, Manitoba.

Platystrophia laticosta Meek.

Lorraine (Ord.).

Orthis (Platystrophia) laticosta (James) Meek, Pal. Ohio, I, 1873, p. 116, pl. 10, fig. 4 .

Orthis (Platystrophia) eypha James, Cincinnati (qnart. Jour. Sci., I, 1874, p. 20. 


\section{Platystrophia laticosta Meek-Contimuel.}

Orthis laticosta Niller, Cineinuati Quart. Jour. Sci., II, 1875, 1. 27.

Platystrophia hiforatia var. laticosta llall and Clarke, l'al. Now York, VIII, Pt.

1, 18!2, 1).223, pl. 513, figs. 5-9

Loc. Cincinnati, ete, Ohio.

Platystrophia lynx (Eichwalı).

Lorraine (Ord.).

'Terebratula lynx Eichwald, Skizzo von Podolis, 1830, p. 202.

Delthyris lynx (partim) IFall, Jal. New York, I, 1847, p. 133, pl. 32D, fig. 1.-

Rogers, Geol. I'emsylyania, 1I, I't. 11, 1858, p. 820, tig. 616.

Orthis (Platystrophia) biforata var. lyux Meek, Pal. Ohio, J, 1873, p. 114, pl. 10,

fig. 1.-Hall, Secoud Aun. Rep. X. Y. State Geol., 1883, pl. 35, figs. !, 10, 15.

Orthis lyux (partim) Miller, Cincimati (unat. Jour. Sci., II, 1875, 1. 25.

Orthis biforata Nicholson, Pal. Province Ontario, 1875, p. 16, tig. 5.

Orthis (I'latystrophia) lynx Hall, Second Ann. Rep. N. Y. Stato Geol., 1883, pl. 34, fig. 30.

Platystrophia biforata rar. lynx Hall and Clarke, Pal. New York, VIII, l’t. I, 1892, pp. 202, 223, pl. 5B, figs. 1-4.

Loc. Cincinnati, Ohio, and elsewhere in the Ohio Valley.

Platystroplia regularis Shaler $=$ Platystrophia biforata.

\section{PLECTAMBoNITES Pander. Genotype P. planissima Pander.}

Plectambonites l'ander, Beitrage zur Geognosie des Russ. Reiches, 1830, 1. 90, pl. 3, figs. \&, 16; pl. 28, fig. 19._Hall and Clarke, Pal. New Jork, VIII, Pt. I, 1892, 11. 236, 295.-Winchell and Schuchert, Minnesota Geol. Survey, 11I, 1893, p. 413.-Hall and Clarke, Eleventh Anu. Rep. N. Y. State Geologist, 1894, 1. 290.

Plectambonites arca Slialer=Plectambonites transvel'salis.

Plectambonites gibbosus Winchell and Schuchert. Trenton (Ord.).

Plectambonites gibbosa W. and S., American Geol., IX, 1892, p. 288;-Minnesota Geol. Surrey, III, 1893, p. 416, pl. 32, figs. 13-17.

Loc. Mantorville, Old Concord, and near Cannon Falls, Minnesota.

Plectambonites glaber Slıaler.

Aiticosti (Sil.).

Plectambonites glaber Shaler, linll. Nus. Comp. Zool., 4, 1865, p. 64.

Leptiena glabra Foerste, Proc. Boston Soc. Nat. Hist., XXIV, 1890, p. 294.

Loc. Anticosti.

Plectambonites plicatellus (Ulrich).

Utica (Ord.).

Leptrena plicatella Ulrich, Jour. Cineinnati Soc. Nat. Hist., I, 1879, p. 15, pl. 7, fig. 12.

Plectambonites plicatella Hall and Clarke, Pal. New York, VIII, Pt. I, 1892, pl. $15 \mathrm{~A}$, figs. 34,35 .

Loc. Cincinnati, Ohio; Covington, Kentncky.

Plectambonites productus Hall and Clarke.

Niagara (Sil.).

Plectambonites producta Hall and Clarke, Pal. New York, VIII, Pt. II, 1895, p. 360, pl. 81, figs. 23-25.

Loc. Yellow Springs, Ohio.

Plectambonites sericeus (Sowerby).

Trenton to Clinton (Ord.-Sil.).

Lept:יna sericea J. de C. Sowerby, Murchison's Silurian System, 1839, pl. 19, figs. 1, 2.-1lall, Pal. Now York, I, 1847, pp. 110, 287, pl. 31B, fig. 2; pl.79, fig. 3;Ibidem, II, 1852, 1. 59, pl. 21, fig. 1.-Billings, Canadian Nat. Gool., I, 1856, p. 11, fig. 2.-Rogers, Geol. Pennsylvimia, II, Pt. II, 1858, p. 818, fig. 599.-Billings, Geol. Canada, 1863, p. 163, fig. 139.-Meck, Pal. Ohio, I, 1873, p. 70, pl. 5, fig. 3.-Miller, Cincimuati Quart. Jonr. Sci., II, 1875, p. 57.-Kayser, Palixontographica, Suppl., III, 1876, p. 21, pl. 3, fig. 19.-Hall, Second Ann. Rep. 
Plectambonites sericeus (Sowerby)-Contiuued.

N. Y. State Ġeol., 1883, pl. 46, figs. 25-29.--Foerste, Proc. Bostou Soc. Nat. Ilist., XXIV, 1890, p. 293.-Keyes, Geol. Survey Missouri, V, 1895, p. 75, pl. 39, fig. 9.

Leptana sericea? White, Wheeler's Expl. Survey west of the 100th Merid., IV, 1875 , 1. 70 , pl. 4, fig. 7 .

Strophomena sericea Conrad, Third Ann. Rep. Geol. Survey N. Y., 1840, p. 201.Enmons, Geol. N. Y.; Rep. Second Dist., 1842, p. 394.

Strophomena semiovalis Vanuxem, Geol. N. Y.; Rep. Third Dist., 1842, 1. 47.

Leptiena aspera James, Cincinnati Quart. Jour. Sci., I, 187t, p. 151.

Plectambonites sericea, Hall aud Clarke, Pal. New York, VIII, Pt. I, 1892, 11. 15, figs. 25-29.-Winchell and Schuchert, Minnesota Geol. Survey, III, 1893, p. 414, pl. 32, figs. 10-12.-Whiteaves, Pal. Foss., III, Pt. III, 1897, 1. 17.

Leptiena minnesotensis Sarleson, Mimmesota Acar. Nat. Sci., I1I, 1892, p. 329, pl. 4, figs. 24,25 .

Leptiena precosis Sardeson, Ibidem, 1892, p. 329, pl. 4, figs. 26-28.

Leptarna recedens Sardeson, Ibidem, 1892, p. 330, pl. 4, figs. 29-32.

Leptiena saxea Sardeson, Ibidem, 1892, 1. 330, pl. 4, figs. 33-35.

Loc. England; New York; Ohio; Indiana; Kentucky; Missouri; Wisconsin; Minnesota; Manitoba; Talacastra, Argentine Republic.

Plectambonites tenera Shaler=Plectambonites trausversalis.

Plectambonites transversalis (Wahlenberg). Clinton-Niagara (Sil.).

Anomites transversalis Wahlenberg, Act. Soc. Upsaliensis, III, 1821, 1. 61.

Strophomena elegantula 1Iall, Geol. N. Y.; Rep. Fourth Dist., 1843, 1. 72, fig. 1. Strophomena transversalis Ilall, Ibidem, 1843, p. 105, fig. 4.

Leptena transversalis Hall, Pal. New York, II, 1852, p. 256, pl. 53, fig. 5.-13illings, Canadian Nat. Geol., I, 1856, p. 138, pl. 2, tigss. 14, 15.-11all, Second Ann. Rep. N. Y. State Geol., 1883, pl. 46, figs. 34-36.

Plectambonites arca and tenera Shaler, Bull. Mus. Comp. Zool., 4, 1865, p. 61.

Leptiena transversalis var. elegantula Foerste, Proc. Boston Soc. Nat. Hist., XXIV, 1890, p. 294, pl. 6, tig. 6.

Plectambonites transversalis Hall and Clarke, Pal. New York, VIII, Pt. I, 1892, p. 298, pl. 15, figs. 34-36.-Foerste, Geol. Ohio, VII, 1895, 1. 566, pl. 25, fig. 5; pl. 30 , fig. 13 ; pl. 31 , fig. 6 .

Loc. Europe; New York; Osgood, Indiana; Wisconsin; Dundas and Hamilton, Ontario; Anticosti; Lake Temiscouata, New lirunswick.

Plectambonites transversalis alabamaensis (Foerste).

Clinton (Sil.).

Leptena transversalis var. alabamensis Foerste, Proc. Boston Soc. Nat. IIist., XXIV, 1890, 1. 296, pl. 5, tig. 9.

Loc. Collinsville, Alabama.

Plectambonites transversalis prolongatus (Foerste).

Clintou (Sil.).

Leptiena prolongata Foerste, Bull. Denison Univ., I, 1885, p. 79, pl. 13, fig. 5.

Leptiena transversalis var. prolongata Foerste, Proc. Boston Soc. Nat. Hist., XXIV, 1890, p. 297, pl. 5, tig. 13.

Loc. Dayton, Ohio; Wildwood Station, Georgia.

PLECTORTHIS Hall and Clarke. Genotype Orthis plicatella Hall.

Orthis (group of O. plicatella) Hall, Bull. Geol. Soc. America, I, 1889, p. 20.

Plectorthis Hall and Clarke, PaI. New York, VIII, Pt. I, 1892, pl. 191, 221.Winchell and Schnchert, Minnesota Geol. Survey, III, 1893, 1. 435.-Hall and Clarke, Eleventh Ann. Rep. N. Y. State Geologist, 1894, p. 266.

Plectorthis æquivalvis (Hall).

Lorraine (Ord.).

Orthis iequivalvis Hall (non Davidson, 1847), 1'al. New York, 1, 1847, p. 120, pl.

32 , fig. 6 . 
Plectorthis æquivalvis (Hall)-Continued.

Plectorthis :equivalvis Hall and Clarke, P'al. New York, VIII, I't. I, 1892, I'I. 194, 221.

Loc. Cincinnati, (Hio; Wisconsin (Whitfield).

Plectorthis (?) aurelia (Billings).

Oriskany (Dev.).

Orthis anrelia Billings, Pal. Fossils, II, 1874, p. 34, pl. 3, tig. 3.

Plectorthis? aurelia Hall and Clarke, Pal. New York, V'III, l't. I, 1892, p. 221.

Loc. Indian Cove, Gaspe.

Plectorthis dichotoma Hall.

Lorraine (Ord.).

Orthis dichotoma IIall, Pal. New York, I, 1847, 1. 125, pl. 32, tig. 13.-Nliller, American Pal. Fossils, 1877, p. 117.

Orthis fissicosta Meek (non Hall), Jal. Ohio, I, 1873, p. 106, pl.8, fig. 6.-Miller,

Cincinnati Qnart. Jour. Sci., II, 1875, I. 30.

(Trthis neglecta James, The Palxontologist, 4, 1879, p. 26.

Plectorthis dichotoma Hall and Clarke, l'al. New York, VIII, Pt. I, 1892, p. 221, pl. 5 , fig. 21.

Loc. Cincinnati, Ohio.

Plectorthis ella Hall.

Lorraine (Ord.).

Orflis ella Hall, Thirteenth Rep. N. Y. State Cab. Nat. Hist., 1861, 1. 121.

Orthis ? ella Hall, Fifteen th Rep. Ibislem, 1862, pl. 2, figs. 6-8;-'Twenty-fourth Rep. Ibidem, 1872, pl. 7, fig. 21.-Neek, Pal. Ohio, I, 1873, 1. 105, pl. 8, fig. 9.--Hall and Whitfield, Ibilem, II, 1875, p. 76, pl. 1, tig. 20.-Miller, Cincinnati Quart. Jour. Sci., 1I, 1875, p. 32.

Plectorthis ? ella Hall and Clarke, Pal. New York, VIII, Pt. I, 1892, p. 221, pl. 5, figs. $22,23$.

Loc. Cincinnati, Ohio.

Plectorthis fissicosta Hall.

Orthis iissicosta Hall, Pal. New York, I, 1817, p. 121, pl. 32, 1ig. 7.

Lorraine (Ord.).

Plectorthis fissicosta 11 all and Clarke, I'al. New York, VIII, Pt. I, 1892, pp. 194,22 I.

Loc. Cincinnati, Ohio.

Plectorthis jamesi Hall.

Lorraine (Ord.).

Orthis jamesi Hall, lourteenth Rep. N. Y. State ('ab. Nat. Hist., 1861, 11. 89.Miller, Cincinnati Quart. Jour. Sei., II, 1875, p. 33.-Hall and Whitfield, Pal. Ohio, II, 1875, p. 77, pl. 1, 1igs. 21, 22.

Plectorthis jamesi Ilall and Clarke, Pal. New York, VIII, I’t. I, 1892, pn. 194, 221. Loc. Cincinnati, Ohio.

Plectorthis kankakiensis (McChesney).

Lorraine (Ord.).

Orthis kankakensis McChosney, Now Pal. Fossils, 1861, p. 77 ;-Trans. Chicago Acari. Sci., I, 1868 , p. 29, pl. 9, fig. 3.

Plectorthis kankakensis Hall and Clarke, Pal. New York, VIII, I’t. I, 1892, p. 221, pl. 5, ijgs. 24, 25.

Loc. Wilmington, Illinois; Wisconsin (Whitrield).

Plectorthis plicatella Hall.

Trenton-Lorraine (Ord.).

Orthis plicatella Hall, Pal. New York, I, 1817, p. 122, pl. 32, tig. 9.-Meek, Pal. Ohio, I, 1873, p. 108, jl. 8, fig. 7.-Miller, Cincimnati Quart. Jour. Sci., II, 1875, 1. 30.

QOrthis plicatella Billings, Geol. Canada, 1863, p. 165, lig. 115.

Plectorthis plicatella Hall and Clarke, Pal. New York, VII, Pt. I, 1892, p. 221, 11. 5, figs. 18-20.

Orthis (Plectorthis) plicatella Winchell and Schuchert, Minnesota Geol. Snrvey, III, 1893, p. 436, pl, :33, ligs. 5-7.

Loc. Cincinuati, Olsio; Mildleville and Watertown, New York; Burgin, Kentucky; Cannon Falls, Keuyon, ete., Minnesota; Wisconsin. 
Plectorthis sectistriata (E. O. Ulrich).

Lorraine (Ord.).

Orthis (?) sectostriata Ulrich, Jour. Cincinnati soc. Nat. Hist., II, 1879, p. 15, pl.

7, fig. 11.

Plectorthis? sectostriata Hall and Clarke, Pal. New York, VIII, Pt. I, 1892, p. 221. Loc. Cinciunati, Ohio.

Plectorthis triplicatella (Meek).

Lorraine (Ord.).

Orthis triplicatella Mcek, American Jour. Sci., IV, 1872, 1. 281 ;-Pal. Ohio, I, 1873, p. 109, pl. 8, fig. 8.-Miller, Cinciunati Quart. Jour. Sei., II, 1875, p 31.

Plectorth is triplicatella Hall and Clarke, Pal. New York, VIII, Pt. I, 1892, pl. $194,221$.

Loc. Cincinnati, Ohio.

Plectorthis whitfieldi (N. H. Winchell).

Lorraine (Ord.).

Orthis whitfeldi N. H. Winchell, Ninth Aun. Rep. Geol. and Nat. Hist., Survey of Minuesota, 1881, p. 115.

Orthis pectinella Whitfield (partim, won Emmons non Hall), Geol. Wisconsin, IV, 1882, p. 259, pl. 12, tig. 8.

Plectorthis whitfieldi Hall and Clarke, Pal. New York, VIII, Pt. I, 1892, P. 221. pl. 5 , fig. 26.

Orthis (Plectorthis) whitfieldi Winchell and Schuchert, Minnesota Geol. Sur vey, III, 1893, p. 437, pl. 33, figs. 8-13.

Loc. Spring Valley and Granger, Ninnesota; lelafield, Wisconsin; Lattners Iowa; Savanna, lllinois.

FLETHORHYNCHA Hall and C. (ienotype Rhynehonella speeiosa Hall

Plethorlyucha FIall and Clarke, Pal. Now York, TIII, I't. II, 1893, p. 191 ;Thirteenth Ann. Rep. N. Y. State (ieologist, 1895, \%. 827.

Obs. Proposed as a subgenns of Camarotachia. It, however, does not seem to be worthy even of that rank. The species referred to Plethorhyncha are Camarotachia barrandei Hall, C. pleiopleura (Conrad), and C. speciosa Hall.

Plieatula striatocostata Cox = Meekella striaticostata.

POLYTECHIA IIall and Clarke. Genotype Hemipronites apical is Whitf. Polytøechia Hall aud Clarke, Pal. New York, VIII, Pt. I, 1892, p. 239, figs. 11, 12 ;Eleventh Anu. Rep. N. Y. State Gcologist, 1894, 1. 275.

Polytœchia apicalis (Whitfield).

Caleiferous (Oril.).

Hemipronites apicalis Whitfield, Bull. Anerican Mus. Nat. Hist., 11, 1886, 1. 300, pl. 24, tigs. 1-5.

Polytachia apicalis Hall and Clarke, Pal. New York, VIII, Pt. I, 1892, 1. 239, fig. 11, 12, ,l. 7A, figs. 26-30.

Loc. Fort Cassin, Vermont.

PORAMBONITES Pander. Genotype Porambonites intermedia Pander. Porambonites Pander, Beitrage zur Geognosie des Russ. Reiches, 1830, 1. 95, I1. 3, fig. 9. -Ilall and Clarke, Pal. New York, VIII, Pt. II, 1895, 1. 225.

Obs. Not represented in America.

Porambonites obsemus Hall aud Whitfield=Parastrophia obseurus.

Porambonites ottawaensis Billings = Rhynchotrema ottawaensis.

PROBOSCIDELLA QEhlert. Genotype Productus proboscideus de V'ern.

Probosciclella Ehhlert, Fischer's Manuel de Conchyliologie, 1887, p. 1277.-Hall aud Clarke, Pal. New York, VIII, Pt. I, 1892, 1. 333.

Proboscidella (?) clava (Norwood and Pratten). Upper Carboniferons.

Productus clarus Norwood and Pratten, Jour. Acad. Nat. Sci. Philadelphia, III, 1854, p. 10, pl. 1, fig. 4.

Proboscidella clava Elall and Clarke, Pal. Now York, VIII, Pt. I, 1892, p. 334.

Loc. Graysville, Illinois. 
PRODUCTELLA Hill. Genotype Productus subaculeatus Murchison. Productulla I Iall, Twentieth liep. N. Y. State Cab. Nat. llist., 1867, p. 245;-Pal. New York, IV, 1867, 1. 153.-Nettelroth, Kentucky Fossil Shells, Mem. Kentucky (ieol. Survey, 18\$9, ]'. 69.-Hall aud Clarke, Pal. New York, VIII, Pt. I, 1892, 1. 328;-Wloventh Anu. Rep. N. Y. State Geologist, 1894, p. 298.

Productella arctirostrata IIall.

Chemung (Dev.).

Productus arctirostrata Hall, Tenth Rep. N. Y. State Cab. Nat. Hist., 1857, 1' 177. Productella aretirostrata Pal. New York, IV, 1867, p. 182, pl. 26, figs. 16-23;Socond Ann. Rep. N. Y. State Geol., 1883, pl. 48, fig. 36.-Hall and Clarke, Pal. New York, VIII, I’t. I, 1892, pl. 17, fig. 36.

Loc. Jasper and Calliz, Now York.

Productella arcuata Hall.

Kinderhook (L. Carb.).

Productus arcuatus IIall, Geol. Survey of Iowa, I, Pt. II, 1858, 1. 518, pl. 7, fig. 1.-IIerrick, Bull. Denison Univ., III, 1888, p. 31, pl. 3, fig. 18.-Keyes, Geol.

Survey Missouri, $\mathrm{V}, \mathbf{1 8 9 5}$, p. 40.

Productella areuata Ilall, Second Ann. Rep. N. Y. State Geol., 1883, pl. 48, figs. $31,32$.

Loc. Burlington, Iowa; Granville, Newark, ete., Ohio; Hannibal, Missouri.

Obs. See I'. cooperensis.

Productella bialveata Hall.

Chemung (Dev.).

Produetella bialveata IIall, Pal. New York, IV, 1867, p. 183, pl. 26, figs. 24-28.

Loc. Meadville, Pennsylvania.

Productella boydi IIall.

Chemung (Dev.).

Productus boydi Hall, Tenth Rep. N. Y. State Cab. Nat. Hist., 1857, p. 179, figs. $1-3$.

I'roductella boyili Hall, Pal. New York, IV, 1867, p. 169, pl. 24, figs. 10-16;Second Ann. Rep. N. Y. State Geol., 1883, pl. 48, fig. 24.-Hall and Clarke, Pal. New York, VIII, Pt. I, 1892, pl. 17, fig. 24.

Loc. Phillipsburg, Elmira, ete., New York.

Productella concentrica (Ilall).

Kinderhook (L. Carb.).

Productus concentricus IIall, 'Tenth Rep. N. Y. State Cab. Nat. Hist., 1857, p. 180 ;-Geol. Survey Iowa, I, Pt. II, 1858, 1. 517, pl. 7, fig. 3.-A. Winchell, Proc. Acad. Nat. Sei. Philadelphia, 1862, p. 411 ;-Ibidem, 1865, p. 114; Proc. American Philosophical Soc., XII, 1870, p. 249.-Herrick, Bull. Denison Uuiv., III, 1888, p. 33, pl. 6, fig. 16.

Loe. Burlington, Iowa; Port aux Barques, Michigan; Rockford, Indiana; Sciotoville, etc., Ohio.

Obs. Compare with Productella shmmardana.

Productella costatula Hall.

Chemung (Trev.).

Prorluctella costatnla IIall, Pal. Now York, IV, 1867, p. 180, pl. 26, figs. 9, 15; Second Ann. Rej. N. Y. State Geol., 1883, pl. 48, figs. 18-20, 35.-Hall and Clarke, Pal. New York, VIII, Pt. I, 1892, pl. 17, figs. 18-20, 35.

Loc. Rauclolph Conewango, New Albion, etc., New York.

Productella costatula strigata Hall.

Cliemung (Dev.).

Prodnetella costatula var. strigata Hall, Pal. New York, IV, 1867, p. 181.

Loc. Near Cadiz, New York.

Productella dumosa IIall.

Hamilton (Dev.).

Produetus dumosus Hall, Fourteenth Rep. N. Y. State Cab. Nat. IIist., 1861, p. 99. Productella dumosa Hall, Pal. New York, IV, 1867, p. 162, pl. 23, figs. 38-40;Second Aun. Rep. N. Y. State Geol., 1883, pl. 18, tig. 21.-Hall and Clarke, Pal. New York, VIII, Pt. 1, 1892, pl. 17, fig. 21.

Loc. Delphi, Bellona, Moscow, Hamilton, etc., Now York. 
Productella(?) eriensis Nicholson.

Corniferous (Dev.).

Prodnetella eriensis Nicholson, Geol. Magazine London, n. ser., I, 1874, p. 118;-

Pal. Prov. Ontario, 1874, p. 77, fig. 26.

Loc. Port Colborne and Hagersville, Ontario.

Ols. See Anoplia nucleata Hall.

Productella exanthemata Hall.

Corniferous and Hamilton (Dev.).

Irodnctus exanthematus 1lall, Tenth liep. N. Y. State Cab. Nat. Hist., 1857, p. 174.

Productella exanthemata Hall, Pal. New York, IV, 1867, p. 163, pl. 23, figs. 45, 46;-Second Ann. Rep. N. Y. State Geol., 1883, pl. 48, fig. 17.-Fall and Clarke, Pal. New York, VIII, Pt. I, 1892, pl. 17, fig. 17.

Productus exanthematns ?? Meek and Worthen, Geol. Survey Illinois, III, 1868, p. 412 , pl. 10 , fig. 3 .

Loc. Tinkers Falls and Seneca Lake, New York; Jackson and L'nion rounties, Illinois.

Productella hallana Walcott.

Upper Devonian.

Productus dissimilis Hall (non de Koninck, 1846), Geol. Survey Iowa, I, Pt. II, 1858, p. 497, pl. 3, fig. 7.-Meck, Trans. Chicago Acarl. Sci., I, 1868, p. 91, pl. 13 , fig. 3 .

Productns ? Meek, Ibidem, 1868, p. 91, pl. 13, fig. 4.

Productus (Prodnctella) hallanus Walcott, Mon. IT. S. Geol. Snrrey, VIII, 1884, p. 130, pl. 13, fig. 17.

Productus hallanus Tschernyschew, Mémoires dn Comité Géologique de St. Pétersbourg, III, 1887, p. 114, pl.14, fig. 27.- von Toll, Wissensch. Resultate d. Neusibirischen Exped., 1885 u. 1886, 1889, p. 25, pl. 2, fig. 19.

Productus hallianus Williams, Bull. Geol. Soc. America, I, 1890, pl. 12, figs. 8, 9. Productella dissimilis Whiteaves, Cont. Canadian Pal., I, 1891, p. 216.

Prodnctella hallana Hall and Clarke, Pal. Now York, VIII, Pt. I, 1892, pl. 17A, figs. 11, 12.

Loc. Rockford, Iowa; High Point, Now York; Eureka district, Nevada; Athabasca River, Canada; Urals of Russia.

Productella hirsuta Hall.

Chemung (Dev.).

Strophomena membranacea Vanuxem (non Productus membranacous von Buch), Geol. N. Y.; Rep. Third Dist., 1842, p. 179, figs. 4, 5.

Productus hirsutus Hall, Tenth Rep. N. Y. State Cab. Nat. Hist., 1857, p. 175, figs. 1-3.

I'roductella hirsuta Hall, Pal. New York, IV, 1867, p. 166, pl. 24, figs. 17-29;Second Ann. Rep. N. Y. State Geol., 1883, pl. 48, figs. 28, 39.-Hall and Clarke, Pal. New York, VIII, Pt. I, 1892, pl. 17, figs. 28, 39, 45.

Loc. Phillipsburg and Rockville, Now York; Covingtou, Pennsylvania.

Productella hirsuta rectispina Hall.

Chemung (Dev.).

Productella hirsuta var. rectispina IHall, Pal. New York, 1Y, 1867, p. 168, 11. 24, figs. 30-37; -Second Ann. Rep. N. Y. State Geol., 1883, pl. 48, fig. 37.-Hall and Clarke, Pal. Now York, VIII, Pt. I, 1892, pl. 17, fig. 37.

Loc. Meadville, Pennsylvania.

Productella hirsutiformis (Walcott).

Upper Devenian.

Productus hirsutiforme Walcott, Mon. 1T. S. Geol. Survey, VIII, 1884, 1. 133, pl. 2, fig. 10.

Loc. Eureka and White Pine districts, Nerada.

Productella hystricula Hall=Strophalosia hystrienla.

Productella lachrymosa (Conrad).

Cliemung (Dev.).

Strophomena lachrymosa Conrad, Jour. Acad. Nat. Sci. l'hiladelphia, VIII, 1842 , p. 256 , pl. 14, fig. 9. 


\section{Productella lachrymosa (Conrad)_Continnerl.}

l'rouluetus laclurymosus Ifall, Tenth liep. N. Y. State Cab. Nat. Hist, 1857, J. 177. Prouluete]la laclirymosa liall, Pal. Now lork, [V, 1867, p. 172, pl. 25, figs. 23-28. Loc. Facteryville, Bath, Ellington, ote., Now York.

Productella lachrymosa lima (Coural).

Chremung (Dev.).

Stroplomena lima Conrad, Jour. Acar. Nat. Sei. Philadelphia, VIlI, 1812, 1. 256. Prodnctella lachrymosa var. lima IIall, Pal. Now York, IV, 1867, 1). 174, pl. 25, figs. 29-32;-Serond Ann. Kep. N. Y. Stato Geol., 18.3, pl. 4R, figs. 22, 23.Whiteaves, Cont. Canadian Pal., I, 1891, 1. 217.-1Iall and Clarke, Pal. New Tork, VIII, P't. I, 1892, pl. 17, figs. 22, 23.

Productus (Prodnetrlla) lachrymosus var. limns Walcott, Mon. U. S. Geol. Surrey, V'III, 1881, p. 132, pl. 13, fig. 18.

Loc. Ramblph, Ellington, etc., Now York; Eureka district, Nevada; Mackenzie River, Canada.

\section{Productella lachrymosa stigmata IIall. Chem.and Wav. (Dev. and L.Car.).} Productella lachrymosa var. stigmata Hall, Pal. Now York, IV, 1867, p. 174, pl. 25, figs. 33-41.

? Productus ? Meek, Trans. Chicago Acad. Sci, I, 1868, p. 91, pl. 13, fig. 5.

I'rodnctus (Productella) lachrymosus var, stigmatus Walcott, Mon. U. S. Geol. Survey, VIII, 1881, p. 132.-IJerrick, Bnll. Denison Univ., III, 1888, p. 34, pl. 3 , fig. 28.

Loc. Olean, Conewango, and Randolph, New York; Licking County, Ohio; Enreka district, Nevada; Northwest Territory, Canada.

Productella mæcuruensis Rathbun.

Middle Devonian. Prodnctella mrenrnensis Rathbun, Proc. Boston Soc. Nat. Hist., XX, 1879, p. 17. Loc. Province of Para, Brazil.

Productella marquessi Rowley.

Hamilton (Der.).

Productella marquessi Rowley, American Geologist, XIII, 1894, p. 153, figs. 7, 8. Loc. Callaway County, Missouri.

Productella minneapolis Sardeson=Trematis huronensis.

\section{Productella murchisoniana (de Koninck). Hamilton (Dev.).}

Productus murehisonianus de Koninck, IÍm. de la Soc. Royale des Sciences de Liége, IV, 1816, p. 245, pl. 16, fig. 3.-Norwood and Pratten, Jour. Acad. Nat. Sci. Philatelphia, III, 185t, p. 21.

Loc. Devils Back Bone, Illinois.

\section{Productella navicella Hall.}

Corniferous and Hamilton (Dev.).

Productns navicellus Hall, Tenth Lep. N. Y. State Cal. Nat. Hist., 1857, 1) 172.

Productella navicella Hall, PaI. New Irork, IV, 1867, 1. 156, pl. 23, figs. 1, 3,

9-11;-Second Aun. Rep. N. Y. State Geol., 1883, pl. 48, figs. 8, 9.-IIall aud Clarke, Pal. New York, VIII, Pt. I, 18:2, pl. 17, figs. 8, 9;-Ibiłem, VIII, Pt. II, 189i, pl. 8t, lig. 19.

Productus (Productella) navicellus Waleott, Mon. U. S. Cieol. Survey, VIII, 1884, p. 131, jl. 13, fin. 9 .

Loc. Schoharie Connty, Moscow, and Pavilion, New York; Eureka district, Nevada.

Productella onusta Hall.

Chemung (Dev.).

Proiluetella onusta Hall, PaI. New York, [Y, 1867, p. 184, pl. 26, figs. 29-12;Seeont Aun. Líp. N. Y. State Geologist, 1883, pl. 48, tigs. 40-46, - Iall and Clarke, Pal. New York, VIII, Pt. I, 18!2, pl. 17, figs. 40-13, 46.

Loc. Conewango, Napoli, and New Albion, New York. 
Productella papulata Hall.

Hamilton (Dev.).

Productus papulatus Hill, Pal. New York, IV, 1867, 1). 165, pl. 23, figs. 47, 48.

Productella papulata Hall, Ibirlem, 1867, corrigenda.

Loc. Bellona, Yates County, New York.

Productella productoides (Murchison).

Hamilton (Dev.).

Orthis prodnctoides Murchison, Bull. Soc. Géol. de France, XI, 1810, 1. 254, pl. 2 , fig. 7 .

Strophalosia produrtoides Whiteaves, Cont. Canadian Pal., I, 1889, 1. 112, pl. 15, fig. 2;-Ibillem, 1, 1891, p. 216.

Productella productoides Hall and Clarke, Pal. New York, VIII, Pt. I, 1892, p. 317.

Productella productoides var. membranacea Whiteaves, Cont. ('analian I'al., I, 1892, p. 282.

Loc. Europe; Athabasca River, Lake Manitoba, and Thedford, Canada.

\section{Productella pyxidata Hall.}

Kinderhook (L. Carb.).

Productus pyxidatus IJall, Geol. Survey Iowa, I, I’t. II, 1858, p. 498, pl. 3, fig. 8.- IValcott, Mon. U. S. Geol. Survey, VIII, 1881, 1. 130.

I'roductella pyxidata Hall, Second Ann. Rep. N. Y. State Geol, 1883, pl. 18, fig. 34.-Hall and Clarke, Pal. New York, VIlI, Pt. I, 1892, pl. 17, fig. 34; pl.17A, fig. 14.-Keyes, feol. Survey Missouri, V, 1895, 1. 52.

Loc. Hamburg, Illinois; Lonisiana, Missouri.

Obs. Compare with Productella shumardana.

\section{Productella rarispina Hall.}

Chemrng (Dev.).

Productus rarispinus Hall, Tenth Rep. N. Y. State Cab. Nat. Hist., 1857, p. 178.

Productella ratispina Hall Pal. Now York, IV, 1867, 1. 170, pl. 24, tigs. 1-9; Second Ann. Rep. N. X. State Geol., 1883, pl. 48, fig. 33.-Wall and Clarke, Pal. New York, VIII, Pt. I, 1892, pl. 17, fig. 33.

Loc. Phillipsburg, New York.

Productella semiglobosa Nettelroth.

Corniferous (Dev.).

Productella semiglobosa Nettelroth, Kentucky Fossil shells, Mem. Kentucky Geol. Surver, I889, p. 70, pl. 26, fig. 7.

Loc. Falls of Ohio.

Productella shumardana Hall.

Kinderhook (L. Carb.).

Productus shmmarlianus Hall, Geol. Survey Iowa, I, I't. II, 1858, I. 199, pl. 3, fig. 9 ; pl. 7 , fig. 2.

Prodnetella shmmarcliana Ilall, second Ann. Rep. N. Y. State Geol., 1883, P1. 48, fig. 7.-Hall and Clarke, Pal. New York, VIII, I't. I, 1892, pl. 17, fig. 7.

Productus (Profuctella) shumardianus IIerrick, Bull. Denison Ưniv., III, 1888, p. 32, pl. 6 , fig. $16 ;$ pl. 7 , fig. 18.

Loc. Clarksville, Missouri; Burlington, Iowa; Licking Connty, Ohio.

Obs. The identifications of this species from Dovonian horizons are here referred to P. spinulicosta. P. shumardana is probably synonyuous with I'. pyxidata Hall.

Productella speciosa Hall. Portage, Chem., and Kinderh. (Dev.-L. Carb.). Productus speciosus Hall, 'Tentlı Rep. N. Y. State Cab. Nat. Hist., 1857, 1. 176. Producta speciosa A. Winchell, I'roc. Acal. Nat. Sci. Philadelphia, 1863, 1'. 4.

I'roductella speciosa Hall, Pal. New York, IV, 1867, 1. 175, pl. 25, figs. 1-11;-Second Ann. Rep. N. Y. State Geol., 1883, pI. 48, figs. 25, 26.-Hall and Clarke, Pal. New York, VIII, Pt. 1, 1892, 11. 17, figs. 25, 26.-Kindle, Bull. American Pal., 6, 1896, p. 35.

Productus (Productella) speciosus Walcott, Mon. U. S. Geol. Snrvey, VIII, 1881, p. 133 , pl. 13, fig. 8 , 


\section{Productella speciosa Hall-Continued.}

Prodnetus (l'roductella) rpeensus? Herrick, Bnll. Jonison Univ., I11, 1888, p. 31.

Loc. Leon, Now Albion, and lthaca, New York; licking County, Ohio; Burlington, lowa; linekia listriet, Nevala.

Productella spinulicosta Hall.

Cornifierous to Hamilton (Dev.).

Productus subaculeatus Norwood and Pratton (non Murchison), Jour. Acal. Nat. Sci. P'hilal.lphia, II I, 1854, p. 21.-Meok, King's U. S. Gool. Expl. toth Parl., $1 \mathrm{~V}, 1377,1 \% .36, \mathrm{pl} .3$, tig. 7 .

P'roilutus subaculeatus? Meek, Simpson's Rep. Expl. Groat l3asin Terr. Utah, $1876,1.315$, pl. 1, fig. 3.

Productus spunulicostus Ilall, Tenth Rep. N. Y. State Cal, Nat. Hist., 1857, p. 173.

Productella spinulieosta 1Iall, Pal. New York, IV, 1867, p. 160, pl. 23, figs. 6-8, 25-34; - Second An1. Rep. N. Y. State Geol., 1883, pl. 48, tigs. 3-6.-Whiteaves, Cont. Cauadian Pal., I, 1891, 1. 217, pl. 29, tig. 3; pl. 31, tig. 1.-Hall aud Clarlie, Pal. New York, V111, Pt. I, 1892, pl. 17, figs. 3-6.

Prodinetella subaculeata Hall, Pal. Now York, IV, 1867, 1. 154, pl. 23, figs. 4, 5.Whiteaves, Cont. Canadian Pal., I, 1892, 1. 283.-Hall and Clarke, Pal. New York, VIII, I’t. I, 1892, pl. 17, tigs. 1, 2.

Productella subaculeata? Hall, Second Ann. Rep. N. Y. State Geol., 1883, pl. 48, figs. 1,2 .

Produetus (Productella) subaculeata Walcott, Mon. U. S. Geol. Surrej, VIII, 1884, pp. 128, 214, pl. 7, fig. 2; pl. 13, figs. 19, 20.

Productus (Proluctella) subaeuleatus var, cataractus Hall and Whitfield, Twentyfourth Rep. N. Y. State Cab. Nat. Hist., 1872, p. 198;-Twenty-seventh Rep. Ibiclem, 1875, pl. 9, figrs. 9,10.

Productella subaculeata var, eataracta Nettelroth, Kentucky Fossil Shells, Mem. Kentucky Geol. Survey, 1889, p. 69, pl. 17, figs. 5-9.-Whiteaves, Cont. Canadian Pal., I, 1891, p. 217.

Loc. New York; Ohio; Falls of Ohio; Illinois; Iowa; Wisconsin; Eureka district, Nevada; Utah; Mackenzie and Hay rivers, and Lake Manitoba, Canada.

Ob8. Some anthors are lisposed to regard as synonyms of this species, besides the above, P. pyxidata, P. shumardana, and P. concentrica, and all of these forms are thouglit to be identical with $P$. subaculeata Murchison. For the present it is preferable to retain the name P. spinulicosta for these American Deronian forms. P. pyxidata, P. shumardana, and P. concentrica ar $\theta$ here arranged as species, but will probably be shown to be synonymous with P. spiuulicosta.

Productella striatula Hall.

Chemung (Dev.).

Productella siriatula Hall, Pal. New York, IV, 1867, p. 177, pl. 25, figs. 14-21;Second Auu. Rep. N. Y. State Geol., 1883, pl. 48, figs. 27, 38.-Hall and Clarke, Pal. New York, VIII, Pt. I, 1892, pl. 17, figs. 27, 38, 44.

Loc. New Albion, Conewango, and Cold Spring, New York.

Productella subaculeata of American authors=Productella spı ssta. Productella subaculeata cataracta $\mathrm{Hall}$ and $\mathrm{Whitfield}=$ Procuctella spinulicosta.

Productella subalata Hall.

Middle Devonian.

Productus subalatus Hall, Tenth Rep. N. Y. State Cab. Nat. Hist., 1857, p. 174; Geol. Survey lowa, I, Pt. II, 1858, p. 500, pl. 3, fig. 10.

Prodnctus callawayensis Swallow, Traus. St. Louis Acad. Sci., I, 1860, p. 640.

Productella subalata IIall, Pal. New York, IV, 1867, p. 165, pl. 23, fig. 49; -Second Anu. Rep. N. Y. State Geol., 1883, pl. 48, fig. 16.-Hall and Clarke, Pal. New York, VIII, J't. I, 1892, pl. 17, fig. 16.-Keyes, Geol. Survey Missouri, $\mathrm{V}, 1895$, 1. 52.

Loc. Rock Island, Illinois; Callaway County, Missouri; Spring Valley, Minnesota. 
Productella truncata Hall=Strophalosia truncata.

Productella tullia Hall.

Hamilton (Dev.).

Productella tullia Hall, Pal. New York, IV, 1867, p. 164, pl. 23, figs. 41-44.

Loc. Tully and Delphi Falls, New York.

PRODUCTUS Sowerby. Genotype Anomites productus Martin=Productus martini Sowerby $=$ Productus semireticulatus (Martin).

Productus Sowerby, Mineral Conchology, I, 1814, p. 153.-de Koninck, Recher. Animalx Foss., Pt. I, 1817, p. 11.-Hall, Twentieth Rep. N. Y. State Cab. Nat. Hist., 1867, p. 245 ;-Pal. New York, IV, 1867, p. 146.-Hall and Clarke, Pal. New York, VIII, Pt. I, 1892, p. 321;-Eleventh Ann. Rep. N. Y. State Geologist, 1894, p. 297.

Productus a equicostatus Shumard=Productus cora.

Productus alternatus Norwood and Pratten. Keokuk (I. Carb.).

Productus alternatns Norwood and Pratten, Jour. Acad. Nat. Sci. Philadelphia, III, 1854, p. 20, pl. 2, fig. 1.-Hall, Second Ann. Rep. N. Y. State Geol., 1883, pl. 49, fig. 14.- Hall and Clarke, Pal. New York, VIIl, Pt. I, 189:2, pl. 18, fig. 14.

Productus vittatns Hall, Geol. Survey Iowa, I, Pt. II, 1858, p. 639.-Hall and Clarke, Pal. New York, VIII, Pt. I, 1892, pl. 18, figs. 15-17.-Keyes, Geol. Survey Missouri, V, 1895, p. 43.

Prodnctus vittata Hall, Second Ann. Rep. N. Y. State Geologist, 1883, pl. 49, figs. $15-17$.

Loc. Rocky Run, Haucock County, Illinois; Keokuk, Iowa; Burlingtou group, Burlington, Iowa.

Obs. Compare with Productus fimbriatus and P. gradatus.

Productus altonensis Norwood and Pratten.

St. Louis (I. Carb.).

Prodnctus altonensis Norwood and Pratten, Jour. Acal. Nat. Sci. Philadelphia, III, 1854, p. 7, pl. 1, fig. 1 .

Loc. Alton, lllinois.

Productus americanus Swallow=Productus cora.

Productus andii d'Orbigny =Orthis buchi.

Productus aretirostratus $\mathrm{Hall}=$ Productella arctirostrata.

Productus arcuatus Hall=Productella areuata.

Productus asperns McChesney = Productus nebrascensis.

Productus auriculatus Swallow.

? Upler Carboniferous.

Productus anriculatus Swallow, Trans. St. Lonis Acad. Sci., II, 1863, p. 92.

Productus (?anriculatus) Hall aud Clarke, Pal. New York, VIII, Pt. I, 1892, pl. $17 \mathrm{~A}$, fig. 24.

Loc. Formation and locality not given. ("Near Kausas City, Missouri," H. and C.)

Productus batesianus Derby.

Upper Carboniferous.

Productus batesiauus Derby, Bull. Cornell Univ., 1, 1874, 1. 54, pl. 1, figs. 2, $10-13,15$; pl. 2 , fig. $14 ;$ pl. 6 , fìgs. $4,7,9$.

Loc. Bomjardim and Itaituba, Brazil.

\section{Productus biseriatus Hall.}

St. Lonis (L. Carb.).

Productus liseriatus Hall, Trans. Albany Institnte, IV, 1858, p. 12.-Whitfield, Bull. Ameriean Mus. Nat. Hist., I, 1882, p. 46, pl.6, figs. 8-12.-Hall, Twelfth Rep. State Gool. Indiana, 1883, p, 325, pl. 29, figs. 8-12.-Keyes, Geol. Survey Missonri, V, 1895, p. 43.

Loc. Alton, Illinois; Bloomington aud Spergen Hill, Indiana; Crittenden County, Kentucky; Missouri. 
Productus blairi Miller.

('houtealı (I. Carb.).

Productus blairi Miller, seventrenth liep. State Geol. of Indiana, 1891, p. 79, pl. 13, figs. 16, 17 .

Lor. Seclalia, Missouri.

Productus boliviaensis d'Orbigny.

Upper Carboniferous.

Productus boliviensis d’Orbigny, Voyage dans l'Anérique Méridionale, Pal.,

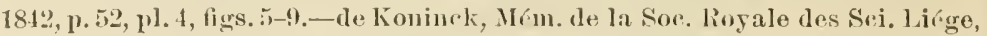
IV, 18.7, p. 177, p]. 8, lig. 2;-Recherehes sur les Animaux Fossiles, I’t. I, 1817, p. 76, ]1. 8, lig. 2.-Norwood and Pratten, Jour. Acad. Nat. Sei. Jhiladelphia, III, 185., P. 11.

Productus cancrini Gabh, Jour. Acal. Nat. Scei. I'hiladelphia, 2d ser., VIII, 1881, 1. 302.

Loc. Yarbichambi and Lake Titicaca, Bolivia; near Richmonı, Missouri.

Productus boonensis Swallow.

Upper Carboniferous.

Productus boonensis Swallow, Trans. St. Lonis Acal. Sci., I, 1858, 1. 217.

Loc. Near the month of Platte River; Kansas and Missouri.

Obs. Compare with Productus undiforns de Koninck.

Productus boonensis elevata Swallow.

Upper Carboniferous.

I'roductus hoonensis var. elevata Swallow, Trans. St. Louls Acad. Sci., I, 1858, p. 217.

Lnc. Near the month of Platte River, Missouri.

Productus boydi Hall=Productella boydi.

Productus buchianus de Koninck.

Upper Carboniferous.

l'rodnctus bnchianus de Koninck, Recherches sur les Animaux Fossiles, P't. I, 1847, p. 129, pl. 18, fig. 4.-Norwood and Pratten, Jour. Acad. Nat. Ses. Philarlelphia, III, 185!, p. 20.

Loc. Belgium; lig Creek, Posey County, Indiana.

Productus burlingtonensis Hall.

Burlington (L. Carb.).

Productns flemingi var. burlingtonensis Ilall, Geol. Survey lowa, I, l’t. II, 1858, p. 598, pl. 12, fig. 3.-Hall and Whitfield, King's IT. S. Geol. Expl. 40th Parl,, IV, 1877, p. 265, pl. 5, figs. 9-12.-1Iall, Second Ann. Rep. N. Y. State Geol., 1883, pl. 49, figs. (i-8.-Herrick, Bull. Denison Univ., III, 1888, \}. 32, pl. 3, figs. 20 (?22).-Hall and Clarke, Pal. New York, VIII, Pt. I, 1892, pI. 18, figs. $6-8$.

Productus burlingtonensis Keyes, Geol. Survey Missouri, V, 1895, p. 41.

Loc. Burlington, Iowa: Quincy, Illinois; Missouri; Oquirrh Mountains, Utah.

Obs. Compare witlı ''. mesialis.

Productus calhomianus Geinitz (non Swallow)=Productus cora.

Productus calhomianus Swallow=Productus semireticulatus.

Productus calhomianus kansasensis Swallow=Productus semireticulatus kansasensis.

Productus callawayensis Swallow=Productella subalata.

Productus cancrini Geinitz=Proluctus pertemuis.

I'roductus canerini Gabb =P. boliviaensis.

Productus capacii d'Orbiguy.

Upler Carboniferons.

l'rodnctus eapacii d'Orbigny, Voyą̧e dans l'Auéruque Méridionale, Pal., 1842, p. 50, pl. 3, figs. 2t-26.

Loc. Jarbichambi, Bolivia. 
Productus carbonarius de Koninck.

Carboniferous.

Productus carbonarius de Koninek, Deseription Animanx Fossiles, 1844, p. 181, pl. 12 bis, fig. 1.-Norwood and Pratten, Jour. Acad. Nat. Sci. Philadelphia, III, 1854, p. 11.

Loc. Belgium; Fountain Blufì, Illinois.

Productus cestriensis Worthen=Productus fasciculatus.

Productus chandlessii Derby.

Upper Carboniferous.

Productus chandlessii Derby, Bull. Coruell Univ., I, 1874, p. 51, pl. 4, figs. 1-4, 7, $9-11,13,16$; pl. 6, fig. 1;-Bull. Mns. Comp. Zool., III, 1876, p. 280.

Loc. Itaituba, Brazil; Yampopata, Bolivia.

Obs. Compare with Productus boliviaensis d'Orbiguy.

Productus clarkianus Derby.

Upper Carboniferons.

Productus clarkianns Derby, Bull. Cornell Univ., I, 1874, p. 59, pl. 6, fig. 6; pl. 9, figs. 12,13 .

Loc. Itaituba and Bomjardim, Brazil.

Productus clavus Norwood and Pratten=Proboscidella clava. Productus concentricus Hall = Productella concentrica.

\section{Productus confragosus Conrad.}

Upper Crrboniferous.

Productus coufragosus Conrad, Trans. Geol. Soc. Pennsylvania, I, 1835, p. 268, pl. 12 , fig. 5 .

Loc. Alleghany Mountaius, Penusylvania.

Obs. Not well establisbed.

Productus cooperensis Swallow.

Kinderhook (L. Carb.).

Productus cooperensis Swallow, Trans. St. Louis Acad. Sci., I, 1860, p. 64C.-A. Winchell, Proc. Acad. Nat. Sci. Thiladelphia, 1865, p. 115.

Productus cooperensis? A. Winchell, Proc. American Philosophical Soc., XII, 1870, p. 249.

Loc. Cooper County, Missouri; Burlington, Iowa; Sciotoville, Ohio.

Obs. Keyes regards this species as a syuonym for Productella arcuata.

Productus cora d'Orbigny.

Upper Carboniferous.

Prodnetus cora d'Orbigny, Voyage dans l'Amérique Méridionale, Pal., 1842, p. 55, pl. 5, figs. 8-10.- - de Koninck, Recherches sur les Animaux Fossiles, Pt. I, 1847, p. 50, pl. 4, fig. 4; pl. 5, fig. 2. Owen, Geol. Rep. Wisconsin, Iowa, and Minnesota, 1852, pp. 103, 136, pl. 5, fig. 1.-Norwool and Pratten, Jour. Acad. Nat. Sci. Philadelphia, III, 1854, p. 6.-Marcou, Geol. North America, 1858, p. 45, pl. 6, fig. 4.-Davidson, Quart. Jour. Geol. Soc. London, XIX, 1863, p. 174, pl. 9, figs. 22, 23.-Geinitz, Carbon und Dyas in Nebraska, 1866, p. 50.Derby, Bull. Mus. Comp. Zool., III, 1876, p. 281.-Dawson, Acadian Geology, 3d ed., 1878, p. 297, fig. 98.-Waagen, Palıontologica Indica, Ser. XIII, I, 1884, p. 677.-White, Thirteeuth Rep. State Geol. Indiana, 1884, p. 126, pl. 26, figs. 1-3.-Herrick, Bull. Denison Iniv., II, 1887, p. 47, pl. 2, fig. 26.Keyes, Proc. Acad. Nat. Sci. Philadelphia, 1888, p. 227 ;-Geol. Survey Missouri, V, 1895, ए. 47 , pl. 37 , fig. 2.

Productus efr. cora Toula, Sitzb. der k. k. Akad. der Wissensch. zu Wien, LIX, 1869, p. 9.

Prodnctus cora? Derby, Bull. Cornell Univ., I, 1874, p. 49, pl. 2, fig. 17 ; pl. 6, fig. 17.

Productus lyelli de Verneuil, Lyell's Travels in North America, II, 1845, 1. 221.Dawson, Acadian Geology, 1855, p. 219, fig. g.

Productus sp. Christy, Letters on Geology, 1848, pl. 5, fig. 1.

Bull. 87 21 


\section{Productus cora d'Orbigny-Continued.}

Productus seuireticulatus Iall, Stanshury's Expl. and Survey Valley Great Salt Ialie, Utalı, 18:2, 1. 411, pl. 3, figs. 3, 5.

Productus pratteniauus Norwood, Jour. Acad. Nat. Sci. I'hiladelphia, III, 1854, 1. 17, fig. 10.-Meek, Niual Rep. U.S. Geol. Survey of Neloraska, 1872, p. 163, pl. 2, fig. 5 ; pl. 5, fig. 13 ; pl. 8, fig. 10.-White, Wheeler's Expl. and Surrey west 100 th Meridian, IV, 1875, p. 113, pl. 7, fig. 1.-Meek, King's U. S. Geol. Expl. 40th l'arl., IV, 1877, p. 72, pl. 7, fig. 7.

Productus aquicostatus Shumarl, Geol. Rep. Missouri, 1, 1855, p. 201, P']. C, fig. 10.-Schicl, Pacilic R. R. Reports, II, 1855, p. 108, pl. 2, figs. 4, 5.-Hall aud Clarke, Pal. Now York, VIII, Pt. I, 1892, figs. 22, 23.

Productus pileiformis MeChesney, New Pal. Fossils, 1860, 1. 40.-Whitfield, Annals N. Y. Acall. Sci., Y, 1891, 1. 582, pl. 13, figs. 13, 14;-Geol. Ohio, VII, 1895, p. 470, pl. 9, figs. 13, 14 .

Produetus americanus Swallow, Trans. St. Lonis Acad. Sci., II, 1863, 1. 91.

Productus flemingi Goinitz (non de Koninck), Carbon und Dyas in Nelıraska, 1866, 1. 52, pl. 4, figs. $1-4$.

Productus koninckianus Geinitz (nou de Verneuil), Jbilem, 1866, p. 53, pl, 1, fig. 5. Productus calhounianus Geinitz (nou Swallow), 1bilem, 1866.

Loc. Throughout the Upper Carboniferous of North Anerica; Itaituba and Barreiriuha, Brazil ; Yampopata, Cochabamha, aud Lake Titicaca, Bolivia; Kashmere.

Obs. Sce Productus nodosus and l'. hildrethianus.

\section{Productus cora mogoyoni Mareou.}

Upper Carboniferous.

Productus cora var. mogoyoni Marcon, Geol. North Auerica, 1858, p. 45, pl. 6, fig. 5.

Loc. Sierra de Mogoyn, or Sierra Blanca, near the extinet volcano San Franciseo, Arizona.

\section{Productus coriformis Swallow.}

St. Lonis (I. Carb.).

Productus coraformis Swallow, Trans. St. Louis Acall. Sci., II, 1863, 1. 91.

Loc. Cooper County, Missouri.

Obs. Keyes regards this species as a symonym for P. lievicostus.

\section{Productus costatoides Swallow.}

Upper Carboniferous.

Productus costatoidles Swallow, Trans. St. Louis Acad. Sci., 1, 1858, p. 217.Newberry, Ives's Rep. Colorado River of the West, 1861, 1. 123.

Loc. Kansas; banks of Colorado River.

Obs. Keyes legards this species as identical with P. longispinus.

\section{Productus costatus (Sowerby ?) de Koninck.}

Upper Carboniferous.

?Productus costatus Sowerby, Mineral Conchology, VI, 1827, p. 115, pl. 560, fig. 1.

Productus costatus de Kouinck, Recherches sur les Animaux Fossiles, Pt. I, 1847, p. 92, pl. 8, fig. 3 ; pl. 10, fig. 3 ; 1l. 18, fig. 3.-Norwood and Pratten, Jom1. Acad. Nat. Sci. Philadelplina, III, 1854, 1. 11.-Marcou, Geol. North Anerica, 1858, p. 46, pl. 5, fig. 5.-Geinitz, Carbon und Dyas in Nebraskil, 1866, p. 51.-Meek, Final Rep. U. S. Geol. Survey Nebraska, 1872, p. 159, pl. 6, fig. 6._White, Wheeler's Expl. and Surver West 100th Meriaian, IV, 1875, p. 109, pl. 8, fig. 2;-Second Anı. Rep. Indiana Burean of Statisties and Geol., 1880, p. 516, pl. 8, figs. 7, 8;-Tenth Rep. State Geol. Indiana, 1881, p. 148, pl. 8, figs. 7, 8.-Hall, Sccond Ann. Rep. N. Y. State Gool., 1883, pl. 50, figs. 8-13.-White, Thirteenth Rep. State Geol. Indiana, 1884, p. 124, pl. 2t, figs. 4-6; pl. 25, figs. 3-5.-Hall and Clarke, Pal. New York, VIII, Pt. I, 1892, pl. 19, figs. 8-13.-Keyes, Geol. Survey Missouri, V, 1895, 1. 51, pl. 36, lig. 1. 
Productus costatus (Sowerby?) de Koninck-Continued.

Productus costatus? Derby, Bull. Mus. Comp. Zool., III, 1876, 1. 280.

Productus costatus var. Hall, Geol. Survey Iowa, I, It. II, 1858, 1. 712, pl. 28, figs. 3, 4.-Meek, King's U. S. Geol. Expl. 40th, Parl., IV, 1877, pl. 7, tig. 4.

Productus portlockianus Norwood and Pratten, Jour. Acad. Nat. Sci. Philadelphia, III, 1854, p. 15, pl. 1, fig. 9.

Productus sp. Rogers, Geol. Penusylvania, II, Pt. II, 1858, p. 833, fig. 687.

Productus viminalis White, Proc. Boston Soc. Nat. Hist., IX, 1862, 1. 29.

Loc. Europe; throughout the Upper Carboniferous of North America; Yampopata, Bolivia.

(1bs. Sowerly's species is of uncertain value. The above synonomy is based upon $P$. costatus as redefined and illustrated by de Koninck.

Productus curtirostratus A. Winchell.

Kinderhook (L。, Carb.).

Producta curtirostra A. Winchell, Proc. Acad. Nat. Sci. Philadelphia, 1865, p. 114.

Procluctus curtirostratus Miller, N. American Geol. Pal., 1889, 1. 364.

Loc. Burlington, Iowa.

Productus delawarei Marcou.

Carboniferous.

Productus delawarii Marcou, Geol. North America, 1858, p. 45, pl. 5, fig. 3.

Loc. Foot of Delaware Mountain, Texas.

Obs. Compare with Productus cora d'Orbigny.

Productus depressus Swallow.

Keokuk (L. Carb.).

Productus depressus Swallow, Trans. St. Lonis Acad. Sci., II, 1863, p. 93.

Loc. Fenton, St. Louis County, Missouri.

Productus dissimilis Hall (non de Koninck)=Productella hallana.

Productus dolorosus A. Winchell. Waverly (L. Carb.).

Productus dolorosus A. Winchell, Proc. Acarl. Nat. Sei. Philadelphia, 1865, p. 114.

Loc. Weymouth, Merlina County, Ohio.

Productus dumosus Hall=Prodnctella dumosa.

Productus duplicostatus A. Winchell.

Waverly (L. Carb.).

Productus duplicostatus A. Winchell, Proc. Acad. Nat. Sci. Philadelphia, 1865, p. 113.-Herrick, Bull. Denison Univ., IV, 1888, p. 21, pl. 11, figs. 26, 29.

Loc. Knox and Licking counties, Ohio; Battlecreek, Michigan.

Productus elegans Norwood and Pratten (non McCoy)=Productus fasiculatus.

Productus exanthematus Hall=Productella exanthemata.

Productus fasciculatus McChesney.

Kaskaskia (L. Carb.).

Productus elegans Norwood and Pratten (non McCoy), Jour. Acad. Nat. Sci. Philadelphia, III, 1854, p. 13, fig. 7.-Whittield, Annals N. Y. Acarl. Sci., V, 1891, p. 581, pl. 13, figs. 15-16;-Geol. Ohio, VII, 1895, p. 469, pl. 9, figs. 15, 16.

Prodnctus fasciculatus McChesuey, New Pal. Fossils, 1860, p. 38.

Productus cestriencis Worthen, Trans. St. Louis Acad. Sci., I, 1860, p. 570.Keyes, Geol. Survey Missouri, V, 1895, p. 44.

?Productus elegans Hall and Whitfield, King's U. S. Geol. Expl. 40th Parl., IV, 1877, p. 268 , pl. 5 , figs. 3,4 .

Loc. Chester and Kaskaskia, Illinois; Leavenworth and Washington County, Incliana; Missouri; Monongalia County, West Virginia; Caldwell County, Kentucky; Newtonville, Ohio; ?Oquirrh Moutains, Utah. 
Productus fentonensis Swallow.

Keokuk (L. Carb.).

I'roductus fentonensis Swallow, Trams. St. Lonis Acul. Sci., II, 1863, 1. 93.

I.oc. Fenton, St. Louis County, Missouri.

Obs. Keyes says this is a synouyu for P'. magnus.

Productus fimbriatus Sowerby.

?St. Louis. ?C Pper Carboniferous.

Productus fimbriatus Sowerby, Mineral Conchology, v, 1824, p. 85, pl. 459, fig.

1.-Norwood and Pratten, Jonr. Acad. Nat. Sei. Philadelphia, III, 1854, p.

19.-Etheridge, (uart. Jour. Geol. Soc. London, XXXIV, 1878, 1. 630.

Loc. Alton, Illinois; Posey County, Indiana; Feilden lsthmus, lat. $822^{\circ} 43^{\prime}$.

Obs. Compare with Productus alternatus Norwood and Pratten.

Productus flemingi Geinitz (non de Koninck)= Productus cora.

Productus flemingi Marcou, and Roemer=Productus longispina.

Productus flemingi burlingtonensis Hall=Productus burlingtonensis.

Productus flexistria McCoy. Kaskaskia (L. Carb.).

Productus flexistria McCoy, Synopsis Carb. Fossils of Ireland, 1844, p. 109, pl. 20, fig. 16.-Norwood and Pratten, Jour. Acad. Nat. Sci. Philadelphia, IJI, 1854, p. 6.

Loc. Chester, Kaskaskia, and Fountain Bluff, Illinois; Stephensport, Kentucky.

\section{Productus giganteus (Martin).}

Upper Carboniferous.

Anomites gigantens Martin, Petrefacta Derbiensia, 1809, 1. 6, 11. 15, fig. 1.

Productns giganteus White, Proc. U. S. Nat. Mus., IlI, 1880, 1. 46;-Twelfth Ann. Rep. U. S. Geol. Survey of the Terr., 1883, p. 132, pl. 36, fig. 1.

Loc. Europe; McCloud River, Shasta County, California.

Productus gracilis A. Winchell.

Waverly (L. Carb.).

Productus gracilis A. Wiuchell, Proc. Acad. Nat. Sci. Philadelphia, 1865, p. 112.Herrick, Bull. Denison Univ., 111, 1888, P. 34, pl. 7, tig. 2.

Productus gracilis? A. Winchell, Proc. American Philosophical Soc., XII, 1870, P. 250 .

Loc. Near Cuyahoga Falls, Sciotoville, and Granville, Ohio.

Productus gradatus Swallow.

Keokuk (L. Carb.).

Productus gradatus Swallow, Traus. St. Louis Acad. Sci., II, 1863, 1. 93.

Loc. Keokuk, Iowa; Lewis and St. Louis counties, Missouri.

Obs. Keyes regards this species as identical with P. vittatus=P. alternatus.

Productus granulosus Phillips.

Ḱeokuk (L. Carb.).

Productus gramlosus P'hillips, Geol. Yorkshire, II, 1836, p. 216, pl. 8, tig. 15.-Norwood and Pratten, Jour. Acad. Nat. Sci. Philadelphia, 1II, 1854, p. 21.

Loc. Nauvoo, Illinois.

Productus hepar Morton.

Upper Carboniferous.

Productus hepar Morton, American Jour. Sci., XXIX, 1836, p. 153, pl. 226, fig. 39.

Loc. Junior Furnace, Scioto County, Ohio.

Obs. Not recognizable.

Productus hildrethanus Norwood and Pratten.

Upper Carboniferous.

Productus hildrethianns Norwood and Pratten, Jour. Acad. Nat. Sci. Philadelphia, III, 185t, p. 18, 1ll. 1, fig. 11.

Loc. Charboniere, Missouri.

Obs. lieyes regards this form as a synouym for $\mathrm{P}$. cora.

Productus hirsutiforme Walcott=Produetella hirsutiforme.

Productus hirsutus Hall=Productella hirsnta.

Productus horridus (non Sowerby)=Productus longispina. 
Productus humboldti d'Orbigny.

Upper Carboniferous.

Productus humboldti d'Orbiguy, Voyage daus l'Amérique Méridionale, Pal., 1842, p. 54, pl. 5, figs. 4-7.-de Koninck, Recherches sur les Animaux Fossiles, Pt. I, 1847, p. 114, pl. 12, fig. 2.-Toula, Sitzb. der k. k. Akad. der Wissenseh., XVIII, 1873, p. 16, pl. 2, fig. 3.-Waagen, Palæontologica Indica, Ser. XIII, I, 1884, 1. 695, pl. 76, figs. 1-3.

Productus hmmboldti ? de Keyserling, Reise in las Petschora-Land, 1846, p. 201, pl. 4, fig. 3 .

Loc. Yarbichambi, Bolivia; south end of Spitzbergen; Nishnei-Irginsk, Russia; Inclia; Kashmere.

Productus inca d'Orbigny $=$ Productus semireticnlatus.

Producta incurvata Shepard=Strophomena incurvata.

Productus indianaensis Hall.

St. Louis (L. Carb.).

Productus indlianensis Hall, Trans. Albany Institute, IV, 1858, p. 13.-Whitfield, Bull. American Mus. Nat. Hist., I, 1882, p. 47, pl. 6, figs. 6, 7.-Hall, Twelfth Rep. State fieol. Indiana, 1883, p. 326, pl. 29, figs. 6, 7 .

Loc. Spergen Hill, Indiana.

Productus inflatus McChesney.

Upper Carboniferous.

Productus inflatus McChesuey, New Pal. Fossils, 1860, p. 40;-Trans. Chicago Acal. Sci., I, 1868, p. 27, pl. 6, fig. 1.

Loc. Leavenworth, Indiana.

Productus ivesi Newberry.

Upper Carboniferons.

Productus ivesi Newberry, Ives's Rep. Colorado River of the West, 1861, p. 122, pl. 2, figs. 1-8.

Loc. Colorado River near month of Diamond River.

Productus koninckianus Geinitz (non de Vermeuil)=Productus cora.

Productus lævicosta White.

Kinderhook (L. Carb.).

Productus lavicostus White, Jour. Boston Soc. Nat. Hist., VII, 1860, p. 230.-

Keyes, Geol. Survey Missonri, V, 1895, p. 41, pl. 38, fig. 1.

Productus levicostus 9 Hall and Whitfield, King's U. S. Geol. Expl. 40th Parl., IV, 1877, p. 266, pl. 5, tigs. 7,8 .

Loc. Burlington, Iowa; Lonisiana, Missouri; Oquirrh Mountains, Utah.

Obs. Compare with P. corieformis.

Productus lasallensis Worthen.

Upper Carboniferous.

Prodnctus lasallensis Worthen, Geol. Survey Illinois, V, 1873, p. 569, pl. 25, fig.

9.-Hall and Clarke, Pal. New York, VIII, Pt. I, 1892, pl. 17A, fig. 13.

Loc. Lasalle, Illinois.

Productus latissimus Sowerby.

Carboniferous.

Productus latissimus Sowerby, Míneral Conchology, 1822, pl. 330.-Meek, Bull.

U. S. Geol. Survey of the Terr., II, 1876, p. 354, 11. 1, fig. 1.

Loc. Europe; Vancouver Islanı.

Productus leuchtenbergensis de Koninck.

Carboniferous.

Productus lenchtenbergensis de Koninck, Recherches sur les Animanx Fossiles,

Pt. I, 1847, p. 121, pl. 14, fig. 3.-Norwood and Pratten, Jour. Acad. Nat. Sci. Philadelphia, III, 1854, p. 19.

Loc. Europe; Masons Landing, Jersey County, Illinois.

Productus longispina Sowerby?

Upper Carboniferous.

? Productus longispinus Sowerby, Mineral Conchology, I, 1814, p. 154, pl. 68, fig. 1.

Productus longispiuns Salter, Quart. Jour. Geol. Soc. London, XVII, 1861, p. 64, pl. 4, fig. 2.-Meek, Final Rep. U. S. Geol. Survey Nebraska, 1872, p. 161, pl. 


\section{Productus longispina Sowerby? -Continued.}

6, fig. 7; pl. R, fig. 6.-Moek and Worthen, Geol. Snrvey Illinois, V, 1873, p. 569, pl. 25, fig. 10.-White, Wheeler's Expl. nul survey west 100th Meridian, IV, 1875, p. 118, pl. 8, tig. 5.-Meek, King's U. S. Geol. Expl. 40th P'arl., IV, 187 , p. 78 , pl. 8, fig. 4.-Hall, Second Ann. Rep. N. Y. State Geol., 1883, pl. 50, tigs. 1-4.-White, Thirteenth Rep. State Geol. Indiana, 1884, p. 127, pl. 24, ligs. 10, 11.-Merrick, Bull. Denison Univ., II, 1887, p. 48, pl. 2, figs. 25, 27, 28.-Leyes, Geol. Snrvey Missonri, V, 1895, p. 45, fig. 4.

Productus flemingi Roemer (non de Koninck), Kreidebillung Texas, 1852, p. 89, pl. 11, fig. 8.-Marcon, Geol. North America, 1858, p. 47, pl. 6, fig. 7.

Prodnetus splendeus Norwoot and Pratten, Jour. Acad. Nat. Sci. Philalelphia, III, 1854, p. 11, pl. 1, fig. 5.-Schiel, Pacific R. R. Reports, II, 1855, p. 108, pl. 1, fig. 3.-Hall and Clarke, Pal. New York, VIII, Pt. I, 1892, pl. 19, figs. 1-4.

Productus splendens (?) Meek and Hayilen, Proc. Arad. Nat. Sci. Philadelphia, III, 1859, p. 25.-Newberry, Ives's Rep. Colorado River of the West, 1861, p. 124.

Productus wabashensis Norwood and Pratten, Jour. Acal. Nat. Sci. Philadelphia, III, 1854, l. 13, pl. 1, fig. 6.

Prodnetus horridus Geinitz, Carloon uncl Dyas in Nebraska, 1866, p. 55, pl. 4, fig. 7.

Productus orlignyanus Geinitz (?non le lioninck), Ihidem, 1866, p. 56, pl. 4, figs. 8-11.

Productus (Marginifera) splendens Smith, l'roc. American Phil. Soc., XXXV, 1897, p. 29.

Loc. Throughont the Upper Carboniferous of the United States; Bolivia.

Obs. Since considerable nncertainty exists as to Sowerby's species, it may be better to adopt $P$. orbignyanns de Koninck for the above syuonymy. $P$. costatoides is also regarded by Keyes as a synonym tor P. longispinus.

Productus longus Meek.

Carboniferous.

Productus sp. nudet. Meek, King's U. S. Geol. Expl. 40th Parl., IV, 1877, p. 67.

Productus longus Meek, Ibidem, 1877, end of description.

Productus ivesi? Meek, Ibidem, 1877, pl. 7, fig. 6.

Loc. White Pine district, Nevada.

Productus lyelli de Verneuil=Productus cora.

Productus magnicostatus Swallow.

Upper Carboniferous.

Prodnetus magnicostatus Swallow, Trans. St. Lonis. Acal. Sci., I, 1860, p. 641.

Loc. Johnson County, Missonri.

Obs. Keyes regards this species as a synonym for $\mathbf{P}$. semireticulatus.

Productus magnus Meek and Worthen. Keokuk (L. Carb.).

Prodnctus magnus Meek and Worthen, Proc. Acad. Nat. Sci. Philadelphia, 1861, p. 142;-Geol. Survey Illinois, III, 1868, 1. 528, pl. 20, fig. 7.-Keyes, Geol. Survey Missonri, V, 1895, p. 41.

Loc. Monroe Connty, Illinuis; St. Genevieve Connty, Missouri.

Ols. Compare with $\mathbf{P}$. fentonensis.

Productus margaritaceus Phillips.

Upper Carboniferous.

Producta margaritacea Phillips, Geol. Yorkshire, II, 1836, p. 215, pl. 8, fig. 8.

Prodnctns margaritaceus Norwood and Pratten, Jonr. Acar. Nat. Sci. I'hiladelphia, III, 1854, p. 6.

Loc. Near Richmond, Missomi.

Productus marginicinctus Prout.

St. Louis (L. Carb.).

Productus marginicinctus Prout, Trans. St. Lonis Acar. Sci., I, 1857, p. 43, pl. 2, figs. 1-16.-Hall, Geol. Survey Iowa, I, I’t. II, 1858, 1. 674, pl. 24, fig. 3.Keyes, Geol. Survey Missonri, V, 1895, p. 43.

Loc. St. Lonis, Missouri; Milan, Illinois.

Obs. See Prodnetus wortheni Hall. 


\section{Produetus martini Sowerby $=$ Productus semireticulatus.}

Productus mesialis Hall.

Keokuk (L. Carb.).

Productus mesialis Hall, Geol. Survey Iowa, I, Pt. II, 1858, p. 636, pl. 19, tig. 2;Seeond Ann. Rep. N. Y. State Geol., 1883, pl. 49, tigs. 9, 10.-1lall and Clarke, Pal. New York, VIII, I't. I, 1892, pl. 18, figs. 9, 10.

Loc. Keokuk, Iowa; Nauvoo, Illinois.

Obs. Keyes regards this species as identical with l'. burlingtonensis.

\section{Productus mesolobus Phillips.}

Carboniferous.

Prodıctus mesoloba Phillips, Geol. Yorkshire, II, 1836, 1. 215, nI. 7, figs. 12, 13.

Proluetus mesolobns Etheridge, Quart. Jonr. Geol. Soc. London, XXXIV, 1878, p. 630.

Loc. Europe; Feilden Isthmus, lat. $82 \cup 43$ '.

Productus mexicoanus Shumard.

Upper Carboniferous.

Productus mexicanus shumard, Trans. St. Lonis Acal. Sci., I, 1858, 1). 291.Kayser, Richthofens China, IV, 1883, p. 182, pl. 28, fig. 7.

Productus mexicanus? White, Wheeler's Expl. and Survey west 100th Meridian, IV, 1875 , p. 120 , pl. 8 , fig. 6 .

Loc. Guadalupe Mountains, New Mexico; Lincoln County, Nevada; Lo-Ping, China.

Productus morbillianus A. Winehell.

Burlington (L. Carb.).

Prodncta morbilliana A. Winchell, Proe. Acad. Nat. Sci. Philadelphia, 1865, p. 113.

Loc. Burlington, Iowa; Sciotoville, Ohio.

Productus multistriatus Meek.

Carboniferous.

Productus nultistriata Neek, Proc. Acad. Nat. Sci. Philadelphia, 1860, p. 309.

Productus multistriatus Neek, Simpson's Rep. Expl. Great Bisin 'Terr. Utal, 1876, 1). 350, pl. 1, fig. 8;-King's U. S. ('eol. Expl. 40th Parl., IV, 1877, p. 76, pl. 8 , fig. 3 .

Loc. Utah and Nerada.

Productus muricatus Norwood and Prattel.

Upyer Carboniferous.

Productus muricatus Norwood and l'ratten (non Phillips), Jour. Acad. Nat. Sci. Philadelphia, III, 1854, p. 14, pl. 1, fig. 8.-White, Wheeler's Expl. and Survey west 100 th Meridian, IV 1875 , p. 120, pl. 8, fig. 4.-Herrick, Bull. Denison Univ., II, 1887, p. 49.-Keyes, Proc. Acad. Nat. Sci. Philadelphia, 1888, p. 228.

Loc. Pike Connty, Illinois; near Richmond, Missouri; Des Moines Valley, Iowa; Flint Ridge, Ohio; Lake County, Colorado; northern New Mexico.

Obs. Since Phillips's P. muricatus is regarded as a synonym for P. costatus, there is 110 need for another specific name for Norwom and Pratten species.

Productus nanus Meek and Worthen.

Upper Carboniferous.

Prodnctus nanus Meek and Worthen, Proc. Acal. Nat. Sci. Philadelphia, 1860, p. 450;-Geol. Survey Illinois, II, 1866, p.320, pl.26, fig. 4.-Keyes, Proc. Acal. Nat. Sci. Philadelphia, 1888, 1. 227.

Loc. Jefferson County, Iowa; northern Now Mexico (White).

Productus navicelliu Hall=Productella navicella.

\section{Productus nebraskaensis Owell.}

Upper Carboniferous.

Prodıctus nebrascensis Owen, Geol. Rep. Wisconsin, Inwa, and Minnesota, 1852, p. 584, pl. 5, fig. 3.-McChesney, 'Trans. Chicago Acar. Sci., I, 1868, 1. 24, pl. 1, fig. 7.-Meek, Final Rep. U. S. Geol. Survey Nebraska, 1872, 1. 165, 11. 2, fig. 2 ; pl. 4, fig. 6 ; 11. 5, fig. 11.-Meek aud Worthen, Geol. Survey Illinois, V, $1873,1.569$, pl. 25, fig. 8.-White, Wheeler's Expl. and Survey west 100th Meridian, IV, 1875, 1.116, pl.8, fig. 3.-Meek, King's U. S. Geol. Expl.40th Parl., IV, 1877, p. 65.-White, Thirteentl Rop. State Geol. Iudiana, 1884, p. 122, pl. 24, figs. 7-9.-Herrick, Bull. Denison Univ., II, 1887, 1.49, pl.2, 


\section{Productus nebraskaensis Owen-Continued.}

fị. 30.-Hall and Clarke, lal. New York, VIll, P't. I, 1892, Jl. 19, figs. 5-7.Keyes, Geol. Survey Missouri, V, 1895, 1). 18, 11. 37, fig. 3.

l'roductus nebrascensis? Herrick, Bull. Denison Univ., III, 1888, p. 31, pI. 1, fig. 24 ; pl. 3, fig. 23.

Produetus rogersi Norwool and Pratten, Jour. Acad. Nat. Sci. Philadelplia, 2d ser., IIl, 1854, p. 9, pl.1, fig. 3.-liall, Pacific R. R. Reports, III, 1856, 1. 101, pl. 2, figs. 11, 15.-Heek and Hayden, Proc. Acad. Nat. Sci. Philadelphia, 1859, p. 26. - Newberry, Ives's Rep. Coloralo River of the West, 1861, p. 121.-Hall, Second Ann. Rep. N. Y. State Geol., 1883, pl. 50, figs. 17, 18.

Productus asperns McChesney, New l'al. Fossils, 1860, p. 34.-Hall, Second Ann. Rep. K. Y. State Geol., 1883, pl. 50, figs. 5-7.

I'roductus wilberanus McChesney, New Pal. Fossils, 1860, P. 36 ;-Trans. Chicago Acad. Sci., I, 1868, p. 26, pl. 1, fig. 8.

Strophalosia horrescens Geinitz (non Murchison Vern. and Keyser.), Carbon und Dyas in Nebraska, 1866, p. 49.

Loc. Bellerne, Missouri; Illinois; Indiana; Ohio; Nebraska; New Mexico; Nevada; Arizona; Utah.

Obs. Compare with P. norwoodi.

Productus nevadaensis Meek.

Upper Carboniferous.

Productus nevadensis Meek, King's U. S. Geol. Expl. 40th Parl., IV, 1877, p. 64, pl. 8, fig. 2 .

Loc. White Pine district, Nevada.

Obs. Compare with Productus punctatus (Martin).

Productus newberryi Hall.

Waverly (L. Carb.).

Productus newherryi Hall, Tenth Rep. N. Y. State Cah. Nat. Hist., 1857, n. 180.A. Winchell, Proe. Acad. Nat. Sci. Philadelphia, 1865, p. 115.-Herrick, 1311. Denison Unir., IV, 1888, r. 20, pl. 10, figs. 24, 25.-Hall and Clarke, Pal. New York, VIII, Pt. I, 1892, pl. 18, figs. 1-3.

Productella newberryi Hall, Second Ann. Rep. N. Y. State Geol., 1883, pl. 49, figs. 1-3.

Loc. Medina County and Newark, Ohio.

Productus newberryi annosus Herrick.

Waverly (L. Carb.).

Productus newberryi var. annosus Herrick, Bull. Denison Univ., IV, 1888, p. 20, pl. 3, fig. 17;-Geol. Ohio, V11, 1895, pl. 23, fig. 13.

Loc. Alexandria, Ohio.

Productus nodicostatus Herrick.

Waverly (I. Carb.).

Productus nodocostatus Herrick, Bull. Denison Univ., IV, 1888, p. 23.

Loc. Rushrille, Ohio.

Productus nodosus Newberry.

Upper Uarboniferons.

Productus nodosus Newberry, Ives's Rep. Colorado River of the West, 1861, p. 124, pl. 1, fig. 7;-Macombes' Rep. Expl. Exped. Santa Fe to the Great Colorado River of the West, 1876, p. 140, pl. 3, fig. 3.

Loc. Santa Fe, New Mexico.

Obs. Probably a synonym for Productus cora d'Orbigny.

Productus norwoodi Swallow.

Upper Carboniferous.

Productus (Strophalosia?) norwoodii Swallow, Trans. St. Louis Acad. Sci., I, 1858, p. 182.

Productus norwoodi Meek and Hayden, Jrov. Acad. Nat. Sci. Philadelphia, 1859, p. 35 .

Loc. Cottonwood Valley, Kansas.

Obs. Compare with Productus pustulosus Plillips and P. scabriculus (Martin).

Regarded by keyes as a synonyı for P. nebraskaensis. 
Productus occidentalis Newberry.

Upper Carboniferous.

Productus occidentalis Newberry, Ives's Rep. Colorado River of the West, 1861, p. 122, pl. 2, figs. 9, 10 .

Loc. Banks of Cascale River near the junction of Great and Little Colorado rivers.

Prodnetus orbignyanus Geinitz (non de Koninck)=Productus longispinus.

Productus ovatus Hall.

St. Louis (L. Carb.).

Productus ovatus Hall, Geol. Survey Iowa, I, Pt. II, 1858, p. 674, pl. 24, fig. 1 ;Second Ann. Rep. N. Y. State Geol., 1883, pl. 49, fig. 19.-Hall and Clarke, Pal. New York, VIII, Pt. I, 1892, pl. 18, fig. 19.

Loc. Ottumwa and Keosanqua, Iowa.

Productus papilio Gabb.

Upper Carboniferous.

Productus papilio Gabb, Jour. Acad. Nat. Sei. Philadelphia, 2d ser., VIII, 1881, p. 302, pl. 42, fig. 12.

Loc. Lake Titicaca, Bolivia.

Productus papulatus Hall=Productella papulata.

Productus parvulus A. Winchell.

Kinderhook (L. Carb.).

Producta parvula A. Winchell, Proc. Acad. Nat. Sci. Philadelphia, 1863, p. 4.

Loc. Burlington, Iowa.

Productus parvus Meek and Worthen.

Kaskaskia (L. Carb.).

Productus parvus Meek and Worthen, Proc. Acal. Nat. Sci. Philarlelphia, 1860, p. 450;-Geol. Survey Illinois, II, 1866, p. 297, pl. 23, fig. 4.-White, Wheeler's Expl. and Survey west 100th Merid., IV, 1875, p. 83, pl. 5, fig. 6.

Loc. Cbester, Illinois; Mountain Spring, Nevada.

Productus (?) pectinoideus Shepard.

Producta pectenoilea Shepard, American Jour. Sci., XXXIV, 1838, p. 150, fig. 4.

Loc. Vermilionville, Lasalle County, Illinois.

Obs. The geological position of this species may lie 'Trentou or Upper ('arboniferous. The illustration is unsatisfactory.

Productus pertenuis Meek.

Upper Carboniferons.

Productus canerini Geinitz (non de Vernenil), Carbon und Dyas in Nebraska, 1866, p. 54, pl. 4, fig. 6.

Productus pertenuis Meek, Final Rep. U. S. Geol. Survey Nebraska, 1872, p. 164, pl. 1 , fig. 14 ; pl. 8 , fig. 9 .

Loc. Nebraska City, Nebraska; Leavenworth, Kansas; Kansas City, Missonri.

Productus peruvianus d'Orbigny.

Upper Carboniterous.

Productus peruvianus d'Orbigny, Voyage dans l'Amérique Méridionale, Pal., 1842, p. 52, pl. 4 , fig. 4.

Loc. Yarbichambi, Bolivia.

Obs. Probably a synonym for Productus semireticulatus.

Productus phillipsi Norwood and Pratten.

Carboniferous.

Productus phillipsii Norwood and Pratten, Jonr. Acad. Nat. Sci. Philadelphia, III, 1854, p. 8, jl. 1, fig. 2.

Loe. Big Canyon, Humboldt River, Utah.

Productus pileiformis McChesney=Productus cora.

Productus pileolus Shumard.

Upper Carboniferous.

Productus pileolus Shumard, Trans. St. Louis Acad. Sci., I, 1858, p. 291.

Loc. Gualalupe Mountains, Texas. 
Productus pocillum Morton.

Upper Carbonilerous.

Productuy pocillum Morton, Amer. Jour. Śri., XXIX, 1836, p. 150, pl. 2, fig. 2.

Loc. J'ntnin Ilill, Ohio.

Obs. Not rocogruizablo.

Proảuctus popei Shıumard.

Upper Carboniferous.

l'roductus popoi Shumard, 'Trans. St. Louis Aead. Sci., I, 1858, p. 290, pl. 11, $\operatorname{lig} .8$.

Loc. Now Mexico and 'Texas.

Prodnctus portlockianus Norwood and Pratten=Productus costatus. Productns prattenianus Norwood=Productus cora.

Productus punctatus (Martin).

Upper Carboniferons.

Anomites punetatns Martin, Petrefacta Dorbiensia, 1809, 1. 8, pl. 37, fig. 6.

Procluetus punctutus? Morton, Americun .Jour. Sei., XXIX, 1836, p. 153, pl. 26, fig. 38.

Proluctus punctatus Shumarl, Marey's Rep. U. S. Expl. Red River, Louisiana, 1853, 1. 201, pl. 1, fig. 5; pl. 2, fig. 1.-Norwool and Pratten, Jour. Acar. Nat. Sei. Philadelphia, III, 1854, p. 19.-Narcon, Geol. North America, 1858, p. 48, pl. 6, fig. 12.-Geinitz, Carbon unt Dyas in Nebraska, 1866, 1. 55.McCllesney, Trans. Chicago Acad. Sci., I, 1868, 1. 27, pl. 1, figs. 10, 11.-Meek, Final Rep. U. S. Geol. Survey Nobraska, 1872, p. 169, pl. 2, fig. 6; pl. 4, figr. 5.-Meek and Worthen, Geol. Survey Illinois, V, 1873, p. 569, pl. 25, fig. 13.White, Wheeler's Expl. and Survey west 100th Meridian, IV, 1875, p. 114, pl. 7, ifg. 2;-Eleventh Rep. State Geol. Indiana, 1882, p. 373, pl. 42, figs. 1-3.Hall, Second Ann. Rep. N. Y. State Geol. 1883, pl. 50, figs. 14-16.-White, 'Thirteenth Rep. State Geol. Indiana, 1884, 1. 124, pl. 27, figs. 1-3.-Herrick, Bull. Denison Unir., II, 1887, p. 48, pl.2, fig. 29.-Hall and Clarke, Pal. New Tork, VIII, 1't. I, 1892, pl. 17A, fig. 21; pl. 19, figs. 14-18.-Keyes, Geol. Survey Missouri, V, 1895, p. 51, pl. 37, fig. 1.-Smith, Proc. American Phil. Soc., XXXV, 1897, p. 29 (cxtract).

Prodnctus semipnnetatıs Sheppard, American .Jour. Áci., XXXIV, 1838, p. 153, fig. 9.

Productus tubulospinus MeChosuey, New Pal. Fossils, 1860, p. 37.

Prodnctus allied to punctatus Etheridge, Quart. Jour. Geol. Soc. Lonelon, IXXIV, 1878, p. 630.

Loe. Enrope; Ohio; Iutiana; Illinois; Missonri; Arkansas; Nebraska; Iowa; Novada; Now Mexico; Feilden Isthmus, lat. $82 \circ 13^{\prime}$.

Productus pustulosus Phillips.

Upper Carboniferous.

Prodneta pustulosa Phillips, Geol. Yorkshire, II. 1836, p. 216, pl. 7, tig. 15.

Productus pustulosus Mareon, Geol. North Ameriea, 1858, p. 48, pl. 6, fig. 1.Geinitz, Carbon und Dyas in Nebraska, 1866, p. 55.

Prołnetus pyxidiformis Marcon, Geol. North America, 1858, p. 48, pl. 6, fig. 3.

Prodnctns pustulosns? Meek and Haylen, Proc. Acal. Nat. Sei. Philadelphia, 1859, 1. 26.

Loc. Europe; Leavenworth, Kansas; Tigeras, New Mexico.

Obs. See Proeluetus norwoodi.

Produetus pyxidatus $\Pi$ all = Productella pyxidata.

Productus pyxidiformis de Koninck=Prodnctus pustulosus.

Productus raricostatus Herrick. Waverly (L. Carb.).

Productus raricostatus Herrick, Bull. Denison Univ., IV, 1888, p. 19, pl. 3, fig. 19 ;-Geol. Ohio, VII, 1895, 1l. 22, fig. 9.

Loc. Moots Run, Ohio.

Productus rarispinus Hall=Productella rarispina. 
Productus reticulatus Gabb.

Upper Carboniferous.

Produetus reticnlatus Gabb, Jonr. Aead. Nat. Sci. Philadelphia, 2d ser., VIII, 1881, p. 302, pl. 42, tig. 13.

Loc. Lake Titicaca, Bolivia.

Productus rhomianus Derby.

Upper Carboniferous.

Productus rhomianus Derby, Bull. Cornell Univ., I, 1874, p. 56, pl. 3, tigs. 20, $41-44,49$.

Loc. Bomjardim and Itaituba, Brazil.

Productus rogersi Norwood and Pratten = Prorluctus nebraskaensis.

Productus rushvillensis Herrick.

Waverly (L. Carb.).

Produetus rushvillensis Herrick, Bull. Denison Univ., IV, 1888, p. 22, pl. 3, fig. 15 ;-Geol. Ohio, VIl, 1895, pl. 23, fig. 15.

Loc. Rushville, Newark, and Loudonville, Ohio.

Productus scabriculus (Martin).

Lower and Upper Carboniferous.

Anomites seal,riculus Martin, Petrefacta Derhiensia, 1809, p. 8, pl. 36, fig. 5.

Productus seabrieulus Norwood and Pratten, Jour. Acad. Nat, Sei. Philadelphia, III, 1854, p. 17.-Mareou, Geol. North America, 1858, p. 47, pl. 5, fig. 6.Nerwberry, I ves's Rep. Colorado River of the W'est, 1861, p. 125.

Produetus seabrienlus? Geinitz, Carbon und Dyas in Nebraska, 1866, p. 54.

Loc. Europe; Pecos Village and Santa Fe, New Mexico; Plattsmouth, Nebraska; Caldwell Connts, Kentucky; Kashmere.

Productus scitulus Meek and Worthen.

St. Louis (L. Carb.).

Produetus seitulus Meek and Worthen, Proc. Acad. Nat. Sei. Philadelphia, 1860, p. 451 ;-Geol. Survey Illinois, II, 1866, p. 280, pl. 20, fig. 5.

Loc. Alton, Illinois.

Productus semipunetatus Sheppard=Productus punctatus.

Productus semireticulatus Hall, 1852 (non Martin)=Proluetus eora.

Productus semireticulatus (Martin). Lower and Upper Carboniferous.

Anomites semiretieulatus Martin, Petrefaeta Derbiensia, 1809, p. 7, pl. 32, figs. 1,$2 ;$ pl. 33 , fig. 4.

Prodnetus inca d'Orbigns, Yojage dans l'Amérique Néridionale, Pal., 1842, p. 51, pl. 4, figs. 1-3.-Derby, Bull. Mus. Comp. Zool., III, 1876, p. 280.

Productus semireticulatus Norwood and Pratten, Jour. Aearl. Nat. Sei. Philadelphia, III, 1854, p. 11.-1 Iall, Paeifie R. R. Reports, IlI, 1856, p. 103, pl. 2, figs. 16,17 ;-Geol. Survey Iowa, I, Pt. II, 1858, p. 637.-MIreou, Geol. North Ameriea, 1858, p. 46, pl. ז, fig. 4; 1ll. 6, fig. 6.-Shumarl, Trans. St. Lonis Acad. Sei., I, 1858, p. 292.-Newberry, Ives's Rep. Coloraclo River of the West, 1861, p. 124.-Salter, Quart. Jonr. Geol. Soe. London, XVII, 1861, p. 64, pl. 4, fig. 1.-Davidson, Ibidem, XIX, 1863, p. 174, pl. 9, figs. 20, 21.-Meek, Pal. California, I, 1864, p. 11, pl. 2, fig. 4.-Winehell, Proe. Acad. Nat. Sci. Philadelphia, 1865̃, p. 115.-Ceinitz, Carbon und Dyas in Nebraska, 1866, p. 51.Toula, Sitzb. der k. k. Akad. der Wissensch. zn Wien, IX, 1869, p. 9.Meek, Final Rep. U. S. Geol. Survey Nebraska, 1872, p. 160, pl. 5, fig. 7.Derlıy, linll. Cornell Univ., I, 1874, p. 47, pl. 4, fig. 8; pl. 6, fig. 18; pl. 7, figs. 5-7, 15, 16. -White, Wheeler's Expl, and Survey west of the 100th Deridian, IV, 1875, p. 111, pl. 8, fig. 1.-Meek, ling's U. S. Geol. Expl. 40th Parl., IV, 1877, p. 69, pl. 7, fig. 5. - Hall and Whitfield, lbidem, 1867, p. 267, pl. 5, figs. 5, 6.-Dawson, Acadian Geol., 3d erl., 1878, p. 296, fig. 97.-Etheridge, Qnart. Jonr. Geol. Soe. London, XXxIV, 1878, p. 629--Hall, Seconil Ann. Rep. N. Y. State Geol., 1883, pl. 49, figs. 11-13; pl. 50, figs. 19-23.-White, Thirteenth Rep. State Geol. Indiana, 1884, p. 125, pl. 24, figs. 1-3.-Herriek, Bull. Denison Univ., III, 1888, p. 31, pl. 1, fig. 26; pl. 3, fig. 24; pl. 7, fig. 11; pl. 10, 


\section{Productus semireticulatus (Martin)-Contimed.}

lig. 6.-IIall :111 Clarke, PaI. New York, VIII, Pt. I. 1892, pl. 17A, figs. 16-18; 11. 18, figs. 11-13; pl. 19, figs. 19-23.-Keyes, Geol. Survey Missouri, T, 1895, 1. 50, pl. 36 , fig. 4 .

Productus calhouniauus Swallow, Trans. St. Louis Acarl. Sci., I, 1858, Pp. 181, 215.-Meek and Hayden, Proc. Acad. Nat. Sei. Philadelphia, 1859, p. 26.Newlerry, Ives's Rep. Colorado River of the West, 1861, p. 123.

I'rodıctus setigerus Hall, Geol. Survey Iowa, I, Pt. II, 1858, p. 638, pl. 19, fig. 3. Productus setigerus var. keokuk Hall, Geol. Survey Iowa, I, Pt. II, 1858, p. 639, pl. 19, fig. 4.

P'rorluctus martini A. Winchell, Proc. Acad. Nat. Sci. Philadelphia, 1863, p. 4.

Productus magnus Hall and Clarke, Pal. New York, VIII, Pt. I, 1892, pl. 17A, tig. 15.

Loc. Europe; thronghout the Carhoniferons of North America; Feilden Isthmus, lat. $82^{\circ} 43^{\prime}$; Vixixil and Sansiguan, Cnatemala; Yarbichambi, Bolivia; Bomjarlim and Itaituba, Brazil; Tibet and Kashmere.

Obs. See Productus peruvianus d'Orbigny and P. naguicostatus.

Productus semireticulatus kansasensis Swallow. Upper Carboniferous.

Productus calhounianus var. kansasensis Swallow, Trans. St. Louis Acad. Sci., I, 1858 , p. 216.

Loc. líansas and Missonri.

Productus semistriatus Meek.

Upper Carboniferous.

Productus semistriatus Mleek, Proc. Acad. Nat. Sci. Philadelphia, 1860, p. 309.Meek, Simpson's Rep. Expl. Great Basiu Terr. Utah, 1876, p. 349, pl. 1, fig. 7;-King's I'. S. Geol. Expl. 40th Parl., IV, 1877, 1. 74, pl. 7, fig. 8.-White,

Wheeler's Expl, and Survey west 100th Meridian, 1881, Appendix, p. V.

Loc. Utah and northern New Mexico.

Productus setigerus Hall=Productus semireticulatus.

Productus setigerus var. keokuk Hall=Productus semireticulatus.

Productus shumardianus Hall=Productella shumardana.

Productus speciosus Hall=Productella speciosa.

Productus spinulicostus Hall=Productella spinulicosta.

Productus splendens Norwood and Pratten=Productus longispina.

Prodnctus subaculeatus of American anthors=Productella spinulicosta. Productus subalatus Hall=Productella subalati.

Productus subhorridus Meek.

Carboniferous.

Prodnctus subhorridus Meek, King's U. S. Geol. Expl. 40th Parl., IV, 1877, p. 75, pl. 7 , fig. 3.

Loc. Wasatch Mountains, Utah.

Prodnctus sulcatus Castelnan=Leptæua rhomboidalis.

Productus sulcifer de Verneuil=Leptrua rhomboidalis.

Productus swallovi Beecher.

Kaskaskia (L. Carb.).

Koninckina americana Swallow, Trans. St. Lonis Acad. Sci., II, 1863, p. 94.

Productus swallovi Beecher, American Jour. Sci., 3d ser., XL, 1890, p. 214.

Loc. Barretts Station, St. Lonis Conuty, Missouri.

Productus symmetricus McChesney.

Upper Carboniferous.

Productus symmetricus MeChesney, New Pal. Fossils, 1860, p. 35;-Trans. Chieago Acal. Sci., I, 1868, p. 25, pl. 1, fig. 9.-Neek, Final Rep. U. S. Geol. sinvey of Nebraska, 1872 , p. 167 , pl. 5 , fig. 6 ; pl. 8 , fig. 13.-White, Thirteentlı Rep. State Geol. Iudiana, 1884, p. 123, pl. 25, figs. 1 and 2.-Hall and 


\section{Productus symmetricus McChesney-Continued.}

Clarke, Pal. New York, VIII, Pt. I, 1892, pl. 17A, figs. 19, 20.-Keyes, Geol. Survey Missouri, V, 1895, p. 48, pl. 36, fig. 2.

Loc. Lasalle aud Springfield, Illinois; Iowa; Missouri ; Nebraska; Indiana.

\section{Productus tenuicostatus Hall.}

St. Louis (L. Carb.).

Productus teuuicostatus Hall, Geol. Survey Iowa, I, Pt. II, 1858, p. 675, 11. 21, fig. 2;-Second Ann. Rep. N. Y. State Geol., 1883, pl. 49, tig. 18.- Hall and Clarke, Pal. New York, VIII, Pt. I, 1892, pl. 18, fig. 18.-Keyes, Geol. Survey Missouri, V, 1895, p. 44.

Loc. Milan, Illinois.

\section{Prouluetus truncatus Hall=Strophalosia truncata.}

Productus tubulospinus Sheppard=Productus punctatus.

Productus undiferus de Koninck.

Upper Carboniferous.

Productus undiferıs de Koninck, Mém. de la Soc. Royale des Sciences de Lí́ge, IV, 1846, p. 153, pl. 5, fig. 4; pl. 11, fig. 5.-Norwood and I'ratten, Jour. Acad. Nat. Sci. Philadelphia, III, 1854, p. 9.

Loc. Europe; Caseyville, Illinois; Posey County, Indiaua.

Obs. See Productus boonensis Swallow.

Productus villiersi d'Orbigny.

Upper Carboniferous.

Productus villiersi d'Orbiguy, Voyage dans l'Amérique Mériđionale, l'al., 1842, 1. 53, pl. 4, figs. 12, 13.-de Koninck, Rechercbes snr les Animax Fossiles, Pt. I, 1847, p. 109, pl. 11, fig. 1.-Norwood aud Pratteu, Jour. Aead. Nat. Sci. Philadelphia, III, 1854, p. 17.

Loc. Yarbichambi, Bolivia; Keg Creek, Missouri.

Productus viminalis White.

Burlington (L. Carb.).

Productus viminalis White, Proc. Boston Soc. Nat. Hist., IX, 1862, 1. 29.

Loc. Burlington, Iowa.

Obs. White regards this species as a synonym for Productus costatus Sowerby.

Productus vittatus Hall=Productus alternatus.

Productus wabashensis Norwood and Pratten=Productus longispina.

Productus wallacianus Derby.

Upper Carboniferous.

Productus wallacianus Derby, Bull. Cornell Unir., I, 1874, p. 57, pl. 3, tigs. $46-48$; pl. 6 , fig. 5 .

Loc. Bomjardim and Itaituba, Brazil.

Productus wilberanus McChesney=Productus nebraskaensis.

Productus wortheni Hall.

Keokuk (L. Carb.).

Productus wortheni Hall, Geol. Survey Iowa, I, Pt. II, 1858, p. 635, pl. 19, fiç. 1.

Loc. Nauvoo, Illinois.

Obs. Compare with Productus marginicinctus Prout.

Productus weyprechti Toula.

Upper Carboniferous.

Productus weyprechti Toula, Sitzb. dor k.k. Akad. der Wissensch. zu Wien, 1873 , p. 138, pl. 1 , fig. 4.

Productus weyprechti? Etheridge, Quart. Jour. Geol. Soc. London, XXXIV, 1878, p. 631 .

Loc. Cape Joseph Henry, lat. $82^{\circ} 50^{\prime}$.

PROTORHYNCHA Hall and Clarke.

Genotype Atrypa dubia Hall.

Protorhyncha Hall and Clarke, Pal. New York, VIII, Pt. II, 1893, p. 180;Thirteenth Ann. Rep. N. Y. State Geologist, 1895, p. 824. 
Protorhyncha (?) antiquata (liilling's).

Lower Cambrian.

Cannalla antiqnata Billings, l'al. Fussils, I, 18ti1, 1) 10, fig. 13;-Cool. Vormont,

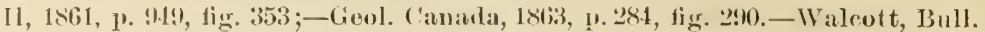
I. S. (ieol. Survey, 30, 188t, 1. 122, 11. 7, fig. 8:-Tenth Ann. Rep. U. S. Geol. Survey, 1s:1, p. 61:3, pl. 72, lig. 3.

Camarella ? antiruata Ifall and Clarke, Pal. Now lork, VIII, Pt. II, 1893, p. 220. Loc. Swanton. Vermont.

Protorhyncha dubia IIall.

Atrylu dubia IIall, Pal. New York, T, 1847, p. 21, 11. 4 bis, fig. 5.

Chazy (Ord.).

Rhynchonellat dubia IIall, Twelfth Rep. N. Y. State Cah. Nat. Hist., 1859, p. 66. P'rotorhyucha dubia 1 fall and Clarke, Yal. Now York, V1II, Pt. 1I, 1893, p. 180.

Loc. Chazy, New York; Highbridge, Kentucky; Lascassis, Temessee.

Protorhyncha (?) minor (Walcott).

Lower Cambrian.

Camarella (?) minor Walcott, Proc. U. S. Nat. Mus., XII, 1889, 1. 36;-T'enth Ann. Tiep. U. S. Geol. Survey, 1891, p. 614, pl. 72, fig. 4.-Hall and Clarke, Pal. New York, V1II, Pt. II, 1893, 1. 221.

Loe. Stissingrille, New York.

Obs. Nay be the type of a new genus. Its affinities are rather with the Rhynchonellidio than with Pentameridie.

Protorthis Hall and Clarke= Billingsella.

Protosiphon Matthew.

Genotype P. kempanus Miathew.

Protosiphon Matthew, Geol. Mag., dec. IV, IV, 1897, p. 70.

Protosiphon kempanus Matthew.

Lower Cambrian.

Protosiphou kempanum Matthew, Geol. Mag., dee. IV, IV, 1897, p. 70, figs. 1-4.

Loc. Long Island, Kings County, New Brunswick.

Protozyga Hall and Clarke=Zygospira.

Pseudocrania anomala A. Winchell=Orthothetes anomalus.

PTYCHOSPIRA Hall and C. Genotype Terebratula ferita von Buch.

Ptychospira Hall anl Clarke, Pal. New York, VIII, Pt. II, 1893, p. 112, fig. 102 ;Thirteenth Anu. Rep. N. Y. State Geologist, 1895, p. 792.

Ptychospira sexplicata (White and Whitfield.) Waverly (L. Carb.). Retzia sexplicatit White and Whitfield, Proc. Boston Soc. Nat. Hist., VIII, 1862, p. 294.

Ptychospira sexplicata Hall and Clarke, Pal. New York, VIII, Pt. II, 1893, p. 112, pl. 50, figs. 13,$14 ;$ pl. 83, fig. 28.

Loc. Burlington, lowa.

PUGNAX Hall and C. Genotype Rhynchonella acuminata (Martin).

Pugnax Hall and Clarke, Pal. New York, VIII, Pt. II, 1893, p. 202 ;-Thirteenth Ann. Rep. N. Y. State Geologist, 1895, p. 828.

Obs. Subgenus of Hypothyris.

Pugnax (?) dawsoniana (Davidson).

Upper Carboniferous.

Rhy nchouella dawsoniana Davidson, Quart. Jour. Geol. Soc. London, XIX, 1863, p. 172, pl. 9, figs. 13,14 .

Rhynchonella? dawsoniana Dawson, Acadian Geology, 3d el., 1878, p. 294, fig. 93.

Puguax (?) dlawsonianus Hall and Clarke, Pal. New York, VIUI, Pt. II, 1893, p. 214 , pl. 62 , firse. 30-33.

Loc. Lennox Passage, Nova Scotia. 
Pugnax globulina (Phillips sp. ?) (Davirlson).

Upper Carboniferous.

Q'Tereliratula globulina Phillipss, Eneyl. Metr., IV, 1834, 11. 3, fig. 3.

Camarophoria? globulina? Davidson, Quart. Jour. Geol. Soe. London, XIX, 1863, 1. 171, pl. 9, figs. 11, 12 .

Camarophoria globnlina? Dawson, Acadian Geology, 3d ed., 1878, p. 293, fig. 92. Pugnax globulina Hall and Clarke, Pal. New York, VIII, Pt. II, 1893, 1. 214.

Loc. De Bert River, Nova Scotia.

Pugnax grosvenori Hall.

St. Louis (I. Carb.).

Rhyuehonella grosvenori Hall, Trans. Alhany Institute, IV, 1858, p. 10.-Whitfield, Bull. Ameriean Mus. Nat. Hist., I, 18×2, 1. 53, pl. 6, figs. 31-34.-Hall, Twelfth Rej. State Feol. Iudiana, 1883, p. 331, pl. 29, figs. 31-34.

Pugnax grosvenori Hall ant Clarke, l'al. New York, VIII, Pt. II, 1895, pl. 60, figs. 13-17.

Loc. Spergen Hill and Bloomington, Indlana; Alton, Illinois; near Princetolı, Kentucky.

Pugnax mutata Hall.

Keokuk and St. Louis (I. Carb.).

Rhynehonella mutata Hall, Trans. Alhany Institute, IV, 1858, 1) 10;-Gieol. Survey Iowa, I, Pt. 1I, 1858, 1. 658, pl. 23, fig. 2.-Whitfield, Bull. American Mus. Nat. IIist., I, 1882, 1. 52, pl. 6, fig. 46.-Hall, Twelfth Rep. State Geol. Indiana, 1883, p. 332, pl. 29, figs. 43-45.

Pngnax mutatus Hall and Clarke, Pal. New York, VIII, Pt. II, 1893, p. 204, pl. 60, figs. 18-22.

Loc. Alton and Varsaw, Illinois; Boonville, Missouri.

Pugnax ottumwa (White).

St. Lonis (L. Carb.).

Rhynehonella ottumwa White, Proe. Boston Soc. Nat. Hist., IX, 1862, p. 23 ;-

Twelfth Ann. Rep. U. S. Geol Survey 'Terr., 1883, p. 165, pl. 41, fig. 5.

Pugnax ottumwa Hall aut Clarke, Pal. New York, VIII, Pt. II, 1893, p. 204, pl. 60 , figs. 23-26.

Loc. Ottumwa and Oskaloosa, Iowa; Clark County, Missouri.

Pugnax pugnus (Martin).

Upper Devonian.

Conchyliolithus Anomites pugnus Martin, Petrefacta Derbiensia, 1809, tab. 22, figs. $4,5$.

Terebratula pugnus Sowerby, Mineral Couchology, 1825, pl. 425, figs. 1-6.

Rhynehonella pugnns Davilson, Mon. British Carb. Brach., Pal. Soc., 1860, p. 97, pl.32, figs. 1-15.-Williams, Americun Jonr. Sci., 3d ser., XX V , 1883, p.99.Waleott, Ilon. U. S. Geol. Survey, VIII, 1884, p. 155, pl. 14, fig. 7.-Clarke, Bull. IT. S. Cieol. Survey, 16, 1885, p. 73.-Whiteaves, Cont. Canalian l’al., I, 1891, pl. 230, 290.

?Rhyuchonella pugnus Dawson, Acadian Geology, 3d ed., 1878, p. 295.

Pugnax pugnus Hall and Clarke, Pal. New York, VIII, Pt. II, 1893, p. 203, pl. 60, figs. 6-10.

Loc. Europe; High Point, New York; Enreka district, Nevada; Mackenzie and Athabasca rivers, Canada; in the Carboniferous of Windsor and East River, Nova Seotia (Dawson); San Sala Valley, Texas (Roemer).

Pugnax pugnus alta (Calvin).

Upper Devonian.

Rhynchonella alta Calvin; paper read hefore the Iowa Acad. Sei., and a named plotographie plate distributed.

Rhynehonella pugnus var. alta Williams, Bull. Geol. Soe. Ameriea, I, 1890, pl. 12, figs. 5-7.

Pugnax altus IFall and Clarke, Pal. New York, VIII, Pt. II, 1893, p. 203, pl. 60, fig8. 1-5.

Loc. Solon, Iowa. 
Pugnax pugnus missouriensis (Shmmard).

Waverly (L. Carb.).

lihynchonella missonriensis Shumard, Geol. Rep. Missouri, 1855, p. 204, pl. 5C, fig. 5a (non figs. 5l, 5c = P'ugnax striaticostata). -Meek and Worthen, Geol. Survey Illinois, II, 1866, p. 153, pl. 14, fig. 4.-Keyes, Geol. Survey Missouri, i', 1895, p. 100.

Pugnax missonrieusis Hall and Clarke, Pal. New York, VII, Pt. II, 1893, p. 204, pl. 60, figs. 33, 34; pl. 62, figs. 41, 45.

Loc. Cooper County, Missonri; Burlington, lowa; Rockford, Indiana; Sciotoville and Richfield, Ohio.

Pugnax rockymontana (Marcou).

Upper Carboniferons.

Terebratula rockymontana Marcon, Geol. N. America, 1858, p. 50, pl. 6, fig. 13.

Rhynchonella eatoni:e formis McChesney, New Pal. Fossils, 1860, p. 49.

Rhyuchonella rockymontana White, Wheeler's Expl. and Survey west 100th Merid., IV, 1875, p. 131, pl. 9, fig. 1.

Pngnax eatoniiformis Hall ani Clarke, Pal. New York, VIII, Pt. 1I, 1893, p. 204, pl. 60, figs. 11, 12 .

Loc. Pecos Village, New Mexico; Cedar Range, Utah; Graysville, Illinois.

Pugnax striaticostata (Meek and Worthen). Kinderhook (L. Carb.). Rhynchonella missouriensis Shumard, Geol. Rep. Missonri, 1855, p. 204, Pl. C, figs. 5b, 5c (non 5a=Pugnax puguus unissouriensis).-Meek and Worthen, Geol. Survey Illinois, III, 1868, p. 450, pl. 14, fig. 7.

Rhynchonella striatoeostata Meek and Worthen, Ibidem, III, 1868, p. 452.

Puguax striatocostata Hall and Clarke, Pal. New York, VIII, Pt. II, 1893, p. 204.

Loc. Cooper Conuty, Missonri.

Pugnax swallovana (Shumard).

Upper Carboniferous.

Camarophoria swallovana Shnmard, Trans. St. Lonis Acad. Sci., 1, 1859, p. 394, pl. 11, fig. 1 .

Pugnax swalloviana Hall and Clarke, Pal. New York, VIII, Pt. II, 1895, p. 201, pl. 60, figs. 27-32.

Loc. Gnadalupe Mountains of New Mexico and Texas.

Pugnax utah (Marcou).

Upper Carboniferous.

Terebratula utah Marcou, Geol. N. America, February, 1858, p. 51, pl. 6, fig. 12. Rhynchonella (Camarophoria) osagensis Swallow, Trans. St. Louis Acad. Sci., I, June, 1858 , p. 219.

Rhynchonella utah, Meek and Hayden, Proc. Acad. Nat. Sci. Philadelphia, 1859, p. 27.-Newberry, Ives's Rep. Colorado River of the West, 1861, p. 128.White, Wheeler's Expl. and Survey west 100th Meridian, IV, 1875, p. 128, pl. 9, fig. 2;-Thirteenth Rep. State Geol. Indiana, 1881, p. 132, pl. 25, fig. 6.

?Rhyuchonella species Salter, Quart. Jour. Geol. Soc. London, XVII, 1861, p. 64, pl. 4 , fig. 5 .

Camarophoria globulina Ceinitz (non Phillips), Carbon und Dyas in Nebraska, 1866, p. 38 , pl. 3 , fig. 5 .

Rhyuehonella osagensis Meek, Fiual Rep. U. S. Geol. Survey Nebraska, 1872, p. 179, pl. 1, fig. 9; pl. 6, fig. 2.-Meek aud Worthen, Geol. Survey Illinois, V, 1873, p. 571, pl. 26, fig. 22.

Pugnax utah Hall aud Clarke, Pal. Now York, VIII, Pt. II, 1893, p. 204, pl. 60, figs. 39-42.

Rhynchonella nta Ḱeyes, Geol. Survey Missouri, V, 1895, p. 103, pl. 41, fig. 7.

Loc. Salt Lake City, Utah ; Indiana ; Illinois ; Iowa ; Missouri ; Kinsas ; Arkausas; Nelıraska.

Obs. Compare with Pugnax pleurodon. 
RAFINESQUINA Hall and C. Genotype Strophomena alternata Emmons.

Strophomena (non Rafinesque) Billings, Canadian Nat. Geol, I, 1856, p. 133 ;Canadian Jour., VI, 1861, p. 329;-Pal. Fossils, I, 1862, p. 115.-I1all, Pal. New York, IV, 1867, p. 76.-Meek, Pal. Ohio, I, 1873, p. 73.-N. II. Winchell, Ninth Ann. Rep. (ieol. Nat. Hist. Survey Minuesota, 1881, 1. 118. - Shaler, Fossil Brachiopoda of the Ohio Valley, 1887, p. 4.--Herrick, Bull. Denison University, IT, 1888, 1. 14.-Nettelroth, Kentucky Fossil Shells, Mem. Kentucky Geol. Survey, 1889, p. 159.

Rafinesquina Hall and Clarke, Pal. New York, VIII, Pt. I, 1892, p. 281.--Winehell and Sehuchert, Minnesota Geol. Surrey, III, 1893, p. 400.-Hall and Clarke, Eleventh Ann. Rep. N. Y. State Geologist, 1894, p. 279.

\section{Rafinesquina alternata (Emmons).}

Trenton to Lorraine (Ord.).

Leptrena alternata Conrad, Second Ann. Rep. N. I. Geol. Survey, 1838, p. 115 (undefined).-Hall, Pal. Now York, I, 1847, pl. 102, 286, pl.31, fig. 1; pl.31A, fig. 1; pl. 79, fig. 2.-Rogers, Geol. Penmsylvania, II, Pt. II, 1858, 1. 818, fig. 600 .

Strophomena alternata Conrad, Third Ann. Rep. N. Y. Geol. Survey, 1839, P. 63 (undefined);-Fourth Rep. Ibidem, 1840, p. 201 (nudefined);--Fifth Rep. Ibidem, 1841, p. 37 (nudefined).-Emmons, Geol. N. Y.; Rep. Second Dist., 1842, 1.395, fig. 3.-Billings, Cauadian Nat. Geol., I, 1856, p. 204, figs. 3, 4;Canadiau Nat. Geol., V, 1860, 1. 51;--Pal. Fossils, 1, 1862, p. 117;--Greol. Canada, 1863, p. 163, fig. 140.-Meek, Pal. Ohio, I, 1873, p. 88, pl. i, fig. 1.Miller, Cincimmati (quart. Jour. Sei., II, 1875, 1.51.-White, Second Ann. Rep. Indiaua Burean of Statistics and Geol., 1880, p. 481, pl. 1, figs. 6, 7; - Tenth Rep. State Geol. Indiana, 1881, p. 113, pl. 1. figs. 6, 7.-Hall, Second Aun. Rep. N. Y. State Geol., 1883, pl. 38, figs. 6-11.-Shaler, Fossil Brachiopocia of the Ohio Valley, 1887, p. 4, pls. 2, 3.-lieyes, Geol. Survey Missouri, Y, 1895, 1), 70, pl. 39, fig. 3 .

Orthis huroniensis Castelnan, Essai systime Silurien l'Amírique Septentrionale, 1843, p. 37, pl. 14, fig. 6.

Orthis plana Castelnan (non Pander), Ibidemu, 1843, p. 38, pl. 14, fig. 1.

Strophomena angulata? Owen, Geol. Expl. Iowa, Wisconsin, ant Illinois, 1844, pl. 18 , figs. 1,3 .

Strophomena auticostieusis Shaler, Bull. Mus. Comp. Zool., 4, 1865, p. 62.

Rafinesquina alternata Hall and C'larke, Pal. New York, VIII, Pt. I, 1892, p. 282, 11. 8, figs. 6-11, 27, 28; Pt. II, 1895, pl. 84, figs. 17, 18.-Winchell aud Sehnehert, Minnesota Geol. Survey, III, 1893, p. 404, pl, 31, figs. 32-34.-Whiteares, Pal. Foss., III, l't. III, 1897, p. 171.

Loc. New York; Ohio; Indiana; Illinois; Missonri ; Visconsin ; Minuesota ; Canada; Manitoba; Anticosti.

Obs. This species was not definerl or fignrerl hy lonrad. The first illustration was given by Emmons, and in the following year it was fignred and defined by Custelnau as Orthis huroniensis.

\section{Rafinesquina alternata alternistriata Hall.}

Lorraine (Ord.).

Leptæna alternistriata Hall, Pal. New York, I, 1847, p. 109, pl. 31 B, lig. 1.

Strophomeni alternistriata Hall, Twelfth Rep. N. Y. State Cab. Nat. Hist., 1859, p. 70.

Strophomena alternata var. alternistriata Miller, Cincinnati Qnart. Jonr. Sei., II, 1875, p. 53.

Rafinesquina alternistriata Hall and Clarke, Pal. New York, VIII, Pt. I, 1892, p. 283.

Loc. Cincinnati, Ohio; Maysville, Kentucky; Madison, Indiana.

Obs. Meek regarded this variety as a synonym for S. alternata.

Bull. 87-22 
Rafinesquina alternata fracta (Meek).

Lorraine (Ord.).

stroplomena alternata var. fraeta Meek, Pal. Ohio, I, 1873, p. 91, pl. 7, fig. 3.

Strophomena fracta Miller, Cincinnati Quart. Jour. Sei., I, 1874, p. 13;--Hirlem, II, 1875, P. 54 .

Joe. Cincinnati, Ohio.

Ratinesquina alternata loxorhytis Winchell and Schuchert=R. kingi. Ran̂nesquina alternata loxorhytis (Meek). Lorraine (Ord.).

strophomena alternata var. loxorhytis Meek, Pal. Ohio, I, 1873, p. 91.-Miller,

Cincinnati Quart. Jour. Sci., II, 1875, 1. 13.

loc. Cinciunati, Ohio.

Rafinesquilia alternata nasuta (Comrad).

Lorraine (Grd.).

Strophomena nasuta Comral, Jour. Acad. Nat. Sci. Philadelphia, VIII, 1842, l). 260.-Lmmons, Geol. New York; Rep. Third I list., 1842, 1. 403, fig. 3.

Strophomena alternata var. nasuta Miller, Cincinnati Quart. Jour. Sci., II, 1875, p. 53.

Loc. Jefferson County, New York; Cincinnati, Ohio.

Rafinesquina (?) atava (Mattliew).

Calciferous (Ord.). Strophomena atava Matthew, Trans. Royal Soc. Canada, 1893, 1. 102, 11. 7, fig. 8 . Loc. Mary Island, near St. Joln, New Brnnswick.

Rafinesquina aurora (Billings).

Galeiferous (Ord.). Strophomena anrora Billings, Pal. Fossils, I, 1865, p. 218, tig. 202.

Loc. Table Head, etc., Newfoundland.

Rafinesquina ceres (Billings). Lorraine and Anticosti (Ord. and Sil.). Strophomena ceres Billings, Canadian Nat. Geol., V, 1860, 1. 54;-Pal. Fossils, I, 1862, p. 119.

Loc. Anticosti.

Rafinesquina deltoidea (Conrad).

Trenton and . Utica (Ord.). Strophomena deltoirlea Conrad, Third Ann. Rep. N. Y. Geol. Survey, 1839, 1.

64;-Fifth Rep., Ibidem, 1841, 1. 37.- Vanuxen, Geol. N. Y.; Rep. Third Dist., 1842, p. 46, fig. 2.-Emmons, Geol. N. Y.; Rep. Second Dist., 1842, p. 389, fig. 2.-Billings, Geol. Canada, 1863, p. 163, fig. 141.-Keyes, Geol. Survey Missouri, $\mathrm{V}, 1895, \mathrm{~N}, 69$.

Strophomena camerata Conrad, Jour. Acarl. Nat. Sci. Philadelphia, VIII, 1842, p. 254 , pl. 14 , fig. 5 .

Leptrena camerata Hall, Pal. New York, I, 1847, p. 106, pl. 31A, fig. 2.

Leptrena deltoidea IIall, Ibidem, 1847, p. 106, pl. 31A, fig. 3.

Streptorhynehns (Stroplionella) deltoilea Hall, Second Ann. Rep. New York State Geol., 1883, pl. 42, figs. 1, 2, 4 (non fig. 3).

Refinesquina deltoilea Hall and Clarke, Pal. New York, VIII, Pt. I, 1892, pl. 9A, figs. 1, 2, 4.-Winchell and Schuchert, Minnesota Geol. Survey, III, 1893, p. 403, pl. 3I, figs. 30, 31.-Whiteaves, Pal. Foss., III, Pt. III, 1897, p. 170.

Loe. Trenton Falls, etc., New York; St. Paul, Cannon Falls, etc., Minnesota; Oshkosh, Wisconsin; Dubuque, Iowa; Pike Connty, Missonri; Ottawa and Lake Winnipeg, Canada.

Rafinesquina fasciata Hall.

Chazy (Ord.).

Leptiena fasciata Hall, Pal. New York, r, 1847, p. 20, pl. 4 bis, tig. 3.

Stropliomena fasciata Hall, Twelfth Rep. N. Y. State Cab. Nat. Hist., 1859, 1. 70. Rafinesquina fasciata Hall and Clarke, Pal. New York, VIII, Pt. 1, 1892, 1. 283. Loc. Chazy, Clinton County, New York.

Obs. Should he compared with R. alternata.

Rafinesquina imbrex (Pander).

Lorraine (Ord.).

Strophomena imbrex(?) Billings, Pal. Fossils, 1, 1862, p. 128, fig. 106.

Loc. Europe; Anticosti. 
Rafinesquina incrassata (Hall).

Chazy and Black River (Ord.).

Leptrena incrassata Hall, Pal. Now York, I, 18.7, 1. 19, pl. 4 bis, fig. 2.-Rogers,

Geol. Peunsylvania, II, Pt. II, 1858, p. 817, fig. 591.

Strophomena incrassata Billings, Canadian Nat. Geol., IV, 1859, p. 443.

Loc. Chazy, New York; Mingan Islaud, Canadiı.

Rafinesquina kingi (Whitfield).

Lorraine (Ord.).

Strophomena kingi Whitfield, Ann. Rep. Geol. Survey Wisconsin, 1877, p. 72 ; -

Geol. Wisconsin, IV, 1882, p. 261, pl. 12, figs. 15, 16.

Ratinesquina alternata var. loxorhytis Winchell and Schuchert, Minnosota Geol.

Survey, III, 1893, p. 407, pl. 31, tigs. 35-37; pl. 32, tigs. 59, 60.

Ratinesquina kingi Hall and Clarke, Pal. New York, VIII, Pt. 1, 1892, p. 283.

Loc. Delafield, Wisconsin; near Spring Valley, Minnesota.

Rafinesquina lata Whiteaves.

Lorraine (Ord.).

Rafinesquina lata Whiteaves, Canarlian Rec. Sci., 1895, p. 392 ;-Whiteaves, Pal.

Foss., III, Pt. III, 1897, p. 172, pl. 19, figs. 2-5.

Loc. Red River Valley and Lake Winnipeg, Manitoba.

Rafinesquina mesicosta (Shumard).

? Trenton (Orcl.).

Leptiena mesacosta Shumari, Geol. Rep. Missouri, 1855, 1. 205, PI. C, fig. 2.Keyes, Geol. Survey Missouri, V, 1895, p. 76.

Loc. Cape Girardeat, Missouri.

Rafinesquina minnesotaensis (N. H. Winchell).

Trenton (Ord.).

Strophomena deltoidea Owen (non Conrad), Geol. Expl. Iowa, Wisconsin, and Illinois, 1814, pl. 16, fig. $8 ; \mathrm{pl} .17$, fig. 6 .

Lepterna deltoidea Owen, Geol. Rep. Wisconsin, Iowa, and Minnesota, 1852, 1. 620 , tab. $2 \mathrm{~B}$, fig. 10 (not the milldle fignre).

Strophomena inerassata Hall (non 1817), Geol. Wisconsin, I, 1862, p. 42, fig. 16.-Hall (non 1817), Second Ann. Rep. N. Y. State Geol., 1883, pl. 38, figs. 1-5.

Strophomena mimnesotensis N. H. Winchell, Ninth Ann. Rep. Geol. Nat. Hist. Survey Minnesota, 1881, p. 120.

Ratinesquina minnesotensis Hall and Clarke, Pal. New York, VIlI, Pt. I, 1892, 1. 283.-Winchell aud Schuchert, Minnesota Geol. Survey, III, 1893, 1. 401, pl. 31 , figs. $25-29$.

Loc. Minueapolis, etc., Minnesota; Beloit, Wisconsin; Decorah and MeGregor,

Iowa; central Kentucky; Lebanon, Tennessee.

Obs. This species is probably not identical with R. incrassata (Hall) of the Chazy terrane.

Rafinesquina minnesotaensis inquassa (Sardeson).

Trenton (Ord.).

Strophomena inquassa Sardeson, Bull. Miunesota Acad. Nat. Sci., III, 189", p. 331, pl. 5, figs. 22-24.

Rafinesquina minnesotensis var. inquassa Winchell anl Schuchert, Minuesota Geol. Surver, III, 1893, p. 403, pl. 31, tigs. 27, 28.

Loc. Minneapolis and St. Paul, Minnesota; Mineralpoint, Wisconsin.

Rafinesquina nitens (Billings).

Lorraine (Ord.).

Strophomena nitens Billings, Canalian Nat. Geol., V, 1860, p. 53, tig. 1;-Pal.

Fossils, I, 1862, p. 118, fig. 97 ;-Geol. Canada, 1863, 1. 209, fig. 208.

Ratinesquina nitens Hall and Clarke, Pal. New York, VIII, Pt. I, 1892, p. 283.

Loc. Anticosti.

Rafinesquina (?) obscura Hall.

Clinton (Sil.).

Leptæna obscura Hall, Pal. New York, II, 1852, pp. 62, 103, pl. 21, figs. 2, 6. Strophomena obscura Hall, Twelfth Rep. N. Y. State Cab. Nat. Hist., 1859, 1. 82. Strophomena obscura? Foerste, Proc. Boston Soc. Nat. Hist., XXIV, 1890, p. 306, pl. 6 , figs. $15,16$.

Ratinesquina ? obseura Hall and Clarke, Pal. New York, VIII, I’t. I, 1892, p. 283.

Loc. Near Utica and Kirkland, New York; Cumberland Gap, Tenuessee. 
Rafinesquina squamula (James).

Lorraine (Ord.).

Strophomena siluamula .lanes, (ineimuti (quart. Jour Sci., I, 1874, p. 335).

Rátinesquinat squamula Itall and Clarke, Pal. New York, VHI, I’t. I, 1892, 1. 283. Loc. Cincinnati, Ohio.

Rafinesquina tenuilineata (Conrad).

Treston (Ord.).

Atropliomena tenulineata Comad, Jour. Acad. Nat. Sci. Philadolphia, VIH, 1842, 1. 259.- Hall, Twelfth Rep. New York State Cah. Nat. Hist., 1859, p. 70. Leprarna tenuilineata Hall, Pal. New York, I, 1847, p. 115, pl. 31B, fig. 8.

Loc. "Occurs in Trenton limestone."

Rafinesquina ulrichi (Jimes).

Utica (Ord.).

strophomena (?) ulrichi James, The Palæontologist, 1, 1878, p. 6.

Ratinesquina ulrichi IIall and Clarke, Pal. New York, VIII, Pt. I, 1892, F'. 283, pl. $15 \mathrm{~A}$, tigs. 37,38 .

l.oc. Cincinuati, Ohio.

RENSSEL ÆRIA Hall.

Genotype Terebratula ovoides Eaton.

Rensseleria Hall, Twelfth Rep. N. I. State Cal. Nat. IIist., 1859, 1. 39;--Pa1.

New York, III, 1859, 1. 454.-Dall, Imerican Jonr. Conchology, VI, 1870, p. 105.-Claypole, Proc. Americau Philosophical Soc, 1883, p. 235. - Hall aud Clarke, Pal. New York, VIII, Pt. II, 1893, p. 255;-Thirtecnth Aun. Rep. N. Y. State Geologist, 1895,1 , 849.

Rensselæria æquiradiata (Conratl).

Lower Helderberg (Dev.).

Atrypa sequiradiata Conrad, Jour. Acad. Nat. Sci. L'hiladelphia, VIfl, 1842, p. 266, pl. 16, fig. 17 .

Meganteris aquiradiata Hall, Tenth Rẹ.. N. Y. State Cal. Nat. Hist., 185T, 1. 99, figs. 1-3.

Rensselaria cquiradiata Hall, Pal. New York, III, 1859, p. 255, 11. 45, fig. 3.Hall and Clarke, Pal. New York, VIII, Pt. 11, 1×93, 1, 25x, pl. 76, figs. 23-25.

Loc. Cherry Valley, Schoharie, and Carlisle, New York; Arisaig, Nova Scotia (Ami).

Rensselæria cayuga Hall and Clarke.

Oriskany (1)ev.).

Rensselieria cayuga Hall and Clarke, Pal. New York, VIII, Pt. II, 1895, p1. 258, 370, pl. 75 , figs. $1,2$.

Loc. Cayuga, Ontario.

Rensselæria condoni McChesney $=$ Megalanteris condoni.

Rensselæria cumberlandiæ Hall.

Oriskany (Dev.).

Meganteris cumberlandice Hall, Tenth Rep. N. Y. State Cab. Nat. Ilist., 1857, p. 101.

Rensselipria cumberlandix Hall, Pal. New York, III, 1859, ]. 464, pl. 108, fig. 1.Hall and Clarke, Pal. New York, VIII, Pt. II, 1893, p. 258, pl. 77, figs. 23-25. Loc. Cumberland, Maryland.

Rensselæria elliptica Hall.

Lower Helderberg (Dev.).

Meganteris elliptica Hall, Tenth Rep. N. Y. State Cab. Nat. Hist., 1857, 1. 98.

Rensseluria elliptica Hall, Pal. New York, III, 1859, p. 256, pl. 45, fig. 4.-Hall and Clarke, Ibidem, VIII, Pt. H1, 1893, p. 258, pl. 76, figs. 26-28.

Loc. Schoharie County, New York.

Reusselaria elongata Hall=Amphigenia elongata.

Rensselæria intermedia Hall.

Oriskany (Dev.).

Rensselæria intermedia Hall, Pal. New York, III, 1859, p. 463, pl. 108, fig. 2.Hall aud Clarke, Pal. New York, VIII, Pt. I1, 1895, pl. 77, figs. 26-28.

Loc. Cumberland, Maryland.

Reusselæria johanni Hall=Newberrya johannis. 
Rensselæeria lavis Hall=Meristella lavis.

Rensselæria lavis Meek=Newberrya levis.

Rensselæria marylandica Claypole $=$ Newberrya claypolei.

Rensselæria marylandica Hall.

Oriskany (Der.).

Rénsseleria marylandica Hall, Pal. New York, III, 1859, p. 461, pl. 108, fig. 3.Hall and Clarke, Pal. New York, VIII, Pt. II, 1893, p. 258, pl. 76, figs. 8-20. Loc. Cumberland, Maryland.

Rensselæria mutabilis Hall. Lower Hellerberg (Dev.). Meganteris mutabilis Hall, Tenth Rep. N. Y. State Cab. Nat. IIist., 1857, p.97.

Rensseleria mutabilis IIall, Pal. Now York, III, 1859, p. 254, pl. 45, fig. 2.-Hall and Clarke, Pal. New York, VIII, Pt. II, 1893, 1)1. 258, 259, figs. 178, 179; pl. 76, figs. 1-3a, 21, 22.

Loc. Albany and Colnmbia counties, New York.

Rensselieria ovalis Hall= Megalanteris ovalis .

Rensselæria ovoides (Eaton).

Oriskany (Dev.).

Terebratula oroides Eaton, Geological Text-Book, 1832, p. 45.

Terebratula perovalis Eatou, Ibidem, 1832, 1. 45.

Atrypa elongata Conrad, Thirl Anu. Rep. N. Y. Geol. Surves, 1839, p. 65.Vannxem, Geol. N. Y. ; Rep. Third Dist., 1842, p. 123, fig. 2.-Hall, Ibidem, Fourth Dist., 1843, p. 138, fig. 2 ;-(Conrar) Fiftcenth Rep. N. I. State Cab. Nat. Hist., 1862, pl. 11, fig. 14.

Pentamerus deshayesii Castelnan, Essai système Silurien l’Amérique Septentrionale, 1843, p. 38 , pl. 15 , figs. $1,2$.

Moganteris ovoides Hall, Tenth Rep. N. Y. State Cab. Nat. Hist., 1857, p. 102.Rogers, Geol. Penusylvania, II. Pt. II, 1858, p. 826, fig. 619.

Rensselæria ovoides Hall, Pal. New Tork, III, 1859, p. 456, pl. 104, figs. 1-4; pl. 105, figs. 1-6.-Billings, Geol. Canala, 1863, p. 961, fig. 470;-Pal. Fossils, II, 1874, p. 41, pl. 3, figs. 7, 10.-Hall and Clarke, Pal. New York, VIII, Pt. II, 1893, p. 258, pl. 75, figs. 5-9; pl. 76, figs. $16,18$.

Loc. New York; Pennsylvania; Maryland; Virginia; Gaspé, Canada.

Rensselæria ovulum Hall and Clarke.

Oriskany (Dev.).

Rensselreria ovulum Hall and Clarke, Pal. Now York, VIII, Pt. II, 1895, pl. 75, figs. 3,4 .

Loc. Caynga, Canada.

Rensselaria portlandica Billings='Trigeria portlandica.

Rensselaria suessana Hall=Beachia suessana.

Rensselandia Hall= Newberrya.

RETICULARIA MeCoy. Genotype Terebratula? imbrieata Sowerby. Reticularia MeCoy, Carboniferons Fossils of Ireland, 1844, p. 142.-Waagen, Palaontologica Iudica, Ser. XIII, I, 1883, p. 538.

Reticularia bicostata (Vannxem). Niagara (Sil.).

Orthis bicostatus Yanuxem, Geol. N. Y.; Rep. Third Dist., 1842, p1. 91, 94.

Spirifer bicostatus Hall, Pal. New Iork, I, 1852, p. 263, pl. 54, fig. 4.-Uall and Clarke, Pal. New York, YIII, Pt. II, 1893, pr. 19, 37, pl. 36, fig. 7.

Spirifera hicostata Hall, Scoond Ann. Rep. N. Y. State Geol., 1883, pl. 61, fig. 7. Loc. Vernon Center, New York; Lonisville, lientueky.

Reticularia bicostata petila (Hall).

Niagara (Sil.).

Spirifera bicostata? var, petila Hall, Descrip. n. sp. of Fossils from Waltron, Indiana, 1879 , p. 15 .

Spirifera bicostata var. petila Hall, Eleventh Rep. State Geol. Indiana, 1882, p. 279, pl. 27, figs. 8, 9;-Traus. Albany Institute, X, 1883, p. 71. 


\section{Reticularia bicostata petila (Hall)-Continued.}

Spirifer bicostatus var. petilus Beceher and Clarke, Mem. N. Y. State Mus., I, 1889, p. 75, pl. 6, figs. 1-3.

Loc. Waldron, Indiana.

Reticularia canandaiguæ (Hall and Clarke).

Hamilton (Dev.).

Spirifer eanandaignse Hall and Clarke, Pal. New York, VIII, Pt. II, 1895, p. 360, pl. 37, tigs. 23-25.

Joc. Centerfield and Canandaigna Lake, New York.

Reticularia clara (Swallow).

Kaskaskia (L. Carb.).

Spirifera clara Swallow, Trans. St. Lonis Acad. Sei., II, 1863, p. 86.

Lor. St. Generieve County, Missonri.

Reticularia cooperensis (Swallow).

Kinderhook (L. Carb.).

Spirifera cooperensis Swallow, Trans. St. Lonis Acad. Sci., I, 1860, p. 643.-

Meek and Worthen, Geol. Survey Illinois, II, 1866, p. 155, pl, 14, fig. ־-

Kieyes, Geol. Survey Missouri, V, 1895, p. 78.

Spirifer hirtus White and Whitfield, Proc. Boston Sor. Nat. Hist., VIIY, 1862, p. 293.-Hall and Clarke, Pal. New York, VIII, Pt. II, 1893, pp. 21, 37, pl. 38, fig. 14 (? pl. 84, figs. 36,37 ).

Spirifera semiplicata Hall, Thirteenth Rep. N. Y. State Cab. Nat. Hist., 1863, 1. 111.

Spirifer hirtus? A. Winchell, Proc. Acad. Nat. Sci. Philadelphia, 1865, p. 119;Proc. American Phil. Soc., XII, 1870, p. 251.

Loc. Chontean Springs, etc., Missouri; Rockford, Indiana; Burlington, Iowa; Hickman County, Tennessee.

Reticularia fimbriata (Conrad).

Oriskany-Ithaca (Dev.).

Delthyris fimbriatus Conrad, Jour. Acad. Nat. Sci. Fhiladelphia, VIII, 1842, p. 263.-Hall, Geol. N. Y.; Rep. Fonrth Dist., 1813, p. 208, fig. 10.

Spirifer fimbriatus IIall, Geol. Survey Iowa, I, Pt. II, 1858, p. 505, pl. 4, fig.5.Billings, Canadian Jour., VI, 1861, 1). 257, figs. 68-70;-Geol. Canada, 1863, p. 372, fig. 393.-Hall and Clarke, Pal. New York, VIII, Pt. II, 1893, pI. 17, 20, 21, 33, 37, pl. 36, figs. 17-22; pl. 38, figs. 9, 10.

Spirifera fimbriata Hall, Pal. New York, IV, 1867, p. 214; pl. 33, figs. 1-11;Second Anu. Rep. N. Y. State Geol., 1883, pl. 61, figs. 17-22.-Whiteaves, Cont. Canadian Pal., I, 1892, 1. 286.

Spirifer compactus Meek, Trans. Chicago Acai. Sci., I, 1868, p. 102, pl. 14, fig. 11. Spirifer (Martinia) riclsardsoni Meek, Trans. Chicago Acad. Sci., I, 1868, p. 104, pl. 14, fig. 2.

Spirifera (M.) richardsoni Whiteaves, Cont. Canadian Pal., I, 1891, p. 226;Ibidem, 1892, p. 287, pl. 37, fig. 7.

Spirifera conradana Miller, American Pal. Foss., 2 d el., 1883, p. 372.-Nettelroth, Kentucky Fossil Shells, Mem. Kentucky Geol. Survey, 1889, p. 110, pl. 7, figs. 11-13.

Spirifera (M.) undifera Walcott, Mon. U. S. Geol. Snrvey, VIII, 1884, pl, 3, figs. 3,6 ; pl. 14, fig. 11.

Loc. New York; Ohio; Falls of Ohio; Illinois; Iowa; Maryland; Virginia; Eureka district, Nevada; Ontario and lakes Manitolya and Winnipegosis; Mackenzio River, Northwest Territory, C'anada.

Obs. Mr. Walcott is correct in regarding this speries the same as Spirifer undiferus Roemer. Conrad's species, however, was published in 1842, while that of Roemer is two years later, or in 1814. S. richardsoni is a young specimen of S. compacta which Mr. Walcott has shown to be a synonym for s. undiferus. See Retienlaria knappiana. 
Reticularia franklini (Meek).

Hamilton (Dev.).

Spirifer (Martinia) franklini Meek, Trans. Chicago Acad. Sci., I, 1868, p. 107, pl. 14, fig. 12 .

Spirifera (M.) glabra var. franklini Whiteaves, Cont. Canadian Pal., I, 1891, p. 225.

Loc. Mackenzio River, Northwest Territory, Canada.

Obs. The type specimen in the U. S. National Museum collection proves to be closely related to Reticularia lievis Hall.

Reticularia guadalupensis (Shumard).

Upper Carboniferous.

Spirifera guadalnpensis Shumard, Trans. St. Louis Acad. Sci., I, 1859, p. 391.

Loc. Guadalupe Mountains, Texas.

Reticularia knappiana (Nettelroth).

Corniferous (Dev.).

Spirifera knappiana Nettelroth, Kentucky Fossil Shells, Mem, Kentucky Geol. Survey, 1889 , p. 122 , pl. 7 , fig. 14.

Loc. Falls of Ohio.

Obs. Probably the same as R. fimbriata.

Reticularia lævis (Hall).

Portage (Dev.).

Delthyris levis Hall, Geol. N. Y.; Rep. Fourth Dist., 1843, p. 245, fig. 1.

Spirifera levis Hall, Pal. New York, IV, 1867, p. 239, pl. 39, figs. 1-12.

Spirifer levis Williams, American Jour. Sci., 3d ser., XX, 1880, 1. 456.-Hall and Clarke, Pal. New York, VIII, Pt. II, 1893, pp. 19, 33, 37, pl. 38, figs. 11-13; pl. 84, fig. 29.-Kindle, Bull. Anerican Pal., 6, 1896, p. 36.

Spirifera (Martinia) glabra var, levis Williams, Anu. Now York Acarl. Sci., II, 6, 1881, pl. 14, figs. 1, 2.-Walcott, Mon. U. s. Geol. Survey, VIII, 1884,1. 140. Loc. Ithaca and Cortlandville, New York.

Reticularia modesta (Hall).

Lower Helderberg (Dev.).

Spirifer modestus Hall, Tenth Rep. N. Y. State Cab. Nat. Hist., 1857, p. 61;Pal. New York, III, 1859, p. 203, pl. 28, fig. 1.-Hall and Clarke, Pal. New York, VilI, Pt. 11, 1893, p. 37, pl. 38, figs. 1, 3.

Loc. Cumberland, Maryland.

Reticularia nevadaensis (Walcott).

Upper Devonian.

Spirifera (M.) glabra var. nevadensis Walcott, Mon. U. S. Geol. Survey, VIII, 1884, p. 139, pl. 3, fig. 5 ; pl. 14, tig. 14.

Loc. Eureka district, Nevala.

Reticularia (?) nympha (Billings).

Lower Helderberg (Dev.).

Spirifera nympha Billings, Proc. Portland soc. Nat. Hist., I, 1863, 1. 116, pl. 3, fig. 15.

Loc. Masardis, Maine.

Reticularia perplexa (MeChesney).

Upper Carboniferous.

Spirifer lineatus Shumard, Geol. Survey Missouri, 1855, p. 216.-Hall, Pacific R. R. Reports, III, 1856, p. 101, pl. 2, figs. 6-8.-Marcou, Geol. N. America, 1858, p. 50, pl. 7, fig. 5.-Newberry, Ives's Rep. Colorado River of the West, 1861, p. 127.-Swallow, Trams. St. Lonis Acad. Sci., II, 1866, p. 408.-Hall and Clarke, Pal. New York, VIII, Pt. II, 1893, pp. 10, 11, 17, 21, 30, 39, pl. 38, figs: $2,4,7,8$.

Spirifer porplexus MeChesuey, New Pal. Fossils, 1860, p. 43.

Spirifer lineatus? Meek, Geol. Survey California, I, 1864, p. 13, pl. 2, fig. 6.

Spirifer lineatus var. perplexus Swallow, Trans. St. Louis Acarl. Sci., II, 1866, p. 408.

Spirifera lineata Meek, Final Rej. U. S. Geol. Survey Nebraska, 1872, pl. 2, fig. 3.-Keyes, Proc. Acad, Nat. Sci. Philadel phia, 1888, p. 230.

Spirifer (Martinia) perplexa Derlıy, Bull. Cornell Univ., I, 1874, p. 16, pl. 3, figs. $27,39,40,45,50$; pl. 8 , fig. 13 . 


\section{Reticularia perplexa (McChesney)-Contimed.}

spirifora (Martinia) lineata? White, Whoeler's lixpl. and Survey west 100th Meridian, III, Appendix, 1881.

Spirifera (Martinia) lineata White, Eleventh liep. Stato fieol. Indiana, 1882, p. 372, pl. 12, figs. 4-6;-Thirteonth Rep. State Gool. Indiana, 188.1, 1. 1:3, pl. 27, ligs. 4-6.-Herri॰k, Bull. Denison Univ., II, 1887, p. 46, pl. 1, fig. 13.Whithelı, smmals N. Y. Acak. Sei., V, 1891, p. 603, pl. 16, figs. 3-5;-Cicol. Ohio, v11, 1895, p. 488, pl. 12, figs. :3-5.

Spirifera porplexa Keyes, Geol, Survey Missouri, Y', 1895, p. 84.

Lor. Olio; Indiana; Illinois; Missouri; Iowa; Kentucky; California; Texas; Pecos and Tigeras, New Mexieo; Shasta Connty, California; Bomjarlim and Itaituba, Brazil.

Obs. This speries is not ilentica! with Reticularia lineata Martin, as found in England and Belgium. Reticularia psendolineata (Hall) is more closely allied to that speeies than R. perplexa (MeChesney).

Reticularia perplexa striatilineata (Swallow).

Upper Carboniferous.

Spirifor lineatus var. striatolineatus Swallow, Trans. St. Lonis Acad. Sci., II, 1866, p. 408.

Loc. Missouri.

Obs. Regarled by keyes as a synonym for R. perplexa.

Reticularia præmatura (Hall).

Chemming (Dev.).

Spirifera priematura Ifall, Proc. American Thilosophical Soc., X, 1866, 1. 246;-

Pal. New York, IV, 1867, p. 250, pl. 33, tigs. 31-35;-Second Ant. Re1. N. Y. State Geol., 1883, pl. 61, figs. 23-25.

Martinia prematura Herrick, Geol. (hhio, VII, 1895, pl. 23, fig. 12.

Spirifer prematurus Hall and Clarke, Pal. New York, V1II, Pt. II, 1893, 1. 37, pl. 36 , figs. $23-25$.

Loc. Meadrille and Oil Creek, Pennsylvania.

Reticularia pseudolineata (Hall).

Burlington-Keokuk (L。 Carb.).

Spirifer psendolineatus Hall, Geol. survey Iowa, I, Pt. I1, 1858, p. 645, 11. 20,

fig. 4.-?llerrick, 13ull. Geol. Soc. America, II, 1891, p. 45, pl. 1, fig. 18.-Hall and Clarke, Pal. New York, VIII, Pt. II, 1893, pl. 21, 37, pl. 36, figs. 28-30.

Spirifera lineatoides Swallow, Trans. St. Lonis Aead. Sei., I, 1860, p. 645.

Spirifera psendolineata Saflord, Geol. Tennessee, 1869, 1. 360.-Hall, Secom Ann. Rej.. N. Y. State Geol., 1883, 11. 61, figs. 28-30.

Reticularia pseudolineata Waagen, Palitontologica Indica, Ser. XIII, I, 1883, p. 542 .

Spirifera lineatoides and psendolineata Keyes, Geol. Surrey Missouri, V, 1895, pp. 81,82, pl. 40, fig. 6 .

Loc. Keokuk, Iowa; Warsaw, Illinois; Crawfordsville, Indiana; Missouri.

Obs. See R. perplexa (McChesney).

Reticularia setigera (IIall).

Kaskaskia (L. Carb.).

Spirifer setigerns Hall, Geol. Survey Iowa, I, Pt. II, 1858, p. 705, pl. 27, fig. 4.I Iall and Clarke. Pal. New York, VIII, Pt. II, 1893, pp. 21, 37, pl. 36, figs. 26, 27.

Spirifera setigera Hall and Whitfield, King's T. S. Geol. Expl. toth Parl., IV, 1877, 1. 270, 11. 5, figs. 17, 18.-Hall, Second Ann. Re1. N. I. State Geol., 1883, pl. 61, tigs. 26, 27.-Kiejes, Geol. Survey Missouri, V, 1895, p. 83.

Reticularia setigera Waagen, Palnontologica Inılica, Ser. XIII, I, 1883, p. 542. Loc. Kaskaskia and Chester, Illinois; Caldwell and Crittenden counties, Kentucky; Oquirrh Mountains, Utah.

Obs. See R. translata.

Reticularia subundifera (Meek and Worthen).

Hamilton (Dev.).

Spirifera sulunılifera Meek and Worthen, Geol. Survey Illiuois, IlI, 1868, p. 434, pl. 10, tig. 5. 
Reticularia subundifera (Meek and Worthen)-('ontinued.

Spirifera (M.) undifera var. subundifera Walcott, Mon. U. S. Geol. Survey, VIII, 1884, p. 145.

Loc. Rock Island, Illinois.

Reticularia (?) temeraria (Miller).

Lower Carboniferous. Spirifera temeraria Miller, Jour. Cincinnati Soc. Nat. Hist., IV, 1881, p. 314, pl. 7, fig. 9.

Loc. Lake Valley mining district, Now Mexico.

Reticularia tenuispinata (Herrick).

Waverly (L. Carb.). Spirifora (Martinia) tenuispinata Herrick, Bull. Denison Univ., IV, 1888, p. 27, p]. 2 , fig. 4 .

Spirifer tenuispinatus Herrick, Geol. Ohio, VII, 1895, pl. 15, fig. 4.

Loc. Granville, Ohio.

Reticularia translata (Swallow).

Kaskaskia (L. Carb.).

Spirifera translata Swallow, Trans. St. Lonis Acad. Sci., II, 1863, 1. 85.

Loc. Chester, Illinois; St. Marys, Missouri.

Obs. Regarded by Keyes as a synonym for R. setigera.

RETZIA King. Genotype Terebratula adrieni de Verneuil. Retzia King, Mon. Pormian Fossils, Pal. Soc., 1850, p. 137.-Hall, Sixteenth Rep. N. Y. State Cab. Nat. Hist., 1863, p. 53, figs. 1-3 on p. 55.- Fall and Clarke, Pal. New York, VIII, Pt. II, 1893, p. 103, figs. $80-100$ on pp. 106, 107 ; Thirteenth Anu. Rep. N. Y. State Geologist, 1895, p. 787.

Obs. It is very probable that all of the species here referred to Retzia will prove to belong to other genera.

Retzia altirostris White=Eumetria altirostris.

Retzia chloe Billings=Parazyga hirsuta.

Retzia (?) circularis Miller.

Choutean (I. Carb.).

Retzia circularis Miller, Eighteenth Ann. Rep. Geol. Survey Indiana, 1894, 1). 316, pl. 9, figs. 32-34.

Loe. Sedalia, Missouri.

Retzia compressa Meek= Hustedia mormoni.

Retzia dubia Billings =Trematospira dubia.

Retzia electra Billings = Rlıynchospira electra.

Retzia engenia Billings= Rhynchospira engenia.

Retzia evax Hall=Homœospira evax.

Retzia formosa Whitfield=Rhynchospira formosa.

Retzia (?) granulifera Meek.

Lorraine (Ord.).

Retzia (Trematospira) granulifera Meek, Proc. Acad. Nat. Sci. Philadelphia, 1872,

p. 318 ;-Pal. Ohio, I, 1873, p. 128, pl. 11, fig. 6.

Trematospira (?) granulifera Miller, Cincinnati Quart. Jour. Sci., II, 1875, p. 61.

Loc. Cincinnati, Ohio.

Obs. This species is probably a rhynchonelloid.

Retzia hippolyte Billings=Trematospira hippolyte.

Retzia (?) jamesiana Rathbun.

Middle Devonian.

Retzia jamesiana (Hartt) Rathbun, Bull. Buffalo Soc. Nat. Hist., I, 1874, p. 243, pl. 10, figs. 23, 27-38.

Retzia ? jamesiana Derby, Archives do Museu Nacional do Rio de Janeiro, IX, 1890, p. 79.

Retzia ef. jamesiana A. Ulrich, N. Jahrh. f. Mineral, Beilageband, VIII, 1892, p. 68 , pl. 4, fig. 14 .

Loc. Erere and Rio Maecuru, Province of Para, Brazil; Bolivia. 
Retzia mareyi Shumard=Eumetria marcyi.

Retzia meekana Shmmard=Hustedia meekana.

lietzia mormoni Mareou=Hustedia mormoni.

Retzra osagensis Swallow = Acambona osagensis.

Retzia papillata Shumard= Hustedia papillata.

Retzia (?) plicata Miller.

Choutean (L. Carh).).

Retzia plicata Miller, Eighteenth Anu. Kep. Geol. Survey Indiana, 1894, 1. 316, pl. 9, figs. 29-31.

Loc. Sellalia, Missouri.

Retzia polypleura $\mathrm{A}$. Wiuchell.

Portage (Dev.).

Retzia polypleura A. Winchell, Proc. Acad. Nat. Sci. F'hiladelphia, 1862, p. 406.

Loc. Port aux Barques, Michigan.

Retzia (?) popeana Swallow.

? Chonteau (L. Carb.).

Retzia (?) popeana Swallow, Trans. St. Louis Acad. Sci., I, 1860, p. 654.

Loc. Locality and formation not giveu.

Retzia punctulifera Shumard=Hustedia mormoni.

Retzia radialis Walcott (non Phillips)=Hustedia mormoni.

Retzia sexplicata White and Whitfield=Ptychospira sexplicata.

Retzia sobrina Beecher and Clarke=Homcospira sobriua.

Retzia (?) subglobosa Hall.

Schoharie (Der.).

Rhynchospira subglobosa Hall, Pal. New York, IV, 1867, p.421, p1.63, figs. 23-25.-

IIall and Clurke, Pal. New York, V1II, Pt. II, 1895, pl. 49, fig. 22.

Retzia subglobosa Milk.r, N. American Geol. and Pal., 1889, p. 367.

Loc. Schoharie, New York.

Retzia subglobosa McChesney=Hustedia mormoni.

Retziā triangularis Miller $=$ Hustedia triangularis.

Retzia vera Hall=Eumetria mareyi.

Retzicu vera costata $\Pi$ Iall=Eumetria mareyi costata.

Retzia verneuiliana Hall=Eumetria mareyi.

Retzia ? wardiana Rathbun=Trigeria wardiana.

Retzia woosteri White=Eumetria woosteri.

RHINOBOLUS Hall. Genot. Rhynobolus sp. H.= ?Oboıus galtensis Bill.

Rhynobolus Hall, Notes on some New or Imperfectly known Forms among the Brachiopolla, 1871, p. 5;-Ibidem, 1872, p. 5, pl. 13, fig. 10;-Twenty-thirl Rep. N. Y. State Cab. Nat. Hist., 1873, p. 247, pl. 13, fig. 10.-Waagen, Palreontologica Indica, Ser. XIII, I, 1885, p. 761.-Hall and Clarke, Pal. New York, VIII, Pt. I, 1892, pp. 44, 46, 161;-Eleventh Ann. Rep. N. Y. State Geologist, 1891, 1. 239.

Rhinobolus davidsoni Hall and Clarke.

Niagara (Sil.).

Rhinobolus davidsoni Ilall and Clarke, Pal. New York, VIlI, Pt. I, 1892, pp. 45,

176, 1l. 4 13, figs. 10-12.

Loc. Near Grafton, Wisconsin.

Rhinobolus galtensis (Billings).

Guelph (Sil.).

Obolus galtensis lilliugs, Pal. Fossils, I, 1862, p. 168, fig. 153.

Obolellina gaItensis Billings, Canadian Nat. Geol., VI, 1871; P. 222;-Ibidem, 1872 , p. :328.

Trimerella minor Iall, American Jonr. Conch., VII, 1871, p. 83, pl. 11, fig. 6 .

?Rhynobolus s1.? Hall, Twenty-third Rep. N. Y. State Cab. Nat. Hist., 1873, p. 247, pl. 13, fig. 10. 
Rhinobolus galtensis (Billings)-Continued.

Trimerella (?) galtensis Davidson and King, Quart. Jour. Geol. Soc. London, XXX, 1874, p. 151, pl. 18, fig. 13; pl. 19, fig. 4.

Rhynobolus galtensis Whiteaves, Pal. Fossils, III, 1884, p. 7, pl. 2, fig. 1; pl. 8, fig. 3.-Hall and Clarke, Pal. New York, VIII, Pt. I, 1892, p.45, pl.4B, figs. 7-9.

Loc. Galt, Elora, Hespelar, and Durham, Ontario.

RHIPIDOMELLA (Ehlert. Genotype Terebratula michelini L'Éveillé. Rhipidomys (Ehlert (non Wagnor, 1844), Fischer's Manuel de Conchyliologie, 1887, p. 1288.-Hall, Bull. Geol. Soc. America, I, 1889, p. 21.

Rhipidomella Eulert, Journal de Conchyliologie, 1891, p. 372.-Hall and Clarke, Pal. New York, VIII, Pt. I, 1892, p. 209 ;-Eleventh Ann. Rep. N. Y. State Geologist, 1894, p. 271.

Rhipidomella alsa Hall.

Scholiarie (Dev.).

Orthis alsus Hall, Sixteenth Rep. N. Y. State Cab. Nat. Hist., 1863, p. 33;-Pal.

New York, IV, 1867, p. 36, pl. 4, figs. 2-7.

Rhipidomella alsa Hall and Clarke, Pal. New York, VIII, Pt. I, 1892, p. 225.

Loc. Albany County, Now York.

Obs. Probably a synonym for R. peloris Hall.

Rhipidomella assimilis Hall.

Lower Helderberg (Dev.).

Orthis assimilis Hall, Pal. New York, III, 1859, p. 175, pl. 15, fig. 1.

Rhipidomella assimilis Hall and Clarke, Pal. New York, VIII, Pt. I, 1892, p. 224. Loc. Schoharie, New York.

Rhipidomella burlingtonensis Hall.

Burlington (L. Carb.).

Orthis michelini var. burlingtonensis Håll, Geol. Survey Lowa, I, P’t. II, 1858, p. 596 , pl. 12 , fig. 4 .

Rlipidomella burlingtonensis Hall and Clarke, Pal. New York, VIII, Pt. I, 1892, p. 225 , pl. 6 A, fig. 13 ; pl. 20 , figs. 5,6 .

Orthis burlingtonensis Keyes, Geol. Survey Missouri, V, 1895, p. 63, pl. 38, fig. 7. Loc. Burlington, Iowa; Quiney, Illinois; Hannibal, Missouri.

Rhipidomella circulus Hall.

Clinton (Sil.).

Orthis circulus Hall, Geol. N. Y. ; Rep. Fourth Dist., 1813, p. 71, fig. 1;-Pal. New York, II, 1852, p. 56, pl. 20, fig. 6.-13illings, Canadian Nat. Geol., I, 1856, p. 134, pl. 2, fig. 1 .

Rhipidomella circulus Hall and Clarke, Pal. New York, VIII, Pt. I, 1892, pp. 210, 224 , pl. 6A, figs. $1,2$.

Loc. Reynales Basin, New York; Hamilton, Ontario.

Rhipidomella clarkensis (Swallow).

Keokuk (L. Carb.).

Orthis clarkensis Swallow, Trans. St. Lonis Acad. Sci., II, 1863, 1. 81.

Rhipidomella clarkensis Hall and Clarke, l'al. New York, VIII, Pt. I, 1892, 1. 225.

Loc. Clark Connty, Missouri.

Obs. Keyes regards this species as a synonym for Schizophoria swallovi.

Rhipidomella cleobis Hall.

Onondaga (Dev.).

Orthis cleobis Hall, Sixteenth Rep. N. Y. State Cab. Nat. Hist., 1863, p. 35;-

Pal. New York, IV, 1867, p. 41, pl. 5, tigs. 9, 10.

Rhipidomella cleobis Hall and Clarke, Pal. New York, VIII, Pt. I, 1892, p. 225.

Loc. Williamsville and Clarence, New York.

Rhipidomella cumberlandiæ Hall.

Oriskany (Dev.).

Orthis cumberlandise Hall, PaI. New York, III, 1859, p. 481, pl. 95 A, figs. 20, 21.

Rhipidomella cumberlandia Hall and Clarke, Pal. New York, VIII, Pt. I, 1892, p. 225.

Loc. Cumberland, Maryland. 
Rhipidomella (?) cuneata (Owen).

Hamilton (Dev.). Orthis cmeata Owen, Geol. Survey Wisconsin, Iowa, and Minnesota, 1852, p. $585, \mathrm{pl} .3 \Lambda$, fig. 10.

Rhipidomella cuneata 1 Hall and Clarke, Pal. Now York, VIII, Pt. I, 1892, p. 225. Loe. New Buttalo, Iowa

Rhipidomella cyclas Hall.

Mareellus and Hamilton (Dev.). Orthis cyelas IIall, Thirteenth Rep. N. Y. State Cab. Nat. Hist., 1860, 1. 7x;Pal. New York, IV, 1867, p. 52, pl. 7, figs. 2, 3.

Rhipiłomella eyclas Hall and Clarke, Pal. New York, VIII, Pt. I, 1892, p. 225. Loc. York, I’avilion, Bellona, ote., New York.

Rhipidomella dalyana (Miller).

Burlington (I. Carb.). Orthis dalyana Miller, Jour. Cincinnati Soc. Nat. Hist., IV, 1881, p. 313, pl. 7, fig. 8. Rhipidoniella dalyana Hall and Clarke, Pal. New York, YrII, Pt. I, 1892, p. 225. loc. Lake Valley mining district, New Mexico.

Rhipidomella discus Hall.

Lower Helderberg (Dev.).

Orthis disens Hall, Pal. New York, III, 1859, p. 165, pl. 10A, figs. 7-12.

Rhipidomella disens Hall and Clarke, Ibidem, VIII, Pt. I, 1892, pp. 210, 225.

Loc. Hudson, Catskill, etc., New York; Square Lake, Maine.

Rhipidomella dubia Hall.

St. Lonis (L. Carb.).

Orthis dubins Hall, 'Trans. Albany Institute, IV, 1858, p. 12.-Whitfield, Bull.

American Mus. Nat. Hist., I, 1882, p. 45, pl. 6, figs. 1-5.-Hall, Twelfth Rep.

State Geol. Indiaua, 1883, p. 324, pl. 29, figs. 1-5.

Orthis cooperensis Swallow, Trans. St. Lonis Acad. Sci., II, 1863, p. 82.

Rhipidomella dubia IIall and Clarke, Pal. New York, VIII, Pt. I, 1892, p1. 210, 225 , pl. 6A, figs. 18-22.

Orthis dubia Keyes, Geol. Survey Missonri, Y, 1895, p. 64.

Loc. Spergen Hill and Bloomington, Indiana; Alton, Appanoose, etc., Illinois: Boonville and Barretts Station, Missonri ; Keokuk, Jown; Caldwell County, Kentucky.

Obs. Typical examples of R. cooperensis have been studied in Professor Hall's collection.

Rhipidomella eminens Hall.

Lower Helderberg (Dev.).

Orthis eminens Hall, Tenth Rep. N. Y. State Cab. Nat. Hist., 1857, p. 42 , figs. 1, 2;-Pal. New York, III, 1859, p. 167, pl. 11, figs. 7-14.

Rhipidomella eminens Hall and Clarke, Pal. New York, VIII, I’t. I, 1892, pp. $210,225$.

Loc. Schoharie, Carlisle, etc., New York.

Rhipidomella goodwini (Nettelroth).

Hamilton (Dev.).

Orthis goodwini Nettelroth, Kentucky Fossil shells, Mem. Kentucky Geol. Snrvey, 1889, 1. 39, pl. 17', figs. 30-32.

Loc. Falls of Ohio.

Rhipidomella hartti (Rathbun).

Middle Devonian.

Orthis hartti Rathbun, Proe. Boston Soc. Nat. Hist., XX, 1879, p. 23.

Loc. Provinee of Para, Brazil.

Rhipidomella hybrida (Sowerby).

Niagara (Sil.).

Orthis hybrida Sowerby, Murchison's Silurian System, 1839, p. 630, pl. 13, fig. 11.-HIall, Geol. N. Y.; Rep. Fourth Dist., 1813, p. 105, fig. 7;-Pal. New York, II, 1852, p. 253 , pl.52, fig. 4.-Roemer, Die Silurische Fauna des West. Tennessee, 1860 , 1. 63, pl. 5, fig. 6.-Meek and Worthen, Geol. Survey Illinois, 1868, p. 371, pl. 7, fig. 7.-Hall, Twenty-eighth Rep. N. Y. State Mus. Nat. Hist., 1879, p. 149, pl. 21, figs. 18-25;-Eleventh Rep. State Geol. Indiana, 1882, 1. 285, pl. 21, figs. 18-25;-Second Anu. Rep. N. Y. State Geol., 1883, pl.36, 
Rhipidomella hybrida (Sowerby)-Continued.

figs. 1-5.-Foerste, Bull. Denison Univ., I, 1885, p. 83, pl. 13, fig. 10.-Beec̉er and Clarke, Mem. N. Y. State Mus., I, 1889, p. 17, pl. 1, figs. 13-18.-Nettelroth, Kentucky Fossil Shells, Mem. Kentucky Geol. Survey, 1889, p. 39, pl. 32, figs. $32-35$.

Orthis hybrida? Hall, Trans. Albany Institute, IV, 1863, p. 209.

Rhipidomella hybrida Hall and Clarke, Pal. New York, VIII, Pt. I, 1892, pp. 210, 224 , pl. 6, figs. 1-5.

Orthis (Rhipidomella) hybrida Foerste, Geol. Ohio, VII, 1895, p. 584, pl. 25, fig. 10.

Loc. Europe; Lockport, ete., New York; Waldron, Indiana; Dayton, Ohio; Louisville, Kentucky; Perry County, Tennessee; Perry County, Missouri; Arisaig, Nova Scotia (Ami).

Rhipidomella idonea Hall.

Hamilton (Dev.).

Orthis idonea Hall, Pal. New York, IV, 1867, p. 52, pl. 63, figs. 1-5.

Rhipidomella idonea Hall and Clarke, Pal. New York, VIII, Pt. I, 1892, p. 225. Loc. Moscow and Eighteen Mile Creek, New York.

Rhipidomella inca (d'Orbigny).

Devonian. Orthis inca d'Orbigny, Voyage dans l'Amérique Méridionale, Pal., 1842, p. 38.

Spirifer inca d'Orbigny, Ibidem, 1842, pl. 2, figs. 10-12.

Loc. Cochabamba, Bolivia.

Rhipidomella leucosia Hall.

Hamilton (Dev.).

Orthis leucosia Hall, Thirteenth Rep. N. Y. State Cab. Nat. Hist., 1860, p. 80;Pal. New York, IV, 1867, pp. 48, 63, pl. 7, fig. 4; pl. 8, figs. 9, 10;-Second Ann. Rep. N. Y. State Geol., 1883, pl. 36, tig. 16.

Rhipidomella leucosia Hall and Clarke, Pal. New York, VIII, Pt. I, 1892, p. 225, pl. 6 , fig. $16 ;$ pl. $6 \Lambda$, fig. 9 .

Loc. Eighteen Mile Creek, Canandaigua Lake, ete., New York; Cumberland, Marylaud.

Rhipidomella livia (Billings).

Corniferous (Dev.).

Orthis livia Billings, Canadian Journal, u. ser., V, 1860, p. 267, figs. 14-16;Geol. Canada, 1863, p. 369, fig. 385.-Hall, Pal. New York, IV, 1867, p. 38, pl. 5, fig. 4.-Billings, Pal. Fossils, II, 1874, p. 32, figs. 14-16.-Nettelroth, Kentucky Fossil Shells, Mem. Kentucky Geol. Surrey, 1889, p. 40, pl. 16, figs. 23,$24 ;$ pl.17, figs. 33-35.

Rhipidonella livia Hall and Clarke, Pal. New York, VIII, Pt. I, 1892, p. 225.

Loc. Walpole, Ontario; New York; Columbus, Ohio; Falls of Ohio; Indian Cove, Gaspé.

Rhipidomella lucia (Billings).

Oriskany (Dev.).

Orthis lucia Billings, Pal. Fossils, II, 1874, p. 35, pl. 3, fig. 4.

Rhipidomella lucia Hall and Clarke, Pal. New York, VIII, Pt. I, 1892, 1. 225.

Loc. Indian Core, Gaspé.

Rhipidomella media (Shaler).

Anticosti (Sil.).

Orthis media Shaler, Bull. Mus. Comp. Zool., 4, 1865, p. 65.-Billings, Catalogue Silurian Fossils of Anticosti, 1866, p. 41.

Loc. Anticosti.

Rhipidomella michelini (L'Eveillé).

Waverly (L. Carb.).

Terebratula michelini L'Éveillé, Mém. Société Géol. de France, II, 1835, p. 39, pl. 2, figs. 14-17.

Orthis michelini Yandell and Shumard, Cont. Geol. Kentucky, 1817, p. 21.A. Winchell, Proc. Acad. Nat. Sci. Philadelphia, 1865, p. 116.

Orthis michelini? A. Winchell, Proc. American Philosophical Soc., XII, 1870, p. 251.-Hall, Second Ann. Rep. N. Y. State Geol., 1883, pl. 36, figs. 19-21. 
Rhipidomella michelini (L'Éveillé)—Continued.

Rhipiclomella michelini IIall and Clarke, Pal. Now York, VIII, Pt. I, 1892, pp. 19.1, 225, pl. 61 , fig. 12.

Loc. South of Louisville, and near Lebanon, Kentucky; Newark, Granville, etc., Ohio; Shafers, Pennsylvania; Lake Valley mining district, New Mexico.

Obs. It is probable that the American identitications of this species are the same as R. oweni Hall and Clarke.

Rhipidomella missouriensis (Swallow).

Chouteau (L. Carb.).

Orthis missouriensis Swallow (non Shumard, 1855), Trans. St. Lonis Acad. Sci., I, 1860, 1. 639 .

Rhipidomella missouriensis Hall and Clarke, Pal. New York, VIII, Pt. I, 1892, p. 225 , pl. $6 \mathrm{~A}$, figs. 16,17 .

Loc. Cooper and Marion counties, $M^{\prime \prime}$ issouri.

Rhipidomella (?) mitis (Hall).

Schoharie (Dev.).

Orthis mitis Hall, Sixteenth Rep. N. Y. State Cab. Nat. Hist., 1863, p. 34;-Pal.

New York, IV, 1867, p. 37.

Loc. Albany and Schoharie counties, New York.

Rhipidomella musculosa Hall.

Oriskany (Dev.).

Orthis musculosa Hall, Teuth Rep. N. Y. State Cab. Nat. Hist., 1857, p. 46 ;-Pal.

New York, III, 1859, p. 409, pl. 91, figs. 1-3; 11. 95, figs. 1-7.

Rhipidoinclla musculosa Hall and Clarke, Pal. New York, VIII, Pt. I, 1892, pp. $190,210,225, \mathrm{pl} .6 \mathrm{~A}$, fig. 5 .

Loc. Scholırie and Albany counties, New York; Cumberland, Maryland.

Rhipidomella nevadaensis (Meek).

Carboniferous.

Orthis michelini (non L’Éveillé) var. Mleek, king’s U. S. Geol. Expl. 40th Parl., IV, 1877 , p. 63, pl. 7, fig. 1.

Orthis nevadensis Meek, Ibidem, 1877; end of description.

Rhipidomella nevadensis Hall and Clarke, Pal. New York, VIII, Pt. I, 18:2, p. 225 .

Loc. White Pine district, Nevada.

Rhipidomella oblata Hall.

Lower Helderberg (Dev.).

Orthis oblata Hall, Tenth Rep. N. Y. State Cab. Nat. Hist., 1857, p. 41, figs. 1-5;-Pal. New York, III, 1859, p. 162, pl.10, figs. 1-22.-Whitfield, Geol. Wisconsin, IV, 1882, 1. 320, jl. 25, figs. 1, 2.

Rhipidomella ohlata Hall and Clarke, Pal. New York, VIII, Pt. I, 1892, pp. 210, 225 , pl. 6A, figs. 3,4 .

Loc. Schoharie, Carlisle, Hudson, ete., New York; Waunakee, Wisconsin.

Rhipidomella oblata emarginata (Hall).

Lower Helderberg (Dev.). Orthis oblata var. emarginata Hall, Pal. New York, III, 1859, p. 164, pl. 10A, figs, 4-6.

Loc. Cumberland, Maryland.

Rhipidomella occasus Hall.

Kinderhook (L. Carb.).

Orthis occasus Hall, Thirteenth Rep. N. Y. State Cab. Nat. Hist., 1860, p. 111.

Rhipilomella occasus Hall and Clarke, Pal. New York, VIII, Pt. I, 1892, p. 225.

Loc. Rock ford, Indiana.

Obs. Compare with R. thiemei White.

Rhipidomella oweni Hall and Clarke.

Waverly (L. Carb.). Orthis (Rhipidumella) oweni Hall and Clarke, Pal. New York, VIII, Pt. I, 1892, p. 342, pl. 6, figs. 19-21.

Loc. Buttonmon]d Knobs, south of Lonisville, Kentucky.

Obs. See R. michelini L'Eveillé. 
Rhipidomella pecosi (Marcou).

Upper Carboniferous.

Orthis pecosi Marcon, Geol. N. America, Febrnary 1858, p. 48, pl. 6, fig. 14.White, Wheeler's Expl. Survey west 100th Meridian, IV, 1875, p. 125, pl. 9 , fig. 5.-Kayser, Richthofen's China, IV, 1883, p. 177, pl. 24, fig. 1.-Waagen, Palieontologica Indica, Ser. XIII, I, 1884, p. 573, pl. 56, figs. 1-3.-White, Thirteenth Rep. State Geol. Indiana, 1884, p. 129, pl. 32, figs. 20-22.-Keyes, Geol. Survey Missouri, V, 1895, p. 64.-Smith, Proc. American Phil. Soc., XXXV, 1897, p. 27 (extract).

Orthis carbonaria Swallow, Trans. St. Lonis Acad. Sci., I, June, 1858, p. 218.Meek, Final Rep. U. S. Geol. Survey Nebraska, 1872, p. 173, pl. 1, fig. 8.Meek and Worthen, Geol. Survey Illinois, T, 1873, p. 571, pl. 25, fig. 4.-Hall, Second Ann. Rep. N. Y. State Geol., 1883, pl. 37, figs. 1-1.

Orthis sl. undet. Meek, Pal. California, I, 1861, 1. 10, pl. 2, fig. 5.

Rhipidomella pecosi Hall and Clarke, Pal. New York, VIII, Pt. I, 1892, pp. 210, 226 , pl. 7 , figs. 1-4.

Loc. Throughout the Upper Carboniferons of North America; Lo-Ping, China; Amb, India.

Rhipidomella peloris Hall.

Schoharie (Dev.).

Orthis peloris Hall, Sixteenth Rep. N. Y. State Cab. Nat. Hist., 1863, p. 32 ; Pal. New York, IV, 1867, p. 34, pl. 4, figs. 1, 8-10.

Rhipidomella peloris Hall and Clarke, Pal. Now York, VIII, Pt. I, 1892, p. 225, pl. 6 A, fig. 6 .

Loc. Clarksville and knox, New York.

Obs. Probably the same as R. alsa Hall.

Rhipidomella penelope Hall.

Hamilton (Dev.).

Orth is penelope Iall, Thirteenth Rep. N. Y. State Cab. Nat. Hist., 1860, p. 79, figs. 1, 2;-Pal. New York, IV, 1867, p. 50, pl. 6, fig. 2;-Second Ann. Rep. N. Y. State Geol., 1883, pl. 36, figs. 6-13.

Rhipidomella penelope Hall and Clarke, Pal. New York, VIII, Pt. I, 1892, pp. 211, 225, pl. 6, figs. 6-13; pl. 6A, fig. 10 (?11).

Loc. Hamburg, Alexander, Pavilion, York, Moseow, etc., New York.

Rhipidomella penniana (Derby).

Upper Carboniferous.

Orthis penniana Derby, Bull. Cornell Univ., I, 1874, p. 26, pl. 5, figs. 13, 15, 17, $19-22$; pl. 8 , fig. 2.

Rhipidomella penniana Hall and Clarke, Pal. New York, VIII, Pt. I, 1892, pp. 210,225, pl. 7 , figs. $5-10$.

Loc. Bomjardim and Itaituba, Brazil.

Rhipidomella pennsylvanica (Simpson). Chemung (Dev.).

Orthis peunsylvanica Simpson, Trans. Anerican Philosophical Soc., n. ser., XVI, 1889, p. 437, fig. 1 .

Loc. Tioga and MeKean counties, Pennsylvania.

Rhipidomella rhynchonelliformis (Shaler).

Anticosti (Sil.).

Orthis rhynchonelliformis Shaler, Bull. Mus. Comp. Zool., 4, 1865, p. 66.-Billings, Catalogue Sil. Foss. Anticosti, 1866, p. 42.

Loe. Anticosti.

Obs. Probably a variety of Rhipidomella uberis (Billings).

Rhipidomella semele Hall.

Onoudaga (Dev.).

Orthis semele Hall, Sixteenth Rep. N. Y. State Cab. Nat. Hist., 1863, p. 34;-Pal.

New York, IV, 1867, p. 40, pl. 5, figs. $7,8$.

Rhipidomella semele Hall and Clarke, Pal. New York, VIII, Pt. I, 1892, p. 225.

Loc. Erie County, New York; Columbus, Ohio. 
Rhipidomella solitaria Hall.

Hamilton (Dev.).

Orthis solitaria Hall, Thirteenth Rep. New York State Cab. Nat. Hist., 1860, 1). 80 ;-Pal. New York, IV, 1867, p. 45, pl. 7, fig. 1.

Rhipillomella solitaria Hall and Clarke, Pal. New York, VIII, Pt. I, 1892, p. 225. Loc. York, New York.

Rhipidomella subcirculus (Simpson).

Clinton (Sil.).

Orthis subcircula Simpson, 'Trans. American Philosophical Soc., u. ser., XVI, 1889, l. 437 , fig. 2.

Loc. Miflin and Huntington counties, Pennsylvania.

Rhipidomella subelliptica (White and Whitfield). Kinderhook (I. Carb.). (rothis subelliptica White and Whitfield, Proc. Boston Soc. Nat. Hist., VIII, 1862, p. 292 .

Rhipidomella subelliptica Hall and Clarke, Pal. New York, VIII, Pt. I, 1892, p. 225.

Loc. Burlington, Iowa.

Rhipidomella suborbicularis Hall.

Hamilton (Dev.).

Orthis suborbicularis Hall, Geol. Survey Iowa, I, Pt. II, 1858, p. 486, pl. 2, fig. 1.

Rhipidomella suborbicularis Hall and Clarke, Pal. New York, VIII, I’t. I, 1892, p. 225.

Loc. Rock Island, Illinois.

Rhipidomella thiemei (White). Chemung (Dev.) and Kinderhook (L. (arb.).

Orthis thiemii, White, Jour. Boston Soc. Nat. Hist., VII, 1860, p. 231 ;---Twelfth Rep. Hayden's U. S. Geol. Survey Terr., 1883, p. 164, pl. 41, fig. 4.

Orthis thiemii? Hall, Pal. Now York, IV, 1867, p. 63, pl. 8, fig. 2.

Rhipidomella thiemii Hall and Clarke, Pal. New York, VIII, Pt. I, 1892, p. 225, pl. $6 \mathrm{~A}$, figs. 14,15 .

Loc. Burlington, Iowa ; In the Chemung group at Leon, Napoli, aud New Albion, New York.

Rhipidomella tubulistriata Hall.

Lower Helderberg (Dev.).

Orthis tubulostriata Hall, Tenth Rep. N. Y. State Cab. Nat. Hist., 1857, p. 42 ;Pal. New York, III, 1859, p. 166, pl. 11, figs. 1-6.

Rhipidomella tubulostriata Hall and Clarke, Pal. New York, VIII, Pt. I, 1892, p1. 210, 225.

Loc. Albany County, New York.

Rhipidomella uberis (Billings).

Anticosti (Sil.).

Orthis tequivalvis Shaler (non Hall, 1847), Bull. Mus. Comp. Zool., 4, 1865, p. 66.

Orthis uberis Billings, Catalogue Sil. Foss. Anticosti, 1866, p. 42.

Rhipidomella uberis Hall and Clarke, Pal. New York, VIII, Pt. I, 189:, p. 224.

Loc. Anticosti.

Obs. See Rhipidomella rhynchonelliformis (Shaler).

Rhipidomella vanuxemi Hall.

Corniferous-Hamilton (Dev.).

Orthis vannxemi Hall, Tenth Rep. N. Y. State Cab. Nat. Hist., 1857, p. 135, figs. 1-7;-Cieol. Survey Iowa, I, Pt. II, 1858, p. 487, pl. 2, tigs. 2, 3.-Billings, Canarlian Jour., V, 1860, 1. 269.-A. Winchell, Proc. Acad. Nat. Sci. Philadelphia, 1862, p. 409.-Billings, Geol. Canada, 1863, p. 384, fig. 417.-Hall, Pal. New Xork, IV, 1867, pl). 40, 47, pl. 5, fig. 6; pl. 6, fig. 3;-Second Ann. Rep. N. Y. State Geol., 1883, pl. 36, tigs. 14, 15.-Nettelroth, Kentucky Fossil Shells, Mem. Kentucky Geol. Survey, 1889, p. 45, pl. 16, figs. 4-6, 12-14.Ilerrick, Geol. Ohio, VII, 1895, pl. 20, fig. 10. 
Rhipidomella vanuxemi Hall-Continued.

Rhipidomella rannxomi Hall and Clarke, Pal. New York, VIII, Pt. I, 1892, p. 225 , pl. 6, figs. 14, 15 ; pl. 6A, figs. 7,8 .

Loc. New York; Columbus, Ohio; Falls of Ohio ; Rock Island, Illinois; Bnffalo, Iowa; Bosanquet, Ontario; Huron group, Port anx Barques, Michigan.

Rhipidomella vanuxemi pulchella (Herrick.)

Waverly (L. Carb.).

Orthis vanuxemi var. pulchella Herrick, Bull. Denison Univ., III, 1888, p. 38, pl. 5, fig. 9.

Orthis vanuxemi var. graeilis Herrick, Geol, Ohio, VII, 1895, pl. 21, fig. 9.

Loc. Granville, Ohio.

RHYNCHONELLA Fischer de Waldheim. Genotype R. loxia Fischer de Waldheim.

Rhynchonella Fischer de Waldheim, Notice des Fos. Gouv. Moscou, 1809, p. 35, tab. II, figs. 5, 6.-Hall, Thirteenth Rep. N. Y. State Cab. Nat. Hist., 1860, p. 65.-Meek and Hayden, Pal. Upper Missonri, Smitbsonian Cont. to Knowl., XIV, 172, 1861, p. 70.-Hall, Pal. New York, IV, 1867, p. 332;Twentieth Rep. N. Y. State Cab. Nat. Hist., 1867, p. 269.-Dall, American Jour. Conch., VI, 1870, p. 151 ;-Ibidem, VII, 1871, 1). 70.-Billings, Pal. Fossils, II, 1874, 1. 35.-Nettelroth, Kentucky Fossil Shells, Mem. Kentucky Geol. Survey, 1889, 1). 72.-Hall and Clarke, Pal. New York, VIII, Pt. II, 1893, pp. 177, 178;-Thirteenth Aun. Rep. N. Y. State Geologist, 1895, p. 822.

Rhynchonella ænigma (d'Orbigny).

Jurassic.

Terebratula i’ny gma d’Orliguy, Voyage clans l'Amérique Méridionale, Pal., 1842, p. 62, jl. 22, figs. 10-13.

Terebratula concinna (non Sowerhy) Bayle and Coquand, Mém. Soc. Géol. France, ser. ii, IV, 1851, p. 23, pl. 8, figs. 4-6.

Rhynchonella ienigma Gottsche, Palieontographica, Suppl., III, 1878, p. 34.

Rhynchonella cfr. xuignta Steinman. Nenes Jahrb. f. Min., Beilageband, 1881, p. 253.

Loc. Guasco, Coquimbo, Dona Ana, Chile; Copiapo, Caracoles, and Iquique, Peru.

Rhynchonella æquiplicata Gabb.

Triassic.

Rhynchonella requiplicata Gabb, Geol. Survey California, Pal., I, 1864, 1). 35, pl. 6, fig. 37 .

Loc. Cinnabar district, Humboldt Mountain, Nevada.

Rhynchonella æquiradiata Miller=Camarotœehia xquiradiata.

Rhynchonella requivalvis Hall=Lissopleura aequivalvis.

Rhynchonella abrupta Hall=Uncinulus abruptus.

Rhynchonella acadiaensis Davidson.

Upper Carboniferous.

Rhynchonella acadiensis Davidson, Qnart. Jour. Geol. Soc. London, XIX, 1863, p. 172, pl. 9, fig. 16.-Dawson, Acadian Geol., 3d ed., 1878, p. 294, fig. 94.

Loc. Brookfield, Nova Scotia.

Rhynchonella acinus IIall=Camarotochia acinns.

Rhynchonella acinus convexa Foerste = Camarotœchia acinus convexa.

Rhynchonella acutiplicata Hall.

Lower Helderberg (Dev.).

Rhynchonella acntiplicata Hall, Tenth Rep. N. Y. State Cab. Nat. Hist., 1857, p. 73, fig. 7 ;-Pal. New York, III, 1859, p. 232, pl. 33, fig. 3.

Loc. Schoharie, New York.

Bull. 87 23 
Rhynchonella (?) acutirostris Hall.

Chazy (Ord.).

Atrypa acutirostra IIall, l'al. Now York, I, 18+7, p. 21, pl.4 bis, fig. 6.

Rhynchonellil acutirostris Hall, Twelfth Rep. N. Y. State Cal. Nat. Hist., 1859, 1). 65.

Loc. Chazy, Now York.

Ols. This spocies is referred to Zygospira by Whitfield.

Rhynchonella ainsliei Winchell=Rhynchotrema ainsliei.

Rhynchonella algeri McChesney.

Upper Carboniferons.

Rhynchonella algeri McChesney, New l’al. Fossils, 1860, p. 51.

Loc. Near New Harmony, Indiana.

Rhynchonella allegania Williams.

Chemung (Dev.).

Rhychonella allegauia Williams, Bull. U. S. Geol. Survey, 41, 1887, p. 87, pl. 4, figs. 1-8.

Loc. Olean and Little Genesee, New York; Bradford, Pennsylvania.

Rhynchonclla alta Calvin = Pugnax pugnus aita.

Rhynchonella altilis Hall=Camarotechia plena.

Rhynchonella altiplicata Hall.

Lower Helderberg (Dev.).

Rhynchonella altiplicata Hall, Tenth Rep. N: Y. State Cab. Nat. Hist., 1857, p. 72, figs. 1-4;-Pal. New York, III, 1859, p. 231, pl. 33, fig. 2.

Loc. Albany and Schoharie comnties, New York.

Rhynchonella alventa Hall=Centronella alveata.

Rhynchonella ambigua Calvin.

Middle Devonian.

Rhynchonella ambigua Calvin, Bull. U. S. Geol. and Geogr. Survey Terr., IV, 1878 , p. 729.

Loc. Independence, Iowa.

Rhynchonella anduin Gottsche.

Jurassic.

Terebratula inigma (non d'Orb.) Darwin, Geol. Observations Sonth America, 1846, pl. 215, 233, pl. 5, figs. 10-12.-Burmeister and Giebel, Abh. Naturf. Gessel. Halle, VI, 1862, p. 128.

Terebratula subtetrieda (non Davidson) Conrad, U. S. Astronomical Exped. Sonthern IIemisphere, 1855, p. 282, pl. 42, tig. 8.

Rhynchonella anduin Gottsche, Palæontographica, Suppl., III, 1878, p. 34, pl. 4, figs. 4-7.

Loc. Iquique, Porteznelo de Hanflas, and Cordillera de Doma Ana, Chile.

Rhynchonella angulata Geinitz (non Linné)=Enteletes hemiplicatus.

Rhynchonella (?) anticostiensis Billings.

Lorraine (Ord.).

Rhynchonella anticostiensis Billings, Pal. Fossils, I, 1862, p. 142, tig. 119;Geol. Canada, 1863, p. 211, fig. 212.

Rhynchonella (?) anticostiensis Winchell and Schuchert, Minnesota Geol. Surver, III, 1893, p. 464, fig. 34 .

Rhyuchonella anticostiensis var. Whiteaves, Pal. Foss., III, Pt. III, 1897, p. 179.

Loc. Anticosti; Wilmington and Savanua, Illinois; Lattners, Iowa; Wisconsin ; Manitoba.

Obs. Compare with R. argenturbica Wlite.

Rhynchonella (?) antisiensis (d'Orbigny).

Lower Devonian.

Terebratula antisiensis d'Orbigny, Voyage dans l'Amérinne Mréridionale, Pal., 1812, p. 36, pl. 2, figs. 26-28.

? Rhynchonella ef, antisiensis A. Ulrich, N. Jahrb. f. Mineral., Beilageband, VIII, 1892, p. 57, pl. 4, figs. 1-7.

Loc. Cochabamba, Tarabueo, Bolivia. 
Rhynchonella antonii Gabb.

? Cretaceous. Rhynchonella antonii Gabb, Jour. Acad. Nat. Sci. Philadelphia, 2d ser., IV, 1881, p. 299 , pl. 42 , fig. 10.

Loc. Cerro de San Antonio, and near Chota, Peru.

Rhynchonella arctirostrata Swallow.

St. Louis (L. Carb.). Rhynchonella arctirostrata Swallow, Trans. St. Louis Acad. Sci., II, 1863, p. 84. Loc. Cooper County, Missouri.

Obs. Regarded by Keyes as a synonym for R. subcuneata=Camarophoria subcuneata.

Rhynchonella (?) argentea Billings.

Anticosti (Sil.).

Rhynchonella ? argentea Billings, Catalogue Silurian Fossils Anticosti, 1866, p. 43.

Loc. Anticosti.

Rhynchonella argenturbica White=-Rhynchotreta inæequivalvis.

Rhynchonella aspasia Billings.

Lower Helderberg (Dev.).

Rhynchonella aspasia Billings, Proc. Portland Soc. Nat. Hist., I, 1863, p. 111, pl. 3 , fig. 6.

Loc. Square Lake, Maine.

Rhynchonella barquensis A. Winchell.

Marshall (L. Carb.).

Rhynchonella barquensis A. Winchell, Proc. Acad. Nat. Sci. Philadelphia, 1862, p. 408.

Loc. Port aux Barques, Michigan.

Rhynchonella barrandi Hall=Camarotøechia barrandei.

Rhynchonella (?) belliformis Nettelroth.

Niagara (Sil.).

Rhynchonella bellaforma Nettelroth, Kentucky Fossil Shells, Mem. Kentucky Geol. Survey, 1889, p. 73.

Loc. Louisville, Kentucky.

Rhynchonella belemnitica Quenstedt.

Jurassic.

Rhynchonella belemnitica (Qnenst.) Moricke, N. Jahrb. f. Mineral., Beilageband, IX, 1894, p. 61.

For locality and observations see R. plicatissima.

Rhynchonella bialveata Hall.

Lower Helderberg (Dev.).

Rhynchonella ? bialveata Hall, Tenth Rep. N. Y. State Cab. Nat. Hist., 1857, 1. 73 ;-Pal. New York, III, 1859, p. 233, pl. 34, figs. 1-4.

Loc. Albany County, New York; Square Lake, Maine.

Rhynchonella (?) bidens Hall.

Clinton (Sil.).

Atrypa bidens Hall, Pal. New York, II, 1852, p. 69, pl. 23, fig. 3.

Rhynchonella bidens Hall, 'Twelfth Rep. N. Y. State Cab. Nat. Hist., 1859, p. 77.

Loc. Lockport, New York.

Rhynchonella (?) bidentata (Hisinger).

Niagara (Sil.).

Terebratula bidentata Hisinger, Kongl. Svenska Vet.-Akad. Handl., för 1825, 1826 , p. 343 , pl. 7 , fig. 5 .

Atrypa bidentata Hall, Pal. New York, II, 1852, p. 276, pl. 57, fig. 3.

Rhynchonella bidentata Hall, 'Twelfth Rep. N. Y. State Cab. Nat. Hist, 1859, p. 77.

Loc. Lockport, New York.

Rhynchonella billingsi Hall=Camarotochia billingsi.

Rhynchonella booensis Shumard=Leiorhynchus boonense.

Rhynchonella brevirostris Blliugs=Anastrophia brevirostris. 
Rhynchonella camerifera $\mathrm{A}$. Winchell.

Marshall (L. Carb.).

Rhynchonella camerifera $\Lambda$. Winchell, Proc. Acad. Nat. Sci. Philadelphia, 1862, P. 408.

Loc. Port anx Barques, Michigan.

Rhynchonella campbellana Hall=Uncinulns campbellanus.

Rhynchonella camura IIall=Trematospira camura.

Rhynchonella capax Hall=Rhynchotrema capax.

Rhynchonella caput-testudinis White=Camarophoria caput-testudinis.

Rhynchonella caracolensis Gottsche.

Jurassic.

Rhynchonella caracolensis Cottsche, Palientographica, sippl., III, 1878, 1. 44, pl. 4, fig. 8.-Steinm in, Nenes Jahrb. f. Mineral., Beilageband, 1881, 1. 253.Möricke, Ibidem, Beiligeband, IX, 1894, 1. 61.

Loc. Iquique, Chile; Caracoles, Bolivia.

Rhynchonella carbonaria MeChesney.

Upper Carboniferous.

Rhynchonella carbonaria McChesney, New Pal. Fossils, 1860, p. 51.

Loc. Near Farmington, Illinois.

Rhynchonella carica Hall=Camarotechia carica.

Rhynchonella carolina Hall=Camarotechia carolina.

Rhynchonella eastanea Meek $=$ Hypothyris castanea.

Rhynchonella congregata Hall=Canarotochia congregata.

Rhynchonella contracta Hall=Camarotechia contracta.

Rhynchonella contractir vai". saxatilis Hall=Camarotechia contracta saxatilis.

Rhynchonella colletti Miller.

Niagara (Sil.).

Rhynchonella colletti Niller, Eighteenth Ann. Rep. Geol. Survey Indiana, 1894, p. 311, pl. 9, figs. 8,9 .

Loc. Wabash, Indiana.

Rhynchonella cooperensis Shumard.

Kinderhook (L. Carb.).

Rhynchonella cooperensis Shumard, Gool. Rep. Missouri, 1855, p. 204, pl. C, fig. 4.

?Camarophoria cooperensis Walcott, Mon. U. S. Geol. Survey, VIII, 1884, p. 224, pl. 18 , fig. 6.

Loc. Cooper County, Missouri: Eureka district, Nevada.

Rhynchonella (?) corinthia Billings.

Rhynchonella corinthia Billings, Pal. Fossils, I, 1865, p. 220.

Loc. 'Table Head, Newfoundland.

Rhynchonella cuneata Billings, and Hall= Rhynchotreta cuneata americana.

Rhynchonella dawsoniana Davidson=Pugnax dawsoniana.

Rhynchonella (?) decemplicata Sowerby.

Clinton (Sil.).

Rhynchonella decemplicata Foerste, Proc. Boston Soc. Nat. Hist., XXIV, 1890, p. 320 , pl. 6, figs. 23,24 .

Loc. England; Cumberland Gap, Tennessee.

Rilynchonella dentata Fall=Rliynchotrema dentatum.

Rhynchonella dotis Hall=Camarotechia dotis.

Rhynchonella dryope Billings.

Oriskany (Dev.).

Rhyuchouella drfope Billings, Pal. Fossils, II, 1874, p. 37, pl. 3A, fig. 1.

Loc. Grand Greve, Gaspé. 
Rhynchonella dubia Hall=Protorhyncha dubia.

Rhynchonella duplicata Hall=Camarotechia duplicata.

Rhynchonella eatonirformis MeChesney=Pugnax rockymontana.

Rhynchonella emacerata Hall.

Clinton (Sil.).

Atrypa emacerata Hall, Pal. New York, II, 1852, p. 71, pl. 23, fig. 6.-Dawson, Acadian Geology, 3d ed., 1878, 1) 599.

Rhyuchonella emacerata Hall, 'Twelfth Rep. N. Y. State Cab. Nat. Hist., 1859, i). 77.

Loc. Sodus and Rochester, Now York; Arisaig, Nova Scotia.

Rhynchonella eminens Hall.

Lower Helderberg (Dev.).

Rhynchonella eminens Hall, Tenth Rep. N. Y. State Cab. Nat. Hist., 1857, p. 78;-Pal. New York, III, 1859, p. 237, pl. 37, figs. 3, 4.

Loc. Albany County, New York.

Rhynchonella emmonsi Hall and Whitfield = Hypothyris emmonsi.

Rhynchonella endlichi Meek = Camarotochia endlichi.

Rhynchonella ererensis Rathbun.

Middle Devonian.

Rhynchonella ererensis Rathbun, Proc. Boston Soc. Nat. Hist., XX, 1879, p. 32.

Loc. Erere, Province of Para, Brazil.

Rhynchonella eurekaensis Walcott.

Lower Carboniferous.

Rhynchonella eurekensis Walcott, Mon. U. S. Geol. Survey, VIII, 1884, p. 223, pl. 18 , fig. 8 .

Loc. Euroka district, Novada.

Rhynchonella (?) eva Billings.

Anticosti (Sil.).

Rhynchonella eva Billings, Catalogue Sil. Foss. Anticosti, 1866, p. 44.

Loc. Anticosti.

Rhynchonella evangelina Hartt.

Upper Carbouiferous.

Rhynchonella evangelina Hartt, Dawson's Acadian Geology, 3d ed., 1878, p. 299.

Loc. Windsor, Nova Scotia.

Obs. Compare with Pugnax pugnus as identified by Davidson, from the same locality.

Rhynchonella excellens Billings.

Oriskany (Dev.).

Rhyuchonella excellens Billings, Pal. Fossils, II, 1874, p. 36, figs. $17,18$.

Loc. Indian Cove, Gaspé.

Rhynchonella eximia Hall=Camarotœchia eximia.

Rhynchonella explanata McChesney=Camarophoria explanata.

Rhynchonella fitchana Hall.

Oriskany (Dev.).

Rhynchonella fitchana Hall, Tenth Rep. N. Y. State Cab. Nat. Hist., 1857, 1. 85;Pal. New York, III, 1859, p. 441, pl. 103, fig. 1.

Loc. Carlisle, New York.

Rhynchonella formosa Hall=Rhynchotrema formosum.

Rhynchonella fringilla Billings=Cumarotochia fringilla.

Rhynchonella gainesi Nettelroth.

Hamilton (Dev.).

Rhynchonella gainesi Nettelroth, Kentucky Fossil Shells, Mem. Kentucky Geological Survey, 1889, p. 76, pl. 31, figs. 6-9.

Loc. Jefferson County, Kentucky.

Rhynchonella glacialis Billings=Camarotœehia glacialis

Rhynchouella glansfagea Hall=Centronella glansfagea. 
Rhynchonella gnathophora Meek.

Jurassic.

Rhynchouella gnathophora Meok, Geol. Survey California, Pal., I, 1864, p. 39, pl.

8, tig. 1.

Rhyuchonella gnathophora? IIall and Whitfield, King's U. S. Geol. Expl, 40th 1'⿺ri., IY, 1877, p. 284, pl. 7, fig. 6.

Loc. l'lumas County, California; Tinta Range, Utah.

Rhynchonella greenana Ulrich=Leiorhynchus greeneanum.

Rhynchonella guadalupæ Shumard.

Upper Carbonifcrous.

Rhynelıonella guadalupe Shumard, Trans. St. Lonis Aead. Sci., I, 1858, p. 295, pl. 11, fig. 6 .

Loc. Guadalupe Mountains, New Mexico and Texas.

Rhynchonella halli Gabb.

Triassic.

Rhyuchouella halli Gabb, Jour. Acad. Nat. Sci. Philadelphia, 2d ser., IV, 1860, 1. 308 , pl. 48, fig. 29.

Loc. Bath County, Virginia.

Rhynchonella heteropsis A. Winchell.

Kinderhook (L. Carb.).

Rhynchonella heteropsis A. Winchell, Proc. Acad. Nat. Sci. Philadelphia, 1865, p. 121.

Loc. Burlington, Iowa; Hamburg, Illinois; Medina County, Ohio.

Rhynchonella horsfordi Hall=Camarotœechia horsfordi.

Rhynchonella hubbardi A. Winchell. Marshall (L. Carb.).

Rhynchonella hubbardi A. Winchell, Proc. Acad. Nat. Sci. Philadelphia, 1862, p. 407 ;-Ibidem, 1865, p. 122.

Loc. Marshall and Port aux Barques, Michigan; Summit County, Ohio.

Rhynchonella huronensis A. Winchell.

Huron (Dev.).

Rhynchonella huronensis A. Winchell, Proc. Acar. Nat. Sci. Philadelphia, 1862, p. 409.

Loc. Port aux Barques, Michigan.

Rhynchonella huronensis precipua $\mathrm{A}$. Winchell.

Huron (Dev.).

Rhynchonella huronensis var. precipua A. Winchell, Proc. Acad. Nat. Sci. Philadelphia, 1862, p. 409.

Loc. Port aux Barques, Michigan.

Rhynchonella (?) hydraulica Whitfield.

Waterlime (Sil.).

Rhynchonella hydranlica Whitfield, Aunals N. Y. Acad. Sci., II, 1882, 1. 194;-

Ibidem, T, 1891, p. 512, pl.5, fig. 17 ;-Geol. Ohio, V'II, 1895, p. 414, pl. 1, fig. 17.

Loc. Greenfield, Ohio.

Rhynchonella ida Hartt.

Upper Carboniferous.

Rhynchonella ida Hartt, Dawson's Acadian Geology, 3i ed., 1878, p. 298.

Loc. Windsor, Nova Seotia.

Rhynchonella iilinoisensis Worthen.

Upper Carboniferous.

Rhynchonella illinoisense Worthen, Bull. Illinois State Mus. Nat. Hist., 2, 1884, p. 24 ;-Geol. Survey Illinois, VIII, 1890, 1, 104, pl. 11, fig. 3.

Loc. Peoria, Illinois.

Rhynchonella increbesceus Hall, 1860 (non 1847)= Rhynchotrema capax. Rhynchonella increbescens Hall=Phynchotrema in requivalve.

Rhynchonella indentata Shumard.

Upper Carboniferous.

Rhynchonella indentata Shmmard, Trans. St. Lonis Acad. Sci., I, 1859, p. 393.

Loc. Guadalupe Mountains, New Mexico.

Rhynehonella indianensis Hall=Camarotœelia indianaensis. 
Rhynchonella inæquiplicata Hall.

Upper Hellerberg (Dev.). Rhynchonella inequiplicata Hall, Tenth Rep. N. Y. State Cab. Nat. Hist., 1857, p. 126.

Loc. "Western New York."

Rhynehonella intermedia Barris=Hypothyris emmonsi.

Rhynchonella inutilis Hall.

Lower Helderberg (Dev.).

Rhynchonella inutilis Hall, Tenth Rep. N. Y. State Cab. Nat. Hist., 1857, 1. 74;-

Pal. New York, III, 1859, p. 223, pl. 34, figs. 7, 8.

Loc. Albany County, New'York.

Rhynchonella (?) janea Billings. Lorraine and Anticosti (Ord. and Sil.). Rhynchonella janea Billings, Catalogue Sil. Fossils Anticosti, 1866, p. 43.Foerste, Proc. Boston Soc. Nat. Hist., XXIV, 1890, p. 316, pl. 5, figs. 23, 24.

Loc. Anticosti; Collinsville, Alabama.

Rhynchonella kokomoensis Miller $=$ Wilsonia kokomoensis.

Rhynchonella lacunosa (Sehlotheim).

Jurassic.

Terebratulites lacunosa Schlotheim, Leonhardt's Min. Tasch., VII, 1813, pl. 1, fig. 2.

Rhynehonella lacunosa Davidson, British Oolitı and Liassic Brach., Pal. Soc, 1852, p. 96, pl. 16, figs. 13, 14.-Aguilera, Datos para la Geologia de Mexico, 1893, p. 18;-Bol. Com. Geológica de Mexico, I, 1895, p. 1, pl. 1, figs. 1-13.

Loc. Europe; Rancho Alamitos, Sierra de Catoreo, Mexico.

Rhynchonella lacunosa arolica Oppel.

Jurassie.

Rhynchonella lacunosa var. arolica Aguilera, Datos para la Geologia de Mexico, 1893, p. 18;-Bol. Com. Geológica de Mexico, I, 1895, p. 1, pl. 1, figs. 14-25; pl. 2 , figs. $1,2$.

Loc. Europe; Rancho Alamitos, Sierra de Catorce, Mexico.

Rhynchonella lævis Simpson.

Clintou (Sil.).

Rhynchouella (Stenochisma) litvis Simpson, Trans. American Philosophical Soc., n. ser., XVI, 1889 , p. 443 , fig. 8.

Loc. Blair County, Pennsylvauia.

Rhynchonella (?) lamellata Hall.

Coralline (Sil.).

Atrypa lamellata Hall, Pal. New York, II, 1852, p. 329, pl. 74, fig. 11.

Rhynchonella lamellata Hall, 'Twelfth Rep. N. Y. State Cab. Nat. Hist., 1859, p. 78 .

Loo. Schoharie, New York.

Rhynchonella laura Billings=Leiorhynehus laura.

Rhynchonella lingulata Gabb.

Triassie.

Rhynchonella lingulata Gabb, Geol. Survey California, Pal., I, 1864, p. 34, pl. 6, fig. 36.

Loc. Humboldt Connty, Nevarla.

Rhynchonella louisvillensis Nettelroth.

Corniferous (Dev.).

Rhynchonella louisvillensis Nettelroth, Kentucky Fossil shells, Mem. Kentucky Geol. Survey, 1889, p. 77, pl. 31, figs. 1-4.

Loc. Falls of Ohio.

Rhynchonella macra Hall.

St. Lonis (L. Carb.).

Rhynchonella macra Hall, Trans. Albany Institute, IV, 1858, 1. 11.-Whitfield, Bull. American Mus. Nat. Hist., I, 1882, p.52, pl.6, figs. 40-42.-Hall, Twelfth Rep. State Geol. Indiana, 1883, p. 334, pl. 29, figs. 40-42.

Loc. Alton, Illinois. 
Rhynchonella mainensis Billings.

Lower Helderberg (Dev.).

Rhyuchonella mainensis Billings, Proc. Portland Soc. Nat. Hist., I, 1863, p. 110, pl. 3, fig. 4.

Loc. Square Lake, Maine.

Rhynchonella manflasensis Möricke.

Jurassie.

Rhynchonella man flasensis Möricke, Neues Jahrb. f. Mineral., Beilagebaud, IX, 1894, p. 62, pl. 5, figs. 7a-7e.

Loc. Manflas and Melon, Chile.

Rhynchonella mansoni Salter=Atrypa mansonii.

Rhynchonella marshallensis A. Winchell=Camarote chia marshallensis.

Rhynchonella mauçensis Whiteaves.

Cretaceous.

Rhynchonella mandensis Whiteaves, Mesozoic Fossils, Geol. Surv. Canada, I, 1884, p. 252, pl. 33, fig. 8.

Loc. Maud Island.

Rhynchonella medea Billings.

Corniferous (Dev.).

Rhynchonella metlea Billings, Canadian Jour., n. ser., Y, 1860, 1. 271;-Geol.

Canada, 1863, p. 370 , fig. 388.

Loc. Township of Rainham, Ontario.

Rhynchonella medialis Simpson.

Waverly (L. Carb.).

Rhynchonella medialis Simpson, Trans. American Philosophical Soc., n. ser.,

XVI, 1889, p. 444, fig. 9.

Loc. Warren, Pennsylvania.

Rhynchonella (?) metallica White.

Upper Carboniferous.

Rhynchonella metallica W'hite, Wheeler's Expl. and Survey west 100th Merill.,

Prel. Rep., 1874, p. 20 ;-Ibidem, Final Rep., IT, 1875, p. 129, pi. 10, fig. 10.

Loc. Lincoln County, Nevada.

Obs. Probably an Uncinulus.

Rhynchonella mica Billings=Zygospira mica.

Rhynchonella (?) micropleura A. Winchell.

Marshall (L. Carb.).

Rhynchonella (Retzia?) micropleura A. Winchell, Proc. Acad. Nat. Sci. Philadelphin, 1865, p. 122.

Loc. Battlecreek, Michigan.

Rhynchonella minnesotensis Sardeson=Rhynchotrema indeuivalvis. Rhynchonella missouriensis Shumard, fig. 5a (uon 5b, 5c) =Puguax pugnus missouriensis.

Rhynchonella missouriensis Shumard, figs. 5b, 5e (non 5a)=Pugnax striaticostata.

Rhynchonella multistriata Hall.

Oriskany (Dev.).

Rhynchonella multistriata Hall, Tenth Rep. N. Y. State Cah. Nat. Hist., 1857, 1. 85 ;-Pal. New York, 1II, 1859, p. 440, pl. 102, fig. 3 ; pl. 106, fig. 3.

Loc. Helderberg Mountains, New York.

Rhynchonella mutabilis Hall=Uncinulus mutabilis.

Rhynchonella mutata Hall=Pugnax mutatik.

Rhynchonella myrina Hall and Whitfield.

Jurassic.

Rlyuchonella species? Meek and Hayden, Swithsonian Cont. to Knowl., XIV, 172,1865 , p. 71, pI. 4, fig. 3.

Rhynchonella myrina Hall and Whitfield, King's U. S. Geol. Expl. 40th Parl., IV, 1877, 1. 28.1, pl. 7 , figs. 1-5.-Whitfield, Powell's Geol. Geogr. Survey

Rocky Monutain Region, 1880, p. 347, pl. 3, figs. 6, 7.

Loc. Uinta Range, Utah; Black llills, Dakota. 
Rhynchonella neenah Whitfield.

Lorraine (Ord.).

Rhyuchonella neenah Whitfield, Geol. Wisconsin, IV, 1882, P. 265, pl. 12, figs. 19-22.

Khynchonella (?) neenah Winchell and Schuchert, Geol. Survey Minuesota, III, 1893, p. 465 , pl. 34 , figs. $35-37$.

Loc. Ironridge, Clifton, etc., Wisconsin; Savanua, Illinois; Lattners, Iowa.

Rhynchonella neglecta Hall=Camarotochia neglecta.

Rhynchonella negleeta var. seobina Meek=Camarotœchia neglecta.

Rhynchonella nitens Dana=Terebratula nitens.

Rhynehonella nobilis Hall= Uncinulus nobilis.

Rhyuchonella nucleolata Hall=Uneinulus nucleolatus.

Rhynchonella nucula (Sowerby).

Silurian.

Terebratula nucula Suwerby, Murchison's Silurian System, 1839, pl. 5, fig. 20.

Rhynehonella uucula Etheridge, Quart. Jour. Geol. Soc. London, XXXIV, 1878, p. 595.

Loc. England; Bessels Bay, lat. $81^{\circ} 6^{\prime}$.

Rhynchonella nutrix Billings.

Anticosti (Sil.).

Rhynchonella nutrix Billings, Catalogue Silurian Fossils Anticosti, 1866, p. 43.

Loc. Anticosti.

Rhynchonella oblata Hall.

Oriskany (Dev.).

Rhyuchonella oblata Hall, Tenth Rep. N. Y. State Cab. Nat. Hist., 1857, p. 86 ;Pal. New York, III, 1859, p. 439, pl. 102, figs. 1, 2.

Loc. Albany and Schoharie counties, New York.

Rhynchonella obsolescens Hall.

Kinderhook (L. Carb.).

Rhynchonella (Eatonia) obsolescens Hall, Thirteenth Rep. N. Y. State Cab. Nat. Hist., 1860, p. 111.

Loc. Rockford, Iudiana.

Rhynehonella obtusiplicata Hall=Camarotechia obtusiplicata.

Rhynchonella occidens Walcott.

Lower Devonian.

Rhynchovella occidens Walcott, IIon. U. S. Geol. Survey, VIII, 1884, p. 152, pl. 15, fig. 3 .

Loc. Eureka district, Nevada.

Rhynchonella opposita White and Whitfield. Kinderhook (L. Carb.). Rhynchonella opposita White and Whittield, Proc. Boston Soc. Nat. Hist., VIII, 1862, p. 294.

Loc. Burlington, Iowa.

Rhynchonella orbieularis Hall=Camarotcechia orbieularis.

Rhynchonella orientalis Billings.

Chazy (Orel.).

Rhynchouella orientaIis Billings, Canadian Nat. Geol., IV, 1859, 1. 443, fig. 21 ;Geol. Canada, 1863, p. 126, tig. 51.

Loc. Mingan Island.

Rhynchonella osagensis Swallow=Pugnax utah.

Rhynehonella ottumwa White=Pugnax ottumwa.

Rhynchonella parvini MeChesney=Camarophoria subtrigona.

Rhynehonella perlamellosa Whitfield=Rhynehotrema perlamellosum.

Rhynchonella perrostellata Swallow.

St. Louis (L. Carb.).

Rhynchonella perrostellata Swallow, Traus. St. Lonis Acad. Sci., II, 1863, 1. 85.

Loc. Cooper County, Missouri. 
Rhynchonella persinuata $\Lambda$. Winchell.

Kinderhook (L. Carb.).

lihyuchonella persinuata A. Winchell, Proc. Acad. Nat. Sci. Philadelphia, 1865, p. 121.

Loc. Burlington, Iowa.

Rhynchonella phoca Salter=Atrypa phoca.

Rhynchonella pipira Derby.

Upper Carboniferous.

Rhynchonella pipira Derby, Bull. Cornell Univ., I, 1874, p. 24, pl, 3, figs. 18. 2:3, $25,26,31$.

Loc. Bomjardim and Itaituba, Brazil.

Rhynchonella pisa Hall and Whitfield.

Niagara (Sil.).

Rhynchonella pisa Hall and Whitfield, Pal. Ohio, Il, 1875, p. 135, pl. 7, tigs. 18-22.-Nettelroth, Kentucky Fossil Shells, Mem. Kentucky Geological Survey, 1889 , p. 78 , pl. 32 , figs. 24-27.

Loc. Highland County, Ohio; Louisville, Kentucky.

Rhynchonella planiconvexa Hall, Lower Helderberg (1)ev.).

Rhynchonella planoconvexa Hall, Tenth Rep. N. Y. State Cab. Nat. Hist., 1857,

p. 75 ;-Pal. New York, III, 1859, p. 235, pl. 34, fig. 22.

Loc. Albany County, Now York.

Rhynchonella plena Hall=Camarotœchia plena.

Rhynchonella pleiopleura Hall=Camarotochia pleiopleura.

Rhynchonella pleurodon (Phillips).

Upper Carboniferous.

Terebratula pleurodon Phillips, Gool. Yorkshire, II, 1836, p. 222, pl. 12, figs. 25-30.

Rhynchonella pleurodon Davidson, Mon. British Carb. Brach., 1860, p. 101, pl. 23, figs. 1-15. -Toula, Sitzungsb. der k. k. Akad. zu Wien, LIX, 1869, p. 7, pl. 1, fig. 6.-Etheridge, Quart. Jour. Geol. Soc. London, XXXIV, 1878, p. 632 .

Loc. Europe; "Common in the Carboniferous rocks of America," Davidson; Bolivia; Feilden Isthmus, lat. $82^{\circ} 43^{\prime}$.

Obs. Compare with Pugnax utah (Marcois).

Rhynchonella plicata Hall.

Medina (Sil.).

Atrypa plicata Hall, Pal. New York, II, 1852, p. 10, pl. 4, fig. 6.

Rhynchonella plicata Hall, Twelfth Rep. N. Y. State Cab. Nat. Hist., 1859, p. 78. Loc. Lockport, New York.

Rhynchonella plicatella (Linné).

Niagara (Sil.).

Atrypa plicatella? Hall, Pal. New York, II, 1852, p. 279, pl. 58, figs. 3, 4.

Rhynchonella plicatella Hall, Twelfth Rep. N. Y. State Cab. Nat. Hist., 1859, p. 78.

Atrypa plicatella Miller, N. American Geol. Pal., 1889, p. 337.

Loc. Europe; Wolcott, New York.

Rhynchonella plicatilis (Sowerby).

Cretaceous.

Terebratula plicatella Sowerby, Mineral Conchl., V, 1825, p. 167, tab. 503, fig. 1.

Rhynchonella plicatilis Davidson, British Cretaceons Brach., Pal. Soc., I, 185:, p. 75, pl. 10, figs. 37, 42.-Eichwald, Geog. Paleont. Bemerk. Halb. Mang. Aleutischen Inseln, 1871, p. 200.

Loc. Eugland; Alaska.

Rhynchonella plicatissima Quenstedt.

Jurassic.

Rhynchonella plicatissima (Quenst.) Möricke, Nenes Jahrb. f. Mineral., Beilageband, IX, $189 \pm$, p. 61.

Loc. Sierra de la Teruera, Coquimbo, Guasco, and Copiapo, Chile.

Ob8. Möricke says that Terebratula ienigma Forbes in great part belong to this species and R. belemnitica. 
Rhyuchonella plicifera Hall=Camarotøchia plena.

Rhynchonella principalis Hall.

Oriskany (Dev.).

Rhynchonella principalis Hall, Tenth Rep. N. Y. State Cab. Nat. Hist., 1857, p. 84 ;-Pal. New York, III, 1859, p. 443, pl. 106, fig. 4.

Loc. Auburn, New York.

Rhynchonella prolifica Hall=Camarotœehia prolifica.

Rhynchonella pugnus of authors= P'ugnax pugnus.

Rhynchonella pustulosa White=Rhynchopora pustulosa.

Rhynchonella pyramidata Hall=Uncinulus pyramidatus.

Rhynchonella pyrrha Billings.

Anticosti (Sil.).

Rhynchonella pyrrha Billings, Catalogue Sil. Foss. Anticosti, 1866, p. 44.

Loc. Anticosti.

Rhynchonella ramsayi Hall.

Oriskany (Dev.).

Rhynchonella ramsagi Hall, Pal. New York, III, 1859, p. 446, pl. 101A, figs. 7, 8.

Loc. Cumberland, Maryland.

Rhynchonella (?) raricosta Whitfield.

Corniferous (Dev.).

Rhynchonella ? raricosta Whitfield, Annals N. Y. Acad. Sci., II, 1882, p. 201;Ibidem, V, 1891, p. 522, pl. 6, fig. 6;-Geol. Ohio, VII, 1895, p. 421, pl. 2 , fig. 6.

Loc. Columbus, Ohio.

Rhynchonella reticulata Hall=Dictyonella reticulata.

Rhynchonella ricinula Hall.

St. Lonis (L. Carb.).

Rhynchonella ricinula IIall, Trans Albany Institute, IV, 1858, p. 9.-Whitfield,

Bull. American Mus. Nat. Hist., I, 1882, p. 53, pl. 6, fig. 46.-Hall, Twelfth

Rep. State Geol. Indiana, 1883, P. 330, pl. 29, fig. 46.

Loc. Spergen Hill, Indiana.

Rhynchonella ringeus Swallow=Camarophoria ringens.

Rhynchonella robusta Hall.

Clinton (Sil.).

Atrypa robusta Hall, Pal. New York, II, 1852, p. 71, pl. 23, fig. 7.

Rhyuchonella robusta Hall, Twelfth Rep. N. Y. State Cab. Nat. Hist., 1859, p. 78.

Loc. Lockport, New York.

Rhynchonella rockymontana Mareou=Pugnax rockymontana.

Rhynchonella royana Hall.

Corniferous (Dev.).

Rhynchonella? (Stenocisma?) royana Hall, Pal. New York, IV, 1867, p. 338, pl. 54, figs. 20-23.

Loc. Near Leroy, New York.

Rhynchonella rudis Hall.

Lower Helderberg (Dev.).

Rhyuchonella rudis Hall, Tenth Rep. N. Y. State Cab. Nat. Hist., 1857, p. 75 ;

Pal. New York, III, 1859, p. 235, pl. 34, figs. 20, 21.

Loc. Hudson, New York.

Rhynchonella rugicosta Nettelroth.

Niagara (Sil.).

Rhynchonella rugiecosta Nettelroth, Kentucky Fossil Shells, Mem. Kentucky

Geol. Survey, 1889, p. 78, pl. 32, figs. $48-51$.

Loc. Louisville, Kentucky.

Rhynchonella saffordi Hall=Wilsonia saffordi.

Rhynchonella saffordi var. depressa= Wilsonia saffordi depressa.

Khynchonella sageriana A. Winchell=Camarotnechia sageriana.

Rhynchonella sancta Sardeson=Rhynchotrema incquivalve laticostatum.

Rhynchonella sappho Hall=Camarotrechia sappho. 
Rhynchonella schucherti Stanton.

Upper Cretaccous (Knoxville).

Rhynchonella schucherti Stanton, Bull. U. S. Geol. Survey, 133, 1896, p. 31, pl, 1, tigs. $1-4$.

Loc. Paskenta, California.

Tihynchonella seobina Meek=Camarotorchia neglecta.

Rhynchonella semiplicata (Conrad).

Lower Helderberg (Dev.).

Atrypa semiplieata Conrad, Fifth Ann. Rep. Geol. Survey N. Y., 1841, 1. 56.

Rhyuchonella semiplieata Ilall, Tenth Rep. N. Y. State Cab. Nat. Hist., 1857, p. 65, figs. 1, 2;-Pal. New York, II1, 1859, p. 224, pl. 29, fig. 1.

Loc. Scholis fie aud Carlisle, New York.

Rhynchonella septata Hall.

Oriskany (Dev.).

Rhynchonella septata Hall, Pal. New York, III, 1859, p. 443, pl. 103, fig. 2.

Loc. Albany Connty, New York.

Rhynchonella sordida Hall.

Trenton (Ord.).

Atrypa sordida Hall, Pal. New York, I, 1817, p. 148, pl. 33, fig. 16.

Rhynchonella sordida Hall, Twelfth Rep. N. Y. State Cab. Nat. Hist., 1859, p. 66.

Loc. Not given.

Rhynchonella speciosa Hall=Camarotechia speciosa.

Rhynchonella stephani Hall=Camarotochia stephani.

Rhynchonella (?) striata Simpson.

Waverly (L, Carb.).

Rhynchonella striata Simpson, Trans. American Phil. Soc., n. ser., XYI, 1889, p. 444, fig. 10.

Loc. Near Warren, Pennsylvania.

Obs. Compare with Camarophoria ringens and C. caput-testudinis.

Phynchonellasstriatocostata Meek and Worthen = Pugnax striaticostata. Rhynchonella stricklandi Sowerby=Uncinulus stricklandi.

Rhynchonella subacuminata Webster.

Chemung (Dev.).

Rliynchonella suhacuminata Webster, American Naturalist, XXII, 1888, p. 1015.

Loc. Near Rockford, Iowa.

Rhynchonella subcircularis A. Winchell.

Marshall (L. Carb.).

Rhynchonella subcircularis A. Winchell, Proc. Acad. Nat. Sci. Philadelphia, 1862, p. 408.

Loc. Port anx Barques, vlichigan.

Rinynchonella subcuneata Hall=Camarophoria subcuneata.

Rhynchonella subtetrædra (Conrad).

? Uretaceous.

Terebratula sulutetriedra Conrad, U. S. Astronomical Exped. Southern IIemispliere, 1855, 1. 282, pl. 42, fig. 8.

Loc. Portezuelo de Manplas and Cordillera de Dona Ana at an altitude of 13,432 feet alsove the ocean.

Rhynchonella subtrigona Meek and Worthen=Camarophoria subtrigona.

Rhynchonella subtrigonalis Hall.

Trenton (Ord.).

Atrypa subtrigonalis Hall, Pal. New York, I, 1847, p. 145, pl. 33, fig. 12.

Rhynchonella subtrigonalis Hall, Twelfth IRep. N. Y. State Cab. Nat. Hist., 1859, p. 66.

Loc. Turin, New York.

Obs. Compare with Rhynchotrema inæquivalve. 
Rhynchonella sulciplicata Hall.

Lower Helderberg (Dev.). Rhynchonella sulcoplicata Hall, Tenth Rep. N. Y. State Cab. Nat. Hist., 1857, p. 76.-Pal. New York, III, 1859, p. 236, pl. 35, fig. 1.

Loc. Albany Connty, New York.

Rhynchonella tayloriana (Lea).

? Jurassic.

Terebratula tayloriana Lea, Trans. American Phil. Soc., n. ser., VII, 1841, p. 259, pl. 10, fig. 12.

Loc. Habana, Cuba.

Rhynchonella tennesseensis Hall (non Roemer)=Uncinulus stricklandi.

Rhynchonella tennesseensis Roemer.

Niagara (Sil.).

Rhynchonella tenuesseensis Roemer, Die Sil. Fauna des West. Tennessee, 1860, p. 72, pl. 5, fig. 14.-Hall and Whitfield, Twenty-seventh Rep. N. Y. State Cab. Nat. Hist., 1875, pl. 9, figs. 24-26;-Pal. Ohio, II, 1875, p. 136, pl. 7, figs. $16,17$.

Loc. Perry County, Tennessee; Louisville, Kentucky; Yellow Springs, Ohio.

Rhynchonella tethys Billings=Camarotochia tethys.

Rhynchonella tetrædra (Sowerby).

Liassic.

Terebratula tetredra Sowerby, Mineral Conchology, I, 1812, p. 191, pl. 83, fig. 5.Bayle and Coquand, Mém. Soc. Géol. France, ser. ii, IV, 1851, 1. 17, pl. 7, figs. 9-10.

Rhyuchonella tetradra Davidson, British Oolitic and Liassic Brach., Pal. Soc., 1852, p. 93, pl. 18, figs. 5-10.-Behrendsen, Zeit. der Denschen geol. Gessel., XLIII, 1891, p. 396.-Möricke, Nenes Jahrb. f. Mineral., Beilageband, IX, 1894, p. 63.

Loc. Europe; Portezuelo Ancho, Argentine Republic; Manflas, Las Amolanas, etc., Chile.

Rhynchonella (?) tetraptyx A. Winchell.

Kinderhook (L. Carb.).

Rhynchonelia ? tetraptyx A. Winchell, Proc. Acad. Nat. Sci. Philadelphia, 1865, p. 120.

Loc. Rockford, Indiana.

Rhynchonella tenuistriata Nettelroth.

Corniferons (Dev.).

Rhynchonella tennistriata Nettelroth, Kentucky Fossil Shells, Mem. Kentucky Geol. Survey, 1889, p. 82, pl. 7, figs. 27-29.

Loc. Fails of Ohio.

Rhynchonella texana Shumard.

Upper Carboniferous.

Rhynchonella texana Shumard, Trans. St. Louis Acad. Sci., I, 1859, 1. 393.

Loc. Mouth of Delaware Creek, Texas.

Rhynchonella thalia Billings=Camarotœehia billingsi.

Rhynchonella thera Walcott=Camarophoria thera.

Rhynchonella transversa Hall.

Lower Helderberg (Dev.).

Rhynchonella transversa Hall, 'Tenth Rep. N. Y. State Cah. Nat. Hist., 1857, p. 74, figs. 5, 6;--Pal. New York, III, 1859, p. 234, pl. 34, figs.9-16.

Loc. Albany County, New York.

Rhynchonella triplicata Quenstedt.

Jurassic.

Rhynchonella triplicata (Quenst.) Möricke, Nenes Jahrb. f. Mineral., Beilageband, IX, 1894, p. 63 .

Loc. Europe; Quebrada de la lglesia, etc., Chile. 
Rhynchonella tuta Miller.

Burlington (L. Carb.).

Rhynchonella tuta Miller, Jour. Cincinuati soc. Nat. Hist., IV, 1881, p. 315, pl. 7. fig. 11.

Loc. Lake Valley mining district, New Mexico.

Rhynchonella unica $\Lambda$. Winchell.

Kinderhook (L. Carb.).

Rhynchonclli unica A. Winchell, Proc. Acad. Nat. Sci. Philadelphia, 1865, p. 122.

Loc. Burlington, Iowa.

Rhynchonella unisulcata Hall=Pentagonia unisulcata.

Rhynchonella utah of authors=Pugnax utah.

Rhynchone' a vellicata $\mathrm{Hall}=$ Uncinulus vellicatus.

Khynchonella ventricosa Hall=Camarotoechia ventricosa.

Rhyuchonella venustula Hall=Hypothyris cuboicles.

Rhynchonella vicina Billings.

Anticosti (Sil.).

Rhynchonella vicina Billings, Catalogne Sil. Foss. Anticosti, 1866, 1) 44.

Loc. Anticosti.

Rhynchonella (?) warrenensis Swallow.

Lower Devonian.

Rhynchonella warrenensis Swallow, Trans. St. Louis Acad. Sci., I, 1860, p. 653.

Loc. Callaway County, Missouri.

Rhynchonella wasatchensis White=Seminula wasatchensis.

Rhynchonella whitiana Miller=Camarotechia whitei.

Rhynchonella whitii Hall (non Winchell)=Canarotæchia whitei.

Rhynchonella whitei A. Winchell. Marshall (L. Carb.).

Rhynchonella whitei A. Winchell, Proc. Acad. Nat. Sci. Philadelphia, 1862, 1. 407.

Loc. Marshall, Michigan.

Rhynchonella whitneyi Gabb.

Cretaceous (Shasta).

Terebratella whitneyi Gabb, Geol. Survey California, Pal., II, 1869, p. 35, pl. 2, fig. 62.

Rhynchonella whitneyi Gabb, Ibidem, 1869, p. 204, pl. 34, fig. 105.-Stantou,

Bull. U. S. Geol. Survey, 133, 1896, p. 32, pl. 1, figs. 5-10.

Loc. Napa and Colusa counties, California.

Rhynchonella wilmingtonensis (Lyell and Sowerby).

Eocene.

Torebratula wilmingtonensis Lyell and Sowerby, Quart. Jour. Geol. Soc. Loudon, 1, 1815, 1. 431.

Rhynchonella wilmingtonensis Conrad, American Jour. Conch., I, 1865, p. 35.

Loc. Wilmington, North Carolina.

Rhynchonella wilsoni Sowerby $=$ Wilsonia wilsoni.

Rhynchonella wortheni Hall=Camarophoria wortheni.

RHYNCHOPORA King. Genotype Terebratula geinitziana de Verneuil.

Rhynchopora King, Ann. Mag. Nat. Hist., 2d ser., XVII, 1856, p. 506.-Hall and

Clarke, Pal. New York, VIII, Pt. II, 1893, p. 210;-Thirteenth Ann. Rej.

N. Y. State Geologist, 1895, p. 832.

Rhynchoporina Ehlert, Fischer's Manuel de Conchyliologie, 1887, p. 1305.

Rhynchopora pustulosa (White).

Kinderhook (L. Carb.).

Rhynchonella pustulosa White, Jour. Boston Soc. Nat. Hist., VIII, 1860, p. ‘26.-

Hall and Whittield, Kiug's U. S. Geol. Expl. 40th Parl., IV, 1877, p. 257, pl. 4, figs. 12-14.

Rhynchopora pustulosa Hall and Clarke, Pal. New York, VIII, Pt. II, 1893, p. 210 , pl. 58, fiess. 1-4.

Loc. Burlington, Iowa; Wasatch Range, Utah; Lake Valley mining district, Now Mexico (Miller). 
RHYNCHOSPIRA Hall.

Genotype Waldheimia formosa Hall.

Rhynchospira Hall, Twelfth Rep. N. Y. State Cab. Nat. Hist., 1859, p. 29 ;-Pal.

New York, III, 1859, pp. 213, 484;-Sixteenth Rep. N. Y. State Cab. Nat. Hist., 1863, p. 58, figs. 12-17;-Pal. New York, IV, 1867, p. 276.-Hall and Clarke, Ibiden, VIII, Pt. II, 1893, p. 108, fig. 101;-Thirteenth Ann. Rep. N. Y. State Geologist, 1895 , p. 791.

Retzia Billings, Canadian Journal, VI, 1861, p. 147.

Rhynchospira (?) acadiæ (Hall).

Arisaig (Sil.).

Trematospira acadice Hall, Canadian Nat. Geol., V, 1860, p. 146, fig. 4.-Dawson, Acadian Geology, 3d ed., 1878, p. 597.

Loc. Nova Scotia.

Rhynchospira aprinis Hall=Homœespira apriniformis.

Rhynchospira (?) ashlandensis Herrick. Waverly (L. Carb.).

Rhynchospira ? ashlandensis Herrick, Bull. Denison Univ., IV, 1888, p. 25, pl.3, fig. 16 ;-Geol. Ohio, VII, 1895, pl. 23, fig. 16.

Loc. Lyon Falls, Ohio.

Rhynchospira electra (Billings).

Lower Helderberg (Dev.).

Retzia electra Billings, Proc. Portland Soc. Nat. Hist., 1863, p. 114, pl. 3, fig. 11.

Rhynchospira elcetra Hall and Clarke, Pal. New York, VIII, Pt. II, 1893, p. 111, pl. 50, figs. 29-31.

Loc. Square Lake, Maine.

Rhynchospira equiradiata Hall=Camarotochia rquiradiata.

Rhynchospira (?) eugenia (Billings). Corniferous (Dev.).

Retzia engenia Billings, Canadian Jour., VI, 1863, p. 147, fig. 58 ;-Geol. Canada, 1863 , p. 373 , fig. 395 .

Rhynchospira (q) eugenia Hall and Clarke, Pal. New York, VIII, Pt. II, 1893, p. 111, pl. 50, figs. 41-43.

Loc. Walpole, Ontario.

Rhynchospira evax Hall=Homneospira evax.

Rhynchospira formosa Hall.

Lower Helderberg (Dev.).

Waldhoimia formosa Hall, Tenth Rep. N. Y. State Cab. Nat. Hist., 1857, p. 88.

Trematospira (Rhynchospira) formosa Hall, Pal. New York, III, 1859, p. 215, pl. 36 , fig. $2 ; \mathrm{pl} .95 \mathrm{~A}$, figs. $7-11$.

Rhynchospira formosa Hall, Pal. New York, IV, 1867, p. 278, figs. 1-6.-Hall and Clarke, Pal. New York, VIII, Pt. II, 1893, p. 109, fig. 101, p1. 50, figs. 21-25.

Retzia formosa Miller, N. Amcrican Gcol. Pal., 1889, p. 366.-Whitfield, Annals N. Y. Acad. Sei., V, 1891 , p. 512, pl. 5, figs. 15, 16;-Geol. Ohio, VII, 1895, p. 413, pl. 1, figs. $15-16$.

Loc. Helderberg Monntains, New York; Square Lake, Maine; Greenfield, Ohio.

Rhynchospira globosa Hall. Lower Helderberg (Dev.).

Waldheimia globosa Hall, Tenth Rep. N. Y. State Cab. Nat. Hist., 1857, p. 87.

Trematospira (Rhynchospira) globosa Hall, Pal. New York, III, 1859, p. 215, pl. 36 , fig. 1.

Rhynchospira globosn Hall and Clarke, Ibidem, VIII, Pt. II, 1893, p. 111.

Loc. Helderberg Mountains, New York.

Rhynchospira (?) helena (Nettelroth).

Trematospira helena Nettelroth, Kentucky Fossil Shells, Mem. Kentucky Geol.

Survey, 1889, p. 137, pl. 32, figs. 40-43.

Loc. Lonisville, Kentucky.

Rhynchospira lepida IIall=Trigeria lepida. 
Rihynchospira nobilis Hall=Cyclorhina nobilis.

Rhynchospira rectirostris Hall.

Oriskany (Dev.).

Willlheimia rectirostra ILalI, Tenth Rej. N. Y. State Cah. Nat. Ilist., 1857, p. 89.

Trematospira (Rhynehospira) rectirostra Hall, Pal. New York, III, 1859, p. 217,

pl. $95 \mathrm{\Lambda}$, fim. 1 , and $1.4 \times 5$.

lihynchospira rectirostra Hall and Clarke, Ilidem, VIII, Pt. II, 1893, p. 111.

Loc. Cumberland, Maryland.

Rhynchospira scansa Hall and clarke.

Waverly (L. Carb.).

Rhyuchospira scansa Hall and Clarke, Pal. Now York, VIII, Pt. II, 1845, pl, 50,

fig. 45 .

Loc. Ackean County, Pennsylvania.

Rhynchospira (?) sinuata Hall.

A risaig (Sil.).

Rhynchospira sinnata Hall, Canadian Nat. Geol., V, 1860, p. 146.-Dawson,

Acarlian Geology, 3d ed., 1878, p. 597 .

Retzia sinuata Miller, N. American Feol. Pal., 1889, ‥ 367.

Loc. Arisaig, Nova Scotia.

Rhynchospira subglobosa Hall=Retzia subglobosa.

RHYNCHOTREMA Hall.

Genotype Rhynchonella capas Conrad.

Rhpnchotrema Hall, Thirteenth Rep. N. Y. State Cab. Nat. Hist., 1860, p. 68, figs. 12-14.-Waagen, Palæontologica Indica, Ser. XIII, I, 1883, p. 410.Winchell and Schuchert, Minnesota Geol. Survey, III, 1893, 1\% 458.-Hall and Clarke, Pal. New York, VIII, Pt. II, 1893, p. 182 ;-Thirteenth Ann. Rep. N. Y. State Geologist, 1895 , p. 825.

Rhynchotrema ainsliei N. H. Winchell.

Trenton (Ord.).

Rhynehonella ainsliei N. H. Winchell, Fourteenth Ann. Rep. Geol. Nat. Hist. Snrvey Minnesota, 1886, p. 315, pl. 2, figs. 5, 6.

Rhynchotrema aimsliei Winchell and Schuchert, Minnesota Geol. Survey, III, 1893 , p. 459, pl. 34, figs. 1-8.

Loc. Mimneapolis, St. Paul, etc., Minnesota; Decorah, Iowa.

Rhynchotrema capax (Conrad).

Lorraine (Ord.).

Atrypa capax Conrad, Jour. Acad. Nat. Sci. Philadelphia, VIII, 1842, 1. 261, pl. 14, fig. 21.

Atrypa increbescens (partim) Hall, Pal. New York, I, 1847, p. 146, pl. 33, figs. 13i, 13k-13y.-Billings, Canadian Nat. Geol., I, 1856, p. 207, figs. 15, 16.-Hall, Thirteenth Rep. N. Y. State Cab. Nat. Hist., 1860, p. 66. figs. 6, 7, 9-11.

Rhynchonella increbescens (partim) IIall, Geol. Wisconsin, I, 1862, p. 123, pl. 11, fig. 2.

Rhynchonella capax Billings, Geol. Canada, 1863, p. 211, fig. 213.-Meek, Pal. Ohio, I, 1873, p. 123, pl. 11, fig. 2.-Miller, Cinciunati Quart. Jour. Sci., II, 1875 , p. 17. - White, Second Ann. Rep. Indiana Burcau of Statistics and Geol., 1880, p. 489, pl. 1, figs. 9-11;-Tenth Rep. State Geol. Indiana, 1881, p. 121, pl. 1, figs. 9-11.-Whitfield, Geol. Wisconsin, IV, 1882, p. 263, pl. 12, figs. 26, 27.-Keyes, Geol. Survey Missouri, V, 1895, p. 99, pl. 41, fig. 12.

Rhynchotrema capax Winchell and Schuchert, Minnesota Geol. Surves, III, 1893, p. 462, pl. 3t, figs. 30 34.-Hall and Clarke, Pal. New York, VIII, Pt. II, 1893, pl. 183, 185, pl. 56, figs. 14-18, 20-27; pl. 83, fig. 31.-Whiteaves, Pal. I'oss., III, Pt. III, 1897, p. 178.

Loc. Richmond, Indiana; Oxford, etc., Ohio; Wilmington, Illinois; Cape Girardean, Missonri; Stoekbridge. Ironridge, ete., Wisconsin; Lattners, Iowa: Spring Valley, Minnesota; Anticosti; Lake Winnipeg, Manitoba; Fort Churchill, Hndson Bay. 
Rhynchotrema dentatum Hall.

Trenton and Lorraine (Ord.).

Atrypa dentata Hall, Pal. New York, I, 1847, p. 118, pl. 33, fig. 14.

Rhynchonella dentata Hall, Twelfth Rep. N. Y. State Cab. Nat. Hist., 1859, p. 65.-Meek, Pal. Ohio, I, 1873, p. 12I, pl. 11, fig. 3.-Miller, Cincinnati Quart. Jour. Sci., II, 1875, p. 18.- White, Second Ann. Rep. Indiana Burean of Statistics and Geol., 1880, p. 490, pl. 1, figs. 12-14;-Tenth Rep. State Geol. Iudiana, 188I, p. 122, pl. 1, figs. 12-14.

Rlyynchotrema dentata Hall and Clarke, Pal. New York, VIII, Pt. II, 1893, p. 185. ?Rhynchonella dentata Keses, Geol. Survey Missouri, V, 1895, p. 100, pl. 11, fig. 3.

Loc. Turin, New York; Dayton and Oxford, Ohio; Richmond, Indiana; near Nashville, Tennessec.

Rhynchotrema formosum (Hall).

Lower Helderberg (Dev.).

Rhynchonella formosa Hall, Tenth Rep. N. Y. State Cab. Nat. Hist., 1857, p. 76, tigs. 1-5;-PaI. New York, III, 1859, p. 236, pl. 35, fig. 6.

Stenocisma formosa Hall, Pal. New York, IV, 1867, p. 334.-Hall and Clarke, Ibidem, VIII, Pt. II. 1893, p. 187, pl. 56, figs. 41-45.

Loc. Sehoharie and Albany counties, New York; Lake Temisconata, New Brunswick, and Arisaig, Nova Scotia (Ami).

Rhynchotrema inæquivalve (Castelnau).

Trenton (Ori.).

Spirifer inæquivalvis Castelnau, Essai Système Sil. l'Amérique Septeutrionale, 1843, p. 40, pl. 14, fig. 8 .

Atrypa increbescens (partim) Hall, Pal. Now York, I, 1847, 1'p. 146, 289, pl. 33, figs. 13a-13h; ?pl. 79, fig. 6.

Rhyuchonella increbescens (partim) Billings, Canadian Nat. Geol., I. 1856, p. 207, figs.11-14.-Hall, Twelfth Rep. N. Y. State Cal,. Nat. Hist., 1859, p. 66.-Billings, Geol. Canada, 1863, p. 168, fig. 153.-Nettelroth, Kentucky Fossil Suells, Mem. Kentucky Geol. Survey, 1889, p. 83, pl. 34, figs. 26-29.

Rhyuchonella argenturbica White, Wheeler's Expl. and Survey west 100th Morul., IV, Prel. Rep., 1874, p. 14;-Ibidem, Final Rep., 1875, p. 75, pl. 4, fig. 12.

Trematospira (?) quadriplicała Miller, Cincinnati Quart. Jonr. Sci., II, 1875, p. 60 , figs. 6,7 .

Rhynchotreta qualriplicata Miller, N. American Geol. Pal., 1889, p. 370.

Rhyuchouella ininnesotensis Sardeson, Bull. Minnesota Acad Nat. Sci., III, 1892, p. 333, pl. 4, tigs. 21-23.

Rhynchotrema inxquivalvis Winchell and Schnchert, Minuesota Geol. Survey, III, 1893, p. 459, pl. 31, figs. 9-25.-Whiteaves, Pal. Foss., IIl, Pt. III, 1897, p. 179.

Rhynchotrema increbescens IIall and Clarke, Pal. New York, VIII, Pt. II, I893, pl. $183,185$.

Loc. Drummonds Island (Castelnan); New York; Kentucky; 'Temnessee; Illinois; Wisconsin; Iowa; Minnesota; Silver City, New Mexico; Ottawa, Canada; Lake Winnipeg, Manitoba.

Obs. Compare Rhynchonella subtrigonalis.

Rhynchotrema inæquivalve laticostatum Win. and Scluch. Trenton(Ord.).

Rhyuchotrema inæquivalvis var. laticostata W. and S., American Geol., IX, April 1, 1892, 1. 293;-Minnesota Geol. Survey, III, 1893, 1. 461, pl. 31, figs. $26-29$.

Rhynchonella sancta Sardeson, Bull. Minnesota Acad. Nat. Sci., 1II, April 9, $1 \times 92$, p. 333, pl. 4, tigs. 19, 20.

Loc. Camon Falls, Minnesota.

Rhynchotrema ottawaense (Billings).

Trenton (Ord.).

Porambonites? ottawaensis Billings, Pal. Fossils, I, 1862, p. 140, fig. 117.

Bull. 87 - 24 
Rhynchotrema ottawaense (Billings)-Continued.

Protorhyneha? aud Orthorhynchula? ottawaensis IIall and Clarke, Pal. New York, VIII, It. II, 1893, pl. 181, 228.

Loc. Pauquette Rapids, Canada; near Murfreesboro, Tennessee.

Rhynchotrema perlamellosum (Whitfield).

Lorraine (Ord.).

Rhynchonella perlamellosa Whitfield, Amn. Rep. Geol. Survey Wisconsin, 1877, p. 73.-Tames, The I'alieontologist, 2, 1878, p. 15.-Whitfield, Geol. Wisconsin, IV, 1882, 1. 265, pl. 12, figs. 23-25.

Loc. Delafield and Iron Ridge, Wisconsin; Oxford, Ohio.

RHYNCHJTRETA Hall. Genotype Rhynchonella cumeata Dalman. Rhynehotreta Hall, Twenty-eighth Rep. N. Y. State Mus. Nat. Hist., 1879, p. 166, figs. 1-1;-Eleventh Rep. State Geol. Indiana, 1882, p. 309.-Nettelroth, Kentucky Fossil Shells, Mem. Kentucky Geol. Survey, 1889, 1. 84.-Hall and Clarke, Pal. New York, VIII, Pt. II, 1893, p. 185 ;-Thirteenth Anu. Rep. N. Y. State Geologist, 1895, p. 825.

Rhynchotreta cuneata americana Hall.

Niagara (Sil.).

Atrypa cuneata Hall (non Dalman), Geol. N. Y.; Rep. Fourth Dist., 1843, Table of Organie Remains, 13, figs. 3, 4;-Pal. Nèw York, II, 1852, p. 276, pl. 57, fig. 4.-Billings, Canadian Nat. Geol., I, 1856, p. 138, pl. 2, fig. 13.

Rhynchonella cuneata Hall, Twelfth Rep. N. Y. State Cab. Nat. Hist., 1859, p. 77.-Billings, Geol. Canada, 1863, p. 315, fig. 323.

Rhynchotreta emeata var, americana Hall, Twenty-eighth Rep. N. I. State Mus. Nat. Hist, 1879, p. 167, pl. 25, figs. 29-38;-Eleventh Rep. State Geol. Indiana, 1882, p. 310, pl. 25, figs. 29-38.-Nettelroth, Kentrieky Fossil Shells, Mem. Kentucky Geol. Surrey, 1889, p. 85, pl. 32, figs. 58, 59, 62, 63.-Beecher and Clarke, Mem. N. Y. State Mus., I, 1889, p. 47, pl. 4, figs. 12-22.-Hall and Clarke, Pal. New York, VIII, Pt. II, 1893, p. 187, pl. 56, figs. 31-38.

Loe. Lockport, ete., New York; Hamilton, Ontario; IValdron and Osgood, Indiana; Lonisville, Kentucky; Milwankee, Wisconsiu.

Rhynobolus Hall=Rhinobolus.

REILERELLA Hall and Clarke. Genotype Orbicula grandis Vanux.

Rnemerella Hall and Clarke, Pal. New York, VIII, Pt. I, 1892, p. 137, fig. 65;Eleventh Ann. Rep. N. Y. State Geologist, 1894, p. 257.

Rœmerella grandis (Vanuxem).

Hamilton (Dev.).

Orbicula grandis Vanuxem, Geol. N. Y.; Rep. Third Dist., 1812, p. 152, fig. 4.

Discina grandis Hall, Pal. New York, IV, 1867, p. 17, pl. 1, fig. 18; pl, 2, figs. 32, 33.-Nettelroth, Kentueky Fossil Shells, Mem. Kentucky Geol. Survey, 1889, p. 33, pl. 3, fig. 3.

Diseina (Orbiculoidea?) grandis Hall and Whitfield, Twenty-fourth Rep. N. Y. State Cal. Nat. Hist., 1872, p. 187 ;-Twenty-seventh Rep. Ibidem, 1875, pl. 9 , figs. 33-35.

Rœmerella grandis Hall and Clarké, Pal. Now York, VIII, Pt. I, 1892, p. 137, fig. 65, pl. 4E, figs. 29-31.

Loc. Cazenovia and Pratts Falls, New York; Columbus, Ohio; Falls of Ohio.

ROMINGERINA Hall and Cl. Genotype Centronella julia A. Winchell. Romingerina Hall and Clarke, Pal. New York, VIII, Pt. II, 1893, 1. 272;-Thirteenth Ann. Rep. N. Y. State Geologist, 1895, p. 855.

Romingerina julia (A. Winchell).

Waverly (L. Carb.).

Centronella julia A. Winchell, Proe. Acal. Nat. Sei. Philadelphia, 1862, 1. 405;Ihidem, 186.5, p. 123.-Hall, Pal. New York, IV, 1867, p. 419, pl. 61A, figs. 41-46.-Herrick, Bull. Denison Unir., IIJ, 1888, p. 49, pl. 2, fig. 5. 
Romingerina julia (A. Winchell)—Continued.

Romingerina julia Hall and Clarke, Pal. New York, VIII, Pt. II, 1893, p. 271, figs. 187, 188, pl. 79, figs. 28-30.

Loc. Port Aux Barques, Michigan; Cuyahoga and Licking counties, Ohio. ?In the Chemung at Rushford, New York (Williams).

SCAPHIOCELIA Whitfield.

Genotype S. boliviaensis Whitfield.

Scaphiocelia Whitfield, Trans. American Inst. Min. Engi., XIX, 1891, p. 106.Hall and Clarke, Pal. New York, VIII, Pt. 1I, 1893, p. 275;-Thirteenth Ann. Rep. N. Y. State Geologist, 1895, p. 857.

Scaphiocœlia boliviaensis Whitfield.

Middle Devonian.

Scaphioccelia boliviensis Whitfield, Trans. American Inst. Min. Engi., XIX, 1891, p. 106, figs. 1-4.-Hall and Clarke, Pal. New York, VIII, Pt. II, 1893, p. 276, figs. 193-196.

Loc. Sercre or Qnechista, Bolivia.

SCENIDIUM Hall.

Genotype Orthis insignis Hall.

Skenidium Hall, Thirteenth Rep. N. Y. State Cab. Nat. Hist., 1860, p. 70, figs. 1-5.-Waagen, Paleontologica Indica, Ser. XIII, I, 1884, p. 549.

Scenidium Ehlert, Bull. Societe d'Etudes Scientifiques d'Angers, 1887, p. 4, extract.-Hall and Clarke, Pal. New York, VIII, Pt. I, 1892, p.241.-Winehell and Schuchert, Minnesota Geol. Survey, III, 1893, p. 381.-Hall and Clarke, Eleventh Ann. Rep. N. Y. State Geologist, 1894, p. 276.

Scenidium anthonense Sardeson.

Trenton (Ord.).

Skenidium halli Safford, Geol. 'Tennessee, 1869, p. 287 (undefined).

Skenidium anthonensis Sardeson, Bull. Minnesota Acar. Nat. Sci., III, 1892, p. 333, pl. 4 , fig. 7 .

Scenidium halli Hall and Clarke, Pal. New York, VIII, Pt. X, 1892, p. 242, pl. 7A, figs. 33-39.

Scenidinm anthonensis Winchell and Schnchert, Minnesota Geol. Survey, III, 1893, p. 381, figs. 20-23.

Loc. Minneapolis, St. Paul, and Cannon Falls, Miunesota; Dixon, Illinois; Lebanon, 'Tennessee.

Scenidium devonicum Walcott=Dalmanella devonica.

Scenidium halli Safford $=$ S. anthonense.

Scenidium insigne Hall.

Lower Helderberg (Dev.).

Orthis insignis Hall, Pal. New York, III, 1859, p. 173.

Skenidium (Orthis) insignis Hall, Ibidem, 1859, pl. 10A, figs. 13-15.

Skenidium iusignis Hall, Thirteenth Rep. N. Y. State Cab. Nat. Hist., 1860, p. 70, figs. 1-5;-Second Ann. Rep. N. Y. State Geol., 1883, p. 37, figs. 31-35.

Scenidium insigne Hall and Clarke, Pal. New York, VIII, Pt. I, 1892, p. 242, pl. 7, figs, 31-35.

Loc. Helderberg Mountains, New York; Perry County, 'Tennessee.

Scenidium (?) merope (Billings).

Trenton and Lorraine (Ord.).

Orthis merope Billings, Pal. Fossils, I, 1862, p. 139, fig. 116.

Scenidium ? merope Hall and Clarke, Pal. New York, VIII, Pt. I, 1892, p. 242, 1)1. $7 \mathrm{~A}$, figs. 31,32 .

Loc. Ottawa, Cauada; Cincinnati, Ohio; Burgin, Kentucky.

\section{Scenidium pyramidale Hall.}

Orthis pyramidalis Hall, Pal. New York, II, 1852, p. 251, pl. 52, fig. 2.

Niagara (Sil.).

Skenidium pyramidalis Hall, Thirteenth Rep. N. Y. State Cab. Nat. Hist., 1860, p. 70.

Skenidinm pyramidata Hall, Secoud Anu. Rep. N. Y. State Geol., 1883, pl. 37, figs. 29, 30 . 


\section{Scenidium pyramidale Hall-Continued.}

Scenielinm pyramidale Iall and Clarke, Pal. New York, VIII, Pt. I, 1892, 1. 242, pl. 7 , tigs. 29,$30 ;$ pl. $7 \mathrm{~A}$, figs. 40-42.

Lor. Lockport, Now York; Arisaig, Nova Scotia ( $\Lambda \mathrm{mi})$.

SCHIZAMBON Waleott.

Genotype S. typicalis Walcott.

Schizambon Walcott, Mon. U. S. Geol. Survey, VlII, 1884, 1. 69.-Ilall and Clarke, Pal. New York, VIII, Pt. I, 1892, 1p. 113, 167.-Winchell and Schuchert, Minnesota Geol. Survey, III, 1893, 1. 360.-Hall and Clarke, Eleventh An1. Rep. N. Y. State Geologist, 1891, 1. 253.

Schiz: \&ibonia Whlert, Fischer's Manuel de Conchyiologie, 1887, 1. 1266.

Schizambon (?) dodgei Winchell and Schuchert. Trenton (Ord.).

Schizambon (?) dodgii W. and S., Hinnesota Geol. Survey, III, 1893, 1. 361, pl. 30 , figs. 5-7.

Loc. Sandyhill, New York.

Schizambon (?) fissus canadaensis (Ami).

Utica (Ord.).

Siphonotreta scotica Whiteaves, American Jour. Sci., 3d ser., XXIV, 1882, p.

278 ;-Canadian Nat. Geol., X, 1883, p. 396.

Siphouotreta scotica var. canadensis Ami, Ottawa Naturalist, I, 1887, p. 124.

Schizamlon (?) fissus var. cauadensis Hall and Clarke, Pal. New York, VIII, Pt. I, 1892, p. 115, pl. 4, tigs. 32-36.

Loc. Gloucester, Ontario.

Schizambon (?) lockei Winchell and Schuchert.

Lorraine (Ord.).

Schizambon (?) lockii Wiuchell and Schuchert, Minuesota Geol. Survey, III, 1893, p. 362, pl. 30, figs. 8-10.

Loc. Cincinuati, Ohio.

Schizambon typicalis Walcott.

Pogonip or Caleiferous (Ord.).

Sehizambon typicalis Wal'ott, Mon. U. S. Geol. Survey, VIII, 1884, p. 70, pl.1, fig. 3.-Hall and Clarke, Pal. New York, VIII, Pt. I, 1892, p. 114, fig. 65, pl. 4, figs. 27-30.

Loc. Enreka district, Nevada; Maniton, Colorado.

SCHIZOBOLUS Ulrich.

Genotype Discina truncata Hall=Lingula concentrica Vanuxem.

Schizobolus Ulrich, Cont. American Pal., I, 1886, p. 25, pl. 3, tig. 3.-Hall and. Clarke, Pal. New York, VIII, Pt. I, 1892, p1. 87, 165;-Eleveuth Aun. Rep.

N. Y State Geologist, 1894, p. 246.

Schizobolus concentricus (Vanuxem).

Genesee (Dev.).

Lingula concentri'a Vanuxem, Geol. N. Y. ; Rep. 'Thirl Dist., 1812, 1. 168, fig.4.Hall, Geol. N. Y.; Rep. Fourth Dist., 1843, p. 223, fig. 4.

Discina truncata Hall, Sixteenth Rep. N. Y. State Cab. Nit. Hist., 1863, p. 28;Pal. New York, IV, 1867, p. 23, pl. 1, fig. 15; pl. 2, figs. 36, 37.

Discina (Trematis) truneata Hall and Whitfield, Twenty-fourth Rep. N. Y. State Cab. Nat. Hist., 1872, p. 187.

Trematis truncata Hall, Twenty-third Rep. Ibidem, 1873, pl. 13, fig. 20.

Sehizobolus truncatus Ulrich, Cont. American Pal., I, 1886, p. 25, pl.3, fig. 3.Hall and Clarke, Pal, New York, VIII, Pt. I, 1892, p. 87, pl. 3, figs. 11-14.

Loc. Ogdens Ferry, Cayuga Lake, etc., New York; Falls of Ohio; Madison County, Kentucky.

SCHIZOCRANIA Hall and Whitfield. Genotype Orbicula ? filosa IIall. Schizocrania Hall and Whitfield, Pal. Ohio, II, 1875, p. 71.-Hlall and Clarke, Pal.

New York, VIII, Pt. I, 1892, PI. 142, 168. - Winchell and Schuchert, Minnesota Geol. Survey, III, 1893, p. 369.-Hall and Clarke, Eleventh Anı. Rep. N. Y. State Geologist, 1894, 11. 259. 
Schizocrania filosa Hall.

Trenton-Lorraine (Ord.).

Orbicula? filosa Hall, Pal. New York, I, 1847, p. 99, pl. 30, fig. 9.

Trematis filosa Billings, Geol. Canada, 1863, p. 159, fig. 126.-IIall, Twenty-third Rep. N. I. State Cab. Nat. Hist., 1873, pl. 13, figs. 21, 22.

Trematis (?) filosa Miller, Cincinnati Quart. Jour. Sci., II, 1875, p. 15.

Schizocrania filosa Hall and Whitfield, Pal. Ohio, II, 1875, p. 73, pl. 1, figs. 12-15.-Hall and Clarke, Pal. New York, VIII, Pt. I, 1892, p. 143, pl. 4G, figs. 22-30.-Winchell aud Schuchert, Minnesota Geol. Survey, III, 1893, p. 370 , fig. 31 ; pl. 29, figs. 29-31.

Loc. Middleville, Utica, etc., New York; Ottawa, Canada; Cincinnati, Ohio; Caunon Falls and Minneapolis, Minnesota.

Schizocrania (?) helderbergia Hall.

Lower Helderberg (Dev.).

Schizocrania (?) helderbergia Hall and Clarke, Pal. New York, VIII, l’t, I, 1892, pp. 144, 179, pl. 4G, figs. 34, 35.

Loc. Near Clarksville, New York.

Schizocrania (?) rudis Hall.

Trenton (Ord.).

Trematis rudis Hall, Twenty-third liep. N. Y. State Cab. Nat. Hist., 1873, p. 243, pl. 13, fig. 19.

Sehizocrania (?) rudis Hall and Clarke, Pal. New York, VIII, Pt. I, 1892, p. 144, pl. $4 \mathrm{G}$, fig. 21 .

Loc. Clifton, Teunessee.

Schizocrania schucherti Hall and Clarke.

Trenton (Ord.).

Schizocrania schucherti Hall and Clarke, Pal. New York, VIII, Pt. I, 1892, p1. 143, 179, pl. 4G, figs. 31-33.

Loc. Covingtou, Kentneky.

Schizocrania superincreta Barrett.

Lower Helderber@ (Dev.).

Trematis (Schizocrania) superincreta Barrett, Amnals N. I. Acad. Sci., I, 1878, p. 122 .

Schizocrania (?) superiucreta Hall and Clarke, Pal. New York, VIII, Pt. I, 1892, p. 144.

Loc. Port Jervis, New York.

SCHIZOPHORIA King.

Genotype Orthis resupinata (Martin).

Schizoploria King, Mlon. Permian Fossils, l'al. Soc., 1850, 1. 106.-Hall, Bull. Geol. Soc. America, I, 1889, 1. 21.-Hall and Clarke, Pal. New York, VIII, Pt. I, 1892, p. 211 ;-Eleventh Ann. Rep. N. Y. State Geologist, 1894, p. 272.

Schizophoria carinata Hall.

Chemung (Der.).

Orthis carinata Hall, Geol. N. Y.; Rep. Fonrth Dist., 1813, p. 267, fig. 1;-Pal. New York, IV, 1867, p. 58, pl. 8, figs. 30-32;-Second Ann. Rep. N. Y. State Geol., 1883, pl. 36, fig. 22.

Schizophoria carinata Hall and Clarke, Pal. New York, VIII, Pt. I, 1892, 11). 213, 226, pl. 6, fig. 22.

Loc. Painted Post, High Point, etc., New York.

Schizophoria cora (d'Orbigny).

Upper Carboniferous.

Orthis cora d'Orbigny, Voyage dans l'Amérique Mŕridionale, Pal., 1842, p. 48.

Terebratula cora d'Orbigny, Ibidem, 1842, pl. 3, figs. 21-23.

Orthis resupinata var. latirostrata Tonla, Sitzungsb. der k. k. Akad. der Wissensch. zu Wien, LIX, 1869, 1. 8. pl. 1, fig. 7.-Derby, Bull. Coruell ITuiv., I, 1874, p. 63.

Loc. Yarbichambi and Cochabamba, Bolivia.

Schizophoria macfarlani (Meek).

Middle and Upper Devonian.

Orthis macfarlani Meek, Trans. Chicago Acad. Sci., I, 1868, p. 88, pl. 12, fig. 1.Meek and Worthen, Geol. Survey Illiwois, III, 1868, p. 423, pl. 13, fig. 10.- 
Schizophoria macfarlani (Meek)-Continued.

Kayser, Richthofen's China, IV, 1883, p.91, pl.13, fig. 3.-Walcott, Mon. U.S.

Geol. Survey, VIII, 1884, p. 114.

Schizophoria macfarlanii Hall and Clarke, Pal. New York, VIII, Pt. I, 1892, pl). 190, 212, 225, pl. 6A, figs. 28-32.

Loc. Independence, Iowa; Howard and High Point, New York; Markenzie River, Canada; Lower Deronian, Eureka district, Nevada; Sonthwesteru China.

Schizophúria manitobaensis Whiteaves.

Upper Deronian.

Orthis (Schizophoria) manitolensis Whiteaves, Cont. Canadian Pal., I, 1892, p. 283 , pl. 37, figs, $3,4,5$.

Loc. Lake Winnipegosis, Canada.

Schizophoria multistriata Hall.

Lower Helderberg (Dev.).

Orthis multistriata Hall, Tenth Rep. N. Y. State Cab. Nat. Hist., 1857, p. 45, figs. 1, 2 ;-Pal. New York, IIl, 1859, p. 176, pl. 15, fig. 2.

Schizophoria multistriata Hall and Clarke, Ibidem, VIII, Pt. I, 1892, pp. 212, 226 , pl. 6 A, fig. 25.

Loc. Schohario and Catskill, New York.

Schizophoria (?) peduncularis Hall.

Lower Helderberg (Dev.).

Orthis peduncularis Hall, Pal. New York, III, 1859, p. 174, pl. 13, fig. 16.

Schizophoria ? peduncularis Hall and Clarke, Pal. New York, VIII, Pt. I, 1892, p. 226.

Loc. Helderberg Mountains, New York.

Schizophoria propinqua Hall.

Upper Helderberg (Dev.).

Orthis propinqua Hall, Tenth Rep. N. Y. State Cab. Nat. Hist., 1857, p. 110;Pal. New York, IV, 1867, p. 43, pl. 5, fig. 3;-Second Ann. Rep. N. Y. State Geol., 1883, pl. 36, figs. 30, 31.

Schizophoria propinqua Hall and Clarke, Pal. New York, VIII, Pt. I, 1892, pp. 212, 226, pl. 6, fig. 30 .

Loc. New York; Columbus, Ohio.

Schizophoria resupinata (Martin).

Carboniferøns.

Orthis resupinata Hail and Whitfield, King's U. S. Geol. Expl. 40th Parl., IV, 1877 , p. 265, pl. 5, figs. 1,2 .

Schizophoria resupinata Hall and Clarke, Pal. New York, VIII, 1't. I, 1892, pp. $194,213,226$.

Loc. Oquirrh Mountains, Utah; Lake Valley mining district, New Mexico.

Schizophoria resupinoides (Cox).

Upper Carboniferous.

Orthis resupinoides Cox, Owen's Geol. Survey Kentucky, II, 1857, p. 570, pl. 9, fig. 1.-Worthen, Geol. Survey Illinois, VIII, 1890, p. 106, pl. 11, fig. 4.

Orthis resupinoides? White, Wheeler's Expl. and Survey west 100 th Meridian, Appendix, 1881, p. xxiii.

Schizophoria resupinoides Hall and Clarke, Pal. New York, VIII, Pt. I, 1892, pp. $213,226$.

Schizophoria efr. resupinoides Smith, Proc. American Phil. Soc., XXXV, 1897, p. 28 (extract).

Loc. Hancock County, Kentucky; Manuelitos Creek, New Mexico; ? White and Conway counties, Arkansas.

Obs. Probably identical with Schizophoria resupinata.

Schizophoria senecta Hall and Clarke.

Clinton (Sil.).

Orthis (Schizophoria) senecta Hall and Clarke, Pal. New York, VIII, Pt. I, 1892, 1. 343, pl. $6 \mathrm{~A}, \mathrm{figs} .23,24$.

Loc. Reynales Basin, Niagara County, New York. 
Schizophoria striatula (Schlotheim). Middle and Upper Devonian.

Anomia Terebratulites striatulus Schlotheim, Min. Taschenbuch, VIII, 1813, pl. 1, fig. 6 .

Orthis striatnla Davidson, Brit. Devonian Brach., Pal. Soc., 1865, p. 87, pl. 17, figs. 4-7. - Whiteaves (non Schlotheim), Cont. Canadian Pal., I, 1891, pp. $218,283$.

Orthis impressa Hall, Geol. N. X.; Rep. Fourth Dist., 1843, p. 267, fig. 2 ;-Pal. New York, IV, 1867, p. 60, pl. 8, figs. 11-19.-Whitfield, Geol. Wisconsin, IV, 1882, p. 326, pl. 25, figs. 13-15. - Walcott, Mon. U. S. Geol. Survey, VIII, 1884, p. 115, pl. 13, fig. 13.-Kindle, Bull. American Pal., 6, 1896, p. 36.

Orthis lentiformis? Owen (non Hall), Geol. Survey Wiscousin, lowa, Minnesota, 1852, pl. 3, figs. 10, 10a, young specimen. [See specimens in U. S. Nat. Mus., Cat. Invert. Foss., 17918.]

Orthis iowensis Hall, Geol. Survey Iowa, I, Pt. II, 1858, p. 488, pl. 2, fig. 4.Billings, Hind's Rep. Expl. Assiniboine and Saskatch., 1859, p. 187, fig. 1.Meek, Trans. Chicago Acad. Sci., I, 1868, 1. 90, pl. 12, fig. 2.-White, Second Ann. Rep. Indiana Bureat of Statistics and Geol., 1880, p. 501, pl. 5, figs. 10-12;-Tenth Rep. State Geol. Indiana, 1881, p. 133, pl. 5, figs. 10-12.Keyes, Geol. Survey Missouri, V, 1895, p. 62, pl. 38, fig. 6.

Orthis iowensis var. furnarius Hall, Geol. Survey Iowa, I, Pt. II, 1858, p. 489, pl. 2, fig. 5.-Meek and Worthen, Geol. Survey Illinois, III, 1868, p. 424, pl. 13 , fig. 9 .

POrthis iowensis? A. Winchell, Proc. Acad. Nat. Sci. Philadelphia, 1862, p. 410. Orthis propinqua Nettelroth (non Hall), Kentucky Fossil Shells, Mem. Kentucky Geol. Survey, 1889, p. 43, pl. 16, figs. 1-3, 7-11.

Schizophoria iowensis Hall and Clarke, Pal. New York, VIII, Pt. I, 1892, pp. 212, 226 , pl. 6 A, fig. 29.

Schizophoria impressa Hall and Clarke, Ibidem, 1892, pp. 212, 216, pl. 6, fig. 31; 1). $6 \mathrm{~A}$, figs. $26,27$.

Loc. New York; Falls of Ohio; Illinois; Iowa; Milwaukee, Wisconsin; Perry County, Missouri; Eureka distriet, Nevada; Mackenzie River Valley, Northwest Territory, Canada.

Obs. The writer has compared American forms with O. striatula from the Eifel, Germany, and he agrees with authors in regarding both as one species. Orthis (Schizophoria) macfarlani is often found associated with 0 . striatula and may be only a variety of it.

Schizophoria swallovi Hall.

Burlington ( $\mathrm{L}$. Carb.).

Orthis swallovi Hall, Geol. Survey Iowa, I, Pt. II, 1858, p. 597, pl. 12, fig. 5 ;Second Ann. Rep. N. Y. State Geol., 1883, pl. 36, figs. 23, 24.-Keyes, Geol. Survey Missouri, V, 1895, p. 63, 1, 38 , fig. 5.

Schizophoria swallori Hall and Clarke, Pal. Now York, VIII, Pt. I, 1892, pp. 213, 226, pl. 6, figs. 23, 24.

Loc. Burlington, Iowa; Quincy, Illinois; Pike County, Missouri.

Obs. Compare with Rhipidomella clarkensis.

Schizophoria tioga Hall.

Portage and Chemung (Dev.).

Orthis interliueata Hall (non Sowerby), Geol. N. Y.; Rep. Fourth Dist., 1843, p. 267 , figs. 3,4 .

Orthis tioga Hall, Pal. Now York, IV, 1867, p. 59, pl. 8, figs. 20-29;-Second Ann. Rep. N. Y. State Geol., 1883, pl. 36, tigs. 17, 18.-Whitfield, Annals N. Y. Acad. Sci., V, 1891, p. 561, pl. 12, fig. 3;-Geol. Ohio, VII, 1895, p. 453, pl. 8, fig. 3.

Schizophoria tioga Hall and Clarke, Pal. New York, VIII, Pt. I, 1892, pp. 212, 226, pl. 6, figs. 17, 18.

Loc. Factoryville, Elmira, etc., New York; Lake County, Ohio. 
Schizophoria tulliensis ( $V$ anuxem).

Tully (1)ev.).

Orthis tulliensis Vannxem, Geol. N. Y.; Rep. Thirt Dist., 1842, p. 164, fig. 2.Hall, Pal. Now York, IV, 1867, p. 55, pl. 7, fig. 5.-Waleott, Mou. U. S. Geol. Survey, V1I1, 185.1, p. 115, pl. 2, fig. 12.-Willians, Bull. Gool. Soc. Amorica, I, 1890, 1. 492, pl. 12, fig. 16.

Orthis resupinata llall (nou Martin), Geol. N. Y.; Rep. Fourth 1)ist., 1843, p. 215, lig. :-

Orthis (Nehizoploria) tullieusis Hall, Serond Ann. Rep. N. Y. State Geol., 1883, 1. 36 , figs. $25-299$.

Schizophoria tullinnsis 11 all and Clarke, Pal. New York, VIIl, Pt. I, 1892, pp. 212, 226, pl. 6, tigs. 25-29.

Loe. Tully, Tinkers lalls, and Ovid, New York; Eureka district, Nevada.

SCHIZOTRETA Kintorga.

Genotype S. elliptica Kutorga.

Schizotreta Kutorga, Verhand. Kais. Min. Gessel. zu St. Petersburg, V1J, 1848, p. 273.-I Iall and Clarke, Pal. New York, VIII, Pt. 1, 1892, pp. 135, 169.Winchell and Schuchert, Minnesota Geol. Snrvey, HII, 1893, 1. 365.-Hall and Clarke, Eleventh Ann. Rep. N. Y. State Geologist, 1894, p. 257.

Schizotreta conica (Dwight).

Trenton (Ord.).

Orbicnloidea conica Dwight, American Jour. Sci., 3d ser., AIX, 1880, p. 452, pl. 21, figs. 1-11.

Schizotreta conica Ilall and Clarke, Pal. New York, VIII, Pt. I, 1892, pp. 126, 135 , pl. 4E, figs. $6-8$; pl. $4 \mathrm{~F}$, fig. 7 .

Loc. Near Nowburg, New York.

Schizotreta minutula Wincheli and Schnchert.

Lorraine (Ord.).

Schizotreta minntula Winchell and Schuchert, IImuesota Geol. Survey, I11, 1893, I. 366, fig. 28.

Loe. Near Granger, Minuesota.

Schizotreta ovalis Hall and Clarke.

Trenton (Ord.).

Orliculoilea (Schizotreta) ovalis Hall and Clarke, Pal. New York, VIII, Pt. I, 1892, 1. 177, pl. 4E, figs, 4, 5.

Loc. Middleville, New York.

Schizotreta pelopea (Billings).

Trenton and Lorraine (Ord.).

Discina pelopea Billiugs, Pal. Fossils, I, 1862, p. 52, fig. 56;-Geol. Canarla, 1863, p. 159 , fig. 124 .

Discina concortensis sardeson, Bull. Miunesota Acad. Nat. Sci., III, 1892, p. 328, pl. 4, figs. 13,1 .

Schizotreta pelopea, Winchell and Schuchert, Minnesota Geol. Snrvey, III, 1893, 1. 365, pl. 29, figs. 26-28.

Loc. Montreal, Canada; Mautorville, Old Concord, and Spring Valley, Minnesota; Dubuque, Iowa; Neenah, Wisconsin; in the Utica at Ottawa, Canada (Ami).

Schizotreta tenuilamellata (Hall).

Niagara (Sil.).

Orbicula tenuilamellata Hall, Pal. Now York, II, 1852, p. 250, pl. 53, fig. 3.

Discina forbesi Nicholson (non Daviỏson), Pal. Prov. Ontario, 1875, p. 62.

Discina solitaria Ringueberg, American Naturalist, 1882, p. 175, figs. a-e.

Discina elara Spencer, Bull. Univ. State Missouri, 1, 1881, p. 56;-Trans. St. Lonis Acad Sci., IV, 1886, p. 606, pl. 8, fig. 5.

Schizotreta teuuilamellata Beecher, American Jour. Sci., ił ser., XLI, 1891, p. $357, \mathrm{pl}, 17$, fiec. 11.

Orbiculoidea (Schizotreta?) tennilamellata Hall and Clarke, Pal. New York, VIII, Pt. I, 1892, pp. 127, 135, pl. 4 E, figs. 9-11; pl. 4F, figs. 2-6.

Loc. Lockport, New York; Hamilton, Ontario, and Arisaig, Nora Scotia (Ami). 
SELENELLA IIall and Clarke. Genotype S. gracilis Hall and Clarke. Selenella Hall and Clarke, Pal. New York, VIII, Pt. II, 1893, P. 271;-Thirteenth Ann. Rep. N. Y. State Geologist, 1895, p. 855.

Selenella gracilis Hall and Clarke.

Corniferous (Dev.).

Selenella gracilis Hall and Clarke, I'al. New York, VIII, Pt. II, 1893, p. 271, figs. 184-186.

Loc. Ontario.

\section{SEMINULA McCoy emend Hall and Glarke.}

Genotype Terebratula pentiedra Phillips=Athyris ambigua (Phillips).

Semiunla McCoy, Synopsis Carb. Fossils Ireland, 1844, pp. 150, 158.-Hall and Clarko, Pal. New York, VIII, Pt. II, 1893, p. 93;-Thirteenth Ann. Rep. N. Y. State Geologist, 1895 , p. 781.

Seminula argentea (Shepard).

Upper Carboniferous.

Terebratula argentea Shepard, American Jour. Sci., XXXIV, 1838, p. 152, fig. 8.

Terebratula roissyi d’Orbigny (non L'Éveillé), Voyage dàns l'Amériuque Méridionale, Pal., 1842, p. 46.

Terebratula autisiensis d'Orbigny, Ibidem, 1842, p. 46 (non p. 36).

'Terebratula peruviana d'Orbigny, Ibidenı, 1842, p1. 3, figs. 17-19 (non p. 36).

Terebratula subtilita Hall, Stansbury's Exped. Great Salt Lake of Utah, 1852, p. 409, pl. 4, figs. 1, 2.-Shumard, Narey's Rep. U. S. Expl. Red River of Louisiana, 1853, p. 202, pl. 4, fig. 8. -Schiel, l'acific Railroal Rep., II, 1855, p. 108, pI. 1, fig. 2.-Hall, Ibidem, III, 1856, p. 101, pl. 2, figs. 3-5.-Marcon, Geol. N. America, 1858, p. 52, pl. 6, fig. 9.-Hall, Geol. surrey Iowa, I, Pt. II, 1858, 1. 714.

Terobratula (?) subtilita Davidson, Mon. British Carboniferons Brach., Pal. Soc., 1857 , p. 18, pl.1, figs. 21, 22; 1860, p. 86; 186:, p. 217, pl.17, figs. 8-10.

Spirigera subtilita Meek and Hayden, Proc. Acad. Nat. Sci. Philadelphia, 1859, p. 20. - White, Wheeler's Expl, and Survey west of the 100th Meridian, IV, 1875, p. 141, pl. 10, fig. 6 .

Athyris differentis McChesney, New Pal. Fossils, 1860, p. 47.

Athyris subtilita Newberry, Ives's Rep. Colorado River of the West, 1861, p. 126.Salter, Quart. Jour. Geol. Soc. London, XVII, 1861, p. 61, pl. 4, fig. 4.-Geinitz, Carbon und Dyas in Nebraska, 1866, p. 40, pl.3, figs. 7-9.-Ncek, Final Rep. U.S. Geol. Survey, Nebraska, 1872 , p. 180, pl. 1, fig. 12 ; pl. 5, fig. 9 ; pl.8, fig. 4.-Meek and Worthen, Geol. Survey Illinois, V, 1873, p. 570, pl. 25, fig. 14.Derby, Bull. Cornell Univ., I, 1874, p. 7, pl. 1, figs. 5, 8 (not 7 =- Spirigerella (lerbyi); pl. 3, figs. 8, 16, 19; pl. 6, tig. 2; 1)l.9, tig.4.-Meek, Simpson's liep. Expl. Great Basin Terr. Utah, 1876, 1. 350, pl. 2, fig. 4;-Bull. U. S. Geol. and Geogr. Survey Terr., II, 4, 1876, pI. 1, fig. 2.-Derby, Bull. Mus. Comp. Zool., III, 1876, p. 279.-Newberry, Macomb's Rep. Expl. Exped. from Santa Fe to the Great ('oloracle River of the West, 1876, p. 138.-Meek, King's U. S. Geol. Expl. 40th Parl., IV, 1877, 1. 83, pl. 8, fig. 6.-White, Thirteenth Rep. State Geol. Indiana, 1884, p. 136, pl. 35, figs. 6-9.-de Koninck, Anuales du Musće Royal d'Histoire Natmelle de l'elgique, XIV, 1887, p. 73, pl.18, figs. 1-4, 7-10, 12-28; pl. 19, figs. 47-56.-Herrick, Bul\}. Denison Univ., II, 1887, 1. 44, pl. 2, fig. 23.-Keyes, Proc. Acad. Nat. Sci. Philadelphia, 1888, p. 231.Whitfield, Anmals N. Y. Acad. Sei., V, 1891, p. 604, pl. 16, figs. 7-9;-Geol. Ohio, VII, 1895, p. 488, pl. 12, figs. 7-9.

Spirifera (Athyris) subtilita Toula, Sitzungsb. der k. k. Akad. der Wissensch. zu Wien, LIX, 1869, p. 6, pl. 1, fig. 5.

Seminula subtilita Hall and Clarke, Pal. New York, VIII, Pt. II, 1893, p. 95, figs. 66,67 , and 58,59 on p. 86 ; pl. 47 , figs. $17-31$.

Athyris argentea Keyes, Geol. Survey Misseuri, V, 1895, p. 92, pl. 39, fig. 11.

Loc. Thronghout the Upper Carboniferous of North America; Brazil aud Bolivia, South America; England; India; Thibet and Kashmere.

Obs. See Seminula charitouensis, S. caput-serpeutis, S. hawni, and S. singletonii swallow. 
Seminula caput-serpentis (Swallow).

Upper Carboniferous.

Spirigera caputserpentis Swalluw, Trans. St. Louis Acad. Sci., 11, 1863, p. 90.

Loc. Missomri and Kansas.

Obs. Regarled hy Keyes as a synonym for S. argeuter.

Seminula charitonensis (Swallow).

Upper Carboniferous.

Spirigera charitonensis Swallow, Trans. St. Louis Acarl. Sci., I, 1860, p. 651.

Loc. Chariton and Randolph connties, Missouri.

$O b$. Probably a synonym for Seminula argentea.

Seminula claytoni (Hall and Whitfield).

Kinderhook (L. Carb.).

Athyris claytoni Hall and Whitfield, King's U. S. Geol. Expl. 40th Parl., IV, p. 256, $187 \pi$, pl. 4, figs. 15-17.

Loc. Little Cottonwood, Wasatch Range, Itah.

Seminula dawsoni Hall and Clarke.

Upper Carboniferous.

Athyris subtilita Davidson (non Hall), Qnart. Jour. Geol. Soc. Loudon, XIX, 1863, p. 170, pl. 9, figs. 4, 5.-Dawson, Acadian Geology, 3il ed., 1878, p. 290, fig. 88 .

Seminula dawsoni Hall and Clarke, Pal. New York, VIII, Pt. II, 1895, pp. 95, 96, 364 , figs. 69-71; pl. 47, figs. 32-34.

Loc. Windsor, Nova Scotia.

Seminula formosa (Swallow).

Keokuk (L. Carb.).

Spirigera formosa and enzona Swallow, Trans. St. Louis Acad. Sci., II, 1863, p. 91. Athyris formosa Keyes, Geol. Survey Missouri, V, 1895, p. 91.

Loc. Boonville, Missonri.

Seminula hawni (Swallow).

Upper Carboniferous.

Spirigera hawni swallow, Trans. St. Lonis Acal. Sci., I, 1860, p. 652.

Loc. Missonri.

Obs. Probably a synonym for Seminula argentea.

Seminula maconensis (Swallow).

Upper Carboniferons.

Spirigera maconcusis Swallow, Trans. St. Louis Acad. Sci., I, 1860, 1) 651.

Loc. Montgomery County, Missouri.

Seminula parva (Swallow).

Keokuk (L. Carb.).

Terebratula parva Swallow (non d'Archiac, 1846), Trans. St. Lonis Acal. Sci., II, 1863, p. 83.-Keyes, Geol. Survey Hissonri, V, 1895, p. 105.

Terebratula cooperensis Miller, N. American Geol. and Pal., 1889, p. 384.

Loc. Keokuk, Iowa; Monroe and Cooper connties, Missonri.

Obs. Specimens of this species in Professor Hall's collection seen ly the writer do not'show a punctate shell structure, but are distinctly fibrous.

Seminula persinuata (Meek).

Carboniferous.

Athyris (?) persinnata Meek, King's U. S. Geol. Expl. 40th Parl., IV, 1877, p. 81, pl. 9, fig. 4 .

Loc. White Pine district, Nevada.

Seminula (?) plattensis (Swallow).

Upper Carboniferous.

Spirigera plattensis Swallow, Trans. St. Lonis Acad. Sci., II, 1863, p. 87.

Loc. Missouri; Kansas; Nebraska.

Seminula (?) rogersi II all and Clarke.

Upper Helderberg (Dev.).

Seminula rogersi Hall and Clarke, Pal. Now York, VIIl, Pt. II, 1895, pp. 97, 364, pl. 47, figs. 1-4.

Loc. Pendleton, Indiana.

Seminula singletonii (Swallow).

Upper Carboniferous.

Spirigera singletonii Swallow, Trans. St. Lonis Acad. Sci., II, 1863, p. 87.

Loc. Boone and Andrain counties, Missouri.

Obs. Probably a synonym for Seminula argentea. 
Seminula subquadrata Hall.

Kaskaskia (L. Carb.).

Athyris subquadrata Hall, Geol. Survey Iowa, I, Pt. II, 1858, p. 703, pl. 27, fig. 2, woodent p. 708.-Whitield, Anuals N. Y. Aead. Sci., V, 1891, p. 585, pl. 14, figs. 1-3;-Geol. Ohio, VII, 1895, 1. 472, pl. 10, figs. 1-3.-Keyes, Geol, Survey Missonri, V, 1895 , p. 92.

Athyris subquadrata? Hall and Whitfield, King's U. S. Geol. Expl. 40th Parl., IV, 1877, p. 271, pl. 5, figs. $19,20$.

Seminula subquadrata IIall and Clarke, Pal. New York, VIII, Pt. II, 1893, p. 95, pl. 47 , figs. $7-9,15,16 ;$ pl. 84 , figs. 30,31 .

Loc. Chester, Illinois; Crittenden County, Kentucky; Newtonville and Maxville, Ohio; Oquirrh Mountains, Utah.

Obs. See Cleiothyris elintonensis.

Seminula titicacaensis (Gabb).

Upper Carboniferous.

Terebratula titicacensis Gabb, Jour. Aead. Nat. Sci. Philadelphia, 2d ser., VIII, 1881, p. 302, pl. 42, fig. 11.

Loc. Lake Titicaca, Bolivia.

Seminula trinucleus Hall.

St. Louis (L. Carb.).

Terebratula trinuelens Hall, Trans. Albany Institute, IV, 1858, p. 7 ;-Geol. Survey Iowa, I, Pt. II, 1858, p. 659, pl. 23, figs. 4, 5.

Athyris trinuclea Whitfield, Bull. Ameriean Mus. Nat. Hist., I, 1882, p. 50, pl. 6, figs. 22-27.-Hall, Twelfth Rep. State Geol. Indiana, 1883, p. 329, pl. 29, figs. $22-27$.

Seminula trimuelea Hall and Clarke, Pal. New York, VIII, Pt. II, 1893, pp. 94, 95, fig. $65 ; \mathrm{pl} .47$, figs. $5,6,10-14$.

Loc. Bloomington and Spergen Hill, Iudiana; Alton, Illinois; Boonville, Missonri; Princeton, Kentueky.

Obs. See Cleiothyris rellexa.

Seminula wasatchensis (White).

Upper Carboniferous.

Rhynehonella wasatehensis White, Wheeler's Expl. and Survey west of 100th Meridian, Prel. Rep. 1874, p. 19;-Ibidem, Final Rep., 1875, p. 130, pl.9, fig. 3.

Loc. Wasatch Range, near Provo, Utah.

Obs. Is related to S. subtilita. The great anterior thickening is due to old age.

Sieberella CEhlert, and Hall and Clarke=Gypidula.

Obs. It may prove that Sieberella will be useful as a subgenus of Gypidula.

SIPHONOTRETA de Vern. Genotype Crania unguiculata Eichwald.

Siphonotreta de Vernenil, Géol. de la Russie d'Europe et des Mont. de l'Oural, II, 1845, p. 286.-Dall, Bull. U. S. Nat. Nus., 8, 1877, p. 62.-Hall and Clarke, Pal. New York, VIII, Pt. I, 1892, pp. 110, 167.-Winehell and Schuehert, Minuesota Geol. Survey, III, 1893, p. 358.-Hall and Clarke, Eleventh Ann. Rep. N. Y. State Geologist, 1894, 1. 252.

Siphonotreta (?) micula McCoy.

Calciferous (Ord.).

Siphonotreta? mieula Ami, Rep. Progress Geol. Nat. Hist. Survey Canada for $1887-88,1889$, ग. $52 \mathrm{~K}$.

Loc. Great Britain; near Laevis, Canada.

Siphonotreta (?) minnesotaensis Hall and Clarke.

Trenton (Ord.).

Siphonotreta ? minnesotensis Fall and Clarke, Pal. New York, VIII, Pt. I, 1892, pp. 112, 177, pl. 4, figs. 37, 38.-Winchell and Sehuehert, Miuuesota Geol.

Survey, III, 1893, p. 358 , pl. 29, figs. $23,24$.

Loc. Minneapolis, Minnesota.

Siphonotreta scotica Whiteaves=Schizambon ? fissus americanus.

SPHÆROBOLUS Matthew. Genotype Lingulella ? spissa Billings. Sph:erobolus Matthew, Trans. Royal Soe. Canada, 2d ser., I. 1896, 1. 263. 
Sphærobolus spissus (Billings).

Lower Ordovician.

Lingulella ? spissa l3illings, Canadian Nat. Geol., 1t, ser., VI, 1872, 1. 468, fig. 5 ;-l'al. Fossils, II, 1874, p. 67, fig. 36.

Splur robolus spissis Matthew, Trans. Royal Sor. ('anada, 2 s ser., I, 1896, p. 263, pl. 1, fig. 5.

loc. Bell Island, Newfoundland.

SPIR.FER Sowerby.

Genotype Anomites striatus Martin.

Spirifer Sowerloy, Mineral Conehology, II, 1815, r. 11.-Billings, Canadian Nat.

Geol., I, 1856, p. 134. -Meek and Hayden, Pal. Upper Missouri, Smithsonian

Cont. to linowlerlge, XIY, 172, 1864, 1. 17.-Mall and Clarke, PaI. New York,

VIII, J't. II, 1893, PI. 1-40;-Thirteenth Anu. Rep. N. Y. State Geologist, 1895, 1. 751 .

Spirifera Billings, Canadian Journal, VI, 1861, 1. 253.-Hall, Twentieth Rep. N.

Y. State Calo. Nat. IIist., 1867, p. 251 ;-Pal. New York, IV, 1867, p. 186.White, Wheeler's Expl. and Survey west of the 100th Merid., 1875, p. 90.IIerrick, Bull. Denison University, IV, 1888, p. 14.-Nettelroth, Kentncky Fossil Shells, Mem. Kentucky Geol. Survey, 1889, p. 105.-Hall, Bull. Geol. Soc. America, I, 1890, p. 567 ;-Ninth Ann. Rep. N. Y. State Geol., 1890, 1. 9.

Spirifer acanthopterus (Conrad).

? Hamilton (Dev.).

Delthyris acanthoptera Courad, Jour. Acad. Nat. Sei. Philadelphia, VIII, 1842, p. 264.

Loc. Oneontal, Otsego Countr, New York.

Spirifer acuminatus (Conrad).

Corniferous and Hamilton (Dev.).

Deltbyris acuminata Courar, Third Ann. Rep. N. Y. Geol. Survey, 1839, p. 6..

Delthyris prora Conrad, Jour. Acad. Nat. Sci. Philadelphia, VIII, 1842, p. 263.

Terebratula acmuinatissima Castelnan, Essai Syst. Silurien l'Amérique Septentrionale, 1843, p. 40, pl. 14, fig. 16.

Spirifer 'ultrijugatus Yanilell and Shumard (non Roemer, 1844), Cont. Geol. Kentucky, 1817, p. 10.

Spirifer acuminata Hall, Tenth Rep. N. Y. State Cab. Nat. Hist., 1857, 1. 135.

Spirifera acuminata Hall, Pal. New York, [V, 1867, p], 198, 231, pl. 29, figs. 9-18; pl. 35, fig. 24.-Nettelroth, Kentucky Fossil Shells, Mem. Kentucky Geol. Survey, 1 889 , p. 105, 11. 8, figs. 1-8.

Spirifer acnminatus White, Second Rep. Indiana Burean of Statisties and Geol., 1880, p. 503, pl. 4, figs. 1-3;-Tenth Rep. State Geol. Indiana, 1881, p. 135, pl. 4, figs. 1-3.-Hall and Clarke, Pal. New lork, V'IIl, Pt. 1I, 1893, pp. 31, 39, pl. 39 , figs. 39-42.

Loc. Schoharic, Williamsville, Clarence Hollow, Hamilton, Madison, etc., New York; Columbus and Sandusky, Ohio; Falls of Ohio.

Spirifer acuticostatus de Koninek.

Upper Carboniferons.

Spırifer acuticostatus de Koninck, Animanx Fos. Carls. Belgique, p. 265, pl. 17, fig. 6.

Spirifera acnticostata Davidson, Quart. Jour. Geol. Soe. London, XIX, 1863, p. 171, 1,1. 9, figs. 7, 8.-Dawson, Acadian Geol., 3ł ed., 1878, p. 292, fig. 91.

Loc. Europe; Brookfield and Shnbenacadie, Nova Scotia.

Spirifer agelaius Meek.

Lower Carboniferons.

Spirifer triralialis? Meek (non Phillips), Sixth Ann. Rep. U. S. Geol. Survey Terr., 1873, p. 470.

Spirifer agelaius Meek, Ibidem, 1873, p. 470, footuote.-White, Twelfth Aun. Rep. U. S. Geol. Surrey Terr., 1883, p. 135, pl. 34, fig. 10.

Loc. Near Virginia City, Montana.

Spirifer alatus Casteluau (non Schlotheim)=Spirifer aliformis. 
Spirifer aliformis de Verneuil.

Upper Helderberg (Dev.).

Spirifer alatus Castelnau (non Schlotheim), Essai Système Silurien l'Amérique Septentrionale, 1843 , p. 42 , pl. 12 , fig. 4.

Spirifer alæformis de Verneuil, Ibidem, 1843, 1. 42 , footnote.

Loc. Schoharie, New York.

Obs. Compare with Spirifer arenosus.

Spirifer alba-pinensis Hall and Whitfield.

Kinderhook (L. Carb.).

Spirifera albapinensis Hall and Whitfield, King's U. S. Geol. Expl., 40th Parl., IV, 1877, p. 255, pl. 4, figs. 7,8 .

Loc. Wasatch Range, Utah.

Obs. Appears to be a synonym of $\$$. centronatus.

Spirifer aldrichi Etheridge.

Devollian.

Spirifer aldrichi Etheridge, Quart. Jour. Geol. Soc. London, XXXIV, 1878, p. 634, pl. 29, fig. 2 .

Loc. Dana Bay, lat. $82^{\circ} 42^{\prime}$.

Spirifer alta $\mathrm{Hall}=$ Cyrtia alta.

Spirifer amarus Swallow.

Hamilton (Dev.).

Spirifer amarus Swallow, Trans. St. Louis Acad. Sci., I, 1860, p. 642.

Loc. On page 658 it is given as Callaway County, Missouri, in association with Hamilton terrane fossils. It is probably the same as $\mathrm{S}$. annie Swallow.

Spirifer angustus Hall.

Hamilton and Portage (Dev.).

Spirifer angusta Hall, Tenth Rep. N. Y. State Cab. Nat. Hist., 1857, p. 164, fig. in text.

Spirifera angusta Hall, Pal. New York, IV, 1867, p. 230, pl. 38A, figs. 23-32.Whittield, Geol. Wisconsin, IV, 1882, p. 329, pl. 26, fig. 3.-Hall, Second An». Rep. N. Y. State Geol., 1883, pl. 54, figs. 11-17.

Spirifer augustıs Hall and Clarke, Pal. New York, VIII, Pt. II, 1893, pp. 31, 39, pl. 24, tigs. 14-17.

Loc. Livingston and Genesee counties, and Ithaca, New York; Portage group of New York (Williams); Milwaukee, Wisconsin.

Spirifer annæ Swallow.

Hamilton (Dev.).

Spirifer anne Swallow, Trans. St. Louis Acad. Sci., I, 1860, p. 611.

Loc. Callaway County, Missouri.

Obs. See S. amarus.

Spirifer annectans Walcott.

Lower Carboniferous.

Spirifera annectans Walcott, Mon. U. S. Geol. Surrey, VIII, 1884, p. 216, pl. 18, fig. 7 .

Loc. Eureka district, Nevada.

Spirifer antarcticus Morris and Sharpe.

Lower Devonian.

Spirifer antarcticus Morris and Sharpe, Quart. Jour. Geol. Soc. London, II, 1846, p. 276 , pl. 11, fig. 2.

Loc. Falkland Islands.

Obs. Compare with S. boliviaensis, S. chuquisaca, and S. orbignyi.

Spirifer arata Hall=Spirifer granulosus.

Spirifer arcticus Houghton.

Devonian.

Spirifer areticus Houghton, Jour. Royal Dublin Soc., I, 1857, 1. 183.

Obs. The writer has not seen this journal.

Spirifer arctisegmentum Hall.

Upper Helderberg (Dev.).

Spirifer aretisegmenta Hall, 'Teuth Rep. N. Y. State Cab. Nat. Hist., 1857, 1. 131. Spirifera aretisegmenta Hall, Pal. Now York, IV, 1867, p. 208, pl. 31, figs. 9, 10;- 


\section{Spirifer arctisegmentum Hall-Continued.}

Second Ann. Rep. X. Y. State Gcol., 1883, pl. 59, figs. 10-12.-Nettelroth, Kentucky Fossil Shells, Mem. Kontucky Geol. Surves, 1889, p. 108, pl. 12, figs. $14,15$.

Spirifer arctisegmentus Hall and Clarke, Pal. New York, VIII, Pt. II, 1893, p. 36, pl. 3 !, figs. $10-12$.

Lor. Stafford and Cenesee counties, New York; Fulls of Ohio.

Spiriter arenosus (Comad). Oriskany and Corniferous (Dev.).

Delthyris arenosa Conad, Third Ann. Rep. N. Y. Geol. Survey, 1839, p. 65.Mather, Geol. N. I.; Rej. First Dist.. 1843, p. 342, fig. 1.-Hall, Ibidem, Rep. Fourth Dist., 1843, p. 148, fig. 1.

Delthyris arenaria Vannem, Geol. N. Y.; Rep. Third Dist., 1842, p. 123, fig. 1; p. 124 , fig. 5 .

Spirifer arenosa Rogers, Geol. Pennsylvania, II, Pt. II, 1858, p. 826, fig. 650.Hall, Pal. New York, III, 1859, p. 425, pl. 98, figs. 1-8; Il. 99, figs, 1-10; pl. 100 , figs. 1-8.

Spirifera arenosa Billings, Gcol. Canada, 1863, p. 960, fig. 465.-Hall, Second Anu. Rep. N. Y. State Geol., 1883, pl. 55, figs. 3-7.

Spirifera unica IIall, Pal. New York, IV, 1867, p. 203, pl. 30, fig. 21; pl. 55, fig. 8.

Spirifer arenosus Hall and Clarke, Pal. New York, VIII, Pt. II, 1893, pp. 24, 27, 37, pl. 29, figs. 1-4; pl. 30, figs. 3-8.

Loc. Schoharie, Clarence Hollow, etc., New York; Cumberland, Maryland; Virginia; Frankstown, Penusylvania; Cayuga, Ontario.

Spirifer argentarius Meek =Spirifer pinonensis.

Spirifer arrectus Hall=Spirifer murchisoni.

Spirifer asper Hall.

Hamilton (Dev.).

Spirifer aspera Hall, Geol. Survey Iowa, 1, Pt. II, 1858, p. 508, pl. 4, fig. 7.

Spirifera (Cyrtina) aspera Whitfield, Geol. Wisconsin, IV, 1882, p. 331, 11. 26, figs. 1,2 .

Spirifer asper Hall and Clarke, Pal. New York, VIII, Pt. II, 1893, pp. 29, 31, 32, 39 , pl. 25 , figs. $20-25$.

Loc. Inclependence and Rockford, Iowa ; Rock Island, Illinois ; Milwaukee, Wisconsin; Canaudaigua, New York.

Spirifer asperatus Ringueberg.

Niagara (Sil.).

Spirifera asperata Ringueberg, Bull. Buffalo Soc. Nat. Sci., V, 1886, p. 16, pl. 2, fig. 5.

Loc. Lockport, New York.

Spirifer atwateranus Miller $=$ Spirifer iowaensis.

Spirifer audaculus (Conrad). Marcellus and Hamilton (Dev.).

Delthyris andacula Conrad, Jour. Acad. Nat. Sci. Philadelphia, VIII, 1842, p. 262.

Delthyris medialis Hall, Geol. N. Y.; Rep. Fourth Dist., 1843, p. 208, fig. 8.Rogers, Geol. Pennsylvania, II, Pt. II, 1858, p. 828, fig. 669.

Spirifer eatoni Hall, Tenth Rep. N. Y. State Cal. Nat. Hist., 1857, p. 157.

Spirifer medialis Hall, 1bidem, 1857, p. 164, fig. 1.

Spirifera medialis Hall, Pal. New York, IV, 1867, p. 227, pl. 38, figs. 1-25,Second Anu. Rep. N. Y. State Geol, 1883, pl. 54, figs. 1-13.-Nettelroth, Kentucky Fossil Shells, Mem. Kentucky Geol. Survey, 1889, p. 125, pl. 26, figs. 2-5. Spirifera medialis var, eatoni Hall, Pal. New York, IV, 1867, pl. 38, figs. 12-18.

Spirifera andacula Whitfield, Geol. Wisconsin, IV, 1882, p. 329, pl. 25, figs. 25, 26.

Spirifer andaculus Ifall and Clarke, Pal. New York, VIII, Pt. II, 1893, pp. 29-31, 39, pl. 24, figs. 1-13; pl. 29, fig. 5.

Loc. Otsego, Cayuga, Moscow, Darien, ete., New York; Falls of Ohio; Milwaukee, Wisconsin. 
Spirifer audaculus macronotus Hall.

Hamilton (Dev.).

Delthyris macronota Hall, Geol. N. Y. ; Rep. Fonrth Dist., 1843, p. 206, fig. 5.

Spirifera macronota Hall, Pal. New York, IV, 1867, p. 231, pl. 38A, figs. 1-22 ;Second Amu. Rep. N. Y. State Geol., 1883, pl. 51, figs. 18-27.

Spirifer audaculus var. macronotus Hall and Clarke, Pal. New York, VIII, Pt. II, 1895, pl. 24, figs. 18-27.

Loc. Bristol, Moscow, Darien, etc., New York.

Spirifer buarquianus Rathbun.

Middle Devonian.

Spirifera buarquiana Rathbun, Proc. Boston Soc. Nat. Hist., XX, 1879, p. 28.

Loc. Rio Maecurn, Province of Para, Brazil.

Spirifer belphegor Clarke.

Genesee (Dev.).

Spirifera belphegor Clarke, Bull. U. S. Geol. Survey, 16, 1885, p. 30, pl. 3, fig. 13.

Loc. Ontario County, New York.

Spirifer bicostatus Hall=Reticulara bicostata.

Spirifer bicostatus var. petilus Hall=Reticularia bicostata petila.

Spirifer bidorsalis Winchell.

Hamilton (Dev.).

Spirifera bidorsalis A. Winchell, Geol. Rep. Lower Peninsuta of Michigan, 1866, p. 93.

Loc. Grand Traverse district, Michigan.

Spirifer biforatus var. lynx Ball=Platystrophia biforata.

Spirifer bifurcatus Hall=Spirifer leidyi.

Spirifer billingsanus Miller.

Oriskany (Der.).

Spirifera superba Billings (non Eichwald), Pal. Fossils, II, 1874, 1. 45, pl. 3A, fig. 3 .

Spirifera billingsana Miller, N. American Geol. Pal., 1889, p. 372.

Loc. Indian Cove, Gaspé.

Spirifer bilobus Hall=Bilobites bilobus.

Spirifer bimesialis Hall.

Upper Devonian.

Spirifer bimesialis HalI, Geol. Survey Iowa, I, Pt. II, 1858, p. 507, pl.4, fig. 6.一 Hall and Clarke, Pal. New York, VIII, J't. II, 1893, pp. 17, 36, pl. 34, figs. 23-26.

Spirifera bimesialis Hall, Second Ann. Rep. N.Y. State Geol, 1883, pl.59, figs. $23-26$.

Loc. Independence, Iowa; Naples, New York (Clarke).

Spirifer biplicatus Meek (non Hall)=Spirifer centronatus.

Spirifer biplicatus Hall.

Kinderhook (L, Carb.).

Spirifer biplicata Hall, Geol. Survey Iowa, I, Pt. II, 1858, p. 519, pl. 7, fig. 5.

Spirifera biplicata Herrick, Bull. Denison Univ., III, 1888, p. 45; IV, 1888, p. 25, pl. 2, fig. 8 .

Spirifer biplicatus Herrick, Geol. Ohio, VII, 1895, pl. 15, fig. 8.

Loc. Burlington, Iuwa; Quincy, Illinois; Richtield, etc., Ohio.

Spirifer boliviaensis d'Orbigny.

Devonian.

Spirifer boliviensis d'Orbigny, Toyage dans l'Amérique Méridionale, Pal., 1842, p. 37, pl. 2, figs. 8,9 .

Loe. Cochabamba and Chnquisaca, Bolivia.

Obs. Compare with S. antarcticus and S. hawkinsi.

Spirifer boonensis Swallow.

Upper Carboniferous.

Spirifer booensis Swallow, Trans. St. Lonis Acad. Sci., I, 1860, p. 616.

Loc. Boone, Randolph, and Monroe counties. Missouri.

Obs. Regarded by Kieyes as a synonym for S. rockymontanus. 


\section{Spirifer byrnesi Nettelroth.}

Hamilton (Jev.).

Spirifera byrnesi Nettelroth, kentucky Fossil Shells, Mem. Kentucky Geol, Survey, 1889 , p. 109, pl. 10, figs. 1-5?, 31-31, 36-39.

Loc. Falls of Ohio.

\section{Spirifer cameratus Derby (non Morton)=Spirifer. condor.}

\section{Spirifęr cameratus Morton.}

Upper Carboniferous.

Spírifer cameratus Morton, Americau Jour. Sci., XXIX, 1836, P. 150, 1]. 2, fig. 3.-

IIall, Pacifie Railroad Reports, III, 1856, p. 102, pl. 2, ligs. 9, 12;-Geol. Survey Iowa, 1, l't. II, 1858, p. 709, pl. 28, fig. 2.-Goinitz, Carbon und Dyas in Nebraska, 1866, 1. 44.-Meck, Final Rep. U. S. Geol. Surrey Nebraska, 1872, p. 183, 11. 6, fig. 12; pl. 8, fig. 15.-Meek and Worthen, Geol. Survey llinois, V, 1873, p. 573, pl. 25, fig, 7.-Tonla, Nenes Jahrbueh f. Mineral., 1874, p. 240 ;-Sitzungsb. der Kais. Akad. der Wissen. zu Wien, 1875, p. 513. -White, Wheeler's Expl. Survey west 100th Merislian, IV, 1875, p. 132, pl. 10, fig. 1.-Newberry, Macomb's Rep. Expl. Exped. from Santa Fe to the Great Colorado River of the IVest, 1876, p. 138.-Meek, Simpson's Rep. Exp]. Great Basin Terr. Utah, 1876, p. 353, 11. 2, fig. 3.-Ha!l and Clarke, lal. New York, VIII, l’t. II, 1893, pp. 26, 38, pl. 32, figs. 9-15.

Spirifer mensebachanus Roemer, líreidebildung 'Texas, 1852, p. 88, pl. 11, fig. 7. Spirifer triplicatus IIall, Stansbury's Expl. Survey of the Valley of Great Salt Lake, Utah, 1852, p. 410, pl. 4, fig. 5.

Spirifer inequicostatus? Owen, Geol. Survey Wisconsin, Iowa, and Miunesota, 1852, p. 586, pl. 5, fig. 6. [See specimens in U. S. Nat. Mus., C'at. Invert. Foss., 17954.]

Spirifer fasiger Owen (nou Koyserling), Ibidem, 1852, pl. 5, fig. 4.

Spirifer striatus var. triplicatus Marcou, Geol. N. Ameriea, 1858, p. 49, p]. 7, fig. 3 .

Spirifer species Rogers, Geol. Pennsylvania, II, Pt. II, 1858, p. 833, fig. 694.

Spirifer eimerata Meek and Hayden, Proc. Acad. Nat. Sci. Philadelphia, 1859, p. 27.

Spirifera eamerata Newberry, Ives's Rep. Colorado River of the West, 1861, p. 127.-White, Second Ann. Rep. Indiana Burean Statistics and Geol, 1880, p. 517, pl. 8, fig. 3;-Teuth Rep. State Geol. Indiana, 1881, p. 149, p]. 8, fig. 3.-Hail, Seeond Ann. Rep. N. Y. State Geol., 1883, pl. 57, figs. 9-15.White, Thirteenth Rep. State Geol. Indiana, 1884, p. 132, pl. 35, figs. 3-5.Herrick, Bull. Denison Univ., I1, 1887, 1. 45, pl. 2, fig. 2צ.-Kę̧es, Proe. Acad. Nat. Sci. Philadelphia, 1888, 1, 230;-Geol. Survey Missouri, V, 1895, p. 83 , pl. 40 , fig. 5 .

Spirifera camerata var. kansasensis Swallow, Trans. St Louis Acad. Sci., II, $1867,1.109$.

Spirifer (Trigonotreta) eamerata Neek, King's U. S. Geol. Expl. 40th Parl., IV, 1877, p. 91, pl. 9, fig. 2.

Loc. Putnam Hill, Ohio; throughout the Upper Carboniferous of North America; western side of Spitzbergen (Tonla).

Obs. S. caneratus is often regarderl as identical with S. striatus (Martiu). The latter species, however, is closely and finely reticulated with concentric growth lines, while in S. cameratus the plications are crowder with small pustules arranged in radiating lines. See S. condor and S. striatus.

\section{Spirifer cameratus var. kansasensis Swallow =Spirifer cameratus.}

\section{Spirifer cameratus percrassus Swallow.}

Upper Carboniferous.

Spirifer cameratus var, percrassus Swallow, Trans. St. Louis Acad. Sci., II, 1866, p. 409.

Loc. Missouri and liansas.

Ob8. Regarded by kieyes as a synonfin for S. cameratus. 
Spirifer capax Hall=Spirifer euryteines.

Spirifer canandaiguæe Hall and Clarke=Reticularia canandaiguæ.

Spirifer carteri Hall=Syringothyris carteri.

Spirifer carteri Meek (non Hall)=Syringothyris texta.

Spirifer catskilleusis Emmons=Spirifer mesistrialis.

Spirifer cedarensis $\mathbf{O}$ wen $=\mathrm{S}$. iowaensis.

Spirifer centronatus A. Winchell.

Waverly (L. Carb.).

Spirifer centronatus A. Winchell, Proc. Acad. Nat. Sci. Philadelphia, 1865, p. 118. -White, Wheeler's Expl. Snrrey west 100th Merid., IV, 1875, p. 86, pl. 5 , fig. 8 .

Spirifera (Trigonotreta) biplicata (Hall??) Meek, Pal. Ohio, II, 1875, p. 290, pl. 14, fig. 5 .

Spiriferi centronata Hall and Whitfield, King's U. S. Geol. Expl. 40th Parl., IV, 1877 , p. 254, pl. 4, figs. 5,6 .

Loc. Cuyahoga Falls, Ohio; Black Hills, South Dakota; Wasatch Range, Utah; Mlountain Spring, Nevada; Yellowstone Park.

Obs. See S. alba-pinensis.

Spirifer chileusis Forbes=Spiriferina rostrata.

Spirifer chuquisaca A. Ulrich.

Middle Devonian.

Spirifer chuquisaca A. Ulrich, N. Jahrb. f. Mineral., Beilageband, VIII, 1892, p. 65, pl. 4, figs. 19, 20.

Loc. Chahuarani, Tarabneo, etc., Bolivia.

Obs. Compare with S. boliviaensis and S. antareticus.

Spirifer clarus Swallow=Reticularia clara.

Spirifer clavatulus IICChesney.

Burlington (L. Carb.).

Spirifera clavatula McChesney, New Pal. Fossils, 1861, p. 81;-Trans. Chicago Acall. Sci., I, 1868, p. 36, pl. 6, fig. 5 .

Loc. Burlington, Iowa.

Spirifer clintoni Hall=Spirifer granulosus.

Spirifer clio Hall=Delthyris consobriua.

Spirifer compactus Meek=Reticularia fimbriata.

Spirifer concinnus Hall.

Lower Helderberg (Dev.).

Spirifer concinna Hall, Tenth Rep. N. Y. State Cab. Nat. Hist., 1857, p. 60, figs. 1-3.

Spirifera concinna Hall, Pal. New York, III, 1859, p. 200, pl. 25, fig. 2; pl. 28, fig. 7;-Second Ann. Rep. N. Y. State Geol., 1883, pl. 55, figs. 1, 2.

Spirifer concinnus Hall and Clarke, Pal. New York, VIII, Pt. II, 1893, pp. 24, 27, 38, pl. 30, figs. 1, 2.

Loc. Helderberg Mountains, New York.

Spirifer condor d'Orbigny.

Upper Carboniferous.

Spirifer condor d'Orbigny, Voyage dans l'Amérique Méridionale, Pal., 1842, p. 46, pl. 5, figs. 11-14.-Waagen, Palæontologica Indica, Ser. XIII, I, 1883, p. 514.

Spirifer striatus var. multicostatus Toula, Sitzungsb. der kais. Akad. der Wissensch. zu Wien, 1869, p. 3, pl. 1, tigs. 2-4.

Spirifera camerata Derby (non Morton), Bull. Cornell Unir., I, 1874, p. 12, pls. 1, 2, 4, 5;-Bull. Mus. Comp. Zool., III, 1875, p. 279.

Loc. Bolivia; Bomjardim and Itaituba, Brazil; Yampopata and the Island of Titicaca, Bolivia; Pichis River, Peru.

Bull. 87-_25 
Spirifer condor d'Orbigny-Continued.

Obs. "It has for a long time been considered a synonym of S. striatus and later of S. cameratus. It is distinct, however, from the former by the lamellose stria of growth and from the latter by these as well by the nearly entire absence of bundling of the ribs" (Waagen).

Snirifer comadaums Miller=Reticularia timbriata.

Sp'irifel consobrina d'Orbiguy = DeIthyris consobrina.

Spirifer consors A. Winchell.

Hamilton (Dev.).

Spirifer consors A. Winchell, Geol. Rep. Lower Peninsula of Michigau, 1866, p. 93.

Loc. Grand Traverse district, Michigan.

Spirifer cooperensis Waagen=Reticularia cooperensis.

Spirifer corticosus Hall.

Hamilton (Dev.).

Spirifer corticosa Hall, Tenth Rep. N. Y. State Cab. Nat. Hist., 1857, p. 160.

Spirifera corticosa IHall, Pal. Now York, IV, 1867, [b. 236.

Loc. Cumberland, Maryland.

Obs. Compare with S. granulosus.

Spirifer(?) costalis Castelnau.

? Upper Helderberg (Dev.).

Spirifer costalis Castelnau, Essai Systéme Silurien l'Amérique Septentrionale, 1843, p. 41 , pl. 14, fig. 7 .

Loc. Schoharie, New York.

Spirifer crispatus Ball and Clarke.

Niagara (Sil.).

Spirifer crispatus Hall and Clarke, Pal. New York, VIII, Pt. II, 1895, p. 360, pl. 36, figs. $9,10$.

Loc. "Maryland."

Spirifer crispus (Hisinger).

Niagara and Coralline (Sil.).

Terebratula crispa Hisinger, Svenska Vet.-Akad. Handlingar, 1826, tab. 7, tig. 4.

Delthyris staminea Hall, Geol. N. I. ; Rep. Fourth Dist., 1843, p. 105, fig. 3.

Spirifer crispus Hall, American Jour. Sci., XX, 1849, p. 228;-Pal. New York, II, 1852, p. 262, pl.54, fig. 3; p. 328, pl. 74, fig.9.-Beecher and Clarke, Mem. N. Y. State Mus., I, 1889, p. 75, pl. 6, figs. 6, 7.-Hall and Clarke, Pal. New York, VIII, Pt. II, 1893, pp. 19, 20, 36, pl. 36, figs. 1-6.

Spirifera crispa Hall, Twenty-eighth Rep. N. Y. State Mus. Nat. Hist., 1879, p. 157, pl. 24, figs. 6-12, 19 ;-Eleventh Rep. State Geol. Indiana, 1882, p. 295, pl. 24, figs. 6-12, 19;--Secoud Anu. Rep. N. Y. state Geol., 1883, pl. 61, figs. 1-6.

Loc. Europe; Lockport, Lewiston, and Schoharie, New York; Hamiltou and Arisaig, Nova Scotia (Ami); Ontario; Waldron, Indiana.

Spirifer crispus simplex Hall.

Niagara (Sil.).

Spirifera crispa var. Hall, Trans. Albany Institute, IV, 1863, p. 212.

Spirifera crispa rar. simplex Hall, Twenty-eighth Rep. N. Y. State Mus. Nat.

Hist., 1879, p. 157, pl. 24, figs. 1-5;-Eleventh Rep. State Geol. Indiana, 1882,

p. 296, pl. 2f, figs. 1-5.-Nettelroth, Kentucky Fossil Shelis, Mem. Kentucky Geol. Survey, 1889, p. 111. pl. 17, figs. 36, 37.

Spirifer erispus var, simplex Beecher and Clarke, Mem. N. Y. State Mus., I, 1889, p. 75 , pl. 6 , figs. 4,5 .

Loc. Waldron, Indiana; Louisville, Kentucky.

Spirifer cultrijugatus Yandell and Shumard=Spirifer acuminatus.

Spirifer cumberlandiæ Hall.

Oriskany (Dev.).

Spirifer cumberlandice Hall, Tenth Rep. N. Y. State Cab. Nat. Hist., 1857, p. 63;-Pal. New York, III, 1859, p. 421, pl. 96, fig. 9.-Hall and Clarke, Pal. New York, VIII, Pt. II, 1893, pp. 17, 36, pl. 33, fige. 16-23. 


\section{Spirifer cumberlandiæ Hall-Continued.}

Spirifera cumberlandi: Hall, Secour Ann. Rep. N. Y. State Geol., 1883, pl. 58, figs. 16-23.

Loc. Cumberland, Maryland.

Spirifer cuspidatus of American authors=Syringothyris carteri.

Spirifer cuspidatiformis Miller=Syringothyris texta.

\section{Spirifer cyclopterus Hall.}

Lower Helderberg and Oriskany (Dev.).

Spirifer cycloptera Hall, Tenth Ann. Rep. N. Y. State Cab. Nat. Hist., 1857, p. 58 ;-Pal. New York, III, 1859, p. 199, pl. 25, fig. 1.

Spirifera cycloptera Billings, Geol. Canada, 1863, p. 957, fig. 457 ;-Pal. Fossils, II, 1874, p. 48, pl. 3A, fig. 4.-Hall, Second Ann. Rep. N. Y. State Geol., 1883, pl. 61 , figs. 12,13 .

Spirifer cyclopterus Hall and Clarke, Pal. New York, VIII, Pt. II, 1893, p. 36, pl. 36, figs. 12,15 .

Loc. Helderberg Mountains, New York; Gaspé and New Brunswick.

Spirifer cyrtinaformis Hall and Whitfield=Cyrtia cyrtiniformis.

Spirifer davisi Nettelroth.

Hamilton (Der.).

Spirifera davisi Nettelroth, Kentucky Fossil Shells, Mem. Kentucky Geol. Survey, 1889 , p. 112, pl. 12, figs. 1-4.

Loc. Falls of Ohio.

Spirifer deltoideus Herrick.

Waverly (L. Carb.).

Spirifera deltoidea Herrick, Bull. Denison Univ., IV, 1888, p. 2T, pl. 2, fig. 7 .

Spirifer deltoideus Herrick, Geol. Ohio, VII, 1895, pl. 15, fig. 7 .

Loc. Licking County, Ohio.

Spirifer desideratus Walcott.

Lower Carboniferous.

Spirifera desiderata Walcott, Mon. U. S. Geol. Survey, VIII, 1884, p. 217, pl. 7, fig. 8 .

Loc. Eureka district, Nevada.

Spirifer disjunctus Sowerby.

Chemung (Dev.).

Spirifera disjuncta Sowerby, Trans. Geol. Soc., 2d ser., V, 1810, pl. 53, fig. 8; pl. 54, figs. 12, 13.-Davidson, Mon. British Devonian Brach., Pil. Soc., 1864, p. 23, pl. 5, figs. 1-12; pl. 6, figs. 1-5.-Hall, Pal. New York, IV, 1867, p. 243, pl. 41, figs. $1-19$; pl. 42 , figs. 1-20;-Second Ann. Rep. N. Y. State Geol., 1883, pl. 55, figs. 14-17.-Walcott, MIon. U. S. Geol. Survey, VIII, 1884, p. 134. -Whiteaves, Cont. Canadian Pal., I, 1891, p. 221, pl. 29, fig. 4.

Delthyris perlatus Conrad, Fifth Ann. Rep. N. Y. Geol. Survey, 1841, p. 54.

Delthyris chemungensis Conrad, Jour. Acad. Nat. Sci. Philadelphia, VIII, 1812, p. 263.

Delthyris prolata Vanuxem, Geol. N. Y.; Rep. Third Dist., 1812, p. 179, fig. 3.

Delthyris euspidata Hall (non Martin), Geol. N. Y.; Rep. Fourth Dist., 1813, p. 270, fig. 1.-Rogers, Geol. Pennsylvania, II, Pt. II, 1858, p. 829, fig. 683.

Delthyris disjuncta? Hall, Geology N. Y.; Rep. Fourth Dist., 1813, p. 269, fig. 3. Delthy̧ris acanthota Hall, Ibidem, 1843, p. 270, fig. 2.

Delthyris inermis Hall, Ibidem, 1843, p. 270, fig. 4.

Spirifer disjunctus Hall and Clarke, Pal. New York, VIII, Pt. II, 1893, pp. 21, $24,27,37,49$, pl. 30, figs. 14, 15, 17.-Herrick, Geol. Ohio, VII, 1895, pl. 23, fig. 11.

Loc. Europe; New York; Pennsylvania; Eureka district, Nevada; Peace, Hay, and Liards rivers, Canada.

Spirifer disjunctus occidentalis Whiteaves.

Upper Devonian.

Spirifera disjuncta rar. ocoidentalis Whiteaves, Cont. Canadian Pal., I, 1891, p. 222 , pl. 29, fig. 5 .

Loc. Hay River, Canada. 
Spirifer disjunctus sulcifer Hall and Clarke.

Chemung (Dev.).

Spirifera disjunctus var. sulcifer $I$ Iall and Clarlie, Pal. New York, VIII, Pt. II, 1895, p. 361, pl. 30, fig. 16.

Loc. Near Olcan, New York.

Spirifer disparilis Hall=Metaplasia disparilis.

Spir er divaricatus Hall.

Corniferous and Hamilton (Dev.).

Spirifer diraricata Hall, Tenth Rep. N. Y. State Cab. Nat. Hist., 1857, p. 133.

Spirifer renustus Hall, Thirteenth Rep. Ibidem, 1860, p. 2 .

Spirifera divaricata Hall, Pal. New York, IY, 1867, 1. 213, pl. 32, figs. 1-6.--Nettelroth, Kentucky Fossil Shells, Mem. Kentucky Geol. Survey, 1889, p. 113, pl. 11, figs. $6-11$; pl. 12, figs. 5-11.

Spirifer divaricatus Hall and Clarke, Pal. New York, VIII, Pt. II, 1893, pp. 24, 27,39, pl. 38, figs. $15-17$.

Loc. Scholıarie, Stafford, Williamsville, York, etc., New York; Port Colborne, Canada; Falls of Ohio; Lebanon, Kentucks.

Obs. Compare with S. multicostatus Castelnau.

Spirifer dubius Hall= Pentamerella dubia.

Spirifer dubius Nettelroth.

?Niagara (Sil.).

Spirifera dubia Nettelroth, Kentucky Fossil Shells, Mem. Kontucky Geol. Survey, 1889, p. 115, pl.33, figs. 23, 24.

Loc. Loursille, Kentucky.

Spirifer duodenarius (Hall).

Upper Helderberg (Der.).

Delthyris duodenaria Hall, Geol. N. Y.; Rep. Fourth Dist., 1813, p. 171, fig. 5.

Spirifera duodeuaria Billings, Canadiau Jour., n. ser., V, 1861, p. 256, figs. 65-67;Geol. Canada, 1863, p. 372, fig. 394.-Hall, Pal. New York, IV, 1867, p. 189, pl. 27, figs. 13-16; pl. 28, figs. 24-33;-Second Ann. Rep. N. Y. State Geol., 1883, pl. 58, figs. 8-13.-Nettelroth, Kentucky Fossil Shells, Mem. Kentucky Geol. Survey, 1889, p. 114, pl. 12, figs. 12, 13, 16.

Spirifera duodenaria? Rathbun, Proc. Boston Soc. Nat. Hist., XX, 1879, p. 25.

Spirifer duodenarins Hall aud Clarke, Pal. New York, VIII, Pt. II, 1893, pp. 19, 37 , pl. 33, figs. 8-15.

Loc. New York, Ontario, Columbus, Ohio; Falls of Ohio; Rio Maecuru, Province of Para, Brazil.

Spirifer duplicatus Hall=Spirifer dupliplicatus.

Spirifer duplicicosta Phillips.

Carboniferous.

Spirifer duplicicostus Phillips, Geol. Yorkshire, II, 1829, p. 218, pl. 10, fig. 1.

Spirifera duplicicosta Etheridge, Quart. Jour. Geol. Soc. London, XXXIV, 1878, p. 628 .

Loc. Europe; Feilelen Isthmus, lat. $82^{\circ} 43^{\prime}$.

Spirifer dupliplicatus (Conrad).

Hamilton (Dev.).

Delthyris dupliplicata Conrad, Jour. Acad. Nat. S‘i. Philadelphia, VIII, 1842, p. 261, pl. 14, fig. 16.

Spirifera duplicata Hall, Pal. New York, IV, 1867, pp. 223, 236.

Loc. Near Smyrna, New York.

Obs. Compare with S. granulosus Conrad.

Spirifer eatoni Hall=Spirifer audaculus.

Spirifer elizæ Rathbuu.

Spirifer elizie (Hartt MS.) Rathbun, Bull. Buffalo Soc. Nat. Sci., I, 1874, p. 239, pl. 8 , figs. 15,21 ; pl. 9, fig. 22.

Spirifera elize Rathbun, Proc. Boston Soc. Nat. Hist., XX, 1879, 1. 28.

Loc. Erere, Province of Para, Brazil. 
Spirifer engelmanni Meek and Worthen (non Meek)=Spirifer worthenanus.

Spirifer engelmanni Meek.

Middle Devonian.

Spirifera eugelmanni Meek, Proc. Acad. Nat. Sci. Philadelphia, 1860, p. 308.Simpson's Rep. Expl. Great Basin Terr. Utah, 1876, p. 346, pl. 1, fig. 1.King's U. S. Geol. Expl. 40th Parl., IV, 1877, p. 41, pl. 3, fig. 3.

Loc. Neils Valley, Utah; White Pine district, Nevada.

Spirifer eudora Hall.

Niagara (Sil.).

Spirifera eudora Hall, Annual Rep. Geol. Survey Wisconsin, 1861, p. 25;-Geol.

Rep. Wisconsin, I, 1863, p. 69, pl. 5 ; p. 436;-'Trans. Albany Inst., IV, 1863, p. 211 ;-Twentieth Rep. N. Y. State Cab. Nat. Hist., 1867, p. 370, pl. 13, figs. 5,7 ;-Ibidem, Twenty-eighth Rep., 1879, p. 156, pl. 24, figs. 13-18;-Eleventh Rep. Stato Geol. Indiana, 1882, p. 294, pl. 24, figs. 13-18;-Second Ann. Rep. N. Y. State Geol., 1883, pl. 51, figs. 19-21, 29.

Spirifer eudora Hall and Clarke, Pal. New York, VIII, Pt. 1I, 1893, pp. 13, 35, pl. 21, figs. 19-21, 29.

Loc. Racine, Wisconsin; Waldron, Indiana; Louisville, Kentucky.

Spirifer euruteines Hall (non Owen)=S. fornacula.

Spirifer euruteines var. fornacula Hall=S. fornacula.

Spirifer euryteines Owen.

Hamilton (Dev.).

Delthyris euruteines Owen, Rep. Geol. Expl. Iowa, Wisconsin, and Illinois, 1844, p. 69 , pl. 12 , fig. 9 .

Spirifer enruteines Owen, Geol. Survey Wisconsin, Iowa, and Minnesota, 1852, p. 586, pl. 3, figs. 2, 6. [See specimens in U. S. Nat. Mus., Cat. Invert. Foss., 17924.]

Spirifer parryaua Hall, Geol. Survey Iowa, I, Pt. II, 1858, p. 509, pl. 4, fig. 8.Kejes, Geol. Surv. Missouri, V, 1895, p. 77, 11. 40, fig. 4.

Spirifer capax Hall, Geol. Survey Iowa, I, Pt. II, 1858, p. 520, pl. 7, fig. 7.

Spirifera parryana Billings, Canadian Jour., VI, 1861, p. 261, figs. 77, 78;-Geol. Canada, 1863, p. 386, fig. 422.-Hall, Second Ann. Rep. X. Y. State Geol., 1883, pl. 52, figs. 8, 9.—Calvin, Bull. Lab. State Uuiv. Iowa, 1888, p. 19.

Spirifera fornacula Meek and Worthen (nou Hall), Geol. Survey Illinois, III, 1868 , p. 433 , pl. 13 , fig. 8 .

Spirifera capax Hall, Second Ann. Rep. N. Y. State Geol., 1883, pl. 52, figs. 15-17.

?. Spirifera parryana Walcott, Mon. U. S. Geol. Survey, VIII, 1884, p. 137, pl. 14, fig. 10.

Spirifer parryanus Hall and Clarke, Pal. New York, VIII, Pt. II, I893, pp. 29, 31, 39, pl. 22, figs. $8,9,15-17$.

Loc. Pine Creek and elsewhere in Iowa; Eureka district, Nevada; Bosanquet, Ontario, Canada.

Obs. Owen described this species in 1839 , but it was not published until 1844 . In $1841 \mathrm{O}$ wen sent Professor Hall specimens from the Falls of the Ohio labeled S. euruteines. This species was again refigured in his report of 1852 , where he cites the same localities as in 1844 (p. 32 last paragraph), adding Falls of Ohio and Columbus, Ohio. Professor Hall is correct in regarding the Ohio specimens as distiuct from those of the $\mathrm{M}$ ississippi Valley, but is in error in thinking that figures $6-6 \mathrm{~b}$ of the 1852 report are drawn from an Ohio Falls specimen. These figures are of the same specimen as of figure 9 of the 1844 report, which is from Pine Creek, Iowa. The type specimens are in the National Museum collection. Owen's figure 2 is the same species as Hall's S. capax, while his figure 6 is a small individual of S. parryana Hall. Professor Calvin has shown these two species to be identical. Therefore it follows that $S$. euryteines must be restricted to the specimens from the Mississippi Valley. For the specimens from the Falls of the Ohio S. fornaculus Hall will be the proper nawe. 
Sprifer extemmatus Hall= Syringothyris extemata.

Spirifer fasciger Owen (non Keyserling)=Spirifer cameratus.

Spirifer fastigatus Meek and Worthen (non Morton)=Spirifer mortonantus.

Spirifer fastigatus Morton.

?Lower Carboniferous.

s irifer fastigatus Morton, American Jour. Sci., XXIX, 1836, p. 152, ⒈ 14, tig. 35.

Loc. Junior Furnace, Scioto County, Ohio.

Obs. Not recognizable.

Spirifer filicosta A. Winchell.

Hamilton (Dev.).

Spirifera filicosta A. Winchell, Report Lower Peninsula of Michigan, 1866, p. 94.

Loc. Grand Traverse district, Michigan.

Spirifer (?) fimbriatus Morton

Upper Carhoniferous.

Spirifer fimbriatus Morton, American Jour. Sci., XXIX, 1836, p. 150, pl.2, n̂g. 1.

Loc. Putuam Hill, Ohio.

Obs. Not recognizable.

Spirifer fimbriatus Hall=Reticularia fimbriata.

Spirifer fischeri Castelnau=Spirifer macropleura.

Spirifer foggi Nettelroth.

Niagara (Sil.).

Spirifera foggi Nettelroth, Kentucky Fossil Shells, Mem. Kentucky Geol. Surves, 1889 , p. 117, pl. 32, figs. 28-31.

Loc. Louisville, Kentucky.

Spirifer forbesi Norwood and Pratten.

Burlington (L. Carb.).

Spirifer forbesi Norwood and Pratten, Jour. Acad. Nat. Sci. Philadelphia, III, 1854, p. 7:3, pl. 9, fig. 3.-Hall, Geol. Survey Iowa, I, Pt. II, 1858, p. 600, pl. 13, fig. 1.-Hall and Clarke, Pal. New York, VIII, Pt. II, 1893, pp. 26, 38, pl. 37, fig. 18 .

Spirifera forbesi lieyes, Geol. Survey Missouri, V, 1895, p. 80, pl. 40, fig. 3.

Loc. Burlington, Iowa; Hannibal, Louisiana, and Sedalia, Missonri.

Spirifer formosus Hall.

Hamilton (Dev.).

Spirifer formosa Hall, Tenth Rep. N. Y. State Cab. Nat. Hist., 1857, p. 154.

Spirifera formosa Hall, Pal. New York, IV, 1867, p. 220, pl. 28, tigs. 12-16.

Loc. Bakeoven, Illinois.

Spirifer fornaeula Meek and Worthen (non Hall)=Spirifer euryteines.

Spirifer fornacula Hall.

Hamilton (Micl. Dev.).

Spirifer fornacula Hall, Tenth Rep. N. Y. State Cab. Nat. Hist.. 1857, p. 154.

Spirifera euruteines Hall (non Owen), Pal. New York, IV, 1867, 1. 209, pl. 31, figs. 14-19.-White, Second Ann. Rep. Indiana Burean of Statistics and Geol., 1880, p. 504, pl. 4, figs. 4, 5;-Tenth Rep. State Geol. Indiana, 1881, p. 136, pl. 4, figs. 4, 5.-Nettelroth, Kentucky Fossil Shells, Mem. Kentucky Geol. Survey, 1889, p. 115, pl. 6, figs. 1-7, 9, 11-17.

Spirifera euruteines var. fornacula Hall, Pal. New York, IV, 1867, p. 211, pl. 31, figs. 11-13.-Whitfielı, Geol. Wisconsin, IV, 1882, p. 330, pl. 25, fig. 22.Nettelroth, Kentucky Fossil Shells, Mem. Kentucky Geol. Survey, 1889, p. 117, pl. 6 , figs. $8,10,18-20$.

Loc. Jackson County. Illinois; Falls of Ohio; Columbus, Ohio; Milwankee, Wiscousin (Whitfield).

Obs. See remarks on S. eurytcines Owen.

Spirifer fornax Hall.

Hamilton (Dev.).

Spirifer fornax Hall, Tenth Rep. N. Y. State Cab. Nat. Hist., 1857, p. 155.

Loc. Illinois. 
Spirifer franklini Meek=Reticularia franklini.

Spirifer fultonensis Worthen.

Upper Carboniferous.

Spirifera fultonensis Worthen, Geol. Survey Illinois, V, 1873, p. 572, pl. 25, fig. 5.

Loc. Canton, Illinois.

Spirifer gaspensis Billings.

Oriskany (Dev.).

Spirifera gaspensis Billings, Pal. Fossils, II, 1874, p. 44, pl. 3, fig. 8.

Loc. Gaspé.

Spirifer gibbosus Hall.

Niagara (Sil.).

Spirifer gibbosus Hall, Ann. Rep. Geol. Survey Wisconsin, 1861, p. 25.

Spirifera gibbosa Hall, Twentieth Rep. N. Y. State Cab. Nat. Hist., 1867, 1. 370, pl. 13 , figs. 6,8 .

Loc. Racine, Wisconsin.

Obs. Probably the same as S. eudora Hall.

Spirifer glabrus Davidson= Martinia glabra.

Spirifer glabrus var. contractus Meek and Worthen=Martinia glabra contracta.

Spirifer glabrus nevadensis Walcott=Reticnlaria nevadaensis.

Spirifer glanscerasus White=Martinia glanscerasi.

Spirifer granuliferus Hall=Spirifer granulosus.

Spirifer granulosus (Conrad).

Hamilton (Dev.).

Delthyris granulosa Conrad, Third Ann. Rep. Geol. Survey N. Y., 1839, 1. 65.

Delthyris granulifera Hall, Geology N. Y.; Rep. Fourth Dist., 1843, p. 206, fig. 1.

Delthyris congesta Hall, Ibidem, 1843, p. 206, fig. 2.-Rogers, Geol. Pennsylvauia,

II, Pt. II, 1858, p. 828, figs. $670,673$.

Spirifer huroniensis Castelnau, Essai Système Silurien l'Amérique Septentrionale, 1843 , p. 41 , pl. 12 , fig. 6 .

Spirifer osteolatus Yandell and Shumard, Cont. Geol. Kentucky, 1847, p. 14.

Spirifer granulifera Hall, Tenth Rep. N. Y. State Cab. Nat. Hist., 1857, p. 163.

Spirifer arata Hall, Tenth Rep. N. Y. State Cab. Nat. Hist., 1857, p. 161.

Spirifer clintoni Hall, Ibidem, 1857, p. 157.

Spirifer oweni Hall, Ibilem, 1857, p. 129.-Hall and Clarke, Pal. New York, VIII, Pt. II, 1895, pl. 22, figs. 1-7.

Spirifera oweni Hall, Pal. New York, IV, 1867, p. 197, pl. 29, figs. 1-8;-Second Ann. Rep. N. Y. State Geol., 1883, pl. 52, figs. 1-7.-Nettelroth, Kentucky Fossil Shells, Mem. Kentucky Geol. Survey, 1889, p. 126, pl. 7, figs. 1-10.

Spirifera grannlifera Hall, Pal. New York, IV, 1867, p. 223, pl. 36, figs. 1-13;Second Ann. Rep. N. Y. State Geol., 1883, pl. 53, figs. 1-15.

Spirifera arata Hall, Pal. New York, IV, 1867, p. 285.

Spirifer granulosus Hall, Pal. New York, VIII, Pt. II, 1893, pp. 29, 30, 31, 39, pl. 23, figs. 1-15; pl. 29, figs. 9-12.

Loc. Schoharie, Moscow, Darien, Canandaigua, etc., New York; Penusylvania; Cumberland, Maryland; Virginia; Falls of Ohio; Alpena, Michigan.

Spirifer gregarius Clapp.

Upper Helderberg (Dev.).

Delthyris gregaria Yandell and Shumard, Cont. Geol. Kentucky, 1847, pp. 9, 10. (Nomina nudum.)

Spirifer gregaria (Clapp MS.) Hall, Tenth Rep̣. N. Y. State Cab. Nat. Hist., 1857, p. 127.

Spirifera gregaria Billings, Canadian Jour., n. ser., VI, 1861, p. 260, figs. 74-76 ;Geol. Canarla, 1863, p. 372, fig. 391.-Hall, Pal. New York, IV, 1867, p. 195, pl. 28, figs. 1-11.-White, Second Ann. Rep. Indiana Burean of Statistics and Geol., 1880, pl. 4, figs. 10, 11; -Tenth Rep. State Geol. Indiana, 1881, p. 136, pI. 4, figs. 10, 11.-Nettelroth, Kentuck F Fossil Shells, Mem. Kentucky Geol. Survey, 1889, p. 119, pl. 8, figs. $9-13$; pl. 10, figs. 6-10. 
Spirifer gregarius Clapp-Continned.

Spirifer gregarius IXll and Clarke, Pal. New York, VIII, Jt. II, 1893, pl. 17, 36, pl. 29, fig. 7 ; pl. 37, figs. 11, 12.

Loc. Falls of Ohio; Columbns, Ohio; Genesee and Erie counties, New York; Ontario.

Spirifer grieri Hall.

Upper Helderberg (Dev.).

Spirifer grieri Hall, Tenth Rep. N. Y. State Cab. Nat. Hist., 1857, p. 127;Pal. New York, IV, 1867, p. 194, pl. 27, fig. 29; pl. 28, figs. 17-23.-Hall and Clarke, Pal. New York, VIII, Pt. II, 1893, pp. 24, 27, 38, pl. 30, figs. 9-13.

Spirifera grieri Hall, Second Ann. Rep. N. Y. State Geol., 1883, pl. 55, figs. 9-13.Nettelroth, Kentucky Fossil Shells, Mem. Kentucky Geol. Survey, 1889, p. 120 , pl. 9, figs. 8-14.

Loc. Clarence, Williamsville, etc., New York; Columbus, Ohio; Falls of Ohio. Spirifer grimesi Hall. Kinderhook and Burlington (L. Carb.). Spirifer grimesi Hall, Geol. Survey Iowa, I, Pt. II, 1858, p. 604, pl. 14, figs. 1-5. Hall and Clarke, Pal. New York, VIII, Pt. II, 1893, pp. 23, 25, 38, pl. 31, figs. $8,16-19$.

Spirifer allied to grimesi Etheridge, Quart. Jour. Geol. Soc. London, XXXIV, 1878 , p. 628 , pl. 25 , fig. 5 .

Spirifera grimesi Hall, Second Ann. Rep. N. Y. State Geol., 1883, pl. 56, figs. 8, 16-19.-Keyes, Geol. Survey Missouri, V, 1895, p. 79.

Loc. Burlington, Iowa; Quincy, Illinois; Fielden Isthmus, lat. $82^{\circ} 43^{\prime}$; Hannibal, Louisiana, Sedalia, etc., Missouri.

Spirifer guadalupensis Shumard=Reticularia guadalupensis. Spirifer hannibalensis Swallow=Syringothyris carteri.

Spirifer hartti Rathbun.

Middle Devonian.

Spirifera hartti Rathbun, Proc. Boston Soc. Nat. Hist., XX, 1879, 1. 29.

Loc. Rio Maecuru, Proviuce of Para, Brazil.

Spirifer hawkinsi Morris and Sharpe.

Lower Devonian.

Spirifer hawkinsii Morris and Sharpe, Quart. Jour. Geol. Soc. London, II, 1846, p. 276, pl. 11, fig. 1 .

Loc. Falkland Islands.

Spirifer hemicyclus Meek and Worthen.

Oriskany (Dev.).

Spirifer hemicyclns Meek and Worthen, Geol. Survey Illinois, III, 1868, p. 399, pl. 8 , figs. 6,7 .

Loc. Union and Alexandria counties, Illinois.

Spirifer hemiplicatus Hall=Enteletes hemiplicatus.

Spirifer hesione Billings=Delthyris raricosta.

Spirifer hirtus White and Whitfield=Reticularia cooperensis.

Spirifer hobbsi Nettelroth.

Hamilton (Dev.).

Spirifera varicosa var. Hall, Pal. New York, IV, 1867, p. 206, pl. 31, fig. 23.

Spirifera hobbsi Nettelroth, Kentucky Fossil Shells, Mem. Kentucky Geol. Survey, 1889, p. 121, pl. 10, figs. 21, 22, 26-30, 35, 40.

Loc. Falls of Ohio.

Spirifer homfrayi Gabb=Spiriferina homfrayi.

Spirifer hungerfordi Hall.

Chemung (Dev.).

Spirifer hungerfordi Hall, Geol. Survey Iowa, I, Pt. II, 1858, p. 501, pl. 4, fig. 1.Tschernyschew, Mémoires du Comité Géologique de St. Petersbourg, III, 3, 1887, p. 62.-Hall and Clarke, Pal. New York, VIII, Pt. II, 1893, np. 23, 25, 37, pl. 29, fig. 6; pl. 37, figs. 26-30.-Webster, Anericau Naturalist, XXII, 1888, p. 1101 .

Loc. Rockford, Iowa. 
Spirifer huroniensis Castelnau = Spirifer granulosus.

Spirifer huronensis A. Winchell.

Portage (Dev.).

Spirifer huronensis A. Winchell, Proc. Acad. Nat. Sci. Philadelphia, 1862, p. 406.

Loc. Port aux Barques, Michigan.

Spirifer imbrex Hall.

Burlington (L. Carb.).

Spirifer imbrex Hall, Geol. Surves Iora, I, Pt. II, 1858, p. 601, pl. 13, fig. 2.-

Hall and Clarke, Pal. Now York, VIII, Pt. II, 1893, pp. 26, 38, pl. 31, figs. 11, 12.

Spirifera imbrex Hall, Second Ann. Rep. N. Y. State Geol., 1883, pl. 56, figs.

$11,12$.

Loc. Burlington, Iowa; Hannibal and Louisiana, Missouri.

Spirifer inæquivalvis Castelnau = Rhynchotrema inæequivalvis.

Spirifer incertus Hall.

Burlingtou (L. Carb.).

Spirifer incerta Hall, Geol. Survey Iowa, I, Pt. II, 1858, p. 602, pl. 13, fig. 3.

Loc. Burlington, Iowa.

Spirifer inconstans Hall=Spirifer nobilis.

Spirifer increbescens Hall.

Kaskaskia (L. Carb.).

Spirifer increbescens IHall, Geol. Survey Iowa, I, Pt. II, 1858, p. 706, pl. 27, fig.

6.-Hall and Clarke, Pal. New York, VIII, Pt. II, 1893, pp. 27, 39, pl. 30,

figs. 27-30 ; pl. 31, figs. 1-3.-Keyes, Geol. Survey Missouri, V, 1895, p. 82.

Spirifera increbescens Hall, Second Ann. Rep. N. Y. State Geol., 1883, pl. 55, figs. $27-30 ; \mathrm{pl}$. 56, figs. $1-3$.

Loc. Kaskaskia and Chester, Illinois; Kentucky.

Obs. Not synonymous with S. bisulcatus Sowerby, as stated by Meek and Safford. It has also been referred to $\mathrm{S}$. trigonalis (Martin).

Spirifer increbescens americanus Swallow.

Kaskaskia (L. Carb.).

Spirifer increbescens var. americana Swallow, Trans. St. Lonis Acad. Sci., II, 1866, p. 410.

Loc. Illinois and Missonri.

Obs. Regarded by lieyes as a synonym for S. increbescens.

Spirifer increbescens transversalis Hall.

Kaskaskia (L. Carb.).

Spirifer increbescens var. transversalis Hall, Geol. Survey Iowa, I, Pt. II, 1858, p. 708 , pl. 27 , fig. 6 .

Loc. Kaskaskia and Chester, Illinois.

Spirifer inequicostatus Owen=Spirifer cameratus.

Spirifer insolitus Winchell=Martinia ? insolita.

Spirifer intermedius Hall.

Oriskany (Dev.).

Spirifer intermedia Hall (non Brongniart, 1829), PaI. New York, III, 1859, p. 424.

Loc. Cnmberland, Maryland.

Spirifer inutilis Hall.

Upper Devonian.

Spirifer inutilis Irall, Geol. Survey Iowa, I, Pt. II, 1858, p. 505, pl. 4, fig. 4.

Spirifera inutilis Whiteaves, Cont. Canadian PaI., I, 1891, p. 223.

Loc. Independence, Iowa; Athabasca River, Canada.

Spirifer iowaensis Owen.

Middle Devonian.

Spirifer iowensis Owen, Geol. Snrvey Iowa, Winconsin, and Minnesota, 1852, p. 585, pl.3, fig. 1. [See specimens in U. S. Nat. Mus., Cat. Invert. Foss., 17925.]

Spirifer pennatus Owen (non Atwater), Ibidem, 1852, p. 585, pl. 3, figs. 3, 8 . [Ibidem, Cat., 17919, 17920.]

Spirifer ligus Owen, Ibidem, 1852, p. 585, pl. 3, fig. 4, and pl. 3A, fig. 2 [Ibidem, Cat., 17921, 17922].-Hall and Clarke, Pal. New York, VIII, Pt. II, 1893, pp. 31, 39, pl. 22, figs. 19-24; pl. 29, fig. 13.-Kieves, Cool. Survey Missouri, $\mathrm{V}, 1895, \mathrm{p} .77$. 


\section{Spirifer iowaensis Owen-Continued.}

Spirifer cedarensis Oren, Geol. Survey Iowa, Wisconsin, and Minnesota, 1852, 1. 586 , 1)l. 3, fig. 5. [See specimens in U.S. Nat. Mus., Cat. Invert. Foss., 17 923.]

Spiriter pennata Hall, Geol. surves, Iowa, I, Pt. II, I×58, 1). 510, pl.5, fig. 1.

?Spirifera allied to pennata Etheridge, Quart. Jour. Gool. Soc. London, XXXIV, 1878,1 . 633 , pl. 29, fig. 1.

Spirifera atwaterana Miller, Proc. Darenport Acal. Sci., 1878, p. 222.-Nettelroth, Kentucky Fossil shells, Mem. Kentucky Geol. Surrey, 1889, p. 107.

Spirifera pennata Whittield, Geol. Wisconsin, IV, 1882, p. 330, pl. 26, fig. 4.Hall, Second Anu. Rep. N. Y. State Geol., 1883, pl. 52, figs. 19-24.

Loc. New Buffalo, Independence, etc., Iowa; Rock Island, Illinois; Milwaukee, Wiscousin; Falls of Ohio; south of Cape Joseph Henry, lat. $82^{\circ} 42^{\prime}$.

Obs. Oten's type specimens of S. iowaensis, S. pennatus, S. ligns, and S. cedarensis are preserved in the National Museum collection. The six specimens of these species show, when compared with a large series of similar shells from Iowa, that they are but variations of a very variable and widely distributed Spirifer of the Deronian of the Mississippi Valley. The width and degree of curvature of the ventral area and the length of the cardinal line are extremely variable features in S. iowaensis. Upon these characters Owen has based his species. The name S. iowaensis has been selected not only because it is very appropriate but also since it is the first one describer. S. parryanus is another closely allied species, but can be separated generally by its wider ventral area and in the cardiual lines not being drawn out into more or less mucronate extensions.

Spirifer kelloggi S̊̉wallow.

Keokuk (L. Carb.). Spirifera kelloggi Swallow, Trans. St. Louis Acad. Sci., IJ, 1863, p 86.-Keyes, Geol. Survey Missouri, V, 1895, p. 81.

Spiriferina kelloggi Safford, Geol. Tennessee, 1869, p. 360.

Loc. Keokuk, Iowa; Tennessee.

\section{Spirifer kennicotti Meek.}

Middle Devonian.

Spirifer kennicotti Meek, Trans. Chicago Acad. Sci., 1, 1868, p. 101, pl. 14, fig. 9.

Loc. Mackenzie River Valley, Northwest Territors, Canada.

Obs. This species is much like S. pennatus Miller, but with the fold and sinus plicated. It is unlike S. disjunctus, to which it has been referred by Whiteaves, in its shallow visceral cavity.

Spirifer kentuckiensis Shumard=Spiriferina cristata.

Spirifer kentuckiensis var. propatula Swallow = Spiriferina cristata.

\section{Spirifer keokuk Hall.}

Keokuk (L. Carb.).

Spirifer striatns? var. attenuatus? Owen (non Sow.), Geol. Survey Wisconsin. lowa, Minnesota, 1852, pl.3A, fig. 8. [See specimens in U. S. Nat. Mus., Cat. Invert. [oss., 17944.]

Spirifer keokuk Hall, Geol. Survey Iowa, I, Pt. II, 1858, p. 642, pl. 20, figs. 3 and $2 d$;-Second Ann. Rep. N. Y. State Geol., 1883, pl. 55, figs. 21-24.-Hall and Clarke, Pal. New York, VIII, Pt. II, 1893, pp. 27, 38, pl. 30, figs. 21-24; pl.37, figs. 13-15.

Spirifer keokuk var. Hall, Geol. Survey Iowa, I, Pt. II, 1858, p. 676, pl. 24, fig. 4.

Spirifer keokuk? Neek, Bull. U. S. Geol. Geogr. Survey Terr., II, 1876, p. 355, pl. 1, fig. 3 .

Spirifera keokuk Keyes, Geol. Survey Missouri, T, 1895, p. 81, pl. 40, fig. 2.

Loc. Keokuk, Iowa; Nanyoo and Warsaw, Illinois; Utah; Rushrille and Loudonville, Ohio (Herrick).

Obs. See S. littoni. 
Spirifer keokuk shelbyensis Swallow.

Warsaw (L. Carb.).

Spirifer keokuk var. shelbjensis Swallow, Trans. St. Lonis Acad. Sci., II, 1866, p. 410.

Loc. Shelby County, Nissouri.

Spirifer knappanus Nettelroth=Reticularia knappiana.

Spirifer lateralis Hall.

Warsaw (L. Carb.).

Spirifer lateralis Hall, Geol. Survey Iowa, I, Pt. II, 1858, 1. 661, pl. 23, fig. 7.Hall and Clarke, Pal. New York, VIII, Pt. II, 1895, pl. 32, figs. 1-3; pl. 37, fig. 19.

? Spirifera lateralis Hall, Second Ann. Rep. N. Y. State Geol., 188 ?, pl. 57, figs. 1-3.

Loc. Clifton and Warsaw, Illinois.

Spirifer latior Swallow.

Chontean (L. Carb.).

Spirifer latior Swallow, Trans. St. Louis Acad. Sci., II, 1863, p. 86.

Loc. Cooper County, Missouri.

Obs. Compare with S. marioneusis.

Spirifer lævigatus Swallow= Martinia lævigata.

Spirifer lavis Hall=Reticularia levis.

Spirifer laminosus Geinitz (non McCoy)=Spiriferina cristata.

Spirifer leidyi Norwood and Pratten. St. Louis (L. Carb.).

Spirifer leidyi Norwood and Pratten, Jour. Acad. Nat. Sci. Philadelphia, III, 1854, p. 72, pl. 9, fig. 2.-Hall and Clarke, Pal. New York, YIII, Pt. II, 1893, pp. 27,39, pl. 30, figs. $25,26$.

Spirifer bifurcatus Hall, Trans. Albany Institute, IV, 1857, p. 8 .

Spirifera bifurcata Whitfield̄, Bull. American Mus. Nat. Hist., I, 1882, p. 4ī, pl. ti, figs. 13-15.-Hall, Twelfth Rep. State Geol. Indiana, 1883, p. 326, 11. 29, tigs. 13-15.

Spirifera leidyi Hall, Second Aun. Rep. N. Y. State Geol., 1883, pl. 55, tigs. 25, 26.Walcott, Mon. U. S. Geol. Survey, VIII, 1884, p. 216, pl. 18, fig. 4.-Keyes, Geol. Surrey Mlissouri, V, 1895, 1. 82.

Loc. Chester, Illinois; Spergen Hill, Indiana; Princeton, Kentncky; Utah; Eureka district, Nevada.

Spirifer leidyi chesterensis Swallow.

Káakaskia (L. Carb.).

Spirifer leidyi var. chesterensis Swallow, Trans. St. Louis Acad. Sci., II, 1866, p. 409.

Loc. "Above the St. Louis limestone," Missonri.

Obs. Regarded by Keşes as a synonym for S. leidyi.

Spirifer leidyi merimacensis Swallow.

Warsaw (L. Carb.).

Spirifer leidyi var. merimacensis Swallow, Trans. St. Louis Acad. Sci., II, 1866, p. 410.

Loc. Barrets Station, St. Lonis Counț, Missouri.

Obs. Regarled by keyes as a synonym for S. leirlyi.

Spirifer ligus Owen=S. iowaensis.

Spirifer lineatoides Swallow=Reticularia psendolineata.

Spirifer lineatus of American authors=Reticularia perplexa.

Spirifer lineatus striatolineatus Swallow=Reticularia perplexa striatilineata.

Spirifer linguiferoides Forbes =Spiriferina rostrata.

Spirifer littoni Swallow.

St. Louis (L. Carb.).

Spirifer littoni Swallow, Trans. St. Louis Acad. Sci., I, 1860, p. 646.

Loc. St. Louis County, Missouri.

Obs. Regarded by Keyes as a synonym for S. keokuk. 
Spirifer logani Hall.

Keokuk (L. Carb.).

Spirifer logani Hall, Geol. Snrvey Iowa, I, Pt. II, 1858, p. 617, pl. 20, fig. 7; pl. 21, figs. 1. 2.-IIall and Clarke, Pal. Now York, VIII, Pt. II, 1893, pp. 25, 38, pl. 32, figs. 7,8 .

Spirifera Ingani A. Winchell, Proc. American Phil. Soc., XII, 1870, p. 245.-Hall, Scound Ann. Rep. N. Y. State Geol., 1883, pl. 57, figs. 7, 8.-Keyes, Geol. Survey Missouri, $V, 1895$, p. 81.

Loc. Nauroo, Illinois; Clark County, Missouri; Tennessee.

Spirifer lyelli de Verneuil=Spirifer peunatus.

Spirifer macbridei Calvin.

Upper Devonian.

Spirifera macbridei Calvin, American Jour. Sci., 3d ser., XXV, 1883, p. 433.-

Calvin, Bull. Lab. Nat. Hist. State Univ. Iowa, II, 1892, p. 166, pl. 12, fig. 3.

Spirifer macbridii Hall and Clarke, Pal. New York, VIII, Pt. II, 1893, pp. 29, 31, 39, pl. 25, figs. 9-16(?17-19).

Loc. Rockford, Iowa.

Spirifer macconathei Nettelroth.

Hamilton (Dev.).

Spirifera macconathii Nettelroth, Kentucky Fossil Shells, Mem. Keutucky Geol.

Survey, 1889, p. 123, pl. 11, figs. 1-5.

roc. Falls of Ohio.

Spirifer macra Meek (non Hall)=Spirifer strigosus.

Spirifer macrus Hall.

Upper Helderberg (Dev.).

Spirifer macra Hall, Tenth Rep. N. Y. State Cab. Nat. Hist., 1857, p. 134.

Spirifera macra Hall, Pal. New York, IV, 1867, p. 190, pl. 27, figs. 17-28;-Second Ann. Rep. N. Y. State Geol., 1883, pl. 59, figs. 1-3.

Spirifer macrus Hall and Clarke, Pal. New York, VIII, Pt. II, 1893, pp. 17, 36, pl. 34, figs. 1-3.

Loc. Schoharie, Williamsville, ete., New York; Columbus, Ohio.

Spirifer macronotus Hall $=\mathrm{S}$. audaculus macronotus.

Spirifer macropleura (Conrad).

Lower Helderberg (Dev.).

Delthyris macropleura Conrad, Fourth Ann. Rep. N. Y. Geol. Surver, 1840, p. 207.-Vanuxem, Geol. N. Y.; Rep. Thiri Dist., 1842, p. 120, fig. 1.-Mather, Ibidem, Rep. First Dist., 1843, p. 343, fig. 1.

Spirifer macropleurus Castelnan, Essai Système silurien l'Amérique Septentrionale, 1843 , p. 41 , pl. 13 , fig. 5 .

Spirifar fischeri Castelnau, Ibidem, 1843, p. 42, pl. 13, fig. 4.

Spirifer macroplenra Hall, Pal. Few York, III, 1859, p. 202, pl. 27, fig. 1; pl. 28, fig. 8.-Hall and Clarke, Pal. New York, VIII, Pt. II, 1893, pp. 13, 35, pl. 20, figs. 22-24. 27.

Spirifera macropleura Billings, Geol. Canada, 1863, p. 957, fig. 456 ;-Proc. Portlanil Soc. Nat. Hist., 1863, p. 117, pl. 3, fig. 16.-Hall, Secoud Ann. Rep. N. Y. State Geol., 1883, pl. 51, figs. 22-24, 27.

Loc. Scholiarie, Carlisle, Catskill, etc., New York; Square Lake, Maine; Cum. berland, Maryland; Perry County, Tennessee.

Spirifer macrothyris Hall.

Upper Helderberg (Dev.).

Spirifer macrothyris Hall, Tenth Rep. N. Y. State Cab. Nat. Hist., 1857, p. 132.Hall and Clarke, Pal. New York, VIII, Pt. II, 1893, pp. 29, 31, 39, pl. 23, figs. $16-18$.

Spirifera macrothyris Hall, Pal. New York, IV, 1867, p. 202, pl. 30, figs. 16-20;Second Ann. Rep. N. Y. State Geol., 1883, pl. 53, figs. 16-18.

Loc. Williamsville and Clarence Hollow, New York; Cayuga, Ontario; Columbus, Ohio. 
Spirifer mæcuruensis Rathbun.

Middle Devonian.

Spirifer mæcurueusis Rathbun, Proc. Boston Soc. Nat. Hist., XX, 1879, p. 30.

Loc. Rio Maecuru, Proviuce of Para, Brazil.

Spirifer maius Billings=Martiuia maia.

Spirifer manni Hall.

Upper Helderberg (Dev.).

Spirifer manni Hall, Tenth Rep. N. Y. State Cab. Nat. Hist., 1857, p. 128.

Spirifera manni Hall, Pal. New York, IV, 1867, p. 211, pl. 31, figs. 20-30.

Loc. Sandusky and Columbus, Ohio; Williamsville, New York.

Spirifer marcoui Waagen.

Upper Carboniferous.

Spirifer striatus Marcou (non Martin), Geol. North America, 1858, p. 49, pl. 7, fig. 2.

Spirifer marcoui Waagen, Palæontologica Indica, Ser. XIII, I, 1883, p. 510, pl. 47.

Loc. Shasta County, Cailfornia; Tigeras, New Mexico; Vancouver Island.

\section{Spirifer marcyi Hall.}

Hamilton (Dev.).

Spirifer marcyi Hall, Tenth Rep. N. Y. State Cab. Nat. Hist., 1857, 1. 158, figs. 1, 2.-Hall and Clarke, Pal. New York, VIII, Pt. II, 1893, pp. 29, 39, pl. 22, figs. 10-14.

Spirifera marcyi Hall, Pal. New York, IV, 1867, p. 226, pl. 37, figs. 10-20;-Second Ann. Rep. N. Y. State Geol., 1883, pl. 52, figs. 10-14.

Loc. Covington; Cayuga and Seneca lakes, New York; Columins, Ohio (Whitfield).

Spirifer marionensis Shumard.

Chouteau (L. Carb.).

Spirifer marioneusis Shumard, Geol. Rep. Missouri, 1855, p. 203, pl. C, fig. 8.-Hall, Geol. Survey, Iowa, I, Pt. II, 1858, p. 501, pl.6, fig. 1.-Hall and Clarke, Pal. New York, VIII, Pt. II, 1893, pp. 25, 38, pl.31, fig. 15.-Herrick, Geol. Ohio, VII, 1895, pl. 15, fig. 2.

Spirifera marionensis A. Winchell, Proc. American Phil. Soc., XII, 1870, p. 252.Hall, Second Ann. Rep. N. Y. State Geol., 1883, pl. 56, fig. 15.-Herrick, Bull. Denison Univ., III, 1888, p. 43, pl. 6, figs. 2-4; pl. 7, fig. 11; IV, 1888, p. 26, pl. 2, fig. 2.-Keyes, Gool. Surv. Missonri, V, 1895, p. 78.

?Spirifera mariouensis Nettelroth, Kentucky Fossil Shells, Mem. Kentucky Geol. Snrver, 1889, p. 124.

Loc. Louisiana and Hanuibal, Missouri; Portsmouth, Sciotuville, etc., Ohio; ? Falls of Ohio.

Obs. Compare with S. osagensis, S. missouriensis, and S. rernonensis.

Spirifer medialis Hall=Spirifer audaculus.

Spirifer meeki Swallow.

Burlington (L. Carb.).

Spirifer meeki Swallow, Trans. St. Louis Acad. Sci., I, 1860, p. 645.

Loc. Pettis and Saline counties, Missouri.

Spirifer meristoides Meek= Martinia meristoides.

Spirifer mesacostalis Hall=Delthyris mesicostalis.

Spirifer mesistrialis Hall.

Portage and Chemung (Dev.).

Delthyris mesastrialis Hall, Geol. N. Y.; Rep. Fourth Dist., 1843, p. 269, fig. 1.

Spirifer catskillensis Emmons, Manual of Geolog 5,1860 , p. 151.

Spirifera mesastrialis Hall, Pal. New York, IV, 1867, p. 242, pl. 40, figs. 14-22, and p. 417.

Spirifer mesastrialis Hall aud Clarke, Pal. New York, VIII, Pt. II, 1893, pp. 14, 35, 1). 37, figs. 4, 5.

Loc. Schoharie, Cortlandville, Cayuta Creek, and Ithaca, New York.

Spirifer metus Hall = Cyrtia meta.

Spirifer meusebachanus Roemer=Spirifer cameratus. 
Spirifer mexicanus Shumard.

Upper Carboniferous.

spirifera Mexicana Shumard, Trans. St. Louis Acat. Sci., I, 1858, p. 292, pl. 11, fir. 4 , and p. 390.

Loc. Guadalupo Mountains, Now Mexico and Texas.

Spirifer missouriensis Swallow.

Choutean (L. Carb.).

Spirifer missouriensis Swallow, Trans. St. Lonis Acull. Sci., I, 1860, I. 643.

I.oc. Cooper Connty, Missouri.

Obs. Regarded by Keyes as a synonym for S. marionensis.

Spirifer modestus Hall=Reticularia modesta.

Spirifer mortonanus Miller.

Keokuk (L. Carb.).

Spirifera fastigata Meek and Worthen (non Worthen), Proc. Acad, Nat. Sci,

Philadeiphia, 1870, p. 36 ;-Geol. Survey Illinois, VI, 1875, p. 521, pl. 30, fim. 3.

Spirifera mortonana Miller, Americau Pal. Fossils, 2 d ed., 1883, p. 298.

Spirifer mortonanus Hall and Clarke, Pal, New York, VIII, Pt. II, 1893, pp. 26, 38, pl. 38 , figs. $18,19$.

Loc. Crawfordsville, Indiana; Kings Mountain and Lebanon, Kentucky.

Spirifer mucronatus Conrad=Spirifer pennatus.

Spirifer multicostatus Castelnau.

?. Corniferous (Dev.).

Spirifer multicostatus Castelnau, Essai Système Silurien l'Amérique Septentrionale, 1843 , p. 42 , pl. 12, fig. 3 .

Loc. Schoharie, New York.

Obs. See S. divaricatus.

Spirifer multigranosus Worthen=Spirifer texasanus.

Spirifer multistriata Hall=Trematospira inultistriata.

Spirifer mundulus Rowley. Burlington (L. Carb.).

Spirifera mundula Rowley, American Geologist, XII, 1893, p. 307, pl. 14, figs. $10-12$.

Loe. Louisiaua, Missouri.

Spirifer murchisoni Castelnau.

Oriskany (Der.).

Spirifer murchisoni Castelnan, Essai Système Silurieu l'Amérique Septentrionale, 1343, p. 41, pl. 12, figs. $1,2$.

Spirifer arrecta Hall, Pal. Now York, III, 1859, p. 422, pl. 97, figs. 1, 2.

Spirifera arrecta Billings, Geol. Canada, 1863, p. 960, tig. 466.-Hall, Second Ann. Rep. N. Y. State Geol., 1883, pl. 58, figs. 21-27.

Spirifer sp. a A. Ulrich, N. Jahrb. f. Mineral., Beilageband, VIII, 1892, p. 67, pl.4, fig. 22.

Spirifer arrectus Hall and Clarke, Pal. New York, VIII, Pt. II, 1893, pp. 17, 19, 37, pl. 33, figs. 24-27.

Loc. Schoharie and Albany connties, New York; Cumberland, Maryland; Cayuga, Ontario; near Totora, Bolivia.

Obs. Castelnau's tigures prove conclusively that he was the first to describe this species.

Spirifer mysticensis Meek.

Lower Carboniferous.

Spirifera mysticensis Meek, Sixth Ann. Rep. U. S. Geol. Survey Terr., 1873, p. 466. - Hiller, North American Geol. and Pal.. 1889, p. 374.

Loc. Ontlet of Mystic Lake, Montana.

Spirifer neglectus Hall.

Keokuk (L. Carb.).

Spirifer neglectus Hall, Geol. Surrey Iowa, I, Pt. II, 1858, p. 613, pl. 20, fig. 5.

Spirifera neglecta Meek and Worthen, Geol. Survey Illinois, Vi, 1875, p. 523, pl. 30, figs. 1c, 2a.-Walcott, Mon. U. S. Geol. Survey, VIII, 1884, p. 217, pl. 18, fig. 10. 


\section{Spirifer neglectus Hall-Continued.}

? Spirifera neglecta de Koninck, Anuales du Mnsée Royal d'Historie Nat. de Belgique, XIV, 1887, p. 134, pl. 31, figs. 10-15.

Loc. Keokuk, Iowa; Warsaw and Nauvoo, Illinois; Eureka district, Nevada; ? Belgium.

Spirifer newberryi Hall.

Spirifera newberryi Hall, Second Ann. Rep. N. Y. State Geol., 1883, pl. 56, figs. $9,10$.

Spirifer newberryi Hall and Clarke, Pal. New York, VIII, Pt. II, 1895, p. 362, pl, 31, figs. 9, 10.

Loc. Northern Obio.

Spirifer niagaraensis (Conrad).

Niagara (Sil.).

Delthyris niagarensis Conrad, Jour. Acad. Nat. Sci. Philadelphia, VIII, 1842, p. 261.-Hall, Geol. N. Y.; Key. Fourth Dist., 1843, p. 105, fig. 1.

Spirifer niagarensis Hall, Pal. New York, II, 1852, p. 264, pl.54, fig. 5.-Hall and Clarke, Pal. New York, VIII, Pt. II, 1893, pp. 14, 35, pl. 21, figs. 1-4, 25; pl. 37, fig. 1 .

Spirifera niagarensis Billings, Canadian Nat. Geol., I, 1856, p. 137, pl. 2, tig. 8 ; Geol. Canada, 1863, p. 317, fig. 329.-Hall, Second Ann. Rep. N. Y. State Geol., 1883, pl. 51, figs. 1-4, 25.

Loc. Lockport, Rochester, etc., New York; Osgood, Indiana.

Spirifer niagaraensis oligoptychus Roemer.

Niagara (Sil.).

Spirifera niagarensis var. oligoptychus Roemer, sil. Fauna West. Tennessee, 1860, p. 68, pl. 5 , fig. 8 .

Spirifer macropleurus Satî̀ord, Geol. Tennessee, 1869, p. 321.

Loc. Decatur County, Tennessee.

Obs. Compare with S. eudorus Hall and S. macropleurus Conrad.

Spirifer nictauvensis Dawson.

Oriskany (Dev.).

Spirifera nictavensis Dawson, Acadian Geology, 3d ed., 1878, p. 499, fig. 176;Canadian Nat. Geol., n. ser., IX, 1879, p. 3.

Loc. Near Nictanx, Nova Scotia.

Spirifer nobilis Barrande.

Spirifer nobilis Barrande, Ueber die Brach. der Sil. Schicht von Böhmen, 1817.-

Hall and Clarke, Pal. New York, VIII, Pt. II, 1893, pp. 14, 35, pl. 29, fig. 16; pl. 37 , figs. 2,3 .

Spirifer racinensis MeChesney, Now Pal. Fossils, 1861, p. 84.

Spirifer 1nconstans Hall, Ann. Rep. Geol. Survey Wisconsin, 1861, p. 26 ;- Feol. Rep. Wisconsin, I, 1862, p. 69, fig. 6 ; p. 436.

Spirifera nobilis Hall, Twentieth Rep. N. Y. State Cab. Nat. Hist., 1867, p. 372, pl. 13, figs. 14-16.

Spirifera racinensis McChesney, New Pal. Fossils, 1868, p. 84.

Loc. Raciue, Wisconsin; Chicago, Illinois.

Spirifer norwoodaua Hall=Spiriferina norwoodana.

Spirifer norwoodi Meek=Cyrtia norwoodi.

Spirifer nova-mexicanus Miller.

Burlington (L. Carb.).

Spirifera novamexicana Miller, Jour. Cincinuati Soc. Nat. Hist., IV, 1881, p. 314, pl. 7, fig. 10.

Loc. Lake Valley mining district, New Mexico.

Spirifer nymphus Billings=Reticularia nympha.

Spirifer obtusus Gabb=Spiriferina obtusa. 
Spirifer octocostatus Hall.

Lower Helderberg (Dev.).

Spirifer octocostata Mall, 'Tenth Rep. N. Y. State Cab. Nat. Hist., 1857, p. 62 ;Pal. New York, III, 1859, p. 205, pl. 28, fig. 4.

Loc. Cumberlanc, Maryland.

Spirifer octoplicatus Hall=Spiriferina cristata.

Spir" er opimus Hall= Spirifer rockymontanus.

Spirifer orbignyi Morris and Sharpe.

Lower Devonian.

Spirifer orbignii NIorris and Sharpe, Quart. Jour. Geol. Soc. London, II, 1846, p. 276, pl. 11, fig. 3 .

Loc. Falklind Islands.

Obs. Probably identical with S. antareticus.

Spirifer oregonensis Shumard.

Upper Carboniferous.

Spirifer oregonensis Shumard, Trans. St. Louis Acad. Sci., II, 1863, p. 108.

Loc. Near Fort Filnore, New Mexico.

Spirifer orestes Hall and Whitfield.

Chemung (Dev.).

Spirifera orestes Hall and Whitfield, Twenty-third Rep. N. I. State Cab. Nat.

Hist., 1872, p. 237, pl. 11, figs. 16-20.-Hall, Second Ann. Rep. N. Y. State Geol., 1883, pl. 55, fig. 20.

Spirifer orestes Hall and Clarke, Pal. New York, VIII, Pt. II, 1893, pp. 27, 38, pl. 30 , tig. 20.

Loc. Riockford, Iowa; Naples, New York.

Obs. Compare with S. strigosus.

Spirifer osagensis Swallow.

Chouteau (L. Carb.).

Spirifer osagensis Swallow, Trans. St. Lonis Acad. Sci., I, 1860, p. 641.

Loc. Pettis County, Missouri.

Obs. Regarded by Keyes as a synonym for S. marionensis.

Spirifer ovalis Phillips.

Carboniferous.

Spirifer ovalis Phillips, Geol. Yorkshire, II, 1836, p. 219, pl. 10, fig. 5.-Etheridge, Quart. Jour. Geol. Soc. London, XXXIV, 1878, p. 629.

Loc. Europe. Feilden Isthmus, lat. $82^{\circ} 43^{\prime}$.

Spirifer oweni Hall=Spirifer granulosus.

Spirifer paradoxus (Schlotheim).

Corniferous (Dev.).

Terebratula paradoxa Schlotheim, Petrefactenkunde, VII, 1813, p. 249, tab. 2, fig. 6.

Spirifer paradoxus? Meek and Worthen, Geol. Survey Illinois, III, 1868. p. 415, pl. 10, fig. 2 .

Loc. Europe; Union and Jackson connties, Illinois.

Spirifer parryana Hall=S. euryteines Owen.

Spirifer peculiaris Shumard.

Kinderhook (L. Carb.).

Spirifer? pecnliaris Shumard, Geol. Rep. Yissouri, 1855, p. 202, Pl. C, fig. 7.

Spirifera (Martinia) peculiaris White, Wheeler's Expl. and Survey west 100th Meridian, IV, 1875, p. 90, pl. 5, fig. 7 .

Loc. Cooper County, Missouri; Mountain Spring, Nevada.

Spirifer pedroanus Rathbun.

Middle Devonian.

Spirifera jedroana (Hartt) Rathbun, Bull. Buffalo Soc. Nat. Sci., I, 1874, p. 237,

pl. 8, figs. 1-9, 13, 14, 16-20;-Proc. Boston Soc. Nat. Hist., XX, 1879, p. 27.

Loc. Erere and Province of Para, Brazil.

Spirifer pennatus Owen=Spirifer iowaeusis. 
Spirifer pennatus (Atwater). Marcellus, Hamilton, and Chemung (Dev.).

Terebratula pennata Atwater, Anerican Jour. Sci, Arts, II, 1820, p. 244, pl. 1, figs. 2,3 .

Delthyris mucronata Conrad, Fifth Ann. Rep. Geol. Snrvey New York, 1841, p. 54.-Vanuxem, Geol. N. Y.; Rep. Third Dist., 1812, p. 150, fig. 3.-Hall, Ibidem, Rep. Fourth Dist., 1843, p. 198, figs. 2, 3; p. 205, fig. 3 (non p. 270, fig. $3=$ S. pennatus posterus).-(Conrad) Hall, Fifteenth Rep. N. Y. State Cab. Nat. Hist., 1862, pl. 11, fig. 18.

Spirifer sowerbyi Casteluau, Essai Syst. Silurien l'Amérique Septentrionale, 1843, pl. 13, fig. 1 (non Fischer).

Spirifer lyelli de Verneuil, Ibidem, 1843, p. 43.

Spirifer mucronata Billings, Canadian Nat. Geol., I, 1856, p. 474, pl. 7, figs. 9, 10.Rogers, Geol. Pennsylvania, II, 1858, p. 828, tig. 668.

Spirifera mucronata Billings, Canadian Jour., 11. ser., VI, 1861, p. 254, figs. 5962 ;-Geol. Canada, 1863, p. 386, fig. 424.-Hall, Pal. New York, IV, 1867, p. 216, pl. 34, figs. 1-32.-Nicholson, Pal. Prov. Ontario, 1874, 1. 80.-Whitfield, Geol. Wisconsin, IV, 1882, p. 328, pl.25, figs.27, 28.-Hall, Second Aun. Rep. N. Y. State Geol., I883, pl.59, figs. 13-22.-Calvin, American Geologist, I, 1888, p. 82.-Nettelroth, Kentucky Fossil Shells, Mem. Keutucky Geol. Survey, 1889, p. 126 , pl. 31 , figs. 10,11 .

Spirifer mucronatus var. Williams, Bull. Geol. Soc. America, I, 1890, pl. 12, fig. 13.

Spirifer mucronatus Hall and Clarke, Pal. Now York, VIII, Pt. II, 1893, pp. 14, 17, 36, pl. 29, fig. 8; pl. 34, figs. 13-22.

Loc. New York, Pennsylvania, Maryland, Virginia; Bosanquet, Ontario; Milwankee, Wisconsin.

Obs. Atwater's specimen was found in the drift of Ohio. Mr. Miller is correct in regarding it the same as the well-known S. mueronatus.

Spirifer pennatus posterus Hall and Clarke.

Chemung (Dev.).

Delthyris mueronata (partim) Hall, Geol. New York; Rep. Fourth Dist., 1843, p. 270 , fig. 3 .

Spirifer mucronatus var. posterns Hall and Clarke, Pal. New York, VIII, PA. II, 1895, p. 361, pl. 34, figs. 27-31.

Loc. Tompkins County, New York.

Spirifer pennatus tulliensis Williams.

Tully (Dev.).

Spirifer mucronatus var. tulliensis Williams, Bull. Geol. Soc. America, I, 1890, p. 491, pl. 12, fig. 12.

Loc. Tinkers Falls, New York.

Spirifer pentlandi d'Orbiguy.

Carboniferous.

Spirifer pentlaudi d'Orbigny, Voyage dans l'Amérique Méridionale, Pal., 1842, p. $48, \mathrm{pl} .5$, figs. 15 .

Loc. Lake Titicaca, Bolivia.

Spirifer perforata Hall='Trematospira perforata.

Spirifer perextensus Meek and Worthen.

Corniferous (Dev.).

Spirifera perextensa Meek and Worthen, Geol. Survey Illinois, III, 1868, p. 414, pl. 10, fig. 1.

Loc. Near Jonesboro, Union County, Illinois.

$\mathrm{Ob}$. Regarded by lieyes as a synonym for $\mathrm{S}$. ligus $=\mathrm{S}$. iowaensis.

Spirifer perlamellosus Hall=Delthyris perlamellosa.

Spirifer perplexus McChesney=Reticularia perplexa.

Bull. $87-26$ 
Spirifer pertenuis Hall.

Hamilton (Dev.).

Spirifer pertemuis Ilall, Tenth Rep. N. Y. State Cab. Nat. Ilist., 1857, p. 163.

Spirifera perextensa Hall, Pal. New York, IV, 1867. p. 236.

Loc. C'umberland, Maryland (IVhitfield).

()bs. Compare with S. macronota Hall.

Spiri er pharovicinus A. Winchell.

Huron (Dev.).

spirilera pliaroviciua A. Irinchell, Proc. Acad. Nat. Sci. Pliladelphia, 1862, p. 406.

Loc. Port anx Barques, Michigan.

Spirifer pinonensis Meek.

Lower to Upper Devonian.

Spirifer (Trignonotrcta) pinonensis Meek, Proc. Acal. Nat. Sci. Philadelphia, 1870, 1. 60;-King's U. S. Geol. Expl. 40th Parl., IV, 1877, p. 45, pl. 1, fig. 9.

Spirifer (Trigonotreta) argentariıs Meek, King's U. S. Gcol. Expl. 40th Parl., IV, 1877, 1. 4\%, pl. 4, fig. 4.

Spirifera pinonemsis Walcott, Mon. U. S. Geol. Survey, VIII, 1884, p. 138, pl. 4, fig. 1 .

Loc. White Pine and Eureka districts, Nerada.

Spirifer planoconvexus Shumard=Ambocolia planiconvexa.

Spirifer plenus Hall=Syringothyris plena.

Spirifer plicatella of authors=Spirifer radiatus.

Spirifer pluto ('larke.

Genesee (Dev.).

Spirifera pluto Clarke, Bull U. S. Geol. Survey, 16, 1885, p. 31, pl. 3, fig. 12.

Ioc. Ontario County, New Tork.

Obs. See Leiorhynchus hecate Clarke.

Spirifer prematura Hall=Reticularia prematura.

Spirifer propinquus \#all=Syringothyris texta.

Spirifer prorus Conrad=Spirifer acuminatus.

Spirifer psendolineatus Irall=Reticularia pseudolineata.

Spirifer pulchrus Meek=Spiriferina pulchra.

Spirifer pyramidalis Hall=Cyrtina pyramidalis.

Spirifer pyxirlatus Hall=Metaplasia pyxidata.

Spirifer quichuus d'Orbigny.

Devonian.

Spirifer quichua d'Orbigny, Voyage dans l'Amérique Méridionale, Pal., 1812, p. 37 , pl. 2, fig. 21.

Loc. Chuquisaca, Bolivia.

Spinifer racinensis McChesney = Spirifer nobilis.

Spirifer radiatus Sowerby.

Clinton and Niagara (Sil.).

Spirifer plicatella var. radiata Sowerby, Miueral Conchology, V, 1825, p. 493, figs. 1, 2 .

Delthyris bialveata Conrad, Jour. Acad. Nat. Sci. Philadelphia, VIII, 1842, p. 261, pl. 14, fig. 17.

Delthyris radiata Hall, Geol. N. Y.; Rep. Fourth Dist., 1843, p. 105, fig. 2.

Spirifer radiata IIall, Pal. New York, II, 1852, Pl). 66, 265, pl. 22, figs. 2ঐ-25 (non $2 a-2 c=$ Cyrtia weta); pl. 54, fig. 6 .

Spirifera rariata Billings, Canadian Nat. Geol., I, 1856, p. 135, pl. 2, figs. 2, 3;Geol. Canada, 1863, p. 317, fig. 328.-1Iall and Whitfield, Twenty-serenth Rep. N. I. State Cab. Nat. Ilist., 1875, pl. 9, figs. 17, 18.-Hall, 'wentyeighth Rep. Ibilem, 1879, p. 157, pl. 21, figs. 20-30.-White, Seeond Ann. Rep. Indiana Purean of Statisties and (ieol., 1880, p. 497, p]. 3, figs. 5, 6;'Tenth Rep. State Geol. Indiana, 1881, p. 129, pl. 3, figs. 5, 6.-Hall, Eleventh 


\section{Spirifer radiatus Sowerby-Continued.}

Rep. Ibidem, 1882, p. 296, pl. 24, figs. 20-30.-Whitfield, Geol. Wisconsin, IV, 1882, p. 287, pl. 17, figs. 1, 2.-Hall, Second Ann. Rep. N. Y. State Geol, 1883, 11. 51, figs. 9-13,26 (?14-17).-Nettelroth, Kentucky Fossil Shells, Mem. Kentucky Geol. Survey, 1889, p. 130, pl. 29, figs. 13-16.-Foerste, Proc. Boston Soc. Nat. Hist., XXIV, 1890, 1. 313, pl. 5, fig. 6 .

Spirifer radiatus Beecher and Clarke, Mem. N. Y. State Mus., I, 1889, 1. 77, pl. 6, figs. 9-11.-Hall and Clarke, Pal. Now York, VIII, Pt. II, 1893, N1. 13, 35, pl. 21 , figs. 5, 9-13, 26 (?14-18).

Spirifer tenuistriatus Shaler (non Hall), Bull. Mus. Com. Zool., 1, 1865, ¡. 70.

Spirifera plicatella Billings, Catalogne Silurian Fossils of Anticosti, 1866, p. 48.

Spirifora plicatella var. radiata Hall, 'Twentieth Rep. N. Y. State Cal. Nat. Hist., 1867, p. 371, pl. 13, figs. 9-11.

Loc. Europe; Lockport, Rochester, etc., New York; Ilanilton, Ontirio; Squatook Lake, New Brunswick; Waldron and Osgood, Indiana ; Lonisville, Kentucky; Cumberland Gap, Temnessee; Bridgeport, Illinois; Racine, Wauwatosa, and Milwaukee, Wisconsin.

\section{Spirifer raricostus Hall=Delthyris raricosta.}

\section{Spirifer rectiplicatus (Courad).}

Atrspa rectiplicata Conrad, Jour. Acal. Nat. Sci. Philadelphia, VIII, 1812, p. 265.

Loc. "Helderberg Monntains in Mliddle Silurian limestone."

Obs. May be the same as Metaplasia pyxidata Hall.

Spirifer richardsoni Meek=Reticularia fimbriata.

Spirifer rockymontanus Marcou.

Upper Carboniferous.

Spirifer rockymontani Mareou, Geol. North America, March, 1858, 1. 50, pl. 7, tig. 4 .

Spirifer opima Hall, Geol. Survey Iowa, I, Pt. II, Decemher, 1858, p. 711.

Spirifera subventricosa IIcChesney, New Pal. Fossils, 1860, 1. 41;-Trans. Chicago Acad. Sci., I, 1868, p. 35, pl. 1, fig. 4.

Spirifera opima Derby, Bull. Cornell University, I, 1874, p. 15, pl. 1, tig. 4; pl. 2, fig. 7 ; pl. 4, fig. 12.-Hall, Second Ann. Rep. N. Y. State Gioul., 1883, 11. 56, tigs. 4-7.-Herrick, Bull. Denison Univ., II, 1887, p. 14. 11. '2, fig. 23. Spirifera (Trigonotreta) opima Meek, Pal. Ohio, II, 1875, p. 329, pl. 19, figs. 14a1.th (?1.4e);-King's U. S. Geol. Expl. 40th Parl., IV, 1877, p. 88, pl. 9, fig. 6.

Spirifera rockymontana White, Wheeler's Expl. and Survey west 100th Merid., $[\mathrm{V}, 1875$, p. 134, pl. 11, tig. 9.-Keyes, Proc. Acad. Nat. Sci. Philudelphia, 1888, p. 231 ;-Geol. Survey Missonri, V, 1895, p. 84.

?Spirifera rockymontana? Whittield, Anuals N. Y. Acad. Sci., V, 1891, p. a8t, pl. 13, fig. 20;-Gcol. Ohio, VII, 1895, p. 471, pl. 9, figr. 20.

Spirifer opinus Hall and Clarke, Pal. New York, VIII, Pt. II, 1893, 1'p. 27, 39, pl. 31, figs. $4-7$.

Loc. Tigeras and Canyon of San Antonio, New Mexico: Oquirrl Range, Utah; Arkausas; Iowa; Nissouri; Illinois; Indiana; Ohio; Marylaud; W'est Virginia; Bomjardim and Itaituba, Brazil; Chester group at Newtunville, Ohio (Whitfield).

Ub8. See S. boonensis.

\section{Spirifer rostellatus Hall.}

Kéeokuk (L. Carb.).

Spirifer rostellata Hall, Geol. Survey Iowa, I, Pt. II, 1858, p. 641, pl. 20, fig. 2.

Spirifer rostellatus Hall and Clarke, Pal. New York, VIII, Pt. II, 1893, p. 26, pl. 32, fig. 5.

Loc. Skunk River, Iowa. 
Spirifer rostellum Ilall and Whitfield.

Niagara (Sil.).

Spirilera rostellm Hall and Whitfeld, Twenty-fourth Rep. N. Y. State Cab. Nat. Hist., 1872, 1. 182 ;-Hall, 'Twenty-seventh Rep. Ibidem, 1875, pl. 9, figs. 1113.-Neitelroth, Kentucky Fossil Shells, Mem. Kentueky Geol. Survey, 1889, 1. 129, pl. 29, fig. 25 ; pl. 27, figs. 17-19.

Spirifera (Cyrtia) rostellum Foerste, Proe. Hoston Soc. Nat. Hist., XXIV, 1890, 1. 313, , 1. 5 , tigr. 5 .

Loc. Louisville, Kentueky; Collinsville, Alalama.

Spirifer rostratus Morton.

Upper Carboniferous.

Spirifer rostrata Morton, American Jour. Sei. Arts, 1836, p. 152, pl. 14, fig. 34.

Loc. Junior Furnace, Seioto County, Ohio.

06s. Poorly defined. May be a species of Athyris.

Spirifer rugicostus Hall=Delthyris rugicosta.

Spirifer saffordi Hall.

Lower Helderberg (Dev.).

Spirifer saffordi Hall, Pal. New York, 1Il, 1859, p. 203, pl. 28, tig. 2.

Loc. Decatur County, Tennessee; Hudson, New York.

Spirifer scobina Meek.

Carboniferous.

Spirifera scobina Meek, Proc. Acad. Nat. Sei. Philadelphia, 1860, p. 310.

Spirifer (Spiriferina?) scobina Mook, Simpson's Rep. Expl. Great Basin Terr. Utah, 1876, p. 351, pl. 2, fig. 5.

Spirifera (Trigonotreta) seobina Mleek, King's U. S. Geol. Expl. 40th Parl., IV, 1877 , p. 90, pl. 9, fig. 1.

Loc. Divide between Long and Ruby Valleys, Utah.

Spirifer sculptilis Hall=Delthyris sculptilis.

Spirifer segmentum Hall.

Upper Helderberg (Dev.).

Spirifer segmentus Hall, Tenth Rep. N. Y. State Cab. Nat. Hist., 1857, p. 131.

Spirifera segmenta Hall, Pal. New York, IV, 1867, p. 207, pl. 31, figs. 14-19.Nottelroth, Kentucky Fossil Shells, Meim. Kentucky Geol. Survey, 1889, p. 132, pl. 13, figs. $36-38$.

Loc. Falls of Ohio; Columbus, Ohio.

Spirifer semiplicatus Hall=Reticularia cooperensis.

Spirifer setigerus Hall=Reticularia setigera.

Spirifer sheppardi Castelnau=Platystrophia biforata.

Spirifer sillanus A. Winchell.

Waverly (L. Carb.).

Spirifera sillana A. Winchell, Proe. Aead. Nat. Sei. Philadelphia, 1865, p. 119.

Loc. Near Cuyahoga Falls, Ohio.

Spirifer similior Winchell and Marcy.

Niagara (Sil.).

Spirifera (Martinia) similior W. and M., Mem. Boston Soe. Nat. Hist., I, 1865, 1. 93.

Pentamerus similior Hall, Twentieth Rep. N. Y. State Cab. Nat. Hist., 1868, p. 397.

Loc. Bridgeport, Illinois.

Obs. This shell has spirals.

Spirifer solidirostris White= Spiriferina solidirostris. Spirifer sowerbyi Castelnau (non Fischer)=Spirifer pennatus. Spirifer spinosus Norwood and Pratten=Spiriferina spinosa.

Spirifer striatiformis Meek.

Waverly (L. Carb.).

Spirifera (Trigonotreta) striatiformis Meek, Pal. Ohio, II, 1875, p. 280, pl. 14, fig. 8.

Spirifer striatiformis Herrick, Bull. Denison Univ., III, 1888, p. 44, pl. 3, fig. 26;

pl. 6, figs. 6, 7;-Geol. Ohio, VIl, 1895, pl. 15, fig. 9.

Loc. Sciotoville and Licking County, Ohio. 
Spirifer striatus Mareou (non Martin)=Spirifer marcou.

Spirifer striatus (Martin).

Carboniferons.

Anomites striatus Martin, Petrefacta Derbiensia, 1809, pl. 23.

Spirifera striata Davidson, Mon. British Carb. Brach., Pal. Soc., 1857, p. 19, pl.2, figs. 12-21; pl. 3, figs. 2-6.-White, Wheeler's Expl. aud Survey west of 100th Meridian, IV, 1875, pp. 88, 134, pl.5, fig. 10.-Hall and Whitfield, King's U. S. Geol. Expl. 40th Parl., IV, 1877, p. 269, pl. 5, figs. 13-15.-Hartt, Dawson's Acadian Geology, 3d ed., 1878, p. 301.-Miller, Jour. Cincinnati Soc. Nat. Hist., IV, 1881, p. 2.

Loc. Mountain Spring, Nevada; Oquirrh Mountains, Utah; Lake Valley mining district, New Mexico; Windsor, Nova Ścotia.

Spirifer striatus attennatns Owen=S. keokuk.

Spirifer striatns multicostatns Tonla $=$ Spirifer condor.

Spirifer striatus triplicatus Marcou=Spirifer camaratus.

Spirifer strigosus Meek.

Deronian.

Spirifera macra Meek (non Hall), Proc. Acad. Nat. Sci. Philadelphia, 1860, p. 309.

Spirifera strigosa Meek, note appended to extras of the paper mentioned above.-

IVebster, American Nat., XXII, 1888, p. 1102.

Spirifer strigosus Meek, Simpson's Rep. Expl. Great Basin Terr. Utah, 1876, p. 347, pl. 1, fig. 5 .

Spirifera (Trigonotreta) strigosa Meek, King's U. S. Geol. Expl. 40th Parl., IV, 1877, p. 43, pl. 3, fig. 5 .

Loc. Neils Valley, Utah; Nerada; Rockford, Iowa.

Obs. See S. orestes.

Spirifer subæqualis Hall.

Warsaw (L. Carb.).

Spirifer subiequalis Hall, Geol. Survey Iowa, I, Pt. II, 1858, p. 663, pl. 23, fig. 9;-Second Ann. Rep. N. Y. State Geol., 1883, pl. 56, figs. 13, 14.- Hall and Clarke, Pal. New York, VIII, Pt. II, 1893, pp. 26, 36, pl. 31, tigs. 13, 14.

Loc. Warsaw, Illinois.

Spirifer subattenuatus Hall. Chemnng and Marshall (Uev.-L. Carb.). Spirifer sp. undet. Owen, Rep. Geol. Survey Wisconsiu, Iowa, and Minuesota, 1852, pl. 3, fig. 9 .

Spirifera submncronata Hall, Geol. Survey Iowa, I, Pt. II, 1858, p. 504, pl. 1, fig. 3. Spirifer subattenuata A. Winchell, Proc. Acad. Nat. Sci. Philarlelphia, 1862, p. 405.-Whiteares, Cont. Caualian l'al., I, 1891, p. 223.

Loc. Independence and Bufialo, Iowa; Rock Islaud, Illinois; Naples, New York; Athabasea River, Canada; in the Marshall gronp at Port aux Barques, Michigan.

Spirifer subcardiformis Hall.

Warsaw (I. Carb.).

Spirifer subcardiformis Hall, Geol. Survey Iowa, I, Pt. II, 1858, p. 660, pl. 23, fig. 6. Spirifera subcardiformis White, Twelfth $\Lambda \mathrm{m}$. Rep. U. S. Geol. Survey'Terr., I883, p. 165, pl. 41, fig. 2.

Loc. Alton, Illinois; Spergen Hill, Indiana.

Spirifer subcuspidatus Hall=Syringothyris texta.

Spirifer subdecussatus Whiteaves.

Hamilton (Dev.).

Spirifera subdecussata Whiteaves, Cout. Canadian Pal., I, 1889, p. 114, pl. 15, fig. 3.

Loc Moravianton Thames River, Canada.

Spirifer subelliptice McChesney=Spiriferina subelliptica.

Spirifer sublineata Meek=Martinia sublineata.

Spirifer submueronatu Hall, 1858 (non 1857)= Spirifer subattenuatus. 
Spirifer submucronatus Hall.

Oriskany (Dev.).

Spirifer submucromata. IIall, 'Tenth Rep. N. Y. State Cal. Nar. JJist., 1857, p.62;-

Pal. New York, III, 1859, p. 419, pl. 96, fig. 7.

Spirifera sulmmeronata Hall, Second Ann. Rep. N. Y. State Geol., 1883, pl. 58, figs. 5-7.

Spirifor sulumueronatus Hall and Clarke, Pal. New York, VIIl, Pł. II, 1893, p1). 17, 36, p) 3.3, figs. 5-7.

Loc. Cumberland, Maryland.

Obs. J'ossibly tho young of' Spirifor cumberiandia.

Spirifer suborbicularis Hall.

Keokuk (L. Carb.).

Spirifer suborlicularis IIall, Geol. Survey Iowa, I, l’t. II, 18:8, p. 6.14.

Spirifera suborbicularis Meek and Worthen, Geol. Snrvey Illinois, VI, 1875, 1). 523, pl. 30, fig. 1.

Loc. lícoluk, lowa: Warsaw and Nauvoo, Illinois.

Spirifer subrotundatus Hall.

Kinderhook (L. Carb.).

Spirifer sulurotundata Hall (non McCoy, 1855), Geol. Survey Iowa, I, Pt. II, 1858, p. 521, pl. 7 , fig. 8 .

Spirifera subrotundata Keyes, Geol. Survey Missouri, V, 18:5, p. 78.

Lor. Burlington, Iowa; Sciotoville, Ohio (IViuchell).

Obs. This specific nane was tirst nsed by McCoy in 1855 lunt is nsually regarted as a syuonvm for S. piuguis Sowerby. Do Koninck, lowevor, retains MeCoj's name as late as 1887.

Spirifer substrigosus Webster.

Chemung (Dev.).

Spirifera substrigosa Weloster, American Nat., XXII, 1888, p. 1101.

Loc. Near Rockforl, Iowa.

Spirifer subsulcatus Hall.

Arisaig (Sil.).

Spirifer subsulcata IIall (non Dalman, 1828), Canadian Nat. Geol., Y, 1860, 1\% 145.

Spirifera subsulcata Dawson, Acadian Geology, 3d ed., 1878, p. 597.-Miller, N. American Geol. and Pal., 1889, p. 376.

Loc. Arisaig, Nora Srotia.

Spirifer subumbona Hall=Martinia subumbona.

Spirifer submudifera Meek and Worthen=Reticularia subundifer:

Spirifer subvaricosus IIall and Whitfield.

? Hamilton (Dev.).

Spirifera subvaricosa Hall and Whitfield, Twenty-third Rep. N. Y. State Cal. Nat. II ist., 1872, p. 237, pl. 11, figs. 12-15.

Loc. Waterloo, Iowi.

Spirifer subventricosns McChesney=Spirifer rockymontana.

Spirifer suleatus Hall=Delthyris suleata.

Spirifer sulcifer Sinumard.

Upper Carboniferons.

Spirifer sulcifera Shmmard, Trans. St. Lonis Acal. Sci., I, 1858, p. 293, pl. 11, fig. 3.

Loc. Guadalupe Mountains, New Mexico.

Spirifer superbus Billings (uon Eielıvald)=Spirifer billingsana.

Spirifer taneyensis Swallow.

Choutean (L. Carb.).

Spirifer taneyensis Swallow, Trans. St. Lonis Acad. Sci., I, 1860, p. 645.

Spirifera taneyensis Koyes. Geol. Snrey Missonri, Y, 1895, p. 78.

Loe. Taney Comuty, Missour.

Spirifer temeraria Miller = Retienlaria temeraria. 
Spirifer tenuicostatus Hall.

Keokuk and Warsaw (L. Carb.). Spirifer tennicostata Hall, Geol. Survey Iowa, I, Pt. II, 1858, 1. 66'2, pl. 23, fig. 8. Loc. Keokuk, Iowa; Warsaw-and Dallas, Illinois.

Spirifer tenuimarginatus Hall.

Keokuk (L. Carb.). Spirifer teuuimarginata Hall, Geol. Survey Iowa, I, Pt. II, 1858, p. 64I, pl. 20, fig. 1.

Spirifera tenuimarginata Hall, Second Ann. Rep. N. Y. State Geol., 1883, pl. 57, figs. 4-6.

Spirifer tenuimarginatus Hall and Clarke, Pal. New York, VIII, I’t. II, 1893, p. $38, \mathrm{pl} .32$, figs. 4,6 .

Loc. Warsaw, Illinois.

Spirifer tenuis Hall.

Hamilton (Dev.).

Spirifer tenuis IIall, Tenth Rep. N. Y. State Cal. Nat. Hist., 1857, p. 162.

Spirıfera tenuis Hall, Pal. New York, IV, I867, p. 236.

Loc. Cumberland, Maryland.

Obs. Compare with Spirifer granulosus Conrad.

Spirifer tenuispinatns Herriek=Reticularia tenuispinata. Spirifer tenuistriatus Shaler (non Hall) $=$ Spirifer radiatus.

Spirifer tenuistriatus Hall.

Lower Helderberg (Dev.).

Spirifer tenuistriata Hall, Pal. New York, III, 1859, p. 201, pl. 28, tig. 3.

Spirifera tenuistriata 1Iall, Seeond Anu. lep. N. Y. State Geol., 1883, pl. 61, fig. 8.

Spirifer tenuistriatus Hall aud Clarke, l'al. New York, VII, Pt. II, 1895, pl. 36, fig. 8.

Loc. Deeatur County, Tennessee.

Spirifer texasanus Meek.

Upper Carboniferons.

Spirifer (Trigonotreta?) texana Meels, Proc. Aead. Nat. Sci. I'hiladelphia, 1871, p. 179.

Spirifer (Trigonotreta?) texanus Moek, Macomb's Rep. Expl. Exped. from Santa Fe to the Great Colorado of the West, 1876, p. 139, pl. 3, fig. 5.

Spirifera multigranosa Worthen, Geol. Survey Illinois, VIII, 1890, 1. 105, pl. 11, fig. 5.

Spirifer texanus Hall aud Clarke, l'al. New lork, VIII, Pt. II, 1893, 1p. 26, 38, pl. 37 , ligs. 16,17 .

Loc. Young and Jack counties, Texas; Springtield, Illinois.

Spirifer textus $I$ all=Syringothyris texta.

Spirifer translatus Swallow=Retieularia translata.

Spirifer transversus MeChesney = Spiriferiua transversa.

Spirifer tribulis Hall.

Oriskany (Dev.).

Spirifer tribulis Hall, Pal. New York, III, 1859, p. 420, jil. 96, lig. 8;-Second Ann. Rep. N. Y. State Geol., 1883, pl.58, figs. 1-1.-Hall and Clarke, I'al. New

York, VIII, Pt. II, 1893, pp. 19, 37, pl.33, figs. I-4.

Loc. Cumberland, Marçland.

Obs. Possiluly the young of Spirifer murehisoni.

Spirifer trigonalis (Martin).

Carboniferous.

Anomites trigonalis Martin, Petrefacta Derbiensia, tab. 36, 1809, 1ig. 1.

Spirifera trigonalis Walcott, Mon. U. S. Geol. Survey, VIII, 1854, 1. 215, pl. 18, fig. 11.

Loc. Europe; Eureka district, Nevada.

Spirifer triplicatus Hall=Spirifer eamaratus.

Spirifer triradialis Meek (non Phillips)=Spirifer agelaius. 


\section{Spirifer troosti Castelnau.}

? Formativn.

spirifor troosti Castelnau, lissai Systime Silurien l'Amérique septentrionalo,

1813, p. 41, pl. 12, fig. 5 .

Lor. "Kientucky."

Spirifer tullius Hall.

Hamilton (Dev.).

Spirifera tullia llall, l'al. New York, IY, 1867, p. 218, pl. 35, tigs. 1-9);-Second Amm. Rre. N. Y. sitate Geol., 1883, 11. 52, fig. 18.

Spirifera tullia var. Whiteaves, Cont. Canalian Pal., I, 1891, 1. 224, pl. 32, fig. 1. Spirifer tullius llall and Clarke, Pal. New York, VIII, Pt. 11, 1893, 1'1. 14, 35, pl. 22, tig. 1s; pl. 37, tigs, 6, 7 .

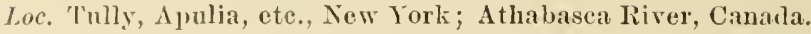

Spirifer tumidus Bayle and Coyuand=Spiriferina rostrata.

Spirifer undiferus Roemer= Reticularia undifera.

Spirifer unica Hall=Spirifer arenosus.

Spirifer urbanus Calvin.

Hamilton (Dev.).

Spirifera urbana Calvin, Bull. Lab. Univ. of Iowa, 1888, p. 28.-Bull. Lab. Nat.

Ilist. State Univ. Iowa, 11, 1892, p. 166, pl.12, fig. 1.

Loc. Iowa City and Linn County, Iowa.

Spirifer utahensis Meek=Cyrtia norwoodi.

Spirifer valenteana Rathbuu.

Miıldle Devonian.

Spirifera valentcana (Hartt MS.) Rathbun, Bull. Bufialo Soc. Nat. Sci., I, 1874, p. 241, 11. 8, fig. 11.

Loc. Erere, Province of Para, Brazil.

Spirifer vanuxemi Hall.

Tentaculite (Sil.).

Orthis plicata Vanuxem (non Sowerby), Geol. New York; Rep. Third Dist., 18F, 1. 112, fix. 1.

Orthis? (Delthyris) plicatus Hall, Ibidem, Fourth Dist., 1843, p. 142, fig. 1.

Spirifer vanuxemi Hall, Pal. New York, I1l, 1859, p. 198, pl. 8, figs. 17-23;-Second Rep. N. Y. State Geol., 1883, pl. 61, tig. 11.-Hall aurl Clarke, Pal. New York, VIII, Pt. II, 1893, 1). 19, 36, pl. 36, ig. 11.-Whitfield, Geol. Ohio, V'll, 1895, p. 411, pl. 1, figs. 4, 5.

Spirifera vanuxemi Whitfield, Annals X. Y. Acad. Sci., V, 1891, P. 509, 11. 5, figrs. $4,5$.

Loc. Albany and Schoharie counties, New York; Put in Bay Island, Lake Erie.

Obs. Vanuxem's specific name is restorerl, since sowerby's species is an Orthis.

\section{Spirifer varicosus Hall.}

Corniferous (Dev.).

Spirifer varicosa Hall, Tenth Rep. N. Y. State Cah. Nat. IIist., 1857, 1. 130.

Spirifera varicosi Billings, Canadian Jour., VI, 1861, p. 255, figs. 63, 64;-Geol. Canada, 1863, p. 960, tig. 467.-Hall, Pal. New York, IV, 1867, 1. 205, pl.31, figs. 1-4;-Seeond Rep. N. Y. State Geol., 1883, pl, 59, figs. 4-8.-Walcott, Mon. I. S. Geol. Survey, VIII, 1881, p. 136.-Nettelroth, Kentucky Fossil Shells, Mem. Kentucky Geol. Survey, 1889, p. 131, pl. 10, tigs. 11-20, 23-25.

Spirifer varicosns Hall and Clarke, Pal. Now York, VIII, Pt. II, 1893, pp. 17, 36, pl. 3t, figs. 4-8.

Loc. Williamsville, New York; Woodstock, Canada; Columbus, Ohio; Louisville, Kentucky; Lureka district, Nevadi.

Spirifer ventricosa Hall= Nucleospira ventricosa.

Spirifer venustus Hall=Spirifer divaricatus.

Spirifer vernonensis Swallow.

Chouteau (L. Carb.).

Spirifer vermonensis Swallow, Trans. St. Lonis Acal. Sci., I, 1860, p. 64t.-A.

Winchell, l'rue. Aead. Nat. Sci. Philadelphia, 1865, p. 119.

Loc. St. Jonis County, Missouri.

Ob8. Regarded by kieyes as a syuonym for S. marionensis. 
Spirifer vernonensis ozarkensis Swallow.

Choutean (L. Carb.).

Spirifer vernonensis var. ozarkensis Swallow, 'Trans. St. Lou is Acarl. Sci., I, 1860, p. 644.

Loc. 'Taney County, Missouri.

Obs. Regarded by lieyes as a syuonym for S. marionensis.

Spirifer vogeli vou Aminon.

Middle Devonian.

Spirifer vogeli von Ammon, Zeits. Gesell. fïir Erdk., Berlin, XXVIII, 1893, p. 362, fig. 6 .

Loc. Titquarassn, Mato Grosso, Brazil.

Spirifer waldronensis Miller and Dyer=Mimulus waldronensis.

Spirifer waverlyensis A. Winchell.

Waverly (L. Carb.).

Spirifer waverlyensis A. Winchell, Proc. Amer. Phil. Soc., XII, 1870, p. 251.

Loc. "Newark, Ohio" (A. Wiuchell's MS.).

Spirifer whitneyi Hall.

Chemung (Dev.).

Spirifer whitneyi Hall, Geol. Survey Iowa, I, Pt. II, 1858, p. 502, pl. 4, fig. 2.-

Hall and Clarke, Pal. New York, VIII, I’t. II, 1893, pl. 24, 57, pl. 30, figs. 18, 19.

Spirifera whitneyi Hall, Pal. New York, IV, 1867, pp. 243, 417;-Second Rep.

N. Y. State Geol., 1883, pl. 55, figs. 18, 19.-Tschernysehew, Mém. du Comité

Géol. de St. Petersbourg, III, 1887, p. 60.

Loc. Rockford, Iowa; North Saskatchewan, Canada; Russia.

Spirifer williamsi Hall and Clarke.

Chemung (Dev.).

Spirifer williamsi Hall and Clarke, Pal. New York, VIII, Pt. II, 1895, p. 361, pl. 37 , figs. 20-22.

Loc. Allegany County, New York.

Spirifer winchelli Herrick.

Waverly (L. Carb.).

Spirifer winchelli Herrick, Bull. Denison Univ., III, 1888, p. 46, pl. 5, figs. 2, 3; pl. 2, fig. 16 ;-Geol. Ohio, VII, 1895, pl. 21, ligs. 2, 3.

Loc. Granville, Ohio.

Spirifer worthenanus Schuchert.

Oriskany (I)ev.).

Spirifera engelmanni Mcek and Worthen (non Meek, 1860), Geol. Survey fllinois,

III, 1868 , p. 398, pl. 8, fig. 5 .

Spirifera wortheni Meek (non Hall, 1857), King's U. S. Geol. Expl.40th Parl., IV, 1877, p. 42.

Spirifera worthenana Schuchert, Ninth Aun. Rep. N. Y. State Geol., 1890, p. 54.

Loc. Union County, Illinois.

Spirifer wortheni Meek (non Hall)=Spirifer worthenanus.

Spirifer wortheni Hall.

Hamilton (Dev.).

Spirifer wortheni Hall, Tenth Rep., N. Y. State Cab. Nat. Hist., 1857, P. 156.-

Hall and Clarke, Pal. New York, VIII, Pt. II, 1895, pl. 27, figs, 19, 20.

Loc. Calhoun County, Illinois.

Spirifer ziczae Hall (non Roemer)=Delthyris consobrina.

SPIRIFERINA d'Orbigny.

Genotype Spirifer walcotti Sowerby $=$ S. rostrata (Sehlotheim).

Spiriferina d'Orbigny, Paris Acad. Sci., Comptes Rendus, XXV, 1847, p. 268;Anu. Sci. Nat., XIII, 1850, p. 334.-White, Proc. Boston Soe. Nat. Hist., IX, 1862, p. 24.-Waagen, Palieontologica Indica, Ser. XIII, I, 1883, p. 498.-Hall and Clarke, Pal. New York, VIII, Pt. II, 1893, p. 51;-Thirteenth Ann. Rep. N. Y. State Geologist, 1895, 1. 764. 
Spiriferina aciculifera (Rowley).

kinderhook (L. Carb.).

Apirifera acienlifera Rowley, American Geologist, X11, 1893, p. 307;-Ibideu, 1843, pl. 11, figs. 13, 14.

Loc. Louisiana, Missonri.

Spiriferina (?) alia Hall and Whittield.

Triassic.

Spipifera (Spiriferiua?) alia 11 all and Whithele, King's I. A. Geol. Expl. 40th

Parl., IV, 1877, 1. 281, pl. 6, fig. 17.

Loc. Dun Glen l'ass, Pah-Ute Range, Nevada.

Spiriferina billingsi Shumard.

Uiper Carboniferous.

Spiriferina billingsi Shumard, 'Trums. St. Louis Acad. Sci., I, 1858, p. 29. 391.

Loc. Guadalnpe Momntains, New Mexico and Texas.

Spiriferina binacuta A. Winchell.

Burlington (L. Carb.).

spiriferina binacuta $A$. Winchell, Proc. Acad. Nat. Sci. Philadelphia, 1865, p. 120.

Loc. Burlington, Iowa.

Spiriferina borealis Whiteaves.

Triassic.

Spiriferina borealis Whiteaves, Cont. Canadian Pal, I, 1888, p. 128, pl. 17, hig. 1, abstract.

Loc. Liard River, Canarla.

Spiriferina clarksvillensis A. Winchell.

Choutean (L. Carb.).

spiriferina elarksvillensis A. Winchell, Proc. Acat. Nat. Sci. Philadelyhia, 1865, p. 119.- Keyes, Geol. Survey Missouri, V, 1895, 1. 85.

Loc. Clarksville, Mlissouri.

Spiriferina cristata Walcott $=S$. spinosa.

Spiriferina cristata (Schlotheim).

Upper Carboniferous.

Terebratulites eristatus Schlothein, Beit. zur Naturg. der Verst.; Akad. der Wiss. zu Miinchen, 1816, p1. 1, fig. 3.

Spirifer octoplicata? Hall (non Sowerby), Stansbury's Exped. Great Salt Lake of Utah, 1852, 1. 409, pl. 4, fig. 4.

Spirifer kentnckyensis Shumard, Geol. Snrvey Missonri, I, 1855, 1. 203.-Hall, Pacific Railroad Rep., I1I, 1856, p. 102, pl. 2, figs. 10, 11.-Meek and Hayden, Proc. Acad. Nat. Sei. Philadelphia, 1859, p. 27.

Spiriferina eristata Davidson, Quart. Jonr. Geol. Soc. Londlon, 1863, p. 170, p1. 9, fig. 6.-Dawson, Acadian Geol., 3d ed., 1878, p. 291, fig. 90.-Walcott, Mon. U. S. Geol. Survey, VilI, 1884, p. 218, pl. 18, figs. 12, 13.-Smith, Proc. American Phil. Soc., $\mathrm{XXY}, 1897, \mathrm{p} .32$.

Spirifer laminosns Geinitz (non McCoy), Carb. und Dsas in Nebraska, 1866, p. 45, pl. 3, fig. 19.

Spirifer kentuckyensis var. propatnlus Swallow, Trans. St. Lonis Acad. Sci., II, $1866, \mathrm{p}, 489$.

?Spiriferina octoplicata Toula, Sitznngsb. der kais. Akad, der Wissensch. zu Wien, LIX, 1869, 1'. 5.

Spiriferina kentuckyensis Meek, Final Rep. U. S. Geol. Survey of Nebraska, 1872, p. 185, pl. 6, fig. 3; pl. 8, tig. 11.-White, Wheeler's Expl. and survey west 100th Merictian, IV, 1875, p. 138, pl. 10, fig.4;-Thirteenth Rep. Indiana State Geol., 1884, 1. 135, pl. 35, ligs. 13, 14.-líeyes, Proc. Acad. Nat. Sci. Philadelphia, 1890, p. 231.-Ilall and Clarke, 1'al. New York, VIII, Pt. 1I, 1893, p. 52, fig. 41, p1. 29, fig. 17.-liejes, Geol. Survey Mlissouri, V, 1895, p. 86 .

Spiriferina cristata? Etherilge, Quart. Jour. Geol. Soc. London, XXXIV, 1878, p. 629.

Spirifer (Spiriferina) kentuckyensis HIall, Second Rep. N. Y. State Geol., 1883, pl. 61, figs. 14-16. 
Spiriferina cristata (Schlotheim)-Continned.

Loc. Europe; Kentucky; Indiana; Illinois; Missouri; Iowa; Kansas; Arkansas; Nebraska; Texas; New Mexico; Utah; Arizona; Nevada; Nova Scotia; Cape Joseph Henry, lat. $82^{\circ} 43^{\prime}$; near Cochabamba, Bolivia.

Obs. See Spiriferina octoplicata and S. norwoodana.

Spiriferina depressa Herrick.

Waverly (L. Carb.).

Spiriferina depressa Herrick, Bull. Denison Univ., III, 1888, p. 47, pl. 10, fig. 3. Loc. Near Granville, Ohio.

Spiriferina gonionotus Meek.

Upper Carboniferous.

Spiriferina sp. undet. Meek, King's U. S. Geol. Expl. 40th Parl., IV, 1877, p. 84, pl. 8 , fig. 5 .

Spiriferina gonionota Meek, Ibidem, 1877, at end of description.

Loc. Diamond Mountains, Nevada.

Obs. Compare with Spiriferina laminosa (McCoy).

Spiriferina homfrayi (Gabb).

Triassic.

Spirifer ? homfrayi Gabb, Geol. Survey California, Pal., I, 1864, p. 35, pl. 6, fig. 38.

Spiriferina homfrayi Hall and Whitfield, King's U. S. Geol. Expl.40th Parl., IV, 1877, p. 281, pl. 6, fig. 18.

Loc. Star Canyon, Humbolit County, Nevada; Dun Glen Pass, Pah-Ute Range, Nevada.

Spiriferina kentuckyensis Shumard=Spiriferina cristata.

Spiriferina kentuckyensis propatula Swallow=Spiriferina cristata.

Spiriferina cfr. munsteri Davidson.

Jurassic.

Spiriferina ef. munsteri (Dav.) M̈̈ricke, Nenes Jahrbneh f. Mineral., Beilageband, IX, 1894, p. 60.

Loc. Enrope; Cordillere of Copiapo, Chile.

Spiriferina norwocdana (Hall).

Warsaw (L. Carb.).

Spirifer norwoodana Hall, Trans. Albany Inst., IV, 1858, p. 7.

Spiriferina norwoodana Whitfield, American Mas. Nat. Hist., I, 1882, p. 48, pl. 6, figs. 16, 17.-Hall, Twelfth Rep. State Gool. Indiana, 1883, p. 327, pl. 29, figs. 16, 17.

Loc. Spergen Hill, Indiana; Alton, Illinois; Princeton, Kentucky.

Obs. P'robabiy identieal with Spiriferina cristata.

Spiriferina obtusa (Gabb).

Triassic.

Spirifer obtusus Gabb, American .Jour. Conch., V, 1870, p. 17, pl. 7, fig. 16.

Lor. "Voleano," Nevala.

Spiriferina octoplicata (Sowerby).

Upper Carboniferous.

Spirifer octoplicita Sowerby, Mineral Conch., 1827, p. 120, pl. 562, figs. 2-4.

Spiriferina eristata var. octoplicata Davidson, Mon. British Carb. Brach., Pal. Soe., 1857, p. 38, pl. 7, figs. 37-47.

Spiriferina spinosa var. campestris White, Wheeler's Expl. and Survey west 100th Meril., Prel. Rep., 1874, p. 21.

Spiriferina octoplicata White, Ibidem, Final Rep., 1875, p. 139, pl. 10, fig. 8.

Lor. Europe; Santa Fe, New Mexico; northern Colorado; Lincolu County, Nevada.

Obs. Proluably identical with Spiriferina cristata.

Spiriferina pulchra Meek.

Upper Carboniferous.

Spirifera pulchra Meek, Proc. Aead. Nat. Sei. Philadelphia, 1860, 1. 310.

Spiriferina pulchra Meek, Pal. Upper Missouri, Smithsonian Cont. to Knowl., XIV, 1864, 172, p. 19;-King's U. S. Geol. Expl. 40th Parl., IV, 1877, p. 85, pl. 8 , tig. $1 ;$ pl. 12, fig. 12. 


\section{Spiriferina pulchra Meek-Continued.}

spirifer (Spiriferina) pulcher, Meck. Simpson's Rep. Lxpl. Groat Basin Terr. Itah, 1876, p. 352, pl. 2, fig. 1.

Loc. White Pino district, Nevala; long and Ruby valleys, Utah.

Spiriferina rostrata Sehlotheim.

Jurassie.

s. rifer chilensis Forbes, I) rrwin's Geol. Ohscrvations S. America, 1846, p. 267, pl. 5 , figs. 15, 16.

Spirifer lingniferoides Forhes, Ibidem, 1846, p. 267, pl. 5, figs. 17, 18.

Spirifer tumidns Bąyle and Coqnand, Mém. Géol. Soc. France, ser. ii, IV, 1851, p. 19, pl. 7, ligs. 11,12 .

Spirifer chilensis and rostratus Burmeister and Geibel, Abb. Naturf. Gesell. Halle, V'I, 1862, p. 125.

Spiriferina rostrata (Schl.) Möricke, Neues Jahrb. f. Mineral., Beilageband, IX, 1894, p. 59.

Loc. Enrope; Sicra de la Ternera, Las Amolanes, Rio Claro, Tres Crnces, Manflas, Cordillera de Guiseo, and Juntas, Chile.

\section{Spiriferina solidirostris White.}

Kinderhook (L. Carb.).

Spirifer solidirostris White, Jour. Boston Soc. Nat. Hist., VII, 1860, p. 232.

Apiriferina solidirostris White, Ibidem, IX, 1862, p. 24.-A. Winchell, Proc. Aead. Nat. Sei. Philadelphia, 1865, p. 120.-Herrick, Bnll. Denison Univ., 11I, 1888, 1. 47, pl. 2, figs. 9-11; pl. 5, fig. 13;-Geol. Ohio, VII, 1895, pl. 21, fig. 13.

Loc. Burlington, Iowa; Hamburg, Illinois; Newark and Sciotoville, Ohio.

Spiriferina spinosa (Norwool aud I'ratten). Kaskaskia (L. Carb.).

Spirifer spinosa Norwood and Pratten, Jonr. Acad. Nat. Sei. Philadelphia, 2d ser., III, 1856, p. 71, pl. 9, fig. 1.-Hall, Gcol. Survey Iowa, I, Pt. II, 1858, p. $706, \mathrm{pl} .27, \mathrm{fig} .5$.

Spiriferina spinosa? Derby, Bull. Cornell Univ., I, 1874, p. 23, pl. 6, figs. 8, 13, 14. Spiriferina spinosa Hall, Second Ann. Rep. N. Y. Stato Geol., 1883, pl. 60, figs. $26-29$.

Spiriferina cristata Walcott, Mon. U. S. Geol. Survey, VIII, 1881, p. 218, pl. 18, figs. 12, 13.- Hall and Clarke, Pal. New York, VIIl, Pt. 1I, 1893, 11. 52-54, pl. 35 , figs. $26-29$.

?. Spiriferina spinosa Herrick, Bull. Geol. Soc. America, II, 1891, p. 46, pl. 1, fig. 19.

Loc. Kaskaskia, Alton, and Chester, Illinois; Bloomington, Indiana; Crittenden Connty, Kentucky; Itaituba, Brazil.

Spiriferina spinosa campestris White $=$ Spiriferina octoplicata.

Spiriferina subelliptica (Michesuey).

Keokuk (L. Carb.).

Spirifer subelliptica McChesney, New Pal. Fossils, 1860, p. 43.

Spiriferina suhelliptica Hall and Clarke, Pal. New York, VIII, Pt. II, 1893, p. 51 , pl. 35 , figs. 21, 22.

Loc. Buttonmonil Knob, Kentucky; New Providence, Indiana.

Spiriferina subtexta White. Burlington (L. Carb.).

Spiriferina? subtexta White, Proe. Boston Soc. Nat. Hist., IX, 1862, p. 25.

Loc. Burlington, Iowa.

Spiriferina transversa (McChesney).

Kaskaskia (L. Carb.).

Spirifer transversa MeChesney, New Pal. Fossils, 1860, p. 42;-Trans. Chicago Acad. Sei., 1, 1868, p. 34, pl. 6, fig. 3.-Hall, Second Rep. N. Y. State Geul., 1883, pI. 60, figs. 19-22. 
Spiriferina transversa (McChesney)-Continued.

Spiriferina transversa Derby, Bull. Cornell Univ., I, 1874, p. 21, pl. 2, figs. 4, 5, 6, 13; pl. 13, figs. 12-14, 17; pl. 5, fig. 4.-Hall and Clarke, Pal. New York, VIII, Pt. II, 1893, pp. 46, 64, pl. 35, figs. 19, 20, 23-25.

Loc. Buzzards Roost, Alabama; Litchfield, Kentucky; Bonjardim and Itaituba, Brazil.

Spirigera d'Orbigny = Athyris.

Spirigera eborea $\Lambda$. Winchell=Athyris fultonensis.

Spirigera planosulcata White (non Phillips)=Cleiothyris crassicardimalis.

SPIRIGERELIA Waagen.

Genotype S. derbyi Waagen.

Spirigerella Waagen, Palreontologica Indica, Ser. XIII, I, 1883, p. 450.-Hall and Clarke, Pal. New York, VIII, Pt. II, 1893, p. 98;-Thirteenth Ann. Rep. N. Y. State Geologist, 1895, p. 782.

Spirigerella derbyi Waagen.

Upper Carboniferous.

Athyris subtilita (partim) Derby, Bull. Coruell Univ., I, 1874, p. 7, pl. 1, fig. 7 (not the other figures).

Spirigerella derbyi Waagen, Palieontologica Indica, Ser. XIII, I, 1883, p. 453, pl. 35, figs. 4-7, 9-13; pl. 37, figs. 11-13.-Hall and Clarke, Pal. New York, VIII, Pt. II, 1893, p. 99, fig. 73.

Loc. Bomjardim and Itaituba, Brazil.

Stenochisma CEhlert (non Conrad or Hall)=Camarophoria.

STENOCHISMA Conrad. Genotype Terebratulites schlotheimii Conrad (non von Buch) =Rhynchonella formosa Hall.

Stenocisma Conrad, Second Ann. Rep. N. I. Geol. Survey, 1839, pp. 58, 59.Meek and Hayden (partim), Pal. Upper Missouri, Smithsonian Cont. to Knowl., XIV, 172, 1864, p. 16, footnote.-Hall, Pal. New York, IT, 1867, pp. 334, 335.Waagen, Palæontologica Indica, Ser. XIII, I, 1883, yp. 411, 431, 436.-Miller, N. American Geol. and Pal., 1890, p. 337.-Hall and Clarke, Pal. New York, VIII, Pt. II, 1893, p. 187 ; - Thirteenth Ann. Rep. N. Y. Statc Geol., 1895, p. 826.

Obs. The above synonymy is retainci for historical purposes. The only species left in the genus by Hall and Clarke is the type species, Rhynchonella formosa, which seems to be nothing more than a Rhynchotrema. This will leave Stenochisma without a species. This name, however, should not displace either Rhynchotrema or Camarotœchia, since it was not defined, and in addition to this was founded by Conrad upon an erroneous identification. Nor can the view of Ehlert be adopted, i. e., that Stenochisma should displace Camarophoria King, because Conrad gave as the type C. schlotheimii. This name did not apply to von Buch's species, but to the shell now known as Rhynchonella formosa Hall.

All the species formerly referred to Stenochisma will be found under Camarotechia except $R$. formosa, which is referred to Rhynchotrema.

Stenocisma Hall, 1857 (non Courad, 1839, Hall, 1867)=Zygospira.

STREPTIS Davidson.

Genotype Terebratula grayi Davidson.

Streptis Davidson, Geol. Mag., VIII, 1881, p. 150, pl. v, fig. 13.-Hall and Clarke, Pal. New York, VIII, Pt. I, 1892, p. 274 ;-Eleventh Ann. Rep. N. Y. State Geologist, 1894, p. 289.

Streptis grayi Davidson.

Niagara (Sil.).

Terebratula grayii Davidson, Bull. Soc. Géol. France, 2d ser., V, 1848, p. 331, pl. iii, fig. 33. 
Streptis grayi Davidson-Continuel.

Atrypa? grayi Davidson, British Sil. Braeh., Paleontographical Soe. (1866), 1867,

P. 141, pl. xiii, figs. 14-22.

streptis grayi Williams, American Jour. Sei., 3d ser., XLVIII, 1891, 1. 331.

Loc. Lugland; Batesville, Arkansas.

Strep ${ }^{\text {tis }}$ waldronensis Beecher and Clarke=Mimulus waldronensis. STREPTORHYNCHUS King.

Genotype Terebratulites pelargonatus Schlotheim.

Streptorhynelus King, Mon. Permian Fossils, Pal. Soc, 1850, 1. 107.-Derby (partim), Bull. Cornell Univ.; I, 1874, pp. 32, 39.-Hall and Clarke, Pal. New York, VIII, Pt. I, 1892, p. 267 ;-Eleventh Ann. Rep. N. Y. State Geologist, 1894, p. 288.

Streptorhynchus aequivalvis Hall=Orthothetes inaqualis. Streptorhymchus agassizi Rathbun=Orthothetes agassizi. Streptorhynchus approximata James=Strophomena approximata. Streptorhynchus aretostriata Walcott=Orthothetes chemungensis are-

tistriatus.

Streptorhyuchus biloba Hall=Derbya biloba.

Streptorhynchus cardinale Whitfield=Strophomena carcinalis.

Streptorhynchus chemungensis Hall=Orthothetes chemungensis.

Streptorhynchus coreanus Derby=Derbya correaua.

Streptorhynchus crenistria Keyes (non Phillips)=Derbya crassa.

Streptorhynchus crenistrius American authors=Orthothetes crenistria. Streptorhynchus elongatus James=Strophomena rugosa.

Streptorhynchus filitextus Hall=Strophomena incurvata. Streptorhynchus flabellım Whitfield=Orthothetes flabellum.

Streptorhynchus hallianus Derby.

Upper Carboniferous.

Streptorlynehus halliauus Derhy, Bull. Cornell Univ., I, 1874, p. 35, pl. 5, figs. 1, 2, 5, 8, 12, 14, 16, 18; pl. 8, fig. 3.-Hall and Clarke, Pal. New York, VIII, Pt. I, 1892, p. 268 , pl. 11, figs. $6 \div 17$.

Loc. Bomjardim and Itaituba, Brazil.

Streptorhynchus hallanum Miller=Strophomena halli.

Streptorhynchus hemiaster Winchell and Marcy=Orthothetes sub. planus.

Streptorhynchus hydraulicum Whitfield=Orthothetes liydraulicus. Streptorhynchus in:equalis Winchell=Orthothetes iniequalis.

Streptorhynchus inflatus White aud Whitfield=Orthothetes inflatus. Streptorhynchus lens White=Orthothetes lens.

Streptorhynchus minor Walcott=Strophomena minor.

Streptorhynchus (?) multistriata (Meek and Hayden).

Upper Carboniferous.

Orthisina nmbraculum? Meek and Hayden, Proc. Acad. Nat. Sei. Philadelphia, 1859 , p. 26.

Orthisina multistriata Mcek and Hayten, Ibilem, 1859, at encl of deseription.

Loc. Fort Riley, Kansas.

Streptorhynchus neglectus .Tames=Strophomena neglecta.

Streptorhynchus oceidentalis Newberry=Meekella oceidentalis. 
Streptorhynchus pandora Billings=Orthotletes pandora.

Streptorhynchus perversus=Orthothetes chemungensis perversus. Streptorhynchus planoconvexus $\mathrm{Hall}=$ Strophomena planiconvexa. Streptorhynchus planumbonus Hall=Strophomena rugosa. Streptorhynchus primordiale Whitfield=Billingsella primordialis Streptorhynchus pyramidalis Newberry = Meekella pyramidalis. Streptorhyuchus robusta Hall=Derbya robusta.

Streptorhynchus subplanus HaIl=Orthothetes subplanus. Streptorhynchus subsulcatım Sardeson = Strophomena scofieldi. Streptorhynchus subtenta Hall, 1SS3=Strophomena trentonensis. Streptorhynchus tapajotensis Derly =Orthothetes tapajoteusis. Streptorhynchus tenuis Hall=Orthotletes tenus.

Streptorhynchus ulrichi Hall and Clarke.

Kaskaskia (L. Carb.).

Streptorhynchus ulrichi IIall and Clarke, Pal. New York, V'III, I't. I, 1892, pp. 268,351, pl. 11B, fig. 15 .

Loc. Crittenden Connty, Kentucky.

Streptorhynchus umbraculum Winchell=Orthothetes umbraculum.

Streptorhynchus vetusta James=Strophomena vetusta.

Streptorhynchus woolworthianus Hall=Orthothetes woolworthianus. Stricklandia Billings=Stricklandinia.

Stricklandia arachne Billings=Syntrophia arachne.

Stricklandia arethusa Billings = Syntroplia arethusa.

STRICKLANDINIA Billings. Genotype Stricklandia gaspensis Bill. Stricklandia Billings, Canadian Nat. and Geol., IV, 1859, p. 132 ;-Canarlian Journal, VI, 1861, p. 265 ;-Pal. Fossils, I, 1862, p. 84;-Proc. Portland Soc. Nat. Hist., 1863, p. 114.-Waagen, I'alirontologica Inrlica, Ser. XIII, I, 1883, 1. 412.

Stricklandinia Billings, Canadian Nat. and Geol., VIII, 1863, p. 370.-Hall, Twentieth Rep. N. Y. State Cab. Nat. Hist., 1867, ]. 160;-Pal. New York, IV, 1867, p. 369.-Billings, Pal. Fossils, II, 1874, p. 78.-Nettelroth, Kentucky Fossil Shells, Mem. Kentucky Geol. Survey, 1889, p. 64.-Hall and Clarke, Pal. New York, VIII, Pt. II, 1893, p. 249 ;-Thirteenth Ann. Rep. N. Y. State Genlogist, 1895 , p. 847 .

Stricklandinia anticostiensis Billings.

Anticosti (Sil.).

Stricklautinia antirostiensis Billings, Canadian Nat. and Geol, VIII, 1863, \%. 370.--IIall and Clarke, Pal. New York, VIII, Pt. II, 1893, p. 251, 11. 73, figs, 12-14.

Loc. Anticosti.

Stricklandinia billingsana Dawson.

Arisaig (Sil.).

Stricklandinia billiugsiana Dawson, Canadian Nat. and Geol., 2d ser., IX, 1880, 1. 341.

Loc. Nova Scotia.

\section{Stricklandinia brevis Billings.}

Anticosti (Sil.).

? Spirifer species? Hall, Pal. New York, II, 1852, p. 66, pl. 22, fig. 3.

Stricklandia brevis Billings, Canadian Nat. and Geol., IV, 1859, p. 135.

Stricklandinia brevis Billings, Pal. Fossils, II, 1874, p. 84, pl. 6, fig. 2.-Hall and Clarke, Pal. New York, VIII, Pt. II, 1893, p. 251.

Loc. Anticosti ; ISodus, Wayne Comty, New York. 
Stricklandinia canadaensis Billings.

('linton (Sil.).

Stricklandia cantudensis Billiugs, Canadian Nat. and Geol., iv, 1859, 1. 135.

Stricklaudinia canalensis Billings, Pal. Fossils, II, 1874, p. 81.-Hall and Clarke, P'al. Now York, VIII, It. II, 1893, ए. 251.

Loe. Near 'Thorold, Ontario.

Strick'andinia castellana White.

Niagara (Sil.).

Stricklandinia castellana White, I'roc. Acacl. Nat. Sci. Philarlelphia, 1876, p. 30.-

Hall and Clarke, Pal. New York, VIII, Pt. II, 1893, p. 251, pl. 73, figs.3-7.

Loe. Castle Grove, Jones Connty, Iowa.

Stricklandinia chapmani Hall and Clarke.

Niagara (Sil.).

Stricklandinia ehapmani Hall and Clarke, Pal. New York, VIII, Pt. II, 1895, pl. 83 , tig. 40.

Loc. IIanilton, Ontario.

Stricklandinia davidsoni Billings.

Anticosti (Sil.).

Stricklandinia davidsoni Billings, Geol. Mag., V, 1868, p. 59, pl. 4, figs. 1-1d;-

Pal. Fossils, II, 187t, p. 86, pl. 6, fig. 1.-White, Proc, U. S. Nat. Mus., III, 1880, p. 48.-Hall and Clarke, Pal. New York, VIII, Pt. II, 1893, p. 251, pl. 73, fig. 15.

Loe. Antieosti; eastern Cauada; Ringgold, Catoosa County, Georgia.

Stricklandinia deformis Meek and Worthel.

Niagara (Sil.).

Stricklandinia deformis Neek and Wortben, Proc. Acad. Nat. Sci. Philadelphia, 1870, p. 37 ;-Geol. Survey Illinois, VI, 1875, p. 502, pl. 24, fig. 5.-Hall and Clarke, Pal. New York, VIII, Pt. II, 1893, p. 251, pl. 73, figs. 8-10.

Loc. Carroll County, Illinois.

Obs. Probahly the same as S. melissa.

Stricklandinia elongata Billings=Amphigenia elongata.

Stricklandinia elongata curta Meek and Worthen=Amphigen'a curta.

Stricklandinia gaspiensis Billings.

Gaspé (Sil.).

Stricklandia gaspicusis Billings, Canalian Nat. and Geol., IV, 1859, p. 134.

Stricklandinia gaspiensis lBillings, Pal. Fossils, II, 1874, p. 83, fig. 49;-Hall and

Clarke. Pal. New York, VIII, Pt. II, 1893, p. 251, pl. 73, fig. 11.

Loc. Bay of Chaleurs, Canada.

Stricklandinia lens (Sow erby).

Silurian.

Atrypa lens Sowerby, Murehison's Silurian System, 1839, pl. 21, fig. 3.

Stricklandiuia lens Billings, Catalogne Sil. Foss. Anticosti, 1866, p. 45.-Foerste,

Proc. Boston soe. Nat. Hist., XXIV, 1890, 1. 321, pl. 5, figs. 1-4.

Loc. England; Anticosti; Collinsville, Alabama.

Stricklandinia lirata (Sowerby).

Anticosti (Sil.).

Spirifer liratus Sowerby, Murehison's Silurian System, 1839, pl. 22. fig. 6.

Stricklandinia lirata Daviđson, Mon. British sil. Brach., Pal. Soc., 1867, p. 159, pl. 20, figs. 1-13.-Billings, Cat. Sil. Foss. Anticosti, 1866, p. 45.

Loc. Europe; Anticosti.

Stricklandinia (?) louisvillensis Nettelroth.

Niagara (Sil.).

Stricklandinia louisviliensis Nettelroth, Kentucky Fossil Shells, Mem. Kentucky

Geol. Survey, 1889, p. 65, pl. 34, figs. 31-34.

Loc. East of Louisville, Kentucky.

Stricklandinia melissa Billings.

Anticosti (Sil.).

Stricklandinial nelissa Billings, Pal. Fossils, II, 1871, p. 89, pl, 7, fig. 4.-Hall and Clarke, I'al. New York, VIII, Pt. II, 1893, p. 251.

Loc. Anticosti.

Obs. Probably the same as S. deformis. 
Stricklandinia multilirata Whitfield.

Guelph (Sil.).

Stricklandinia nultilirata Whitfield, Ann. Rep. Geol. Survey Wisconsin, 1877, p. 81 ;-Geol. Wisconsin, IV, 1882, p. 315, pl. 23, figs. 3-5.-Hall and Clarke, l'al. New York, VIII, Pt. II, 1893, p. 251, pl. 73, figs. 1, 2.

Loc. Sheboygan, Wisconsin.

Stricklandinia salteri Billings.

Anticosti (Sil.).

Stricklandinia salteri Billings, Geol. Mag., V, 1868, p. 61, pl. 4, figs. 2-2a;-Pal. Fossils, II, 1874, p. 87, pl. 7, fig. 1.-White, Proc. U. S. Nat. Mus.. III, 1880, p. 48.-Hall and Clarke, Pal. New York, VIII, Pt. II, 1893, p. 251.

Loc. Anticosti; Ringgold, Catoosa Connty, Georgia.

Stricklandinia (?) subquadrata Herrick.

Upper Carboniferous.

Stricklandinia ? snbquadrata Herrick, Bull. Denison Univ., II, 1887, p. 49, pl. 1, fig. 14.

Loc. Flint ridge, near Newark, Ohio.

Obs. Probably a terebratuloid.

Stricklandinia triplesiana Foerste.

Clinton (Sil.).

Strieklandinia triplesiana Foerste, Bull. Denison Univ., I, 1885, p. 89, pl. 14, figs. 13, 14.-Proe. Bostou Soc. Nat. Hist., XXIT, 1890, 1. 323;-Geol. Ohio, VII, 1895, P. 594, pl. 26, figs. 13, 14.

Loc. Dayton, Ohio.

STRINGOCEPHALUS Defrance.

Genotype S. burtini Defrance.

Strygocephalns Defrance, Dict. Sei. Nat., LI, 1827, p. 102, pl. 75, fig. 1.

Stringocephalus Sindberger, Leonhard und Bronn's Jahrl. fiir Min., 1842, p. 386.-Dall, American Jour. Coneh, Y' I, 1870, p. 112.-Hall and Clarke, Pal. Now York, VIII, Pt. II, 1893, p. 282, figs. 203-207.

Stringocephalus burtoni Defrance.

Middle Devonian.

Strygocephalns burtoni Defrance, Dict. Sci. Nat., I.I, 1827, 1) 102, pl. 75, fig. 1.

Stringocephalns burtoni Whiteaves, Trans. Royal Soc. Canada, VIII, 1891, p. 93 ;Cont. to Canadian Pal., I, 1891, 1. 235, 11. 29, figs. 10-11; p. 290.-Hall and Clarke, Pal. New York, VIII, Pt. II, 1893, 1). 283, fig. 203.

Loc. Europe; Lakes Manitoba and Winnipegosis and the "Ramparts," Maekenzie River, British America. Two loose specimens have been found near Devonian rocks in southern Minnesota.

STROPHALOSIA King.

Genotype Orthis exeavata Geinitz.

Strophalosia King, Ann. and Nag. Nat. Hist., XIV, 1814, n. 313;-Ibidem, XVII, 1846, p. 92 ;-Mon. Permian Fossils, Pal. Soe, 1850, p. 93.-Hall, Twentioth Rep. N. Y. State Cal. Nat. Hist., 1867, p. 245 ;-Pal. New York, IT, 1867, p. 146.-Beecher, American Jour. Sci., 3l ser., XI, 1890, p. 240.-Hall and Clarke, Pal. New York, VIII, Pt. I, 1892, p. 314;-Eleventh Ann. Rep. N. Y. State Geologist, 1894, p. 295.

Strophalosia beecheri Rowley.

Kinderhook (L. Carb.).

Strophalosia beecheri Rowley, American Geologist, XII, 1893, p. 308, pl. 14, figs. 18, 19.

Loc. Louisiana, Missouri.

Strophalosia cornelliana Derby.

Upper Carboniferous.

Strophalosia cornelliana Derby, Bnll. Cornell L'niv., I, 1871, p. 15, pl. 3, figs. 28, 30, 32, 33, 35-38; pl. 4, fig. 5; pl. 8, fig. 17 ; pl. 9, figs. 10, 11.-Hall and Clarke, Pal. New York, VIII, Pt. I, 1892, pl. 15b, figs. 36, 37.

Loc. Bomjardim, Brazil.

Strophalosia cymbula Hall and Clarke.

Keokuk (L. Carb.).

Strophalosia cymbula Hall and Clarke, Pal. New York, VIII, Pt. I, 1892, pl. 17A, figs. $3,4,8,9$.

Loc. Near Louisville and Lebanon, Kentncky.

Bull. 87 $-27$ 
Strophalosia (?) guadalupensis (Shumard).

Upper Carboniferous.

Aulosteges guadalupensis Shumard, Trans. St. Lonis Acad. Sci., I, 1858, p. 292, nl. 11 , fig. $5 ;$ p. 390 .

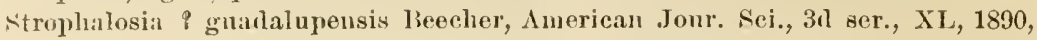
1. 241.

Loc. Guadalupe Mountains, New Mexico aud 'Texas.

Struphalosia horrescens Geinitz (non Murchison, de Vernenil, and Keyserling)=Productus nebraskaensis.

Strophalosia hystricula Hall. Chemung (Dev.).

Prodnctella hystrienla Hall, Pal. New Tork, IV, 1867, p. 178, pl. 26, figs. 1-8; Second Ann. Rep. N. Y. State Geol., 1883, 11. 48, figs, $29,30$.

Strophalosia hystricula Hall and Clarke, Pal. New York, VIII, Pt. I, 1892, p. 316, pl. 15 B, fig. 31 ; pl. 17 , figs. 29,30 .

Loc. lorestrille, Conewango, and Eust Randolph, New York.

Strophalosia keokuk Beecher.

Keokuk (L. Carb.).

Strophalosia keokuk lieecher, American Jour. Sci., 3d ser., XI, 1890, p. 244, pl.9, figs. 18-24.-IIall and Clarke, Pal. New Vork, YIII, Pt. I, 1892. 1. 316, pl. 17A, figs. $5-7$.

Loc. Keokuk, Iowa.

Strophalosia muricata (Hall).

Chemung (Dev.).

Clionetes muricata Hall, Pal. New York, IV, 1867, p. 143, pl. 22, figs. 29-13.

Chonetes (Productella?) muricata Hall, Second Ann. Rep. N. Y. State Geol., 1883 , pl. 47 , figs. $12,16,30 ; 38,42$.

Strophalosia? muricata Beecher, American Jour. Ści., 3 l ser., XI, 1890, p. 241. Strophalosia muricata Hall and Clarke, Pal. New York, VIII, Pt. I, 1892, p. 316, pl. 16, figs. $12,16,30,38,42$.

Loc. Fllington, New York, and Meadville, Pennsylvania.

Strophalosia nummulina A. Winchell. Kinclerhook (L. Carb.). Strophalosia? nummularis A. Winchell, Proc. Acad. Nat. Sei. Philadelplia, 1863, p. 4.

Strophalosia? nummulina Beeeher, American Jour. Sci., 3ત ser., XL, 1890, n. 242. Strophalosia nummularis IIall aud Clarke, Pal. New Tork, VIII, Pt. I, 1892, p. 316. Loc. Tiurlington, Iowa.

Strophalosia radicans (A. Winchell). Hamilton (Dev.). Crania radicans $A$. Winchell, Rep. Lower Peninsula Michigan, 1866, p. 92.

Strophalosia radicans Beecher, American Jonr. Sci., 3d ser., XL, 1890, PI. 240, 243, pl.9, figs. 14-17.-Hall and Clarke, Pal. New York, VIII, Pt. I, 1892. p. 316 , pl. $15 \mathrm{~B}$, figs. $27-30$.

Loc. Grand Traverse region, Michigan.

Strophalosia rockfordensis Hall and Clarke.

Upper Devonian.

Strophalosia rockfordensis Hall and Clarke, Pal. Now York, VIII, Pt. I, 1892, pl. 316, 353, pl. 17A, figs. 1-3; Pt. II, 1895, pl. 84, figs..20-22.

Loc. Rockford, Jowa.

Strophalosia scintilla Beecher.

Chontean (L. Carb.).

Strophalosia scintilla Beecher, American Jour. Sci., 3d ser., XL, 1890, p. 243. pl.9, figs. 10-13.-Hall and Clarke, Pal. New York, VIII, Pt. I, 1892, p. 316, pl. 15B, figs. 32-31.

Loc. Pike County, Missonri.

Strophalosia spondyliformis (White and St. John). Upper Carboniferous. Aulosteges spondyliformis White aurl St. John, Trans. Chicago Acad. Sci., I, 1868, p. 118, fig. 2. 
Strophalosia spondyliformis (White and St. John)-Continned.

Strophalosia spondyliformis Beecher, American Jour. Sci., 3d ser., XL, 1890, p. 242.-Hall and Clarke, Pal. New York, VIII, Pt. I, 1892, pl. 17A, figs. $25,26$.

Loc. Appanoose and Pottarattamie counties, Iowa.

Strophalosia truncata (Hall). Hamilton, Portage, and Ithaca (Dev.). Strophomena pustulosa Hall (non Productus pustulosus Phillips), Geol. N. Y.; Rep. Fourth Dist., 1843, p. 189, fig. 4.

Productus truncatus Hall, Tenth Rep. N. Y. State Cal. Nat. Hist., 1857, p. 171. Productella truncata Hall, Pal. New York, IV, 1867, p. 160, pl. 23, tigs. 12-24;-Second Ann. Rep. N. Y. State Geol., 1883, pl. 48, figs. 10-15.-Kindle, Bull. American Pal., 6, 1896, 1. 35.

Productus (P.) truncatus Walcott, Mon. U. S. Geol. Survey, VIIl, 1884, p. 131, pl. 14, fig. 2 .

Productella (Strophalosia!) truncata Whiteaves, Cont. Cauadiau Pal., I, 1889, p. 112, pl. 16, figs. 1, 2.

Strophalosia truncata Beecher, American Jour. Sci., 3r ser., XL, 1890, 1. 24-Hall and Clarke, Pal. New York, VIII, Pt. I, 1892, p. 316, pl. 15B, figs. 24-26; pl. 17, figs. 10-15.

Loc. New York; Thedford, Ontario; Eureka district, Nerada.

STROPHEODONTA Hall. Genotype Strophomena demissa Conrad. Stropheodonta Hall, Pal. New York, II, 1852, p. 63.-Hall and Clarke, Pal. New York, VIII, Pt. I, 1892, p. 284.

Strophodonta Hall, Geol. Survey Iowa, I, 1858, p. 491.-Billings, Canadian Jour. Sci. Arts, n. ser., VI, 1861, 1. 332;-Proc. Portland Soc. Nat. Hist., 1863, p. 108.-Hall, Pal. New York, IV, 1867, p. 78.-Nettelroth, Kentucky Fossil Shells, Mem. Kentucky Geol. Survey, 1889, p. 142.

Brachy prion Shaler, Bull. Mus. Comp. Zool., 4, 1865, p. 63.

Brachyprion and Douvilina Hall and Clarke, Pal. New York, VIII, Pt. I, 1892, pp. 220, 286, 288, 289, 292; Eleventh Ann. Rep. N. Y. State Geologist, 1894, pp. $280,281$.

Stropheodonta acanthoptera (Whiteaves).

Upper Silurian.

Strophomena acanthoptera Whiteaves, Canadian Rec. Sei., 1891, 1. 29.1, pl. 3, figs. $1,-2$.

Loc. District of Saskatchewan and Lake Winnipegosis, Canarla.

Stropheodonta alveata Hall.

Tpuer Helderberg (Dev.).

Strophodonta alveata Hall, Sixteeuth Rep. N. Y. State Cab. Nat. Hist., 1863, p. 36 ;-Pal. New York, IV, 1867, p. 81, pl. 11, figs. 1-3.

Loc. Albany County, New York.

Stropheodonta arcuata Hall.

Chemung (Dev.).

Strophodonta arcuata Hall, Geol. Survey Iowa, I, 1858, p. 492, pl. 3, figs. 1a-1c, 2a-2f.-Calvin, Bull. U. S. Geol. Survey, IV, 1878, p. 728.-Whiteaves, Cont. Canadian Pal., I, 1892, p. 285.

Strophodonta arcuata? Walcott, Mon. U. S. Geol. Surrey, VIII, 1881, p. 121.

Stropheodonta arcuata Hall and Clarke, Pal. New York, VIII, Pt. I, 1892, p. 289, pl. 15B, figs. 1-3.

Loc. Rockford, Iowa; Naples, New York; Eureka district, Nevada; Lake Winnipegosis, Canada.

\section{Stropheodonta beckei Hall.}

Lower Helderberg (Dev.).

Strophodonta beckii Hall, Pal. Now York, III, 1859, p. 191, pl. 22, figs. 1a-1t.Meek, American Jour. Sci., $2 d$ ser., XI, 1865, p. 33.-Hall, Second Ann. Rep. N. Y. State Geol., 1883, pl. 44, figs. 23, 24.

Strophomena (Strophodonta) beckii Hall, Tenth Rep. Y. Y. State Cab. Nat. Hist., 1857, p. 52, figs. 1-4. 


\section{Stropheodonta beckei Hall-Continnerl.}

Stropheolonta (Teptostrophia) bocki Hall and Clarko, P'al. New York, VII, Pt. T, 1892, p. 288, pl. 13, tigs. 23, 24.

Lor. Albany and Schohario conntios, New Tork; Kennody Channel, Aretic rogion.

Stropheodonta blainvillei (Billings).

Lower Devoniau.

$S^{+}$rophomona blainvillei Billings, Pal. Fussils, II, 187.1, p. 28, pl. 2, fig. 1; pl. 3, fig. 1.

Stropheodonta (Leptostrophia) blainvillii Hall and Clarke, Yal. New York, VIII, Pt. 1, 1892, 1. 288.

Loc. Gaspé, Canada.

Obs. Compare with S. perplanil.

Stropheodonta callawayensis Swallow.

Hamilton (Dev.). Strophodonta callawayensis, quadrata, and aquicostata Swallow, Trans. St. I.ouis Acad. Sei., I, 1860, p.638.

Loc. C'allamay C'ounty, Missouri.

Obs. See S. navalis.

Stropheodonta callosa Hall.

Uper Helderberg (Dev.).

Strophodonta callosa Hall, Sixteenth Rep. N. Y. Stato Cal. Nat. Hist., 1863, p. 36;-Pal. Now York, IV, 1867, 1. 82, pl. 11, figs. 4-10; pl. 12, figs. 8, 9.

Chonetes (Strophodonta?-) callosa Hall, Second Ann. Rep. N. Y. State Geol., 1883 , pl. 47, fig. 37 .

Stropheodonta callosa Hall and Clarke, VII, Pt. I, 1892, pl. 16, fig. 37.

Loc. Albany County, Now York.

Stropheodonta calvini Miller.

Chemung (Dev.).

Strophodonta quadrata Calviu (non Sivallow, 1860), Hull. U. S. Geol. Geogr. Survey Terr., IY, 1878, p. 728.

Stroplodonta calvini Miller, Cat. American Pal. Foss., 2d ed., January, 1883, p. 298.-Walcott, Mon. U. S. Geol. Survey, VII1, 1884, p. 122, pl. 13, fig. 6. Strophodonta exilis Calvin, American Jour. ši., $34 \mathrm{~L}$ ser., XXV, June, 1883, p. 443. Loc. Rockford and Independence, lowa; Eureka district, Nevada.

Stropheodonta canace Hall and Whitfield. ('hemung (Dev.). Strophodonta eanace Hall and Whittield, Twenty-third Rep. N. Y. State Cab. Nat. Hist., 1873, p. 236, pl. 11, figs. 8-11; a astract of same in 1872;-King's U. S. Geol. Expl. 40th Parl., IY, 1877, p. 216, pl. 3, figs. 1-3.

Loe. Rockford, Iowa; White Pine district, Nevada; Naples, New York.

Stropheodonta cincta A. Winchell.

Hamilton (Dev.).

Strophodonta cincta A. Winchell, Rep. Lower Peninsula Michigan, 186t, p. 93.

Loc. Grand Traverse region, Michigan.

Obs. Insufficiently defined to be recognized.

Stropheodonta concava Hall. Corniferons and Hamilton (Dev.). Strophomena (Strophodonta) concava Hall, Tenth Rep. N. Y. State Cab. Nat. Hist., 1857, pp. 115, 140, fig. 1.

Strophodonta concava IIall, Pal. New York, IV, 1867, p. 96, pl. 16, figs. 1a-1h;Second Ann. Rep. N. Y. State Geol., 1883, pl. 45, figs. 16-2?.

Stropheodonta concava Hall and Clarke, Pal. New York, VIII, Pt. I, 1892, pl. 14, figs. 16-23.

Loc. New York, from Cayuga Lake westward to Lake Erie.

Stropheodonta corrugata (Conrad).

Clinton (Sil.).

Strophomena corrugata Conrad, Jour. Acad. Nat. Sci. Philadelphia, VIII, 1812, p. 256, pl. 14, fig. 8.-Hall, Geol. N. Y.; Rep. Jourth 1)ist., 1813, p. 73, fig. 2 on p. 72 ; - Twelfth Rep. N. Y. State Cab. Nat. Hist., 1859, p. 82,-Foerste, Proc. Boston Soc. Nat. Hist., XXIV, 1890, p. 303, pl. 6, fig. 25. 
Stropheodonta corrugata (Conrad)-Continued.

Leptiena corrugata Hall, Pal. Now York, II, 1852, p. 59, pl. 21, figs. 2a-2e.

Strophodonta corrugata Hall, Second Ann. Rep. N. Y. State Geol., 1883, pl. 46, fig. 1.

Stropheodonta corrugata Hall and Clarke, PaI. New York, VIII, Pt. I, 1892, pl. 15, fig. 1; Pt. Il, 1895, pl.84, fig. 11 .

Loc. Rochester, Wolcott, etc.. New York; Cumberland Gap, Tennessee.

\section{Stropheodonta (?) corrugata pleuristriata (Foerste.)}

Clinton (Sil.).

Leptrena corrugata (partim) Hall, Pal, New York, II, 1852, p. 59, pl, 21, figs. 2 d, 2 . Strophomena corrugata var. pleuristriata Foerste, Proe. Boston Soc. Nat. Hist., XXIV, 1890, p. 303, pl. 6, figs. 26, 27.

Loc. Cumberland Gap, Tenuessee.

Stropheodonta (?) costata Owell.

Hamilton (Dev.).

Strophodonta (?) costata Owen, Geol. Survey Wisconsin, Iowa, and Minnesota, 1852, p. 585, pl. 3 A, fig. 5 ; pl. 3 , tigs. 11, 11a.

Loc. Davenport, Iowa.

Stropheodonta crebristriata Hall.

Upper Hellerberg (Dev.).

Strophomena crehristriata Comrad, Jour. Acad. Nat. Sci. Philadelphia, VIII, 1842, p. 254, pl. 14, fig. 3.

Strophorlonta crebristriata Ilall, Sixteenth Rep. N. Y. State Cab. Nat. Hist., 1863, p. 37 ;-Pal. New York, IV, 1867, p. 86, pl. 11, figs. 12, 13, $18-21$.

Loc. Albany and Schoharie counties, New York.

Stropheodonta demissa (Conrad).

Middle and Upper Devonian.

Strophomena demissa Conrad, Jour. Acad. Nat. Sci. Philadelphia, VIII, 1842, p. 258, pl. 11, fig. 14.-Rogers, Geol. Pennsylvania, II, 1858, 1. 827, fig. 666.Billings, Canadian Jonr. Sci. Arts, 2 d ser., VI, 1861, 1. 341, figs. 116-118;Geol. Canada, 1863, p. 367, figs. 377a-d.

Strophorlonta dimosa(?) Owen, Geol. Survey Wisconsin, Iowa, and.Minnesota, 1852, tal. 3A, fig. 14. [See specimens in U. S. Nat. Mus., Cat. Invert. Foss., 17917.]

Strophomena (Strophoronta) demissa IIall, Tenth Rep N. Y. State Cab. Nat. Hist., 1857, p. 137, fig. 1.-Meek, Trans. Chicago Acad. Sci., I, 1868, 1. 87, figs. 6a-c.

Stropùomena (Strophodonta) subilemissa Hall, Tenth Rep. N. Y. State Cab. Nat. IIist., 1857, 1. 145.-Week (non Hall), Trans. Chicago Acarl. Sci., I, 1868, 1. 88, pl. 13 , fig. 7 .

Strophodonta demissa Hall, Geol. Survey Inwa, I, Pt. II, 1858, p. 495, pl. 3, fig. 5;Pal. New York, IV, 1867, p. 81, pl. 11, figs. 14-17; 1, 12, figs. 1-5.-Nicholson, Fal. Prov. Ontario, 1873, p. 65.-White, Second Aun. Rep. Indiana Bureau of Statistics and Geol., 1880, p. 500, pl. 4, figs. 6, 7; -Tenth Rep. Incliana State Geol., 1881, p. 132, pl. 4, figs. 6, 7.-Whitfield, Geol. Wisconsin, IV, 1882, p. 327, pl. 25, fig. 18.-Hall, Secoml Ann. Rep. N. Y. State Geol., 1883, pl.45, figs. 7-12.-Walcott, Mon. U. S. Geol. Survey, VIII, 1884, p. 118, pl, 2, fig.9.Nettelroth, Kentucky Fossil Shells, Mem. Kentucky Geol. Survey, 1889, p. 143, pl. 18, figs. 10-16; pl.33, fig. 22.-Whiteaves, Cont. Cauadian Pal., I, 1891, p. 219.-Keyes, Geol. Surrey Missouri, V, 1895, p. 70, pl. 39, fig. 7.

Stropheodonta demissa Hall and Clarke, Pal. New York, VIII, Pt. I, 1892, pl. 14, figs. $7-12$.

Loc. New York; Penusylvania; Ohio; Indiana; Kentucky; Illinois ; Iowa ; Wisconsin; Ontario; Mackenzie and Athabasca rivers, Canarla; Eureka district, Nevada. 
Stropheodonta erratica $\Lambda$. Winchell.

Hamilton (I)ev.).

strophodonta orratica and varieties solidicosta and fissicosta $A$. Winchell, Rep. Lower Peninsula Miehigan, 1866, p. 93.

Loc. Grand Traverse region, Michigan.

Obs. This species mas prove to be only a local variation of S. costata Owen.

Stropheodonta feildeni Etheridge.

? Lower Devouian.

Strophodonta feildeni Etheridge, Quart. Jour. Geol. Soc. London, XXXIV, 1878, p. 598, pl. 25 , fig. 4 .

Loc. Cape Hilgarl, lat. $79^{\circ} 41^{\prime}$.

$O b s$. Since this species is very closely related to S. magnifica of the Oriskany sandstone the horizon is probably Lower Devonian.

Stropheodonta galatea (Billings).

Lower Devonian.

Strophomena galatea Billings, Pal. Fossils, I1, 1874, p. 20, fig. 9.

Loc. Indian Cove, Gaspé, Canada.

Stropheodonta (?) geniculata (Shaler).

Anticosti (Sil.).

Brachyprion geniculatum Shaler, Bull. Mus. Comp. Zool., 4, 1865, 1) 63.

Loc. Near Southwest Point, Anticosti.

Stropheodonta (?) gilpeni (Dawson).

Upper Arisaig (Sil.).

Strophomena gilpeni Dawson, Cauadian Nat. Geol., n. ser., IX, 1880, p. 341.

Loc. Nova Scotia, Canada.

Stropheodonta hemispherica Hall.

Upper H elderberg (Dev.)

Strophomena (Strophodonta) hemispherica Hall, Tentl. Rep. N. Y. State Cal. Nat. Hist., 1857, p. 113.

Strophodonta hemispherica Hall, Pal. New York, IV, 1867, p. 90, pl. 13, figs. 12, 13;-Second Ann. Rep. N. Y. State Geol., 1883, pl. 45, fig. 23.-Nettelroth, Kentueky Fossil Shells, Nem. Kentucky Geol. Survey, 1889, p. 144, pl 18, figs.4-6.

Loc. New York; Ohio; Indiana; Kentucky; Ontario.

Stropheodonta inæquiradiata Hall.

Upper Helderberg (Der.).

Strophomena (Strophodonta) inæquiradiata Hall, Tenth Rep. N. Y. State Calb.

Nat. Hist., 1857, p. 113, figs. 1-3.

Strophomena inierquistriata Billings, Canadian Jonr. Sci. Arts, VI, 1S61, p. 338, fig. 113 ;-Geol. Canata,1863, p. 367, fig. 375;-Pal. Fossils, II, 1874, 1. 24, fig.13; pl. 2 , fig. 4 ; 1. 240.

Strophodonta inequiradiata Flall, Pal. New York, IV, 1867, p. 87, pl. 11, figs. 24-31 ; pl. 12, fig. 12; pl. 13, figs. 6-11;-Second Ann. Rep. N. Y. State Geol., 1883, pl. 45, figs. 13, 14.-Walcott, Mon. U. S. Geol. Survey, VIII, 1884, p. 120, pl.11, fig. 11. Stropheodonta inequiradiata Hall and Clarke, Pal. New York, VIII, Pt. I, I892, pl. 14, figs. $13,14$.

Loc. Allany and Schoharie connties, New York; Columbus, Olio; Eureka district, Nevada; Gaspe Bay, Canada.

Stropheodonta inæquistriata (Conrad). Corniferons to Hamilton (Dev.). Strophomena insequistriata Conrad, Jour. Acad. Nat. Sci. Philadelphia, VIII, 1842, p. 254, pl.14, fig. 2.-Hall, Geol. N. Y. ; Rep. Fourth Dist., 1843, p. 200, fig. 4.Billings, Canatian Jour. Sci. Arts, VI, 1861, p. 338, figs. 113, 114;-Geol. Canada, 1863 , p. 367 , fig. 375 .

Strophomena (Strophodonta) inæquistriata Hall, Tenth Rep. N. Y. State Cab. Nat. Hist., 1857, 1. 142.

Strophodonta inequistriata Hall, Pal. New York, IV, 1867, p. 93, pl. 12, figs. 6-8; p. 106, pl. 18, fig. 2 ;-Second Ann. Rep. N. Y. State Geol., 1883, pl. 45, figs. 1-6.Nettelroth, Kentucky Fossil Shells, Mem. Kentncky Geol. Survey, 1889, p. 145, pl. 17, figs. 10, 11. 
Stropheodonta inæquistriata (Conrad)-Continued.

Stropheodonta (Douvillina) inaquistriata Hall and Clarke, 1'al. New York, VIII, I't. I, 1892, p. 289, pl. 14, figs. 1-6; pl. 15B, fig. 9.

Loc. Caledonia, Moscow, Darien, ete., Now York; Ontario, Canala; Milwaukee, Wisconsin; Falls of Ohio.

Stropheodonta indenta (Courad).

Lower Helderberg (Dev.).

Leptena indenta Conrad, Second Ann. Rep. N. Y. Geol. Survey, 1838, pp. 112, 117.

Strophomena indenta Billings, Proc. Portland Soc. Nat. Hist., 1863, p. 109, pl. 3, fig. 3.

Strophodonta indenta Miller, Ameriean Pal. Fossils, 1877, p. 135.

Loc. "IIelderberg Mountains," New York; Square Lake, Maine; Gaspe, Canada.

Stropheodonta interstrialis (Phillips).

Middle Devonian.

Orthis interstrialis Phillips, Pal. Foss. Cornw. and W. Somerset, 1811, p. 61, pl. 25, fig. 103.

Strophodonta interstrialis Whiteaves, Cont. Cauadian Pal., l, 1892, p. 286, pl. 37, fig. 6 .

Loc. Europe; Lake Wiunipegosis, Canada.

Stropheodonta interstrialis (Vanuxem).

Ithaca (Dev.).

Strophomena interstrialis Vanuxem (non Phillips), Geol. N. Y.; Rep. Third Dist. 1812, p. 171, fig. 1 .

Strophorlonta mucronata IIall, Pal. New York, IV, 1867, p. 111, pl. 15, figs. 13, 14. Loc. Ithaca, Elmira, Bath, ete., New York.

Obs. My attention was directed to the above synonyny ly Professor Winliams and as well that of S. mucronata Conrad (non Hall).

Stropheodonta iowaensis Oweu.

? Upper Devonian.

Strophodonta iowensis Owen, Geol. Survey Wisconsin, lowa, and Minnesota, 1852, p. 585.

Loc. Pine Creek, near Rockford, Iowa.

Stropheodonta irene (Billings).

Upper Helderberg (Dev.).

Strophomena irene Billings, l'al. Fossils, II, 1874, p. 27, p1. 2, fig. 5.

Stropheodonta (Leptostrophia) irene Hall and Clarke, Pal. New York, VIII, Pt. I, 1892, p. 288.

Loe. Grand Greve, Gaspé Bay, Canada.

Stropheodonta junia Hall.

Hamilton (Dev.).

Strophomena (Strophodonta) textilis IIall (non 1852), Tenth Rep. N. Y. State Cab. Nat. Hist., 1857, p. 141, figs. 1-3.

Strophodonta textilis IIall, Pal. New York, IV, 1867, p. 108, pl. 18, figs. 3, 4.

Strophodonta junia Hall, Ibidem, 1867, corrigenda;-Sccond Ann. Rep. N. Y. State Geologist, 1883, pl. 46, fig. 16.

Stropheodonta (Leptostrophia) junia 1 Iall and Clarke, Pal. New York, VIII, Pt. I, 1892, p. 288, pl. 15, fig. 16.

Loc. York, Moscow, Darien, etc., New York.

Stropheodonta kemperi Swallow.

Hamilton (Dev.).

Strophodonta kemperi Swallow, Trans. St. Lonis Acad. Sci., I, 1860, 1.636.

Loc. Callaway Comnty, Missouri.

Stropheodonta(?) leda (Billings).

Anticosti (Sil.).

Strophomena leda Billings, Canadian Nat. and Geol., V, 1860, p. 55, figs. 2, 3 ; -

Pal. Fossils, I, 1862, p. 120, figs. 98, 99;-Geol. Canada, 1863, p. 311, fig. 316.

Brachyprion leda Shaler, Bull. Mus. Comp. Zool., 4, 1865, p. 63.

Stropheodonta leda Hall and Clarke, Pal. New York, VIII, Pt. I, 1892, p. 288.

Rafinesquina leda Whiteaves, Pal. Foss. I1I, Pt. III, 1897, p. 172.

Loc. East Point, Anticosti, Lake Winnepeg, Manitoba. 
Stropheodonta lincklæni IIall.

Oriskany (J)ev.).

Strophohlonta lincklinni Hall, 'Touth liep. N. Y. State Cab. Nat. Hist, 1857, p.

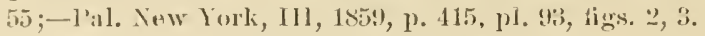

Loc. Albany and sehohario connties, New York.

Stropheodonta macra (Winchell and Marcy).

Niagara (Sil.).

Strophomena macra W. and M., Mem. Boston Soe. Nat. Hist., I, 1865, p. 91.-

Hall, Twentioth Rep. N. Y. State Cab. Nat. Hist., 186i7, p. 392.

Loc. Probably near Clicago, Illinois.

Stropheodonta macrostriata (IValeott).

Lower Devonian.

Chonetes macrostriata Walcott, Mon. IT. S. Geol. Survoy, VIII, 1884, p. 126, pl.

2 , fig. 13 ; jl. 13 , fig. 14.

Loc. Enreka district, Nerada.

Obs. The type material proves it to lue a stropheodonta.

Stropheodonta magnifica Hall.

Oriskany (Dev.).

Strophodonta magnifica Hall, Tenth Rep. N. Y. State Cab. Nat. Hist., 1857, p. 54;-Pal. New York, 111, 1859, 11, 414, 482, pl. 93, fic. 4; pl. 94, fig. 2; pl. 95, fig. 8; pl. 45A, figss. 15-19;-Second Ann. liep. N. Y. State Geol., 1883, pl. 44, figs. 27,28 .

Strophomena magnitiea billings, Canadian Jour. Sci. Arts, V1, 1861. p. 348;Geol. Canaki, 1863, p. 961, fig. 468 .

Stropheodonta (Leptostrophia) magnifica Hall and Clarko, Pal. New York, VIII, Pt. 1, 1892, p. 288, pl. 13, tigs, 27, 28.

Loc. Albany and Schoharie counties, Now York; Cumberland, Marylaud; county of Haldimand, Ontario, Canada.

Stropheodonta magniventer Hall.

Oriskany (Dev.).

Strophoclonta magniventra Hall, Tenth Rep. N. Y. State Cah.. Nat. Hist., 1857, P. 54 ;-Pal. Now York, III, 1859, p. 411, pl. 92, figs. 2, 3; pl. 95, fig. 9;Second Aun. Rep. N. Y. State Geol., 1s83, pl. 41, figs. 25, 26.

Strophomena magniventra lillings, Canadian Jour. Sci. Arts, VI, 1861, p. 349;Geol. Canada, 1863, p. 961, fig. 469;-Pal. Fossils, II, 1874, p. 22, figs. 10-12, and pl. 2, fig. 2.

Stropheodonta (Leptostrophia) magniventra llall aul Clarke, Pal. New York, VIH, Pt. I, 1892, 1. 288, pl. 13, figs. 25, 26.

Loc. Albany and Schoharie counties, New York; Cayugra, Ontario, and Gaspé Bay, Canada.

Stropheodonta mucronata (Courad).

Portage aud Chemung (Der.). Strophomena mueronata Conrad, Jonr. Acal. Nat. Sei. Philadelphia, V11I, 1842, p. 257 , pl. 14, lig. 10.

Strophomena interstrialis Hall, Geol. N. Y.; Rep. Fourth Dist., 1813, p. 266, fig. 5. Strophorlouta cayuta Hall, Pal. New York, IV, 1867, p. 110, pl. 19, figs. 1-5;Second Ann. Rej). N. Y. State Cieol., 1883, pl. 46, figs. 18. 19.

Stropheodonta (Douvilliua) cayuta Hall and Clarke, Pal. New York, V1II, Pt. I, 189:, 1. 289, pl. 15, figs. 18, 19 ; pl. 15B, figs. 7, 8; Pt. II, 1895, pl. 84, fig. 13.

Loc. Stenben County, New York.

Obs. See S. interstrialis.

Stropheodonta navalis Swallow.

Hamilton (Dev.).

Strophodonta navalis, cymbiformis, subcymbiformis, and altidorsata Swallow,

Trans. St. Lonis Acal. Sei., I, 1860, Jp. 635, 636, 637.

Strophodonta eymbifornis Keyes, Geol. Survey Missouri, V, 1895, p. 74.

Loc. Callaway County, Missonri.

Obs. The ten species of Stropheorlonta described in this transaction by Swallow are all from one loeality and appear to be wothing more than peculiar variations of S. temissil Conrad. No other locality is known where a species 


\section{Stropheodonta navalis Swallow-Continued.}

of Brachiopoda has taken on as many variations as has S. demissa in the vicinity of Fulton, Missouri. Mr. D. K. Greger has furnisher the writer over one hundred examples of this species and no two are exactly alike. Swallow's ten species are here reduced to three and one variety: $\mathrm{S}$. navalis and var. boonensis, S. kemperi, and S. callawayensis.

Keyes (Geol. Survey Missouri, V, 1895) regards s. navalis, callawayensis, quadrata, and requicostata as synonyms for S. demissa, while S. cyubiformis, subcymbiformis, kemperi, inflexa, and boonensis are regarted by him as but oue species, S. cymbiformis. S. altidorsata is regarded as "insufficiently described.'

Stropheodonta navalis boonensis Swallow.

Hamilton (Dev.).

Strophodonta booensis and inflexa Swallow Trans. St. Louis Acal. Sci., 1, 1860, pP. 637, 638.

Loc. Callaway County, Missouri.

Stropheodonta nearpassi Barrett.

Coralline limestone (Sil.).

Leptana_-Hall, Pal. New York, II, 1852, pl. 7t, fig. 3.

Strophodonta nearpassi Barrett, American Jour. Sci., 3d ser., XV, 1878, 1. 372. Loc. Near Port Jervis, New York.

\section{Stropheodonta parva Owen.}

Hamilton (Dev.).

Strophodonta parva Owen, Geol. Survey Wisconsin, Iowa, and Minuesota, 1852, p. 584, pl. 3 A, fig. 9 .

Loc. New Buffalo, Iowa.

Obs. This may prove to be young S. demissa.

Stropheodonta parva Hall.

Uper Helderberg (Dev.).

Strophodonta parva Hall, Sixteentl Rep. N. Y. State Cal,. Nat. Hist., 1863, p. 37 ;-Pal. New Jork, IV, 1867, p. 85, pl. 11, fìgs. 5, 11

Loc. Albany aud Schoharie connties, New York.

Stropheodonta patersoni Hall.

Oriskany to Corniferous (Dev.).

Strophomena (Strophodonta) patersoni Hall, Tenth Rep. N. Y. State Cab. Nat. Hist.,.1857, p. 114, figs. 1-5.

Strophomena? petersoni Billings, Canadian Jour. Sei. Arts, 2đ ser., VI, 1861, p. 340 , fig. 115 .

Strophomena patersoni Billings, Geol. Canara, 1863, P. 367, fig. 37.4-Nicholson, Pal. Prov. Ontario, 1873, p. 67.

Strophodonta patersoni Hall, Pal. New York, IV, 1867, p. 89, pl. 12, figs. 9-11; pl. 13, figs. 1-5;-Second Ann. Rej. N. Y. State Geol., 1883, pl. 45, fig. 15.Walcott, MIon. U. S. Geol. Survey, VIII, 1884, p. 119.

Stropheodonta patersoni Hall and Clarke, Pal. New York, VIIl, Pt. I, 1892, pl.14, fig. 15.

Loc. Schoharie, Stafiord, Williamsville, ete., New York; Columbus, Ohio; Bakeoven, Illinois; Eureka distriet, Nevala; county of Haldimand, Ontario, Canada.

Stropheodonta perplana (Comrad). Upper Helderberg-Chemung (Dev.). Strophomena perplana Conrad, Jour. Acacl. Nat. Sci. Pbiladelplia, VIII, 1842, p. 257, pl.14, fig. 11.-Rogers, Geol. Pennsylvania, II, Pt. II, 1858, p. 827, fig. 665.Billings, Canadian Jour. Sei. Arts, 2d ser., VI, 1861, p. 343;--Proc. Portland Soc. Nat. Hist., 1863, p. 109.-Nicholson, Pal. Prov. Ontarie, 1873, p. 64.

Strophomena delthyris Conrad, Jour. Acad. Nat. Sci. Philadelphia, V1II, 1842 p. 258, pl. 14, fig. 19.

Strophomena pluristriata Conrad, Ibidem, 1842, p. 259.

Strophomena erenistria Hall, Geol. N. Y.; Rep. Fourth Dist., 1843, p. 171, fig. 4. 


\section{Stropheodonta perplana (Comad)-Contiuued.}

Stroplomena (Strophodonta) crenistria IJall, Touth liep. N. Y. State Cab. Nat.

Ilist., 1857, p. 111.

Strophomena (Strophodouta) fragilis Hall, Ibideu, 1857, 1, 143.

Stroplıodonta fragilis 11all, Geol. Iowa, I, Pt. 11, 1858, p. 496, pl. 3, fig. 6.

Strophoilonta perplana Hall, Pal. New lork, IV, 1867, pp. 92, 98, pl. 11, fig. 22;

pl. 12, figs. 13-15; pl. 17, fig. 1.-Rathbun, I'roc. Boston Soe. Nat. Hist., XX,

1879, p. 25.-IIall, Second Ann. Rep. N. Y. State Geol., 1883, pl. 46, tims.

2-15.-Walcott, Mon. U. S. Gool. Survey, VIII, 188.t, p. 120, pl. 13, fig. 11.-

Nettehotlı, Kentucky Fossil Shells, Mem. Kentucky Geol. Survey, 1889, p.

147, pl. 18, fig. 17.-Beecher, Americau Jour. Sci., 3d ser., XLI, 1891, p. 357,

pl. 17, fig. 17.-Whiteaves, Cont. Canalian Yal., 1, 1891, p. 220.

Stropheodonta (Leptostrophia) perplaua Hall and Clirke, Pal. New York, VIII,

l’t. 1, 1892, p. 288, pl. 15, figs. 2-13.

Loc. New York; Pennsylvania; Maryland; Ohio; Indiana; lientucky; Illinois;

Iowa; Wisconsin; Eureka district, Nevada; Square Lake, Maine; Ontario

and Peace River, Canada; Rio Maccuru and Rio Curua, Province of Para, Brazil.

Stropheodonta perplana nervosa Hall. Portage and Chemung (Dev.). Strophomena nervosa IIall, Geol. N. Y. ; Rep. Fourth Dist., 1843, p. 266, fig. 1. Strophodomta perplana var, nervosa Hall, Pal. New York, IV, 1867, p. 113, pl.

19, figs. 13-16;-Second Ann. Rep. N. Y. State Geol., 1883, pl.46, tig. 17.

Stropheodonta perplaua var, nervosa Hall and Clarke, Pal. Now York, VIII, Pt.

I, 1892, figs. 14, 15, 17.

Loc. Ithaca, Bath, Campbelltown, ete., New York.

\section{Stropheodonta perplana tulliensis Williams.}

Tully (Dev.).

Strophodonta perplana var. tulliensis TVilliaws, Bull. Geol. Soc. America, I, 1890, 1. 493, pl. 12, figs. 1-4.

Loc. Cuyler, New York.

Stropheodonta planulata Hall.

Lower Helderberg (Dev.).

Strophodonta plauulata Hall, Pal. New York, III, 1859, 1. 184, pl. 16, figs. 9-12.

Loc. Schoharie, Dryhill, and Litehfield, New Tork.

Stropheodonta plicata Mall.

Hamilton (Dev.).

Strophodonta plicata Hall, Thirteenth Rep. N. Y. State Cab. Nat. Hist., 1860, p.

90 ;-Pal. New York, IV, 1867, p. 114.-Nettelroth, Kentucky Fossil Shells,

Mem. Kentucky Gcol. Survey, 1889, 1. 149.

Loc. Iowa City and Independence, Iowa; Therlforl, Ontario; Falls of Ohio.

Stropheodonta prisca Hall.

Clinton (Sil.).

Stropheodonta prisea Hall, Pal. New York, II, 1852, p. 63, pl. 21, fig. 9.

Loc. Kirkland, Oneida County, New York.

Stropheodonta profunda Hall.

Clinton and Niagara (Sil.).

Leptæna profunda Hall, Pal. New York, II, 1852, 1. 61, pl. 21, tigs. 4, 5.

Strophomena profunda Hall, Twelfth Rep. N. Y. State Cab. Nat. Hist., 1859, 1. 82.

Strophomena niagarensis Wincheli and Marey, Mem. Boston Soc. Nat. Hist., I, 1865 , p. 92, pl. 2, fig. 9.

Strophodonta profunda Hall, Twentieth Rep. N. Y. State Cab. Nat. Hist., 1867, pp. 369, 392, pl. 13, figs. 3, 4;-Twenty-eighth Rep. N. Y. State Mus. Nat. Hist., 1×79, p. 151, p)l. 23, figs. 9, 10;-Eleventh Rep. Iudiana State Geol., 1882, 1. 289, pl. 23, tigs. 9, 10; pl. 27, fig. 18;-Second Ann. Rep. N. I. State Geol, 1883, p]. 11, figro. 1-5 (?figs. 19, 20). -Nettelroth, Kentucky Fossil Shells, Mem. Kentucky Gool. Survey, 1889, p. 148, 1l. 29, fig. 26; pl.17, figs. 20,21 . 


\section{Stropheodonta profunda Hall-Continned.}

Stropheodonta (Brachyprion) profunda Hall and Clarke, Pal. New York, VIII, Pt. I, 1892, pl. 13, figs. 1-5 (? 19, 20); pl. 20, figs. 29-31; Pt. II, 1895, pl. 84, fig. 12.

Loc. Lockport, New York; Waldron, Indiana; Britgeport, Illinois; Racine, Wisconsin; Louisville, Kentucky.

Stropheodonta textilis Hall.

Coralline (Sil.).

Stropheodonta textilis Hall, Pal. New York, II, 1852, p. 327, pl. 74, fig. 6.

Stropheodonta (Leptostrophia) textilis Hall and CIarke, Pal. New York, VIII, Pt. I, 1892, p. 288.

Loc. Schoharie, New Tork.

Stropheodonta tullia (Billings).

Upper Helderberg (Dev.).

Strophomena tullia Billings, Pal. Fossils, II, 187t, p. 29, pl. 2, fig. 6.

Stropheodonta (Leptostrophia) tullia Hall and Clarke, Pal. New York, VIII, Pt. I, 1892, p. 288.

Loc. Mount Joli and Split Rock, Percé, Canada.

Stropheodonta variabilis Calvin.

Chemung (Der.).

Strophodonta variabilis Calvin, Bull. U. S. Geol. Geogr. Survey Terr., IV, 1878, p. 727.

Stropheodonta variabilis Hall anıl Clarke, Pal. New York, VIII, Pt. I, 1892, p. 289 , pl. 15B, figs. 4-6.

Lor. Independence, Iowa; Naples, New York.

Stropheodonta varistriata (Conrad).

Lower Helderberg (Der.).

Strophomena varistriata Conrad, Jonr. Acad. Nat. Sci. Philadelphia, V1II, 1842, p. 255, pl. 14, fig. 6.-Billings, Pal. Fossils, II, 1874, p. 26, pl . 2, fig. 3.

Strophomena rectilateris Conrad, Jour. Acad. Nat. Sci. Philadelphia, VIII, 1812, p. 255, pl. 14, fig. 7 .

Strophomena impressa Conrad, Ibidem, 1842, p. 255.

Strophodonta varistriata Hall, Pal. New York, III, 1859, p. 180, pl. 8, figs. 1-16; pl. 16, figs. 1-8; - Second Ann. Rep. N. Y. State Geol., 1883, Il. 4t, figs. 6-16 (? figs. 21, 22).

Stropheodonta (Brachy prion) varistriata Hall and Clarke, Pal. New York, VIII, Pt. I, 1892, pl. 13, figs. 6-16, 21, 22.

Loc. Albany and Schoharie counties, New Tork; Dalhonsie, New Brunswick, and Gaspé, Canada.

Stropheodonta varistriata arata Hall.

Lower Helderberg (Dev.).

Strophodonta varistriata var. arata Hall, Pal. New Jork, III, 1859, p. 183, pl. 18, fig. 1;-Second Ann. Rep. N. Y. State Geol., 1883, pl. 44, figs. 17, 18.

Stropheodonta varistriata var. arata Hall and Clarke, Pal. New York, VIII, Pt. I, 1892, pl. 13, figs. 17, 18 .

Loc. Hudson and Albany counties, New York; Arisarg, Nova Scotia (Ami).

\section{Stropheodonta vascularia Hall.}

Oriskany (Dev.).

Strophodouta vasenlaria Ifall, Pal. New York, III, 1859, p. 412, pl. 92, fig. 4; pl. 95, fig. 10 (? pl. 93, fig. 2).

Loc. Albany Connty, New York. .

Stropheodonta (?) ventricosa (Shaler).

Brachsprion ventricosa Shaler, Bull. Mus. Comp. Zool., 4, 1865, p. 63.

Loc. Sonthwest Point, Anticosti.

Strophodonta sequicostata $S$ wallow $=$ S. callawayensis.

Strophodonta altidorsata Swallow =S. navalis.

Strophodonta ampla Hall=Strophonella ampla. 
Strophodonta boonensis Swallow $=$ S. navalis boonensis.

Stropholonta ralata Hall=Strophonella calata.

Strophorlonta cavmubona Hall=Strophonella cavumbona.

Strophodonta cayuta Hall=Stopheoronta mueronata.

Strophodonta cymbiformis Swallow=S. navalis.

Strop rodonta exilis Galvin = Stropheodonta calvini.

Strophodonta fragilis Hall=S. perplana.

Strophodonta geniculata Hall=Strophonella genienlata.

Strophodonta hearlleyana Hall = Strophonella headleyana.

Strophodonta hybrida Hall and Whitfield=Strophonella reversa.

Strophodonta imitata A. Winchell=S. demissa imitata.

Stroplodonta inflexa Swallow =S. navalis boonensis.

Strophodonta intermedia Hall= Hipparionyx proximus.

Strophodonta leavenworthana Hall=Strophonella leavenworthana.

Strophodonta mueronata Hall=S. interstrialis.

Strophodonta nacrea Hall =Pholidostrophia iowaensis.

Strophodonta punctulifera Hall=Strophonella punctulifera.

Strophodonta qualrata Swallow=S. callawayensis.

Strophodonta quadrata Calvin (non Swallow) =S. calvini.

Strophodonta reversa Hall=Strophonella reversa.

Strophodonta striata Hall=Strophonella striata.

Strophodonta subeymbiformis Swallow =S. navalis.

Strophodonta subdemissa Hall=S. demissa.

Sirophodonta textilis Hall, 1857 (not 1852)=S. junia.

STROPHOMENA (Rafinesque) Blainville. Genotype S. rugosa Blainv.

Strophomena Blainville, Mannel de Malacologie et Conchyliologie, I, 1825, 11. 513, pl. 53, fig. 2.-Defrance, Dictionnaire des Sciences Naturelles, LI, 1827, p. 151 and atlas.-King, Mon. Permian Fossils, Pal. Soc., 1850, p. 103.-Meek (partim), Pal. Ohio, I. 1873, p. 73.-CEhlert, Niseher's Manuel de Conelypliologie, 1887, ך. 1281.-IIall and Clarke, Pal. New York, VIII, Pt. I, 1892, p. 245.Winchell and Selnehert, Minnesota Geol. Survey, III, 1893, p. 381.-Hall and Clarke, Eleventh Ann. Rep. N. Y. State Geologist, 1891, p. 283.

Strophomenes Rafinesque, Dese. Remarkable Objects in the Cabinet of Professor Rafinesque, 1831, p. 4 .

Hemipronites Meek and Hayden, Pal. Upper Missonri, Smithsonian Cont. to Knowl. XIV, 172, 1864, 1. 24.-Miller, Cincinnati Quart. Jonr. Sci., II, 1875, p. 41.

Obs. This genus is charaeteristic of the Ordovician, and probably does not extend into the Silurian, where Orthothetes replaces Strophomena. A unmber of Silurian speeies are still left under Strophomena since their generie charaeters are unknown.

Strophomena acanthoptera Whiteaves=Stropheodonta acanthoptera. Strophomena acutiraliata Hall=Chonetes acntiradiatus.

Strophomena alternata Emmons=Rafinesquina alternata.

Stroplomena alteruata fracta Meek=Rafinesquina alteruata fracta.

Strophomena alternata loxorhytis Meek= Rafinesquina alternata loxorhytis.

Strophomena altermistriata Hall= Rafinesquina alternata alternistriata. 
Strophomena (?) alterniradiata Shaler.

Anticosti (Sil.).

Strophomena alternicadiata Shaler', Bull. Mus. Comp. Zool., 4 , 1865, p. 63.

Loc. Southwest Point, Anticosti.

Strophomena ampla Hall=Strophonella ampla.

Strophomena anologa Davidson, 1863=Lept:ena rhomboidalis.

Strophomena angulata Owen=Rafinesquina alternata.

Strophomena anticostiensis Shaler=Rafinesquina alteruata.

Strophomena (?) antiquata Sowerby.

Anticosti (Sil.).

Strophomena antiquata Sowerby, Murchison's Silurian System, 1839.-Billings, Pal. Fossils, I, 1862, p. 129, fig. 107.

Loc. Europe; Anticosti; forks of the Chatts River, Gaspé.

$O b s$. This identification is doubtfinl.

Strophomeua approximata (James).

Lorraine (Ord.).

Streptorhynchus approximata James, The Paleontologist, 5, 1881, p. 43; 2, 1878, p. 15.

Loc. Dearborn County, Indiana.

Obs. Not defiued so as to be recognizable.

Strophomena aretostriata Hall=Orthothetes chemungensis aretostriatus.

Strophomena (?) arcuata Shaler.

Anticosti (Sil.).

Strophomena arcuata Shaler, Bull. Mus. Comp. Zool., 4, 1865, p. 62.

Loc. Ellis Bay, Anticosti.

Strophomena (?) arethusa Billings.

Lorraine (Ord.).

Strophomena arethnsa Billings, Pal. Fossils, I, 1862, p. 132.

Loc. Observation Cape, Anticosti.

Strophomena atava Matthew=Rafinesquina atava.

Strophomena aurora Billings=Rafinesquina aurora.

Strophomena bifurcata Hell=Orthothetes chemungensis.

Strophomena billingsi Winchell and Schuchert.

'Trenton (Ord.).

Strophomena recta Billings (non Conrad), Pal. Fossils, I, 1862, p. i30, fig. 108.

Strophomena billingsi W. and S., Miunesota Geol. Survey, III, 1893, p. 397, fig. 32.-Whiteaves, Pal. Foss., III, I't. IIl, 1897, 1. 170.

Loc. Ottawa, Canada; St. Paul, Caunon Falls, and Fountain, Minnesota; East Selkirk, Manitoba.

Strophomena (?) bipartita Hall. Coralline (Sil.).

Lept:ena bipartita Hall, Pal. New York, II, 1852, p. 326, pl. 74, figs. 4, 5.

Strophomena bipartita Hall, Twelfth Rep. N. Y. State Cah. Nat. Hist., 1859, p. 82.

Loc. Schoharie, New York.

Strophomena blainvillii Billings=Stropheodonta blainvillei.

Strophomena camerata Conrad=Rafinesquina deltoidea.

Strophomena cardinalis (Whitfield).

Lorraine (Ord.).

Streptorhynchus cardinale Whitfield, Geol. Wisconsin, IV, 1882, p. 261, pl. 12, figs. 9, 10.

Strophowena cardinale Hall and Clarke, Pal. Now York, VIII, Pt. I, 1892, p. 252.

Loc. Delafield, Wisconsin.

Strophomena carinata Conrad, $1838=$ Tropidoleptus carinatus.

Strophomena carinata Conrad, 1842 (non 1838)=Chonetes coronatus. Strophomena ceres Billings=Rafinesquina ceres. 
Strophomena chemungensis Comad = Orthothetes chemungensis.

Strophomena concava Hall=Stropheodonta concava.

Strophomena comradi Hall (1859)=Strophonella conradi.

Strophomena conradi Hall and Clarke.

Trenton (Ord.).

Strophomena conradi Inll and Clarke, Pal. New York, VIII, Pt. I, 1892, 1). 344, pl. 9 A, fig. 3 ; pl. 20 , ligs. 32,33 .

Loc. Jacksonburg, New York.

Strophomena convexa $\mathrm{O}$ wen $=\mathrm{S}$. incurvata.

Strophomena cornuta Hall=Chonetes cornutus.

Strophomena corrugata Conrad $=$ Stropheodonta corrugata.

Strophomena crebristriata Conrad=Stropheodontal crebristriata. Strophomena crenistria Hall=Stropheodonta perplana.

Strophomena (?) declivis James. Lorraine (Ord.).

Strophomena declivis James, Cincinnati Quart. Jour. Sı:i., I, 1874, p. 240.

Loc. Boyds Station, Kientucky.

Strophomena deflecta Comrad=Dinorthis deflecta.

Strophomena delthyris Conrad=Stropheodonta perplana.

Strophomena deltoidea Conrad=Rafinesquina deltoidea and R. minnesotaensis.

Strophomena demissa Courad=Stropheodonta demissa.

Strophomena depressa Vanuxem=Leptiena rhomboidalis.

Strophomena depressa ventricosa Hall=Leptrena rhomboidalis ventricosa.

Strophomena (?) doneti Salter.

Silurian.

Strophomena doneti Salter, Jour. of a Voyage in Baffins Bay and Barrow Straits, 1852.

Loc. Wellington Channel.

Strophomena elegantula Hall=Plectambonites transversalis.

Strophomena (?) elliptica Conrad.

Niagara (Sil.).

Strophomena elliptica Conrad, Third Ann. Rep. Geol. Survey New York, 1839, p. 64.

Loc. Rochester, New York.

Strophomena (?) elongata Conrad. Lower Helderberg (Dev.).

Strophomena elougata Conrad, Jonr. Acad. Nat. Sci. Philadelphia, VIII, 1842, p. 259.

Loc. Schoharie, New York.

Strophomena emaciata Winchell and Schuchert.

Trenton (Ord.).

Strophomena emaciata W. and S., American Geol., IX, 1892, 1). 287 ;-Minnesota Geol. Survey, III, 1893, p. 399, pl. 31, figs. 22-24.

Loc. Near Cannon Falls, Minnesota.

Strophomena euglyphya Conrad, and Roemer=Strophonella punctulifera.

Strophomena fasciata Hall=Rafinesquina fasciata.

Strophomena filitexta Meek, White, and Hall=S. neglecta or S. incurvata.

Strophomenes flexilis Rafinesque.

"Limestone of Ohio."

Sime paper as for S. levigata, 1831, p. 4.

Obs. Not defined so as to be recognizable. 
Strophomena fluctuosa Billings.

Lorraine (Ord.).

Strophomena fluctuosa Billings, Cauadian Nat. Geol., V, 1860, p. 57, fig. 6;-Pal. Fossils, I, 1862, p. 123, fig. 102;-Geol. Canada, 1863, p. 209, fig. 207.-Hall and Clarke, Pal. New York, VIII, Pt. I, 1892, p. 251, pl.11 A, figs. 4, 5.-Winchell and Schuchert, Minnesota Geol. Survey, III, 1893, p. 395, pl. 31, figs. 14-17.

Loc. Charletor Point, Anticosti; Spring Valley, etc., Minuesota.

Strophomena fontinalis $\mathrm{White}=$ Dinorthis fontinalis .

Strophomena fragilis Hall=Stropheodonta perplana.

Strophomena galatea Billings=Stropheodonta galatea.

Strophomena gibbosa James = Leptrena rhomboidalis.

Strophomena (?) gibbosa Conrad.

Upper Helderberg (Dev.).

Strophomena gibbosa Conrad, Fifth Ann. Rep. Geol. Surrey New Tork, 1841, p. 54.

Loc. Helderherg Mountains, New York.

Strophomena gilpeni Dawson $=$ Stropheodonta gilpeni.

Strophomena halli Sardeson=Leptrena charlottre.

Strophomena hallie Miller.

Utica (Ord.).

Streptorlınchns (?) liallie Miller, Cincinnati Quart. Jour. Sci., I, 1874, p. 148, figs. $14-16$.

Streptorhynchus hallanum Miller, North American Geol. and Pal., 1889, p. 378.

Strophomena hallie Hall and Clarke, Pal. New York, VIII, Pt. I, 1892, p. 252.

Loc. Cincinnati, Ohio.

Strophomena hanoverensis Foerste = Strophonella striata.

Strophomena hecuba Billings.

Lorraine (Ord.).

Strophomena hecuba Billings, Canadian Nat. Geol., V, 1860, p. 60, fig. 7;-Pal. Fossils, I, 1862, p. 126, fig. 104;-Geol. Canada, 1863, p. 209, fig. 206.-Hall and Clarke, Pal. New York, VIII, Pt. I, 1892, p. 252.

Loc. Anticosti.

Strophomena hemispherica Hall=Stropheodonta hemispherica.

Strophomena (?) imbecilis Billings. ? Calciferous (Ord.).

Strophomena imbecilis Billings, Pal. Fossils, I, 1865, p. 219.

Loc. Near Portland Creek, Nowfoundland.

Strophomena imbrex Billings=Rafinesquina imbrex.

Strophomena impressa Conrad $=$ Stropheodonta varistriata.

Strophomena inaquiradiata Hall=Stropheorlonta inequiradiata.

Strophomena incrassata $=$ Rafinescquina incrassata and $R$. minnesotaensis:

Strophomena incurvata (Shepard).

Trenton (Ord.).

Producta incurvata Shepard, American Jour. Sci., XXXIT, 1838, 1. 144, figs. 1, 2.

Orthis incurvata Castelnau, Essai sur le Systime silurien de l'Amérique Septentrionale, 1843 , p. 38.

Strophomena convexa Owen, Geol. Expl. Iowa, Wisconsin, and Illiuois, 1814, p. 70, pl. XVIS, fig. 2.

Leptena filitexta Hall, Pal. New York, I, 1847, p. 111, pl. 31B, fig. 3.

Strophomena filitexta Billings, Canadian Nat. Geol., I, 1856, p. 203, figs. 1, 2.Hall, Twelfth Rep. N. Y. State Cab. Nat. Hist., 1859, p. 70.-Billings, Geol. Canada, 1863, p. 164, fig. 142.-Hall and Clarke, Pal. New York, VIII, Pt. I, 1892, p. 251, pl. 9, figs. 1-7; pl. 9A, figs. 11-14 (uon figs. 10,15=S. neglecta).

Streptorhyuchus filitexta Hall, Second Ann. Rep. N. Y. Stato Geol., 1883, pl. 39, figs. $1-7$; pl. 42 , figs. 11-14 (non figs. $10,15=$ S. neglecta). 
Strophomena incurvata (Shepard)-Continued.

Strophomena incurvata Winchell and Schuchert, Minnesota Geol. Survey, III, 1893, 1). 385, fl. 30, figs. 36-40.-Whliteaves, Pal. Foss., III, Pt. III, 1897, p. 167.

Loc. New York; Kentncky; Tennessee; Missouri; Wisconsin; Iowa; Minnesota; Manitoba; Canada.

Strophomena inquassa Sardeson=Rafinesquina minnesotaensis inquissa.

Strophomena interstrialis Hall=Stropheodonta mueronata.

Strophomena interstrialis Vanuxem, and Hall=Stropheodonta inter. strialis.

Strophomena irene Billings=Stropheodonta irene.

Strophomeua ithacensis Vanuxem=Atrypa reticularis.

Strophomena (?) julia Billings.

Anticosti (Sil.).

Strophomena julia Billings, Pal. Fossils, I, 1862, p. 127, fig. 105.

Leptiena julia Shaler, Bull. Mus. Comp. Zool., 4, 1865, p. 65.

Loc. Anticosti.

Strophomena kingi Whitfield=Rafinesquina kingi.

Strophomena lævis Emmons.

Birdseye (Ord.).

Strophomena lavis Emmons, Geol. New York; Rep. Second Dist., 1842, p. 385, fig. 97:.

Loc. Great Bend, Jefierson County, New York.

Strophomena lachrymosa Conrad=Productella lachrymosa.

Strophomena leda Billings=Stropheodonta leda.

Strophomena lepida Hall=Pholidostrophia iowaensis.

Strophomenes levigata Rafinesque.

"Kentucky limestone."

Enumeration and Account of Some Remarkable Natural Objects in the Cabinut of Professor Rafinesque, 1831, p. 4.

Obs. Not defined so as to be recognizable.

Strophomena lima Conrad = Productella lachrymosa lima.

Strophomena lineata Conrad $=$ Chonetes lineatus.

Strophomena macra Winchell and Marcy=Stropheodonta macra.

Strophomena magnifica Billings=Stropheodonta magnifica.

Strophomena magniventra Pillings=Stropheodonta magniventer.

Strophomena membranacea Vanuxem=Productella hirsuta.

Strophomena minnesotensis Winchell=Rafinesquina minnesotaensis.

Strophomena (?) minor (Walcott).

Pogonip (Ord.).

Streptorhynchus minor Walcott, Mon. U. S. Geol. Survey, VIII, 1884, p. 75, pl. 1I, fig. 9.

Loc. Enreka district, Nevada.

Strophomena (?) modesta Conrad.

? Clinton (Sil.).

Strophomena modesta Conrad, Thiril Ann. Rep. N. Y. Geol. Snrvey, 1839, p. 64.

Loc. Rochester, New York.

Obs. Compare with Plectambonites sericea and P. elegantula.

Strophomena mueronata Hall (uon Conrad)=Chonetes mucronatus.

Strophomena mucronata Conrad (non Hall)=Stropheodonta mucronata. Strophomena nacrea Hall=Pholidostrophia iowaensis.

Strophomena (?) nassula Conrad.

Carboniferous.

Strophomena nassula Conrad, Proc. Acad. Nat. Sei. Philadelphia, I11, 1846, p. 23.

Loc. Jersey Shole, Lycoming County, Pennsylvania. 
Strophomena uasuta Conrad=Rafinesquina alternata nasnta.

Strophomena neglecta (James).

Lorraine (Ord.).

Strophomena filitexta Meek (non Hall), Pal. Ohio, I, 1873, p. 83, pl. 6, fig. 5.

? Strophomena filitexta White, U. S. Geol. and Geogr. Survey west 100th Merid., IV, 1875 , p. 69 , pl. 4 , fig. 8 .

Hemipronites filitextus Miller, Cincinnati Quart. Jonr. Sci., II, 1875, p. 43.

Streptorhynchus neglecta James, The Paleontologist, 5, 1881, p. 41.

Streptorlıychus filitextus (partim) Hall, Second Ann. Rep. N. Y. State Geol., 1883, pl. 42. figs. 10, 15 (non figs. 11-14); pl. 39, figs. 1-7.

Strophomena filitexta Hall and Clarke, Pal. New York, VIII, Pt. I, 1892, pl. 9A, figs. 10, 15 (non figs. 11-14); pl. 11A, fig. 3 .

Strophomena neglecta Winchell and Schuchert, Minnesota Geol. Survey, III, 1893, p. 388.

Loc. Oxford, Clarksville, Waynesville, etc., Ohio; Richmond, Versailles, etc., Indiana; Savanna, Illinois; ? Silver City, New Mexico.

Strophomena neglecta acuta Winchell and Schuchert. Lorraine (Ord.).

Strophomena neglecta var. acuta W. and S., Minnesota Geol. Survey, III, 1893, p. 388 , pl. 31, figs. $6,7$.

Loc. Spring Valley, Minnesota.

Strophomena ? nemea Hall and Whitfield=Dalmanella pogonipensis. Strophomena nervosa Hall=Stropheodonta perplana nervosa.

Strophomena niagarensis Winchell and Marey=Stropheodonta profunda.

Strophomena nitens Billings=Rafinesquina nitens.

Strophomena nutans Meek.

Lorraine (Ord.).

Strophomena (Hemipronites) nntans (James) Meek, Pal. Ohio, I, 1873, p. 77, pl. 6, fig. 1.

Hemipronites nutans Miller, Cincinnati Quart. Jour. Sci., II, 1875, p. 46.

Streptorlynchus nutans Miller, N. American Geol. P'al., 1889, 1. 378.

Strophomena nutaus Hall and Clarke, Pal. New York, VIII, Pt. I, 1892, 1. 251, pl. 8, fig. 11 ; pl. 9A, figs. 5-7; pl. 11A, figs. 6,7 .

Loc. Oxfurd, Clarksville, ete., Ohio; Richmond, Versailles, ete., Indiana.

Strophomena obscma Hall=Rafinesquina obscura.

Strophomena (?) orthididea Hall.

Clinton (Sil.).

Leptrena orthididea Hall, Pal. New York, II, 1852, p. 62, pl. 21, fig. 7.

Strophomena orthididea Hall, Twelfth Rep. N. Y. State Cab. Nat. Hist., 1859, p. 82.

Loc. Kirkland, Oneida County, New York.

Strophomena patenta Hall=Strophonella patenta.

Strophomena patersoni Hall=Stroplieodonta patersoni.

Strophomena pecten Roemer, and Billings $=$ Orthothetes subplanus.

Strophomena peetinacea Hall=Orthothetes chemungensis.

Strophomena perplana Conrad=Stropheodonta perplaua.

Strophomena philomela Billings.

Anticosti (Sil.).

Strophomena philomela Billings, Canadian Nat. Geol., V, 1860, p. 56, figs, 4, 5 ;Pal. Fossils, I, 1862, p. 122, figs. 100, 101 ;-Geol. Canada, 1863, 1. 311, fig. 317.

Loc. Auticosti.

Strophomena planiconvexa Hall.

Lorraine (Ord.).

Leptana planoconvexa Hall, Pal. New York, I, 1847, p. 114, pl. 31B, fig. 7.

Bull. 87_-28 


\section{Strophomena planiconvexa Hall-Continned.}

Strophonena planoconvexa Hall. 'Twelfth Rep. N. Y. State Cab. Nat. Hist., 1859, 1. 70.-1lall and Clarko, Pal. New York, VIII, Pt. 1, 1892, 1. 251, pl. 9, figrs. 19,20 .

Strophomen: (Ilemipronites) planoconvexa Meek, Pal. Ohio, I, 1873, p. 82, p]. 6, fig. 2.

If smipronites planoconvexa Miller, Cincinnati Quart. Jour. Sci., Il, 1875, p. 48. Streptorlyynchus planoconvexus Miller, Aucrican Pal. Fossils, 1877, p. 134.Hall, Sncoul $A$ n. Rep. N. Y. Stato Geol., 1883, pl. 39, figs. 19, 20.

Loc. Cincinuati, Ohio.

\section{Strophomena planidorsata Winchell and Schuchert.}

Lorraine (Ord.).

Strophomena planodorsata IT. and S., American feol., IX, 1892, p. 286;-Minnesota Geol. Nurver, III, 1893, p. 393, pl. 31, figs. 8-10.

Lac. Spring Valley, Minnesota; Iron Ridge, Wisconsin; Wilmington, Illinois. Strophomena planumbona Hall=S. rugosa.

Strophomena plicata Meek=S. rugosa subtenta.

Strophomena plicifera Hall=Dalmanella plicifera .

Strophomena pleuristriata Conrad=Stropheodonta perplana.

Strophomena profunda Hall=Stropheodonta profunda.

Strophomena punetulifera Vanuxem = Strophonella punctulifera.

Strophomena pustulosa Hall (non Phillips)=Strophalosia truncata.

Strophomena radiata Vanuxem=Strophonella radiata.

Strophomena recta Conrad $=$ Dinorthis deflecta.

Strophomena recta Billings=S. billingsi.

Strophomena rectilateraria Meek and Worthen=Strophonella cavum. bona.

Strophomena rectilateris Conrad=Stropheodonta varistriata.

Strophomena (?) reticulata Shaler. Niagara (Sil.).

Strophomena retienlata Shaler, Bull. Mus. Comp. Zool., 4, 1865, p. 62.

Loc. Anticosti.

Strophomena rhomboidalis=Leptæna rhomboidalis.

Strophomena rngosa Hall (non Blainville)=Leptæua rhomboidalis.

Strophomena rugosa (Rafinesque MS.) Blainville. Lorraine (Ord.). Strophomena rugosa (Rafinesque) Blainville, Malacologie et Conchyliologie, I, 1825, p. 513, pl. 53, figs. 2, 2a.-King, Mon. Permian Fossils, Pal. Soc., 1850, p. 103.-Hall and Clarke, Pal. New York, VIII, Pt. I, 1892, p. 247, figs. 13, 14. -Winchell and Schuchert, Minnesota Geol. Survey, III, 1893, p. 390, pl. 31, figs. 4, 5. -Whiteaves, Pal. Fóss., III, Pt. III, 1897, p. 168.

Strophomenes rugosa Defrance, Dictiouaire des Seiences Natnrelles, I, 1827, p. 151 and atlas.

Leptena planumbona Hall, Pal. New York, I, 1847, p. 112, p1. 31, fig. 4.

Leptæna (n. sp.?) Oren, Geol. Survey Wisconsin, Iowa, Minnesota, 1852, pl. 2B, fig. 21. [See specimens in U.S. Nat. Mns., Cat. Invert. Foss., 17876.]

Strophomena plauumbona 1Iall, Geol. Wisconsin, I, 1862, 1. 54, fig. 7.-White, Second Ann. Rep. Indiana Bureau Statistics and Geol., 1880, p. 183, pl. 2, figs. 13, 14;-Tonth Rep. Indiana State Geol., 1881, p. 115, pl. 2, figs. 13, 14.-Shaler (partim), Mem. Kentucky Geol. Survey, 1887, p. 13, pls. 4, 5.-Keyes, Geol. Survey Missonri, V, 1895, 1. 73.

stropbomena (Hemipronites) planumlona Meek, Pal. Ohio, I, 1873, 1. 79, pl. 6, fig. 3 . 
Strophomena rugosa (Rafinesque MS.) Blainville-Continued.

Streptorhynchus (Strophomena) elongata James, Cincinnati Quart. Jour. Sci., I, 1874, p. 240.

Hemipronites planumbona Miller, Cincinnati Quart. Jour. Sei., II, 1875, p. 45. Streptorhynchus planumbonus Miller, American Pal. Fossils, 1877, p. 134.

Streptorhyuchus elongata Mickelborough and Wetherbs, Jour. Cincinnati Soc. Nat. Hist., I, 1878, p. 76.

Streptorhynchus planumbona Hall, Second Ann. Rep. N. Y. State Geol., 1883, pl. 39, figs. $15-17$; pl. 42, tigs. 8,9 .

Strophomena planumbona or rugosa Hall and Clarke, Pal. New York, VIII, Pt. I, 1892, p. 25I, pl. 9 , figs. $15-17$; pl. 94 , figs. 8,9 .

Loc. Ohio; Indiana; Kentucky; Missonri ; Minuesota and Anticosti. Lower Fort Garry, Manitoba. Probably also at Lattners, Iowa, and Iron ridge, Wisconsin.

Strophomena rugosa subtenta (Hall).

Lorraine (Ord.).

Strophomena subtenta Conrad, Fifth Aun. Rel. N. Y. Geol. Survey, 1841, j. 37

(undefined).-Billings, Pal. Fossils, I, 1862, p. 132, fig. 109 on p. 130.

Lepterna subtenta Hall, P'al. New York, I, 1847, p. 115, pl. 311, fig. 9.

Strophomena (Hemipronites) plicata (James) Meek, Pal. Ohio, I, I873, p. 81, pl.

6 , fig. 4.

Hemipronites subtenta Miller, Cincinnati Quart. Jour. Sei., II, 1875, p. 46.

Strophomena rugosa var. subtenta Winchell and Schuchert, Minuesota Geol.

Survey, III, 1893, p. 393. - Whiteaves, Pal. Foss., III, Pt. III, 1897, p. 169.

Loc. The same as for S. rugosa.

Strophomena rugosa ventricosa $\mathrm{H}$.=Leptrena rhomboidalis ventricosa.

Strophomena scofieldi Winchell and Sehuchert.

'Trenton (Ord.).

Strophomena scofieldi W. and S., American Geol., IX, April, 1×92, p. 286;-

Minnesota Geo]. Survey, III, 1893, p. 398, pl. 31, figs. 18-21.

Streptorhynchus subsulcatum Sardeson, Bull. Mimmesota Acal. Nat. Sci., III, April 9, 1892, p. 335, pl. 4, fig. 39.

Loc. Cannon Falls, Minueapolis, and St. Paul, Minnesota; Beloit, Wisconsin.

Strophomena semifasciata Hall=Strophonella semifasciata.

Strophomena semiovalis Conrad (nou Shaler)=Plectambonites sericeus.

Strophomena (?) semiovalis Shaler.

Anticosti (Sil.).

Strophomena semiovalis Shaler, Bull. Mus. Comp. Zool., 4, 1865, p. 61.

Loc. Anticosti.

Strophomena septata Winchell and Schuchert.

Trenton (Ord.).

Strophomena septata W. and S., American Geol., IX, 1892, p. 285;-Minnesota Geol. Survey, III, 1893, 1. 390, pl. 30, figs. I-3.

Loc. St. Panl, Minneapolis, aud Rochester, Minnesota.

Strophomena sericea $=$ Plectambonites sericeus.

Strophomena setigera Hall=Clınetes setigerus.

Strophomena (?) siluriana Davidson.

Silurian.

Strophomena siluriana Daviclson, British Sil. Brach., Pal. Soc., 1871, p. 303, pl. 47, figs. 1-4.-Etherilge, Quart. Jour. Geol. Soc. Londlon, XXXIV, 1878, p. 597.

Loc. England; Cape Leidy, lat. $79^{\circ} 38^{\prime}$.

Strophomena sinuata Emmons (non Meek)=S. sulcata.

Strophomena sinuata Meek.

Lorraine (Ord.).

Strophomena (Hemipronites) sinnata (James) Meek, Pal. Ohio, I, 1873, p. 87, pl. 5, fig. 5 (non S. sinuata Emmons, 1855).

Hemipronites sinuata Miller, Cincinuati Quart. Jour. Sci., II, 1875, p. 50.

Strophomeua sinuata Hall and Clarke, Pal. New York, VIII, Pt. I, 1892, p. 251.

Loc. Cincinnati, Ohio. 
Strophomena squamula .James=Rafinesquina squawula.

Strophomena striata Hall=Strophonella striata.

Strophomena subplana Conrad=Orthothetes subplanus.

Stropliomena subtenta Conrad=S. r'ugosa subtenta.

Strophomena sulcata (Vernenil).

Lorraine (Ord.).

L. Jtipna sulcata Verneuil, Bull. Geol. Sor. France, $2 d$ ser., V, 18.18, p. 3\%0.

Strophonena sinuata Eimmons, American Geol., I, 1855, p. 199, fig. 61.

Strophomena (Hemipronites?) sulcata Meek, Pal. Ohio, I, 1873, p. 85, pl. 5, tig. 4.

Hemipronites suleata Miller, Cincinnati Quart. Jour. Sci., II, 1875, p. 48, tig. э.

Streptorhynehus suleatus Hall, Second Anu. Rep. N. Y. State Geol., 1883, pl. 3!), tigs. $8,9$.

Strophomena sulcata Hall and Clarke, Pal. New York, VIII, Pt. I, 1892, p1. 9, figs. 8,$9 ;$ pl. $11 \mathrm{~A}$, fig. 8 .

Loc. Oxford, Clarksville, ete., Ohio; Richmond, Indiana.

Strophomena syrtalis Conrad $=$ Chonetes coronatus.

Strophomena (?) talacastrensis Kayser.

Ordovician.

Strophomena talacastrensis Kayser, Pali'ontographica, Suppl., IHI, 1876, p. 20, pl. 3, tig. 20.

Loc. Talacastra, Cordillere San Juan, Argentime Republic.

Strophomena tennilineata Conrad=Rafinesquina temnilineata.

Strophomena tenuistriata=Leptrena rhomboidalis.

Strophomena textilis Hall=Stropheodonta junia.

Strophomena thalia Billings.

Trenton (i) ril.).

Strophomena thalia Billings, Canadian Nat. Geol., V, 1860, p. 59 ;- Pal. Fossils, I, 1862, p. 125, fig. 103;-Geol. Canada, 1863, p. 161, fig. 143.-Hall aud Clarke, Pal. New York, VIII, Pt. I, 1892, p. 251.

Loc. Ottawa, Canada.

Strophomena transversalis Hall=Plectambonites transversalis.

Strophomena trentonensis Winchell and Schuchert. Trenton (Ord.).

Leptrua subtenta (partim) Hall, Pal. New York, 1, 1847, p. 115.

Streptorhynchus subtenta Hall, Second Ann. Rep. N. Y. State Geol., 1883, pl. 39, tig. 18.

Strophomena subtenta Hall and Clarke, Pal. New York, VIII, Pt. I, 1892, P. 251, pl. 9, fig. 18 . .

Strophomena trentonensis W. and S., Minnesota Geol. Survey, III, 1893, p. 389, pl. 30 , fig. 41.

Loc. Cannon Falls. Minneapolis, and Fountain, Minnesota ; Janesville and Beloit, Wisconsin; Frankfort, Kentucky; Nashville, Tennessee; Trenton Falls, New York.

\section{Strophomena trilobata (Oweli).}

Trenton (Ord.).

Leptiena trilobata Owen, Geol. Survey Wisconsin, Iowa, Minnesota, 1852, p. 584, pl. 2, figs. 17, 18. [See specimens in U. S. Nat. Mus., Cat. Invert. Fos.., 17875.]

Strophomena trilobata Miller, American Pal. Fossils, 1877, p. 138.-Winchell and Schuchert, Minnesota Geol. Survey, III, 1893, p. 395, pl.31, figrs. 12, 13.Whiteaves, Pal. Foss., IIl, Pt. III, 1897, pp. 169, 241.

Loc. 'Turkey River, lowa; Goodhue County, Minnesota; Lake Winnipeg, Manitoba.

Strophomena tullia Billings=Stropheodonta tullia.

Strophomena ulrichi James=Rafinesifuina ulrichi.

Strophomena unicostata Meek and Worthen=Rafinesquina micostata. 
Strophomena undulatus Vanuxem=Leptiena rhomboidalis.

Strophomena undulosa Courad=Leptiena undulosa.

Strophomena varistriata Conrad =Stropheodonta varistriata.

Strophomena vetusta James.

Lorraine (Ord.).

Stroptorhynclıus (Strophomena) vetusta James, Cincinnati Quart. Jour. Sei., I, 1874,1 . 241.

Streptorhynchus vetusta Mickelborough and Wetherby, Jour. Cincinnati Soc. Nat. Hist., I, 1878, 1). 76.-James, The Paleontologist, 2, 1878, p. 15.

Loc. Upper part of Cincinnati group in Obio and Indiana.

Strophomena winchelli Hall and Clarke.

Trenton (Ord.).

Streptorhynchus (Strophonella?) deltoidea Hall (non Leptæna deltoidea 1847), Second Ann. Rep. N. I. State Geol., 1883, pl. 39, figs. 10, 12-14 (non fig. 11= S. nutans).

Strophomena winchelli Hall and Clarke, Pal. Now York, TIII, Pt. I, 1892, p. 344, pl. 9, figs. 10, 12-14; pl. 20, fig. 26. -Winchell and Schuchert, Minnesota Geol. Survey, III, 1893, p. 394, pl. 31, fig. 11.

Loc. Janesville, Clifton, and Oshkosl, Wisconsin.

Strophomena wisconsinensis Whitfield.

Lorraine (Ordl.).

Strophomena wisconsinensis Whitfield, Geol. Wiseonsin, IT, 1882, p. 263, pl. 12, figs. 11-13.

Strophomena winconsinensis Hall and C'larke, Pal. New York, VIII, Pt. I, 1892, p. $251, \mathrm{pl} .11 \mathrm{~A}$, figs. $1,2$.

Loc. Delafield, Wisconsin.

Strophomena woolworthana Hall=Orthothetes woolworthana.

STROPHONELLA Hall. Genotype Strophomena semifasciata Пlall.

Strophonella IIall, Twenty-eighth Rep. N. Y. State Mus. Nat. Hist., 1879, p. 153 ; Elerenth Rep. Indiana State Geologist, 1882, p. 291.-Hall and Clarke, Pal. New York, VIII, Pt. 1, 1892, p. 290;-Eleventh Aun. Rep. N. I. State Geologist, 1894, 1. 282.

Strophonella ampla Hall.

Upper Helderberg (Dev.).

Strophomena (Strophodonta) ampla Hall, Tenth Rep. N. Y. Stato Cab. Nat. Hist., 1857, 1. 111, figs. 1, 2.

Strophomena ampla Billings, Canadiau Jonr. Scci. Arts, VI, 1861, p. 345, figs. 119, 120;-Geol. Cauada, 1863, p. 367, figs. 376, 378.

Strophodonta amp]a Hall, Pal. New York, IV, 1867, p. 93, pl. 14, fig. 1.

Strophonella ampla Hall, Twenty-eighth Rep. N. Y. State Mus. Nat. Hist., 1879, p. 154;-Second Aun. Rep. N. Y. State Ficol., 1883, p]. 43, figs. 13-15.-Hall and Clarke, Pal. New York, VIII, Pt. I, 1892, p. 293, p]. 12, figs. 13-15.

Loc. Albany and Schoharie connties, Cherry Valley, Williamsville, etc., New York; Colnmbus, Ohio; Ontario, Canada.

Obs. Compaje with S. sehohariensis (Castelnau).

Strophonella cælata Hall.

Chemming (Dev.).

Stroplodonta celata Hall, Pal. New York, IT, 1867, p. 112, pl. 19, figs. 6, 7.

Strophonella cirlata Hall, Twenty-eighth Rep. N. Y. State Mus. Nat. Hist., 1879, p. 151;-Second Ann. Rep. N. Y. State Geol., 1883, pl. 43, fig. 21.-Hall and Clarke, Pal. New York, VIII, Pt. I, 1892, p. 293, pl. 12, fig. 21; pl. 15B, fig. 10. Loc. Near Elmira, New York.

Strophonella cavumbona Hall.

Lower Helderberg (Dev.).

Strophodonta cavumbona Hall, Tenth Rep. N. Y. State Cab. Nat. Hist., 1857, 1). 51 ;-Pal. New York, III, 1859, p. 187, 11. 21, figs. 1-3.

Stropliomena (Strophodonta) carmmbona Meek and Worthen, Geol. Surv. Illinois, III, 1868, p. 374, pl. 7, fig. 10. 


\section{Strophonelia cavumbona Hall-Continued.}

Strophomena rectilateraria Meek and Worthen, lbiclem, 1868, p. 375.

strophonella cavumbona Hall and Clarke, Pal. New York, VIII, P't. I, 1892, pp. $291,292$.

Loc. Schoharie, Iludson, and C'atskill, New York; Yerry County, Missonri.

Obs. l'robably synonymous with S. punctulifera.

Stropnonella costatula Hall and Clarke.

Niagara (Sil.).

Strophonella costatula Hall and Clarke, Pal. New York, VI1I, Pt. 1I, 1895, p. 359, pl, 81, tigss. $15,16$.

L.or. Louisville, Kentucky.

Strophonella (?) conradi Hall.

Lower Helderberg (Dev.).

Strophomena conralli Hall, Pal. New York, III, 1859, p. 194, pl. 16, figs. 13, 14.

strophonella? couradi lIall and Clarke, Pal. New York, VIIl, Pt. I, 1892, n. 292. Loc. Schoharie, New York.

Strophonella crassa Rowley.

Hamilton (Dev.).

Strophonella erassa Rowley, Ameriean Geologist, XIII, 1891, p. 153, figs. 4-6.

Loc. Callaway County, Missouri.

Strophonella geniculata ( Hall).

Lower Helderberg (Dev.). Strophodonta genienlata Hall, PaI. New York, III, 1859, p. 483, pl. 23, fig. 6.

Loc. Cumberland, Maryland.

Strophonella headleyana Mall.

Lower Helderberg (Dev.).

Strophomena (Stropholonta) headleyana Hall, Tenth Rep. N. Y. State Cab. Nat. Hist., 1857, p. 49, figs. 1, 2.

Strophodonta headleyana Hall, Pal. New York, III, 1859, p. 185, pl. 20, figs. 1-3.Meek, American Jonr. Sei., 2d ser., XL, 1865, p. 33.

Strophonella headleyana Hall and Clarke, Pal. New York, VIII, Pt. I, 1892, p. 292. Loc. Schoharie, Hudson, ete, New York; Kennedy Channel and Cape Frazire, Aretic regions.

Strophonella leavenworthana Hall.

Lower Helderberg (Dev.).

Strophomena (Strophodonta) leavenworthana Hall, Tenth Rep. N. Y. State Cab.

Nat. IIist., 1857. 1. 53.

Strophodonta leavenworthana Hall, Pal. New York, III, 1859, p. 189, pl. 21, figs. $5-7$; pl. 23, figs. 1-3.

Strophonella leavenworthana Hall, Twenty-eighth Rep. N. Y. State Mus. Nat.

Hist., 1879, 1. 154;-Second Ann. Rep. N. Y. Stato Geol., 1883, pl.43, figs. 6-9.Hlall and Clarke, Pal. New York, VIII, Pt. I, 1892, p. 292, pl. 12, figs. 6-9.

Loc. Albany and Sehoharie counties, New York.

Strophonella (?) patenta Пall.

Clinton (Sil.).

Leptrena patenta Hall, Pal. New York, II, 1852, p. 60, pl. 21, fig. 3.-Rogers, Geol. Pennsylvania, II, Pt. II, 1858, p. 823, fig. 631.

Strophomena patenta Hall, Twelfth Rep. N. Y. State Cab. Nat. IIist., 1859, p. 82.Hall and Whitfield, Pal. Ohio, II, 1875, p. 115, pl. 5, fig. 10.-Foerste, Bull. Denison Univ., II, 1887, p. 105, pl.8, figs. 34-37;-Proe. Boston Soe. Nat. Hist., XXIY, 1890, p. 300, pl. 5, fig. 22.

Streptorhyuchus patenta Hall, Second Anu. Rep. N. Y. State Geol., 1883, pl. 42, figs. 16-18.

Strophomena? (Strophonella?) patenta Hall and Clarke, Pal. New York, VIII, Pt. I, 1892, pl. 291, 292, pl. 9A, figs. 16-18.

Strophomena (Strophonella) patenta Foerste, Geol. Ohio, VII, 1895, p. 569, pl. 27, figs. $35-37$.

Lor. Rynales Basin, Medina, ete., New York; Dayton, Ohio; Hanover, Indiana; Collinsville, Alabama. 
Strophonella punctulifera (Conrarl).

Lower Helderberg. (Dev.).

Leptrena punctulifera Conrad, Second Rep. N. Y. Geol. Survey, 1838, pp. 112, 117. Strophomena euglypha Conrad, Fifth Rep. N. Y. Geol. Survey, 1841, p. 36.Roemer, Sil. Fauna d. West. Tennessee, 1860, 1. 66, pl. 5, fig. 3.-Etheridge, Quart. Jour. Geol. Soc. London, XXXIV, 1878, p. 597.

Strophomena punctulifera Vauuxem, Geol. N. Y. ; Rep. 'Third. Dist., 1842, p. 122, fig. 5.-Rogers, Geol. Penusylvania, I1, Pt. II, 1858, p. 825, fig.648.-Billings, Proc. Portland Soc. Nat. Hist., 1863, p. 108, pl. 3, fig. 2;-Geol. Canala, 1863, p. 957, fig. 448;-Pal. Fossils, 1I, 187.4, p. 31, pl. 3, fig. 2.

Strophomena (Strophodonta) punctulifera I Iall, Tenth Rep. N. Y. State Cab. Nat. Hist., 1857, p. 50, fig. 1.

Strophodonta punctulifera Hall, Pal. New York, III, 1859, p. 188, pl. 21, fig. 4 ; pl. 23, figs. 4-7.-Walcott, Mon. U. S. Geol. Snrvey, VIII, 1884, p. 121, pl. 13 , fig. 10.

Strophonella punctulifera Hall, 'Twenty-eighth Rep. N. Y. State Mus. Nat. Hist., 1879, p. 154 ; -Second. Ann. Rep. N.Y. State Geol., 1883, pl. 43, figs. 10-12.--Hall and Clarke, Pal. New York, VIII, Pt. I, 1892, p. 292, pl. 12, figs. 10-12.

Loc. Albany and Schoharie counties, New York; Square Lake, Maine; Pennsylvania; Decatur Connty, Tennessee; Dalhousie, New Brunswick, and Gaspé, Canada; Eureka district, Nevala; Cape Hilgard and Cape Louis Napoleon, Aretic regions.

Obs. See S. cavumbona Hall.

Strophonella (?) radiata (Vauuxem).

Lower Helderberg (Dev.).

Strophomena radiata Vanuxem, Geol. N. Y.; Rep. 'Thrrd Dist., 1842, p. 122, fig. 6.-Hall, Tenth Rep. N. Y. State Cab. Nat. Hist., 1857, p. 50, fig. 1;-Pal. Now York, III, 1859, p. 193, pl. 21, figs. 8, 9; pl. 18, fig. 3 .

Streptorhynchus radiatus Miller, Ameriean Pal. Fossils, 1877, p. 134.

Strophonella rarliata Hall and Clarke, Pal. N 3 w York, VIII, Pt. I, 1892, p. 292.

Loc. Hudson, Albany, and Schobarie conuties, New York.

Strophonella reversa Hall.

Chemung (Der.).

Strophodonta reversa Hall, Geol. Snrvey Iowa, I, Pt. II, 1858, 1. 494, pl. 3, fig. 4.

Strophodonta hybrida Hall and Whitfield, 'Twenty-third Rep. N. Y. State Cab. Nat. Hist., 1873, p. 239.

Strophonella reversa Hall, Twenty-eighth Rep. N. Y. State Mus. Nat. Hist., 1879, p. 154.-Hall and Clarke, Pal. New York, VIII, Pt. I, 1892, p. 293, pl. 12, figs. 16-20.

Strophonella? (Strophodonta) reversa Hall, Second Ann. Rep. N. Y. State Geol., 1883, pl. 43, figs. 16-20.

Loc. Rockford, Iowa; Naples, New York.

Strophonella schohariensis (Castelnau).

? Upper IIelderberg (Dev.).

Orthis schohariensis Castelnau Essai Syst. Sil. l'Amérique Septentrionale, 1843, p. 36, pl. 14, fig. 5.

Loc. Schoharie, New York.

Obs. Compare with S. ampla.

Strophonella semifasciata Hall.

Niagara (Sil.).

Strophomena (Strophodonta?) semifasciata Hall, Trans. Albany Inst., IV, 1863, p. 210.

Strophonella semifasciata Hall, Twenty-eighth Rep. N. Y. State Mus. Nat. Hist., 1879, p. 154, pl. 22, figs. 1-3; pl.23, figs. 7,8;-Eleventl Rep. Indiaua State Geol., 1882, p. 292, pl. 22, figs. 1-3; pl. 23, figs. 7, 8;--Second Ann. liep. N. Y. State Geol., 1883, pl. 43, figs. 4, 5.-Hall and Clarke, Pal. New York, VIII, Pt. I, 1892, pl. 12, figs. 4,5 .

Loc. Waldron, Indiana; Wisconsin. 
Strophonella striata Hall.

Niagara (Sil.).

Strophomena striata Hall, (ieol: N. Y.; Rep. Fourth J)ist., 18.3, p. 104, fig. 3;-

Twelfth liep. N. Y. State Cal.. Nat. Hist., 1859, 1.82.

Strophodonta striata Iall, Twenty-eighth liep., Ibiclem, 1879, p. 152, pl. 23, figs. 1-6; - Eleventh Rep. Indiana St:ıte (ieol, 1882, 1. 290, pl. 23, tigs. 1-6.-Nettelroth, Kentucky Fossil shells, Mem. Kentucky (ieol. Survey, 1889, 1). 14!).

Lopitiona striata Hall, Pal. New York, II, 1852, p. 25!', pl. 53, lig. 7.

Strophodonta (Strophouella?) striata Hall, Second Anu. Rep. N. Y. State Geol, 1883 , pl. 43 , tigs. 1-3.

Strophonella striata Beecher and Clarke, Mem. N. Y. State Mus., I, 1889, 1). 25, pl. 3, figs. $1-8$.

Stropliomena hanoverensis Foerste, Proc. Boston Soc. Nat. Ilist., XXIY, 18:10, p. 301, pl. 6, fig. I.

Strophouella (Amphistrophia) striata Hall aud Clarke, Pal. New York, VIII, l't. I, 1892, p. 292, pl. 12, figs. 1-3.

Strophomena (Orthothetes) hanoverensis Foerste, Geol. Ohio, VH, 1895, p. 567, pl. 27, fig. 34; pl. 31, fig. 1.

Loc. Lockport, New York; Waldron aul Hanover, Indiana; Lonisville, Kentucky. Syntrielasma Meek and Worthen=Enteletes.

SYNTROPHIA Hall and Clarke. Cienotype Triplesia lateralis Whittiell. Syntrophia Hall and Clarke, Pal. New York, VIII, Pt. I, 1892, p. 270;--Ibidem, Pt. Il, 1893, p. 216;-Thirteenth Ann. Rep. N. Y. State Geologist, 1895, p. 836.

\section{Syntrophia arachne (Billings).}

Upper cambrian.

Stricklandia? arachne Billings, Pal. Fossils, I. 1862, 1. 85, tig. 77.

Syutrophia arachne Hall and Clarke, Pal. New York, VIII, I't. II, 1893, 1. 216.

Loc. Point Levis, Canada.

Syntrophia arethusa (Billings).

Upper Cambrian.

Stricklandinia 9 arethusa lillings, Pal. Fossils, I, 1862, p. 85, tig. 78.

Syntrophia arethusa Hall and Clarke, Pal. New York, VIII, Pt. II, 1893, p. 216.

Loc. Point Levis, Canada.

Syntrophia (?) armanda (Billings).

Upper Cambrian.

Orthis? armanda Billings, Pal. Fossils, I, 1865, p. 303, fig. 293.-Hall and Clarke,

Pal. New York, VIII, Pt. I, 1892, p. 217.

Loc. Phillinsburg, Canada.

Obs. This species may prove to be a Billingsella. In the interior of the ventral valve "the clental plates seem to form an imperfect triangular chamber" (Billings). If there is present a true spondyliom and the foramen is "apparently open" O. armanda will prove to be more nearly related to Syntrophia than to any other genus. If, however, there is present only an imperfect triangular chamber ant the foramen closed bs a deltidium, then the speeies is probably a Billingsella.

Syntrophia barabuensis (A. Winchell).

Upper Cambrian.

Orthis harabuensis A. Winchell, American Jonr. Sei., 2d ser., XXX VII, 1864, 1. 228. Leptiena baribnensis Whitfieh, Ann. Rep. Geol. Survey Wisconsin, 1877, p. 60 ;Geol. Wisconsin, IV, 1882, pp. 171, 195, pl. 1, figs. 6, 7; pl. 3, fig. 6.

Ssntrophia barabnensis Hall and Clarke, Pal. New York, YIII, Pt. II, 1893, p. 216.

Loc. Near Baraboo, Wisconsin.

Syntrophia calcifera (Billings).

Upper Cambrian.

Camarella caleifera Billings, Canadian Nat. Geol., VI, 1861, 1. 318, fig. 3;-Geol. Canata, 1863, 1. 231, tig. 247 ;-Pal. Fossils, I, 1865, 1. 220.-Meek, Sixth Ann. Rep. U. S. Geol. Survey Terr., 1873, r. 461. 


\section{Syntrophia calcifera (Billings)-Continued.}

Triplesia calcifera Walcott, Mon. U. S. Geol. Survey, VIII, 1884, p. 75, pl. 11, fig8. 7,8 .

Triplecia? calcifera Hall and Clarke, Pal. New York, VIII, Pt. I, 1892, p. 270.

Syntrophia (?) calcifera Hall and Clarke, Ibiclem, VIII, Pt. II, 1893, p. 218, pl. 62, fig. 24.

Loc. Point Levis and Phillipsburg, Canada; Cow Head, Nowfoundland; near Malade City, Utah; Enreka district, Nevada; Carter Connty, Missouri (Keyes).

Syntrophia lateralis (Whittield).

Calciferous (Ord.).

Triplesia lateralis Whitfield, Bull. American Mns. Nat. Hist., 1886, p. 303, pl. 24, figs. 9-11.

Syntrophia lateralis Hall and Clarke, Pal. New York, VIII, Pt. 1, 1892, 1. 270;Ibidem, VIII, Pt. II, 1893, p. 216, pl. 62, figs. 1-10.

Lor. Fort Cassin, Vermont.

Syntrophia primordialis (Whitfield).

Upper Cambrian.

'Triplesia primordialis Whitfiell, Anu. Rep. Geol. Survey Wisconsin, 1877, p. 51 ;-Geul. Wisconsin, IV, 1882, p. 172, pl. 10, figs. 1, 2.

'Triplecia primordialis Hall and Clarke, Pal. New York, VIII, Pt. 1, 18.2, 1. 271. Syntrophia primordialis Hall and Clarke, Pal. New York, VIII, Pt. II, 1893, p. 218. Loc. Adams Connty, Wisconsin.

SYRINGOTHYRIS A. Winchell.

Genotype Spinifer carteri Hall.

Syriugothyris A. Winchell, l'roe. Acal. Nat. Sei. Philadelpliia, 1863, p. 6.Meek, Ibidem, 1865, p. 275;-Pal. Ohio, II, 1875, 1. 288.-White, Wheeler's Expl. Survey west 100th Meril., IV, 1875, p. 90.-Herrick, Bull. Denison Univ., IV, 1888, p. 14.-Schuchert, Ninth Ann. Re 1 '. N. Y. State Geol., 1890, p. 28.Hall and Clarke, Pal. New York, VIII, Pt. II, 1893, P. 47;-Thirtcentl Ann. Rep. N. Y. State Geologist, 1895, p. 760.

Syringothyris alta Schuehert $=$ Cyrtia alta.

\section{Syringothyris angulata Simpson.}

Waverly (L. Carb.).

Syringothyris angulata Simpson, 'I'rans. Anerican Phil. Soc., li. ser., XYI, 1889,

p. 410, fig. 5.-Sehnchert, Ninth Aun. Rep. N. Y. State Geol., 1890, 1. 32.

Loc. Warren, Penusylvania.

Syringothyris carteri (Hall).

Waverly and Burlington (L. Carb.).

Spirifer carteri Hall, Tenth Rep. N. Y. State ('al. Nat. Hist., 1857, 1). 170.-Deek (partim), Pal. Ohio, II, 1875, p. 285 (not his figures=S. texta Hall).

Spirifer (Crytiaq) hannibalensis Swallow, Trans. St. Louis Acad. Sci., I, 1860, p. 647.

Syringothyris typa Winchell, Proc. Acad. Nat. Sci. Philadelphia, 1863, p. 7 ;Proe. Am. Phil. Soc., XII, 1870, p. 252.-Hall and Clarke, Pal. New York, VIII, Pt. II, 1893, pp. 8, 48, 50, pl. 26, figs. 6, 7, 10; pl. 27, figs. 1-3.

Spirifer euspidatus Meek, I'roe. Acad. Nat. Sci., Philadelphia, 1865, p. 275;-Aın. Jour. Sci., 2d ser., XLIII, 1867, p. 407.

Spirifer cuspidatus 9 Neek, U. S. Geol. Expl., 40th Parl., IV, 1877, p. 87.

Syringothyris cuspidatus Walcott (non Martin), Mon. U.S. Geol. Survey, VIIr, 1884, p. 219, pl. 3, tig. 11.-Herrick (partim), Bull. Denison Univ., 1II, 1888, p. 41, pl. 1, fig. 7; pl.2, fig. 17 (non pl. 5, figs. $4-7=$ S. herricki).

Syringothyris carteri Schuchert, Ninth Ann. Rep. N. Y. State Geol., 1890, p. 30.Keyes, Geol. Survey Missonri, V, 1895, p. 87, pl. 40, fig. 10.

Syringoth yris ty pa IAall and Clarke, Pal. New York, VIII, Pt. II, 1893, p. 48, fig. 40. Syringothyris hannibalensis Hall and Clarke, Pal. New York, VIII, Pt. II, 1895, pl. 25, figs. 33-35.

Loc. Licking Connty and Bedforl, Ohio; Burlington, Iowa; Marion and Pike, counties, Missouri; White Pine and Eureka districts, Neviula; near Cleudenin, Montana. 


\section{Syringothyris cuspidatus Walcott, and Herrick=S, carteri.}

Syringothyris extenuata (Hall).

Waverly (L. Carb.).

Spirifer exteunatus Ilall, Geol. Survey lowa, I, l’t. II, 1858, 1. 520, pl. 7, fig. 6.-

White, Wheeler's Expl. and Surv. Wrst 100th Meriıl., 1875, 1. 88, 11. 5, fig.9.

Syringothyris halli A. Winchell, Proc. Acad. Nat. Sci. Philatelyhia, 1863, p. 8.

Ny ingothyris extenuata Schnehert, Niuth Ann. Rep. N. Y. Stato Geol,, 1890, p. 33.-Keyes, Geol. Survey Missouri, V', 1895, p. 86.

Loc. Burlington, Iowa; Clarksville, Missouri; Battlecreek, Michigan; Monutain Spring, Nevada.

\section{Syringothyris gigas ('Troost).}

Subcarboniferous.

Cyrtia gigas Troost, Sixth Geol. Report 'Tenuessee, 1841, p. 12.

Syringothyris gigas Sehuchert, Ninth Amn. Rep. N. Y. State Geol., 1890, p. 33.

Loc. Harpeth River, Tennessee.

Syringothyris halli Winciell=S. carteri extenuata.

Syringothyris herricki Schuchert.

Waverly (L. Carb.).

Syringothyris enspidatus Ierrick (partiu), Bull. Denison Univ., III, 1888, pl. 5, figs. 4-7 (not pls. 1, 2).

Syringothyris herricki Schuehert, Ninth Ann. Rep. N. Y. State Geologist, 1890, p. 36.-Herriek, Geol. Ohio, VII, 1895, pl. 21, figs. 4-7.

Loc. Granville, Ohio.

Syringothyris missouri Hall and Clarke.

Chouteau (L. Carb.).

Syringothyris missonri Hall and Clarke, Pal. New York, VIII, P't. II, 1895, 1).

363 , pl. 39, figs. 29-31.

Loc. Chouteau Springs, Missouri.

Syringothyris (?) plena (Hall).

Burlington (L. Carb.).

Spirifer plena Hall, Geol. Survey Iowa, I, 1858, p. 603, pl. 13, fig. 4 .

Syringothyris? plena Schnehert, Ninth Aun. Re1. N. I. State Geologist, 1890, p. 37. Spirifer plenus Hall and Clarke, Pal. New York, VIII, Pt. II, 1893, pp. 31, 39, 48, pl. 37, figs. 32, 33 .

Syringothyris plena Keyes, Geol. Snrvey Missouri, V, 1895, p. 88, pl. 40, fig. 8 . Loc. Burlington, Iowa; Hannibal, Missouri; Quincy, Illinois.

\section{Syringothyris randalli. Simpsou.}

Waverly (L. Carb.). Syringothyris randalli Simpson, Trans. American Phil. Soc., n. ser., XVI, 1889, p. 441, fig. 6.-Sehnchert, Ninth Aun. Rep. N. Y. State Geologist, 1890, p. 36.-Hall and Clarke, Pal. Now York, VIII, Pt. II, 1893, p. 50, pl. 27, figs. 13-16. Loc. Near Warren and Union City, Pennsylvania.

Syringothyris texta (Hall).

Waverly to Keokuk (L. Carb.).

Spirifer cuspidatus Yandell and Shumard, Cont. Geol. Kentuck 5,1847, pp. 19, 21. Spirifer textns Hall, Tenth Rep. N. Y. State Cab. Nat. Hist., 185̄, p. 169.-

IVhite, Second Aun. Rep. Indiana Burean Statistics and Geol., 1880, p. 512, pl. 7, figs. 1, 2;-Tenth Rep. Indiana State Geol., 1881, p. 144, pl. 7, figs. 1, 2.

Spirifer subcuspidatus Hall, Geol. Survey Iowa, I, 1858, p. 616, pl. 20, fig. 5;-

Pal. New York, IV, 1867, p. 249.

Spirifor propinquns Hall, Geol. Survey Iowa, I, 1858, p. 647.-Meek and

IVorthen, Geol. Survey Illiuois, 1868, III, p. 530, pl. 19, tig. 8.

Spirifer carteri Meek (partim), Pal. Ohio, II, 1875, pl. 14, fig. 7.

Spirifer cuspidatiformis Miller, North Ameriean Geol. Pal., 1889, p. 372.

Syringothyris texta Schuchert, Ninth Anu. Rep. N. Y. State Geol., 1890, p. 34.-

Keyes, Geol. Survey Missouri, Y, 1895, T. 88.

Syringothyris subcuspidatus aud texta Hall and Clarke, Pal. New York, VIII, I’t. II, 1893, p. 50, pl. 26. figs. 8, $11(99,12)$; pl. 27, figs. 4-12, 18.

Loc. New Albany aud New Providence, Indiana; near Louisville, Kentucky; Sciotoville, Ohio; Keokuk, Iowa; Warsaw and Nauvoo, Illinois. 
Syringothyris typa Winchell=S, carteri.

TEREBRATELLA d'Orbigny.

Genotype Terebratula chilensis Brod.=Terebratula dorsata Gmelin.

Terebratella d'Orbigny, Pal. Franc. Ter. Cret., IY, 1847, p. 110.-Dall, American Jour. Conch., VI, 1870, p. 115.-Beecher, Trans. Connecticut Acad, IX, 1893, p. 377.

Terebratella californica Stanton.

Terebratella californica Stanton, Bull. U. S. Geol. Survey, 133, 1896, p. 33, pl. 1, figs. $12,13$.

Loc. Cottonwood Creek, Tehama County, California.

Terebratella (?) dubitanda (Cooper).

? Upper Cretaceous.

Megerlia dubitanda Cooper, Bull. California State Mining Bureau, 4, 1894, p. 50 , pI. 3 , figs. 48,49 .

Loc. Lajolla and Point Loma, California.

Terebratella (?) imbricata (Cooper).

? Upper Cretaceous.

Megerlia imbricata Cooper, Bull. California State Mining Bureau, 4, 1894, p. 51, pl. 3, figs. 50,51 .

Loc. Lajolla, California.

Terebratella obesa Gabb.

Cretaceous (Chico).

Terebratella obesa Gabb, Geol. Survey California, Pal., I, 1864, p. 205, pl. 26, fig. 191.

q'Terebratella obesa Whiteaves, Mesozoic Fossils, Geol. Survey Canada, I, 1884, p. 245.

Loc. Texas Flat, Placer County, Califoruia; Que:n Charlotte Island.

Terebratella plicata (Say).

Cretaceous.

Terebratula plieata Say, American Jour. Sei., II, 1820, p. 43 ;-Jour. Acad. Nat. Sci. Philadelphia, VI, 1829, p. 73, pl. 3, figs. $5,6$.

Terebratula sayi Morton, Syn. Cret. United States, 1834, p. 71, pl. 3, figs. 3, 4;American Jonr. Sci,, XLVIII, 1845, p. 283.

Terebratella plicata d'Orbigny, Prod. Pal., 1849, p. 259.-Gabb, Proc. American Phil. Soc., VIII, 1861, p. 193.-Credner, Zeitscr. d. Denschen Geol. Gessel., 1870, p. 224.-Whitfield, Mon. U. S. Geol. Survey, IX, 1885, p. 12, pl. 1, figs. $5-9$.

Loc. New Jersey.

Terebratella vanuxemi (Lyell and Forbes).

Cretaceous.

Terebratula vamuxemiana Lyell and Forbes, Proc. Geol. Soc. London, 1844, p. 308, with fignres.

Terebratula vanuxemi Lyell and Forbes, Quart. Jour. Geol. Soc. London, I, 1815 , p. 62 , with figures.

Terebratella vanuxemiana d'Orbigny, Prod. Pal., 1819, p. 259.-Gabb, Proc. Acad. Nat. Sci. Philadelphia, 1861, p. 19;-Proc. American Phil. Soc., V1II, 1861, p. 191. - Whitfield, Mon. U. S. Geol. Survey, IX, 1885, p. 14, pl. 1, figs. 1-4.

Terebratella vanuxemi Hollick, Trans. N. Y. Acal. Sci., XI, 1892, p. 98, pl. 1, fig. 6.

Loc. New Jersey; Tottenville, Staten Island.

Terebratella whitneyi Gabb=Rhynchonella whitneyi.

TEREBRATULA Llhwyd.

Genotype T. perovalis Sowerby.

Terebratula Llhwyd, Lithophylacii Britannici Ichuographia, 1696.-Hall, Pal. New York, IV, 1867, p. 386.-Dall, American Jour. Conch., VI, 1870, p. 101.Nettelroth, Kentucky Fossil Shells, Ment. lientucky Geol. Survey, 1889, p. 153.

Terebratula aenigma d'Orbigny=Rhynchonella ænigma. 
Terebratula arnigma Darwin= Rhynchonella anduin.

T'erehratula ar'uminatissima Castelnan=Spirifer acuminatus.

Terebratula andii d'Orbigny= Enteletes andii.

Terebratula antissiensis d'Orbigny= Rhynchonella antissiensis.

Terebratnla atlantica Morton=Terebratulina atlantica.

Tereuratula arenata Swallow (non Roemer)=Dielasma shumardamm.

Terebratula augusta Hall and Whitfield.

Triassic--Jurassic.

Terelıratula augusta Hall and Whitfield, King's U. S. Geol. Expl. 40th l'arl., IV, 1877, p. 285, pl. 7. figs. 7-10.-White, Buh. U. S. Geol. Survey Terr., IV, 1880, p. 108;-Twelfth Ann. Rep. U. S. Geol. Survey Terr., 1883, p. 109.

Loc. Shoshone Springs, Nevada; Triassic, southwestern Idalo.

Terebratula bicanaliculata Schlotheim.

Jurassic.

Terebratula bicanaliculata Schl., Mśm. Soc. Grol. France, 2d ser, IV, 1851, p. 31, pl. 8, figs. 17-19.

Terebratula cornuta Burmeister and Geibel, Ahh. Naturf. Gessel. Halle, V1, 1862, 1. 127.

Lor. Europe; Dona Ana, Chile.

Terebratula bisacula McChesney.

Kaskaskia (L. Carb.).

Terebratula bisacula McChesney, Descriptions New Fossils, 1861, p. 82.

Loc. Chester and Golconda, Illinois.

Terebratnla borealis Castelnan = Clitambonites borealis.

Terebratula bovidens Morton=Dielasma bovidens.

Terebratula brevilobata Swallow.

Warsaw (L. Carb.).

Terebratula brevilobata Swallow, Trans. St. Louis Acad. Sci., II, 1863, p. 84.

Loc. Ste. Genevieve Connty, Missonri.

Terebratula burlingtonensis White=Dielasma burlingtonensis.

Terebratula eamila Morton=T. harlani.

Terebratula canipes Ravenel.

Jackson (Eocene).

Terebratula canipes lavenel, Proc. Acad. Nat. Sci. Philadelphin, II, 1844, p.97.-

Conrad, Americau Jour. Conch., I, 1865, p. 15.

Loc. South Caroliua.

Terebratula carneoidea Guppy.

Eocene.

Terebratula carneoilea Gupps, Quart. Jour. Geol. Soc. Londou, XXII, 1866, p. 296 , pl. 19, fig. 2 .

Lor. San Fernando, Trinidad,

Obs. May be the same as living Terebratula cubensis Pourtales (Dall)=Lioth ris sphenoidea. (Philippi). The latter also oecurs fossil in the Pliocene of Calabria and Sicily (Davidsou).

Terebratula chiliensis d'Orbigny.

Qnarternary.

Terebratula chilensis d’Orbiguy, Voyage dans l'Amérique Mérid., Pal,, 1842, p. 163.

Loc. Coquimbo, Chile.

Terebratula choctawensis Shumard=Kingina wacoensis.

Terebratula concinna Bayle and Coquand=Rhynchonella suigma.

Terebratula cooperensis Miller=Seminula parva.

Terebratula copiapensis Miöricle.

Jurassic.

Terebratula copiapensis Möricke, Nenes Jahrb. f. Mineral, Beilageband, IX, 1894, p. 63 , pl. 2, figs. 5a-5c.

Loc. Quebrada de Maricunga, Chile. 
Terebratula demissirostris Conrad.

Eocene.

Terobratula demissirostra Courad, Kerr's Geol. North Carolina, App. A, 1875, p. 18, pl. 3 , tig. 1.

Loc. Wilmington, North Carolina.

Terebratula derbyana Rathbun.

Middle Devonian.

Tereloratula derbyana (Hartt MS.) Rathbun, Bull. Buffalo Soc. Nat. Hist., I, 1874, 1. 236, pl. 10, figs. 15, 17, 22, 24, 25.-Rathbun, Proc. Boston Soc. Nat. Hist., XX, 1879, p. 35.

Loc. Erere, Province of Para, Brazil.

Terebratula domeykana Bayle and Coquand.

Jurassic.

Terebratula domeykana Bayle and Coquand, Mém. Soc. Géol. France, $2 d$ ser., IV, 1851, p. 30, pl. 8, figs. 1-3.-Burmeister and Geibel, Abh. Naturf. Gessel. Halle, VI, 1862, p. 126.-Möricke, Neues Jahrb. f. Mineral., Beilageband, IX, 1894, p. 64.

Loc. Sierra de la Ternera, Dona Ana, and Juntas, Chile.

Terebratula dorenbergi Felix.

Upper .Jurassic. Terebratula dorenbergi Felix, Paleontographica, XXXVII, 1891, p. 176, pl. 27, figs. $8-8 \mathrm{~b}$.

Loc. Cerro de Titania, Oaxaco, Mexico.

Terebratula elia Hall.

Middle Devonian.

Terebratula elia Hall, Pal. New York, IV, 1867, p. 390, pl. 60, figs. 26-28.

Los. Waterloo, Iowa.

Terebratula elongata of American authors=Dielasma bovidens.

Terebratula emarginata Sowerby.

Jurassic.

Terebratula emarginata (Sowerby) Bayle and Coquand, Mém. Soc. Géol. France, $2 \mathrm{~d}$ ser., $1 \mathrm{~V}, 1851$, p. 32, pl. 8, figs. 7-9.

Loe Europe; Dona Ana, Chile.

Terebratula ficoides Bayle and Coquand.

Jurassic.

Terebratula ficoides Bayle and Coquand, Mém. Soe. Géol. France, 2d ser., IV, 1851 , p. 30 , pl. 8 , figs. 20-22.

Loc. Dona Ana, Chile.

Terebratula floridana Morton=Terebratulina floridana.

Terebratula formosa Hall=Dielasma formosum.

Terebratula fragilis Morton=Terebratula harlani.

Terebratula gaudryi d'Orbigny = Enteletes gaudryi.

Terebratula geniculosa McChesney=Dielasma bovidens.

Terebratula glossa Conrad=Terebratulina atlantica.

Terebratula gorbyi Miller=Dielasma gorbyi.

Terebratula gottschei Steinman.

Jurassic.

Terebratula gottschii Steinman, Nenes Jahrb. f. Min., Beilageband, 1881, p. 252, pl. 14, figs. 7,8 .

Loc. Caracoles, Bolivia.

Terebratula gracilis Swallow (nou Von Buch) $=$ T. swallovana.

Terebratula guadalup: Roemer=Terebratulina guadalupe.

Terebratula halliana Gabb = Terebratulina atlantica.

Terebratula harlani Morton.

Upper Cretaceous.

Terebratula harlani Morton, American Jour. Sei., XVIII, 1829, p. 250, pl. 3, fig. 16 ;-lbidem, XVII, 1829, p. 283 ;-Jour. Acad. Nat. Sci. Philatelphia, VI, 1829, p. 73, pl. 3, tigs. 1-4, 7, 8;-Syn. Cret. U. S., 1834, p. 70, pl. 3, fig. 1; pl.9, 


\section{Terebratula harlani Morton-Continued.}

figs. 2, 8, 9.-Gabb, Proc. Acad. Nat. Sci. Philadolphia, 1861, p. 18;-Proc. American Plil. Soc., VIII, 1861, p. 196.-C'resher, Zeit. 1l. Doutschen Geol. Gessel, 1870, 1. 2:21.-Whittield, Mon. I. S. Geol. Survey, 1X, 1885, p. 6, pl. 1, figs, 15-23.

Terebratula fragilis Morton (non Schloth.), Jonr. Acad. Nat. Sci. Philadelplia, VI, 1829, 1. 75, pl. 3, figs. 3, 4 ;-American Jour. Sei., XVIII, 1829, 1. 250, pl. 3, lig. 17 ;-lbidem, XVII, p. 283 ;-Syn. Cret. U. S., 1831, p. 70, pl. 3, fig. 2.

Terebratula perovalis Morton (nou Sowerby), Jour. Acad. Nat. Sci. Philadelphia, VI, 1829 , p. 77 , pl. 3 , figs. 7,8 .

Terebratula canilla Morton, Syn. Cret. U. S., 1834, p. 70, in text.

Terebratula harlani var. discoidea Morton, Syu. Cret. U. S., 1833.

Terebratula harlani var. rectilatera Morton, Ibidem.

Terebratula subfragilis d'Orbigny, I'rod. Pal., II, 1849, f'. 258.

Terebratula atlantica (non Morton) Gabb, l'roc. Acal. Nat. Sci. Philulelphia, $1861, p, 18$.

Loc. New Jersey; Delaware and South Carolina.

Terebratula harmonia Hall=Ennella harmonia.

Terebratula hastata of American authors=Dielasma bovidens.

Terebratula helena Whitfield.

Upper Cretaceous.

'Terebratula helena Whittield, Ludlow's Rep. Black Hills Dakota, 1875, p. 103, figs. $5-10$.

Loc. North of Belle Fourche, South Dakota.

Terebratula hochstetteri Toula=Dielasma hochstetteri.

Terebratula hohmanni Möricke.

Jurassic.

Terebratula hohmanni Möricke, Neues Jahr. f. Mineral., Beilageband, IX, 1894, p. 64, pl. 6 , figs. $4 \mathrm{a}, 4 \mathrm{~b}$.

Loc. Quebrada de Maricunga, Chile.

Terebratula humboldtensis Gabb.

Triassic.

Terebratula humboldtensis Gabb, Geol. Survey California, Pal., I, 186t, 1). 34, pl. 6, fig. 35.-Hall and Whitfield, King's U. S. Geol. Expl. 40th Parl., IV', 1877, p. 282, pl. 6, tigs. 22-24.-Whiteaves, Cont. Canadian Pal., I, 1889, p. 129.

Loc. Star Canyon, Humboldt County, and Dun Glen Pass, Pal-Ute liangre, Nevada; Nicola Lake, Canada.

Terebratula ignaciana d'Orbigny.

Jurassic.

Terebratula ignaciana d'Orbigny, Voyage dans l'Amérique Mérid., Pal., 1842, p. 63, pl. 22, figs. 14, 15.-Darwin, Geological Observations on South America, 1846, p. 216.

Loc. Cordillere du Chili, South America.

Terebratula inca Forbes $=\mathrm{T}$. perovalis.

Terebratula inconstans Herrick=Cryptonella inconstans.

Terebratula inornata McChesney.

"Keokuk to Coal Measures."

Terebratula inornata McChesney, Now Pal. Fossils, 1860, p. 48.

Loc. Sangamon County, Illinois.

Terebratula itaitubensis Derby $=$ Dielasma itaitubeuse.

Terebratula jucunda Hall.

Micdle Devonian.

Terebratula jucunda Hall, Pal. New York, IV, 1867, p. 390, pl. 60, figs. 29-31.-

Nettelroth, Kentucky Fossil Shells, Mem. Kentucky Geol. Survey, 1889, p. 15.

Loc. Waterloo, Iowa; Jefferson and Clark counties, Indiana.

Terebratula lachryma Morton=Terebratulina lachryma. 
Terebratula lacunosa Schl.

Jurassic.

Terebratula lacunosa (Schl.) Bayle and Coquand, Mém. Soc. Géol. France, ser. ii, IV, 1851, p. 29, pl. 3, figs. 10, 11.

Loc. Europe; Dona Ana, Chile.

Terebratula lapillus Morton.

Coal Measures.

Terebratula lapillus Morton, American Jour. Sci., XXIX, 1836, p. 153, pl. 26, fig. 36.

Loc. Junior Furnace, Scioto Comnty, Ohio.

Obs. Not determinable.

Terebratula lecta Guppy.

Eocene.

Terebratula lecta Gulpy, Qnart. Jour. Geol. Soc. London, XXII, 1866, p. 296, pl. 19 , fig. 3.

Loc. San Fernando, Trinidad.

Terebratula lens Hall=Cryptonella lens.

Terebratula leonensis Conrad=Kingena leonensis.

Terebratula liardensis Whiteaves.

Triassic.

Terebratula liardensis Whiteaves, Cont. Canadian Pal., I, 1889, p. 130, pl. 17, fig. 2. (Abstract of same pul. 1888.)

Loc. Liard River, Canada.

Terebratula lincklisni Hall=Eunella lincklani.

Terebratula marcyi Shumard=Eumetria marcyi.

Terebratula meridionalis Conrad.

Oolite or Cretaceous.

Terebratula meridionalis Conrad, U. S. Astronomical Exped. to the Southern

Hemisphere, 1855, p. 282, pl. 42, fig. 10.

Loc. Cordillera de Dona Ana, Chile.

Terebratula mesogona Castelnan.

Formation.?

Terebratula mesogona Castelnan (non Phillips), Essai Syst. Sil. l'Amérique Sep tentrionale, 1843 , p. 40, pl. 13 , fig. 3 .

Loc. Vicinity of Quebec, Canada.

Obs. Undeterminable.

Terebratula mexicana Hall.

? Upper Carboniferons.

Terebratula mexicana Hall, Emory's Rep. U. S. and Mexican Bound. Survey, I, 1857 , pl. 20, fig. 2.

Loc. Not given.

Obs. Undefined. Compare with Seminula argentea.

Terebratula millipunctata Hall=Dielasma bovidens.

Terebratula mormoni Marcou=Hustedia mormoni.

Terebratnla navicella Hall=Centronella navicella.

Terebratula nitens Conrad.

Miocene.

Terebratula nitens Dana, Wilkes's U. S. Exped., X, 1849, p. 726, pl. 19, fig. 1.

(Conrad's earlier description I have not found.)

Rhynchonella nitans Conrad, American Jour. Conch., 1865, p. 154.

Terebratula nuciformis Morton.

Coal Measures.

Terebratula nuciformis Morton, American Jour. Sci., XXIX, 1836, p. 150, pl. 2, fig. 5.

Loc. Putnam Hill east of Flint Ridge, Ohio.

Obs. Not defined so as to be recognizable.

Terebratula uncula Sowerby=Rhynchonella nucula.

Terebratula occidentalis Miller = Dielasma occidentale.

Terebratula ovoides Eaton=Rensselæria ovoides. 
Terebratula ontario Hall.

Hamilton (Dev.).

Terebratula ontario 1Iall, Pal. New York, IV, 1867, p. 418, pl. 60, figs. 45-48.

Lof. Canandarigua Lake, New Jork.

Terebratula ornithocephala Bayle and Coquand=T. subovoides. Terebratula parva Swallow= Seminula parva.

Terebratula patagonica Sowerby.

Tertiary.

'Terebratula patagonica Sowerby, Tarwin's Geol. Observations on South Am»rica, 1846, p. 25, pl. 2, fig. 25.

Loc. St. Josef and St. Jnlian, Patagonia.

Terebratula pennata Atwater $=$ Spirifer pennatus.

Terebratula (Zeilleria) perforata Piette.

Jurassic.

Terebratula (Zeilleria) perforata (Piette) Möricke. Nenes Jahrh. f. Mincral., Beilagebant, IX. 18:4, p. 65.

Loc. Europe; Sierre le la Ternera, Chile.

Terebratula perinflata Shunard.

Upper Carboniferous.

Terebratula perinflata Shnmard, Trans. St. Louis Acad. Sci., I, 1859, 1). 392.

Loc. Guadalupe Mountains, Texas.

Terebratula perovalis Eaton (non Sowerby)=Rensselæria ovoides. Terebratula perovalis Morton (non Sowerby)=T. harlani.

Terebratula perovalis Sowerby.

Jurassic.

Terebratula inca Forbes, Darwin's feol. Observations S. America, 1846, p. 268 , pl. 5, figs. 19-20.

Terebratula perovalis Bayle and Coquand, Mém. Soc. Géol. France, ser. ii, IV, 1851, p. 22, pl. 8, figs. 15, 16.-Crottsche, Palieontographica, Suppl., III, 1878, p. 33, pl. 4, fig. 9.-Steinman, Nenes Jahrh. f. Min., Beilageband, I, 1881, p. 252.-Möricke, Ibidem, Peilageband, IX, 1894, p. 65, pl. 3, figs. 6a-6r.

Loc. Enrope; Manflas, Tres Cruces, Iquique, and Espinazito, Chile; Caracoles, Bolivia.

Terebratula peruviana d'Orbigny=Seminnla argentea.

Terebratula planirostra Hall=Cryptonella planirostris.

Terebratula planosulcata Heek and Worthen=Cleiothyris roissyi.

Terebratula plicata Say=Terebratella plicata.

Terebratula poeyana Lea.

?.Jurassic.

Terebratula poeyana Lea, Trans. Ameriean Phil. Soc., n. ser.. VII. 1841, p. 260, pl. 10 , fig. 13.

Loc. Habana, Cuba.

Terebratula prisea $=$ Atrypa reticularis.

Terebratula punctata Sowerby.

Liassic.

Terebratula punetata Sowerby, Mineral Conch., I, 1812, p. 46, tab. 15, fig. 1.Davidson, British Oolitic and Liassic Brach., Pal. Soc., 1852, p. 45.-Burmeister and Geihel, Ahh. Naturf. Gessel. Halle, VI, 1862, p. 127.

Terehratula clr. punetata Behrendsen, Zeit. der. Dentschen Geol. Gessel., XLIII, 1891, p. 395.

Terebratula (Wallheimia) punctata (Sowerby) Möricke, Nenes Jahrh. f. Mineral., Beilageband, IX, 1894, p. 66.

Loc. Europe; Portezuelo Ancho, Argentine Republic; Manflas, Juntas, Chile.

Terebratula raimondiana Gabb.

?Cretaceons.

Terebratnla raimondiana Gabb, Jonr. Acad. Nat. Sci. Philadelphia, $2 d$ ser.,

vill, 1881, p. 298, pl. 42, fig. 9.

Loc. Near Ollon, Pern. 
Terebratula reticularis $=$ Atrypa reticularis.

Terebratula rectirostra $\mathrm{Hail}=$ Cryptonella rectirostris.

Terebratula repellini d'Orbigny.

Jurassic.

Terebratula repellini Anguilera, Datos para la Geologia de Mexico, 1893, p. 18.

Loc. Enrope; Mexico.

Terebratula robusta Whiteaves.

Jurassic (?Cretaceous).

Terebratula robusta TVhiteaves, Cont. Canadian Pal., I, 1889, p. 163, pl. 22, figs. $1,2$.

Loc. Rocky Mountains, near Devils Lake, Canada.

Obs. The horizon of this locality is probably Jurassic (Stanton).

Terebratula rockymontaua Marcou=Pugnax rockymontana.

Terebratula romingeri Hall=Crancena romingeri.

Terebratula rowleyi Worthen=I)ielasma rowleyi.

Terebratula royssii d'Orbigny (non L'Éveillé)=Seminula argentea.

Terebratula royssii Marcou=Cleiothyris roissyi.

'Terebratula sacculus Dawson, and Davidson= Dielasma sacculus.

Terebratula semisimplex White.

Triassic.

Terehratula semisimplex White, Bull. U. S. Geol. Surrey Terr., I, 1879, p. 108.

Loe. Sontheastorn Idaho.

Terebratula serpentina Owen=Eumetria marcyi.

Terebratula shumardana Miller=Dielasma shumarlanum.

Terebratula simulator Hall=Eunella simulator.

Tercbratula spiriferoides Eaton $=$ Athyris spiriferoides.

Terebratula subexcavata Conrad.

Oolite or Cretaceous.

Tereliratula subexcavata Conrad, U. S. Astronomical Exped. to the Southern Hemisphere, 1855, p. 282, pl. 41, fig. 4.

Loc. Cordillera de Dona Ana, Chile.

Terebratula snbfragilis d'Orbigny $=\mathrm{T}$. harlani.

Terebratula subovoides Roemer.

Lias (Jurassic).

Terebratula ornithorephala (non Sowerby) Bayle and Coquand, Mém. Soc. Géol. Frauce, $21 \mathrm{l}$ ser, IV, 1851, p. 18, pl. 8, figs. 12-14.

Terebratul:t subovoides Behrendsen, Zeit. der Dentschen Geol. Gessel., XLIII, 1891, ア. 395.-MÏricke, Nenes Jahrb., f. Nineral., Beilagebanıl, IX, 1894, p. 66.

Loc. Enrope; Valle lenas amorillas, Rio Salado, Argentine Republic; Mine Aurolanas, Manflas, and Tres Cruces. Chile.

Terebratula subnumismalis Davidson?.

Lias (Jurassic).

Terebratnla subnumismalis Davidson, British Oolitic and Liassic Brach., Pal. Soc., 1852, 1. 36, pl. 51, fig. 10.

Terehratula efr. subnumismalis Hehrendsen, Zeit. der. Dentschen Geol. Gessel., XLIII, 1891, p. 396.

Loc. Europe; Rio Salado, Argentine Republic.

Terebratula subretziforma McChesney.

Kaskaskia (L. Carb.).

Tcrebratula subretziaforma MeChesney, Descrip. New Fossils, 1861, p. 82.

Loc. Fountain Bluft, Illinois.

Terebratula subtetredra Conrad=Rhynchonella anduin.

Terebratula subtilita Hall=Seminula argentea.

Terebratula sullivanti Hall=Eunella sullivanti.

Bull. 87_-29 
Terebratula swallovana Miller.

Kaskaskia (L. Carb.).

Terebratula gracilis swallow (nou von Buch), Trans. St. Louis Acad. Sci., II, $1863, \mathrm{p} .83$.

Terebratulia swallovana Miller, American Pal. Foss., $2 d$ ed., 1883, p. 299.

Loc. St. Marys, Missouri; Chester, Mllinois.

Terebratula fayloriana Lea=Rhynchonella tayloriaua.

Terebratula tetriedra Sowerby = Rhynchonella tetrierlra.

Terebratula titicacensis $\mathrm{Gabb}=$ Seminula titicaeaensis.

Terebratula traversensis A. Winchell.

Hamilton (Dev.).

Terebratula traversensis A. Winchell, Rep. Lower Peninsula Michigan, 1866, p. 95.

Loc. Graul Traverse region, Michigan.

Terebratula trinitatensis Guppy.

Eocene.

Terebratula trinitatensis Guppy, Quart. Jour. Geol. Soc. London, XXI1, 1866, p. 296, pl. 19, fig. 1.

Loc. Sanfernando, Trinidar.

Terebratula trinucleus Hall=Seminula trinuclens.

Terebratula turgida Hall=Dielasma turgiduin.

Terebratula turpis Verneuil=Clitambonites borealis.

Terebratula utah Marcou (non Hall and Whitfield)=Pugnax utah.

Terebratula (?) utah Hall and Whitfield. Lower Carboniferous.

Terebratula utah Hall and Whitfield, King's Geol. Expl. 40th Parl., IV, 1877, p. 258 , pl. 4 , fig. 18.

Loc. Cottouwood Divide, Wasatch Range, Utah.

Obs. Not well establisherl. Based upon a single dorsal valve. May be a Dielasma.

Terebratula valenciennii Castelnan = Meristella nasuta.

Terebratula wacoensis Roemer $=$ Kingena wacoensis.

Terebratula wilmingtonensis Lyell and Sowerby=Rhyuchonella wilmingtonensis.

Terebratula (?) cfr. zieteni Loriol.

Jurassic.

Terebratula cfr. zieteni Aguilera, Bol. Com. Geologica de Mexico, I, 1895, p. 1, pl. 2 , tigs. 6,7 .

Loe. Rancho Alamitos, Sierra de Catorce, Mexico.

TEREBRATULINA r'Orb. Genotype Anomia caputserpentis Linné.

Terebratulina d'Orbiguy, Ann. Des. Sci. Nat., VIII, 1848, p. 67.-Hall and Clarke, Thirteenth Ann. Rep. N. Y. State Geol., 1895, p. 872.

Terebratulina atlantica (Morton).

Upper Cretaceous.

Terebratula atlantica Morton, Jour. Acad. Nat. Sci. Philadelphia, VIII, 1842, p. 214.

Terebratula halliana Gabb, Proc. Acad. Nat. Sci. Philadelphia, V, 1861, p. 19.

Terebratulina halliana Gabb, Proc. American Phil. Soc., VIII, 1861, p. 200.

Terebratula glossa Conral, American Jour. Conch., V, 1869, p. 42, pl. 1, fig. 22.

Terel)ratulina atlantica Whitfield, Mon. U. S. Geol. Survey, IX, 18\$5, p. 9, pl. 1, figs.

10-13.-Hollick. Trans. N. Y. Acad. Sci., XI, 1892, p. 98, pl. 1, fig. 8.

Loc. New Jersey; Tottenville, Staten Island.

Terebratulina filosa Conrad.

?Cretaceous.

Terebratulina filosa Conrad, American Jour. Conch., II, 1866, pp. 77, 105, pl. 9, figs. 4,5 .

Loc. Unioutown, Alabama. 
Terebratulina floridana (Morton).

Cretaceous.

Terebratula floridana Morton, Syn. Cret. U. S., 1834, p. 72, pl. 16, fig. 17.

Terebratulina floridaua d'Orbigny, Prod. Pal., II, 1849, p. 258.-Whitfield, Mon.

U. S. Geol. Survey, IX, 1885, p. 11.

Loc. Prairie Bluff, Alabama.

Terebratulina gracilis (Sehlotheim).

Eocene.

Terebratula gracilis Schlotheim, Die Petrefactenkunde, 1820, p. 270.

Terebratnlina gracilis Conrad, American Jour. Conch., I, 1865, p. 15.

Loc. Europe; Alabama.

Terebratulina guadalupæ (Roemer).

Upper Cretaceous.

Terebratula gaudalupe Roemer, Texas, 1849, p. 408;-Kreidebildung von Texas, 1852, p. 82, pl. 6, fig. 3.-Gabb, Proc. Acad. Nat. Sci. Philadelphia, 1861, p. 19.

Loc. New Braunfels, Austin, and 200 miles north in Dallas County, Texas (Hill).

Terebratulina halliana Gabb='T. atlantica.

Terebratulina lachryma (Morton).

(Cretaceous?) Eocene?

Terebratula lachryma Morton, Syn. Cret. U. S., 1834, p. 72, pl. 10, fig. 11; pl. 16, fig. 6.

Terebratulina lachryma d'Orbign5, Prod. Pal., 1849, p. 396.-Gabb, Proc. Acad. Nat. Sei. Philadelphia, 1861, p. 19;-Proc. American Phil. Soc., VIII, 1861 p. 200.-Conrad, American Jour. Conch., I, 1865, p. 15.-Whitfield, Mon. U. S. Geol. Survey, IX, 1885, p. 12, pl. 1, f.g. 14.

Loc. New Jersey; Claiborne, Alabama.

TORYNIFER Hall and Clarke. Genotype T. criticus Hall and Clarke.

Torynifer Hall and Clarke, Pal. New York, VIII, Pt. II, 1895, explanation to pl. 81.

Torynifer criticus Hall and Clarke.

St. Louis (L. Carb.).

Torynifer criticus Hall and Clarke, Pal. New York, VIII, Pt. II, 1895, pl. 84, figs. 34,35 .

TREMATIS Sharpe.

Genotype Orbicula terminalis Sharpe (uon Emmons)=T. millipunetata Hall.

Trematis Sharpe, Quart. Jour. Geol. Soc. London, IV, 1847, p. 66.-Dall, Bull. Mus. Comp. Zool., III, 1871, p. 37;-Bull. U. S. Nat. Mus., 8, 1877, p. 73.Hall and Clarke, Pal. New York, VIII, Pt. I, 1892, pp. 138, 168.-Winchell and Schuchert, Minnesota Geol. Survey, III, 1893, p. 367.-Hall and Clarke, Eleventh Ann. Rep. N. Y. State Geologist, 1894, p. 258.

Trematis crassipuncta Ulrieh.

Lorraine (Ord.).

Trematis crassipuncta Ulrich, American Geologist, IV, 1889, p. 22; III, p. 378, fig. 7 .

Loc. Cincinnati, Ohio.

Trematis (?) dyeri Miller.

Lorraine (Ord.).

Trematis dyeri Miller, Cincinnati Quart. Jour. Sci., I, 1874, p. 347, fig. 39.

Trematis (?) dyeri Hall and Clarke, Pal. New York, VIII, Pt. I, 1892, p. 142.

Loc. Cincinnati, Ohio.

Trematis filosa Billings=Schizocrania filosa.

Trematis fragilis Ulrich.

Trenton (Ord.).

Trematis fragilis Ulrich, American Geologist, IV, 1889, p. 21 ; III, p. 378, fig. 6.-

Hall and Clarke, Pal. New York, VIII, Pt. I, 1892, p. 142, pl. 4G, fig. 14.

Loc. Near Covington, Kentucky. 
Trematis huronensis Billings.

Bhlack River (Ord.).

'Trematis huronensis Billings, Pal. Fussils, I, 1862, p. 53, fig. 59 on p. 52;-Geol. Canadia, 1863, p. 159, lig. 130.

Productella minneapol is Sarleson, Kull. Minnesota Acad. Nat. Sci., III, 1892, p. 332 , pl. 4, figs. 11, 12.

Trematis huronensis? Winchell and Schnchert, Minnesota Geol. Survey, III, -393, p. 368, fig. 29.

Loc. Pallidean Islands, Lake Huron; Minneapolis, Mimesotal.

Trematis millepunctata Hall.

Utica and Lorraine (Ord.).

Trematis millepunctata Hall, Description n. sp. ('rinoidea and other Fossils, 1866, p. 14;-Twenty-fourth Rep. X. Y. State Cal. Nat. Hist., 1872, p. 221, pl. 7, figs. 22-25.-Hall and Whitfield, Pal. Ohio, II, 1875, P. 70, pl. 1, figs. 4-7.-Miller, Cincinnati Quart. Jour. Sci., 1I, 1875, p. 16.-Hall and Clarke, Pal. New York, V1II, Pt. I, 1892, p. 139, pl. 4G, figs. 4-10.

Loc. Cincinnati, Ohio.

Obs. See T. quinenneialis and T. reticularis.

Trematis montrealensis Billings.

Trenton (Ord.).

Trematis montrealensis Billings, Pal. Fossils, I, 1862, p. 52, tig. 57;-Geol. Canada, 1863, p. 159, fig. 128.

Loc. Montreal, Canada.

Trematis oblata Ulrich.

Utica and Lorraine (Ord.).

Trematis punctostriata Hall and Whitfield (non Hall, 1873), Pal. Ohio, II, 1875, p. 70 , pl. 1 , figs. 8,9 .

Trematis oblata Ulrieh, American Geologist, [V, 1889, p. 23; III, p. 378, fig. 9.Hall and Clarke, Pal. Now York, VIII, Pt. I, 1892, P. 142, pl. tG, fig. 20.

Loc. Cincinnati, Ohio.

Trematis ottawaensis Billings.

Trenton and Lorraine (Ord.).

Trematis ottawaensis Billings, Pal. Fossils, I, 1862, p. 53, fig. 58 on p. 52;-Geol. Canarla, 1863, p. 159, fig. 129;-Cat. Sil. Fossils Anticosti, 1866, p. 11.-Hall and Clarke, Pal. Now York, VIII, Pt. I, 1892, p. 139, pl. 4G, figs. 15-17.-Winchell and Schuchert, Minnesota Geol. Survey, III, 1893, p. 369, fig. 30.

Loc. Ottawa, Canada; Anticosti; 'Trenton Falls, New York; Frankfort, Kentucks; St. Paul, Minnesota.

Trematis? panuulus White=Iphidea pannulus.

Trematis punctostriata Hall and Whitfield $=\mathrm{T}$. oblata.

Trematis punctistriata Hall.

Lorraine (Ord.).

Trematis punctostriata Hall, Twenty-third Rep. N. Y. State Cab. Nat. Hist., 1873, p. 243, pl. 13, figs. 17, 18.-Hall and Clarke, Pal. New York, VIII, Pt. I, 1892, p. 142, pl. $4 \mathrm{G}$, figs. 11-13 (?3).

Loc. Clifton, Tennessee.

Trematis (?) pustulosa Hall.

Lorraine (Ord.).

Trematis: pustulosa Hall, Descrip. n. sp. Crinoidea and other Fossils, 1866, p. 15 ;-Twenty-fourth Rep. N. Y. State Cab. Nat. Hist., 1872, p. 222.

Loc. Near Horicon, Wisconsin.

Trematis quincuncialis Miller and Dyer. Lorraine (Ord.). Trematis quincuncialis Miller and Dyer, Cont. to Pal., II, 1878, p. 8, pl. 3, fig.9. Loc. Lebanon, Ohio.

Obs. Seems to be only a variety of 'T. millepunctata occurring at a higher horizon. 
Trematis reticularis (Miller). Lorraine (Ord.).

Crania reticularis Miller, Cincinnati Quart. Jour. Sci., II, 1875, p. 280, fig. 1.

Loc. Brookville, Indiana.

Obs. The type specimens have been examined and appear to be young T. millepunctata.

Trematis rudis Hall=Schizocrania rudis.

Trematis terminalis Emmons.

Trenton (Ord.).

Orbicula terminalis Emmons, Geol. New York; Rep. Second Dist., 1842, p. 395, fig. 4. - Hall, Pal. New York, I, 1847, p. 100, pl. 30, fig. 11.

Trematis terminalis Emmons, American Geologist, Pt. II, 1855, p. 201, fig. 63.Billings, Geol. Canala, 1863, p. 159, fig. 127.-Hall and Clarke, Pal. Now York, VIII, Pt. I, 1892, 1. 139, pl. 4G, figs. 1, 2.

? Trematis terminalis Miller, Cincinnati Quart. Jonr. Sci., II, 1875, p. 14.

Loc. Middleville, Trenton Falls, Watertown, and elsewhere in New York.

Trematis truncata Hall=Schizobolus concentricus.

Trematis umbonata Ulrich.

Lorraine (Ord.).

Trematis nmbonata Ulrich, American Geologist, IV, 1889, 1. 23 ; III, 1889, fig. 8 on p. 378.-Hall and Clarke, Pal. New York, VIII, Pt. I, 1892, p. 139, pl.4G, figs. $18,19$.

Loc. Covington, Kentucky; Cincinnati, Ohio.

TREMATOBOLUS Matthew.

Genotype T. insignis Matthew.

Trematobolus Matthew, Canadian Ree. Science, 1893, p. 276.- Hall and Clarke, Eleventh Ann. Rep. N. Y. State Geol., 1894, p. 252.

Trematobolus insignis Matthew.

Middle Cambrian.

Trematobolus insign is Matthew, Canadian Record Seienee, 1893, 1. 276, fig. 1; Trans. Royal Soe. Canada, Vol. XI, 1894, p. 88, pI. 16, fig. 4a-d ;-Trans. N. Y. Acad. Sei., XIV, 1895, p. 122, pl.4, flg. 2.

Loc. St. Martins, New Brunswick.

TREMATOSPIRA Hall.

Genotype Spirifer? perforatus Hall.

Trematospira Hall, Ial. New York, III, 1859, p. 207 ;-Twelfth Rep. N. Y. State Cab. Nat. Hist., 1859, p. 27 ;-Pal. New York, IV, 1867, 1. 271.-Nettelroth, Kentucky Fossil Shells, Mem. Kentucky Geol. Survey, 1889, p. 135.-Mail and Clarke, Pal. New York, VIII, I't. II, 1893, p. 124;-Thirteenth Ann. Rep. N. Y. State Geologist, 1895, p. 798.

qTrematospira Hall, Sixteenth Rep. N. Y. State Cab. Nat. Hist., 1863, p. 54.

Trematospira acadie Hall and Clarke $=$ Rhynchospira acadia.

Trematospira camura Hall. Niagara (Sil.).

Atrypa camura Hall, Pal. New York, II, 1852, p. 273, pl. 56, fig. 3.

Trematospira cammra Hall, Tal. New York, IlI, 1859, p. 212, pl. 28 А, fig. 1.-Hall and Clarke, Pal. New York, VIII, Pt. 1I, 1893, p. 126, pl. 49, figs. 2-4.

Rhynehonella camura Billings, Geol. Canada, 1863, p. 315, fig. 322.

Loc. Lockport, New York.

Trematospira costata Hall.

Lower Hellerberg (Dev.).

Trematospira costata Hall, Pal. New York, III, 1859, p. 210, pl.28A, 1859, fig. 4 ;Ibidem, IV, 1867, p. 276, figs. 5, 6.-Hall and Clarke, Pal. New York, VIII, Pt. II, 1895, pl. 49, figs. 19, 20.

Loc. Albany aud Sehoharie comnties, New York.

Trematospira deweyi Hall= Parazyga deweyi.

Trematospira disparilis Hall=Atrypina disparilis. 
Trematospira dubia (Billings).

Lower Ilelderberg (Dev.).

lietzi: dubia Billiugs, Proc. Portland Soc. Nat. Hist., I, 1863, p. 113, pl. 3, fig. 10.

Trematospira dubia IIall and Clarke, Pal. New York, VIII, Pt. II, 1893, p. 126, 11. 49 , ligrs. $15,16$.

Loc. Squaro Lake, Maine.

Trematospira equistriata Ilall and Clarke. Lower Helderberg (Dev.).

Trenatospira oquistriata Hall and Clarke, I’al. Now York, VIII, Pt. I:, 1895, pl. 49 , fig. 17.

Loc. Cumberlaud, Marşland.

Trematospira gibbosa Hall.

Hamilton (Dev.).

Trematospira gibbosa Hall, Thirteenth Rep. N. Y. State Cab. Nat. Hist., 1860, p. 82 ;-Pal. New York, IV, 1867, p. 272, pl. 45, figs. 7-15.-Hall and Clarke, Pal. New York, VIII, Pt. II, 1895, pl. 49, figs. 23-27.

Loc. Bellona, York, and Darien, New York.

Trematospira helena Nettelroth=Rliynehospira helena.

Trematospira hippolyte (Billings). Lower Helderberg (Dev.).

Retzia hippolyte Billings, Proc. Portland Soc. Nat. Hist., 1863, p. 112, pl. 13, fig. 9.

Trematospira hippolyte Hall and Clarke, Pal. New York, VIII, Pt. II, 1893, p. 126 , pl. 49, figs. 7,8 .

Loc. Square Lake, Maine.

Trematospira hirsuta Hall=Parazyga hirsuta.

Trematospira imbricata Hall=Atrypina imbricata.

Trematospira (?) liniuscula A. Winchell.

Hamilton (Dev.).

Trematospira ? liniuscula A. Winchell, Rep. Lower Peninsula Michigan, 1866, p. 94 .

Loc. Grand Traverse region, Michigan.

Trematospira matthewsoni MeChesney=Atrypa marginalis.

Trematospira maria (Billings).

Lower Helderberg (Dev.).

Retzia maria Billings, Proc. Portland soc. Nat. Hist., 1863, p. 112, pl. 3, fig. 8.

Trematospira maria Hall and Clarke, Pal. Now York, VIII, Pt. II, 1893, p. 126, pl. 49 , fig. 21.

Loc. Square Lake, Maine.

Trematospira multistriata Hall.

Lower Helderberg (Dev.).

Spirifer multistriata Hall, Tenth Rep. N. Y. State Cab. Nat. Hist., 1857, 1. 59, figs. $1-6$.

Trematospira multistriata Hall, Pal. New York, III, 1859, p. 209, pl. 24, fig. 3; pl. 28A, fig. 5;-Ibidem, IV, 1867, p. 276, figs. 1-3.-Hall and Clarke, Pal.

New York, VIII, Pt. II, 1893, p. 126, tig. 110, pl. 49, figs. 9-14.

Retzia multistriata Billings, Geol. Canada, 1863, p. 958, fig. 458.

Loc. Schoharic, New lork.

Trematospira nobilis Hall=Cyclorhina nobilis.

Trematospira perforata Hall.

Lower Helderberg (Dev.).

Spirifer? perforata IIall, Tenth Rep. N. Y. State Cab. Nat. Hist., 1857, p. 60.

Trematospira perforata Hall, Pal. New York, III, 1859, p. 208, pl. 28A, fig. 3;Ibidem, IV, 1867, p. 276.-Hall and Clarke, Pal. New York, VIII, Pt. II, 1895, pl. 49 , figs. $5,6$.

Loc. Albany and Schoharie counties and Hudson, New York.

Trematospira simplex Hall.

Lower Helderberg (Dev.).

Trematospira simplex Hall, Pal. New York, III, 1859, p. 211, pl. 28A, fig. 2.-Hall aud Clarke, Pal. New York, VIII, Pt. II, 1895, pl. 49, figs. 17, 18.

Loc. Decatur Connty, Tennessee. 
Trematospira quadriplicata Miller=Rhynchotrema inæquivalve.

Trematospira tennesseensis Hall and Clarke. Lower Helderberg (Dev.). 'Trematospira tennesseensis Hall and Clarke, Pal. New York, VIII, Pt. II, 1895, pl. 83 , figs. 21-23.

Loc. Perry County, Tennessee.

TRIGERIA (Bayle partim) Hall and Clarke.

Genotype Terebratula gueraugeri de Vernenil.

Trigeria Bayle (partim), Explic. Carte Géol de France, Atlas, 1875, pl. 13.-Hall and Clarke, Pal. New York, VIII, Pt. II, 1893, pp. 272, 273, fig. 189;-Thirteenth Rep. N. Y. State Geologist, 1895, p. 856.

Trigeria gaudryi (Chlert).

Oriskany (Dev.).

Centronella gaudryi Ehlert, Bull. Soc. Geol. France, 34 ser., V, 1877, p. 593, pl. 10, fig. 8;-Bull. de la Soc. d'Etudes Scientif. d'Angers, separate 1883, p. 2, pl. -. figs. 10-17.

Trigeria gandryi Hall and Clarke, Pal. New York, VIII, Pt. II, 1893, p. 273, fig. 189, pl. 76, figs. 6,7 .

Loc. Frauce; Cumberland, Maryland.

Trigeria (?) lepida Hall.

Hauniltou (Dev.).

Rhynchospira lepida Hall, Thirteenth Rep. N. Y. State Cab. Nat. Hist., 1860, p. 83 ;-Pal. New York, IV, 1867, p. 276, pl. 45, figs. 1-6.

Retzia lepida Miller, N. American Geol. Pal., 1889, p. 366.

Trigeria ? lepida Hall and Clarke, Pal. New York, VIIl, Pt. 11, 1893, p. 274, pl. 50, figs. $36-40$.

Loc. Canandaigna Lake and Bellona, New York.

Trigeria (?) margarida (Derby).

Middle Devonian.

Centronella (?) margarida Derby, Archivos do Museu Nacional Rio de Janeiro, IX, 1890, p. 84 , with figures in text.

Trigeria? margarida Hall and Clarke, PaI. New York, VIII, Pt. II, 1893, p. 274. Loc. Head of Paraguay; Matto Grosso, Brazil.

Trigeria (?) portlandica (Billings).

Lower Helderberg (Dev.).

Rensseleria portlandica Billings, Proc. Portland Soc. Nat. Hist., I, 1863, p. 115, pl. 3, fig. 12 .

Trigeria? portlandica Hall and Clarke, Pal. New York, VIII, Pt. II, 1893, 1. 273. pl. 76 , figs. 4,5 .

Loc. Square Lake, Maine.

Trigeria (?) wardiana (Rathbui).

Middle Devonian.

Retzia wardiana (Hartt) Rathbun, Bull. Buffalo Soc. Nat. Sci., I, 1874, p. 245, pl. 10, figs. 2-5. 8, 9, 11, 12, 14, 16.-Rathbun, Proc. Boston Soc. Nat. Hist., XX, 1879, p. 31 .

Retzia? wardiana Derby, Arehivos do Museu Nacional do Rio de Janerio, IX, 1890, p. 78.

Trigeria? wartiana Hall and Clarke, Pal. New York, VIII, Pt. II, 1893, p. 274. Loc. Province of Para, Brazil.

TRIMERELLA Billings.

Genotype T. grandis Billings.

Trimerella Billings, Pal. Fossils, I, 1862, p. 166.-Dall, American Jour. Conch., VI, 1870, p. 160 ;-Ibidem, VII, 1871, p. 79.-Davidson and King, Q11art. Jour. Geol. Soc. London, $\mathrm{XXX}$, 1874, 1) 143.-Dall, Bull. U. S. National Mus., 8, 1877, p. 74.-Hall and Clarke, Pal. New York, VIII, Pt. I, 1892, pp. 33, 46, $163 ;-$ Eleventh Ann. Rep. N. Y. State Geologist, 1894, p. 236.

Gotlandia Dall, American Jour. Coneh., VI, 1870, p. 160. 
Trimerella acuminata Billings.

Guelph (Sil.).

Trinelella acmminata Billings, Pal. Fossils, J, 1862, I'p. 167, 168, figg. 152;Amrrican Jonr. Sci., 3ıl ser., I, 1871, p. 471;-Anı. Mağ. Nat. II ist., 4th ser., VIII, 1871, 1. 140.-Dall, American Jour. Conch., VII, 1871, p. 82.-Davidson and King, Quirt. Jour. Geol. Soc. Lomion, XXX, 1874, 1. 146, pl. 15, figs. 4-7; [1]. 16, figs. 1, 2.-Nicholson, Pal. Prov. Ontario, 1875, 1) 68, 1ig. d.-Hall and Clarko, Pal. New York, VIII, Pt. I, 1892, 11. 4I, fig.6.

Loc. Galt, New Hopo, ancl Hespelar, Ontario; near Hillsboro, Ohio; Port Byron, Illinois; Gotland and Farö.

Trimerella billingsi Dall.

Guelph (Sil.).

Trimerella billingsi Dall, American .Jour. Conch., VII, 1871, p. 82, pl. 11, figs. 1-3.-Davidson and King, Quart. Jour. GeoL. Soc. London, XXX, 1874, p. 150, pl. 16 , figs. \&, 9 .

Loc. New IIope, Ontario, Canada.

Trimerella dalli Davidson and King.

Guelph (Sil.).

Trimerelli dalli Davidson and Jing, Quart. Jonr. Geol. Soc. London, XXX, 1874, p. 154, pl. 15, figs. 1-3.-Hall and Clarke, Pal. New York, VIII, Pt. I, 1892, ill. $4 \mathrm{~A}$, fig. 10.

Loc. Hespelar, Elora, and New Hope, Ontario, Camada.

Trimerella galtensis Hall=Rhinobolus galtensis.

Trimerella grandis Billings.

Guelph (Sil.).

Trimerella grandis Billings, Pal. Fossils, I, 1862, T'p. 166, 167, fig. 151.-Dall, American Jour. Conch., II, 1870, p. 160;-Ibiclen, VII, 1871, p. 82.-Hall, 'Twenty-third Rep. N. Y. State Cab. Nat. Ilist., 1873, pl. 13, figs. 11-16.Davidson and King, Qnart. Jonr. Geol. Soc. London, XXX, 1874, pl. 13, figrs. 2, 3.-Nicholson, Pal. Prov. Ontario, 1875, p. 67, fig. 37.-Hall and clarke, Pal. New York, VIII, Pt. I, 1892, pl. 4A, figs. 1, 2; pl. 4B, figs. 2-5.

Loc. Galt, New Hope, and Elora, Hespelar, Ontario, Canada; near Hillsboro, Ohio; Wisconsin.

Trimerella minor Dall=Rhinobolus galtensis .

Trimerella ohioensis Meek.

Niagara (Sil.).

Trimerolla vhioensis Meek, American Jour. Sci., 3 d ser., I, 1871, p. 305.-Dall, Americau Jour. Conch., VII, 1871, p. 83.-Davidsou and King, Geol. Mag., IX, 1872.-Meek, Pal. Ohio, I, 1873, p. 183, pl. 16, fig. 1.-Daridson and King, Quart. Jour. Geol. Soc. London, XXX, 1874, p. 153, pl. 16, figs. 3-7; pl. 19, figs. 1-2.-Hall and Clarke, Pal. New York, VIII, Pt. I, 1892, pl. 4A, figs. 3-9.

Loc. Genoa, Ottawa County, Ohio; Port Byron, Illinois; Ontario, Canada.

TRIPLECIA Hall.

Genotype Atrypa extans Emmons.

Triplesia Hall, Pal. New York, III, 1859, 1. 522;-Twelfth Rep. N. Y. Stato Cah, Nat. Hist., 1859, p. 44.-Waagen, Palieontologica Indica, Ser. XIII, I, 1884, 1. 576 .

'Triplecia Hall and Clarke, Pal. New York, YIH, Pt. 1, 1892, p. 269.-Winchell and Schnchert, Mimmesota Geol. Survey, III, 1893, p. 408.-Hall and Clarke, Eleventh Ann. Rep. N. Y. State Geologist, 1894, p. 289.

Dicraniseus Meek, American Jour. Sci., 3d ser., IV, 1872, 1. 279.-Pal. Ohio, I, 1873, p. 576.

Truplecia cuspidata Hall.

Trenton (Ord.).

Atrypa cuspidata Hall, PaI. New York, I, 1847, p. 138, pI. 33*, fig. 1, and p. 318.

Triplesia cinspidata IIall, Pal. New York, III, 1859, p. 522.-Hall and Clarke, Pal. New York, VIII, Pt. I, 1892, 1. 270.

Loc. Lowville, Lewis County. New York. 
Triplecia extans (Emmons).

Trenton (Ord.).

Atrypa extans Emmons, Geol. N. Y.; Rep. Second Dist., 1842, p. 395, fig. 6.Hall, Pal. New York, I, 1847, p. 137, pl. 33, fig. 1.

'Triplesia extans, Hall, Ibiclem, IlI, 1859, p. 523, figs. 1-3.

Triplecia extans Hall and Clarke, Pal. Now York, VIII, Pt. I, 1892, p. 270, pl. 11C, figs. 1-7.

Loc. Watertown, Lowville, and Boonville, New York.

Triplecia niagaraensis Hall and Clirke.

Niagara (Sil.).

Triplecia niagarensis Hall and Clarke, Pal. New York, VIII, Pt. II, 1895, pl. 83, figs, 16-20.

Loc. Near Milwaukee, Wisconsin.

Triplecia nucleus IIall.

Trenton (Ord.).

Atrypa nuclens IHall, Pal. New York, I, 1847, p. 138, pl. 33, fig. 2.

Triplesia nucleus Hall, Ibiden, IIl, 1859, p. 522.

Triplecia nucleus, Hall and Clarke, Pal. New York, VIII, Pt. I, 1892, p. 270, pl. 11C, figs. 8, 9 .

Loc. Middleville, New York.

Triplecia ortoni Meek.

Clinton (Sil.).

Dicraniscus ortoni Meek, American Jour. Sei., 3l ser., IV, 18i2, p. 280.

Triplesia ortoni Meek, Pal. Ohio, I, 1873, p. 178, pl. 15, fig. 1.

Triplecia ortoni, Hall and Clarke, Pal. New York, VIII, Pt. 1, 1892, p. 270; pl. 11C, figs. 12-20.-Foerste, Geol. Ohio, VII, 1895, p. 585.

Loc. Dayton, Ohio; Newson, Temnessee.

Triplecia (?) radiata Whitfield.

Calciferous (Ord.).

Triplesia radiata Whitfield, Bull. American Mus. Nat. Hist., II, 1889, p. 43, pl. 7, figs. 5-8.

Triplecia radiata, Hall and Clarke, Pal. New York, VIII, Pt. I, 1892, p. 271.

Loc. Beckmantown, New York.

Triplecia ulrichi Winchell and Sehuchert.

Lorraine (Ord.).

Triplecia ulrichi W. and S., Minnesota Geol. Survey, III, 1893, p.409, fig. 34.

Loc. Wykoff and Spring Valley, Minnesota.

Triplesia ambigua Hall=Camarella ambigua.

Triplesia calcifera Walcott $=$ Syutrophia ealcifera.

Triplesia congesta Hall= Hyattella congesta.

Triplesia lateralis Whitfield=Syntroplita lateralis.

Triplesia primordialis Whitfield=Syntrophia primordialis.

Triplesia putillus Hall=Mimulus waldronensis.

Triplesia quadricostata $\Pi$ all = Hyattella congesta.

TROPIDOLEPTUS Hall. Genotype Strophomena carinata Conrad.

Tropidoleptus Hall, Tenth Rep. N. Y. State Cab. Nat. Hist., 1857, P. 152 (undefined);-Twelfth Rep. Ibilem, 1859, p. 31 (undefined); 'Twentieth Rep.Ibidem, 1867, pp. 165, 279;-Pal. New York, IV, 1867, p. 404.-Nettelroth, Kentucky Fossil Shells, Mem. lientucky Geol. Survey, 1889, p. 46.-Hall aud Clarke, Pal. New York, VIII, Pt. II, 1893, p. 302 ;-Thirteenth Aun. Rep. N. Y. State Geologist, 1895, p. 870.

Tropidoleptus carinatus (Conrad).

Marcellus and Hamilton (Dev.).

Strophomena carinata Conrad, Third Ann. Rep. N. Y. Geol. Snrvey, 1839, p. 61.

Leptana laticosta (Hall) de Verneuil, Bull. Soc. Geol. France, 21 ser., IV, 1847, p. 703 .

Tropidoleptus cariuatus IIall, Tenth Rep. N. Y. State Cab. Nat. Hist., 1857, p. 151, figs. 1, 2;-Twelfth Rep. N. Y. State Cab. Nat. Hist., 1859, p. 31, figs. 


\section{Tropidoleptus carinatus (Conrad)-Continued.}

1-4.-Rogrers, Geol. Pennsylvania, II, Pt. II, 1858, p. 828, fig. 672.-Hall, Pal. New York, IV, 1867, 1. 407, pl. 62, tig8. 2, 3.-Meek aud Worthen, Geol. Survey Illinois, III, 1868, p. 427, pl. 13, fig. 2.-Rathbun, Bull. Buffalo Soc. Nat. Sci., I, 1874, P. 254, pl. 9, fig8. 1, 9, 10, 26.-Derby, I3ull. Mus. Coup. Zool., III, 1876, p. 282.-Rathbun, Proc. Boston Soc. Nat. ITist., XX, 1879, p. 35.-Netteloth, Kentucky Fossil Shells, Mem. Kentucky Geol. Survey, 1889, p. 146, pl. 17, figs. 14, 15.-A. Ulrich, N. Jahrb. f. Mineral., lieilageband, VIII, 1892, p. 73 , pl. 4, figs. 32-31.-IIall and Clarke, Pal. New York, VIII, Pt. II, 1893, p. 304 , figs. 227,228 , pl. 82 , figs. $26-36$.

Loc. New York; Falls of Ohio ; Columbus, Ohio ; I'onnsylvania ; Jackson County, Illinois; Erere, Provin ce of Para, Brazil; Islaud of Coati, Lake Titicaca (Agassiz), and Rio Sicasica (Ulrich), Bolivia, Sonth America; South Africa (UIrich); France; Germany and England.

\section{Tropidoleptus occidens Hall.}

Hamilton (Dev.).

Tropidoleptus occidens Hall, Thirteenth Rep. N. Y. State Cab. Nat. Hist., 1860, p. 91 ;-Pal. New York, IV, 1867, p. 408, pl.61A, figs. 50-52.-Hall and Clarke, Pal. New York, VIII, Pt. II, 1895, pl. 82, figs. 37, 38.

Loc. Iowa City, Iowa.

UNCINULUS Bayle. Genotype Rhynchonella subwilsoni d'Orbigny. T'ncinulus Bayle, Explic. de la Carte Géolug. Frauce, IV, Atlas, 1878, pl. 11, figs. 17-20.-Waagen, Palieontologica Indica, Ser. XIII, I, 1883, p. 424.-CEhlert, Fischer's Manuel de ConchylioIogie, 1887, p. 1306.-Hall and Clarke, Pal, New York, VIII, Pt. II, 1893, p. 195 ;-Thirteenth Ann. Rep. N. Y. State Geologist, 1895, p. 828.

\section{Uncinulus abruptus Hall.}

Lower Helderberg (Dev.).

Rhynchonella abrupta Hall, Tenth Rep. N. I. State Cab. Nat. Hist., 1857, p. 68, fig. 1;-Pal. New York, III, 1859, p. 228, pl. 31, fig. 3.

Uncinulus abruptus Hall and Clarke, VIII, Pt. II, 1893, p. 199, pl. 58, tigs. 15-21. Loc. Albany and Schoharie counties, New York.

Uncinulus campbellanus (Hall).

Lower Helderberg (Dev.).

Rhyuchonella campbellana Hall, Tenth Rep. N. Y. State Cab. Nat. Hist., 1857, p. 79 ;-Pal. New York, III, 1859, p. 239, pl. 43, fig. 2.

Loc. Albany County, Now York.

Uncinulus mutabilis IIall.

Lower Helderberg (Dev.).

Rhynchonella mutabilis Hall, 'Tenth Rep. N. Y. State Cab. Nat. Hist., 1857, p. 66, figs. 1-7;-Pal, New York, III, 1859, p. 225, pl. 29, fig. 4 ; pl. 30, figs. 1, 2.

Uncinulus mutabilis Hall and Clarke, Pal. New York, VIII, Pt. II, 1893, p. 199, pl. 58, figs. 22-25.

Loc. Schoharie and Carlisle, Now York.

Uncinulus nobilis Hall.

Lower Helderberg (Dev.).

Rhynchonella nobilis Hall, Tenth Rep. N. Y. State Cab. Nat. Hist., 185T, p. 80, figs. 1-3.-Rogers, Geol. Pennsylvania, II, 1858, 1). 825, fig. 645.-Hall, Pal. New York, III, 1859, p. 240, pl. 43, fig. 3.

Uncinulus nobilis Hall and Clarke, Pal. New York, VIII, Pt. II, 1895, pl. 58, fig. 26.

Loc. Albany and Schoharie counties, New York; Pennsylvania.

Uncinulus nucleolatus Hall.

Lower Helderberg (Dev.).

Rhynchonella nucleolata IIall, Tenth Rep. N. Y. State Cab. Nat. Hist., 1857, 1. 68 ;-Pal. New York, III, 1859, p. 227, pl. 31, tigs. 1f, 2.-Billings, Proc. Portland Soc. Nat. Hist., 1863, 1. 110, pl. 3, fig. 5. 


\section{Uncinulus nucleolatus Hall-Continued.}

Uncinulus nucleolata Hall and Clarke, Pal. New York, VIII, Pt. II, 1893, p. 199.

Loe. Schoharie and Carlisle, New York; Square Lake, Maine; St. Blaudine, New Brunswick, Canada.

\section{Uncinulus pyramidatus Uall.}

Lower Helderberg (Dev.).

Rhynchonella pyramidata Hall, Tenth Rep. N. Y. State Cab. Nat. Hist., 1857, p. $70 ;-$ Pal. New York, III, 1859, p. 229, pl. 32, figs. 1, 2.

Uncinulus pyramidatus Hall and Clarke, Pal. New York, VIII, Pt. II, 1895, pl. 58, figs. $27,28$.

Loc. Albany County, New York.

Uncinulus stricklandi (Sowerby).

Niagara (Sil.).

Terebratula stricklandi Sowerby, Murchison's Sil. System, 1839, pl. 13, fig. 19.

Rhynchonella tennesseensis Hall (non Roemer), Trans. Albany Institute, IV, 1860, p. 228 ;-Twenty-eighth Rep. N. Y. State Mus. Nat. Hist., Doc. ed., 1876, pl. 26, figs. 34-40.-White, Second Ann. Rep. Indiana Burean of Statistics and Geol., 1880, p. 496, pl. 3, figs. 2-4 ;-'Tenth Rep. State Geol. Indiana, 1881, p. 128, pl. 3, figs. 2-4.

Rhynchonella stricklandi Hall, Twenty-eighth Rep. N. Y. State Mus. Nat. Hist., Doc. ed., 1879, p. 165, ,l. 26, figs. 34-40;-Eleventh Rep. State Geol. Indiana, 1882, p. 308, pl. 26, figs. 31-40.-Nettelroth, Kentucky Fossil Shells, Mem. Kenticky Geol. Survey, 1889, 1. 81, pl. 27, figs. 9-11; pl. 29, figs. 3-6.

Uncinulus (Unciuulina) stricklandi Hall and Clarke, Pal. New York, VIII, Pt. II, 1895 , pl. 58 , figs. $38-40$.

Loc. Europe; Waldron, Indiana; Louisville, Kentucks.

Uncinulus vellicatus Hall. Lower Helderberg (Dev.). Rhynchonella vellicata Hall, Tenth Rep. N. Y. State Cab. Nat. Hist., 1857, pp. 69, 71, figs. 2, 3;-Pal. New York, III, 1859, p. 230, pl. 33, fig. 1.

Uncinulus vellicata Hall and Clarke, Pal. New York, VIII, Pt. II, 1895, p. 199. Loc. Albany and Schoharie counties, New York; Dalhousie, New Brunswick, Canada.

VITULINA Hall.

Genotype V. pustulosa Hall.

Vitulina Hall, Thirteenth Rep. N. Y. State Cab. Nat. Hist., 1860, p. 72, figs. 1, 2;Pal. New York, IV, 1867, p. 410.-Hall and Clarke, Pal. New York, V'III, Pt. II, 1893, p. 138;-Thirteenth Ann. Rep. N. Y. State Geologist, 1895, p. 804.

Vitulina pustulosa Hall.

Hamilton (Dev.).

Vitulina pristulosa Hall, Thirteenth Rep. N. Y. State Cab. Nat. Hist., 1860, p. 82 ;-Pal. New York, IV, 1867, p. 410, pl. 62, fig. 1.-Rathbun, Bull. Buffalo Soc. Nat. Sci., I, 1874, p. 255, pl. 9, figs. 2, 6-8, 11-13, 15, 20, 21, 27, 32.-Derby, Bull. Mus. Comp. Zool., III, 1876, p. 282.-Rathbun, Proc. Boston Soc. Nat. Hist., XX, 1879, p. 36.-A. Ulricl, N. Jahrh. f. Mineral., Beilageband, VIII, 1891, p. 273 ;-Ibidem, Bcilageband, VIII, 1892, p. 71, pl. 4, figs. 26-29.-Hall and Clarke, Pal. New York, VIII, Pt. II, 1893, pp. 139, 317, pl. 82, figs. 18-25.

Loe. Near Tully and Tinkers Falls, New York; IIonroe County, Pennsylvania; Erere, Province of Para, and provinces Parana and Matto Grosso, Brazil; island of Coati, Lake Titicaca, Tarabuco and Rio Sicasica, Bolivia; South Africa.

WALDHEIMIA King.

Genotype W. flavescens Lamarck. Waldheimia King, Molr Permian Fossils, Pal. Soc., 1850, p. 81.-Dall, American Jonr. Conch., VI, 1870, p. 107.

Waldheimia (?) catorcensis Aguilera.

Waldheimia catorcensis Aguilera, Bol. Com. Geologica de Mexico, I, 1895, p. 1, pl. 2 , fig. 8 .

Loc. Rancho Alamitos, San Luis, Potosi, Mexico. 
Waldheimia compata White and St. John=Cryptacanthia eompacta.

Waldlecimia coutinloana Derby= Harttina eontinhoana.

Waldheimia deweyi IIall=Parazyga deweyi.

Walkheimia formosa Hall= Rhynehospira formosa.

Waldheimia globosa Hall= Rhynchospira globosa.

Waldr simia imbricata Cooper=Terebratella? imbricata.

Waldheimia keunedyi Jall.

Mineerue.

Waldheimia kennedyi Dall, Proc. California Acad. Sci., 1874 (extract, p. 4).

Loe. Cerros Island, Lower California.

Waldheimia rectirostra Hall=Rhynchospira rectirostris.

Whitfieldia Davidson=Meristina.

WHITFIELDELLA Hall and Clarke. Genotype Atrypa nitida Hall.

Whitfieldella Hall and Clarke, Pal. New York, VIII, Pt. II, 1893, p. 58:-Thirteenth Ann. Rep. N. Y. State Geologist, 1895, p. 766.

Whitfieldella (?) billingsana (Meek and Worthen). Niagara (Sil.). Centronella billingsiana Meek and Worthen, Geol. Survey Illinnis, III, 1868, p. 352, figs. a, b, c; $p^{l} .6$, fig. 5 .

Loc. Alexander Connty, Illinois.

Whitfieldella (?) bisulcata (Vannxem).

Lower Helderberg (Dev.).

Atrypa bisulcata Vanuxem, Geol. N. Y.; Rep. Third Dist., 1812, p. 112.

Merista bisuleata IIall, Pal. New York, III, 1859, p. 253.

Loc. Litchfield, New York.

Whitfieldella cylindrica Hall.

Atrspa cylindrica Hall, Pal. New York, II, 1852, p. 76, pl. 24, fig. 2.

Atrypa crassirostra 1Fall, Pal. New York, 1852, p. 269, pl. 55, fig. 4.

Merista cylindrica Hall, Twelfth Rep. N. Y. State Cal. Nat. Hist., 1859, p. 77.

Athyris cyliudrica Billings, Geol. Canada, 1863, p. 317, fig. 333;-Geol. Canada, 1863, p. 317, fig. 332 .

Meristella (?Meristina) eylindriea Meek, Pal. Ohio, I, 1873, p. 180, pl. 15, fig. 2. Whitfieldella cylindrica Hall and Clarke, Pal. New York, VIII, Pt. II, 1893, p. 60, pl. 40, figs. 16-22.

Loc. Lockport, New York; Hillsboro, Ohio; Hanilton, Ontario; Anticosti.

Whitfieldella (?) harpalyce (Billings).

Lower Hellerberg (Der.).

Athyris harpalyee Billings, Proc. Portland Soc. Nat. Hist., 1863, p. 116, pl. 3, fig. 14.

Whitfieldella (?) harpalyee Hall and Clarke, Pal. New York, VIII, Pt. II, 1893, p. 60.

Loc. Sriuare Lake, IIaine.

Whitfieldella hyale (Billings).

Charionella ? hyale, Billings, Pal. Fossils, I, 1862, p. 166, fig. 150.

Whitfieldella hyale Hall and Clarke, Pal. New York, VIII, Pt. II, 1893, p. 60.

Charionella hyale Hall and Clarke, Ibidem, pl. 42, figs. 20, 21.

Loc. Galt and Elora, Ontario; Wisconsin (Whitfiold).

Whitfieldella intermedia Hall.

Clinton-Niagara (Sil.).

Atrypa intermedia Hall, Pal. New York, II, 1852, p. 77, pl. 24, figs. 3, 4, ?6.-Rogers,

Geol. Pennsylvania, II, 1858, Pt. II, p. 823, fig. 631.

Merista intermedia Hall, Twelfth Rep. N. Y. State Cab. Nat. Hist., 1859, p. 77.

Atuyris intermedia Nicholson and Hinde, Canadian Jour. Sci., XIV, 1874, 1. 157.-

Nicholson, Pal. Prov. Ontario, 1875, p. 61, fig. 32A. 
Whitfieldella intermedia Hall-Continued.

Whitfieldella intermedia Hall and Clarke, Pal. New York, VIII, Pt, II, 1893, p. 60 , pl. 40 , figs. $1,2$.

loe. Lockport, New York; Thorold, Ontario; Penusylvania.

Whitfieldella (?) julia (Billings).

Anticosti (Sil.).

Athyris julia Billings, Pal. Fossils, I, 1862, p. 146, fig. 124.

Meristella julia Miller, N. American Geol. Pal., 1889, p. 354.

Loc. Anticosti.

Whitfieldella (?) naviformis Hall.

Clinton-Niagara (Sil.).

Atrypa naviformis Hall, Geol. New York; Rep. Fourth Dist., 18.13, p. 71, fig. 3;-

Pal. New York, II, 1852, p. 76, pl. 24, fig. 1.-Nicholson and Hinde, Canadian Jour. Sci., n. ser., XVI, 1874, pp. 144, 157.

Meristella naviformis Hall, Twelfth Rep. N. Y. State Cab. Nat. Hist., 1859, p. 78. Athyris naviformis Billings, Geol. Canala, 1863, p. 317, fig. 320.-Nicholson, Pal. Prov. Ontario, 1875 , p. 62, fig. 32E.

Whitfieldella naviformis Hall and Clarke, Pal. Now York, VII, Pt. II, 1893, p. 60, pl. 40 , fig. 3.

Loc. Rochester, Sodus, etc., New York; Dundas, Ontario Anticosti.

Whitfieldella nitida Hall.

Niagara (Sil.).

Atrypa nitida Hall, Geol. New York; Rep. Fourth Dist., Tables of Organic Remains, 13, 1843, fig. 5;-Pal. New York, IJ, 1852, p. 268, pl. 55, fig. 1.Billings, Canadian Nat. Geol., I, 1856, p. 137, pl. 2, fig. 9.

Merista nitida Hall, Twelfth Rep. N. Y. State Cab. Nat. Hist., 1859, p. 78.

Athyris nitida Hall, Geol. Canada, 1863, p. 317, fig. 334.

Meristella nitida Hall, 'Trans. Albany Institute, IV, 1863, p. 226.

Meristiua nitida Hall, Pal. New York, 1Y, 1867, p. 299;-Twenty-eighth Rep. N. Y. State Mus. Nat. Hist., 1879, p. 169, pl. 25, figs. 1-7;-Eleventh Rep. State Geol. Iudiana, 1882, p. 300, pl. 25, figs. 1-7.-Nettelroth, Kentucky Fossil Shells, Mem. Kentucky Geol. Survey, 1889, p. 102, pl. 33, figs. 10, 11.Beecher and Clarke, Mem. N. Y. State Mus., I, 1889, p. 70, pl. 7, figs. 6-10.

Whitfieldella nitida Hall and Clarke, PaI. New York, VIII, Pt. II, 1893, p. 59, figs. 43, 44; pl. 40, figs. 4-13.

Loc. Lockport, otc., New York; Hamilton, Ontario; Waldron, Indiana; Louisvilla, Kentucky; Anticosti.

Whitfieldella nitida oblata Hall.

Niagara (Sil.).

Atrypa nitida var. oblata Hall, Pal. Now York, II, 1852, p. 269, pl. 55, fig. 2.

Merista nitida var, oblata Hall, Twelfth Rep. N. Y. State Cab. Nat. Hist., 1859, p. 78 .

Loc. Lockport, etc., New York.

Whitfieldella (?) nucleolata (Hall.)

Coralline (Sil.).

Atrypa nucleolata Hall, Pal. New York, II, 1852, p. 328, pl. 74, tig. 10.

Merista nucleolata Hall, Twelfth Rep. N. Y. State Cab. Nat. Hist., 1859, p. 78.

Meristella nucleolata Whitfield, Geol. Wisconsin, IV, 1882, p. 321, pl. 25, tig. 5.

Loc. Schoharie, New York; near Milwaukee, Wisconsin.

Whitfieldella oblata Hall.

Atrypa oblata Hall, Pal. New York, II, 1852, p. 9, pl. 4, figষ. 4, 5.

Merista oblata Hall, Twelfth Rep. N. Y. State Cab. Nat. Hist., 1859, p. 78.

Whitfieldella (?) oblata Hall and Clarke, Pal. New York, VIII, Pt. II, 1893, p. 60.

Loc. Lockport, New York.

Whitfieldella sulcata (Vanuxem).

Waterlime (Sil.).

Atrypa sulcata Vanuxem, Geol. New York; Rep. Third Dist., 1842, p. 112, fig. 5.-

Hall, Ibidem, Rep. Fourth Dist., 1843, p. 142, fig. 5.

Merista sulcata Miller, American Pal. Fossils, 1877, p. 115.

Loc. Near Vienna village, Now York. 
WILSONIA Kayser.

Genotype Terebratula wilsoni Sowerby.

Wilsonia Kayser, Zoitschr. ،l. „leutsch. geolog. Gesselsch., XXIII, 1871, p. 502.Hall and Clarke, Pal. New York, VIII, Pt. 11, 1893, 1. 195 ;-Thirteenth Aun. Rep. N. Y. State Geologist, 1895, p. 827.

Uncinulina Bayle, Explic. de la Carte Gcolog. France, IV, 1878, Atlas, pl. 13, figs. 13-16.

Obs. A subgenus of Camarotœchia.

Wilsonia kokomoensis (Miller).

Waterlime (Sil.).

Rhynchonella kokomoensis Miller, Eighteenth Ann. Rep. Geol. Survey Indiana, 1891, p. 312, pl. 9, figs. 22-24.

Loc. Kokomo, Indiana.

Wilsonia saffordi Hall. Niagara and Lower Helderberg (Sil. and Dev.). Rhynchonella saffordi Hall, Canadian Nat. Geol., V, 1860, n. 146.-Hall and Whitfield, Twenty-seventh Rep. N. Y. State Cab. Nat. Hist., 1875, pl. 9, figs. 27-29.-Dawson, Acadian Geol., 3d ed., 1878, p. 598.-Nettelroth, Kentucky Fossil Shells, Mem. Kentucky Geol. Survey, 1889, p. 79, pl. 27, figs. 22-24; pl. 33, figs. 4-6.

Wilsonia saffordi Hall and Clarke, Pal. New York, VIII, Pt. II, 1893, p. 198, pl. 58, figs. 5-14.

Loc. In the Arisaig group of Nova Scotia; Perry County, Tennessee; Louisville, Kentucky.

Wilsonia saffordi depressa (Nettelroth).

Niagara (Sil.).

Rhynchonella safiordi var. depressa Nettelroth, Keutucky Fossil Shells, Mem. Kentucky Geol. Survey, 1889, p. 80, pl. 33, fig. 1-3.

Loc. Louisville, Kentucky.

Wilsonia wilsoni (Sowerby).

Niagara (Sil.).

Terebratula wilsoni Sowerby, Mineral Conchology, 1818, p. 118, fig. 3.

Rhynchonella wílsoni Roemer, Sil. Fauna d. West. Tennessee, 1860, p. 71, pl. 5, fig. 13.

Wilsonia wilsoni Hall and Clarke, Pal. Now York, YIII, Pt. II, 1893, p. 198.

Lnc. Europe; Decatur County, Tennesseo; Louisville, Kentucky; Lake Temisconata, Now Brunswick.

YORKIA Walcott.

Genotype $\mathrm{I}$. wanneri Walcott. Yorkia Walcott, Proc. U. S. Nat. Hus., XIX, 1897, p. 714.

Yorkia wanneri Walcott.

Lower Cambrian. Yorkia wanneri Waleott, Proc. IJ. S. Nat. Mus., XIX, 1897, p. 715, pl. 60, figs. 1-1e. Loc. Enigsville, Pennsylvauia.

Yorkia (?) washingtonensis Walcott.

Lower Cambrian.

Yorkia (?) washingtonensis Walcott, Proc. U. S. Nat. Mus., XIX, 1897, p. 715, pl. 60 , fig. 3.

Loc. Salem, Wrashington County, New York.

ZYGOSPIRA Hall.

Genotype Atrypa modesta Hall.

Stenocisma Hall (non Conrad), Pal. New York, I, 1817, p. 142.-Meek and Hayden, Pal. Upper Missouri, Snithsonian Cont. to Knowl., XIV, 1864, p. 16.

Zygospira Hall, Fifteenth Rej. N. Y. State Cab. Nat. Hist., 1862, p. 154, figs. 1, 2.-Billings, Canadian Nat. Geol., VII, 1862, p. 393.-Hall, Twentieth Rep. N. Y. State Cab. Nat. Hist., 1867, p. 267.-Meck, Geol. Survey, Illinois, III, 1868, p. 377.-Davidson, Suppl. British Silurian Brachiopoda, Pal. Soc., 1882, p. 122.-Winchell and Schuchert, Minnesota Geol. Survey, III, 1893, p. 465.Beecher and Schuchert, Biol. Soc. Washington, VIII, 1893, pp. 71-82.-Hall and Clarke, Pal. Now York, VIII, Pt. II, 1893, p. 154.

Anazyga Davidson, Suppl. British Silurian Brachiopoda, Pal. Soc., 1882, p. 128. 
ZYGOSPIRA Hall-Continued.

Hallina Winchell and Schuchert, Minnesota Geol. Survey, III, 1893, p. 471.

Protozyga Hall and Clarke, Pal. New York, VIII, Pt. II, 1893, p. 151.

Protozyga, Hallina and Zygospira Hall and Clarke, Thirtecnth Ann. Rep. N. Y.

State Geologist, 1895 , pp. 809, 810, 812.

Zygospira requila Sardeson $=Z$. nicoletti.

Zygospira anticostiensis Davidson=Catazyga erratica.

Zygospira cincinnatiensis Meek.

Lorraine (Ord.).

Zygospira cincinnatieusis (James) Neek, Pal. Ohio, I, 1873, p.126, pl.11, fig. 5.-

Miller, Cincinnati Quart. Jour. Sci., II, 1875, p. 59.-Hall and Clarke, Pal.

New York, VIII, Pt. II, 1895, pl. 54, figs. 13, 14.

Loc. Cincinnati, Ohio.

Zygospira concentrica Ulrich.

Lorraine (Ord.).

Zygospira concentrica Ulrich, Jour. Cincinnati Soc. Nat. Hist., II, 1879, p. 14, pl. 7 , fig. 10.

Loc. Cincinnati, Ohio.

Zygospira deflecta Hall.

Trenton (Ord.).

Atrypa deflecta Hall, Pal. New York, I, 1847, p. 140, pl. 33, fig. 4.

Zygospira deflecta Hall and Clarke, Pal. New York, VIII, Pt. II, 1893, p. 157.

Loc. Lewis County, New York; Ottawa, Canada.

Zygospira exigua (Hall).

Trenton (Ord.).

Atrypa exigna Hall, Pal. New York, I, 1847, p. 141, pl. 33, fig. 6.

Genus? exigua Hall, Twelfth Rep. N. Y. State Cab. Nat. Hist., 1859, p. 66.

Protozyga exigua Hall and Clarke, Pal. New York, VIII, Pt. II, 1893, p. 149, figs. 137, 138, pl. 54, figs. 47, 48.

Loc. Lowville, Watertown, and Martinsburg, New York.

Zygospira erratica Davidson = Catazyga erratica .

Zygospira headi Hall=Catazyga headi.

Zygospira kentuckiensis .James.

Lorraine (Ord.).

Zygospira modesta var. kentuckiensis James, The Paleontologist, 1878, p. 7.

Zygospira kentuckiensis Nottelroth, Kentucky Fossil Shells, Mem. Kentucky Geol. Survey, 1889, p. 138, pl. 34, figs. 21-25.-Hall and Clarke, Pal. New York, VIII, Pt. II, 1895, pl. 5.t, figs. 11, 15, 16.

Loc. Oldham and Jefferson connties, Kentucky.

Zygospira (?) mica (Billings).

Anticosti (Sil.).

Rhynchonella mica Billings, Cat. Sil. Foss. Anticosti, 1866, p. 44.

Zygospira? mica Hall and Clarke, Pal. New York, VIII, Pt. II, 1893, p. 157.

Lor. Division 4 of the Anticosti group, Anticosti.

Zygospira (?) minima Hall.

Niagara (Sil.).

Zygospira minima Hall, Descrip. n. sp. Foss. Waldron, Indiana, 1879, p. 14;-

Eleventh Rep. Indiana State Geologist, 1882, p. 305, pl. 27, fig. 7;-Trans.

Albany Institute, X, 1883, p. 70.

Loc. Waldron, Indiana.

Zygospira modesta Hall.

Utica and Lorraine (Ord.).

Atrypa modesta (Say) Hall, Pal. New York, I, 1847, p. 141, pl. 15, fig. 15;-Thir-

teenth Rep. N. Y. State Cab. Nat. Hist., 1860, p. 69.

Zygospira modesta Hall, Fifteenth Rep. N. Y. State Cab. Nat. Hist., 1862, p. 154 ;-Twentieth Rep.Ibidem, 1867, p. 267, figs. 1, 2.-Meek, Pal. Ohio, I, 1873, p. 125, pl. 11, fig. 4.-Miller, Cincinnati Quart. Jour. Sci., II, 1875, p. 58.Davidson, Suppl. British Sil. Brachiopoda, Pal. Soc., 1882, p. 122.-Winchell 


\section{Zygospira modesta Hall-Continued.}

and schnclert, Minnesota Geol. Survey, III, 1893, p.467, pl. 34, figs. 42-44.-

Hall and Clarke, Yal. New York, VII1, Pt. II, 1893, p. 155, figs. 146-149, 11.

54, figs. 7-10, 12.-Keyes, Geol. Survey Missonri, T, 1895, 1. 98.

Rhynchouella? modesta Billings, Geol. Canada, 1863, p. 211, fig. 211.

Loc. Cincinnati, Ohio; Turin, ete., New York; Lattners, Iowa; Spring Valley, Minnesota; Wisconsiu; St. Lonis Connty, Missonri; Ottawa, Canala (Ami).

Zygospira nicoletti Wiuchell and Schnchert.

Trenton (Ord.).

IIainina nicoletti W. and S., American Geol., IX, April 1, 1892, p. 293;-Minnesota Geol. Snrviy, IIl, 1893, p. 474, pl. 34, figs. 59-62.

Zrgospira aquila Sardeson, Bull. Minnesota Geol. Surves, III, April 9, 1892, p. 335 , pl. 4, tigs. 15-18.

Zygospira nicolleti Beecher and Schnchert, liol. Soc, W'ashington, VIII, Pt. II, 1893, p. 71, pl. 10, fig. 23 ; pl. 11, figs. 11, 12.

Loc. Minneapolis, Rochester, and Fountain, Minnesota; Decorah, Iowa; Beloit, Wisconsin; Anburn, Missonri.

\section{Zygospira paupera Billings.}

Anticosti (Sil.).

Zygospira panpera Billiugs, Cat. Sil. Fossils Anticosti, 1866, p. 46.-Hall and Clarke, Pal. New York, VIII, Pt. II, 1893, p. 157.

Loc. Dirision 3 of Anticosti group, Anticosti.

Zygospira putilla Hall and Clarke.

? Lorraine (Ord.).

Zygospira putilla 11 all aud Clarke, Pal. Now York, VIII, Pt. II. 1893, p. 157, figr. 150, p. 365, pl. 54, figs. 35-37; pl. 83, figs. $29,30$.

Loc. Pike County, Missonri.

Zygospira recurvirostris (Hall).

Atrypa recurvirostris Hall, Pal. New York, I, 1817, p. 140, pl. 33, fig. 5.

Rhynchonella recurvirostris Billings, Geol. Canada, 1863, p. 168, fig. 152.

Anazyga recurvirostra Davidson, Suppl, British Sil. Brachiopoda, Pal. Soc., 1892, p. 129.

Zygospira recurvirostra Winchell aud Schuchert, Minnesota Geol. Survey. III, 1893, p. 466, pl. 31, figs. 38-41.-Beecher and Schnchert, Biol. Soc. Washington, VIII, 1893, p. 71, 11. 10, figs. 7-21; pl.11, figs. 1-10.-Hall and Clarke, Pal. New York, VIII, Pt. II, 1895, pl. 54, figs. 1-6.-Whiteaves, Pal. Foss., III, Pt. 11I, 1897, p. 180.

Loc. New York; Kentucks; Iowa; Ninnesota; Wisconsin; Ottawa, Canada; Lake Winnipeg, Nanitoba. Accorling to Billiugs it occnrs also in the Lorraine gronl of Anticosti.

Zygospira saffordi Winchell and Schuchert.

Trenton (Oril.).

Hallina saffordi W. and S., American Geol., IX, 1892, p. 292;-Miunesota Geol. Survey, 111, 1893, p. 173, pl. 34, figs. 55-58.-Hall and Clarke, Pal. New York, VIII, Pt. II, 1895, pl. 83, figs. $36-38$.

Zygospira saffordi Beecher and Schnchert, Biol. Soc. Washington, VIII, 1893, p. 71, pl. 10, fig. 22; pl.11, figs. 13, 13:--Hall and clarke, Yal. New York, VIII, Pt. II, 1893, p. 151, figs 139-141.

Loc. Lebauon, Temessec; Highbrilge, Kentucky.

Zygospira (?) subconcava Meek and Worthen. Lower Helderberg (Der.). Zygospira snbconeava Meek and Worthen, Geol. Surver. Illinois, III, 1868, p. 380, pl. 7 , fig. 1.

Loc. Perry Comty, Missouri.

Zygospira uphami W. and S.=Catazyga uphami. 
[Take this leaf ont and paste the separater titles upon three of rour catalogne carls. The first and second titles need no aldition; over the third write that subject under which you would place the book in your library.]

\section{LIBRARY CATALOGUE SLIPS.}

United States. Department of the interior. (U. S. geological surrey.) Department of the interior | - | Bulletin | of the | United States | geological survey | no. 87 | [Seal of the department] |

Washington | government printing office | 1897

Second title: United States geologieal survey | Charles D. Walcott, director | - | A synopsis | of | American fossil brachiopoda | including | bibliography and synonymy | by | Charles Schuchert | [Vignette] |

Washington | government printing office | 1897

$8^{\circ} .464 \mathrm{pp}$.

\section{Schuchert (Charles).}

United States geological surver | Charles D. Walcott, director | - | A syuopsis | of | American fossil brachiopoda | including | bibliography and synonymy | by | Charles Schuchert | [Vignette] ]

Washington | government printing office | 1897

8. $464 \mathrm{pp}$.

[United States. Department of the interior. (U. S. geological strvey.) Bulletin 87.]

United States geological survey | Charles D. Walcott, director | - | A synopsis | of | American fossil brachiopoda|including | bibliographs and synonymy | by | Charles Schuchert | [Viguette] |

Washington | government printing office | 1897

8․ $464 \mathrm{pp}$.

[UNited States. Department of the interior. (U. S. geological survey.) Bulletin 87.] 


$$
\begin{aligned}
& 6 \\
& 4>7
\end{aligned}
$$


QE Schuchert, Charles

796 A synopsis of American fossil

S39 Brachiopoda including

P\&A Sci。

bibliography and synonymy

$$
1897
$$

PLEASE DO NOT REMOVE CARDS OR SHPS FROM THIS POCKET UNIVERSITY OF TORONTO LIBRARY 


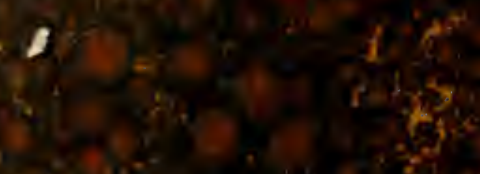

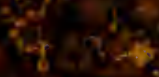

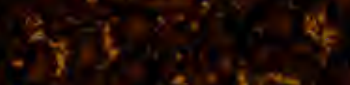

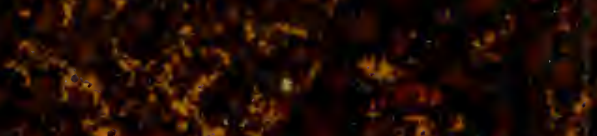

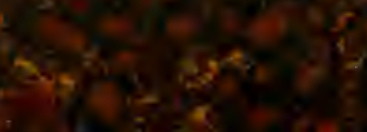

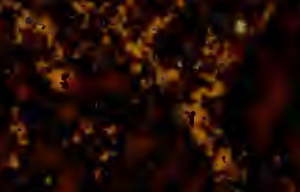

a. $x_{6}$ 48

$-\frac{1}{4}=$

$8+5$

28$$
\text { s }
$$

$\left(\frac{6}{2}\right.$

$\frac{3}{3}=$

s.

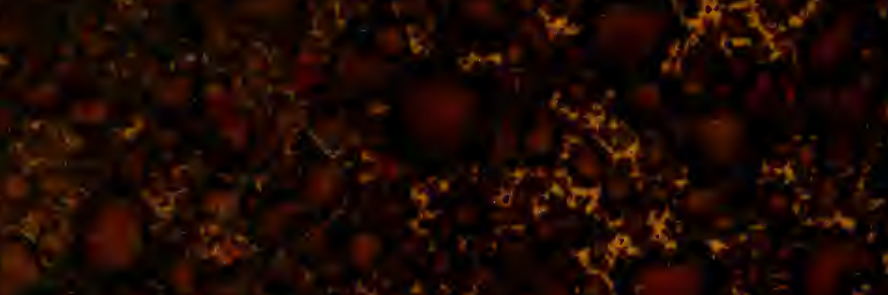

(8).

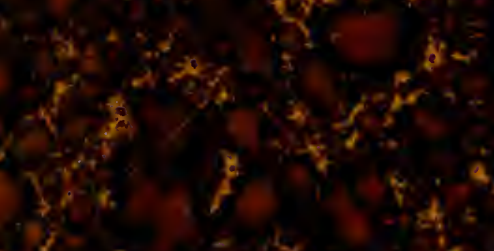

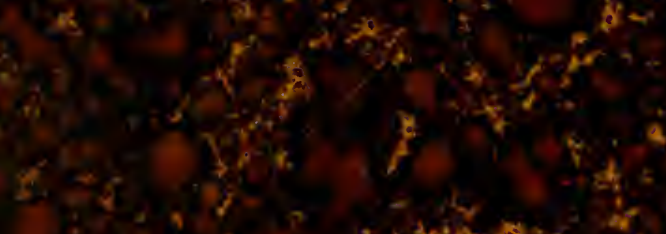

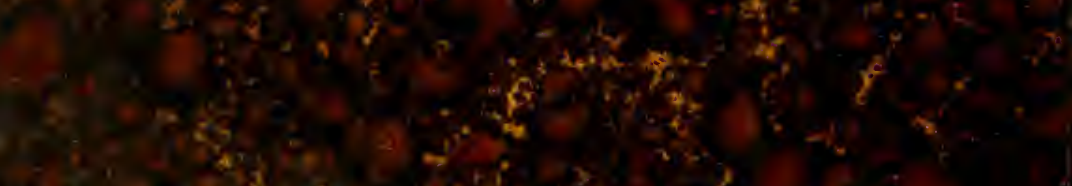

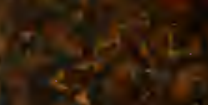

$=\log ^{2}: 1$

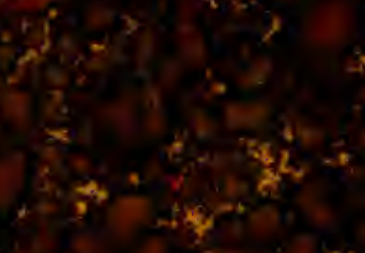

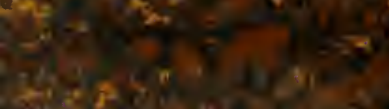

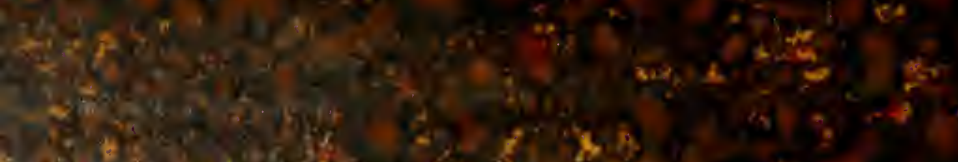

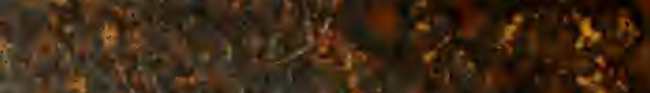

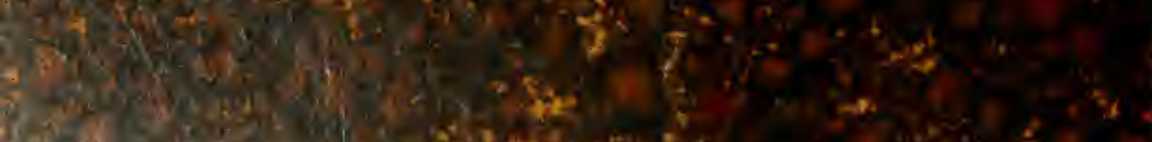

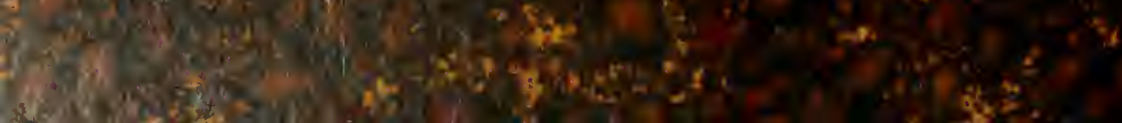

